551.7

\title{
0939
}

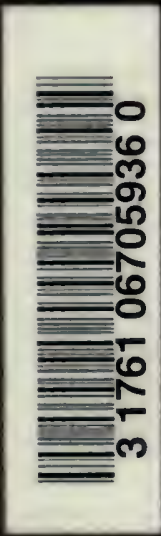

STUDENTSS HANDBOOK OI

TRATIGRAPHICAL GEOLOGY

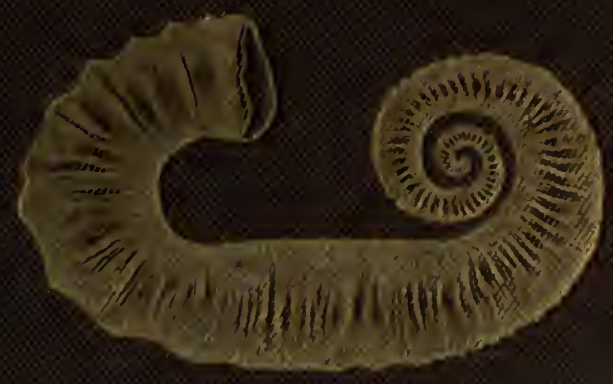



Markin a Peacrek. Sec q9o. 
Digitized by the Internet Archive in 2007 with funding from Microsoft Corporation 


\section{THE STUDENT'S HANDBOOK}

OF

\section{STRATIGRAPHICAL GEOLOGY}




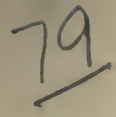

SA 79 'THE STUDENT'S HANDBOOK

OF

\section{STRATIGRAPHICAL GEOLOGY}

BY

A. J. JUKES-BROWNE, B.A., F.R.S., F.G.S.

LATE OF THE GEOTOGICAL BLRVEY OF ENTLLAND AND WALES AUTHOR OF THE 'BULDINO OF TUE BRITISH ISLE8,' ETC.

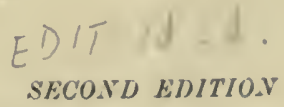

ILLUSTRATED WITH MAPS, DIAGRAMS, AND FIGURES OF FOSSILS

1) LONDON: EDWARI STANFORI

12, 13, 14 LONG ACRE, W.C.

3) 1912 
I $1 B R A R$ P

AUG 31967 


\section{PREFACE}

Is preparing a new edition of this volume I lave not only revised and partly rewritten the deseriptions of the British strata, but have enlarged the scope of the work by giving more eomplete aceounts of the eontinental representatives of each system or series of roeks. I have, however, strictly eonfined myself to the geology of Europe, because any adequate account of Asiatie or American strata, with their fossil contents, would have made the volume too bulky. For such further information the student must eonsult a larger treatise, such as Sir A. Geikie's Text-liook of Geology or de Lapparent's Traité de Grologie.

It has often been said that the British Isles present us with an epitome of the geology of Europe; but though it is true that we possess representatives of nearly all the great series of strata whieh form the geologieal reeord, yet some of them are missing, such as the Stephanian Series, the Middle Trias (Muschelkalk, ete.), and the Miocene (except for the Bovey Beds), while others consist of freshwater deposits instead of the more universal marine facies. Consequently, a student who is only aequainted with the British rocks is ignorant of many important formations and fossils, and is apt to take limited and ineomplete views of the stratigraphical systems and their problems.

In thinking it desirable to supply such supplementary 
information I am supported by many teachers of geology, who wish their students to take a broader view and to learn more about the geology of Europe, with perhaps less local detail of English subdivisions and zones. In order to show how such wider knowledge can be utilised and made interesting, I have appended to each chapter a brief sketch of the conclusions which may be drawn from the facts with regard to the physical and geographical conditions under which cach great series of strata was accumulated in the European region.

Further, in three cases I have ventured to express these conclusions in the form of cartographical restorations, i.e. of the Lower Devonian, the Upper Trias, and the Lower Cretaceous. Such maps form a conspicuous feature in the later editions of de Lapparent's treatise, but have not yet been inserted in an English text-book. In a future edition I may be able to include maps of other epochs; meantime, I would suggest that students should endeavour to make their own geographical restorations from the descriptions which I have given. I need hardly seek to justify such advice, for, as Professor Watts has remarked, such maps "group together. numbers of facts and inferences with which it was previously difficult to retain touch;" ... they "systematise future research, they direct to the places where the discovery of new facts is desirable."

In the work of revision I have sought the assistance of those geologists who have paid special attention to particular formations. Their writings are, of course, referred to in the text, but I have to thank the following friends and correspondents for reading portions of certain chapters, and for useful information thereon:-C. T. Clough, Edward Greenly, W. G. Fearnsides, J. E. Marr, A. Vaughan, E. A. Newell 
Arber, T. G. Bomrey, and H. Woods. I am specially indebted to $\mathrm{Mr}$. Woods for revising all the deseriptions and lists of fossils, and for amending the nomenclature, both of genera and species, in accordanee with current views.

Finally, I may point out that many additional illustrations have beeu inserted, not only of fossils but of maps and sections, so that there are now over two hundred figures and groups of fossils. Moreover, two of the older maps, those of North Wales and Devoushire, have been replaced by more correct representations, in accordance with recent publications.
A. J. JUKES-BROWNE.

Westleigh, Tolrquy,

November 1911. 



\section{CONTENTS}

\section{CHAPTER I}

THE SUCCLSSION OF STRATIFIED ROCKS

Scope of the Subject-Succession of Stratified Rocks-Nounenclature of Rock-groups-Definition and Delinitation of Systems-Stratigraphical Breaks-Palæontological Evidence

\section{CHAPTER II \\ STRATIGRAPHICAL PALAONTOWGY}

Origin of Species-Inperfection of the Geological Record-Succession of Faunas-Zones-Synchronism and Homotaxis .

\section{CHAPTER III}

、 THE LITERATURE OF HISTORICAL GEOLOGX

Maps-Publications on Stratigraplyy-Publications on l'aleontology-Books on Palæogeography

\section{CHAPTER IV}

THE ARCHALX ROCKS

A. Classification and Nomenclature; B. British Representatives : Scotland, Ireland, Wales, Ëngland; C. Arulnean Rocks in Europe: France, Austria andel switscrlund, Bohemin, Scandinavia-References . . . . . . . 


\section{CHAPTER V}

THE CAMBRIAN SYSTEM

A. Nomenclature and Classification-B. Life of the Period-C. PAGE

British Cambrian Rocks: Wales, Nidland Counties, Lake District and Isle of Man, Ireland, Scotland-D. The Cambrian of Northern Europe: France, Iberian Peninsula, Belgium and the Ardennes, Scandinavia, Rissia, Germany and Bohemia-E. European Geography and Conditions of Deposition-Refcrences

\section{CHAPTER VI \\ THE ORDOVICIAN SYSTEM}

A. Nomenclature and Divisions-B. Life of the Period-C. British Ordovician Rocks: Wales, Shropshire, Cumberland and Westmoreland, Scotland, Ireland-D. Some European Areas: France, Spain and Portugal, Belgium, Bohemia, Scandinavia, Russia-E. Conditions of FormationReferences

\section{CHAPTER VII}

\section{THE SILURIAN SYSTEM}

A. Nomenclature and Divisions-B. Life of the Period-C. British Silurian Rocks: Typical Silurian Area, Wales, Westmoreland, South of Scotland, Ireland-D. Continental Equivalents: Scandinavia, Russia, Bohemia, Germany, Belgium, France, Pyrenees, Spain and Portugal-E. Conditions of Deposition-References . . . . . .

\section{CHAPTER VIII}

\section{DEVONIAN AND OLD RED SANDSTONE SYSTEM}

General Classification-I. The Devonian Facies-A. The Marine Fauna-B. British Devonian Rocks: Devon and Cornwall, The South of Ireland-C. Devonian of the Continent : France, Spain, Tha Ardennes, Germany, Bohemia, Poland and Russia -II. The Old Red Sandstone Facies-A. Flora and FaunaB. Stratigraphy of the Old Red Sandstone: Wales, Scotland, North of Ireland, Norway, Arctic Regions-C. Geography and History of the Period-References 


\section{CHAPTER $1 \mathrm{X}$}

\section{THE CARBONIFEROUS SISTEM}

\section{The Aronian Series}

A. Life of the Period-B. British Avonian Strata: Bristol amd South Wales, North Wales, Stafford and Derby, South Lancashire and Yorkshire, North Lancashire and Viestmore. land, Northumberland and Berwick, Scotland, Ireland, Decon and Cornwall-C. Continental Representatives: F'rance amb Belgium, Germany, South of France, Pyrences, and Spain, Iinssia-D. Conditions of Deposition-References

\section{CHAPTER X}

\section{THE CARBOXIFEROUS SYSTES (continued)}

\section{Westphalian Series}

A. Subdivisions and General Relations-B. Life of the PeriodC. Westphalian Series in Britain: South Pennine and Midland Arca, Cumberland and. Northumberland, Scollanel, Ireland, South Wales and Bristol Area, Devon and Cornurall -D. Continental Representatives : W'estphalia, Liclyium and France, Sarrebruck Area, Silesia, Moratia and Poland, Russia, Mediterrancan liegion . . . . . .

\section{The Stephanian Series}

A. The Stephanian Facies $-B$. The Uralian Facies - C. The Formation of Coal-seams-Referenees . . . . .

\section{CHAPTER XI \\ THE PERMIAN STSTEM}

A. Nomenelature and Subdivisions - B. Life of the Periud -C. British Permian Rocks : Midland Area, Devon and Somersed. North-castern Area, North-uestern Area and Ireland, Scollawd -D. Continental Permian Strata: France, Germuny liussia -E. History of the Period-References . . . . 


\section{CHAPTER XII}

THE TRIASSIC SYSTEM

A. Nomenclature and Classification-B. Life of the Period: Marine Fauna, Lacustrine Fauna-C. The Trias in Britain: Bunter Series, Keuper Series-D. The Trias in Europe: Germany, Alpine Region, France-E. The History of the European Trias-References . . . . . . .

\section{CHAPTER, XIII}

THE JURASSIC SYSTEM

A. Nomenclature and Division-B. Life of the Period . . 382

\section{The Lias or Lower Jurassic Series}

A. The British Lias: Subdivisions, Fauna, Stratigraphy: Southwest Province, Midland Counties, Yorkshire, Cumberland, Ireland and Scotland-B. Continental Liassic Strata: France, Gernany, Sweden, Alpine Rcgion, Hungary . . . .

\section{Middle Jurassic Series}

A. Stages and Zones-B. Life of the Period-C. Middle Jurassic of England: Inferior Oolite (Bajocian), Bath Oolites (Bathonian) - D. Middle Jurassic of Scotland - E. Continental Equivalents: France, Germany, Alpine Fucies . . .

\section{Upper Jurassic Series}

A. Subdivision and Nomenclature-B. Life of the Period-C. Upper Jurassic of England : Oxford Clay, Corallian, Kimeridge Clay, Portland Beds, Purbeck Beds-D. Upper Jurassic of Scotland-E. Continental Equivalents : France, Germany, Alpine Facies, Russian Facies-History of the Jurassic Period

\section{CHAPTER XIV \\ THE CRETACEOUS SYSTEM}

A. Nomenclaturc and Subdivisions-B. Life of the Period . . 


\section{Lower Crelaceous Series}

A. Lower Cretaceous Life. B. British Representatives: South of PAUS Binglund, Midland District, Vorthern District, Scolland-C. Continental Representatives: Provence, The Jura, Ciermany, liussin .

\section{Upper Cretaceous Series}

A. Stages and Zones-B. Characteristic Fossils-C. The Upper Cretaceous of Britain: England, Ircland, "nel Scollaml-D. Continental Representatives: Northern France, Denmark and Sweden, The Mcditerranean Region, Germany, Boltemia and Silesia, Russia-E. The History of the Period-References .

\section{CHAPTER XV}

\section{THE PALAOGENE STSTEM}

\section{The Eocene Series}

A. Life of the Period-B. British Eocene Deposits-C. Kegion of Voleanic Activity-D. Continental Equivalents: Belyium, The Paris Basin, Southern Europe

\section{The Oligocene Series}

A. Nomenelature and Divisions-B. Life of the Period-C. The English Series-D. Continental Representatives: Belyium, Germany, Switzerlaud, The Paris Basin, Central Fronce, Italy and Dalmatia . . . . . . . .

\section{CHAPTER XVI \\ THE SEOGENE SYSTEM \\ I. The Miocene Series}

A. Nomenclature and Divisions-B. Life of the Period-C. The Miocene in England-D. Continental Miocene: France, Switzcrlanul, Austria, Ituly, Belgium and Germany-E. History of the Miocene Period 


\section{The Pliocene Series}

A. Subdivisions and Nomenclature-B. Life of the Period-C. PACE

British Pliocene Deposits-D. Continental Pliocene Deposits : Belgium and Holland, Franee, Italy, Austria and the Balkans, Germany-E. History of the Pliocene Period-References

\section{CHAPTER XVII}

\section{THE PLEISTOCENE SERIES}

A. General Considerations-B. Glaciation and Glacial Deposits -C. Glacial Deposits of Britain: Central and Northern Seotland, South of Sentland and North of England, Yorkshire and Lincolnshire, East Anglia, The Midland Area, Wales and the West of England, Ireland-D. The Glacial Deposits of Europe-E. Non-Glacial Deposits : Classification and Fauna, British Deposits, Continental Deposits-F. Some Phases of Pleistoccne Geography-References 


\section{CHAPTER I}

\section{THE SUCCESSION OF STRATIFIED IROCKS}

Scope of the Subject.-In some manuals of Geology this branch of the subject is called Stratigraphical Geology, because it chiefly consists in the description of the great stratified series of rocks which make up the mass of the earth's crust. It is sometimes called historical geology because it should comprise not only a description of the varions rocks which were formed during ench period of the world's history, but also some description of the fossils found in each formation, and some account of the physical conditions under which the rocks thenselves were deposited, with a notice of the changes in the relative position of land and sea which took place from tine to time; all this should be made as complete as the imperfection of the geological documents will allow.

In brief, historical geology should gather up the knowledge acquired in all the other departments of the science, and should apply it to the elncidation of the history of the earth, or of a portion of the earth, from the earliest time of which any records exist down to the time of human history.

At present there are only a few limited areas of the earth's surface about which we have anything like a full stratigraphical knowledge, and much remains to be learnt even in the areas about which we know most. Historical geology, therefore, is yet in its infancy; bnt enough is now known of the stratigraphical geology of Europe to make it possible to give an outline of its geological history, and American geologists are rapidly making it possible to do the same for North America.

The Succession of Stratifled Rocks-The general principles on which stratigraphical geology is founded are easily understood, and the manner in which the order and succession of rock-groups is established will now be briefiy explained. The mere succession of strata in any district or country, however, is 
one thing, and the grouping of such strata into larger systems, representing definite geological periods, is another thing, and one which requires consideration from several points of view. A subsequent chapter, therefore, will be devoted to a discussion of the principles upon which divisional lines may be drawn in any established succession of rock-groups.

The two principal tests by which the relative age of different strata is determined are-(1), Superposition ; (2), Fossil contents.

The conclusions to be drawn from the superposition of strata are explained in most text-books of physical geology, and the law of vertical succession which forms the basis of the whole fabric of historical geology may be stated as follows:- "In any succession of beds each one represents the conditions which prevailed over a certain area for a certain length of time, the lowest is the oldest, the uppermost is the newest, and the relative age of the others is indicated by their relative position." If the strata are inclined, the right order is ascertained by making a geological survey of the district, and constructing a section at right angles to the general strike of the beds.

Again, by tracing any one set of strata horizontally along their strike from one part of a district to another, where perhaps there are other rocks of a different kind, we obtain a datum of reference by which to determine whether the rocks in the second area are newer or older than those in the first.

So long as there is pliysical and geological continuity between the different portions of a district, i.e. so long as some one member of a conformable series of strata can be followed continuously, such a survey generally affords sufficient data for ascertaining the relative position of the rocks which occur in the district, and for constructing a table of their vertical succession. But when either geographical or geological continuity is interrupted-that is, when a district or country is separated from others of like structure either by the sea or by tracts of totally different rocks - then we must begin all over again, and construct an independent table of strata for the new district. For example, Wales is a district to all parts of which one system of classification and nomenclature can be applied. Similar groups of rocks occur in Ireland on the one hand, and in Cumberland on the other; but Wales is physically separated from Ireland by the Irish Sea, and geologically separated from Cumberland by the Triassic plains of Cheshire and Lancashire; hence the same system of nomenclature could not be used in the other districts, the vertical succession had to be determined independently, and local names given to the different subdivisions in each district before they could be in any way compared with one another. 
But, it may be asked, when two such districts have been independently investigated, how are we to correlate the two tables of strata, and ascertain which rocks or rock-groups were approximately contemporancous? It is here that a knowledge of fonils (Palrontology) comes to our aid, and enables us to identify rocks by their fossil contents, so that strata in different districts and of different lithological characters may be inchuded in the same natural group or system, bccause they contain the same or closely similar species of fossils. This was the principle discovered and applied at the beginning of last century by Dr. William Smith, who is often called the Father of British Geology, and who was certainly the founder of that branch of the science which is the subject of the present volume.

The book in which Smith recorded his discovery of the stratigraphical usc of fossils was entitled Strata identified by Organised Fossils, and was published in 1816. Hc had previously madc out the succession of the strata which occur near Bath, and bad observed that each well-marked group of beds contained a special assemblage of fossils. As his acquaintance with Englisls rocks became larger he noticed that there was a similar succession clsewhere, and thus (in the words of his nephew and biographer") "he inferred that each of the separatc pcriods occupied in the formation of the strata was accompanied by a peculiar series of the forms of organic life, that these forms characterised those periods, and that the different strata could be identified in distant localities and otherwise doubtrnl cases by peculiar embedded organic remains."

The experience of subsequent observers confirmed and established this inference, which has become a guiding principle in stratigraphical geology. Further rescarch, moreover, has brought out the more definite conclusion that thcre has been a continuous succession of life-forms, that species and geuera and families, and even whole orders of bcings, have comc into existence, have flonrished, and have then gradually dicd out, ncver to recur. It is this nonrecurrence of species which gives a special value to fossils as a test of age and as a means of correlation. The same kind of rock has been formed again and again during the history of the world, but when once a species has died out it has never appeared again.

It must not be supposed, lowever, that the stratigraphical succession of rocks presents us with a complete record of the history of the earth, or that it will evcr supply us with examples of all the species which have lived upon the earth's surface On the contrary, the records preserved to ns are very incomplete, and many pages are wanting in every chapter of the great volume, so

1 Menoirs of William Smith, by John Phillips, F.R.S., 184 . 
that historical geology cannot be defined as a complete History of the Earth; it would be more correctly described as Scenes from the History of the Earth.

Nomenclature of Rock-groups.-As soon as it was recognised that the rocks which compose the earth's crust were not a mere congeries of rock-masses without order or sequence, but that when properly interpreted they arranged themselves in an orderly succession of formations, then it was. seen to be necessary that names should be given to all parts of this wonderful succession of stratified deposits.

The history which can be read from the "records of the rocks" is a very long one, although, as has already been stated, it is by no means a complete history. Every natural region of the earth's surface has its own geological history, but the same great periods of time can be recognised in all. Geological history, like human history, has its early or pristine times, its medirval times, and its later or more modern times; it may perhaps be said to consist of several volumes, and of course each of these volumes consists of several chapters dealing with so many successive periods.

Stratigraphical nomenclature is not very satisfactory, for it has been gradually developed in a synthetic manner, and is not the consistent and harmonious arrangement which it might have been had the older geologists possessed our present knowledge of the rocks. In early days the greater rock-groups were generally called formations; thiss we read of the Old Red Sandstone formation, the New Red Sandstone formation, the Carboniferous formation, and the Chalk formation. Afterwards, as a knowledge of their fossil contents increased, the relative time-values of these formations were better understood, and some of them were united with others to form systems, but the number of such systems was not fixed, nor did any definite idea exist as to what entitled a series of rocks to rank as a system. There is still some difference of opinion on this point, but doubtless agreement will ultimately be attained.

It was also early perceived that the older formations differed very greatiy from the later deposits both in mineral characters and in fossil contents. It was noticed that the oldest rocks were generally crystalline schists, that the next oldest were more or less altered and indurated, while the later were often soft and clearly stratified, and the most recent were usually loose and unconsolidated. Hence Werner in Germany used names which may be translated as equivalent to primitive, transition, stratified, and alluvial rocks, and the French introduced the more convenient terms Primary, Secondary, and Tertiary divisions.

It was supposed that the rocks belonging to these eras of time 
differed essentially in their original nature and uode of formation. Subsequent investigation proved this idea to be an error, and Professor Phillips consequently proposed another set of namea based on palreontological facts, namely, Palecozoic, Mesoroic, and Cenozoic, signifying respectively times of ancient, middle, and recent life. The two former of these have been very generally adopted, but Tertiary is still preferred to Cænozoic, and there is no reason now why its correlatives, Primary and Secondary, should not be employed as time-words, instead of the more cumbrous Palieozoic and Mesozoic.

Professor E. Forbes thought that the faunas of the Secondary and Tertiary had so great an affinity that the whole succession was more naturally divisible into two eras, which he termed Palscozoic and Neozoic. No doubt this is strictly correct, but the triple division has been found very convenient in Europe, and is more generally adopted.

Since these terms were proposed, however, a series of stratified rocks has been discovered below those which were called Primary or Palæozoic, and for these several names have been proposed. Of these Archrean is the best, for pre-Cambrian is too indefinite, and the others, Azoic and Eozoic, are founded on the respective assumptions (1) that they contain no organic remains, (2) that they contain the relies of the first dawn of life in the world. Such sinall traces of life as have been discovered in these rocks do not suggest anything very different from that of Palxozoic time, but they may for the present be termed Eozoic.

In the following table of systems the oldest is placed at the bottom and the newest at the top to indicate their natural superposition and order in the chronological scale.

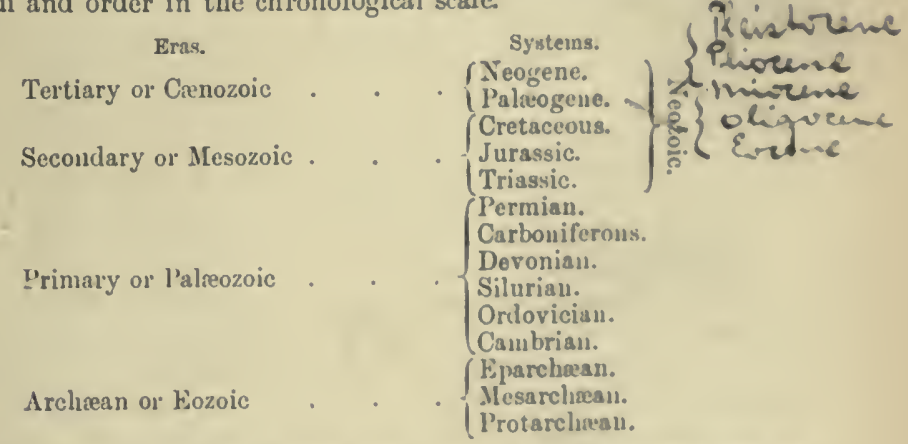

Nomenclature.-With regard to the naucs of the syztems in the above table some explanation is required. Such names as 
Carboniferous and Cretaceous are used in a far wider sense than their mere lithological signification. These names were originally given to certain British formations, in which the most conspicuous elements were respectively beds of coal and chalk; but they have since acquired a chronological meaning, and are used as systematic names for the periods of time during which the rocks were formed. They have also been adopted in other countries for rock-groups, which occupy the same relative place in the geological succession.

The Cretaceous Systen then includes, not only the Chalk, but also the underlying beds of sand and clay, which contain a similar assemblage of genera and species. Moreover, the Cretaceous System includes not only the Chalk and its associated beds in Europe, but all the rocks which were formed during the same period of the earth's history. Elsewhere, therefore, as in North America, the system may consist of sandstones, shales, and coal-seams without a bed of real chalk in it.

So the Carboniferous System means that system of strata of which the British Coal-measures form an integral part, but which includes several other rock-groups, all united by a community of fossils. It is these fossils, and not the occurrence of coal-seams, which are the criterion of the so-called Carboniferous period, for, as above mentioned, in America there are coals of Cretaceous age. In the same way, when we speak of the Carboniferous Limestone Series, we do not mean a group which everywhere consists of linestone, but one to which the great Carboniferous limestone belongs; when traced nortliward through England, this limestone is found to split up into separate beds, which finally become subordinate to thick masses of sandstone and shale.

The Devonian System is now considered to include the great series of rocks which are still called the Old Red Sandstone. This is a particularly awkward and unsatisfactory name for an important group of rocks. It was called old because it lay beneath the Carboniferous rocks, above which came another group of similar red sandstones. The latter were formerly termed New Red Sandstone, but this has been divided into two distinct systems which have received appropriate names, and it is to be hoped that "Old Red Sandstone" also will soon be replaced by a better name. As Jukes observed fifty years ago, ${ }^{1}$ " it is avowedly a provisional designation, just exactly as the names of all the great gromps of stratified rocks are provisional. They are temporary names adopted for present purposes, and have grown into use, and will continue to be used until they are superseded by more appropriate terms, which increasing knowledge cnly can show to be more appropriate."

1 Manual of qeology, second edition, 1862, p. 429. 
In many respects those names which have a geographical or historical origin are the most satisfactory-names taken from thowe of towns, rivers, mountain ranges, provinces, or the ancient races which inhabited such provinces; as Jurassic (from the Jura range), Devonian (from the county of Devon), Cambrian (from the Roman name of North Wales), Silurian (from the tribe of the Silures). These will probably remain as permanent names for systems to which they are applied.

Deflnition and Delimitation of Systems.- The number of systems into which the geological series should be divided, and the horizons at which the planes of separation are placed, are points requiring some consideration, because they involve certain principles of classification. The divisional lines are generally drawn where natural breaks occur, either in the sequence of the strata themselves, or in the succession of fossil species which they contain. Such breaks are therefore of two kinds, (1) Stratigraphical, (2) Palacontological.

1. Stratigraphical Breaks. - The nature of stratigraphical breaks or unconformities is explained in all handbooks of pliysical geology, and in the present connection we have to deal only with their relative importance and value in classification. The most complete and satisfactory measure of any unconformity is the thickness of strata which were deposited in other areas during the time represented by the gap between the two unconformable formations.

It is not every unconformity which is of sufficient importance to form a plane of division between two systems. Thus in Wales there is a great local unconformity within the Silnrian System, but this does not exist in other areas. Again, in Northampton and Jincolnshire there is unconformity between two portions of the Jurassic System, while no such break exists either in the south of England or in Yorkshire.

A break which is represented elsewhere by several thousand feet of rock implies the lapse of a considerable period, and being always accompanied by a great change in the fossils, might be taken as a line of division between two systems. But if systems were to be rigidly limited by physical unconformities, and defined as a series of beds formed during a complete oscillation of downward and upward movement, the classification of the rocks in one area will break down when applied to those of other districts, because the gaps will occur at different horizons in different areas. Thus in Britain alone three different classifications at least would be required for the Primary rocks, as the following columns will show, a $\longrightarrow$ being taken to mean a break or unconformity. 
South Wales. Carboniferous. Upper O.R.S. Middle O.R.S. Lower O.R.S. Silurian.

Ordovician.

Cambrian.
North Wales. Carboniferous.

Silurian.

Ordovician.

Cambrian.
Scotland. Carboniferous. Upper O.R.S.

Lower O.R.S. Silurian.

Ordovician.

Cambrian.

Thus, if we adopted the arrangement warranted by the stratigraphical breaks which occur in South Wales, we should have two separate systems, and two only, for there is a general conformity between the Cambrian and Ordovician, and from the Silurian to the Carboniferous.

In North Wales, however, the break between the Ordovician and Silurian is much less marked, while there is certainly one above the Cambrian, and there is an entire absence of Old Red Sandstone, so that we should make three separate systems. Again if we pass to the south of Scotland we find complete conformity between the Ordovician and Silurian, and no marked break between the latter and the Old Red Sandstone, but a great one between the two divisions of this Red Sandstone formation. Rence we might also make three systems in Scotland, but they would be quite different from those in Wales and would be of very unequal value.

As in this case, so also in others, a classification founded on physical breaks may be conveniently used for a limited district, and until further knowledge is acquired; but the breaks in the succession are certain to be filled up elsewhere by transitional beds, and as these may be of systematic value, we must always be prepared for the possible intercalation of another system between any two groups that are divided by a decided unconformity. ${ }^{1}$

In brief, it must be admitted that unconformities are geological accidents, and if our classification and nomenclature are to be applicable to any large section of the earth's crust, they must be based, not on stratigraphical but on palæontological facts. The Ordovician, Devonian, and Jurassic are systems so established; and, in process of time, as our knowledge becomes more and more complete, it is probable that the number of systems will be finally determined in the same manner. They will always be more or less arbitrary divisions, since it will be difficult to say what number of

I The student can read with advantage Professor Lapworth's article on the "Classification of the Lower Palæozoic Rocks" in the Geological Magazine, Dec. 2, vol. vi. p. 1 (1879). 
peculiar genera would entitle a series of beds to the rank of a system; but a general agreement will doubtless be reached in tince Meauwhile the student will do well to regard our present clasifica. tion as provisional, and to remember that, though divixional lines must be drawn somewhere, passage beds and transition groups are of frequent occurrence in nature.

2. Palcontological Evidence.-But although we inust rely mainly on palieontological evidence in separating one system from another, it must not be supposed that every sudden change of fauna is to be taken as introducing a new systen, or that such a change always indicates a period of non-deposition, and therefore a greater or less break in the succession; unless this coincides with a physical break, the mere fact of such a change does not necessarily prove any great lapse of time. The change may be caused in several ways, either by rapid depression, by a sudden inmigration of new forms, or by elevation with or without continuous deposition.

It is conceivable, for instance, that rapid depression, causing a considerable increase in the depth of the water, and removing the area farther away from the coast line, would produce what has been termed a palæontological break in a comparatively short period of time, and without any discontinuity of deposit. The beds below a certain plane would embed the remains of a shore fauna, while those ahove it would contain a deep-water assemblage, which might be very different even if the deposits were of similar lithological cliaracter. Depression, by the submergence of barriers, may also cause much more extensive changes; we have only to consider what would result from the submergence of certain existent isthmuses, such as those of Panama and Suez, to realise what nust have repeatedly happened in the past. The balance of life in both provinces would be altogether disturbed and upset, resulting in the extinction of some forms, the inter-migration of others, and the development of some new varieties and species.

Moreover, an alteration in the physical geography of one area may indirectly, but very greatly, affect the clinste and life of another distant area; thus, if the whole isthmus of Panana were now to be submerged, the Gulf Stream would probably be direrted from its present course, the result of which would be an immediate refrigeration of the British climate and a consequent immigration of Boreal and Arctic species into the Celtic province. Again, if the Gulf Stream remained, but the opening into the Arctic ocean were closed, the British climate would be aneliomted, 13oreal forms would disappear, and a more southern ascemblage would occupy the area.

Elevation of the sea-botton will produce similar direct changes 
to those caused by depression; a deep-sea area, where deposition has been very slow, may by elevation be brought nearer to a coast line, and beds containing a deep-sea fauna may be succeeded immediately by others more rapidly accumulated, and embedding a shallow-water assemblage. The change of life in such a case would be great, but the lapse of time would not be correspondingly long. If, however, elevation is continued till the area is raised above the sea-level, and remains for a time as a land surface, then a plane of erosion will be formed, and the cliange of fauna will be accompanied by stratigraphical discontinuity. The break then niay be very considerable, but it may or may not coincide with the epoch of change from one fauna to another in an adjacent area of subsidence.

Notwithstanding this, it is true that the continuity of deposition may outlast the duration of a certain fauna; and it may become necessary to draw a line between two faunas of systematic importance in the midst of a conformable series of strata; in sucl a case it will naturally be drawn where the greatest palæontological break occurs. In other words, a life-assemblage, characteristic of one period in the world's history, may continue to inllabit any area until such changes occur as to cause the introduction of an assemblage which has been gradually developed outside that area, and these changes may take place witl or without interruption of deposition in that particular area.

From the preceding remarks it will be seen that it is impossible to define a system as a series of deposits formed during one complete downward and upward movement or oscillation of some one part of the earth's surface. Moreover, if we could so define a system, the systems of one region could not be coeval with those of other regions. Systems must therefore liave a palæontological value, and a system may perhaps be defined as a consecutive series of strata formed during the prevalence of certain generic forms of life throughout a large part of the earth's surface.

The student must be prepared to find that systems founded on the differences in successive faunas will not include anything like equal thicknesses of rock. If, as appears most probable, the differentiation of species and the development of higher forms has progressed in a constantly increasing ratio, it is clear that the timevalue of systems based on such changes will become less and less as we approach modern times. It is certainly a fact that the same forms of life extend through a much greater thickness of rock in the earlier than in later geological times; and there is no reason for supposing that the production of rocks went on more rapidly (at any rate during later Palæozoic periods) than at the present time; limestones must always have been of slow and 
grudual growth, and yet the persistence of species through the Carboniferons Limestone Series is truly remarkable, while the limestones of the Jurassic and Cretaceons periods, though of far less thickness, are divisible into numerous paliwontological zones or belts, each having many species which do not appear in the next. The changes in the forms of life inhabiting any marine area being thus more rapid in later geological times, an equal amount of change would naturally be accomplished in less time, and consequently, if systems are to be ineasured by palreontological difference, the newer systems must include less thicknesses of rock.

But even when allowance is made for this, it is impossible to regard the divisions of Tertiary time introduced by Sir Ch. Lyell as being of the same relative importance as the systems of older date with which they are usually ranked. Even the Eocene, as understood by Lyell, was hardly of the same palsontological value as Cretaceous or Silurian, while the Miocene and Pliocene are still less entitled to rank with such systems. The Oligocene has been created at the expense of Lyell's Eocene, but it is now admitted that these two together form a group which may rank as a system, while the remaining three groups, Miocene, Pliocene, and Pleistocene, may be regarded as making up another system of deposits. For these two systems M. Hohnes has proposed the names Palcogene and Neogene, and though they are not altogether satisfactory the names have been largely accepted on the European continent.

Systems are divided into sections or formations, which are usually denominated as Upper, Middle, and Lower, unless any special names have been proposed for then. These sections are again divided into stages or groups, to which local names are generally given, and these again are often divisible into zones.

The following is a tabular view of the twelve fossiliferous systems which overlie the Archæan rocks, together with their primary divisions, according to the nomenclature which will be adopted in this volume, and is applicable to the greater part of Europe. This list of systems is merely a table from which no iden of relative thickness can be obtained, but the adjoining colunnuar view is drawn to scale and is intended to give some idea of the relative thicknesses of these systems. 
Systems.

Primary Divisions.

Relative Thickness.

\begin{tabular}{|c|c|c|}
\hline \multirow{3}{*}{ Neogene } & \multirow{3}{*}{$\begin{array}{l}\text { Pleistocene. } \\
\text { Pliocene. } \\
\text { Miocene. }\end{array}$} & MEOQENE \\
\hline & & PALTOQENE \\
\hline & & CRETACEOUS \\
\hline Palieogene & $\left\{\begin{array}{l}\text { Oligocene. } \\
\text { Eocene. }\end{array}\right.$ & JURASSIC \\
\hline \multirow[t]{2}{*}{ Cretaceous } & \multirow{4}{*}{$\begin{array}{l}\left\{\begin{array}{l}\text { Upper. } \\
\text { Lower. }\end{array}\right. \\
\left\{\begin{array}{l}\text { Upper (White Jura). } \\
\text { Middle (Brown Jura). } \\
\text { Lower (Lias). }\end{array}\right.\end{array}$} & 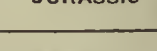 \\
\hline & & TRIASSIC \\
\hline \multirow{2}{*}{ JURASSIC . } & & PEAMIAN \\
\hline & & \multirow{3}{*}{$\begin{array}{c}\text { CARBO- } \\
\text { NIFEROUS }\end{array}$} \\
\hline Triassic . & $\left\{\begin{array}{l}\text { Keuper. } \\
\text { Muschelkalk. } \\
\text { Bunter. }\end{array}\right.$ & \\
\hline Permila . & $\left\{\begin{array}{l}\text { Magnesian Limestone (Zechstein). } \\
\text { Red Sandstone (Rothliegende). }\end{array}\right.$ & \\
\hline Carbonifirous & $\left\{\begin{array}{l}\text { Stephanian. } \\
\text { Westphalian (Coal-Measures). } \\
\text { Avonian (Carboniferous Limestone). }\end{array}\right.$ & DEVONIAN \\
\hline Devonian. & $\left\{\begin{array}{l}\text { Upper. } \\
\text { Middle. } \\
\text { Lower. }\end{array}\right.$ & SILUAIAN \\
\hline SILURIAN & $\left\{\begin{array}{l}\text { Downtonian or Ludlow Beds. } \\
\text { Salopian or Wenlock Beds. } \\
\text { Valentian=Llandovery Beds. }\end{array}\right.$ & ORDOVICIAN \\
\hline ORDOVICIAN & $\left\{\begin{array}{l}\text { Bala Series. } \\
\text { Llandilo Series. } \\
\text { Arenig Series. }\end{array}\right.$ & \\
\hline CAMBRIAN & $\left\{\begin{array}{l}\text { Upper (Olenian). } \\
\text { Middle (Paradoxidian). } \\
\text { Lower (Olenellian). }\end{array}\right.$ & CAMBRIAN \\
\hline
\end{tabular}

The actual thickness of any system of strata varies of course in different parts of the same country, and for the construction of the diagram the full average thickness of each stage has been taken from English districts where the whole system is well developed. The diagram does not, therefore, show the maximum thickness of any system. Moreover, in other parts of the world the Permian and Triassic Systems are represented by marine deposits which reach a thickness of 9000 to 10,000 feet. 
Further, the Neozoic division is much thicker on the European continent than it is in England, for in the Alpe thick deposits come in between the Triassic and Jurassic Systems, and the Neogene Series is of much greater thickness in Sonthern Europe than it is in the north. 


\section{CHAPTER II}

\section{STRATIGRAPHICAL PALEONTOLOGY}

IT was stated on p. 3 that ever since the surface of the earth became a fit habitation for plants and animal life there has been a succession of life-forms, and that remains of these faunas are found as fossils in the stratified rocks. It was also stated that this succession was incomplete owing to gaps in the series. The causes which have produced this imperfection of the record may now be indicated, so that the reader may understand what kinds of creatures are likely to occur as fossils and what are not. It will also be shown that, where the succession is continuous and fossils are fairly abundant, they can be used for the establishment of smaller subdivisions of the series and for the comparison of such subdivisions in different areas. Finally a few words on the distribution of species at the present day will explain some limitations in the application of palæontological evidence, and the difference between synchronism and homotaxis in correlating the rock-groups of different countries.

Origin of Species.-At the outset of this inquiry we are met by the question, What is a species? Before the publication of Darwin's book on the Origin of Species nost people regarded a species as the result of a special creation of a definite kind of plant or animal, yet all who studied either plants or animals were obliged to admit that some species displayed many varieties, and also that it was difficult to say what amount of difference should constitute a species.

Lamarck in 1801 was the first to propound the doctrine that all existing species are descended from other species, but few naturalists gave credence to his views, and it was not till 1859, when Darwin published his book, that the world became familiar with such a doctrine.

On the primary point of the appreciation of differences Darwin remarks (Origin of Species, sixth edition, p. 41), "Certainly no 
clear line of demarcation has as yet been drawn between species and sub-species-that is, the forms which in the opinion of some naturalists come very near to, but do not quite arrive at, the rank of species; or again between sub-species and well-marked varieties, or between lesser varieties and individual differences ; and a series [of specimens] impresses the mind witl 1 the ides of an actual passage." Further on he says, "Fron these remarks it will be seen that I look at the term species as one arbitrarily given, for the sake of convenience, to a set of individuals closely resembling each other, and that it does not essentially differ from the term variety, which is given to less distinct and more fluctuat. ing forms."

Darwin and Wallace developed their views about the same time, and both accounted for the existence of so many varieties, species, and genera of organisms by indicating the various causes and conditions which influence all kinds of organisms and tend to modify their habits, forms, and members. They have shown how the constant struggle for existence and the frequent changes of environment may have developed or have increased a tendency to variation, and how this variation results in the formation of varieties and species. Natural selection (or the selective action of natural processes) results also in the extinction of unany forms and in the survival of a few-namely, of those few which are the inost capable of accommodating themselves to the more rigorous and changed conditions of existence. This is called the "survival of the fittest." It is by the infinite repetition of these proceses that species which are now widely different may have been evolved from a coinmon ancestor.

Another consequence of natural selection is the preservation of those varieties and species which chance to possess peculiarities that are useful to them in the struggle for existence. Thus as Darwin says (op. cit. p. 103), "it leads to the improvement of each creature in relation to its organic and inorganic conditions of life, and consequently in most cases to what must be regarded as an advance in organisation." In other words, it leads to the evolution of ligher and higher forms of life.

Now if the descendants of varieties may become different species, and if the descendants of different species may in course of time become so differentiated that most naturalists would rank them as different genera, and if this process has been going on during the whole of geological time, since the world first became fit to support life; then we might expect that the successive assemblages of fossils preserved for us in the rocks of the earth's crust would furnish us with a long succession of links between one 
species and another, and would connect the generic forms of the present with those which have long been extinct. Unfortunately, however, though many such links have been found, and though more come to light every year, so that the genealogy of many genera can be satisfactorily made out, yet there are reasons why we can never hope to find all the links in the chain.

Imperfection of the Geological Record.-That the truth of Darwin's theory of the origin of species cannot at once be proved, and the complete genealogy of modern genera be constructed from the records of the past, is due to the imperfection of that very geological record which would otherwise contain the obvious proof or refutation of the hypothesis. This imperfection results from two causes, (1) the conditions which limit the entombment and preservation of organic remains, (2) the frequent erosion and destruction of the deposits in which they have been buried.

1. Conditions of Entombment. - If we consider the manner in which deposits are now taking place, we shall perceive that the preservation of many kinds of organic remains in these deposits is likely to be an exceptional and accidental occurrence. Deposition of sediment is not an uninterrupted process likely to ensure the conservation of specimens of the greater number of plants and animals living at any one time, but is, on the contrary, so discontinuous that only a small proportion of any fauna or flora would be entombed in such a way as to be permanently preserved, either in terrestrial or marine deposits.

On land, generations of animals may die and moulder away, shells, bones, and all, without any remains being transported to places where deposits are accumulating. Mr. F. C. Selous remarks that in South Africa " no organic matter lasts very long when exposed to the weather, and even the skull and leg bones of an elephant would, I think, crumble to dust and absolutely disappear in less than fifteen years from the date of the animal's deatl." 1 In some countries where the climate is very dry they may last longer, but still ultimately decay and crumble into dust.

Of the larger land animals a few are occasionally buried in bogs or drowned in lakes and rivers, and still fewer are carried down by rivers to the sea. The animals which live in fresh water and the leaves of plants stand a better chance of preservation in those parts of the country where lacustrine and fluviatile deposits are being formed; but these purely freshwater beds occupy but small areas, and are particularly liable to subsequent destruction, so that as a rule our kwowledge of the terrestrial and fluviatile fauna of any period is derived from the specimens which were carried down

${ }^{1}$ Sport and Travel, by F. C. Selons, 1900, p. 156. 
the streams during floods, and were buried in the estuarine deposits at the mouths of large river's.

The creatures which inhabit the sea have a much letter clance of being preserved as fossils, since deposity of one kind or another are constantly being formed over large areas of the sea-bottom, especially where sulusidence is in progress. Yet even among marine forms of life there are inany which would only rarely be entombed; those animals, for instance, which live on rocky shores and in clear water would not be preserved except where deposits of limestone were in process of formation. The majority of the crentures embedded would be those which lived on sandy and muddy bottoms, together with some of the free-swimming forms which moved through the water above.

Lastly, of the creatures so embedded only a small proportion would ultimately remain; those, namely, which possessed hard structures capable of fossilisation after the softer parts had decayed and disappeared. The following table shows at a glance which kinds of aninals, out of all those which live in the sea, would be likely to leave memorials behind them and which would perish without leaving any trace of their existence.

Sub-kingdoms. Groups with Hari Structures.

Protozoa.

Porifera.

Calenterata.

Eclinoderma.

Vermes.

Arthropoda.

Molluscoida.

Mollusca.

Vertcbrata.
fForaminifera.

Radiolaria.

Silicispongix.

$\{$ Calcispongia.

Sertularida.

Hydrocorallina.

Graptolitoida.

Stromstoporoidea.

Some Alcyonaria.

All classes.

STubicola and the loorny

$\{$ jaws of Nereids.

All classes.

$\{$ Bryozoa.

A Brachiopoda.

Lamellibranchia.

Scaphopoda.

Gastropoda

Cephalopoda

'Teeth, bones, and

scales of all kinds.
Madreporaria.
Perishable Group.

Flagellata.

Infusoria.

Myxosplougia.

Ceratospongia.

Hydroida (except

Sertularida).

Siphonophora.

Díscophora.

Actiniaria.

Alcyonaria (some).

Ctenophora.

None.

SHirudinea.

OOligochæeta. except Nudibranchiata.

except some Cuttle-fish.

Tunicata.

But although all the classes of creatures entered in the second column possess hard parts which are capable of preservation, it does not follow that these are always preserved. Their conversion 
into fossils depends partly on the solidity and character of the substance of which the hard parts are composed, and partly on the rapidity with which the remains are covered up and embedded in sediment. Lastly, their final preservation as fossils depends upon the conditions to which the embedding rock is subsequently exposed, upon its conservation or destruction.

The remains of those creatures which live in deep water or over deep water, such as many Foraminifera, Radiolaria, siliceous sponges, and pteropods, have such delicate tests and spicules that they often fall to pieces and become nere debris before they can be embedded in sediment; for in deep water the accumulation of sediment is usually a very slow process. The thin shells of the Radiolaria and the Pteropoda are especially liable to rapid disintegration, and consequently they are rare as fossils, although they are known to have existed from very early times.

2. Subsequent Removal of Organic Remains.-The proportion of those remains which would otherwise be preserved is further diminished by the subsequent destruction of some of them by the action of percolating water. All water which percolates downward from terrestrial surfaces contains carbonic acid, and such carbonated water attacks and dissolves carbonate of lime, and also that form of silica which enters into organic structures. Hence all such embedded remains are liable to solution and removal under certain circumstances.

So long as the deposit containing embedded organisms remains below the sea in which it was formed, it is probable that the changes which take place are slight and gradual. It is when the fossiliferous deposit is raised above the level of the sea and is added to the dry land that changes are apt to take place. Even then, if the rock has formed part of a thick series deposited during a long period of subsidence, and has remained buried beneath others for some time before the whole mass is raised to form land, most of the fossils in it are likely to be preserved, for the rock becomes consolidated and remains saturated with saline water, which probably contains as much carbonate of lime as it is capable of holding in solution under such conditions. Many fossils exhibit changes of structure which have very probably been effected during upheaval and while the rock was in a water-soaked condition; thus the substance of shells is frequently converted into crystalline calcite, and in other cases the calcareous shell is replaced by chalcedonic silica.

Those parts of a formation, however, which come to form the surface portions of newly raised land, i.e. those parts which are raised above the lowest summer level of saturation, are subjected 
to the action of percolating water, with the result that many shells are dissolved, leaving only the hollows in which they lay. These hollow spaces may remain empty or they may be filled subse. quently with infiltrated mineral matter; or if disturbances take place before the final consolidation of the rock, the internal cast inay be squeezed on to the exterual impression of the shell and receive an impress of its ornamentation. In any of these cases some record of the original organisu remains, lut if the rock material is a loose sand or other very soft kind of sediment all trace of the organism may be destroyed.

With regard to the durability of the original shell much depends, on its original mineral composition. In some shells and tests the carbonate of lime consists of the variety known as calcite, while in others it has the structure of arragonite, and it is a wellascertained fact that arragonite is much less stable than calcite. It was pointed out by Mr. Sorby ${ }^{1}$ that shells composed of arragonite disappeared much faster than the calcite shells when both were exposed to carbonated waters, and he pointed out that the creatures which possess hard calcareous structures can be separated into two sets according to the nature of the calcareous substance. These two sets may be tabulated as follows:-

Calcitic Structures.

Foraminifera.

Fchinodermata.

Aunelida.

Most Bryozoa.

Brachiopoda.

Oysters and Pectens.

Crustacea.
Arragonite Structures.

Calcareous sponges.

Actinozoa (corals, etc.).

Lamellibranchia (except Oysters, Pectens, and the outer layer of Spondylus, Pinns, and Mytilus).

Gastrojoda (witl a few exceptions). Cephalopoda.

Professor P. F. Kendall has also made observations and experiments which confirm those of Mr. Sorby." He has pointed out that in the Coralline Crag of Aldeburgh some fussils remain perfect, while of others there are only casts, and that the casts are without exception of arragonite shells, while the former are calcitic structures, such as Bryozoa, Echinoderms, Serpula, Brachiopoda, and the biralve Molluscan genera, Anomia, Ostrea, Pecten, Lima, and Pinna; with the latter, however, occurred the Gastropod shell Scalaria, which he thought nust be calcitic, an inference which subsequent experiment proved to be correct.

3. Destruction of Fossiliferous Deposits. There is another set of agencies which contribute to render the geological record a very imperfect one. When any mass of marine deprosit is raised into

1 Quart. Journ. Geol. Soc. vol. xxxv. (1879), Pres. Addrese

2 Geol. Mag. 2 ind Dec. vol. x. p. 487. 
land, there is not only an absence of deposition, but there commences an actual destruction of the records previously accumulated. In the first place, as the rising deposit passes through the plane of the sea-level, it is exposed to the erosion of the waves, and if the latest deposits are not very thick, and the process of elevation is not very rapid, the probability is that only small portions will escape destruction. These portions will remain for a time as plains, marsh lands, and raised beaches; but as elevation continues, they will be brought gradually under the influence of atmospheric agencies, and exposed to continual wear and tear so long as they remain above the sea.

It follows, therefore, that only deposits of considerable thickness will survive the attacks of destructive agencies, and remain to form a permanent part of the earth's crust, but thick deposits cannot be accumulated in shallow seas, which are the most favourable to life, so long as the sea-bed remains stationary or is being elevated. Thick formations can only be accumulated in areas where constant subsidence has been in progress, or where the shore originally shelved rapidly into deep water, as ofl the coast of the Riviera. In the latter case the sediment will be rapidly accumulated, and will not contain so many or such varied forms of life; but under the former conditions, if the supply of sediment was sufficient to keep the sea shallow and to embed the organic remains, a formation rich in fossils, and thick enough, when upraised, to resist erosion, would be formed. We must, therefore, conclude with Darwin, "that nearly all our ancient formations, which are throughout the greater part of their thickness rich in fossils, have thus been formed during subsidence." 1

This conclusion that most of our great fossil-bearing formations have been deposited during subsidence has a very important bearing on the question before us, viz. whether the rocks are likely to contain the remains of an uninterrupted succession of species, or whether the record is more or less incomplete; for, as Darwin remarks :-

"During periods of elevation the area of the land and of the adjoining shoal parts of the sea will be increased, and new stations will often be formed-all circumstances favourable, as previously explained, for the formation of new varieties and species; but during such periods there will generally be a blank in the geological record. On the other hand, during subsidence the inhabited area and number of inhabitants will decrease (excepting on the shores of a continent when first broken up into an archipelago), and consequently during subsidence, though there will be much extinction, few new varieties or species will be formed;

1 Origin of Species, sixth edition, p. 273. 
and it is during these very periods of subsidence that the depositn which are richest in fossils have been accumulated." I

Succession of Faunas.-Fron the considerations above mentioned it will be seen that we cannot expect to fund all the transitional forms which, if the theory of evolution be correct, must have connected one species with another, and have linked together all the past and present species of any one genus into one long chain of life. All that we can hope to find are certain cases where so large a number of closely allied species and varieties have been preserved as to furnish $11 \mathrm{~s}$ with strong evidence of their having been links in such a chain.

There are, moreover, two well-established generalisations from palieontological facts which lead to a very sigmificant inference; these considerations are (1) that the assemblage of fossils found in any formation has a general character internediate between the assemblages above and below: and (2) that the fossils from two consecutive formations are far more closely related to each other than the fossils from two more remote formations. Commenting on these Darwin observes: ${ }^{2}$ "On the theory of descent, the full meaning of the fossil remains from closely consecutive formations being closely related, though ranked as distinct species is obvions As the accumulation of each formation has often been interrupted, we ought not to expect to find in any one, or in any two, formations all the intermediate varieties between the species which appeared at the commencement and close of these periods; but we ought to find, after intervals very long as measured by years, but only moderately long as measured geologically, closely allied forms or, as they have been called by some authors, representative species; and these assuredly we do find. We find, in short, such evidence of the slow and scarcely sensible mutations of specific forms as we have the right to expect."

In spite, therefore, of the imperfection of the record, the knowi succession of life-forms does give very great support to the theory of evolution. Every succeeding fossil assemblage contains not only a larger number and greater variety of forms, but also some which are distinctly more specialised and more advanoed in organisation. It is an acknowledged fact that many of the more ancient forms of life were what are termed "compreliensive types" i.e. types which combine the structural characters of two or more different orders or classes of creatures, which are now completely differentiated from each other. In many cases also ancient animals resemble the embryos of the more recent animals belouging to the same classes.

1 op. cit. p. 275.

2 Op. cil. sixth edition, p. 307. 
Beyond all this there can be traced a distinct and decided progress in the types of life as we ascend the geological scale. It is true that in the earliest fauna yet known we start with a number of more or less specialised invertebrate types, but the nore highly organised orders of Gastropods, Cephalopods, Crustacea, and Echinoderms do not appear till later periods; Fish are not known earlier than Silurian times; Amphibia commence in the Carboniferous; Reptiles in the Permian and Trias; Birds in the Jurassic; Mammals of low organisation in the Trias; higher Mammals, including Lemurs, appear in the Eocene, but true monkeys are not yet known from beds of greater age than the Miocene.

Zones.-It only remains to indicate how the succession of lifeforms may be utilised for the purposes of subdivision and correlation, when we have to deal with a continuous succession of deposits, and more especially with a great thickness of one kind of deposit, such as shale or limestone. During the accumulation of such a mass of sediment it would seem that small changes were continually taking place in the personnel of the fauna, new forms taking the place of old ones, some species dying out and others coming in from elsewhere; so that when the fossils are carefully collecterl from each successive bed it is found that they form assemblages of species, each extending through a certain thickness of beds and thus characterising a band or zone within the formation.

A zone, therefore, is a certain thickness of stratified material which contains a certain assemblage of fossil species, some of these species being either restricted to the band or particularly abundant in it. Moreover, it is not merely a specially fossiliferous band in a thick mass of sedinient, but is one of a succession of zones, each stage in a fossiliferous series being usually divisible into two, three, or more zones.

The following remarks on zones are quoted from the author's memoir on the Cretaceous Rocks of Britain." "By the fauna of a zone we generally mean all the fossils which have been or can be found in the beds which are recognised as belonging to the zone. But what may be termed the critical fauna of a zone is the much smaller assemblage of fossils which are either restricted to it or are specially abundant in it. One of these species is then chosen as the index of the restricted assemblage of species, and the name of this fossil is given to the zone, so that we speak of it as the zone of this fossil, e.g. the zone of Ammonites varians, or the zone of Belemnitella mucronatie

"The reader must be cautioned against becoming possessed with

1 "The Cretaceous Rocks of Britain," vol. i. p. 34, Mem. Geol. Survey. 
the idea that a zone is a set of beds characterised by the occurrence of one particular species, and that every bed which yields this index-species must belong to the zone. It un the renembered that this particular species is only one of several or mauy, and that it is this assenblage of species which is the guide to the zone.

"The value and importance of a zone depends partly on the number of restricted species and partly on the extent of country over which it can be traced. The thickness of a zone is of conrse a stratigraphical accident, depending merely on the amount of sediment deposited at any locality during the lifetime of the zonal fauna. Thus a zone may be in one area only a few feet in thickness, in another it may be 20 or 30 feet, and in a third it may expand into 200 or 300 feet.

"The limits of a zone may be definite or indefinite. Where sedimentation has been continuous and fairly rapid, the limits of the zones will naturally be indefinite; some of the characteristic species of one zone may survive into the overlying zone, and others which are characteristic of the latter may make their first appearance in the former. Thus in many cases it is impossible to say exactly where the one zone ends and the other begins, and though by careful collecting one may fix it with fair certainty in one section, one cannot be certain of taking exactly the same plane of separation in another quarry or cliff which is a few miles away from the first. Thus where a zone is complete its limits are indefinite, but the succession of zones will be the same in both places.

"Where a zone las definite limits it is generally because sedimentation ceased for a time, and in many cases because au erosive current swept away some of the sediment which hal previously been accumulated, thus destroying the continuity of the record and producing what is called a 'surface of contemporaneous erosion.' Even if the current was only strong enough to prevent the accumulation of sediment, it causes a break in the record, because for a time there is no embedment and preservation of organic remains. In this way, therefore, a zone or a sub-zone may die out when traced in a certain direction."

In some cases still smaller zonal subdivisions may be recoguised, consisting of one or two beds which are characterised by one or more peculiar species; these may be called sub-zones or hemert, but there is not necessarily a complete succession of such sub-zones, nor can they be expected to have so wide a geographical extension as zones; they are merely special horizons, aud equivalent to the niveaux of French geologists.

Synchronism and Homotaxis.-It was stated in Chapter I. that when two districts are plyysically separated from one another 
we have to rely entirely on community of fossils in comparing the rocks of the one with those of the other; and if the rocks so compared were deposited originally within the limits of the same life-province, the groups which contain similar assemblages of species may safely be regarded as contemporaneous.

To take an example, no one would liesitate to correlate the members of the Ordorician and Silurian Systems in North Wales and the Lake District by means of the fossils they contain, because there is every reason to suppose that the two districts formed part of the same province during those periods. Similarly the members of the Lower Cretaceous Series in the Isle of Wight and in the Weald may be correlated with some degree of exactitude; but the same group of beds in Lincolnshire contains such a different set of fossils that it obviously belonged to a different life-province, and it is impossible to indicate the exact equivalents of the several members of the southern series.

Again, when we come to compare districts at a still greater distance from one another-as, for instance, Wales and Bohemia, Sussex and the South of France, or England generally with North America-we find that there is certainly a general resemblance in the vertical succession of fammas which have flourished in the respective areas, i.e. the rock-series in each country can be divided into groups, which are characterised by the presence of the same genera; but the species are different, and it would be a mistake to conclude that portions of formations containing assemblages of the same genera in countries so far apart were contemporaneous in the same sense as the members of the Silurian Series in Wales and Cumberland are contemporaneous.

A group of species originating in one locality and spreading along the coasts of a continent would take a long time to travel from Europe to America even if there were continuous coast lines. Sometimes their progress would be arrested for a time, until physical or geographical changes allowed them to advance; at other times they would make their way by accommodating themselves to varying conditions and by throwing out collateral varieties. The date of their first appearance in one part of the world would be very much in advanse of their arrival in the other, so that the fact of two distant formations containing fossils of closely allied species can be no proof of their being really contemporaneous.

It is certain, however, that in every part of the world the geological sequence discloses the same general succession of lifeforms. The progress of development may have been retarded here and accelerated there, but the strccessive fossil assemblages are similar to one another, and the order in which they occur is the 
same all over the world. We never find a Carboniferous faun antedating a Silurian or Devonian famna, though we may find the first succeeding the second without the presence of the intermediate Devonian assemblage. This common onder of succession has been termed Homotaxis, and the Silurian System of Britain is spoken of as homotaxial with and equivalent to the Silurian of America; even the larger subdivisions of the one may be paralleled with those of the other, as homotaxial eqnivalents or representatives, so that we may speak of the Niagara Group as equivalent to the Wenlock Beds, understanding by this that the groups are homotaxial equivalents and not absolutely coeval formations.

To sum up the preceding observations, the occurrence of the same assemblage of species at different localities may be taken as evidence that the beds containing them are of the same age, and were formed at the same time. Again, a knowledge of the general succession of generic forms enables us to fix the relative age of any set of fossils, and, consequently, the homotaxial position of the beds containing them. In other words:

1. Assemblages having many species in common may be regarded as contemporaneous.

2. Assemblages having many genera in common may be regarded as homotaxial equivalents. 


\section{CHAPTER III}

\section{THE LITERATURE OF HISTORICAL GEOLOGY}

IT is believed that some information as to the principal geological publications and as to the facilities for ascertaining what has been published about any particular system or series of beds would be useful to the student.

During the first half of the last century, and indeed up to about the year 1860 , publications on stratigraphical geology were comparatively few, and it was possible for any geologist to have a fair acquaintance with all that had been written on the subject; but as time went on the number of workers increased, and more numerous additions were made every year to our knowledge of British rocks and fossils, as well as of their equivalents in other countries.

Every year added a volume to the publications of the Geological Societies of London, Edinburgh, Glasgow, Manchester, and other centres, to the volumes of the Palrontographical Society and of the Geological Magazine. The Geological Survey also have issued a long succession of maps and memoirs, most of which have appeared within the last forty years.

At the present day, therefore, it is almost impossible for any one to make himself acquainted with all that has been written on the stratified rocks of Great Britain, and quite impossible to have at the same time a good knowledge of the fossils which they contain. Consequently in these branches of geology, as in the case of other sciences, the tendency is toward the specialising of knowledge. After the student has acquired a certain amount of knowledge about the successive geological systems and their characteristic fossils he probably becomes specially interested in one of them, or in the rocks which occur in some particular district, and then he wishes to know in what books and memoirs accounts of that series of rocks or of that particular district have appeared.

The descriptive parts of this volume contain only the more 
important facts respecting each system of rocks. The look in designed to include only so much information about each grent series of stratified deposits as the student inaj be expected to read and to have before him for constant reference. Descriptions of each successive series will be given with a certain anount of detail concerning the variations which they exhibit in the British Islands, and their representatives on the European continent will be indicated in a more concise manner, but yet iu sufticient detail to give the student some idea of their known extent and of the conditions under which they were deposited.

But the task of selecting information from the great mas of detail which has now been accumulated is not an easy one, and further, what is regarded as specially important in one part of the country may seen of less importance in another part, for vaturally each teacher will wish his pupils to become specially acquainted with the rocks of the country or district in which they live. I propose, therefore, in this chapter to indicate briefly what are the most important and useful publications, how they can be obtained, and how they should be used, in order that the reader may learn how to extend his knowledge of any particular series of rocks, or to find out what has been published about the geology of any special district.

The publications may be grouped under four heads-Maps, Stratigraphy, Palæontology, Palrogeography.

\section{MAPS}

It is necessary that the student should have access to a geological map of the Britislı Islands. Every teacher will doubtless see the necessity of exhibiting one in his lecture-room, but every student should as soon as possible acquire one for himself. Fortunately a good cheap map of the British Isles is no longer a desideratum, for one is now issued by the Geological Survey at the low price of $2 \mathrm{~s}$. There are several others on a larger scale at a higher price, as well as good separate maps of England, Scotland, and Ireland.

The following general maps may be recommended :-

1. Geological Survey Index Map. Scale 25 miles to an inch, 2s.

2. Geological Map of the British Isles, from Stanford's London Atlas. Price as separate map, 10s, 6d.

3. Stanford's Geological Allas of Great Britain and Ireland, edited by H. B. Woodward, and edition enlarged, with plates of characteristic fossils. Price $12 \mathrm{~s}$. $6 \mathrm{~d}$. Het. 
4. Geological Map of England and Wales, by Woodward and Goodchild, $17 \frac{1}{2}$ miles to an inch. Price $5 \mathrm{~s}$, in case $7 \mathrm{~s} .6 \mathrm{~d}$.

5. Geological Map of England and Wales, by Sir A. Geikie. Scale 10 miles to an inch. Price 10s.

6. Geological Map of Scotland, by Sir A. Geikie (Bartholomew). Scale 10 miles to an inch. Price 6s.

7. Map of the Surface Geology of Ireland, by Sir A. Geikie (1908). Scale 10 miles to an inch. Price 4s. 6d.

8. Geological Map of Western and Central Europe, reduced from the International map. Stanford. (In preparation.)

Besides the small index map above mentioned the Geological Survey publishes a larger Index Map on the scale of 4 miles to an inch, a new edition of which is in course of publication in 19 sheets, most of which are issued and priced from 2s. to 2s. $6 \mathrm{~d}$.

If maps of a special district are required the reader should write for a catalogue of the maps issued by the Geological Survey of the United Kingdom, this catalogue being obtainable from Mr. E. Stanford, Long Acre, London; or from W. and A. K. Johnston, Edinburgh, or from Hodges, Figgis, and Co., Dublin.

Besides the index map above mentioned the Geological Survey issues two sets of maps on the scale of one inch to a mile, one being known as the "Old Series," the other as the "New Series."

\section{StratigRAPHY}

It will be couvenient to mention first those books and memoirs which are of a general nature but yet give more information about certain formations than will be found in this volume.

The most complete Manual of Geology in English is Sir A. Geikie's Text-book of Geology, 4th edition (1903) published by Macmillan and Co. in 2 volumes, price 32s.. The second volume deals with Stratigraphical Geology and includes accounts of the foreign equivalents of each systen, not only in Europe but in other parts of the world. A similar work in French is De Lapparent's Traité de Géologie, 5th edition (1905), in 3 volumes, price $35 \mathrm{~s}$.

A useful epitomé of the geology of many counties and districts in England and Wales will be found in the Jubilee volume issued by the Geologists' Association in four parts, price 5s, each (1910). Each article in this publication has been written by a geologist who is specially well acquainted with the district he describes.

The Geological Survey has published the following memoirs, which deal either with special formations or with districts of considerable size and importance :- 
The Geology of North Wales, by Sir A. Rannay, 2nd edition (1881). Price 21s. with map and sections.

The Geology of the N.W. Highlands of Scotland, by B. X. Peach, J. Horne, and others (1907). Price 10s 6d.

The Geology of the Southern Uplunds of Scolland, by B. N. Peach, J. Horne, and otlsers (1900). Price 158.

The Geology of London and of Part of the Thames Vulley, by W. Whitaker, in two volumes (1889). Price $1 \mathrm{ls}$,

Guide to the Geology of London and the Neighbourhood, by W. Whitaker and H. B. Woodward. Price ls.

The Geology of the Bristol and Somerset Coal-field, by H. B. Woodward (1876). Price 18 s.

The Triassic and Pernian Rocks of the Midland Counties of England, by F. Hull (1869). Price 5s.

The Geology of the Weald, by W. Topley (1875). Price 17s. $6 \mathrm{~d}$.

The Geology of the Isle of Wight, by C. Reid and A. Strahan (1889). Price 8s. 6d.

The Geology of the Isle of Purbeck and Weymouth, by A. Strahau (1898). Price 10s. 6d.

The Jurassic Rocks of Britain-

Vol. I. Yorkshire, by C. Fox-Strangways (1892). Price 8s. 6 d.

Vol. II. Yorkshire, by C. Fox-Strangways Tables of Fossils. Price 12s.

Vol. III. The Lias of England and Wales, by H. B. Woon. ward (1893). Price 7s. 6d.

Vol. IV. The Lower Oolitic Rocks of England, by H. B. Woodward (1894). Price 10s.

Vol. V. The Middle and Upper Oolitic Rocks of England, by H. B. Woodward (1895), with Bibliograplyy of Jurassic Literature. Price 78,6d.

The Cretaceous Rocks of Britain-

Vol. I. The Gault and Upper Greensand, by A. J. JukesBrowne (1900). Price 9s.

Vol. II. The Lower and Middle Chalk of Eingland, by A. J. Jukes-Browne and W. Hill (1903). Price 10k

Vol. III. The Upper Chalk of England, by A. J. Jukes. Browne and W. Hill (1904). Price 10太

The Pliocene Deposits of Britain, by C. Reid (1890). Price 5s. $6 \mathrm{~d}$.

A list of the smaller or more local memoirs (explanations of various sheets of the one-inch map) will be found in the Catalogue 
of Maps and Memoirs issued by the Survey. Many of them have lists of the publications referring to the district under description.

The next most important solrce of information is the Quarterly Journal of the Geological Society of London, the publication of which commenced in 1845. There is an excellent index to the first fifty volumes of this Journal, which can be purchased from the Geological Society, Burlington House, London (price 10s.). This index gives references to the names of authors, of places, and of subjects, so that by its means it is easy to ascertain what papers have been published in the Journal on any particular area or any set of beds. This index deals with the yearly volumes between 1845 and 1894 .

The Geological Society also publishes every year a list of the various items of geological literature which have been added to its library. This publication began in 1894, with a list for the latter half of that year (price 1s.). Each succeeding annual part is issued in a paper cover (price 2s.), and is divided into two portions, the first being an index of authors' names with titles of papers, and the second an index of subjects, and each separate paper in all the publications purchased or received by the Geological Society is entered in these indices, as well as all the papers published in the Quarterly Journal of the Society since 1894. It will be seen, therefore, that this annual list forms a fairly good index to the geological literature of the whole world.

Before this work was taken in hand by the Geological Society of London two attempts had been made in England to establish an annual record of geological literature. These were :-

1. The Geological Record, consisting of six annual volımes (1874-1879), edited by W. Whitaker, giving short. abstracts of all papers, British and foreign; and two volumes (for 1880 to 1884 inclusive), edited by W. Topley, giving titles only. Published by Taylor and Francis, London. Price 16s, per volume.

2. The Annals of British Geology, by J. F. Blake (Dulau and Co., London). Four volnmes (1890-1893). Price of the vol. for $1890,5 \mathrm{~s}$, of others, $9 \mathrm{~s}$.

The volumes of the Geological Magazine contain many articles on stratigraphical geology, and a general Index to all the volumes from 1864 to 1903 has been published, price $21 \mathrm{~s}$.

'The Geologists' Association publishes Proceedings which contain many useful papers, and each volume contains the proceedings and communications of two years, with accounts of excursions and a good index. The first volume is for the years 1868-69.

Of the provincial societies which publish geological papers the 
chief are the following:-the Geological Societies of Edinburgh, Glasgow, Manchester, and Liverpool, the Yorkshire Geological and Polyteclnic Society, and the Royal Geological Society of Cornwall.

Particulars respecting the above and all other scientific societies in the United Kingdom will be found in the Official Year-Book of Scientific and Leamed Societies, published by C. Griflin and Co., Strand, London. Price 7s. 6d. each annual volume.

The British Islands lave been the scene of repeated volcanic eruptions, and volcanic products are interbedded with the sediments of all the Palrozoic systems, except perhaps the Permian. Brief descriptions of the contemporaneous volcanic rocks will be given in the following pages after that of the sedimentary rocks of each period, but the reader will find this part of the subject admirably treated by Sir Archibald Geikie in his Ancient Volcanoes of Great Britain (Macmillan and Co., 2 vols. 1897, price 36s.).

\section{P'ALEONTOLOGI}

For the proper study of historical geology it is essential that the student should have some knowledge of the forms and strnctme of the different classes of animals, and especially of the Invertebrate classes. This general acquaintance he can get from a careful perusal of Mr. H. Woods's small manual of Palaontology in the Cambridge Natural Science Series (second edition, 1899, price 6s.), but he may sometimes find it necessary to refer to larger books on the subject. Of these the best are:-

A Manual of Palcontology, by Messrs. Nicholson and Lydekker, third edition, in two volumes (1889), price $42 \mathrm{~s}$.

Zittel's Text-book of Palceontology, the American edition of 1900, published by Macmillan and Co., vol. i., price $25 \mathrm{~s}$.

Outlines of Vertebrate Palocontology, by A. S. Woodward, Camb. Univ. Press, price 14s.

Besides these may be mentioned a series of volumes now being issued under the title of A Treatise on Zoology, edited by Professor E. R. Lankester, and published by A. and C. Black. This series will be complete in ten parts, of which nine have been published. Price from 12s. $6 \mathrm{~d}$. to $15 \mathrm{~s}$. per part. Fossil forms are dealt with in most of them.

The stratigraphical geologist, however, has to deal with fasils principally as important aids in determining the relative age of rocks, and he has therefore to make himself acquainted with the fossils which are most characteristic of the diflerent systems, and especially with those species which have a restricted range within each system and thus cliaracterise stages and zones. 
Lists of characteristic fossils will be given in this volume, together with figures of some of them. The student will, however, be glad to know where he may find figures of other species, and he may consult the following books with advantage :-

For Palæozoic fossils a useful book is Baily's Characteristic British Fossils, vol. i. (Palæozoic), with 42 plates (1875). Copies of this can still be obtained from Messrs. Dulau and Co., 37 Soho Square, London. Price 10s.

For Tertiary fossils Lowry's Chart of Characteristic Tertiary Fossils can be recommended. (Stanford. Price 4s.)

For fossil Crustacea Woodward and Lowry's Chart of Fossil Crustacea is good, thougl not limited to British species.

The more recent memoirs of the Geological Survey-that is to say most of those published since 1890-contain fignres of some of the characteristic fossils of the formations described. The memoirs on the Jurassic rocks and on the Cretaceous rocks may be specially mentioned as containing many figures of fossils that will be useful to the student.

For illustrations of fossil plants and for information on their structure Seward's Fossil Plants should be consulted (Cambridge Nat. Science Manuals, two volumes, price 12s. each). Studies in Fossil Botany, by D. H. Scott (A. and C. Black), is also excellent.

As works of reference which ought to be found in every library of scientific books the publications of the Palæontographical Society must be mentioned, for these volumes are the great storehouse of illustrations of British fossils. The annual quarto volume of the Society costs only 21s., and contains parts of four or five monographs, with from thirty to forty plates. The Society was established in 1847 , and a list of the monographs which have been completed and of those which are in progress can be obtained from Messrs. Dulau and Co. (Soho Square, London). The completed monographs can be purchased separately, and include monographs on Fossil Corals, Echinoderms, Brachiopoda, Trilobites, Devonian Fossils, Mollusca of the Crags, Cretaceous Bivalves, and Ammonites of the Lias.

Another work of reference is Etheridge's Fossils of the British Isles, vol. i. (Clarendon Press, Oxford, 1888), which is a complete list of the fossils recorded from the Palæozoic rocks of Britain up to that year, showing the range of each species.

\section{PaLAOGEOGRAPHY}

The geography of the earth's surface has gone through a long series of phases and mutations. Each period may be said to have 
had a geography of its own, but the special phase with which it opened slowly changed toward the evolntion of the ensuing phase by the upheaval of one region and the sulsidence of others, or by a general regional movement of elevation or subsidence. Sometimes indeed great changes seem to have taken place within the duration of a single period. The present arrangenent of land and sea, as well as their relative heights and depths, is nierely the last of these phases, but it is at the same time a result of the geographical evolution which has been in progress ever since the earth's crust was cool enough for water to condense and settle upon it; in other works, modern geography is the outcome of all the past geographical changes.

The restoration of ancient plases of geography, the attempt to indicate the limits of the seas and the positions of the land areas of any age or period, is one of the most difficult problems that a geologist can endeavour to solve. Shore-lines are seldom preserved, and the essay involves a careful consideration of the conditions under which various local deposits have been formed, and a studied use of the scientific imagination in estimating the original extension of deposits, of which only small portions are in many cases preserved or exposed.

Such endeavours to restore the geographical couditions of past periods must at present be tentative, and with respect to the older periods they are probably more suggestive than real; but they exercise the faculty of inductive reasoning, and they help to show the student that there are aims and objects to be attained by the study of historical geology which are more interesting than the mere enuneration of rock-groups or the recognition of characteristic fossils.

A brief account of the conditions under which each series of rocks has been accunulated and of the relative positions of land and sea in the European region during each period will be given in the following pages; but for more detailed consideration of the geographical changes in the British area the reader is referned to the author's treatise on the Building of the British Isles (thirl edition, 1911, Stanford), and to Professor Hull's Contributions to the Physical History of the British Isles (1882, Stanford). He will also find maps that deal with a wider area in the last edition (fifth) of De Lapparent's Traité de Géologie (1905). 


\section{CHAPTER IV}

\section{THE ARCH FAN ROCKS}

\section{A. Classification and Nomenclature}

IN this chapter we shall deal with the oldest rocks which are known to enter into the surface-structure of the earth's crust, rocks which can be seen to emerge from below the oldest fossiliferous (Cambrian) strata, not only in Britain but in many other parts of the world.

These primitive formations consist mainly of crystalline rocksgranite, gneiss, and crystalline schists-but they also include great thicknesses of stratified rocks, partly sedimentary and partly volcanic, which have not been altered beyond recognition as such rocks. Gneisses and crystalline schists belong to a category of their own and are generally termed metamorphic rocks, yet they have certainly not all been formed in the same way, and the determination of their relative age and manner of formation is often a very difficult nratter. Even the stratified Archæan rocks cannot be classified and correlated in the same way as those of the Palrozoic systems can, because they are destitute of fossils, except some minute microscopic bodies, and because they vary greatly in lithological composition and in the extent of metamorphic change which they have undergone.

Consequently, when a succession of pre-Cambrian rocks has been made out in any one area, it is very difficult to correlate the divisions which are observable in this area with those which can be made out in another. Even with regard to larger divisions, of the rank of series or systems, European geologists have not yet formulated any classification which has met with general acceptance. They differ as to the number of rock-groups which can be recognised in some of the principal areas of pre-Cambrian rocks, and also as to the relative age of some of the component rock-masses; and in some cases it is a matter of dispnte whether certain schists and 
phyllites are of Archrean age at all, or are metamorphosed sedinents of much later date.

All agree, however, in admitting that in the regions where large tracts of pre-Cambrian rocks are exposed, there is a general succession from an older to a younger series, and that in some areas there is a distiuct break and unconformity between the older and younger series. Thus there is no doubt that the Archaan rock can be divided into two distinct systems, and some continental geologists advocate the restriction of the name Archrean to the older series and apply that of pre-Caubrian to the newer and nore distinctly stratified series. This, however, is not a satisfactory nomenclature, for the term pre-Cambrian is an indefinite and iuconvenient name for a system or a period, though it is a useful adjective in a general sense. It is better, therefore, to call all preCambrian rocks Archean, using the term Protarchæan for the oldest and Nearchean or Eparchaan for the younger series.

Difficulties, however, still remain, because in some countries, and notably in America, the older crystalline rocks have been divided into two and even three series, while in some areas two series of distinctly stratified rocks are believed to exist. Ultinately it may be possible to divide the whole into three distinct systems, as suggested by Professor Bonney, which may then be called Protarchæan, Mesarchæan, and Eparchæan. ${ }^{1 a}$

Meanwhile at the present time the rock-groups which have been recognised in different areas are known by different local names: so that not only every country, but almost every separate district in which Archran rocks are exposed, has its own special nomenclature, and it is seldom possible to correlate the groups establisbed in one country with those of another.

Under these circumstances it is obvious that the Archasu rocks caunot be described in separate chapters on a stratigraphical basis, but must be dealt with regionally, those of ench large aren being described separately and successively. As regards their total thickness exaggerated ideas seem to prevail in some quarterk Attempts to estimate the thickness of crystalline schists are quite untrustwortly, and where that of the stratified series can be estimated their thickness is not more than that attained by Cambrian or Silurian strata in some districts, i.e from 10,000 to 16,000 feet.

a References will be fouml at the enil of the chapter. 


\section{B. British Representatives}

\section{Scotland}

By looking at any geological map of Scotland the reader will see that, if the Outer Hebrides are included, about two-thirds of the whole country are occupied by gneissic, schistose, and semicrystalline rocks, which are believed to be older than the Cambrian. There is now no doubt that this great region of the Scottish Highlands includes several series of pre-Cambrian rocks, and the region is divisible into three areas: (1) a western area, including the Hebrides, the western parts of Sutherland and Ross, and tracts in Skye, Mull, and Islay ; (2) a broad medial area extending from the north coast of Sutherland to the south of Inverness; (3) the Central Highlands from Aberdeen to Argyllshire.

Parts of these three areas are shown on the accompanying nap (Fig. 1), and they appear to include three different series of Archran rocks, though each area contains representatives of more than one division, and it is only in the west that the relative positions of two of these divisions are quite clear.

The western belt is marked off from the median tract by a thrust-plane of enormous displacement which is known as the Moine thrust. The western outcrop of this plane runs from Whiten Head near Loch Eriboll in a S.S.W. direction, through Sutherland and Ross and through the Sound of Sleat. Thence it probably passes outside the Isles of Mull and Islay. West of this line the Archran rocks are comparatively unaltered and seem, indeed, to have undergone little change from the condition in which they existed when the early Cambrian sandstones were deposited, while the areas to the east of them have been subjected to enormous pressures, with resulting dynamic metamorphism produced at some post-Cambrian date.

The north-west area in Sutherland and Ross has long been known for its clear presentation of three distinct rock-systems, though the precise ages of these three systems was for a long time in doubt. Each is separated from that below by a great unconformity, and the highest of them is now known to be Cambrian. The other two have been named the Torridonian or Torridon sandstone, and lowest of all the Hebridean or Lewisian gneiss.

The following description of the Hebridean gneiss is taken from the Report of the geological mapping of the area, published in $1888 .^{2}$ In the cliffs between Cape Wrath and Loch Torridon they present two types of structure, appearing in some parts as "massive rudely foliated crystalline rocks, with few divisional planes, or [in other 


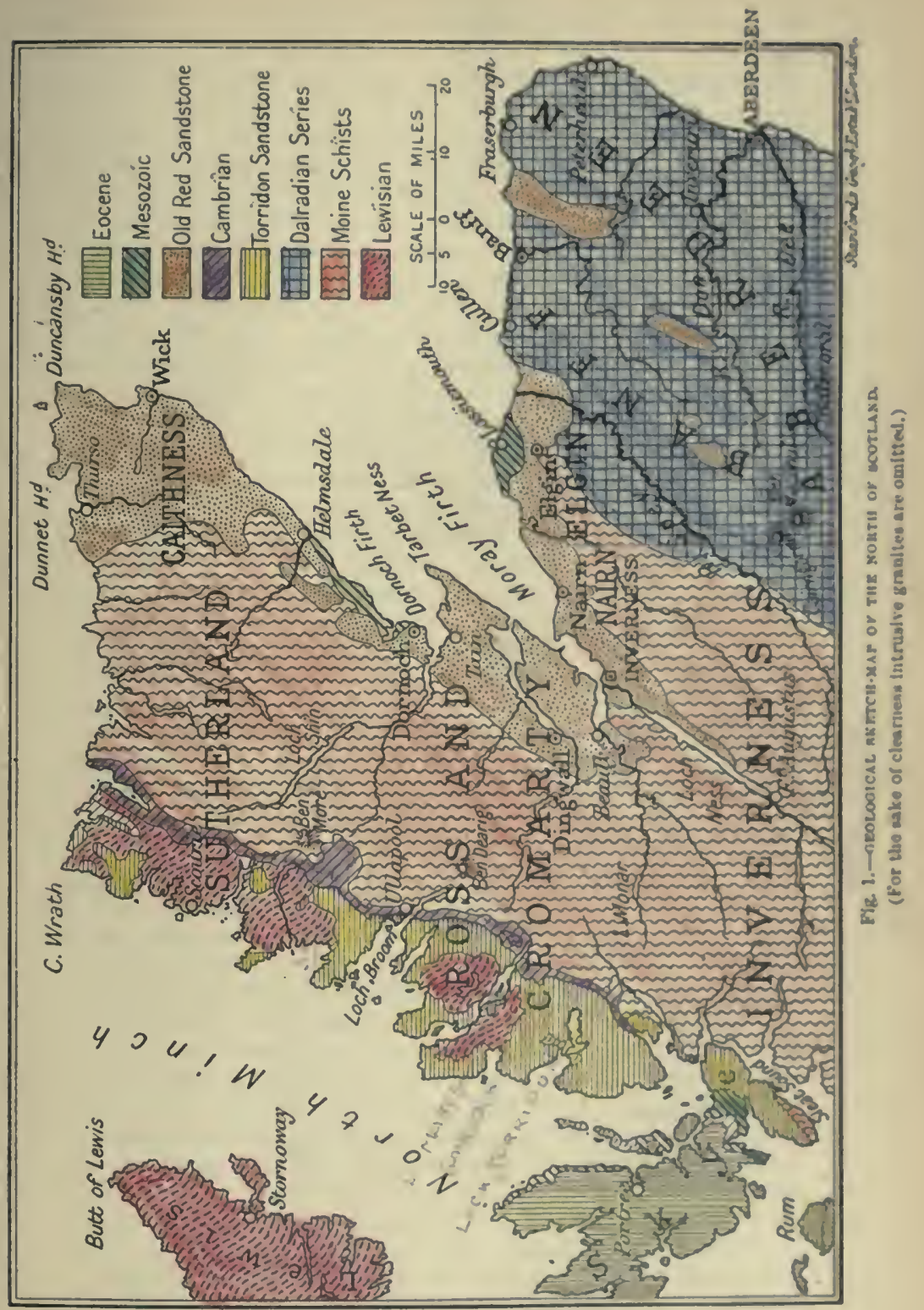


parts] as well-banded gneisses in which the constituents have a distinct parallel arrangement. Both varieties are traversed by segregation veins and pegmatites. The prominent minerals are plagioclase felspar, pyroxene (angite), hornblende, quartz (frequently opalescent), and magnetite. It is worthy of note that mica is a rare constituent of these original types of gneiss. On close examination it is apparent that the bands present certain lithological varieties of variable thickness; some consisting mainly of pyroxene or hornblende and a small quantity of plagioclase felspar; some of plagioclase, pyroxene or hornblende, and opalescent quartz; others of opalescent quartz and felspar. These varieties frequently cross the lines of schistosity, and are evidently dne to differences in the nature of the materials prior to the development of the foliation."

In some places these foliated rocks include masses of non-foliated basic igneous rock (gabbros, peridotites, augite-granulites, and diorites), arranged in lenticular belts which are more or less parallel to the foliation. These patches and belts are intersected by veins of grey pegmatite, consisting mainly of felspar and quartz, and varying in thickness from a few inches to several yards. Bnt when these non-foliated masses are carefully traced it is found that they pass laterally into the rudely foliated basic gneisses and that the pegmatites merge into quartz-felspar schists. Hence it is concluded that almost the entire mass consisted originally of igneous rocks, and that the gneisses have been developed by deformation alone; but that there was an original differentiation of the felspathic and hornblendic elements, either by separate intrusion or by fluxion, while the rocks were still in a viscous condition. There is no doubt, however, that the members of the original complex must have been subsequently affected by intense pressure inducing plastic deformation and metamorphism.

The gneisses are also traversed by other dykes of basic igneous rock -diabase, epidiorite, and picrite-but these are nevertheless of a date anterior to that of the overlying Torridon sandstone which they do not enter. Most of these dykes run from S.E. to N.W. or W.N.W. Moreover, detailed mapping of the area has shown that after the intrusion of the igneous dykes, and still before the deposition of the Torridonian, the whole region was subjected to intense lateral pressure which caused much plication of the gneisses and produced bands of disruption or "shear-zones" which run approximately east and west.

In certain parts of the area, i.e. near Gairloch and Loch Maree, rocks of a different character make their appearance and seem to lie within a broad and deep synclinal fold of the Hebridean gneiss. ${ }^{3}$ They consist of schists which are clearly altered sediments, but their 
relation to the gueiss is uncertain because the planes of contact seem to be shear-planes with bands of crushed rock, but they are clearly older than the Torridon sandstone.

This schistose series consists for the most part of unica-schist, graphite-schist, and crystalline limestone, with bands that may represent altered quartzite and chert; and there are also broad outcrops of hornblende-schist which are probably dykes or sills of basic igneous rock. There are several bands of limestone, varying in thickness from 3 to 30 feet; one of the best known is the Letterewe limestone, which is a cream-coloured rock containing lumps of actinolite; it was formerly extensively quarried. Another band at Ardlair is a white saccharoid dolomite.

The existence of this tract of metamorphosed sediments to the west of the great thrust-plane is important, because it may be regarded as a remnant of a mass of such rocks which was originally nuch more extensive, and seems to occupy an intermediate position between the Hebridean gneiss and the Torridon sandstone. We shall presently see that the more highly metamorphosed complex of rocks to the eastward includes representatives of a similar schistose series, and it has been reasonably supposed that the Loch Maree Series represents some of the sedimentary rocks into which the Hebridean gneisses were intruded.

Hebridean gneisses are found on the western border of Invernes, opposite Skye, and in the peninsula of Sleat; they form the islands of Coll and Tiree and occur in Iona and Soa; they are also exposed in the north-east part of Colonsay and again in the southwesteru part of Islay which terminates in the precipices of Rhinns Point. The gneisses of Islay are similar to those of the north-west, but Dr. Teall observes 4 that under the microscope they show evidence of profound modification by pressure, "the general result of which has been to crush the original constituents and thus to produce microscopic breccias, not holocrystalline schista."

The features of the belt of faulted and overthrust masses of rock which separates the western and eastern areas of the Northern Highlands are sufficiently illustrated in Figs, 2 and 3, drawn by the Officers of the Geological Survey, and the details of its structure need not be described in this place. It is only necessary to note that the rocks which occupy the country to the east of the great Moine thrust have been so crushed, crumpled, and metanorphosed that they now have special aspects of their own.

Part of the great niedian area of schistose rocks is shown on the map (Fig. 1); it comprises the greater parts of Sutherland, Ross, Cromarty, and Inverness; it extends across the "great glen" into Nairn and Elgin, and southwards through the Forest of Athol 

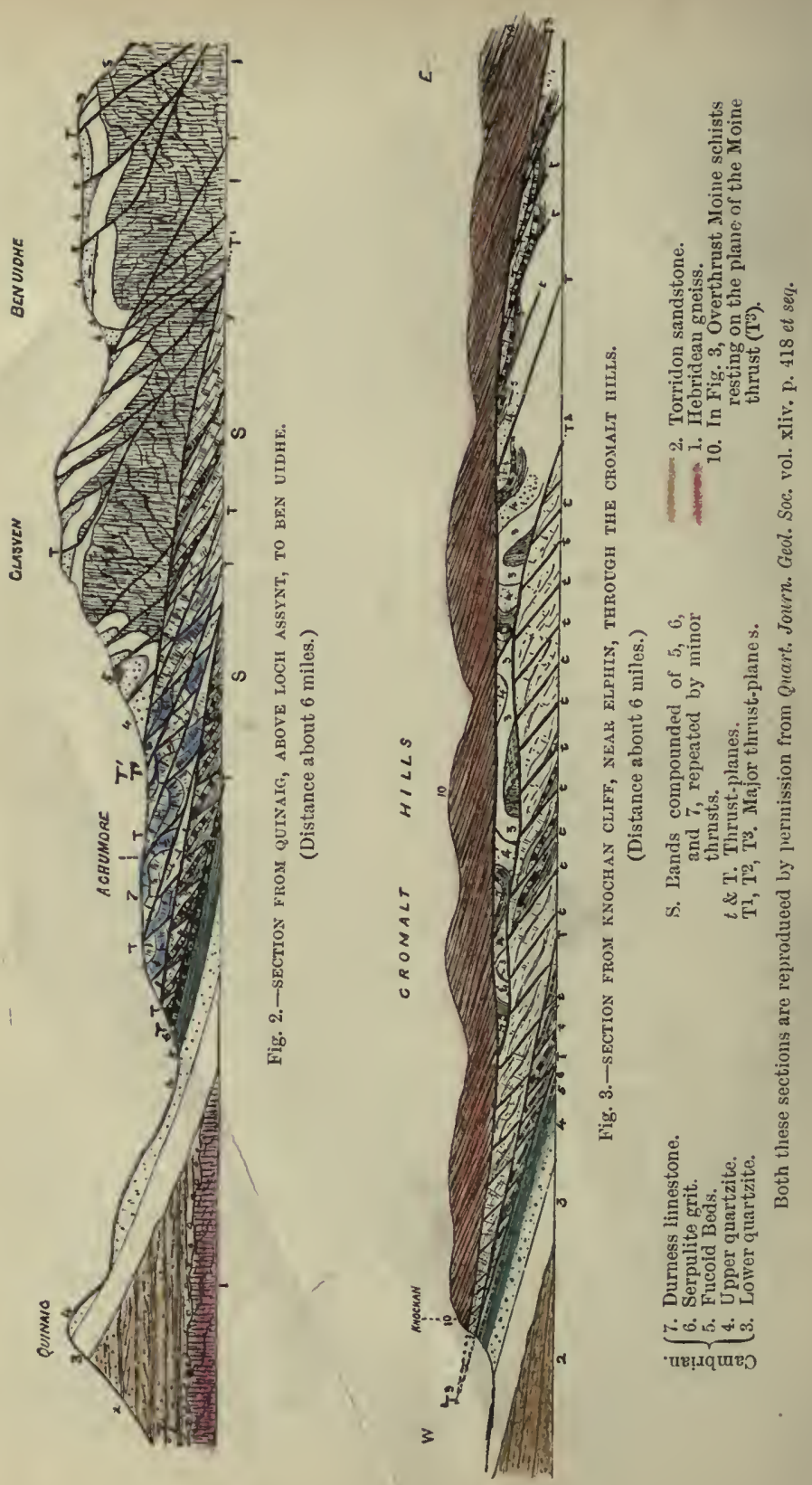
to and beyond Loch Rannoch, as well as to the eastern end of Loch Leven, but south of this line it becomes infolded with the Grampian Series.

The whole of this area has now been surveyed by the staff of the Geological Survey of Scotland, and some important conclusions have been reached. These have been cautiously announcod from time to time in the anmual "Summaries of Progress," from which extracts and abstracts will here be given.

In 1904 and 1905 it was found that over a large a rea embracing parts of Ross, Inverness, and Nairn the metamorphosed rocks could be separated into two divisions : (1) a complex group cousisting partly of gneisses of Hebridean type and partly of altered sedimentary rocks; (2) certain gneissic schists of both siliceous and pelitic types which, being intimately connected, were termed the Moine schists Further, the mapping of these areas showed that the Hebridean gneisses occurred as inliers surrounded by Moine schists, and that the latter appeared to lie unconformably ou all the nembers of group 1; the lowest part of the granulitic schists being a band containing fragments of felspathic gneiss and haviug all the aspect of a sheared conglomerate.

These conclusions have been confirmed by subsequent work, and the altered sediments in the Hebridean complex are found to include crystalline marbles, calcareous silicates, and brown micaschists which are often graphitic, associated with banded hornbleudic gneisses. The reader will perceive that there is a striking resemblance between this series and that of the Loch Maree Beds above described. Dr. Flett, writing in 1905, says "such rocks are a characteristic part of the Lewisian in certain areas " (i.e. Glenelg and Loch Maree) and remarks that they differ widely from any of the Moine Schist Series. It is evident that two sedimentary series are present in the Moine schist area, the one associated with the Hebridean, and of considerable thickness, but largely eroded aurl removed before the deposition of the other (i.e. the Moine sclists).

The Moine schists present two different types of rock which can be separately mapped; these are (1) psammitic sclists or flaggy granulites composed of quartz, felspar, and biotite, (2) pelitic or argillaceous schists now converted into mich-schists in which white muscovite mica predominates. The mapping of Roes and Invernese lias led to the belief that these are not nerely successive but that there are two bands of psammitic and two of pelitic schists; there are also occasional seams of quartz-schist and of calcareous schist. The wliole mass of the Moine schists lias apparently been formed out of a series of sandstones and sandy shales.

Proof of the last statement has recently been obtained by Mesers 
Clough and Crampton ${ }^{5}$ from a study of the aureole or zone of contact-metamorphism round the gneissic granite of Carn Chuinneag in Ross-shire. Within this zone the Moine sediment was altered and indurated before the incidence of the dynamic metamorphism, the consequence being that the beds have to a large extent escaped the effects of that metamorphism and can be recognised as hornfelses formed from the alteration of ordinary sandstone and shales

The hornfelses occur where a sandy shale was in contact with the granite; it is now a hard and splintery rock, and where least affected by subsequent shearing it shows both a clastic structure and the original lamination. The more quartzose bands often contain minute pebbles of rounded quartz; and "On the surfaces of certain layers there are markings strongly suggestive of sun-cracks and ripple-marks, and others which may possibly represent wormtubes." Moreover, the beds lie with gentle inclinations, and they dip at right angles to the general direction of the foliation-bedding or shearing of the neighbouring schists. Lastly, intermediate stages between the typical hornfels and the foliated schists have been observed; and it is clear that all the rocks were solid at the time when the pressure-foliation was induced, the granite being then converted into a gneiss and the shales into mica-schists, while the rocks of the indurated aureole were more resistant and are consequently much less altered.

The Moine schists and the underlying Hebridean rocks have now a common foliation which has obscured that which previously existed in the older series: they have also a common flexion and plication, the rock-masses being folded into a complex system of isoclines, the prevalent strike of which is from S.S.W. to N.N.E., though they vary in direction round the inliers of Hebridean gneiss.

The above description applies more particularly to the areas north and west of the Great Caledonian Glen. East of the faults which run along this glen the country is occupied by large tracts of similar quartzo-felspathic schists, which, however, differ in being more persistently flaggy, the layers being alternately more and less micaceous. Hence the name Eilde Flags has recently been used as a special designation of this portion or facies of the Moine schists. ${ }^{6}$

We now pass to the equally large area of the Central Highlands, which extends across the centre of Scotland from parts of Aberdeen and Kincardine on the N.E. through Perthshire and Argyllshire to the coasts of Cantire and Islay. This area is occupied mainly by three different kinds of rocks, first and principally by a series of metamorphosed sediments comprising quartzites, phyllites, and limestones, secondly of small tracts of Eilde flags, and thirdly of 
large intrusive masses or bosses of granite. The stratified series has been called the Grumpian Series by Dr. Hicks ' (1883) and the Dalradian by Sir A. Geikie ${ }^{8}$ (1891).

The mapping of this extensive area by the Geological Survey has beell in progress for many years, and reports on succensive portious liave been published in the annual "Summaries of Progres." From these we learn that the successive belts of altered stratified rocks are not difficult to follow, but that, owing to the isoclinal folding and the intense plication, it is not easy to unravel the true succession from oldest to newest. In Argyllshire, however, where the unetamorphism is less and the physical structure less complicsted, the succession appears to be as follows, according to E. B. Bailey, ${ }^{6}$ though it is not yet known whether it should be read npwards or downwards.

9. Eilde flags.

8. Glen Coe quartzite (white and tine-graiued).

7. Leven schists, grey phyllites, and others with quartzite bands.

6. Ballacliulish limestone and black slates (= Easdale slates).

5. Striped Transition Series (not always present).

4. Appin and Loch Awe quartzite (a pebbly rock).

3. Appin limestone (cream coloured).

2. A ppin phyllites, with bands of flaggy quartzite.

1. Cuil Bay slates (black).

The section (Fig. 4) represents Mr. Bailey's theory of the arrangement of these groups in a series of recumbeut folds, and from it the reader will understand the difficulty of ascertaining the real order of succession.

With regard to the total thickness of these groups no exact measurements have been made, but Mr. Bailey states that "even the thinnest of them, the Appin limestone, is probably not less than 100 feet thick, while the Leven schists, Glen Coe quartzite, and Eilde flags must each of them reach about 1000 feet; the other nembers of the sequence should doubtless be reckoned iu huudreds of feet. These rough estimates refer to original thickness of depasition. Now over wide areas various groups are reduced to mere films, ... elsewhere agaiu their dimensions have been nightily incrensed by reduplication." We may infer, therefore, that the whole series, exclusive of the Eilde flags, must lave been originally between 4000 and 5000 feet thick at least.

The Appin quartzite is specially interesting because what may be its base is generally a pebble-bed or conglomerate; morever, the Appin limestone sometimes passes througl a pebbly calcareous rock into the quartzite, so that the evidence of superposition is doubtful. The pebbles are chiefly of quartz and pink folspar. In other parts of the Highlands what seems to be the same quartzite 
has a border or base containing stones of the size of boulders as well as pebbles.

The above may be an ascending or descending sequence. Hitherto it has been generally supposed that the rocks of the Central Highlands are younger than those to the north-west of them, but this is an assumption, and the intermediate position of the Moine schists between the unaltered Heloridean area and the Grampian range may be merely a geographical and structural accident. It does not follow that they are of intermediate age, and we shall see in the sequel that the general order of succession in the metamorphic area may have to be read from south-east to north-west.

We must now return to the north-western area and give some

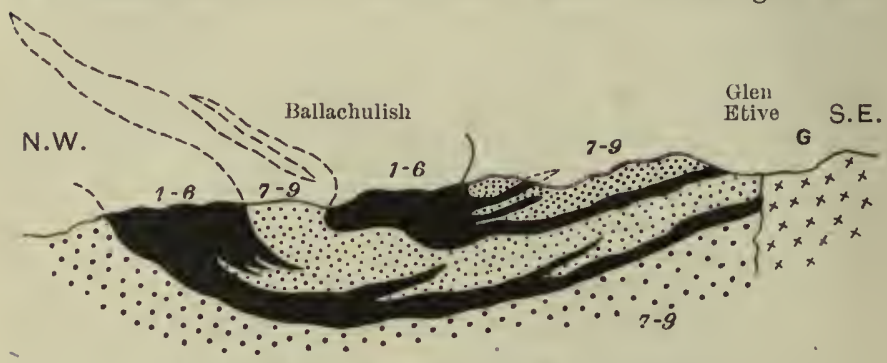

Fig. 4.-SECtion FROM LOCH LINNHE TO LOCH ETIVE.

Copied from Mr. Bailey. Distance about 14 miles.

The numbers refer to those in the succession given on p. 43 .

account of the Torridon sandstone, which in that area is the only formation occupying an intermediate position between the Hebridean complex and the Cambrian quartzites. There is, however, a remarkable gap and unconformity between the gneisses and the Torridon sandstones, and this gap must represent a long interval of time. In some places the surface of the gneiss is a gently undulating plain, but elsewhere it had been carred into a series of hills and valleys, the former rising to heights of from a few hundred to more than 2000 feet above the valley-bottoms. ${ }^{9}$

Moreover, the basement beds of the Torridonian are generally in the form of a conglomerate or breccia, the components of which have been mainly derived from the underlying gneisses, but except in this conglomerate fragments of gneiss are by no means abundant in the overlying coarse sandstones, and most of the pebbles found in them consist of rocks which differ from any now exposed in Sutherland or Ross. They include many kinds of rocks, both igneous and sedimentary, such as spherulitic felsite, felspar-porphyry 
veill-quartz, quartzite, grit, chert, and jasper; and Dr. Teall laas found from microscopical exanination that the felsites and porphyries are "identical in all essential respects with the felsites [i.e. devitrified rhyolites] belonging to the Uriconian Series of Shropshire."

In these pebbles, therefore, we seem to have traces of a vanished formation, of later date than the Hebridean gneiss, from which the component materials of the Torridonian deposits were principally derived. It would be interesting to compare the volcanic rocks with the felsites and porphyries which occur in Sweden and seem to occupy an intermediate position between the equivalents of the Hebridean and Torridonian Series.

In the extreme north between Cape Wrath and Loch Inchard, the Torridonian is not more than 1200 to 1500 feet thick, but farther sonth the beds not only thicken but another set of beds come in at the base, till round Loch Maree and Loch Torridon its thickness amounts to more than 8000 feet. The whole formation las been divided into three gromps by Messrs. Peach and Horne, as shown in the following table.

\begin{tabular}{|c|c|c|}
\hline Groups. & Nature of Materials. & Thickuess. \\
\hline 3. Aultbea Group & $\begin{array}{l}\text { Chocolate-coloured sandstones } \\
\text { and flags with grey flags and } \\
\text { partings of shale }\end{array}$ & 2000 to 4500 \\
\hline 2. Applecross & $\begin{array}{l}\text { Coarse arkose with jebbles of } \\
\text { quartz, quartzite, etc. }\end{array}$ & \\
\hline 1. Diabeg Group & $\begin{array}{l}\text { Red sandstones and mudstones } \\
\text { with grey grits and blaek } \\
\text { shales and caleareous bands }\end{array}$ & $\begin{array}{l}500 \text { in Gairloch } \\
4400 \text { in Kishorn }\end{array}$ \\
\hline
\end{tabular}

Still farther sonth in Skye Mr. Clough finds that the lowest or Diabeg Group expands in a remarkable way, and that it there attains a thickness of about 7000 feet, so that although in that island the Aultbea Group is not represented there are 12,000 feet of Torridonian deposits, and may have been as much as 16,000 feet $^{30}$

Mr. Clough has made the following suldivisions of the Torridonian of Skye in descending order :-

e. Applecross Group. Red and chocolate arkoses with jebbles of various rocks; estimated at 5000 feet.

d. Kinloch Beds. Alternating beds of dark-grey sandy shale and fue grey or buff grit; about 3500 feet.

c. Seamraig Beds. Greenish-grey grits with some beds of sandy shale ; 2600 feet.

b. Loch na Dal Beds. Sandy shales and fine grits; 600 feet.

a. Epidotic grits and conglomerates. About 300 feet. 
The four lower divisions represent an expansion of the Diabeg Group, and it will be noticed that they include two important developments of shaly deposits. From the facts recorded in the Geological Survey Memoir it nay be inferred that the Torridonian Series originally presented a succession of overlapping beds, the lower members thinning out northwards beneath the higher beds as indicated in the diagram, Fig. 5 . In other words we may suppose that deposition began in the south and extended northwards as land in that direction was gradually submerged.

Small patches of Torridonian sandstone occur in the island of Lewis, and show that the series had a western extension; outliers of it have also been detected beneath the Cambrian rocks of East Sutherland, so that it must originally have occupied a very large area, and probably extended beyond the shores of Scotland both

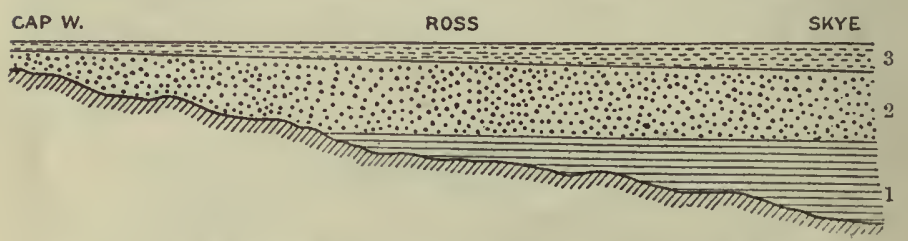

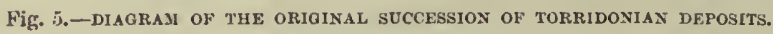
3. Aultbea Group.
2. Applecross Group.
1. Diabeg Group.

on the east and on the west. It was, however, to a large extent destroyed and broken up into isolated tracts during the time which elapsed before the deposition of the lowest Cambrian.

The most southerly occurrence of the Torridon Series in Scotland is in the Isle of Islay, where there is an interesting and suggestive collocation of Archran rocks. ${ }^{11}$ Hebridean and Torridonian are only found in the western part of the island, while the eastern and larger part is occupied by two groups, quartzites and schists, one of which is a continuation of the Grampian Series. The two tracts are separated by a thrust-plane which runs from Loch Gruinard on the north, through Loch Skerrols and near Bridgend, to the east side of Laggan Bay on the south. The Torridonian sequence resembles that of Skye, having an epidotic grit and conglomerate at the base, overlain by a thick group of grey slates and grits, which are succeeded by the Bowmore grits, a series of red, green, and grey felspathic grits or arkoses like those of the Applecross Group. Owing to intense plication no estimates of thickness can be made. Moreover, the whole series has been affected by dynamic metamorphism and converted into slates, phyllites, and more or less schistose grits. 
The Grampian Series of Eastem Islay comprises the following members in descending order :-

$\begin{aligned} & \text { 4. Islay limestone. } \\ & \text { 3. Black slates and phyllites }\end{aligned}=$ Ballachulish limestone and slates.

2. Phyllites with thin quartzose bands (=Striped Series).

1. Quartz-selists (=Appin quartzite).

This series is overlain unconformably by quartzites and shales which greatly resemble those of the Cambrian in Skye, but as no fossils other than worm-tracks and annelid-burrows have been found, the correlation is not proved. These newer quartzites have a conglomerate at the base which contains pebbles of all the older rocks in the island, and includes many of the Islay limestone.

In Islay, therefore, not only is the Grampian Series brought into apposition with Hebridean and Torridonian rocks, but there is evidence which amounts to a strong presumption that it is of pre-Cambrian age. It is, moreover, a noteworthy fact that nothing comparable to the Moine Series has been found in the island.

The Geological Survey has not yet ventured to record any definite conclusion with respect to the relative ages of the Moine schists, the Torridonian, and the Grampian Series. In the absence of any official declaration it is only possible to indicate the trend of the evidence, so far as it has been published in the Reports and Menoirs of the Survey. Reviewing this evidence one cannot fail to be struck with the fact that on the western side of the great thrust-planes, where the succession is clear and post-Canibrian disturbance is small, only two Archran Series are found, i.e. the Hebridean and the Torridonian. On the other hand, in the much larger area to the eastward there are at least three such series, Hebridean, Moine, and Grampian; further, it seems very probable that both of the two last are newer than the Hebridenn, and also that both are pre-Cambrian, but the relative age of the Moine schists is still a matter of doubt.

Two alternatives present themselves, either (1) the Moine Series may be a separate intermediate system, or (2) they may be merely. sheared and metamorphosed Torridonian deposits of the Skye facies.

If they are to be regarded as a separate Mesarchaan System (either with or without the Grampian Series), two awkwand questions have to be answered, $(a)$ what has become of the Torridonian strata east of the Moine thrust? and $(b)$ why is there nothing in the western, except the Torridonian, that is comparable to the Moine schists ? The evidence recently disclosed enables us to assume that the Moine schists were originally a series of 
felspathic sandstones and sandy shales; moreover there is reason to believe that they are divisible into four zones, the first and third being purely arenaceous, the second and fourth pelitic or argillaceous. Again, there is evidence that where they are in contact with the Hebridean there is an unconformity between the two. Thus there must have been a striking resemblance between the Torridonian and the Moine schists in their original condition.

The idea that the Moine schists and flags are only Torridonian in an altered form is by no means new, for it was suggested as long ago as 1899 by Sir A. Geikie in tho following passage :-12 "Probably the Torridon sandstone was largely drawn upon in the process of the manufacture of these schists, and there may also have been Cambrian or even later sediments which underwent the same conversion into a foliated crystalline condition." The progress of investigation has tended to eliminate the latter possibility, but to confirm the first supposition.

Thus Messrs. Horne and Teall, writing of the eastern schists in the memoir on the N.W. Highlands, pointed out that in several cases tracts of Torridon sandstone below and near the thrust-planes show a tendency to break down into schistose grits, and again that the Moine schists which immediately overlie the Moine thurust. are less completely crystalline than those lying farther to the east, similar cataclastic structures being not uncommon in them, so that "the question has arisen as to whether they iepresent crystalline schists more or less broken down or sedimentary rocks which are on the way, so to speak, to become Moine schist" (op. cit. p. 600).

On the other hand, Dr. Horne and Professor Gregory hold that the Moine schists are pre-Grampian, because in several localities the Grampian Series rests directly upon them. Some of these cases are explicable by overthrusts, but in Glen Tilt the Blair Athol limestone lies unconformably on an eroded surface of Moine schist. These geologists consequently believe in the existence of four Archran Systems in the following ascending order-(1) Hebridean, (2) Caledonian (i.e. Moine schists), (3) Dalradian (=Grampian), (4) Torridonian.

\section{Ireland}

The Archæan rocks of Ireland deserve a brief notice because they are for the most part a continuation of the Scottish Grampian Series. There are two lare areas in Ireland where such rocks come to the surface from benerth the Palaozoic formations. One of these areas includes the grears: part of Donegal and the western part of Derry with a portion or Tyrone; the other comprises the 
western parts of Mayo and Galway, and the two areas are almost connected by a narrow tract of the same rocks, which runs from south-west to north-east for a distance of 60 miles, extending from near Castlebar through the Ox Mountains to Hamilton in Leitrim.

So far as yet known fundamental gneiss is only expoeed in Tyrone, the gneisses of the western areas being all intrusive gneissic granites. There is no great fault or thrust-plane separating unaltered Hebridean from later schists, as in the north-west of Scotland; or if such a plane exists it must lie outside the northwest coast of Donegal. Neither is there anything to correspond with the Torridonian or with the Moine schists of Scotland.

(1) Fundamental Gneiss.-In Tyrone this forms a long narrow tract of hilly country extending north-east from near Carrickmore to Slieve Gallion, about $18 \mathrm{miles,}$ and having a maxinum width of 3 or 4 miles. Sir A. Geikie has described it as " an undoubted core of Archran gneiss, resembling in all essential characters the Lewisian rocks of the north-west of Scotland." 18 More recently its position has been discussed by Professor G. A. J. Cole, who also regards it as the oldest local rock and mentions the occurrence of a much later intrusive granite, which includes fragments of the gneiss and of the schists which flank the ridge. ${ }^{14}$

(2) Donegal Schists.-The gneiss of Tyrone is surrounded by a group of coarse volcanic agglomerates-tuffs and lavas-which pass up into green chloritic schists and silvery micaschists like those of the Grampian Series. The lavas are chiefly basic and are often plainly amygdaloidal and on the north-west side of the ridge are singularly fresh and unaltered, a condition which Sir A. Geikie attributes to the protection afforded them by the ridge during the time of great pressure from the south-east. The tuffs have suffered much more from deformation and are now silky green chloritic schists, but they seem originally to have been deriver from the same magma as the lavas (op. cit. p. 42).

Farther to the north-west, in Donegal and in Loudonderry, these volcanic rocks are succeeded by quartzites and black schists with bands of crystalline limestone. A sinilar assemblage of sedimentary and igmeous rocks is found in Galway, Mayo, and the Ox Mountains. These of Slieve Gamph and the Ox Mountains have been recently described by Mr. M'Henry, who considers the descending succession to be as follows :- 15

4. Quartzite passing down into a sheared conglomerate which is often a "Boulder-bed."

3. Limestone, often altered to whitish marble or greeu ophicalcite.

2. Black shales and graphitic grits.

1. Pebbly grits with bands of black shale or schist. 
This series has been extensively invaded by igneous rocks, both basic and acid, the dykes and veins of the latter cutting through the former which are consequently the older, though all are compressed and sheared by still later movements of the crust.

The "Boulder-bed" has been identified in varying thickness all over Galway, Mayo, and Donegal. The boulders in it are almost all of an unfoliated granite, unlike anything now visible at the surface. They are mostly angular or sub-angular, only a few being rounded, and are sparely distributed in a fine-grained matrix. They vary in size up to $3 \frac{1}{2}$ feet across, and Mr. M'Henry has suggested that the bed is a genuine boulder-clay of glacial origin, but its constant superposition on a limestone over such a large region makes this rather unlikely.

Besides the dykes and veins of igneous rock there are large tracts of more or less foliated granite which have often the appearance of being interbedded with the schists, but they sometimes pass into banded gneiss, which is thus shown to be a composite rock formed by the intrusion of tongues of granite into the schists, the banding being due partly to the incorporation of the latter and partly to a flow structure developed in the granite itself, while the whole mass has been sharply flexured, compressed, and sheared by the subsequent pressures.

Describing the granitic dome of Ardara in West Donegal, Professor Cole ${ }^{16}$ points out that the pure granite of the central mass has a border zone of banded gneiss, which is of composite origin and not an original gneiss nor a mylonised rock. "The phenomena," he says, "are those of intrusion along the pre-existing foliation-planes of a schist, and a good gneissose rock results, set with inclusion-flecks, in which these foliation-planes are still apparent."

Whatever may be the age of these intrusive gneissic granites, that of the schistose series seems now to be practically settled by the discovery of Arenig rocks in Mayo and their superposition ou the schists south of Killary Harhour. This disposes of the old view that the schists were only metamorphosed Ordovician sediments.

\section{Wales}

Archæan rocks come to the surface both in North and South Wales; they occupy large parts of Anglesey and smaller areas in Carnarvonshire, while in Pembroke round St. David's they are known as the Pebidian Series (see map, Fig. 16).

Anglesey.-Much has been written about the Archæan rocks of Anglesey, and many conflicting views have been published. A good description of the rocks themselves was given by Ramsay in 
his memoir on the "Geology of North Wales"; the plutonic complex of the central area was described by Dr. C. Callaway ${ }^{17}$ in 1902 ; Sir A. Geikie noted the resemblance between some of the schists and those of Scotland'; the north-western part of the island was mapped by Dr. C. Matley, and the Ordovician tracts separated from the Archaean schists in 1899. ${ }^{18}$ Finally, during the last fifteen years the whole island has been re-surveyed by Mr. E. Greenly, whose nap and memoir will shortly be published by the Geological Surveys Meantime I am indebted to Mr. Greenly for the follow. ing condensed account of the pre-Caubrian rocks.

Though no fossiliferons Cambrian rocks have been found in the island the relation of the schistose complex to the Ordovician, and of the Ordovician to Cambrian on the mainland, leaves no doubt of the pre-Cainbrian age of that complex.

Rocks of Archran age reach the surface in five principal areas and in several smaller inlying tracts. They consist for the most part of greenish sclistose grits, alternating with gritty phyllites and fine chloritic mica-schists; there are also other mica-schists, about the origin of which some difference of opinion still exists There are, moreover, many bands of quartzite and of limestone, some being of considerable thickness.

Across the central part of the island, ranging south-west and north-east, is an axis-like tract of highly crystalline rocks, including various types of basic and acid rocks which have a deep-seated aspect, i.e. gneisses, hornfelses, diorite, and granite. The relations of this group to the sedimentary series have been mucls obscured by subsequent movements, but some of the granites are certainly intrusive into the adjacent rocks which are now in the condition of crystalline hornfels.

Interbedded with the sedimentary rocks in niany parts of the island are bands of basic igneous rock. Most of these are now chloritic and hornblendic schists, with (locally) large masses of glaucophane schist. Some of the cliloritic schists were probably volcanic tuffs, but here and there, especially in the soutli-west near Newborough, the original structure is beautifully preserved, and the lavas are of that pillowy or ellipsoidal form and variolitic type with which radiolarian cherts are so often associsted.

No mmaltered cherts have been found, but nodules and lumpe of red jasper occur abundantly in these lavas, filling the interspaces between the ellipsoids. Similar jasper also occurs in the form of nodules and thin beds in many of the limestones, and seams of fine jaspery purple phyllite are also of frequent occurrence. From this mode of occurrence these jaspers have been regarded by some writers as altered radiolarian cherts, but their radiolarian origin has not yet been proved. 
The whole Archæan complex of Anglesey was affected by very powerful pre-Ordovician earth-movements. In sone parts they are closely folded and minutely corrugated, in other places so sheared and torn that the harder and more resistant beds have been broken up and are now merely a series of phacoids or lenticular masses, floating as it were in a kind of matrix formed out of the softer beds. Further, the movements induced varying degrees of metaniorphism, so that there are few of the rocks which have not been converted into more or less crystalline schists.

Under these circumstances and in the absence of fossils it has not been found possible to establish anything like an order of succession; at the same time it is nearly certain that more than one of the Archæan systems is present in the island. There is even some reason to think that the central complex of gneissic rocks is a fragment of a massif older than the great sedimentary series, but its outer members are so welded to that series by a common foliation that direct evidence can hardly be expected.

The general sequence of events seems to have been as follows:Upon an ancient floor, of which hardly anything is known, but which was composed in part at any rate of plutonic rocks, a great series of grits and shales, with quartzites and limestones, was laid down. At some period during the deposition of these sediments a volcanic episode occurred, and basic lavas with ellipsoidal structure were poured out on the sea floor, after which the interstices of the lava-flows were infiltrated with silica in the form of chert.

After the accumulation of all these sediments and volcanic materials, but before the beginning of Ordovician time, crust movements on the most powerful scale supervened, causing the whole complex to be crushed, folded, and sheared in a most complicated manner. The rocks were in fact practically reduced to the condition in which they are now found before the deposition of the oldest local members of the Ordovician Series, and probably before the commencement of Cambrian time.

Carnarvonshire.-Rocks similar to the sedimentary series of Anglesey are found again on the western side of the Lleyn promontory and form a long strip from Bardsey Island to Nevin, with a width of from 1 to 2 miles. This district exhibits the same series of schists and slates, of purple and green colours, with broken bands of limestone and quartzite, and a similar association of basic lavas and tuffs with jaspery infiltrations. According to Mr. J. F. Blake there is rather a larger development of volcanic material than in Anglesey, especially in the south-west where there is much volcanic ash and some masses of coarse agglomerate.

Two other small strips of pre-Cambrian rocks come to the 
surface farther north, one extending from Llanllytin on the soutls to Penrhyn on the north, a distance of abont 15 miles, with a maximum width of 2 miles (see map, Fig. 19). This tract consists of a rhyolitic felsite succeeded by breccias and schists

A second tract extends from Carnarvon to Baugor, a distance of about 10 miles, with a width of over a mile in the central part. This latter lias been well described by Professors Bonney and Hughes, ${ }^{19}$ who have shown that there are three sets of rocks in the ridge, (1) a granitoid rock at the southern end (Twt Hill), (2) a reddish-purple quartz-felsite, (3) a series of felspathic grits, slates, and agglomerates (the "altered Cambrian" of the Geological Survey). These last are overlain by other conglomerates of Lower Cambrian age. With respect to the relations of these rocks the following facts appear to be well established :-

(1) That the quartz-felsite was a rhyolite, and probably a rhyolitic lava-How.

(2) That between this rhyolite and the basal Cambrian conglomerate there is a series of volcanic and sedimentary deposits which are not less than 3000 feet thick.

(3) That the Cambrian conglomerate contains many fragments of the quartz-felsite and some of granitoid rock (consisting of quartz and felspar) like that of Twt Hill.

This set of pre-Cambrian rocks has been called the Bangor Series, and it should be noted that this series differs from that found in Anglesey and the Lleyn in several particulars. The volcanic rock is acid not basic, all the rocks are less altered and less flexured, and they directly underlie the base of the Cambrian System.

Pembrokeshire.-The oldest rocks in South Wales crop out in the neighbourhood of St. David's (see map, Fig. 16). A preCambrian age was first claimed for them by Dr. H. Hicks in 1871, and the results of his examination of the district were published in several papers. ${ }^{20}$ His conclusions may be thus suminiarised : that the base of the Cambrian System is marked by a conglomerate containing pebbles of the underlying rocks; that this conglonerate rests on a series of schistose volcanic tuft's and breccias, under which is another set of quartz-felsites and halleflintas. Below these again comes a granitoid rock which he regarded as a still older mass of metamorphic rock. To this last he gave the name of Dimetian; the overlying volcanic series he called Pebidian (see Fig. 6).

In 1883, however, these conclusions were called in question by Sir A. Geikie, who maintained the correctness of the Geological Survey mapping, holding that the granite is an intrusive mass of igneous rock, and that the volcanic series (Pebidian) is a down- 

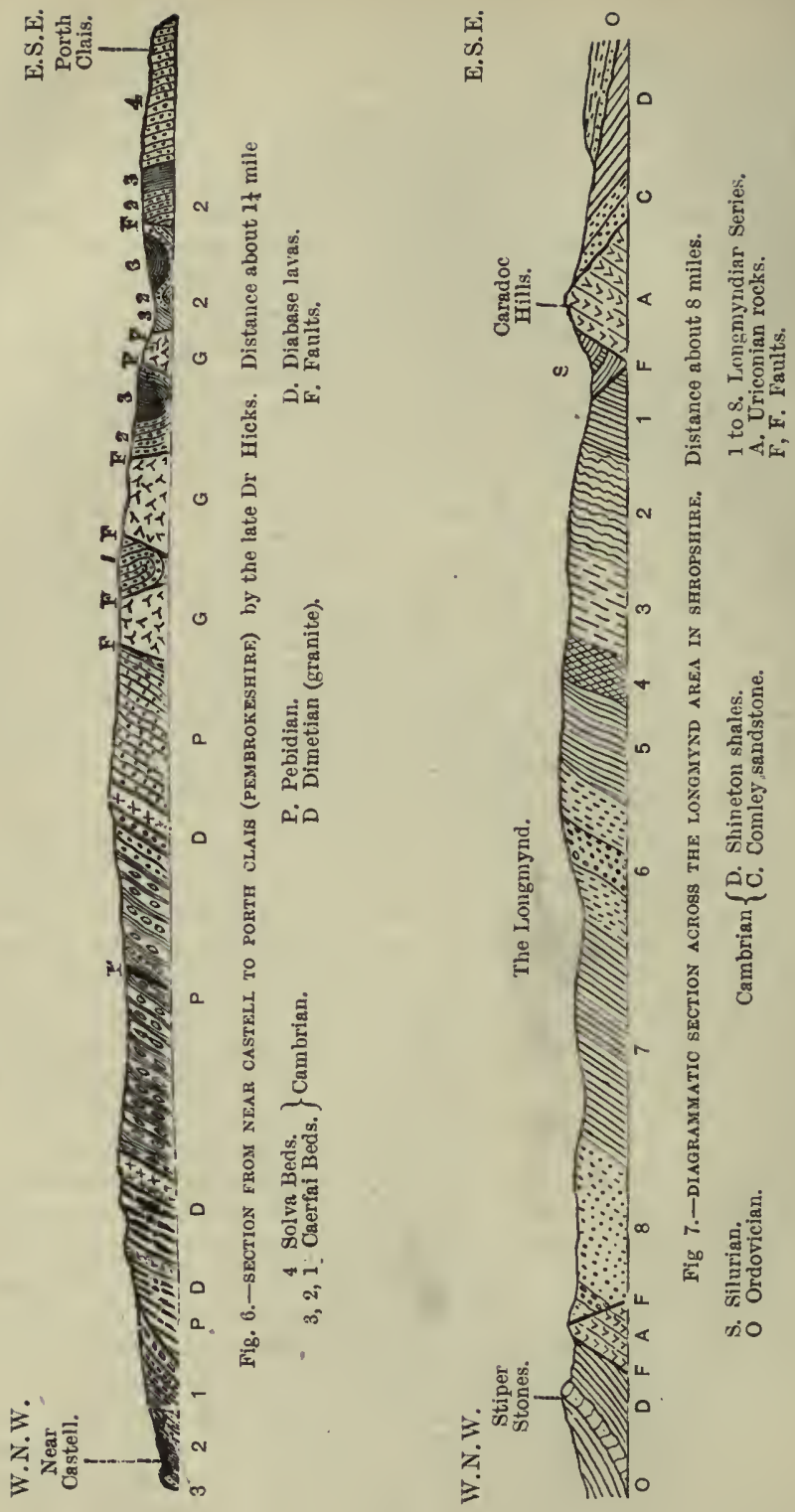
ward continuation of the Lower Cambrians, the apparent breal: between them being only a surface of contemporaneous erosion. ${ }^{21}$

Still more recently (1908) the district has been studied and mapped by Mr. J. F. N. Green, ${ }^{22}$ who appears to have finally established the relative positions and ages of the rocks concerned. He confirms the existence of a basal Cambrian conglomerate and of an extensive pre-Cambrian Series, which is the Pebidian of Hicks.

These Pebidian rocks occupy an area of about 7 miles in length, with a maximum width of 2 miles; and according to Mr. Green they consist almost entirely of trachytic and felsitic tuffs, more basic in the lower part, more acid and felspathic in the higher part, the total thickness being over 3000 feet. A well-narked band of conglomerate occurs in the middle of the series and lenticles of shale are seen at several horizons. There do not seem to be any interbedded contemporaneous lava-flows, but rounded pebbles of rhyolite, trachyte, and andesite occur in the tuffs.

The materials of this series are evidently the products of a large volcano or group of volcanoes spread out under water, but whether on the floor of lake or sea cannot be determined. At some later epoch, but still in pre-Cambrian time, the series was invaded by a large intrusive mass of granite and by a number of quartz-porphyry dykes which probably proceed from the deeper parts of the granitic mass.

We arrive, therefore, at the conclusion that Hicks was correct in his reading of the main stratigraphical sequence, but wrong about the age of the granite; while Sir A. Geikie rightly interpreter the relations of the granite, but was mistaken about the base of the Cambrian and in denying the existence of Archsean rocks in Pembrokeshire.

\section{England}

Rocks of Archran age rise to the surface in the following localities: (1) Shropshire (Longmynd, Wrekin, etc.), (2) Warwickshire (Nuneaton), (3) Leicestershire (Charnwood Forest), (4) The Malveru Hills, (5) Devon (Start Point area), (6) Cornwall (Lizard area).

Shropshire.-The largest and most complete area in Fingland is that of the Longinynd, Caradoc, and Wrekin districts. These tracts are shown in Fig. 21. That of the Longnynd has a length of about 10 miles along its western border, with a further outcrop on Haughmond Hill; its greatest breadth is about 6 miles, and it is bounded on each side by lines of fault, and inside the eastern fault another narrow strip is exposed to the south of the main outcrop.

The exact age of the Iongmynd rocks cannot be determined by 
superposition, for their base is not seen and the oldest rocks which overlie them are Silurian. Outside this central area are small tracts of other rocks which are demonstrably pre-Cambrian, but they are chiefly of volcanic origin while those of the Longmynd are sedimentary. Lastly, there is a small faulted inlier of micaceous schist near Rushton which may be older than any of the others.

The volcanic series is known as the Uriconian, from the hill called the Wrekin and the Roman town of Uriconium at its foot. The mass of the Wrekin ridge is made up of a succession of rhyolitic lavas with interbedded bands of ash, grit, conglomerate, and agglomerate. Midway along the ridge there is an intrusive mass of dulerite, and at each end (i.e. on Ercal Hill and Primrose Hill) are patches of granitoid rock which may be intrusive or may belong to an older series. This uncertainty is due to the fact that the junctions appear to be faults, ${ }^{23}$ but pebbles in a conglomerate near the Wrekin prove that the rocks of the surrounding country at the time of its formation consisted principally of (1) a coarse granitoid gneiss like that of the Wrekin, (2) crystalline schists, both quartzose and micaceous, and (3) grits which have clearly been part of a sedimentary series.

Rocks similar to those of the Wrekin occur in the Wrockwardine Hills to the north-west, as well as in the Caradoc and Cardington Hills near Church Stretton, and this volcanic series everywhere strikes nearly east and west, while the Longmyndian and Cambrian rocks strike north-east and south-west (see map, Fig. 21). On the western side of the Longmynd, Pontesford Hill is largely made up of rhyolitic lavas like those of the Wrekin, with intrusive dolerites.

The Longmyndian or sedimentary series of the Longmynd is divisible into an eastern and western portion. The eastern part appears to be the older, and if there is no reduplication of beds the succession is as follows (see Fig. 7), in descending order :-

5. Greenish slates weathering purple, with some grits.

4. Hard greywacke (indurated sandy beds).

3. Purple slates.

2. Banded slates and greywackes.

1. Soft dark shales.

The apparent thickness of these rocks is over 15,000 feet, and they dip regularly; to the north-west, the annelid markings and rain-spots on their upper surfaces proving this to be the true dip, and that we follow an upward succession in going from east to west. No definite fossils have been obtained except soine impressions, which may be those of a Lingulella.

Passing westward this series is succeeded by another set of beds, consisting (1) of reddish felspathic grits with a thick band of con- 
glomerate in the middle, (2) liard purple slates, and (3) purple and reddish-brown grits with lenticular beds of conglomerate. It is uncertain whether this is a true succession, for it is just possible that the double set of reddish grits and conglomerates is a reduplication.

The relation of the western series to the eastern series is also a point of dispute. Professor Blake believed the former to be unconformable to the latter and to be of the same age as some of the grits in the Uriconian Group. In his view the esstern or grey series is the oldest rock-group in the district and the Uriconisn is newer. In favour of this view it may be remarked that the basal Cambrian sandstones have only been found in contact with the Uriconian and not upon any part of the Longnyndian. On the other hand, numerous fragments of the Uriconian rliyolites occur not only in the conglomerates of the western series, but also occasionally as small fragments in the grits of the eastern series. The evidence of actual unconformity is considered very dubious by Dr. Callaway, who also points out that the strike of the two Lougmyndian Series is parallel (from N.N.E. to S.S.W.), while that of the Uriconian is quite different (from east to west). ${ }^{24}$

The balance of evidence seems to be in favour of Dr. Callaway's view, in which case the order of succession would be (1) Uriconian, (2) Eastern Longmynd Series, (3) Western Longwynd Series In this connection it may be mentioned that this last (the red series) has a close lithological resemblance to the Torridon sandstones and it will be remembered that the conglomerates of the latter contain pebbles of a Uriconian rhyolitic type. This tends to confirm Dr. Callaway's opinion and suggests a conparison between the Longmyndian as a whole and the Torridonian of Scotland.

Malvern Hills. - The oldest rocks of the Malvern Hills are also pre-Cambrian, and are interesting because the greater part consists of highly crystalline gneissic rocks, which are probably altered igneous rocks, and are comparable to the Hebridean gmeisses of Scotland and Ireland. This group is known as the Malvernian. Side by side with these is a sumall tract of rocks comparable with the Uriconian of Shropshire, and consisting of rhyolites, andesites, basalts, and felspathic tuffs. ${ }^{25}$ There is nothing here comparable to the Longmyndian Series, but the district lias undergone an enormous amount of compression with plication, shearing, and faulting, as will be seen from the section, Fig. 8 .

Charnwood Forest.-Suall tracts of volcnuic tuffs and breccias, resembling those of the Uriconian, occur at Barnt Green near Birmingham and at Caldecote near Numeaton, and are in both cases covered umconformably by Cambrian strata. A larger tract 
of similar rocks forms the upland district of Charnwood Forest in Leicestershire.

The "Charnian Series" has been described by Messrs. Bonney and E. Hill, ${ }^{26}$ and more recently by Professor Watts, ${ }^{27}$ from whose memoirs the following account is taken. The exposures (partly concealed by Trias) extend over an area about 8 miles long by 5 in breadth, and the strike of the rocks is from north-west to southeast, the general structure being that of a broad anticline broken by faults and flexures. The apparent thickness of the beds exposed, as estimated from a section drawn by Professor Watts, is about $\mathbf{3 5 0 0}$ feet, but neither base nor top is seen.

The oldest rocks (Blackbrook Beds) are hard greenish slates and hornstones, which seem originally to have consisted largely of volcanic dust; with these are some fine gritty beds containing visible quartz-grains, but they are nevertheless hard flinty rocks. The overlying (Maplewell) group consists of coarse volcanic

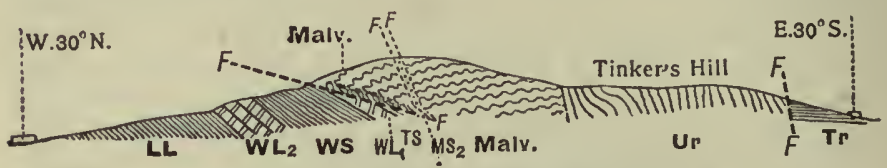

Fig. 8.-SECTION ACross the herEFordshIRE BEACON.

By Professor T. T. Groom (Quart. Journ. Geol. Soc. Ivi. p. 141).

Tr. =Trias. Malv, = Malvernian. F.F. $=$ Faults.

LL to $\mathrm{MS}_{2}=$ Silurian Rocks. Ur. $=$ Uriconian.

breccias and grits with tuff's and ashes, some of the latter being of such fine grain that they form hornstones and slates, either green or purple in colour.

The highest group (Brand Beds) has a conglomerate at the base which contains rounded pebbles of felsite, quartz, quartzite, and slate; this passes up into brown and purple quartzites with some interstratified sandy shales, in which what seem to be worm-casts have been found. These beds are succeeded by green and purple slates (Sivithland slates).

In the north-west corner of the area, forming Bardon Hill and Peldar Tor, there are irregular masses of a porphyritic andesite and dacite, associated with coarse agglomerates. These seem to indicate the site or proximity of a volcanic vent. In the southern part of the area there are large intrusive masses of augite-syenite, and on the east is the hornblendic granite of Mount Sorrel, a rock which is largely quarried for road-metal.

Devon and Cornwall.-The only other exposures of Archæan rocks in England are the two small areas of the Bolt and Start 
district in Devon and the Lizard promontory in Cornwall, and in neither case can the Archiean age of the rocks be proved becanee the adjacent strata belong to the Devonian System.

The area in Devon is that part of the connty which lies inside the headlands of Start Point, Prawle Point, and Bolt Head. It has a length of about 9 miles with an extreme width of 3 from north to south. The rocks of which it consists are divisible into two groups, a lower set of mica and quartz schists and an upper one of green hornblende-epidote schists, known as the Green schists, and obviously altered basic igneous rocks.

The general structure of the eastern half of the ares is that of an irregular anticline, bent over and inverted on the southern side. The northern border is believed to be a fault, and there is everywhere a rapid if not immediate change from foliated rocks to Devonian slates which are comparatively unaltered, except by cleavage and dislocations. Some geologists have maintained that the schists are only highly altered Devonian slates, and have appealed to the facts, - that there is a progressive increase in the intensity of the cleavage in these slates south of Brixhain; that there are appearances of a passage from slates to schists in some places along the boundary line; and that the general strike of both series is the same, i.e. from west to east. It must be remembered, however, that the dominant flexuring of this part of England dates from late Carboniferous time (Armorican folding), while the appearance of a passage may be caused by the occurrence of crushed and broken schists between two lines of fault. If this area is altered Devonian the metamorphism can only be due to the influence of some local cause, such as the existence of a subterraneau Inass of granite, but the balance of evidence seems to be in favour of their Archæan age. ${ }^{28}$

\section{Archean Rocks in Europe}

Outcrops of Archiean rocks, or what are generally regarded as Archrean rocks, occur in France, Spain, Switzerland, Austria, Bohemia, Saxony, the north of Russia, Finland, and Scandinavia Only the more important of these areas can here be described.

\section{France}

In France the chief exposures are found in the north-west . (Brittany and Normandy) and in the Central Plateau.

Brittany.-Pre-Cambrian rocks, witl associated masscs of 
granite, occupy large parts of Brittany, together with the western portions of Normandy, Maine, and Anjou. They have been well described by Prufessor C. Parrois, from whose memoirs the following account has been compiled. ${ }^{29}$ He and other French geologists are inclined to divide them into two main series which they call (1) Archæan and (2) Brioverian, but as they again subdivide the lower series into three portions, and as no break has been observed between any of the divisions, they can be equally well arranged in three series, thus :-

3. Phyllades des St. Lo (=Brioverian).

2. The mica-schists of Groix.

1. The schists of Audierne and gneiss of Quimperlé.

The oldest group is a complex of which a granitoid rock sometimes seems to be the oldest member, but more often the lowest rocks are mica-schists which include bands of ribboned gneiss, white leptynite, amphibolite, and eclogite. In the south these rocks form a continuous tract from 10 to 16 miles in breadth extending from the Bay of Audierne on the west to the valley of the Loire, a distance of about 140 miles. In the north there are two bands of similar rocks, one passing from Brest to Leon with probably a submarine continuation to Guernsey, the other near St. Malo.

Professor Bonney infornis me that he has not seen anything in Western or Northern Brittany, nor in the Cotentin, which is quite comparable with the Hebridean and Malvernian gneiss, and he is inclined to doubt whether such gneiss exists in the region.

The schists of Groix seem to be an upward continuation of the series, being truly crystalline schists of micaceous, chloritic, graphitic, and sillimanitic varieties, with subordinate bands of quartzite (sericitic and graphitic), hornstone, and pyroxenic marble (cipolin). These resemble the Loch Maree Beds.

The Brioverian Series consists of much less altered rocks of a typical Eparchæan character. They exhibit three different facies in different parts of the region : (a) the facies of St. Lo in Normandy and of Central Brittany, comprising the phyllades of St. Lo and Lamballe, the phyllades of Gourin, which include a band of limestone, and the green flags of Neant at the top; $(b)$ the Trégorrois facies in the north of Brittany, consisting of phyllades and quartzose rocks with interstratified eruptives (porphyrites and diabases); (c) lastly, the southern facies, which consists mainly of shales with interbedded bands of coarse felspathic sandstone, recalling the Torridonian of Scotland and suggesting that the Brioverian land lay to the south of Brittany.

These Brioverian deposits are unconformably overlain by the 
purple conglomerate which forms the base of the Cambrian System, and no fossils have been found in them except some microscopic bodies which resenble Radiolaria and Foraminifera.

The Central Plateau. - This is a large region extending from La Chatre and Moulins on the north (Departinents of the Indre and Allier) to the Cevennes in the south, a distance of about 220 miles, while, between Chalus and Brive on the west to the valley of the Rhone on the enst, its breadth is over 160 miles.

This great area consists of a complex of granites, granulites, gneisses of several kinds, micaceous schists, and phyllites, but to what extent these rocks are of pre-Cambrian age is at present uncertain, because the Palrozoic rocks by which they are doubtles surrounded are almost everywhere concealed and overstepped by Mesozoic strata. It is only in the southern border (in the Tarn and Herault Departments) that rocks of Palrozoic age are found in contact with them.

The granites are doubtless all intrusive rocks and the granitoid gneisses may be foliated portions of the same intrusions, like those of Donegal ; while the more highly crystalline portions of the complex are probably those which are most closely associated with these intrusions, being inerely the more altered portions of the micaschist series into which the igneous rocks were intruded. No break or clear plane of separation has been detected in any part of the schistose series, but in several districts along or near the borders of the region there are tracts of still less altered and obviously sedimentary rocks, including arkose sandstones, quartzites, slates, and phyllites comparable with the Brioverian. A long strip of such rocks occurs between Brive and Tulle in the Correze, where Messrs. de Launay and Mouret have described the following descending succession :- ${ }^{30}$

Dark-grey slates and argiilites.

Green slates and phyllites.

Greenish sericitic and micaceous quartzites.

Similarly in the Cevennes on the outer borders of the gneissic rocks there is a considerable thickness of satiny schists or phyllites (schistes luisantes). In the district of Montagne Noir these schists include bands of limestone and appear to pass up into a set of shales and limestones which contain Cambrian fosils. Hance M. Bergeron regards the whole mass of the Montagne Noir as Cambrian, 31 repeated in many parallel flexures and becoming more and more metamorphosed toward the central axis of the mass till the rocks pass into mica-schists and gneisser. He states that the limestones resist alteration longer than the shales, but gradually 
become greenish from the development of augite or hornblende crystals, which increase in size till the rock passes into amphibolite or pyroxemite. By others, however, some of the phyllites are considered to be of Brioverian age.

\section{Austria and Switzerland}

A long tract of crystalline rocks, some of which are probably Archæan, extends from the Graian and Cottian Alps on the borders of France and Italy through the southern part of Switzerland (Pennine, Lepontine, and Rhætian Alps), and is continued eastward through the Tyrol into Carinthia and Styria.

According to von Hauer's map of the Eastern Alps, the fundamental rock of that region is a group of banded hornblendic and micaceous gneisses, which he terms "the Central Gneiss"; outside this is a series of micaceous schists, followed by a formation called the Thonschiefer, i.e. silvery or sheeny schists.

The gneisses of the "Central " group are only occasionally exposed along the central axis of the chain. Those of the Velber-Tauern Pass and the neighbouring Gross Venediger are thus described by Professor Bonney:32 "These, whether micaceous or hornblendic, recalled to my mind certain members, but not the most coarsely crystalline, of the Hebridean of Scotland and the Laurentian of Canada, which are often distinctly modified by subsequent pressure. We also find slightly foliated, coarsely crystalline, granitoid rock with nodes or enclosures, probably a granite subsequently modified, the upper part of the mountain chiefly consisting of the latter rock." The Gross Venediger rises to a height of 12,000 feet.

Overlying these gneisses and apparently passing down into them is a series of fine-grained gneisses and mica-schists, often distinctly banded with white (quartzose) and dark (biotitic) layers, and this bedding-foliation is often modified by a subsequent cleavagefoliation. With these rocks are associated bands of porphyritic gneiss which Professor Bonney regards as igneous rocks intruded into them before the production of the earlier foliation.

The Thonschiefer Series is a well-defined group of rocks which extends throughout the Eastern Alps from the Swiss border nearly as far as Gratz. It consists mainly of leaden-coloured micaceous schists which have glistening sheeny surfaces, but it includes bands of a more quartzose schist with some of calc-schist and crystalline limestone.

Again, in the Western Alps of France, Italy, and Switzerland, Professors Bonney, Gastaldi, and others have recognised a similar succession of (1) coarse banded gneisses apparently succeeded by 
(2) finer greisses and mica-schists, often traversed by dykes of serpentine and epidiorite, and finally a series (3) of nicaceous, calcareous, and chloritic schists, between which and the older schists there is a marked lithological difference and contrast.

Recently, however, grave doubts have been thrown upon the view that these are all Archiean rocks, upon the age of the gueis by Professor J. W. Gregory, ${ }^{33}$ and upon that of the schistes lustrés by Kilian and Parona. Professor Gregory admits the apparent sequence, but fails to find anything like a continuous band of "central gneiss" as represented on certain maps; only independent isolated masses of gneiss which appear to be intrusive granites of very recent date. Monsieur Parona, again, has discovered layers of chert containing Radiolaria in the silvery schists, and the generic assemblage suggests a Carboniferous or even Mresozoic age.

Professor Gregory has specially studied the gneisses of the Cottian Alps and finds that there is clear evidence of contactmetamorphism both in the gneisses and the adjoining schists; that the gneisses invade different parts of the schist series with transgressive junctions; that they include large blocks of the schists and serpentines; that the schists are occasionally traversed by dykes of aplite which appear to be apophyses of the gneissic granite, while the latter is not itself cut by any of the later igneous rocks.

He concludes that the gneiss is really a granite of Pliocene date and that the silvery schists are mainly Palæozoic and probably of Carboniferous age. Thus if these views are correct the only Archran rocks in the Cottian, and indeed in all the Western and Italian Alps, are the series of mica-schists and calc-schists into which the Tertiary granite has been injected.

\section{Bohemia}

Another large area of Archran rocks is exposed in Bolemia and Saxony, extending from the valley of the Danube on the south through the Bohemian Highlands (Bohmer Wald) and the Erzgebirge, and as far as Chemnitz and Dresden on the north, while eastward it ranges into Moravia. In the northern part of this region there is a basin of Palrozoic strata extending from Pilsen to Prague, and on the bolder of this the highest Archiean rocks can be seen to pass below the Cambrian strata.

The Archæan rocks of this region seem to resemble those of the Eastern Alps, and a similar threefold division of them has been made, those supposed to be the oldest consisting of gneisses much interpenetrated by granites. In apparent succession to these are mica-schists and phyllites, with intercalations of amphibolites 
serpentines, eclogites, and crystalline limestones, evidently a series of metamorphosed stratified rocks. Finally on the borders of the Palæozoic basin these schists graduate upward into dark-grey clayslates (Thonschiefer) with some more siliceous layers of lydite or hornstone. These are the Przibram shales which formed the base of Barrande's "Stage A," but as they are overlain unconformably by Cambrian conglomerates they are now separated from the rest of that stage and classed as Archæan.

As in the case of the Alpine Series much doubt has recently been thrown on the old interpretation of the stratigraphy of this area. Some of the gneisses, as well as the granites, are now regarded as intrusive rocks, and no break or definite unconformity has beell detected in the series, so that the whole of it may belong to the later portion of Archran time; at any rate nothing demonstrably

\section{Gr. Ossagebirge Gr.Arber:}

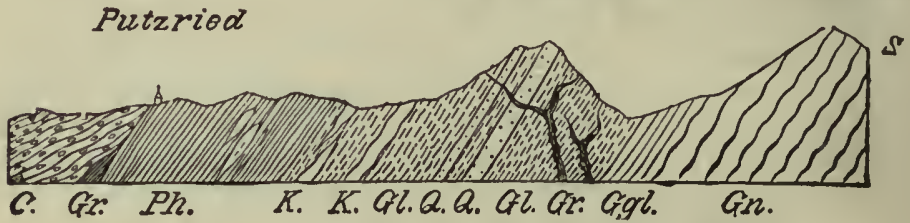

Fig. 9.-SEction throvgh PART of the bohMer Wald (Gumbel).

C. Cambrian.

Ph. Phyllite.
K. Cryst. limestone. Q. Quartzitic schist.
Gl. Mica-schist. Gr. Granite dyke.
Gyl. Gneissic granite. Gn. Gneiss.

Protarchæan and comparable to our Hebridean has yet been recognised.

\section{Scandinavia}

The most extensive exposures of the Archæan platform in Europe are to be found in Norway, Sweden, and Finland. The whole surface area of Finland, except where covered by drift and alluvium, consists of a complex of Archæan rocks with many intrusive masses of granite and porphyry. The greater part also of the Scandinavian peninsula is occupied by a similar complex, which, however, passes beneath a broad, central, and axial band of Cambrian, Ordovician, and Silurian deposits.

The natural eastern border of this band of Palæozoic sediments is obscured by very large tracts or sheets of overthrust and metamorphosed rocks which, according to Scandinavian geologists, include representatives both of the later Archæan and of the Palæozoic Systems. There is consequently a close correspondence 
between the general structure of Scandinavia and that of Scotland, but the overthrust sheets in the former region are on a much larger scale, and appear to include a larger number of formations. Moreover there is this great difference between the two regions, that the forces producing the thrusts have acted from opposite directions, i.e. from the east in Scotland and from the west in Scandinavia; so that in the latter case the unaltered rocks are found in the areas whicl lie to the east of the overthrust tracts, i.e. in Sweden and Finmark.

The large areas occupied by Archaan rocks in the FennoScandian region are partly shown in Fig. 10, which, however, does not include the more eastern districts. The Swedish and Fimnish geologists ${ }^{34}$ now recognise no less than four series or systems of preCambrian rocks: (1) a fundamental complex which is conparable with the Hebridean of Scotland; (2) the Kalevian, which is a series of altered sediments and volcanic rocks; (3) the Jatulian (principally quartzites); (4) the Jotnian and Sparagmite andstones, which seem to correspond with the Torridonian of Scotland.

The fundamental rocks are gneisses of several kinds, some being granitic gneisses which seem to be deformed and foliated granites; another type is the garnetiferous gueiss which is regarded as a combination of stratified gneiss (paragneiss) and gneissic granite (ortlogneiss); while there are also banded grey gneisses (cosrse and fine) and some red granitoid gneiss.

Above these gneisses, and apparently in stratigraphical sequence, is a sedimentary series which in Sweden is called the "Porphyry" Leptite "Group. This consists of mica-schists, green schists, leptites (=altered felspathic tuffs), schistose porphyrites (lavas), crystalline limestones, and iron ores; these rocks occur in regular bedded succession and alternation, but the bedding-planes are nearly always vertical, and the rocks themselves are crystalline. The series seems to be comparable with that of Loch Maree and Glenelg, but is on a much inore extensive scale.

In parts of Lapland, Finland, and Olonetz (Russia), Dr. Sederholm has separated another series of metamorphosed sediments under the name of Kalevian (see Fig. 10), which he regards as newer than the Dalecarlian porphyrites and yet clearly older than the Jatulian. This series consists mainly of quartzites which are often micaceous, and pass into muscovite-schists; they also include lands of conglomerate and occrsionally of talc-schist and dolomite. There are also intercalated sheets of metabasite (i.e. epidiorite).

This series has not yet been identified in Sweden, but Dr. Sederholm thinks it is included in the greatly folded and plicated complex of Northern Sweden, while in the south (Sulaland) there 


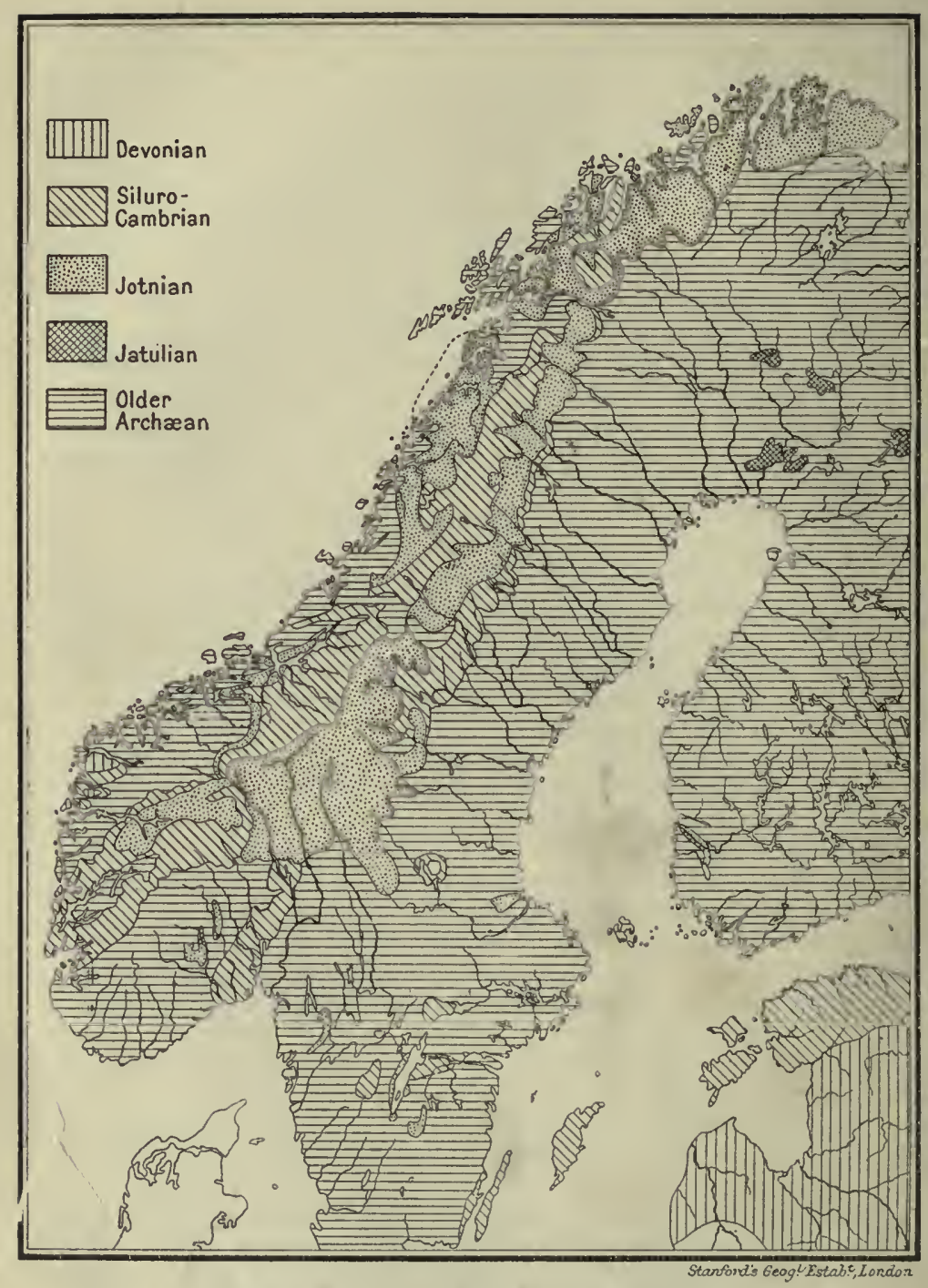

Fig. 10. - GeOLOGICAL SKETCH-MAP OF FENYO-SCANDIA, Showing the areas of Archæan and Palæozoic rocks.

(Based on a map by A. E. Törnebohm.) 
are quartzitic schists on the borler of a large area of granite which much resembles the post-Kalevian granites of Finland.

Here it may be remarked that all the areas occupied by these older Archiean rocks are invaded by large tracts of granite, inost of which are older than the succeeding Jatulian and Jotuian Series.

The typical Jatulian is found in the east of Finland and in Olonetz. It rests with inarked unconformity on the Kalevian, though itself consisting principally of white quartzites with bands of epidiorite. At or near the base are conglonerates containing rolled pebbles of granite, gneiss, and older vitreous quartzites. The Jatulian quartzites often show ripple-marks and desiccation-cracks Above them are dolomitic limestones and shales (or slates), and in several places beds of anthracitic coal occur. The total thicknees is about 2000 feet.

Whether there are any rocks of Jatulian age in Sweden is a matter of doubt. Sederholm regards the Dal formation, which occupies an area to the west of Lake Venern, as Jatulian, but his only reason is that the beds are strongly flexured and affected by pressure-metamorphism. Dr. 'Törnebohm dissents from this view and maintains that the Dalsland Series is Jotnian, the petrological resemblance being very close and the succession very clear, as given below :-

4. Schistose grits, grading into mica-schists

$\cdot \quad \cdot 1300$

3. White quartzite, with some beds of red slate. $\quad . \quad 1500$

2. Dark slates with intercalations of earthy limestone and red sandstone, and two or three sheets of schistose greenstone (=altercd basic igneous rock)

1. Reddish quartzitic sandstoncs, with beds of arkose and con. glomerate at the base.

The typical Jotnian is a great red sandstone formation which has a great developinent in Central Sweden and Norway, extendiug in a nearly continuous band from the area near Lake Miosen to the extreme north-eastern end of Finmark, a distance of about 860 miles. It may be regarded as including the Sparagmite and. stone of Norway, though, where the two come together, the latter overlies the Jotnian with a certain amount of unconformity or contemporaneous erosion, but the time value of the break does not seem to be greater than that between the linglish Keuper and Bunter, so that they form parts of one and the same system. Each part of the series is over 2000 feet thick.

To the east of the overthrust areas the Jotnian sandstones are quite unaltered and lie in nearly horizontal sheets. At the base 
there is a conglomerate, the pebbles in which are chiefly of quartzporphyry and orange-coloured quartzite. The mass of the formation consists of brownish-red or chocolate-coloured felspathic sandstones, in which false-bedding, ripple-marks, and desiccation-cracks are frequently observable. In the higher part thin layers of red shale occur, and there are also intercalated sheets of diabasic lava, some being intrusive sills and others extruded lava-flows which are sometimes amygdaloidal.

In Scandinavia these Jotnian and Sparagmite sandstones rest nearly everywhere on the rocks of the Protarchæan complex, and the unconformity between them is as striking and profound as that between the Torridomian and Hebridean of Scotland. In the latter country, as stated on p. 39, there is evidence of an intermediate formation having existed. In Scandinavia remmants of this (the Jatulian) still exist, but if it ever extended far toward the north it was destroyed before the formation of the Jotnian.

In the western metamorphosed tract the place of the Jotnian sandstones seems to be taken by the Are schists; these are mainly quartzose flags and gneissic schists, including white mica-schists and brown garnetiferous schists. Högbom remarks that petrographically and tectonically the Are schists very much resemble the Moine schists of Scotland. Both he and Törnebohn believe that they have originated from the Sparagmite sandstones, the latter becoming "transformed to mylonites, sericite schists, and white mica-schists within the western thrust areas and the crystallinity increasing from east to west." There is, however, a greater petrological difference between them than can be accounted for in this way, and there "must also have existed a primary difference between the eastern sparagmites and the western schists, a change of facies characterised partly by the entrance of basic igneous rocks into the western series, partly by the substitution of argillaceous and slaty sediments for the gritty sparagmites and conglomerates. The basic rocks just mentioned, which probably are to a great extent tufaceous (i.e. altered tuffs), repeatedly alternate with these argillaceous beds. Generally speaking, one can say that this change of facies goes on slowly from the east or south-east to the west or north-west."

\section{REFERENCES}

1 Bonney in Building of the British Isles, by Jukes-Browne. Third edition, p. 21. (Stanford, 1911.)

2 "Report on Geology of North-West Highlands," Quart. Journ. Geol. Soc. vol. xliv. p. 378 (1888).

3 See "The Geological Structure of the North-West Highlands of Scotland," Mem. Geol. Survey, 1907, p. 192, etc. 
" "Geology of the Isle of Islay," Mem. Geol. Survey (1907), p. 15.

s "The Augen-gneiss and Moine Sediments of Rom-shire," by C. T. ('lough, C. B. Cranstou, and J. S. Flett, ('ed. Mag. (1910), p. 337.

6 E. B. Bailey in Quart. Journ. (Jeol. Suc. vol. Ixv. p. 599.

7 Hicks in Proc. Geol. Assoc. vol. viii. 1) 270.

8 Sir A. Geikie, Pres. Address Geol. Soc. (1891), p. 75.

9 "Geological Structure of North-West Highlands" (supra cil.), p. 275.

10 "Geological Structure of North-West Flighlands" (supra cit.), p. 348.

11 "Geology of the Isle of Islay" (rupra. cil.). p. 19.

18 Sir A. Geikie in Sum. I'rog. Geol. Surcey for 1S99, p. 23.

13 Sir A. Geikie in Pres. Address Geol. Soc. (18:1), n. 41.

is G. A. J. Cole in Trans. Roy. Irish Acad. vol. xxxi. p. 431 (1900).

Is M'Henry in I'roc. Roy. Irish Acad. vol. xxiv. 1). 371 (1903).

16 Cole, "On Composite Gneisses in Boylagh," Proc. Roy. Irish Acal. vol. xxiv. n. 203 (1903).

it Callaway, Quart. Journ. Geol. Soc. vol. lviii. p. 662 (1902).

18 Matley, Quart. Journ. Geol. Soc. vol. Ix. p. 635 (1899).

19 See Huglies, Quart. Journ. Geol. Soc. vol. xxxiv. p. 137 (1878); and Bouney, op. cit. vol. xxxv. p. 309 , vol. $x \times x i x . p .478$ (with inal)).

20 Hicks in Quart. Journ. Geol. Soc. vols. xxxii., xxxiv., and xxxv.

21 Sir A. Geikie, Quart. Journ. Geol. Soc. vol. xxxix, p. 261 (1883).

22 E. J. N. Green, Quart. Journ. Geol. Sic. vol. lxiv. p. 363 (1908).

23 Callaway in Quart. Journ. Geol. Soc. vol. xxxv. p. 643 (1879).

2s Callaway in Quart. Journ. Geol. Soc. vol. xlvii. p. 109 (1891).

25 Consult Callaway, Quart. Journ. Geol. Soc. vol. xxxvi. p. 536 (1880) and vol. li. p. 1 (1895); Acland, vol. liv. p. 556 (1893); and Groom, vol. lv: p. 129 (1899).

${ }_{2 B}$ Bonney and Hill in Quart. Joum. Geol. Soc. vols. xxxiii., xxxiv., and xxxvi. (1877-1879).

27 W. W. Watts in Geol. Mag. for 1896, p. 485, and I'roc. Geol. Assoc. vol, xvii. p. 375 .

28 Bonney, Qreart. Journ. Geol. Soc. vol. xl. p. 1 (1834); Miss C. A. Raisin, op. cit. vol. xliii. p. 715 ; and W. A. E. Ussher, Mem. (ieol. Survey (Kingsbridge, 1904).

22 See papers on "Central Brittany," Proc. Geol. Assoc. rol. xvi. p. 101 (1900), and "Excursion en Bretagne," Livret-Guide de Congrls Gid. Internat. for 1900.

$1^{30}$ See Bulletins de la Carte Geol. de France for 1889 and 1890.

"11 Bergeron, "Etude Géol. du S. du Plateau Central," aud Lirrel-Guide du Cong. Geol. Int. for 1900, "Excursion en Montagne Noir."

s2 Bonney, Quart. Journ. Geol. Soc. vol. xlv. p. $\$ 9$ (1839).

33 J. W. Gregory, Quart. Journ. Geol. Soc. vol. 1. p. 232 (18\$4).

s Consult A. F. Törnebohı, Livret-Guide I. of Interuat. Geol. Congresa at Stockholm (1910); Högboin, "Pre-Cambrian Geology of Swolen," Bull. Geol. Inst. Upsala, vol. x. (1910); and Sederholm, "Les Ruches pre-quater. naires de la Fenno-Scandia," extrait de $l$ Attas de sinlande, Helsingfora (1910). 


\section{CHAPTER V}

\section{THE CAMBRIAN SYSTEM}

\section{A. Nomenclature and Classification}

THE establishment of three separate systems among the Lower Palæozoic rocks was not accomplished without much controversy, for in early days only two were recognised, and both were made more comprehensive than they ought to have been.

The well-known name Silurian (from the British tribe of Silures who inhabited the western parts of Wales and its borders) was first introduced by Sir Roderick Murchison in 1835 to designate the series of rocks which he had studied in the land of the Silures (Shropshire, Herefordshire, and South Wales); he divided this system into an upper and a lower series. ${ }^{1} a$

In the meantime, between the years 1831 and 1835, Professor Sedgwick had worked out the complete succession of the Palæozoic rocks in North Wales, and in 1835 he proposed the name Cambrian for this series, which he divided into three portions, calling them Lower, Middle, and Upper Cambrian. For the beds which overlie this series in the Berwyn Mountains he adopted Murchison's name of Silurian. ${ }^{2}$

Sedgwick worked out the succession from below upwards, and Murchison worked from above downwards, and for a long time neither was aware of the fact that their systems overlapped each other. Murchison supposed that Sedgwick's Cambrian lay entirely below his Silurian, but when the fossils were collected and described, it was found that the Upper Cambrian was equivalent to the Lower Silurian, and this fact led to much subsequent controversy.

As Murchison became the Director-General of the Geological Survey, his nomenclature was naturally adopted by the surveyors, and as they found that his Lower Silurian had no natural base, group after group of Sedgwick's Cambrian was gradually absorbed

\footnotetext{
a For references see end of the chapter.
} 
into it, till the Lower Silurian came to include the whole of the rocks (below the Upper Silurian) in which any fossils had been found. This was obviously unfair and unscientific, since the so. called Lower Silurian was in reality a part of Sedgwick's Cambrian Series, the delineation of which by Sedgwick was accurate and complete. Still it was done, and the name Lower Silurian was generally adopted both in England and abroad.

The fact is, Sedgwick and Murchison both deseribed nore than one system of rocks, and each included two systems under one name. Sedgwick had clearly a right to call one system Cambrian and Murchison to call one Silurian, but there is really a thind intermediate system, containing the second great fauna in the lifehistory of the globe, and to this neither geologist had a distinct claim. For this intermediate system Professor Lapworth proposed the name Ordovician (from the tribe of the Ordovices who inlabited North Wales), remarking, "That so long as present systems of nomenclature survive, nothing can disturb the application of the title Cambrian to the rocks of the 'Primordial Series,' and that of Silurian to the strata of the 'Third Fauna.' It is vastly different, however, with the intermediate series, which has been the object of incessant disputes from the day it was recognised until now." This proposal lias met with very general acceptance, and has recently been adopted by the Geological Survey.

The following table shows the original arrangements of Sedgwick and Murchison, that formerly used by the Geological Survey, and lastly the one which is now in general use.

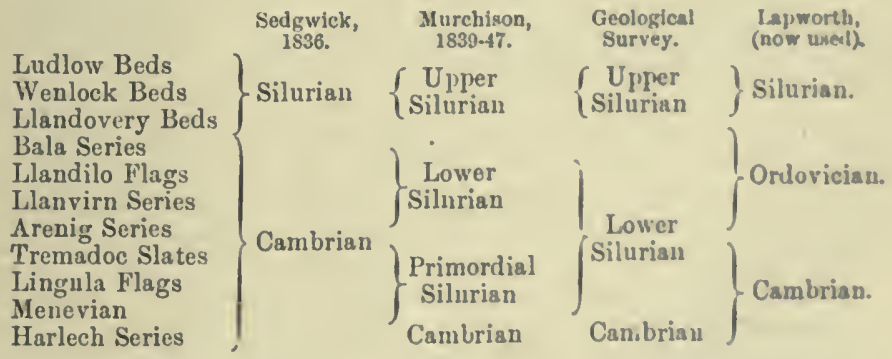

Classiflcation of the Cambrian System.-Since the time of Sedgwick and Murchison the Cambrian rocks have been investigated much more completely, and fossils have been found at various horizons down to the very base of the systen. Fresh subdivisions have been established and new names introduced into the nomenchture. A Menevian Group has been separated from the Lingula flags, and 
the Harlech Series was found to be divisible into two groups (the Caerfai and the Solva Beds). It has, moreover, been found that the whole succession is divisible into series which are characterised by special genera of trilobites, and that in many places a further subdivision can be made into zones based on the limitation of certain fossils (see p. 22). Thus the old lithological grouping has been modified to agree with the palieontological evidence, and the best modern arrangement of the rock-groups that compose the Cambrian system in England is as follows :-

Upper $\left\{\begin{array}{l}\text { Tremadoe Beds } \\ \text { Lingula Flags (in three stages) }\end{array}=\right.$ the Bryograptus fauna.
Middle $\left\{\begin{array}{l}\text { Menevian Beds } \\ \text { Solva Beds }\end{array}\right\}$
Lower $=$ Caerfai Beds

\section{B. Life of the Period}

Great interest attaches to the fossils which have been found in the Cambrian rocks, because, with the exception of the few organic remains mentioned on p. 61 , they include the remains of the oldest animals hitherto discovered. At the same time the number of different classes of creatures which exist in the oldest Cambrian fauna make it certain that ancestors of these creatures must have existed in pre-Cambrian times, and there can be little doubt that some of them will sooner or later be discovered in the higher pre-Cambrian rocks.

The fossils which have been found in the Lower and Middle Cambrian of Wales and Shropshire are referable to the following groups-Porifera, Cystidea, Annelida, Brachiopoda, Gastropoda, and Crustacea; while representatives of Actinozoa, Crinoidea, Graptolitoida, and Lamellibranchia have also been obtained from rocks of the same age in North America. The very existence of so many different kinds of animals at this early period is a remarkable fact, and is a proof of the great gap which exists between the Cambrian and the pre-Cambrian rocks of Westeru Europe.

But although referred to many different classes, examination of the fossils themselves reveals the fact that most of them are represented by lowly and more or less generalised forms-that is, forms which combine in themselves characters that are now only found in two or more distinct families or orders of beings. Thus Archoeocyathus and its allies have been classed by some with the Sponges and by others with Corals, and they are now regarded as a primitive family intermediate between Porifera and Actinozoa, and possibly representing the stock from which both these classes were derived. 
The Cystidea again are placed by systematists at the bottom of the Echinoderma, and appear to represent an early stage in the evolution of the Echinoderm race.

Two of the Lower Cambrian Brachiopods (Lingulella aud Orbiculoidea) are low forms of that class, and the others, Obolella and Kutorgina, were not much more highly organised. No Lamellibranchia have yet been found in the Lower Cambriau of Europe, but some small fossils fomd in North America are referred to this class. The Gastropoda are represented by the genus Hyolithes and its allies, which are usually referred to the Pteropods, though their real aftinities are very doubtful. More typical Gastropods appear in the Lower Cambrian of Anerica and in the Middle Cambrian of Scotland.

Crustacea are represented by the Entomostraca and Trilobita. The former are true Crustacea of low organisation; the latter exhibit a curious mingling of characters, which have led some authors to exclude then from the Crustacea, but Professor Beecher 4 remarks that Trilobites show the clearest evidence of primitive ('rustacean affinities.

In the Middle and Upper Cambrian Hydrozoa (Graptolites), Crinoid and Asteroid Echinoderns, Phyllucarid Crustacea, a few Lamellibranchs and Gastropods, with some Nautiloid Cephalo. poda make their appearance The occurrence of Cephalopoda, the highest of the Molluscan classes, suggests that the evolution and development of marine Mollusea imust have been especially rapid during this early period of the earth's history, or else that their ancestors existed somewhere long before Cambrian times.

The following are the principal characteristic species of the several faunas which have been recognised in the Cambrian System.

\section{Lower Cambrian (Olenellus Futua)}

Ostracoda. Leperditia canbrensis.

Annelida. Serpulites fistula, Scolitluus linearis.

Trilobila. Olenellus Callavei, O. Lapworthi, O. internedius, Olenel. loides armatus.

Irrachiopoda. Lingulella primæva, Orbicnloidea caerfaiensis, Kutorgina cingulata, Obolella Salteri, Acrotreta Sabrius.

Gastropoda. Hyolithes princeps, Ortliotheca Gecri, Stenotheca rugosa, Coleoloides typicalis, Salterella pulchella, S. Maccullochi.

\section{Niddle Cumbrian (Paraloxides Fauna)}

P'orifera. Protospongia fenestrata (S. and M.), P. major (S.).

Cysidea. Protocystis menevensis (M.).

a S. indicates oceurrence in Solva Beds, M. in Menevian. 

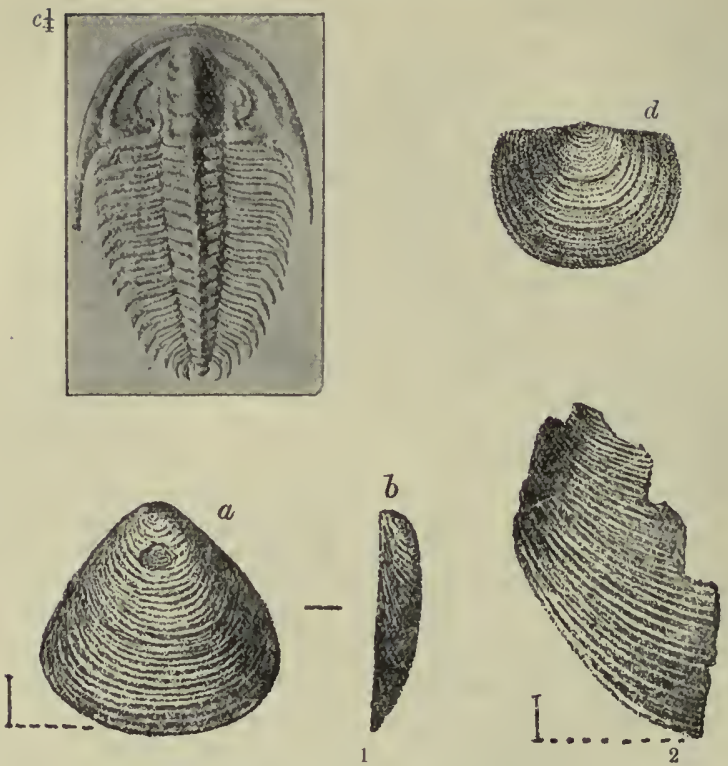

Fig. 11.-GROUP OF LOWER CAMBRIAN YOSSILS.

1. $a, b$. Obolella Groomi (enlarged).

2. The same (shell highly enlarged). c. Olenellus Callavei (reduced).

d. Kutorgina cingulata (enlarged).
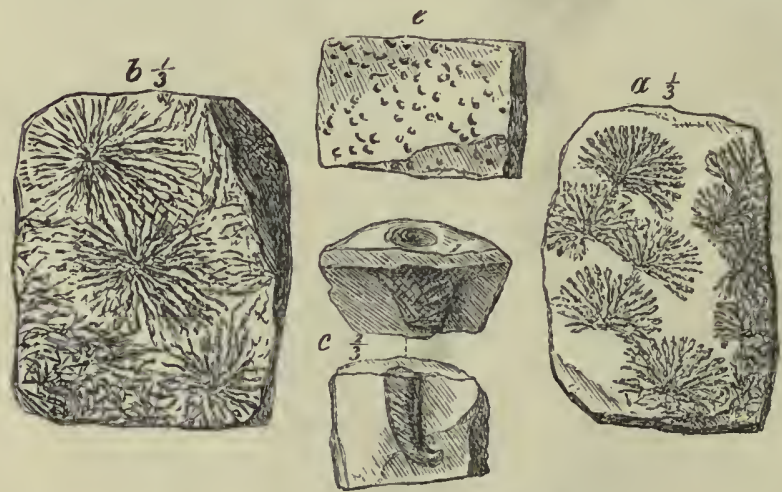

Fig. 12.-GROUP OF IRISH CAMBRIAN FOSSILS.

a. Oldhamia antiqua.

b. Oldhamia radiata. c. Histioderma hibernicum.

e. Arenicolites didyma. 
Trilobila. Paradoxides Harknessi (S.), P. aurora (S.), P. Davidis (M.), Erinnys venulosa (M.), Conocoryphe Lyelli (S.), C. solvensis (S.), Plutonia Sedgwicki (S.), Solenopleuro variolaris (M.), Agnostus cambrensis (S.), Microdiscus sculptus (S.), M. punctatus (MI.).

Brachiopoda. Lingulella ferruginea (S. and MI.), Obolella sagittalis, (S. and M.), Orbiculoides pileolus (S. and M.), Orthis Hicksi (M.).
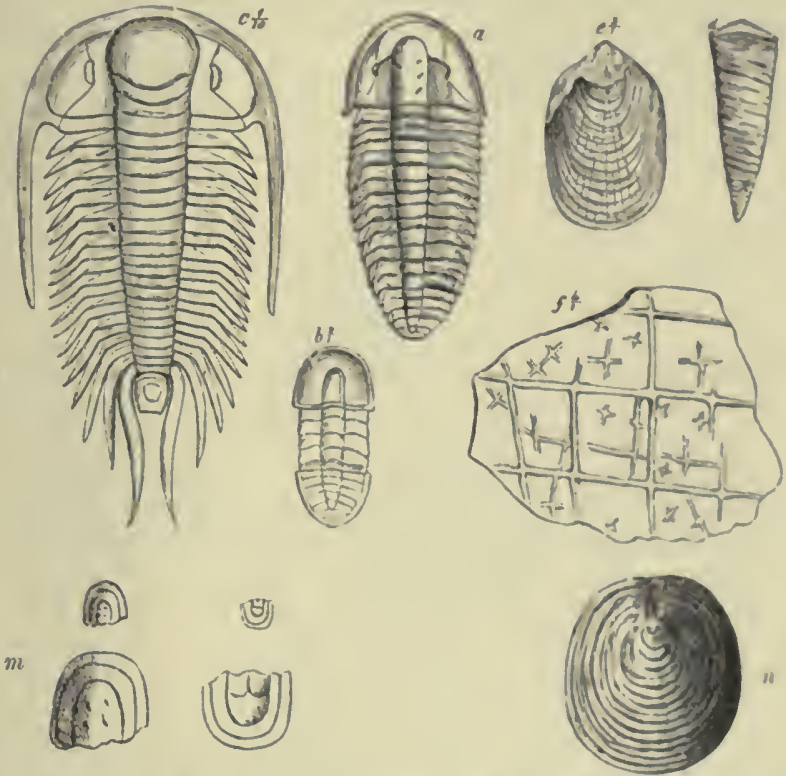

Hig. 13.-GROUP OF LOWER CANBRIAX YOSBILA.

u. Conocoryphe Lyelli.

b. Microdiscus sculptus.

$\therefore$ Paradoxldes Davidis. d. Hyolithes corrugat11.

e. Lingulella ferruginea.

f. Protospongia fenestella. m. Ignostuy Cambrensis (nat. sleo and enlangwl). n. Orbilculolelow pllinolus (much enlarged).

Gastropoda. Hyolithes antiqua (S.), H. corrugata (M.), Cyrtotheca hamula (M.).

\section{Upper Cambrian (Lingula Flays)}

Annelida. Cruziana semiplicata, Oldhamia antiqua, O. radiata, Histioderma libernica.

Trilobilu. Olenus cataractes, O. micrurus, P'eltura searahneoides, Parabolina spinulosa, Conocoryphe buceplala, Agnostus pisiformis, $\Lambda$. trisectus.

Phyllocarida. Hymenocaris vermicauda. 
Brachiopoda.

Gastropoda.

Hydrozoa.

Echinoderma. Trilobita.

Brachiopoda.

Lamellibranchia.

Gastropoda.

Cephalopoda.

Lingulella Davisii, Orthis lenticularis (and in Tremadoc).

Bellerophon cambrensis.

\section{Upper Cambrian (Tremadoc)}

Dictyograptus socialis (=Dictyonema), Bryograptus Callavei, B. Kjerulfi.

Dendrocrinus cambrensis, Palæasterina ramseyensis.

Asaphellus Homfrayi, Ogygia scutatrix, Niobe Homfrayi, Angelina Sedgwicki, Sphærophtlialmus alatus, Peltura punctata.

Lingulella lepis, Obolella Belti, O. sabrinæ, Orthis lenticularis, and O. Carausi, Orthisina festinata.

Palæarca Hopkinsoni, Glyptarca primæva, Ctenodonta menapiensis.

Hyolithes cuspidatus, Conularia Homfrayi, Bellerophon arfonensis.

Orthoceras sericeum, O. mendax, Cyrtoceras præcox.

\section{British Cambrian Rocks}

Range and Relation to Rocks below.-Cambrian rocks rise to the surface in several parts of England and Wales, as well as in Ireland and Scotland, but they nowhere occupy any large tract of country and they exhibit several very different facies, so that it is with some difficulty that the component members of these isolated exposures can be compared with one another.

In Wales, the typical area, there are four districts where Cambrian strata emerge from beneath the overlying Ordovician, namely in Pembrokeshire, Merionethshire, Carnarvonshire, and Anglesey. In England there are six outcrops, but all are small; these are (1) The Malvern Hills, (2) The Wrekin area in Shropshire, (3) The Lickey (N. Worcestershire), (4) near Nuneaton in Warwickshire, (5) The Lake District, and (6) The Isle of Man.

In Ireland rocks which are believed to be of Upper Cambrian age occur in Wicklow and Wexford, but they contain very few organic remains, and none of the Welsh Cambrian fossils have yet been found in them.

In Scotland they have only yet been recognised in the extreme north-west (Sutherland, Ross, and Skye), where they consist mainly of limestones, and thus exhibit a very different facies from those occurring in the more southern areas.

Wherever the base of the Lower Cambrian Series is exposed, it is seen to rest unconformably upon an eroded and planed down surface of the Archæan rocks. This is conspicuously the case in Scotland and in most of the English localities, but the base is not exposed in Cumberland, the Isle of Man, nor in Ireland. 

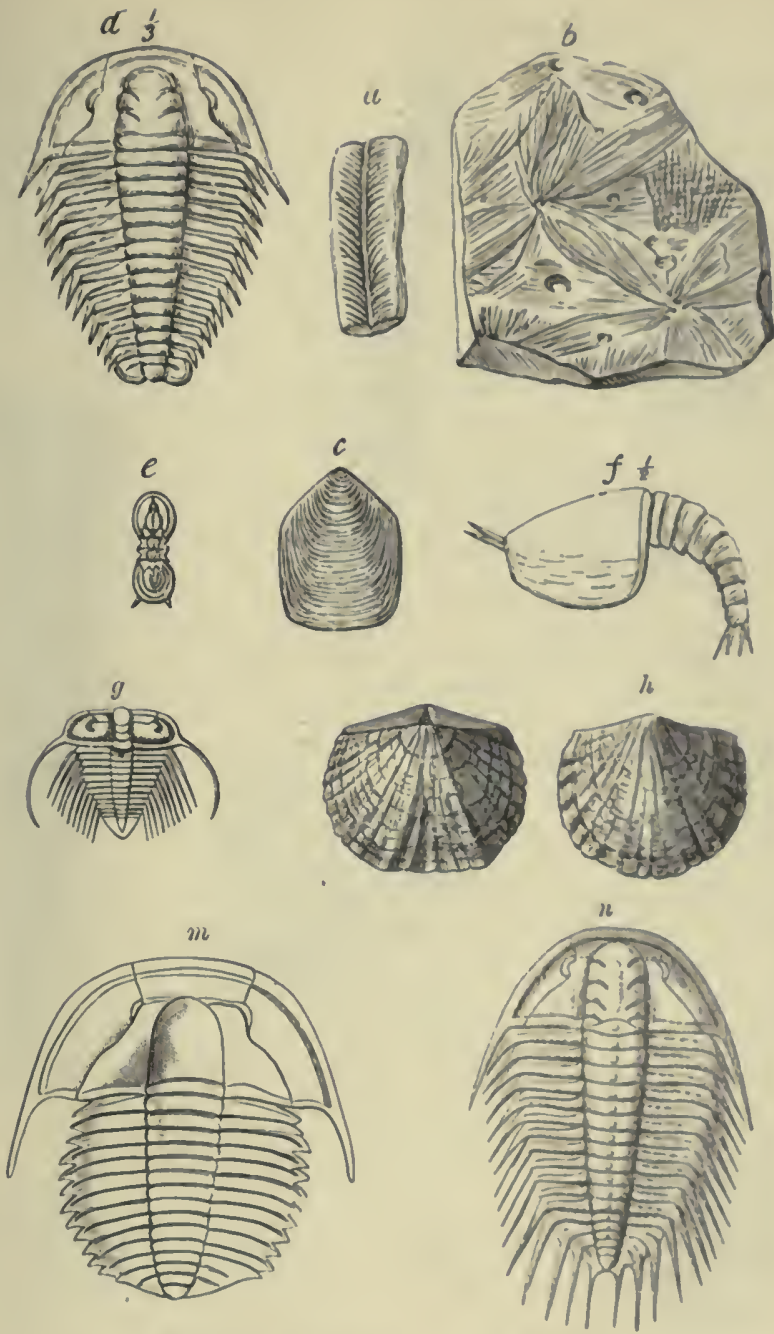

Fig. 14.-GRovP OF Livgula flan roesila

a. Cruziana semipificate.

b. Dictyonema socinle.

c. Lingulella Davisi.

d. Olenus micrurus.

e. Agnostus pisiformis. f. Hymenocarls vermicanda.

g. Sphuerophthalnutus alatue.

h. Ortlsin fenticularix.

m. Cunocory phe bueepluale.

n. P'arabolina spinulosa. 


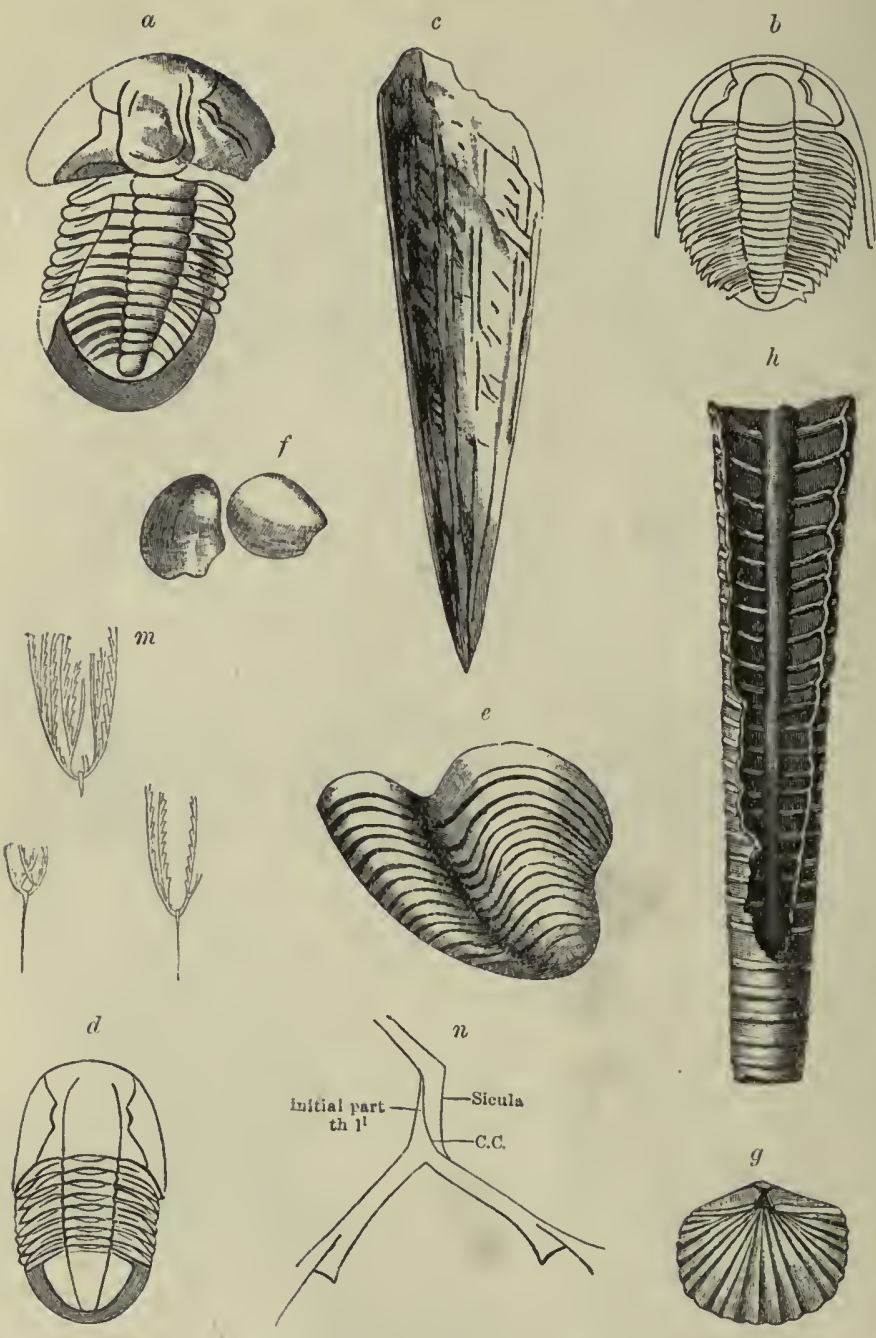

Fig. 15. - GROUP OF TREMADOC Fossils.
a. Asaphus Homfrayi.
b. Angelina Sedgwicki.
c. Conularia Homfrayi.
d. Niobe Homfrayi.
e. Bellerophon arfonensis.

f. Palæarea Hopkinsoni.

g. Orthis Carausi.

h. Orthoceras mendax.

$m$. Bryograptus Kjerulfi.

$n$. Part of same magnitied. 


\section{The Cambrian of Wales}

Though the exposed tracts of Cambrian rocks in Wales are rather far apart it will be convenient to treat the whole as one area, because the several tracts are doubtless portions of oue continuous subterranean mass, and because in process of time the same stages and subdivisions will probably be recognised in all the separate districts.

Both in this and subsequent chapters I shall assume that the student possesses a copy of the cheap general Geological Map of the British Islands, published by the Geological Survey (see p. 27), so that he may see at a glance the relative positions of the areas described. 'The descriptions here given will in some cases be illustrated by special maps, and for other parts of the country the reader can obtain the Index maps of Eugland and Southeru Scotland, which are published in sheets (see p. 28).

The Cambrian rocks of North Wales were first described and classified by Professor Sedgwick, and the lowest series of beds, in which he found no fossils, were terined by him the Harlech yrits. The beds in Pembrokeshire were first properly identified and described by Dr. H. Hicks, ${ }^{5}$ who obtained fossils from the equivalents of the Harlech grits, and was thus led to divide the series into two groups which he named respectively the Caerfai Beds and Solva Beds. He was also the first to separate the Menevian from - the Lingula flags, and to make a detailed map of the St. David's area which is reproduced in Fig. 16.

We shall now indicate the representatives of the three divisions of the Cambrian (Lower, Middle, and Upper) in each of the separate areas, so far as it is possible to do so.

Olenellian or Lower Cambrian-In Pembrokeshire this series, named Caerfai Beds by Dr. Hicks, is estimated to have a thickness of about 1600 feet, and to consist of the following sets of beds in descending order:-

Purple sandstones with Amelid tracks . Fech.

Red shales with Lingulella primeva, Diseina, and fragments of Olenellus Flaggy sandstones with Anmelid niarkings Conglomerates

The basal bed of this series is the Cambrian conglomerate so frequently mentioned in the preceding chapter. Near St. David'B it is about 60 feet thick, and consists of well-rounderl jebbles set in a matrix which is a mixture of sandy and aslyy materials; 
solnetimes the ashy element appears to predominate, sometimes it is a true arkose, consisting of quartz-sand and decomposed felspar. The pebbles vary in size, ranging up to a foot in diameter; they consist principally of a reddish quartzile and of quartz, but include some of quartz-felsite, porcellanite, schist, and granitoid rock, all derived from the underlying pre-Cambrian rocks.

In Merioneth the equivalents of the Caerfai Series are to be found in the central parts of the Harlech dome (see Fig. 19). The

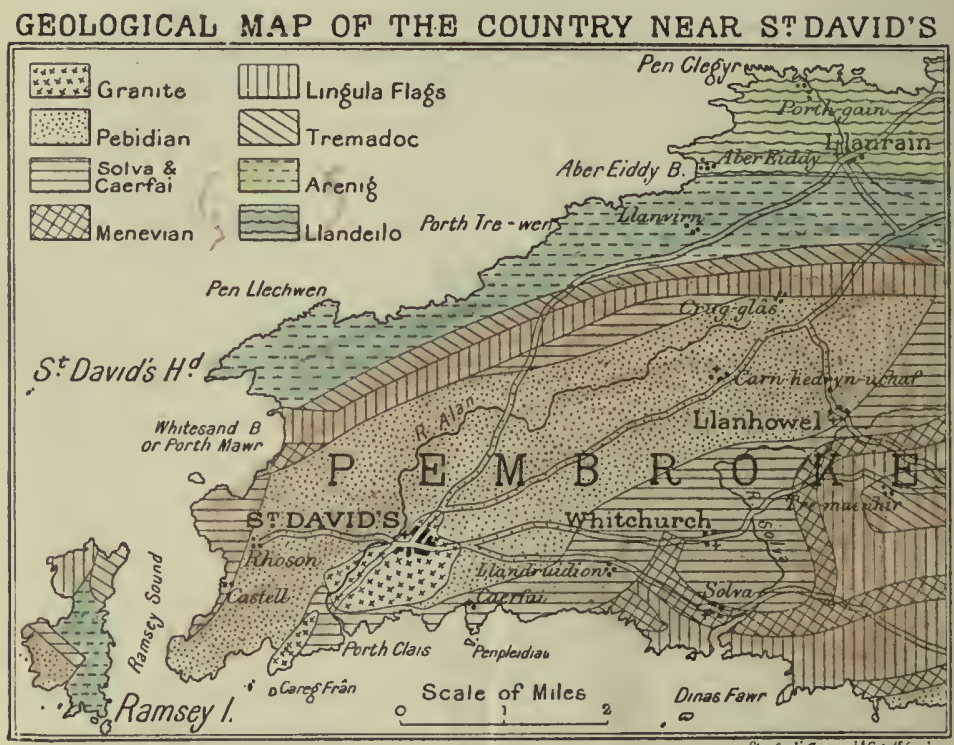

Fig. 16. - MAP OF PART OF jOUTH WALES (after Hicks).

great Harlech Series, believed to be from 5000 to 6000 feet thick, was not subdivided by Sir A. Ramsay and the officers of the Geological Survey, but quite recently Professor Lapworth and Dr. T. S. Wilson have mapped a large part of the district and have determined the sequeice of the beds. Their detailed descriptions have not yet been published, but they have allowed a summary of the succession to be printed in a paper by Mr. A. R. Andrews, and from this the following brief account is gleaned.

The lowest keds occupy the coast between Egryn Abbey and Llanfair and extend eastward to the Rhinog Mountains. The red felspathic grits of Dolwen are probably not far from the base of the 
series, which, however, is not exposed. Above them are blue and purple slates and grits (the Cefu Slate Group) of which there may be 1000 feet. These are succeeded by the Ihinoy grits, which lave a thickness of about 2500 feet. These two groups may be regarded as representing the Lower Cambrian.

Passing under the great mountain mass of the Suowdon range, the Harlech Series again emerges and occupies a considerable area in Carnarvonshire from the coast near Clynnog to Penrlyn and Llanllechid on the north-west, lying on both sides of the axial ridge of Archrean rocks. The basal beds are grits and conglonerates, which contain pebbles of granite, quartz-felsite, and porcellanite derived from the pre-Cambrian rocks described in the precoding chapter. These are succeeded by a thick series of purple and green slates, some of which are worked at the celebrated slate quarries of Penrhyn and Llanberis; above these again are coarse grits and sandstones. The total thickness on the eastern side of the anticline near Llanberis is estimated at about 3000 feet.

The beds exposed in and near the Penrhyn slate quarries were described by Professor T. M'K. Hughes in 1889, from wliose pajer the following condensed account of the succession is taken:-

$$
\text { Lingula llags with L. Davisii. }
$$

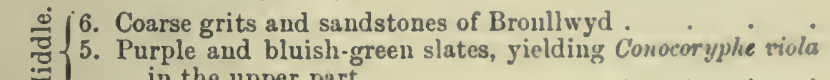

$\cdot$ in the upper part .

4. Band of fine red grit (15 feet).

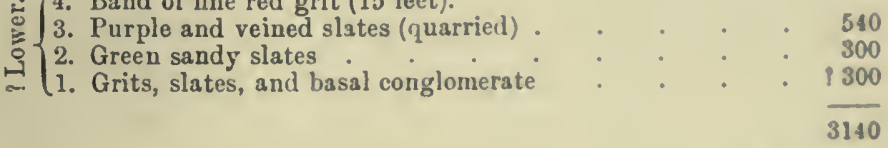

Of these beds 1 to 4 may represent the Caerfai Series, but as no fossils have yet been found in them correlation is uncertain.

Paradoxidian or Middle Cambrian.-This series is distinguished by the presence of seversl species of the Trilobite genus Paradoxides. In Pembrokeshire it was divided by Dr. Hicks into two stages, the Solva Group and the Menevian Group, Menevia being the ancient name of St. David's. He also recognised the following subdivisions or zones:- 


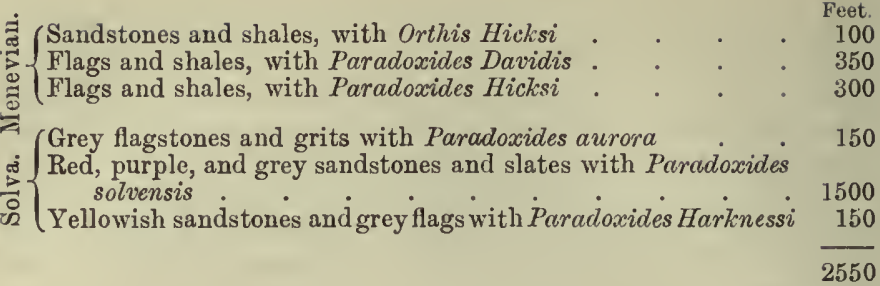

The lowest beds are yellowish sandstones with some pebble beds, and above these are grey flags which have yielded a number of fossils, including Paradoxides Harknessi, Plutonia Sedgwicki, Microdiscus sculptus, Conocoryphe Lyelli, Agnostus cambrensis, and Hyolithes antiqua. The central group is of "great thickness and yields fragments of fossils at different horizons, but it was only near the top that Dr. Hicks found Paradoxides solvensis and Conocoryphe solvensis with some other fossils. The upper beds contain other species of Paradoxides and Conocoryphe, while Agnostus cambrensis and Lingulella ferruginea occur in all three groups.

The Menevian Group consists mainly of dark-grey flagstones and black shales, and from the middle zone Dr. Hicks obtained 28 species of fossils belonging to the Trilobite genera Paradoxides, Conocoryphe, Microdiscus, Anopolenus, Arionellus, Erinnys, Agnostus, and Holocephalina with Brachiopods of the genera Lingulella, Discina, Obolella, and Orthis; and some Gasteropod Mollusca of the genera Hyolithes, Stenotheca, and Cyrtotheca.

In Merioneth, according to Messrs. Lapworth and Wilson, the series is represented by the following succession of beds:-

Clogan Beds (= Menevian), black shales and slates

Feet.

Gamlan Shales, a series of grey and greenish shales and flags, with

beds of grit which thicken eastward

250

Barmouth Grits, thick felspathic grits with some bands of pebbles Hafotty or Manganese Shales, grey and green shales and flags with

grits which thicken eastward.

No fossils have yet been found in the great series of greenishgrey shales and grits which seem to be the equivalents of the Solva stage, but the Menevian has yielded 19 species, including 5 species of Agnostus, 2 of Anopolenus, 3 of Paradoxides with Microdiscus punctatus, Lingulella ferruginea, and Hyolithes corrugata.

In Carnarvonshire the Solva Group is evidently represented by the upper green and purple slates of Llanberis and of Penrhyn 

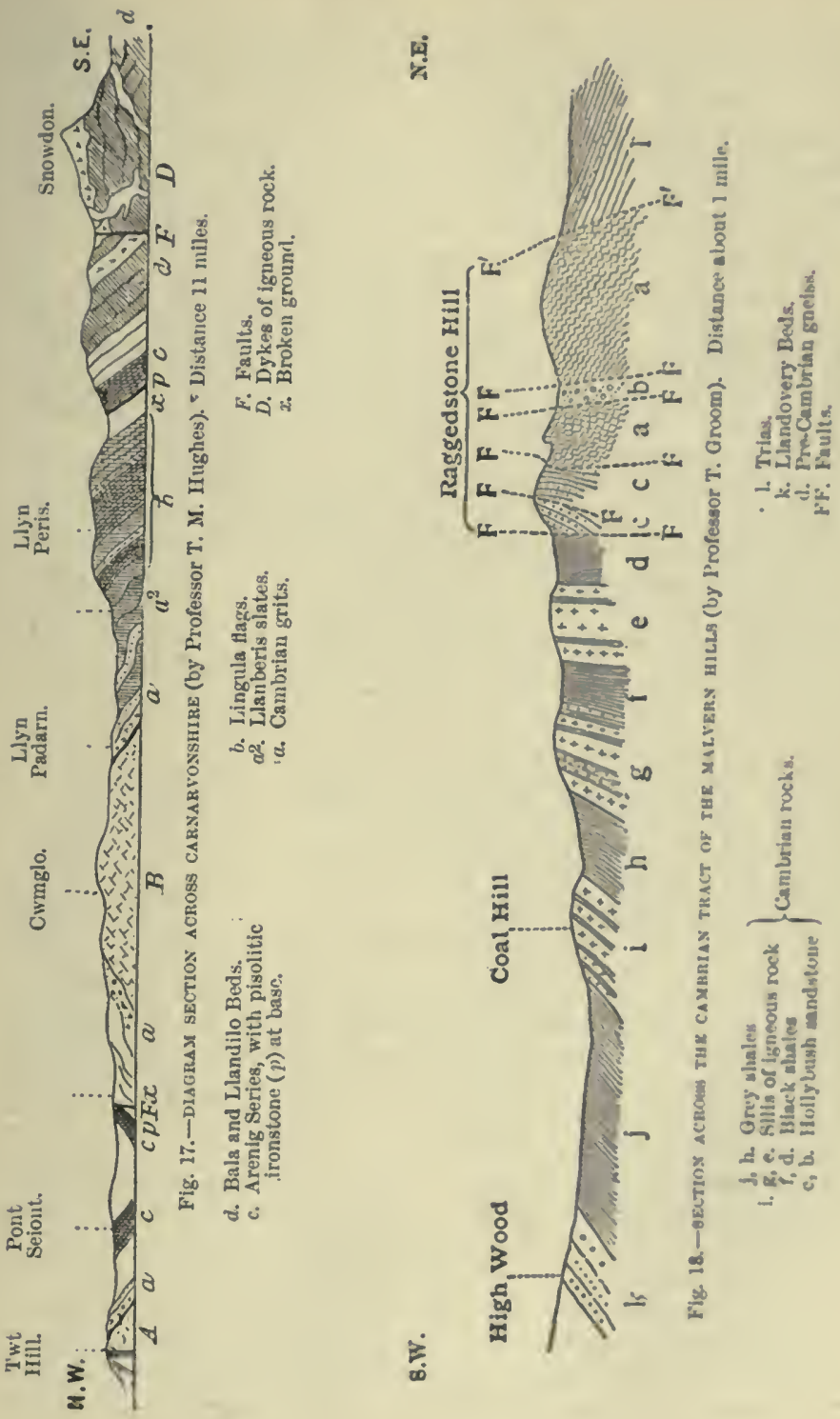
in which Conocoryphe viola was found (see p. 81), but nothing like the black Menevian slates and mudstones appears to exist in that area. Whether originally present and now cut out by faults, or whether they were eroded before the deposition of the Lingula flags, is a question for future investigation. Mr. Fearnsides is of opinion that there are local unconformities at the base of the Upper Cambrian, and that this absence of the Menevian in Carnarvonshire is probably due to erosion.

Olenian or Upper Cambrian.-As already stated this consists of the groups known as the Lingula flags and the Tremadoc Beds, and as in the case of the molrlying Middle and Lower Cambrians their thickness is greatest in Merioneth, which seems to have been near the centre of the Welsh basin of deposition in Cambrian time.

In Pembrokeshire the total thickness of this division is not half that which it attains in Merioneth, though some of the same zones or subdivisions seem to be represented. The area has not yet been resurveyed by the Geological Survey and Dr. Hicks' account of them is still the best available, but Mr. J. F. N. Green considers it probable that there is a break or non-sequence between the Lingula flags and the Tremadoc. ${ }^{7}$ The succession is as follows :-

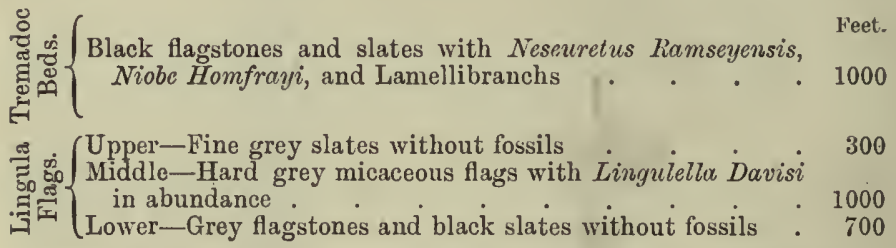

These beds appear to form a continuous band along the northern side of the Cambrian area from Whitesand Bay to the country soutl of Llanvirn and beyond Crugglas (see Fig. 16); east of St. David's they are seen in Solva Harbour, and inland they spread eastward round another tract of Lower and Middle Cambrian rocks of which little is yet known.

Another small tract of Lower Tremadoc Beds is found round Tremanhire, a place about 4 miles east of St. David's; they are brought in above the Lingula flags by a synclinal flexure, and have yielded many of the same fossils as in Ramsey Island.

Tremadoc slates have also been found to the south of Caermarthen by the Misses Crossfield and Skeat, and their presence there is interesting as it was unsuspected. They yielded Orthoceras sericeum and two new species of Trilobites, Peltura punctata and Ogygia 
murginata. The outcrop forms a narrow band between that of the Ordovician and the area of Old Red Sandstone to the soutl.

\section{GEOLOGICAL MAP OF A PART OF NORTH WALES}

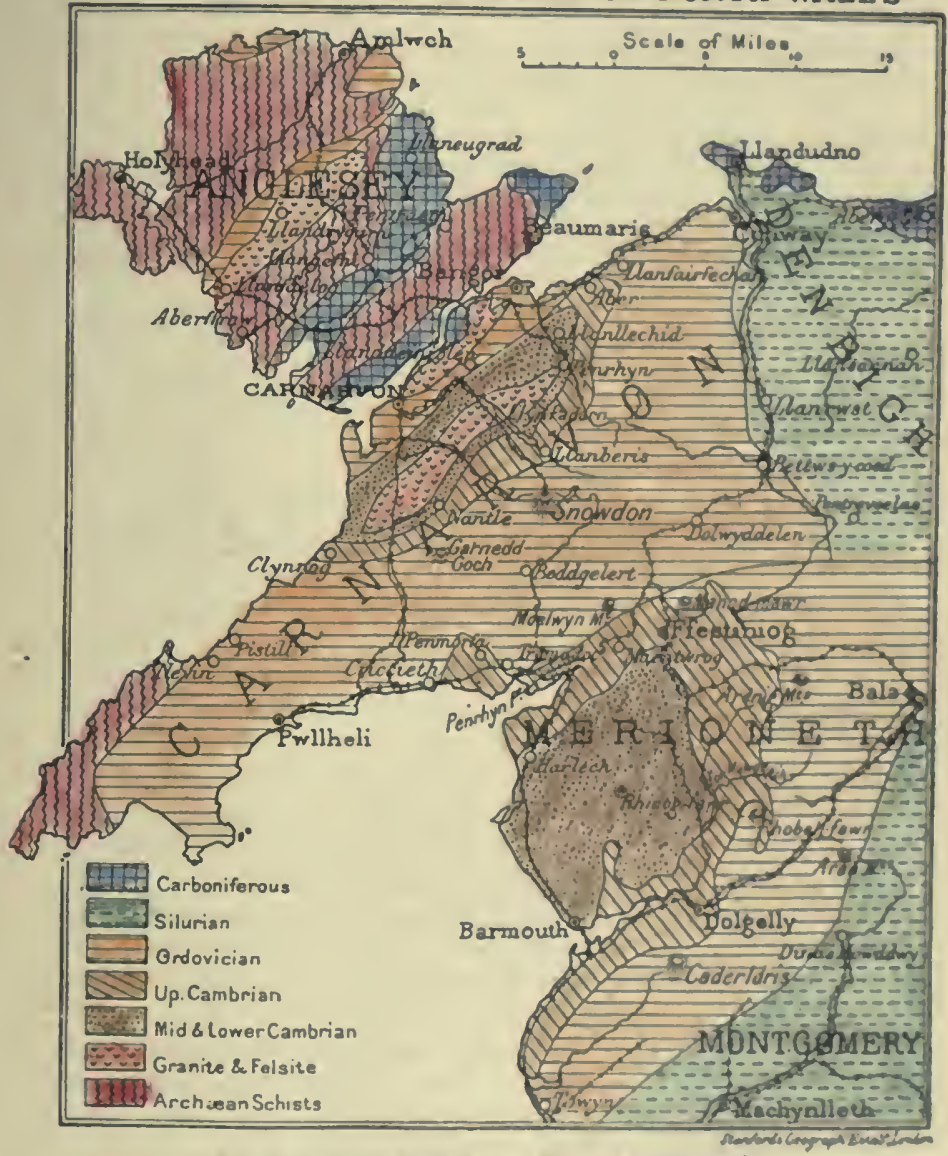

Fig. 19,-MAP OF NORTH WALES (mom recent sources).

In Merioneth the Lingula flags alone attain a thickness of over 6000 feet, while the overlying Tremadoc Beds have a maxinum thickness of about 2000 feet.

The Lingula flags form a continuous belt all round the 
Harlech dome (see Fig. 19). They are well exposed near Dolgelly and Ffestiniog and were studied in 1867 by Mr. Belt, who subdivided them into three groups, each characterised by a certain assemblage of Trilobites and other fossils. More recently they have been examined by Professor Lapworth and Dr. Wilson (op. cit.), who appear to accept and confirm Belt's main divisions, wlich are as follows with thicknesses corrected by the later estimates.

Deet.

Dolgelly f Soft black shales with Peltura scarabcoides . $\quad 300$

Beds $\{$ Hard blue slates with Parabolina spinulosa . . 300

Ffestiniog f Bluish-grey flags with Olenus micrurus . . . $\quad$. 50

Beds $\{$ Grey micaceous flags with Hymenocaris . . . $\quad 3000$

Maentwrog $\int$ Black slates and flags with Olenus gibbosus . $\quad$. 1600

Beds (Dark-grey flags and shales with 0 . catarcetes . . 1000

About 6250

The lower portion of the Maentwrog Beds has been termed the Vigra Beds by Messrs. Lapworth and Wilson, and the higher

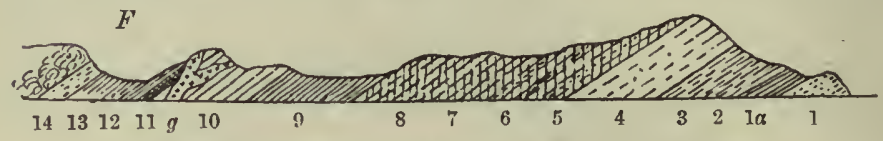

Fic. 20. - SECTION ACROSS THE PENRHYN PROMONTORY (after Salter).

12, 13. Llanvirnian.

11. Arenig Grit.

2 to 4 . Lower Tremadoc.

5 to 10. Upper Tremadoc.

1 and $1 a$. Iingula flags.

$g$. Intrusive dyke of igneous rock.

There is probably a fault below the letter $F$.

portion the Pen Rhos Beds. The former contain beds of fine siliceous grit from 2 to 3 feet thick, while in the latter such grits are only from $\frac{1}{2}$ to 2 inches thick. Two species of olenus and Agnostus pisiformis are the characteristic fossils.

The Ffestiniog Group is a thick mass of flagstones with only a few bands of black shale; they are usually hard and consequently form higher ground than the underlying shales. The most abundant fossil throughout is Lingulella Davisii.

The Dolgelly Group consists of soft blue and black shales, which appear to have been formed in much deeper water and though only 600 feet probably represent as long a period of time as the whole of the Ffestiniog Beds. They resemble the Alum shales of Sweden.

The best section of the Tremadoc slates in North Wales is in the cliffs of the Penrliyn promontory south-east of Tremadoc in Merioneth. According to Mr. Salter ${ }^{8}$ the succession which can here be seen is as follows:- 

Arenig $\left\{\begin{array}{l}\text { 12. Black slates with iron stsius. } \\ \text { 11. Gartl Hill grit. }\end{array}\right.$

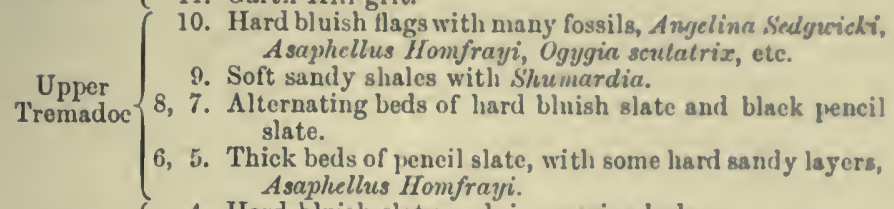
Lower
Tremadoc $\left\{\begin{array}{r}\text { 4. Hard bluish slaty rock in massive beds. } \\ \text { 2. Dark iron-stained slates, with Psilocephalus innolalus, } \\ \text { Niobe Iomfrayi, Diclyograptus socialis. }\end{array}\right.$
1. Lingula flags - Black slates with Olenus.

Mr. Fearnsides has recently described a sinilar succession near Tremadoc our the east side of the Lleyn peninsula, where the Upper Tremadoc Beds (440 feet thick) yield species of Aruphellus, Angelina Shumardia, Symphysurus, and Dikellocephalus.

The Tremadoc Beds do not form a continuous band round the Lingula flags of Merioneth, for in certain places they seem to disappear beneath the base of the Arenig Series (Ordovician); it is now believed that there is an actual unconformity letween the two series and that the Arenig often completely oversteps the whole of the Tremadoc Group so as to rest on Lingula flags

In Carnarvonshire the thickness of the Lingula flags is much less, but near Llanberis and Nant Ffrancon they are apparently from 2000 to 2500 feet thick. On each side of Llyn Peris the nearly vertical Harlech grits are succeeded by dark slates which represent the Maentwrog Beds, with a thickuess of about 1000 feet, and these are followed at the eastern end of the lake by hard quartzose grits (3.Ffestiniog beds), which are estimated by Ramsay to be about 1300 feet thick. ${ }^{10}$ These beds are traceable northward through Elidyr-fawr, and a good section is exposed in the southern cliffs of Marchlyn-nıwr, where Ramsay found Olemus micrurus and Lingulella Davisii in certain grey and brown grits. It is noticeable that some of these grits are of coarse grain, and occasionally conglomeratic, thus differing from the finer-grnined flagstones of Merioneth. The Upper Lingula flags or Dolgelly Beds have not yet been identified in Carnarvon owing to the rarity of fossils, but are probably represented by a part of the overlying slates.

On the western side of the Llanberis anticline the thicknes of the Cambrian Series seems to be still further reduced, and when they again emerge on the eastern flank of the Bangor-Carnarvon ridge there are only slates overlying the basal grits and couglomerates

Professor Hughes ${ }^{11}$ has traced these basal beds along the eastern flank of the pre-Cambrian ridge all the way from Twt Hill near 
Carnarvon to Garth Point near Bangor. The pebbles vary according to the rocks on which the conglomerate locally rests; near Carnarvon they are chiefly quartz, near Llanddeiniolen and near Bangor they include pebbles of quartzite, andesite, felsite, and quartz.

Sir A. Ramsay was of opinion that the whole of the Lingula flags had thinned out near Bangor, that the grits were of Harlech age and were overlain unconformably by Arenig shales. This, however, is not the generally accepted view, for there is 110 evidence of such unconformity, and if the diminution of thickness is due to thinning out toward a shore line we should expect the lower beds to thin out and disappear before the upper beds. The facts may be explained as a simple case of overlap, and we may suppose that the whole of the Harlech Series (i.e. Lower and Middle Cambrian) has thinned out with probably some of the Lingula slates (Maentwrog Beds), and that the lowest Cambrians between Llanddeiniolen and Bangor represent the Lingula grits of Elidyr-fawr and Marchlynmawr. They may, however, be of still later date.

Whether Tremadoc Beds exist to the north-west of Snowdon has not yet been ascertained because of the scarcity of fossils in the mass of dark slates which intervenes between the Lingula grits and the Arenig grits.

\section{Midland Counties}

Cambrian rocks are brought to the surface in four distinct and isolated areas in the Midlands, viz. (1) Malvern Hills, (2) The Wrekin (Shropshire), (3) the Lower Lickey Hill (Worcestershire), and (4) Nuneaton (Warwickshire). In lithological characters, and to some extent also in their fossil contents, these Midland rocks differ very much from the typical Cambrian of Wales, and according to Professor Lapworth ${ }^{12}$ they approximate more closely to the Cambrian of Scotland and of the continent of Europe. The total thickness of the system is very much less in the Midlands than in Wales, and though it is believed that in the western areas the succession is incomplete, it appears to be unbroken near Nuneaton, where the thickness of the exposed beds is only about 2200 feet, and if 800 feet are added for the concealed upper beds, the total is then only 3000 . The whole system is divisible into a lower arenaceous division, comparable to the Caerfai and Solva Beds of South Wales, and an upper shaly division, representing the Lingula flags and the Tremadoc Beds.

The Arenaceous Division.-At the south-west end of the Malvern Hills the Archæan schists are bordered by beds of quartzite 
and of greenish flaggy micaceous sandstone which have been called the Hollybush sandstone. In these beds Dr. T. T. Groom has recognised the following descending succession :- 13

2. Hollybush Sandstone, consisting of:

b. Massive glauconitic sandstones, from 550 to 700 feet thick, with several species of Hyolithes (including $H$. fistula), Kutorgina cingulata var Phillipsi, etc.

a. Shaly sandstone, with calcareous bands and seams of quartzite, not less than 220 feet, with $K u t$. Phillipsi, Obolella sp., Linnarssonia sagittalis, Hyolithes sp.

1. Hollybush Quartzite.-Quartzites and conglonnerates of unknown thickness, with Kutorgina, Obolella, aud Hyolithes.

The conglomerates in the quartzite contain pebles of metanorphic quartzite, rhyolite, andesite, and red granopliyre, and the mass was supposed to rest unconformably on the pre-Caubrian rocks. It is probable that such was their relation, but Professor Groom believes the present junction planes to be faults, and thinks that the quartzite may have been several hundred feet thick, though only 50 or 60 feet of it can now be seen.

In Shropshire the Wrekin ridge, as well as the Uriconian rocks of the Caradoc and Cardington Hills, are flanked on their eastern sides by a series of Cambrian rocks, the lowest being a lard quartzite like that of Malvern (see map, Fig. 21, here reproducel] by permission of Professor C. Lapworth); but its base is seet to rest directly and unconformably on the Archwan rocks, and it contains pebbles of rhyolite, tuff, etc, derived from them.

This quartzite is about 300 feet thick, and is succeeded by a series of sandstones, limestones, grits, and shales which are generally known as the Comley sandstone, though they iuclude reprosentatives of two faunal divisions. This series is supposed to be about 500 feet thick. Its true age was first recognised by Dr. C. Callaway in 1877, and the Olenellus fauna was first discovered in it by Professor C. Lapworth in 1888. Still later exploration by Mr. G. S. Cobbold has resulted in the discovery of more foreils and has shown that the succession of fossiliferous beds at Couley is as follows:-14

Paradoxides (Flaggy slales and grits. Beds
Coarse calcareous grit with fragments of sandstone and
limestone derived from beds below.

Olenellus $\left\{\begin{array}{l}\text { Black limestone with phosphatic nodules (1 foot). } \\ \text { Grey limestones with black phosphatio nol ules (4 feet). } \\ \text { Pret }\end{array}\right.$

Beds $\{$ Purplish-red sandy limestone with Olenellus. Greenish felspathic sandstoues. 


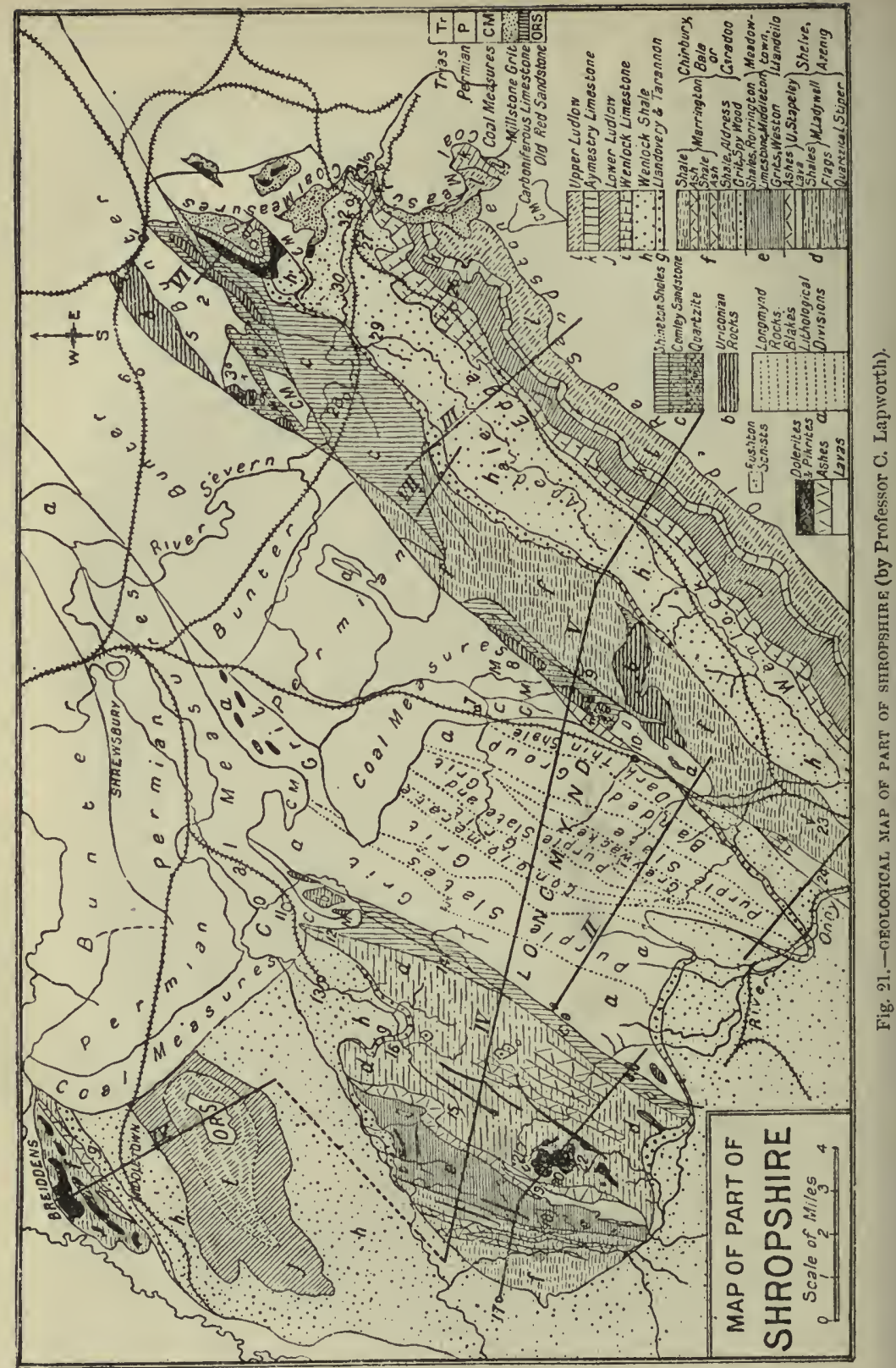


The red limestone contains Olenellus Cullavei, Microdiscus helena with new species of Plychoparia and Micmaccia, and Kutorgina cingulata. The grey linestones have yieldel new species of Protolemis, Microdiscus, Anomocare, and Molicana, with soine Brachiopoda. The black limestone contains Hyolites, Satterella, and Brachiopoda.

The overlying conglomeratic grit with its derived fragments indicates a local brenk with erosion of the bods below so that it may be inferred that the latter are only a part of the series originally deposited. This upper grit has yielded three species of Paradoxides (P. Groomi, P. rugulosus, and P. of. Davidis).

In the Lickey district there is an exposure of quartzite which is almost certainly of Lower Cambrian age, though no foesils except worm-burrows have yet been found in it. It consists of flagg!

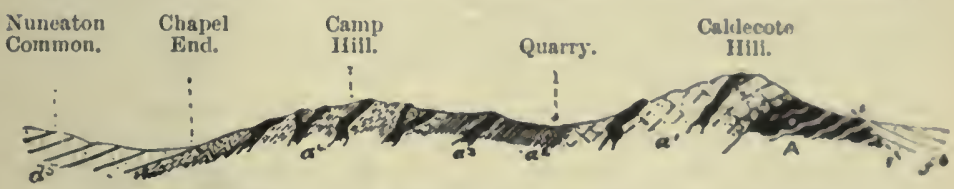

Fig. 22. - SEctios fros NuNeatox to caldrcote huL (Lajwortli).
$\rho^{9}$. Keuper marls.
$d^{5}$. Coal-measures.
(t). Oldbury shales.
$a^{3}$. Purley shales.
$a^{2}$. Ilyolithes Beds.
a). Cambrisn quartzite.
A. Caldecote volcanic rocks.
piorito dykes sliow'n in blnck.

quartzites, with intercalated purple shales like those next de. scribed.

Near Nuneaton there is a remarkable tract of Canbrian rocks which before the discovery of fossils was supposed to be of Carboniferous age. It is about 9 miles in length, with a width of a mile where broadest, and the structure of the district is shown iu the section drawu by Professor Lapworth (Fig. 22). The arenacouts division has been called the Hartshill quartwile, and is about 600 feet thick. The lowel part consists of alternating beds of siliceous grit and purple or grey shale, the grits consisting of sand set in a chalcedonic cement, and forming a very hard rock which has usually a pale pink colour. No fossils have yet been found in them. The iniddle portion consists of thick beds of quartzitic grit with very little shale, and has not yielded any fossils. The Upper or Camp Hill Group is a inuch more varied set of beds, consisting at the base of thin-bodked glauconitic grits, followed by randy unicaceous shales about 50 feet thick, in which are two notable beds, one a pebble bed or conglomerate, and the other a led of rod limestone about 2 feet thick. The highest member is a mas of 
purple false-bedded quartzitic sandstone containing many grains of glauconite and about 50 feet thick.

The limestone and associated red shales have yielded several species of Hyolithes and of Orthotheca, with Stenotheca rugosa, Coleoloides typicalis, Kutorgina cingulata and Iphidea labradorica, and Orthisina transversa. The facies of the fama is that of the Lower Cambrian or Olenellus zone, though no trilobites have yet been fornd.

The Shaly Division (Upper Cambrian).-In the Malveru area this is over 2000 feet thick, and is divisible into two parts. The lower 800 feet are black shales with bands of basaltic lava which have generally been regarded as contemporaneous lava-flows, but which Dr. Groom finds to be intrusive sills. These shales have yielded Peltura scarabooides, Ctenopyge Bisulcata, Agnostus trisectus, Sphorophthalmus alatus, etc.- - species which are characteristic of the Lower Dolgelly Beds of North Wales. The upper part of the Malvern shales is composed of bluish or yellowish-grey shales, with many intrusive sills of basalt and diabase. Dr. Groom ${ }^{15}$ found them to be of much greater thickness than was previously supposed, and from his section, reproduced in Fig. 18, it will be seen that they are at least 1300 feet thick. Their highest beds contain Dictyograptus socialis, Agnostus dux, Cheirurus Frederici, Acrotreta Sabrince, with species of Asaphus and Olenus; most probably they are of Lower Tremadoc age. No representatives of the Menevian, Maentwrog, or Ffestiniog beds have yet been recognised, but the boundary between the Hollybush sandstone and the Malvern shales seems to be a faulted one, so that beds of intermediate age may be faulted out.

In Shropshire the Shineton shales occupy a tract two miles broad in the valley of the Severn by Shineton and Cressage, and they extend both to the north-east and south-west (see map, Fig. 21). They also occur at Pedwardine, and again in a long narrow strip on the west side of the Longmynd, where they underlie the Arenig Beds of the Stiper stones. Their true age was first made known by Dr. Ch. Callaway, ${ }^{16}$ who discovered in them fossils of Upper Cambrian types. They are soft, fissile, micaceous shales of a dark-blue colour, weathering to olive-green and yellow. Their base is not seen, and their junction with the Comley sandstone appears to be a fault, so that here, as at Malvern, the central part of the Cambrian System seems to be missing. The lowest beds ccntain Dictyonema. The highest beds are more fossiliferous and have yielded many trilobites, including Eulonia monile, Olenus Salteri, Asaphellus Homfrayi, A. Crofti, and Shumardia salopiensis, with the Cystidean Macrocystella Marice. 
The total thickness is estimated at about 1500 feet and the bets are clearly of Tremadoc age.

Passing again to Nuneaton, where the Hartshill quartzite is succeeded by the Stockingford shales, we have what apprears to bo a complete successiou without break or fanlting. Profeser Lapworth has divided the slialy series into three groups, of which the following is a brief description, taking then in descending order :-

Upper or Merevale Shales. -Only seen near Mleverale, and consisting of greenish-grey shales in which Dictyograptus is abundant. The thickness exposed inay be 200 feet.

Middle or Oldbury Shales. - Blaek shales, with some bands of grey shale : in highest beds are Spharophthalmus alatus and Ctenopnyge pecten: in the lower Agnostus pisiformis, Leptoplastus Sulleri, Beyrichin Angelini, and a Lingulella. Thickness probably 800 feet.

Loucer or Purley Shales. - Reddish-purple mudstones and shales, with some green and grey bands, containing minute Limgnelella, Obolclla sagittalis, Acrothele granulata, and a Conocoryyphe. Thiekness ahout 600 feet.

The fauna of the Purley shales is comparable with that of the Conocoryphe exulans zone of Sweden, which belongs to the Paradoxides division and is homotaxial with our Menevian Series. The black Oldbury shales are comparable with the black shales of Malvern and the Lower Dolgelly Beds. The Merevale shales appear to represent the lowest part of the Shineton shales and of the Malvern grey shale. No horizon comparable with the mass of Lingula flags has been recognised, but this may be due to the scarcity of fossils in the lower part of the Oldbury shales.

\section{Lake District and the Isle of Mun}

In the uortheru part of the Lake District around Skiddaw Mountain, Derwent, and Crummock Waters there is a great thick. ness of dark-coloured slates, with bands of hard grit aud occasional beds of conglomerate. To these beds Sedgwick gave the name of Skiddaw slates; the higher portion of them is of Ordovician (Arenig) age, but the lower part is Cambrian (Tremadoc and Lingula flags). The Cambrian age of this portion was snspected by Sedgwick and maintained by Clifton Ward, lut not until 1894 was this view. confirmed by good palwourtolugical evidence. ${ }^{17}$

Mr. Ward took a certain band of grit occurring north of Skiddaw as the base of the Arenig Series and identified with it certain Alaggy grits near Buttermere, but this has not been confirmed and the boundary line between Cambrian and Ordovician has not yet been 
determined, the difficulty being that the rocks are so much folded, contorted, and faulted that it is almost impossible to trace particular beds in the mass of slates. Few fossils except graptolites have been found, and these occur in definite bands of a more earthy kind of slate than the rest, so that, as Dr. Marr observes, "whether these beds are of the same age as the black glossy unfossiliferous slates, or whether they are newer beds folded as synclines among these slates, yet remains to be ascertained."

The only locality indeed where graptolites of Tremadoc species have yet been found is Barth near Keswick, where the following species were obtained by Miss G. L. Elles ${ }^{18}$ in 1898-Bryograptus Kjerulfi (see Fig. 15 m), B. ramosus, B. Callavei, Chonograptus tenellus, and $C h$. flexilis.

The greater part of the Isle of Man is occupied by a similar series of slates and grits, now known as the Manx slates. These have been divided by Mr. Lamplugh into three portions which seem to be consecutive, though no recognisable fossils have been found in any of them, and the crush-phenomena produced by lateral compression are even more strongly developed in that island than in Cumberland. ${ }^{19}$

The subdivisions traced by Mr. Lamplugh strike from N.E. to S.W., and the Lonan flags on the eastern side are believed to be the lowest; these seem originally to have been flagstones, mudstones, and shales, but are now hard, cleaved, crumpled, and frilled rocks. North-west of them is a band of quartz-veined, thin-bedded grits (the Agneash grits), and west of them are the Barrule slates, a mass of dark-blue slaty rocks, which closely resemble the Skiddaw slates. Of the Lonan flags Mr. Lamplugh observes that lithologically they have a close resemblance to the Bray Head Series described below.

\section{Ireland}

So far as present knowledge extends Cambrian rocks only occur in the south-east of Ireland in the counties of Dublin, Wicklow, and Wexford. The facies is one of grits, flagstones, and shales like that of Wales, but the base is not exposed and none of the Welsh fossils have yet been discovered in the Irish area. The rocks are indeed so cleaved and altered by metamorphic agencies that until recently it has been an open question whether they were of Eparchæan or Cambrian age.

The determination of their age rests mainly on the discovery of their characteristic fossil Oldhamia (see Fig. 12) in rocks of Cambrian age elsewhere. It is certainly curious that Oldhamia should not have been found in the Cambrian of Wales, but in the 
Arlennes of North-west France both the Irish species of Oldhumia occur in the slates of Fumay which underlies beds of Tremadoc age. Oldhamia radiata has also been found in Belgium, and another species (O. occidens) has been obtained from the Upper Cambrian of North America.

In further confirmation of this determina. tion of age it has been ascertained that the supposed unconformity between the Areaig Beds and the lunderlying rocks in Ireland is of an illusory character. The beds formerly regarded as conglomerates in Wexford have proved to be crush-breccias, and elsewhere the junction beds of the two series are so plicated into one another that it is impossible to find a dividing line, and so far as Messrs. Egan and M'Henry could ascertain in their revision of $1898,{ }^{20}$ there is no evidence of any stratigraphical break between them.

One of the best sections of these Cambrian rocks is that exhibited in the cliffs of Bray Head near Dublin, whence they are sometimes called the Bray Head Series. At the northeru end of this clift section are red, purple, and green slates and grits, succeeded on the south by alternating grits and shales. The beds are bent into numerous sharp folds, so that the real thickness is nuch less than a ppears at first sight. Jukes and Du Noyer estimated the exposed succession at between 3000 and 4000 feet, but neither the base nor summit is actually visible. These rocks are also well exposed on the coast of Howth, east of Dublin, where they include some remarkable breccias.

No fossils have been found in these beds except the two or three species of Oldhamia, the trumpet-shaped worm-tubes known as Histioderma, and some spherical borlies with radiating spines which may be Radiolaria. The nature of the nuarkings called Oldhamia has not been definitely ascertained; Professor Sollas has pointed out that thase of 0 . radiata

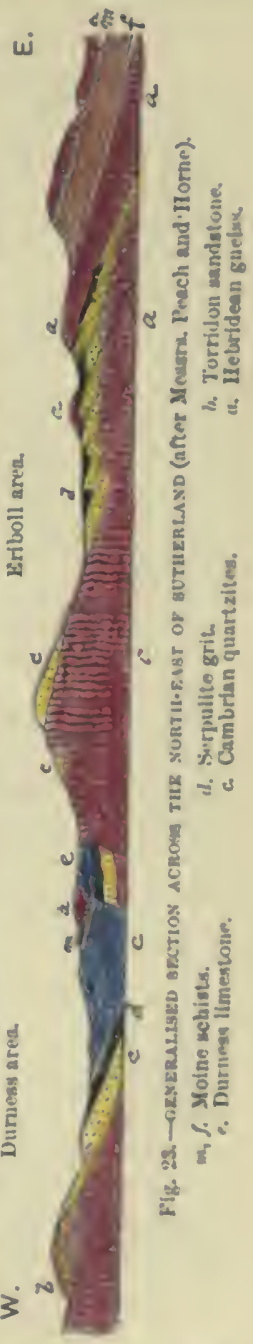
are grooves and may have been made by the anterior end of a worn, but those of $O$. antiqua are ridges on the upper snr- 
faces of bedding planes, and no explanation of them has yet been suggested.

\section{Scotland}

In the north-west of Scotland Cambrian rocks flank the eastern side of the tract occupied by the Hebridean and Torridonian, all the way from Durness and Eriboll on the north coast down to the island of Skye. Before the discovery of Olenellus in these rocks they were supposed to be of Ordovician age.

In the north of Sutherland there are two tracts of Cambrian, the relative positions of which are shown in Fig. 23. The beds of the Durness area are arranged in the form of a basin truucated on the eastern side by a fault which brings them against the Archæan gneiss; on the west they are seen to rest unconformably on this gneiss and on the red Torridon sandstone. The Durness basin is separated from that of Loch Eriboll by a proninent ridge of Archran gneiss, which, however, bears an outlier of the Cambrian basement beds. The Eriboll area exhibits the same series as that of Durness, but they are crushed and faulted in a remarkable manner, and are cut off' on the east by a thrust-plane, which carries some of the Archæan gneiss over the Cambrian Series, so that here the ordinary test of age by superposition becomes useless.

The total thickness of the beds composing the Cambrian System of Scotland is estimated as at least 2000 feet, but the upper limit is not reached, being everywhere concealed beneath the masses of crushed and sheared rock which have been carried westward onto and over the Cambrian strata. The exposed portion is divisible into two series, an arenaceous below and a calcareous series above. These can also be subdivided as follows :-21

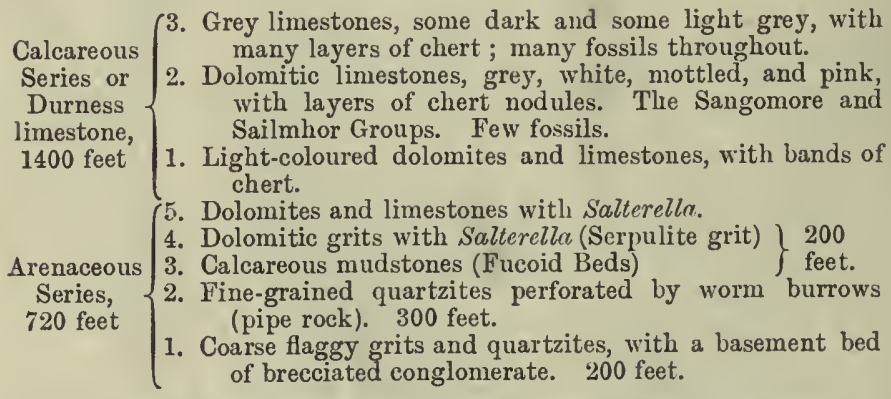

The most abundant fossils in the Durness limestone are Cephalopoda-Orthoceras, Piloceras, and Lituites. Next in number 
are Gastropoda, but bivalves (Lamellibranchia and Brachiopoda) are not rare. Archoocyathus (see p. 72) is of frequent occurrence, as are also sponges of the geniss Calathium or Archiroscyphia.

In 1891 fragments of Olenellus (O. Lapworthi) and specimens of IIyolithes were found in the Serpulite grits and Fiscoid Beds of Ross, proving them to be of Lower Cambrian age. Hence it is probable that the lower part of the Calcareons Series is of Middle Cambrian age (Paradoxidian), but the higher and more fossiliferous part is of Upper Cambrian age, corresponding to the Upper Lingula flags and 'Tremadoc slates of Wales.

The Cambrian succession in Skye has been worked out by Mr. C. T. Clough, who found that the same subdivision could be made as in Durness. Moreover, the Olenellus fauna was again discovered in the Fucoid Beds at Tokavaig and Ord. No fossils, however, could be found in the lower part of the Durness limestone, the thickness of which to the top of the Sailmhor Group Mr. Clough estimates at 830 feet. But higher beds are found in Strath, and in 1898 these yielded many fossils, including Calathium and Archaoscyphia; a trilobite of the genus Solenopleura; Orthisina festinata and O. striatula; a bivalve, Euchasma Blumenbachice; species of Pleurotomaria, Murchisonia, Maclurea, and Holopea, with Piloceras, Orthoceras, and Trocholites.

The fauna of the Durness limestone, as regards both genera and species, has much more affinity with that of the Cambrian of North America than with that of Wales or England. It may in fact be inferred that the Scotch Cambrian belongs to a North Atlantic or North American area of life and deposition, in which the physical conditions differed considerably from those of the South British and Central European area.

The only other part of Scotland where rocks occur which seem to be of Cambrian age is along the sonth-castern border of the Central Highlands in Perth, Forfar, and Kincardine. They occur in narrow faulted strips along a line from Blairgowrie in Perth to Stonehaven on the coast, and consist of grey shales and grits, jasper and jaspery phyllite, with lenticular sills and possibly interbedded flows of basic igneous rock (dolerite). They were described by Mr. G. Barrow as the "Green Rock and Jasper Series," 23 and from the resemblance between them and rocks of Arenig age in the Southern Uplands he regarded them as probably Ordovician; but a more recent discovery of fossils in the same series as exposed on the coast near Stonehaven makes it probable that they are of Cambrian age.

This discovery was made by Mr. R. Canpbell 23 in a set of black shales with layers of jasper and chert intercalated with bands or sills 

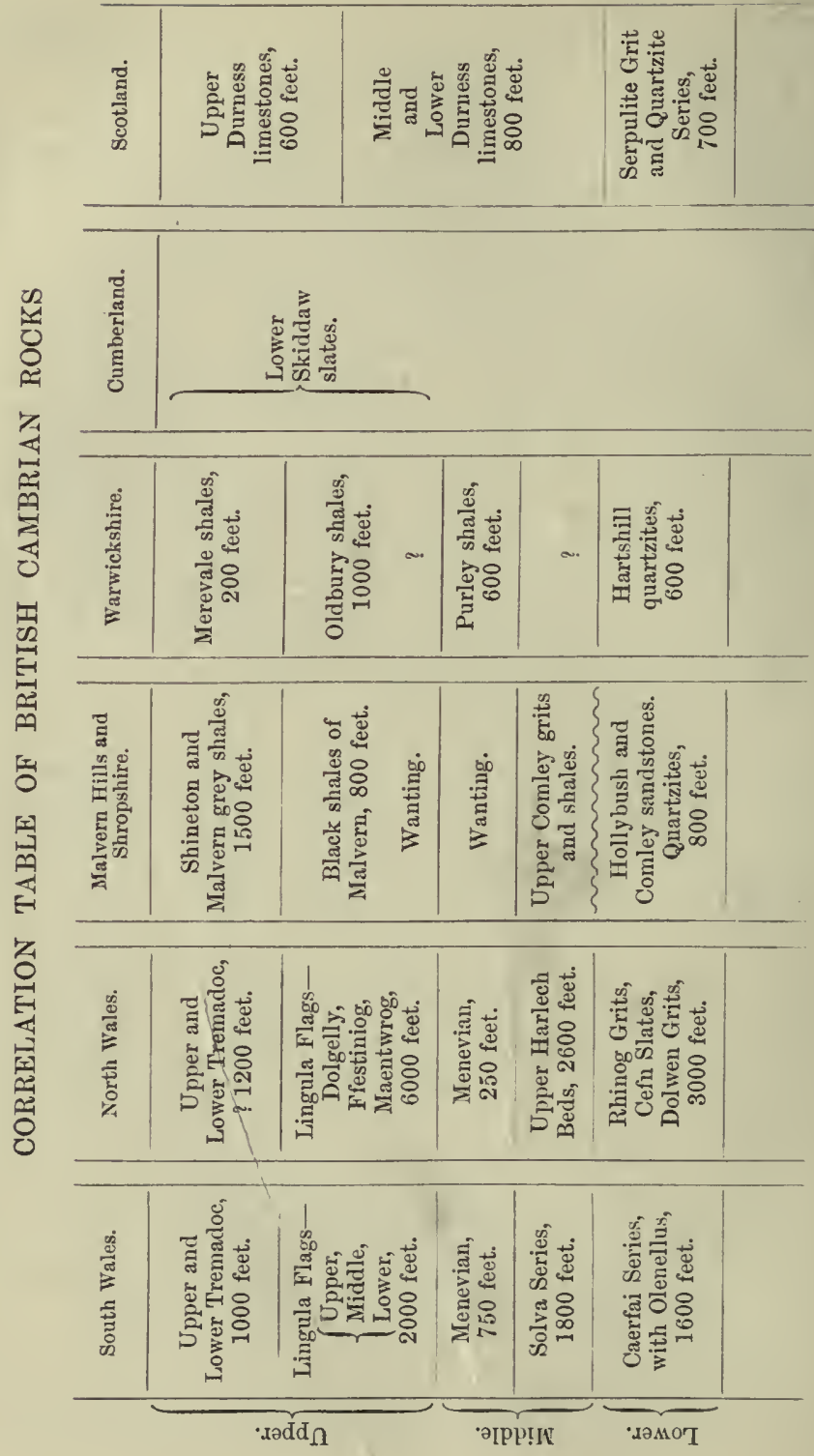
of green igueous rock. Dr. Peach reports that the fossils include species of Lingulella, Obolella, Acrotreta, Linnarssonia, and Siphono. treta, and a few speciniens of a Phyllocarid Crustacean allied to Lingulocaris. These genera, he remarks, are found in both Upper Cambrian and Lower Urdovician, but the absence of graptolites is indicative of the former rather than the latter.

\section{The Cambrian of Northern Europe}

\section{France (North-West)}

Cambrian strata are found in many parts of Brittany and Normandy troughed in between the tracts of Archwan rocks, the main flexures of the distriet striking roughly from west to east. The system is most fully developed in the southern and eastern parts of the region, some portions of it being apparently absent in the west and north.

In the north-west (around Brest and Tréguier) the Cambrian Series consists of two groups differing wuch in lithological characters. These are (1) a basal purple conglomerate passing up into sandstones, 300 to 500 feet, (2) purple and green slates, about 400 feet. ${ }^{24}$ No fossils have been found in these rocks, and they are succeeded by coarse grey felspathic sandstones (Gres - felspathique), which are either of Tremadoc or Arenig age.

In the south and south-east of Brittany the Cambrian is represented by much thicker masses of deposit. Thus to the south and west of Rennes the purple conglomerate and sandstone is 1700 feet thick, and the overlying slates are estimated to be 7000 feet. Farther east in Mayenne there is a more varied series comprising a basal conglomerate, purple slates with beds of grit and limestone, coarse sandstones, and andesitic lavas, with finally green slates containing Lingulella Criei. In the lower beds only a few specimens of Lingulella and Dinobolus have yet been found, but MIr. Fllert believes them to represent the whole of the Lower and Middle Cambrian Series (Olenellian and Paradoxidiaus). ${ }^{25}$

The correlation of the southern and northeru series is not easy because of the rarity of fossils. Professor de Isapparent gave no definite correlation, but seemed to assume that the basal conglomerates are everywhere of the same age. If this is so then there is probably a gap in the northern series between the slates and the Gres felspathique. On the other hand, the northern area may have been land in Iower Cambrian time, and the conglomerates may be shore deposits which would be of later and later date as we passed from south to north and 
north-west, till only the Upper Cambrian is represented. On this view the correlation would be as follows, and the great difference in thickness more easily accounted for :-

Southern area.

(ُ) Freen and purple slates.

\{urple slates.

ஜ Purple sandstones.

In Normandy a somewhat different facies of the Cambrian is found, inasmuch as it includes an important limestone formation which is largely quarried for marble. Near Caen, May, and Clécy the succession is :-

Green slates and limestone, without fossils Massive limestones (red and grey marbles) Red slates and red marblo Purple sandstone and conglomerate
Northern area.

$\left.\begin{array}{l}\text { Green and purple slates } \\ \text { Purple sandstones, etc. }\end{array}\right\} 880$ feet.
Feet.

130

250

20

200

600

All these beds thicken southward till, near Montbard and Fourneaux, they have a combined thickness of nearly 2000 feet, while the overlying felspathic sandstones thin out entirely, and finally, south of St. Lo, the whole series disappears beneath an overstep of the Grès armoricain (Arenig) on to the Archæan rocks, and the Cambrian only comes in again to the south of Ernée and Mayenne.

\section{Iberian Peninsula}

Cambrian rocks occur in several parts of Spain and Portugal, in Asturias and Galicia, in Leon, in Seville near Ciudad-Real, and near Busaco in Portugal; the Paradoxides fauna having been found in several of these districts. The area which has been most completely explored and described is that of Asturias and Galicia in the north-west, and in 1882 Dr. Barrois referred the following groups to the Cambrian :- ${ }^{26}$

La Vega $\left\{\begin{array}{c}\text { Greenish sandy shales with beds of green sandstone-100 to } \\ 300 \text { feet. }\end{array}\right.$ Beds 300 feet.

Limestones and shales-60 to 200 feet.

Rivadeo Green quartzites and slates.

Beds $\{$ Green slates and bluish phyllites.

The upper group yielded species of Paradoxides, Conocoryphe, Arionellus, and Trochocystites bohemicus, so that it is clearly of Middle Cambrian age. It is overlain by conglomerates and sandstones with Bilobites which are comparable with the Grès fels- 
pathique of Brittany, and there is consequently an absence of the Upper Cambrian (Olenus fauna). Below the La Vega Beds and aplarently in conformable succession are the unfossiliferous Rivadeo slates, which may in part represent the Lower Cambrian, but Dr. Barrois compared them with the Phyllades de St. Lo which were at that time classed as Cambrian. Further investigation is therefore required in this area where no base has yet been recognised.

\section{Belgium and the Ardennes}

In the Ardennes district there are four separate areas where Cambrian rocks come to the surface, but only those of Rocroi and of Stavelot are of any considerable size. ${ }^{27}$ The one lies mostly in France, forming a hilly plateau traversed by the deep ravine of the Meuse between Deville and Fumay; the other is on the borders of Belgium and Germany around Spa and Stavelot. The rocks have the same facies in both areas; they are much flexured and faulted, but a definite succession has been made and the Belgian geologists group them in three stages as below:-

3. Salmian, consisting of slates and quartzo-phyllites in which Dictyo. graptus has been found.

2. Reviniun, black slates and dark-grey quartzites.

1. Devillian, greenisl 1 and grey quartzites with bands of purple and green slate containing Oldhamia.

The base is not exposed, and no fossils except Oldhamia radiata and 0 . antiqua have been found in the Devillian, which may be of Middle or Upper Cambrian age; while the Salmian may certainly be correlated with the British Tremadoc Beda,

In Belgium there is another area where a succession of Cambrian rocks are found, i.e. in the valley of the Thyle south of Brusiels. Here the lowest beds resemble the Devillian and also contain Oldhamia; above them, near Mousty, M. Malaise has described a set of black slaty shales with black limestones and bauds of chert, and in the limestones he has found small Ostracoda which he refers to Leperditia punctatissima and Primitia solvensis (Lingula flag species); these black beds are succeeded by quartzo-phyllades which he also refers to the Lingula flags, and he correlates the Cambrian of the Ardennes and of Brabant as follows :- 28

Ardennes.

Salmian $\left\{\begin{array}{l}\text { Upper. } \\ \text { Lower. }\end{array}\right.$ Revinian

Devillian $\left\{\begin{array}{l}\text { Üpper } \\ \text { Lower }\end{array}\right.$
Brabant.

Not recognised. Assize de Villers.

Assize de Mousty.

Assizo de Tubize.

Assize de Blaumont. 
In connection with the Cambrian Series of Belgium the recent recognition of similar rocks beneath the eastern counties of England is of much interest, for at Stutton near Ipswich the boring made in 1894-5 entered hard quartzitic rocks at a depth of 994 feet, and traversed them to a total depth of 1525 feet. These rocks are really dark-grey quartzo-phyllades, which M. Mourlon has recognised as resembling those of Villers, near Ath. At Harwich and Weeley in Essex the rocks found below the Gault are dark-grey and purple slates, in which an Orthoceras was found. These must be either of Tremadoc age or a part of the overlying Ordovician Series as developed in Belgium.

\section{Scandinavia}

It is interesting to note that in Norway, Sweden, and Northern Russia the Cambrian strata occur in broad, flat-lying sheets as originally deposited, and are so little altered that they have more the aspect of our Mesozoic clays, shales, and sandstones than of Palæozoic rocks. Moreover, those of Scandinavia present a complete succession of highly fossiliferous beds, and yet their thickness is only a few hundred feet.

The Cambrian Series of this region consists everywhere of a lower arenaceous division and an upper argillaceous division, the lower being from 350 to 550 feet thick and the upper from 200 to 400 feet. The system is most fully developed in Sweden, and especially in the districts of Scania and Westrogothia, where there is the following succession in descending order (slightly altered from Linnarsson and Tullberg). ${ }^{29}$

IV. Passage Beds (thickness about 50 feet=Tremadoc).

3. Ceratopyge limestone, with C. forficula.

2. Shumardia shales.

1. Dictyograptus shales, with Dictyograptus and Obolella Salteri.

III. Olenus shales in five zones, with three bands of limestone, thickness from 70 to 200 feet (=Lingula flags).

5. Zone of Parabolina heres.

4. Zone of Peltura scaraboeoides and Sphorophthalmus alatus.

3. Zone of Eurycare and Leptoplastus.

2. Zone of Parabolina spinulosa.

1. Zone of Olenus truncatus, O. gibbosus, and Ag. pisiformis.

II. Paradoxides shales, divisible into four principal zones, and from 80 to 160 feet thick (= Menevian and Solva Beds).

4. The Andrarum limestone with 5 feet of shale above; Agnostus loevigatus, $\backslash$ Paradoxides Forchhammeri, and Orthis Hicksi.

3. Zone of Par. Davidis and Conocoryphe coqualis.

2. Zone of Par. 'T'essini with the exsulans limestone at base containing Conocoryphe exsulans and Par. palpebrosus.

1. Zone of Agnostus atavus, Paradoxides olandicus, and the black Alum shale at the base. 
I. Olenellus Beds, chiefly sandstones homotaxial with tlıe Hartshill quartzite and Caerfai Beds, 350 to 550 feet.

4. Phosplatic limestone (few fossils).

3. Sandy shales with Olenellus Kjerulfi and Arionellus primuevus (5 to 10 feet).

2. Fucoid sandstone with Obolella favosa, 200 to 350 feet.

1. Eophyton sandstone with Mfichwitzia monilifera and the markings called Eophyton and Cruzianr, 150 to 200 feet.

The basal sandstones rest unconformably upon the Arcliaan gneisses.

\section{Russia}

In the Baltic provinces of Russia there is a still more remarkable development of the Cambrian System. The arenaceous division is partly replaced by blue clay, and the black trilobite shales are absent. The succession is as follows:-

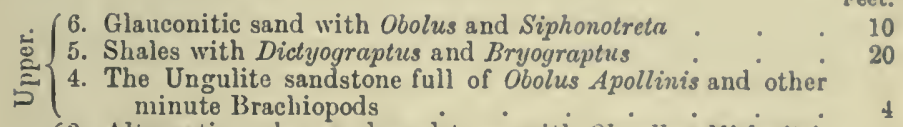

$\dot{0} \int 3$. Alternating clays and sandstones with Olencllus Michwitzi,

Mickwitzia monilifera, and a Scenella . . . 50

\& 2. The blue clay, without fossils . . . . . . 300

1. Ferruginous sandstones, resting on granitoid rock . . 300

Professor F. Schinidt ${ }^{30}$ has pointed out that the base of the Ungulite sandstone is sharply divided from the beds below, and sometimes contains pebbles derived from them. Hence there appears to be a gap at this point, which will account for the complete absence of any representatives of the Paradoxides and Olenus shales, unless the thin band of Ungulite sandstone is a partial equivalent of the latter. The underlying clays and sandstones are evidently the equivalents of the Fucoid and Eophyton sandstones, while the two highest members are comparable with the beds which occupy the same position in Sweden.

\section{Germany and Bohemia}

It is very probable that Cambrian rocks underlie the greater part of Germany, but they are only exposed in a few places One of these is the Hohe Venn, south of Aix-la-Chapelle, where there are slates, quartzites, and phyllites, resembling those of the Ardennes and containing both Oldhamia and Dictyograptus. Another and larger area is found in the Fichtel Mountains and the 
Thuringia Wald, north-east of Bavaria, but it is only at Leimitz, near Hof, that well-preserved fossils have been obtained; the fauna, consisting chiefly of Trilobites, Brachiopoda, and a few Cystidea, appears to belong to the highest Cambrian (Upper Tremadoc and Ceratopyge limestone).

In Bohemia the existence of Cambrian rocks was first made known by Barrande in 1852, whell he recognised his Stage C as containing a "primordial fauna." Subsequent writers have modified Barrande's classification, and have fonnd a still older fauna in his Stage B. To agree with the British Cambrian System it must also include part of $\mathrm{D}$, and will then consist of the following groups:-

Stage D 1. Pisolitic ironstones, sandstones, and sandy conglomerates with diabasic lavas and tuffs.

Stage C. Greenish slates with a Paradoxides fauna (P. bohemicus and P. spinulosus), Conocoryphe, Arioncllus, Ellipsocephalus, etc.

Stage B. Sandstones and flags with an Olenellus fauna passing down into coarse conglomerate which rests unconformably on Stage A (Przibram schists).

A more detailed stndy of this Cambrian Series has been made by Pompeckj, ${ }^{31}$ who describes the lowest part (Stage B) as consisting of a conglomerate passing up into grits, sandstones, and flags which contain species of the Trilobites Sao, Solenopleura, Ellipsocephalus, and Ptychoparia, with Stenotheca and Orthis; this is an Olenellus fauna, thongh that genus has not yet been found. Dr. Marr ${ }^{32}$ remarks that these rocks strougly resemble our Harlech Series and are of great thickness. The Paradoxides Beds are slaty shales with a thickness of about 1000 feet. Above them is a conglomerate supporting greenish grits which contain Lingula Feistmanteli and probably represent part of our Lingula flags. Above these are pisolitic ironstones of black, green, and red colours which contain a few fossils-Erinnys Grimmi, Amphion Lindnaueri, and Orthis desiderata; this small assemblage having the aspect of a passage fauna and being therefore probably of Tremadoc age.

From this account it will be seen that the Bohemian sequence is not quite complete; in fact, there seems to be a break and unconformity between Stages C and D. The beds of Stages B and C are only found over a sniall portion of the area near the town of Beroun, and are overlapped by the conglomerates of $D 1$ which then rest directly on the Archæan rocks. Moreover, no species of Olenus lias yet been found in Bohemia, from which it may be inferred that there is little if anything to represent the lower and middle parts of our Lingula flags, the Lingula grits of Stage D corresponding probably with the Dolgelly Beds of Wales. The 
total thickness of the Cambrian in Bohemia may be about 3000 feet.

The only other exposure of Cambrian rocks in Central kurope is in Russian Poland, round Sandomir on the Vistula, where some shales, associated with quartzites and conglomerates, liave yielded species of Paradoxides (? P. bohemicus), Agnostus (fallax and gibbus), and Liostracus Linnarsoni; evidently a Middle Cambrian fauna.

\section{E. Foropean Geography and Conditions of Deposition}

Any attempt to restore the geographical conditions of the early Palrozoic periods must be a task of great difficulty. There are large areas where the rocks of these early systems are deeply buried below those of newer times, and the exposures which we can study are only so many isolated portions of some ancient sea-floor; while the traces of contemporaneous lands are only to be found where some series of strata are absent or where coarse detrital deposits are unusually thick. Nevertheless, wherever Palaozoic rocks can be followed over a considerable area some indications of the direction from which the sediment was transported can usually be found, and of the conditions under which it was deposited.

It will therefore be useful to indicate such evidence as we possess for answering the question-under what geographical and physical conditions were the Cambrian strata of Northeru and Western Europe accumulated?

In the first place, some general considerations are suggested by a comparison of the deposits in Wales, England, Sweden, and Russia. The enormons thickness of the Welsh Cambrians, which have a maxinum thickness of about 11,000 feet, as compared with a possible 3000 feet in Warwickshire, less than 1000 feet in Sweden, and only 680 feet in Russia, is a point of great significance ; but the inference to be drawn from these figures depends on other stratigraphical facts. If the lower beds were not represented in the Swedish and Russian succession, it might be inferred that the north of Europe was a land-area during the earlier part of the period, and was gradually submerged by the waters of a sea which sprend over it from the south-west, and this view was actnally suggested in 1876 before the Olenellus famma was recognised in Europe. The facts as we now know them, howerer, will not allow of such an inference; the Swedish succession is as complete as that of Warwickshire or Sonth Wales, and the difference in thickness is caused mainly by the great increase in the amount of sandy material in the Cambrian sediments as we pass from east to west, or rather from north-east to south-west. 
In the western areas arenaceous material prevails not only in the Lower Cambrian, but also in the Middle and Upper divisions, for in North Wales a large part of the Lingula Flag Series cousists of flagstones which become coarse quartzose grits as they are followed through Carnarvonshire. On the other hand, in Scotland, Sweden, and Russia sandstone is practically confined to the lowest stage, all the higher portions of the system consisting of limestone and shale.

As the Swedish geologist Linnarsson wrote in 1876, "The facts rather tend to show that most of the Swedish Cambrian rocks were deposited in a deeper sea and farther from land than the British." He points out that the small thickness of the Olenus Beds over such a large area in Sweden can only be explained on this view, for they are so thin compared with the Lingula flags of Wales that the rate at which sediment was accumulated in Wales must have been fifty or sixty times as rapid as it was in Sweden. This must have been due to the much greater proximity of land, while all the facts connected with the Upper Cambrians of Sweden lead us to infer that they were deposited in a deep sea and far from land.

We uay therefore conclude that the greater part of the materials forming the Cambrian deposits in France, Wales, and England were derived from lands which lay to the west of France and to the north-west of Wales. That which lay west of France and south-west of Wales was probably part of a large land-area or continent, occupying part of what is now the Atlantic Ocean, and terminating eastward in a promontory which iucluded the northern part of Brittany during early Cambrian time, but was submerged in the later part of the period.

The land to the north-west of Wales may have been an island or another promontory of the Atlantic continent. It included Anglesey and probably stretched across the Irish Sea into Ireland, but until more is known about the structure of the north of Ireland it is impossible to say how far it reached in that direction.

Open sea seems to have extended across the North Atlantic region from America to the north of Scotland with circumpolar or Arctic land again to the north of it, for it is only in this way that the American character of the Scottish Cambrian fauna can be satisfactorily accounted for (see The Building of the British Isles, 3rd edition, p. 63). This northern sea may not have been very deep, but its waters must have become deep enough and clear enough in Middle Cambrian time for the formation of limestone, and in the Scottish limestones there is evidence that the accumulation of shell-debris and calcareous matter went on very slowly; for 
the condition of the larger fossils in these beds is such that they must have lain for a long time on the sea-floor and have suffered greatly from decay and partial solution before they were protected by a covering of other calcareous materials.

Mr. Peach ${ }^{33}$ has observed that the shells are generally inperfect and seldom show the external markings; the Lamellibranchs, though often found with attached valves and in their natural position, are yet often so imperfect that they have clearly suffered much from solution before complete embedment. Again the outer walls and the septa of the chambered Cephalopods lave in most cases been largely or wholly destroyed, so as to leave only the thick colunin of the central siphuncular portion of the shell.

Moreover, these limestones contain many nodules of chert arranged in layers like the flints and cherts in Cretaceous deposits, and sometimes in continuous layers or sheets. These cherts contain sponge-spicules, and though no Radiolaria can now be recognised in them it is very probable that the silica was derived partly from Radiolaria and partly from siliceous sponges.

The occurrence of glauconite grains in certain beds, not only in Scotland but in the Upper Cambrian of Sweden and Russia, is also indicative of clear water, slow deposition, and some distance from land; for it is probable that the conditions favourable for the production of glauconite on sea-floors have not materially changed from Cambrian time to the present day. Those conditions are found where the water is clear and the bottom currents are fairly strong but carry little sediment, and where the depth of water is from 200 to 500 fathoms; the actual depth, however, seems to be less important than the other conditions.

Passing now to the more sonthern parts of the European region we find proofs of the existence of a Cambrian Sea in Portugal, Spain, Provence, and Sardinia ; so that it seems probable that the whole of Western and Southern Europe was covered by this sea, though there may have been islands within its linits. It is ouly in Bohemia that we seem to approach one of the borders of this sea, for there the older Cambrian deposits are limited to one part of the area, the Upper Cambrian overlapping on to Archasn rocks. Even this land may have been an island, but if it was part of a large tract that must have lain to the east or south of Bohemia

Another point to be noted with regard to the plyysical conditions of Cambrian time is that very little volcanic activity showed itself in the European region till toward the close of the period. After the violent and long-continued outbursts of volcanic energy which prevailed in pre-Cambrian times, there seems to have been a period of quiescence and subsidence before the subterranean forces acquired 
power enough to burst forth again into surface eruptions. During the later part of the period volcanic activity became rife in several parts of the region, notably in Wales, Brittany, and Bohemia.

\section{REFERENCES}

${ }^{1}$ On the "Silurian System of Rocks," by R. I. Murchison, Phil. Mag. third series, vol. vii. p. 46 (1835).

2 On the "Silurian and Cambrian Systems," by Professor Sedgwick and R. I. Murchison, Rep. Brit. Assoc. 1835, part ii. pp. 59-61.

3 On the "Tripartite Classification of the Lower Palæozoic Rocks," Geol. Mag. Dec. 2, vol. vi. p. 12 (1879).

4 In Zittel's Palocontology, English edition (1900), vol. i. p. 622.

5 Hicks in Quart. Journ. Geol. Soc. vol. xxvii. p. 384, and vol. xxi. p. 39; also Popular Science Rev. 1881.

6 A. R. Andrew, Gcol. Mag. for 1910, pp. 159, 201, 261.

7 J. F. N. Green, Proc. Geol. A ssoc. vol. xxii. p. 135 (1911).

8 Salter in Ramsay's Geology of North Wales, ed. 2, p. 62.

9 Fearnsides, Quart. Journ. Geol. Soc. vol. 1xvi. p. 142 (1910). 166.

10 Ramsay, "Geology of North Wales," Mem. Geol. Surv. 2nd edition, p.

11 T. M'K. Hughes, Quart. Journ. Geol. Soc. vol. xxxiv. p. 137, vol. xxxv. p. 628; and Proc. Geol. Assoc. vol. viii. p. 199.

12 C. Lapworth, "Geology of the Birmingham District," Proc. Geol. Assoc. vol. xv. p. 313 (for 1898).

13 T. T. Groom, Quart. Journ. Geol. Soc. vol. lviii. p. 89.

14 Cobbold, Qucart. Journ. Geol. Soc. vol. lxvi. p. 19 (1910).

15 T. T. Groom, Quart. Journ. Geol. Soc. vol. Iv. p. 157 et seq (1899).

${ }^{16}$ C. Callaway, Quart. Journ. Geol. Soc. vol. xxxiii. p. 652 (1877).

17 J. E. Marr, Geol. Mag. for 1894, p. 122.

18 Miss G. L. Elles, Quart. Journ. Geol. Soc. vol. liv. p. 463.

19 G. W. Lamplugh, "Geology of the Isle of Man," Mcm. Geol. Surv.

20 Egall and M'Henry, Sum. Prog. Geol. Surv. for 1898, p. 57.

${ }^{21}$ See "Geological Structure of the N.W. Highlands," Mfem. Geol. Surv.

22 G. Barrow, Quart. Journ. Geol. Soc. vol. Ivii. p. 328 (1901).

23 R. Campbell, Geol. Mag. for 1911, p. 63.

24 C. Barrois, Proc. Geol. Assoc. vol. xvi. p. 101, and Congrés Géol. Internat. for 1900 (Excursions).

${ }^{25}$ D. P. Ehlert, Congrès Géol. Internat. for 1900, Livret Guide (Mayenne).

${ }_{26}$ Barrois, "Terrains anciens des Asturies," etc., Mem. Soc. Géol. Nord (de France), Tome 2 (1882).

27 J. Gosselet, Congrès Géol. Internat. for 1900, Livret Guide (Ardenne).

${ }^{2 s}$ C. Malaise, Bull. Acad. Koyal de Belg. for 1910.

${ }^{29}$ See Mobery in Geol. Foren. Stockholm. Forandl. for 1910.

${ }^{30}$ Schmidt, Quart. Journ. Geol. Soc. vol. xxxviii. p. 514.

31 Pompeckj, Jahrb. K. K. Geol. Reichsaust. xlv. p. 495.

32 Marr, Palocozoic Rocks, Sedgwick Prize Essay for.

${ }^{33}$ Peach in "Geol. Structure of the N.W. Highlands." 


\section{CHAPTER VI}

\section{THE ORDOVICIAN SYSTEM}

\section{A. Nomexclature axd Divisioxs}

THE grounds on which this system lias been established have already been explained (see p. 70). It is the Upper Cambrian of Sedgwick and the Lower Silurian of Murchison and the Geological Survey. The system has usually been divided into three series with the following names:-

3. Upper Ordovician or Bala Series.

2. Middle Ordovician or Llandilo Series.

1. Lower Ordovician or Arenig Series.

The names are taken from places in Wales where the several series are well developed, i.e. the Arenig Mountains in Merioneth, the town of Llandilo in Carmarthenslire, and the town of Bala in Merioneth. This succession was first established in North Wales by Sedgwick. Part of it was studied at the same time in Shropshire and Carmarthen by Murchison, who described the local equivalents of the Bala Series under the name of Caradoc Sandstone, and after their identity had been demonstmited the beds were for a time called the Bala and Caradoc Series

These divisions, lowever, were not separately mapped either by Murchison or by the Geological Survey, so that they were never clearly marked off from one another, nor was any definite horizon recognised as the base of the Llandilo Series or as that of the Bala Series. The first to establish divisions or a strictly palronto. logical basis was Dr. H. Hicks ${ }^{l}$ who in 1875 recognised hoth the Arenig and Llandilo Beds in Pembrokeshire, and subsequently found that they were separated by a set of black shales which contained a new and distinct fauna ${ }^{2}$ These he called the Llanvirn Beds, but for a long time this group was regarded as a superfluous division, only embodying what should or could be classified as the Upper Arenig and the Lower Llandilo stages. 
Gradually, however, it has been found that the fauna of the Llanvirn Beds has more than a local value and is really distinct from those above and below. A portion of the Llanvirnian outcrop was mapped by Messrs. Marr and Roberts in $1885,{ }^{3}$ and other portions subsequently by the Geological Survey, with the result that in a recent memoir Dr. Strahan announces that the only possible course is to restrict both the Arenig and Llandilo Series, and to establish an intermediate Llanvirn Series. ${ }^{4}$

Dr. Marr has also advocated the separation of the Upper Bala from the rest of that series because it contains many species which do not occur or are rare in the lower beds, but the true value of this Ashgillian fauna has yet to be proved, and in this volume I shall not recognise more than four main divisions in the Ordovician System, namely :-

4. Bala Series (Ashgillian and Caradocian).

3. Llandilo Series or Llandeilian.

2. Llanvirn Series or Llanvirnian.

1. Arenig Series or Arenician.

\section{B. Life of the Period}

Taken as a whole, the special features of the Ordovician fauna are (1) the abundance of branched and biserial graptolites belonging to the families Dichograptida, Dicranograptida, Glossograptida, Leptograptidoe, and Diplograptida. Of these the first includes the following genera-Dichograptus, Tetragraptus, Loganograptus, Didymograptus, and Phyllograptus; in the Dicranograptidæ are Dicellograptus and Dicranograptus. The Glossograptidæ include Glossograptus and Lasiograptus. The Leptograptidæ include Leptograptus and Nemagraptus (=Conograptus), while Diplograptus, Crytograptus, and Climacograptus belong to the Diplograptidx.

(2) The appearance of many new trilobite genera-* Aglina, Acidaspis, Ampyx, *Amphion, Asaphus, Calymene, Encrinurus, Harpes, Homalonotus, Illcenus, Lichas, Phacops, *Placoparia, Proëtus, Remopleurides, Sphcerexochus, Staurocephalus, *Stygina, and *Trinucleus, those with an asterisk not surviving this period.

(3) The abundance of Cystideans, eight genera, and twenty-three species, occurring in the Bala Group.

(4) The abundance of Orthidx, and the appearance of the following genera of Brachiopoda-Atrypa, Leptona, *Orthisina, Rhynchonella, Siphonotreta, Strophomena, Trematis, and Triplesia.

The occurrence of graptolites throughout the Ordovician System in almost all areas where shales were deposited has afforded a means of subdivision into stages or zones and of correlating the 
successive nembers of one local series with those of another and with those of other countries. The following is a table of the yones recognised in the British Islands:-

\begin{tabular}{|c|c|c|}
\hline \multirow{4}{*}{ Bala Series } & \multicolumn{2}{|c|}{ Zone of Dicellograptus anceps. } \\
\hline & ", & $\begin{array}{l}\text { complanatus. } \\
\text { Pleurograptus linearis. }\end{array}$ \\
\hline & ,", & Dicranograptus Clingani. \\
\hline & ", & Clinıacograptus Wilsoni. \\
\hline Llandilian & " & Didymograptus superstes. \\
\hline & $"$ & $\begin{array}{l}\text { Didellograptus divaricatils. } \\
\text { Didymograptus II rehisoni. }\end{array}$ \\
\hline Llanviri & $"$ & ", bifidus. \\
\hline Arenician & ", & hirundo. \\
\hline & ", & xtensus \\
\hline
\end{tabular}
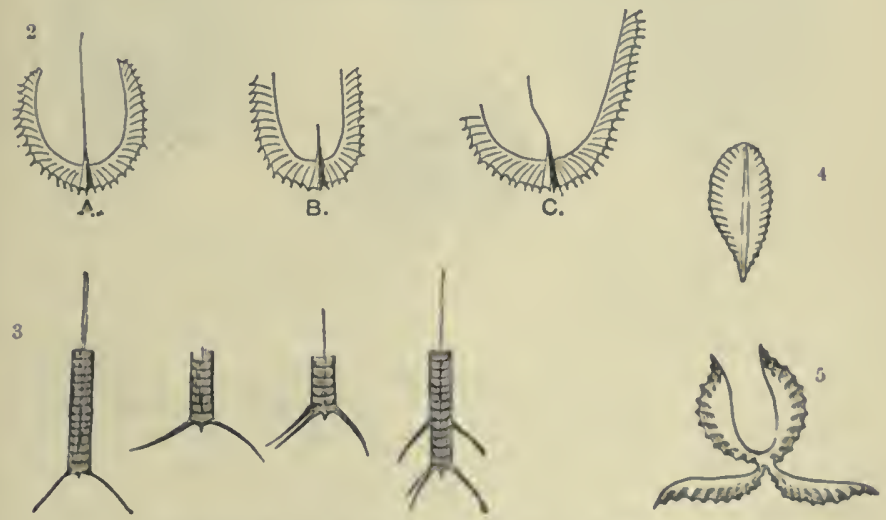

Fig. 24.-GROUP OF ARENIG AND SKIDDAW GRAPTOLITES.

1. Didymograptus hirundo.

2. Didymograptus gibberulus.

3. Cryptograptus antennarius.

4. Phyllograptus typus.

5. Tetragraptus quadribrachiatus.

'The following are the principal species which characterise the several divisions of the Ordovician System :-

\section{Fossils of the Arenig Series}

Hydrozoa. Tetragraptus quadribrachiatus, T. serra, Didymograptus extensus, D. hirundo, D. gibberulus, Pliyllograptus typus, Dendrograptus arbuscula, Diplograptus dentatus, Azygograptus suecicus. 
Crustacea.

Ogygia Selwyni, O. marginata, Eglina binodosa, $\mathbb{E}$. caliginosa, Calymene parvifrons, Caryocaris Wrighti. Brachiopoda. Lingula petalon, Monobolina plumbea, Orthis alata.

Lamellibranchia. Redonia anglica, Palæarca amygdalus.

Gastropoda. Hyolithes (Theca) vaginula.

Cephalopoda. Orthoceras sericeum.

Hydrozoa.

\section{Fossils of the Llanvirn Series}

Didymograptus bifidus, Did. Murchisoni, Did. nanus, Did. acutidens, Diplograptus (Amplexograptus) confertus, Diplograptus calcaratus, Glossograptus ciliatus.

Trilobita.

Ampyx nudus, Illæenus Hughesi, Placoparia canıBrachiopoda. Lingula attenuata.

brensis, Phacops llanvirnensis, Barrandea Homfrayi.
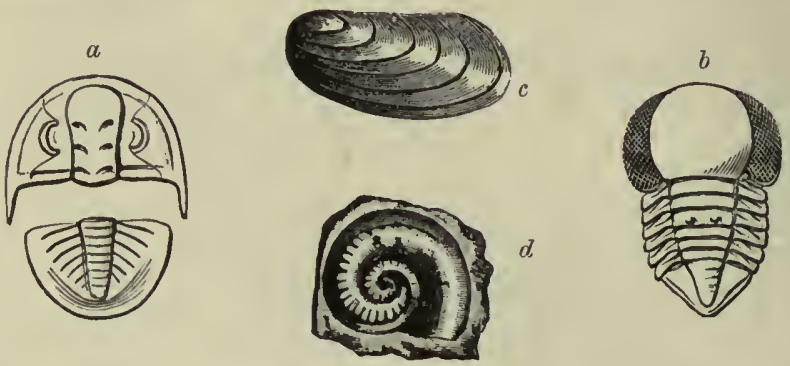

Fig. 25.-GROUP OF ARENIG FOSSILS.

a. Ogygia Selwyni.

b. Eglina binodosa. c. Palæarca amygdalus.

d. Euoinphalus corndensis.

Gastropoda. Euomphalus corndensis, Pleurotomaria llanvirnensis, Cephalopoda. Conoceras llanvirnense, Orthoceras caeresiense.

Radiolaria.

\section{Fossils of the Llandilo Series}

Species of Styptosphæra, Spongoplegma, Diploplegma, Stauroplegma, Haliomma, Dorysphæra, Doryplegma, Triplosphæra.

Foraminifera. Saccammina Carteri.

Hydrozoa.

Didymograptus superstes, Diplograptus foliaceus, Dicellograptus divaricatus, and D. sextans, Nemagraptus (Cœnograptus) gracilis, Dicranograptus ramosus.

Crustacea.

Asaphus tyrannus, Ogygia Buchi, Ampyx nudus, Trinucleus fimbriatus, Agnostus M'Coyi, Acidaspis Jamesi.

Brachiopoda. Lingula brevis, Orthis alata, O. confinis, Siphonotreta micula (ranges into Bala).

Gastropoda. Maclurea Logani, M. magna, Ophileta compacta, Bellerophon perturbatus (passes to Bala).

Cephalopoda. Orthoceras Avelinei. 

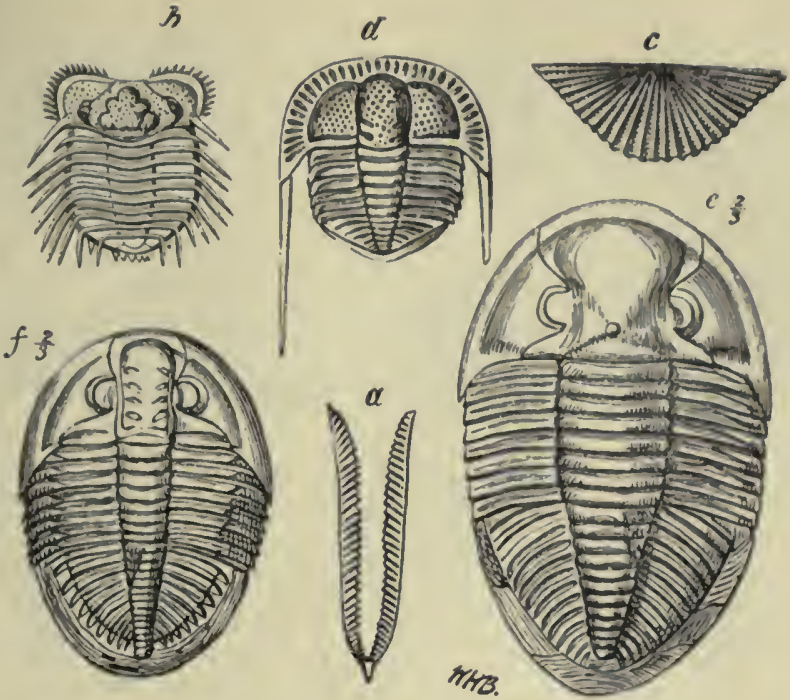

Fig. 20.-GROUP OF AKENT: AND LLANDILO FossLLy.

a. Didsmograptus Murchisoni,

b. Acidaspis Jamesi (Irish).

c. Urthis alata (Areuig). d. Trinucleus flubriatus.

c. Asaphus tyrannus.

f. Orgygia Buchi.
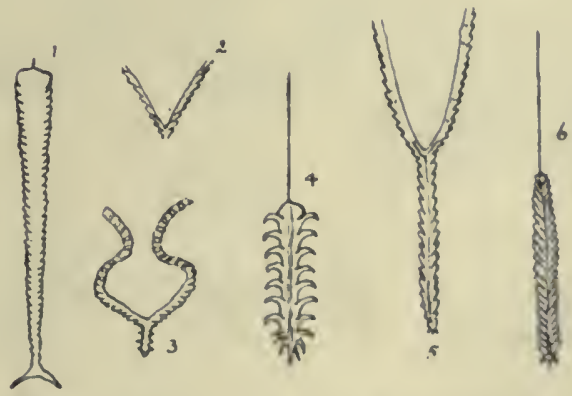

Fig. 2T.-GROUP OF LLANDILO AND HALA GRABTOLITEN.

1. Climacograptus bicornis.

2. Dicellograptus sextans.

3. Dicellograptus ziczac.
4. Glossograptus Hiucksi.

5. Dicranogtaptus ramosus.

6. Diplograptus foliaceus. 

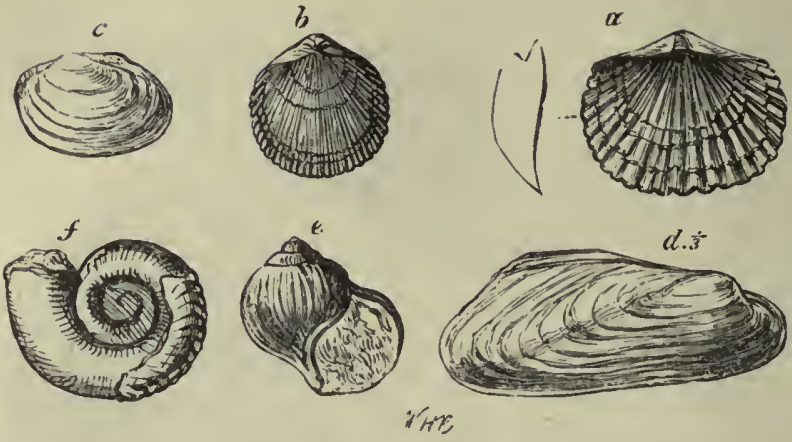

Tig. 28.-(iRouP of BALA FossiLs.

u. Orthis flabelluinm.

1. Orthis elegantula.

c. Ctenodonta semitruncata. rl Modiolopsis expansa.

e. Holopea concinna.

f. Lituites hibernicus.
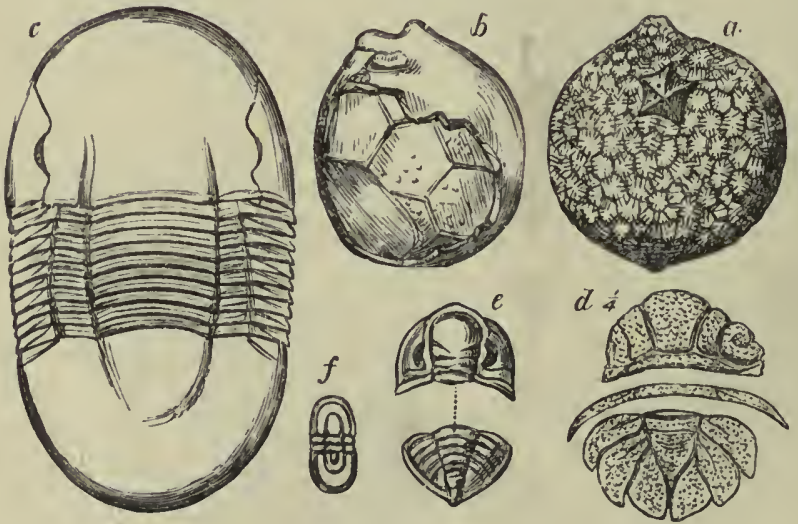

Fig. 29.-CROUP OF BALA FOSSILS.

a. Echinosphera aurantium.

t. Sphæronites munitus.

c. Illanus Davisii. d. Lichas hibernicus.

e. Phacops apiculatuss.

f. Agnostus trinodus. 


\section{Fossils of the Bulce Series}

Actinozoa. Fuvosites crassa, Monticulipora tibrosa, Nebulipora

lens, Lyopora fuvosa, Halysites catenularius.

Hylrozoa. Climacograptus Wilsoni, Dicranograptus Clingani, Pleurograptus linearis, Dicellograptus anceps, D. complanatus, D. truncatns, Leptograptus flaccidus.

E'chinoderme. Rhaphanocrinus basalis. Echinosplirera aurantiun, Sphe-

Crustacer. ronites munitus, S. Litchi, Hemicosnites rugatus.

$\Lambda$ grnostns trinodns, Trinucleus concentricus, T. seticornis, Illenus Davisi, I. Bowmanui, Homalonotus bisulcatus, Phncops apiculatus, P. Brongniarti, Lichas laxatus, L. hibernicus, Staurocephalus globiceps.

Bryoza.

Monticulipora favulosa, M. petropolitana, Phyllopora Hisingeri, Ramipora hochstellaris.
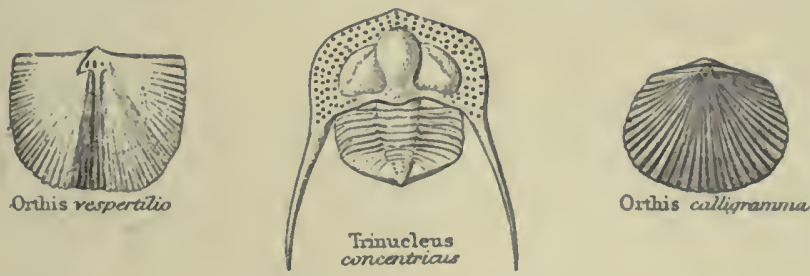

Hig. 30. -THREE BALA FOSSILS.

Brachiopode. Orthis actonie, O. flabellulum, O. calligramma, 0. Liforata, 0 . hirnantensis, 0 . vespertilio, Leptæua (Plectambonites) sericea, Strophomena expansa, S. siluriana, Trematis corona.

Lam:llibranchia. Ctenodonta varicosa, Palearca edmondiiformis, Modo. lopsis obliqua, M. expansa, M. inodiolaris.

Grestropoda.

líolopea eoncinna, Cyclonena crebristria, Murchisonia simplex, Ecculiomplalus Bucklandi, Tentaculites anglicus, Hyolithes(Theea) triangularis, Bellerophon nodosus.

Cephalopodce. Cyrtoceras sonax, Ortlioceras vagans, Trochoceras cornuarietis.

\section{British Ordovtcian Rocks}

Ordovician rocks occupy much larger areas of the surface in Great Britain than the Cambrian rocks, and are also found in several parts of Ireland. In Wales they occupy nearly all the western and central portions of the country, ontsicle the Cambrian outcrops. They pass enstward beneath the overlying Silurian strata, and portions of them emerge again in Shropshire and Radnorshire. 
Rocks of this age occupy a large part of the Lake District, where they were first studied by Sedgwick. The Isle of Man is an isolated fragment of this Cumbrian area, while to the eastward, in Yorkshire, some small exposures occur, proving the extension of Ordovician rocks beneath the newer strata in that direction.

In the south of Scotland, Ordovician and Silurian rocks range across from Wigtown to Berwickshire, and form the mass of the Southern Highlands, their northern boundary being generally the great line of fanlt which runs from Girvan in Ayr to the Lammermuir Hills.

Ordovician rocks occur in many parts of Ireland and exhibit several different facies, one of these facies being found in the northwest (Galway, Mayo, Donegal, and Londonderry), another in the north-east (Down, Cavan, and Meath), another in the south-east (Wicklow, Wexford, and Waterford, with extensions into Clare and Tipperary).

In most places the Ordovician rocks seem to succeed the Cambrian in conformable sequence, but in North Wales there appears to be a decided break of continuity, the basal grit of the Arenig Series lying unconformably on the Cambrian and passing transgressively across the inembers of the Tremadoc Series on to those of the Ffestiniog Group. From an examination and survey of the country around the Arenig and Aran Mountains Mr. Fearnsides has expressed his belief that the Cambrian rocks of North Wales were ridged up into a series of low flexures striking north and south before the deposition of the Arenig sediments. ${ }^{5}$ This physical disturbance was probably due to the intense volcanic action which shortly afterwards led to the establishment of surface volcanoes, and to the outpouring of the great masses of lava and ashes which are such conspicuous features in the Ordovician Series of Merioneth and Carnarvonshire.

\section{Wales}

Arenig Series.-The typical district of this group is supposed to be that of the Arenig Mountains in Merioneth; but the series. as now restricted is not there very thick, and it will be more convenient to begin with South Wales, Pembroke, and Carmarthen, where it has a fuller development.

The outcrop of the Arenig Series on Ramsey Island and round St. David's Head is shown on Fig. 16, p. 80. From the latter point its ontcrop runs eastward and curves round the St. David's an ticline to near Haverfordwest, and thence eastward to Carmartlien and Llangarthwey. 
Dr. H. Hicks described the Lower Arenig, near St. David's, as consisting of fine black slates and shales, which are best exposed in Ramsey Island, where they have yielded Didymograptus extensus, Phyllograptus stella, Trigonograptus ensiformis, and T. truncatus. They also contain Ogygia scutatrix and Asaphellus homfrayi. Some of the same beds are seen in Whitesand Bay on the mainland, but are faulted against the Tremadoc slates. He believed this group to be about 1000 feet thick.

What must be called the Upper Arenig (Middle Arenig of Hicks) are a series of black slates and flagstones with some beds of gritty sandstone, and they have yielded many of the characteristic Arenig trilobites, Ogygia peltata, Aglina grandis, Trinucleus Gibbsi, and Ampyx Salteri, and the graptolites Tetragraptus serra, T. crucialis, and Didymograptus patulus. These beds are about 1500 feet thick.

The equivalents of this series have recently been mapped in Carmarthenshire for the Geological Survey by Messrs. Cantrill and H. Thomas, who have termed them the Tetragraptus Beds and have divided them into two stages or zones, (1) that of Didymograptus extensus, (2) that of Did. hirundo. The former includes the greater part of the series, and is over 1000 feet thick; lithologically it consists of blue-black shales and mudstones with grits and conglomerates at the base which mark it off from the underlying Tremadoc slates. The npper zone appears to be ouly about 200 feet thick.

North of Carmarthen the Arenig Series passes under the flexured mass of higher Ordovician rocks which occupy the central area of Wales (Cardigan, Brecknock, and Montgomery), not again coming to the surface till brought up by the great Harlech or Merionethshire anticline. Round this it forms a nearly continuous outcrop from Towyn on the coast throngh the Cader Idris, Aran, and Arenig ranges, and thence through the Migneint district to Manod Mawr, north of Ffestiniog (see Fig. 19), where it seems to be faulted against higher beds. Throughout this tract of country from Cader Idris to the Arenig Mountains, the place of the Arenig Series appears to be entirely below the beds of volcanic ash and the intrusive masses of andesite which were formerly included in this series. In the district of Arenig Fawr and Moel Llyfnant the succession of beds has been mapped and described by Mr. Fearnsides, ${ }^{6}$ and the position of the Arenig Beds is shown in the section drawn by him and reproduced by his permission in Fig. 31 . The series here is only about 600 feet thick, but both zones can be recognised, and the sequence is as follows :- 


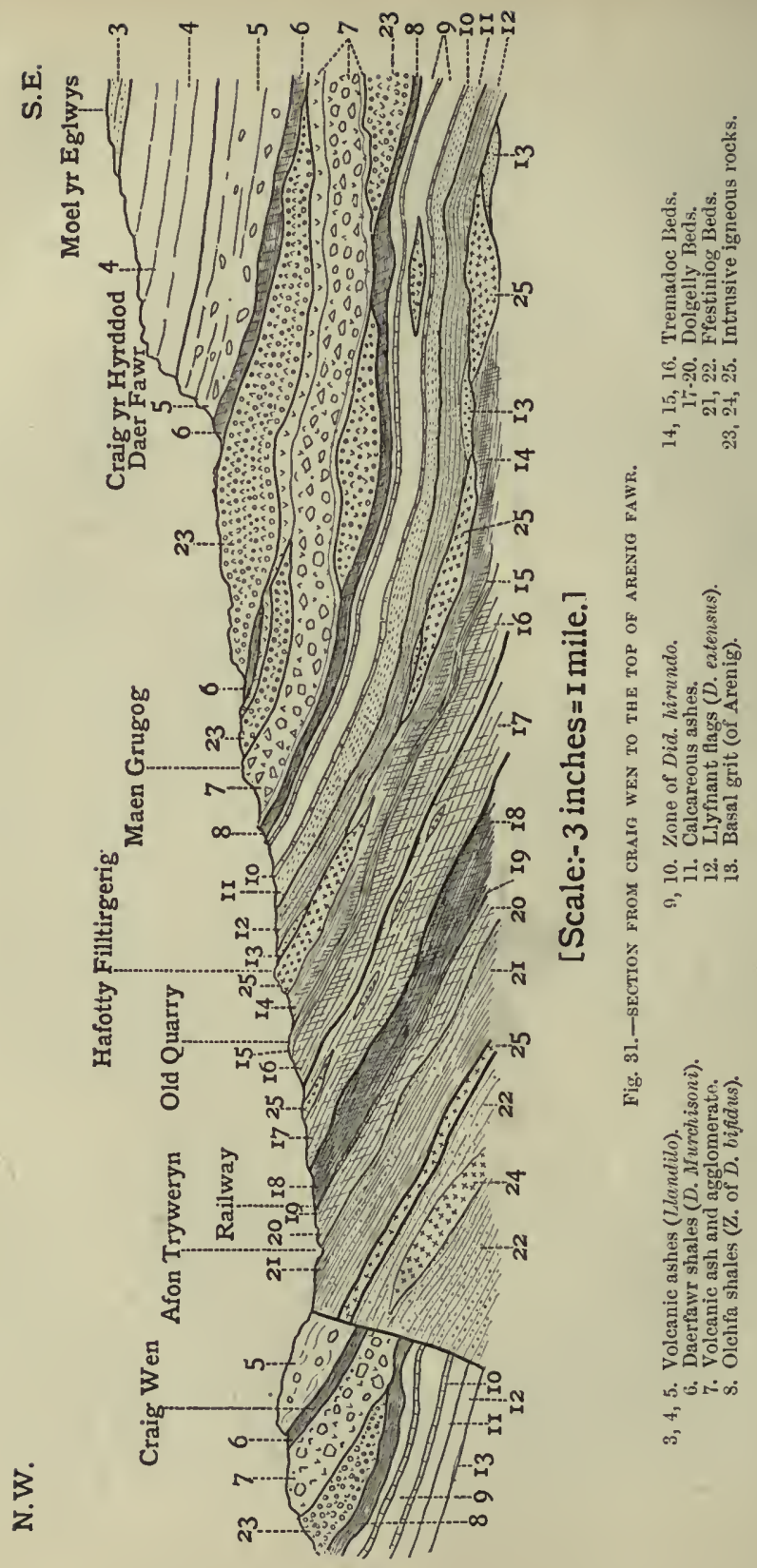


5. Dark calcareous shales with Didymograptus hirundo and Tetragraptus serra.

4. Erwent or Ogygia linestone, yielding Ogygia Selvoyni, Orthoceras sericeum, Monobolina plumbea, etc.

3. Henllan ashes-liard, grey, compact beds with Calymene parvifrons

2. Llyfnant Hags with Did. extensus and $D$. deflexus

1. Basal grit, varying in thickness from

On the north side of the Harlech anticline the series is found in the Moëlwyn Mountains, north-west of Ffestiniog, the basal grit being there overlain by 800 feet of liard spotted flagstones in which only a species of Tetragraptus has yet been found. The limestone is absent, and the Did. hirundo shales seem to be represented by bands of slate intercalated with thick beds of volcanic ash and agglomerate.

JVestward the basal grit has been found above the Tremadoc Series, but the overlying beds are so broken by faults that no succession can be made out. They come in again in the southern part of the Lleyn peninsula where grits and flags with extensiform graptolites pass across the edges of the Lingula flags and rest on the Archran rocks near Aberdaron. On the eastern side these beds are overlain by a band of grit and breccia 60 to 70 feet thick containing fragments of schist, graulite, etc., derived from the Archran rocks, and this is succeeded by dark shales which have yielded Didymograptus hirundo. Above them are beds of ironstone and manganese-ore with blue mudstones containing Azygograptus suecicus.

Arenig slates also form part of the great slate country in Carnarvonshire north-west of the Snowdon range, but the details of this area have not yet been worked out. The complete series has, however, been indicated by Miss G. L. Elles ${ }^{7}$ along the banks of the river Seiont at Carnarvon, where the zone of $D$. extensus consists of calcareons flags and shales containing that species with Azygograptus suecicus and Eglina binodosa. To the sonth of these beds are micaceous flags and shales yielding $D$. hirundo, $D$. nitidus, and numerons phyllopods, and these are succeeded by black shales with a Llanvirn fauma. The outcrops extend for a distance of about 2000 yards with a dip of from $40^{\circ}$ to $50^{\circ}$ to the south-east, and the series seems therefore to be about 1400 feet thick.

Arenig Beds have also been recognised on both sides of the Menai Strait, but in Central Anglesey they are believed to have thinned out and to be overlapped by the Llanvirn Beds. 
ஸे

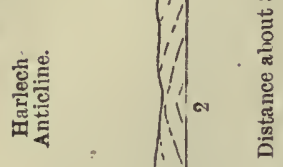

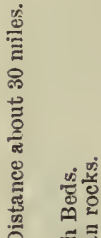

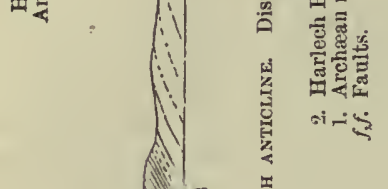

6.

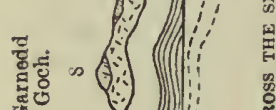

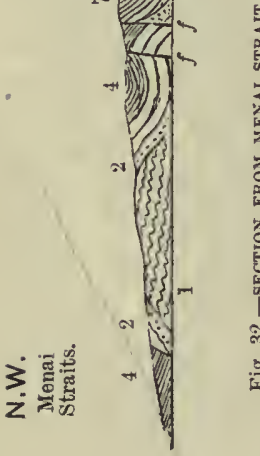

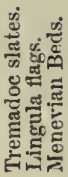

แ่ ชึक

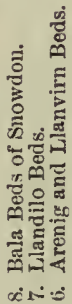

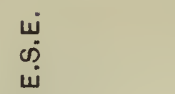

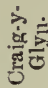

is

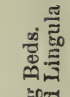

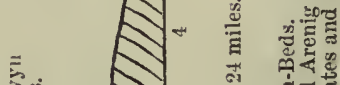

ڤีำ

苟

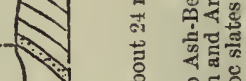

유용

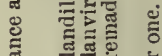

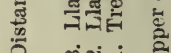

लंsin

\%

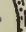

गु

ค ตี๊

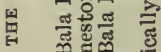

ㄱ

-

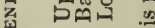

ङ

幽

총

농

है ह

क्ष

हैं

㤐葛 
Llanvirn Series.-This group was separated from the berls below and above it by Dr. Hicks in 1881. It takes its nane from that of a village near Llanrain in Pembrokeshire (see map, Fig. 16), where the slates have yielded many of the characteristic trilobites and graptolites of the Iower Ilanvirnian or \%one of Didymograptus bifudus. This species and its congeners D. artus, D. nanus, and D. Murchisoni are often termed the tming-fork graptolites, as distinguished from the extensiform species which prevail in the underlying Arenig Beds.

The lower stage is probably from 1200 to 1500 feet thick in Pembrokeshire, and consists of dark-grey flags and slates. The upper stage or zone of D. Murchisoni consists of fine black slates interbedded with felspathic tnflis and has a thickness of about 500 feet.

These beds have now been mapped by the Geological Survey from Haverfordwest eastward, through Narberth and Carmarthen. Along this tract the lower stage maintains its thickness, but the Murchisoni Beds are much reduced, being only 230 feet near St. Clears, while east of Carmarthen they appear to thin out lelow the base of the overlying Ffairfach Grit (Llandilo).

Passing now to Merioneth there is no doubt that the Llanvirnian can be followed all round the great Harlech geanticline, but they have not yet been separated from the Arenig and Llandilo Series. Their position on Arenig Fawr is indicated in Mr. Fearuside's section (Fig. 31, p. 118), the base being marked by a lsand of shale with $D$. bifidus which is overlain by a volcanic series consisting of ash and agglomerate with thick intrusive masses or laccolites of hypersthene-andesite. Above these, however, is an outcrop of shale containing Diplogruptus foliacens and other species which suggest a ligh horizon in the Murchisoni zone.

The position of the Llanviruian in the Moelwyn area lias not yet been ascertained, but fartlier west in the promontory of Penrliyn (see Fig. 20), it appears to be faulted down against the basal Arenig grit, for the black slates of Ty Obrey which adjoin that grit have yielded fossils which prove them to be of Llanvirn age. Albove them are asliy slates and asl beds passing under a thick volcanic series.

In Carnarvon the Llanvirn Series lias not yet been separated as a stratigraphical division from the beds above and below, but as mentioned on p. 119, the bifulus zone has been recognised as succeeding the hirundo-beds on the river Seiont near Carnarron.

Its existence in Anglesey has a specinl interest, because in the central part of that island it forms the base of the Ordovician System, and has a basal conglomerate which rests directly on the 
Archæan rocks. The lowest horizon from which fossils have been obtained are sandstones overlying the basal conglomerate near Llanfaelog (see Fig. 34). . These fossils are an Orthis resembling 0 . Carausi and fragments of a trilobite regarded by Professor Hughes as a Neseuretus, but the specimen is probably Calymene Tristani, while the slates which succeed the sandstones contain graptolites of Upper Llanvirn species. Moreover, as Dr. Matley has pointed out, there is a complete absence both in Central and Northern Anglesey of the characteristic Arenig graptolites. ${ }^{8} \mathrm{He}$ therefore infers that the lowest fossiliferous rocks in Central Anglesey are equivalents of the beds now classed as Llanvirnian, while in the north of the island even these do not appear, and must have been overlapped by the Bala Series.

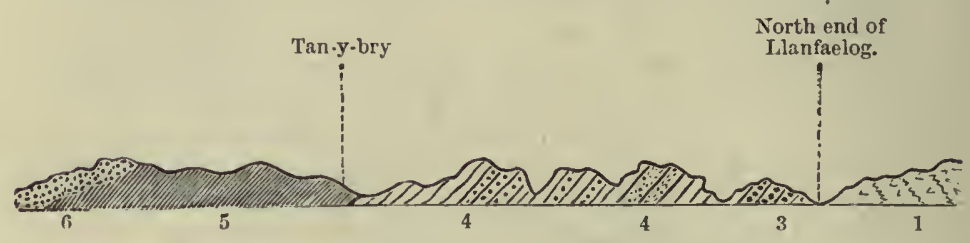

Fig. 34. -section west of llaxfaelog (Dr. H. Hicks).

Scale 6 inches to a mile.

6. Blown sand.

5. Black slates and dark flags.

4. Flagstones and sandstones.
3. Basal conglomerate (? Ordovician).

1. Granitold Series.

Llandilo Series.-The typical area of these beds and the place from which they take their name is Llandilo in Carmarthenshire, where the series originally described by Murchison as the "Llandilo flags" forms a natural group, well marked off, both in regard to its lithological characters and its fossil contents, from the underlying Llanvirn Series. Hence the Geological Survey have recently found it necessary (as already stated) to adopt the latter series as a primary division and to restrict the Llandilo Series within its original limits.9

Near Llandilo and north-eastwards to Llangadock the group consists mainly of grey calcareous flagstones weathering to a yellowish brown. These are about 2500 feet thick, and in their lower part they contain many beds of hard bluish-grey limestone, most of them being fossiliferous and yielding both Ogygia Buchi and Asaphus tyrannus. Under these beds is a hard massive calcareous grit., the Ffairfach grit, which has a thickness of about 150 feet and aiso contains Asaphus tyrannus. 
When traced westward, howerer, this grit thins ont and its place is taken by a band of volcanic ash, while the upper part of the flagstone series passes into black shale, the whole at the same time greatly diminishing in thickness, so that near Carnarthen the group is less than 900 feet thick and the succession is :-

Hendre shales with Dicellograptus divarientus ".

Hendre shales with Dicellograptus divaricatus . . . 500

Vlandilo flags and limestones . • • . • • about 250

Volcanic ash with Asaphus tyrannus . . . . . about 70

Still farther west the "Asaphus ash" also thins ont, and the flaggy limestones are condensed into one band of dark grey or black limestone which rests directly on the Llanvirnian slaales.

On the north side of the St. David's anticline the series lias again become much thicker and is divisible into two stages as below:-

Black slates and flags with Ogygia Buchi and Calymene duplicala

Calcareous flags and limestone with Asaphics tyrannus and Calymene cambrensis

Feet.

1000

about 800

The restricted Llandilo Series has not yet been mapped either in Merioneth or Carnarvonshire. The upper andesitic and rhyolitic ashes of the Arenig Mountains are regarded by Mr. Fearnsides as belonging to this series, and they are unconformably overlain by a fossiliferous limestone which seems to belong to the Bala Series. In the anticline of the Berwyn Mountains to the eastward Ilandilo Beds appear again with a more normal facies, having a band of limestones at or near the base which are about 400 feet thick and are full of such fossils as Asaphus tyrannus, Calymene cambrensis, Orthis turgida, etc.

In the Snowdonian district there is a great development of volcanic rocks which were included by Ramsay in the Bala Series, but are now thought to be largely of Llandilo age; for upon the highest volcanic rocks of Snowdon rest black shales crowded with species of Diplograptus which seem to indicate a low horizon in the Bala Series.

The lavas and ashes of the Snowdon range seem to have issued from a group of volcanic vents which probably formed volcanic islands in the Ordovician sea. Near the actual centres of eruption both ashes and lavas are found, the latter being usually rhyolites, but in other localities, presumably more distant from the volcanic vents, ashes are the prevalent deposit, and these are interstratified with some bands of slaty shale. This volcanic series extends to the very northern extremity of Carnarvonshire. 
Bala Series. - In Pembrokeshire this series was described for the first time in any detail by Messrs. Marr and Roberts in $1885 .^{10}$ They examined the succession of beds near Haverfordwest and Narberth, and established divisions which have been adopted by the Geological Survey officers, who have since mapped the beds through Pembroke and Carmarthen, and have at the same time fixed the horizon of passage between the Llandilo and Bala Series in this area.

The limestones are seldom all developed in one locality, being lenticular beds which thin out entirely in some directions, but when each occurs it is on the same horizon and the complete succession is given as follows:-

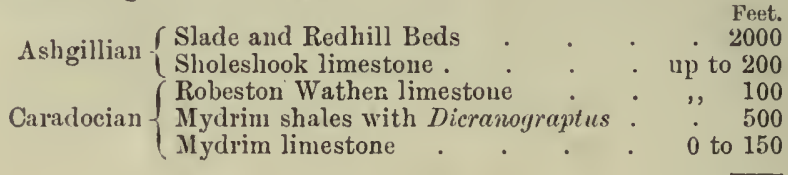

$$
\begin{aligned}
& \Lambda \text { bout } \overline{2900}
\end{aligned}
$$

The Mydrin limestone is quite local, and in its absence the horizon call only be distinguished by the change in the species of graptolites, the lower part of the Mydrim shales being characterised by Dicranograptus Nicholsoni, the middle part by Mesograptus multidens, Dicranograptus Clingani, and Diplograptus calcaratus ; while the uppermost 100 feet yield Diplograptus truncatus and Climacograptus minimus.

The overlying limestones are most fully developed near Narberth, the lower beds consisting of fairly pure limestone, black in tint and crowded with corals of the genera Heliolites, Halysites, and Favosites, with many Brachiopods, but few trilobites. The Sholeshook limestone has quite a different assemblage, being grey or greenish in colour, impure and sandy in texture, and characterised by an abundant trilobite fauna including Staurocephalus globiceps, Trinucleus seticornis, Phacops Brongniarti, and Cheirurus juvenis, with many Cystideans, Gastropoda, and Cephalopoda.

The overlying beds form a monotonous series of bluish-grey mudstones which are only fossiliferous on certain horizons; they sonetimes include bands of limestone containing Favosites fibrosus and sometimes more sandy beds which contain many species of Orthis, while the shales contain Leptcena sericea.

Northward this Bala Series extends over a considerable area, and probably occupies large parts of Central Wales, along the anticlinal axes of the numerous flexures into which the rocks of that region have been folded, bnt little information about them is at present available. 
In North Wales they are typically developed near Balil, lut the base of the series has not yet leen deteruined by graptolitic evidence. There is a great thickness of sandy shales below the Bala limestone, and some portion of them is probably of Balit age, but the greater part of the Lower Bala Group of Sedgwick is now regarled as Llandilian.

The beds which have been grouperl as Bala limestone inchude two distinct horizons or zones; and the name Bala limestone is now restricted to the lower of these zones, the Rhiwlas limestone, which was formerly exposed at Rhiwlas, north of Bala, lxeing the equivalent of the Sholeshook limestone in Pembrokeshire.

Even the main mass of the Bala limestone is often split up into several beds by the intercalation of ealcareous sandstone or shale,

S.

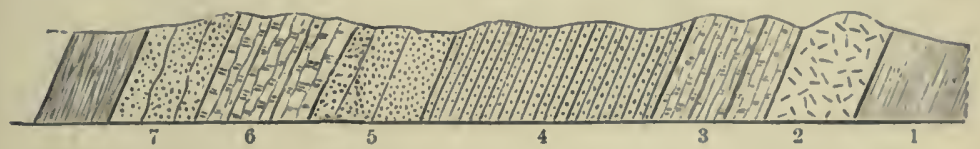

Fig. 35. - SECTIOS THROUGH THF BALA LIMESTONE SEAR IELLLIRIS, SOUTH OF BALA LAKE (Ruddy).

S. Shales with Iepternu serieer.

$\because$ Coarse sand, many fossils.

is. Crystalline limestone.

5. Coarse sarkl like No. :
4. Sandy' shales, trilobitu's.

8. Sandy limestone, brachiopods.

2. Voleunic a*h.

1. Shales with Orthis.

as at Gellygrin, to the south of Bala Lake, as described by Mr. T. Ruddy. ${ }^{11}$ Here there is a lower limestone, 12 feet thick and containing many fossils, sueceeded by sandy shales with mauy of the characteristic Bala, triloljites, and some feet ligher a hard, massive, crystalline limestone 18 or 20 feet thick, the whole groul' of beds ( 5 to 8 in Fig. 35) being about 50 fect thick.

The characteristic fassils of the Bala limestone are Trintueleus concentricus, Asaphus Powisi, Phacops apiculatus, Homalonotus bisulcatus, Orthis vespertilio, 0 . spiriferoides, and 0 . biforata. Thave of the Rhiwlas limestone are Cyrtoceras sonux, Orthocerus ragans, Trinucleus seticomis, Ampyx tumidus, Encrinurus sexcostatus, Stanrocephalus clavifrons, Phacops Brongniarti, Lepterna tenuicincta, Spharonites Litchi, Echinosphare aurantium, Hemicosmites rujatus and other cystid Echinoderns.

Above this limestone there is some $\mathbf{1 5 0 0}$ feet of sandy shale, the upper beds of which contain graptolites of Silurian (i.e. Llandovery) species. The exact horizon at which the divisional line should be drawn has not yet been ascertained, but the thickness of Upper Bala Beds is probably not less than 1000 feet. 
Fron the above account it will be seen that the succession in the typical Bala district may be summarised as below :-

Upper fGrey sliales and shaly saudstones .

Feet.

Bala $\{$ Rhiwlas limestone

Lower $\{$ Bala limestone

Bala $\{$ Grey sandy shales

about 1000

10 to 20

10 to 50

perhaps 1600

About 2600

The snccession in the Berwyn Mountains to the eastward has been described by Mr. D. C. Davies, and more recently by Messrs. Groom and Lake. ${ }^{12}$ From the account given by the latter of the series exposed near Glyn Ceiriog, it appears that a great thickness of beds (the Paudy Series) below the Bala limestones must be included in the Bala Series. These beds consist of volcanic ashes, sandstones, and slates, and some of them contain many of the characteristic Bala fossils; their total thickness being about 1600 feet. In the Ceiriog district the true Bala limestone appears to be faulted out, but elsewhere there is from 200 to 300 feet of such limestone, containiug the nsual trilobites, brachiopoda, and corals. Above this are calcareous shales and bands of limestone containing the fauna of the Rhiwlas beds. These are succeeded by shales of a considerable thickness.

To the north and nortli-west of the Bala district the limestones appear to thin out or to pass into a nodular calcareous tuff. In the Lleyn peninsula the place of the Bala Series is occupied by a thick set of sandy shales and mudstones of an olive-green colour, and including thin beds of felspathic grit which are largely made up of volcanic detritus.

The Bala Series can be traced nortliward to Conway, and the snccession near tliat place has been described by Miss G. L. Elles, ${ }^{13}$ who has divided the beds into the following groups:-

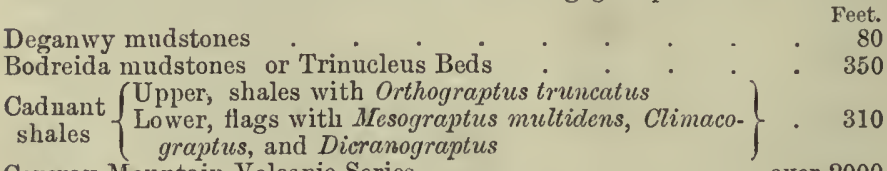
Conway Mountain Volcanic Series

over 2000

Miss Elles regards the Lower Cadnant shales as Llandilian, but almost all the species of graptolites recorded by her from these beds occur also in the Mydrim shales of Carmarthen, and as the total thickness of the sedimentary beds at Conway is only 740 feet, it is probable that the base of the Bala Series is to be found in the wolcanic rocks. 

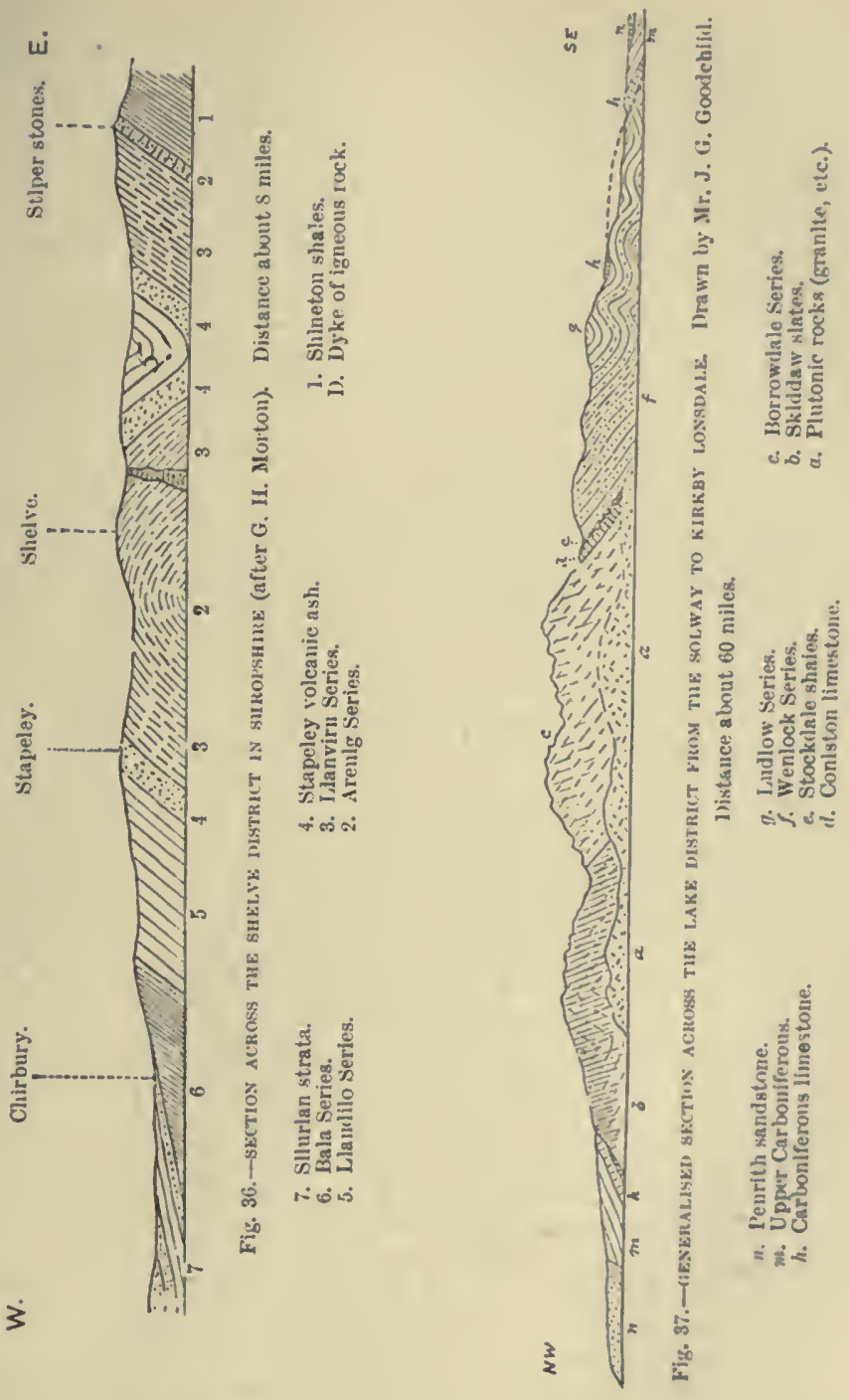


\section{Shropshire}

As the Ordovician Series of South Shropshire is a continuation of the Welsh facies of the formation, it is unnecessary to give a detailed account of the local subdivisions. For a description of these the student is referred to that given by Professors Lapworth and Watts in Proc. Geol. Assoc. vol. xiii. p. 312 . Only a brief summary will here be given, with a separation of the Llanvirnian by means of the graptolite zones which Miss Elles has more recently been able to establish.

The Ordovician Series is brought up to the surface in Shropshire by the broad compound geanticline, of which the Longmynd may be regarded as the central axis (see map, Fig. 21, and section, Fig. 7). The principal area of Ordovician rocks is on the western side of the Longmynd, around Shelve and Corndon, where the general dip is westward, and the whole succession is found from Arenig to Upper Bala. On the easteru side (Caradoc area) the outcrop is narrow and only equivalents of the Bala Series occur, resting directly either on Archrean or on Cambrian rocks. From this disposition it is evident that all the lower members of the Ordovician System thinned out against the shores of a land-area consisting of the older rocks, and that this land did not sink below the Ordovician Sea until the begiuning of Caradocian time.

Arenig Series.-The base of this division consists of a hard siliceous grit or quartzite forming the ridge called the Stiper stones ; above this are grey and green fiagstones with interbedded shales, in which Professor Lapworth has found Ogygia Selwyni, Tetragraptus quadribruchiatus with species of Phyllograptus and Trigonograptus which mark them as Lower Arenig. In the higher part of the series both Didymograptus extensus and D. hirundo have beeu found, so that probably the whole of the Welsh Arenig,is represented and the total thickuess may be 1500 feet.

Llanvirn Series.-The Hope shales, which have yielded Did. bifidus, form the lower part of this series and are succeeded by hard andesitic tufis with intercalations of shale which prove the whole to have been deposited in water. These beds are overlain by flags and shales with few fossils, but at the top are the Betton shales with Didymograptus Murchisoni. The thickness of this series is probably about 2000 feet.

Llandilo Series.-This is represented by the Meadowtown Beds, a series of flags and flaggy limestones containing Asaphus tyrannus and Ogygia Buchi, overlain by black mudstones and shales with Leptograptus flaccidus and Nemograptus gracilis. Their thickness has not been estimated, but is probably about 1000 feet. 
Bala and Caradoc Series.--Continuing the above successior in the Shelve district the Bala Beds are well exposed in the Spy Wood section. At the base are the Spy Wool grits and flags passing up into shales; these beds yield Trinucleus concentricus, Orthis calligranma, Diplograptus truncatus, Climacograptus bicornis, and other fossils. Above comes the Marrington Group, a set of grey and black shales with interstratified beds of andesitic ashes and breccias or agglomerates; the lighest shales are overlain unconformably by the Silurian (Upper Llandovery Beds), the Hirnant Beds not being exposed.

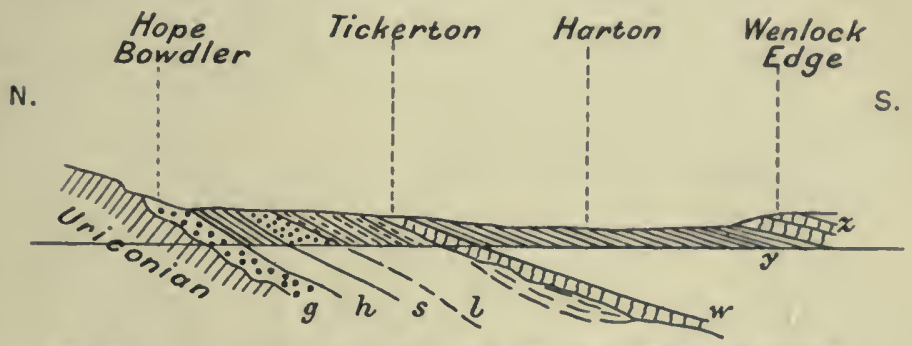

Fig. 38,-8Ection NeAR hope boWDLer in sMropshire (after E. S. Cobbold).
z. Wenlock limestone.
l. Longville flags.
$h$. Harnage shale.
\%. Wenlock shale.
s. Chatwall sandstone.
g. Hoar Edge grits.

ic. Llandovery Beds.

On the eastern side of the Longmynd the succession in the Caradoc district was first worked out by Murchison and formed the type of his "Caradoc sandstone." This was subsequently proved to be only a local facies of the Bala Series. The succession as corrected by Callaway and Lapworth is as follows:-

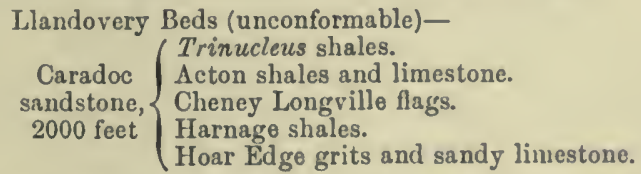

All these beds contain fossils, and the Acton Beds have yielded Lichas laxatus, Ampyx, Orthis Actonia, O. flabellulum, and many corals, so it is probable that they represent the Bala limestone. The highest or Hirnant Beds are concealed by the overstep of the Silurian.

\section{Cumberland and Westmoreland}

Ordovician rocks occupy a large area in the Lake District, which was the scene of Professor Sedgwick's earliest work on the 


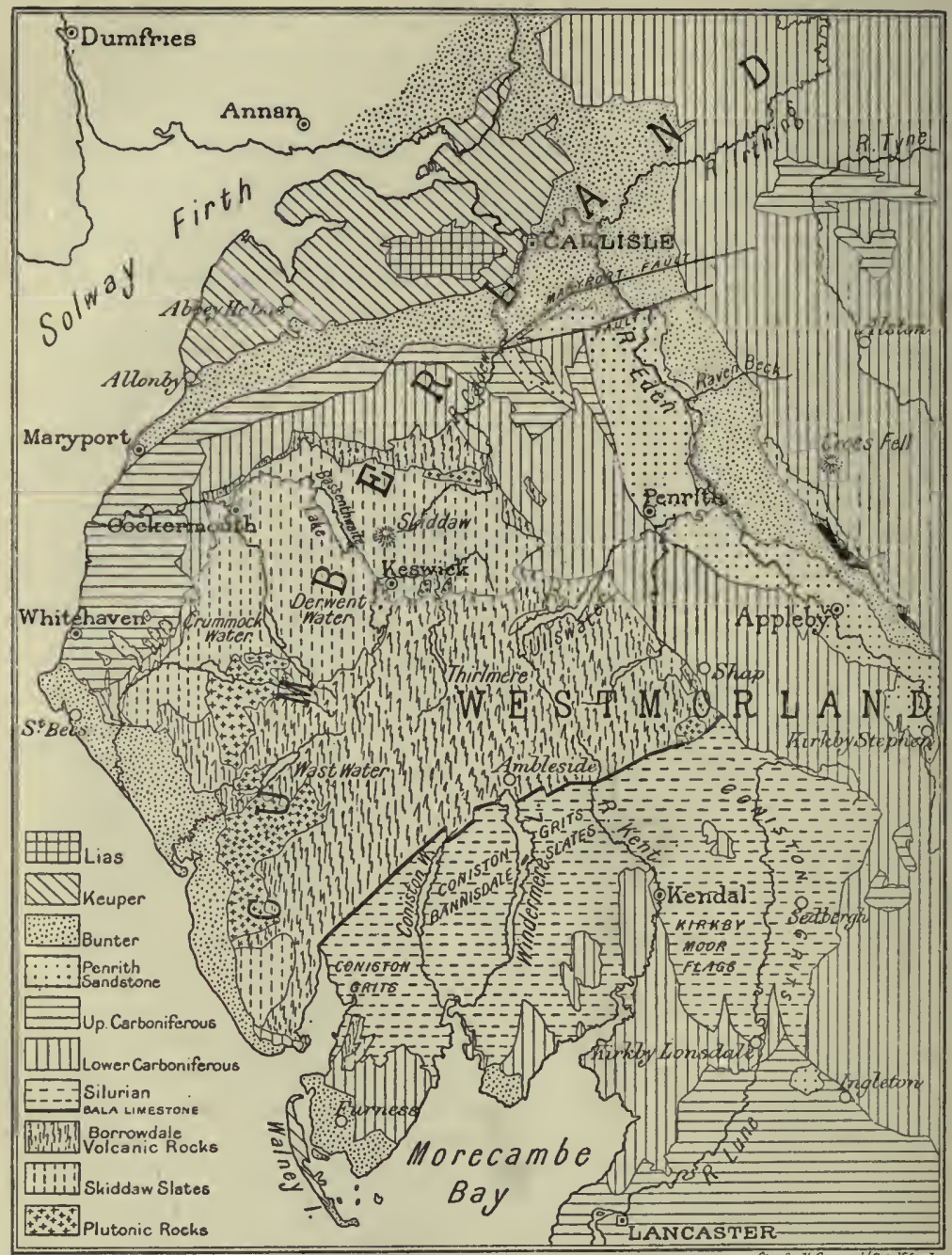

SCALE OF MILES

Fig. 39.-MAP OF CUMBERLAND AND WESTMORELAND. 
rocks of this system (1832-36). All the mountainous region lying north-west of a line drawn from the estuary of the Duddon by Hawksliead and Ambleside to the valley of the lowther Beck consists essentially of Ordovician rocks (see the inap, Fig. 39, and section, Fig. 37 ).

They are also found in a long narrow inlier, known as the Cross Fell inlier, on the eastern side of the Vale of Eden in the worth-east of Westmoreland, bounded on the one side by Carboniferous limestone and on the other by New Red Sandstone.

The Ordovician rocks of this area are divisible into four series, which are roughly equivalent to those of Wales.

Skiddavian Series. - It was stated on p. 93 that the greater part of the great mass of slates which have generally been known as the Skiddaw slates was of Ordovician age, but as the highest portions belong to the Llanvirnian Series it is only the central portion which is strictly the equivalent of the Welsh Arenig Series, and for this part the name Skiddavian may be used. Its basement beds are certain beds of grit which are called the Watch Hill grits in the memoir of the Geological Survey on the country between Appleby, Ulleswater, and Haweswater (1897).

Above this horizon the slates have yielded both trilobites and graptolites, which have enabled Dr. J. E. Marr and Miss G. L. Elles ${ }^{14}$ to recognise three zonal divisions which, however, cannot at present be correlated exactly with those of Wales. They are :-

3. Upper Tetragraptus Beds, yielding Tetragraptus serra, Didymograptus indentus (var. nanus), and Phyllograptus typus.

2. Dichograptus Beds, Dichograptus 8-branchiatus, and Did. patulus.

1. Lower Tetragraptus Beds, with T'etr. Bigsbyi.

The whole series is so greatly flexured and faulted that it is impossible to form any'accurate estimate of its thickness.

Llanvirn Series. - This is typically developed in the Cross Fell area, where the two well-known components of the series have been distinguished under the names of Ellergill and Milburn Beds respectively; the former being black slates containing Didymograptus bifidus and Glossograptus armatus, the latter being mainly volcanic rocks (ashes and lavas) interstratified with slates which have yielded Did. Murchisoni and Diplograptus dentaius.

In the Lake District beds belonging to the lower stage occur near Threlkald and Troutbeck, east of Kieswick, and thase of the upper stage near Ulleswater and elsewhere.

Llandilo Series.-This consists of an immense thickness of rolcanic rocks-rhyolitic and andesitic lavas with thick beds of ash and agglomerate (see map, Fig. 39), which are generally of 
green or purple colour. They are the "Green Slate and Porphyry Group" of Sedgwick, afterwards called the Borrowdale Series. Their total thickness is estimated to be 12,000 feet, but not all of this is of Llandilo age; as above stated the lower part is evidently of Llanvirnian date, the central part must be Llandilian, and the highest part may be of Bala age; for in the Lake District the volcanic series is directly succeeded by the Coniston limestone, but in the Cross Fell inlier there are stratified beds containing Bala fossils between the limestone and the highest rhyolite of that area.

Bala Series.-The thickness of the stratified portion of this series, even including those of Roman Fell, is much less than the corresponding beds in Wales (i.e. about 300 feet), but a regular zonal succession can be made out. The series has beel subdivided by Dr. Marr ${ }^{15}$ as follows :-

$\begin{array}{cll}\text { Ashgillian } & \begin{array}{l}\text { Coniston area. } \\ \text { Shales. } \\ \text { Staurocephalus limestone. }\end{array} & \begin{array}{c}\text { Cross Fell area. } \\ \text { Applethwaite limestone. }\end{array} \\ \text { Sleddale Beds } & \begin{array}{l}\text { Ashill shales. } \\ \text { Conglomerate. } \\ \text { Stile End Beds. }\end{array} & \begin{array}{l}\text { Keisley limestone. } \\ \text { Roman Fell Group- Rhyolite. }\end{array}\end{array}$

The "Corona Beds" are a set of calcareons shales, limestones, and ash beds, about 100 feet in thickness, and they contain many brachiopods, such as Trematis corona, Lingula tennigranulata, Orthis testudinaria. The limestones consist largely of the tests of a small Crustacean called Beyrichia.

The Applethwaite limestone consists of calcareous shales with bands of limestone and a peculiar bed of white horny limestone at the top. Overlying this is a bed of grey limestone about 5 feet thick which contains the fauna of the Rhiwlas and Sholeshook limestones, i.e. many Cystidean Echinoderms with Staurocephalus clavifrons, Phacops apiculatus, and Orthoceras vagans.

The limestones are succeeded by dark blue and grey shales which yield many of the same fossils that occur at similar horizons in North Wales.

\section{Scotland}

The southern uplands of Scotland are largely composed of Ordovician and Silurian rocks folded together into a number of anticlinal and synclinal folds, each fold having its subsidiary plications, so that the country has a complicated structure, and can only be successfully mapped by careful attention to fossils. The older views about this region were mistaken because the fossils were not sufficiently studied, and because it was supposed that 


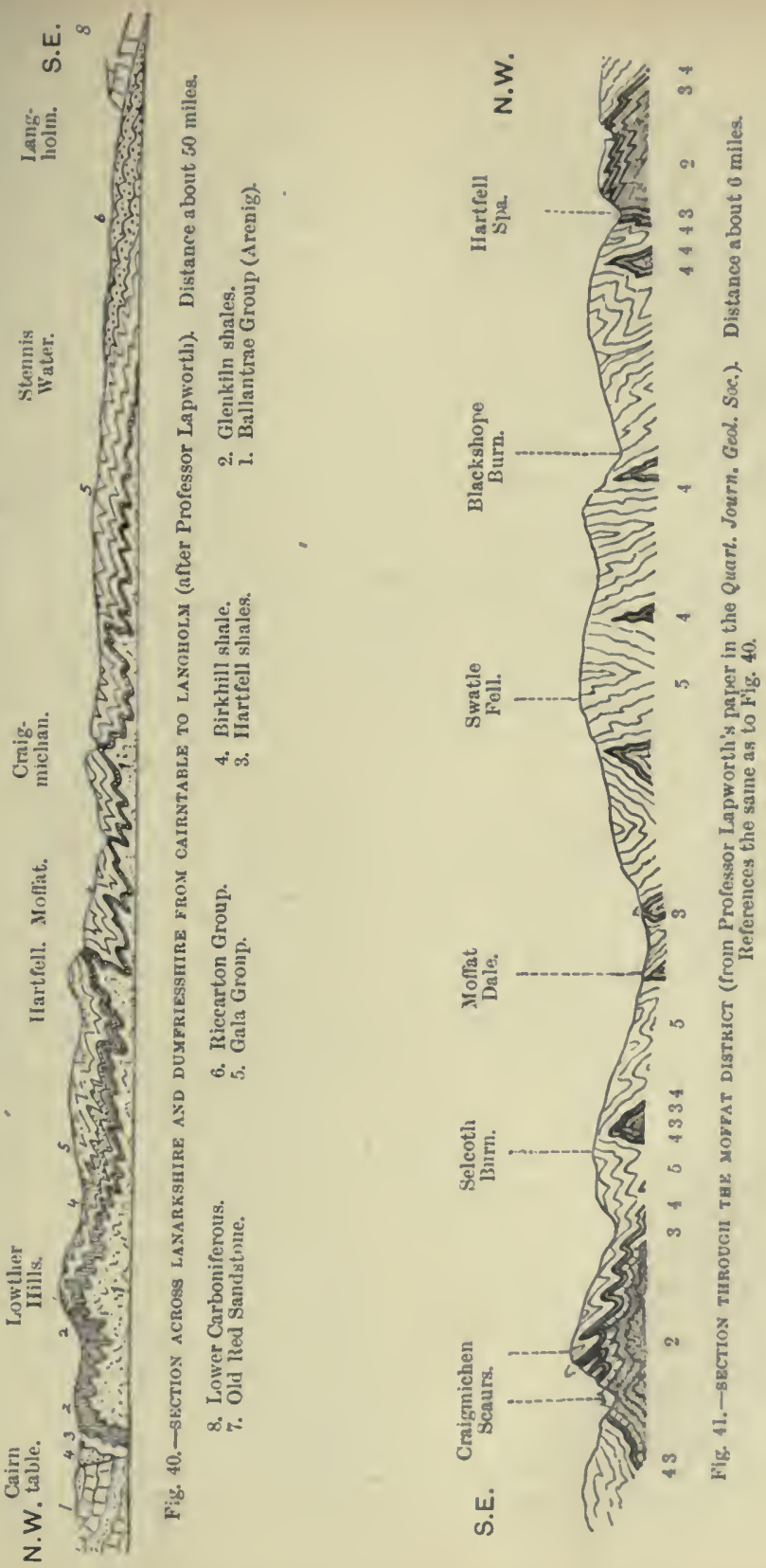


graptolites were characteristic of Llandilo Beds and did not occur outside their limits. The true structure and succession of strata in this region was first established by Professor Lapworth, whose researches on the Girvan and Moffat districts are embodied in two detailed papers, and who afterwards summed up the structure of the whole region in another one, to which the student should refer. ${ }^{16}$ More detailed descriptions are given in the "Geology of the Southern Uplands," Mem. Geol. Surv. 1899. The sections, Figs. 40 and 41 , are taken from Lapworth's paper's.

The special interest of this region is that it presents us with two very different facies of sedimentation, which, however, can be traced through changing intermediate facies from the one area to the other. In Ayrshire (Girvan, etc.) the Ordovician has the ordinary facies of a formation accumulated at no great distance from a continental coast-line, consisting as it does of a considerable thickness of conglomerates, sandstones, shales, with at least one bed of limestone. The other type, found in Dumfries and Wigtownshire, is one that must have been formed in much deeper water, for there the whole system is condensed into a small thickness of darkcoloured mudstones, shales, and chert-beds. The base of it is not exposed, but the total thickness from the summit of the Bala Series down to the base of the Arenig chert-beds is only about 185 feet, as compared with a thickness of 3500 feet in Girvan.

Professor Lapworth divided the Ordovician of this region into three groups or series, which are roughly equivalent to Arenig, Llandilo, and Bala, and these divisions have been adopted by the Geological Survey of Scotland. The graptolitic facies of the formation lends itself to easy zonal subdivision and to correlation with other areas, so that the names given to the middle and upper parts of this succession, i.e. Glenkiln shales and Hartfelt shales, have been widely used as if they were synonymous with Llandilo and Bala. The progress of discovery in Wales, however, has shown that the divisional line between the Glenkiln and Hartfell shale is not quite on the same horizon as that taken in South Wales between the Llandilo and Bala.

Moreover, nothing comparable to the Llanvirn Series has yet been identified in Scotland. No shales yielding Didymograptus bifidus or Did. Murchisoni have been found. In the one area there is a distinct unconformity at the base of the Llandilo with a conglomerate above the break; in the other there is merely an abrupt change from one kind of sediment to another. It is evident, however, that a chapter of the geological record is missing in this region, and the following tabular view gives the established divisions without any attempt to correlate them with those of Wales. 
Drumauck Beds, 400 foet-

b. Shales with Stauroeephalus.

a. Shales with Trinuclens seticornis.

Siralloci Flags, 800 feet-

Flagstones and shales with Dicellograptus truncatus.

WIITEHolse BEDs, 300 feet-

b. Beds with Dicellograptus complanatus.

a. Beds with Leptogr. flaccidus.

A kdwell Flags, 1000 feet-

b. Beds with Dicrano. ramosus and Diplograptus rugosus.

a. Beds with Crypto. tricornis and Diplograptusfoliaecus.

Balclatchie Bens, 100 feet-

Grits and sandstones with Climacograptus bicornis and Cryptogr. tricornis.

Shales with Glossograptus Hinclsi.

Besan Coxglomerate, 500 feet. Stixchar Grovp, 100 feet-

b. Shales with Didymograptus superstes and Dicellograptus sextans.

a. Limestones with Maclurea Logani.

KirkLdNo Beds, 200 feet-

Sandstones and conglomerates with Orthis confinis.

Unconformity here.

Radiolabian Cherts, red and grey cherts, mudstones, and voleanic tuffs, 70 feet.

Black shales of Bennane Head with Tetragraptus quadribrachiatus, 4 feet.

Volcanic Rocks, lavas and tuffs with thin shales containing Tctr. quadribraehiatus, 1500 feet seen.
Hartrell Sitales, 100 feet-

6. Zone of Diecllograptus an. eeps and $D$. truncatus.

5. Barren mudstones.

4. Zone of Dieello. complanatus.

3. Zone of Pleurograptus linearis and Lepto. fluccidus.

2. Zone of Dicranograptus Clingani and D. ramosus.

1. Zone of Climaeogr. Wilsoni and Cryptogr. tricornis.

Glexkilx Shales, 50 feet-

Black shales with Didymo. graptus superstes, Dicel. sextans, and Diplograptus dentatus.

Yellow mudstones with chert. bauds.

Black shales with Cecnograptus gracilis and Didymo. graptus superstes.

\section{Radiolarian Cuert Bejs-}

Mudstones and shales with lajers and lenticular nodules of chert, 150 to 200 feet.

Volcanic tuffs at Trowdale, 150 feet. Base not seen. 
Arenig Series.-From this table it will be seen that so far as the beds are exposed the greater part consists of volcanic rocks, but that the highest member is a group of mudstones and shales interstratified with lenticular layers of red and grey chert which are full of the remains of Radiolaria. From this fact it has been inferred that these beds were oceanic deposits formed under a great depth of water and at a great distance from land. Elsewhere, however, I have shown that such an inference calnot be drawn from the mere occnrrence of Radiolaria (see Building of the British Isles, 3rd edition (1911), pp. 12 and 72).

The narrow compass, within which the beds representing the Ordovician System are compressed in the Mofiat district, is shown in Fig. 42, which is reduced from a section in the Survey Memoir.

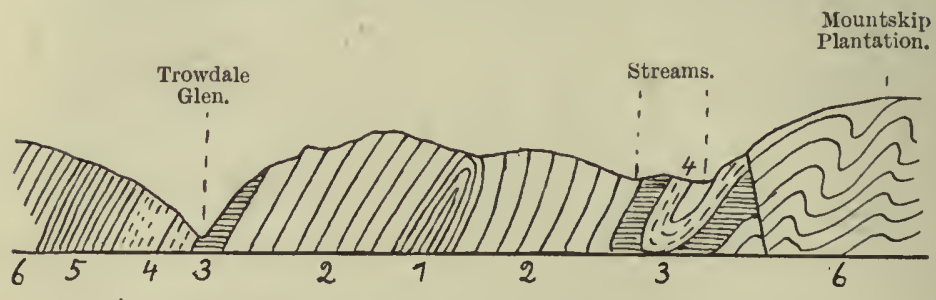

Fig. 42. - SECTION THROUGH TROWDALE IN THE URR VALLEY.

(Scale about 750 feet to an inch.)

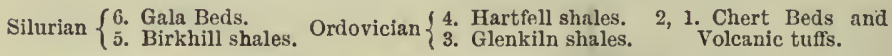

In the Barr Series the Stinchar limestone is an interesting horizon, for many of its fossils are not found anywhere in England, but occur in the Trenton limestone of North America; such are Maclurea Logani, M. magia, Murchisonia angustata, the spongelike coral Tetradium, and Saccamina Carteri; there are also many corals (Lyopora favosa, etc.) and brachiopods, with Lichas sexcostatus? Illcenus latus, I. Bowmanni, and Calymene Blumenbachi, most of which range from Upper Llandilo to Bala Beds.

The Balclatchie Beds are inclnded in the Barr Series by Professor Lapworth, bit he speaks of them as forming a transitional band or zone, and many of the graptolites range into the Hartfell shales. Messrs. Peach and Horne place these beds in the Ardmillan or Bala Series, but leave the Benan conglomerate in the Barr Series. It is possible that the plane of divisions should be drawn between the Balclatchie shales and the overlying grits.

The Ardmillan Series, which is the equivalent of the Welsh Bala Beds, consists of a great thickness of alternating flagstones, 
sandstones, mudstones, and shales. It is interesting to note that near the top of the highest (Drunmuck) group there is a thin bed of grit which has yielded Staurocephalus globiceps, Trinucleus Bucklandi, a species of Palkaster and other fossils, associated with shales containing Dicellograptus anceps and Diplograptus truncatus. The graptolites show that these beds are equivalent to the highest part of the Hartfell shale, but there are no limestones comparable with those of Bala and Coniston.

Beds of the Moffat type, dark shales and mudstones, have been traced all across Southern Scotland, from the Lammermuir Hills through the northern parts of Selkirk and Dumfries and the central parts of Kirkcudbright and Wigtown. Beds of an intermediate type form a broad belt to the north of this, varying from 5 to 15 miles in width, from the Moorfoot Hills to the northern part of Wigtownshire.

No deposits of Ordovician age have yet been proved to exist in the Central or Northern parts of Scotland. The only rocks which may possibly be of that age are the green igneous rocks, green shales, and jasper beds which occur between lines of fault along the southern border of the Central Highlands; but these are now believed to be Upper Cambrian (see p. 97).

\section{Ireland}

Ordovician rocks occur in several parts of Ireland, as will be seen by a reference to the map in Chapter IX.; and they must originally have been deposited over nearly the whole of the Irish region. The largest area is that which spreads through Waterford, Wexford, Wicklow, and Kildare, and is penetrated by the large granitic massif which occupies so much of Carlow and Wicklow. The sediments of this area have much resemblance to those of Wales, and may be regarded as a continuation of the latter, but they are much more altered by subsequent igneous intrusions and by concomitant earth pressures, so that they are greatly plicated, crushed, and cleaved.

The tract in the north, extending from Down to County Cavan, presents a facies similar to that of the condensed series of Southeru Scotland, and the same type of graptolitic shale recurs in the south-west round Lough Derg on the borders of Clare and Tipperary. In the north-west, however (Galway and Mayo), there is a very different set of beds of a more littoral character.

Eastern Facies.-The eastern parts of this area were revised by Messrs. Egan and M'Henry of the Geological Survey during the years 1898 and $1899 .{ }^{17}$ 'They found that there was apparently 
a conformable passage from the Cambrian into the Ordovician, though the beds along the line of junction are everywhere so mingled together by subsequent plication and crushing that no definite boundary could be drawn between them. The lowest Ordovician Beds are a set of banded slates and fine grits which are generally known as the Ribband Series. They have yielded fossils near Arklow, Courtown, and Kilrea, which included species of Tetragraptus, Phyllograptus, and Didymograptus, and a Bryograptus like Kjerulfi. Hence they appear to represent a Tremadoc horizon as well as the Arenig and Llanvirn Series.

Above the Ribband Series are black slates which contain a graptolite fauna of Llandilo age, i.e. Dicranograptus Nicholsoni, D. ramosus, Canograptus gracilis, Diplograptus mucronatus, and

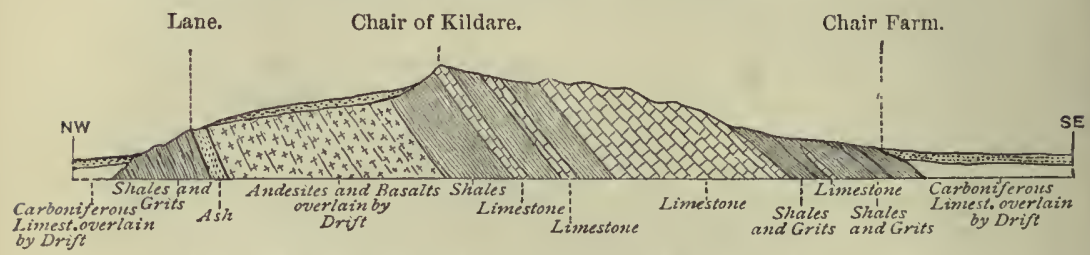

Fig. 43. - section ACross the ChaIr of KiLdARE (Reynolds and Gardiner).

Horizontal scale, 6 inches to a mile.

Leptograptus flaccidus. These beds are succeeded by shales and limestones of Bala age which have yielded many fossils.

At Portraine, on the coast north of Dublin Bay, there is a small inlier of Ordovician, and the cliffs show an interesting section of Bala deposits. The succession has been described by Messi's. Gardiner and Roberts, ${ }^{18}$ and consists of the following; (1) andesitic lavas, (2) coarse ashy conglomerate, (3) calcareous ash beds with layers of limestone and shale, (4) limestones full of corals, (5) compact grey limestone with many trilobites and brachiopods, including Illanus Bowmanni, Staurocephalus sp., Trinucleus seticornis, and Spherexochus mirus. Thus it appears that after a series of volcanic eruptions in the near vicinity, the water became clear and suitable for the growth of corals, which produced layers and beds of coralliferous limestone, but nothing at all resembling a coral reef. Some change then occurred, probably subsidence, causing a deepening of the water, in consequence of which the corals died out, and their place was taken by trilobites and brachiopods, whose remains are the chief components of the upper limestone.

A more extensive exposure of the series is found in another inlier 
among the Carboniferous rocks of Kildare. The succession there is slown in Fig. 43, reproduced by permission of Messrs. Reynolds and Gardiner ${ }^{19}$ who have described the rocks seen. All the beds belong to the Bala Series, and have a thickness of about 2200 feet, the main limestone being about 550 feet thick, and containing many trilobites and brachiopods; the fauna is that of the Bala limestone, nor do the overlying shales yield Ashgillian species, though beds of a higher horizon may be present.

Northern Facies.-In the counties Down, Arnagh, Monaghan, and Cavan the thickness of the Ordovician Beds is reduced to a band of black sliales and mudstones exactly resembling those of Moffat and the southern Scottisl belt. Many years ago, from exposures south of Belfast Lough, Mr. Swanston obtained all the characteristic graptolites of the Glenkiln and Hartfell shales. There are also some narrow inlying anticlinal exposures among the neighbouring Silurians, and in one of these near Slane (County Meath) Mr. M'Henry lias found some layers of banded Radiolarian chert and dark shales yiclding Lower Llandilo or Arenig graptolites. ${ }^{20}$

The main band of Ordovician runs from north-east to soutl. west, and in Monaghan and Cavan is from 3 to 9 miles broad. The strata pass north-westward below the Carboniferous rocks, and a portion of them emerges on the southern side of the Archxan ridge near Pomeroy in Tyrone. The Arenig and Llandilo Series appear to have thiuned out and to be overlapped by the Bala deposits, which rest directly on the old rocks. The beds are about 350 feet thick and have a conglomerate at the base, overlain by sandstones, flagstones, and mudstones which have yielded a fauna coinparable to that of the Drummuck Beds of Ayrshire (Aslgillian); moreover they are conformably succeeded by Silurian strata. ${ }^{21}$

Western Facies.-Ordovician rocks occupy a considerable area on the borders of Mayo and Galway between Killary Harbour and Lough Mask, and there is another tract between Clew Bay and Castlebar. The most complete succession is found in the cliffs and escarpments of the tracts along Killary Harbour. On the south side the lowest beds seen are black shales and cherts about 60 feet thick, containing four species of Tetragraptus with Dichograptus 8-brachiatus. These beds are succeeded by coarse conglomeratic grits with bands of shale which have yielded Didymograptus extensus and Diplograptus dentatus; this group is 2500 feet thick, and the grits contain pebbles of red granite and quartz-felsite like those which occur in the Archrean rocks to the north and south. ${ }^{22}$

On the south side of the Harbour these grits seems to be 
replaced by the Doolough green slates and grits which contain the same graptolites. They pass up into the Mweelrea grits-red and green felspathic grits which in the lower 3000 feet include bands of shale yielding Ogygia Buchi and brachiopods, but no graptolites ; they are evidently of Llandilian age. In conformable succession is an enormous and monotonous series of reddish felspathic grits, without a single parting of shale and quite destitute of fossils, but they are probably of Bala age. Thus we have the following correlation :-

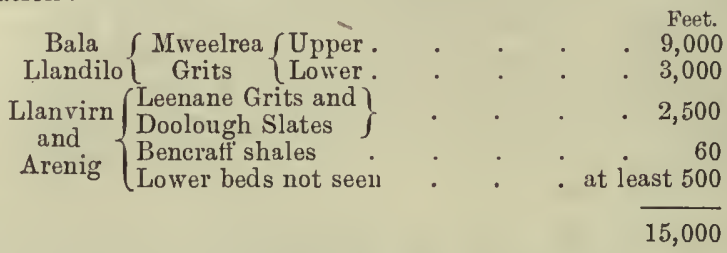

To the eastward in the Glensaul and Tourmakeady districts a much greater thickness of Arenig Beds is exposed, and they consist partly of coarse grits and conglomerates, partly of a thick mass of volcanic materials, which lower include some fossiliferous beds of limestone and shale. Omitting the felsitic lavas, most of which are intrusive, the succession described by Messrs. Gardiner and Reynolds in this area may be summarised as follows :- ${ }^{23}$

Coarse conglomerate and sandstone (very thick)

Feet.

Calcareous tuffs, with bands of limestone

Massive agglomerate of felsite-fragments

Volcanic tuffs with a shale yielding Didymograptus hirundo and

D. gibberulus

Coarse felspathic grits and tuffs . . . . . . . . 700

Coarse quartzose and some felspathic grits . . . . . 150

Fine siliceous grits including a black shale with Tetragrapti and cherts containing Radiolaria. . . . . . . 150

Coarse grits and conglomerates . . . . . seen for over 800

It will be seen that the base of the Arenig Series is not exposed, but as the lowest conglomerates contain pebbles of gneiss, micaschist, and hard grit they probably rest upon Archæan rocks.

The lowest fossiliferous band has yielded five species of Tetragraptus, associated with Didymograptus extensus, D. nanus, and small forms of $D$. bifidus. The only other species found at the higher horizon is Diplograptus dentatus, and the fauna might be Arenig or Llanvirn. The limestones contain a peculiar trilobite fauna, which leads Mr. Cowper Reed to correlate them with the 
Cystidean and Asaphus limestones (Llanviruian) of Sweden and Russia, species common to both being Nileus armadillo and Chasmops cf. Odini; while others occur in Canada, the genera Bathyurus and Bathyurellus being essentially American.

The overlying conglomerate has the appearance of lying unconformably on these upper beds, but it is lithologically similar to the Leenane grits, and is probably of the same age.

\section{Some European Areas}

\section{France}

To British geologists the most inportant region in France where Ordovician rocks are exposed is that of Brittany, Normandy, and Anjou. In this region they lie in the long synclinal troughs which run roughly from west to east and are nost fully developed in the central part of the region, from Grandchamp north of Vannes by Redon and Chateaubriand to Angers in Maine-etLoire. ${ }^{24}$ Along this tract the following general succession has been established (see Fig. 44), though some of the subdivisions are not continuous throughout its extent.

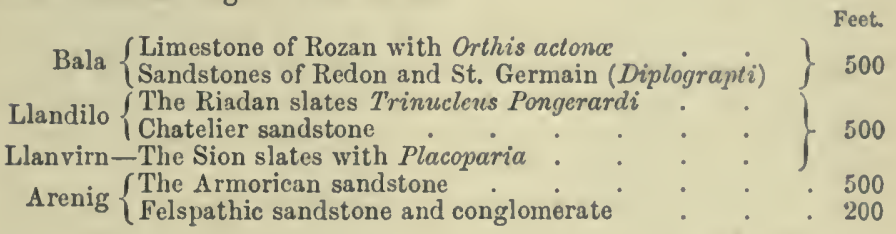

The felspathic sandstones (Grès felspathique) are poorly developed in the south of Brittany, but are very thick in the north, from 500 to 1000 feet, and have clearly been formed from the erosion of Archran and granitic rocks during the interval between the Cambrian and Ordovician sedimentation in this part of France. They may indeed be partly of Tremadoc age (see p. 99).

The Armorican sandstone (Grès armoricain) consists of hard white sandstones with few fossils, chiefly Lamellibranchs of the genera Redonia, Ctenodonta, and Actinodonta and annelid tracks (Scolithes, Bilobites). It also is much thicker along the northern outcrops than along the southern, where it is sometimes less than 100 feet. Eastward, in Anjou, it is largely represented by shales.

The Sion slates generally have a bed of oolitic ironstone at their base, and the slates contain graptolites of the geminus and Murchisoni types with the trilobites Placoparia Zippei, Asaphus Guettardi, and Calymene Tristani. 
In the south of Brittany the Llandilo Series begins with the sandstone of Chatelier (see Fig. 44), which is overlain near Poligny by the black slates of Riadan, the latter containing Trinucleus Pongerardi, Acidaspis Buchi, Illcenus Beaumonti, and Calymene arago. In Northern Brittany the series is largely composed of sandstone.

The sandstones of Redon and St. Germain-sur-Ille represent part of the Bala Series, but as they contain few fossils and pass up into Silurian sandstones it is difficult to separate the one from the other, except in the west (Crozon, near Brest), where the two sandstones are separated by a band of limestone yielding Orthis Actonice and Illcenus Munieri.

In Normandy the facies is somewhat different and the general succession is as follows :- ${ }^{25}$

Bala-Green slates with Trinucleus Grenicri $\quad$ Feet. Llandilo-Grès de May with Homalonotus, eteri . . 200 Llandio-Grès de May with Homalonotus, etc. . . . . 500 Llanvirn-Blue slates with Calymene Tristani . . . . 300 Arenig $\left\{\begin{array}{l}\text { Grc̀s armoricain } \\ \text { Grès fols }\end{array}\right.$

It will be seen that in most parts of this area the total thickness is not more than 1500 feet, for the Grès felspathique is only found in the west of the Cotentin and is overlapped to south and west by the Gres armoricain. The overlying Calymene slates correspond with those of Sion and Angers and generally have a bed of ironstone at the base.

The Grès de May has recently been subdivided into 4 zones characterised by certain species; these in descending order are :-

4. Sandstones with Conularia pyramidata.

3. Shales and grits with Trinucleus Bureaui and Cal. Tristani.

2. Sandstone with Homalonotus (Vicaryi and 3 other sp.).

1. Sandstones with Dalmanites armoricanus and Homalonotus.

Orthis budleighensis is another common fossil in the lower part of the Grès de May. The highest member of the Ordovician, the shale with Trinucleus Grenieri, is not always present; it is found near Cap la Hague and has a bed of sandstone above it, and thus it is possible that elsewhere it is represented by some of the highest beds of the Grès de May.

In connection with the Ordovician of Normandy brief mention may be made of the area of Ordovician rocks which has long been known to exist in Cornwall. The area occupied by the older Palæozoic rocks in the south-west of Cornwall has recently been resurveyed, but only a small portion of it has been proved to be 

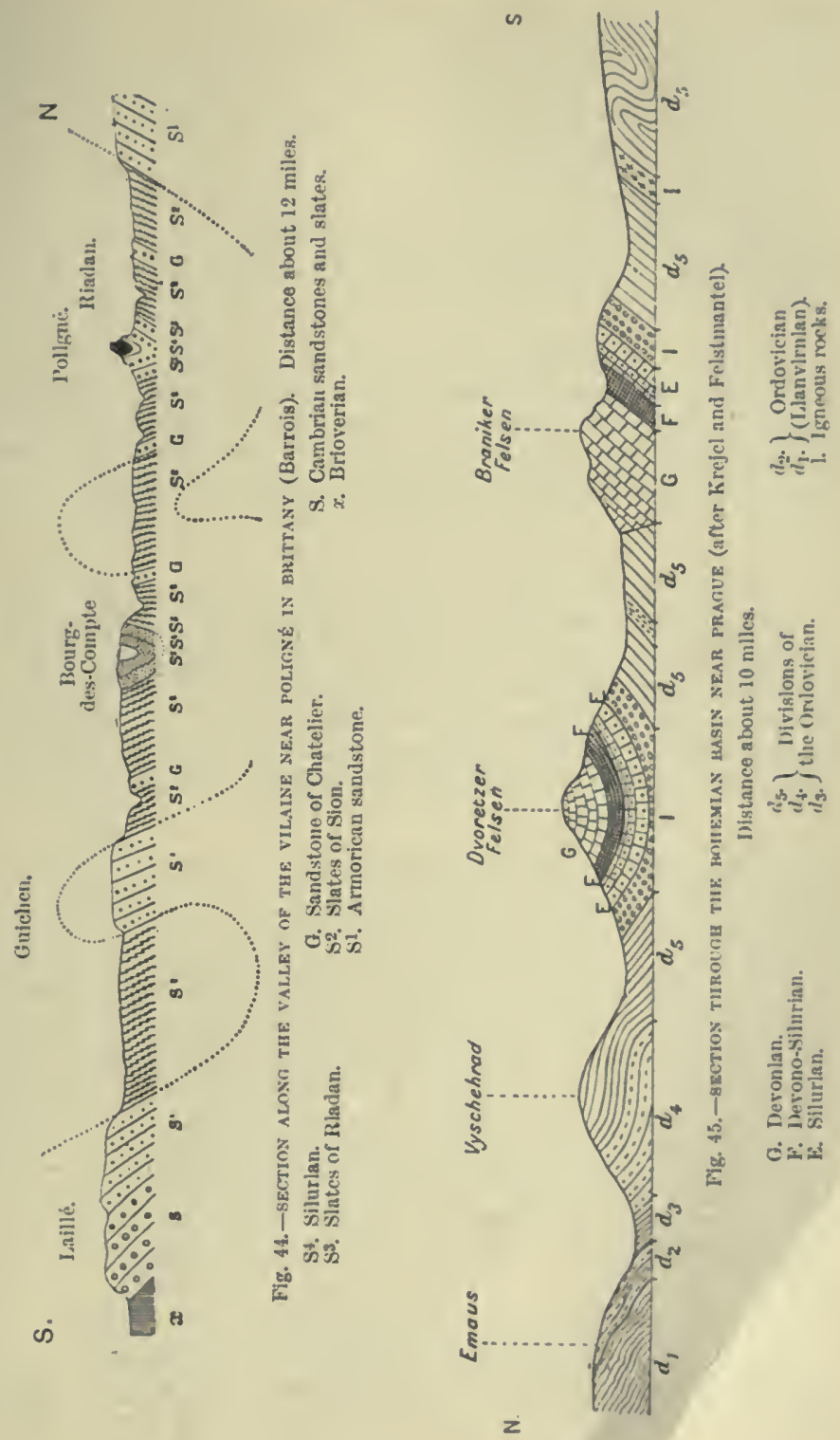
Ordovician by the occurrence of fossils ; this is the Gorran quartzite near Mevagissey, in which Calymene Tristani has been found and which may therefore represent a part of the Grès de May. Following this quartzite in what is believed to be descending order are the following divisions :- 26

Veryan Beds, bluish shales with thin beds of limestone and of chert with Radiolaria.

Portscatho Beds, bluish slates and fine gritty flags.

Falmouth Beds, green and grey slates with layers of sandstone.

Mylor Series, banded slates with alternating layers of fine siliceous grit.

The base is not exposed and no fossils have been found in any of these beds, so that their age is quite uncertain, and their general facies is different from any series in Normandy or Brittany. There is, however, a certain amount of resemblance between them and the Cambro-Ordovician sequence of Belgium (as described below).

\section{Spain and Portugal}

Rocks of Ordovician age are found in many parts of Spain and Portugal, and the facies which they present in the northern and central parts of these countries is similar to that of Brittany. This facies is well exposed in the cliffs of Asturia on the north coast of Spain. The succession there seen has been described by Professor C. Barrois ${ }^{27}$ and compared with that of Brittany-

Asturia.

Brittany.

Calcareous shale of el Horno with Endoceras.

Luarca slates with Calymene Tristani.

White and green grits and dark slates (Cabo Busto). Grès armoricain. Variegated grits with Lingulella Heberti.

Grès felspathique.

The strata are much flexured and faulted, so that accurate estimates of the thickness could not be made, but Dr. Barrois considered the two lower sets of arenaceous deposits to have a thickness of from 1200 to 1500 feet. The Luarca slates are probably about 300 feet, and the highest beds about 50 feet. The similar succession found at Almaden in Ciudad Real has been described by de Prado (Bull. Soc. Geol., France, ser. 2, vol. xii. p. 91), and that of Portugal by Delgado in Terrenes Palceozoicos do Portugal 'Lisboa, 1876).

\section{Belgium}

Although the exposures of Ordovician rocks in Belgium are very mall, they are interesting because they and another small 
tract in Thuringia are the only exposed areas of this system between the extreme west of Europe and Bohemia. In Belgiun it is probable that Ordovician rocks form a continuous subterranean outcrop, ruming for some distance from west to east beneath the Cretaceous deposits south of Ostende and Brussels, but they are only exposed in two or three valleys where the rivers have cut down to them through the superincumbent strata. ${ }^{28}$

One of these tracts is round the highest tributaries of the rivel Senne, sonth of Brissels; another is at the head of the Dyle valley, east of Nivelles; and a third forms a long band north of Namur, from Gembloux on the west to near Huy on the Meuse. The rocks are much compressed, cleaved into slates, and folded into steep-sided anticlines and synclines so that only a general succession. has been made out by the discovery of fossils at certain localities. Thus in Brabant the Llanvirn and Arenig faunas have not yet been detected; in Namur a Llanvirn horizon has been found, bnt the Arenig does not seem to be exposed.

The lowest beds near Huy are black satiny slates yielding Aiglina binodosa and Didymograptus Murchisoni. Near Oxhe to the west are black micaceous grits and slates containing Homalonotus bisulcatus, Trinucleus favus, and Orthis redux (probably Llandilo), while at Fosse a Bala fauna has been found in gritty slates with bands of felspathic sandstone; the fossils including Trinucleus seticornis and Calymene incerta. The same fossils with Orthis Actonice have been found near Gembloux.

\section{Bohemia}

In the Bohemian basin, the position of which is shown on Stanford's map of Central Europe, the Ordovician succession is fairly complete and has a total thickness of about 3000 feet. It is wholly comprised in the Stage D of Barrande, who indicated his systems by letters without giving them special names (see Fig. 45). His sequence is as follows:-

D 5. Grey and green shales with Ampyx Portlocki, Agnoslus tardus, Spharexochus latens, and Dicellograptus anceps.

D 4. Sandy micaceous shales, with species of Trinucleus, Eiglina, Calymene, and Cheirurus.

D 3. Black shales with Asaphus nobilis and Trinucleus Goldfussi.

D 2. Hard grits and shales with Asaphus ingens, Placoparia grandis, Acidaspis Buchi, etc.

D 1, g. Black shales with Placoparia Zippei, Barrandea crassa, Ogygia desiderala, Redonia, and Didymograpli.

Below the last beds and dividing them from the Upper Cambrian 
are a series of volcanic rocks-porphyritic lavas with massive beds of ash and agglomerate, which seem to occupy the place of the Arenig Series of Wales.

The groups D 1 and 2 represent the Llanvirn Series, and might be called the Placoparia Beds. D 3 occupies the place of the Llandilo Series, though it is only a thin band, and part if not the whole of D 4 is probably of the same age, but D 5 is undoubtedly the equivalent of our Bala Series; its highest portion, however, seems to have been removed by erosion before the deposition of the Silurian.

\section{Scandinavia}

When we pass from Central to Northern Europe we come to a region which was evidently at a considerable distance from the contemporaneous lands and continents, and we find that sedimentation was confined to deposits of limestone and shale. Some geologists have too hastily inferred that these deposits are formed under a great depth of water, but the facts do not warrant such a conclusion, only pointing to the existence of an open sea far away from continental land and favourable for the formation of shelly and crinoidal limestones. It was, however, clearly traversed by currents which carried a certain amount of fine argillaceous sediment, and this in some areas completely prevented the continuous formation of limestones.

In Norway Ordovician rocks are believed to occupy considerable areas, but in most places they are more or less metamorphosed into schists and are plicated with similarly altered Cambrian and Silurian rocks, so that their stratigraphy is difficult to unravel. It is only in the south around Christiania (see the map, Fig. 10) that an undisturbed sequence is found.

In the south of Sweden also there are several tracts (marked on Fig. 10) where a similar succession can be studied; the chief of these are (1) Dalarne, north-west of Stockholm; (2) Nerike, west of Stockholm; (3) in the Gothlands, on each side of Lake Vettern; (4) in Skima, the most southerly part of Sweden; and (5) in the islands of Oland and Gottland (Visby), in the Baltic.

Within this area also the succession varies, large portions which consist of graptolitic shales in the west and south being replaced by limestones towards the east, and also toward the north in the upper part of the series. The general succession and correlation are as follow :-29 
Argillaceous facies. क $2 \begin{gathered}\text { Brachiopod shales with Stauro- } \\ \text { cephalus } \\ \text { Trinucleus shales ( } T \text {. anceps) } \\ \text { Zono of Climacograptus rigosus } \\ , \text { Dicranograptus Clin- } \\ \text { gani }\end{gathered}$

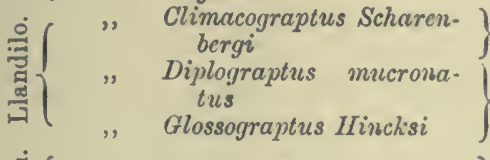

" $\quad$ Didymograptus geminus

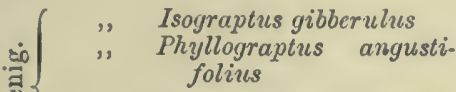

Didymograptus balticus T'etragrapti
Calcareous facles.

Leptiena limestone of Dalarne.

Chasmops limestono (C. macrurus).

Beyrichia limestone.

Linıestone with Ancistroceras.

Lst. with Illanus centaurus.

" Asaphus and Echinospharites.

Sphreronites and trilo. bites.

Megalaspis limbata and many Cephalo. pods.

Megalaspis planilimbata, Niobe, and Symphysurus.

There are several important points to be noticed in regard to this sequence. The first is that the whole succession, though quite complete and capable of minute subdivision, is only from 300 to 400 feet thick. The second point is that the beds are liorizontal and undisturbed. The third is that there is an upward passage from the Cambrian (see p. 102) to the lowest bed which can be classed as Arenig, so that the Swedish geologists prefer to include the Tremadoc in the Ordovician Systein. Fourthly there is the replacement of shales by limestones.

In the Christiania and Westgothland districts, and in the greater part of Scania, the Arenig and Llanvirn Series are represented by the Lower Graptolite shales about 150 feet thick, but parts of these are replaced by limestone eastward till in Oland the whole consists of limestone. This limestone formation is generally known as the Orthoceras limestone from the abundance of Orthoceratidx, and it is only in recent years that its complete equivalence to the graptolitic sliales has been established by Moberg, Törnebohm, Hedstrom, and Wiman.

In the same way the graptolitic shales with a Glenkiln species are replaced eastward by an Ancistroceras limestone and a higher band principally composed of the tests of Beyrichia (a small Crustacean), while the Chasmops limestone is a still higher horizon occurring in the Christiania district.

In Scania the Bala Series is represented by shales with 
Hartfell species of graptolites, but in Dalame it is replaced by a limestone full of Leptona sericea. The brachiopod shales appear to represent the Upper Bala or Asligillian division, their lower part in Scania consisting of a greenish argillaceous limestone and the upper of blue flaggy shales.

\section{Russia}

Ordovician and Silurian rocks occupy a broad area along the south side of the Gulf of Finland, both in the islands of Dago and Oesel, and on the mainland as far east as the southern shore of Lake Ladoga. Part of this area is shown in Fig. 10. The deposits are chiefly limestones with soft marls and shales, quite unaltered but slightly inclined to the south, and their total thickness is about 300 feet. $^{30}$ The succession is as follows :-
8. Borkholm Beds (marls and limestone) • . . 40
Bala 7. Lyckholm limestones (corals and trilobites) : $\quad 50$
Llandilo $\left\{\begin{array}{lr}\text { 6. Wesenberg limestone and marls } & 30 \\ \text { 5. Jewe limestones and shale, Chasmops bricculenta }: & 100\end{array}\right.$
and $\{$ 4. Limestones with Chasmops Odini . . . . 40
Llanvirn 3. Fchinosphærites limestone . . . . . 30
Arenig $\{$ 2. Vaginatus limestone (Orthoceras vaginatus) . $\quad 10$

Of these beds Nos. 1 and 2 correspond with the lower part of the Orthoceras limestone of Sweden, and the next three with its upper part. The age of No. 6 is uncertain, but it contains species of Chasmops and Encrinurus. The higher beds represent the Trinucleus shales and Leptæna limestone. It will be seen that the whole series is essentially calcareous and just as condensed as the Swedish facies, having evidently been formed very slowly in clear water and far from land.

\section{E. Conditions of Fonmation}

From the facts mentioned in the preceding pages it may be inferred that so far as the European region is concerned the geographical conditions of Ordovician time were on the whole similar to those of Cambrian time. Scandinavia and Russia were still farther removed from any large tract of land, and the continued slow subsidence of that area favoured the continual deposition of fine mud or the formation of shelly limestones in water of considerable but not oceanic depth.

The much greater thickness of deposit in Bohemia shows that in passing southwards we approach one of the larger Ordovician 
land-areas, and the position of this land seems to be fairly well indicated by the fact that the fauna found in Bolrenia differs grently not only from that of Northem Europe but also from those of the French and British Ordovician. Thus the number of species common to the Ordovician of Britain and Sweden is mucl larger than the number common to Sweden and Bohemia. It seems clear, thereforc, that the Bohemian area belonged to a different life province, and that the land from which the Bohemian sediments were derived lay to the south and south-east of that country, over the region now occupied by Hungary, Roumania, Turkey, the Black Sea, and Asia Minor.

It is probablc that nearly the wholc of Central and Western Europe was covered by the Ordovician Sea, though there may have beel some islands of a fair size. We have indeed evidence of one such island in the centre of the English area, for the absence of Arcnig, Llanvirn, and Llandilo rocks to the west of the Longmynd proves that part of Shropshirc was land during the greater portion of the period, while the presence of the Caradoc sandstone shows that it was submerged (in part at least) toward the close of Ordovician time.

Of the size and extent of this island we have little to guide us in forming an opinion, but it cannot have reached very far north since Ordovician strata occur at Settle in Yorkshire, and its chief extension was probably eastward. Where the Cambrian is exposed in the Midland counties, as in the Lickey Hills (Worcestershire) and near Nuneaton (Warwickshire), wc find it succeeded either by Silurian or Carboniferous rocks, so that probably the whole of the Midland area from Shropshire to Northamptonshirc was land during the Ordovician period.

Another island may have existed in the area of the Ardennes where Devouian rocks rest directly on Cambrian.

With regard to the Atlantic region the existence of continental land to the west and north-west of Ireland at this time is proved not only by the enormous thickness of Ordovician deposits in Mayo, but also by the presence of American forms of trilobites in the Arenig limestones of that area (sec p. 141). It will be remembered that the Cambrian limestones of Scotland contain a fauna of American affinities, and this fauna is supposed to have migrated along the shores of a North Atlantic land. In Arenig time this land seems to liave becn greatly eularged so as to touch the north-west of Ireland, and thus to afford similar facilities for the migration of American species to the Irish area.

How far this Atlantic continent extended over Scotland we do not know at present, but though the old supposition that parts of 
the metamorphic complex of the Central Highlands are Ordovician rocks is still held tenaciously by certain authorities the progress of geological research has made this theory more and more improbable. There is therefore good reason to suppose that no such rocks are there, and if this is so the Atlantic land probably extended over the greater part of Scotland, as indeed I have ventured to indicate elsewhere (Building of the British Isles).

Lastly there must also have been a land-area of considerable size in a more southern part of the Atlantic to the west of France and Spain, for it is only from that direction that the materials constituting the Ordovician deposits of those countries can have been derived. The felspathic sandstones and conglomerates of Brittany show that part of this land extended very near to France, and also that it consisted very largely of granitic and Archæan rocks.

The greater part of the Ordovician sediments are of the normal detrital character-conglomerates, sandstones, flagstones, grits, mudstones, and shales, the materials of which must have been derived from the land tracts which existed in the positions above indicated.

Limestones were also formed wherever the water was clear enough to permit shell-bearing creatures to live and flourish in great numbers, so that their shells and tests accumulated to form layers on the sea-floor. The chief components of such limestones are Mollusca, Brachiopoda, Crustacea, Bryozoa, and Cystidean Echinoderms. A few genera of corals also contributed to their formation, but do not seem to have been very abundant.

Besides these sediments some of the Arenig shales include layers and nodules of chert which contain remains of Radiolaria, and concerning these some erroneous ideas have arisen as to the conditions indicated by the presence of Radiolaria. This matter has been discussed in the third edition of my Building of the British Isles (1911), but it may be well to mention here that those, however, who claim that the radiolarian cherts of this region are "oceanic deposits" jump to a very important conclusion from a very small amount of evidence. Only two reasons have been given for such an inference: (1) the existence of the Radiolaria, which at the present day form deposits on oceanic floors, (2) the small thickness of the Arenig-Llandilo Beds; but neither of these caif be taken as evidence of oceanic conditions. As a matter of fact Radiolaria occur in waters of all depths, and have been found in deposits of many ages, notably in the Oxfordian and in the Lower Eocene of Northern France, in each case combined with sponge spicules to form a peculiar siliceous rock termed gaize. 
Thus the cherts and black shales of the Arenig Series may be compared with the gaize and black clays of the Oxfordian, but have no resemblance to modern oceanic deposits, which are red, yellow, grey, and white, but never black. There are no fine red clays nor forminiferal linestones among the Scottish Arenig and Llandilo Series, like those which are associated with Tertiary oceanic deposits in Barbados and elsewhere, and the utmost that can safely be inferred from the character and small thickness of the Scottish deposits is that they were formed in clearer water and at a greater distance from land than the Arenigs of Wales.

Finally, it should be noted that in the British area this was a period of great volcanic activity, volcanic vents being opened from time to time on the sea-floor, and probably in most cases they were built up into volcanic islands from which subaerial eruptions took place. This happened in one part of the region or another throughont the whole period. Thus there are volcanic rocks of Arenig age in Pembroke, Merioneth, Scotland, and Ireland (Mayo); of Llanvirn age in Merioneth and Cumberland; of Llandilo age in Merioneth, Carnarvon, and Cumberland ; of Bala age in Waterford and Dublin.

\section{REFERENCES}

1 H. Hicks, Quart. Joum. Geol. Soc. vol. xxxi. p. 167 (1875).

2 H. Hicks, Pop. Sci. Reviero for 1881, p. 289 ; see also Proc. Geol. A ssoc. vol. vii. p. 291 (1882).

${ }^{3}$ Marr and Roberts, Quart. Journ. Geol. Soc. vol. xli. p. 476 (1885). Surv.

4A. Strahan, "Geology of the Country round Carmarthen," Mem. Geol.

B W. G. Fearnsides, "North and Central Wales," in Geology in the Field, published by Geol. Assoc. (Stanford 1910), p. 786.

B W. G. Fearnsides, Quart. Journ. Geol. Soc. vol. 1xi. p. 608 (1905).

7 Miss G. L. Elles in Geol. Mag. for 1904, p. 199.

8 C. Matley, Quart. Journ. Geol. Soc.

- See Memoirs of Geol. Survey ou Llandilo, Amman ford, and Carmarthen.

10 Marr and Roberts (op. cit. above).

11 T. Ruddy, Quart. Journ. Geol. Soc. vol. xxxv. p. 200.

12 Groom and Lake, Quart. Journ. Geol. Soc. vol. xlix. p. 426.

13 G. L. Elles, Quart. Joum. Geol. Soc. vol. lvi. p. 169 (1909).

14 J. E. Marr, Geol. Mag. for 1894, p. 122.

15 J. E. Marr, Geol. Mag. for 1892, p. 97.

16 C. Lapworth in Quart. Jourm. Geol. Soc. vol. xxxiv. p. 25, and vol. xxxviii. p. 538 ; and in Geol. Mag. for 1889, pp. 20 and 69.

17 Messrs. Egan and M'Heury, Sum. Prog. Geol. Survey for 1899 and 1900.

${ }^{18}$ Gardiner and Roberts, Quart. Journ. Geol. Soc. vol. liii. p. 520.

19 Reynolds and Gardiner, Quart. Journ. Geol. Soc. vol. lii. p. 523.

20 Summary Prog. Geol. Survey for 1896, p. 48.

${ }^{21}$ Carruthers and Mfuff, Irish Naturalist for 1909, p. 7. 
22 J. R. Kilroe. Proc. Roy. Irish Acad. vol, xxvi. p. 129 (1907).

23 Gardiner and Reynolds, Quart. Journ. Geol. Soc. vol. 1xv. p. 104, and vol, lxvi. p. 253.

24 Barrois in Proc. Geol. Assoc. vol. xvi. p. 108.

25 A. Bigot, Bull. Soc. Géol. France, s. 4, tome iv, p. 861.

26 "Geology of Mevagissey," Mem. Geol. Surv. : (1907).

27 Barrois, "Terrains anciens des Asturies," Mem. Soc. Géol. Nord, 1882.

28 C. Malaise, Bull. Acad. Roy. de Belg. for 1910.

29 See W. G. Fearnsides in Geol. Mag. for 1907, pp. 186 and 257 ; and the Livret-guides of the International Geol. Congress for 1910.

30 O. Schmidt, Quart. Journ. Geol. Soc. vol. xxxviii. p. 514 (1882). 


\section{CHAPTER VII}

\section{SILURIAN SYSTEMI}

\section{A. Nomenclature and Divisions}

Nomenclature.-The reasons for restricting the name Silurian to the system called Upper Silurian by Murchison have been given on p. 71 , but no mention was there made of a subordinate question, namely, the line of separation between the Ordovician and Silurian. Originally the whole of the strata subsequently called Llandovery Beds were included by Murchison in his Upper Caradoc Group, but in 1854 Sedgwick and M'Coy proved that the uppermost sandstones (to which they gave the name of May Hill sandstone) had no connection physically or palrontologically with the Bala rocks, but formed the natural base of Murchison's (Upper) Silurian Series in the typical Silurian areas.

Recognising the justice of this correction, Murchison then separated the beds from the Caradoc sandstone (Bala), and created a new group under the name of "Llandovery rocks," subdividing it into two stages-a lower (linked by some species to the Bala Series) and an upper (closely connected with the Wenlock rocks), but clearly united to one another by a community of Pentameri and other fossils. This Llandovery Group he regarded as forming a transition series between his Lower and Upper Silurian.

Some geologists, however, objected to this arrangement on the ground that there is frequently a physical break (overlap leading to unconformity) between the Lower and Upper Llandovery, so that the latter in such localities is dissociated altogether from the former and from the Bala Beds. Consequently, Sedgwick, Jukes, and others drew the line of separation at the base of the Upper Llandovery or May Hill sandstone. But elsewhere there is little or no want of conformity between the members of the Llandovery, and it was pointed out in Chapter II. that small regard must be paid to such local transgressions and unconformities, unless they coincide with a palæontological break. 
Recent researches have shown that the Upper Llandovery is usually succeeded by a series of pale grey and green shales (Tarannon shales), and that these three subdivisions (Lower Llandovery, Upper Llandovery, and Tarannon shales) "are far more closely allied to each other than they are to the beds above or below, and that they should be considered as the three consecutive members of a single formation." 1 The Llandoveries were formed in fact during a period of local upheaval and oscillation which intervened between the quiet periods of the Bala and Wenlock Beds. For their equivalents in South Scotland Professor Lapworth has proposed the name Valentian, from the Roman narne of that province, and this is a convenient designation for the lowermost group or series of the Silurian rocks in Britain.

The second natural division of the Silurian System is typically developed at Wenlock in Shropshire and at Woolhope in Herefordshire. This series was described by Murchison under the name of the "Wenlock formation," and at the localities above-mentioned it consists mainly of shales with a band, of limestone at the base and another at the top; but in North Wales and other parts of Britain there are no such limestones, and the only means of delimitation is by the graptolite fauna.

The third division is the "Ludlow formation" of Murchison, which in Shropshire and Herefordshire consists of shales and mudstones with a band of limestone in the middle. Although the shales below the Aymestry limestone were placed in this group by Murchison, he admitted that they were merely a continuation of the Wenlock Series, and for some time it seemed doubtful if they could be separated from it when the Wenlock limestone was absent. Recently, however, it has been shown that they can be distinguished by their graptolites, ${ }^{2}$ and, further, that the Aymestry limestone comes within the highest graptolite zone.

Since, however, these beds are linked to the Wenlock Group by the presence of graptolites and by a common assemblage of trilobites and brachiopoda, Professor Lapworth has proposed to unite them with the Wenlock Beds and to regard them as a primary division under the name of Salopian.

The highest beds referable to the Silurian System are a set of shales, flagstones, and sandstones in which no graptolites are found, but which contain remains of a remarkable group of Arachnida-the Eurypterida-and also the bones of certain fish which are the earliest vertebrates found in the British Isles. For these beds the name Downtonian has been proposed, but Clunian from Clun Forest, proposed by me in 1885 (Geol. Mag.), would in some respects be a better name. 
This arrangement of the Silurian succession into Valentian, Salopian, and Dorontonian has been adopted by many English writers, but it may be doubted whether it is any real improvement on that hitherto employed and still used by the Geological Survey. It is quite as important to recognise that the central mass of beds can be divided into two groups by the different types of graptolites as it is to admit that they are united by a certain community of species. Thus the Wenlock Beds are characterised by species of Cyrtograptus and by the Monograptus priodon type, and the higher beds by species of the $\boldsymbol{M}$. colonus type. Thus the whole system can be divided into four much more equal groups or series on a palsentological basis, and it is probable that this will form the classification of the future. Meantime the several arrangements are shown in the following table:-

\begin{tabular}{|c|c|c|c|}
\hline \multicolumn{2}{|c|}{ Downtonian-Eurypterid Series } & \multirow{3}{*}{$\begin{array}{l}\left\{\begin{array}{l}\text { Downton Beds } \\
\text { Upper Ludlow Beds }\end{array}\right. \\
\left\{\begin{array}{l}\text { Aymestry linestone } \\
\text { Lower Ludlow shale }\end{array}\right. \\
\left\{\begin{array}{l}\text { Wenlock limestone } \\
\text { Wenlock shales } \\
\text { Woolhope limestone }\end{array}\right.\end{array}$} & \multirow[b]{2}{*}{$\begin{array}{l}\text { Ludlow } \\
\text { Series. }\end{array}$} \\
\hline & M. Colonus Series & & \\
\hline Salopian & $\left\{\begin{array}{l}\text { MI. priodon and } \\
\text { Cyrtograptus } \\
\text { Series }\end{array}\right.$ & & $\begin{array}{l}\text { Wenlock } \\
\text { Series. }\end{array}$ \\
\hline & $\begin{array}{l}\text {-Rastrites and } \\
\quad \text { Pentamerus Series }\end{array}$ & $\left\{\begin{array}{l}\text { Tarannon shate } \\
\text { Upper Llandovery } \\
\text { Lower Llandovery }\end{array}\right.$ & $\begin{array}{l}\text { Llandovery } \\
\text { Series. }\end{array}$ \\
\hline
\end{tabular}

In dealing with the stratigraplyy of the system, I shall use the new grouping as affording convenient divisions in the description of the beds, but shall indicate the correlation of the priodon and colonus series in different areas, so that the student can, if he chooses, adopt the alternative arrangement of Llandovery, Wenlock, and Ludlow Series.

\section{B. Life of the Period}

The following is a brief synopsis of the principal genera which are found in the Silurian System :-

Plantæ.-It is in this system that the earliest remains of plants have been found. Some of these remains are doubtful, but there is general agreenent with regard to Nematophycus and Pachytheca. The former occurs in the form of silicified stems and have been found in Wenlock Beds. Pachytheca is a name given to small spherical bodies which may be seeds.

Hydrozoa.-Graptolites are abumdant in the lower beds, but gradnally decrease in numbers and die out in the upper beds. The family Monograptide, including the genera Monograptus, Cyrtograptus, and Rastrites, appears to be confined to the Silurian, 
and the only other families represented are the Diplograptidæ and Retiolitidæ. Stromatoporoids become abundant in the Silurian, and are associated with corals as important rock-builders. The principal genera are Stromatopora, Labechia, and Clathrodictyon.

Actinozoa.-Corals are very abundant in the limestones and calcareous beds; most of the Ordovician genera occur, Favosites, Heliolites, Halysites, and Omphyma are very common, and the following commence their existence in the British area:Acervularia, Alveolites, Cystiphyllum, Arachnophyllum, and Stauria : while the following have only been found in the rocks of this system, Goniophyllum, Rhizophyllum, Thecia, and Palococyclus.

Echinoderma - Of this phylum the crinoids are by far the most abundant, more than fifty species having been found in British Silurian strata. The following genera are specially characteristic of the Silurian : Callicrinus, Clonocrinus, Crotalocrinus, Dimerocrinus, Herpetocrinus, Marsipiocrinus, Pisocrinus, and Periechocrinus; and besides these the genera Cyathocrinus, Ichthyocrinus, Eucalyptocrinus, Hapalocrinus, and Taxocrinus make their first appearance. Cystideans continue to occur, and the genera Lepadocrinus, Placocystis, Pseudocrinus, Prunocystis, and Schizocystis are specially characteristic of the Silurian period.

Echinoids, which are first found in the Ordovician of Russia, make their appearance in the Silurian of Britain, where they are represented by the genera Echinocystis, Palocodiscus, and Palcechinus.

Crustacea.-Trilobites, though not quite so numerous as in the Ordovician, continue to be common, most of the species belonging to the genera Calymene, Phacops, Encrinurus, Harpes, Acidaspis, Illcenus, Homalonotus, Lichas, Cheirurus, Proetus, and Deiphon, only the last being exclusively Silurian.

Arachnida.-Besides trilobites, another remarkable and extinct order of Arthropods is abundant-the Eurypterida, represented by the genera Eurypterus, Pterygotus, Stylonurus, and Slimonia. The Xiphosura, which are allied to the Eurypterida, also occur, but are much less numerous, the principal genera being Hemiaspis, and Neolimulus.

Brachiopoda are remarkably abundant. Most of the Ordovician genera recur, such as Lingula, Orthis, Leptcena, Camarotochia, and other Rhynchonellidæ, Strophomena, Glassia, and Triplecia; and the following genera make their first appearance: Atrypa, Chonetes, Dayia, Cyrtia, Cyrtina, Meristina, ? Meristella, Pentamerus (Conchidium), Stricklandia, Rhynchotreta, Wilsonia, Nucleospira, and Spirifer.

Lamellibranchia.-Members of this class also become more 


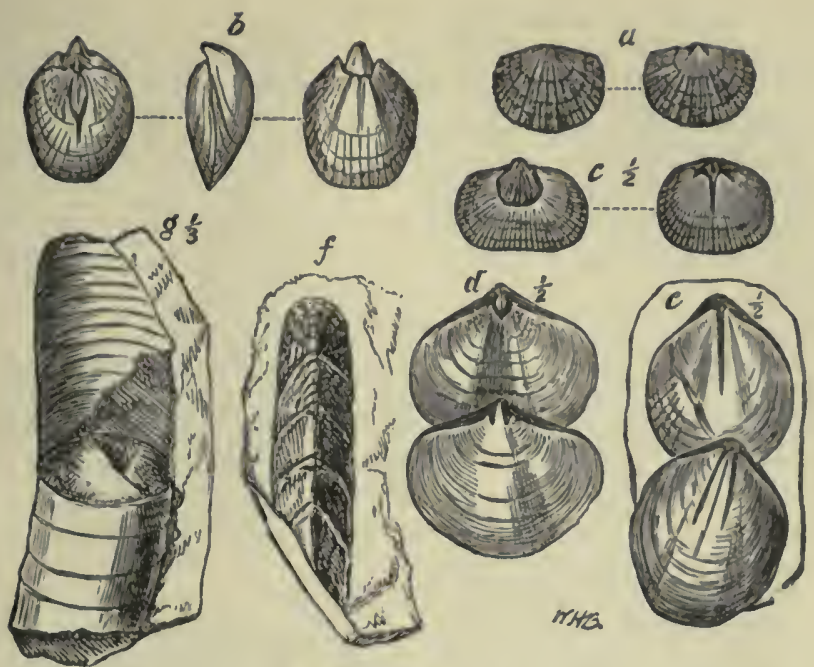

Fig. 46. -GROL'P OF LLANDOVERY FOSSILS.
a. Atrypa hemispherica.
b. Meristella angustifrons.
c. Orthis reversa.

1. Stricklandia lens.

e. P'entamerus oblongus.

f. Chiton Griflithi?

g. Cyrtoceras approximatum.

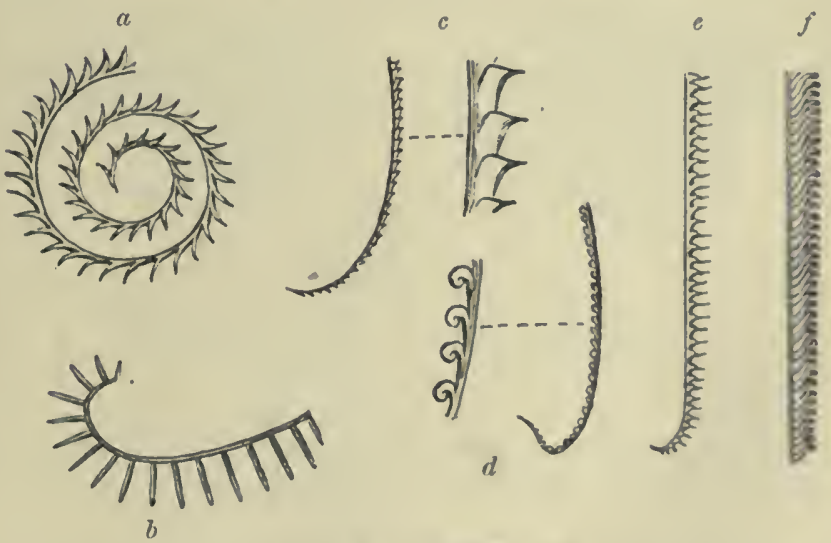

Fig. 47. - SILURIaN Graptolites.
a. Monograptus spiralis.
b. Rnstrites peregrinus.
c. Monograptus gregarius.

d. Mronograptus exiguur.

e. Monogtaptus Sedgwicki.

f. Monograptus priodon. 
abundant in the Silurian period, about 100 species being known in England belonging chiefly to the following genera, Cardiola, Cardiomorpha, Ctenodonta, Orthonota, Cleidophorus, Grammysia, Ambonychia, Pterincea, Conocardium, Lunulicardium, and Modiolopsis.

Gastropoda are fairly numerous, about sixty species being known from the English Silurian. Most of them are referable to the following genera: Pleurotomaria, Murchisonia, Bellerophon, Platyschisma, Omphalotrochus (Horiostoma), Cyclonema, Eunema, Holopea, Holopella, Platyceras (=Acroculia), and Subulites. The last genus is noteworthy as possessing a channelled mouth, and Murchisonia has a very short anterior canal, all the rest being holostomous.

Cephalopoda.-These are also numerous; but all the genera belong to the Nautiloidea; they include species of Orthoceras, Phragmoceras, Gomphoceras, Trochoceras, Tretoceras, Ophidioceras, Cyrtoceras, Actinoceras, and Ascoceras, the last being only known as a Silurian form.

Fishes.-The earliest remains of vertebrate animals hitherto found in Britain occur in the Ludlow Series, and are the remains of fish belonging to the sub-class or order Ostracodermi. The chief genera are Pteraspis, Cephalaspis, Auchenaspis, Scaphaspis, and Eukeraspis. The sub-class Elasmobranchii is represented by Onchus (spines) and shagreen-like plates referred to Coelolepis and Thelodus.

The greater part of the Silurian System is capable of subdivision into zones by means of the graptolite faunas, and though these are not equally developed in all localities they always occur in the same order of succession. No species have yet been recognised in the Upper Ludlow Beds, but from the Aymestry limestone down ward the following zones have been recognised:-

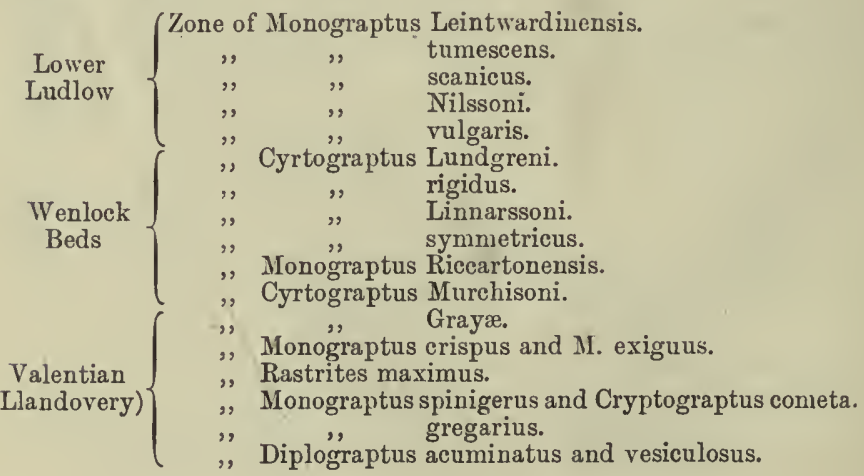



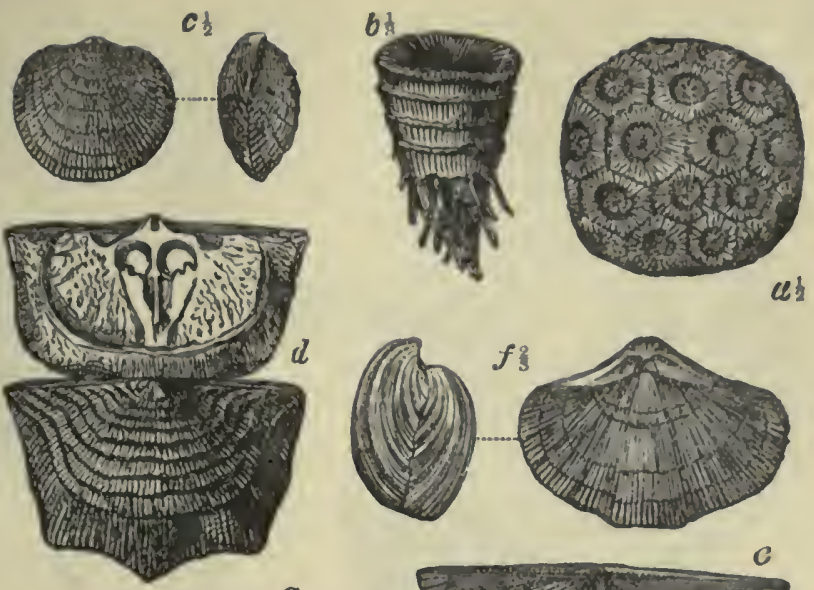

\section{$d$}

$g$
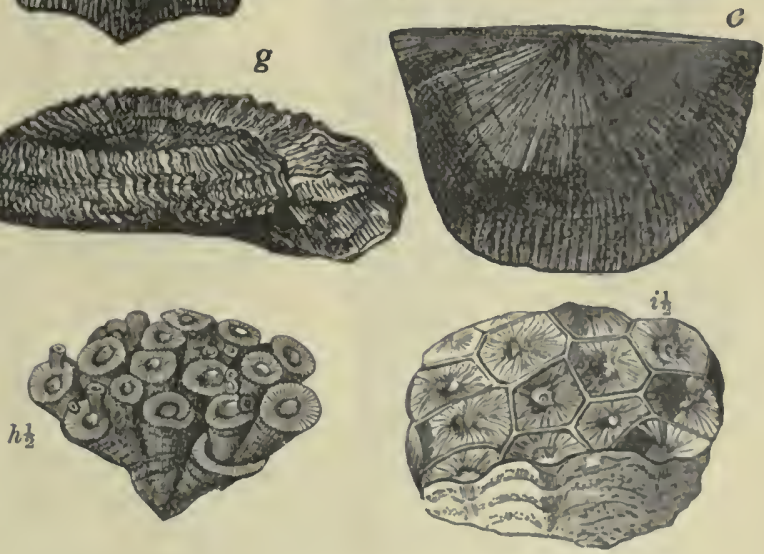

Fig. 48.-GROUP OF WENLOCK YOSBILS,
6. Acervularia luxurians.
b. Omphyma subturbinatum.
c. Atrypa reticularis.
i. Leptrens rhomboidalis.

i. Arachnophyllum Murchisoni.

e. Strophonella euglypla.

f. Spirifer plicatellus.

g. Horiostoma discors.

h. Cyathophyllum truncatum.

The following are some of the other fossils which are specially characteristic of each of the three Silurian series or divisions :-

\section{Fossils of the Llandovery and Valentian Series}

Hydrozoa. Actinozoa.
(See table of graptolite zones.)

Lindstrœmia bina, Lind. subduplicata, Pinacopora Grayi. 
Echinoderma.

Crustacea.

Brachiopoda.

Palæchinus Phillipsi (but none are common).

Illænus æmulus, Phacops Weaveri, Ph. elegans.

Lingula crumena, Atrypa hemispherica, Meristella crassa, M. angustifrons, Stricklandia lens, Pentamerus oblongus, $\mathrm{P}$. undatus, Orthis reversa.

Lamellibranchia. Ctenodonta Eastnori, Orthonota amygdalina, and O. inornata (both range into Wenlock).
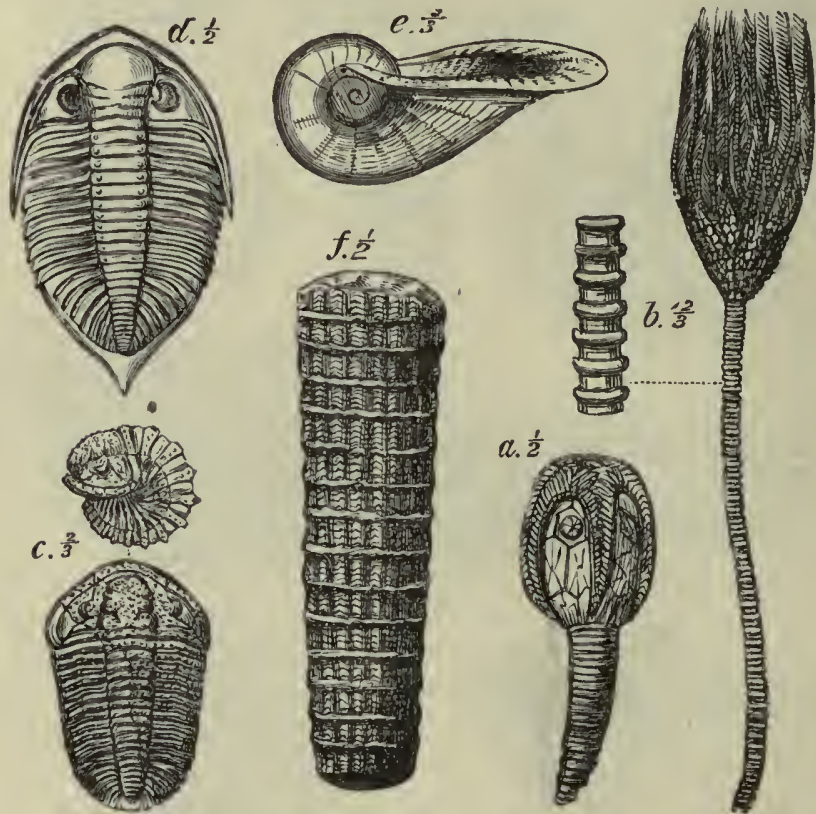

Fig. 49. $\rightarrow$ GOUP OF WEXLOCK FOSSILS.

a. Lepadocrinus quadrifasciatus.

$b$. Periechocrinus moniliformis.

c. Calymene Blumenbachi. d. Phacops caudatus.

e. Bellerophon dilatatus.

f. Orthoceras annulatum.
Gastropoda.

Cephalopoda.

Hydrozoa. Actinozoa.
Turbo tritorquatus, Holopella cancellata, Omphalotrochus prenuntius.

Tretoceras bisiphonatum, Cyrtoceras approximatum, Orthoceras conicum.

\section{Fossits of the Wenlock Series}

(See table of graptolite zones.)

Acervularia luxurians, Arachnopleyllum Murchisoni, A. typus, Strombodes diffluens, Cyathophyllum truncatum, Omyphyma turbinatum, Heliolites interstinctus (from Bala), Favosites gottlandicus. 

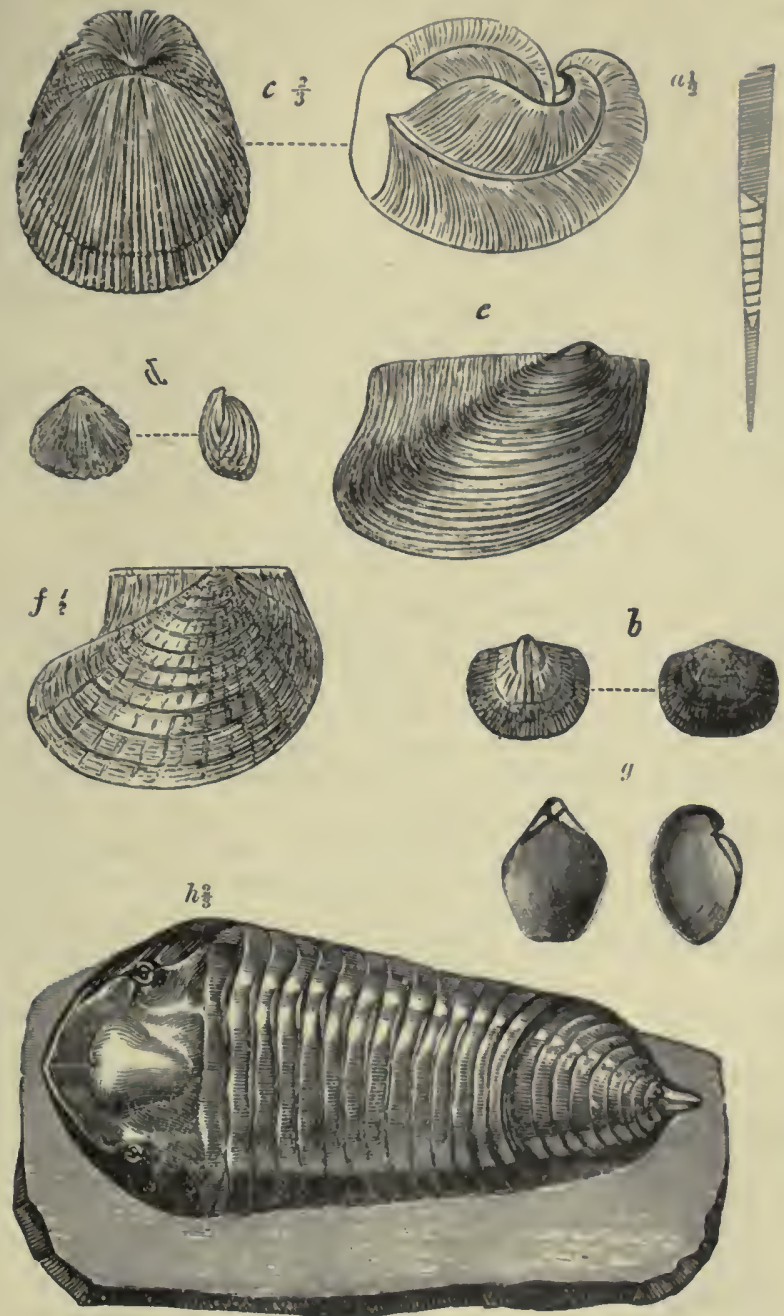

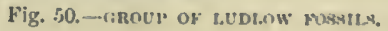
". Orthoceras tenuicinctum.
b. Orthis iumata.
c. Peutamerus huighti.
d. Rhynehonella nucula.

e. Pleringa retroflexa.

f. Avicula Danbyi.

g. Dayia navicula.

h. IIomalonutus delyhhinocephatns. 
Echinoderma. Actinocrinus (Glyptocrinus?) pulcher (from Llandov.), Periechocrinus moniliformis, Crotalocrinus rugosus, Marsipiocrinus cælatus, Lepadocrinus quadrifasciatus.

Crustacéa.

Illænus barriensis, Phacops caudatus (Val. to Lud.), P. Downingiæ, Calymene Blumenbachii (Bala to Lud.), Encrinurus punctatus, Lichas anglicus (to Lud.).

Brachiopoda. Atrypa reticularis, Pentamerus galeatus, Strophonella euglypha, Lcptæna rhomboidalis (Llan. to Lud.), Orthis rustica, O. elegantula (Bala to Lud.), Spirifer plicatellus, Retzia? Barrandi, Wilsonia Wilsoni, Camarotochia borcalis, Cyrtia exporrecta.

Lamellibranchia. Cardiola interrupta, Grammysia cingulata.

Gastropoda. Horiostoma discors, H. rugosus, Eunema cirrhosis, Platyceras (Acroculia) haliotis, Bellerophon dilatatus.

Ceplualopoda. Orthoccias annulatum, Phragmoceras ventricosum, Gomphoceras pyriforme, Trochoceras asperum, Barrandeoceras bohemicum.

\section{Fossils of the Ludlow Scries}

Porifera.

Echinoderma.

Iscliadites Kcenigi, Favospongia Ruthveni.

Ichthyocrinus pyriformis (from Wenlock), Lap worthura Miltoni, Palæaster Ruthveni, Palæocoma Colvini, Palæodiscus ferox, Echinocystis poinum.

Crustacea.

Arachnida.

Brachiopoda.

Homalonotus delphinocephalus (from Wenl.), $H$. Knighti, Acidaspis coronata, A. Hughesi.

Pterygotus arcuatus, Eurypterus abbreviatus, Hemiaspis linuloides.

Pentamerus Knighti, Dayia navicula, Camarotcechia nucula (from Val.), Orthis lunata, Chonetes striatella (and var. lata), Orbiculoidea rugata, Lingula cornea, L. Lewisi (from Wenl.).

Lanellibranchia. Avicula Danbyi (from Val.), Pterinea retroflexa, Cardiola striata, and C. interrupta (botli from Wenl.), Ortlionota semisulcata.

Gastropoda. Cyclonema coralli, Murchisonia coralli, Holopella gregaria, Platyschisma hclicites.

Ceplualopoda.

Pisces.

Orthoceras bullatum, $O$. tenuicinctum, $O$. ludense, 'Trochoceras giganteum, Ascoceras Barrandi.

Scaphaspis ludensis, Cephalaspis ornatus, Auchenaspis Salteri, Thelodus parvidens.

\section{British Silurian Rocks}

Range and Relation to Older Rocks.-Silurian rocks occupy surface-tracts in the following districts. They form a continuous outcrop of varying width through Wales from Carmarthenshire in the south to the Denbigh coast on the north. They spread westward through Radnorshire and parts of Shropshire, and they reappear from beneath newer rocks as inliers in Stafford- 
shire, Hereford, and Monmouth. In all probability they have a cousiderable snbterranean extension under Central and Southern Eugland, for they appear as far south as Cardiff and the Mendip Hills, and have been reached in borings at Ware in Hertfordshire and at Rochester in Kent.

In North Lancashire and Westmoreland they again rise to the surface in a considerable tract south of that occupied by the Ordovician, exteuding from the Duddon estuary on the west to Sedburgh and Rathay Bridge on the east, a distance of about 35 miles with an average width of 14 miles.

In the south of Scotland they cover a much larger area, danging completely across the Southern Uplands from the Mull of Galloway to the coast of Berwick. There is also an outlying tract in Lanark, and it is probable that they underlie parts of the Central Lowlands, for the same Lanarkian Beds have recently been recognised on the coast of Kincardine.

In Ireland there are many isolated exposures in the south and west and a large area in the north-east, occupying parts of Down, Armagh, Monaghan, Cavan, and Louth.

In most parts of the British Isles there is no great break or unconformity between the Silurian and Ordovician, but it so happens that in the typical districts of Shropshire and Radnorshire a strong local discordance and unconformity is found, due evidently to local uplifts which produced more than one break in the sequence. In other areas the sea-floor may have been raised and the deptl of water lessened without any part of it being lifted above the surface of the sea and brought into the sphere of erosive agrencies. Under such circumstances uplift is indicated only by changes in the character of the sediment and in the component members of the marine fauna.

\section{The Typical Silurian Area}

We shall consider this as including all the more eastern expostures, and especially thase which occur between the Welsh borders and the valley of the Severu. It will embrace not only the Wenlock and Ludlow districts of Shropshire, but that of Presteign in Radnor, as well as those of Malveru, Woolhope, and May Hill in Hereford, Usk in Monmonth, and the outcrops in Staffordshire. These were the places where the beds were first studied by Murchison, and where they present a more calcareons and more richly fossiliferous facies than in any other part of Britain.

Llandovery Beds. - In this region the Lower Llandorery is absent, and the Tarannon shales are very thin, so that the 
total thickness of the Valentian Series is much less than it is in Wales.

In the southern districts (Usk, May Hill, Woolhope, and Malvern) the group consists of the May Hill sandstone and the Woolhope shales. The former is about 1000 feet thick, and consists of (1) a lower set of sandstones and conglomerates of grey and purple colours about 600 feet thick, and yielding the usual fossils, together with Ctenodonta Eastnori and Lingula crumena; (2) an upper set of grey laminated sandstones and shales from 320 to 500 feet thick with Pentamens lens, $P$. undatus, etc., the highest beds being shales which are doubtless equivalent to the

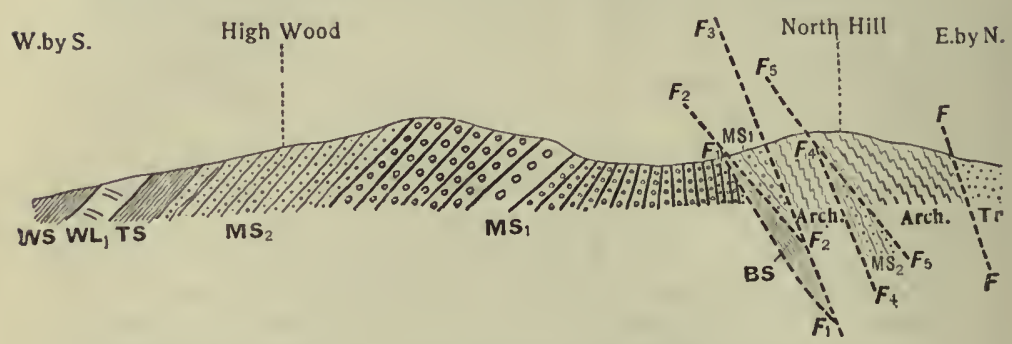

Fig. 51.-SEction THROUGH High WOOD NEAR WEST MaLvekn (Professor (irooin). (Scale 6 inches to 1 mile.)

Tr. Trias.

WS. Wenlock sliale.

Wh. Woolhope limestons:

WS. Woollope shale.
MS. Upper I May Hill sandstone.
MS $_{1}$. Lower $f$ Lay

Bs. Black shales (Cambrian). FF. Faults.

Tarannon shales. The conglomerates rest unconformably upon the Cambrian shales where these are exposed, but elsewhere they are faulted against the Archiean rocks. The Woolhope shales are not more than 200 feet thick, consisting of green and purple shales with thin layers of limestone.

In Shropshire the group consists of the following members:--

Purple shales (=Taraunon shale) . . . 200 to 400 feet.

Pentanerus limestone . . . 30 to 40 ,"

Basement grits and conglonerates. - . 0 to 120 ",

The basement beds rest unconformably on Ordovician, Cambrian, and Longmyndian in different parts of the area, varying greatly in thickness, and in places thinning out altogether so as to leave the overlying limestone in contact with the older rocks. Thus the Pentamerus limestone is really a sandstone rendered calcareous by the quantity of included fossil shells. The commonest fossils are 
Pentamerus oblongus, I'. undutus, Striclilundia lens, Atrypa hemispherica, Strophomena pecten, Encrinurus punctatus. The overlying shales consist in the Wenlock district of purple, rerl, and green shales with few fossils, and are distinguishable by their colours from the overlying Wenlock shales.

Salopian Series.-The succession of limestones ancl shales which form this series at Woolhope and Malvern is shown in Figs. 51 and 52. The Woolhope limestone is from 50 to 250 feet thick, the Wenlock from 250 to 400, and the Aymestry about 250 feet, while the intervening shales vary from 500 to 900 in different places, and the average total thickness of the series is over 2000 feet.

The Woolhope limestone is also present near Presteign in Raclnor, but thins out northward and is only represented in Shropshire by a band of calcareous and fossiliferous shale. The whole series forms a broad band from the southern border of this comnty to the river Severn at Coalbrookdale, the Wenlock and Ayınestry limestones forming well-marked escarpment ridges, rising above the outcrops of the shale as the beds are here dipping steadily to the east (see map, Fig. 21). 'The succession found near Wenlock was well described by Mr. W. Maw in $1881,{ }^{3}$ from whose paper Fig. 53 has been copied.

The Buildwas Beds, which here represent the Woolhope limestone, are exposed in a small cliff opposite Buildwas Abbey, and are shales which yield an immense number of small brachio. poda, Orthis biloba, 0. elegantula, O. Learisi, O. hybrida, Leptana seymentum, Nucleospira pisum, and Atrypa (3 Retzia) Barrandi. Mr. Maw considered these beds to represent the Woolhope limestone of more southern localities. The Tickwood Becls are shales with layers of nodular limestone, the shales predominating in the lower part and the limestones in the higher part below the massive limestone of Wenlock edge, so that it is not easy to say where the one ends and the other begins. Fossils are abundant in these beds.

The Wenlock limestone is well exposed at Benthall Edge and in quarries near Wenlock; it is a grey eartliy limestone, generally lying in thin beds with shaly partings, and is highly fossiliferous. Some of the beds appear to be largely made up of corals which weather out finely in the spoil-heaps, while others contain quantities of Brachiopoda and Mollusca.

The Lower Ludlow shales consist of soft grey sandy shales, often showing a tendency to spheroidal structure, and their total thickness is about 900 feet in the Wenlock and Ludlow district. In the Wenlock area they do not contain graptolites, but liave yielderl many other fossils, of which the following are some of the 


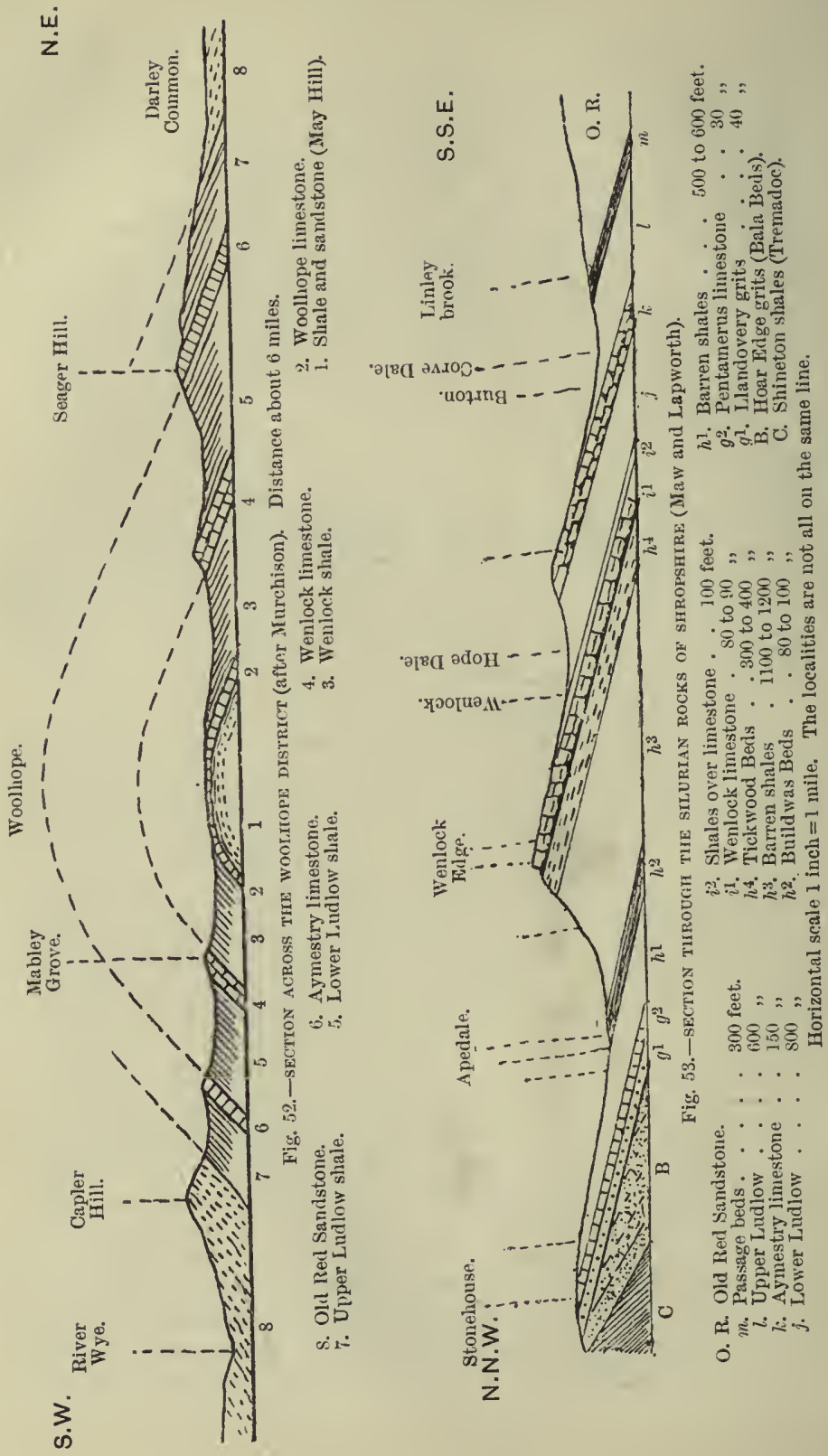


commonest : Lingula lata, Wilsonia Wilsoni, Camurotochia nucula, Leptena levigata, Chonetes striatella. At the top of these shaless there are some beds of earthy flagstone which are quarried and are known as the Leintwardine flags; they contain remains of starfish (Lapworthura and Palcocoma), large Orthoceras, and Arthropods of the genera Pterygotus and Eurypterus.

The Aymestry limestone is a bluish-grey earthy limestone of varying thickness, and often split into several beds by intercalated bands of shale. At Aymestry it is well exposed in the gorge of the river Lugg and is said' to be 175 feet thick. Its commonest fossils are Pentamerus Knighti, Lingula Lewisi, Wilsonia Wilsoni, and Dayia naricula. The outcrops of the Ludlow Beds in the typical district of Ludlow and Aymestry are shown in Fig. 56. The total thickness of the series in Shropshire is about 2600 feet.

In Staffordshire the Woolhope limestone reappears at Great Barr, east of Walsall, the Wenlock Beds are well exposed at Dudley and the ligher beds at Sedgeley, the Silurian at all these places being brought up in anticlinal flexures from which the overlying Carboniferous rocks lave been removed by denudation.

Downtonian. - In Shropshire the Upper Ludlow shales consist in the lower part of soft grey shales with thin bands of limestone, and in the upper part of grey and green calcareous flags at the top of which is a bed of greenisl-grey argillaceous sandstone surnounted by greenish laminated sandstones, inclinding a thin layer consisting of the bones and spines of fish and large Crustacea ; this layer is known as the "bone bed," and has been met with at many localities.

The bone bed is succeeded by the Downton sandstone, a finegrained and thin-bedded yellowish sandstone which is quarried for building stone at Downton Castle near Ludlow, and contains Lingula cornea, Pteraspis Banksi, Eurypterus lineatus, and otler Merostomata. This is about 50 feet thick, and is succeeded by reddish flagstones and olive-green shales which yield Lingula cornea with remains of fish and Crustacea. Above these are purple sandstones without fossils.

In a recent paper the Misses Elles and Slater ${ }^{4}$ recognise the following subdivisions, with a total thickness of 540 feet:-

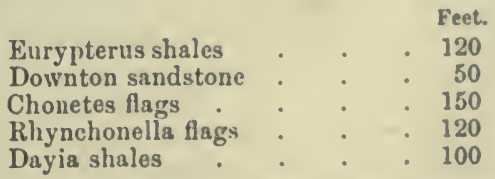

A similar series reappears in the Woolhope and Malvern districts 
and are well exposed in the cutting near Ledbury station, west of Malvern, where the sequence is as follows:-

$$
\begin{aligned}
& \text { Old Red marls and sandstones } \\
& \text { Ledbury shales } \quad \cdot \quad \cdot \quad \cdot \quad \cdot \quad \cdot \quad \cdot \quad 400
\end{aligned}
$$

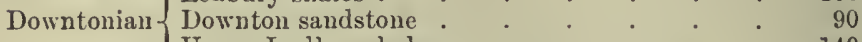

$$
\begin{aligned}
& \text { Upper Ludlow sliales } \\
& \text { Aymestry limestone (seen in the tunnel) . . . - }
\end{aligned}
$$

From the Ledbury shales Lingula cornea with remains of Cephalaspis and Pterygotus have been obtained.

The most southerly occurrences of Silurian rocks of Salopian type are at Fortworth, in Gloucestershire, and in the Mendip Hills, where a small inlier has recently been discovered and described. It is noteworthy that where the base of the Devonian comes to the surface in Cornwall it does not rest on Silurian but on Ordovician and older rocks, having probably overlapped the Silurian.

\section{Wales}

The Valentian attains its greatest thickness in Central Wales where it occupies large parts of Cardigan and Radnor, and has a maximum thickness of 5000 feet. The most complete development of the Llandovery Beds is found within the western part of the area near Rhyader in Radnor, and has recently been worked out by Mr. H. Lapworth, from whose account the following is taken. ${ }^{5}$ He describes the Lower Llandovery under the name of the Gwastaden Group, the Upper Llandovery as the Caban Group, and the Tarannon shale as the Rliyader pale slates. The Gwastaden Beds seem to succeed the Bala Beds without any break, but there is a strong unconformity between the Gwastaden and Caban Groups, and the latter is overlapped by the Rhyader slates, so that the structure of the district is somewhat complicated. Fig. 54 is a diagrammatic view constructed by Mr. Lapworth of the succession and of the relations of the rock-groups when faults and folds are eliminated.

$\mathrm{He}$ estimates the thickness of the Gwastaden Series at over 1000 feet, that of the Caban Group as 1500 (maximum); that of the Rhyader (Tarannon) slates is not given, but they extend over a large area of ground between Rhyader and Llanidloes, where they are probably 1500 feet thick, so that in this district the Llandovery or Valentian Series has a total thickness of nearly 5000 feet.

When traced eastward or south-eastward the Gwastaden Beds are found to thin ont entirely and the thickness of the Caban Beds and Tarannon shales is greatly reduced. North-east of Builth they form quite a narrow band and rest unconformably on Llandilo 


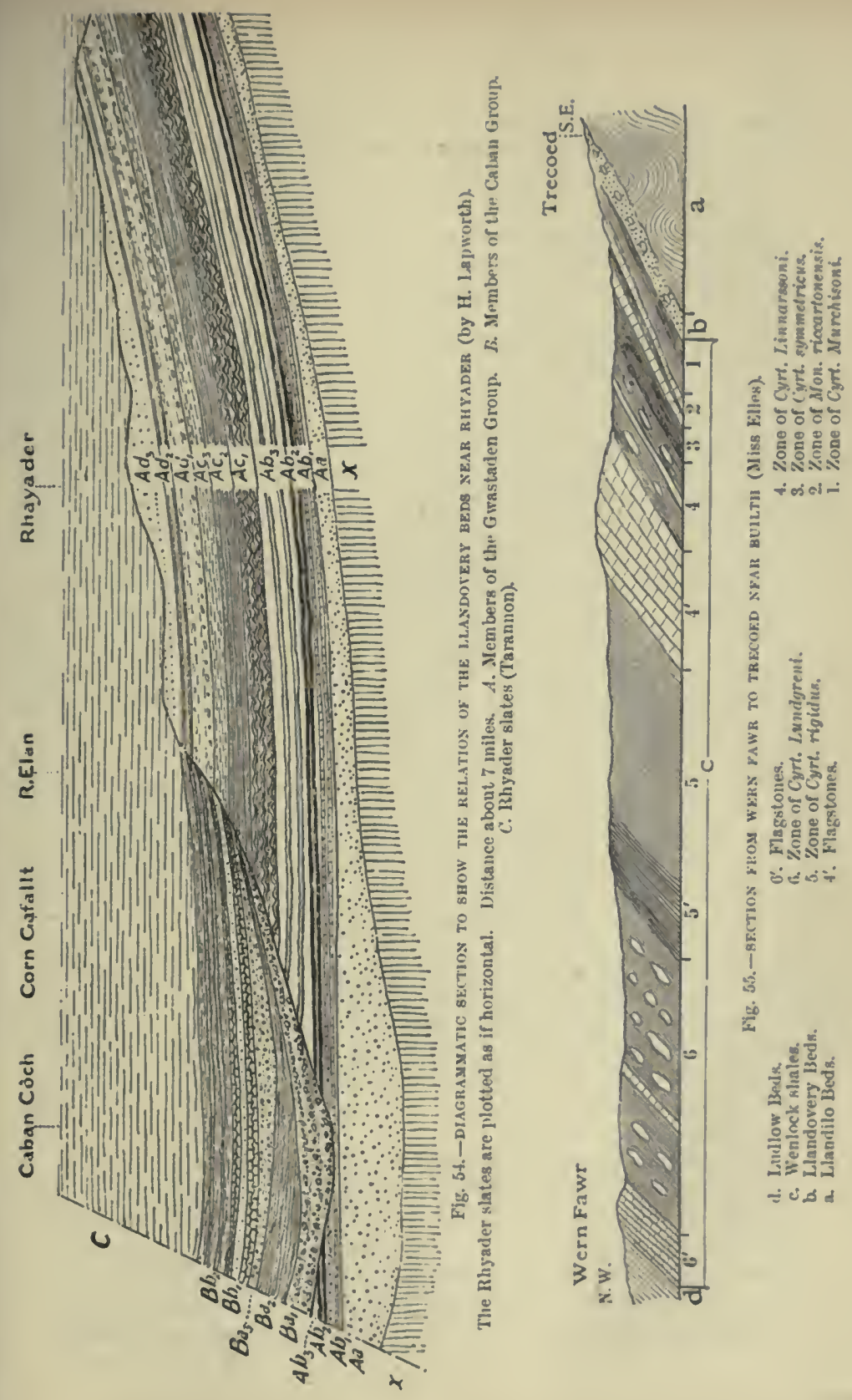


slates. Southward they extend into Carmarthenshire, both Upper and Lower divisions being well developed at Llandovery, but south of that place they are cut out by faults.

Northward the Rhyader facies is continued through Montgomery, but the several members of the series become much thinner till, near Bala and Corwen on the Dee, the whole is reduced to less than 1000 feet. At Corwen it consists of the following beds :-

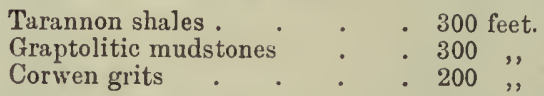

The position of these beds is shown in Fig. 57. The Corwen grits are grey and white sandstones with bands of coarse and pebbly sandstone, and are believed to vary from 50 to 300 feet in thickness. They contain few fossils, but Meristella crassa and Pentamerus oblongus have been found, which are Lower Llandovery species. Above them are soft bluish-grey or black mudstones which contain Monograptus gregarius, $M$. tenuis, and Climacograptus normalis; and these pass up into the pale Tarannon slates.

In North Denbigh the whole series is less than 500 feet thick, but the zonal succession of beds lias been more fully made out by the Misses Elles and Wood, ${ }^{6}$ these being :-

$$
\begin{aligned}
& \text { Beds. }
\end{aligned}
$$

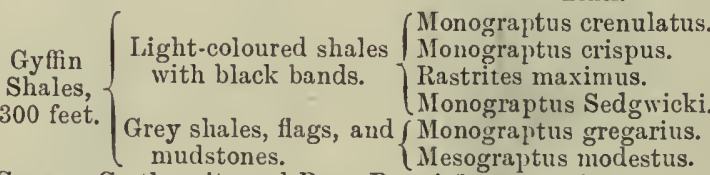

$$
\begin{aligned}
& \text { Conway Castle grits and Bryn Dowsi flags, } 150 \text { feet. }
\end{aligned}
$$

The lowest beds contain Diplograptus tamariscus, Climacograptus normalis, and other species of Lower Llandovery graptolites.

Salopian.-When the Wenlock Beds are traced westward from Presteign through Radnorshire both the limestones are found to thin out, leaving a continuous series of mudstones and shales. The Lower Ludlow shales also persist, but the Aymestry limestone at their summit disappears.

The subdivision of this mudstone series was practically impossible so long as lithological differences only were relied upon as a means of classification, but in 1880 Professor Lapworth drew attention to the graptolite fauna of these beds, and expressed the belief that "by the aid of the lowly graptolite the geologist of the future will be able to read off the natural succession" of the monotonous Silurian mudstones. This has been accomplished 
in Radnorshire and West Shropshire by Miss G. I. Filles' and Miss E. M. R. Wood, ${ }^{\mathrm{S}}$ the forner dealing with the Wenlock snecession and the latter with the Lower Ludlow.

The comntry round Builth may be taken as the type of this graptolitic facies of the Wenlock Series, and Miss Elles has shown

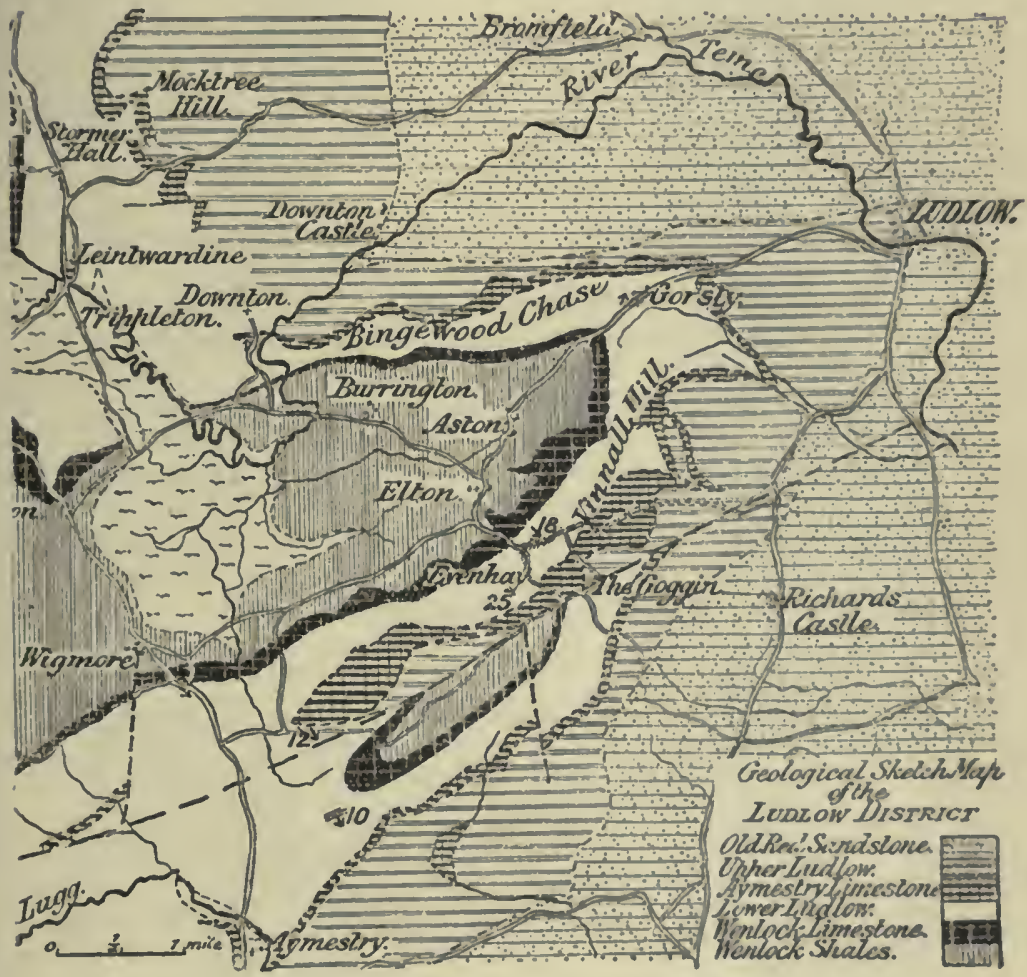

Fig. 56. - MAP OF THE I.l'DLOW DISTRICT.

that it contains a fauna of twenty-three species and rarieties of graptolites, by means of which it can be divided into six zones. The succession of the beds is shown in Fig. 55, which is taken by perinission from her paper. The total thickness appears to be about 2500 feet, but there are two partial brenks in the series, for the flagstones of zone 4 overlap the beds below, so that in one place they rest on the lower part of zone 2, and again, there is 
reason to think that the upper beds of zone 5 are sometimes concealed by an overlap of zone 6 (Cyrtograptus Lundgreni), which represents the Wenlock limestone.

The shales overlying this zone are similarly divisible, and Miss Wood has distinguished five zones in the following descending order :-

5. Zone of Monograptus Leintwardinensis, inclnding the

Feet.

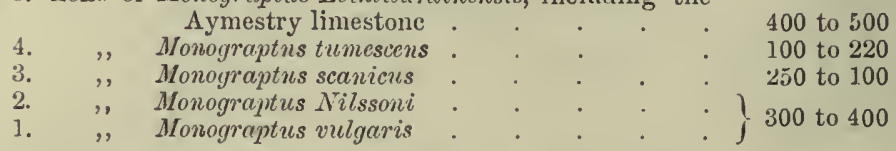

Thus the total thickness of the Salopian Series in the Builth district is about 2600 feet.

When these beds are followed northward they become more arenaceous, thick felspathic grits and micaceous flags appearing in the Wenlock shales, while the higher beds are gradually replaced by a great mass of saudstones, grits, and flagstones iu which fossils are much less abuudant. This is the aspect presented by the Salopian Series in Denbighshire, where parts of them have been studied by Mr. Philip Lake, ${ }^{9}$ Professor T. M'K. Hughes, ${ }^{10}$ Dr. H. Hicks, ${ }^{11}$ and by the Misses Elles and Wood ${ }^{12}$ (see Figs. 57 and 58). Combining the olservations and correlatious of these authors, we find that the succession may be generalised as follows:-

6. Gritty sandstones and wavy banded concretionary mudstones of Moel Ganol.

5. Grey banded mudstones and sandstones with Acidaspis Hughesi.

4. Nantglyn flags with Actinocrinus pulcher, Camarotechia nucula, Dayia navicula, Orthoceras Sedgwicki, O. primavum, Cardiola interrupta, and Monograptus Nilssoni.

3. Moel Ferna slates with Monoyraptus priodon and Mr. Flemingi.

2. Pen-y-glog grit with Meristella tumida, Strophomena depressa, Phacops sp., and Encrinites.

1. Pen-y-glog slates witl Cyrtograptus Murchisoni, Gladiograptus geinitzianus, Monograptus priodon, and Mr. vomerinus.

The slates at the base are the equivalents of the lower part of the Wenlock shales, and the same fossils have been found in beds overlying the Tarannon shales near Conway. The Moel Ferua Beds must include the representative of the Wenlock limestone, but they yield very few fossils. The Nantglyn flags represent the Lower Ludlow Beds, and Miss Elles has recognised two zones in them, a lower zone of Monograptus vulgaris and a higher one of $M$. Nilssoni. In the valley of the Dee Mr. Lake found some micaceous flagstones which contain Monograptus Leintwardinensis in abundance, 

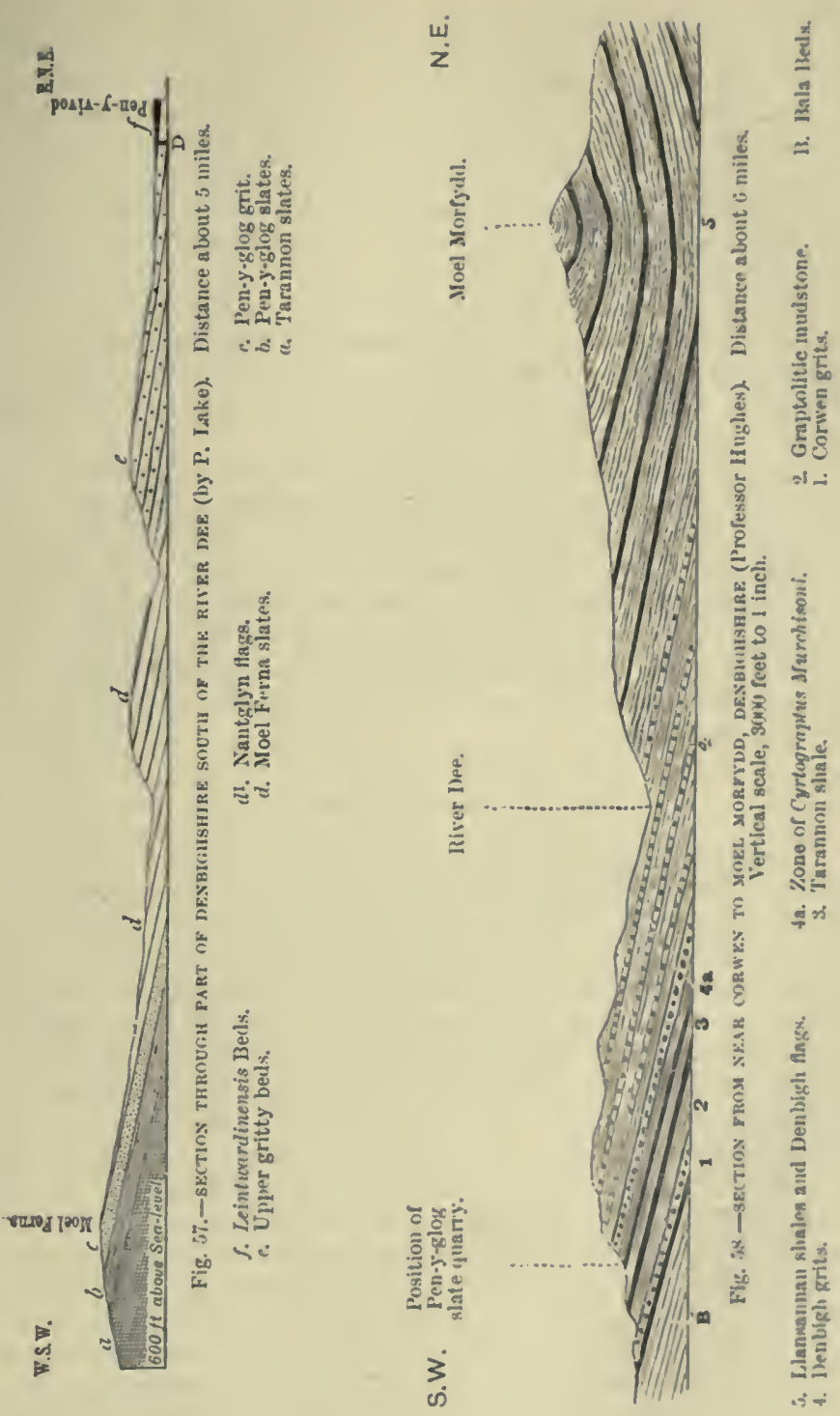
and these cannot be far below the horizon of the Aymestry limestone. This zone is probably to be found in the banded beds (No. 5) of the Clywd valley section, but has not yet been detected there. In South Denbigh the highest beds occur at Dinas Bran near Llangollen, and have yielded Orthoceras Sedgwicki, Cucullela coarctata, Dayia navicula, Chonetes minima, and other fossils.

The series is believed to be over 5000 feet thick, and is nevertheless incomplete owing to the unconformable superposition of the Carboniferous rocks.

Downtonian.-In the country round Kington, Clun, and Radnor Forest these graptolitic shales are succeeded by a great thickness of brownish sandy shale with beds of brown flagstone and sandstone, which are shown in the sections of the Geological Survey to be from 1700 to 2000 feet thick.

The highest beds in Denbighshire, i.e. the sandstones and mudstones of Moel Ganol, may represent the Upper Ludlow shales, but proof of such equivalence has not yet been found. That beds of Ludlow age did originally extend over Denbigh is proved by the occurrence of fossiliferous pebbles in the conglomerate at the base of the Carboniferous Series near Abergele. ${ }^{13}$ These are pebbles of green and red sandstone containing Orthis lunata, 0. filosa, Chonetes striatella, Spirifer elevatus, Pterinca retroflexa, and a few other species.

\section{Westmoreland}

The Silurian sequence in the north of England does not differ greatly from that of North Wales, but it is much more complete, has been more fully investigated, and the beds are also rather more fossiliferous, so that they are more easily subdivided. For a long time the correlation of the Westmoreland Groups with those of Shropshire and Radnor was very uncertain, but the recent studies of graptolites by Messrs. Marr and Nicholson, ${ }^{14}$ by Miss G. Elles, ${ }^{15}$ and by Misses Watney and Welch ${ }^{16}$ have placed the comparison on a sounder basis.

Valentian.-Where the sections are most complete, as in Stockdale and at Spengill, there are no arenaceous beds of the Llandovery type, but a series of shaly mudstones resting directly on the Ashgill shales with apparent conformity (see Fig. 37). In some parts of the area, however, the lowest shales are replaced by a few feet of gritty conglomerate. The ordinary facies is known as the Stockdale Shales; their total thickness is not more than 250 feet, but divisible into two sub-groups: (1) the Skelgill Beds, (2) the Browgill Beds. By the Geological Survey 
the groups are called (1) the graptolitic mudstones and (2) the Pale slates,

The Skelgill Beds have a thickness of 70 or 75 feet, and have at the base a thin limestone containing Atrypa flexuosa, suceeded by shale with Dimorphograptus confertus. The niddle beds contain Monoyraptus gregarius and Rastrites peregrinus, with Encrinurus punctatus and Phacops gluber. The higher beds yield Monograptus spinigerus and $M$. Clingani, with nany trilobites, and in the Spengill section there is a still higher band containing Rustrites maximus in alundance.

The Browgill Beds are thicker (abont 140 feet) but less foseiliferous. They are divisible into three parts: (1) a zone of Monograptus turriculatus; (2) a zone of Monograptus crispus; (3) barren shales and grits.

Salopian.-This series attains a very great developnent in Westmoreland and consists almost entirely of flagstones, sandstones, and grits, with only subordinate bands of shale. The equivalents of the Wenlock Beds are really of less thickness than they are in Shropshire, but those above the horizon of the Wenlock limestone (zone of Cyrt. Lundgreni) are very much thicker. The following is a tabular view of the lithological divisions and the graptolitic zones :-

Divisions.

Zorıes.

Bannisdale slates (4000 fect). Sandy unudstones) with beds of hard sandstone. Orthoceras M. Leintwardinensis. primavus and 0 . subundulatum.

Coniston grits (4000 feet). Red grits and flags MI. tumescens. with Cardiola interrupta, Pterineatenuistriata, M. Mcanicns.
Dayia navicula, and Orthis lunata.

Coldwell flags (2000 feet). Grey flags and grits M. vulgaris with Acidaspis Hughesi, Actinocrinus pulcher, $\}$ (probably).
Monograptus colonus, and M. Remeri. Coldwell grits ( 800 feet). Coarse grey grits. C. Lundgreni. Brathay flags (1000 feet). Fine-gruined bluish C. rigidus. laninated flagstones, comparable with the M. Riccartonensis. Wenlock shales and divisible into 3 zones. $\int$ C. Murchisoni.

Downtonian. - This group seens to be represented by certain beds which succed the Bannixdale slates and consist in the lower jart of bluish thin-bedded sandstones with subordinate leds of shale, containing Protaster Miltoni, Dayia navicula, Cucullellu Cawdori, Phacops Downingia, and other fossila. There is also a calcareous band which contains Palaaster, Proëtus latifrons, and Dayia navicula, and has been identified by Mr. Aveline with the Aymestry limestone. These beds are about 1200 feet thick.

The highest beds, or The Kirkby Moor flugs, are massive greenish and grey sandstones, with calcareous (fossiliferous) bands, passing 
up into thin-bedded flags. This group is more than 2000 feet in thickness. Fossils are abundant, the following being some of the most characteristic:-Lingula cornea, Discina rugata, Spiriferc elevata, Grammysia cingulata, Orthoceras ludense, and Trochoceras ibex.

\section{South of Scotlend}

The Silurian succession in this region was first deciphered by Professor Lapworth, ${ }^{17}$ who described the two special facies exhibited by the rocks of Valentian age near Moffat in Dunfries, and near Girvan in Ayrshire. More recently the whole region of the southern uplands has been described in detail by Messrs. Peach and Horne. ${ }^{18}$ The Silurian rocks occupy the southern half of the upland region in a broad belt from 20 to 30 miles in width, extending from the Berwick coast on the east to that of Wigtown on the west. On the northern side they occur as isolated exposure in Ayrshire, in Lanark, and in the Pentland Hills.

Valentian.-In Dumfries and the central belt the lowest beds are soft black shales, known as the Birkhill shales; they lie conformably upon the Hartfell shales (Bala), are equivalent to the Skelgill shales of Westmoreland, and are of about the same thickness (140 feet) (see Figs. 40 and 41, p. 133). They are rich in graptolites, and are divisible into the following zones:--

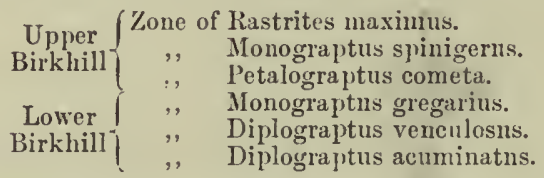

These shales are succeeded by a thick series of sediments, from 3000 to 4000 feet, which are the equivalents of the Browgill Beds and the Tarannon shales. They are called the Gala Group by Professor Lapworth, and have been divided by the Survey into three stages, but fossils are rare except in the lowest or Abbotsford flags, which contain Monograptus turriculatus, M. crispus, M. exiguus, etc.

In the Girvan area the Birkhill shale is represented by a much thicker series of a Llandovery type, and about 1000 feet thick. The lower beds contain Lower Llandovery fossils, while the succeeding beds include a limestone with many Upper Llandovery fossils, such as Pentamerus oblongus, Stricklandiu lens, Illenus cemulus, and Phacops Stolkesi. Above this, and representing the Gala Group, are the Penkill Beds (also 1000 feet thick), the topmost of these being mudstones containing Cyrtograptus Grayce. 
Salopian.-In the main belt the Gala Group is succeded by the Riccartou Beds, a series of conglomerates, grits, mudstones, and shales from 1000 to 1500 feet thick, and containing Cyrtograptus Murchisoni, Monograptus vomerinus, and M. priodon. At Raeberry near Kirkcudbright there are still higher beds, consisting of green marls with limestone uodules, which are either highest Wenlock or possibly Lower Ludlow: These are 700 feet thick.

In the Girvan area the representatives of the Wenlock Beds consist largely of unfossiliferous flagstones, and only the lower part of the series is exposed. This is divided into two gronps by Professor Lapworth. The lower or Bargauy Group has a thickness of about 700 feet, the only fossils being the graptolites Monograptus acus and M. priodon. The higher group he called the Straitou Beds, at the base of which are olive-green flags well seen at Drumyork, succeeded by shales containing Monograptus vomerinus, Cardiola fibrosa, Orthonota truncata, and other fossils. The highest beds seen are purplish grits and conglomerates, the exposed thickness of the Straiton Group being about 900 feet.

The highest beds referable to the Wenlock Series are well exposed in Lanark, where they are no less than 2200 feet thick (see table below), and yet do not include any beds comparable to those near Straiton; hence there seems to be a gap in the succession, and the full thickness of this series in Scotland is not yet known.

Ludlow Series.-These beds are not found in the main belt nor in the Girvan district, but only in Lanark and the Pentland Hills, where the following succession has been recognised :-

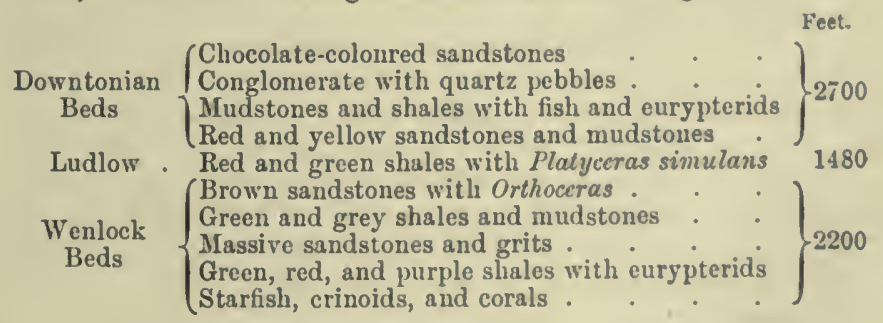

The beds which are bracketed as having a thickness of 2700 feet were formerly grouped with the Old Red Sandstone, but are regarded by the Geological Survey as the equivalents of the Downton and Ledbury Beds. They include a band of shales which has yielded many remains of fish and Merostomata. The fish fauna is of great interest, as two of the genera belong to a family which has hitherto been known only from scales; these genera are Thelodus and 
Lanarkia, belonging to the family Cnelolepida, which, according to Dr. Traquair, are nearly related to the Pteraspida, although they have superficial resemblances to the sharks. Other new genera found in these beds are Ateleaspis, Birkenia, and Lasanius. The Merostomata include species of Stylonurus and Eurypterus, and the Crustacean Ceratiocaris is also present. The underlying Ludlow shales have yielded the earliest British arachnid in the form of a scorpion (Palcoophonus), a genus first described from remains in the Silurian of Gottland (Sweden).

\section{Ireland}

Rocks of Silurian age succeed the Ordovician Series in many parts of Ireland; they may be described as exhibiting two different facies, the one comparable with the Scotch type and the other witl the Llandovery-Wenlock type.

Eastern Facies.-Valentian rocks of the Birkhill-Gala type occur in the north-eastern and central counties, and probably they extend under the whole of Central Ireland down to the coasts of Clare and Waterford. Rocks having the same general character as the Birkhill shales and Gala Series of Southern Scotland range through the counties of Down, Armagh, Monaghan, and Cavan; it has, in fact, been found that the greater part of the tract which was coloured as "Lower Silurian" on the older geological maps of Ireland consists of Valentian rocks. ${ }^{19}$ The older beds (Birkhill shales) occur chiefly along the north-west border of the area, and have yielded the characteristic graptolites, Diplograptus folium, Monograptus gregarius, $M$. Sedgwicki, and Rastrites maximus. South of this zone are rocks of Gala type containing Monograptus priodon, $M$. turriculatus, and $M$. riccartonensis, while in County Louth there are rocks comparable to the Riccarton Group with Wenlock fossils.

Graptolitic Valentian Beds have also been found near Pomeroy in Tyrone, and again far to the south-west in Queen's County, Clare, Tipperary, and Limerick, where large inliers of Silurian rocks are brought up by anticlinal domes from beneath the old Red Sandstones.

Western Facies.-In the district lying between Lough Mask and Killary Harbour (County Mayo), and again in the Dingle promontory of Kerry, there are thick developments of the whole Silurian System, and here the deposits give evidence of the close proximity of land.

In Mayo, north of Killary Harbour, Llandovery sandstones rest on Arenig Beds, but south of that inlet they overlap the Ordovician 

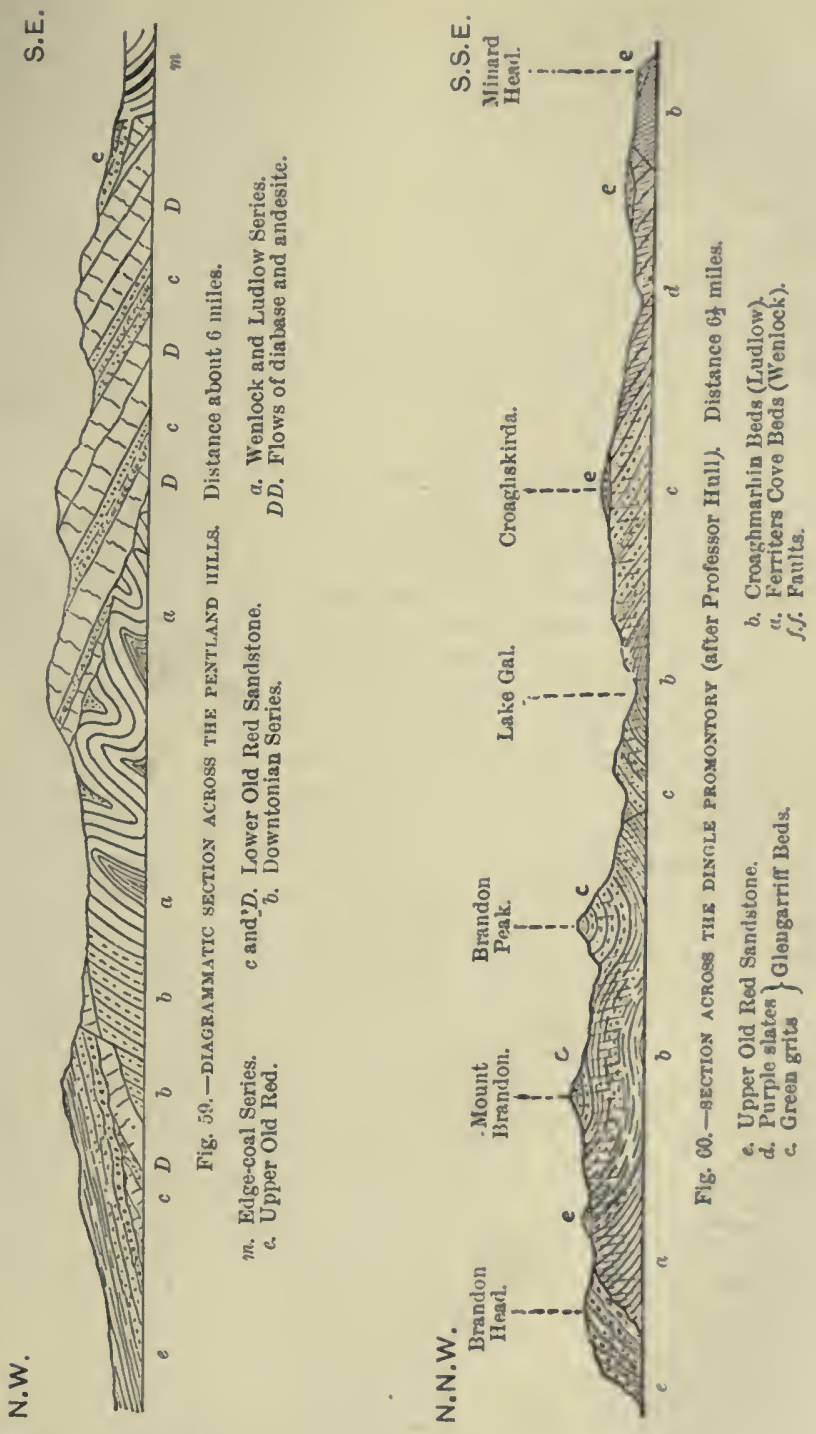
and rest directly on the Archæan rocks, their base being a breccia consisting of angular lumps of quartz and schist. Above this are red mudstones and a band of calcareous grit with Upper Llandovery fossils succeeded by a massive conglomerate consisting mainly of rounded pebbles and boulders of quartzites like those of Connemara. Then comes a thick series of coarse grits alternating with green sandy slates which have yielded a few fossils of Wenlock species, Monograptus riccartonensis and $M$. vomerinus. These beds may be about 2000 feet thick. Above them are the Salrock Beds, dull red and green shales, with thin bands of grit, and having a thickness of about 3000 feet. They contain a small species of Lingula (L. Symondsi) with Pterinara retroflexa and Modiolopsis complanata. They probably represent the greater part of the Ludlow and Downton Beds.20

In the Dingle promontory the ascending succession is as follows ${ }^{21}$ (see Fig. 60) :-

(1) Smerwick Beds, a thick series of red, green, and yellow sandstones with bands of conglomerate; fossils rare, but Atrypa hemispherica and others have been found.

(2) Ferriters Cove Beds, greenish sands and shales with bands of red sandstone; these beds are $\mathbf{2 5 0 0}$ feet thick and contain fossils of Wenlock species.

(3) Croaghmarhin Beds, hard brown calcareous grits with Pentamerus Knighti and other Ludlow fossils. These dip southward at a high angle and pass below a great series of green and purple grits and shales which are known as the Glengarriff grits, and believed to be of Devonian age.

Here, also, there are evidences of contemporaneous volcanoes. The best sections are in the cliffs near Clogher Head, where the interstratification of the lavas and tuffs with the fossiliferous Wenlock Beds is beautifully exposed. Sir A. Geikie describes the lavas as nodular felsites, the nodules being from the size of a pea to that of a hen's egg, and the associated pyroclastic rocks vary from fine pumiceous tuffs to coarse agglomerates. One of these beds is a coarse agglomerate about 15 feet thick, consisting of large blocks of felsite embedded in calcareous sandstone which is full of the casts of brachiopods, crinoids, and corals. The district has been recently examined by Messrs. S. H. Reynolds and C. T. Gardiner, who found that some of the lavas are rhyolites, and that all are of acidic character. ${ }^{22}$

From these facts we learn that a volcano existed in this part of the Silurian Sea, and that from time to time it burst into eruption, pouring forth lava streams and ejecting showers of stones and ashes, 
which fell into the surrounding sea and were spread out on its floor, while between each epoch of eruption marine sediments of the usual kind were greatly accumulated. The part of the sen in which these deposits were formed was probably not very far from the shores of a continent occupying a large area in what is now the Atlantic Ocean.

\section{Coxtinextal Equivalests}

Rocks of Silurian age occur in Scandinavia, Russia, Poland, Thuringia, Bohemia, Carinthia, the Alps, Belgium, France, and Spain. We can only refer to the more important areas.

\section{Scandinavia}

Undisturbed and unaltered Silurian strata not only occur in the same parts of Norway and Sweden, and succeed those of the Ordovician System (see p. 146), but they also form the island of Gottland in the Baltic, which thus becomes a link between the Swedish and Russian areas (see map, p. 66).

The Silurian Series exhibits several different facies in different parts of the Scandinavian region, and shows great variation in thickness. It is most fully developed in Scania, where sedimentation in the form of graptolitic shales continued throughout the whole of Valentian and Wenlock times, a bed of limestone only occurring at the top of the system, the full thickness of which is there about 4000 feet. This great series is divisible into zones which can be correlated with those of Great Britain.

In the Christiania district the deposits are very diflerent, consisting of an alternating series of limestones and sliales, and the total thickness is not much over 1200 feet, but is not complete at top.

In Oland and Gottland, again, to the east the facies is essentially calcareous, shales prevailing only in the lowest part, and the whole system is condensed into a thickness of something less than 200 feet in Gottland. The base, however, is not seen, though the sequence extends down as low as the equivalent of our May Hill sandstone (Upper Llandovery), neither do the highest beds conle into these islands.

The Gottland limestones are shallow-water and not deep-water deposits. ${ }^{23}$ They consist largely of crinoidal limestones, but these are replaced locally by beds which are so largely composed either of Stromatoporoids or Corals (or of both) that they liave clearly been formed by the growth of these organisms in situ. There 


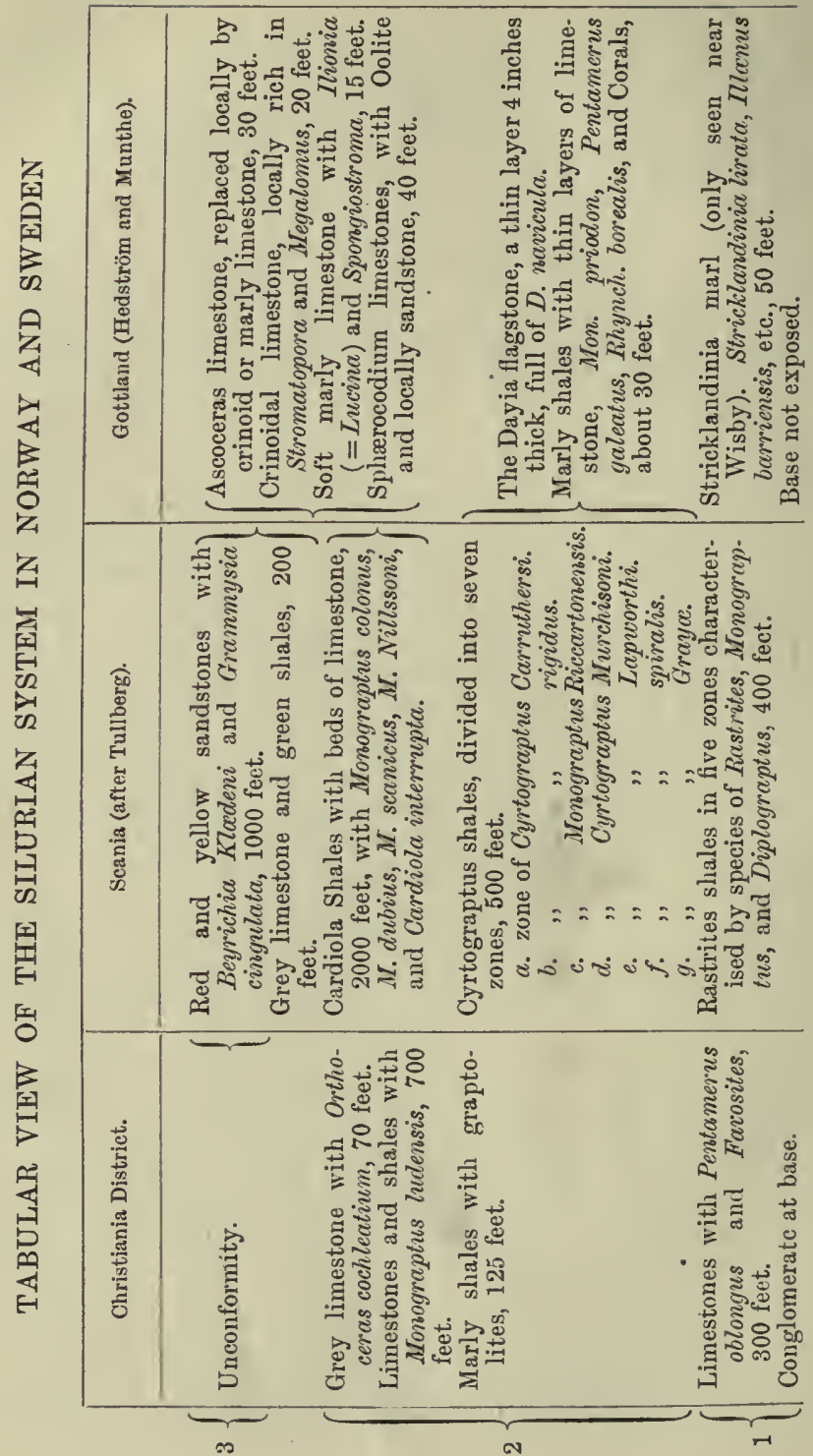


are also beds of oolite and of marly limestone which are rich in Spongiostroma, a kind of calcareous alga, and thin bands unade up of Sphorocodium, which is another alga of solid globular form.

The succession of beds found in these three districts is given in an abstract form on p. 182, the figures $1,2,3$ indicating the equivalents of the Valentian, Salopian, and Downtonian Series.

From the above account it will be seen that the Silurian of Gottland is quite an abnormal development of the systern, and as such is not at all suitable to be taken as its typical facies. Herce the fashion which has come into vogue among continental geologists of using the term Gothlandian instead of Silurian is unfortunate and unnecessary.

It will be noticed that the equivalents of our Llandovery and Wenlock Beds are of comparatively small thickness, and that throughout the Scandinavian region the larger part of the sediments belong to the time of our Ludlow Beds with representatives of the Downtonian in Scania.

The highest beds are most fossiliferous in the Ramsåsa district of Scania, where they are often full of Leperditia incqualis and Tentaculites. Homalonotus Knighti, Phacops Downingix, Spirifera elevata, Pterinoea retroflexa, and a Pterygotus also occur.

\section{Russia}

The Gottland type of the system is found again on the Russian side of the Baltic in Esthonia and Livonia, the beds having clearly been once continuous across the intervening space. From the following table it will be seen that they are very little thicker than in Gottland, when allowance is made for their forming a more complete succession both at top and base. ${ }^{24}$

$3\{$ Grey and yellow limestones with Euryplerus Fischeri, Hemiaspis Feet.

rugosa, Platyschisma helicites
Dolomite and marls, with a Wenlock fauna : : : :

2 Limestone with Pentamerus estonus and Illonus barriensis, passing into a coralliferous limestone . . . . 50

Raikull Beds with few fossils (Phacops elegans). $\quad: \quad 100$

$1\left\{\begin{array}{l}\text { Limestone largely composed of Pentamerus borealis } \\ \text { Joerden Beds - sliales and marls with Encrimus punctatus, } \\ \text { Rhynchonella affinis, and corals }\end{array}\right.$

$\overline{325}$

These beds pass southward beneath the Deronian Series, and when the Silurian reappears in Russian Poland near Kielce it presents a very different facies. The sequence has not yet been completely worked out, but consists in the lower part of shales 
which seem from their graptolites to include representatives of zones from the horizon of the Tarannon shales to the Lower Ludlow (Climacograptus, Mon. priodon, Mon. colonus), succeeded by arenaceous beds (grauwacke) containing Beyrichia Klcedeni and Spirifer elevatus. Above these are sandstones, some of the beds containing remains of Placoderm fishes and others Spirifers.

\section{Bohemia}

Passing now to Central Europe we still find in Bohemia a concentrated and largely calcareous facies of the Silurian with a very rich fauna, the limestone beds being crowded with species of Cephalopods, Trilobites, Corals, Brachiopoda, and Mollusca of various kinds. Some of the species are identical with those of Britain and Western Europe, but many are different, though for the most part belonging to the same genera. The beds which represent the Silurian System are all comprised within the stages $\mathrm{E}$ and $\mathrm{F}$ of Barrande, the succeeding stages $\mathrm{G}, \mathrm{H}$, which he included in the system, having since been relegated to the Devonian (see Fig. 45 and p. 221).

Barrande divided his stage $\mathrm{E}$ into two parts, $\mathrm{E}_{1}$ comprising all the shales and $\mathrm{E}_{2}$ the overlying limestone, but these do not correspond with palæontological subdivisions. Moreover, the highest beds of shale are very calcareous and contain large spheroidal limestone-balls or concretions, while layers of shale containing Monograptus colonus are interbedded with the overlying limestones. The succession with Barrande's grouping is :-

$F_{1}$. Black nodular limestone, with graptolites and other fossils . 150 $\mathrm{E}_{2}$. Grey limestones in thick beds with occasional layers of shale (many fossils) . . . . . . . 400

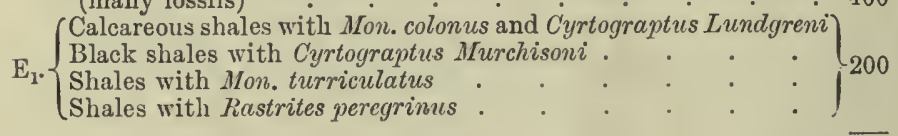

The two lower zones are Valentian, the black shales correspond with our Wenlock shale, and the calcareous shale may be equivalent to the Wenlock limestone. The overlying limestones must represent the whole of the Ludlow Series, for they contain a mixture of Wenlock species of corals and brachiopods with such essentially Ludlow forms as Pentamerus Knighti, Dayia navicula, and Monograptus colonus, as well as a host of peculiar trilobites, lamellibranchs, gasteropods, and cephalopods. 
$F_{1}$ has until recently been regarded as Devonian by German geologists, but the most recent study of the beds and their contents, by $\mathrm{F}$. Seemaun, ${ }^{25}$ has shown that it is more intimately connected, both stratigraphically and faumally, with the top of Stage E than with the beds above. Thus it contains graptolites, Mon. colonus, M. priodon, Callograptus dichotomus, and others, witl Orthoceras subannulare and other species, and lastly, no Goniatites have been found in it. Seemann, therefore, regards this black limestone $\left(F_{1}\right)$ as the top of the Silurian Series, and as forming to some extent a passage from the Silurian to the Devonian. It is, however, clearly marked off from the overlying white and red limestones which, in lis opinion, form the base of the Devonian System (see p. 222).

The fauna of the thick mass of limestone forming Stage $\mathrm{E}$ is a very large one, including 10 fewer than 183 species of trilobites belonging to the genera Acidaspis, Arethusina, Phacops, Proëtus, Illenus, Lichas, Cyphaspis, Cheirurus, Sphærexochus, etc. Of Orthoceras there are 250 species, and of Cyrtoceras, 150. Lamellibranclis are very numerous, and include the genera Dualina (100 sp.), Panenka (84 sp.), Cardiola (65 sp.), Lunulicardium (85 sp.), Paracardium, Pracardium, Kralorna, Pterinau, Vlasta, Redonia, and Prelucina.

\section{Germany}

In Thuringia there is again a normal succession up to a zone of Mon. colonus, abote which there appears to be a break in the sequence; and in the Kellerwald the case is similar, but there shales with Cardiola interrupta, Monograptus, and Cyrtograptus are succeeded by beds with Phacops, Harpes, and Hercynella before they are cut off by the unconformity.

In the Hartz Mountains, however, the stratigraphy is very different. There the oldest rocks exposed are a thick series of grits, mudstones, and shales, witl some limestones which seened to contain a mixed fauna of Silurian and Devonian forms with graptolites. By Beyrich and Lossen they were called the Hercynian and were regarded as an intermediate series between the Silurian and the Devonian Systems, but recent researches have shown that the central core of the range is a dislocated and faulted mass or conplex, and that large parts of it are really Silurian while otlers are Devonian. To the Silurian inust be referred the greywacke of Taune, and the black limestones of the Taunenthal, which contain Cardiola interrupta, as well as the Monograptus slates of Wieda; though these seem to overlie beds with Devonian fossils, and were formerly regarded as the lighest nember of the series. 


\section{Belgium}

Silurian rocks of a normal character are only exposed in the same valleys as disclose those of Ordovician age (see p. 145). The snccession according to the most recent researches of Professor Malaise is as given below :- ${ }^{26}$

Dark slates with Monograptus colonus and M. Nillssoni.

Sandy slates with Mon. vomerinus, Cyrtograptus Murchisoni, and Cardiola interrupta.

Flagstones and shales with Mon. bohemicus.

Black slates and quartzites with Climacograptus normalis. Grey slates with Phacops Stokesi and Halysites.

It will be noticed that nothing above the horizon of the Lower Ludlow is exposed, but ligher beds probably exist under the cover of newer deposits. The Silurian, however, must thin out soutlwards, for no such beds occur in the Ardennes, where a series known as the Gedinnien, and generally regarded as Lower Devonian, rests unconformably on Cambrian rocks.

\section{France}

Silurian sediments occur in several parts of France, but generally present a shaly facies with small developments of limestone and are not rich in fossils. The most complete sequence of zones yet recorded is that of the west of Brittany (Crozon peninsula), where $\mathbf{M}$. Kerforne has been able to recognise the succession of graptolite zones given in the table below. ${ }^{2 \pi}$

Shales with Bolbozoe.

West.

, with Monograptus colonus and Orthoceras in nodules. with Mon. Salweyi.

with Mon. colonus.

, with Mon. Flemingi.

", with $\mathrm{M}$. riccartonensis.

? White Limestone of Erbray.

Black limestone of Briasse with Mon. colonus and $M$. vomerinus.

Shales with layers of calcareosiliceous nodules, Cardiola interrupta, and species of Panenka, Dualina, etc.

, with Cyrtograptus.

,, with M. convolutus.

" with Rastrites Linnæi.

Shales with Cyrtograptus geintizianus.

Cherts with Radiolaria and shales with Rastrites and Mon. lobiferus. Sandstones without fossils.

In the central and eastern parts of Brittany, as well as in Mayenne and Anjou, a similar set of beds is found, though there are some lithological differences, and the graptolite zones have not yet been worked out. The two areas are compared above. 
The thickness of this series of beds lias not been estimated because of the frequent plications. There is also some doubt about the position of the Erbray limestone which contains some Devonian species, such as Spirifer Decheni, Crypheus pectinatus, and at the top Harpes venulosus.

In Normandy (Cotentin) the Silurian similarly consists of sandstone at the base succeeded by black carbonaceous shales (ampelites), the zonal details being at present unknown.

In Southern France (Languedoc) the Silurian presents a series of black sliales and limestones about 650 feet thick. The lower part yields Mon. priodon, M. Flemingi, and higher up $M$. colonus and $M$. bohemicus. Black limestones at the top contain Cardiola interrupta, Slava bohemica, Maminka comata, and other Bohemian species (of E 1 and 2) with numerous fragments of Orthoceras, the fauna being of essentially southern type.

\section{Pyrenees, Spain, and Portugal}

In these countries the Silurian has for the most part an argillaceous facies like that of Brittany. In the Pyrenees it consists of black carbonaceous shales containing graptolites of Valentian and Wenlock species, but there are some calcareous shales, and in the Haute Garonne a black limestone contains several species of Orthoceras with Monograptus priodon.

In Catalonia there is a more complete succession, as below :-

Black calcareous shales, Mon. colonus, M. Nillssoni.

Soft black shales with $M$. priodon.

Black nodular shales with Mr. turriculatus.

Pale shales with $M$. proteus (Valentian).

A similar succession is found in Portugal (Alemtejo and Barrancos), where the top bed is a thin band of limestone comparable to that of Rozan in Brittany.

\section{E. Conditions of Deposition}

The general geographical conditions over Nortlern and Western Europe during the earlier part of Silurian time seem to have been similar to those prevailing in the Ordovician period. There was the same mass of continental land in the Atlautic area, along the borders of which thick deposits of sand and mud were accunulated, but there seems to have been more land over Central England and in the area of the North Sea, for it was probably from such land that the great mass of arenaceous material forming the Wenlock 
Series of North Wales and Westmoreland was derived (see Building of the British Isles, 3rd edition).

The much greater thickness of Silurian deposits in Norway and Scania (as compared with the underlying Ordovician) also testifies to the nearer presence of land. There-was, however, the same open sea over the Baltic area wherein little but limestone was deposited. In the North British area, too, the same strip of comparatively deep water persisted for a time with small sedimentation, though after the epoch of the Birkhill shales the whole British area received a large share of the detritus carried off the land which lay to the north and north-east of it.

The Silurian Sea probably extended over the same parts of the European region as were covered by that of the Ordovician period, but the land of Ardennes and the Rhine provinces, which may have existed in Ordovician time, becomes much more of a certainty in Silurian time. Thus in Belgium the Silurian extends southward to the Crête du Condroz, which separates the basins of Namur and Dinant, but must be overlapped farther south by the Devonian, for it does not emerge on the Cambrian areas of Rocroi and Stavelot (see Fig. 70, p. 216). Passing eastward we find the Devonian rocks forming a continuous band through the Eifel, Hunsruch, and Taunus districts, and resting near Frankfort on Cambrian exactly as they do in the Ardennes.

Southward the land probably included the Odenwald and the Schwarz Wald of Baden, together with the Vosges district on the western side of the Rhine, where a patch of Devonian lies directly on the crystalline Archæan rocks, and no Silurian or Ordovician occur. It may have extended still farther south into Switzerland, but of this there is no actual evidence. The region above indicated measures about 230 miles each way, i.e. from west to east and from north to south, so that it probably included an area of over 70,000 square miles, which is nearly as large as England.

Silurian strata are not found again till we go as far east as the Carnic and Carinthian Alps in Austria, and as far south as Sardinia, but this is probably due to their concealment by newer rocks, and it is very likely that the Silurian Sea was continuous from the south of France (Pyrenees and Languedoc) through Northern Italy to Carinthia, Styria, and Bohemia.

It is noticeable that in Southern Europe, i.e. in Languedoc, Pyrenees, Spain, the Carinthian Alps, and Bohemia, the fauna found in the Silurian strata is very different from that in the more northern areas; so that two distinct life provinces seem to have existed at ti:is time in the European region.

The conditions of deposition which prevailed in this Silurian 
Sea of Western and Central Europe seem to have remained uniform for a considerable time and with little change except that of a slow subsidence; so that little but shale was deposited, while here and there beds of limestone were accunulated, especially in the north-east. During the later part of the period crust movement took place, causing elevation and raising luuch of the northern part of the region above the level of the sea.

With regard to the composition and construction of the Silurian deposits some interesting questions present themselves, especially in connection with the limestones. These often consist of a varied assemblage of organic remains, all the creatures then living in the sea which possessed calcareous shells or structural parts contributing to their formation, but occasionally some particular class of animals, or even one particular species, flourished in such numbers at certain places that their remains constitute almost the entire mass of the resulting bed of limestone.

Thus in some parts of the sea-floor there must have been fields of Crinoids, growing in myriads as they do now in parts of the Caribbean Sea. By the growth and death of successive generations of these fixed "stone lilies," and by the subsequent disintegration of the stems, cups, and arms, beds of crinoidal limestone were slowly accumulated.

In other places certain species of Brachiopoda flourished in such numbers that they must have occupied the sea-floor almost to the exclusion of other creatures, and their remains consequently form a Brachiopod limestone. Occasionally, too, one species so predominates over the others as to be the main constituent of the limestone, as in the case of the Pentamerus borealis limestone of Russia (see p. 183).

Other inportant components of Silurian limestones are Stromatoporoids and Corals which often occur together, but sometimes separately form the chief constituent of a bed or mass of limestone. Some coralliferous limestones are of such a nature that it has been imagined they were coral-reefs of the same kind as those built up by corals at the present day. This, however, is very doubtful for the following reasons.

In the first place, modern coral-reefs are either shore-formations resting unconformably on other rocks (fringing reefs), or they are steep-sided masses of limestone built up in the open sea with deep water on one or both sides of them; and in areas of subsidence such reefs often reach to a great vertical height from the level from which they started. Now the only ancient coral-reefs that are likely to have been preserved are those which had been forned in areas of subsidence, where their lower parts would be flanked and 
protected by deposits of marly limestone composed of coral mud and the remains of other organisms. If such an ancient reef were subsequently raised and truncated by marine erosion and finally preserved as part of the earth's crust, we should have a mass of unstratified reef-rock sharply defined on all sides, from the surrounding beds, and probably of great vertical height in proportion to its horizontal extension. It would not form a lenticular mass nor would it pass into other kinds of limestone.

Again the corals which build up such reefs at the present day belong to families which did not exist in Palæozoic seas, and only made their appearance in those of Triassic time. Corals of the single cup-shaped form are not likely to have been reefbuilders, and though there were compound corals in the Palæozoic seas, such as Heliolites, Favosites, Pachypora, and Alveolites, they belong to the Alcyonaria, and though the living genus Heliopora lives on coral-reefs, no reliable inference can be drawn from this fact with respect to the habit and growth of Heliotites and others; we can only judge from what can be seen of their mode of occurrence in stratified rocks.

The other group of animals which has been credited with reefforming capabilities are the Stromatoporidoe, which are not corals nor Actinozoa of any kind, but are believed to have been Hydrozoa allied to the modern Millepora. They formed massive hemispherical or irregular globular growths of concentric laminæ, and varied in size from a few inches to masses of 3 or 4 feet in diameter. They were sometimes so abundant as to be the principal constituents of thick beds of limestone, which on account of the size of the component masses are often unstratified; thus they certainly formed submarine banks, but such banks are not "reefs."

The beds of coralliferous limestone which occur in the Silurian and Devonian strata of Britain, France, and Germany do not present the aspect of coral-reefs. They are merely lenticular beds or masses, of greater or less horizontal extent, and are often interstratified with shales or occur as bands in a mass of crinoidal limestone. Such a mode of occurrence proves that they were formed on a sea-floor in the ordinary way under a certain depth of water. The corals seem in some places to have formed fields or groves, like those of some modern species of Crinoidea, and the resulting limestone is unstratified, but such limestones must not be called reefs because there is no evidence that they were ever built up to the surface of the sea.

Limestones which have a greater resemblance to coral-reefs occur in Sweden, and some are beautifully exposed in the cliffs of the island of Gottland, where they can be seen to terminate in some 
cases abruptly against another kind of limestone. The Swedish geologists call these beds reefs, and apply the term not only to such beds as are largely made up of corals, but also to those of which the principal constituents are Stromatoporoids or Bryozoa. Thus, writing of the Ascoceras limestone, Munthe says, "It may be considered as a reef-limestone formed chiefly of Stromatopora and of large fragments of Crinoids with marly sediment to fill the interspaces," and it should be noted that the Cephalopod Ascoceras is common in this limestone.

Good descriptions and photographs of these beds are given in the livret-guides provided for the Geological Congress at Stockholm in 1910 and from them it is plain that by the term "reef-limestone" the writers merely mean limestones composed of organic remains which have been accumulated in such a manner as to be unstratified. One such bed is shown to be overlain by stratified Sphærocodium limestone, another by crinoid limestone, and massive colonies of Stromatoporoids sometimes replace crinoid limestone. It is evident that all the beds were formed in shallow water where the sea-floor was swept by strong currents, to the action of which the frequent abrupt termination of some beds and their replacement by others may be ascribed, but it is very doubtful whether any of them ever formed a reef in the proper sense of that term.

\section{REPERENCES}

${ }^{1}$ C. Lapworth, "On the Geological Distribution of the Rlabdophora," Ann. and Mag. Nat. Hist. ser. 5, vol. v. and vi. (1880).

2 Miss E. M. Wood, Quart. Journ. Geol. Soc, vol. lvi. p. 415 (1900).

${ }^{3}$ G. Maw in Geol. Mag. for 1881, p. 100 ; and C. Lapworth in Proc. Geol. Assoc. vol. xiii. p. 324 .

the Misses Elles and Slater, Quart. Journ. Geol. Soc. vol. 1xii. p. 195 (1906).

${ }^{3}$ H. Lapworth, Meart. Journ. Geol. Soc. vol. 1vi. p. 67. (1897).

${ }^{6}$ The Misses Elles and Wood, Quart. Journ. Geol. Soc. vol, lii. p. 273

7 Miss G. L. Elles, Quart. Journ. Geol. Soc. vol. Ivi. p. 370.

8 Miss E. M. Wood, Quart. Journ. Geol. Soc. vol. Ivi. p. 415.

9 P. Lake, Quart. Journ. Geol. Soc. vol. li. p. 9.

${ }^{10}$ T. M' 'K. Hughes, Quart. Journ. Geol. Soc. vol. xxxv. p. 694.

11 H. Hicks, Quart. Journ. Geol. Soc. vol. xxxvii p. 482.

12 Miss G. Elles, Quart. Journ. Geol. Soc. vol. lvi. p. 169.

13 A. Strahan, Quart. Journ. Geol. Soc. vol. xxxv. p. 268.

is Messrs. Marr and Nicholson, Quart. Journ. Geol. Soc. vol. xliv. p. 658.

15 Miss G. L. Elles, Quert. Journ. Geol. Soc. vol. liv. p. 463 (1898).

16 Misses Watney and Welch, Quart. Journ. Geol. Soc. vol. Ixvii. p. 215 (1910).

17 C. Lapworth, Quart. Journ. Geol. Soc. vol. xxxiv. p. 240 and vol. xxxviii. p. 587. 
18 "Silurian Rocks of Britain : vol. i. Scotland," Mem. Geol. Survey.

19 See Summaries of Progress (Geol. Survey) for 1897 and 1898.

20 See Carruthers and Muff in Irish Naturalist, Jan. 1909.

21 Geol. Survey, Ireland, Expl. of sheets 160, 161, and 171.

22 Messrs. Reynolds and Gardiner, Quart. Journ. Geol. Soc. vol. Ivii.

p. 267.

23 See Munthe, Geol. Fören. Stockholm Forhand., Bd. xxxii (1900).

24 O. Schmidt, Quart. Journ. Geol. Soc. vol. xxxviii. p. 514.

25 F. Seemann, Beitr. Paläont. Oesterr.-Ung. xx. p. 69 (1907).

26 C. Malaise, Bull. Acad. Roy. Belge (1910).

27 Kerforne in Bull. Soc. Sci, and M Ied. Quest. (Rennes), vol. x. pp. 1-234 (1901). 


\section{CHAPTER VIII}

\section{DEVONIAN AND OLD RED SANDSTONE SYSTEM}

\section{Gexeral Classification axd Subdivisions}

WE have seen in the last clrapter that, where complete sections are found, the Silurian rocks pass upwards into a thick series of red sandstones (England and Scotland), or into an equally thick series of grey and purple grits (Ireland). It will be shown in a future chapter that the marine Carboniferous rocks always rest upon a set of red and yellow sandstones, which often repose unconformably upon some of the more ancient Palæozoic strata. The marine fauna of the Silurian dies out at the base of the red sandstones, and when we reach the next marine fauna-that of the Carboniferons System-it is totally different from the preceding, so that a long period of tine must have elapsed between the close of the Silnrian era and the commencement of the Carboniferous.

The groups known as the Old Red Sandstone in England and Scotland, and the Glengariff grits or Dingle Beds in Ireland, are clearly some of the rocks which were formed in this interval; and if these were the only records of this portion of geological time, we might find it convenient to regard the whole of the beds which succeed the Silurian Series in conformable sequence as belonging to the Silurian System.

But these are not the only strata which are interposed between the Silurian and Carboniferous Systems. In Devonshire, and in many localities in Enrope, there is a thick series of rocks containing a marine fauna which is evidently of intermediate age; furtler, in Germany the stratigraphical proof of their interposition between Silurian and Carboniferous rocks is complete. It is this marine series which must be taken as the normal type of the intermediate system, and any freshwater deposits which can be sliown to be of the same age must be treated as local contemporaneous or homotaxial strata. In America also both types of the Devonian System are present. 
The Devonian System was established by Sedgwick and Murchison in 1839 because they found in Devon a great series of rocks containing a special assemblage of fossils, and they divided this Devonian System into Lower, Middle, and Upper Groups; the convenience of this division has been confirmed by the researches of continental geologists.

Sedgwick and Murchison also took a leading part in the investigation of the European equivalents of these Devonian rocks, visiting the Rhenish mountains and indicating the existence of rocks containing a Devonian fauna in the Eifel district (1842). The more complete delimitation of the Devonian System was accomplished by F. Römer (1844), Von Dechen (1855), and the Sandbergers (1850-56). A little later came the important researches of Gosselet on the rocks of the Ardennes (borders of France and Belgium), where he established the same order of succession.

The Old Red Sandstone, which elsewhere occupies the position of the Devonian System, is believed to be of lacustrine or estuarine origin. It has been divided into a lower and upper series, with a middle series in Wales, but in Scotland there is a marked unconformity between the upper and lower series, and some are doubtful whether the upper series is really of Devonian age. It is probable that the Lower Old Red Sandstone may be correlated with the Lower Devonian, that the Middle Devonian was formed during the time represented by the unconformity in Scotland and Ireland, but how much of the Upper Old Red Sandstone is really of Devonian age will depend very largely on the results of further researches in North Devon and Ireland.

In dealing with the records of the Devonian period we shall describe the marine facies first, both in England and on the continent, and secondly the rocks known as the Old Red Sandstone.

\section{THE DEVONIAN FACIES}

\section{A. The Marine Fauna}

As already mentioned, the Devonian fauna is intermediate in character between those of the Silurian and Carboniferous. Most of the characteristic Silurian genera become extinct in the Lower and Middle Devonian, while in the Middle and the Upper Devonian many genera which are prominent members of the Carboniferous fauna make their appearance. This is especially the case with the Brachiopoda, for all the Lower Devonian genera are found in the Silurian, while all those in the Upper Devonian range in to the Carboniferous.

- The following is a brief account of the principal genera which 
survive from the Silurian period, and of the more inportant genera which make their first appearance in Devonian rocks.

Among Hydrozoa the Stromatoporoids, which had some representatives in Silurian time, become specially abundant, and are characteristic of Devonian limestones. The principal genera are Stromatopora, Stromatoporella, Actinostroma, Parallelopora, Amphipora, and Stachyodes.

Among Actinozoa, Acervularia, Alveolites, Arachnophyllum, Cystiphyllum, Pachypora, Favosites, Heliolites, Cyathophyllum, Plasmopora, and Syringopora continue from the Silurian; and Zaphrentoid corals, which are rare in the Silurian, now become abundant. Calceola, Heliophyllum, and Pleurodictyum occur only in Devonian rocks. Michelinia, Zaphrentis, Mesophyllum, and Phillipsastrea appear and range into the Carboniferous.

Among Echinoderma the crinoids Cyathocrinus, Ichthyocrinus, and Taxocrinus continue. Ctenocrinus, Cupressocrinus, Hexacrinus, Melocrinus, Sphorocrinus, and Rhipidocrinus are specially Devonian genera. Poteriocrinus and Haplocrinus appear and survive. Of Echinoids certain archaic forms occur, such as Lepidocentrus, which has from five to eleven rows of interambulacral plates.

Among Crustacea trilobites are on the decline, though individuals are sometimes common. Representatives of twelve genera have been found in British Devonian rocks, Acidaspis, Bronteus, Cheirurus, Cyphaspis, Lichas, Harpes, Homalonotus, Dalmanites, Phacops, Trimerocephalus, Proetus, and Dechenella. Of these Phacops, Proetus, Bronteus, and Cyphaspis are the commonest. The species of Dalmanites belong to the section or sub-genus Cryphaus. The Ostracods Beyrichia and Entomis are also common.

Of Brachiopoda many of the Silurian genera survive and many new forms make their appearance; of the latter Centronella, Davidsonia, Rensselcria, Megalanteris, Stringocephalus, and Unciles are known in Britain as Devonian fossils only, while Cumarophoria, Productus, Strophalosia, and Terebratula (Dielasma) range into the Carboniferous.

Of Lamellibranchia the following Silurian genera occur, but those with an asterisk die out within the period: Ambonychia, Myalina, Grammysia, ${ }^{*}$ Leptodomus, Ctenodonta, Cardiola, * Cleidophorus, ${ }^{*}$ Conocardium, Cyrtodonta, ${ }^{*}$ Nucula. Pterinea is very abundant, and the sub-genus with elongate wings (Actinodesma) is specially characteristic. The following genera appear and range into higher strata: Aviculopecten, Ptychopteria, Cucullaa, Parallelodon, Pleurophorus, Edmondia, Prothyris, Megalodon, Curtonotus, Myophoria (?), and Solenopsis.

Among Gastropoda the following genera survive from the 
Silurian and have many Devonian species: Murchisonia, Pleurotomaria, Euomphalus, Straparollus, Platyceras, Loxonema, Macrochilina, and Bellerophon. Besides these Cyclonema, Callonema, and Eunema occur, but die out within the period. Scoliostoma and Philoxene are Devonian only; Naticopsis and Porcellia appear and range upward.

Among Cephalopoda the following continue: Orthoceras,
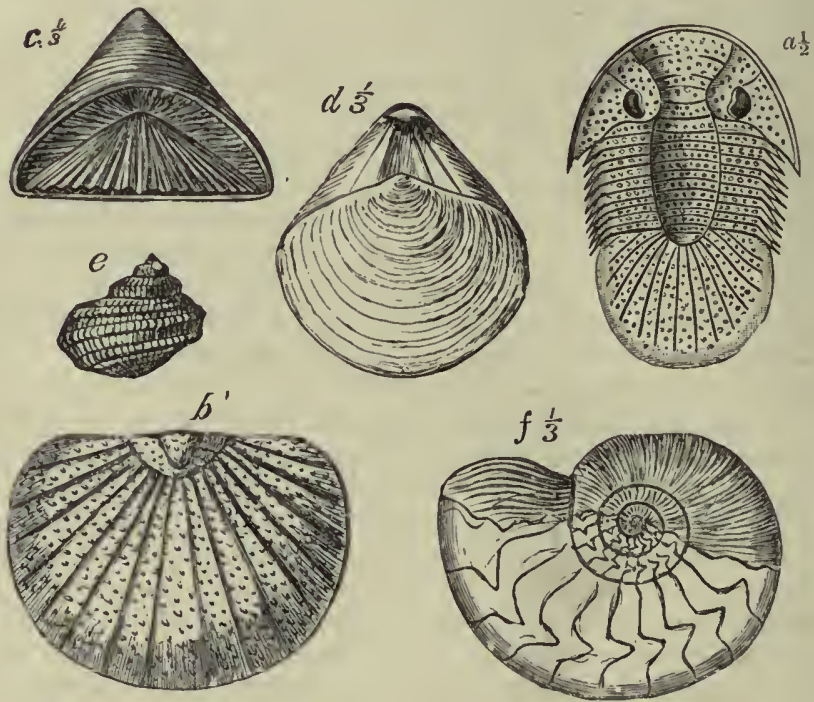

Fig. 61.-GRouP OF DEVONIAN Fossils.

a. Bronteus granulatus.

b. Bront. granulatus (pygidium).

c. Calceola sandalina. d. Stringocephalus Burtini.

e. Pleurotomaria aspera.

f. Clymenia striata.

Cyrtoceras, Gyroceras, Poterioceras, Gomphoceras, and Trochoceras. The last genus becomes extinct. The Ammonoidea make their first appearance and are represented by Clymenia, Bactrites, and the Goniatitidæ, of which the following genera occur: Mimoceras, Anarcestes, Agoniatites, Gephyroceras, Tornoceras, Meneceras, Brancoceras, Beloceras, and Prolecanites. Clymenia is found only in the Upper Devonian.

Of Pisces, Pteraspis, Cephalaspis, Drepanaspis, Coccosteus, Parexus, and Homosteus occur. 

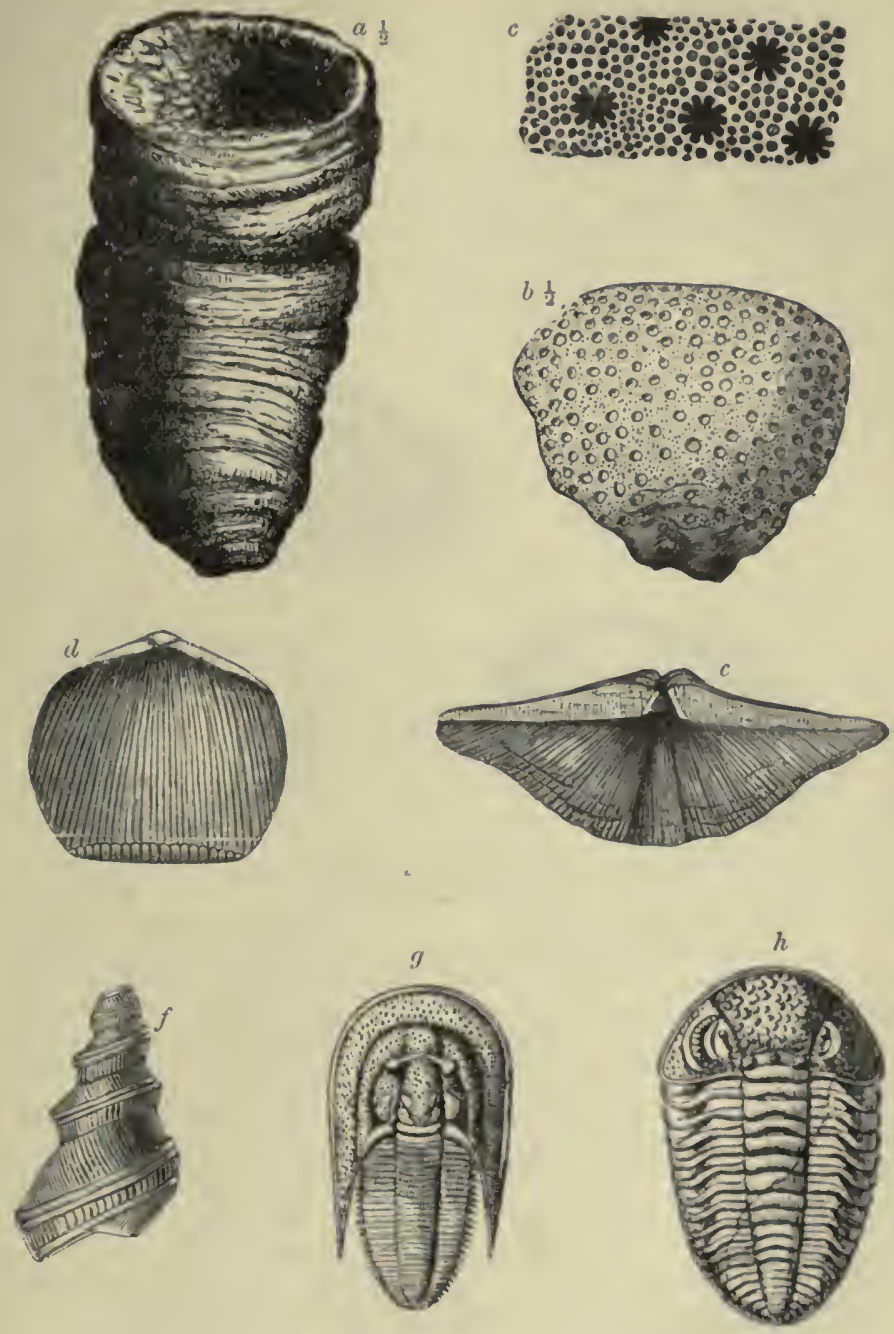

Fig. 62.-OROUP OF DEVONIAN rOBsILS.

a. Cystiphyllum vesicuiosum.

b. Heliolites porosits.

c. H. porosus (magnilled section).

d. Rhynclionella cuboides. c. Spirifer Verneulliii.

f. Murchisonis anguiata.

g. Harpes macrocephalus.

h. Phacops iatifrons. 
The following are some of the most characteristic fossils of each division as found in England, France, and Belgium.

\section{Fossils of the Lower Devonian}

Actinozoa. Pleurodictyum problematicum, Zaphrentis oolitica. Echinoderma. Cyathocrinus megastylus, Ctenocrinus decadactylus. Brachiopoda. Spirifer primævus, S. auriculatus, S. cultrijugatus, S. paradoxus, S. hystericus, Orthis arcuata, Chonetes dilatata, C. sarciuulata, Rensellæria crassicosta, Leptrena laticosta, Rhynchonella daleidensis.
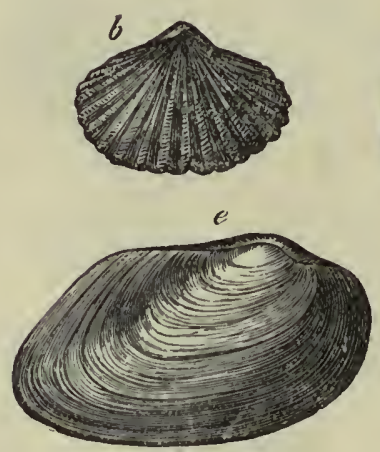

Fig. 63.-GROUP OF UPPER DEVONIAN FOSSILS.

b. Rhynchonella Partridgiæ. c. Ptychopteria damnoniensis.
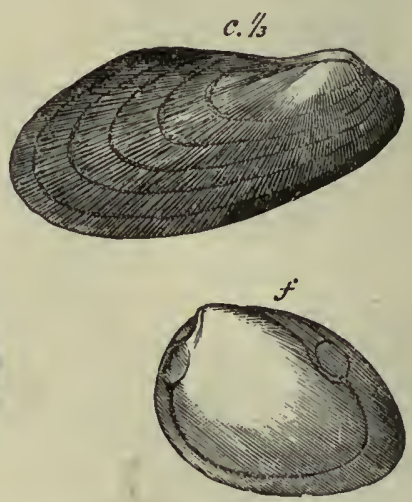

e. Cucullæa unilateralis. f. Curtonotus elegans.

Lamellibranchia. Pteria anisota, Pteria spinosa, Pterinæa costata, Pt. (Kochia) capuliformis, Ctenodonta Krachtæ.

Crustacea.

Gastropoda.

Pisces.

Hydrozoa.

Actinozoa.
Homalonotus armatus, H. Champernowni, H. gigas, Dalmanites laciniatus.

Bellerophon trilobatus, Platyceras fecundus, Macrochilina elongata.

Drepanaspis gemundensis, Coccosteus angustus, Pteraspis.

\section{Fossils of the Middle Devonian}

Stromatopora concentrica, Actinostroma stellulatum, Amphipora ramosa.

Pachypora cristata, Phillipsastræa pengellyi, Mesophyllum damnoniense, Cyathophyllum cæspitosum, C. obtortum, C. hexagonum, Cystiphyllum vesiculosum, Alveolites suborbicularis, Calceola sandalina, Heliolites porosus. 
Echinoderma. Spharocrinus geometricus, Hexacriuus interscapularis,

Crustacea.

Brachiopoda. Cupressocrinus crassus.

Proetus batillus, Bronteus granulatus, B. flabellifer, Phacops Schlotleimi, Cyphaspis ocellata.

Atrypa reticularis, A. desquamata, Stringocephalus Burtini, Pentamerus brevi rostris, Meristella plebeia, Spirifer undatus, S. speciosus, Uncites gryplius, Streptorhyuchus umbraculum, Cyrtina heteroclita.

Lamellibranchia. Megalodon abbreviatus, Conocardium clathratum, Cypricardinia scalaris, Actinopteria placida, Rutotia elliptica.

Gastropoda, etc. Loxonema reticulatum, Macrochilina arculatum, Murchisonia turbinata, M. coronata, M. bilinesta, Pleurotomaria delphinuloides, Philoxene levis, P. serpens, Porcellia bifida.

Cephalopoda.

Agoniatites occultus, Anarcestes subnautilinus, Mimo. ceras gracile, Mrneceras decheni, M. molarium, Trochoceras obliquatum, Orthoceras laterale, Gyroceras nodosum.

Pisces.

Species of Heterosteus, Coccosteus, and Homosteus.

\section{Fossils of the Upper Deronian}

Actinozoa.

Echinoderma.

Crustacea.

Brachiopoda.

Acervularia Goldfussi, A.. pentagona, Chonophyllum perfoliatum, Phillipsastrea Hennahi.

Actinocrinus Porteri.

Phacops granulatus, P. latifrons (also in Mid. Dev.), Entomis serrato-striata.

Spirifera Verueuilli, S. Urei, S. distans, Orthis interlineata, Strophalosia productoides, Rliyuchonella cuboides, R. laticosta, R. letiensis.

Lamellitranchia. Ptychopteria damnoniensis, Cuculløa unilateralis, Ctenodonta (Palæoneilo) lirata, Myophoria deltoida, Prothyris scalprata, Aviculopecten nexilis, Cardiola retrostriata (Cardium palinatum), Posidononya venusta.

Gastropoda. Loxonema anglicum, Pleurotomaria aspera.

Cephalopoda. Gephyroceras intumescens, Tornoceras simplex, Beloceras sagittarium, Clymenia undulata, Clymenia striata, Bactrites gracilis.

\section{B. British Devoxian Rocks}

In Britain the only surface exposures of undoubted marine Devonian rocks occur in Devon, Somerset, and Coruwall; they occupy the northern parts of Devon and Somerset between Morte Bay and the valley of the Tone, as well as the ontlying tract of the Quantock Hills, east of that valley. Dipping southward beneath the central Carboniferous area, they reappear in Sonth Devon and North Cornwall (see map, Fig. 64).

The strike of these rocks is nearly due east and west, and this appears to be naintained in their subterranean extension through the south of England, for rocks with the same Devonian fossils 
have been met with in borings beneath the Cretaceous Beds which underlie London and Essex. They are known to occur in the same position in Belgium, and they emerge again to the surface in the Ardennes, so there is every probability of their being continuous across the intermediate areas.

\section{Devon and Cornwall}

The Devonian rocks in England have been so crushed, plicated, and broken by faults that it is no easy matter to make out the original order of succession either in North or South Devon, and it is almost impossible to estimate their original thickness. It will be noticed that the section, Fig. 66, shows a general incliiiation of the beds towards the north, newer and newer beds coming on in that direction. This is the rule in South Devon and North Cornwall, and yet the prevalent dips actually observed and recorded on the maps of the Geological Survey are toward the south, which would lead one to infer a coniplete inversion of the beds. These dips, however, are those of the minor plications, for not only is the whole system flexured into a succession of curves, but each flexure is frilled into smaller plications.

The following account is compiled from the memoirs of the Geological Survey on the new map of Cornwall and South Devon, and from papers by Mr. W. A. E. Ussher, supplemented by some observations of my own; for North Devon the publications of Jukes, Etheridge, Hicks, and others have been consulted.

The rocks of both the northern and southeru areas are divisible into Lower, Middle, and Upper Series, and in order to deal with each of these series separately we nutst first give a tabular view of the subdivisions which lave been made in each area. In constructing this table a group of rocks occurring in North Devon and known as the Morte slates has been omitted, for reasons which will be mentioned, and because the correlation of the other groups is complete without them. On the map, Fig. 64, these Morte slates are marked as a separate tract of Lower Devonian.

Cornwall and South Devon.
Upper $\left\{\begin{array}{l}\text { Summit not seen. } \\ \text { Styliola and Entomis slates. } \\ \text { Calcareous slates and limestones. }\end{array}\right.$
Middle $\left\{\begin{array}{l}\text { South Devon linestones, with } \\ \text { associated slates and tuffs. }\end{array}\right.$
Lower $\left\{\begin{array}{l}\text { Staddon grits. } \\ \text { Meadfoot Beds. } \\ \text { Dartmouth slates and } \\ \text { Grampound Beds. }\end{array}\right.$

North Devon.

Pilton Beds. Baggy Beds. Pickwell Down Beds. Yllfracombe Beds.

Hangman grits. Lynton Beds. Foreland sandstones. (Base not seen.) 


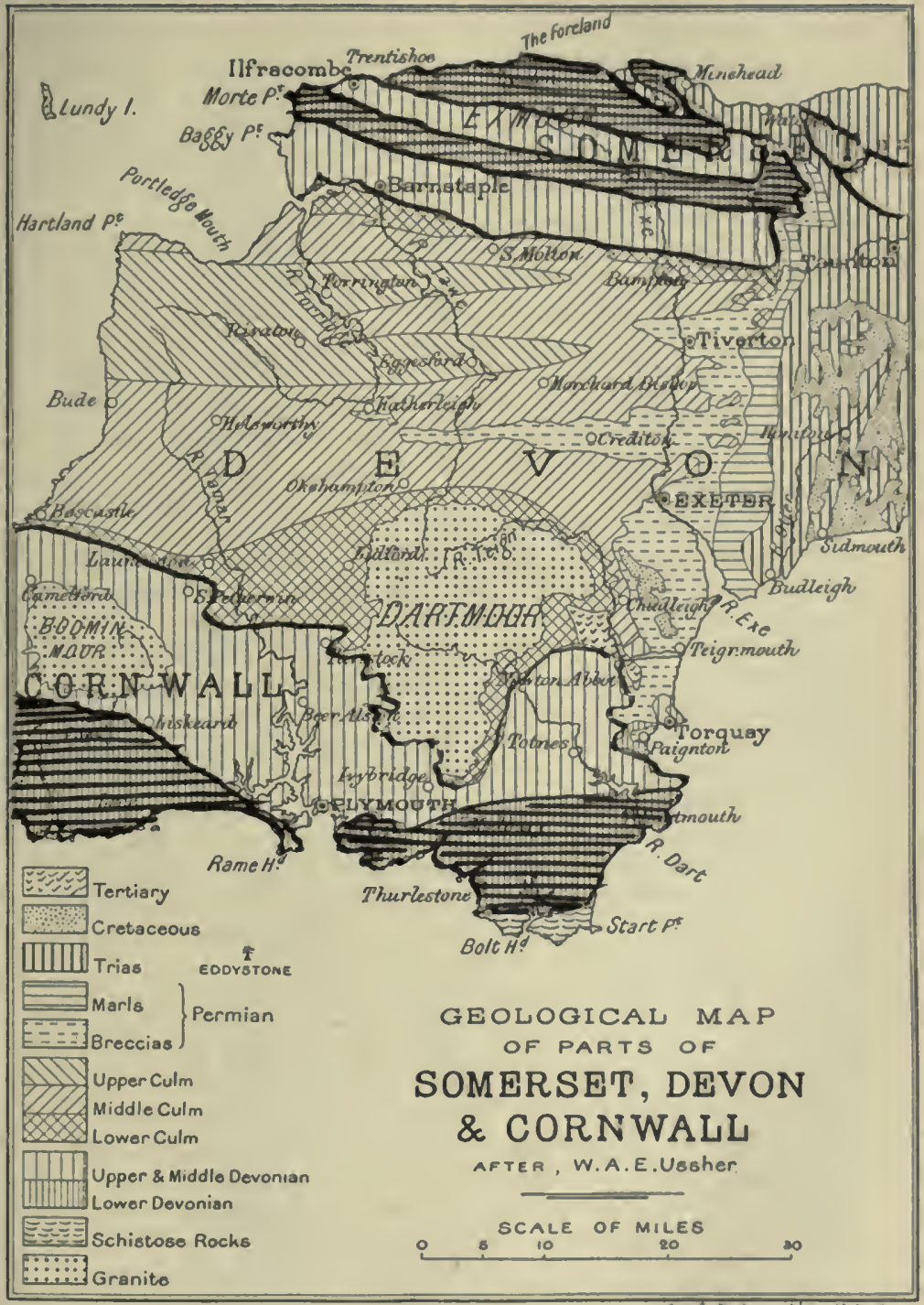

Fig. 64. 
Lower Devonian.-The recent work of the Geological Survey in Cornwall has shown that the basal boundary of the Lower Devonian crosses that county along an east and west line from Porth Towan on the west to near Tregony on the east, whence it bends southward to Veryan and Nare Head (see Index map, 4 miles to 1 inch, sheet 25). From this line northward to St. Evan, Bodmin, and Plymouth, the country is occupied by Lower Devonian grits and slates, interrupted only by the intrusive nass of granite which lies to the north of St. Austell and St. Blazey.

Along the line of boundary above mentioned Devonian grits and conglomerates rest unconformably on rocks which are either of Ordovician or Cambrian age; but these grits do not appear to be the oldest Devonian strata. The surveyors think that the Dartmouth slates are concealed beneath an overlap of the higher beds on to a sloping shore-line, and believe the conglomerates of Grampound, Probus, and Nare Head to be shore deposits belonging to the Meadfoot division of the series. The general structure of North Cornwall is expressed in Fig. 65, which indicates the supposed overlap and the series of monoclinal flexures by which the beds seem to be repeated, but the section must be regarded as merely a diagram of the theoretic structure of the area.

The Dartmouth slates form a thick series of purple, red, and green slates with frequent bands of hard and fine quartzitic grit suclı as are called quartzo-phyllades in France and Belgium. They seem to have a thickness of over 2000 feet, bnt the base has not been seen because it is not brought up in any of the anticlinal flexures. The general position of these beds, according to the view taken by the Geological Survey, is indicated in Fig. 65.

The only definite marine invertebrate yet found in this series is Bellerophon trilobatus, which is stated to be fairly common though badly preserved. Fish remains also occur belonging to the genera Pteraspis, Cephalaspis, and Parexus.

The Meadfoot Group is another set of slates and fine grits, but is distinguished from the Dartmouth slates by the colour of the beds, this being always dark grey. In the Looe district the lowest beds are hard grits and quartzites with bands of grey slate, and it is these beds which are believed to pass southward into the coarse grits of Grampound and Probus. The faults and plications are so numerous that the thickness may be anything from 500 to 1000 feet. The Meadfoot Beds are more fossiliferous than those below, but the specimens are seldom in good preservation. The following are some of those which have been determined:-Pleurodictyum problematicum, Pachypora (? cristata), Spirifer primovus, Sp. hystericus, Orthotetes hipparionye, Stropheodonta gigas, Renselleria 
0
0
5
5
5
2

$z$

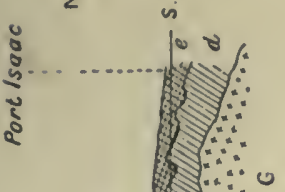

(5)

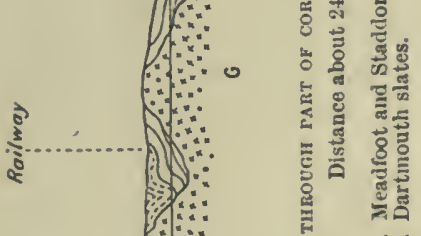

3.0

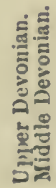

$\stackrel{2}{2}$

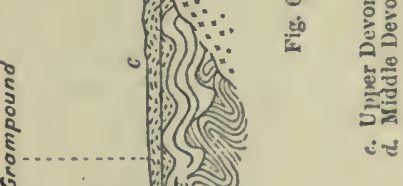

ஸे

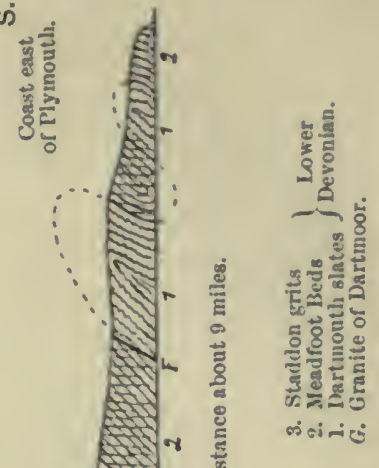

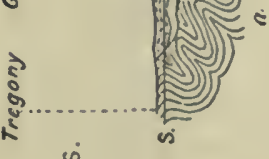
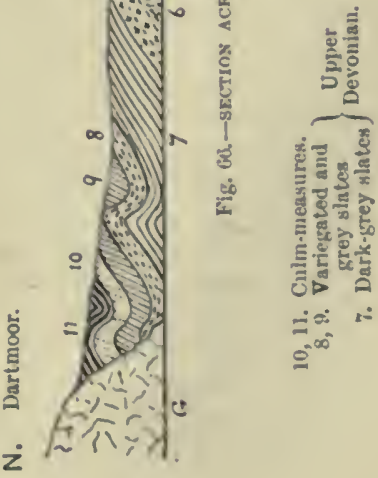
$s p$, and Phacops Ferdinandi. The place whence the beds take their name is Meadfoot Beach, east of Torquay, and near that locality they include bands of fossiliferous brown grit (originally calcareous), from which Homalonotus armatus, Leptona laticosta, Chonetes sarcinulata, Spirifer hystericus, and $S p$. paradoxus have been obtained.

The Staddon grits, which take their name from Staddon Point near Plymouth, are red and purplish-grey grits with intercalations of red shale and mudstone. Their outcrop is nearly continuous from St. Breock Downs to Plymouth, and thence eastward to the coast south of Brixham ; they are brought in again to the northward around Paignton by a local anticline. At Torquay they are exposed on the Warberry and Lincombe Hills which form the centre of a complex and faulted anticline (see Fig. 67), and they have yielded a few fossils, among which are Leptanc laticosta, Bellerophon trilobatus, Streptorhynchus umbraculum, Spirifers, and species of Orthoceras, Cyrtoceras, and Homalonotus.

Passing now to North Devon the first point to be noted is the difference in the lithological character of the lowest beds. The Foreland sandstones occupy the position of the Dartmouth slates, and they contain remains of Pteruspis, but they are hard sandstones or grits, of red, brown, and grey colours, mostly of fine grain, but including some coarse and even pebbly beds. They were clearly deposited much nearer to a shore-line which must have lain in the space now occupied by the Bristol Channel.

The Lynton Beds consist chiefly of hard slates with some beds of grit and occasional calcareous bands, and are supposed to be from 1200 to 1500 feet thick. Fossils are fairly abundant, but in a bad state of preservation. The following have been recorded : Spirifer primovus, Sp. hystericus, S. lovicosta, S. speciosus, Orthis arcuata, Chonetes sordida, and Orthotetes umbraculum. These beds are succeeded by the Hangman grits, which consist of brown, green, yellow, and red sandstones with some coarse red and speckled grits in the upper part. They form the cliffs between Woodabay and Combe Martin Bay, and are probably more than 1500 feet thick. No fossils except a few casts in the highest beds have been found. The Hangman grits correspond in every way with the Staddon grits of South Devon, and the Lynton Beds as clearly represent the Meadfoot Beds.

The Morte slates have already been mentioned, and their position is shown on the map (Fig. 64), and in the section, Fig. 68. Jukes was the first to suspect the existence of a great fault along the southern boundary of the Morte slates, ${ }^{1}$ but he imagined that these slates were of Carboniferous age, and that 

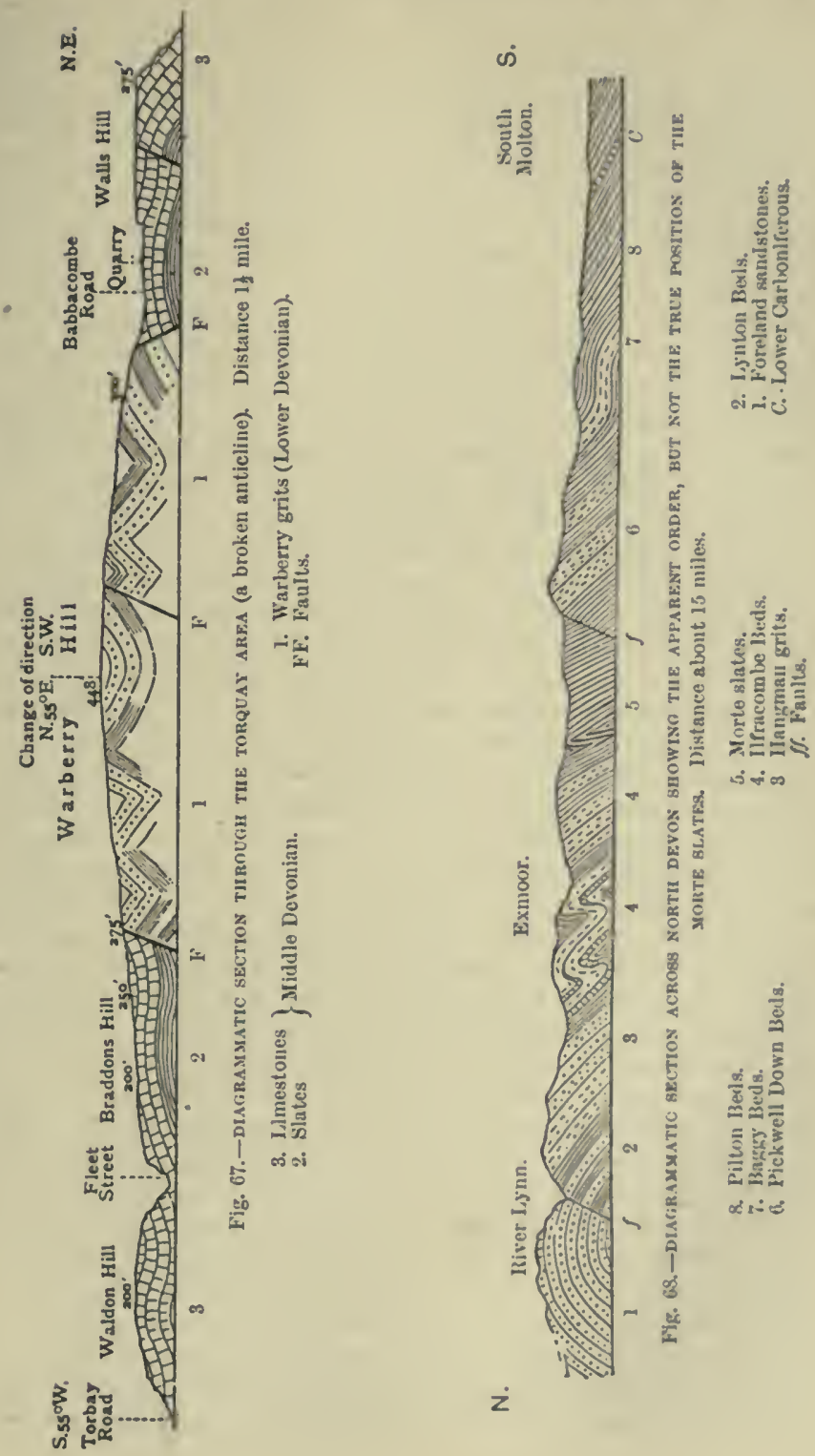
the whole of the North Devon rocks were duplicated by the fault, the Pickwell Down Beds being a repetition of the Foreland Beds, and the succeeding beds on each side of the fault being comparable with one another. This view was combated by Mr. Etheridge, ${ }^{2}$ who found it easy to show that the fossil evidence made it untenable, for the fossils of the Lynton Beds are unquestionably Lower Devonian, while all the fossils found in beds south of the Pickwell Down Group are with equal certainty of Upper Devonian or Carboniferous age.

When Mr. Etheridge wrote, no fossils had been found in the Morte slates, but in 1895 and 1897 Messrs. Hicks and Whidborne ${ }^{3}$ found fossils at several places along their outcrop, and the assemblage appears to indicate the existence of a Lower Devonian fauna. In the papers referred to Dr. Hicks stated his belief that not only is there a fault along the southern boundary of the Morte slates, but one along their northern border, that these slates are in fact thrust up between the two lines of fault, and that they are the oldest rocks in North Devon, but the final conclusion is not generally accepted. It is true that the Morte slates differ from any other slates in North Devon, for they are smooth and glossy, while the Lynton slates are mostly rough and gritty; still it is more probable that they are a facies of the Lynton slates than beds older than the Foreland sandstones.

The fossils referred to were obtained from Morte Bay and Mullacott on the coast, and from Treborough in Somerset. Some of the species are described as new (such as Lingula mortensis); some resemble Silurian forms, such as Orthis rustica; and others are Lower Devonian, e.g. Dalmanites laciniatus, Strophomena teniolata, S. explanata, Chonetes plebeia, and C. sarcinulata.

Middle Devonian.-In South Devon this consists of a series of grey shaly slates in which masses of limestone are lenticularly developed, and in places both are partially replaced by volcanic materials-stratified tuffs and diabase lavas.

The chief interest centres in the limestones, and these are best known from their derelopments at Plymouth, Brixham, Torquay, Totnes, Ipplepen, and Ogwell. The lowest beds, however, are always grey shales, and under the lowest limestone near Torquay these have yielded Calceola sandalina, Spirifer speciosus, Sp. curvatus, Atrypa reticulata, and some other fossils. They evidently correspond with the beds known as Calceola shales in Belgium.

The limestones certainly occur on more than one horizon, and Mr. Ussher has classified them as lower and higher limestones. ${ }^{4}$ The lower set are generally dark grey or nearly black, are well bedded, and consist mainly of crinoid ossicles, beds containing corals 
and Stromatoporoids only occurring at intervals and never being more than 3 or 4 feet thick, while the thickness of such bedded limestone may vary from 100 to 300 feet. Such limestones are typically developed round Dartington and Little Hempstead, near Totnes; they also occur at Ashburton, at Galmpton near Dartmouth, at Torquay, and Babbacombe. 'Theil' most characteristic fossils are: Pachypora reticulata, Favosites fibrosus, Cyathophyllum ccespitosum, Cystiphyllum vesiculosum, Mesophyllum helianthoides, and Alveolites vermicularis.

The higher limestones are of much lighter colour and often make beautiful marbles, being grey or nearly white, pinkish, or grey mottled with red. They are generally massive and unstratified and are frequently largely composed of Stromatoporoids, some masses of which are from 3 to 4 feet across; compound corals occur as scattered and generally broken lumps, the commonest being Pachypora cristata and Heliolites porosus.

These limestones in the Plymouth and Torquay districts pase up into beds which contain a mixture of Middle and Upper Devonian species. These are also massive but shelly limestones, the chief constituents being crinoids, small Stromatoporoids, broken corals and shells. Of corals the commonest are Pachypora cristata, Alveolites suborbicularis, and Phillipsastrea (Smithia) Pengellyi. Of shells there are Stringocephalus Burtini, Rhynchonella cuboides, Pentamerus brevirostris, Spirifer curvatus, Atrypa reticularis, and Cyrtina heteroclita, with, less commonly, the trilobites Bronteus granulatus and Cyphaspis occellata. The fauna of this limestone has been described and figured for the Palxontographical Society by the late G. F. Whidborne. The thickness of massive limestones near Torquay is probably over 200 feet.

In North Devon the Middle Devonian consists of a series of grey slates and flagstones with lenticular layers of earthy limestone. The lower part is sometimes called the Combe Martin Beds, but they are only the lower part of the Ilfracombe Beds and contain a similar fauna; the lower beds are rather more sandy and flaggy, while the higher beds are silvery-grey slates. The whole serie? is intensely plicated, compressed, and cleaved, the observable dips being generally those of isoclinal folds dipping southward so that the actual thickness of the series is nothing like so grest as the breadth of basset-surface would seem to indicate, and may not be more than from 1000 to 2000 feet.

Like all the other divisions of the Devonian in North Devon and Somerset it occupies a continuous band or tract of country, crossing Exmoor and the Brendon Hills from west to east. It crops out again in the Quantock Hills, and presumably it and the 
Lower Devonian had some extension to the northward, but both are absent above the Silurian outcrop in the Mendip Hills, which are only 17 miles north-east of the Quantocks.

Upper Devonian.-In South Devon at certain places, as for instance Plymouth, West Ogwell, and Chudleigh, the massive limestones pass up into red or pink limestone containing Acervularia Goldfussi, A. pentagona, and Chonophyllum with sometimes Rhynchonella cuboides and Spirifer bifidus. In other places a massive grey unfossiliferous limestone is succeeded by red shales with layers of nodular limestone containing the characteristic Goniatites (see p. 199) with Cardiola retrostriata and Phacops cryptophthalmus. These beds are succeeded by red and green shales in which the small Crustacean Entomis serrato-striata is often abundant, with occasionally the small bivalve Posidonomya venusta.

West of Dartmoor, in North Cornwall, these higher beds have a much greater development, occupying a broad tract of country extending from between Padstow and Boscastle on the coast round the north side of Bodmin Moor to the borders of Dartmoor between Tavistock and Bickleigh. They consist of grey, green, red, and purple shales in which impressions of the Pteropod Styliola are often abundant as also is the Entomis. Other fossils only occur locally, but quarries near South Petherwin have yielded a large fauna, the following being some of the species:-Clymenia lovigata, C. striata, Orthoceras Phillipsi, Tornoceras lineare, Ctenodonta antiqua, Cardiola retrostriata, Spirifer Verneuilli, Orthis interlineata, Strophalosia subaculeata, and Phacops granulatus.

In the cliffs on the west coast it has been possible to make out something like a regular succession in spite of faults and plications. The data on which this is based are given in the Survey memoir on the country round Padstow, but the following table is not a copy of that given in the memoir, as I have omitted the flaggy slates of Camel Quarry, which may be of Middle Devonian age and have separated the lower part of the "Striped Slates." The descending succession then reads thus:-

5. Purple, green, and variegated slates.

4. Dark slate and pillow lava.

3. Soft black slates with limestone bands (many fossils).

2. Grey slates and thin limestones and a fossiliferous band yielding many Cephalopoda.

1. Grey shales with scattered phosphate nodules, thin layers of limestone and of black grit.

The phosphatic nodules in the lowest beds contain Conularia complanata; the limestone of Dinas Head (in No. 2) contains black cherts with Radiolarian remains; while the overlying black slates 
are full of Tentaculites, Styliolu, and Buchiola retrostriata, and certain beds have yielded species of Orthoceras, Bactrites, Tornoceras, Mimoceras, Anarcestes, and Agoniatites with remains of Phacops latifrons, $P$. granulatus, aud $P$. levis.

The variegated slates contain Entomis serrato-striata and Posidonomya venusta, and they occupy a syncline which forins an oval area around St. Minver and St. Kew.

Nothing which exactly corresponds to the Petherwyu fauna has been found on or near the coast, and it is thought that its stratigraphical position is above that of No. 5 ; its absence in the west being due either to an overlap of the basal Carboniferous Beds or to faulting.

In North Devon, on the other hand, there appears to be a complete succession, and the difficulty is to determine where the line of division between the two systems should be drawn.

The series has been divided into three stages, the lowest being the Pickwell Down Beds, a set of red, purple, brown, and green sandstones with intercalated bands of shale. They are traceable from Pickwell Dowu near Morte Bay to Wiveliscombe in Somerset, but the only fossils yet found are fish remains and fossil wood.

The Baggy Beds cousist of green shales and yellowish sandstoues and flags, and extend inland from Baggy Point, north of Croyde Bay, by Marwood and Sloly, where are quarries from which many fossils have been obtained, including Ptychopteria damnoniensis, Cucullea unilateralis, Rhynchonella laticosta, Spirifer Verneuilli, Strophalosia productoides, Chonetes hardrensis, and plant remains (Stigmaria and Knorria).

The Pilton Beds consist of bluish-grey slates with thin bands of limestone and of sandstone. They stretch from Croyde Bay inland by Braunton and Pilton and are highly fossiliferous, containing among others Phacops latifrons, Productus prolongus, Spirifer Verneuilli, S. Urei, Orthis interlineata, Strophalosia productoides, Aviculopecten nexilis, Loxonema anglicum, and other Gastropoda. They appear to pass upward into the Lower Carboniferous shales, and the divisional line has not yet been fixed; but this point will be discussed on a later page.

\section{The South of Ireland}

The Devonian rocks of Southern Ireland have generally been treated under the head of Old Red Sandstone, but the more complete knowledge which we now possess of their equivalents in Devon, Comwall, and Brittany makes it probable that they are 
almost entirely of marine origin, and are really comparable with the Devonian Series of these more southern areas.

The upward passage from Silurian to Devonian is exhibited in the coast section of the Dingle promontory in Kerry, where the beds with Ludlow fossils are conformably overlain by grey, brown, and purple slates without fossils, followed by alternations of grey grits and slates, the grits at length predominating and forming a thick series of hard, massive green and purple grits. ${ }^{5}$ The whole of this Gritstone Series is perliaps 8000 feet thick, and is succeeded by slates of red and purple tints, with beds of conglomerate at Parkmore, which curiously enough enclose pebbles containing Silurian fossils. No other fossils have yet been found, and except for the occurrence of these derived pebbles, the whole of these slates and grits might be taken for a continuation of the Silurian rocks, so similar are they to the underlying fossiliferous series.

A similar set of green and purple grits occupies large areas to the south and south-west of Dingle Bay in the Inveragh and Dunkerron promontories, and in the districts of Killarney, Kenmare, and Glengarriff. It has generally been assumed that these "Glengarriff Beds" are the equivalents of the Dingle Beds, but Jukes was doubtful on the point, and Mr. M'Henry is of opinion that the latter are entirely below the Glengarriff Beds. It is possible, lowever, that the actual base of the latter does occur in the Dingle promontory.

The great series known as the Glengarriff Grits consists of several thousand feet of alternating bands of fine-grained grit and slate. The lower part is mainly composed of green grits with subordinate beds of slate; while in the higher part purplish-red slates predominate over the grits. No minor subdivisions have yet been made, and no fossils have been found in them. The thickness of the whole series has been roughly estimated at 8000 feet, but when allowance is made for folds and faults it may prove to be much less than this figure. ${ }^{6}$

The beds have been subjected to such pressures that the shales are cleaved into slates, and the grits rendered nearly as hard as quartzites. They have also been thrown into a succession of regular anticlinal and synclinal folds which range east and west from the west coast of Kerry to the eastern part of Cork. The hard grits of the lower series, though exposed in anticlines, form long ranges of mountains because of their capacity for resisting subaerial erosion, while deep longitudinal valleys have been excavated through the purple slates and the still softer black slates which overlie them and come into the synclines (see map, Fig. 94, and section, Fig. 72). 
In Kerry and the west of Cork there seems to be a complete upward sequence from the greenish grits throngh the purple slates to a series of grey and brown grits with intercalations of dark-grey slate, which group is known as the Coomhola Beds. These contain a marine fauna which is similar to that of the Baggy and Marwood Beds of North Devon, and they are succeedel by a set of dark-grey and black slates which resemble the Pilton Beds, but their fossils have not yet been collected with suflicient care to separate the Devonian and Carboniferous portions of the series. Fig. 69 is a copy of the section drawn by Jukes to illnstrnte the relative position of the beds near Glengarriff Harbour at the head of Bantry Bay.

Jnkes could find no evidence of unconformity; but Professor Hull, going over the district in 1878-80, thought he could detect

s.

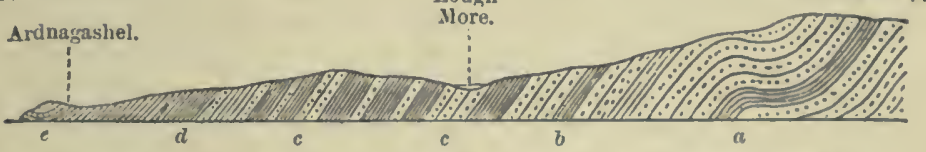

Fig. 69.-Section vear Glesearriff (Jukes). Distance about $2 \frac{f}{y}$ miles.

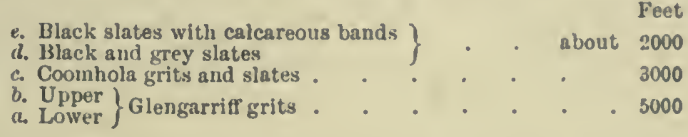

an unconformity between the Coomhola Beds and the Glengarrift Series at Sneem near Kenmare. ${ }^{7}$ His section, however, is by no means convincing.

In the more recent revision of the country round Cork the Geological Surveyors ${ }^{8}$ have failed to find any evidence of a break between the two series, the Upper Glengarriff Beds in that district being succeeded by yellow sandstones and green shales which occupy the place of the Coomhola Beds, and are overlain by shales with Carboniferous fossils. It is true that these yellow sandstones are not the Coomhola Beds and do not contain marine fossils, but only fish and plants of Upper Devonian species. They are in fact the Kiltorcan Beds or Upper Old Red Sandstone of Kilkenny.

From the above account the student will understand that there are still several points to be cleared up in the geologry of the soutli-west of Ireland, and in particular the exact relation between the Coomhola and the Kiltorcan Beds remains to be ascertained. If, however, we consider the sequence found in West Cork and Kerry by itself, we may regard it as a succession of presumably 
marine Devonian rocks, including representatives of the Middle and Upper Devonian, while the lower series is either absent or still awaits recognition.

The correlation of the two areas may possibly be as follows :-

Ireland.

Lower Carboniferous slates.

Coomhola Beds.

Purple slates and grits.

Lower Glengarriff grits.
Devon and Cornwall.

Lower Pilton Beds.

Baggy Beds.

Pickwell Down Beds. r Middle Devonian.

LLower Devonian.

Finally the northern extension of this Devonian Series into Central Ireland must be briefly noticed. The Glengarriff Beds appear at intervals in Limerick, South Tipperary, and Kilkenny, comprising a purple slaty series like the Upper Glengarriff Beds, passing up into a yellow sandstone and shale series like that of Cork. In the Ballyhoura, Galty, and Knockmealdon Mountains these beds rest unconformably on the Silurian, and hence it is probable that the whole Glengarriff Series is similarly unconformable to the older formations, which constitute what may be called the "Caledonian" land. The position of this land is shown by the rapid thinning out of the Glengarriff Series, and the overlap of the uppermost division on to the Silurian in Clare and the north of Tipperary. A similar overlap takes place to the north-east in Carlow, where the Kiltorcan Beds overlap the lower beds on to the granite, and to the eastward in Waterford, where they lie directly on the Ordovician.

Of the Kiltorcan Beds it need only be said that they thicken to the north and east, developing a thick mass of conglomerate at their base which has evidently been derived from the erosion of a land lying in those directions. In Waterford and Kilkenny this is overlain by reddish-brown sandstones succeeded by grey sandstones and red shales, above which are yellow sandstones and olive-green shales. These last are fossiliferous, containing the scales of Coccosteus and Glyptolepis, the bivalve Archanodon Jukesi, which was supposed to be a freshwater inollusc but has since been found in association with marine Carboniferous Mollusca; there are also the remains of ferns, Palcopteris hibernica, Sphenopteris Hookeri, Knorria, and other plants. ${ }^{9}$

\section{Devonian of the Continent}

\section{France}

Marine sediments of Devonian age are found both in the north and south of France, but are most fully developed in the north- 
west, Brittany, Normandy, and Anjou, and in the north-east in the region of the Arlenues. It will be convenient to begin with Britany, which is the nearest to our own Devonian area. The western facies of the system is found in the basin of Finisterre, which extends from the Rade de Brest to Ianfains and Uzel north of Loudeac. For our knowledge of this area we are chiefly indebted to the labours of Professor C. Barrois, who has described the succession as consisting of three natural lithological divisions corresponding with differing bathyınetrical conditions of deposition, i.e. shallow, deeper, and deep. ${ }^{10}$ The lowest and larger part is arenaceous with a thickness of about 3000 feet; the middle part consists of gritty slates and mundstones, with lenticular beds of limestone, and is about 1500 feet thick; the highest part consists entirely of fine shales with thin beds of nodular limestone, and is about 300 fect thick. The last has evidently been formed in much deeper water, for in this small thickness is comprised the whole of the Upper and part of the Middle Devouian.

Palæontologically, however, as many as seven subdivisions can be distinguished in the following descending order :-

7. Shales of Rostellec. Black shales with nodular layers, Torno. - ceras simplex, Bactrites, Entomis, Posidonomya venusta, and 6. Shales of Traouliors. Green and brown, with Rhynchonella cuboides, Rh. pugnus, Pcntanerus globus, and Productus sub. aculeatres.

S Slates of Porsguen. Groenish brown, with layers of calcareous

4. Greywacke of Fret. Gritty calcareous slates with Phacops Potieri, Spirifer paradoxus, and Sp. auriculatus.

3. Greywacke of Faou. Grits and slates witls Spirifer hystericus and Chonetes sarcinulata, and limestone with Athyris undata.

2. Sandstone of Galard, white, with Orthis Monnieri and Syirifer \$. Pellicoi about 300 feet thick.

\{. Plongastel Beds. Alternating beds of hard dark-green quartz9. 1. Plic grit, and rough greenish slates. Fossils rare, Bellerophon trilobatus, Orthoceras planiseptatum, Pteria lazvis, Spirifer ocfoplicatus.

In this succession the Plougastel Beds appear to correspond with our Dartmouth slates and Glengarriff grits; the Galiard and Faou Beds correspond to our Meadfoot Beds and Staddon grits. The Middle Devonian Series is about 800 feet thick, but is very different from that of Sonth Devon, both it and the Upper Devonian having a greater resemblance to the beds in Cornwall.

In the eastem basins of Laval and Angers another Devouian facies is found. Conbining the work of M. Ehlert and the 
correlations made by Professor Barrois the succession may be stated as follows :- 11

Upper $\left\{\begin{array}{l}\text { 7. Shales with Entomis and Posidonomya renusta. } \\ 6 . \text { Limestone of Fresnaic with Bactrites and Tentacula }\end{array}\right.$

Middle 5. Calcareous shales of Pont Maillet.

$\left\{\begin{array}{l}\text { 4. Gritty slates with Spirifer hystericus and Dalmanites } \\ \text { laciniatus. }\end{array}\right.$

Lower $\{$ 3. Limestones with Athyris undata.

2. Sandstone with Orthis Monnieri.

1. Quartzites and slates (Plougastel Beds).

Of these groups only $\mathbf{1}$ to $\mathbf{3}$ are found in the Laval Basin, and the lowest is much thinner than in the west. In the basin of Angers the Plougastel Beds are absent and the series begins with the equivalent of the Gahard sandstone ; the succeeding beds being all liniestones or calcareous shales, and evidently deposited much farthel from land than those of Western Brittany.

In the basin of Ancenis, still farther south, this change from an arenaceous to a calcareous facies seems still more marked, for the lowest beds there are limestones and shales of Middle Devonian age, but it is rather uncertain whether the absence of Lower Devonian is due to non-deposition or to faulting. There can be no doubt, however, that in passing from west to east we pass away from the land-area which supplied the arenaceous material, and this applies both to England and Brittany.

In Normandy only the Lower Devonian cones into the synclines, so that the facies of the Middle and Upper Devonian is unknown. The thickness is not great, for as in the south the Plougastel Beds are absent, and the lowest beds are hard sandstones with Orthis Monnieri, which represent the Grès de Gahard and rest unconformably on Silurian or Ordovician. Othér fossils are rare. The sandstone is succeeded by slates with lenticular beds of limestone which contain Athyris undata, Homalonotus Gervillei, Phacops Potieri, Spirifer Rousseaui, and are clearly the equivalents of the greywacke of Faou and of the Athyris undata limestones of Anjou. The highest beds to be seen are brown mudstones with Pleurodictyum.

\section{Spain}

Devonian strata have been recognised in many parts of Spain, making it probable that nearly the whole of that country was covered by the Devonian Sea. Moreover, although the facies is to a large extent calcareous the fauna is similar to that of Northern France. As an example of the Spanish succession I select that of Asturia, which was described in detail by Professor C. Barrois in $1882 ;{ }^{12}$ this is as follows:- 
Upper, (Red and grey marbles with Goniatiles.

1000 feet Unfossiliterous sandstones (500 feet).

(Limestono of Candas with Spirifer Verneuilli.

Middle, $\left\{\begin{array}{l}\text { Sandstones with Gosseletia deronica (150 foet). } \\ \text { Limestones of Moniello with Calceola sandalina and Cysti- }\end{array}\right.$

1000 feet $\{$ phyllum vesiculosum.

Limestones of Arnao with Spirifer cultrijugalus.

Lower, $\begin{gathered}\text { about } \\ 1800 \text { feet }\end{gathered}\left\{\begin{array}{c}\text { Limestones of Ferrones with Spirifer paradoxus, Rhymchonella } \\ \text { Orbignyana, and many eorals. } \\ \text { Thynch. pila, and Homalonolus. } \\ \text { Furada grits, red and green grits with green and purpleslates } \\ \text { over } 600 \text { feet thiek. }\end{array}\right.$

The lowest beds are conparable with the Plougastel grits and slates, and the overlying limestones are calcareous equivalents of the Gahard and Faou sandstones. The limestones of the Middle Devoninn correspond with the beds which are known as Eifelien in the Ardenues, and it is curious to find the upper part of the series, which is usually calcareous, here represented by sandstones. In the Upper Devonian again there is a still thicker band of sandstones, proving that the deposition of limestone was temporarily interrupted by the invasion of a sand-bearing current, and that continental land was still not far away.

\section{The Ardennes}

In the Ardennes Devonian rocks occupy the greater part of an area lying partly in France and partly in Belgium, which is over 100 miles in length from west to east, and has a maximum width of about 50 miles (see map, Fig. 70). The area really consists of two basins, one broad and regular (basin of Dinant), the other deep, narrow, and isoclinal (basin of Namur), which are brought into apposition by a reverse fault (see Fig. 71). The throw or displacement of this fault amounts to many thousand feet, and the strata of the $t$ wo basins must originally have been separated by an interval of several miles. That this was so is proved by the fact that while the southern basin, that of Dinant, contains a very thick representative of the whole Lower Devonian Series (average about 8000 feet), this is entirely absent in the basin of Namu-.18

Lower Devonian.-On the south side of the basin of Dinant the Lower Series has a total thickness of about 10,000 feet. At the base, resting unconformably on Cambrian, is a conglomerate overlain by coarse felspathic sandstone or arkose; this is succeeded by a series of hand grits and slates, generally of green or red tints, but containing very few fossils. A fossiliferous baud at Montrepuits 
has yielded Homalonotus Rameri, Spirifer Mercurii, Pterinaa ovalis, and Tentaculites; elsewhere remains of Pteraspis have been found. This group of beds, of 'which the slates of St. Hubert are the highest member, are known as the Gedinnian.

The higher stage of the Lower Devonian is called the Coblentzian ; this has 1500 feet of white sandstone (Grès d'Anor) at its base, followed by the greywacke of Montigny, the black sandstone of Vireux, the red slates of Vireux, and the Burnot conglomerate, the

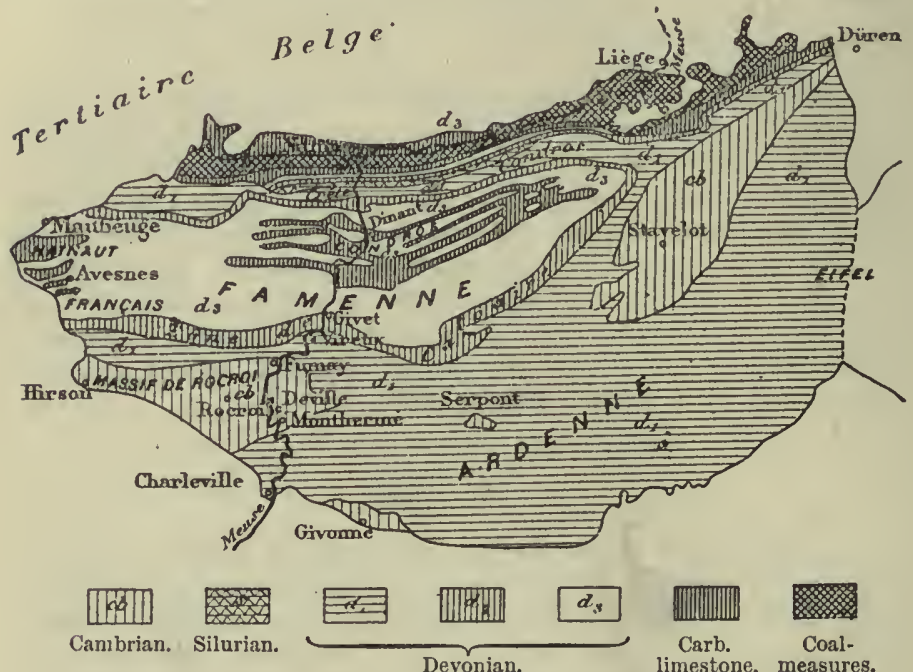

Fig. 70. - MAP OF the ARDENwes (drawn and lent by Professor J. Gosselet). Scale about 35 miles to an inch.

whole being from 5000 to 6000 feet thick. The Anor sandstone has a special fauna, including Spirifer primcevus, Rensselleria crassicosta, R. strigiceps, Avicula lamellosa, and Kochia capuliformis, and appears to represent a series of beds which are more fully developed near Coblentz, and are known as the Taunus quartzite. The grits and mudstones above this white sandstone are characterised by Spirifer paradoxus, S. primavus, Rhynch. daleidensis, and Athyris undata, while the higher beds contain Spirifer paradoxus, Chonetes sarcinulata, Sp. hystericus, and Leptcena Murchisoni.

The whole series becomes thinner toward the north, and along the northern side of the basin it is represented only by the variegated slates of St. Hubert and the Coblentzian Beds in a 
mather diflerent facies, the combined thickness being still, however, about 5000 feet.

Middle Devonian.-This also comprises two divisions, the Eifelian and the Givetian. In the former are now placed the Hierges Beds, flagstones and shales, which are subdivided into a lower zone of Spirifer arduennensis and an upper zone of Sp. cultrijugatus. In the basin of Dinant they are some 500 feet thick, and in the basin of Namur they are the lowest beds (with a basal conglomerate).

The next group is that of the Calceola shales; these are calcareous shales including lenticular beds of limestone which sometimes, as at Nismes and Couvin, swell out to a thickness of

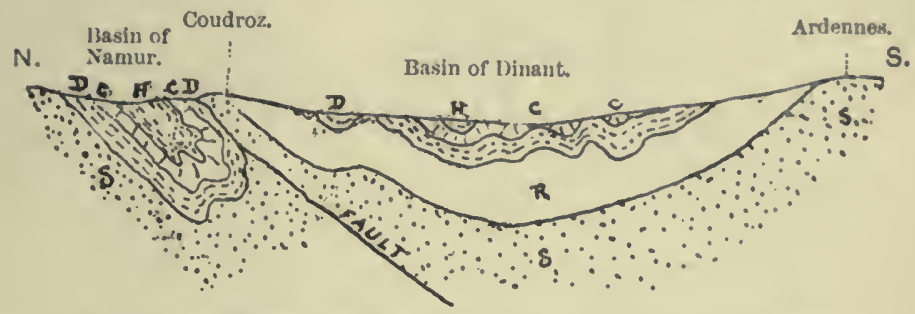

Fig. i1.-SECTION THROVGI THE RASINS OF NAMI'R AND DINANT (Gosselet).

H. Coal-measures.

C. Dinantian.
D. Upper and Middle Devonian. h. Lower Devonian.

S. Cambrian and Orlovician.

300 to 500 feet, hence the group varies greatly in thickuess, but has probably an average of 1000 feet. Its most characteristic fossils are the little coral Calceola sandalina with Cystiphyllum vesiculosum, Mesophyllum helianthoides, Spirifer speciosus, Meristella plebeia, Phacops Schlotheimi, and Bronteus flabellifer.

'The Givétian, in its typical locality near Givet, is a mass of darkgrey limestone, over 1200 feet thick, and is specially cliaracterised by certain Brachiopods, viz. Stringocephalus Burtini, Uncites gryphus, and Spirifer mediotextus, the bivalve Megulodon cucullatus, and the Cephalopods Anarcestes cancellatus, Agoniatites inconstans, and Orthoceras dolatum. The so-called coral reefs of the Givetian are merely thick lenticular masses of unstratified limestone formed by colonies of Stromatoporoids with Favosites, Alveolites, and other corals, such masses being generally surrounded by bedded crinoidal limestones or by calcareous shale aud limestone.

Upper Devonian.-This is also divisible into two stages, the Frasnian and the Famennian. The former consists of shales and 

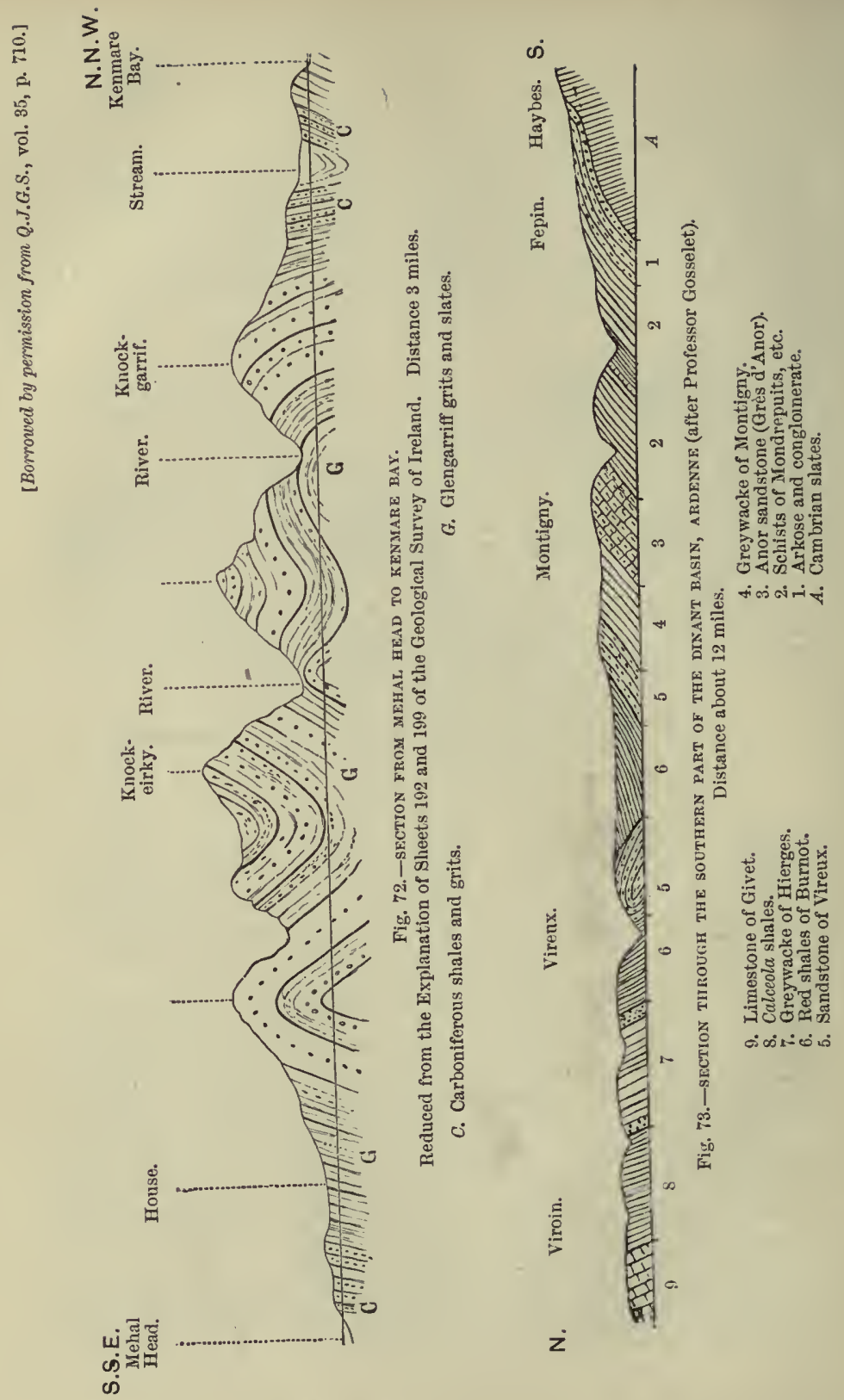
lenticular linestones, is about 900 feet thick near Givet, and is divisible into several zones, as follow :-

Shales of Matagne or zone of Buchiola retrostriata.

Shales and limestones with many fossils.

Zone of Camarophoria and Rhynchonella pugnus.

Zone of Spirifer orbelianus.

In the northern part of the basin, near Frasne, the whole stage consists of limestone which is supposed to be 1600 feet thick. The species Rhynchonella cuboides, l'entamerus brevirostris, Gephyroceras intumescens, and Geph. complanatum range throughout.

The higher stage, Famennian, exhibits two distinct facies, the southern argillaceous and the nortliem arenaceous. The former has been divided into four zones, as follow:-

Etrreungt limestone with Spirifer distans.

Shales with lihynch. ietiensis.

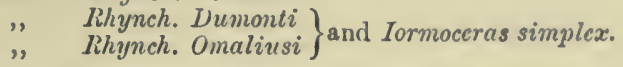

Along the northern border it consists of sliales and sandstones which have been divided as follows by Professor Gosselet:-

5. Shale and limestone (thin and possibly Carboniferous).

4. Sandstones of Dumont, soft brown and micaceous.

3. Calcareous shales of Choisies.

2. Flagstones of Cerfontaine.

1. Green shales of Colleret.

The upper sandstones contain Cucullce Hardingi, C. trapezium, and Palcopteris hibernica. They resemble the Marwood Beds of North Devon.

\section{Germany}

The typical development of the Devonian in Germany is that of the Rhine valley and the neighbouring hill districts of the Eifel, the Hunsruch, and the Taunus. The region is actually connected with the Ardennes, and the succession is very similar, as will be seen from the following tabular description:-

- Nodular limestone and shale with Clymenias.

Shales with Entomis and Posidonomya venustr.

Calcareous shales of Budesheim with Gephyroceras intumescens.

Limestone with Rhynch. cuboides and Camarophoria formosa.

$\stackrel{.}{.} \int$ Giv. $\left\{\begin{array}{l}\text { Limestone with Stringocephlalus (1200 feet). } \\ \text { Crinoid linestones (30 feet). }\end{array}\right.$

$\left\{\begin{array}{l}\text { (Crinoid limestones (30 feet). } \\ \text { Eif. }\left\{\begin{array}{l}\text { Marly limestone witl Calceola, Spirifer speciosus, Phacops } \\ \text { Schlotheimi, etc. }\end{array}\right.\end{array}\right.$

Shaly linestone with Spirifer eultrijugatus. 
Coblentzian in three subdivisions-
c. Slates with Spirifer paradoxus and Phacops laciniatus.
b. Quartzites with Spirifer auriculatus.
a. Greywacke with Homalonotus ornatus, etc.
Hundruch Slates with Phacops Ferdinandi, Homalonotus planus,
Dalmanites rhenanus, and Spirifer primcevus.
Taunus quartzite with Spirifer primavus, Iensellaria crassicosta,
and Homalonotus Rcemeri.
Variegated sandstones and slates with arkose and conglomerate at
the base.

In the Kellerwald district east of the Rhine and north of the Lahn the Middle Devonian consists mainly of shales with occasional bands of limestone, and this series has been subdivided by means of the Goniatites into the following zones:-

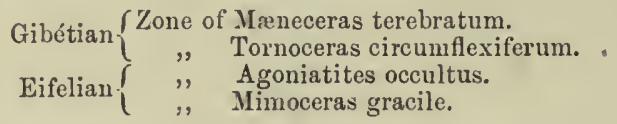

The Harz Mountains also largely consist of Devonian rocks, but these have been the subject of much controversy, and it is only within the last fifteen years that the difficulties have been partially explained. The mountains form a range to the south of Brunswick between Gottingen and Halle, the central part or Brocken being a mass of intrusive granite rising to a height of 3700 feet. The Palæozoic area has a length of about 56 miles and a maximum breadth of 20 , the western part being known as the Upper Harz and the eastern as the Lower Harz. Recent researches have shown that the whole area is much more plicated and dislocated than had been supposed, ${ }^{14}$ and that the supposed mixture of Silurian and Devonian faunas can to some extent be explained by these dislocations, for there is really a basal mass of Silurian age (see p. 185). The extent of this and the plane of division between it and the Devonian rocks have not yet been determined. The facts are these -below the Coblentzian quartzites there is a great thickuess of slates and greywackes (the so-called Hercynian Series), and these contain few fossils except plant remains; but here and there are patches of limestone, and some of these are Devonian and consequently of Gedinnian age. Thus the limestones of Scheerentheg and Klosterholz containing Spirifer hercynicus, Sp. Decheni, and Rhynch. princeps and that of Herzgerode containing the peculiar Gastropod Hercynella (allied to recent Siphonaria) are referable to the Devonian.

The Coblentzian is represented by a set of quartzites without fossils which pass up into fossiliferous sandstones containing many 
species of Spirifer (S. macropterus, S. cultrijugatus, etc.) with Chonetes sarcinulata, Homalonotus gigus, and Ctenocrinus.

'Tle Middle Devonian of the Upper Harz is largely argillaceous, consisting in the lower part of interbedded sliales and argillaceous linestones with Calceola sandalinu and other fossils. Above these are sheets of diabase and a thin band of Stringoceplialus limestone sncceeded by the Goslar shales which, however, seem to be partly of Upper Devonian age. In the Lower Harz the Givétian is better represented by the limestone of Ellingerode with its associated beds of ironstone and volcanic tuff; this limestone has yielded the Goniatites Mreneceras terebratum and Tomocerus cinctum.

The Upper Devonian as developed in the Western Harz com. prises the following beds:-
"Cyrpidina shales" with Eittomis serrato-striata.
Green limestone with Clymenias and Phacoys Ireris.
Black limestone of Altenau with Goniatites retrorsus.
Shales with thin layers of black chert.

Near Clansthal, however, two hills called the Iberg and the Winterberg are of nuch interest, for they are parts of an isolated mass of Upper Devonian limestone, rising throngly the surrounding Carboniferons shales and greywackes, which are folded and crumpled round its sides. This Iberg limestone is believed to be 1300 feet thick, and has more resemblance to a coral reef than any such limestone mass in England or France. It is a massive limestone composed mainly of the remains of corals and shells, including several species of Acervularia, the Brachiopols Rhynch. cuboides, $h$. pugnus, Orthis striatula, and Spirifer bifidus, and the Cephalopods Gephyroceras intumescens and G. Wurmii, with many species of Gastropoda.

Devonian rocks crop ont again to the sonth in Thuringia, but are much broken and flexured, so that there is no continuous succession.

\section{Bohemia}

The Silurian Series recorded on p. 184 is succeeded by limestones which must be referred to the Devonian System, in spite of their containing a mixture of Silnrian and Devonian fossils which caused them to be regarded for many years as a part of the Silurian. These beds form the stages $\mathrm{F}_{2}, \mathrm{G}$, and $\mathrm{H}$ of Barrande (see Fig. 45, 1) 143), and exhibit the following descending succession :- 
$\mathrm{H}_{2}$ and $_{3}$. Grey shales of Hostin with carbonaceous layers Feet.

$\mathrm{H}_{1}$. Grey shales, containing species of Orthoceras, Gyroceras, $\} 850$ and Goniatites

G g3. Nodular limestone with many Cephalopoda

G g2. Calcareous shales with trilobites and brachiopoda

G g1. Nodular limestone with a large fauna

F 2. $\left\{\begin{array}{l}\text { Red crinoidal limestone of Menan } \\ \text { White limestone of Konjeprus }\end{array}\right\}$. . . about 100

Of this series ouly the lower two members are referable to the Lower Devonian, of which they must be regarded as a concentrated calcareous facies formed in fairly deep water and under condition very different from those which prevailed in regions farther nortl and west. The red and white limestones are really different facies of one mass of limestone, the one often replacing or becoming interbedded with the other.

The interrelation and correlation of these limestones has been the subject of a recent study by F. Seeman, ${ }^{15}$ who calls them the zone of Aphyllites fidelis, this species of Goniatite, together with Mimocercus gracile and Anarcestes crispus, being common.

The whole of Stage $G$ belongs to the Middle Devonian, and though near Prague there is a central band of shales, near Beraun to the south-west it is, according to Seemann, entirely composed of limestone, the lower beds being characterised by Anarcestes subnantilinus and the upper by $A n$. occultus. Other common fossils are :-

Bronteus Brongniarti.

Phacops fecundus.

Cheirurus Sternbergi.

Goniatites fecundus.

Orthoceras annulatum.

Gomphoceras biconicum.

Hercoceras nirum.

Pteria grandis.

Chonetes novellus.

Coccosteus Agassizi.

Seemann also refers $\mathrm{H}^{1}$, in which Posidonomya hians is the most characteristic fossil, to the Middle Devoniall, regarding the rest of $\mathrm{H}$ as representative of the Upper Series.

\section{Poland and Russia}

North of Bohemia in Russian Poland, near Lagow and Kielce, there is an interesting conjunction of an arenaceous littoral and a calcareous marine facies. There the lowest Devonian Beds are sandstones with Placoderm fish (Coccosteus, Heterosteus, etc.), associated with other beds containing Spirifer paradoxus. These beds nuust be referred to the highest Coblentzian or lowest Eifelian, 
and there is nothing analogous to the Gediunian fish fauna of Pteraspis and Cephalaspis, etc.; consequently it is supposed that the Lower Devonian has thinned out northwards from Bohemia and eastwards from the Harz district against the shore of a northern Devonian continent; for though the Devonian is largely developed in the Baltic provinces of Russia, it does not include any repre. sentative of the Lower Series.

Both Middle aud Upper Devonian are well developed in Poland; the former by a series of marls and limestones with Calceole sandalina and many of the typical Eifelian and Givétian fossils, the latter by limestone and shales in the following order:-

3. Clymenia shales in three zones.

2. Calcareous shales with Geph. intumescens.

1. Kielce limestone with Rhynch. culoides.

In the Baltic provinces (Livonia and Courland) a red sandstone with fish remains lies unconformably ou both Silurian and Ordovician, and is succeeded by dolomitic limestones with a marine fauna. These limestones are divisible into four bands, the two lower containing a local fauna of Spirifers and other Brachiopods; the third band, however, yields many characteristic Givétian species, so that the lower are doubtless equivalent to the Eifelian, and the highest bed is marked by the abundance of another species of Spirifer (S. Anosoffi).

Finally, there is a second set of sandstones taking the place of the Upper Devonian, and comparable to the British Upper Old Red Sandstone, for they contain Holoptychius and Asterolepis. Eastward, however, in Central Russia they are replaced by red marls and limestones with marine shells, and still farther east, on the flanks of the Oural Mountains, we again find a complete narine facies of the whole Devonian System. Apparently Novaya Zembla was also covered by the Devonian Sea, for at Cape Grebein vertical beds with Proetus are regarded as Lower Devonian, and are conformably succeeded by strata which have yielded Spirifer Anosoffi.

\section{THE OLD RED SANDSTONE FACIES}

As stated on p. 199 the marine Devonian facies does not occur in Britain north of the Bristol Channel, its place in Wales, Scotland, and the north of Ireland being taken by the great series of andstones, marls, flagstones, and conglomerates, which are still known by the cumbrous name of the Old Red Sandstone.

Although this Old Red Sandstone is believed to be divisible into 
three series, a Lower, Middle, and Upper, which may be homotaxial with the Lower, Middle, and Upper Devonian, yet it is not certain

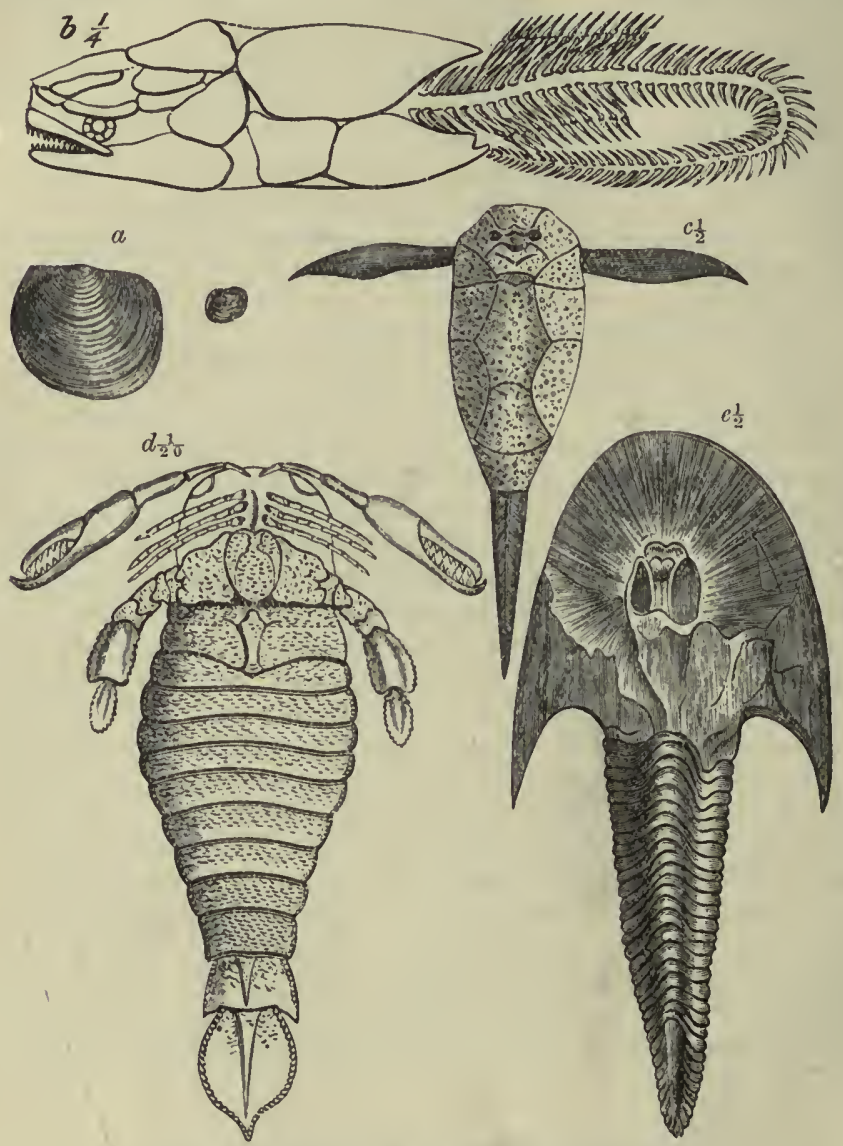

Fig. 74.-FOSSILS FROM THE OLD RED SANDSTONE.

a. Estheria membranacea.

b. Coccosteus decipiens. c. Pterichthys Milleri. d. Pterygotus anglieus.

e. Cephalaspis Lyelli.

that all threctdivisions are found together in one area, and it is certain that inonost parts of the country only two such series exist, the Upper being unconformable to the Lower: 


\section{A. Floma and Fauna}

The fauna of the Old Red Sandstone is not a large one, but in certain localities remains of fish and Eurypterids occur in some abundance; plants also occur, but the only Molluse yet found is the Archanodon Jukesi of the Upper Old Red, and this more closely

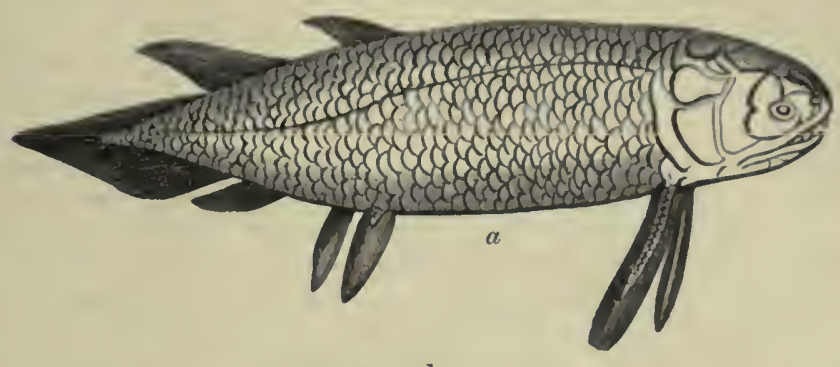

$b$

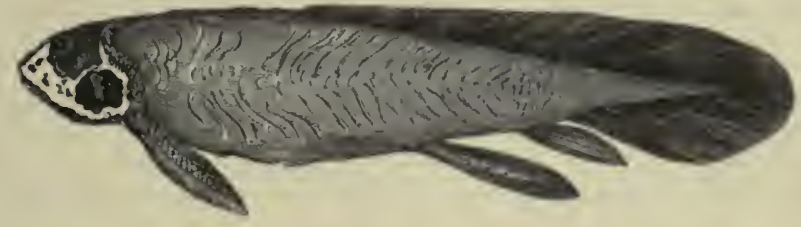

$c$

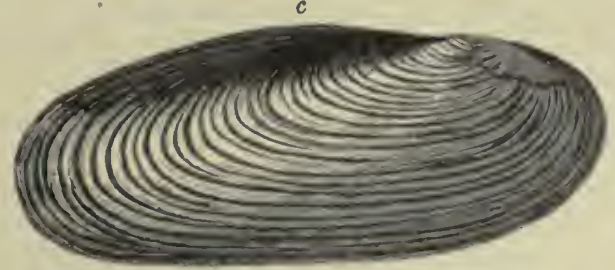

FIg. 75. -FOSSILS OF THE VPPER OLD RED GAND8TONE.

a. Holyptychius nobilissimus.

c. Archanodon Jukesi.

b. Phaneropleuron Andersonl.

resembles a fresh-water mussel than any marine form. From this limited fauna, and the total absence of any unquestionably marine species, it has been supposed that the Old Red Sandstones were lacustrine deposits, and that the greater part of Northern lurope was at this time a continent, within which lay several large lakeareas comparable to those of North America at the present day.

The plants of the Old Red Sandstone are the ancestors of the 
Carboniferous flora, and are chiefly lycopods and ferns. The former include Lepidodendron, Sagenaria, Knorria, Stigmaria, and Psilophyton; ferns are presented by Palceopteris, Neuropteris, and Sphenopteris; Calamites occur, and coniferous wood is also not uncommon.

Fish are the most conspicuous and abundant members of the fauna, and several orders are represented: the Ostracoderms by Cephalaspis, Pteraspis, Scaphaspis, and Holaspis; the Dipnoids by Coccosteus, Phaneropleuron, Dipterus, and Homosteus; the Elasmobranchs by Acanthodes, Cheiracanthus, Diplacanthus; the Crossopterygians by many genera, such as Osteolepis, Glyptolepis, Gyroptychius, Diplopterus, and (in the upper division) Holoptychius. The remains of fish are very abundant at certain horizons in Scotland, but they are not generally distributed through the mass of the formation.

The Merostomata are represented by Pterygotus, Eurypterus, Styloneurus, and the only other organic remains found in British strata are the Phyllopod Estheria, two Myriapods, and a Lamellibranch (Archanodon). In Canada, however, insects of several kinds have been found in rocks of corresponding age and character. The following are some of the more characteristic Old Red Sandstone fossils :-

\section{Fossils of the Lower Division}

Plants. Psilophyton robustum, Parka decipiens.

Myriapoda. Archidesmus Macnoli, Kampecaris forfarensis.

Merostomata. Pterygotus anglicus, Eurypterus pygmæus, Stylonurus Symondsi.

Pisces. Cephalaspis Lyelli, Pteraspis rostrata, Pterichthys cornutus, Pt. Milleri, Mesacanthus Mitchelli, Diplacanthus gracilis, Climatius scutiger, Parexus incurvus.

\section{Fossils of the Midale Division}

Plants. Lepidodendron gaspeanum, Calamites transitionis.

Crustacea. Estheria membranacea.

Pisces.

Coccosteus decipiens, C. minor, Thursius pholidotus, Th. macrolepidotus, Homosteus Milleri, Glyptolepis paucidens, Dipterus macropterus, Osteolepis microlepidotus.

\section{Fossils of the Upper Division}

Plants. Palæopteris hibernica, P. Browni, Cyclopteris Kiltorkense, Stigmaria ficoides, Knorria Bailyana, Sphenopteris filaccida.

Mollusea. Archanodon Jukesi.

Pisces. Holoptychius nobilissimus, Bothriolepis major, Glyptopomus minor, Phaneropleuron Andersoni, Asterolepis maxima, and Psammosteus Taylori. 


\section{B. Stratigraphy of the Old Red Sandstone}

\section{Wales and the Welsh Borders}

In Monmouth, Hereford, and Brecknock a great thickuess of red sandstones and marls intervenes between the Silurian and the Carboniferous, and from these counties extensions of Old Red Sandstone stretch westward through Carmarthen and South Pembroke, northward into Radnor and Shropshire, and eastward into Worcester and Gloucester. It is evident, therefore, that in all these directions the formation originally extended considerably beyond its present limits. According to recent estimates, its maximum thickness in Brecknock may be 7000 feet, but from this central area it thins in every direction, being only 4200 feet at Abergavenny in Monmouth, and $\mathbf{3 5 0 0}$ at Newport; while northward in Shropshire its thickness is believed to be 3700 .

The area over which the sandstones and marls of this system still extend measures over 100 miles from west to east, and about 80 miles from Cardiff in the south to beyond Bridgenorth in Shropshire. The system is naturally divisible into three parts or series, which were long ago recognised by W. S. Symonds, under the names of (1) Lower or Cornstone Series, (2) 3iddle or Brownstone Series, (3) Upper Old Red. These divisions have been adopted by the Geological Survey in their recent revision of South Wales, but there remains much doubt whether the Brownstone Series represents any part of the true Middle Old Red. In the eastern parts of the area the whole seems to form a conformable succession, but when followed westward into Carmarthen the Brownstones thin ont near Kidwelly, and the conglomerate of the Upper Group overlaps on to the lower series. They recur in Gower to the south, but are only 100 feet thick, and seem to belong rather to the Upper Old Red than to be an independent group. Hence the arrangement of the Geological Survey is as follows:-

$$
\begin{gathered}
\text { Upper }\left\{\begin{array}{l}
\text { Yellow and red sandstones, grey grits, and quartz-pebble } \\
\text { eonglonerates. } \\
\text { Seriesnstones. Red and brown sandstones, with oceasional } \\
\text { beds of marl and cornstone. }
\end{array}\right. \\
\text { Lower or } \\
\text { Cornstone }\left\{\begin{array}{c}
\text { Green and dull-red sandstones with some beds of marl, eorn- } \\
\text { stone, and eonglomerate. }
\end{array}\right. \\
\text { Series } \\
\begin{array}{c}
\text { Red marls with beds of nodular limestone (eornstone) and } \\
\text { occasional beds of mieaceous sandstone. }
\end{array}
\end{gathered}
$$

Cornstone Series.- - In Brecknock and the east of Carmarthen this red marl and cornstone series has a great thickness, possibly as much as 4500 feet. The greater part of it consists of hard red 
sandy marls with layers of hard calcareous nodules which sometimes coalesce so as to form beds of compact red or green limestone; while in other cases the embedding marl seems to have been washed away by contemporaneous erosion, leaving the nodules to form a "cornstone conglomerate." The nodules themselves consist of amorphous carbonate of lime, and nothing but obscure traces of plants have been found in them. They have probably been formed by the agency of lime-secreting algæ.

The Senni Beds only occur along the northern outcrop, and gradually thin out westward, disappearing a little before the Brownstones. Their maximum thickness is 1200 feet, and they have been included in the lower series because the remains of Pteraspis have been found in them. Both Pteraspis and Cephalaspis have been found in the Red Marls, and consequently it may be inferred that this Lower Old Red is the equivalent of the Lower Devonian and that there was some water communication, by river or inlet, between the two areas of deposition.

During the resurvey of the Gower district, in the south-west corner of Glamorgan, it was discovered that the underlying Silurian rocks rose to the surface within the Old Red Sandstone area and formed two small inlying tracts; further that the Cornstone Series, though present, thinned out within the area against the slope of the Silurian rocks. Thus some 300 feet of red marls are visible below Rhossili Down, and are overlain by Brownstones which are succeeded, without any sign of unconformity, by 300 feet of quartz-pebble conglomerates (see Fig. 77). On Cefn-y-Bryn, however, the red marls are absent, and Brownstones (only 100 feet thick) rest on the Silurian and are covered as before by the conglomerates. ${ }^{16}$

Still farther west, however, in Pembrokeshire the Red Marl Series regains its normal thickness, being over 3000 feet along its southern outcrop and nearly as much on the northern side. If, therefore, the Gower ridge was continued westward it must have passed some distance to the south of Milford Haven.

Upper Old Red Series.-The Brownstone Group consists mainly of sandstone, bright red or reddish brown, with subordinate beds of marl and occasional cornstones. In the area round Brecknock, where they form the lower slopes of the Brecon Vans and the Black Mountains (see Fig. 76), it may have a thickness of about 2000 feet, but this decreases in all directions. As already stated, they thin out entirely to the westward and do not occur in Pembrokeshire. No fossils of any kind have been found in them.

The highest group of beds is never more than 500 feet thick; it commences with a conglomerate composed in most places of 

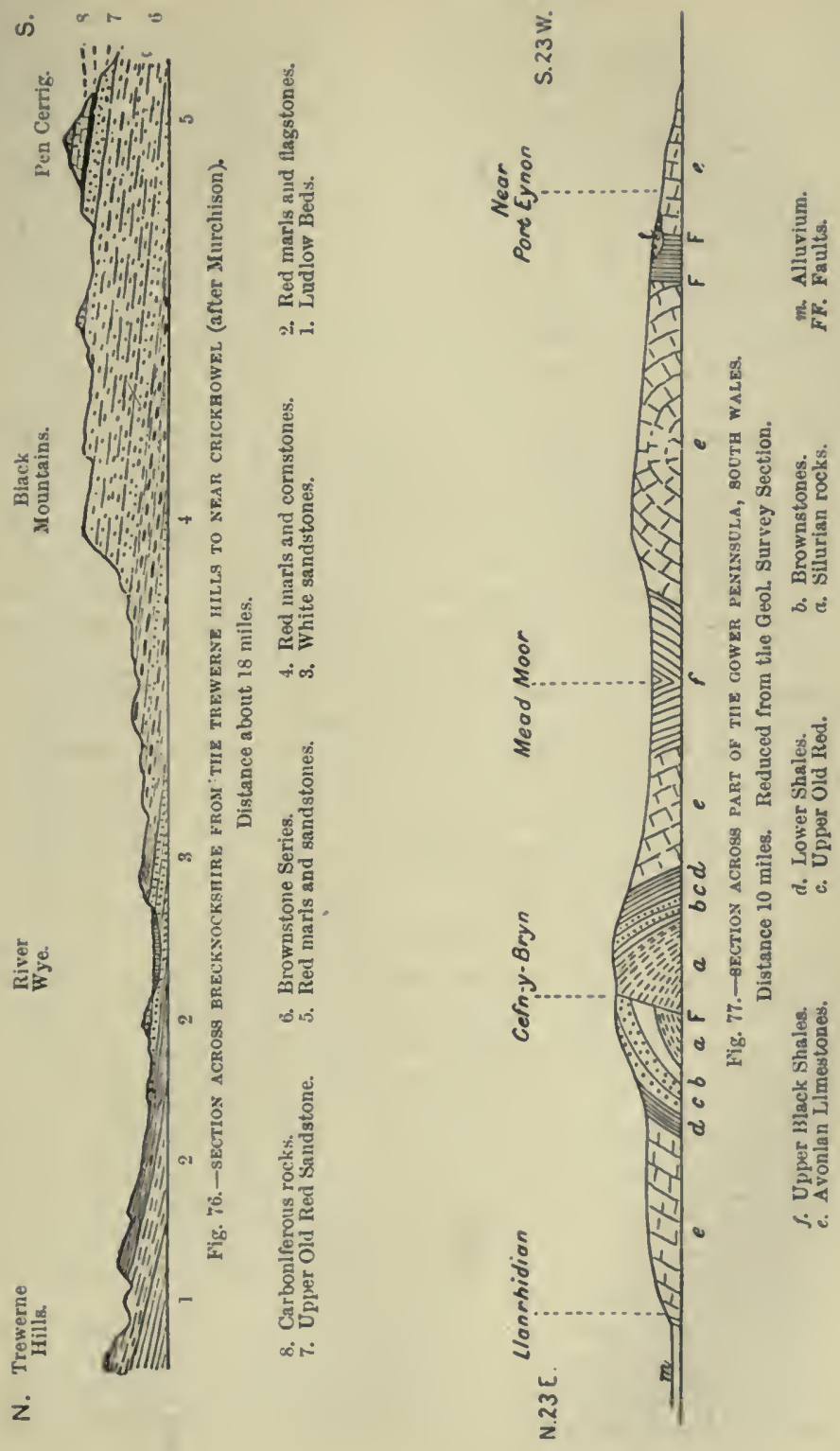
pebbles of vein-quartz which are so water-worn and rounded that they resemble the pebbles of a shingle-beach. In the northern and eastern part the shingle is succeeded by beds of sandstone, marl, and shale which pass up into the Carboniferous Series, and these beds have in several places yielded remains of fish and plants. The fish belong to the genera Bothriolepis, Holoptychius, and Sauripterus, and shells of Archanodon Jukesi have also been found.

In the extreme south and south-west these uppermost beds have a different aspect. Thus in Gower the conglomerate is no less than 300 feet thick and contains, besides the usual quartz pebbles, some of quartzite, together with augular pieces of red jasper, many of which appear to be pieces of silicified rhyolite or other igneous rock. Again in Pembrokeshire, along the northern outcrop and near Tenby, the group consists of quartzitic grits passing up into sandstones, marls, and shales; and at West Angle Bay, south of Milford Haven, two bands of marine fossiliferous beds occur in this sandstone group. The lower band commences about 125 feet below the line taken for the top of the group, and consists of grey shales and sandstones with thin bands of limestone; the second is some 50 or 60 feet higher. Both these bands contain marine shells, chiefly Lamellibranchs such as Ptychopteria damnoniensis, Cuculloea trapezium, Curtonotus elegans, with Rhynchonella laticosta and other characteristic fossils of the Marwood and Pilton Beds in North Devon. Here, therefore, as pointed out by Dr. Stralian, we have evidence of temporary incursions of the sea into an area which had previously lain within the borders of continental land, and was presumably part of a large lake-basin.

\section{Scotland}

In Scotland there are four principal areas where the Old Red Sandstones are found, and in some of them they attain a much greater thickness than in England. These areas are: (1) parts of Berwick, Roxburgh, and of Northumberland, including the Cheviot Hills; (2) the area of the central lowlands, underlying the Carboniferous rocks and coming to the surface both on the southern and the northern side of the great basin; (3) a smaller tract in Argyleshire between the Firth of Lorne and Loch Awe ; (4) a large irregular tract in the north-east, bordering the Moray and Cromarty Firths and stretching northward through the east of Sutherland to Caithness and the Orkney Islands.

It has been imagined that these four areas were distinct and separate basins of deposition, at any rate during the earlier part of the period; that they were disconnected from the sea and formed large inland lakes. Sir Archibald Geikie has indeed proposed 
separate names for these lakes, calling the first Lake Cheviot, the second Lake Caledonia, the third Lake Lorne, and the fourth Lake Orcadie. This view, however, is not sufficiently supported by the facts, so far as the three southern areas are concerned; the Lorne and Cheviot areas were probably only extensions or bays connected with one large Caledonian lake basin, which may also have stretched south-westward into the north of Ireland, for patches of Old Red occur at the very southern end of the Kintyre promontory. The northern area, on the other hand, exhibits a different set of beds which contain a different fish fauna, so that there does seem to lave been a Lake Orcadie or at any rate a separate Orcadian basin of deposition.

In the central area the Lower Old Red Series is of great thickness, but no middle division exists, and the Lower Series is overlain unconformably by the Upper Old Red, which passes conformably into the overlying Carboniferous Series. In the Orcadian area there is nothing which can be identified as Lower Old Red, but there is a great thickness of the Middle Series with an abundant fish fauna, and some patches of Upper Old Red resting unconformably upon the beds below.

There is a further great difference between the rocks of the two areas. In all the southern districts the sandstones are interstratified with thick sheets of andesitic lava and beds of volcanic tuff and agglomerate, giving proof of volcanic action on a very large scale, and from many volcanic vents, throughout the whole of the Lower Devonian epoch. In the Orcadian area, on the contrary, no such volcanic rocks are found, so that the eruptions do not seem to have continued into the time of the Middle Series.

In the following account of the stratigraphic succession of beds these volcanic materials will only be mentioned incidentally, and for more information about them the student is referred to Sir A. Geikie's Ancient Volcanoes of Great Britain (1897).

Caledonian Region.-The Lower Old Red Sandstone is most completely developed on the northern side of the great central or Lowland trough, and the beds are finely exposed in the cliffs of the Kincardine and Forfar coasts. Until quite recently this series was supposed to include all the red rocks visible in Kincardine, but as stated on p. 163 the lowest set of beds must now be regarded as the highest part of the Silurian System.

The base of the Old Red Sandstone is the massive conglomerate which forms Downie Point near Stonehaven, and this is part of a group of coarse sandstones and conglomerates to which Mr. G. Hickling ${ }^{27}$ has given the name of Dunottar Conglomerate (sec Fig. 78). These beds occupy a long stretch of coast-line which 
is here nearly parallel to the strike. Mr. Hickling estimated their thickness to be 5000 feet, and the comparative narrowness of their outcrop is due to their high inclination. The conglomerates of this group consist partly of quartzite pebbles, derived from the quartzites of the Highlands, and partly of angular and subangular fragments of jasper, chert, and "green-rock" derived from the "Margie Series" (see p. 97), showing this series must then have had a considerable northward extension over the Highland region.

The Dunottar Group is succeeded by the Sidlaw Group, which includes the contemporaneous lavas of the Sidlaw Hills and the overlying grey sandstones and flagstones (? 500 feet), which are followed by beds of coarser grain (the Cairnconnon Group), and perhaps 2000 feet thick. The fourth group is the Red Head Series, which consists of red sandstones with bands of hard red shale, and locally soine bluish-grey shales. These beds are overlain by the Auchmithie conglomerate from 500 to 800 feet thick, and mainly composed of large rounded pebbles of quartzite. No fossils have yet been found in any of the beds above enumerated, except a few in the Red Head Series.

The succeeding Arbroath sandstones comprise coarse gritty sandstones and some flagstones, both of red and grey colours, with a single bed of marly limestone at Arbroath, probably on the same horizon as a limestone which has been mapped inland to the westward. Fossils have been found at four horizons in these beds, and include Cephalaspis Lyelli, Pterygotus anglicus, Kampecaris forfarensis, and the plant Parka decipiens.

The highest beds of the whole series (the Edzell shales) are not exposed on the coast, but only occur in the deeper parts of the synclinal trough of Strathmore (see Fig. 78). The following is a tabular résumé of the succession and thicknesses :-

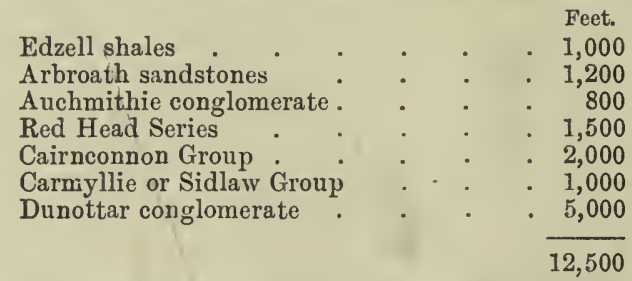

[I am indebted to Mr. Hickling for the drawing of the section across Forfar, from which Fig. 78 has been made.]

The great series of sandstones, conglomerates, and volcanic rocks above described forms a continuous band across Scotland from the coasts of Kincardine and Forfar to that of Dumbarton on 


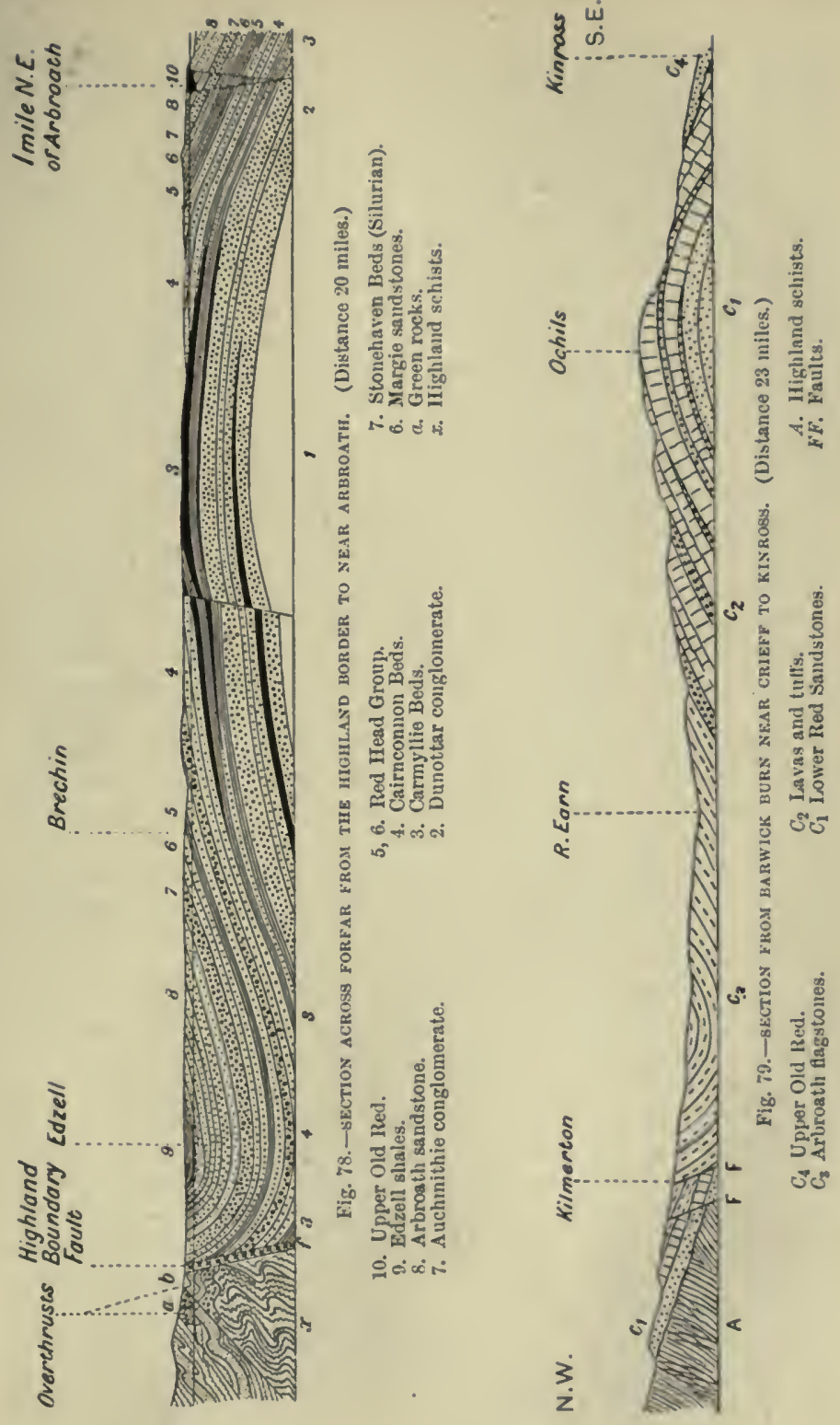


the Firth of Clyde, a distance of about 120 miles. For the greater part of its extent the breadth of outcrop is about 20 miles, but it narrows in Dumbarton where the thickness is probably less.

On the north-west side it is cut off by the great boundary fault; but in Perthshire and the west of Forfar this is not a single but a double line of fault, and there are small tracts of the Old Red rocks beyond the second fault-line, resting on the schists and quartzites of the Highland complex (see Fig. 79). These outliers prove that the formation had originally a considerable extension to the northward over the rocks of the Central Highlands. If, indeed, the thickness of the series in Perthshire was as great as it is on the eastern coast, the height of the mountains which then formed the Highland range must have been well over 12,000 feet, and it is clear that the present hills are but the denuded stumps of a Devonian Alpine Range.

Further, since the lower slopes of this range seem to have been gradually buried beneath the increasing pile of red sandstones and lava-flows, it is not surprising to find a large tract of volcanic rocks in Lorne associated with sediments which prove the whole to be of Lower Old Red age. These rocks form the plateau of Lorne, which consists of a succession of terraces and escarpments, rising to 1700 feet above the sea and composed of felsitic and andesitic lavas with occasional layers of agglomerate, conglomerate, and red shale. At the base, and exposed along the coast near Oban and in Kerrera Island, are shales and flagstones with a boulder conglomerate at the base from 20 to 200 feet thick. These beds have yielded remains of Cephalaspis, Pterygotus, Kampecaris, and the plant Psilophyton. Still farther north in Glencoe is another patch of andesites with some shales in which Psilophyton and Pachytheca have been found.

On the southern side of the great Lowland syncline the Lower Old Red crops out in a more irregular manner, and is only exposed in disconnected areas in Ayrshire, Lanark, and the Pentland Hills. The beds described on p. 177 as forning the highest member of the Silurian System were formerly classed with the Old Red Sandstone, but the base of the latter is now taken at a band of conglomerate containing greywacke pebbles which is recognisable in all three districts. Near Lesmahagow (Lanark) this conglomerate rests with apparent conformity on the red Silurians, and is succeeded by chocolate-coloured sandstone containing Cephalaspis Lyelli, but in Ayrshire and in the Pentlands the basal conglomerate is markedly unconformable to this Silurian Series. ${ }^{18}$ Fig. 59 is a diagram section showing the general relations of these beds in the Pentland district. 
$J$ ust as the northern belt is cut off by the Highland boundary fault, so the southern tracts are cut off by the boundary fault of the Southern Uplands, which runs from the coast near Ballantrae north-eastwards till it passes beneath the Carboniferous basin of Dalkeith. A small tract of Lower Old Red near Eyemouth in Berwickshire shows that the Caledonian area of deposition was prolonged southward, and there can be little doubt that the Cheviot area was also a part of it. The Cheviot Hills consist mainly of massive andesitic lava-flows with intercalations of tuft and ashy sandstone, and there are some beds of sandstone and conglomerate at the base, but of no great thickness.

Passing now to the Upper Old Red Sandstone of the Caledonian region we find this everywhere marked oft from the Lower Series by a great break and unconformity. It occurs only in isolated tracts, and frequently oversteps the limits of the Lower Series on to the older rocks. The interval of time which elapsed between the two epochs of deposition must have been a long one, for Mr. Hickling finds that in Forfar no less than 8000 feet of material had been removed from the main anticline before the Upper Old Red was deposited; in other words, the Lower Series was flexured and then denuded to that extent in the interval which is elsewhere partially filled by the Middle Old Red.

'The Upper Series occupies several more or less extensive tracts in different parts of the region, the largest being that in the south-east, Roxburgh and Berwick, where it extends from the northern borders of the Cheviots by Jedburgh and Earlston to Lauder and Greenlaw, and then all round the Lammermuir Hills to the coast at Dunbar. A smaller tract is found in the Pentland Hills, and others in Lanark and Ayrshire. On the northern side of the Lowland area two long belts of it lie between the boundary of the Lower Series and the outcrop of the Carboniferous sandstones, the one extending from the Clyde to the Forth near Stirling, the other from Kinross and Loch Leven to Cupar and Leuchars in Fife. There are also some small tracts in Forfar.

The following description of the beds composing this Upper Old Red is condensed from the account given by the late J. G. Goodchild, and is applicable to all the more eastern tracts.

The series is divisible into a lower and upper stage; the lower consists of a variable set of conglomerates and sandstones, the coarser beds being at and near the base, and the sandstones becoming finer in grain and more interstratified with marls towards the top; the sandstones also become more and more largely composed of rounded wind-worn grains. The prevalent colour is bright red; the thickness is variable (from 100 to 500 
feet), and fossils are scarce, but scales of Holoptychius occur. The upper or Cornstone Group consists of sandstones and flagstones of pale red or yellow colours with marls and layers of the hard calcareous nodules which are known as cornstones. Fish remains are abundant in places, especially at Dura Den, near Cupar, where most of those mentioned on p. 226 have been obtained. This upper group is just as clearly a lacustrine deposit as the lower part of the series is one of accumulation in dry and wind-swept desert plains. The total thickness in Fifeshire is about 1000 feet.

Orcadian Region.-The present visible extent of the Old Red Sandstone has been mentioned on p. 230, but it must have a much greater extension under the bed of the North Sea both in eastern and northern directions, for the general dip of the beds is to the north-east, and their estimated thickness is 16,000 feet.

The whole of this thickness is ascribed to the Middle Old Red Series because of the peculiar fish fauna which it contains. It is divisible into four fairly distinct groups: ${ }^{19}$ (1) the lowest consists of red conglomerates, sandstones, and mudstones resting on and against the Archæan rocks and largely developed near Berriedale, from which place its outcrop runs N.N.W. to Sandside Bay, west of Thurso; (2) the Lybster Beds or lower flagstone group-dark-blue flags and shales, with occasional beds of sandstone and of black, often bituminous, limestone; (3) the Thurso Beds or upper flagstones, which are of pale grey or green colours and include but few limestones; (4) the John o' Groats sandstones of red and yellow tints. In tabular form the succession and thicknesses are :-

John o' Groats sandstones

Thurso Flagstone Group .

Lybster Flagstone Group

Berriedale Beds

$$
\begin{array}{rrr} 
& \text { Feet. } \\
. & \text { about } 2,000 \\
. \quad y & 7,000 \\
. \quad " \quad & 5,000 \\
& 2,000 \\
\hline & \text { About } 16,000
\end{array}
$$

Fish remains are most abundant in the Flagstone Beds, the lower group yielding Thursius macrolepidotus, Dipterus macropterus, and Osteolepis; the higher beds contain abundant remains of Coccosteus (C. decipiens and C. minor) with many others (see p. 226). The highest group has yielded plant remains, such as Lepidodendron gaspeanum, Palcopteris Browni, and Calamites transitionis, which occur also in the Devonian of Canada.

A fish bed of special importance occurs at Achanarras, some 10,000 feet above the base of the formation, while a similar assemblage of species has been found in the Moray area not very far above the base, and if the two beds are really on the same 
stratigraphical horizon a thickness of about 9000 feet must have thinned out southwards and have been overlapped by the beds containing the Achanarras fauna. Such an overlap had been inferred on other grounds by Sir A. Geikie many years ago, and on this view it is only the highest part of the Middle Old Red Series which occurs in Nairn and Inverness and in the outliers which are found in Aberdeen.

This nortliern basin includes also some tracts of Upper Old Red, which rests with a marked unconformity on the Middle Series. Froin 600 to 800 feet of red and yellow sandstones can be seen. They occupy a tract of some length in Moray and Nairn, and outlying patches occur at Tarbat Ness, round Dornoch, at John $o^{\prime}$ Groats and Dunnet Head, and again in the Island of Hoy.

\section{The North of Ireland}

As already mentioned, several tracts of Lower Old Red occur in the north of Ireland, and others may be concealed beneath the newer strata. One such tract occupies an area about 30 miles long by 10 wide, between Lough Eine and Pomeroy in Tyrone. "It consists for the most part of dark-red and purple conglomerates, often coarse and massive, and of purple pebbly and fine-grained sandstones, . . . with sandy shales. The pebbles in the conglomerate, which vary from the smallest size up to blocks over a foot in diameter, consist of purple felstone, grits, schists, and quartzite. Of all these the felstone pebbles are by far in greatest proportion," and have beel derived from the breaking up of contemporaneous lava streams, some sheets of which still remain interbedded with the conglomerates. ${ }^{20}$

The second area is on the east coast of Antrim between Cushendall and Cushendun. Here again are conglomerates at the base, consisting mainly of quartz pebbles; above these is a series of red and brown sandstones succeeded by a breccia composed of large blocks of quartz-porphyry; the whole is estimated to be 5000 feet thick. This tract forms a link between the Tyrone area and the Lower Old Red of the Kintyre promontoly.

Another tract of similar material has been found in Donegal between Lough Swilly and Mulroy Bay. This consists of a basal conglomerate succeeded by chocolate-coloured sandstones and shales with some pebbly beds, and the naterials are all derived from the surrounding quartzites and schists. The thickness seen is about 800 feet. Nothing corresponding to the Upper Series has been found in the north of Ireland, though it undoubtedly occurs in the southern part of the country (see p. 211). 


\section{Norway}

Some small tracts of red sandstone and conglomerate occur on the west coast of Norway between the Sogne and the Ludvig fiords (see map, Fig. 10). They rest unconformably on Silurian and older rocks, but the maximum thickness is not more than 1200 feet. It is very probable that they belong to the western border of the Orcadian basin of deposition, in which case they are likely to be Middle Old Red Sandstone; but no fossils have yet been found in them to confirm this assumption.

\section{Arctic Regions}

Sandstones of the Old Red facies have also been found in several parts of the Arctic regions, notably in Spitzbergen, Bear Island, and Greenland.

In Spitzbergen, both Lower and Upper Old Red Sandstones occur. The lower beds, exposed in Dickson's Bay, consist of red and green sandstones, and have yielded species of Pteraspis, Cephalaspis, and Acanthaspis. The Upper Old Red has been explored at two localities, the Muner Valley and Grey Hook Point. At the former the beds consist of red and green sandstones with a band of grey shale enclosing ironstone nodules, in which fish of the genera Psammosteus, Asteroplex, Onychodus, and Holoptychius occur, together with plant remains (Lepidodendron and Bothrodendron (=Cyclostigma). At the other place (Grey Hook Point) there is a series of black shales and hard grey sandstones, and these have yielded a number of curious Mollusca which appear to be fresh or brackish-water forms; for no essentially marine genera occur, and they are all bivalves which have been referred by Dr. Kayser to the following genera, Archanodon, Palcomutela, Myalina, Pteria (?), and Nathorstella. ${ }^{2 I}$

The relations of the Upper Series to the Lower have not yet been ascertained, nor the thickness of either, for the whole mass occupies a deep faulted trough which crosses the island from north to south, so that the base is not seen; but de Geer has estimated the parts exposed to be over 4000 feet thick.

Bear Island lies to the south of Spitzbergen, and the greater part of it consists of beds which belong to the Upper Old Red Series. $^{22}$ There is a basal conglomerate resting unconformably on Ordovician limestones and succeeded by a series of sandstones with bands of carbonaceous shale and seams of coal; these beds have yielded many interesting plants, including species of Archoopteris, Sphenopteris (Sphenopteridium), Cephalopteris, Pseudobornia ursina, 
Bothrodendron kiltorkense, and four other species with Stigmaria ficoides and others. There are also remains of the fish Holoptychius giganteus and $H$. monilifer.

Again Upper Old Red has been found on the east coast of Greenland, the beds being red and brown sandstones from which fish of the genera Holoptychius and Asterolepis have been obtained.

From these facts it is clear that the Old Red Sandstone facies has a very large extension in the Arctic regions, and that the continent within which these deposits were formed reached from England to Spitzbergen, and from Greenland at least as far as Sweden, and probably through Northern Russia where sands and marls with fish remains occur near Archangel, without any marine deposits, but marine Devonian strata do occur in Novaya Zembla.

\section{Geography and History of the Period}

The general geographic conditions under which both the marine Deronian and the Old Red Sandstones were deposited have been fairly well indicated in the preceding pages, and the student will doubtless have realised that the greater part of Northern Europe, together with the whole of the North Sea area and part of the Atlantic Region, formed at this period a large continental tract of land. By some author's the Devonian has been called "the first continental period," regarding it from a European point of view, and it is certainly the earliest period for which we can reconstruct a map of land and sea with anything like an approach to accuracy.

I have therefore prepared a map of Northern Europe in Lower Devonian time (Fig. 80 ) and will briefly recapitulate the data on which the southeru boundary or coast-line of the continent has been drawn. Beginning with the western region the great thickness of detrital deposits and the prevalence of fine sand in Brittany, Cornwall, and the south-west of Ireland are plain indications that they must all have been on the borders of a large area of land. We find actual portions of this land in Waterford, Wexford, and South Wales, and again in the southern part of Cornwall. Hence we arrive at the conclusion that the area in which the Glengarriff Beds were deposited was a large land-locked bay bounded by continental land on the north, west, and south, and only opening eastward through a channel from 50 to 70 miles in widtl.

From Cornwall the land seems to have projected as a promontory into the area now occupied by the English Channel, and its southern shore must have passed outside Brittany and then south-westward toward the north of Spain. In Asturia the lowest 


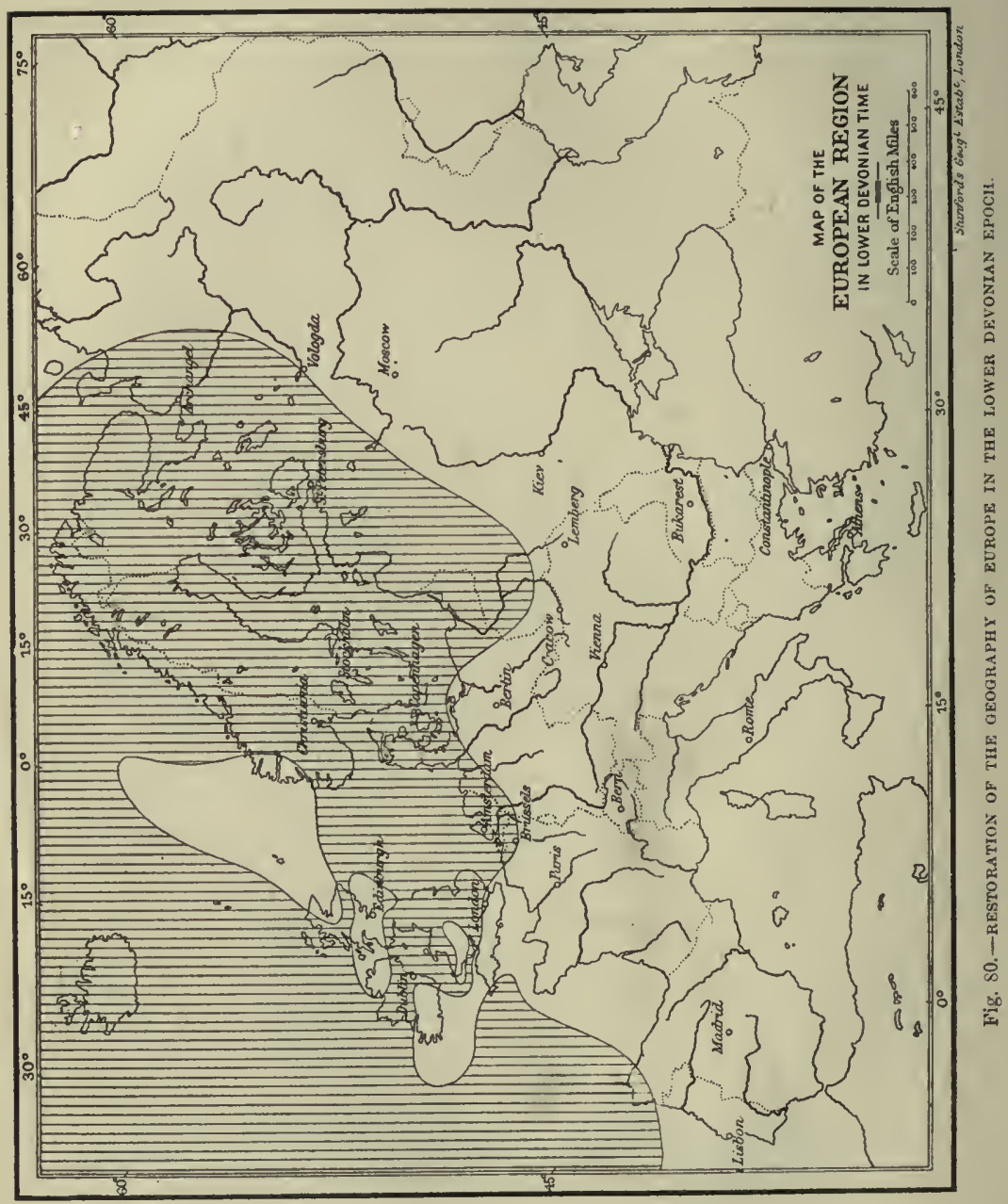


600 feet of the Devonian are hard quartzitic grits and slates of the Plougastel and Glengarrift facies, but from their uuch smaller thickness we may conclnde that the A tlantic land did not reach quite so near to Spain as it did to Brittany, the coast-line probably curving away to the west.

Returning to England it may be noted that rocks containing Upper Devonian fossils have been found in borings at Turnford, near Cheshunt, and below London, but they do not help much in our present quest. In the Ardennes, however, we find definite evidence of the position of the coast-line in Lower Devonian time, for the entire absence of the Lower Series in the basin of Namur proves it to have been land while that of Dinant was covered by the Lower Devonian Sea.

Here it must be pointed out that the supposed existence of land to the south of Dinant and Fepin, with a narrow strait between it and the northern mainland, is founded on a misapprehension of the facts. There was land there in Silurian times, and the basal conglomerate and sandstones of the Devonian testify to its destruction, bnt there is no overlap of successive stages against a slope of older rocks, and there can be little doubt that the whole inass of the Lower Devonian strata in the basin of Dinant passed over the massifs of Rocroi and Charleville; in other words, that this land of Silurian and Ordovician time sank beneath the waters of the Devonian Sea.

The same sea spread eastward over the greater part of Germany, but the great thickness and sandy nature of the Lower Devonian of the Harz Momntains testify to the proximity of land; and when we reach Poland still clearer indications are found, for there a break and unconformity between Silnrian and Devonian presents itself, and we have in the Lowest Devonian deposits an intercalation of marine strata with sandstones of tle Old Red facies, as if a large lagoon were being invaded by the sea. The same conditions are present in Eastern Galicia, which must likewise have lain near the margin of the continent, bnt in the Baltic provinces of Russia we clearly stand on firn Devonian land (see p. 223).

The line drawn on Fig. 80 to indicate the eastern border of this continent is, of course, merely an approximation to its true course; at present we only know that the land did not extend into Central Russia, and that it did not include Novaya Zembla.

In Middle Devonian time there seems to have been a general subsidence, enabling the Southern Sea to extend itself over some of the sonthern and eastern portions of the northern continent. Moreover, it seems that the areas invaded and covered by the Eifelian Sea were of nuch larger extent in the eastern than in the 
western parts of the continent; consequently we must suppose that either the subsidence was greater in the east than in the west, or that there were larger areas of low-lying land in the east. The first hypothesis seems the most probable because the lacustrine area of South Wales lay so close to the border of the continent that we can hardly imagine it to have been at a high level above the sea, nor is the intervening isthmus likely to have been very ligh along its whole length.

The Orcadian basin is indicated on the map (Fig. 80), although we have no proof of its existence as a basin of deposition during Lower Devonian time. It may have existed in the form of a wide valley which, by subsequent disturbances and alterations of level in the northern part of the continent, was converted into a large lake-basin. In any case we must suppose that the river which ran out of this lake opened somewhere into the Middle Devonian Sea, for it can only lave been by means of the ex-current river that the fish made their way into the lake, ascending it as salmon do rivers at the present day. Whether this river flowed eastward or northward is the question, but unless it traversed the range of mountains which certainly then existed in Scandinavia it must have taken a northerly course into a northern sea.

The lapse of time indicated by the slow accumulation of the Middle Devonian shales and limestones must have been very great, and it must not be estimated by the small thickness of such deposits in Brittany and Cornwall, but by their maximum development, which is probably that to be found in the Ardennes and the Rhenish provinces (see p. 215).

Again, it is noteworthy that if we had nothing but the succession of marine deposits as a record of the Devonian period, we should unquestionably have supposed that the whole period was one of quiet and uninterrupted subsidence, and that the epoch of the Middle Devonian merged into that of the Upper Devonian without any great physical change.

The terrestrial deposits, however, furnish us with evidence of a great change, though it is quite possible that this was accomplished without any great surface or subterranean disturbances. The change probably involved some movement of the earth's crust, but this can hardly have been elevation, for it ushered in the subsequent subsidence of Carboniferous time; neither was it immediate subsidence, or we should have had marine beds in the place of the Kiltorcan Beds and Upper Old Red of Wales. Rather it seems to have been a change in the climate and in the terrestrial conditions of deposition.

It is possible that toward the close of Middle Devonian time 
dry and desert conditions prevailed over the central parts of the continent, including the British region; that the lakes shrank to small proportions, if they were not entirely dried up. On this supposition the change which took place may have been a return to more humid conditions, an increase in the rainfall, especially on the mountain ranges, resulting in the birth of torrential streams at certain seasons, which swept out the stones and pebbles that had accumulated in the higher valleys and spread them out on the desert plains, for there is sufficient evidence that the Caledonian area at any rate was such a desert plain.

As the annual rainfall increased, lakes were once more formed, and were again peopled with fish, but new kinds of fish had in the meantime been developed in the surrounding sea, so that the fish of the Upper Devonian lakes were a very different assemblage from that which lived in the older lakes. Finally we have evidence of a slow subsidence of the whole region and of the invasion of these lakes by the waters of a Carboniferous Sea.

\section{REFERENCES}

1 Jukes, Quart. Journ. Geol. Soc. vol. xxii. p. 320 (1866).

2 Etheridge, Quart. Journ. Geol. Soc. vol. xxiii. p. 568 (1867).

${ }^{3}$ Hicks and Whidborne, Quart. Journ. Geol. Soc. vol. Iii. p. 254, and liii. p. 438.

* W. A. E. Ussher, Quart. Journ. Geol. Soc. vol. xlvi. p. 487 (1890).

${ }^{3}$ See E. Hull in Quart. Journ. Geol. Soc, vol, xxxv. p. 703 (1879).

- See Jukes, Quart. Journ. Geol. Soc. vol. xxii. p. 340, and Explanations of sheets of the Geol. Survey Maps of Ireland.

7 See paper by Prof. Hull (above cited).

8 Geology of the Country around C'rrk, 2nd ed. (1905).

9 See Heer in Quart. Journ. Geol. Soc. vol. sxviii. p. 163 (1872).

10 C. Barrois, Proc. Geol. Assoc. vol. xvi. p. 101 (1899).

11 Ahlert in Bull. Soc. Géol., France, for 1889, p. 742 ; and "LivretGuide de l'Excursion en Mayenne," Géol. Congrès Internat., 1900.

12 C. Barrois, "Terr. anciens des Asturies," Mem. Soc. Géol. Nord, 1882.

13 J. Gosselet, Proc. Geol. Assoc. vol. ix. p. 228.

It See Kayser, Zeitsch. deutsch. geol. Ges., Bd. xxxiii. p. 617 (1881); and Koch, Jahrb. k. preuss. geol. Landesanst. xx. p. 237 (1900).

${ }^{13}$ F. Seemanu, Beitr. Paläont. Oesterr.-Ung. xx. p. 69.114 (1907).

16 "Geology of West Gower," Mem. Geol. Survey (1907).

17 G. Hickling, Geol. Mag. for 1908, p. 396.

18 J. G. Goodchild, Proc. Geol. Assoc. vol. xviii. p. 117.

19 Sum. Prog. Geol. Survey for 1898, 1. 87 (with map).

2n J. Nolan in Quart. Journ. Geol. Soc, vol. zxxvi. p. 529 (1880).

${ }^{21}$ See Kayser in Stockholm Yet. $A k$. Bch. Bd. xxvii. (1901); Nathorst in Bull. Soc. Instit. Upsala, vol. x. (1910); and A. S. Woodward in Ann. Mag. Nat. Ilist. s. 6, vol, viii. (1895).

22 See Heer in Quart. Journ. Geol. Soc. vol. xxviii. p. 163. 


\section{CHAPTER IX}

\section{THE CARBONIFEROUS SYSTEM}

THE materials for a history of this period are more ample than those available for the preceding periods. Carboniferous rocks occupy a larger part of the British Isles than the rocks of any other system, and in the search for coal they have also been more extensively studied and explored, so that it has become possible to trace the lateral changes which the component members of the system undergo, and to correlate the strata of different districts with much greater accuracy. Carboniferous strata have also a considerable extension in France, Belgium, Germany, Silesia, and Russia as well as in Spain.

The records of the period are indeed more complete on the continent than they are in the British Isles, for they carry the history of it to a later date in geological time. Continental geologists have found it necessary to divide the whole system into three series, of which only the two older are represented in Britain, so that we have been accustomed to regard the Carboniferous System as consisting of these two, a Lower Carboniferous and an Upper (or Coal-measure) Series. The advance of comparative geology makes this view and our insular nomenclature no longer tenable, and we must either give new names to the British divisions or accept those current on the continent.

Dr. Vaughan has proposed the name Avonian for the southern type of the Lower Carboniferous, and the name Bernician has been used for the northern facies. ${ }^{a}$ No good name has yet been proposed for the rest of the British Series.

French geologists have adopted the name Dinantian for their Lower Carboniferous Series, but it is less comprehensive than the British Avonian. For the higher stages it will be convenient to adopt their names, and others again are used by Russian geologists

a It was first proposed by S. P. Woodward (1856) for the whole Lower Carboniferous Series, and afterwards by Lebour (1877) for the greater part. 
as their facies of the system is almost wholly marine. The nomenclature will therefore be as follows :-

\begin{tabular}{clc} 
England. & \multicolumn{1}{c}{ France. } & Russia. \\
Westplalian. & Stephanian. & Uralian. \\
Aronian. & Westphalian. & Moscovian. \\
& Dinantian. & Dinantian.
\end{tabular}

In England, France, and Belgimm, as well as in Russia, the Aronian consists almost entirely of marine deposits, and in most districts it is mainly composed of limestone. In Gerinany, on the other hand, it consists of carbonaceous shales with beds of sandstone and has long been known as the Culm. The Westphalian is everywhere (except in Russia) a varied succession of sandstones, shales, clays, and coal-seams, which seem to have been deposited on the borders of a sinking land, in deltas and lagoons, where the water was sometimes saline and sometimes brackish or fresh. The Stephanian is also a Coal-Measure Series of similar character in the west of Europe, but passes eastward into the marine Uralian of Russia.

As each of these great series has in some places a thickness of 9000 to 10,000 feet, and as the fauna and flora of each differs considerably from that of the others, it will be convenient to describe them separately and in succession.

\section{THE AVONIAN SERIES}

\section{A. Life or the Epoch}

Plants are naturally not common fossils in marine deposits, so that the number known from this series is not large. The flora is almost the same as that of the Upper Devonian, and the following are the principal genera :-

Archcocalamites (= Bornia), Cheirostrobus, Sphenopteris, (S. affinis and S. elegans), Adiantites, Rhacopteris, Cardiopteris, Heterangium, Lepidodendron, Lepidophloios, and Pitys.

The Dinantian fauna is a rich one, both in genera and species. The following is a brief account of it, new generic appearances being marked with an asterisk.

\section{Hydrozoa-Chatetes.}

Foraminifera.-These become very abundant in the rocks of this period and contribute largely to the formation of some of the limestones, the principal genera being Saccummina, Endothyra, Fusulina, Trochammina, Valvulina, and Lagena.

Anthozoa.-Of corals the most common genera are Aulo- 

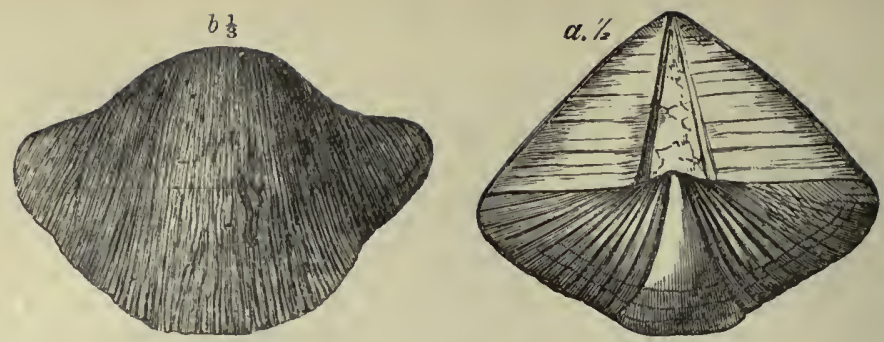

$c$
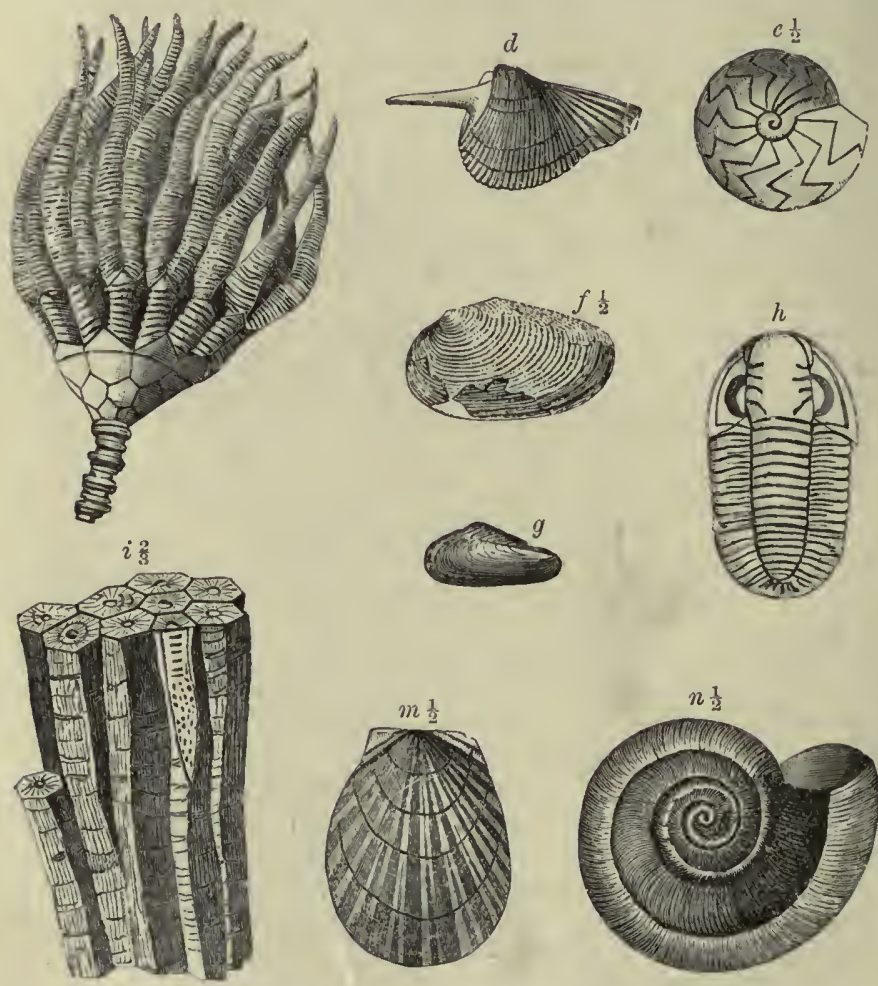

Fig. 81.-GROUP OF CARBONIFEROUS FOSSILS (AVONLAN).

a. Syringothyris euspidata.

$b$. Productus giganteus.

c. Woodocrinus macrodactylus.

d. Conocardium aliforme.

e. Glyphioceras sphæricum.

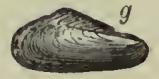

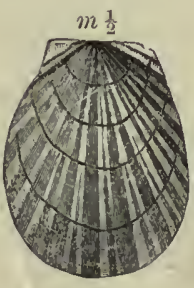

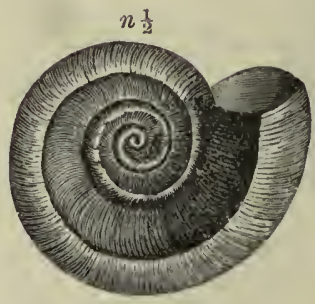

n. Euomphalus pentagonalis.

f. Posidonomya Becheri.

g. Modiola Macadami.

$h$. Phillipsia derbiensis.

$i$. Lithostrotion basaltiforme.

$m$. Aviculopecten sublobatus. 
phyllum, ${ }^{*}$ Lithostrotion, ${ }^{*}$ Lonsdaleia, ${ }^{*}$ Phillipsastrea, Syringopora, Clisiophyllum, ${ }^{*}$ Dibunophyllum, ${ }^{*}$ Cyclophyllum, ${ }^{*}$ Cyathaxonia, ${ }^{*}$ Michelinia, Zaphrentis, Amplexus, Caninia, and Cyathophyllum. None of these survive the Carboniferous period in Europe, though a few occur in the Permian of Asia.

Echinoderma.-Crinoidea are abundant, and their remains often form a large part of the limestones. The chief genera are

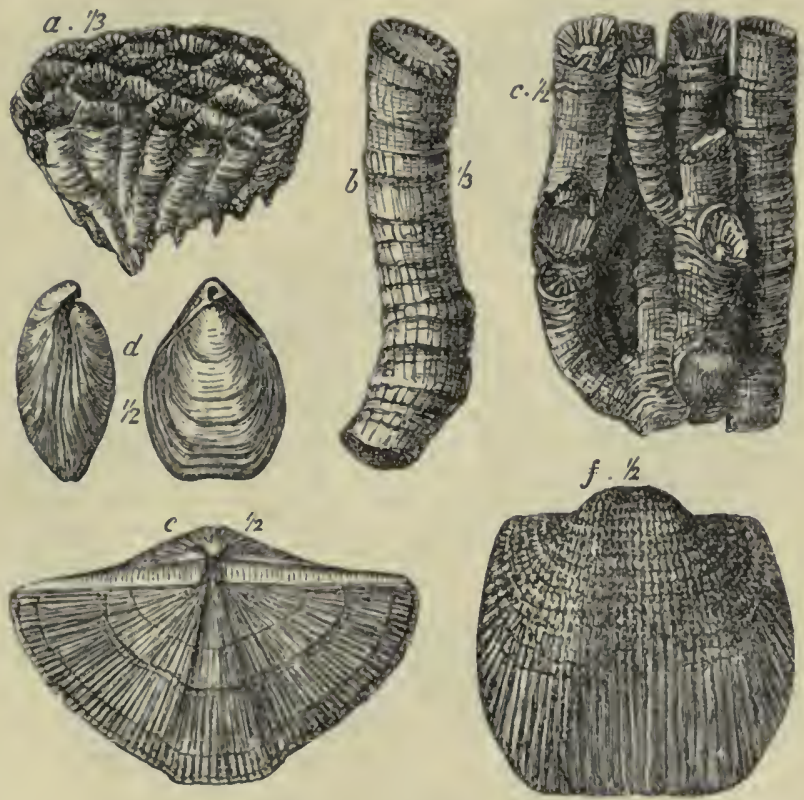

Fig. S2. -GROUP OY CARBOAFEROUS FOSSILS (AVONIAN).

a. Michelinis megastoma.

b. Amplexns coralloides.

c. Lithostrotion afllne. d. Terebratula (Dielasma) hastata. e. Spirifer strintus.

f. Productus semireticulatus.

Actinocrinus, ${ }^{*}$ Platycrinus, Rhodocrinus, Cyathocrinus, Poteriocrinus, Amphoracrinus, ${ }^{*}$ and Woodocrinus.* None of them, witl the possible exception of Cyathocrinus, survived this period. Blastoidea now seen to take the place of the Cystideans of the older Palieozoic rocks, the commoner genera being Granatocrinus, Codaster, and Orophocrinus. Of Echinoidea there are Archcoocidaris, Palcchinus, and Melonites.

Crustacea.-The only surviving genera of trilobites are 
Phillipsia, Griffithides, Proetus, Cyphaspis, and Brachymetopus. None are common, all are small, and all died out, in Europe at any rate, before the close of the period. Small Ostracoda are often abundant belonging to the genera Bairdia, Cypridina, Cypridinella, and others. Dithyrocaris and other Phyllocarids also occur. Schizopoda are also represented and are common. in some parts of Scotland.

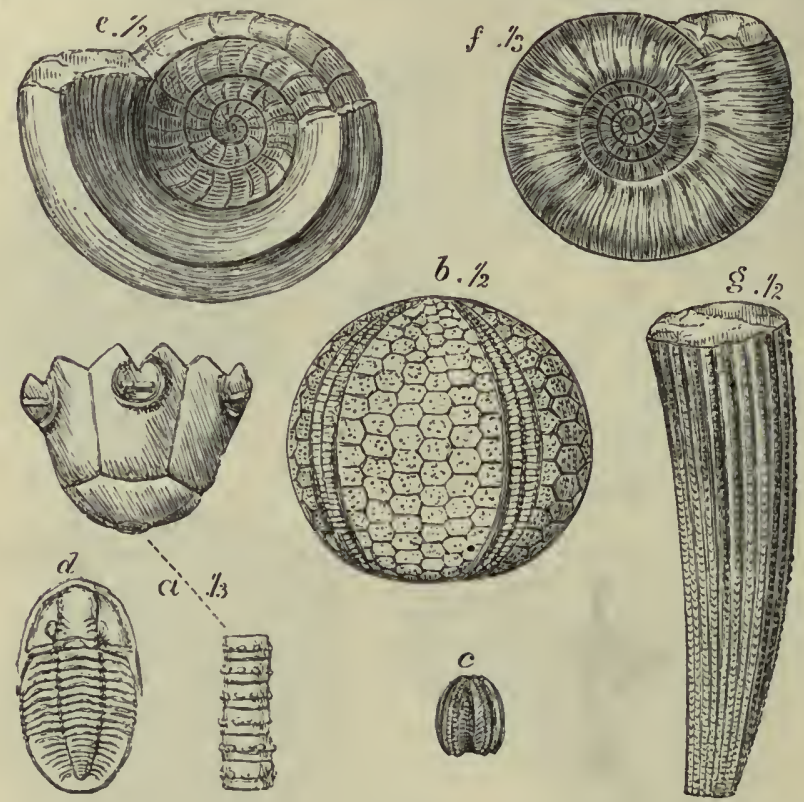

Fig. 83. - Group OF CARBONifErous Fossils (AVONIAN).

a. Platycrinus lævis.

b. Palæchinus gigas.

c. Granatocrinus ellipticus.

g. Orthoceras Gesneri. d. Phillipsia pustulosa.

e. Colonautilus cariniferus.

f. Gastrioceras Listeri.

Brachiopoda.-The only common and distinctive Carboniferous genus is Seminula, but most of the Devonian genera survive, such as Orbiculoidea, Productus, Spirifer, Spiriferina, Rhynchonella (Pugnax and Hypothyisis), Camarophoria, Dielasma, Athyris, Chonetes, and Orthis.

Lamellibranchia.-The following are some of the commoner genera, those with an asterisk making their first appearance: Pterinopecten, Aviculopecten, Crenipecten, Posidoniella, * Parallelodon, 
Conocardium, Myalina, Schizodus, ${ }^{*}$ Leptodomus (Protoschizodus), Edmondia, Cardiomorpha, Pleurophorus, Cypricardiella, ${ }^{*}$ and San. guinolites.*

Gastropoda.-Most of the Devonian genera contime, and the commoner are: Metoptoma, Pleurotomaria, Murchisonia, Bellerophon, Euomphalus, Straparollus, Naticopsis, Capulus, Loxonema,
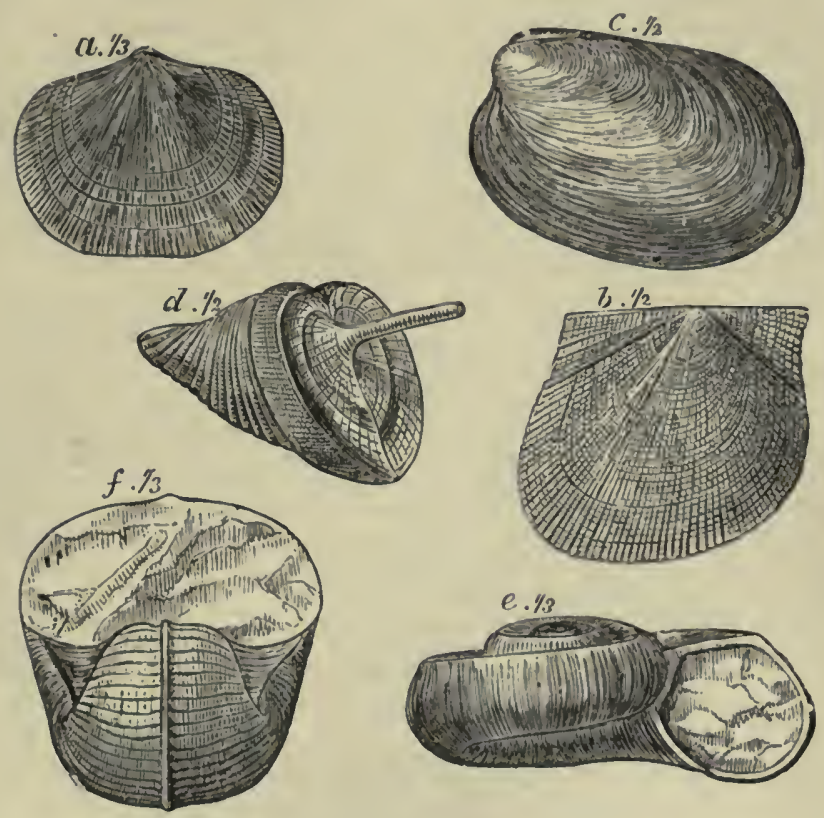

Fig. 84. - Group OF CARBONIFErous Fossils (A MONIAN).

a. Orthis resupinata.

6. Aviculopecten pajyraceus.

c. Cardiomorpha oblonga. d. Conncardium hibernicum.

e. Euomplalus pentagonalis.

$f$. Bellerophon tangentialis.

Macrochilus, and Turbonitella, but very few of these survive the close of the Carboniferous period.

Cephalopoda.-The following are some of the genera which occur : of Nautiloidea there are Orthoceras, Actinoceras, Cyrtoceras, Poterioceras, Temnocheilus, ${ }^{*}$ Celonautilus, ${ }^{*}$ Vestinautilus, ${ }^{*}$ Stroboceras, ${ }^{*}$ Discites; of Ammonidea the following genera belonging to the Goniatitidec, Brancoceras, Pericyclus, ${ }^{*}$ Gastrioceras, Glyphiocerce, Nomismoceras, ${ }^{*}$ Dimorphoceras, ${ }^{*}$ Prolecanites, ${ }^{*}$ Pronorites. ${ }^{*}$ 
Pisces.-Remains of fish are very numerous, and a long list of names founded on the teeth and spines of fish might be given, but the following are known from more complete remains, Eurynotus, Rhizodus, Holoptychius, Megalichthys, Colacanthus, Platysomus. Many of the Carboniferous fish were Elasmobranchs, and most of the remainder are Teleostomi of the Crossopterygian order.

A remarkable fact in the distribution of the marine fauna is the persistence of many species throughout the whole of the Avonian Series. Recent studies of the corals and Brachiopoda have, however, shown that a few species are restricted to certain horizons and that other's are much more abundant within certain zonal limits than they are above or below, and in this way a zonal classification of the great mass of limestones has been established.

The following are some of the most common and characteristic species of the Dinantian Series as a whole :-

Foraminifera.

Hydrozoa.

Actinozoa.

Bryozoa.

Echinoderma.

Brachiopoda.

Lamellibranchia.

Gastropoda.

Cephalopoda.
Saccammina frontiniformis (syn. Carteri), Trochammina incerta, Endothyra.

Chætetes tumidus.

Amplexus coralloides, Cyathophyllum regium, Lonsdaleia floriformis, Clisiophyllum bipartitum, Dibunophyllum turbinatum, Cyathaxonia cornu, Phillipsastrea radiata, Syringopora geniculata, Lithostrotion affine, L. basaltiforme, L. striatum, Zaphrentis Phillipsi, Caninia cylindrica, Michelinia favosa, and M. megastoma.

Fenestella flabellata, Ceriopora gracilis.

Actinocrinus triacontodactylus, Amphoracrinus amphora, Platycrinus lævis, Poteriocrinus crassus, Woodocrinus macrodactylus ; Archæocidaris Urei, Palæchinus sphericus, Pal, gigas, Orbitremites derbiensis.

Athris (Seminula) ambigua, A. (Seminula) ficoides, A. (Cliothyris) Roissyi, Orthis resupinata, Spirifer striatus, S. clathratus, Syriugotliyris cuspidata, Productus semireticulatus, P. giganteus, Dielasma hastatum, Rhynchonella (Hypothyris) pleurodon, R. (Pugnax) acuminata, Spiriferina octoplicata.

Conocardium aliforme, C. libernicum, Pterinopecten papyraceus, Pt. sublobatus, Pt. granosus, Edmondia sulcata, Modiola Macadami, Myalina crassa, Cardionorpha orbicularis, C. oblonga, Posidonomya Becheri.

Euomphalus pentangulatus, Naticopsis plicistria, Pleurotomaria carinata, Murchisonia verneuiliana, Platyceras neritoides, Bellerophon Urei, B. tangentialis, Macrochilus ovalis, Capulus vetustus.

Colonautilus cariniferus, Cyrtoceras Gesneri, Orthoceras undulatum, Actinoceras giganteum, Poterioceras fusiformis, Gly phioceras diadema ( = crenistria), G. sphericum, Pronorites cyclolobus. 
Trilobita.

Entomostraca.

Pisces.

Phillipsia pustulosa, Griffithides globiceps, Brachymetopus ouralicus.

Leperditia Okeni.

Eurynotus crenatus, Rhizodns Hibberti, Elonichtliys Robisoni, Cladodus striatus, Cochliodus contortus, Orodus ramosns, Petalodns acuminatns, Psammodus rugosus.

\section{B. British Avonian Strata}

The surface areas occupied by the Lower Carboniferous or Aronian Series in the British Isles are shown on most geological naps. They are clearly shown on the cheap (2s.) Index map of the Geological Survey, and nost of them are indicated in the maps (Figs. 87 and 94) of this volume. The large extent of the area which they occupy in Ireland is especially noticeable, though the student must remember that in Fig. 94 the superjacent Coalneasures are not shown.

In England it is probable that the limestones extend eastward under large parts of the southern and central counties, but they do not appear to exist in the East Anglian connties, where many borings have been made at different times, but have always found rocks of pre-Carboniferous age beneath the cover of Cretaceous strata.

With regard to the superposition and relation to the older rocks it may be stated generally that the Carboniferous strata follow those of the Upper Devonian or Upper Old Red Sandstone in conformable succession wherever the latter are present; but when these are absent, the Carboniferons rests unconformably upon the older formations.

With respect to the subdivisions of the Avonian Series recent sturdies by Dr. Vanghan, Dr. W. Hind, and Professor Garwood liave shown that it is everywhere divisible into two stages, and as French geologists had already made two similar divisions, their names have been adopted, namely Toumaisian for the lower and $V i s e a n$ for the upper stage. In England each stage appears to be divisible into three zones, but the delimitation of these zones has not yet been determined in all districts. Where fully developed, the normal succession is as follows :-

\footnotetext{
Viséan $\left\{\begin{array}{l}\text { Dy. Cyathaxonia snb-zone. } \\ \text { D. Dibunophyllum zone. } \\ \text { S. Seminula zone. }\end{array}\right.$

C. Syringothyris zone.

Tournaisian $\left\{\begin{array}{l}\text { Z. Zaphreutis zone. } \\ \text { K. Cleistopora zone. }\end{array}\right.$
} 
It should be stated that Dr. Vaughan regards the Cyathaxonia Beds and their equivalents as a sub-zone of the Dibunophyllum zone, but as these equivalents include the Yoredale Beds of Yorkshire and a great part of the "Pendleside Series" of Dr. Hind, which possesses a peculiar fauna of its own, it seens desirable to give special prominence to them in a general scheme, though they are poorly represented near Bristol.

For convenience of description the more or less different facies which the Avonian Series presents in different parts of the British Isles will have to be treated under seven heads, viz. (1) Bristol and South Wales, (2) North Wales and Derbyshire, (3) South Lancashire and Yorkshire, (4) North Lancashire and Westmoreland, (5) Northumberland and Berwick, (6) Scotland, (7) Ireland.

\section{Bristol and South Wales}

The zonal study of the limestone series of the Bristol district by Dr. Vaughan ${ }^{1}$ has made it the typical exposure of that series in Britain. The succession is there complete from the base to the top of the Dibunophyllum zone $\left(\mathrm{D}_{2}\right)$, but no calcareous representative of the Cyathaxonia zone $\left(\mathrm{D}_{3}\right.$ and $\left.\mathrm{D}_{\mathrm{y}}\right)$ occurs in the Mendip or Bristol districts, and its equivalent must be sought in the sandstones which form the lower part of the so-called "Millstone grit."

The actual thickuess of the Limestone Series varies greatly in different parts of the area; it is thickest in the Mendip Hills, rather less at Clifton, and much thinner to the northward. Lithologically the series has been divided into four parts, which, with their varying thicknesses, are given below :-

Upper limestones and shales . . . . . $\begin{array}{llll} & 1200 & 1200 & 830\end{array}$

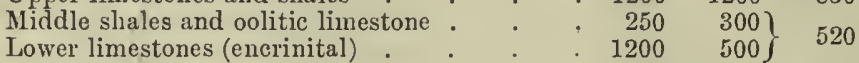

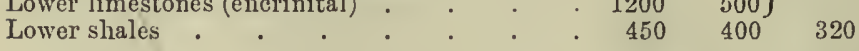

$\overline{3000} \quad \overline{2400} \quad \overline{1670}$

Dolomitisation is prevalent in the middle part of the series, and affects a greater and greater portion as the beds are followed northward. The lithology of the strata is, however, only of local importance, while the zonal divisions established by Dr. Vaughan form a standard by means of which the limestones and shales of other areas, whether they are in similar or dissimilar sequénce, can be compared with the Avon section.

The Cleistopora zone is coextensive with the lower shales, and is divisible into two portions, the lower 100 feet forming the phase 
of Modiola (cf. lata), and the higher beds containing Productus bassus, and near the top an abmudance of Cleistopora geometrica, a small componnd coral of Michelinioid aspect.

The Zaphrentis zone cousists of encrinital limestones characterised in the lower part by an abundance of Spirifer clathratus, and in the upper part by Zaphrentis Konincki.

The Syringothyris zone consists largely of dolomitic and oolitic limestones in which Caninia cylindrica, Michelinia cf. megastoma, and Spirifer (Syringothyris) cuspidatus are comnon and characteristic fossils. Caninia patula marks a lower, and C'yathophyllum (sp. $\phi$ ) au upper sub-zone.

The Seminula zone consists of limestones with shale-partings in the lower part, and beds of pisolitic limestone in the upper. 'The index fossil is the Athyrid Seminula ficoides, but Productus corrugato-hemisphericus is common, as also are massive and dendroid Lithostrotions and Carcinophyllum.

The Dibunophyllum zone consists of limestones, shales, and occasional grits. It is characterised by the abundance of highly developed corals: Dibunophyllum (simple in the lower and advanced in the upper sub-zone; Lithostrotion irregulare, Cyathophyllum Murchisoni are conmon forms; Lonsdaleia floriformis and Cyathophyllum regium mark the upper sub-zone.

At Wickwar, near the northern end of the Bristol coalfield, the limestone series is reduced to 1670 feet, and farther north, in the Forest of Dean area, it is less than 600 feet. In the last-mentioned area the highest limestones are of Seminula age, and are succeeded conformably by sands and quartz-pebble conglomerates that have been referred to the "Millstone grit" although they are of considerably earlier age than the base of the typical Millstone grit of the Midlands and Yorkshire.

In South Wales, at the eastern end of the coalfield, the Avonian Series, with slaales at base and summit, is abont 1000 feet thick near Cardiff and Newport, but thins northward to less than 500 . (The series is, however, incomplete at the top as Millstone grit lies unconformably upon S'eminula and Lower Dibunophyllum Beds.) Westward, near Rhymney, and in the Gower Peninsula, the Aronian attains a thickness of 3000 feet. There the black shales and limestones ${ }^{2}$ above the Dibunophyllum limestone (see Fig. 77) yield a peculiar fanna, including the Goniatites Glyphioceras bilingue, $G$. spirale, and $G$. reticulatum. These are characteristic species of the Pendleside Beds of Lancashire and North Stafford, and belong to a zone or sub-zone which lies between the Dibunophyllum zone of the Bristol area and the typical Millstone grit of the Dovedale country. 

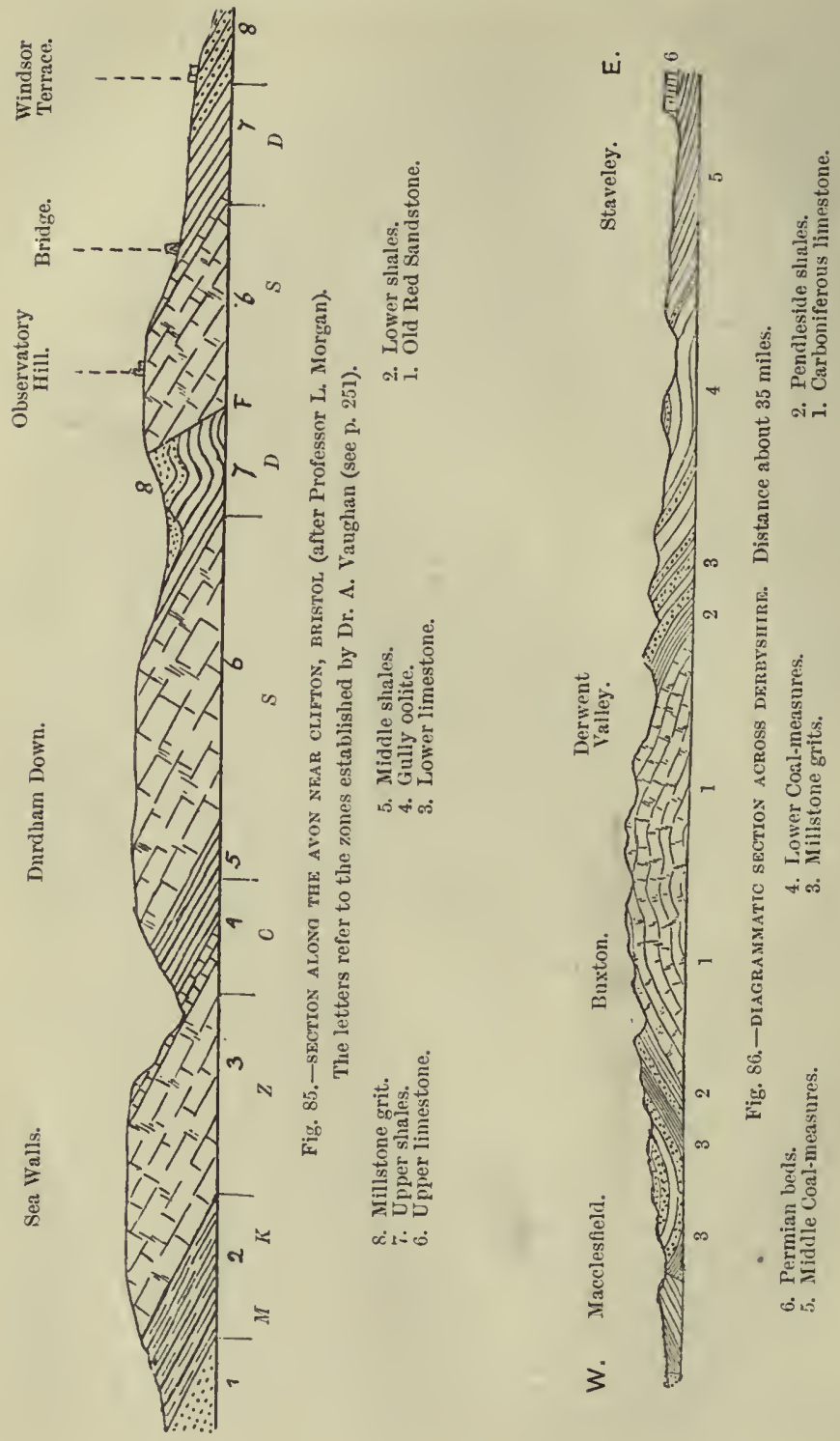
In Pembrokeshire all the zones are well developed, and are tinely exhibited in the coast sections. At Skrinkle Haven the junction of Old Red Sandstone and basal Carboniferous is well shown; the central beds constitute the Tenby anticline, and the "Pendleside" Beds are found north of that place, where they consist of black carbonaceous shales with large ellipsoidal concretions, locally known as bullions. These beds contain Glyphioceras diadema, Pterinopecten papyraceus, and Posidoniella membranacea.

\section{North Wales, Stafford, and Derby}

The great difference between the limestone series of this area and that of South Wales and Gloucestershire is that it belongs entirely to the Viséan stage, the basal beds being on the horizon of the upper part of the Seminula zone; so that there is no representative of the Tournaisian stage.

The lithological divisions were studied and described by Mr. G. H. Morton and Dr. A. Strahan, while the palæon tological zones have recently been worked out by Dr. W. Hind and Mr. J. T. Stobbs. ${ }^{3}$ The most complete sequence is found in Flintshire, and this is given in the following table:-

\begin{tabular}{|c|c|c|}
\hline Lithological Divisions. & Zones. & Thickness. \\
\hline $\begin{array}{l}\text { Holywell shales } \\
\text { Teilia Beds }\end{array}$ & Posidonomya Becheri & 1000 \\
\hline $\begin{array}{l}\text { Cherty sandstones } \\
\text { Aberdo limestone }\end{array}$ & Upper Dibunophyllum & 450 \\
\hline $\begin{array}{l}\text { Grey limestone } \\
\text { White limestone }\end{array}$ & Lower Dibunophyllum & 1100 \\
\hline $\begin{array}{l}\text { Brown limestone } \\
\text { Basal conglomerate }\end{array}$ & Seminula & 450 \\
\hline
\end{tabular}

About $\overline{3000}$

The absence of Caninia makes it fairly certain that only the top of the Seminula zone comes into the succession. The lower part of the Dibunophyllum zone is marked by the presence of that genus with Cyathophyllum Murchisoni, Productus hemisphericus, and $P$. cora.' The highel part contains all the typical fossils of its Bristol equivalent, and the species of Lithostrotion are common, as are also several species of Spirifer and Schizophora resupinata. The sandy beds at the top of this zone consist of compact finegrained sandstone, each bed having a medial band of grey or black chert which is full of sponge spicules. These beds and the Aberdo limestone are regarded as a separate sub-zone characterised by the coral Cyathaxonia and Productus longispina. They form a passage into the overlying stage. 


\section{GEOLOGICAL MAP OF THE NORTHERN PART OF ENGLAND}

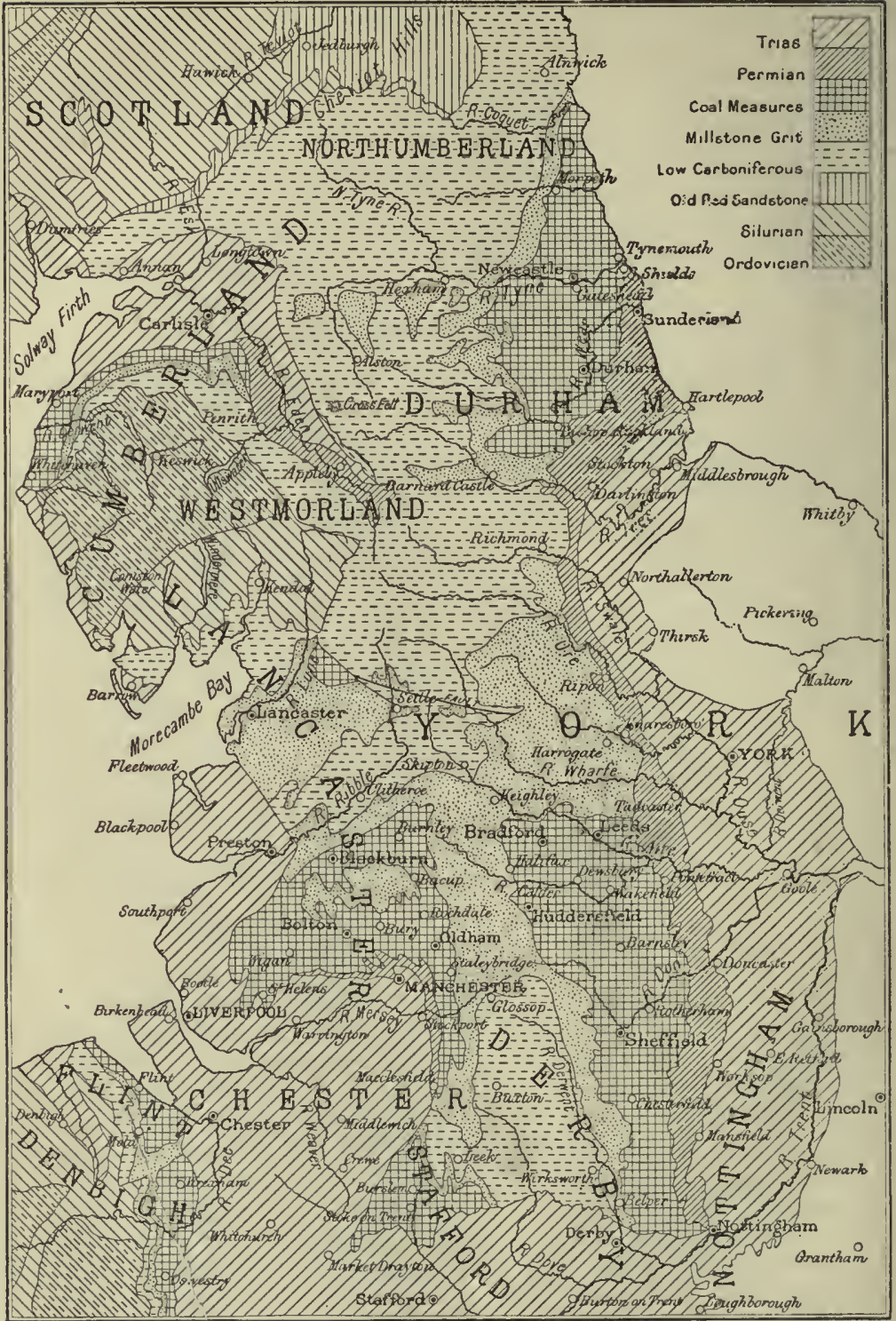

SCALE OF MILEE 
The true position of the Holywell shales was first indicated by Dr. Hinde, and the group is undoubtedly the equivalent of his Pendleside Series. In Flintshire it consists, in the lower part, of black shales with layers of black limestone and chert, yielding the bivalves Posidonomya and Pterinopecten, while the higher part is composed of soft shales in which Posidoniella lavis is common.

Southwards all these beds decrease in thickness rather rapidly, and they finally thin out south of Oswestry, only the ligher part of the limestone with Prod. giganteus appearing again for a short distance in Shropshire, near Lilleshall. Westward the whole series is faulted down into the Vale of Choyd, and portions of it occur along the coast; thus, in the Orme's Head promontory near Llandudno, the greater part of the limestone series is found with a thickness of 1150 feet, though neither the base nor the summit is seen. In Anglesey tracts occur on the border of the Menai Strait, and a larger one is faulted into the central part of the island; the lowest limestones here belong to the white division, and in places they include beds of white sandstone and conglomerate from 90 to 100 feet thick.

In North Staffordshire and Derbyshire the zonal succession has recently been determined by Mr. Sibly, and found to be as follows :-

Deet.

$\mathrm{D}_{3}$ 4. Shales and thin beds of black linestone (Yoredale Beds) . 400

D.2 3. Grey and white limestones containing layers of chert (subzone of Lonsdalcia floriformis)

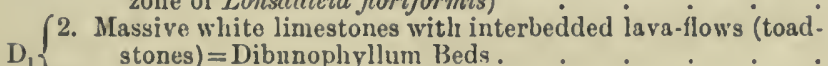
600

1. Datos) = Dibinophyllum Beds.

2400

The actual base is wowlere exposed, and consequently the total thickness of the series is unknown, but it is doubtful whether it exceeds 3000 feet even in the centre of the area. The whole of the series thins out to the south-west before reaching the South Staffordshire coalfield, but continues toward the south-east beneath the small Leicestershire coalfield and wraps round the pre-Canbrian rocks of Charnwood Forest.

The limestones which conrpose the "Mountain limestone" of Derbyshire vary much in lithological character, ${ }^{4}$ some consisting mainly of broken fragments of crinoids and shells, otlers of corals and coral debris, and others being compact and foraniniferal, while in many parts the organisms liave been obscured or destroyed by the chemical clianges of narmorisation or dolomitisation.

The upper surface of $D_{2}$ shows signs of contemporaneous 
erosion, and is overlain by a bed of rolled shells and limestone pebbles with occasional quartz pebbles; it was first found at Castleton, but has since been traced by Dr. W. Hind through the whole of Derbyshire and North Staffordshire. It contains many Brachiopods, trilobites, and teeth of Psammodus, Psephodus, etc., and shows that the current which brought the muddy sediment of the overlying shales was at first strong enough to break up and destroy some of the previously formed limestone, which at that time was, of course, in an unconsolidated condition.

The shales above mentioned are termed the Yoredale shales by the Geological Survey and the Pendleside shales by Dr. W. Hind, but as we shall presently see that the two groups are contemporaneous and not successive, as Dr. Hind supposed, it does

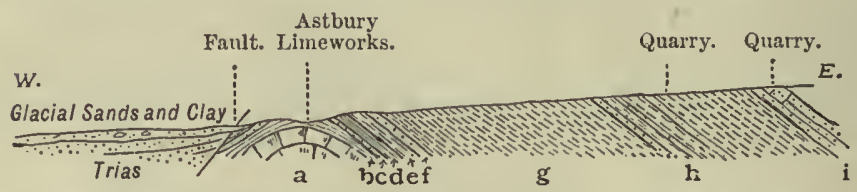

Fig. 88. - SEction throvgh CONGLeton EDGE (by W. Gibson and W. Hind).

$h, i$. Millstone grits. g. Pendleside shales. $b$ to $f$. Grit, tuff, limestone, and shale.

a. Main Avonian limestone.

not matter which name they bear. The relation of these shales to the limestone below and the Millstone grit above is shown in Fig. 88.

\section{South Lancashire and Yorkshire}

The Avonian Series is brought up again from beneath the Millstone grits in Lancashire and West Yorkshire (see map, Fig. 87 ) by an anticlinal flexure which runs in a north-easterly direction from near Blackburn by Clitheroe to Skipton, with a more northerly prolongation by Cracoe across Wharfedale by Burnsall. From these places this division of the system spreads northward and occupies a large irregular tract of ground varying from 15 to 30 miles in width through Yorkshire, Durham, and the eastern parts of Westmoreland and Cumberland.

The rocks of this large area present two different facies, one in the south-west, which has been called the Lancashire or Clitheroe type, and the other to the north, which is known as the Yoredale type. Moreover, the transition from one to the other is rapid, and coincides closely with the line of the Craven fault, which runs obliquely across the area from near Kirkby Lonsdale by Ingleton, Stainforth, and Linton. South of this line the beds 
attain a great thickness and their base is nowhere exposed; north of it the base is exposed in several places, resting on a floor of upturned Ordovician and Silurian rocks, but the series is much thinner (see Fig. 90).

For the following comparative view of the succession in the two areas I am indebted to Dr. Vaughan.

\begin{tabular}{|c|c|c|c|c|}
\hline & $\begin{array}{l}\text { Clitheroe District. } \\
\text { Millstone grit } \\
\text { (4th grit). }\end{array}$ & Feet. & $\begin{array}{l}\text { Ingleton District. } \\
\text { Millstone grit } \\
\text { (4th grit). }\end{array}$ & Feet. \\
\hline & $\begin{array}{l}\text { Bowland sliales } \\
\text { Pendle grit. }\end{array}$ & $\begin{array}{r}50 \text { to } 800 \\
\text {. } 0 \text { to } 300\end{array}$ & SShales & 100 \\
\hline & $\begin{array}{l}\text { Pendleside limestone } \\
\text { Pendleside shales }\end{array}$ & $\begin{array}{r}.100 \text { to } 400 \\
. \quad 1200\end{array}$ & Yoredale Beds & 400 \\
\hline & Clitheroe & es . 2800 & $\begin{array}{l}\text { Sear limestones } \\
\text { Basement Beds }\end{array}$ & 800 \\
\hline
\end{tabular}

The Clitheroe and Cracoe limestones have not yet been completely zonalised, but Dr. Vaughan informs me that the main Clitheroe knolls include representatives of $\mathrm{D}_{1}$ and of $\mathrm{S}$ (Seminula zone), and that the beds at the base of the main knolls belong to $\mathrm{C}_{2}$ (Syringothyris zone), but there is a considerable thickness of limestone below that horizon.

Near Ingleborough the lowest beds are not older than the top of the Syringothyris zone, and the total thickness of Viséan limestones is only 600 feet. $^{5}$ Northward, however, they thicken again considerably till near Kirkby Stephen there is 3700 feet of them. Then they again diminish by the rapid thinning out of the lower beds till in the Cross Fell district they are once more reduced to 600 or 700 feet, and much of this is sandstone. Fig. 91 illustrates the position and composition of the Viséan Group at Ash Fell and Roman Fell, east of Appleby, and the map (Fig. 89) shows the course of the buried ridge of Ordovician rocks which causes this thinning-out-a ridge which forms a natural northern linit to the region we are describing.

Returning now to the north-east of Lancashire the higher stage, comprising the Pendleside and Yoredale Beds, remains to be dealt with. The succession of beds forming the Pendleside Group was filly described by Dr. W. Hind, ${ }^{6}$ and is given above; the black Pendleside shales are characterised by Pusidonomya Becheri and Plerinopecten papyraceus, and the Pendle limestone by the same with Glyphioceras spirale and G. reliculatum. In the Clitheroe and Pendleside districts the total thickness of this group is at least 2500 feet, but it thins northward, and when the Settle faults are crossed its place is takeu by such a different set of beds that the identity of the two groups has been for a long time in 
doubt. This year (1911), however, Mr. Cosmo Johns ${ }^{7}$ has published evidence which seems to show that the Pendle limestone is the equivalent of the "main limestone" near the top of the Yoredale Beds.

The Yoredale Beds consist of limestones with intercalated bands of shale and sandstone, the limestones being persistent bands which have been traced for long distances, and eacli band has received a special name. The highest of the Yoredale limestones is known

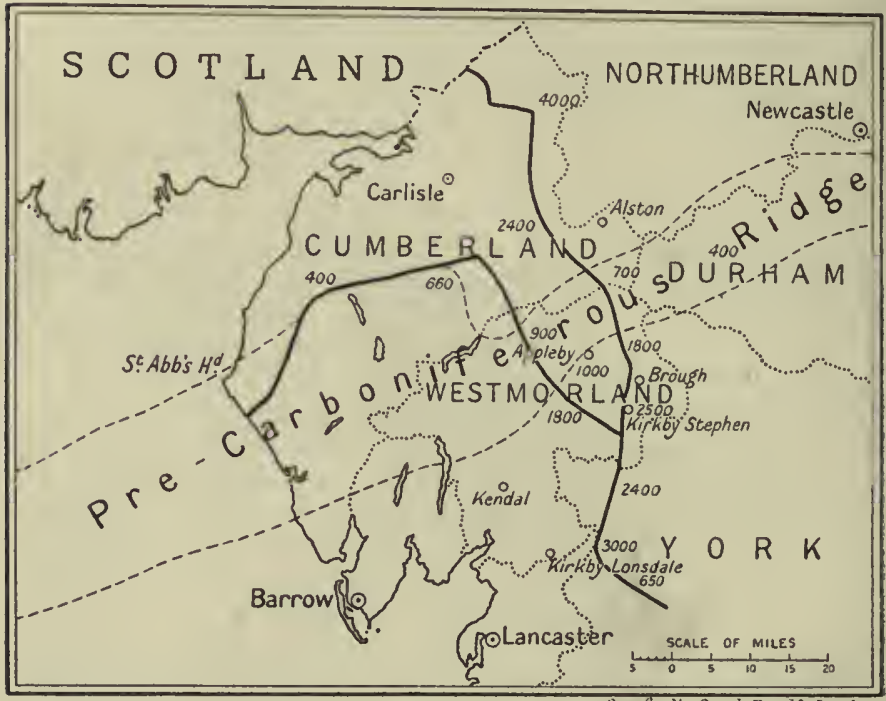

Fig. 89.-MAP OF THE NORTH-WESTERX COUXTIES TO SHOW THE POSITION OF THE PRE-CARBONIFEROUS RIDGE (Goodchild).

as the "main limestone," and the lowest as the "Hardraw limestone." Between these at Ingleborough there are three other limestones, and farther nortl two others come in, so that in Wensleydale there are seven Yoredale limestones.

Dr. Vaughan informs me that the fauna of the Yoredale Beds is identical with that of the upper part of the Dibunophyllum zone of Bristol $\left(\mathrm{D}_{2}\right)$, and thus, if the beds are the equivalents of the Lower Pendleside Group, the latter nust have been formed under different bathymetric conditions.

Above the "main limestone" of Wensleydale there are some peculiar beds which, though of no great thickness (160 feet), are 

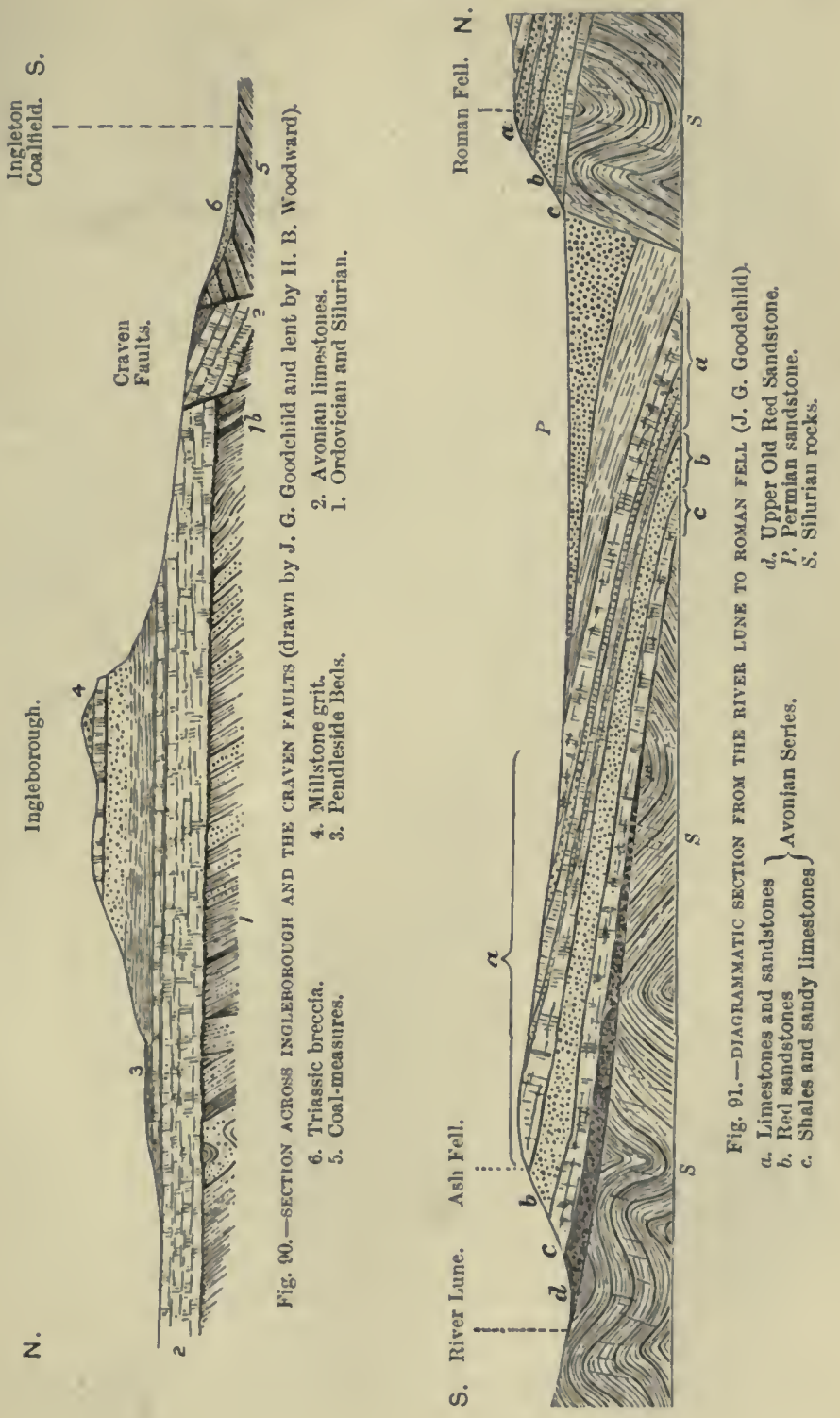
remarkable both in their lithological and palæontological characters. They include two beds of limestone, each of which is overlain by a band of chert-beds; the lower set is known as the "Red Beds," and the upper as the "Crow limestone and chert." The chert in the Red Beds is 42 feet thick, and has yielded a remarkable set of fish teeth, an account of which, with a complete enumeration of the beds at Leyburn in Wensleydale, has been published by Mr. J. W. Davis.

\section{North Lancashire and Westmoreland}

The area occupied by Avonian limestones in this district is shown on the map (Fig. 87), and the beds have been recently studied and classified by Professor Garwood, who finds representatives of both the Tournaisian and Viséan stages. ${ }^{8}$ The fauna, however, contains some special elements, and the relative abundance of species is different from that prevailing near Bristol, so that he found it well to make different zonal divisions, though these can be roughly correlated with the southern zones. The following table is copied from that given by him :-

\begin{tabular}{|c|c|c|c|}
\hline & Zones. & Subzones. & \\
\hline 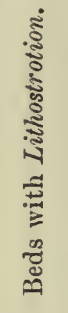 & $\begin{array}{l}\text { Dibunophyllum } \\
\\
\text { Productus corrugato- } \\
\text { hemisphericus } \\
\text { and } \\
\text { Spiriferina laminosa }\end{array}$ & $\begin{array}{c}\left\{\begin{array}{l}\text { Upper }(?) \\
\text { Middle }\left\{\begin{array}{c}\text { Productus latissimus } \\
\text { and } \\
\text { Lonsdaleia floriformis }\end{array}\right.\end{array}\right. \\
\text { Lower }\left\{\begin{array}{c}\text { Cyathophyllum } \\
\text { Murchisoni }\end{array}\right.\end{array}$ & $\left.\begin{array}{l}\mathrm{D}_{3} \\
\mathrm{D}_{2} \\
\mathrm{D}_{1} \\
\mathrm{~S}_{2} \\
\mathrm{~S}_{1}\end{array}\right\}$ \\
\hline 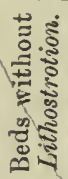 & $\begin{array}{l}\text { Michelizia megastoma } \\
\text { Athyris glabristria }\end{array}$ & 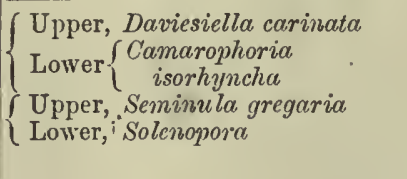 & $\left(\begin{array}{c}\mathrm{C}_{2} \\
\mathrm{C}_{1} \\
\gamma \\
\mathrm{Z}_{2} \text { ? }\end{array}\right\}$ \\
\hline
\end{tabular}

The lowest beds are shales and conglomerates found in Ravenstone 
Dale and near Shap in Westmoreland, and it is these which he refers to the top of the Zaphrentis zone.

The lowest limestones are highly magnesian, and appear to have been deposited under lagoon-like conditions which encouraged the growth of calcareous algre, especially Solenopora, and these have contributed largely to the formation of these beds.

Most of the Visean limestones are rich in Foraninifera, Saccammina being abundant in the D zone. The highest beds are those of Humphrey Head (Morecaube Bay) and of Brampton near Shap. The full thickness is probably over $\mathbf{3 0 0 0}$ feet, but lessens northward.

\section{Northumberland and Berwick}

From the buried ridge of older rocks which is indicated in Fig. 89 the thickness of the Avonian Series again increases; thus the main mass of the Viséan or Scar limestone becomes still further split up by the intercalation of beds of shale and sandstone till, near Alston, it has expanded from about 400 to 1600 feet, with twelve distinct bands of limestone. It has, in fact, assmmed a facies similar to that of the overlying Yoredale Group.

Moreover, the series increases by the incoming of lower and lower beds, some of them representing Tournaisian stages, and at Alston these are 1000 feet thick and about 2000 on the Scottish border. This lower group contains but little limestone, and is largely arenaceous, so that the name of Tuedian was given to it in 1856 by Mr. G. Tate, from its fine derelopinent along the valley of the Tweed.

Similarly in 1877 Professor Lebour proposed the name Bernician for the compound facies which represents the ligher limestones of the Viséan and the Yoredalian stage.

Probably the most convenient provincial classification of the series is that adopted in recent memoirs of the Geological Survey, but this now requires to be brought into line with the zonal classification of more southern areas, and with the "stage" divisions which have been used in the preceding pages. The zonal comparison has been accomplished in large part by Professor Garwood, ${ }^{9}$ and is indicated in the following table, except with regard to the ligher beds, which, being the equivalents of the Yoredale Beds, must represent the highest part of the Dibunophyllum zone if Mr. C. Johns' views are correct :- 
Subdivisions.

Zones. Stages.

Upper Calcareous division (from the Millstone grit
to the top of the Oxford limestone). Saud-
stones and shales with some coals and one
or more beds of marine limestone, $1200-2000$.
stone to base of Dun or Redesdale lime-
stone). Sandstones and shales with coals
and many beds of marine limestone, $800-$
1000 e. Lower Calcareous division (from Oxford lime-

d. Carbonaccous division (Scremerston Beds). Strata prevalently carbonaceous ; linestones chiefly thin, many containing carbonaceous matter ; many coal-seams, 800-2500

(c. Upper Tuedian or Fell Sandstone Group : a belt

of massive grits with grcen, grey, and reddish

shales; coals rare and thin, 500-1600.

b. Lower T'uedian or Cement-stone Group : sandstones and shales with bands of cement-stone passing into limestones near Rothbury and Bewcastle, $500-1500$

a. Basement conglomerates (Upper Old Red Sandstone), 0-500. .

Tuedian Series.- $a$. 'The basement conglonerates occur locally round the Cheviot Hills, and are by some referred to the Upper Old Red Sandstone, but they pass up into the overlying sandstones, and certainly form a local base of the Carboniferous System. They are of a reddish-brown colour, and contain rolled pebbles of the Cheviot porphyrites.

b. This group consists of yellow and reddish sandstones, grey and purple shales, greenish sandy clays (sometimes full of hard siliceous collcretions), and beds of hard cream-coloured earthy limestone or cement-stone. In these beds fossils are rare and badly preserved, but Modiola Macadami occurs. Near the top are limestones in which Professor Garwood has found Syringothyris cuspidata, Athyris glabristria, and Orthotetes crenistria, and these are sufficient to indicate the zonal age.

c. The Fell sandstones form a broad belt of high and rugged country in the west of Northumberland, rising into craggy hills such as those of the Chillingham and Simouside Hills, and the Peel and Bewcastle Fells. These sandstones are divided by bands of shale, and a few thin seams of coal occur. The fossils are chiefly plant remains, but Archanodon Jukesi has been found in the lowest (Harbottle) grit, and Professor Garwood has also discovered a few marine fossils in the lowest beds on the borders of Cumberland; these include Camarophoria isorhyncha and Spiriferina laminosa, which in Westmoreland are restricted to the lower part of the Seminula zone. ${ }^{9}$ 
Bernician Series.-On the sonthern border of Northumberland the Scar limestone of Yorkshire and the Yoredale Beds are still distinguishable as separate stages, but as they are followed northward they lose their distinctive charncters and merge into one great series of alternating limestones, shales, and sandstones, witl many workable beds of coal.

The most remarkable feature of this series is the great development of mechanical sediments in the centre of the county, some of the lower beds expanding into the "Carbonaceons" Group, and many fresh beds of sandstone and shale with coal-seams coming in above the Main Yoredale limestone to form the upper calcareous division, so that the whole is about 6000 feet thick, but again becomes thimner to the northward.

The Curbonaceous division has not yielded many marine fossils, but Professor Garwood has found Spiriferina laminosa with dendroid Lithostrotions, and the groul is referable to $D_{1}$. The lower calcareous group contains species of Dibunophyllum with Cyathophyllum regium and Lithostrotion junceum, so that its zonal age is evident, and it is noteworthy that several of the limestones are largely composed of the Foraminifer Saccammina Carteri.

The Oxford limestone is probably the equivalent of the Hardraw limestone of Durham, and if so the beds above this correspond with the Yoredale Gromp, but the Pendleside Ceplalopoda have not yet been found. On the other hand, the corals Lonsdaleia floriformis and Alveolites septosa, with the Brachiopods Productus giganteus and $P$. latissinus, first appear in and above the Oxford limestone.

\section{Scotkend}

The central lowlands of Scotland display a great thickness of Lower Carboniferous rocks which may be regarded as the equivalents of the Tuedian and Bernician Series of Northumberland, for the Scottisl Series is similarly divisible into a lower group, which is mainly arenaceous, and an upper more varied group of shales, sandstones, limestones, and coals. The lower has been called the Calciferous Sandstone Series, and the upper was termed the Carboniferons Limestone Series, but the equivalents of the main mass of the Carboniferous limestone lie entirely below this "limestone series" of 'Scotland. Thus the nomenclature formerly used by the Geological Survey and adopted in most text-books gives rise to misconception and tends to exaggerate the stratigraphical importance of the upper part of the series. For while the upper portion, which has a thickness of only from 1600 to 1800 feet, 

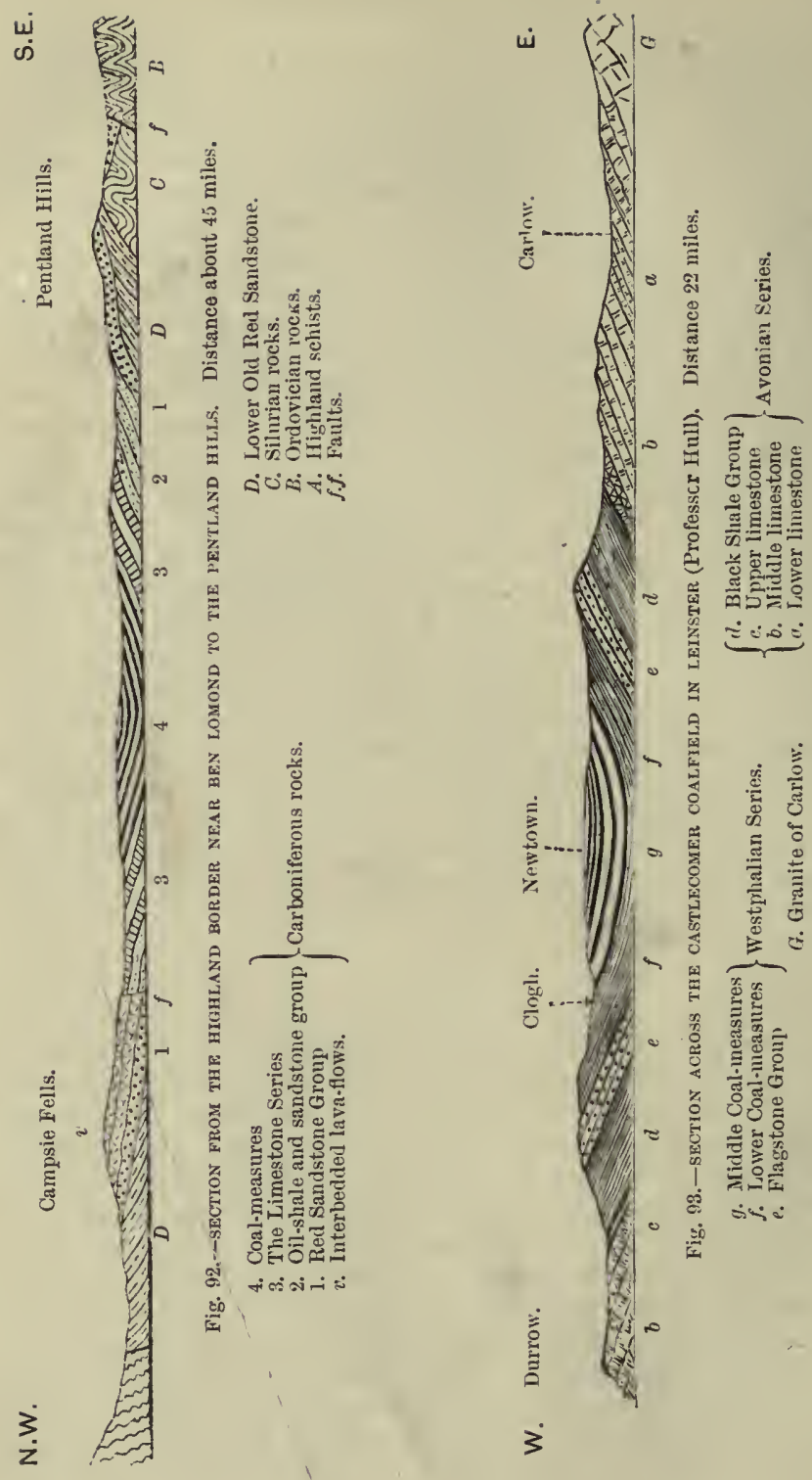
has been divided into three groups, the lower portion, which is nearly 6000 feet thick, was undivided.

According to the late J. G. Goodchild ${ }^{10}$ the lower portion is equally capable of division into three groups, which he called (1) the Ballagan Beds, (2) the Granton and Hailes sandstones, (3) the Oil-shale Group. He regarded the sandstone group as the equivaleuts of the Fell sandstones and the Oil-shales as corresponding with the Carbonaceous division of the Border counties. The Geological Survey has not entirely accepted this nomenclature, ${ }^{11}$ but has included the massive sandstones in the Oil-shale Group becarse some thin oil-shales have been found in them. In the following table Goodchild's divisions are adopted as being convenient and lending themselves to correlation with Northumberland.

Average

Thickness.

500

800

500

2500

1500

1300
Scotch Divisions.

f. Upper Limestone Group

e. Edge Coal Group

d. Lower Limestone Grollp

c. Oil-shale Gronp

$b$. Granton and Hailes sandstones

$a$. Cement-stone (or Ballagan) Beds
Northumberladd.
Yoredale Beds.
Fell sandstones.
Cement-stone Beds.

Cement-stone Group.-In Edinburgh, Linlithgow, and Fife this consists in the lower part of clays, shales, sandstones, and tuffs with some beds of dull compact limestone (cement-stone) and of siliceous sinter; this part is about 200 feet thick. Next in the Edinburgh district comes the volcanic episode of Arthur's Seat, a set of basaltic lavas and tufis with interstratified sandstones and shales, having a total thickness of 750 feet. These are covered by the Abbey Hill shales, which are 300 feet thick and contain marine fossils. The fossils in the lower part of the group are chiefly plant remains and small freshwater Crustacea (Leperditia, Estheria, Bythrocypris, etc.), but at Belhaven, near Dunbar, a flattened form of Modiola Macadami occurs in hundreds.

In the Glasgow district this group has been called the Ballagan Beds, and there it consists entirely of sedimentary deposits, sandstones, shales, and argillaceous limestones, without any contemporaneous volcanic rocks, though the thickness is still from 1200 to 1500 feet.

Granton and Hailes Sandstones.-This group consists of two thick sandstones separated by a band of shales. The lower member is the Granton sandstone, probably about 800 feet thick; the central band consists of the Warlie shales (400 feet), and the upper is the Hailes sandstone, which may be 1000 feet thick. These sandstones form good building stones, but have yielded few 
fossils; but the Wardie shales contain Schizodus pentlandicus, Naiadites obesa, Anthracomya levvis, and others. These beds gradually thin westward till near Glasgow there is only 100 feet of such sandstone.

Oil-shale Group.- This group takes its name from the prevalence of black bituminous shales which contain large quantities of petrolenm, some bands of them being so rich as to yield from 30 to 40 gallons of oil per ton of shale, besides a considerable quantity of sulphate of ammonia as a by-product in the process of abstraction.

Near Edinburgh there is a bed of oil-shale above the Hailes sandstone which makes a convenient base to the group, and about 900 feet above this is the Burdiehouse limestone, a bed of dark-grey limestone 20 to 30 feet thick and crowded with the cases of the small Ostracod Leperditia Okeni (var. burdigalensis). Another limestone band higher up is entirely composed of the shells of Productus semireticulatus and $P$. longispinus.

The group is most fnlly developed in Fifeshire, where it is over 3000 feet thick, containing many seams of oil-shale and no fewer than eighteen beds of limestone containing marine fossils; but the mass of the group consists mainly of shales and sandstones which contain the remains of fish, plants, and estuarine molluses, especially Naiadites obesc. These sediments are interstratified with sheets of volcanic material - basalts and basaltic tuffs-and are pierced by a large number of pipes and bosses of volcanic agglomerate which are the orifices of small volcanic vents.

When followed westward by Stirling and Dumbarton to Renfrew and the Isle of Arran, the oil-shales become much thinner and are interstratified with lava-flows, which in some districts seem entirely to take the place of the sedimentary deposits.

Lower Limestone Group.-Near Edinburgh this group has a thickness of 400 feet to 500 feet, and contains three beds of limestones, but these are seldom more than 12 feet thick, though occasionally swelling out to 30 feet, and in the Bathgate Hills (Linlithgow) to 70 or 80 feet. In Ayrshire the Hurlet, or Main limestone, attains a thickness of 100 feet. Spirifer trigonalis, Productus giganteus, and $P$. semireticulatus are common fossils, and in some places the liniestones are largely crinoidal, i.e. composed of the shelly plates which form the arms and stems of crinoids. These limestones are interbedded with a series of shales, sandstones, and coal-seams, several of the coals being immediately succeeded by a limestone, e.g. the Hurlet coal and limestone, as if there had been times when the shallow lagoons and swamps were suddenly submerged and occupied by marine organisms. 
Edge Coal Group.-This is a shale and sandstone series, and it includes some valuable seams of coal, ironstone, and oil-shale, but no limestones. In Midlothian its thickness is about 800 feet. Some of the beds contain marine shells, others are full of terrestrial plants, showing that the gradual subnergence which was in progress was now and then counterbalanced by the deposition of the sedi. ment brought down in such quantity by rivers.

Upper Limestone Group.-This is about 600 feet in Midlothian; it contains three bands of limestone and four seams of coal, interstratified with sandstone, shale, and fireclay. The limestones contain the same fossils as those of the lower group, and though seldom more than three or four feet thick have been traced over an area of at least 1000 square miles, thus proving that the physical conditions of the period were very uniform over a large area.

In the western part of the area (Glasgow, Renfrew, and Arran) all these equivalents of the Yoredale Beds are mich thinner, the Lower limestones being only 60 feet, the Edge Coal Group about 200, and the Upper limestones about 150 feet. All of them are found in Arran, where the red Corrie limestone is regarded as the equivalent of the Hurlet linestone of the mainland, for many of the beds are stained red in Arran.

\section{Ireland}

In no country can the rocks of the Carboniferous System be better studied than in Ireland. They occupy fully one-half of the superficial area of the country; the whole of the great central plain, which stretches completely across the island from east to west, consisting of Carboniferous limestones, though its surface is often covered by Pleistocene gravels (see mal, Fig. 94). Here and there this limestone plain supports hills of low elevation composed of the Coal-measures, these outliers being the sole remnants of the beds which once spread over the limestone; their survival being due to the circumstance of their lying in synclinal basins.

For the sake of clearness and brevity the chief facts regarding the Avonian Series of Ireland will be given under three heads, (1) Northern counties, (2) The Great Ceutral Plain, (3) Southern counties; the first and thind of these areas each exhibiting a special and peculiar facies of the formation differing greatly from that of the central area.

Northern Counties.-The Carboniferous rocks of the more northern counties are merely an extension of the Scotch facies, but show a passage into the limestoue facies as they are traced into 


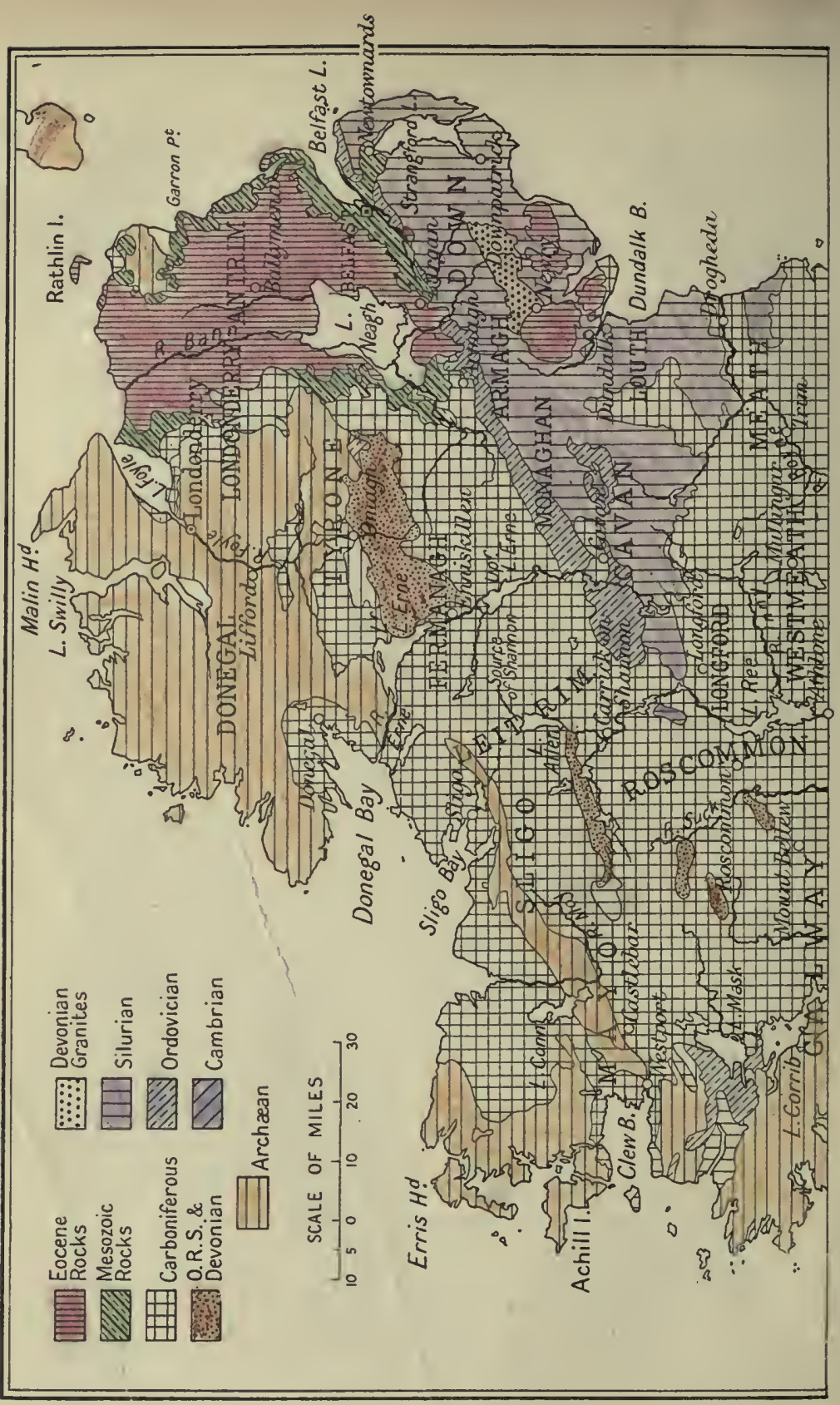




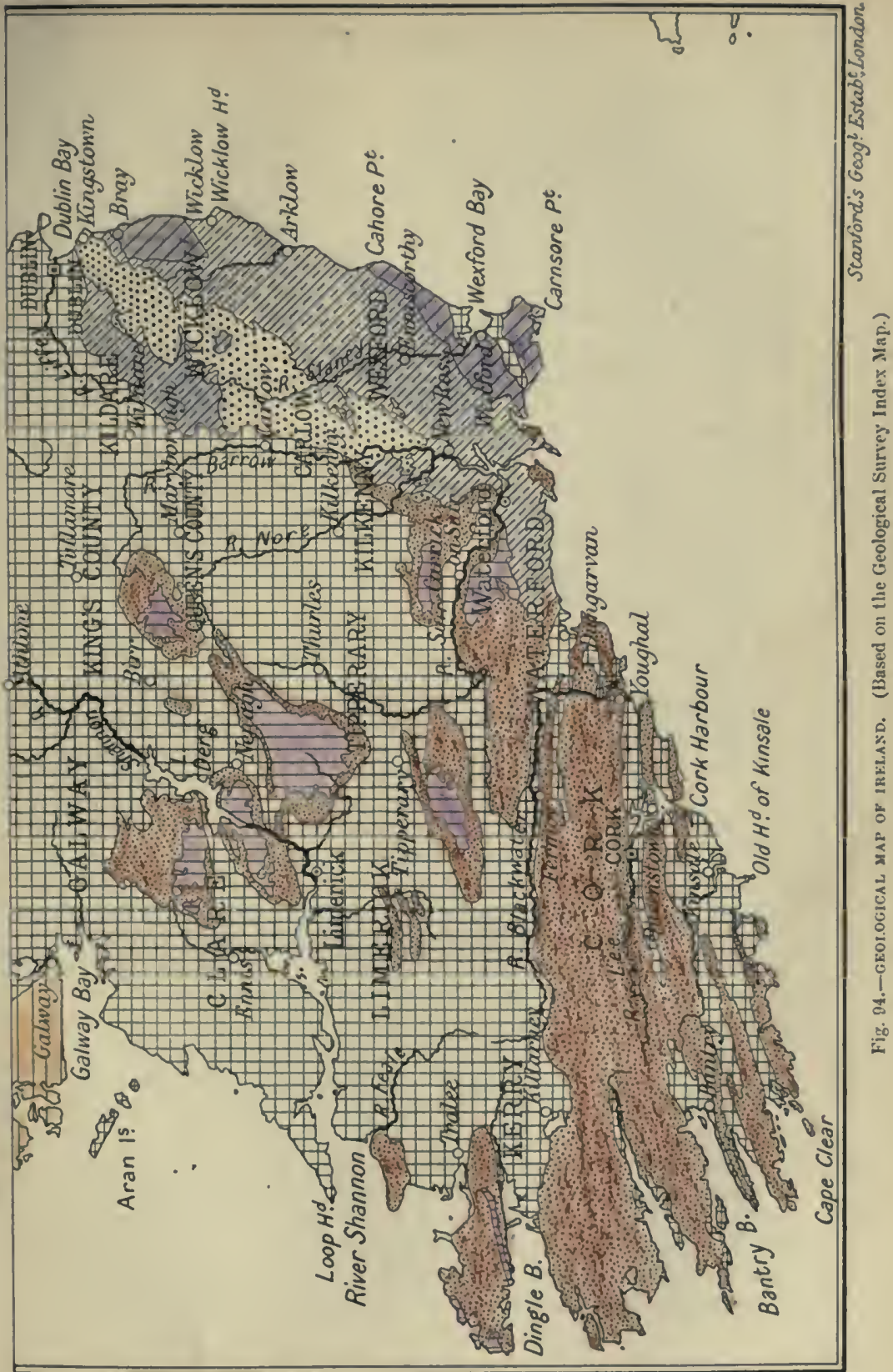


Leitrim and Sligo. In the counties of Derry and Tyrone a series similar to that of Arran and Ayrshire is found; the basement beds of red sandstone and conglomerate resting directly either on the Archæan schists or on the Lower Old Red Sandstone. The Tuedian or Calciferous sandstone is represented by about 2000 feet of strata, about half of which consists of reddish-brown sandstones, succeeded by calciferous sandstones and bands of shale which are well exposed in the valley of the Moyola River near Drapersdown. In these higher beds the commonest fossils are, Leperditia Okeni, Modiola Macadami, and Protoschizodus axiniformis, with Dithyrocaris Colei, Cypris burdigalensis, and remains of fish.

Above these beds, at Cullion and Desertmartin, limestones come in which are arenaceous in the lower beds and dolomitic in the higher; the prevalent fossils are corals (Lithostrotion junceum, $L$. affinis) and Brachiopods (Productus giganteus and Orthis resupinata).

Southwards the lowest beds appear to thin out, while higher beds come in above, so that in Fermanagh, Leitrim, and Sligo there is a more complete succession which, according to Messrs. Hull and Hardman, is as follows :- ${ }^{12}$

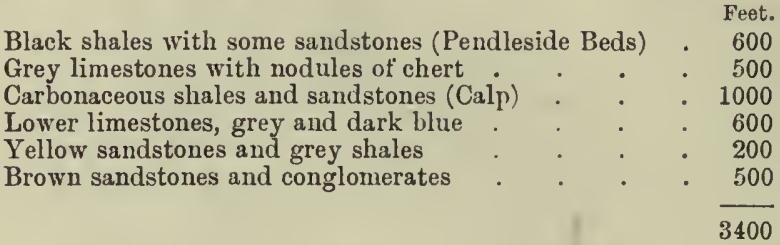

The basal beds are sometimes called Upper Old Red Sandstone, but they rest unconformably upon the Lower Old Red (see p. 237), and are now generally regarded as Lower Carboniferous because they seem to be the equivalents of similar beds in Derry and of the Lower Tuedian of Berwick.

Westward, in Sligo and Mayo, there is a similar stucession, but the basal beds are absent and the lower limestones pass laterally into beds of calcareous breccia and conglomerate, indicating a shore-line. The upper limestone rises into hills with bold craggy escarpments, while the softer beds of the Calp have been eroded into broad vales.

Great Central Plain.-The central part of Ireland, from the shores of Dublin and Meath to Galway Bay and Lough Corrib, is a great tract of low undulating land which seldom rises to more than 300 feet above the sea. In consequence of this low elevation, the general horizontality of the limestones below it, and the prevalence of Pleistocene deposits, exposures are few in the central area, and 
it is only in the outer parts, where the beds rise into hills, that the complete succession can be studied; the best sections are found on its western, eastern, and southern borders.

As the series above described is traced southward through Mayo and Roscommon into Galway it exhibits a change similar to that which takes place in England, namely a thinning of the sandstones and shales and a thickening of the limestones, till the series passes into a great limestone formation nearly 3000 feet thick, witl the same black shales above and a still thicker set of basal sandstones. The following is the lithological succession in Galway and Clare according to Mr. Kinahan and the Survey:-

Upper limestone shales

Feet.
80

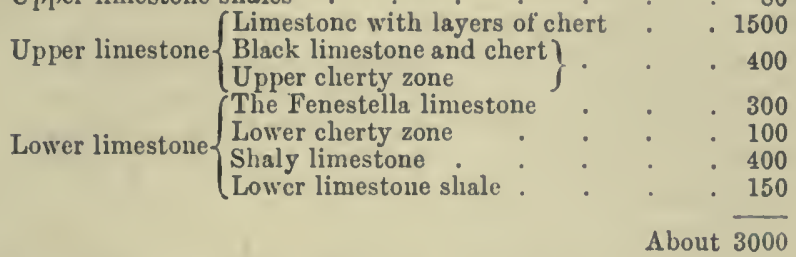

The zonal distribution of fossils in the limestone of Clare county has recently been ascertained by Mr. J. A. Douglas, ${ }^{13}$ and proves to be comparable with that in the Bristol sequence. He tabulates the beds and zones as follows:-

\begin{tabular}{|c|c|c|}
\hline Survey Divisions. & Zones and Sub-zones. & Thickness. \\
\hline $\begin{array}{l}\text { Black Goniatite shales. } \\
\text { Upper Limestone. - Bcdded crinoidal } \\
\text { limestones, both light and dark } \\
\text { grey. Chert occurs in layers and } \\
\text { nodules, some beds of oolitic limc. } \\
\text { stone. }\end{array}$ & $\begin{array}{l}?=\text { Pendleside Beds. } \\
\mathrm{D}_{3} \text { Cyathaxonia. } \\
\mathrm{D}_{2} \text { Lonsdaleia. } \\
\mathrm{D}_{1} \text { Dibunophyllum } \theta . \\
\mathrm{S}_{2} \text { Productus cora. } \\
\mathrm{S}_{1} \text { Prod. semireticu. } \\
\text { latus. }\end{array}$ & 1900 \\
\hline $\begin{array}{l}\text { Lower Unstratified Limestone.-Mass- } \\
\text { ive grey and mottled limestones, } \\
\text { often dolomitic. Bryozoa abundant. }\end{array}$ & $\begin{array}{l}\text { C. Syringothyris } \\
\text { cuspidata. }\end{array}$ & $\begin{array}{c}450 \\
\text { to } \\
1000\end{array}$ \\
\hline $\begin{array}{l}\text { Lower Stratified Limestone.-Lime- } \\
\text { stone with cherts at top, dark-grey } \\
\text { or blue argillaccous limestones. }\end{array}$ & $\begin{array}{l}\mathrm{Z}_{2} \text { Zaphrentis } \\
\text { konincki. }\end{array}$ & 650 \\
\hline $\begin{array}{l}\text { Lowecr Limestone shales. - Black } \\
\text { shales and limestones, green and } \\
\text { yellow sandstones. }\end{array}$ & $\begin{array}{l}\mathrm{Z}_{2} \text { Spirifer clathratus. } \\
\text { Cleistopora zone. } \\
\text { Modiola phase. }\end{array}$ & 150 \\
\hline
\end{tabular}


The basal yellow sandstones contain Lamellibranchs only. The succeeding shales have not yielded Cleistopora, but contain Spiriferina octoplicata and Productus bassus. The other zones contain assemblages which correspond closely with those of the South Wales and Bristol areas. A noteworthy feature is the great development of the Dibunophyllum and Cyathaxonia limestones, which have been termed the Burren limestone, from the district of that name, where they are magnificently exposed. It is thus described by Jukes ${ }^{14}$ :

"A range of hills, rather more than 1000 feet in height, sweeps for about 20 miles along the south side of Givlway Bay. They are formed entirely of bare rock from the sea-level to the hill-tops, the only soil being found in crevices of the rock, or in patches in the hollows of the valleys. This rock is all limestone, in regular beds, which dip gently to the south, at an angle of $1 \frac{1}{2}$ degrees only; and counting from the lowest bed that rises out on the sea-shore to the uppermost, which caps the summit of the hills three or four miles to the southward, there must be a thickness of at least 1600 to 1700 feet of solid limestone shown here."

In Limerick and Tipperary there is a similar succession, and the limestone series attains a thickness of about 3500 feet, its thickest member being the Fenestella limestone (1500 to 1900 feet), while the upper (Burren) limestone has decreased to only 240 feet. The same succession of limestones can be followed eastward through Kilkenny and Carlow, and Fig. 93, across the Castlecomer coalfield, illustrates this part of the area.

East of Thomastown the limestones overlap the lower shales so as to rest directly on the granite of Carlow, and a little to the northward, in County Dublin, shales of the calp facies overlap the limestones, thus giving evidence of another shore-line.

This is confirmed by the sections on the coast of County Dublin near Lough Shinny and Rush, which have recently been examined by Dr. Matley ${ }^{15}$ and Dr. Vaughan. The lowest beds there seen are conglomerates and shales, indicating the close proximity of a coast-line, and these are overlain by limestones belonging to the Dibunophyllum zone. Still higher are limestones with Cyathaxonia, overlain by limestones and black shales with Posidonomya Becheri.

Southern Counties. - When the Carboniferous rocks are traced to the south-west through Cork and Kerry a still greater and much more sudden change takes place in the constitution of the system. This consists in the introduction of what appears to be a distinct group of shales and slates between the Yellow Sandstone and the Carboniferous limestone, and to which Sir R. Griffith gave the 
name of Carboniferous slate. This group of beds has derived special importance from its bearing on the Devonian question, and the whole subject is so associated with the name of Jukes that it would be idle to attempt a better exposition of the interest attaching to the Carboniferous slate than is contained in Mr. Jukes's own description quoted below. ${ }^{16}$

"If we draw a parallel of latitude through the towns of Kenmare, Macroom, and Cork, the great development of Carboniferous slate lies wholly south of that line. If we examine the neighbourhood of the city of Cork itself, we find the [Upper] Old Red Sandstone with plants in its upper beds, and a very short distance above that we get solid Carboniferous limestone, with some black shales or slates between the two, but not more than 200 or 300 feet in thickness. Passing southwards to the mouth of the harbour of Monkstown or Queenstown, and then by Carrigaline and Coolmore, these intermediate black slates or shales thicken to 2000 or 3000 feet, still having the Old Red [or Coomhola Beds] below and the Carboniferous limestone above; but going still farther south by Ringabella to Kinsale, the dark-grey slates and grey grits thicken rapidly to 5000 or 6000 feet, and are nowhere covered by any part of the Carboniferous limestone, though they show here and there highly calcareous bands."

On Whiddy Island at the head of Bantry Bay there are black shales containing Posidonomya Becheri and $P$. membranaceus, the characteristic species of the shales above the limestone, and it is therefore highly probable that the Carboniferous slate is contemporaneous with the whole of the Carboniferous limestone, the lower and upper parts of that formation passing laterally into shales, just as its middle part does to the northward. We may therefore regard the Carboniferous slate as representing the whole of this limestone and its underlying shale, i.e. strata amounting to a thickness of 2600 feet in the northern part of Ireland; such, in fact, was Jukes's opinion.

\section{Devon and Cormuall}

This area has been left till the last, because the equivalents of the Avonian Series occurring therein are in many respects similar to those of the south of Ireland and are very different from the typical Avonian of the Bristol and Mendip area, in spite of the close proximity of the two facies.

Devonshire.-The delimitation of the Upper Devonian and Lower Carboniferous rocks in Devonshire has not yet been worked out. The junction-beds have not been specially described since 
Mr. Salter compared them with those of Pembrokeshire in $1863,{ }^{17}$ but his opinion was that the Pilton Beds included the equivalent of the lower limestone shale. He says, "Nearer Barnstaple these Pilton Beds begin to trough small patches of a barren softer slate which is only seen well developed south of Pilton and occupying the lower ground east and west of Barnstaple." In these soft slates the prevalent fossils are Phillipsia seminifera, Spirifer bisulcatus, S. laminosus, S. cuspidatus, Productus Martini, Orthis Michelini, and other exclusively Carboniferous species.

Shales with a similar set of fossils occur at Fremington west of Barnstaple, and are succeeded by the Coddon Hill Beds consisting of shales and chert-beds; the shales yield the Goniatites characteristic of the lowest Pendleside Beds, i.e. Prolecanites compressus, $P$. mixolobus, and Nomismoceras spirorbis, and the cherts contain Radiolaria. They are overlain by black shales containing Posidonomya Becheri, and black limestones with the same fossil. 18

The combined thickness of all these beds is not very great, apparently not more than 400 to 500 feet, unless a portion of the Pilton Beds is included, and it is impossible to regard them as representing the whole Avonian succession. From the fossils above quoted it looks as if the base and the upper portion of the normal sequence were present, and it is possible that the central beds are cut out by faulting, for the boundary of the Pilton Beds at and east of South Molton is believed to be a fault.

In South Devon and Cornwall nothing comparable with the Pilton or with the Fremington Beds has yet been found. The lowest Carboniferous Beds are either unconformable to or faulted against the highest Devonian rocks ; but the cherts and limestones of the Coddon Hill Group are well developed and appear to be rather thicker than in North Devon. West of Dartmoor they are associated with lava-flows, and the general succession according to Mr. Reid is as follows :- 19

Upper lava of Brent Tor, etc. .

Feet.

Beds of Radiolarian chert . . . . " 70

Black shales and lenticular limestones . . " " 250

Lower lavas . . . . . . . . . . 50

Hard black shale and chert-beds . . . " " 150

I have elsewhere 20 suggested that the break which here seems to exist between the Devonian and Carboniferous Systems may be a result of the volcanic action indicated by the presence of the lavas and by the intrusive mass of Brent Tor, which is supposed to have been a volcanic vent. The sea-floor may have been slowly raised 


\begin{tabular}{|c|c|c|c|c|}
\hline & i & $v^{2}$ & 0 & \\
\hline 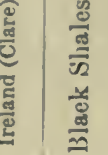 & 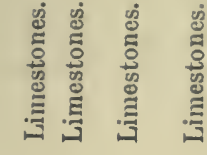 & 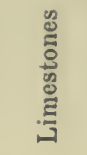 & 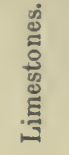 & 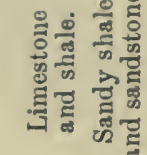 \\
\hline
\end{tabular}
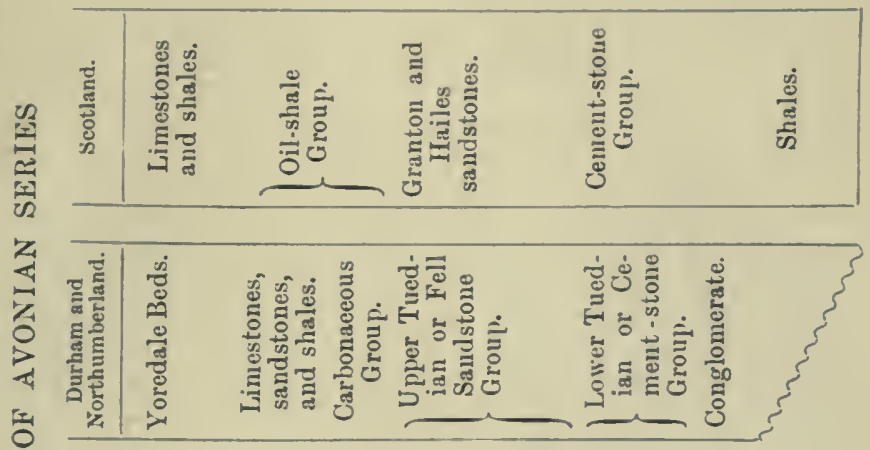

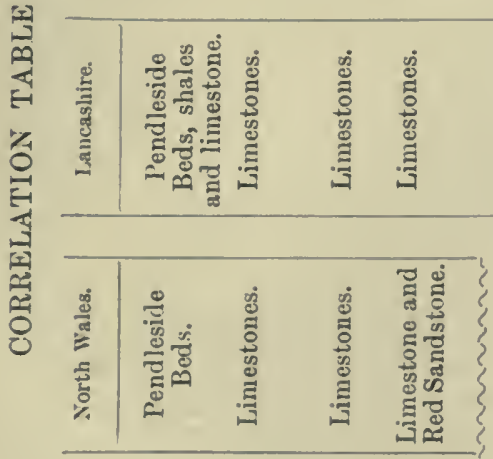

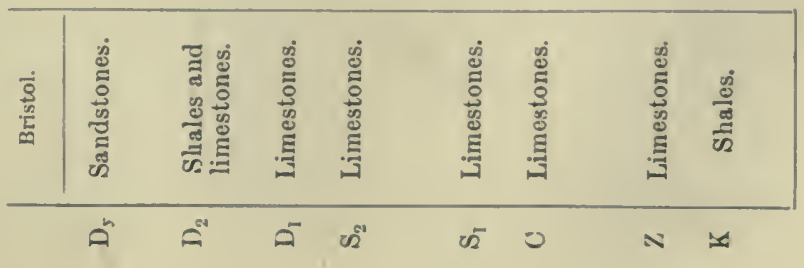


or bulged upward by the rising mass of lava till several submarine vents were established, and during such a movement little deposition would take place. The probability of this view is increased by a comparison of the Cornish sequence with that of Brittany, where a thick volcanic series is overlain by shales that are probably of Viséan and possibly of Yoredale age.

\section{Continental, Representatives}

\section{France and Belgium}

Two very different facies of the Avonian Series are found in the north of France; quite as different as those of Gloucestershire and Devonshire in England, the one being essentially calcareous and the other argillaceous. The former is only found in the north-east of France and in Belgium, the latter occurring in Brittany, Sarthe, and the Loire valley, and round the borders of the Central Plateau. It will be desirable to take the former first since the succession is complete and comparable with that of the Bristol area.

Belgium and N.E. France.-The Carboniferous rocks of this district lie in a set of deep and narrow troughs which succeed one another along a line extending from the Boulonnais on the west by Bethune, Tournai, Mons, Namur, and Liège. French and Belgian geologists use the term Dinantian for this part of the Carboniferous System, but as defined by them its limits are not quite coextensive with the Avonian either at the botton or the top. They also divide it into two stages, the Tournaisian and the Viséan, names taken from the towns of Tournai and Visé. The most complete section of the series is that exposed in the valley of the Meuse by Hastière, Wanlsort, Dinant, and Yvoir, and the succession is repeated in the basin of Namur to the north, at the junction of the Meuse and the Sambre. Visé lies much farther down the valley of the Meuse to the north-east of Liège, and the whole of the Visé limestone has been founa to belong to the highest Avonian zone, that of Dibunophyllum, and to be similar in character to that of Derbyshire; moreover, it is said to rest unconformably on the Devonian, so that it is not a complete development of the so-called Viséan stage.

The most recent descriptions of the Belgian Series are those by Professor de Dordolot, Dr. G. Delépine, and Dr. Vaughan. The following is a brief summary of the faunal sequence as determined by Dr. Vaughan and Dr. Delépine in a joint visit to the Belgian area. ${ }^{21}$ The normal succession is :- 


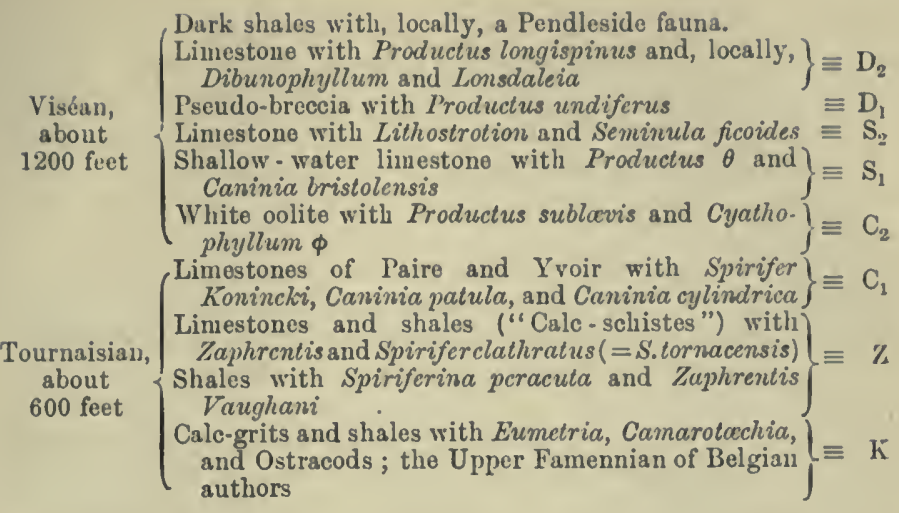

West of the Meuse in the Dinant area $C_{1}$ and $C_{2}$ take on a "knoll" character and are termed Waulsortian; the rocks are nassive mottled limestones with abundant Fenestellids. In these beds characteristic fossils are : Spirifer princeps, S. pinguis, Productus plicatilis, and Amplexus coralloides. East of the Meuse in the Dinant area there is no Waulsortian phase; the black marble of Dinant ("Marbre noir") belongs, probably, to $\mathrm{C}_{2}$. In the Namur basin a large part of the series ( $\mathrm{Z}$ to $\mathrm{C}_{2}$ ) is dolomitised ("Grande Dolomie"). At Visé only Dibunophyllum Beds occur, and these are of the upper knoll type.

This calcareous facies of the Dinantiau can be traced eastward by Liège to Limbourg (Aix la Chapelle), but when it reaches the Rhine the limestones are partly replaced by shales, and what we know as the Pendleside fauna extends downward through a greater thickness of beds. The succession near Dusseldorf is :-

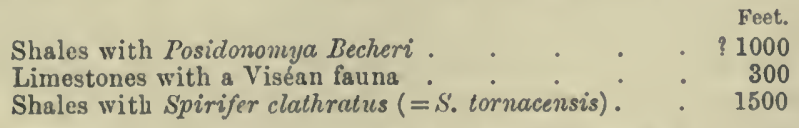

Brittany and Basse Loire.-The Avonian Series of Brittany commences with a volcanic group which is believed to have a thickness of more than 1500 feet in the west, consisting of conglomerates and felspathic tuffs with thick masses of andesite; but these beds only occur on the northern side of the basins of Chateaulin and Laval. The conglomerates rest unconformably on older rocks from Devonian to Cambrian, and as they contain no narine fossils their zonal age is unknown.

Above then in the Chateaulin basin is a great thickness of unfossiliferous black shales with layers of felspatlic sandstone, 
probably 3000 feet thick, and a few fossils (Phillipsia and Productus) have been found in lenticles of limestone near the top. In the basin of Iaval there is a more massive black limestone containing Productus giganteus and other Viséan species, overlain by shales, coal-seams, and sandstones with plant remains (Bornia transitionis, etc.), and in the centre of the basin is a band of red and green limestone.

Only the plant-bearing beds pass into the basin of Ancenis and the Basse Loire district, but these are more than $\mathbf{3 0 0 0}$ feet thick, consisting of shales and sandstones with many beds of anthracitic coal. The plants are those mentioned on p. 245.

From the above account it will be seen that the Tournaisian does not appear to be represented, except perhaps by conglomerates and lavas. The greater part of the series belongs to the Viséan, and the place of the Yoredale Beds is taken by a group of lagunic and estuarine deposits.

\section{Germany}

East of the Rhine in Germany a very different facies prevails, which has long been known as that of the Culm. This consists of a thick series of shales and sandstones; limestones only occurring as lenticular beds or as layers of calcareous nodules. The series is generally divided into a lower and an upper group, the lower being essentially marine, while the higher seldom contains anything but plant remains. In Westphalia, Hesse, and Nassau the Lower Culm has at the base chert-beds and siliceous limestones about 200 feet thick, containing Prolecanites compressus, Pronorites cyclolobus, and Orthoceras striolatum; the overlying beds are dark thin-bedded limestones containing Glyphioceras sphcericum and G. crenistria, with Productus giganteus and Chonetes papillionaceus. Above this are shales abounding in Posidonomya Becheri, and the total thickness is about 1400 feet. The Upper Culm consists of coarser sandstones, often pebbly, and contains the characteristic plants Knorria imbricata, Bornia transitionis, Lepidodendron veltheimianum.

This Culm facies is found also in the Harz Mountains, Thuringia, the Fichtelgebirge, and over a large area in Saxony. It likewise occupies parts of Silesia and Moravia, where it is of great thickness and has a somewhat different facies. According to Stur, the Silesian succession is as follows :-

Shales with plant remains.

Sandstones and shales with Posidonomya Becheri, Glyphioceras sphoricum, etc., and other beds with plants.

Sandstones, shales, and conglomerates with both marine and terrestrial fossils. 
Carboniferous deposits of the Culm type are also found in the south-west of Germany, in the Black Forest and in the Vosges district, with which the tracts in Central France were probably continuous.

\section{South of France, Pyrenees, and Spain}

When we pass into Southern France we enter a region where still another facies prevails. As a type of this the succession found in the Montagne Noire, near Corbières, may be taken. As described by $\mathbf{M}$. Bergeron this is :-

Grey limestone with Productus giganteus.

Sandstones with plants (Lepidodendron veltheimianum).

Shales with Spirifer tornacensis and Posidonomya Becheri.

Radiolarian chert-beds with phosphatic nodules (Glyphioceras diadema), succeeding Upper Devonian.

A similar succession is found at intervals all along the chain of the Pyrenees, with the addition at the base of compact limestones (the "marbres griottes"), variegated with red and brown, which contain Glyphioceras crenistria, Pronorites cyclolobus, and Prolecanites Henslowi. Still farther west in Asturia Professol Barrois has described the following sequence :- 22

Shales and limestones of Lena, with Amplexus coralloules, Lonsduleia floriformis, and Fusulina

The Cañon limestones with few fossils, Poteriocrinus crassus, Prod. uculeatus, Spirifer striatus

"Marbres griottes" with the Goniatites above mentioned : . 60

It is curious to find limestones with what we regard as Pendleside species of Goniatitide here conformably succeeding the Upper Devonian; but there is no doubt about the sequence, and we may regard these forms as southern species which did not find conditions suitable to them in the north-west of Europe until a late date in Dinantian time.

\section{Russia}

In this region the Lower Carboniferous Series is a combination of the Culm and the Dinantian limestone facies. The beds lie for the most part horizontally and are exposed in three large areas, that of Donetz in the south, the Moscow basin in the centre, and on the slopes of the Ural Mountains to the east. Ignoring local variations the general sequence in the Ural and Moscow areas is :- 
3. Limestones with Prod. giganteus.

2. Sandstones, shales, and coal-seams; some of the beds yield Prod. giganteus.

1. Sandstones and shales with lenticular limestones containing Prod. mesolobus.

These beds are from 5000 to 6000 feet thick and appear to represent both the Tournaisian and Viséan stages. In the Donetz. area, according to Tschernyschew, nearly the whole series consists of limestones.

\section{Conditions of Deposition}

The geographical conditions which prevailed in the British area during Avonian time are fully discussed in my Building of the British Isles (3rd ed., 1911), but it will be useful here to extend our view to those parts of the European region which have been briefly mentioned in the preceding pages.

The complete absence of any trace of Carboniferous strata in Norway, Sweden, Lapland, and Finland seems to indicate the existence of land over a large part of Northern Europe during this period. This inference is confirmed by the character of the deposits found in Northumberland, Scotland, and the north-east of Ireland ; these being mainly detrital deposits carried down by rivers and such as would be accumulated in a large bay or gulf. Hence we conclude that the Scandinavian land extended westward across the North Sea and across the north of Scotland into the North Atlantic region.

Again on the eastern side we find a broad band of Carboniferous strata in Russia extending from the Valdai Hills, south-east of St. Petersburg, northwards by the south end of Lake Onega. In this band the lowest beds are terrigenons deposits similar to those of Scotland, and here again, therefore, we are on the borders of continental land.

With regard to the southern border of the Scandinavian land there is less certainty, becanse all evidences of it are buried and concealed beneath the Neozoic deposits of the Germanic region. Probably, however, the coast-line passed across the southern part of the North Sea and across Denmark into the Baltic basin, whence it must have curved north-eastward through the Baltic provinces of Russia. Here it may be pointed ont that the absence of Avonian deposits in Poland is no proof that this country was land at this time. The Carboniferous deposits may have been largely removed from that area before Permian time, and seeing the great thickness which they have in Silesia and as far east as Cracow, it would be 
surprising if they had not extended for sume distance to the north of these places.

Passing now to the Atlantic region there is reason to think that. a large part of this was also occupied by land, and that a part of its coast-line passed through the extreme north-west of Ireland. Again, the'great thickness of shale in the south-west of Ireland and the nortli-west of France indicates the neighbourhood of land and the debouchures of large rivers which carried much sediment derived from such land. We may therefore picture a continent which almost encircled the British area, lying not only to the north but also to the west and south-west of it; and indeed it seems probable that a promontory of this land actually occupied parts of Cornwall, Brittany, and the intervening chaunel area during the Tournaisian epoch.

Another tract of land which was probably connected with the Atlantic continent seems to have stretched across Central France, for in the basin of the Loire the Dinantian (=Avonian) deposits are entirely of terrigenous origin, and are probably all of Viséan and Namurian age, while to the southward in La Vendée even these are absent, and small tracts of Westphalian Coal-measures rest directly on Archæan rocks. We have seen also that when Dinantian Beds come in again to the southward in Asturia, the Pyrenees, and the Montagne Noire they are of quite a different facies, hence the land above indicated seems to have separated a southern from a northern Carboniferous Sea.

From Central France this land may have extended across the valley of the Rhone between Lyons and the Vaucluse, and thence through the Western Alps and Northem Italy, where no traces of Dinantian strata have yet been found. Iand also existed at this time over a certain area to the north of Metz and Sarrebruck, for near the latter place Coal-measures rest directly on the Lower Devonian, but this may have been only a large island.

The limestone facies of the Aronian Series must have been formed in those parts of the Carboniferous Sea which were not subject to the incursion of currents setting ofl the surrounding land. It must originally have extended continuously from the west of Ireland, all round an island which existed in Viséan time over St. George's Channel, Central Wales, and Central England-an island which I have elsewhere called "St. George's Land." Thence these limestones probably extended broadly into the north-east of France and through Belgium into Prussia, nearly as far as the Rhine.

There is no valid reason for imagining any special contraction of the sea space on the Franco-Belgian border, as suggested long ago by Professor Gosselet, and still supported by some French geologists. 
The trough-like syncline in which the limestones lie is a featnre produced by subsequent flexuring; there is no indication of a shore-line either along the northern or the southern line of outcrop, and we have only to prolong the dip of these limestones to see that they must have extended indefinitely both to the northward and to the southward. Who will deny that there may be another synciine under Holland, and that Carboniferous limestone may occur in it?

From the distribution of the limestones, as above indicated, we may infer that no large rivers entered that portion of the Avonian sea which is now Central Ireland, and also that the island tract of St. George's Land had then a dry climate and was without streams of any size. At the same time there is no ground for supposing that the limestones formed around this island were of the nature of coral-reefs. Crinoids and molluscan shells are the predominant constituents of these limestones as they are of the Devonian limestones (see p. 206), and the corals are distributed through the limestones over wide areas, not concentrated in reeflike masses round the shores of the island.

\section{REFERENCES}

1 A. Vaughan, Quart. Journ. Geol. Soc. vol. lxi. p. 181.

2 "Geology of the S. Wales Coalfield," Mem. Geol. Survey, in ten separate parts.

3 Hind and Stobbs, Geol. Mag., 1906, pp. 385, 445, 496.

4 J. W. Sibly in Quart. Journ. Geol. Soc. vol. lxiv. p. 34.

E. J. Garwood, Geol. Mag. for 1907, p. 70.

6 W. Hind, Quart. Journ. Geol. Soc. vol. Ivii. p. 347.

7 C. A. Johns in The Naturalist for 1911, p. 9.

8 E. J. Garwood, Proc. Geol. Soc., May 18, 1911.

9 E. J. Garwood in "Geology in the Field," Geol. Assoc. (1910), p. 661.

${ }^{10}$ Goodchild, Proc. Geol. Soc. vol. xv. p. 117 (1897). ed., 1910.

11 "Geology of the Country around Edinburgh," Mem. Geol. Surv. 2nd

12 R. J. Cruise, Mem. Geol. Surv., Ireland, Expl. of Sheets 66 and 67.

13 J. A. Douglas, Quart. Journ. Geol. Soc. vol. Ixv. p. 538 (1909).

14 Jukes, Manual of Geology, 2nd ed. p. 512 (1862).

15 Messrs. Matley and Vaughan, Quart. Journ. Geol. Soc. vol. Ixiv. p. 413.

${ }^{16}$ Jukes, op. cit. 2 nd ed. p. 510 , 3rd ed. p. 588.

17 Salter, Quart. Journ. Geol. Soc. vol. xix. p. 476 (1863).

18 W. Hind, Geol. Mag., 1904, pp. 392, 584.

19 C. Reid in Sum. Prog. Geol. Surv. for 1908, p. 26.

20 Jukes-Browne, Geol. Mag. 1905, p. 353.

${ }^{21}$ A. Vaughan, Brit. Assoc. Rep. Sect. C. (1910).

22 Barrois, "Terrains anciens des Asturies," Mem. Soc. Geol. Nord (1882), p. 519 . 


\section{CHAPTER X}

\section{THE CARBONIFEROUS SYSTEM (continued)}

\section{WESTPHALIAN SERIES}

\section{A. Subdivisions and General Relations}

As explained on p. 245 the second of the three great series of strata into which the Carboniferous System is now divided has received the name of Westphalian, and to it belong all the beds which have been classed as "Upper Carboniferous" in the British Isles. These generally occur in conformable succession to the Avonian Series, but they often extend beyond the limits of the older series, and come to rest on Silurian or other more ancient rocks. Moreover, even when they overlie the Avonian there are sometimes evidences of a slight break between the two series, and there is always a change in the species of plants above this horizon.

In the British Isles the "Coal-Measure" Series is generally underlain by a set of massive sandstones which are known collectively as the Millstone grit, but this is a very variable group, being sometimes over 3000 feet thick, and sometimes only represented by 300 or 400 feet of sandstone and shale. In the areas where the Coal-measures are most fully developed they reach a thickness of 6000 to 7000 feet, and have been divided into Lower, Middle, and Upper stages. On this basis, therefore, the Westphalian Series is divisible into four stages, and has a maximum thickness of about 10,000 feet.

A more scientific division of the series is one based on the different assemblages of plants that are found in this great succession of strata, and by a study of these Dr. Kidston has recognised three different assemblages, ${ }^{1}$ though the two higher blend into one another through a set of "Transition Beds." The particular differences in these plant-assemblances will be mentioned 
on a later page. The correlation of the two sets of stages is given below.

Upper Coal-measures with Fourth flora.
Transition Coal-measures ,
Middle Coal-measures
$\left.\begin{array}{l}\text { Lower Coal-measures } \\ \text { Millstone grits }\end{array}\right\} \quad$ ",

\section{B. Life of the Period}

\section{The Fossil Flora}

a. Equisetales.-Calamites were gigantic Equiseta or horsetails, and consisted of a large hollow pith cavity encased in a thin cylinder of woody tissue. The central part has generally been filled up with mineral matter, forming the casts which are such common Carboniferous fossils. The outer ligneous envelope, being carbonised and friable, is seldom preserved in a perfect state.

The name Calamites is at present restricted to these jointed stems, while other names, Asterophyllites and Annularia, are given to different varieties of foliage which belonged to Calamites. The fruit is a scaly spike (Calamostachys and Palocostachya), in which sporangia are arranged like those of Equisetum.

Sphenophyllum is the foliage of a plant related to Calamites, but is now known to differ in several respects, and the fruit is a whorled sporophyll resembling that of the recent genus Psilotum.

Calamodendra are casts of the central cavity or pith of plants lesembling Calamites, but having a thick woody outer coating or bark. Calamodendron thus appears to have been a highly developed Equisetum.

b. Lycopodiales.-Lepidodendra were gigantic members of the Lycopodiales, or Club-moss family, having trunks many feet in girth and 40 to 60 feet in height. The trunks branch toward the top into several limbs, which divide again into smaller boughs. The foliage consists of simple linear leaves, which are sometimes found attached to the terminal branches (Fig. 96), and the angular scars on the stem are the marks left by the detachment of these leaves. Ulodendron, Lepidophloios, and Halonia are allied genera.

The scaly cylindrical bodies which are known as Lepidostrobi are the cones which contain the sporangia or seed-cases of the Lepidodendra, and were borne at the extremities of some of the branches.

Sigillaria.-These appear to have been the commonest trees in the swampy portions of the Carboniferous forests, and have evidently supplied the chief mass of the material which forms our 

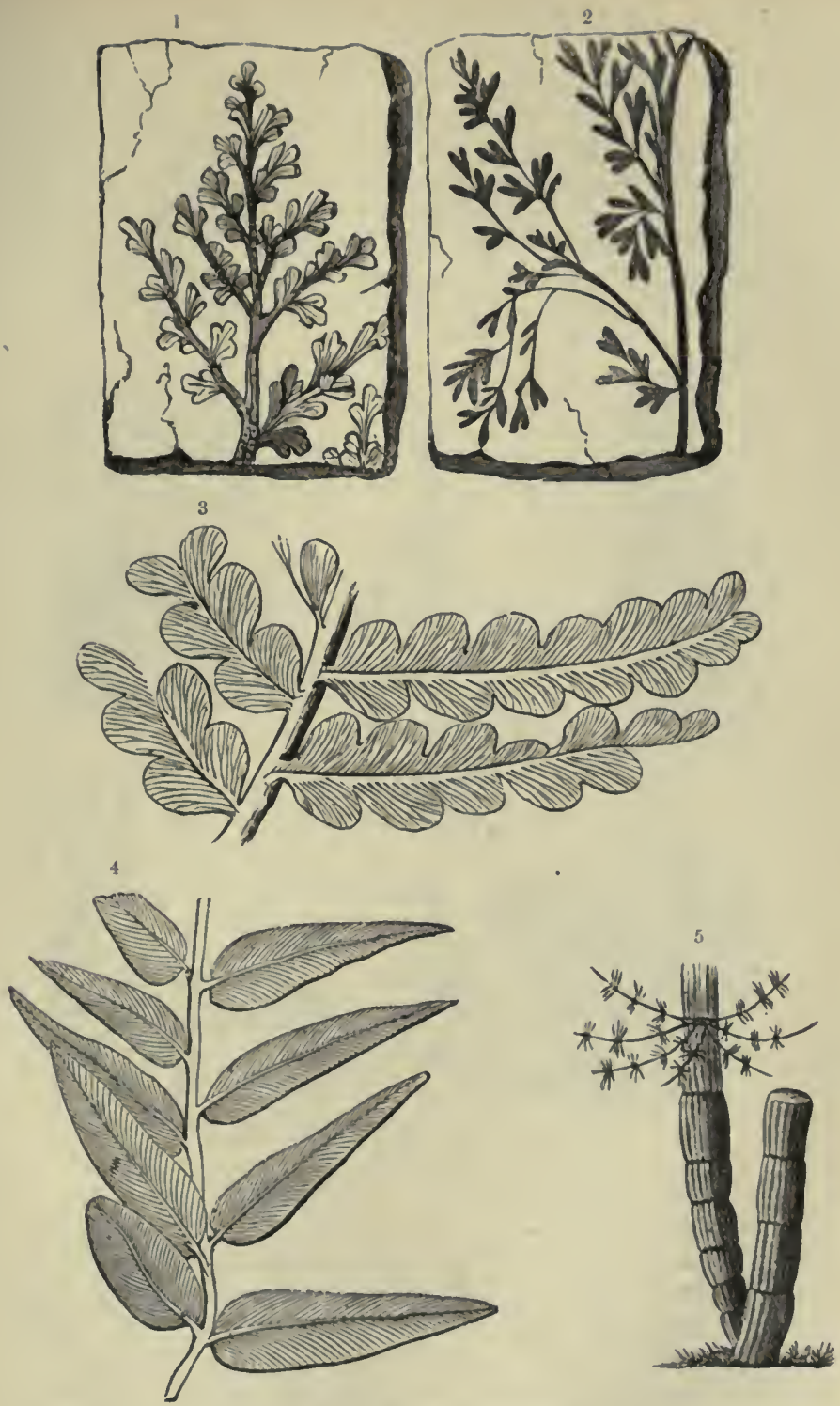

Fig. 95. - CROUP OF COAL-MEASURE PLANT.

1. Sphenopteris linearis.

2. Sphenopteris sftinis.

3. Odontopteris Schlotheimi.

5. Calamites (restored and th of natural size). 
coal-seams, while their roots (Stigmarioe) ramify in the under-clays beneath. They were tall trees, branching at the top, and rivalling the Lepidodendra in height, with a bare trunk fluted longitudinally, and regularly ornamented by the pits or scars left at the points where the leaf-stalks were attached. These leaves were long and narrow, and similar to those of Lepidodendron. The fruit consists of small sporangia borne at the basis of slightly modified leaves; Sigillaria was therefore a Lycopod, and allied to Lepidodendron.

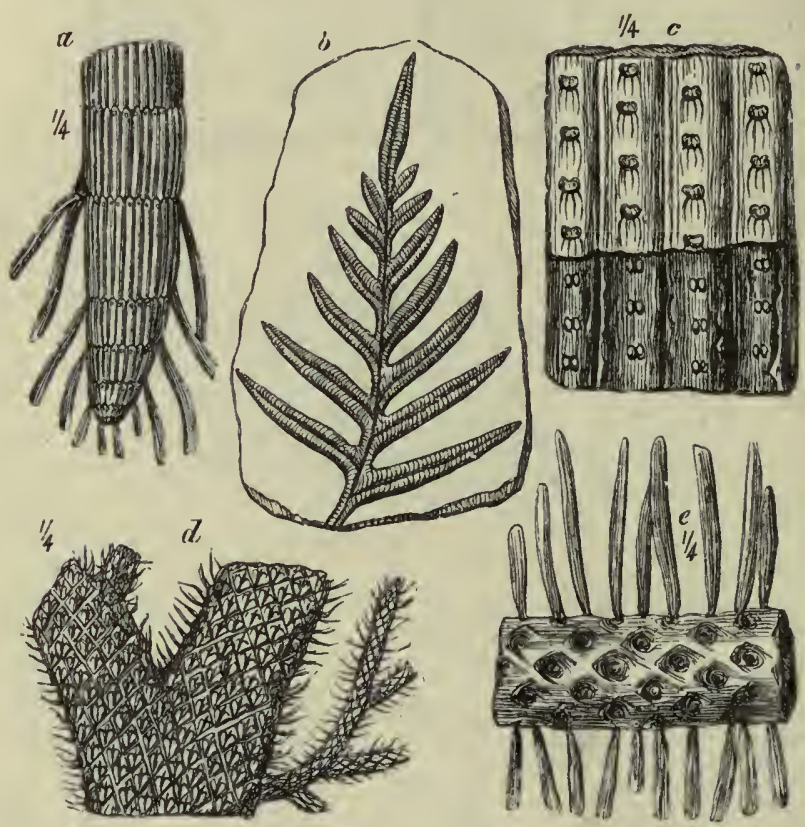

Fig. 96. -GROUP OF COAL-MEASURE PLANTS.

a. Calamites cannæformis (root end).

b. Alethopteris lonchitica. c. Stigmaria ficoides.

c. Sigillaria reniformis.

d. Lepidodendron Sternbergi.

Stigmaria.-The roots of Sigillaria, Lepidodendron, and Bothrodendron are so much alike that it is impossible to distinguish them. Consequently they are all known as Stigmaria, long, branching, and tapering, with numerous rootlets spreading out in all directions; such roots have been found which were upwards of 20 feet in length. Perhaps, like those of the modern mangrovetree, these roots were partly aerial, rising well above the low-water 
mark of the swamp, and uniting in a dome-sliaped manner to support the trunk.

c. Pteridosperms and Primoflices.-Fern-like fronds are abmndant in the Coal-measures, and the roofs of coal-seams are sometimes covered with beautiful inpressions of such fronds. Until recently these were regarded as true ferns, but it has been

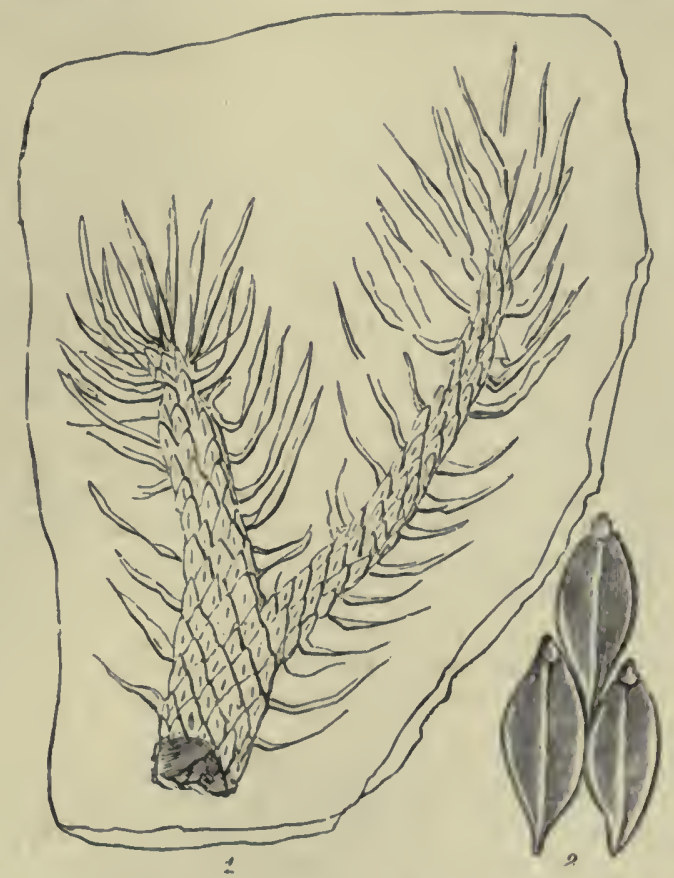

Fig. 97.-LEPIDODENDRON ELEGANB (BROURI1).

1. A terminal branch.

2. Leafoscars from the stem.

found that many of them belong to plants which developed true seeds and not spores like those of existing ferns. They are now regarded as a distinct group of plants, intermediate between ferns and Gymnosperms, and are known as Pteridosperms.

True ferms of an ancient type (Primofilices) are also represented among these leaves, for some have been fonnd bearing sporangia, and stems with leaf-scars like those of moderu tree-ferns also occur. (Psaronius). Fructiferons fronds, however, are rare, and it is 
impossible to distinguish the sterile fronds of these ferns from those of the Pteridosperms; thus some of the fronds known as Pecopteris and Sphenopteris belong to one group and some to the other, so that these names only stand for certain forms of sterile fronds which are similar in their venation and general characters.

In the present state of our knowledge, these names have still to be used generically, and some of the commonest frond-forms thus designated are-Alethopteris (Fig. 96, b), Neuropteris (Fig. 95, 4), Odontopteris (Fig. 95, 3), Pecopteris, Cardiopteris, Linopteris, Mariopteris, and Sphenopteris (Fig. 95, I and 2).

The seeds of the Pteridosperms have long been known under the names of Lagenostoma, Trigonocarpus, Rhabdocarpus, etc.

Cordaitales.-The stems of plants in some respects resembling the true Coniferæ (Pitys and Dadoxylon) have also been ${ }^{-m e t}$ with, especially in the volcanic tuffs of the Scotch Carboniferous Series. The lower slopes of the old volcanoes were doubtless clothed with these trees, their habitat being in such high and dry localities, and not in the swampy ground where the other plants flourished. In the structure of their stems these plants show affinities to the Pteridosperms as well as to the Coniferæ.

Cordaites was a remarkable plant placed by most botanists in a distinct phylum, but by some with the conifers. The stem grew to a height of 20 or 30 feet, and carried a number of long swordshaped leaves with parallel venation, something like those of a yucca. The leaves were attached by broad bases and left large leaf-scars on the stem when they fell off. The tree bore bunches or spikes of fruit (Antholites) with seeds somewhat resembling the fruits of a yew, but more heart-shaped, and these are known as Cardiocarpus.

Some of the plants above mentioned are more abundant in the lower part of the series and some in the higher parts. A study of their distribution has enabled Dr. Kidston ${ }^{1}$ to recognise four successive assemblages of plants in British Coal-measures, and Zeiller has found the equivalents of all but the uppermost in those of the continent. The principal features of these assemblages are given below.

\section{Plants of the Millstone Grit and Lower Coal-Measures}

Lepidodendra are abundant; Sigillaria not very common. Calamites are represented by C. Suckovi and C. ramosus. The prevalent fern forms are Alethopteris and Sphenopteris; common species of the first being $A$. lonchitica and $A$. decurrens, of the second S. obtusiloba. 


\section{Plants of the Middle Stage}

In this stage Sigillaria is more abundant than Lepidodendron, S. elongata, S. polyploca, and S. Brardii being common species. Calamites and Sphenophyllum are also very abundant, though no species is restricted to this division. Fern-like fronds abound, Sphenopteris and Neuropteris reaching their maximum development. Of the former S. (Zeillaria) delicatula, S. (Corynepteres) coralloides are characteristic species.

\section{Plants of the Transition Stage}

These are a mixture of typical middle stage forms, such as Pecopteris Miltoni, Annularia radiata, Sphenophyllum cuneifolium, and Alethopteris lonchitica, with species characteristic of the Upper stage, such as Alethopteris Serli, Neuropteris rarinervis, and Sphenophyllum emarginatum.

\section{Plants of the Upper Stage}

In these beds Calamites become rare, Lepidodendron is not common, and Sigillaria also less abundant. The most abundant plants are fronds of the Pecopteris form, such as $P$. arborescens, $P$. oreopteridea, $P$. polymorpha, and $P$. cyathea, but some forms of Neuropteris ( $N$. rarinervis, $N$. macrophylla, and $N$. ovata are common. Alethopteris Serli and Cordaites angulosostriatus are also typical Upper Coal-measure species.

\section{The Land and Freshwater Fauna}

a. Mollusca.-In the Coal-measure shales, and associated with many of the plants above mentioned, shells somewhat resembling the recent Unio are frequently found. They lave been referred chiefly to three genera, Carbonicola (=Anthracosia), Anthracomya, and Naiadites, and their aftinities have recently been studied by Dr. W. Hind, who refer's the first two genera to the Unionida and the third to the Mytilida, but believes that all of them were freshwater forms. He remarks that their occasional or rare association with marine shells is no proof that they were capable of living in salt water, for their shells may have been carried down by rivers into bays and estuaries.

b. Arthropoda. - True Insects, Myriapods and Arachnids, have also been found in the Coal-measures, including crickets, beetles, and a scorpion. Crustacea also inhabited the waters, the small Ostracoda-Bairdia, Leperditia, and Beyrichia, and the Plyyllopod 
Estheria-swarming in some localities. Several species of Xiphosura allied to the modern Limulus (king-crab) have been described by Dr. Woodward, and referred to the genera Prestwichia and Belinurus. There were also a few Eurypterids, this being their last appearance in England.

c. Fishes.-Fish remains, of Crossopterygian and Elasmobranch genera, are everywhere abundant, but it is difficult to separate entirely the freshwater forms from the marine, because some (like the Mollusca) seem to have been equally at home in salt and brackish water; some of them, like the modern salmon, may have lived in the sea at certain seasons, and in the estutaries and rivers during other parts of the year. The following genera are, however, most frequently associated with the Coal-measure plants :-Celacanthus, Cheirodus, Ctenacanthus, Ctenoptychius, Gyracanthus, Megalichthys, Platysomus, Pleuracanthus, Rhizodus, Rhizodopsis, and Strepsodus.

d. Amphibia. - Thirteen genera of Labyrinthodonts are recorded from British Carboniferous rocks, Anthracosaurus, Loxomma, Ophiderpeton, Urocordylus, etc., mostly from the Jarrow coalfield in Leinster, Ireland. Others (Archegosaurus) occur in Prussia and (Baphetes, Dendrerpeton) in Nova Scotia. Footprints have also been observed in the Forest of Dean coalfield and in the limestone series of Dalkeith, Scotland. The larger of these Amphibians are believed to have measured 7 or 8 feet in length, but others were very small; they were probably fluviatile creatures preying on the fish and Crustacea which swarmed in the swamps and lagoons of the period.

\section{The Marine Fauna}

The Millstone grits are probably marine deposits, for land plants are not common in them, and the intercalated shales sometimes contain marine species of Mollusca as well as fish remains. The Lower Coal-measures were swamp deposits formed along the fringe of sinking land areas, parts of which were from time to time invaded by the sea. Hence marine fossils are found in them at certain horizons. The species which have been found in these beds in Britain and also at two horizons in the Middle Coalmeasures of Staffordshire are tabulated on p. 293. The first two columus show how many of the species range up from the higher parts of the Avonian Series.

\section{Westphalian Series in Britain}

Just as the Lower Carboniferous Series is in most places brought to the surface along tracts of anticlinal flexure, so the Upper: Series 


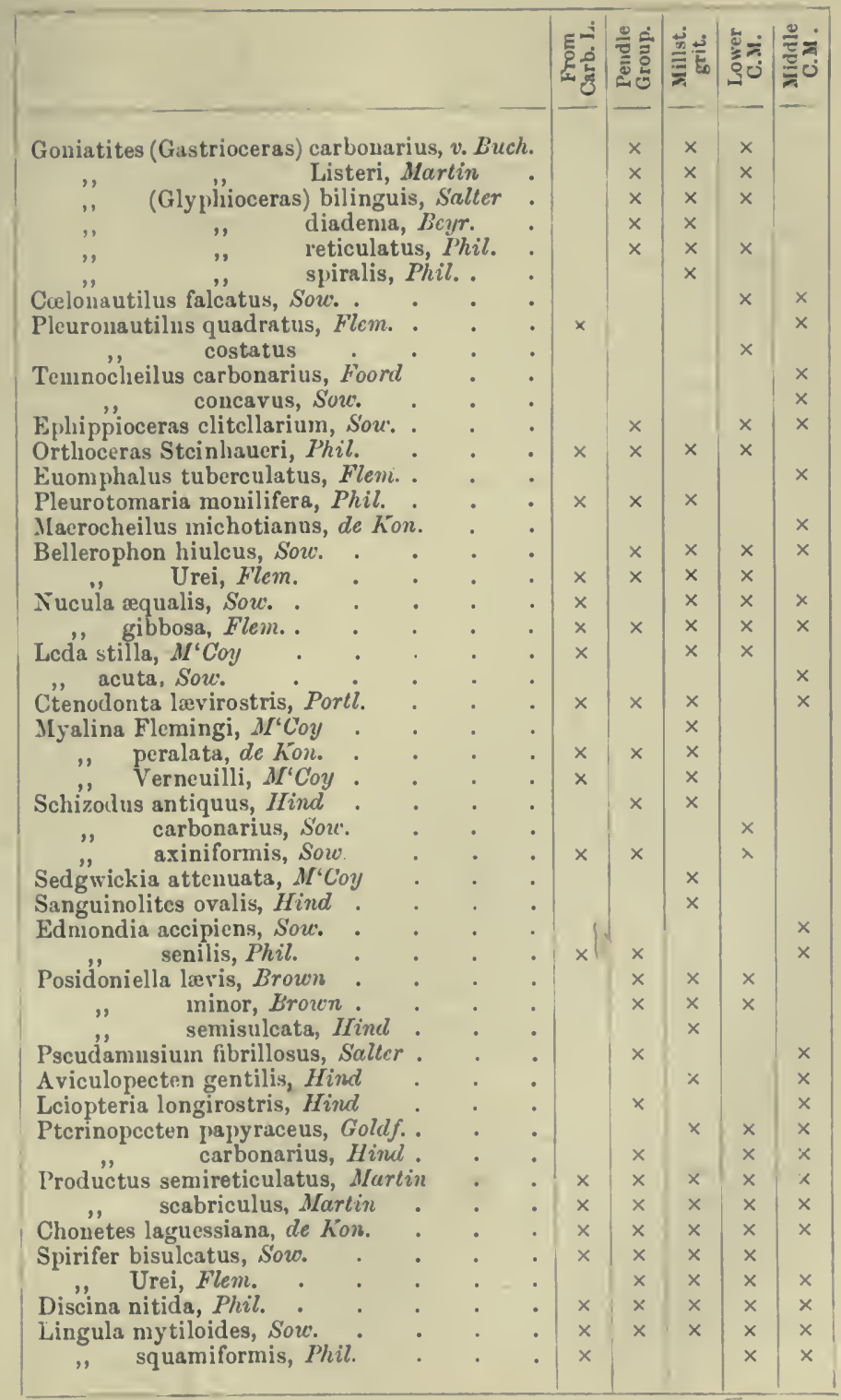


is generally found in synclinal troughs or basins, the highest portion of the series usually lying in the central parts of such basins. All areas where workable coals exist are called coalfields.

Of such coalfields there are no fewer than eighteen in England and Wales, some large and some very small, and if the unproductive Devonshire basin is included there are nineteen. In Scotland there are three coalfields in which Westphalian measures are worked, besides three others in the underlying Avonian Series. In Ireland there are five such basins.

In describing the Coal-measures found in these numerous basins it will be convenient to group them into natural areas wherein a similar succession of strata is found, and as their most complete development is exhibited in the basins which lie on each side of the Pennine Anticline (see Fig. 86), these will be placed first. The areas may therefore be taken in the following order:-

1. The South Pennine and Midland area.

2. The Newcastle Coalfield.

3. Scotland.

4. Ireland.

5. Bristol, Somerset, and South Wales Coalfields.

6. Devonshire.

\section{The South Pennine and Midland Area}

This area will include the Nottingham and Yorkshire coalfield on the east and those of Lancashire and North Staffordshire on the west, the latter probably being connected under the Cheshire basin with the Flint and Denbigh coalfield (see Fig. 98, and the map, Fig. 87). We shall also include the other Midland coalfields to the southward, those of Shropshire, South Stafford, Leicestershire, and Warwickshire, since they are all portions of a series of deposits which originally formed one continuous sheet.

In the basins which flank each side of the Pennine range the complete succession is as follows :-

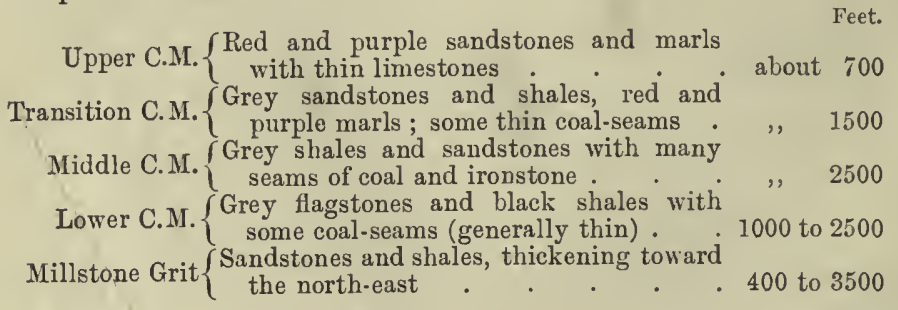


The Millstone Grit consists of several sets of grits and flagstones separated by shales of varying thickness. Its thickness increases to the northward, and finds its nuximum in East Lancaslire and the adjacent part of Yorkshire, where it is said to be over 3500 feet thick. 'Througliout the northern part of the area the following subdivisions can be traced, though the thickness of each varies greatly :-

First grit or rough rock.

Shales.

Second grit.

Shales.

Third or Chatsworth grit.

Shales.

Kinderscout grit, or fourth grit.

The lowest grit takes its name from the high tableland of Kinderscout in the Peak country, which consists of this rock and rises to a height of 2000 feet above the sea. The third grit forms long conspicuous escarpments ou both sides of the central area. The second grit is less persistent than the others, or rather the sliales above thin out so that it coalesces with the first grit. The Rough Rock is a very coarse grit, sometimes passing into a conglomerate of small quartz pebbles. In Lancashire it contains a workable coal-seam called the "Feather-edge coal." The shales below also inclnde thin seams of coal. To the south-west in Staffordshire the middle grits thin out, but the fourth grit appears to be represented on Congleton Edge by a set of grits and shales about 500 feet below the third grit, so that the group here is not less than 1000 feet thick, and lias the Pendleside shales below it.

Still farther south the grits thin out entirely, and they do not appear in the South Staffordshire or Warwickshire coalfields. In Nottingham also they thin southward and have nearly disappeared at Asliby de la Zouch, in Leicestershire, where only 50 feet of such grit is left at the base of the series. A similar small tongue of grit reaches to the Wellington district of Shropshire and then thins out.

Lower Coal-Measures.-These are sometimes called the Gannister measures, gannister being the miners' name for a peculiar hard and compact siliceous underclay (or fireclay) which often forms the floors of the coal-seams. Hard grey flagstones are the predominating beds in this division, with subordinate bands of shale. The coals are generally thin, but two or three from 3 to 4 feet thick are often worked. In the vicinity of the coal-seams plant remains are abmudant, but the fossils in the other beds are generally marine forms (see p. 293). 


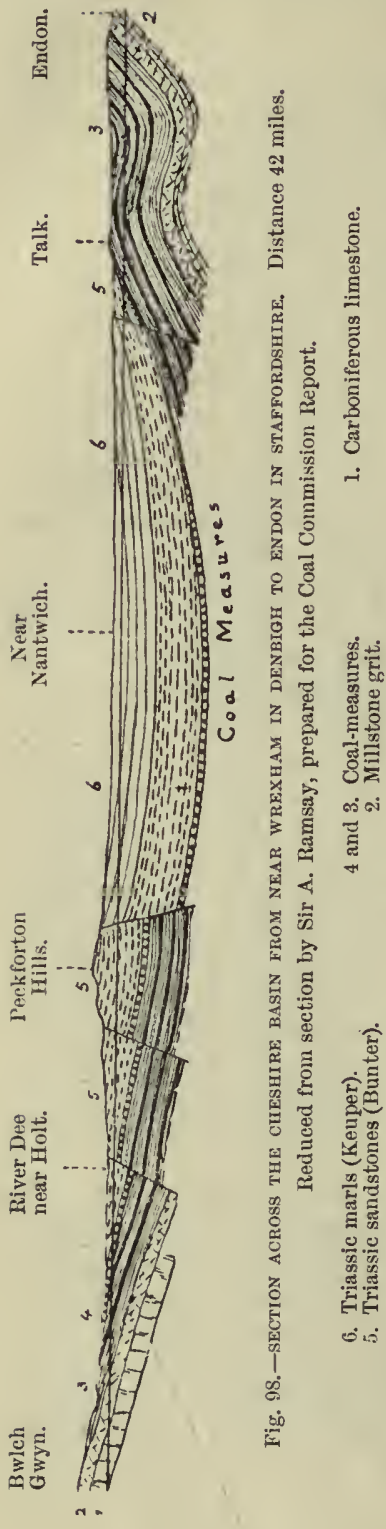

In Nortl Stalfordshire these measures are 2400 feet thick if the top of them is taken at the marine band above the Mansfield coal, but Dr. Kidston is inclined to place it at the Ash coal, still higher up. They are probably quite as thick in Lancashire if the same horizon is taken as the line of division. In Flint they are considered to be about 1000 feet thick and 1800 feet at Wigan, in Lancashire, where they are well exposed in the cuttings of the Wigan and Liverpool railway. Carbonicola acuta, C. robusta, and C. turgida are common in these measures.

On the eastern side of the area there is a similar development of Lower Coal-measures, but the thicknesses assignable to them depend upon the horizon which is taken to be their upper limit. In Nottiugham and Leicester they are said to be about 1000 feet thick, but when the series recurs in Warwickshire they are found to be absent, and must therefore have thinned out against the ridge of ancient rocks which underlie the Charnwood and Nuneaton district. Neither are they found in the South Staffordshire coalfield.

Middle Coal-measures. This group has a wider extension than those below. It is also a more varied series, consisting of grey shales and grey or white sandstones with many seams of coal and of ironstone (carbonate of iron), this association of coals and ironstones in the same series of beds making it commercially the most important group in the whole series.

It is believed to attain its greatest thickness in Lancashire, where if 
measured from the Worsley 4 -foot coal to the flags below the Arley mine coal, the thickness is about 3500 feet. In Yorkshire and Nottiugham these measures are from 2000 to 3000 feet thick, and are so entirely like those of Lancashire that several of the Yorkshire coal-seans can be identified with their counterparts on the west; thus the "Silkstone" of Yorkshire is the "Arley mine" of Lancashire. Layers of nodular carbonate of iron are frequent and have been largely worked. Some of the Coal-measure sandstones near Pontefract, Ackwortl, and Rotherham in Yorkshire are stained red and were formerly mistaken for beds of Permian age.

In Leicestershire these measures are about 1500 feet thick witli ten good coal-seanis, but in Warwickshire they liave shrunk to about 700 feet with only five workable coals.

In North Staffordshire they are probably about 1600 feet if the group is restricted witlin approximately the sane horizons, and in South Staffordshire they are about 1000 feet thick at the northern end of the coalfield, lessening to 500 feet at the southern end, but this may not be entirely due to thiuning. They contain inany good coal-seams, and it is a curions fact that some fourteen seams which are distinct in the north coalesce sonthward by the thinning out of the intervening measures till they form one bed of coal, from 25 to 30 feet thick, which is then known as the "Thick Coal." In Staftordshire three species of Anthracomya are common in these beds-A. Wardi, A. pulchra, and Adamsi.

Transition and Upper Coal-measures.-These stages have been most completely studied in North Staffordshire and Flint, where Dr. W. Gibson found reason to include certain red and purple sandstones wlich had previously been referred to the Permian. For these he proposed the name "Keele Series," but they should be known as the Keele Beds since they are only part of a "series." The following is an abstract of the succession established by Mr. Gibson :-2 Upper C.M.
or $\left\{\begin{array}{c}\text { Red and purple sandstones and marls with three thin } \\ \text { layers of Spirorbis limestone. Fossils, a few }\end{array}\right.$ Keele Beds.

Newcastle Group. Grey sandstones and sliales with four thin scams of coal and a limestone at the base. Fossils, many ferns and plauts (Sigillaria Brardi).

Transition

Coal. measurcs.

Etruria marls. Red and purple marls and clays with thin bands of green grit and a limestone near the base. The clays are largely used for pottery

Feet.

700

300

Blackband Group. Grey sandstones and marls with blackband ironstones and thin seams of coal. Anthracomya Phillipsi and fish teeth . . 300 to 450

Total about 2200 
There is a similar set of beds near Manchester, but they have not yet been fully correlated with the above.

On the eastern side of the Pennine range these beds are con. cealed beneath the newer rocks, but have recently been proved in a boring at Thurgarton, near Southwell, in Nottinghamshire. The cores indicate a succession like that of North Staffordshire, but with a less thickness. Mr. W. Gibson (op. cit. p. 262) gives it as follows :-

Permian (Marl slate).

Feet.

Keele Beds $\left\{\begin{array}{c}\text { Red sandstone and marl with Neuropteris rarinervis and } \\ \text { Pecopteris }\end{array}\right.$ Newcastle

Beds

Etruria marls : red marls and green grits

Grey Coal-neasures below.

N, N.W.

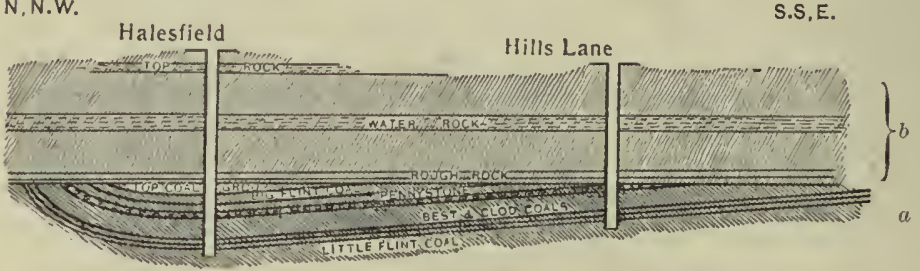

Fig. 99.- SECTION ACROSS THE MADELEy DISTRICT, COALBROOKDALE (W. J. Clarke). a. Middle Coal-measures.

3. Upper Coal-measures.

In Yorkshire near Rotherham there are some red marls and sandstones which are classed as Upper Coal-measures, and probably belong to the Etruria marls, but only 54 feet of them are seen.

When these Upper Coal-measures recur in the more southern coalfields of Shropshire, South Stafford, and Warwick, they are found to be more or less unconformable to those below. This is markedly the case in the Coalbrookdale district of Shropshire, where the whole Carboniferous succession is as follows:-

Upper (Red and purple sandstones and marls (? Keele Beds) 800 and Mottled clays and greenish grits with a limestone Trans. C.M. ( containing Spirorbis (Freshwater Beds) • . 440 Middle Coal-measures with a band containing marine fossils . .600 Lower Coal-neasures or Millstone grit, thinning out south . 0 to 100 A vonian limestones and shales (Productus giganteus) . . 0 to 180

Up to 2100

The lower beds, including the Middle Coal-measures, lie in a 
broad syncline (see Fig. 99), while the Upper Measures are nearly horizontal; the base of the latter being a mottled clay known as "calaminker" overlain by a bed of gravel or conglomerate callerd the "Rough Rock." As this series is traced southwards the lower members thin out and disappear, while the Middle Measures overstep the Millstone grit so as to rest on the Old Red Sandstone, and this is their position in the Forest of Wyre west of Kidderminster and around Bewdley.

In South Staffordshire there appears to be a similar break between the Middle and Upper Measures, for the diminution in the thickness of the Middle Group toward the south is probably in part owing to an overstep on the part of the Upper Measures. According to Professor Lapworth the succession south of Dudley is as follows:-

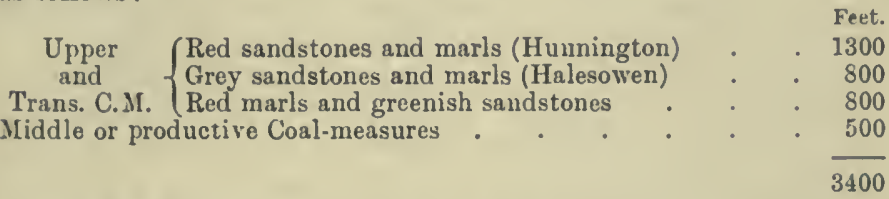

The same succession is found in Warwickshire.

From the preceding account of the stratigraphical arrangement of the several nembers of the Westphalian Series in this region it will be seen that they all become thinner southwards, each stage passing beyond the limits of the one below farther and farther on to the Midland area which was land in Avonian time. Moreover, it is apparent that there was some terrestrial disturbance and uplift in this southern part of the region after the formation of the Middle Coal-ineasures.

It may also be inferred that the main mass of the Westphalian Series above described was deposited in a trough which extended from west to east across what is now tlie Pennine range, and that this trough was continually deepened by subsidence, while in the area to the sontl of it subsidence was interrupted by stationary epochs and at one time by an uplift with consequent flexure and erosion.

- Further, the stndent should note that the existing coalfields on eacl side of the Pennine ridge still extend far below the newer beds which cover their outer parts. Thus the Lancashire coalfield probably passes westward below Liverpool Bay, and the Yorkshire coalfield is known to extend as far as Haxey in Lincolnshire, where a boring has been carried to a deptli of 3185 feet passing through 1457 feet of Coal-measures. It is believed that the subterranean extension of this coalfield reaches as far eastward as Lincoln and Brigg. 


\section{Cumberland and Northumberland Area}

In the north of England there are two coalfields which, though now far apart, were originally parts of one continuous sheet of Coal-measures which spread over the whole of the Lake District and across the broad Pennine Hills. These are the Newcastle coalfield, occupying parts of Durham and Northumberland, and the Whitehaven coalfield in Cumberland. Remnants of the coirnecting strata have been preserved in the small Canonbie coalfield on the border of Dumfries, in a faulted tract south of Haltwhistle in Northumberland, another at Argill near Brough in Westmoreland, and in patches of Millstone Grit on the west side of the Eden Valley.

The Newcastle coalfield is the largest of these tracts; it extends from the northern side of the Tees valley west of Darlington to the mouth of the river Coquet, a distance of about 60 miles. It is limited on the south by an anticlinal flexure which runs from Barnard Castle to the mouth of the Tees, and the Millstone grit runs into the sea near Alnmouth, so that the eastern part of the coalfield passes beneath the floor of the North Sea.

Milistone Grit.-This division is of small thickness, and it is doubtful what beds should be assigned to it. In Yorkshire the Millstone grits thin rapidly as they are followed northward, and in the North Riding are not more than 600 feet thick. Some of the grits, however, are believed to come in again between Teesdale and Tynedale, and have been mapped as forining broad plateaus on the high fells of West Durham, but in this area they lose their coarse gritty character and become indistinguishable from the sandstones and flagstones of the Gannister measures.

Lower Coal-measures.-These beds likewise become much thinner in a northerly direction, so that in Northumberland the whole thickness between the Felltop limestone and the Brockwell coal, which is the lowest workable seam, is only about 350 feet. Of this Mr. Lebour assigns 150 feet to the Gannister measures, and in this thickness there are two seams of coal. A few marine fossils such as Aviculopecten papyraceus and stems of crinoids have been found in these beds.

The Middle Coal-measures maintain their thickness, which in Durham is estimated at 2000 feet, and they contain soine twenty good seams of coal, including the Brockwell seam at the base and the High Main seam, which is the highest known seam in the series. Besides these there are many minor or less valuable seams, bringing the total number to over sixty. Some of the shales contain nodules and bands of ironstone which have occasionally been 
worked, and some of these are so full of Carbonicola shells that they are known as "mussel bands." The sandstones are used for building purposes, and one bed, known locally as the "grindstone post," furnishes the celebrated Newcastle grindstones. No true Upper Coal-measures come into this area, though they may exist under the North Sea.

The Cumberland or Whitehaven coalfield borders the western coast from Whitehaven to Maryport and then runs north-eastward in a narrow tract which is faulted down between the Permian Beds and the Carboniferous limestones. The whole area, indeed, is so broken by faults that the thickness of the Coal-measures is not known, but believed to be over 1500 feet. Lithologically the series is divisible into (1) Productive Measures and (2) the Whitehaven Sandstone; but from an examination of the plant remains Mr. Arber groups the beds in the following manner:-

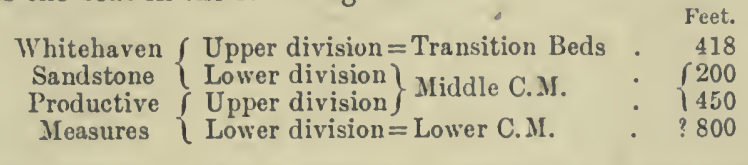

Both divisions of the Whitehaven Sandstone consist of purple sandstones, shales, and conglomerates, which weather to reddish tints, and the upper division includes a bed of Spirorbis limestone.

The Canonbie basin though small is interesting because it is deep enough to bring in still higher beds, and because the strata resemble the English Series more than the Scotch Coal-measures. The following abstract is taken from the full account given by Messrs. Peacli and Horne :-

Messrs. Peach and Hoet.

Upper $\left\{\begin{array}{c}\text { Red and purple sandstones and shales with a Spir. } \\ \text { orbis limestone and } 2 \text { seams of irunstone }\end{array}\right\} \quad 1500$

Middle-White sandstones, grey shales and coals . . . 500

Lower-Grey sandstones, shales and coals $: 750$

I. Grit $\left\{\begin{array}{c}\text { Massive sandstones, some coarse, with shales and } \\ \text { thin coal-seams }\end{array}\right.$

3400

\section{Scotland}

The Westphalian Series is not so fully developed in Scotland as it is in Central England, but it is curiously different from that of Northumberland, for the Lower Coal-measures are of considerable thickness, while the Middle Division, which is the most productive part of the English Series, has a very different facies in Scotland, its beds being often called the "barren" measures because they contain no coal-seams. There are four separnte coalfields occurring 
in three basin-shaped tracts, namely that of Midlothian and Fife on the east, of Lanark and Stirling in the centre, and of Ayrshire on the west.

Millstone Grit.-In the counties of Edinburgh, Fife, Stirling, and Lanark the upper limestones are succeeded by a set of pale red and yellow sandstones in thick beds with occasional layers of shale. This group of sandstones is generally known as the Roslin Sandstone from its fine exposure near that place. Its thickness near Edinburgh and north of the Forth is from 500 to 600 feet, but it thins from the north-east to south-west; in Lanark it is only from 90 to 100 feet, and farther west, in Ayrshire, it is so thin as not to be definitely separable from the Coal-measures.

Recent examination of the plant remains by Dr. Kidston has led to the recognition of a palæontological break in this set of beds ${ }^{3}$ and the fact is confirmed by Dr. Traquair's study of the fish remains; so that the lower part of the Roslin sandstone is now grouped as "Lower Carboniferous" (i.e. Avonian), and the higher part as "Upper Carboniferous" (i.e. Westphalian). In the Edinburgh district the line of division is drawn near a marine band about 230 feet above the highest limestone. The lower beds include several bands containing marine fossils, and Sphenopteris is the only fern-plant; while in the upper part plant remains are more abundant, species of Alethopteris, Neuropteris, and Mariopteris being the most frequent with several species of Sigillaria which range upward but not downward. Mr. Arber informs me that as a matter of fact no true species is common to the two floras found in the Roslin Sandstone.

Lower Coal-measures.-These measures attain a considerable thickness, about 1200 feet in Fife and Midlothian, from 1200 to 1500 in Lanark, and about 1300 in the Clyde Basin. They consist of grey and white sandstones, with shales, coals, fireclays, and ironstones, and ten of the coal-seams are from 2 to 5 feet in thickness. In Lanark and the Clyde basin the base of the series is taken at the slaty-band ironstone, and there are several other continuous beds of blackband ironstone which are of much commercial importance.

These measures contain a flora which is pronounced by Dr. Kidston to be the same as that of the Lower Coal-measures of England. The commonest plants are Neuropteris heterophylla, $N$. gigantea, and Sphenopteris latifolia. They also include two marine bands, one near the base containing Schizodus deltoideus, Conularia quadrisulcata, Lingula mytiloides, and Orbiculoidec nitida; and another above the "Ell" coal containing the same Conularia and Orbiculoidea with Productus scabriculus, Bellerophon Urei, and Aviculopecten papyraceus. 
Middle Coal-measures.-These were formerly referred to the Upper stage because they consist chiefly of red saudstones and shales, and because in some districts they appear to be unconformable to the Lower Measures. From a study of the plant remains, however, Dr. Kidston considers them to belong to the Middle Measures.

The group has a maxinum thickness of 900 feet in Fife, where it comprises red sandstones, red and purple clays, with some thin seams of coal and ironstone.

In Ayrshire the unconformity at the base of these measures is very marked, for they steal across the outcrops of the Lower Coalmeasures until they rest on the uppermost limestone of the Lower Carboniferous, the Millstone Grit being absent as above stated. In the Ayr coalfield these beds include a thin band of fine white limestone containing Spirorbis carbonarius. A few Coal-measure plants have also been obtained from them.

Around Sanquhar in Nithsdale, Dumfries, there is an outlying tract of Coal-measures which rest directly on the Ordovician rocks south of the boundary fault. It has recently been proved that these include both Lower and Middle Measures, and their occurrence shows that Nithsdale became a strait connecting the Ayrshire and Cumberland basins across a ridge which had previously been an island.

\section{Ireland}

Rocks of Upper Carboniferous age occur in several parts of Ireland, but the principal coalfields are four in number, two in the north and two in the south. Of these the following is a brief account.

Southern Counties.-One extensive area occupies parts of the counties of Clare, Limerick, Kerry, and Cork, but the coalseams in this region are few and of variable thickness, so that commercially it is less important than the "Leinster coalfield," which occupies parts of Tipperary, Kilkenny, and Queen's County. The succession in both these areas is similar, but a greater thickness of the Middle Coal-measures comes into the western basin. The groups recognised are :-

4. Middle Coal-measures with several good seams of Munster. Leinster. coal. Fossils are freshwater Mollusca, Crustacea, and Amphibia. . . 2000

3. Lover Coal-measures with thin coals and shale roofs containing marine shells . . . . 900

2. Flagstone group, nicaceous flagstones and shales . 500 
The Flagstone Group is the equivalent of the Millstone Grit of Bristol and South Wales, and the true Lower Coal-measures are the beds which overlie these flagstones, many of the same marine shells occurring in them as in the Gannister Beds of Northern England. ${ }^{4}$ The Jarrow collieries in Queen's County are known for the number of Amphibian remains which have been obtained from them.

Northern Counties.-The most important tract in the north is the Tyrone coalfield, which lies to the north of Dungannon and contains many good seams of bituminous coal. The succession as given by Mr. Hardman ${ }^{5}$ is as follows :-

Niddle Coal-measures. -Soft sandstones and shales with coals, fireclays, and ironstones . . . . Lower Coal-measures.-Hard sandstones and shales with a few thin coals and ironstones. Millstone Grit.-Coarse grits and sandstones

Feet.

About 2000

Upper Carboniferous rocks occupy a considerable area in the counties of Leitrim and Fermanagh, and their sequence is the same as in Tyrone, but only part of the Lower Coal-measures come in above the Millstone Grit.

\section{South Wales and Bristol Area}

This area exhibits a different development of the Westphalian Series from that found in other parts of the British Isles, and it is not yet certain how far the natural divisions of the series in this southern area can be compared and correlated with those of more northern districts. Moreover, the succession found in the great coalfield of South Wales is not the same as that occurring in Bristol and Somerset, and the differences between the two areas may be tabulated as follows:-

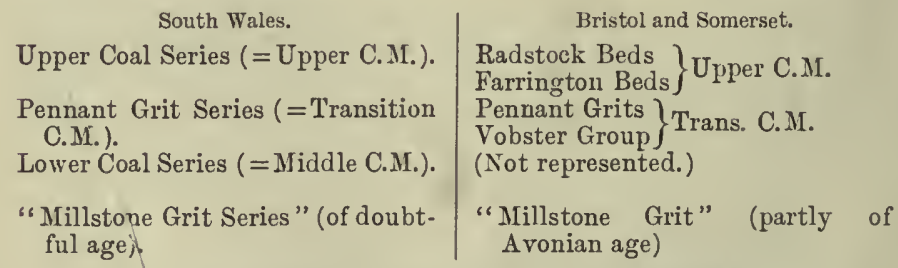

In the Bristol coalfield the Avonian limestones pass up through shales into the Millstone Grit, the lower part of which probably represents the Yoredale Beds of northern areas (see p. 253). As to the age of the higher part there is no evidence, but there seems to 
be a break at the top of the sandstones, for there is nothing comparable to the Lower or to the Middle Coal-measures of the Midlands, at any rate from a palæontological point of view.

In South Wales the so-called Millstone grit may be of any age, for there appears to be a break at the base of it, and the overlying beds which have hitherto been called "Lower Coal-measures" contain the flora of the middle stage, and must be classed as Middle Coal-measures. They everywlicre rest on a sandstone which is known as the Farewell Rock, and though this is at present grouped with the Millstone grit it may properly belong to the overlying Coal-measure Group.

In the following account the stages found in South Wales will be described first, as the succession is there inore complete.

Millstone Grits.-In South Wales the group is very variable. At the eastern end of the basin north of Cardiff it is about 460 feet thick, consisting of a pebbly grit at the base, of shales and sandstones in the iniddle, and a massive sandstone (the Farewell Rock) at the top. Westward, lowever, the group expands to a thickness of over 1500 feet, the greater part consisting of darkgrey shale, but always having the Farewell Rock above, while the basal grits are sometimes present and sometimes thin out, so that in Gower, where it is absent, no line can be drawn between the Bishopston cherts and shales and the overlying barren shales. ${ }^{6}$

The normal succession is well developed in the Ammanford district on the northern outcrop, where the thicknesses are :-

Feet.

Farewell Rock-green and white sandstones .

Dark barren shales with bands of sandstone.

about 200

Quartzitic grits with some bands of shale

, 500

, 600

In the Bristol and Somerset Coalfield the fine-grained sandstones which have been called Millstone Grit form a complete ring round the Coal-measure basins, but are apparently an upward continuation of the Avonian Series, and the relation of their highest beds to the overlying shales has not yet been ascertained. In most places they are about 1000 feet thick, but in the Mendip district they have thinned to $\mathbf{5 0 0}$ feet.

Middle Stage.-According to the evidence of the plants this only occurs in South Wales where it varies inuch in thicknese, and like other nembers of the system expands toward the west and south-west. Thus at the eastern end of the basin it is ouly from 625 to 850 fect thick, but in the centre it is about 1400 feet, and near the south-west margin upwards of 4000 feet. This expansion appears to be due not only to the increased thickness of sandstones and shales, but also to the inconing of fresh 

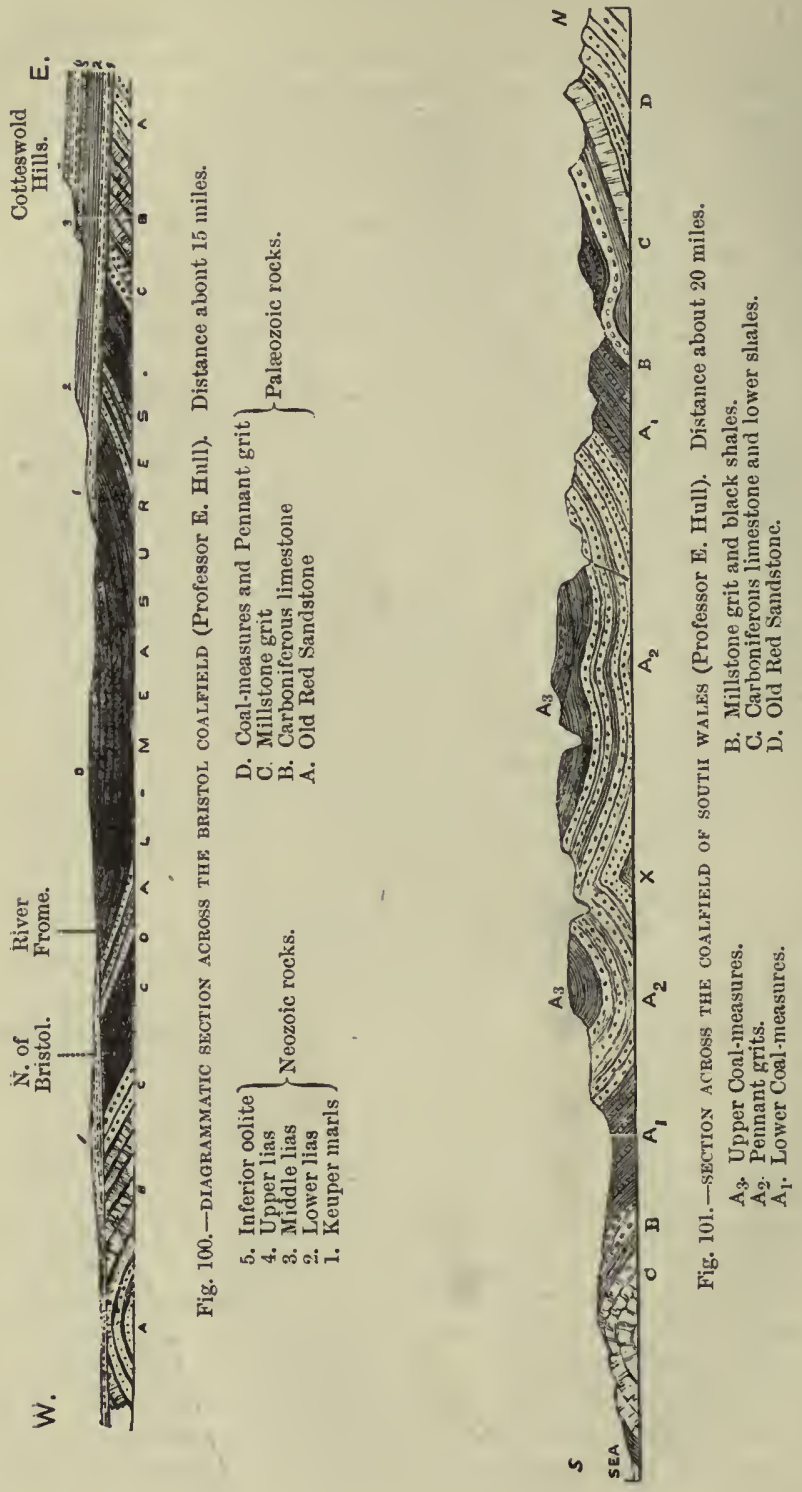
measures, and more coal-seams toward the sonth-west. Many of the coal-seams are not persistent, and it is not easy to correlate the seams which occur in different parts of the basin.

Transition Stage.-In South Wales this stage is represented by the Pennant Grit Series, which consists of massive felspathic sandstones or fine-grained grits, witl some subordinate bands of shale and seams of coal, and it forms the greater part of the high central moorland plateau which is known as the Mynydd. Near Pontypool on the east it is only about 800 feet thick and the coalseams are thin, but west of 'Taff Vale the group rapidly thickens and workable coal-seains set in, so that near Swansea it is over 3000 feet thick, and contains fifteen good seams of coal.

In the Bristol coalfield the Transition stage includes two distinct groups, the Vobster Coal-measures below and the Pennant Grit above. The Vobster Beds consist principally of shales with some sandstones and many seams of coal, and many of the shale bands contain ironstone nodules, so that these measures are rich in coal and iron. The thickness is about 2000 feet, and in the central part of the area (east of Bristol) there are twenty-six coal-seams, but many of these are thin and disappear both to the north and south.

The Bristol measures include several bands which contain marine sliells, and from these Mr. H. Bolton has obtained no fewer than forty-three species. The commonest are Nucula aqualis, Posidoniella lavis, Schizodus antiquus, Lingula mytiloides, Glyphiocerus carbonarium, and Gastrioceras Listeri. Pterinopecten papyraceus also occurs, and by comparison with the list on p. 293 it will be seen that the shells hardly support the evidence of the plants. Mr. Bolton compares the fauna with that of the Gin Mine band in North Staffordshire, which, according to Dr. Kidston, should be placed in the Lower Coal-measures.

The precise age of the Pennant Grits in the Bristol coalfield is not yet known; they may belong to the Transition or to the Upper Coal-measures. They form a sandstone group from 1000 to 1700 feet thick, the prevalent material being a hard grey felspathic sandstone, which makes a durable building stone, and lies in thick beds, so that it can be cut as a freestone. There are some bands of shale and four workable seams of coal.

Upper Coal-measures.-These form a variable series of grey shales, light-coloured sandstones, and coals, which appears to be an expanded equivalent of the red Upper Coal-measures of more northern coalfields.

In South Wales, near Swansea, the group is very thich, having been estimated at about 3000 feet (Pellengare Series). 
All the coal-seams in South Wales undergo a change of character as they are followed from east to west, the seams which are bituminous house-coals in the east becoming hard steam-coals in the central parts of the basin and passing westward into stone-coal or anthracite. It is also found that the coals of the upper measures are more bituminous than those of the lower.

In the Bristol coalfield a thickness of about 2000 feet is found, although the sunmit is nowhere seen ; it is divided into two parts, the lower portion or Farrington Group occurring in both the northern and southern basins, the upper portion or Radstock Group only coming into the southern or Somerset basin.

The small coalfield of the Forest of Dean calls for some notice, because previous correlations of the beds with those of the South Wales and Bristol basins have been altered by a recent study of the fossil plants. It was supposed that there was an upper set of Coal-measures underlain by an equivalent of the Pennant grits. It now appears, however, that all the productive Coal-measures belong to the upper stage, and that the supposed Pennant grits are merely a set of massive sandstones in the lower part of this stage, which thus consists of the following nembers:-

Upper shales and coals (10 seams)

Thick sandstones with 3 coal-seams $\quad . \quad$. . . 850

Trenchard sandstones and 2 coals . . . . . . $\quad$. 77

2407

These beds are directly underlain by the so-called Millstone Grit, and consequently there is no representative of either the Middle or Lower Coal-measures.

\section{Devon and Cornwall}

The "Upper Carboniferous" or Westphalian Series of this area has hitherto generally been called the Culm-measures, but this term has become misleading and should be dropped, for they are simply barren Coal-measures and are not the equivalents of the strata known as Culm-measures in Central Europe.

According to Mr. Ussher ${ }^{7}$ the series is divisible into two parts or stages, which he called Middle and Upper Culm-measures, but this is not confirmed by Mr. Arber who regards the whole succession of beds as forming a single lithological division, the so-called "Eggesford Grits" being only a local variation of type which he has recognised in several localities. ${ }^{8}$

Mr. Arber describes the series as consisting essentially of finegrained sandstones or grits and shales in alternating bands. The beds are highly flexured and broken by faults, many of the sharp. 
anticlinal folds seen in the coast-sections being faulted at the crest and sometimes overthrust. The andstones are hard, of grey, lilac or brownish tints, and usually from 4 to 5 feet thick, but sometimes less; the shales and mudstones are grey or red. These strata include beds of hard impure coal, generally known as culm, and there are also thin umpersistent beds of limestone as well as layers of calcareous nodules.

The nodules near Bideford and Instow have yielded unarine shells chiefly of Gastrioceras carbonarium, G. Listeri, Dimorphoceras Gilbertsoni, Pterinopecten papyruceus, and Posidoniella lavis; and of this assemblage Dr. W. Hind remarks that it resembles that of the Bullion Mine seam in the Lower Coal-measures of Laucashire. In the same district plant remains have been collected by Mr. T. Rogers and Mr. N. Arber, and the latter has shown that the flora is that of the Middle, not of the Lower Coal-measures, so that here, as in the Bristol area, there is a conflict between the evidence of the fauna and the flora. Nothing to indicate the presence of 'Transition or true Upper Measures has yet been found in Devonshire.

In the southern part of the area near Chudleigh and Newton Abbot the base of the Westphalian Series is a conglomerate which lies unconformably on the chert-beds of the Lower Series and in some places appears to overstep them on to the Devonian rocks. It contains pebbles of chert and limestone and a few of granite, which, however, is not like that of Dartmoor. This bed is overlain by a set of alternating grits and shales like those of Bideford, and near Exeter Mr. T. G. Collins has recently obtained fossils which show that they occupy a low position in the series.

\section{Continental Equivalexts}

\section{Westphalia}

We take this area first because the succession of beds therein found is regarded on the continent as the typical development of the series. De Lapparent has well remarked the area might be appropriately called the basin of Münster, since that city overlies the central portion of it. It is only in the southem part of the basin that the Carboniferous rocks come to the surface, the greater part being concealed beneath the Jumssic and Cretaceous strata which form the Westphalian plain. The surface tract extends from near Dusseldorf on the Rhine, by Hagen and Arusberg to Brilon and Marsburg, a distance of about 90 miles. From this outcrop the beds dip northwards and then extend in a series of undulations beneath the great plain, probably reaching as far as the 
Teutoburger Wald before they finally rise again to terminate the broad syncline. The student should refer to Stanford's geological map of Central Europe.

At the base of the series is a thick mass of sandstones (Flotzeere Sandstein), some of which are coarse and pebbly. These beds occupy the place of our Millstone grit and are said to be without fossils. The whole series is believed to be over 11,000 feet thick, and has been divided into the following groups:-

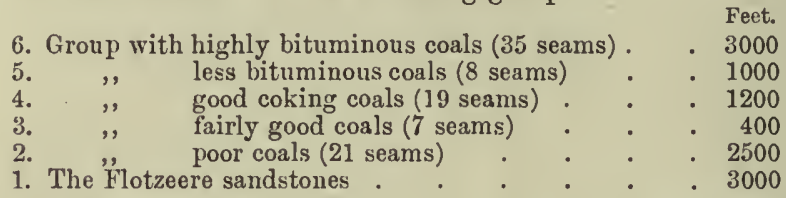

In this succession Cremer has recognised four plant assemblages.

Zone $d=6$, with Neuropteris rarinervis and N. tenuifolia.

Zone $c=5$, with Sphenopteris obtusiloba and Lonchopteris.

Zone $b=3$ and 4, with Sphen. trifoliata and Alethopteris lonchitica.

Zone $a=2$, with Neuropteris Schlehani.

It is specially to be noted that though the succession is complete, and every part of it seems to be fully developed, the flora of No. 2 (zone $a$ ) is not that of our Lower Coal-measures. It contains, however, several bands in which marine fossils occur, the lowest of these being about 600 feet above the base and yielding Gastrioceras Listeri with other species which in England do not range above the lower division.

\section{Belgium and France}

West of the Rhine, a long but rather narrow tract of Carboniferous rocks comes in on the north flank of the high ground formed by the Cambrian and Devonian rocks (see p. 216) and stretches continuously from Aix-la-Chapelle by Liège, Namur, and Mons, and thence still farther under the cover of Neozoic deposits by Valenciennes, Douai, and Bethune to the Boulonnais.

Throughout this tract of country the Carboniferous strata are sharply flexured and much broken by faults. Their sonthern boundary is generally an overthrust fault with a southerly hade and such a great displacement that the Devonian rocks have been carried over the Coal-measures which are in some places actually worked beneath this cover of older rocks.

In Belgium the representative of the Millstone grit seems to be very thin, but it forms a constant band of coarse grit from 30 to 
40 feet thick, and thus separates the Viséan shales (see p. 279) from the overlying Coal-measures. These latter have been divided by Zeiller ${ }^{9}$ in to the following zones :-

4. Zone of the "charbons flénus" (gas-coals) with Pecopteris nervosa, $P$. denlata, Neuropteris rarinervis, Sphenopteris obtusiloba, and Sigil. larin ecsselata.

3. Zone of "clarbons gras," with Sphenopteris nummularia, Neuropteris gigantea, Alethopteris Serli, and Sigillaria polyploea.

2. Zone of "charbons demigras-" Sphenopteris trifoliata, Lonchopteris Ericei, Aleth. Darreuxi, and Sigillaria sculellata.

1. Zone of "charbons maigres -"Neuropteris Schlehani, Alethopteris lochitica, Sigillaria elegans, and some Lepidodendra.

It will be noticed that the succession of coals and of plant-zones is similar to that of Westphalia. The total thickness of this series near Boussu west of Mons is about 2400 metres (=8000 feet), and near Douai it is estimated to be more than 2500 metres.

In the Boulonnais, near Leulingham, Locquinghem, and Ferques, Coal-measures are being worked under overthrust masses of Carboniferous limestone; and anotler trough appears to come in to the north of these overthrusts, part of it lying below Dover where Coal-measures were reached by boring at a depth of 1100 feet from the surface. The same series of troughs and faulted blocks is probably continned westward under the south of England till it emerges again in the coalfields of Bristol and Somerset.

\section{Sarrebruck Area}

Just as the Belgian coalfields lie in a synclinal trough on the northern flank of the broad tract of Devonian rocks which stretches across the Ardenues and the Rhine Valley, so also we find another syncline on its southern flank. The exposed portion of this syncline is known as the Sarrebruck basin, but it is very likely to have a prolongation westward beneath Metz, thougl probably at too great a deptl to be attainable (see Fig. 103).

The deposits in this southern basin, however, differ much from those in the northern, for not only is there an entire absence of the Dinautian Series, but the greater part of the Westphalian is also wanting, and the lowest beds in the basin must rest unconformably upon the Jower Devonian or still older rocks. The bottom of the basin in its deepest part has not yet been reached, but the lowest beds traversed correspond with the highest part of the Belgian Series (the charbons flénus) and are covered by beds which resemble our Upper Coal-measures, while these latter are succeeded by the still higher Steplianian Series. The Westplialian part of the succession is as follows:- 
3. Purple sandstone and shales with thin coals . . about 2000

2. Red sandstones and conglomerate at base . . .

1. Sandstones and shales, both red and grey, with $80^{\circ}$ seams of bituminous coal . . . . . , , 1500

\section{Silesia, Moravia, and Poland}

No large area of Westphalian strata is found again in Central Europe till we reach Silesia, where there are two basins or troughs, the one known as the Lower Silesian or Waldenburg trough and the other as the Upper Silesian basin. The first runs from the Eulengebirge and Waldenburg westward to Schatzlar in Bohemia, and is partly covered by Triassic and Cretaceous rocks. The second lies farther south, its north-east end resting on Devonian near Zuckmantel in Austrian Silesia, and extending south-west far into Moravia (to near Brünn). The thickness of beds in both these areas is considerable, and those of the Waldenburg trough were divided into two stages by Stur:-

2. Schatzlar Beds corresponding with those of Sarrebruck.

1. Waldenburg Beds, with a flora of Culm affinities.

He was inclined to class the lower beds with the underlying Culm, but Weiss regarded them as Westphalian, and Tietze has nnore recently shown that their equivalents in Moravia (the Ostrau Beds) contain a larger number of species belonging to the Schatzlar flora than to that of the Culm. The Ostrau Beds include several marine bands containing Gastrioceras Listeri, Bellerophon Urei, and other species which suggest a correlation with our Lower Coal-measures.

Still farther east a similar succession of Westphalian Beds occurs near Cracow in Poland, where it includes a marine band with Spirifer mosquensis, a species which does not exist in Western Europe, and marks a temporary incursion of the eastern or Moscovian Sea.

\section{Russia}

When we reach Central Russia we find the representatives of the Westphalian Series to be entirely of marine origin, estuarine and semi-terrestrial conditions only prevailing in the southeru basin of Donetz.

In the Moscow basin the whole series consists of limestones, white or yellow in colour, some beds oolitic and some chalky, and many of them highly fossiliferous. This series is known as the Moscovian, and is about 1500 feet thick; it is specially characterised by Spirifer mosquensis and Streptorhynchus (Meekella) eximius, with the large Foraminifer called Fusulina cylindrica, which is sometimes so abundant as to form a Fusulina limestone. 
These limestorres are covered by other beds which also probally belong to the Westphalian Series, for they contain some species common in our Aronian Series, such as Spirifer striatus, Productus cora, and $P$. semireticulatus, together with species of Syringopora, Lonsdaleia, and other corals.

The Moscow basin, though it occupies an area of 13,000 square miles, is probably only a part of a great tract of Carboniferous rocks which underlies the broad Russian plain, for the beds pass in every direction underneath newer strata of Permian, Jurassic, and Cretaceous ages. Moreover they crop out again along the western tlanks of the Ural Monntains in an almost continuous strip, and this (partly covered by Permian) is believed to extend northward to the shore of the Arctic Ocean.

In the Ural Mountains the Moscovian Series consists of limestones with bands of calcareous shale. Spirifer mosquensis and Productus cora are still characteristic fossils, but Cephalopoda are more frequent and include Glyphioceras striolatum, Pronorites cyclolobus, and Gastrioceras marianum.

\section{Mediterranean Region}

A few tracts of Westphalian or Moscovian strata occur in Southern Europe, and they all resemble the Russian type more than that of the nortli-west. Thus in Anstria sandstones and shales, with bands of Fusulina limestone, are infolded with Trias on the western borders of Styria; and again in Carinthia the Gailthal slates (Dinantian) are overlain by sandstones and shales succeeded by Fusulina limestones. A similar series is found to the south in Carniola, Croatia, Bosnia, and Herzegovina.

Westphalian Beds are said to occur in Corsica, and in Spain (Andalusia) there are Coal-measures with Dictyopteris Brongniarti and interbedded limestones with Spirifer lineutus and Sp. mosquensis. Again in Asturia the Sama slates with Dictyopteris and intercalations of marine beds with Schizodus and Posidonomya probably belong to the same series.

\section{THE STEPHANIAN SERIES}

As stated at the begimning of last cliapter (1. 244), no representatives of the lighest portion of the Carboniferous System occur in Britain. This gap in the geological record appears to be due to a general uplift of the whole of North-Western Europe, whereby the low-lying areas in which the older (Westplialian) Coal-measures had been accumulated were raised into dry land. This upheaval, moreover, was accompanied by volcanic disturbances and by crustal 
compression, which resulted in the production of several systems of flexures, but especially of a great series of folds having a general direction from west to east.

This series of flexures is known as the Armorican or Hercynian System, and it extends from the south-west corner of Ireland through South Wales, Devon, and Cornwall. Thence it passes under the whole of Southern England and through the north-east of France and Belgium. Another part of the same series passes through Brittany and Normandy and under the Paris basin till it emerges in the Ardennes. The combined series then-extends through the Rhine Province of Germany, through Westphalia and the rest of Germany to Poland and the northern border of Bohemia. These Armorican flexures are narrow and the synclines are deep; the folds are sometimes overthrust and often broken by faults.

North of this series of flexures in England we find another set, or rather two sets which cross one another nearly at right angles, and it is to the intersection of these two sets of folds that the production of Coal-measure basins is due. The one set runs approximately north and south, and is exemplified in the ridge of the Malvern and Abberley Hills, where Upper Coal-measures are included in one of the flexures, and yet the folding is shown to be pre-Permian by the position of Permian strata on a plane of erosion cut across these flexures. Farther north is the parallel anticline of the South Peunine area, which separates the flanking synclines occupied by the Coal-measures of Nottingham and Yorkshire on the one side and of North Stafford and Lancashire on the other side. Here again the pre-Permian age of the main flexures is indicated by the position of the Permian Beds overlying them in Nottinghamshire, though there may have been further uplifts in Triassic time, and still later in Tertiary times. The North Pennire faults in West Yorkshire, Westmoreland, and Cumberland were also in part pre-Permian.

The other set of flexures runs approximately from W.S.W. to E.N.E., and may be termed the Lancastrian Series. They differ markedly from the nearly parallel Armorican folds in being very broad and comparatively shallow undulations. Such is the broad anticline of the Ribble Valley and its continuation across Yorkshire, which passes eastward under the Permian of that county.

For a fuller account of these flexures the reader is referred to the new edition of my Building of the British Isles (1911), but which of the two series is the older has not yet been determined.

While uplift, disturbance, and erosion were going on in the north of Europe, deposition was still in progress farther south, and more especially over the eastern part of Europe. In the western 
region deposition seems to have been restricted to certain shallowwater areas of a lacustrine character, and only portions of these remain in small isolated basins. It was only in the eust over Russia and the Balkan provinces that open sea prevailed. Consequently there are two very different facies of this series, a western Coal-measure Group (with plants and freshwater fossils) to which the name Stephanian has been given from St. Etienne in France, and an eastern marine facies known as the Uralian from its development in the Ural Mountains. We can only give a brief account of these two facies.

\section{A. The Stephanian Facies}

1. The Flora. - This is characterised by the abundance of certain species of Pecopteris ( $P$. arborescens, $P$. cyathea, etc.), of Callipteridium, Odontopteris, of Cordaites and Calamodendron with the foliage known as Annularia, the non-ribbed Sigillarias, and finally by the appearance of T'cniopteris, of the Conifer Walchia. and the Cycads Pterophyllum and Plagiozamites. Three phases or stages have been recognised by $\mathbf{M}$. Grandeury as existing where the Steplianian Series is complete; these are:-

3. Phase of Calamodendrons.

2. Phase of Anmularia stellata and Pecopteris cyathea.

1. Phase of Ann. sphenophylloides and P. neuropteroides.

The Fauna is not a large one, consisting of some small fresl-water Crustacea (Estheria, Leaia), a few Molluscs (Anthracosia), a number of insects, especially beetles (Eoblattina), and Phasmidæ (Protophasma, Dictyoneura); also some Fish and Amphibians.

2. Stratigraphy.-In France the Stephanian deposits occupy a number of small isolated basins or troughs, most of which are situate on the borders of the "Massif Central," though some occur in the middle of it (see nap, Fig. 102). Many of these patches are doubtless portions of much larger areas or hasins of deposition and were originally continuous, but no attempt has yet been made to ascertain which niay have been connected with one another, and indeed most Frencl geologists seem to assume that they were all disconnected.

The typical district of this region is that of St. Etienne in the Department of the Loire (see Fig. 104), where the succession is stated to be as follows :-

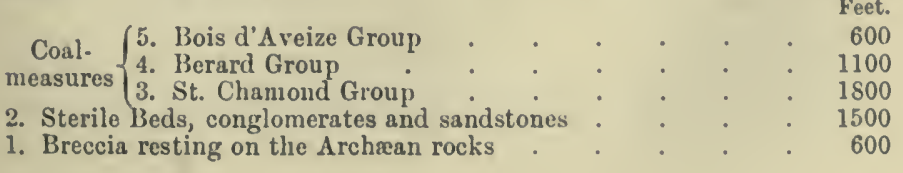


To the north, in the Morvan district, the Dinantian is overlain

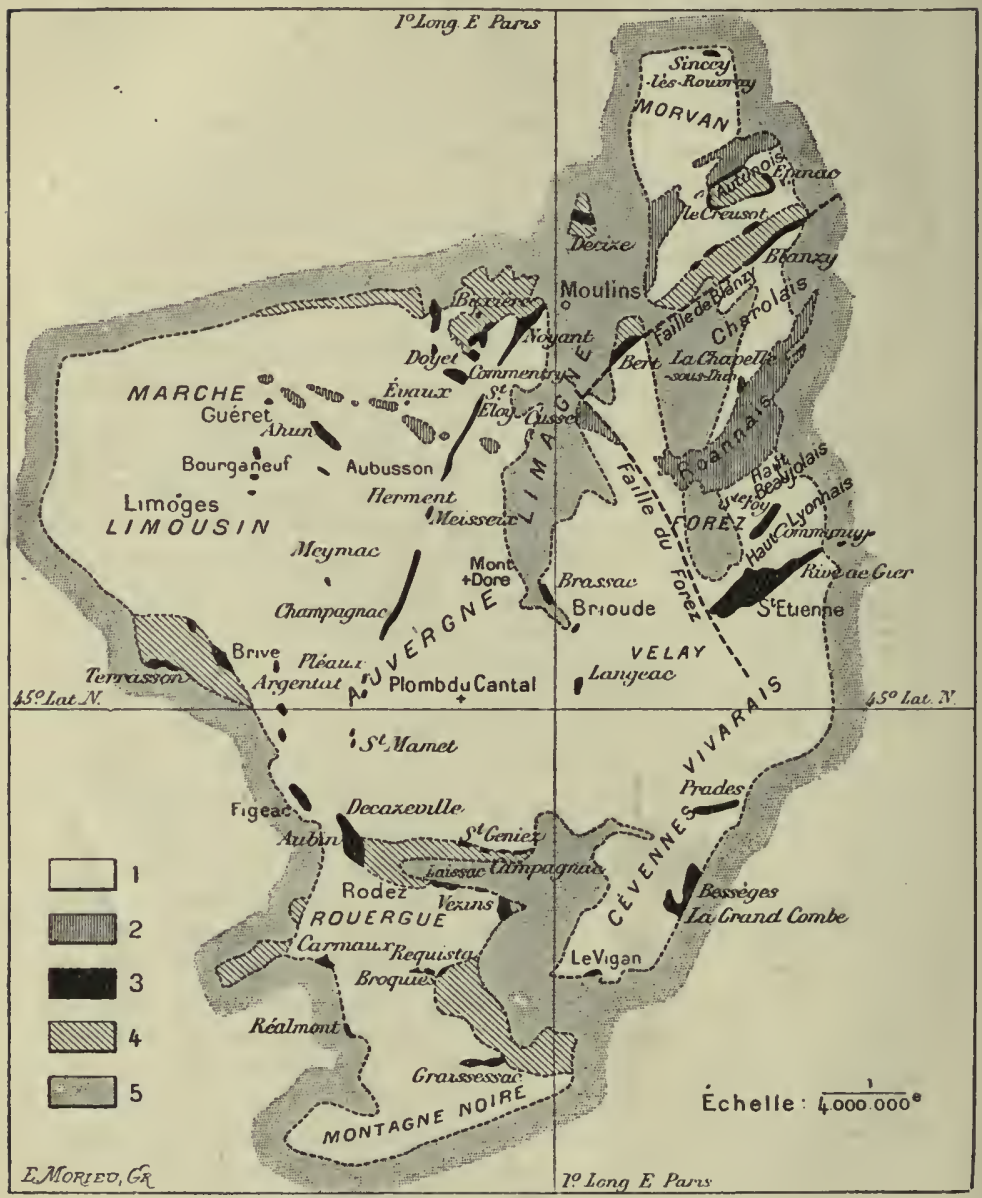

Fig. 102. - MAP OF Central PLATEAU of FRANCE.

Reproduced by permission from de Iapparent's Traité de Géologie.
5. Jurassic rocks.
4. Triassic rocks.
3. Carboniferous.
2. Pernian.
1. Archæan and Igneous rocks.

by flows of quartz-porphyry which may be of Westphalian age; and above these are beds with a Stephanian flora, the lowest being 
sandstones and shales with some beds of coal (from 160 to 300 feet thick) overlain by a mass of sandstones and conglomerates more than 2000 feet thick.

Another small basin in the north, that of Commentry (Allier), is interesting in three respects. One is that it contains a very thick bed of conl ( 40 to 60 feet thick) which in certain directions splits up into 5 or 6 beds, separated by shales and sandstones, just as in the case of the "thick coal" of Staffordshire. Another point is that a shale 15 feet above this coal has yielded a large number of insect remains. Thirdly, one of the beds of sandstone passes at one place into a mass of breccia formed of angular blocks of gneiss and granulite which seem to represent a contemporaneous landslip from neighbouring high ground.

A few small tracts of Stephanian measures occur in Brittany and Normandy, and are mainly of importance because they occur within the region of Armorican flexures and show that deposition had not completely ceased in that region. The most northern of these is at Littry, south-west of Bayeux, the Coal-measures here resting directly on Brioverian slates and being conformably overlain by Permian Beds, and they belong, therefore, to the latest phase of the Stephanian.

In Germany the most western tract of Stephanian Coal-measures in the Germanic region is that of the Palatinate near Sarrebruck (see Fig. 103), where they are known as the Ottweiler Beds. Here they succeed the Westphalian Beds without any break, thougl they overlap the latter on to the Devonian; and they are also conformably overlain by Permian Beds. The greater part of the series consists of felspathic sandstone and conglomerate, testifying to the upheaval and rapid detrition of the country to the north of the basin; but both at the base and again at the top are a few hundred feet of finer sediments, chiefly grey shales with seams of coal. The total thickness is from 2000 to 3000 feet.

The small coalfields of Pilsen and Kradno in Bohemia are specially interesting because they exhibit a still more complete transition from Carboniferous to Permian and include a bed from which remains of many insects, fish, and Amphibia have been obtained by Dr. Fritsch. The plants in and above this bed are Carboniferous, while the vertebrate animals are closely related to forms which have been found in beds of Permian age : fish of the genera Amblypterus, Acanthodes, Palconiscus, and Xenacanthus; Amphibians of the genera Dendrerpedon, Sphenosaurus, Chelidosaurus, Limnerpedon, Keraderpedon, Urocordylus, and Hyalonomus, some of which are figured in the Geological Magazine for 1885 . 


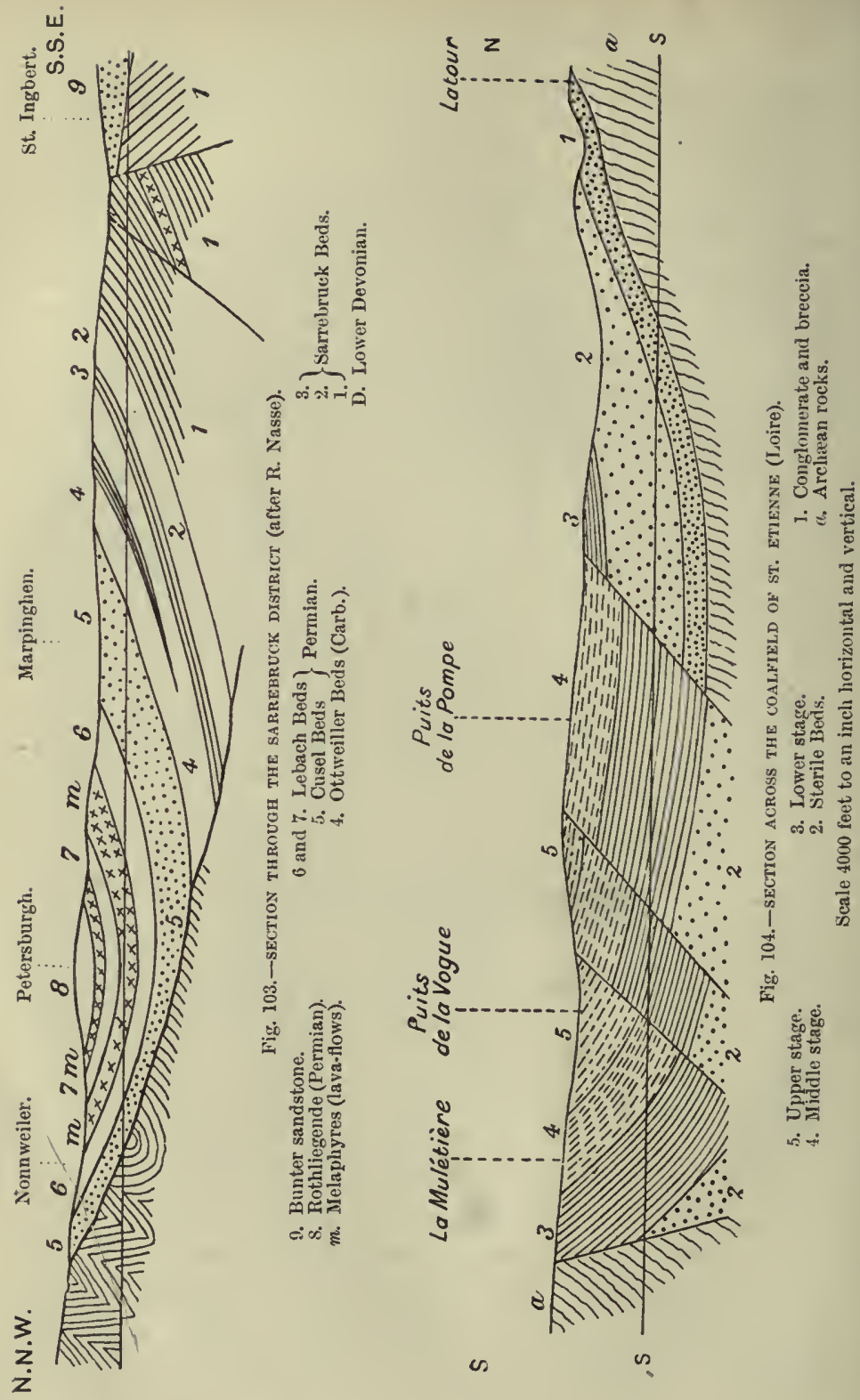


The following is a tabular view of the strata in the Pilsen basin, modified from that given by Feistmantel :- ${ }^{10}$

Permisn \{ Red felspathic sandstones with Araucarites.

Stephanian $\left\{\begin{array}{l}\text { Shales with ironstone nodules (Permian plants). } \\ \text { Shales with Carboniferous plants, a coal-seam and the } \\ \text { Nurschau "gas-coal" (oil-shale). } \\ \text { Lower shales with a coal-seam. }\end{array}\right.$

The plants in the Stephanian shales include Calamites (three species), Sphenopteris Schlotheimi and eight other species, Odontopteris obtusiloba, Dictyopteris Brongniarti, Sigillaria distans, and fragments of Walchia. Both Feistmantel and Röner correlate these beds with those of the Ottweiler Group. Further particnlars will be found in the paper referred to.

\section{B. Uralian Facies}

1. The Fauna.-This is entirely marine in the more typical areas. Foraminifera play an important part in the formation of Uralian limestones, the principal genera being Fusulina, Swagerina, and Doliolina. A spiral Bryozoan, Archimedes, is also a common and characteristic fossil. Brachiopoda are abundant, especially the Terebratuloid Dielasma, the Rhynchonellid Camarophoria, and the Orthotetid Meekella. Spirifers are still common, and the persistent species Productus cora is abundant ; Chonetes is represented by C. uralicus, and shells of the genus Spiriferina make their appearance, together with some which are closely allied to Waldheimia.

of Mollusca the Iamellibranchs Conocardium, Aviculopecten, Schizodus, and other Carboniferous genera occur. The Gastropod Omphalotrochus is common, but Cephalopoda are not numerous; Gastrioceras marianum occurs throughont, and in the highest beds Agathiceras uralicum appears. A few trilobites also survive.

2. Stratigraphy.-The typical development of this series is found on the south-west side of the Urals in the basin of the river Ai (Province of Ufa), where the whole consists of limestone, and three stages or zones are recognised by Tschernyschew, viz. :-

3. Zone of Swagerina princeps and Spirifer sarana.

2. Zone of Productus cora and Meckella eximia.

1. Zone of Omphalotrochus Whitneyi.

The same succession is found in the Moscow basin and in the Tinian district in the north of Russia. The limestones of the middle zone are generally dolomitic.

On the eastern slopes of the Ural Mountains there is a much greater variety of sediments indicating the near proximity of land, 
limestones being interbedded with marls and sandstones, clays and layers of gypsum ; and the highest beds contain a Stephanian flora (Pecopteris arborescens, Annularia longifolia).

The Uralian Sea must have occupied the greater part of Russia, passing southward over the Crimea and south-eastward through the Balkans, Bosnia, Herzegovina, Carniola, and the Julian Alps. Farther west, in the Carnic Alps between Italy and the Tyrol, there is an interesting intercalation of the Uralian and Stephanian facies, i.e. of freshwater and marine beds. The following series lias been described by Schellwein at Krone:-11

Shales with Spirophyton.

Dark-grey limestones with Fusulina and Suagerina.

Sandstone with Pecopteris and Annularia stellata.

Bed containing marine shells.

Shales with Annularia stellata and other plants.

Shales and calcareous sandstones with Camarophoria, Productus, and Phillipsia.

Shales with Pecopteris oreopteroides.

Conglomerates at base (about 200 feet thick).

The total thickness of these beds is about 900 feet, and they are overlain by another Fusulina limestone which is of a light-grey colour and contains a Lower Permian fauna. How much farther west the Uralian Sea extended is not yet known, for no marine strata of this age have been found in Italy or Spain, though deposits with a Stephanian flora occur in both countries.

\section{The Formation of Coal-Seams}

The most important point conmected with the deposition and distribution of the Coal-neasures is the formation of coals; what they are made of, and how they were accuniulated. The reader will find this subject well treated in a little book, On the Natural History of Coal (Camb. Univ. Press), by Mr. N. Arber, but a brief sumnary of the current theories and modern views respecting the origin of coal niay here be given.

A conplete explanation of coal-seams must account for (1) the source of the carbonaceous material; (2) the different existing varieties of coal; (3) the frequent alternations of coals, clays, shales, and sandstones; (4) the great extent of some single beds of coal. The reader is probably aware that there are many kinds of coal which go by different names according to their chemical composition and physical peculiarities. There is so-called "Browncoal," which is little more than lignite or fossil wood; there is glossy Cannel coal, which does not soil the fingers and burns with a clear, continuous flame; there are the Humic or so-called 
Bituminous coals, which vary in their gas-producing qualities; and lastly, there are the hard coals-Steam-coal and Anthracite-the last differing in being smokeless when burnt.

It is now generally agreed that the original substance of all kinds of coal was vegetable matter of some kind, and that many kinds owe their peculiarities to differences in the nature of the vegetable matter of which they were originally composed. Thus the Toula coal of Russia consists entirely of sheets of the bark of the tree called Bothrodendron, and this is so little altered that, when exposed to the weather, it splits up into thin layers. Other coals appear to have been composed of a mixture of woody tissue with leaves and fronds of fern-like plants. Some beds consist of the spores or sporangia of Carboniferous plants; thus Cannel coal is mainly composed of Lycopod-spores, and some Boghead coals of closely packed cellular bodies which are either spores or gelatinous alga arising from their decay.

Some other varieties of coal, however, are due to the amount of chemical clange which the substance has undergone since its original deposition and burial in the earth's crust, as well as to the varying degrees of pressure to which the strata have been subjected at different places. These influences appear to have led to a concentration of carbon in the older coals, or rather to an increase in the proportion of carbon to hydrogen.

Let us next consider the conditions under which the coal-seams are likely to have been accumulated, and it is evident that on this question we can learn much from a study of the associated sediments, that is to say from the general characters and contents of the whole series of measures of which the coal-seams form a part. These beds include sandstones which are generally of fine grain, and often show current bedding; shales which are consolidated silts, i.e. sandy or micaceous muds deposited in successive layers or laminæ; and clays which are more homogeneous muds. All these beds usually contain only remains of plants, and sometimes of insects, with bivalve shells such as Anthracosia and Carbonicola, which were of fresh or brackish-water habitat. Occasionally, however, there are bands which contain marine shells, and from these we may safely infer that the measures in which such beds occur were formed in swamps or marshes liable to incursions of the sea.

There is, in fact, no escape from the conclusion that the Lower and Middle Coal-measures of the British region, and probably most of those in the Continent, were formed in extensive swamps on the borders of sinking land, where the area of alluvial levels, swamps, and brackish lagoons was being continually enlarged at the expense of the sea by the process of silting up and by the outgrowth of 
plants which, like modern mangroves, did not mind having their roots covered by salt water.

So far as to general conditions, but we have still to deal with the formation of the individual coal-seams, and to consider the way in which the coal-material may have been accumulated so as to form a seam or bed, for these are sometimes of great thickness, as much as 20 or 30 feet. There are a certain number of facts which seem to indicate that the vegetation from the decay of which a bed of coal was formed grew on the spot, while other facts have suggested the theory of drift-origin, i.e. that the vegetable materials were drifted by a current into their present situation.

Some writers have maintained the one, and some the other theory; but as Mr. Arber remarks, it is very likely that both theories are equally true, some coals having been formed in the one way and some in the other. He also points out that the significance of certain facts, often appealed to as evidence for one or the other theory, has been greatly exaggerated and misunderstood.

Thus the presence of an underclay containing many Stigmarian rootlets is no proof that the coal above has been formed in situ from plants which grew in that clay; neither does the fact that the roof-bed of a coal contains drifted plant remains prove the coal to have been formed by an accumulation of such drift. The formation of each bed of coal must be individually considered, and its own structure must especially be ascertained and noted; coals which consist entirely of one kind of material, such as the Cannels, were doubtless formed in situ from local growths, while some of those which consist of many sorts of plants may have been formed of drifted materials. Some seams may have been semi-terrestrial growths like modern peats, othels were formed on the floors of large swamp lakes or in brackish-water lagoons, and in some cases these water spaces were clearly near to the estuary of a large river.

Finally, a few remarks may be made on the succession of plantassemblages in the Coal-measures. That there is such a succession in the northern part of England admits of no doubt, and this same succession prevails over a large area, but whether it prevailed all over Europe, wherever the sequence was complete, has not yet been proved. Thus we have seen that what is known at present as the flora of the Lower Coal-measures cannot be recognised in South Wales, nor in the Bristol and Somerset coalfields, and further that it has not been found on the Continent except in a narrow zone of so-called Millstone grit. From the absence of this particular assemblage of plants, or rather from the absence of certain species, it has been inferred that the Lower Coal-measures are not represented in the more Southern areas. 
It is donbtless true that from a botanical point of view the Millstone grit of the Pennine area is only the basal portion of the Lower Coal-measures, and that in other areas, such as Bristol and Sonth Wales, the latter might be represented only by sandstones. Further, it is almost certain that the Millstone grit episode marks a general uplift of the whole British region, and a shallowing of all the areas in which deposition was taking place. This uplift may have been greater in some parts of the region than in others, and deposition may possibly have been stopped for a time in Southern England; but when we pass over into Belgium, and are asked to believe that divisions which have a thickness of 3000 to 4000 feet in England are entirely absent in that country, the case is different. There is no stratigraphical evidence of such a break, and if the absence of beds was due to uplift into dry land, signs of such a break should be clear and conspicuous.

Another and very different explanation presents itself which should be carefully considered by the botanists; this is that the absence of the species in question may be due to geographical limitation. It may be that the particular assemblage found in the lower stage of the northern region did not extend into the southern region, and that the southern assemblage did not extend into the northern region until the epoch of our Middle Coal-measures. In other words, the deposition of Coal-measures may have been contemporaneous in both regions throughout Westphalian times, but the succession of plant-assemblages was different in the two regions, and dependent on slight climatal differences north and south of a certain line of latitude. The truth of this theory must be tested by more careful zonal study both of the plants and of the shells.

\section{REFERENCES}

1 Kidston, Proc. Roy. Phys. Soc., Edin., vol. xii. p. 183.

2 Gibson, Quart. Journ. Geol. Soc. vol. Ivii. p. 251.

8 Peach and Horue, Trans. Edin. Roy. Soc. vol. xl. p. 835 (1903).

+ "Geol. of Edinburgh," Mem. Geol. Survey, 2nd ed. (1910).

- Hardman, Mem. Geol. Surv. Ireland, Expl. of Sheet 35.

" "Geology of S. Wales Coalfield," Parts vii. and viii., Mem. Geol. Survey.

7 Ussher, in Proc. Som. Arch. and N.II. Soc. vol. xlvi. p. 1.

8 Arber, Quart. Journ. Geol. Soc. vol. Ixiii. p. 6 (1907). ;

Zeiller, Bull. Soc. Géol. Fr. (3) xxii. p. 483 (1894).

10 Feistmantel, Geol. Mag. for 1877, p. 105.

11 Schellwein, Pakcontographica, xxxix. 


\section{CHAPTER XI}

\section{THE PERMIAN SYSTEM}

\section{A. Nomenclature and Subdivisions}

IN the early days of geological research all the strata which intervened between the Carboniferous and the Lias were classed together as the New Red Sandstone, but in 1841 and subsequent years Sir R. Murchison saw good reason to divide them into two great series and to believe that the lower series, on account of the Palæozoic aspect of its fauna, formed thc summit of the Palæozoic succession, while the higher strata might be regarded as marking the beginning of Neozoic time.

Further, he found that this lower set of post-Carboniferous rocks was more fully developed in Russia than in any other part of Europe, and was especially well exposed in the province or ancient kingdom of Perm, whence he proposed to call them Permian.

Although the name Permian has been adopted in England, France, and Russia, it made its way very slowly in Germany, mainly because Murchison made mistakes in his grouping of the German rocks. In that country the strata which are really of Permian age fall into two strongly contrasted divisions, and just as the overlying Trias was named from its consisting of three such groups, so the term Dyas was proposed by Marcou in 1859 from the duality of the underlying system. This name was adopted by Geinitz, and was for a time much used on the continent, but Professor Kayser and others have more recently preferred the older name as on the whole a better one.

We have seen that where the Carboniferous System is complete and the Stephanian Series is fully developed there is a passage from it into the Permian. Further, where the Permian System is fully represented it consists of three stages or series, viz. (1) a series of beds like the undcrlying Coal-measures and containing a flora which does not differ much from the Stephanian; this has been 
termed Autunian by the French geologists; (2) a mass of red sandstones well developed in Germany, where they are known as Rothliegende, but for which the name Saxonian has been proposed; (3) a group of limestones and unarls, known in Germany as the Zechstein, but for which Renevier has proposed the name Thuringian.

In the British Isles there are several different facies of Permian, and there is little doubt that these include representatives of the Saxonian and Thuringian, but it is uncertain whether we have any equivalent of the Autunian. In Russia and Southern Asia the whole system consists of marine deposits with a much nore raried fauna, and Russian geologists have proposed special names for parts of their succession. The correlation of English, German, and Russian divisions is shown below :-

English.

Maguesian limestone.

Peurith sandstone?

Shropshire Permian?
Germany.

Thuringian.

Saxonian.

Autunian.
Russia.

Thuringian.

hostromian.

Artinskian.

\section{B. Life of the Period}

\section{The Flora}

The Pernian flora is on the whole very like that of the Carboniferous, fern-like Pteridophytes (Pecopteris, Odontopteris), Calamites, and Tree Ferns (Psaronius) being still the prevalent forms, and many of the same genera being present. At the same time it differs both in the absence of certain genera, in the greater relative development of others, especially Callipteris, and in the presence of numerous Mesozoic types, especially Coniferæ, Cycads, and Ginkgos. Thus Sigillaria and Lepidodendron have almost disappeared, while Walchia is abundant together with the new Coniferous genera Ullmannia. Among (?) Pteridosperms Callipteris, Schizopteris, and (in India and the southern hemisphere) Glossopteris are new and characteristic forms. Cordaites and Cordioxylon (=Araucarites) are not uncommon. Cycads are represented by Pterophyllum and Plagiozamites. Leaves of the curious tree called Ginkgo, still existing in China, are also found, as well as those of Baiera, a long extinct genus of similar affinities.

The following are some of the most characteristic species of plants :-

Pleridosperma. Callipteris conferta, Neuropteris auriculata, Schizopteris Gunbeli, Tæniopteris multinervis.

Equisctales. Calamites gigas, Annularia stellata.

Coniferales.

Walchia piniformis, W. lypnoides, W. filiciformis, Ullmannia Bronni, U. Geinitzi. 


\section{The Fauna}

The Permian fauna is interesting because, as in that of the Carboniferous, it may be said that we possess remains not only of the marine fauna of the period, but also of the inhabitants of its great salt lakes as well as of the fresh waters and of the land.

The typical marine fauna is only found in the east of Europe,
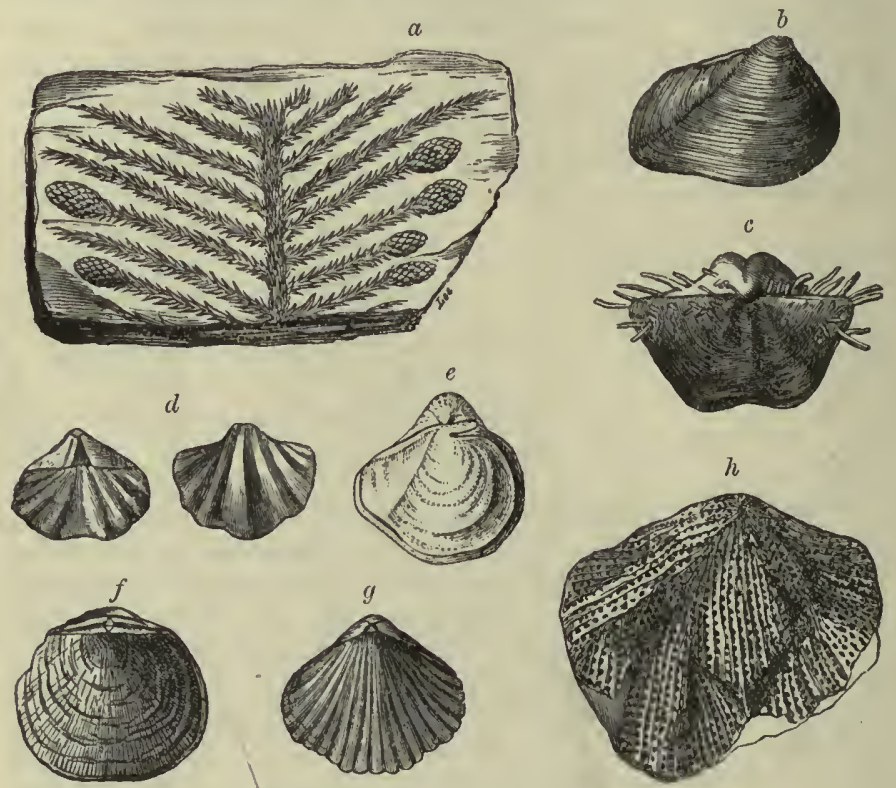

Hig. 105. —rRoup of PERMIAN FossiLs.

a. Walchia hypnoides.

b. Schizodus Schlotheimi.

c. Productus horridus.

d. Spirifer alatus. c. Monotis speluncaria.

f. Strophalosia lamellosa.

g. Camarophoria Schlotheimi.

$h$. Fenestella retiformis.

extending thence in to Asia and America, but in later Permian time arms of this sea extended into Central Europe and into the British Isles, forming landlocked inland seas and large salt lakes resembling the Black Sea and the Caspian of the present day. In these areas we find a limited and dwarfed assemblage of marine species. This marine fauna is largely composed of species which belong to Carboniferous genera, but with these are associated some new forms. The following is a list of the prevalent genera, those to which an asterisk is appended being new introductions :- 
Bryozoa. $\quad$ Fencstella, Synocladia," Acanthocladia.

Brachiopoda. Diclasma, Camarophoria, Spirifer, Productus, Strophalosia, Aulosteges."

Lamcllibranchia. Allorisma, Bakevellia," Gervillia," (Hoernesia), Schizodus, Pseudomonotis, Pleuropliorus.

Gastroporla. Bellcrophon, Loxomenna, Naticopsis, Pleurotomaria.

Cephalopoda. Medlicottia," Popanoceras," Thallassoceras, "Cyclolobus, Temnocheilus.

Pisces. Acrolepis," Acanthodes, Crlacanthus, Amblypterus, Palæoniscus, Xenacanthus. *

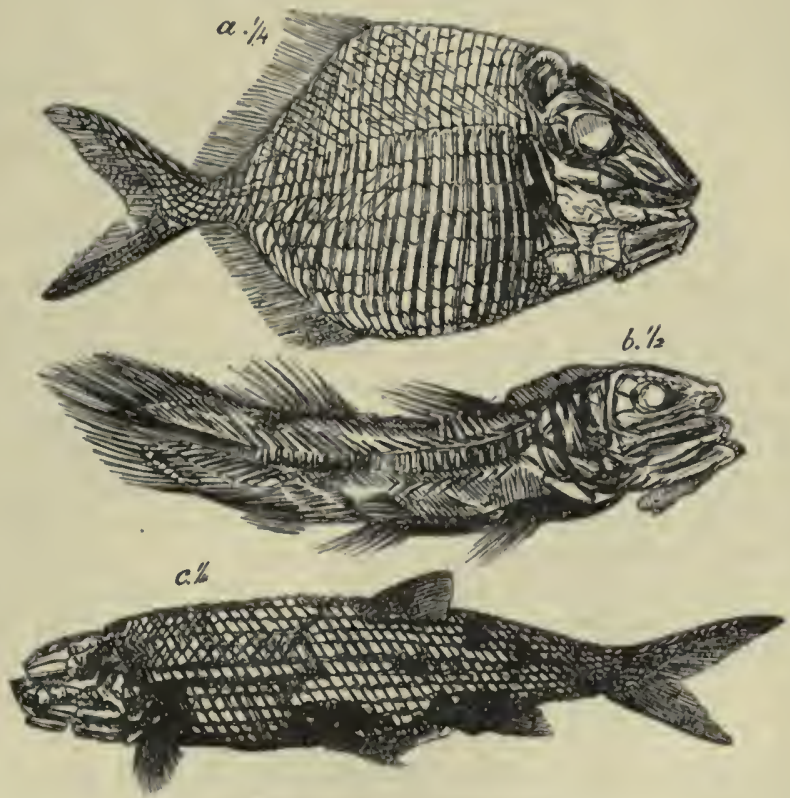

Fig. 106, - -80ME PERMIAN FISU.

a. Platysomus striatus.

b. Colacanthus granulosus.

c. Palæoniscus comptus.

The freshwater and terrestrial fauna is of special importance because it includes the earliest representatives of the Reptilia. The most conspicuous members of this fauna are:-

Crustacea.

Amphibia.

Reptilia.
Uronectes (=Gampsonyx).

Archegosaurus, Actinodon, Branehiosaurus, Dasyceps, Lepidotosaurus.

Two orders of Reptilia are represented, viz. :-(1) Rhynchocephala, by Proterosaurus and Palaohattcria ; (2) Theromorpha, by Pareiasaurus, Elginia, Gordonia, Gcikia. 
The following are some of the most characteristic species of the English and German Permian :-

Bryozoa.

Brachiopoda.

Fenestella retiformis, Synocladia virgulacea.

Camarophoria Schlotheimi, Strophalosia lamellosa, St. Goldfussi, Productus horridus, Dielasma elongata, Spirifer alatus, Lingula Credneri.

Lamellibranchia. Pseudomonotis speluncaria, Pleurophorus costatus, Gervilia (Bakewellia) antiqua, B. ceratophaga, Schizodus obscurus, S. Schlotheimi.

Gastropoda.

Cephalopoda.

Pisces.
Loxonema fasciatum, Natica minima, Pleurotomaria antrina, Turbo mancuniensis.

Temnocheilus Frieslebeni.

Platysomus striatus, P. gibbosus, Palæoniscus comptus, P. macropomus, Coelacanthus granulosus, Acrolepis Sedgwickii, Rhabdolepis macropterus.

\section{British Permian Rocks}

In spite of the fact that the British Permian succession is nowhere complete, and that it is uncertain whether the oldest part of the system is represented, Permian rocks cover considerable areas in England, and it will be convenient to describe them before dealing with those of the continent. The oldest Permian Beds must be those which are most nearly conformable to the Upper Carboniferous, and there can be no doubt that those of the Midland counties occupy this position. Those found in Devonshire resemble the Rothliegende of Germany, and may be of the same age; while there can be no doubt of the Thuringian age of the Magnesian limestones of the north-east of England. We shall therefore take these several areas in the above order.

\section{Midland Area}

Beds which appear to be of Permian age, though no fossils have been found in them, occur in Worcestershire, Staffordshire, and Shropshire, extending as far north as Shifnal, and as far west as Shrewsbury and Alberbury, but not reaching into Denbigh nor into North Staffordshire. The Keele Group of the Upper Coalmeasures was formerly regarded as part of them, and so closely are they connected with it, and so little evidence is there of any unconformity, that Mr. Cantrill regards them as an upward continuation of the Coal-measures. ${ }^{1}$ He also considers them to be passage beds into the Permian and Trias, but they cannot bridge the whole interval between British Coal-measures and Trias. If they are Carboniferous they night be of Stephanian age, but until this is proved it is better to regard them as Permian and as a 

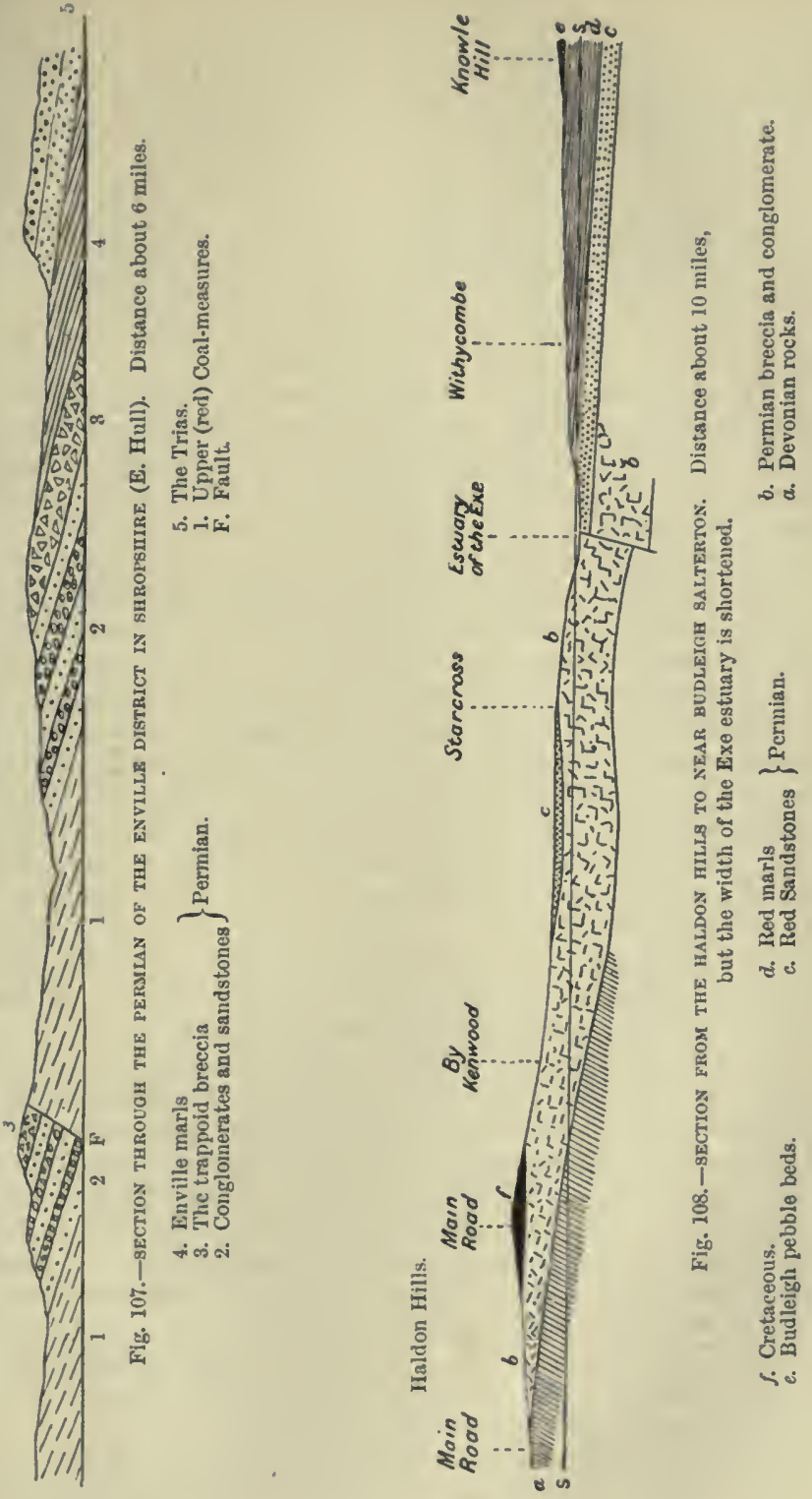
possible equivalent of the French Autunian. They can hardly be newer than that.

Where fully developed this Midland Permian consists of three members or divisions as below.

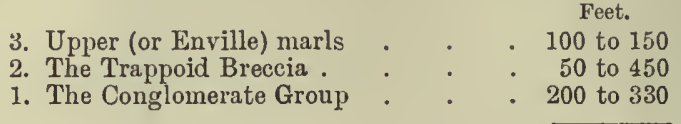

500 to 800

The thicknesses given are those found in the typical districts of Shropshire and South Stafford. When followed southward the conglomerate group thins out and the marls are overstepped by the Trias, only small patches of the breccia being seen at intervals below the latter.

This Permian Series follows the eastern border of the Coalmeasures through Shropshire and Worcester, passing southward on to the Silurian rocks of the Abberley and Malvern Hills. To the eastward it borders the southern half of the South Staffordshire coalfield, but does not extend to its northern extremity.

The Midland Permian, as above restricted, attains its fullest development in Shropshire, and is well exposed in the neighbourhood of Enville on the Staffordshire border (see Fig. 107). Another typical district is that of the Clent Hills in Staffordshire, where the trappoid breccia attains its greatest thickness, but the upper marls are not seen, being presumably concealed by the overstep of the Bunter pebble beds (Trias).

The following account refers more particularly to the Enville district, and has been compiled from a paper by Mr. W. W. King, ${ }^{2}$ who has made a special study of that area.

The Conglomerate Group.-This consists of soft red sandstones and red marls with three interbedded bands of calcareous sandstone and conglomerate, the latter consisting of various pebbles embedded in a sandy matrix, which is cemented by carbonate of lime. The second of these bands is the thickest, being sometimes a massive conglomerate 75 feet thick, and sometimes including lenticular beds of red sandstone with a total thickness of 150 feet. Both conglomerates and sandstones thicken to the north-west and become thinner to the south-west. In the Clent Hills this group is represented by red marls with three bands of sandstone and compact limestone or cornstone, without any conglomerate, but containing small fragments of the older rocks.

The nature of the pebbles varies considerably in different parts of the district. Thus in Shropshire about half the pebbles consist 
of dolomitic Silurian limestone like that which occurs in the Ablerley Hills, the other half consisting largely of Carboniferous limestone and sandstone. In Staftordshire, especially near Baggeridge on the west, and near Barr on the east side of the coalfield, the majority of the pebbles ( 60 per cent) are of Carboniferous limestone, most of the remainder consisting of Wenlock limestone. It is thus a remarkable fact that these conglomerates are essentially limestone conglonierates, but contain the debris of various rocks down to and including the Woolhope limestone.

The Trappoid Breccia was so called because it is largely made up of angular blocks of the compact felspathic lavas and tufts which were formerly known as "traps." They are really rhyolites, hornstones, felspathic tuffs, grits, and agglomerates, and have evidently been derived from pre-Cambrian rocks like those which are known to occur in the Lickey Hills, at Barnt Green near Birmingham, and at Nuneaton. With these are associated many fragments of Llandovery sandstone and a few of Woolhope limestone.

Mr. King remarks that the difference between the assemblage of rocks found in the conglomerates and that in the breccia may be explained on the supposition that during the accumulation of the former valleys in the adjacent country were being cut down through the Carboniferous and Silurian to the Woolhope limestone, while in the later epoch erosion was continued through the Llandovery Beds, and deep into the underlying Archæan rocks. - It is also possible that the materials of the two deposits were brought from different directions.

Another remarkable fact connected with this breccia is that many of the blocks are very large, and that some of them are scratched or striated, the striations resembling those of glaciated stones, so that Sir A. Ramsay was led to infer the existence of glaciers and glacial moraines to account for them. This view, however, has not been sustained, and the striations are now attributed to the grinding of rock-fragments against one another during the many subsequent earth-movements which they have experienced.

This breccia can be traced southward through Worcestershire, where it is often called the Haffield breccia, from its occurrence on Haffield Hill near Great Malvern. This is its most southerly outlier, but others occur on the Abberley Hills, resting on Silurian and Old Red Sandstone.

The Enville marls are only found in Shropshire, and are not seen farther south than Enville, though they doubtless extend much farther southward beneath the Trias. They include a band of Breccia which near Enville is 50 feet thick, but thins out to 
the north-west, while the thickness of marl increases in that direction. It is clear, therefore, that the materials of this breccia, as of the main mass, came from the south and south-east.

In Leicestershire there are a few small but interesting deposits of Permian age, which have been carefully studied and described by Dr. H. T. Brown ${ }^{3}$ and Professor Bonney. ${ }^{4}$ They consist of grey breccias, grey sandstones, and red marls, not more than 60 feet thick in Leicester, but as much as 200 at Polesworth in North Warwick. The breccias thicken to the south and the marls to the north, and their thickness may originally have been greater, as they are overlain unconformably by the Trias. The pebbles in the breccias consist of the following kinds of rocks :-

(1) The larger number (about 60 per cent) are felspathic grits or quartzites, derived from the Cambrian quartzites, but differing slightly from those exposed at Hartshill.

(2) Gritty slates from the same series, averaging 17 per cent.

(3) Flinty slates and argillites, probably Charnwood rocks.

(4) Volcanic rocks, some being felsites and andesites from the pre-Cambrian (Caldecote) Series, some of a rock which may have come from Charnwood, and diorites like those in the Cambrian near Nuneaton.

(5) Fragments of Carboniferous grits, ironstones, and hæmatite ; but pebbles of Carboniferous limestone are rare, except at Polesworth.

In most of the exposed breccias over 80 per cent of the fragments come from the Cambrian quartzite series, and Dr. Brown shows that they have probably been derived from a buried ridge of these rocks which underlies Market Bosworth and runs parallel to the well-known Hartshill ridge. This buried ridge appears to be a faulted anticline, and so exact is the parallelism between these ridges and the principal faults of the Leicestershire coalfield that they may safely be attributed to the same period of earth-movement. These faults are known to be post-Carboniferous, and the undisturbed way in which the breccias lie, bridging over the faults, makes it very probable that they are of Permian age.

The view that these are terrestrial deposits of early Permian age will account for their proximity to the different set of deposits near Nottingham which belong to a late epoch in Permian time.

\section{Devon and Somerset Area}

This area is taken next because its Permian rocks have a strong resemblance to the Saxonian facies, and especially to the Rothliegende of the Hunsruck district between Treves and Bingen, as pointed 
out by Herr von Reinach. ${ }^{5}$ The Devonshire Series is much thicker than that of the Midlands, but thins northward and appears to have been formed in an isolated lake basin which persisted throughout both Permian and Triassic times till it was merged into a larger inland sea (see Fig. 64, p. 201).

The stuccession, where most fully developed in South Devon near Teignmouth, Dawlish, and Exeter, is shown in Fig. 108, and has been described by Mr. Ussher ${ }^{6}$ as follows :-

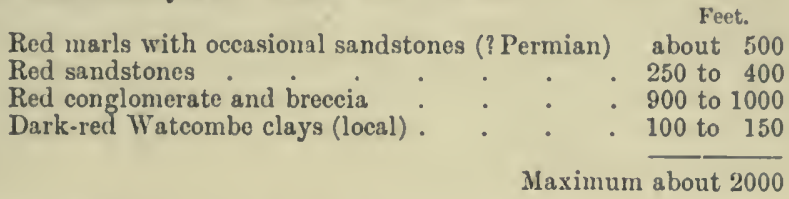

The Watcombe clays occupy some little space north of Torquay by Watcombe, Barton, and Daccombe, and they reappear between Teignmouth and Bishopsteignton. They consist of fine dark-red clay which has long been used for the manufacture of terra-cotta ware, and also for the making of tiles and hard bricks. The deposit seems to fill a broad hollow in the Palwozoic rocks, for it is overlapped by the breccias both to the south and north as well as westward.

The overlapping breccias consist in the lower part of congiomerate and breccia, in which fragments of Devonian limestone are abundant. These beds are well exposed in the fine cliffs between Babbacombe and the estuary of the Teign, and their thickness is estimated at from 400 to $\mathbf{5 0 0}$ feet, but the frequent faults make the estimate uncertain. The higher breccias differ in containing a larger proportion of derived volcanic rocks, chiefly of a peculiar red quartz-porphyry, and some of the boulders are of large size. This portion has a thickness of from 500 to 600 feet, so that the total thickness of breccia is about 1000. These breccias stretch northward beneath the Haldon Hills to Dunchideock and Ide.

South-west of Exeter there are sheets of trachytic and andesitic lava at their base, indicating the contemporaneous existence of volcanoes, but the material of these lavas is quite different from that of the blocks in the breccia, which must have belonged to another set of volcanic eruptions, probably of rather earlier date.

A similar breccia is found in the Crediton valley forming a long tongue which runs westward across the valley of the Tawe, and has an outlier at Hatherleigh (see Fig. 64, p. 201). North of Silverton the breccias pass into loose gravels which contain a different assemblage of stones, evidently derived from rocks to the northward, and the whole series becomes thinner as it is traced into Somerset. 
Near Dawlish and Exeter the breccias graduate upward into sandstones, and these are succeeded by red marls with lenticular beds of sandstone, which seem to be an upward continuation of the series. These marls may be of Thuringian age, and consequently homotaxial equivalents of the Magnesian Limestone Series described below, though never actually connected with that series.

How far these Permian rocks extend eastward beneath the Trias and newer strata we have no means of knowing, but they certainly had a considerable extension southwards, for patches of them occur between Bolt Head and Plymouth, and fragments of red breccia have been dredged from many parts of the sea-floor southeast of Cornwall, in such fresh condition as to indicate the existence of submarine reefs of this rock.

\section{North-Eastern Area}

In this area we have undoubted representatives of the Thuringian stage in the form of fossiliferous magnesian limestones with intercalated red marls. The outcrop of this series is shown on the nup (Fig. 87), from which it will be seen that although the strike of the Permian Beds is at first nearly in accordance with that of the underlying Coal-measures, yet they do not participate in the anticlinal flexures which give an east and west strike to these measures in South Durham. Near the valley of the Tees the Permian oversteps the Coal-measures, and rests first on the Millstone grit, and then on Carboniferous limestones. Farther south it again crosses the Millstone grit onto the Coal-measures of Yorkshire and Nottingham, but it is everywhere unconformable to the latter.

There is a marked lithological change in this series as it is followed from north to south. In Northumberland and Durham it is composed almost entirely of magnesian limestones (i.e. dolomites), and the complete succession of beds, according to Dr. Woolacott's ${ }^{7}$ recent examination of them, is as follows :-

Red marls with thin limestones and beds of salt .
Upper limestones, bedded for the upper $100^{\circ}$ feet, con-

Feet. 500 . $\begin{aligned} & \text { cretionary for some } 200 \text { feet, with a bed of flexible lime- } \\ & \text { stone at the base (10 feet) }\end{aligned}$

Middle limestones-bedded yellow limestones on the coast replaced westward by compact fossiliferous limestones, both often much altered and brecciated.

Lower bedded brown limestones .

150 to 300

The Marl Slate (a brown calcareous shale)
The Yellow sands (soft and without fossils)

40 to 200

The Yellow sands (soft and without fossils).

0 to 150

Total about 1200 
The fauna is restricted (about 140 species) and peculiarly distributed; fossils are most abundant in the Middle limestones, which seem to have formed a shell bank, and only a few Lamellibranchs and Gastropods survive into the Upper Beds. Fish remains occur at two horizons-the Marl Slate and the flexible limestones, and in the beds just above these deposits. Productus horridus is characteristic of the Lower and Middle limestones. For other common fossils see Fig. 105.

In Yorkshire, near Pontefract and elsewhere, the limestones are thinner, but the marl slates are thicker than in Durham, and sometimes rest on white and yellow sands, which in turn rest on an eroded surface of red marls and sandstones belonging to the Upper Coal-measures (see p. 298). In South Yorkshire the succession may be summarised as follows:-

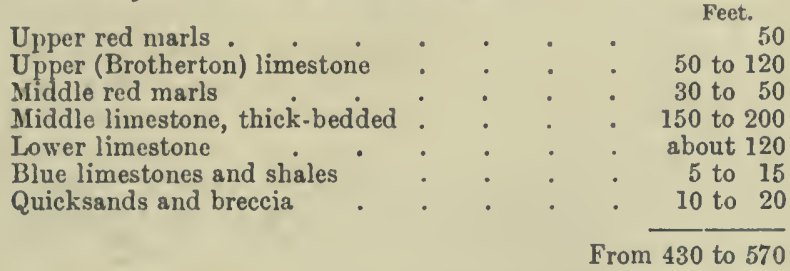

Traced southward into Nottinghamshire, the Upper limestone thins southward and is at the same time overlapped by the Trias, so that the thickness of the Permian at its outcrop is very much diminished, being as follows :-

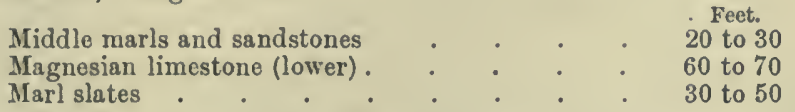

Southward near Kimberley the limestone passes into a yellow calcareous sandstone about 30 feet thick, resting on 15 to 20 feet of shaly ntarl, with a few feet of coarse breccia at the base. This change and diminution in thickness is evidently an indication that we are in this direction approaching the southern shore of the Permian Sea. The breccia contains angular fragments of sandstone and shale derived from the Coal-measures on which it rests, together with pebbles of slate, quart $z$, and quartzite, and it is not unlikely that these were derived from a northerly prolongation or the Charnwood rocks.

From borings made in search of coal near Haxey in Lincolnshire, and near Newark on the eastern border of Notts, it is known that the Permian limestones and marls exist in full force below these places. At Haxey the Permian was entered at 1183 from 
the surface, and its base is supposed to be at 1728 , but may be 68 feet lower. The beds traversed were :-

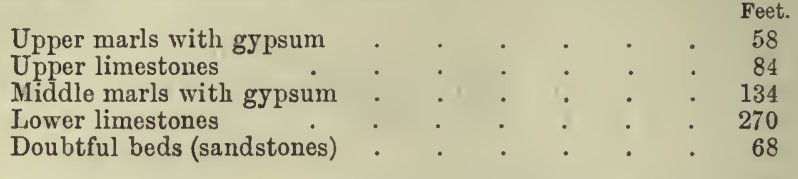

At Newark it consisted mainly of magnesian limestones, with 118 feet of red marl above them, the total being 519 feet, and the base is there clearly marked by a bed of grit and breccia.

\section{North-IVestern Area and Ireland}

On the western side of the Pennine ranges only a few isolated tracts of Permian strata are found, but as they include fossiliferous magnesian limestones, there can be little doubt that they were originally connected with the eastern area and are remnants of an extensive series of deposits which covered a large part of Northern England and spread across the space now occupied by the Irish Sea into the north of Ireland, where patches still exist as far west as Tyrone.

Beginning with the southern part of this area a strip of Permian is found near Stockport and Manchester, consisting of :-

2. Marls and limestones with marine fossils from 300 to 1000

Fossils found in the upper beds at Fallowfield include Pleurophorus costatus, Schizodus Schlotheimi, Bakevellia antiqua, Aucella Hausmanni, and Turbo ielicinus.

Still farther north several small outlying patches of Permian have been found, one east of Preston, another near Clitheroe, where it lies on Carboniferous limestone, and a third rather larger area in the centre of the Burton coalfield; these occurrences show the beds to be completely unconformable to the Carboniferous rocks, just as on the eastern side of the Pennine anticline.

The largest Permian tract is that on the western side of the Vale of Eden, extending from Kirkby Stephen in Westmoreland by Appleby and Penrith to within about 3 miles of Carlisle, where it is faulted down below the Triassic sandstones. Here the lowest member of the series is a bright-red sandstone, known as the Penrith sandstone and having a maximum thickness of $1500^{\circ}$ feet.

In the southern part of the Vale this red sandstone includes 
beds of breccia and conglomerate (locally called brockram) consisting of fragments of limestone embedded in a sandy matrix. These breccias are thickest in the south-east, being sometimes over 100 feet thick, and they thin out northwards till at and north of Penrith they have quite disappeared, and only red Penrith sandstone remains.

The surfaces of some of the sandstone beds bear numerous footprints, some of which seem to be tracks of Labyrinthodonts or other amphibians, and some of reptiles (the lacertoid prints).

Above these sandstones are shales and magnesian limestones; at Hilton Beck, near Appleby, the former are about 40 feet thick and contain remains of the following plauts:-Ullmannia Bronni, $U$. selaginoides, Alethopteris Goepperti, Sphenopteris Naumanni, $N$. dichotoma, Cardiocarpum triangulare, and Odontopteris sp. These

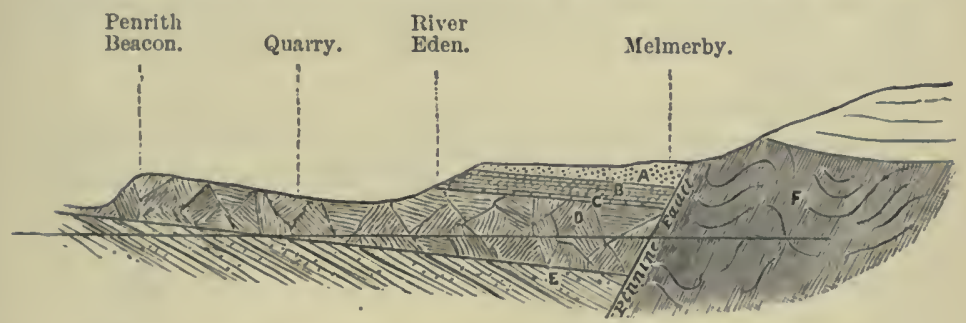

Fig. 109. - SECtION throcgh tHE PERMIAN bEDS NEAR PENRITH (Harkness).
A. Red sandstone.
C. Magnesian limestone.
E. Carboniferous.
B. Red shale.
D. Penrith sandstone.
$F$. Ordovician.

shales thin out northwards, but the magnesian limestone extends rather farther; where thickest there is only 25 feet of it, but probably it is only the base of a much thicker mass since removed or else concealed by the uncouformity of the Trias.

Other small patches of these Permian deposits occur in the west of Cumberland, as on the coast at St. Bees Head, and inland at Egremont and Arlecdon. It should also be mentioned that the Permian Series above described is everywhere overlain by a set of red shales and marls with beds of gypsum, and by some these are classed as Pernian, but Mr. Goodclild has pointed out that they rest sometimes on the limestone, sometimes on the Hilton shales, and sometimes on Penrith sandstones, so that there is a decided unconformity, and the marls sliould be regarded as the base of the Trias.

Permian Beds are found also in the Isle of Man and again at three places in Ireland, one at Cultra on Belfast Lough, another 
near Ardtrea in Tyrone, at both of which they include fossiliferous magnesian limestones; at the third place (Armagh) there are only boulder-beds and breccia resting on Carboniferous limestone.

\section{Scotland}

In Dumfries and Ayrshire there are tracts of bright-red sandstone which have much resemblance to the Penrith sandstone, but till recently no evidence for their identity was forthcoming, and consequently they were regarded by some as belonging to the Trias, and were so classed in the last edition of this book. Mr. G. Hickling, ${ }^{8}$ however, has compared the Reptilian footprints of the Dumfries sandstones with those of the Penrith Beds, and finds that though not identical they àre similar, and differ from those on Triassic sandstones, and further that two of the types seem to be identical with prints in the Permian sandstone of Mansfield (Nottingham).

Dumfries.-In this district the three largest tracts are (1) one extending from the Solway Firth by the mouth of the Nith to and beyond the town of Dumfries, (2) round Lochmaben in Annandale, and (3) round Thornhill in Nithsdale. Professor Harkness was of opinion that the general succession of the beds near Dumfries and Lochmaben is as follows:-

4. Thin bedded sandstones with beds of clay

3. Hard massive breccias and conglomerate : . . 300

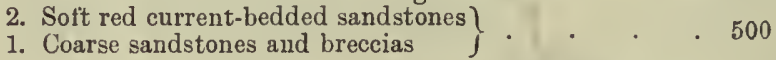

The breccias consist of angular blocks and fragments of various Palæozoic rocks, with some of granite and other igneous rocks, embedded in red sand. The lower sandstones are brick-red in. colour, frequently flaggy and divided by thin seams of dark-red clay, and their surfaces often bear the footprints of Labyrinthodont and other reptiles. Such footprints were first described by Professor Buckland from specimens found in the quarries on Corncockle Moor near Lochmaben, but they are equally common near Dumfries; they also occur in the upper sandstones, the beds of which are separated by rather thicker layers of clay.

In the Thornhill basin farther north there are no breccias, and the greater part of the tract consists of brick-red sandstone, but in the northern part lava-flows and voleanic detritus are interstratified with the lowermost sandstones. The higher sandstones contain beds of shale and clay, and seem comparable to the higher beds near Dumfries. 
Ayrshire. - In the centre of the Ayrshire coalfield near Mauchline lies a pear-shaped area, occupied by rocks similar to those of Thornhill (see Fig. 110), and associated with the volcanic breccias of this district are some beds of a purple sandy limestone, but no fossils have been found in them.

The igneous zone consists of a number of lava-flows which mark successive eruptions, and have probably proceeded from more than one vent, for though they are all of a basic character they vary much in lithological composition. Some of them are basalts, others are magnetite-felspar rocks, while the rock of Mauchline Hill is a picrite composed chiefly of olivine and augite. Magnetite is prevalent in all of them, and its oxidation has given them a red colour, on which account they have been described as "porphyrites."

Besides these interbedded volcanic rocks there is other evidence of the number and activity of the volcanoes. Outside the existing tracts of Trias the Coal-measures are pierced by numerous large

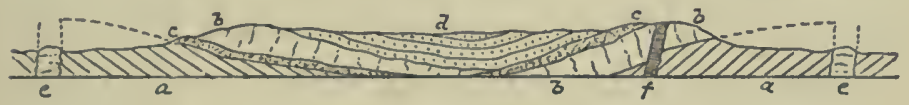

Fig. 110. - section throvgh thz peruian basin of a vrghire (Geikie).

f. Basaltic dyke.

e. Voleanic necks. d. Red sandstones.

c. Volcanic tuffs. b. Lava-flows.

a. Carboniferous rocks.

pipes filled with a coarse unstratified agglomerate, and usually appearing at the surface as small rounded hills or hillocks. Sometimes the agglomerate includes a core or column of lava, and the coal-seams in their neighbourhood are often charred or altered into columnar coke. There can be little doubt that these columns or necks are some of the vents through which the volcanic materials were ejected. The necks are especially numerous in the Dalmellington coalfield, but they occur also in Renfrewshire and Lanarkshire, piercing the highest Coal-measures in those counties.

Moray.-The only other area where Permian Beds lave been recognised is in Moray, one small tract lying to the east of the town of Elgin and another near Cummingstone. The rock is a coarse red false-bedded sandstone, consisting of rounded quartz-grains, and containing sand-worn pebbles; the total thickness of the beds, according to Mr. D. M. S. Watson, ${ }^{9}$ being from 400 to 500 feet. Apparently it was formed in a depression or lake in a wind-swept desert region, for near Elgin it has yielded bones of the characteristic Dicynodont reptiles-Gordonia, Elginia, and Geikia. The similar sandstone near Cummingstone has not yielded bones, but shows footprints which closely resemble some at Mansfeld in Notts, 
and in the Permian of Thuringia. Mr. Watson suggests that they may have been made by Gordonia.

\section{Continental Permian Strata}

\section{France}

Small tracts of Permian rocks occur at many places round the great Central Plateau of France (see map, Fig. 102), most of them abutting against the ancient rocks of this plateau, and passing outward beneath the newer deposits which surround it. They appear to belong to two separate areas of deposition, the one group on the north extending from a point south of Berry by Buxière and Moulins, and reappearing on the Morvan near Autun where there are two basins or troughs. The other area lay to the south and south-west of the plateau, patches of its deposits occurring near Brive, near Rodez in Aveyron, near Carmaux in the Tarm, and again from Broquies in a long strip to Grassessies on the Montagne Noire.

The beds of the Autun basin form the type of the Autunian stage. They overlie the Stephanian measures, and the lowest set of beds which are classed as Autunian are really passage-beds, containing a flora like that of the beds below, except that it includes Walchia piniformis and Callipteris conferta. These beds are abont 1300 feet thick and are entirely of freshwater origin, consisting of sandstones and bituminous shales, with beds of magnesian limestone full of Cyprids ; and they form the zone of Igornay.

They are succeeded by another group of similar rocks (zone of Muse) with two valuable beds of oil-shale, and a more typical Permian flora. Lastly there is an upper stage (zone of Millery) about 1500 feet thick, consisting of shales and thin coal-seams, one of the latter being the famous Boghead coal. The whole series is about 4000 feet.

This Autunian Series has yielded a rich harvest of vertebrate remains; the Amphibia have been described by Gaudry, and include Protriton petrolei, Pleuroneura Pellati, Actinodon Froissardi, and Stereorachis dominans. Fish are numerous, and silicified stems of tree-ferns (Psaronius) are common in the upper beds.

At Bourbon and Buxière the series is not so thick, and consists more largely of felspathic sandstones derived from the erosion of the neighbouring granitic and gneissic rocks. The lowest beds, however, include bands of oil-shale and black limestone, and doubtless belong to the Autunian lake-basin.

Wherever the summit of the Autunian is exposed, it is over- 
lain by sandstones of Saxonian age, grey in the lower part, red and mottled in the upper part, with a combined thickness of about 1600 feet. Nothing comparable with the Zechstein or Magnesian Limestone Series has been found in any part of France.

Of the more southern Permian facies that of Aveyron and Lodève may be taken as typical, the succession in that district being :-

Saxonian, fFine sandstones and black shales passing down into red

1500 feet $\{$ sandstones and marls with Walchia and Callipteris.

Autunian, $\left\{\begin{array}{l}\text { Lodève slates with plant remains. } \\ \text { Blaek shales with Palcooniscus. }\end{array}\right.$

500 feet (Sandstones, shales, and a basal eonglomerate.

The small basin of Littry in Calvados deserves mention because of its proximity to England, and because the deposits which there overlie the Stephanian are referred by French geologists to the Autunian. They consist of red sandstone, succeeded by a bed of magnesian limestone and shales from which remains of Palaconiscus and Amblypterus have been obtained.

\section{Germany}

Permian rocks occupy much larger areas in Germany than they do in France or Britain, and two of these areas may be specially noticed, i.e. that of the Sarre district and that of Saxony and Thuringia.

Surre Valley.-The most extensive area of the Lower Rothliegende or Autunian is that of the Sarre and Nahe district, where they occupy a wide space between the Devonian of the Hunsruck on the north and the outcrop of the Trias on the south. Here, as shown in Fig. 103, the Ottweiler Beds are overlain conformably by the Cusel Beds, consisting of red and grey sandstones and shales with thin layers of coal, and as at Autun they have a Carboniferous flora to which a Permian aspect is imparted by the presence of Walchia piniformis, Callipteris conferta, and Calamites gigas.

The succeeding Lebach Group comprises sandstones at the base, overlain by shales containing ironstone nodules in which are fish remains, scales of Archegosaurus and the Crustacean Gampsonyx. Interbedded with these sediments are sheets of porphyritic andesite and melaphyr.

The Saxonian is represented by a series of red conglomerates, sandstones, and shales, the materials of which have been mainly derived from the detrition of the neighbouring Devonian and Carboniferous rocks. These "Upper Rothliegendes" have a much wider extension northward and eastward than the Autunian, overlapping the latter on to the older rocks. 
Central Germany.-In the central part of Germany (Thuringia and Saxony) the passage-beds are absent, and the Permian is more or less unconformable to the Carboniferous ; but the Lebach Group is well represented, and has yielded many amphibian remains, e.g. of Branchiosaurus, Archegosaurus, and Pelosaurus. Its chief development is in the Erzgebirge basin near Chemnitz and Zwickau, where it consists of coal-bearing beds, with the usual plants in the lower part, together with beds of volcanic tuff and sheets of trachytic lava; and these beds are overlain by a set of red breccias, conglomerates, and sandstones, largely composed of the debris of contemporaneous volcanic rocks.

The Saxonian of this region is a thick mass of conglomerates, sandstones, and marls, the predominant colour of which is red or reddish brown. These beds have a thickness of about 1600 feet in Saxony and nearly 2000 in Thuringia. No fossils occur in them except plant remains and the footprints of reptiles and amphibians,

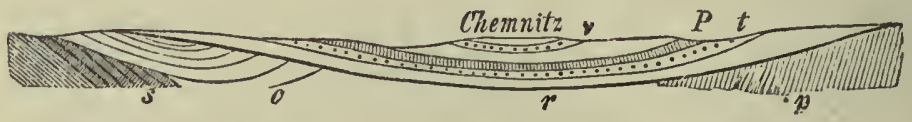

Fig. 111.-SECtion throvgh the ERZGEBIRGe Basin (by Siegert).

$\begin{array}{lll}v . \text { Sandstones and tuffs. } & r . \text { Lebach Beds. } & s . \text { Silurian. } \\ P, t . \text { Lavas and tuffs. } & c_{0} \text { Cnal-measures. } & p . \text { Archæan. }\end{array}$

so that the whole formation up to the top of the Saxonian appears to be of lacustrine and terrestrial origin.

The succeeding division is largely marine, and includes the Zechstein limestone, but as that is really only a small portion of it the name Thuringian is a much better one. This group of beds occupies a considerable area in Central Germany, spreading round the mountain ranges of the Thuringerwald, the Frankenwald, the Reisengebirge, and the Harz, and passing everywhere below the overlapping Trias and Jurassic strata. In its typical development it is a series of limestones and shales of no great thickness, from 400 to 500 feet, but in certain localities it is expanded by the intercalation of enornous masses of gypsum and rock-salt. In the Mansfeld district it has the following components:-

Upper $\int$ Red clay and gypsum.

200 feet $\{$ Clays with lenticular beds of limestone.

Middle Dark bituminous limestone and shale.

150 feet Gypsum and dolomitic breccia.

Lower Magnesian limestone (the Zechstein).

200 feet Bituminous shale (Kupferschiefer).

200 feet (Calcareous sandstone and conglomerate. 
The similarity between this series and the "Magnesian limestone" of England will at once be apparent. The layer of copperbearing shale which overlies the basement beds is only about 2 feet thick, and is the analogue, if not the actual continuation, of our "Marl slate"; it yields similar fish remains (Platysomus gibbosus and Palconiscus Frieslebeni being common species), with scales of Proterosaurus, and occasionally star-fish and Brachiopods, which clearly indicate the invasion of the area by an outer sea.

The fossils of the Zechstein are similar to those of the English limestones, many of the species being the same, and the only Cephalopoda being a few species of Orthoceras and Nautilus. Some of the beds are almost entirely composed of Bryozoa, species of Fenestella, Acanthocladia, and Phyllopora, and these beds are called "Bryozoon-reefs" by German geologists, a misleading term suggesting reef-formation which does not exist, for they are merely lenticular beds of limestone resulting from local Bryozoon growths, like the crinoidal and coralliferous limestones of Devonian and Silurian age.

In Hesse the composition of the Thuringian differs little from the above, but north of the Harz district thick beds of gypsum and rock-salt come in, which are worked at Stassfurt, Egeln, Vienenburg, and other places. The rock-salt is sometimes over 1000 feet thick, and at Sperenberg (south of Berlin) it is over 3000 .

The typical Zechstein facies of the Thuringian extends also eastward into Silesia (north of Gatz).

\section{Russia}

In Russia, as already stated, the Permian is largely marine, but the limestones with marine fossils are often interbedded with sandstones, shales, and marls of estuarine or lacustrine origin. According to Nikitin, in the typical district of the ancient kingdom of Pernianow the provinces of Perm, Samara, and Ufa-the series is divisible as follows:-10
Thuringian $\left\{\begin{array}{l}\text { Red marly sandstone. } \\ \text { Red marly limestone. } \\ \text { Grey limestones and marly sandstones. }\end{array}\right.$
Kostrumian $\left\{\begin{array}{l}\text { Red sandy marls (marine fossils). } \\ \text { Ifarly limestone without fossils. }\end{array}\right.$
Artinskian $\left\{\begin{array}{l}\text { Clays with gypsum and beds of linestone. } \\ \text { Dolomitic liniestones with Permian fossils. } \\ \text { Dolomitic limestones (Perno-Carboniferors). }\end{array}\right.$

The stages were not established when Nikitin wrote, but I have bracketed his subdivisions to show how they probably correspond with the grouping made in the Ural region.

On the western slopes of the Urals the Fusulina limestone of the Uralian is succeeded by a series of sandstones, limestones, and 
marls, partly lacustrine and partly marine, the fauna including some survivals from the Carboniferous, such as Productus cora, P. punctatus, and a species of Phillipsia, but associated with a new and peculiar set of Ammonoids, i.e. Medlicottia, Popanoceras, Agathiceras, and Thalassiceras. The plant remains again are chiefly Permian forms, including Calamites gigas and Callipteris conferta, with several species of Walchia and Ullmannia. This set of beds was called the Artinskian stage by Karpinsky in 1874, and it is clearly a marine representative of the western Autunian.

In the same area, overlying the Artinskian, is Sibertzew's 11 Kosstroma stage, which is evidently the equivalent of the Saxonian. It presents two facies, the one of marls and sandstones (some grey and some red), containing plant remains with Carbonicola and bones of Palceoniscus and Archegosaurus; the other consisting of various kinds of limestone (oolitic, compact, marly, etc.), with a marine famna, including Productus Cancrini, Athyris Roissyi, Dielasma elongatum, and Bakevellia parva.

Still higher are limestones with many Zechstein fossils, but it is noteworthy that Productus Cancrini takes the place of $P$. horridus, and Strophalosia horrescens that of S. Goldfussi. These are overlain by red sandy marls, containing freshwater Unionidæ (Naiadites and Palocomutela), whïcl Nikitin proposed to call the "Tartarian stage." If adopted as an equivalent for the whole of the Russian Thuringian the name might be tseful.

In Vologda (Northern Russia), near the sources of the Little Dwina and Suchona, certain marls and sandstones belonging to the upper stage have acquired importance from Amalitsky's discovery in them of the remains of many reptiles-Pareiasaurus, Dicynodon, Rhopalodon, Elginia, Gordonia, and others, associated with many Unionidæ (Palcanodon, Palceomutela, Oligodon, Carbonicola, etc.), and a flora of mixed Asiatic and European types, i.e. species of Glossopteris and Gangamopteris, with Callipteris, Tceniopteris, Schizoneura, etc. ${ }^{12}$

\section{E. History of the Period}

From the stratigraphical facts, which have been summarised in the preceding pages, we may gather that the Permian period was a natural continuation of the Carboniferous, and that the earliest Permian sediments were accumulated in the same areas and under almost the same physical conditions as those of the preceding Stephanian epoch.

The western lialf of the European area was clearly part of a large continent which extended westward far into the Atlantic 
region, and eastward to the borders of Russia. The northern part of this continent seems to have been a hilly and monntainous region, wherein little deposition of any kind took place until quite the later part of the period. Across the centre of the continent, and traversing its whole breadth from west to east, ran the great Armorican and Hercynian ranges, probably consisting of many mountain ranges with intervening valley-like depressions. To the south of these ranges the country sank to lower levels, and here there were large lakes and swampy depressions in which the Autunian deposits were formed. In these tracts and along the valleys of the rivers which carried the rainfall from the hills to the lower lands grew a rank flora of Carboniferous aspect; and here dwelt many kinds of Amphibia, both small and large, and some primitive Reptilia, the larger of which doubtless fed on the fish which inhabited the lakes and rivers. Such is the picture that we may form of Europe in early Permian time.

The nature of the Saxonian deposits, and the great contrast which they present to the underlying Autunian, indicates that a great change took place; and we may infer that this was caused by a general uplift of the whole continental region, whereby the lakes and marshes were drained, and its lower levels were converted into broad plains separated by ranges of hills and mountains. This change produced a corresponding alteration in the climate of the country, so that its more southern parts passed from a condition of great humidity with mild winters to one of comparative dryness and very cold winters.

Great terrestrial erosion and detrition was another result of the upheaval, leading to the production of the thick deposits of sandstone and conglomerate which form the chief Saxonian accumulations, and to the formation of breccias round the mountain ranges. These breccias are in themselves strong evidence of peculiar climatic conditions. They have been compared, both by Mr. R. D. Oldham and by Professor T. G. Bonney, with the fringes of angular gravel and breccia which flank the hill ranges of Persia and other parts of Central Asia at the present day.

Referring to the Permian breccias Professor Bonney ${ }^{13}$ remarks that the resemblance above mentioned suggests that the climate, both of Germany and Britain, was also similar to that of modern Persia, hot in summer but cold in winter. He also quotes Professor Garwood as pointing ont that the distance to which some of the large blocks have been transported can be explained on the supposition of snow-slopes, without bringing in the agency of glaciers as some have thought necessary. - Professor Garwood had observed in Spitzbergen that the talus-slopes on the hillsides were deeply 
covered by snow in the winter, and that fragments falling on this snow-slope slide down to its outer edge. This process is repeated year by year, so that the talus fringe is continually being extended, and blocks of large size are conveyed to a much greater distance from their sources than would be possible without the snow-slope.

Another accompaniment of this Permian upheaval was the outbreak of volcanic action and the establishment of numerous volcanoes, from which frequent eruptions of lavas and ashes took place. Nor are there wanting evidences of earthquakes, especially in Devonshire, where round Brixham and Torbay the Devonian limestones are riven by fissures from a few inches to 3 feet in width, and these are filled with red sandstone similar to the Permian sandstones, of which patches still remain on the surface of the limestone plateau.

This epoch of high elevation may have lasted for a long time, but at length another change took place; volcanic activity ceased, and as so often happens in such cases a general sinking in and subsidence ensued. Some of the great plains on which the red sandstones and breccias had been accumulated sank below sea-level, and were invaded by the Eastern Sea, becoming a large gulf or landlocked "Mediterranean" sea in which deposits of dolomitic limestone, shale, and marl were formed.

Toward the close of the period, however, this inland sea became isolated, probably by local warping and other irregular crust-movements, so that it was cut off from the outer sea and converted into a great salt lake like the Caspian Sea of the present time. From time to time during dry seasons portions of this sea were dried up, and the salts in solution were precipitated to form the thick masses of gypsum and rock-salt which are such conspicuous members of the highest Permian deposits.

\section{References}

1 Cantrill, Quart. Journ. Geol. Soc. vol. li. p. 528.

2 King, Quart. Journ. Geol. Soc. vol. 1v. p. 97.

3 H. T. Brown, Quart. Journ. Geol. Soc. vol. xlv. p. 22.

4 Bonney, Midland Nat. vol. xv. p. 25 (1892); and Quart. Journ. Geol. Soc. vol. Iviii. p. 188 .

5 Reinach in Ussher, Geol. Mag. vol. xviii.

6 Ussher, Quart. Journ. Geol. Soc. vol. xxxiv. p. 459.

7 Woolacott, Quart. Journ. Geol. Soc, vol. 1xvii. p. 312.

8 Hickling, Men. Manch. Lit. and Phit. Soc., 1909.

9 Watson, Geol. Mag., 1909, p. 102.

10 Nikitin, Congrès géol. internat. (1897), Guides Nos. 1 and 2.

11 Sibertzew, Mém. Com. Gêol. Russe, xv. (1899).

12 Amalitsky in Geol. Mag., 1901, p. 231.

13 Bonney, Quart. Journ. Geol. Soc. vol. Iviii. p. 185. 


\section{CHAPTER XII}

\section{THE TRIASSIC SYSTEM}

With the close of the Permian period the last remmants of Palæozoic life became extinct in the British area, and when after a long continental period the western and northern parts of Europe were again submerged beneath the sea, the waters were tenanted by a very different set of generic forms. The Palæozoic Groups of Cystid and Blastoid Echinoderms, Rugose Corals, Eurypterids, Trilobites, Goniatites, and most of the Palæozoic genera of Nautiloidea had died out, their place being taken by the Euechinoids, Aporose Corals, Siphonate Gastropods, and Cephalopods of the Ammonite and Beleinnite type; many orders of Reptiles appear for the first tine, and the earliest Mammal yet known occurs in the upper beds of the Trias.

The fish of the Triassic and Jurassic periods also exhibit remarkable changes and developments. The Rhizodont Crossopterygian fishes of the Devonian and Carboniferous, and the heterocercal Palæoniscids of Carboniferous and Permian time now become scarce; while a new type of fish (the Protospondyli) with a nearly homocercal tail and a more bony endoskeleton having a tendency to form vertebrx, make their appearance and lead up to the completely vertebrate Teleosteans.

Even where a continuous series of marine deposits bridges over the gap in the history of marine life whicl exists in Northern Europe we find that the above remarks are still practically true, the only exception being the existence of a few Gastropod genera and a few species of Orthocerces in the Trias of the Alps. For reasons which canuot yet be fully explained the Triassic period seems to have been one of rapid organic change and development, and in no class is this more beautifnlly illustrated than in that of the Cephalopoda, the Alpine Trias presenting us with a remarkable assemblage of genera which practically connect the Palazozoic Gonia- 
tites with the Ammonites which are so characteristic of the Mesozoic periods.

A similar dying out of old forms and a rapid spread of newer types took place in the vegetable world. The Palæozoic Lycopodiales-Lepidodendron, Bothrodendron, and Stigmaria-have now all disappeared, while the Cycads which appeared in Permian time now become much more numerous, and are associated with the coniferous Voltzia. Among ferns, though some of them have been referred to Pecopteris and Neuropteris, it is very doubtful whether any belong to these Palæozoic genera; most of them are rather referable to the more recently established genera Chladophlebis and Todites. Many other new genera make their appearance.

Here, therefore, at the base of the Trias is drawn the line between the Palæozoic and Neozoic eras, and here begins that division of Neozoic time which is often called the Mesozoic. It must not be supposed, however, that there is any great break between the two series of formations, for though there is a partial break in Britain, there is complete conformity between the Permian and the Trias, with a passage from one to the other in the Alpine region, and in most parts of Germany.

\section{THE TRIASSIC SYSTEM}

\section{A. Nomenclatere and Classification}

The Triassic System resembles the Devonian System in that it presents us with two very different facies, (1) a terrestrial and lacustrine facies formed within the limits of a large continent, and (2) a marine facies of the usual kind. The first forms the upper part of what used to be known as the New Red Sandstone (see p. 6), but was called the Trias by von Alberti in 1834 on account of its obvious tripartite arrangement in Germany. In England, however, it has only two parts, and these are both of terrestrial or lacustrine origin; in Germany these persist, but the middle beds are limestones containing marine fossils, and consequently there are three series, which have received the following names:-

3. The Keuper (red marls and sandstones).

2. The Muschelkalk (marine limestones).

1. The Bunter (variegated marls and sandstones).

For the normal marine facies of the Trias we must go to the Alps, and the student cannot understand the true relations of the Triassic System to those which precede and follow it until he has learnt something about the important marine facies of the forma- 
tion which exists in the Tyrol and extends throughout Southern Europe.

Moreover, this marine facies las a wide extension over other parts of the world; it spreads through Southern Europe from Spain to Hungary and the Balkans; it is found in Turkestan, Central Asia, and the Himalayas, and a similar marine Triassic System occurs in Siberia, Japan, North America, and again southward in Columbia, Peru, New Zealand, and Australia. In South Africa, in South India, and in Argentina red sandstones with reptilian remains are found, and these regions seem to have formed part of other Triassic continents. In this volume, lowever, it is only possible to give a brief account of the European Trias.

The name Trias, as will be seen, is not a good one, being really applicable to the German facies only, which is a limited and exceptional one. A nomenclature capable of wider application will doubtless be eventually proposed, and inust, of course, be based on the pelagic development of the system. From the recent work of Mojsissovies, Waagen, and Diener on the distribution of the fossils in the pelagic facies, it appears that the system falls more naturally into two great divisions, a lower and an upper, each of which is again divisible into two series.

\section{B. Life of the Period}

\section{The Marine Fauna}

The fauna of the Alpine and Tyrolian Trias, though consisting mainly of Neozoic forms of life, yet includes some survivors of Palæozoic types; the proportion of species belonging to genera which are essentially Palæozoic being stated as only one-tenth of the total number of species composing the fauna.

The Cephalopoda are a remarkable assemblage. A single species of Orthoceras with some of Temnocheilus and Pleuronautilus connect it with Palæozoic faunas, while the genus Nautilus (as now restricted) makes its first appearance. The Ammonoidea, however, are the dominant forms, and include many genera with nearly simple lobes and saddles, such as Ceratites, Lobites, Tirolites, Trachyceras, Tropites, as well as genera with more complex lobes, such as Arcestes, Cladiscites, Ptychites, Pinacoceras, Phylloceras, Rhacophyllites, and Megaphyllites. Dibranchiate Cephalopoda make their first appearance and are represented by precursors of the Belemnitidie in Aulacoceras and Atractites.

Gastropoda are abundant, and include representatives of the Palæozoic genera Murchisonia, Loxonema, Naticopsis, and Euom- 
phalus, with the Neozoic types of Trochus, Turritella, Scalaria, Coelostylina, Cerithium, and Pseudomelania, as well as peculiar forms which have been named Naticella, Chilocyclus, and Ptychostoma.

Of Lamellibranchs Posidonomya, Megalodon, and Myophoria (which is probably inseparable from Schizodus) connect the fauna with Palæozoic life, while certain genera are especially Triassic, such as Halobia (=Daonella), Monotis, Cassianella, Trigonodus, and Anoplophora. There are many representatives of Pteria, Gervillia (Hornesia), Pecten, and Lima; and the following genera make their first appearance, Velopecten, Plicatula, Mytilus, Lucina, Sphoriola, Cardita, Palcocardita, Unicardium, Protocardium, and Homomya.

The Brachiopoda include the last survivors of the ancient genus Spiriferina, with some specially Triassic forms, such as Koninckina, Thecospira, and the Athyroids which Bittner has separated under the names of Tetractinella and Pentactinella. Besides these, species of Terebratula and Rhynchonella are abundant.

Among Echinoderms Cidaris, Hemicidaris, Mesodiadema, and Tiarechinus make their appearance, and the last is restricted to the Trias. Of Crinoids Dadocrinus, Isocrinus, and Encrinus are found.

Corals (Anthozoa) also occur, especially in the limestones of the Upper Trias, and belong chiefly to Cladophyllia, Calamophyllia, Thecosmilia, Isastrea, and Thamnastrea.

Calcareous algæ, however, are the chief limestone builders, and lave been described under the names of Diplopora and Gyroporella.

\section{Lacustrine and Terrestrial Fauna}

This is found in the Bunter and Kelper Series of England, Germany, and France, the animals being those which lived in or near the large inland salt lakes and lagoons, the plants those which grew on their borders and by the rivers which ran into them.

Plantæ.-The ferns are represented by the following genera: Anomopteris, Chelipteris, Chladophlebis, Lacopteris, Coniopteris, Neuropteridium, and Tceniopteris. The Cycads Zamites, Otozamites, and Pterophyllum are common plants. Conifers are represented by Voltzia, Albertia, Baiera, and Schizolepis. The horse-tail Equisetites also makes its appearance, as well as a new genus Schizoneura.

Mollusca. - Shells of this class are very rare, but a few resembling Unio and Anodon have been found, and others in the English Keuper which resemble Thracia, Goniomya, and Pholadomya.

Crustacea.-This class is represented only by the Phyllopod Estheria, which is abundant in the Keuper.

Pisces.-Remains of many kinds of fish occur, especially in the Keuper Beds, the more important genera being Acrodus, 
Hybodus, Ceratodus, Dipteronotus, Gyrolepis, Semionotus, and
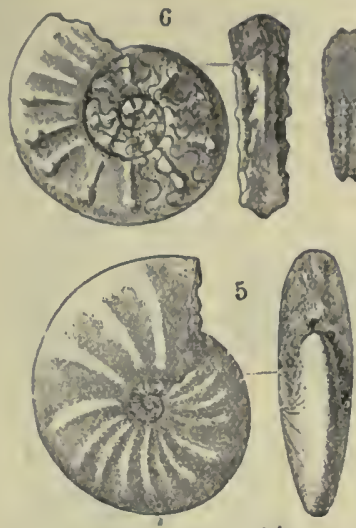

14
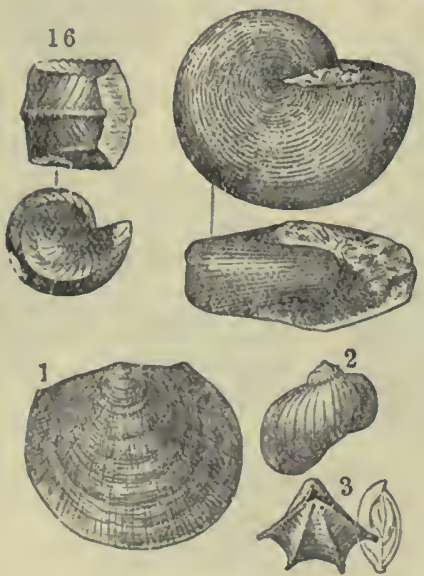
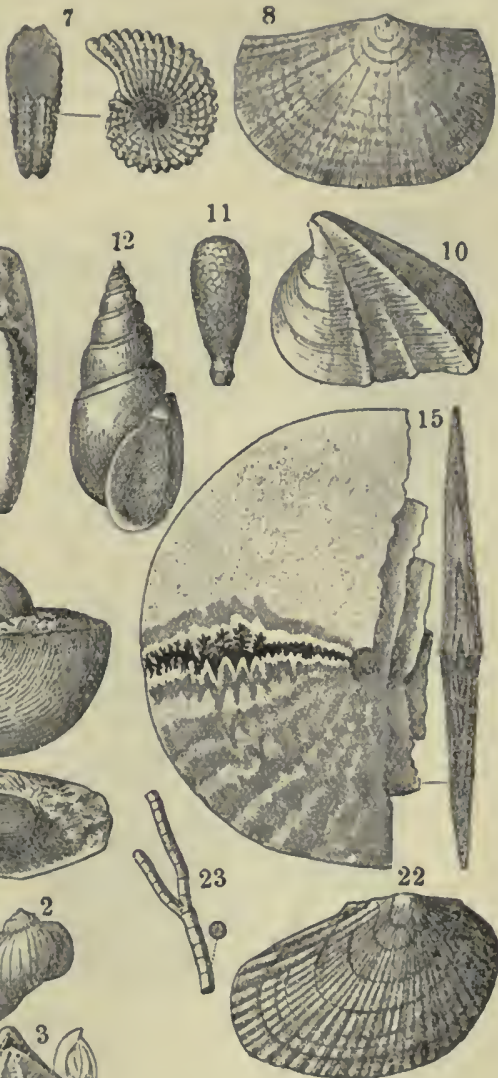

Fig. 112.-GRoUP OF FossILS grost tHE ALPINE triAs.

1. Pseudomonotis Clarai.

2. Naticella costata.

3. Tetractinella trigonella.

5. Ptychites Studer.

6. Ceratites cassianus.

7. Trachyceras ann.

8. Halobia rugosa.
10. Myophoria Kefersteiú.

11. Cldaris dorsata (spine).

12. Chenuitzia gradata.

14. Arcestes tornatus.

15. Pinacoceras Metternichi.

16. Tropites subbullatus.

22. Monotis salinaria.

23. Dadocrinus gracilis.

Saurichthys. The ridged teeth of Ceratodus are abundant in some 
parts of the German Trias, and closely resemble those of the living species of that genus.

Amphibia are still represented by Labyrinthodonts, the chief genera being Labyrinthodon, Mastodonsaurus, and Trematosaurus, but this order does not survive the Triassic period. Their tracks are five-toed, like the rough impress of a man's hand.

Reptilia.-Remains of true reptiles also occur, and include no
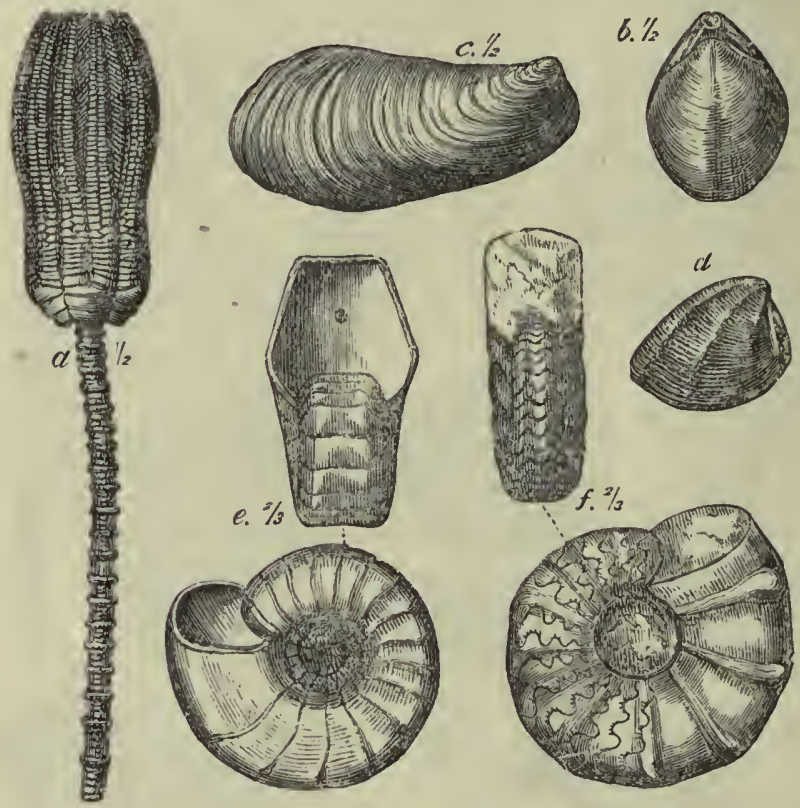

Fig. 113.-GRoup of german MUSChelkalk Fossils.

a. Encrinus ?iliiformis.

b. Terebratula (Coenothyris) vulgaris.'

c. Gervillia (Hoernesia) socialis. d. Myophoria vulgaris.

e. Temnocheilus bidorsatus.

f. Ceratites nodosus.

fewer than seven orders, several of which attained their maximum development in the succeeding Jurassic period. The Sauropterygia are represented by Nothosaurus, the Ichthyosauria by Mixosaurus, and the crocodiles by Stagonolepis, Erpetosuchus, Ornithosuchus, and Belodon. Dinosaurs occur for the first time in the forms known as Palcosaurus, Zanclodon (F Teratosaurus), Thecodontosaurus, and Cladyodon. Most of these creatures appear to have walked on their hind feet, after the fashion of a kangaroo; and as some of them 
had only three toes, their footprints greatly resemble those of gigantic three-toed birls, and were supposed for a long time to have been made by such birds; other genera had four or five toes.

Still more cliaracteristic of the Trias are reptiles belonging to the divisions known as Placodontia, Rhynchocephalia, Dicynodontia, and Theriodontia. The genus Placodus is found in Germany.

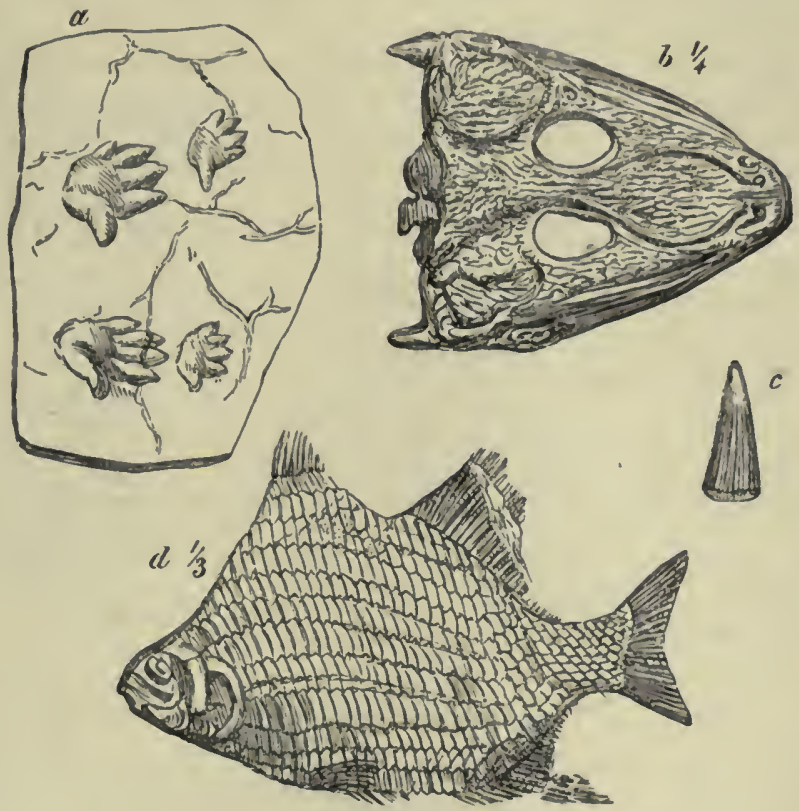

Fig. 114.一TRLASSIC VERTEBRATA.

$a, b, c$. Footprints, skull, and tooth of Mastodonsaurus. d. Dipteronotus cyphus.

The Rhynchoceplialia are represented by Hyperodapedon (which is allied to the modern Sphenodon of New Zealand), Telerpeton, Leptopleuron, and Rhynchosaurus. The Dicynodonts made their appearance in Permian time (see pp. 327 and 348), but the typical genus Dicynodon was first found in the Lower Trias of South Africa; it has not yet been found in the Trias of Europe.

The following are some of the more characteristic fossils of the German and English 'Trias:- 


\section{Fossils of the Bunter}

Plants.

Mollusca.

Amphibia.

Schizoneura paradoxa, Voltzia leterophylla, Albertia elliptica, Ethophyllum speciosum.

(In Germany only) Myoplioria costata, Gervillia Murchisoni, Pleuromya mactroides, Beneckeia tenuis.

\section{A}

Bones of Trematosaurus and Labyrinthodont footprints.

Echinoderma.

\section{Fossils of the Muschelkalk}

Encrinus liliiformis.

Brachiopoda. Terebratula (Cœnothyris) vulgaris, Plicigera trigonella, Rhynchonella decurtata.

Lamellibranchia. Myophoria vulgaris, Gervillia (Hœrnesia) socialis, Pecten discites, Lima striata, Trigonodus Sandbergeri.

Gastropoda.

Cœlostylina gregaria, Undularia scalata, Dentalium torquatium.

Cephalopoda.

Pisces.

Reptilia.

Temnocheilus bidorsatum, Ceratites nodosus, Beneckeia Buchi.

Ceratodus Kaupi, Hybodus major, Acrodus Gaillardoti. Placodus gigas, Nothosaurus mirabilis.

\section{Fossils of the Keuper}

Plants.

Crustacea.

Mollusca.

Pisces.

Amphibia.

Reptilia.

Manmalia.

Equisetites arcnaceus, Pterophyllum Jægeri, Voltzia heterophylla, Schizoneura paradoxa, Danæopsis marantacea, Yuccitcs vogesiacus.

Estheria minuta.

Myophoria Goldfussi, Anoplophora donacina (German). Acrodus ninimus, Dipteronotus cyphus, Hybodus Keuperi, Palæoniscus superstes, Semionotus Bergeri. Mastodonsaurus giganteus.

Hyperodapedon Gordoni, Tclerpeton elginense.

Tritylodon Fraasi (German).

\section{The Trias in Britain}

The general extent of the Triassic deposits in England can be seen from any good geological map, and I assume that the student possesses the smaller Index Map of the Geological Survey.

With respect to the relations between the Trias and the Permian, recent observations have tended to show that the break between them is not of such magnitude as was formerly supposed. The outcrop of the Bunter follows the strike of the underlying Permian more or less conformably, especially in Devonshire, and, again, in the north-east of England; but there is unquestionably a break between them, accompanied by overstep which is unconformity. Some physical changes took place at the close of the Permian period, but the actual lapse of time between the cessation of Permian conditions and the formation of the Bunter Basement Beds may not have been great.

In order to avoid the repetition of detail, and to impart a 
clearer idea of the component strata, it will be best to deal separately with each of the two great divisions of the Trias, for only two exist in Britain, the Bunter and the Kenper.

\section{The Buster Series}

This set of beds has a more restricted range than the Keuper Series, a fact which is not always realised because it is concealed on a geological map by the overlap of the Keuper and the continuous outcrop of the latter all across England from south-west to nortleast. The Bunter is not similarly continuous, but was deposited in two separate basins, a northern and a southern. The northern was much the larger of the two, extending from Worcestershire through the Midland counties, and including a large part of Northern England with probably a branch or gulf which reached into the nortli-enst of Ireland and the soutl-west of Scotland. The southern basin was on the site of the pre-existent Permian lake, covering parts of Devon, Somerset, and the area of the English Channel.

The typical district of the British Trias is that of the Western Midlands, an area embracing Cheshire, South Lancashire, Shropshire, Staftordshire, and Worcestershire. Here the Bunter Series is divisible into three stages as below :-

The Upper Mottled Sandstone, from 200 to 600 feet.

The Pebble Beds, „, 300 , 1000 feet.

The Lower Mottled Sandstone, , 200 , 600 feet.

In describing these Bunter deposits it will be convenient to begin with this typical district, next to trace tlieir extension to the north and north-east, and, finally, to notice their equivalents in the soutl of England.

\section{Central Area}

The Lower Mottled Sandstone.-In Clieshire and Shropshire this is usually variegated in bright red and yellow colours. It generally has a basal breccia abont 2 feet thick lying unconformably on the Permian or the Coal-measures, but is otherwise devoid of pebbles. It always exhibits much oblique bedding, which has the aspect of current bedding, but is not a proof of deposition in water, for the sands may have been æolian, and the bedding be due to the action of wind, for in some of the beds the component quartz grains have the worn face and elongate oval ghape which is characteristic of modern desert sands, the grains resembling millet-seed. 
This Lower sandstone attains its greatest thickness (650 feet) near Bridgenorth, but is still about 400 feet near Chester. It ranges northward to the Mersey and then east-

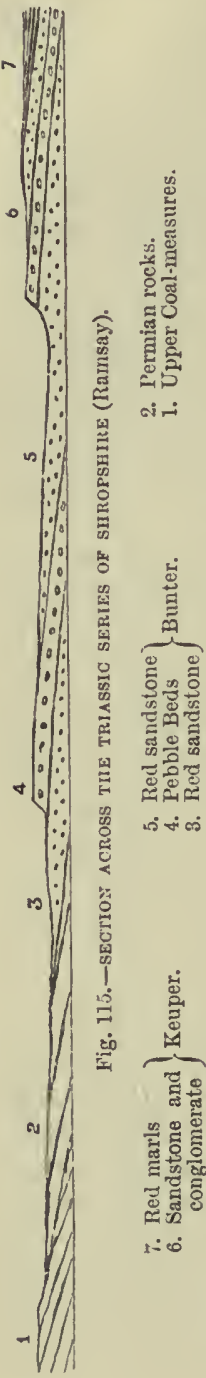
ward along the southern border of the Lancashire coalfield, but thins in that direction, and does not occur at Manchester or Stockport. Moreover, it appears to thin out in every other direction, for, though it is found in places on the west side of the South Statiordshire coalfield, it does not appear on the east side. Southward, again, it extends to Stourport, and is probably contimued underground as far as Worcester, but is overlapped in every direction by the succeeding Pebble Beds.

Clearly, therefore, this sandstone was accumulated within a restricted area, which was probably a desert plain, bounded on the west, southeast, and east by higher ground, but possibly reaching for some distance to the north-west below the Irish Sea.

The Pebble Beds.-These beds are most fully developed in East Shropshire and South Staffordshire. They pass eastward beyond the outcrop of the Lower sandstones, resting unconformably sometimes on the Permian, sometimes on the Coal-measures, as in Cannock Chase (see Fig. 116). In this central area they form a mass of conglomerate which is from 300 to 400 feet thick, and consists of well-rounded pebbles, the nıajority of these being brown and chocolatecoloured quartzites, with which, however, are pebbles of Carboniferous limestone and sandstone, of purple grit, and of some volcanic rocks. At the surface the sandy matrix is generally soft, but when traversed in deep borings it is very hard and highly calcareous.

Near Bridgenorth it has a breccia of angular fragments at its base about 60 feet thick, but this does not seem to extend far. It recurs, however, at Holt, on the river Dee, where it is succeeded by soft red-streaked sandstone overlain by pebbly sandstone, the whole series resembling that at Bridgenorth. Near Liverpool and St. Helens they attain a great thickness, 
consisting of two parts, (1) hard, red-brown, peblly sandstones, about 600 feet thick, and (2) liard, reddish sandstones without pebbles, about 400 feet. Fastward, by Wigan, Manchester, and Stockport, they overlap the Lower Mottled sandstones, so as to rest on the Dyassic and Carboniferous rocks.

On the east side of the South Staffordshire coalfield the Pebble Beds occupy a broad strip of country from Birmingham to the river Tame north-west of Tamworth, and they recur in a narrow strip along the western side of the Ashby coalfield in Leicestershire. In the same way from the borders of North Staffordshire coalfield, they pass eastward to Ashbourn and Derby, lying with complete unconformity on the edges of the Lower Carboniferous rocks.

The Upper Mottled Sandstone.-This resembles the Lower sandstone, but is generally of a bright red, variegated with yellow and white. From Shropshire, north of Shrewsbury, its outcrop runs northward by Ellesmere along the flanks of the Peckforton Hills, which rise to heights of 800 and 900 feet, and thence through Delanere Forest to Runcorn and Warrington on the Mersey. In the Peckforton Hills the outcrop is repeated by several strike faults which have led to the formation of as many nearly parallel escarpments, the western slopes of which are occupied by this soft, reddish sandstone, while their summit ridges consist of the hard basement conglomerate of the Keuper.

In the southern part of the Midland area all the Bunter stages thin out toward the south-east, one overlapping the other, a fact which may be regarded as proof that the pre-Triassic floor sloped from the south-east to the north-west. The following table indicates this attenuation and overlap :-

\begin{tabular}{|l|c|c|c|c|}
\hline & Shropshire. & $\begin{array}{c}\text { West Side of } \\
\text { South Staftord- } \\
\text { shire Coalfield. }\end{array}$ & $\begin{array}{c}\text { East Side of } \\
\text { South Stafforl- } \\
\text { shire Coalfield. }\end{array}$ & $\begin{array}{c}\text { North } \\
\text { Warwick. }\end{array}$ \\
\cline { 1 - 4 } Upper sandstone . & 500 & 300 & 100 & A bsent \\
Pebble Beds. & 400 & 300 & 200 & A bsent \\
Lower sandstone . & 650 & 0 to 100 & Absent & Absent \\
\hline 1550 & 700 & 300 & Nil \\
\hline
\end{tabular}

\section{North-Eastern and Northern Areas}

Having described the typical development of the Bunter Series, it will suffice to indicate briefly their occurrence beyond the limits of this Midland area. 
แ

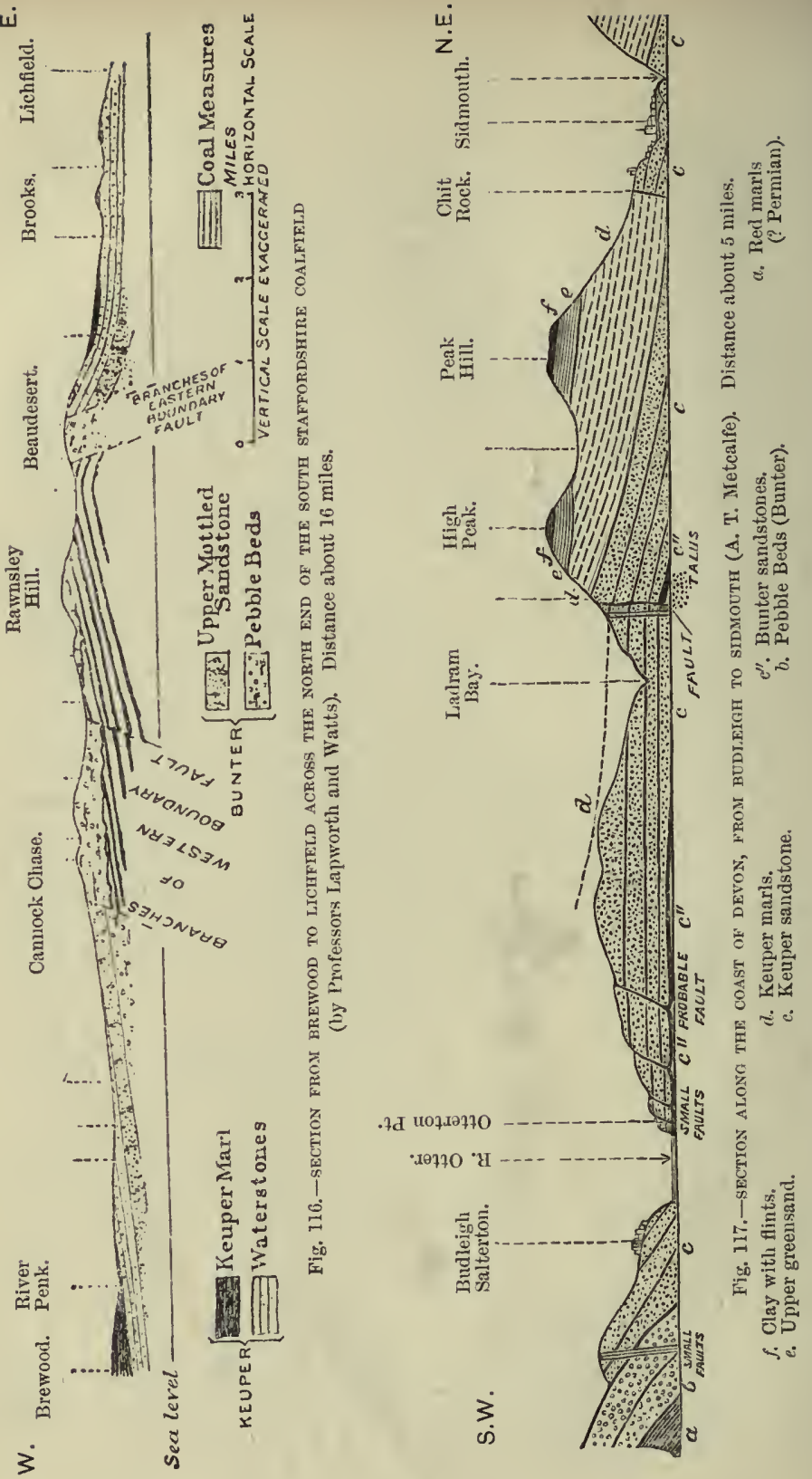


Though overlapped by the Keuper marls in the valley of the 'Irent east and south-east of Derby, the Bunter is probably continuous as a narrow strip beneath them, sinee it recurs near Nottinghain and extends northward for a considerable distance. The Upper Mottled sandstone, however, is alsent throughout this castern area. Near Nottinglam the Lower sandstone has the usual bright-red and yellow tints, but is there only 25 to 30 feet thick; northward, it thickens to about 100 feet at Mansfield. As in the western area, it seems to occupy a tract of limited width, and to be overlapped eastward by the Pebble Beds, which are the lowest recognisable Triassic deposits in deep borings at South Searle near Newark, and at Haxey in North Lincs.

The Pebble Beds form the rock on which Nottingham Castle stands, where they are about 200 feet thick, and consist of a coarse yellowish sandstone full of quartzite pebbles. They range northward through Sherwood Forest by Worksop, Tickhill, and Doncaster. Along this tract the thiekness of the Bunter is about 450 feet, and in a boring near Selby it is 620 feet; but beyond this place the pebbles disappear, and the whole Bunter division is slipposed to thin out near Knaresborough, though it may extend eastward underground beneath South Yorkshire.

There is a similar disappearance of the pebbles on the western side of the Pennine Anticline in North Lancashire, but the combined Bunter sandstones persist and are about 1000 feet thick near Preston and Garstang. They recur in the promontory of Furness on the western side of Morecambe Bay, and extend along the western side of Cumberland to St. Bees (see map, Fig. 39, p. 130), where they are known as the St. Bees' sandstone.

This St. Bees' sandstone is the sole representative of the Bunter in the Carlisle basin, and along the valley of the Eden, unless the underlying gypsiferous marls are included in the Trias (see p. 337). These latter vary in thickuess from 100 to $\mathbf{3 0 0}$ feet, and pass up into the overlying sandstone by intercalations of sandstones and marls. 'The St. Bees' sandstone is sometimes variegated in the lower part, but most of it is of a dull, uniform, brick-red colour. It contains some bands of pebbly sandstone, and its thickness is estimated at over 1000 feet. ${ }^{2}$

A similar sandstone has been foumd by borings in the northern part of the Isle of $\mathrm{Manl}^{3}$; and again in Ireland, near Belfast, where the Keuper is underlain by about 800 feet of soft red and yellow sandstones with some beds of grey and buff sliale.

Rocks of Triassic age oceur again in the Isle of Arrau, oecupying much of the central and souther'n part of that island. The lower portion of them is coloured as "Lower Trias" on the recent map 

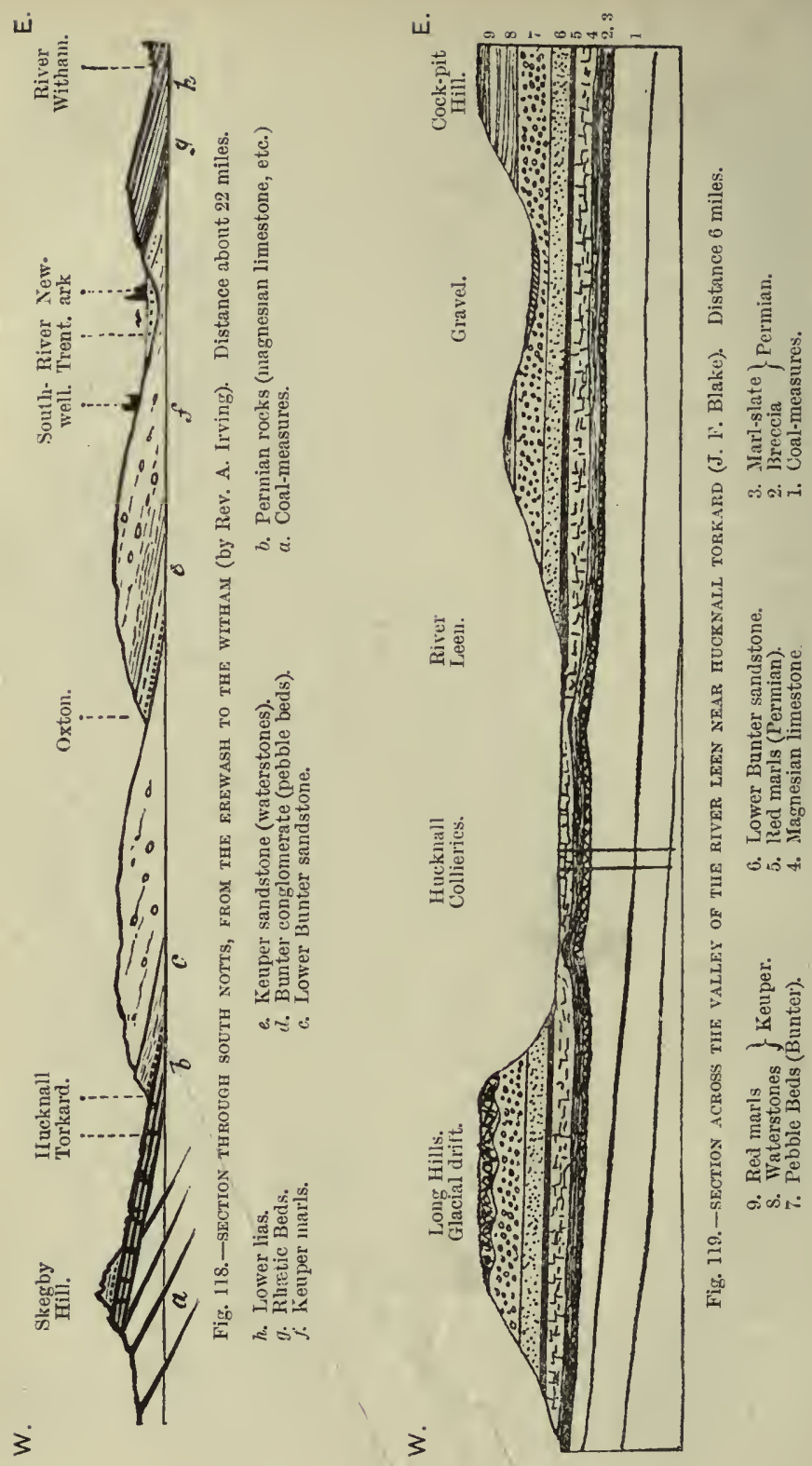
of the Geological Survey, though it was described as Permian in the "Summaries of Progress" for 1896 and 1898. 'These lower beds are about 1000 feet thick, and consist of bright-red sandstones with conspicuous current bedding, thus resembling the Penrith Beds rather than the St. Bees' sandstone. 'They are overlain and overlapped by conglomerates, which are probably of Trinssic age, though they seem to follow in conformable succession.

\section{South-Western Area}

In this district there is nothing comparable witl the Lower Mottled sandstone of the Midlands, and in the typical section of the soutl coast of Devon, near Budleigh Salterton, the Bunter is less than 500 feet thick. It is composed of the following beds:-

2. Coarse red sandstones . . from 350 to 400 feet.

1. The Pebble Bed or conglomerate a about 80 feet.

The Pebble Bed rests directly on the red Permian marls mentioned on p. 333, but without any sign of erosion, for the lowest pebbles are embedded in a sandy clay which is continuous with the inarl below. The mass of the Pebble Bed consists of well-rounded oval pebbles of quartzite and hard grit embedded in a matrix of red sand; it exhibits current bedding and includes lenticular layers of sand. Some of the pebbles contain Devonian fossils, and others are Silurian and Ordovician, resembling the Gres armoricain and the Grès du May of Brittany and the Ordovician rocks of Cornwall. Dark, compact, tourmaline rocks also occur, like some which occur in the metamorpliosed zones round the granite masses of Devon and Cornwall.

According to Professor Bomney, however, the majority of the pebbles do not resemble Devon and Cornwall rocks, while there are some of a hard red quartz-felspar grit whicl resembles the Torridon sandstone of Scotland, but is equally like some parts of the Gres felspatlique at the base of the Ordovician in Normandy. It is, in fact, now generally conceded that this assemblage of pebbles was brought by"a river or rivers from the south, i.e. from Normandy and from land which then occupied the southern part of the English Channel. Oval quartzite and quartz-grit pebbles have, in fact, been dredged from the floor of the Channel at many points from 15 to 50 miles south of the Eddystone.

This conglomerate can be traced inland througl Deroushire into Somerset, but the pebbles become smaller in that direction, and the quartrites becomes less and less abundant, till at Burlescombe the bed passes into a sandy gravel composed chiefly of small quart\%. and grit pebbles. ${ }^{4}$ 
The overlying sandstones are coarse, current-bedded, red sandstones, and in the lower 100 feet they contain a few pebbles of quartz and quartzite, with occasionally subangular fragments of granite, felspathic grit, and lumps of hard red marl. The higher beds are less coarse and more massive, and from these bones of Hyperodapedon have been obtained. These beds occupy the coast from the mouth of the Otter to Sidmouth (see Fig. 117).

\section{The Keuper Series}

This series has a much wider extension than the Bunter, and its higher beds were formed in a great salt lake which covered both the Bunter areas of deposition as well as all the intermediate parts of Central England. Borings at several places in the Midland and Eastern counties have proved that the Kenper sandstones and marls extend eastward beneath the Lias and newer rocks till they thin out against the western slope of the great mass of Palæozoic rocks which underlies the south-east of England.

Thus, a boring at Burford in Oxfordshire passed through 428 feet of Keuper Beds, and entered Coal-measures at 1184 feet from the surface. Borings near Northampton found only 60 to 70 feet of Trias above the older rocks, and one at Culford near Bury St. Edmunds proved its absence. It is also absent below Richmond and London, but appears to pass under the Wealden area as beds underlying Lias, and believed to be of Keuper age, were traversed by a boring at Brabourne in Kent.

As in dealing with the Bunter, we shall first describe the complete and typical development of the Keuper Series in the Midland area, and then indicate such stratigraphical variations as occur when it is traced eastward, northward, and southward.

\section{Typical Midland Area}

In this area the Keuper Series is divisible into three very unequal parts :-

Feet.

Red marls with rock-salt .

"Waterstones," flaggy sandstones and shales .

Basement beds, sandstone, and breccia

from 1000 to 3000

about 200

from 100 to 250

Lower Sandstone or Basement Beds.-The actual base of the series is generally a bed of calcareous breccia, but sometimes a hard pebbly quartz grit; this rests on an eroded surface of the Bunter sandstone (see p. 357), and marks a sudden change in the physical conditions, though the break does not amount to an 
uncouformity, for there is no proof that this basement bed rests on different parts of the Bunter Series in different places.

The overlying sandstones are rather coarse grained and irregularly bedded, generally of bright colours, red or yellow, but sometimes pink or white. The current bedding is remarkable, and the lamme often dip at high angles and change within short distances. ${ }^{5}$ The thickness is variable, but often about 200 feet, and the group is persistent throughout Cheshire, Shropshire, Staffordshire, and Worcestershire. - To the south-east, however, it thins out, and is absent in Warwick.

Fossils have recently been found in the upper part of these beds at Bromsgrove in Worcester ${ }^{6}$; they include both plants and animals. The plants have been identified by Mr. Arber as Equisetites arenaceus, Yuccites vasgesiana, and Voltzia heterophylla (twigs and cones). The animals are Hyperodapedon Gordoni, a Labyrinthodont (? Mastodonsaurus); the fish, Dipteronotus and Acrodus, Estheria minuta, and fragments of Arthropods which are probably scorpions.

The Waterstones are brownish, even-bedded micaceous sandstones and flagstones, with layers of red or green sandy shale; they are therefore very different from the underlying beds upou which they rest with a sharp line of demarcation. ${ }^{7}$ Their surfaces exhibit ripple-marks, sun-cracks, and they contain casts of saltcrystals, all clear indications that they were deposited in shallow water. Their average thickness is about 200 feet, but there is no definite summit to the group as it passes up by intercalations of shale and marl into the overlying Keuper marls.

When traced south-east into Warwickshire, they overlap the Lower sandstones and rest directly on the Carboniferous rocks. In some places the waterstones have yielded bones and teeth of Labyrinthodon, Cladyodon, and Hyperodapedon, and also teeth of the tish Dipteronotus cyphus, but these remains are rare. Reptilian and Labyrinthodont footprints, however, are not uncommon.

The Keuper Marls, though the thickest and most important nembers of the series, are in some respects the least interesting, because they consist of a monotonous succession of red clays (or " marls") varied only by nodular layers and beds of gypsum and occasionally beds of rock-salt, which are sometines from 70 to 100 feet thick.

The thickness of these saliferous marls in Cheshive is from 2000 to 3000 feet ; in Shropshire it is from 1500 to 1800 , thinning eastward to 800 and 700 in Staffordshire, and abont 600 in Warwickshire and Leicestershire. In the last county they overlap the sandstones and are banked against the Archiean rocks of Charnwood Forest, partially filling the valleys between the hills. 
In the Worcester, Warwick, and Leicester areas a bed of grey sandstone, about 20 to 30 feet thick, occurs near the top of the series and is known as the Shrewley sandstone, from Shrewley between Birmingham and Warwick, where it is well exposed. It lias yielded remains of fish (Palconiscus superstes), with Estheria minuta and some casts of bivalve Mollusca, which, according to Mr. E. F. Newton, resemble Goniomya, Pholadomya, and Thracia.

\section{North-Eastern Area}

Basement Beds. - Near Nottingham these are represented by an irregular deposit of white sand, which rests on an eroded surface of the Bunter Pebble Beds and varies from a few inches to many feet in thickness. Mr. J. Shipman has described certain pebbly sandstones more than 100 feet thick, which he regards as representing this deposit. ${ }^{8}$

The Waterstones which succeed generally have a pebbly or conglomeratic bed at the base, and this rests sometimes on the white sand deposit, and sometimes directly on the Bunter, but always on an eroded surface, so that it seems to be unconformable to the beds below. The pebbles are chiefly quartz and quartzite, but Mr. Shipman has detected fragments of trap, slate, chert, and magnesian limestone. The waterstones themselves consist of soft brown sandstones interstratified with red marls, which cause plentiful springs by throwing out the water collected in the sandstones. Ripple-marks and sun-cracks are frequent in these beds.

The Keuper Marls.-These are considered to begin when the marl bands become thicker and the interbedded sandstones become harder and generally white or bluish-grey. Of such beds there is about $\mathbf{1 5 0}$ feet. Gypsum occurs in the marls, and the higher beds are chiefly marl with sheets and nodnles of gypsum. The whole is about 900 feet thick (see Fig. 118).

In Yorkshire the Keuper appears to become thinner and not to exceed 700 feet in thickness; it is still capable of division into an upper red marl group, about 400 feet thick, and a lower series of red and white sandstones from 200 to 300 feet thick, but its lower limit is somewhat uncertain in the northern part of the county.

\section{Cumberland and Irish Sea Area}

Beds of Keuper age overlie the St. Bees' sandstone in the Carlisle basin, and so far resemble the Midland type that they consist of a lower sandstone division and an upper gypsiferous marl group. The former is known as the Kirklinton sandstone 
and is about 500 feet thick; the latter (Red Marls) are estimated at 950 feet.

The Kirklinton sandstone is only seen in the eastern prart of the basin, its outcrop elsewhere being concealed by the Drift deposits. It consists of soft sandstones, which are in some parts red, in others white, or sometimes mottled red and white, and they are probably the equivaleits of the Cheshire "waterstones."

The Keuper marls are also for the most prart buried beneatl Drift, but near Carlisle the sandstones are covered by red and grey marls, which are exposed in several places on the banks of the Eden. West of Carlisle there is believed to be a fault of considerable magnitude, for borings have shown that a great thickness of red shaly unarls with gypsum and rock-salt is brought into the western and deeper part of the basin. ${ }^{\text {? }}$

Keuper marls also occur beneath the northern part of the Isle of Man, borings laving proved a thickness of 557 feet with 21 beds of rock-salt, one of these being 16 feet thick. Below are 800 feet of sandstone, part of which is probably also of Keuper age.

In Ireland the largest area of Trias occurs in the valley of the Lagau, and extends from Lurgan to Belfast, and thence along the northern shore of Belfast Lough as far as Black Head. The beds are also seen at intervals along the coast to the northward as far as lied Bay near Cushendall. They are thickest in the southern part of the area near Belfast. Rock-salt is found at Carrickfergus, where the general succession is as follows:-

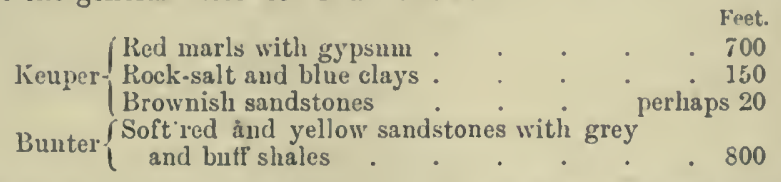

Writing of the Trias in the Isle of Man, Professor Boyd Dawkins remarks that "the unexpected presence of the Saliferous Marls is a link uniting the Triassic strata of the north of the island with those of Barrow on the one hand, and Carrickfergus on the other. It is very probable that these three salt-fields belong to one great saliferous basin underlying the Irish Sea, extending southward and eastward to join that of Fleetwood [in Lancashire], and to the south in the direction of the great salt-field of Cheshire." 10

\section{Mendip and Bristol Channel Area}

It is convenient to deal separately with this area because its conmections with the areas to the north and south are narrow, and because it exlibits a somewliat peculiar local facies of the Keuper. 
As stated on p. 359, this area was land during the formation of the Bunter Beds, and it was not covered by the waters of the Keuper lake until a late epoch in the period; indeed, the Mendip Hills were never completely covered by these waters, and the flanks of these hills display an interesting arrangement of littoral deposits.

These deposits consist of breccias and conglomerates with a calcareous matrix, and are known as the "Dolornitic Conglomerate." They are mainly composed of pebbles of Carboniferous limestone,

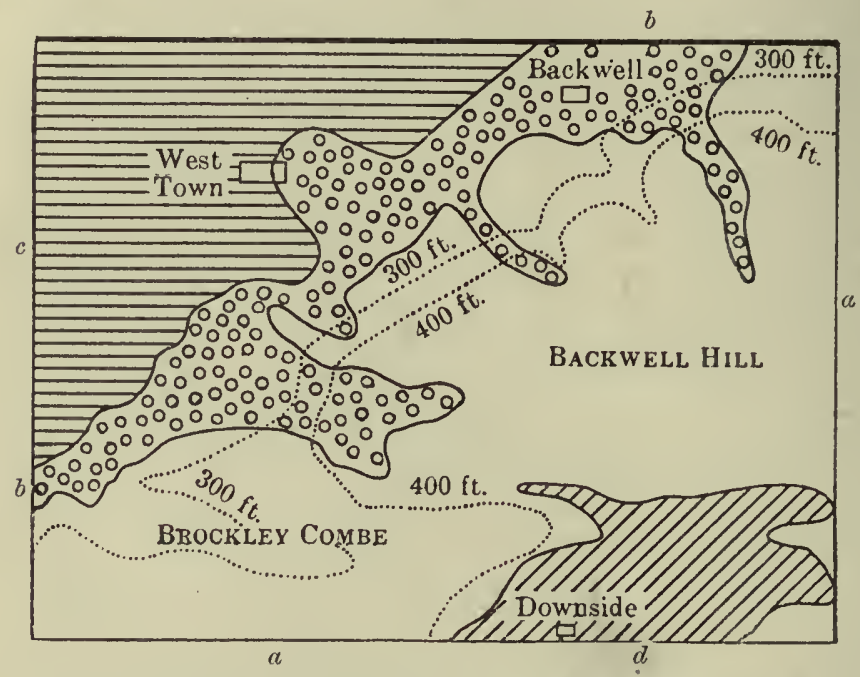

Fig. 120.-GEOLOGICAL MAP OF BACKWELL HILL BETWEEx BRISTOL AND WRINGTOX.

(Surveyed and drawn by Professor S. H. Reynolds.) Scale $1 \frac{1}{2}$ inch to a mile.
d. Lias.
c. Keuper.
b. Dolomitic conglomerate.
a. Carboniferous limestone.

most of these being about the size of a hen's egg, but ranging up to boulders of 2 or 3 feet in diameter, the whole being compacted by a calcareous cement which is generally dolomitic. These beds dovetail into calcareous sandstones and red marls (see Fig. 121), the latter of which fill the wider spaces between the islands of older rocks. Remains of Paloeosaurus and Thecodontosaurus have been found in the conglomerate deposits.

The manner in which the conglomerates run up into the limestone hills along the lines of the old valleys is illustrated in Fig. 120, and, from the contours indicated on this map, it will be seen that these old inlets have no relation to the modern valleys. ${ }^{11}$ 
A contiumation of these beds is found in South Wales, where they occur in patches from Cardift westward as far as Porth Cawl and Kenfig, with a small outlier in Gower which indicates a still further extension to the west. The beds surround islands of Old Red Sandstone and Carboniferous limestone, and their thickness, of course, varies, but there is generally a border or base of dolomitic breccia which passes up into red marls with layers of red and white limestone; these are succeeded by red clays, and, finally, by green clays or marls. ${ }^{12}$

On the Somerset side of the Chamnel a similar set of red breccias, sandstones, and marls is found all round the Quantock Hills, and along the coast from Watchet to Porlock, where they occupy an ancient strait between the Brendon Hills and that called North

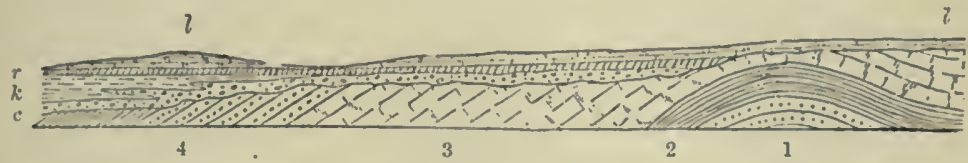

Fig. 121. - SECTION TO SHOW THE RELATIONS OF TUE TRUAS TO THE CARBONIEEROUS ROCK: NEAR SHEPTON MALLET (Somerset).
1. Lower Lias.
r. Rhetic Beds.
$k$. Keuper marls.
c. Conglomerate.
4. Millstone grit.
3. Carb. limestone.
2. Carb. shale.
1. Old Red Sandstone.

Hill on the coast line. The Quantock Hills were an island in the great lake, and the Trias is bedded into a similar old valley or strait on the west of them. ${ }^{13}$

\section{Devonshire}

South of Taunton the thickness of the Keuper Series becomes greater, though the actual outcrop is narrowed by the overstep of the Cretaceous strata which form the Blackdown Hills. The whole series, however, is well exposed on the cliffs of the south coast, from Sidmouth to Seaton and Axmoutl. Here the following succession of beds is foumd :-

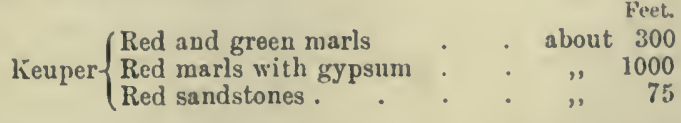

Keuper.-According to Professor Hull and the Rev. A. Irving, ${ }^{14}$ the base of the Kenper division should be taken at a bed of hard breccia about two feet thick which can be seen below the footbridge 
over the Sid at Sidmouth. Above this are pale-red and grey sandstones with seams of marl, succeeded by alternating bands of sandstone and marl, the beds in which sandstones predominate being about 75 feet thick.

The succeding beds are red marls with thin sandstones in the lower 150 feet, but passing up into massive nuarls with a colrchoidal fracture containing strings of gypsum and psendomorphs of rock-salt. These form the lower part of the cliff's as far as Branscombe mouth, but near Beer Head a syncline carries them below the beach. Higher beds occur in the Axmouth and Bindon cliffi, where they finally pass up into the Rhrtic Beds.

\section{Scotland}

- Rocks of Triassic age occur in several parts of Scotland, but, though they resemble the English Trias in consisting largely of red sandstones and marls, their stratigraphical arrangement is different, and this area has therefore been left till the last. The possibility that the Bunter is represented in Arran has been mentioned on p. 361 , but in the more northern districts it is probable that all the beds are of Keuper age.

Arran.-The beds described on p. 361 are succeeded by red sandstones, and these are overlain by red shales and marls. Moreover, recent exploration of the agglomerates which fill up the vent of a huge Tertiary volcano in the central part of the island has led to the discovery of large masses of rock which show a sequence from red marl through Rhætic shales into Lower Lias, thus proving the red marls to be of Keuper age, and to have been succeeded by Rhætic and Liassic Beds, though all other traces of these beds have been destroyed by erosive agencies during Tertiary times. ${ }^{15}$

Western Coast.-Small patches of Trias occur at the base of the Neozoic rocks in Morvern and Ardnamurchan (Argyleshire), in the Isles of Skye and Raasay, and on the coast of Gruinard Bay in Ross-shire. They have been described by Professor Judd, who remarks that the materials forming the breccias, conglomerates, and coarser sandstones have evidently been derived from the older rocks on which these strata repose, usually either the Torridon sandstone or some member of the Highland gneissic series.

A special feature in these Triassic rocks is the abundance of calcareous matter which enters into their composition; fragments of compact limestone (? Durness limestone) abound in the coarser beds; the sandstones often pass into calcareous grits, and bands of cornstone are not unfrequent, while all the beds are frequently traversed by veins of calcspar. As a rule, breccias and 
conglomerates prevail in the lower part of the series, sandstones, narls, and limestones in the upper part, but the succession of beds is very irregular and incoustant. At Gruinard Bay the total thickness exceeds 1000 feet; at Rasay it is probably less than 500 feet, thongh the general snccession is the same; at Lussay, in Skye, it is rednced to a few feet, and southward, in parts of Mull and Morvern, it varies from 50 to 500 or 600 feet.

The following is the succession at Gruinard Bay :-

Feet.

Soft reddish argillaceous and sandy beds with bands of hard white and greenish sandstone.

Red and variegated marls with thin beds of sandstone and concretionary limestone

Red argillaceous sandstones and conglonerates, alternating in the lower part with masses of coarse breccia-conglomerate

500

Eastern Coast.-Sinall tracts of Trias occur in Elgin and on the coast of Sutherland. The tract in Elgin extends from Spynie, north of Elgin, to the coast at Lossiemouth and Stotfield Head. ${ }^{16}$ It rests on the O.R.S., but its base is not exposed. The rock seen in quarries is a white sandstone, massive, fine-grained, and fairly soft, with a thickness of about 200 feet, apparently dipping worth, and overlain at Stotfield by a hard, whitish, cherty limestone, which may be 30 feet thick. This sandstone has yielded remains of eight different reptiles : three Rhynchocephalians, Hyperodapedon, Telerpeton, and Stenometopon; two Crocodiles, Stagnolepis and Erpetosuchus; and two Thecodonts, Ornithosuchus and Scleromochlus.

The same two kinds of rock occur below Dunrobin Castle on the Sutherland coast, i.e. white sandstone dipping north-east, and passing below a cherty rock like that of Stotfield, above which are beds of Liassic age.

\section{The Trias in Europe}

\section{Germany}

Triassic rccks occupy large areas in Central and Southern Germany, in Thuringia, Hesse, North Bavaria, Wiirtemberg, and Lorraine; they are also found in the Eifel district, in Hanover, Brmmswick, and Magdeburg, and finally in the island of Heligoland. From the Rhine district they extend westward to Luxemburg, and throngh the Vosges Mountains into France. They are everywhere divisible into the three series of Bunter, Muschelkalk, and Keuper.

The German Trias was formed under the same plysical and geographical conditions as that of Britain, with which it is prob- 
ably continuous under the bed of the North Sea; in other words, the British area was part of a much larger Germanic region. The German Bunter and Keuper may both be regarded as salt-lake or lagoon deposits, and though the fossils of the Muschelkalk are marine, yet its famna is not a large one, and is evidently that of an inland sea which was only temporarily connected with the open sea to the south. The area over which these limestones occur may be regarded as including what was the deepest part of the great depression occupied by this inland sea.

The subdivisions of the German Trias and their average thicknesses are given in the following table:-

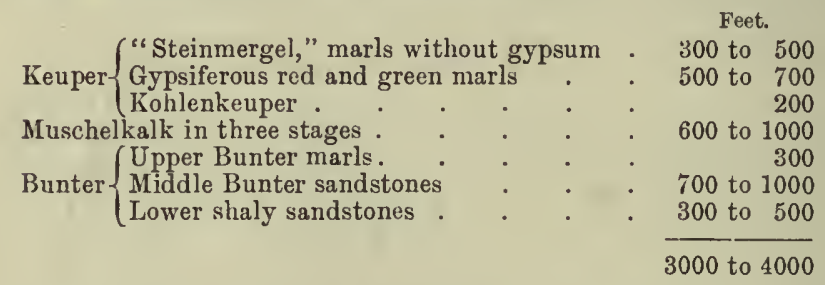

The Bunter.-This is essentially a sandstone series. The lower stage in Northern and Central Germany consists of darkred flaggy sandstones, which succeed with apparent conformity the clays of the Upper Zechstein, but in Western Germany they overstep the whole of the Permian, and rest on the crystalline schists of the Odenwald and the Black Forest. The rest of the Lower Bunter consists of fine-grained micaceous sandstones of various colours, often speckled, and often including angular fragments of red clay; there are also some layers of dolomitic sandstone (Rogenstein). (See Fig. 122.) Fossils are rare.

The main mass of the Bunter sandstone (or Middle Bunter) consists of coarse quartzose sandstones, which generally show current bedding and have a maximum thickness of 1000 feet. No fossils except tracks of Labyrinthodonts have been found.

The Upper Bunter or Röth consists of variegated red and green marls with beds of gypsum and rock-salt. In Thuringia these beds contain layers of dolomitic limestone with marine fossils (Myophoria costata, $M$. vulgaris, and other species which also occur in the Muschelkalk). Westward in the Eifel, the Vosges, and Lorraine the Röth passes into fine argillaceous sandstones containing plant remains, Voltzia, Schizoneura, and Anomopteris.

Muschelkalk.-This is a limestone series, and takes its name from the abundance of bivalve shells ("muscheln ") in many of its beds. It is divisible into three stages. 
'The lower stage is about 300 feet thick, and consists of thinbedded inarly limestones (Wellenkalk) with yellowish porous limestones (Schaunkalk). The chief fossils in the lowest beds are Myophoria orbicularis, Natica gregaria, and Dentalium torquatum, but the higher part of the Wellenkalk is one of the richest fossiliferous zones in the whole series, its fossils including Myophoria vulgaris, Gervillia costata, Pecten discites, Terebratula (Cœnothyris) vulgaris, T. (Aulacothyris) angusta, and Beneckeia Buchi.

The middle stage consists chiefly of dolomitic limestone and marl with beds of gypsuın and rock-salt. Fossils are rare.

The upper beds are hard limestones, consisting mainly of Encrinite stems, overlain by thin-bedded limestone characterised by Ceratites nodosus. These upper beds are rich in fossils, some of the commonest being Encrinus liliiformis, Lima striata, Gervillia (Hormesia) socialis, Terebratula (Conothyris) vulgaris, Myophoria vulgaris, and Temnocheilus bidorsatus.

In the Vosges country some of the Muschelkalk limestones are replaced by sandstones and marls, and the whole division gradually dwindles till it finally thins out and disappears.

The Keuper.-The main area of the German Keuper lies in Franconia and Swabia (Würtemberg), but it also occupies a considerable space in Luxemburg and in Alsace-Iorraine. It occurs also in the middle of the Thuringian basin and to the north-east of the Teutoburger Wald (in Hanover and Brunswick). The series is everywhere divisible into three groups, which have a combined thickness of from 900 to 1200 feet (see Fig. 122).

The Kohlenkeuper consists of dark-grey shales and sandstones with thin beds of shaly coal, but the fossils are marine and brackish water, soine of the beds being crowded with Estheria minuta and Lingula tenuissima, with the teeth of fishes (Ceratodus, Acrodus, and Hybodus). The highest beds of the group are yellow dolomitic limestones-some compact, some oolitic-and these contain Myophoria Goldfussi, M. transversa, and Anoplophora donacina.

The central beds, forming the nain mass of the Keuper, are red and green marls with beds of gypsum and some of rock-salt. Fossils are rare in these marls, but in South Germany (Stuttgart) they include plant-bearing sandstones with Equisetites arenaceum and Pterophyllum Jogeri.

The Steinmergel seems to correspond with the lighest red and green marls of the English Series. They are free from gypsum and rock-salt, but contain thin layers of sandstone and, in Lorraine, beds of dolomite and layers of dolomitic concretions. From these beds many Reptilian remains have been obtained, e.g. Aëtosaurus and Belodon, and the Dinosaurs Dimodosaurus and Zanclodon. 


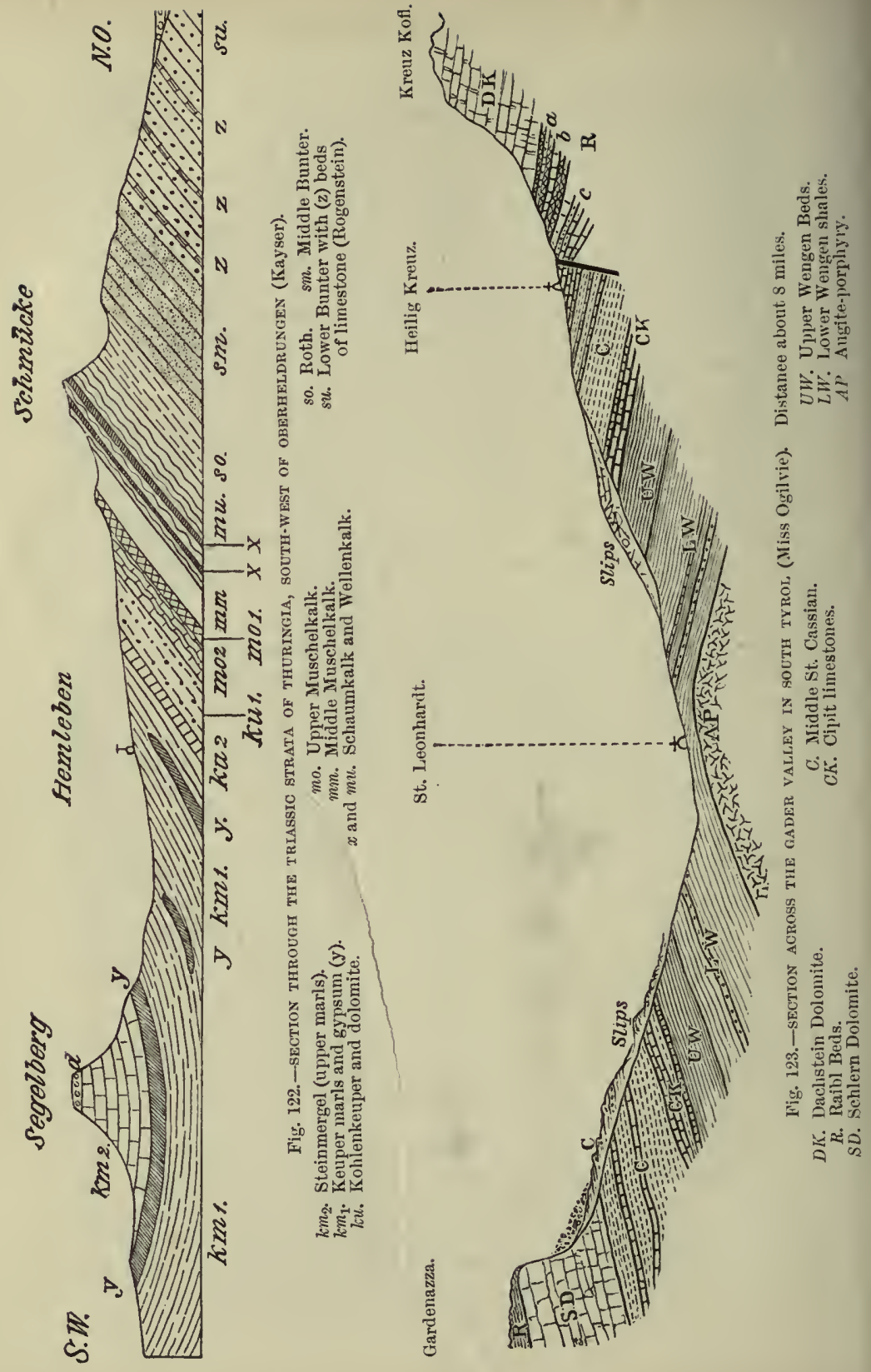




\section{The Alpine Facies}

The Triassic System las no great thickness in the Westem or Central Alps, lut attains a great development in the well-known Dolomite Mountains of the South Tyrol and Carnic Alps, and also in the Vorarlberg, in North Tyrol, Salzburg, and Bavaria, on the northern side of the main crystalline axis of the Alpine chain. The succession of beds forming the lower and middle parts of the system in the northern districts differs considerably from that in the sonthern, but the higher part from the Raibl Berls upwards is similar in both regions. From this and from differences in the Cephalopodan faunas of the two areas it was inferred that there were at first two marine provinces which were more or less separated until the later part of the Triassic period. The northern province has been called the Juvavian, and the southern the Mediterranean province. The former includes Bavaria, the Salzburg district, and Austria proper, extending eastward to the Carpathians; the latter comprises the Lombardy Alps, the Southern Tyrol, Carinthia, with the whole of Italy and the whole Dalnatian and Bosnian region. The progress of research, however, has shown that the differences are less than were supposed, and that, so far as the fossils are concerned, it is rather a matter of relative abundance of species than of difference in fauna.

The thicknesses of the several divisions vary much in different districts, but the total thickness in the North Tyrol is supposed to be about 6000 feet, while in the South Tyrol it is probably about 9000 feet. The following table shows the general snccession in the two regions :-

Southern Region.

8. Lower Dachstein Dolomite .

7. The Raibl Beds.

6. The St. Cassian Beds .

5. The Wengen Beds

4. The Buclienstein Beds

3, 2. The Virgloria limestone

1. The Werfen Beds
Northern Region.

\begin{tabular}{|c|c|}
\hline $\begin{array}{l}\text { Main Dolomite } \\
\text { Raibl or Cardita Beds }\end{array}$ & \} Ǩeuper. \\
\hline Partnach Beds & \\
\hline Reiffling limestone & \\
\hline Guttenstein limestone & $\frac{3}{2}$ \\
\hline
\end{tabular}

Werfen Beds

- Bunter.

The whole system has also been divided into zones and into stages or series of more equal palæontological value, but much diflerence of opinion still exists as to the number of zones and as to their grouping, and many names have been proposed for the different groups or stages. The following table gives the principal zones, which correspoud to the local subdivisions as numbered above, and the names which seem nost applicable to the 
stages, the latter being almost the same as those proposed by Mojsissovics :- ${ }^{17}$
Upper $\left\{\begin{array}{l}\text { E. Juvavian } \\ \text { D. Carinthian } \\ \text { C. Norian }\end{array}\right.$
8. Avicula exilis.
\{7. Trachyceras aonoides.
6. Trachyceras aon.
\{5. Trachyceras archelaus.
Lower $\left\{\begin{array}{l}\text { B. Dinarian } \\ \text { A. Werfenian }\end{array}\right.$
4. Trachyceras Curioni.
3. Ceratites trinodosus.
$\{2$. Ceratites binodosus.
1. Tirolites cassianus.

More recently he has proposed to combine the Norian and Carinthian into one stage or series, for which he adopts the name Tirolian, but the advantage of this is not very apparent.

The Werfenian, or zone of Myophoria costata, is fairly coustant in its lithological and palæontological characters throughout the Alpine and Austrian region. Its prevalent facies is one of red sandy micaceous shales, but in the Carnian Alps there are intercalated beds of marly and dolomitic limestones, and in the Tyrol it also consists of shales and limestones which have been divided into two groups, the Seiss Beds and the Campil Beds. The Anmonoid Tirolites cassianus is found in both provinces, associated with Myophoria costata, Naticella costata (Fig. 112, No. 2), and Pseudomonotis Clarce (Fig. 112, No. 1). In the South Tyrol the thickness of this stage is only 300 to 500 feet.

Dinarian, or Alpine Muschelkalk.-It is at this stage that the differences between the southern and northern provinces become pronounced. In the Southern Alps it is represented by the Virgloria limestone and its equivalent, the Mendola Dolomite, and in the South Tyrol there is a lower set of bedded limestones overlain by Mendola Dolomite. In the more northern districts there are two groups or zones, the Guttenstein limestone or zone of Ceratites binodosus and the Reiffling limestone or zone of $C$. trinodosus. The Dinarian contains many of the same species as the German Wellenkalk, notably Cœnothyris vulgaris, Terebratula (Aulacothyris) angusta, Tetractinella trigonella (Fig. 112, No. 3), Gervillia (Hornesia) socialis, Myophoria vulgaris, and Encrinus liliiformis. The thickness varies from 400 to 1200 feet.

The Norian.-In the sollthern province this comprises the Buchenstein shales, with calcareous nodules containing Trachyceras Curioni, and the Wengen Beds, which include black shales and calcareous grits containing Trachyceras archelaus and Halobia. Lommeli, succeeded by thin-bedded limestones and shales with Posidonomya wengensis. In the Juvavian province these are replaced by the higher part of the Reiffling limestone and by the 
Wetterstein limestores, so that there the stage is wholly calcareous. A large number of peculiar Ammonoids come in with this series, such as Pinacoceras Metternichi, P. parma, Cladiscites tornatus, Arcestes ruber, and species of Diphyllites and Megaphyllites. The thickuess varies from 2000 to 3000 feet.

The Carinthian.-The separation of the two provinces appears to have continued through this group up to the phase of the Raibl Beds, when similar conditions began to prevail over the whole region. In the Mediterranean province the Wengen Beds are overlain by the St. Cassian Beds, a series of fossiliferous marls, sliales, and limestones witl occasional beds of volcanic tuft. Among the large number of fossils wlich these beds afford the following may be mentioned: Trachyceras aon (Fig. 112), Choristoceras eryx, Orthoceras elegans, Naticopsis neritacea, Halobia cassianus, Anoplophora Munsteri, Cidaris dorsata, Encrinus cassianus, Isocrinus propinquus, Thamnastrea Zitteli, Koninchina Leonhardi. The St. Cassian Beds are succeeded by the Raibl Beds, dark-grey marls with lenticnlar beds of limestone and some of gypsum, the chief fossil being Myophoria Kefersteini (Fig. 112, No. 10).

In the St. Cassian area of the Tyrol a nuass of dolomitic limestone, the Schlern Dolomite, from 1000 to 1400 feet thick, comes in between the St. Cassian and the Raibl Beds, ${ }^{18}$ and this thickens southward, replacing more and more of the beds below and above till in the Schlern and Rosengarten districts it rests directly on the Mendola Dolomite of the Norian stage, and is then about 3000 feet thick with a small equivalent of the Raibl strata at the top. Consequently it then represents botl the Norian and Carinthian (see Fig. 123).

In the North Tyrol and Bavaria the St. Cassian Beds are represented by the Partnach Beds with the overlying Raibl Beds, but in the Austrian Alps to the eastward there is a different succession, consisting of (1) the Raugraben shales, (2) the Linz. sandstone with plant remains, (3) the Opponitz limestoure.

Juvavian.-Finally, over the whole region we have the massive dolonitic limestones known in Austria as the Hallstadt and Daclistein limestones and in Lombardy as the Great or Main Dolomite. These masses of limestone are several thousand feet thick, but fossils are rare in them, except casts of the large bivalve Megalodon; Gervillia exilis and Worthenia solitaria, thongh less common, are characteristic species. These limestones pass up into the Kössen or Rhxtic limestones and are by some anthors regarded as Lower Rhæetic, but it is only the Upper Rhxtic or zone of Avicula costata which overlies the Keuper of Germany, France, and England. Hence it is almost certain that the zone 
of $A$. exilis was contemporaneous with the highest part of the Keuper.

The probable correlation of the several series of beds in England, Germany, and the Tyrol is shown in the following table :-

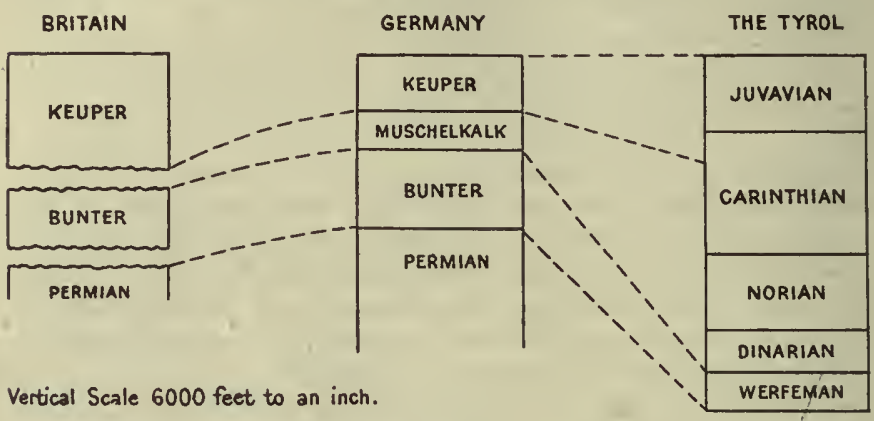

\section{France}

The surface areas occupied by Trias in France are small, though the Keuper probably has a considerable subterranean extension both in the northern and southern parts of the country:

From the Vosges district and the Sarrebruck area in Alsace a broad tract of Trias reaches westward into France, passing under the Jurassic strata which occupy the great basin between the plateau of the Ardennes and that of the Morvan. All the members of the German Trias are here present, but both the Bunter and the Muschelkalk thin rapidly to the westward; their attenuation can be followed along the northern outcrop in Luxemburg, and both are very thin before they are overlapped by the Lias north-west of Arlon.

There can be no doubt that a similar thinning out takes place to the south-west of the Vosges, for when the beds emerge on the borders of the Morvan only Keuper remains, but this is exposed at intervals round the Morvan and along the north side of the Central Plateau from the valley of the Allier to a point about 15 miles west of La Châtre. Though the beds are of no great thickness, they seem to represent the Lower or Kollenkeuper as well as the higher marls. They can be traced southward along the eastern border of the Platean to Macon, Villefranche, and Lyons, the beds consisting of coarse quartzose and felspathic sandstones from 50 to 100 feet thick, surmounted by a pink dolomitic limestone with Myophoria Goldfussi, which is succeeded by Keuper marls.

At Lyons the sandstone rests directly on the ridge of Archæan 
rocks which here crosses the valley of the Rhone between that place and Valence, and it is probable that this was part of the barrier which separated the northern and southern basins of depositions. South of Valence similar deposits set in again and form a long strip by Privas and Largentière, and again in the Lodéve district; they also occur in the Pyrenees and in Eastern Spain, but to find a complete Triassic Series one must go to the Maritime Alps, where lower beds come in and the series expands eastward into the Apennine facies which is similar to that of the Eastern $\mathrm{Al}_{1} \mathrm{~s}$.

The only other Triassic tract in France which need be noticed is that in Normandy, occupying a bay-like depression in the Archean rocks from Valogne and St. Waast on the north to St. Lo and Littry on the south, but thinning out to the west of Caen. The beds consist of gravel and conglomerate at the base, passing up into a dolomitic conglomerate which is succeeded by red sandstones and marls. The maximum thickness is not more than 200 feet, and the whole is probably of Keuper age, the beds being shore deposits, like those round the Mendip and Quantock Hills in England.

\section{E. The History of the European trias.}

From the preceding descriptions of the Triassic strata which are found in different parts of Europe the student will have gathered that considerable geographic changes took place during the course of the period; though these seem to have been accomplished slowly and without the forcible uplift of any mountain chain like that of the Arnorican ranges in Carboniferous time.

The change from Permian to Triassic conditions seens to have been effected by a slow upheaval of the whole of Northern Europe, so that all those parts of the Permian Sea which lay within that region were shallowed and sone portions of then were converted into sandy plains. This seems especially to have been the case in the British area where the north-west gulf of the Permian Sen became a sandy desert, swept by winds which probably blew chiefly from the north, like those which blow over Persia and Beluchistan at the present day at certain times of the year.

Through this plain may have meandered a river fed by the streams which flowed off the western and northern mountains, so that it was a strong and rapid river even though it may have received $n 0$ affluent after leaving the gap between Ireland and Scotland. Such is the theory by which the accumulation of the "Pebble Beds" in the English Midlands has been explained, for the majority of these pebbles are quartzites which are unlike any 
Welsh quartzites, but are identical with those found in the Old Red conglomerates of Scotland, the stones themselves having been originally derived from the Torridon sandstone. ${ }^{19}$

For a discussion of this matter the reader is referred to the author's Building of the British Isles (1911). Here it is only necessary to remark that these pebble beds do not signify more than a brief episode in the Bunter epoch; a few abnornally wet seasons would suffice to pile up all the pebbles which are now spread over Shropshire, Staffordshire, and Worcestershire. They had doubtless been accumulated in the higher tributary valleys of the river-system, and when heavy rains turned the streams of these valleys into rushing torrents, the pebbles were swept down into the main river, which, swollen by the floods, was strong enough to carry them for several hundred miles before they finally came to rest in a bay-like curve of the great plain, for the river must have flowed out westward into and across what is now the basin of the North Sea. There it was doubtless joined by other rivers, all combining to form a still larger one which curved southward and ran into the German lake or lagoon.

That the episode of the English Pebble Beds was not one of much physical importance is proved by the fact that it was followed by a reversion to the preceding conditions, for the Upper Bunter sandstone is so similar in character to the Lower sandstone that outside the area of the Pebble Beds it is difficult to distinguish them, and the sandy facies of the Pebble Beds merges outward into the Upper sandstone.

In Germany the characters of the Lower Bunter sandstone, its ripple marks, sun-cracks, and rain-prints, show that it was deposited in a large lake, probably of fresh water, and the Middle Bunter must be either lacustrine or terrestrial; but the case is different with the Upper Bunter, for its red gypsiferous marls are the deposits of saline water, and in Thuringia the inclusion of a marine limestone marks an incursion of the Southern Sea.

The epoch of the Bunter was brought to an end by a general subsidence of the whole region, the result of which was to bring the sea over the whole of the low-lying Germanic plain. This is the epoch of the Muschelkalk, and the higher level of the British area at this time is indicated by the fact that it was not reached by the Muschelkalk Sea. That sea passed over Hanover and the Island of Heligoland, and probably reached some distance farther west, terminating somewhere below what is now the bed of the North Sea.

Thus for a time the plains and lakes of the Bunter were converted. into arms of the Southern Sea, and communication with 
that sea was established across Bavaria, and perhaps also through Silesia to the east of the Bohemian Highlands. With regard to Russia little evidence is available, because any Triassic rocks which may exist in the western and central parts of that country are concealed beneath a thick cover of Jurassic and Cretaceous strata. In the Astrakall province, however, the Bogdo Mountains are capped by outliers of a limestone which is believed to be of Muschelkalk age, and beds belonging to the Upper Trias occur in the Crimea, so that it is very likely that the Southern Sea spread over a large part of Southern Russia during Muschelkalk time.

We have seen that a great thickness of rock-material was accumulated in this Southern Sea, and that as time went on the deposits formed therein became, at any rate in some parts, more and more calcareous. At the same time it does not seen to have been a deep sea, for apart from Molluscan shells (chiefly Lamellibranclis and Gastropods), the priucipal components of the limestones are calcareous algæ (Diplopora and Gyroporella), which at the present day do not flourish wuch below 150 fathoms. Hence, to account for the much greater mass of deposit in Austro-Alpine region, about 5000 feet as compared with 1000 in Germany, we uust suppose that subsidence was more continuous in the southeru than in the northern region.

The truth of this inference is confirmed by a consideration of the area where the German and Austrian facies of the Trias approach most nearly to one another. Between the Schwartzwald and Bohemia the German Keuper dips southward under the Jurassic strata of the great Danubian plain; while south of this plain, and cropping out from below the same Jurassic and Cretaceous rocks, are the highest members of the Austrian Trias, extending from the Volarlberg to the Salzburg district. The breadth of this intervening tract, which conceals the passage of one facies into the other, between Tübingen and the Vorarlberg is only 100 miles.

There is, no good reason for supposing that this tract conceals a ridge of Palieozoic rock, which could have formed a land-barrier between the two regions; it is much more probable that the one facies passes into the other with a comparatively rapid change, and the facts can be explained on the supposition that the crustmovements were of a counterpoising nature, the southern region continuing to subside while the northern at the begimning of Keuper time underwent a slight uplift with a north-west tilt, so that while the uplift was sufficient to cut off the northern area from the Sonthern Sea the inland waters were able to extend themselves farther west than those of the Muschelkalk had done.

In this manner was produced the great salt lake or inland 


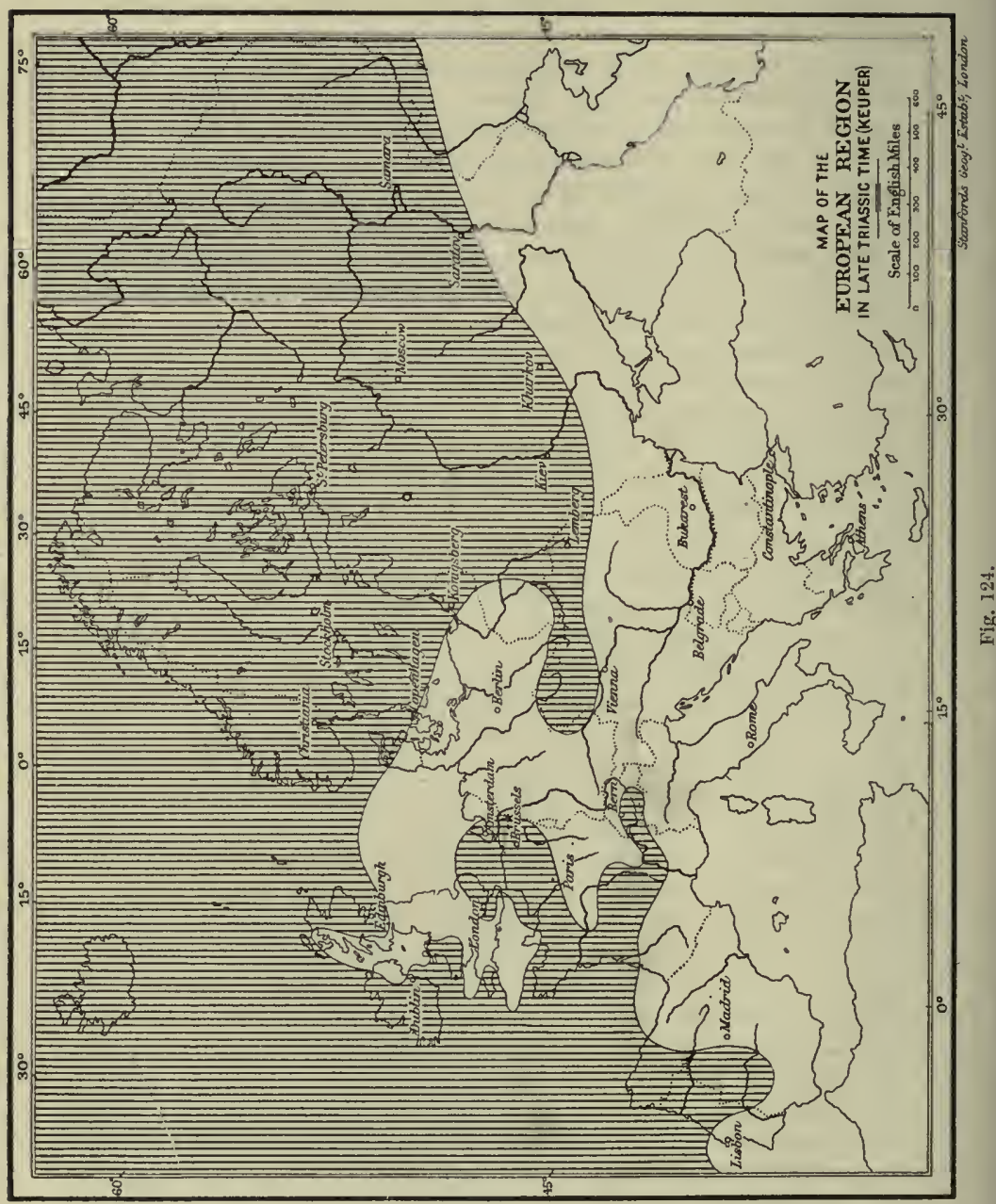


sea in which the red marls and salt deposits of the Keuper were formed; and judging from the relative thickness of the Keuper Series at different places the deepest parts of this inland sea were near Berlin in Germany (Sperenberg boring) and below Cheshire in England. In Fig. 124 I have attempted to restore the geography of Europe in the Keuper epoch, and though I have left an opening between Switzerland and Bohemia, this can only have been open during the time of the Kohlenkeuper, and must afterwards have been closed by local upheaval or in some other manner so as to shut out the waters of the Southern Sea from the northern basin.

The physical aspect of the country surrounding the inland sea must have combined the features of the Syrian desert around the shores of the Dead Sea with those of the country near the Caspian; that is to say, the Anglu-Germanic Sea was bordered in some places with rough and rocky hills, in others by sandy plains, and again in some places by reedy marshes and salt lagoons. We nust not picture the whole region as completely barren and arid, for we know it was inlabited by various kinds of reptiles and Labyrinthodonts; moreover the continued existence of the lake would depend on the water-supply carried into it by rivers, though it is clear that this supply was often less than the amount which evaporated from its surface.

\section{REFERENCES}

1 Lapworth, "Geology of the Birmingham District," Proc. Geol. Assoc. vol. xv. p. 384 (1898).

2 Holmes, "Geology of Cumberland," Proc. Geol. Assoc. vol. xi. p. 231.

3 Boyd Dawkins, Quart. Journ. Geol. Soc. vol. lviii. p. 647 (1902).

- Martin, Geol. Mag., 1909, p. 160.

S Strahan, Geol. Mag., 1881, p. 396.

* Wills, Geol. Mrag., 1907, p. 28.

${ }^{7}$ Strahan, op. cit.

8 Shipman, "Geology of Nottingliam," Proc. Nott. Nat. Hist. Soc., 1889; see also the Geological Survey Menoir on Sheet 126 (1908).

${ }^{9}$ Holmes, op. cit.

10 Boyd Dawkins, op. cil. p. 655.

1 Morgan and Reynolds, Bristol Nat. Hist. Soc. for 1908, p. 5.

12 Strahan, "Geology of South Wales," Geology in the Field, p. 842.

${ }^{13}$ See W. A. E. Ussher, Quart. Joum. Geol. Soc. vol. xxxii. p. 367, and vol. xxxiv. p. 459.

it Hull and Irving, Quart. Journ. Geol. Soc. vol, xlviii. pp. 60 and 68.

15 Judd, Queart. Journ. Geol. Soc. vol. xxxiv. 1). 686 (1878).

16 Watsoll, Geol. Mag. for 1909, p. 102.

17 Mojsissovies, Sitz. Akad. Wien, 1892, p. 769, and 1895, p. 1279.

t8 Ogilvie, Quart. Journ. Geol. Soc. vol. xlix. \%. 1 (1893).

19 Bomey, Quart. Journ. Geol. Soc. vol. 1vi. p. 287 (1900): 


\section{CHAPTER XIII}

\section{THE JURASSIC SYSTEM}

\section{A. Nomenclature and Division}

In the early days of Geolugy part of this system was called the "Oolitic Series" (by Conybeare and Phillips in 1822) from the prevalence of oolitic limestones in the central and upper parts of the system in England, and the Lias was described as a separate series; but on the Continent the equivalents of the former were called the "Jura limestones" by Brongniart and Boué in 1829 from the fact that beds of this age form the entire range of the Jura Mountains between France and Switzerland. In Germany the name "Jura" was adopted by von Buch for the whole system (1839), who divided it into Lower, Middle, and Upper Jura, and this nomenclature is still used in that country. It appears to have been d'Orbigny (1840-46) who first applied the term "Terrain Jurassique" to the whole succession, including the Lias; and at the same time he divided the system into a number of stages, but did not group these into series as von Buch had done.

The arrangement now generally adopted is a division into three series, which are practically those of von Buch, and a further subdivision into stages for which we in England have used local English names, while French geologists employ the latinised names proposed by d'Orbigny with some additions to their number. As a nutter of fact it would be more convenient, and more in accordance with the nomenclature "of older systems, to employ latinised names for the three great series themselves. ${ }^{a}$

The English and French subdivisions are shown in the following table :-

a For the Lower Series the for the Middle Series I lond Roman name of Gloucester, the Roman name of Weymo 'm Lias or Liasian is already in general use ; proposed ${ }^{1}$ the name Glevanian from the at of Clavinian for the Upper Series from 
Upper Jurassic $\left\{\begin{array}{l}\text { P'urbeck Beds } \\ \text { Portland Beds } \\ \text { Kinteridge clay } \\ \text { Corallian Beds } \\ \text { Oxford clay }\end{array}\right.$
Middle Jurnssic $\left\{\begin{array}{l}\text { Great Oolite } \\ \text { Inferior Oolite }\end{array}\right.$
Lower Jurassic $\left\{\begin{array}{l}\text { Upper Lias } \\ \text { Middle Lias } \\ \text { Lower Lias and Rhetic }\end{array}\right.$
\} Portlandian.

Kimeridgian.

Sequanian.

Oxfordian.

Bathoniau.

Bajocian.

Toarciau.

Charmouthian.

f Sinemurian.

Hettangian.

It will be noticed that $I$ follow French geologists in regarding the Rhxtic or zone of Pteria contorta as the basal part of the Liassic Series, while the Germans have generally included it in the Trias These beds were briefly referred to on p. 375 , and reason was there given for restricting the name to this zone, which succeeds that of Gervillia exilis in the Eastern Alps but spreads far and wide beyond the latter over large parts of Europe. There is no doubt that it marks an epoch when the sea once more occupied the Triassic lowlands of Northern and Western Europe, and that over these lowlands it is a mere zone, fron 30 to 40 feet thick, which is nore intimately connected with the overlying Lias than with the underlying Keuper.

In dealing with the stratigraphy of this system it will be convenient to take each of the three great divisions or series separately, and to give a condensed account of the componeut strata of each series, both in Britain and on the Continent, before proceeding to the next one. We can-afterwards review the gentral history of the whole period, and indicate the geographical changes which took place at its close.

\section{B. Life of the Period}

The reader may be reminded that throughout Triassic times our islands formed part of a continent which occupied the northern part of Europe, and some part at least of the North Atlantic region, and that it was not until the Rhretic epoch that the inland lakes of this continent were finally submerged beneath the waters of an open sea. Further, the fauna of the British Rhretic beds or zone of Pteria $[=$ Avicula $]$ contorta in Northern Europe contains but a small number of species, and it was not till the time of the Lias that conditions were farourable for the establishment of a new and abundant marine fauna over the whole region. We are thus suddenly presented with an assemblage of fossils which is very different from those of the Carboniferous and Permian periods, and 
for the ancestors of these we nust search the marine Trias of Southern and Central Europe.

The rate of change in the organic world and the differentiation of species appears to have become much more rapid in Jurassic times than it had been in Palæozoic times, so that any given group of species has a much less vertical range, and consequently a nuch smaller set of strata requires separate description. It will, therefore, be convenient to describe the prevalent genera and the characteristic species of each series separately, but in the first place the distinguishing features of the Jurassic fauna as a whole may be indicated.

In the first place it was an "age of Reptiles," and it is specially characterised by the remarkable development of the orders Dinosauria, Pterosauria, Ichthyopterygia, and Sauropterygia. These orders survived into the Cretaceous period and then became extinct. The Dinosauria were land animals, and many were of gigantic size (from 30 to 70 feet long); in many cases their hind limbs were much longer and stronger than the fore legs, so that they could walk in an upright position like a kangaroo. Some were carnivorous (as Megalosaurus) and some herbivorous (as Cetiosaurus). The Pterosauria are reptiles adapted for the purpose of flight in the air, and thus possess many bird-like characters, such as pneumatic bones, keeled sternum, and more or less bird-like skull ; their membranous wings were attached to the sides of the body and to the greatly elongated fifth digit. The Ichthyopterygia and Sauropterygia were specially adapted for life in the sea, both pairs of limbs being modified into the form of paddles or flippers. Representatives of the orders Crocodilia and Chelonia also occur.

Birds also make their appearance, but are known by two specimens only, found in the lithographic limestone at Solenhofen in Bavaria. They are referred to the genus Archocopteryx, which exhibits strong reptilian affinities, possessing teeth and a long narrow tail of twenty separate vertebræ, each of which apparently carried a pair of feathers; the wings are bird-like, and the creature was about the size of a common pigeon.

It is in Jurassic strata also that the earliest numnials have been found, and these all belong either to the sub-class Prototheria (which includes the living duck-billed nole, Ornithorhynchus, and the spiny ant-eater, Echidna) or to the sub-class Metatheria (which includes the opossums and kangaroos). No placental mammals have been found in the Jurassic System. Mammalian remains have been found at three horizons; the oldest (Microlestes) in the Rhrtic Beds at the very base of the systen, others (e.g. Phascolotherium, Amphitherium), in the Great Oolite, and others (10 genera, e.g. Triconodon) in the very highest group (Purbeck Beds). 
Another special feature of the famna is the great abundance and variety of the Ammonoid Cephalopoda. A few genera such as Phyllocercs appeared in Triassic times, but a large number occur in $J$ urassic rocks, and many are confined to the period. The genus Nautilus, which also dates from the Triassic period, is the only representative of the Nautiloidea. Belemnites, a genus of Dibranchiate Cephalopods, appears in the Lias and reaches its maximum development in Jurassic times.

Gastropods are numerous, especially Nerina, Pleurotomaria, Cirrus, Pseudomelania, Naticu, and Amberlya.

Among Lamellibranchia the Ostreidæ, Pectinidæ, Limidæ, and Pholadomyidre become abundant, and the genus Gryphcea is very characteristic of the period; Trigonia also is abundant.

Among Echinoderms the Euechinoid Group makes its appearance in England, and is very abundant both in species and individuals. The first irregular Echinoid is found in the Upper Lias. Some representatives of the Asteroidea, Ophiuroidea, and Crinoidea also occur. Corals also abound in most of the limestones.

Plants occur at several horizons, and Cycad-like fronds, stems, and "Howers" are so abundant that botanists have called the Jurassic period the "age of Cycads." The chief genera are Zumites, Otozamites, Nilssonia, Pterophyllum, and Williamsonia. Ferns continue to be common, and conifers were represented by genera allied to the modern Araucaria, Cupressus (cypress), and Taxus (yew).

The following are some of the genera which are not known in Britain or France before Lower Jurassic time, though some occur in the Alpine Trias. Those preceded by an asterisk did not survive the Jurassic period.

Anthozoa.-Astroccnia, *Heterastrea, Isastrea, Moutlivaltia, *Stylastrea, Thamnastrea, Thecosmilia, Trochocyathus.

Echinoderma - * Pentacrinus, Isocrinus, Ophioderma, Ophio. lepis, Acrosalenia, Cidaris, Rhabdocidaris, Henipedina, Pseudodiadema.

Crustacea._- Eger, *Eryma, Eryon, Glyphæa, Penæus, *Scaphens.

Brachiopoda.-Waldheimia, Thecidium, Terebratella, Cadomella.

Lamellibranchia,-Astarte, Cardinia, Cardita, Cardium, Protocardia, *Ceromya, Grammatodon, Cucullaa, Trapezium, ${ }^{*}$ Gresslya, Gryphiea, Velopecten, *Hippopodium, Homomya, Inoceramus, Myoconcha, Opis, Ostrea, Plicatula, Perna, Pinna, Pholadomya, Goniomya, Pleuromya, *'Tancredia, Thracia, Trigonia, Unicardium.

Gastropoda.-Actaonina, Amberleya, Cerithium, *Ceritella, 
*Cryptænia, Cylindrites, Dicroloma (= Alaria), *Exelissa, Littorina, Monodonta, Nerita, Neritopsis, Patella, Pseudomelania, *Purpurina, Solarium, Scalaria, *Trochotoma, Turritella.

Cephalopoda._* Egoceras, *Amaltheus, *Arietites, ${ }^{*}$ Coloceras, *Dactylioceras, * Deroceras, Harpoceras, ${ }^{*}$ Haugia, *Hildoceras, *Grammoceras, *Liparoceras, Lytoceras, Holcostephanus, *Ophioceras, * Oxynoticeras, *Paltopleuroceras, *Phylloceras, *Psiloceras, ${ }^{*}$ Schlotheimia, Belemnites.

Pisces.-Acrodus, *Dapedius, *Eugnathus, Hybodus, Lepidotus, *Leptolepis, *Pholidophorus.

Reptilia.- * Dimorphodon (a Pterodactyle), *Scelidosaurus (a Dinosaur), *Steneosaurus and *Pelagosaurus (Crocodiles), *Pliosaurus, Ichthyosaurus, Plesiosaurus, and Eretmosaurus (the last three, however, are represented in the Rhætic bone beds).

\section{THE LIAS OR LOWER JURASSIC SERIES}

\section{A. The British Lias}

Subdivisions.-This series has on the whole a very uniform lithological aspect throughout England. It consists almost everywhere of four successive sets of strata, and might with good reason be divided into four stages instead of the three which are usually adopted in England, for such a subdivision is not inconsistent with the range of the fossils, and is actually in use on the Continent (see table below). Thus (1) its lowest beds are more or less calcareous, and consist generally of thin-bedded limestones and shaly clays; (2) above these comes a thick mass of dark-grey clays; (3) these are succeeded by sandy clays and sandy limestone (marlstone); (4) while at the top are thin limestones and marly clays.

A further subdivision of the Lias into zones has resulted from a careful study of the distribution of its fossils. These zones are each characterised by one or more species of Ammonites, and though some of them are more or less local, and cannot be traced all across England, they can be grouped into nine principal zones which are so traceable. The following table shows the divisions in general use, the principal zones, and the continental divisions:-

Lithology.

Upper $\left\{\begin{array}{l}\text { Clays and } \\ \text { Lias } \\ \text { thin limestones }\end{array}\left\{\begin{array}{l}\text { Grammoceras aalense } \\ \text { Dumortieria radians } \\ \text { Lillia Lilli } \\ \text { Grammoceras striatulum } \\ \text { Dactylioceras commune } \\ \text { Harpoceras serpentinum }\end{array}\right.\right.$
Cont. Equiv.

Toarcian. 
Lithology.

Yones.
Middle (Marlstones and ( Paltoplcuroceras spinatum
Lias ? sandy clays
Lower $\left\{\begin{array}{c}\text { Clays } \\ \begin{array}{c}\text { Limestones } \\ \text { and elays }\end{array}\end{array}\right.$
\{ Amaltheus inargaritatus
Agoccras capricornus
Deroceras armatum
Uptonia Jamesoni
Oxymoticeras oxynotum
f Coroniccras Bueklandi
$\{$ Psiloceras planorbis
$\left\{\begin{array}{l}\text { Chamnouthian. } \\ \text { Sinenurian. } \\ \text { Hettangian. }\end{array}\right.$

Cont. Equiv.

With respect to the Upper Lias there has been much discussion and difference of opinion as to the horizon at which the line should be drawn between the Lower and Middle Jurassic Series. Where the two series are fully developed, as in the south-west of England, there is often a considerable thickness of sand between the Lias clays and the limestones of the Inferior Oolite, and as the sands were clearly passage-beds, some have included them in the Upper Lias, and others have grouped them with the Inferior Oolite.

The recent zonal work of Mr. S. S. Buckman has made it clear that the sands are not always on the same zonal horizon, but may be of any age from the Lilli to the aalense zone. It is also clear that they pass laterally into Upper Lias clays, and that they are as a whole more closely connected with the Lias than with the overlying Inferior Oolite. Moreover, in Yorkshire there is a distinct stratigraphical break between the two series, and it occurs at the base of the "Dogger" sandstone which overlies the zone of Grammoceras aalense. Hence it is convenient to place the divisional line at the summit of the zone of Gram. aalense, and to consider that of Lioceras opalinum as forming the base of the Middle Series.

By adopting this line we are in agreement with the Committee who drew up the scheme of the International Geological map of Europe, and in England it includes all the sands in the Lias except about 5 feet at the top of them near Bridport. In some localities several zones are condensed into a limestone bed of a few feet or even inches in thickness, and this happens sometimes with the lowest zones and sometimes with the highest.

\section{Fossils of the Lower Lics}

Actinozoa. Montlivaltia rugosa, Heterastrea Tomesi.

Echinoderma. Pentacrinus briareus, Isocrinus hasaltiformis, Cidaris Edwardsi.

Brachiopoda. Spiriferina Walcotti, Rhynchouella variabilis, R. rimosa, Waldheimia (Cincta) numismalis.

Lancellibranchia. Pteria (Oxytoma) cygnipes, Cardinia Listeri, Gryphrea arcuata (= incurva), Hipjopodiun ponderosum, Lima (l'lagiostoma) gigantea, Pseudomonotis decussata, Ostrea liassica. 
Gastropoda. Pleurotomaria anglica, Cryptænia expansa, Amberleya elegans.

Cephalopoda. The following Ammonites cliaracterise zones or sub-zones in ascending order : Psiloceras planorbe, Schlotheimia augulata, Coroniceras Bucklandi, Arnioceras scmicostatum, Arietites Turneri, Asteroceras obtusum, Oxynoticeras oxyuotun, Echioceras raricostatum,
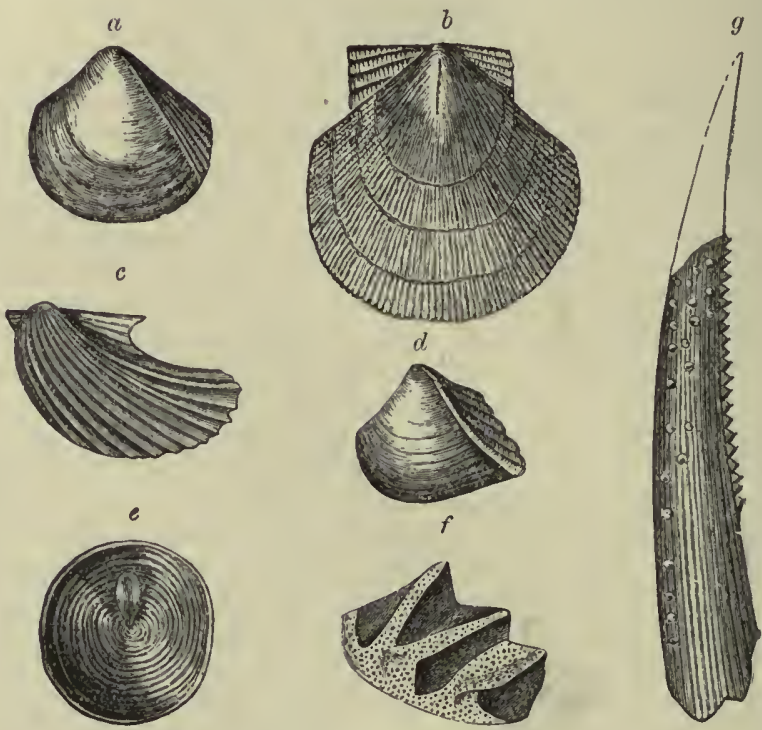

Fig. 125.-CROUP GF RHATIC FOSSILS.

a. Protocardium rhæticum,

$b$. Pecten valoniensis.

c. Pteria contorta. d. Myophoria postera.

e. Orbiculoidea Townshendi.

f. Ceratcdus parvus.

g. Nemacanthus monilifer.

Deroccras armatum, Uptonia Jamesoni, Rliacoceras ibex, Agoceras capricornus, Nautilus striatus, Belemnites acutus, B. elongatus, B. clavatus.

Pisces. Dapedius punctatus, Hybodus reticulatus, Acrodus Anningæ.

Reptilia. Ichthyosaurus communis, Plesiosaurus dolichodeirus.

\section{Fossils of the Middle Lias}

Echinoderma. Ophioderma Egertoni, O. Milleri.

Brachiopoda. Rhynchonella tetrahedra, R. acuta, Terebratula punctata, Waldheimia (Aulacothyris) resupinata, Waldheiniia (Zeilleria) cornuta. 

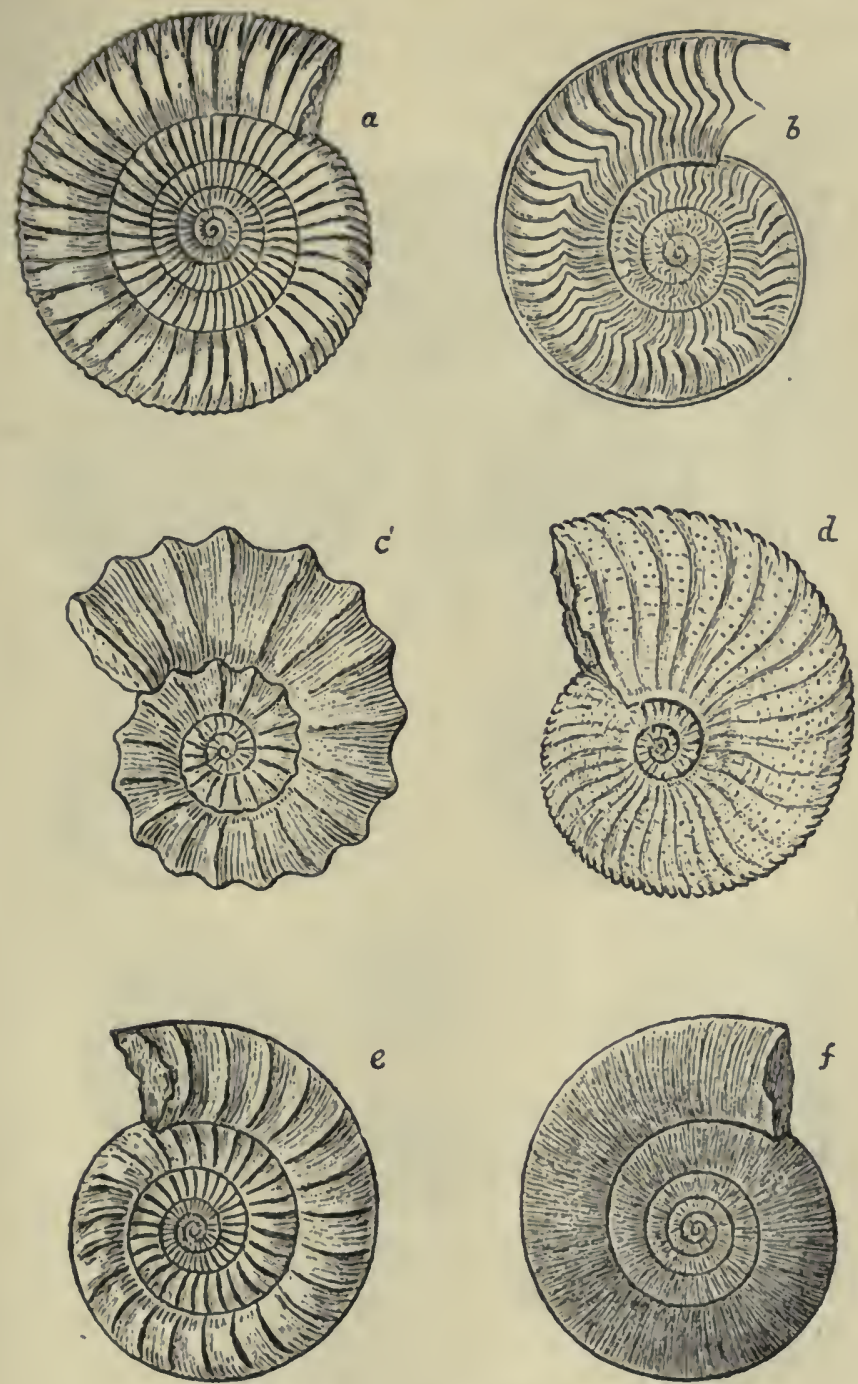

Fig. 120,-LIAsSIC AyMoNITES.
a. Dactylioceras coumune (b).
b. Harpoceras serpentinum (b)
c. Egoceras eapricornus (\$).

d. Amaltheus margaritatus (b).

e. Coronicerss Bucklandi ( $(t)$.

f. Psiloceras planorbe ( $(t)$. 
Lamellibranchia. Pteria (Oxytoma) inæquivalvis, Protocardia truncatum, Gresslya intermedia, Lima punctata, Modiola scalprum.

Gastropoda. Trochus lineatus.

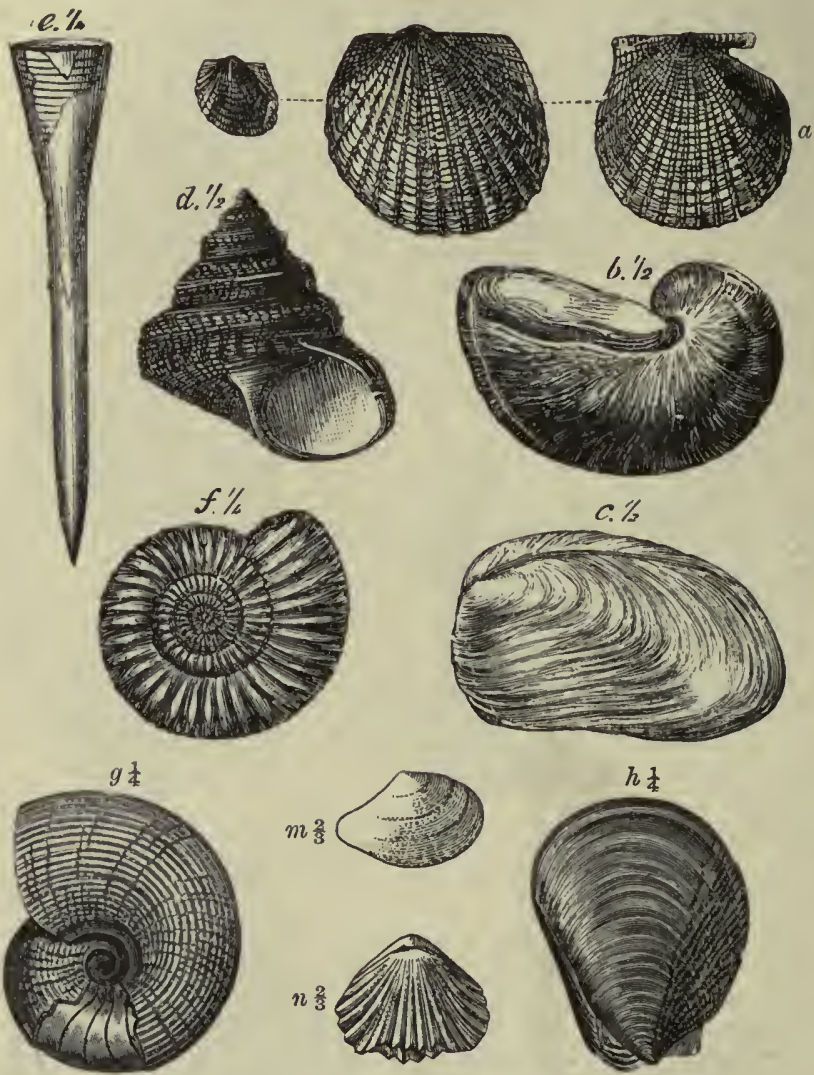

Fig. 127.-GROUP OF LIASSIC FOSSILS.

a. Pseudomonotis decussata.

b. Gryphrea arcuata.

c. Hippopodium ponderosum.

d. Pleurotomaria anglica.

e. Belemnites elongatus. f. Dactylioceras communis.

g. Nautilus striatus.

h. Lima gigantea.

$m$. Leda ovum.

$n$. Rhynchonella tetrahedra.

Cephalopoda. Amaltheus margaritatus, Paltopleuroceras spinatum, Lieptilia. $\begin{gathered}\text { Lytoceras fimbriatum } \\ \text { Pliosaurus propinquus. }\end{gathered}$ 


\section{Fossils of the Upper Lias}

Bchinoderma. Pentacrinus jurensis.

Brachiopoda. Rhynchonella jurensis, Waldheimia (Cincta) Lycetti, Discini reflexa, Cadomclla Moorci. งตาใ Lamellibranchia. Inoceramus dubins, Gresslya donaciformis, Leda ovum, Pecten pumilus, Posidonomya Bronni.

Gastropoda. Trochus lineatus.
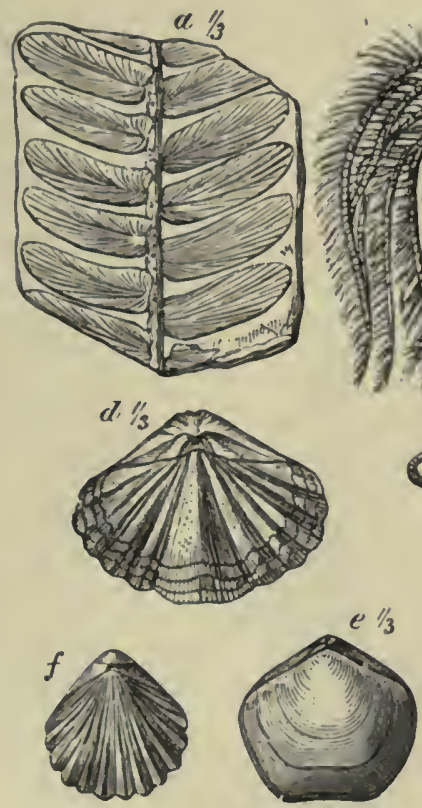

Fig. 12S. - GROUP OF LIASSIC FossIL.

a. Otopteris obtusa.

$b$. Pentacrinus briarens.

c. Ophioderma Egertoni. d. Spiriferina Wricotti.

e. Waidheimia numismalis.

f. Rhynchonella rimosa.

Ccphalopod. Harpoceras serpentinum, Harp. aalense, Harp. striatulum, Daetylioeeras commune, Hildoceras bifrons, Dumortieria radians, Belemnites abbreviatus, B. Voltzii.

Pisces.

Reptilia.

Lepidotus elvensis (=gigas), Leptolepis concentricus. Ichthyosaurus acutirostris, Steneosaurus Chapmanni.

Stratigraphy.-The Lias occupies the coast of Dorset from Lyme Regis to Bridport harbour, it stretches inland to Ilminster, 
Petherton, and Yeovil, and thence passes northward to the Mendip Hills, where all the divisions become very thin. North of Bristol
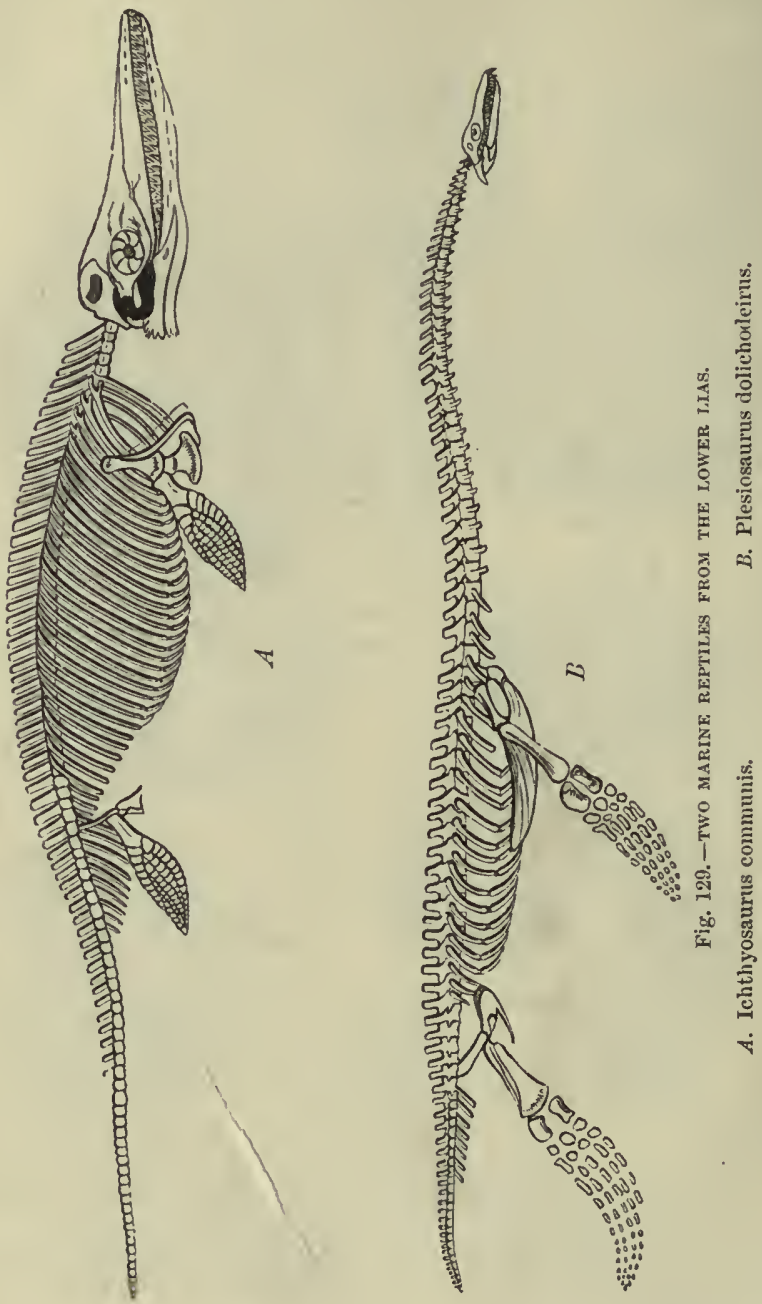

it thickens again and forms a broad tract running through the counties of Gloucester, Warwick; Northampton, Leicester, Lincoln, 
and York. Another fine coast eection is exposed in the cliffs of the Yorkshire coast between Redcar and Whitby.

Outlying tracts of Lias occur in Staffordshire, at Needwood Forest and north of Abbots Bromley; in Shropshire, between Wem and Andlem, and in Cumberland, near Carlisle, proving that the formation originally extended far to the north-west of its main line of ontcrop. There is little doubt, indeed, that the Lias was once coextensive with the Trias, bnt there is no indication that it ever extended very far beyond the limits of the Keuper marls.

In Ireland Liassic rocks crop out in certain places from beneath the Cretaceons rocks of Antrim, and in Scotland remnants of Lias occur above the Trias on the west coast and on the east coast of Sutherland.

With regard to the eastward subterranean extension of the Lias in England, it is known that its upper beds, as they pass beneath the higher members of the Jurassic System, thin very rapidly. Thus in a boring at Burford, in Oxfordshire, the Middle and Upper Lias are together less than 30 feet thick; the Lower Lias is there about 620 feet thick, and the Rhretic is 10 or 12 feet; but between that place and Richmond the Lias has wholly disappeared, allowing rocks of the Middle Jurassic Series to rest directly on rocks which are either of Triassic or of Old Red Sandstone age. It would appear, therefore, that between Richmond and the Malvern Hills the width of ground now occupied by the Lias is less than 100 miles. No trace of Lias has been found in any of the deep borings that have been made in the eastern comnties. Northward it may underlic part of Cambridgeshire, but it thins out beneath Suftolk, a boring at Culford, near Bury St. Edmunds, having proved Cretaceous Beds to rest directly on the Palrozoic rocks.

The chief zonal and provincial features of the British Lias may be indicated under the head of fom provincial areas: (1) the south-west province, including Dorset, Somerset, Gloucester, and Glamorgan; (2) The Midland Counties from Oxfordshire to the Humber ; (3) Yorkshire ; (4) Cumberland, Ireland, and Scotland.

\section{The South-West Province}

An excellent section of the whole Liassic Series is exhibited in the cliffs of the sonth coast of Dorset, from Lyme Regis on the west to Bridport on the east (see Fig. 130), and this may be regarded as the typical section of the English Jias, though some of the zones in the Lower Lias are not so fully developed as they are in the Midlands. 


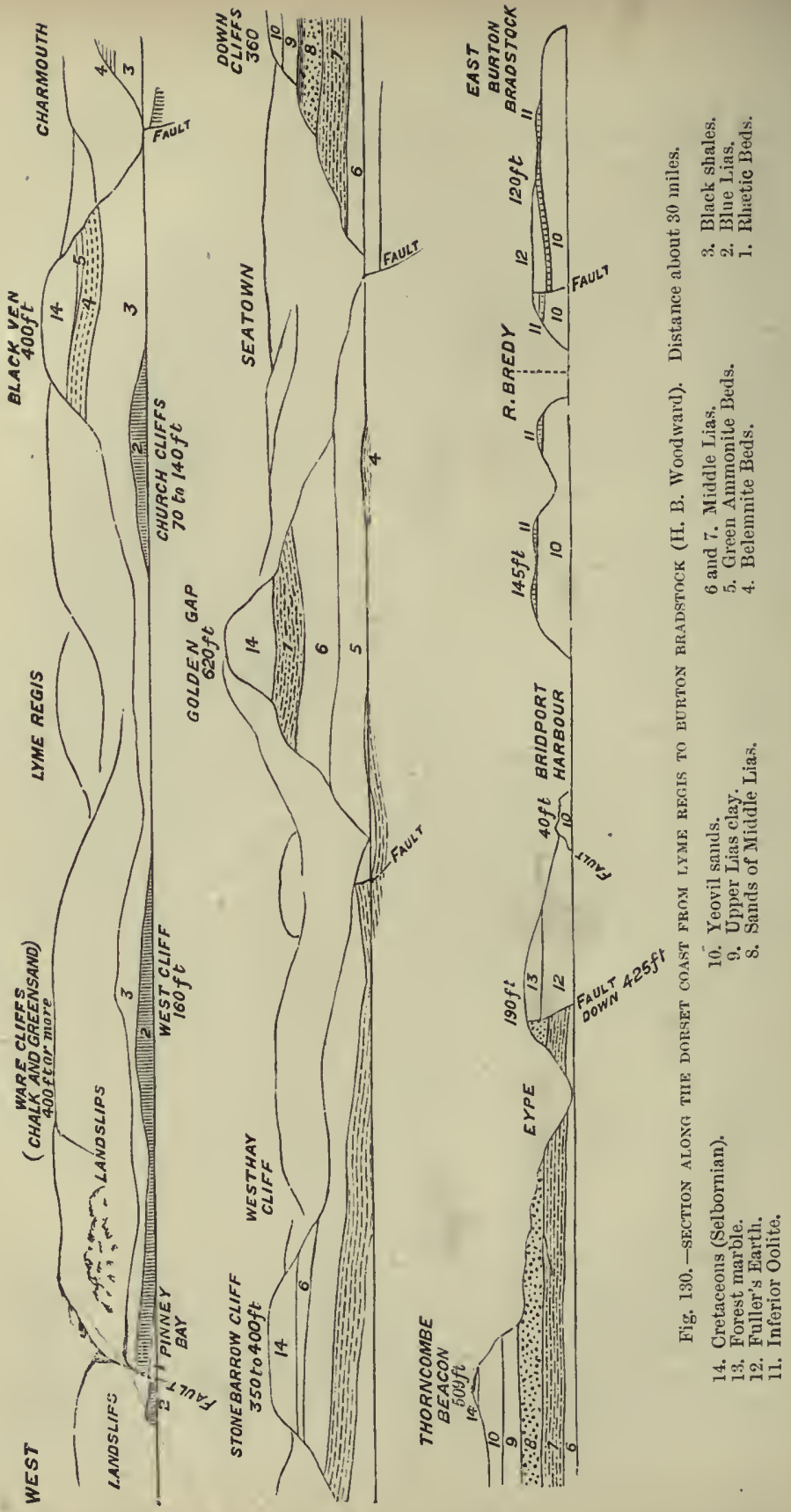


Lower Lias.-The succession of beds which constitute the Lower Lias at Lyme Regis is as follows in descending order :-2

Green Ammonite $\left\{\begin{array}{l}\text { Bluish }- \text { grey marly clays with Iihacoceras } \\ \text { Ledscombei } \\ \text { Bluish-grey marly clays with Platypleuroceras } \\ \text { latacosta }\end{array}\right\} 105$ Belemnite Beds f Pale-grey marls with some marly limestones;

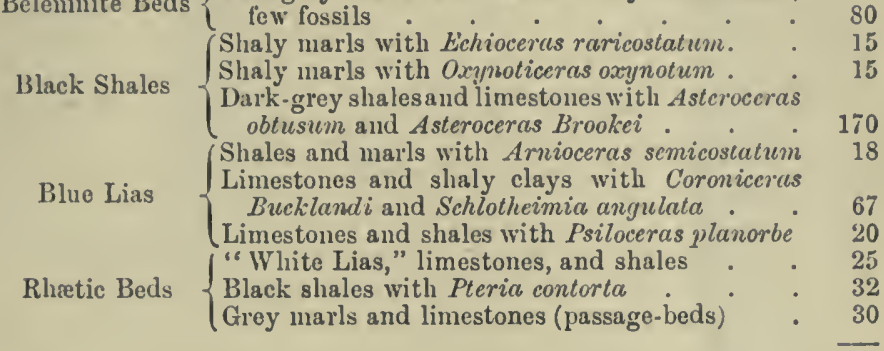

The Rhretic Beds are exposed to the west of Lyme Regis at Charton Bay and Culverhole (see Fig. 131). Throughout Dorset and Somerset there are a set of passage-beds between the Keuper marls and the Rhretic Beds, and these have recently been called the Sully Beds by Mr. L. Richardson. ${ }^{3}$ The base of the Pteria contorta zone is marked by a layer of calcareous grit full of the bones and coprolites of fish and small reptiles; this is also of general occurrence, and is known as "the bone bed." In the White Lias or Upper Rhatic Ostrea liassica and Modiola minima are the commonest fossils.

The succession of zones and sub-zones is normal up to that of Ech. raricostatus, but above that the typical Ammonites are rare. The Belemnite Beds are supposed to represent the armatum, Jamesoni, and ibex zones, but the two latter species of Ammonites do not occur. The succeeding beds may be regarded as the equivalent of the zone of Ayoceras capricomus, and its sub-zone of Aig. Henleyi.

In Somerset the beds forming the Lower Lias are similar to those of the Dorset coast, but the higher zones are seldom exposed. Near Watchet on the Bristol Channel there is a good section of Rhrtic Beds (Black Shales and White Lias, 46 feet) and of Lower Lias for about 150 feet, including the planorbe, angulatum, Bucklandi, and semicostatum zones.

The limestones of these lower zones have been quarried at many places from Ilminster eastward, and are upwards of 200 feet thick, 

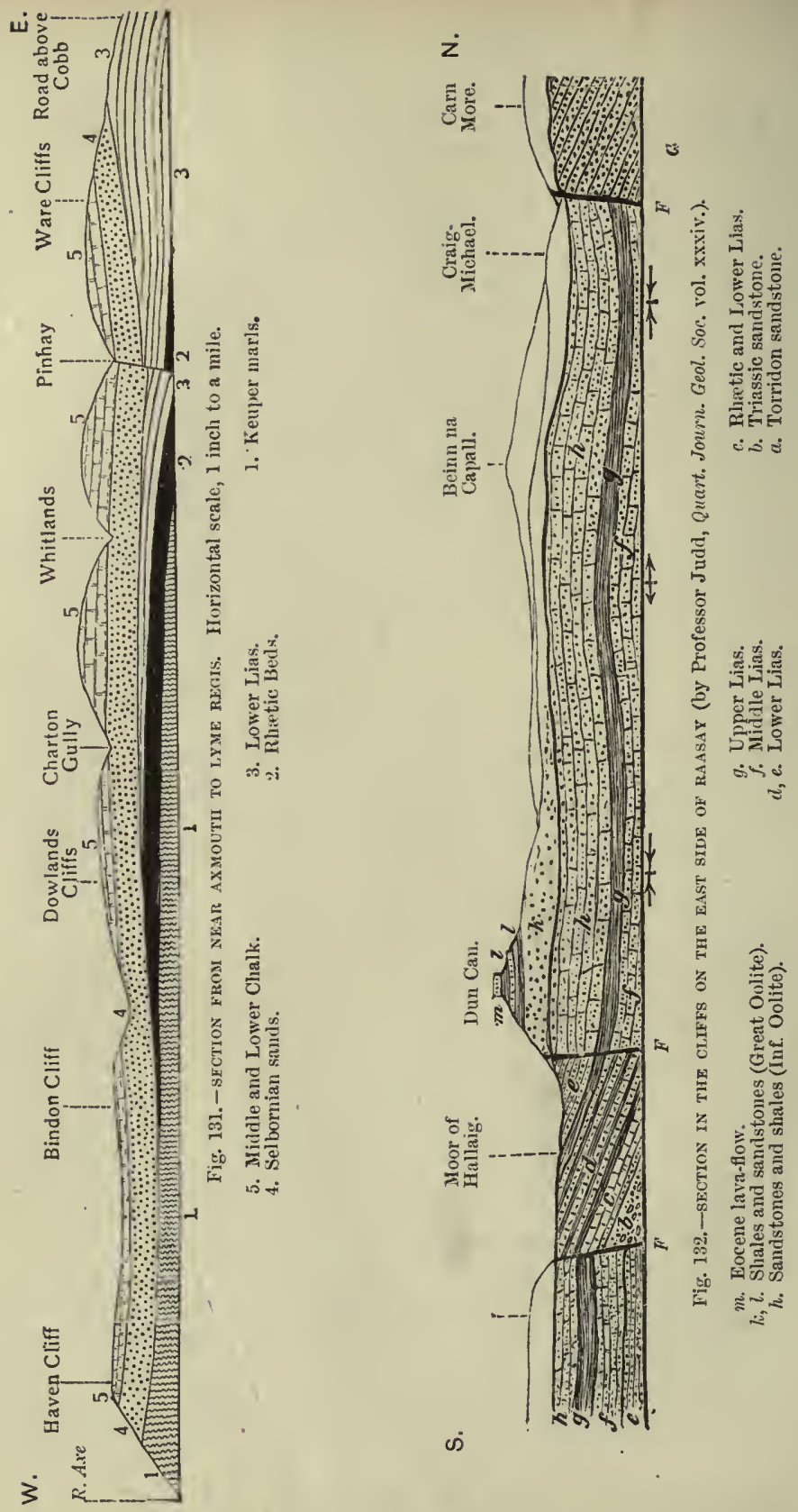
alout half of this belonging to the planorbe zone and the rest to those of Schlotheimia angulata and Coroniceras Bucklandi. 'The quarries at Queen Camel and Street have yielded many fine specimens of Ichthyosaurus, Plesiosaurus, fish, and other fossils, and at the base are shaly limestones which contain remains of insects and Decapod Crustacea (E'ryon).

Evidence that the higher zones persist is found in the occurrence of the Ammonites semicostatus, obtusus, and oxynotus, but it is donbtful if the Lower Lias in Somerset is more than 400 feet thick.

Nortlwards, lowever, there is a rapid thinning, so that at Shepton Mallet the same four zones have a thickness of only 33 feet, overlain by 36 feet of clays and limestones referable to the obtusum and oxynotum zones. Round the Mendip Hills there are only irregular patches of limestone and clay to represent the whole of the Lower Lias. To the north of the Mendips, however, it soon regains its normal aspect and thickness.

Westward, in Soutl Wales, there are fine exposures of the lower beds in the cliffs between Penarth and Dumaven Castle. At Penarth there is a normal sequence of Rhretic Beds with a thickness of about 40 feet, and above them are the usual limestones and shales for 135 feet, but when followed westward they exhibit a remarkable lithological change.

The Rhrtic Beds first pass into a massive oolite, and finally, near Bridgend and Pyle, into pale-green and yellow sandstones with a medial band of green marls, shales, and limestones, the whole being from 40 to 50 feet thick. The shales and limestones. of the overlying Lias pass westward into massive pale-coloured marly limestones which overlap the Rhrtic sandstones so as to. rest, witl a conglomerate base, on the Carboniferous limestone at Sutton and Brocastle near Bridgend. In these beds are corals of the genera Astrocrenia, Montlivaltia, and Thecosmilia, together with Pseulomonotis fallax and Ostrea liassica. Ammonites are scarce, but the higher beds contain Schlotheimia angulata, Arietites Bucklandi, and Arnioceras semicostatum.

Middle Lias.-On the Dorset coast this division is exposed in the cliffs between Charmouth and Bridport, and presents the following succession :-

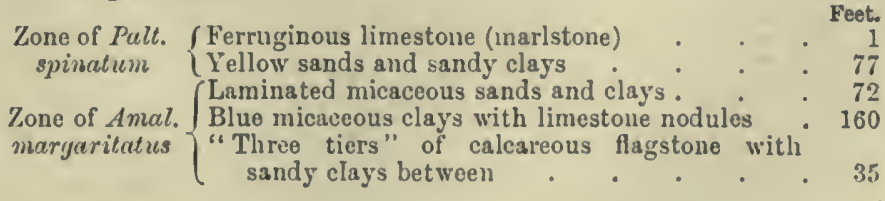


The blue clays contain Amaltheus margaritatus, Belemnites elongatus, Plicatula spinosa, etc., and at their summit is a bed of calcareous sandstone known as the Starfish Bed, from its having yielded two species of Ophioderma. The Marlstone is here very thin.

When followed northward into Somerset the whole group becomes thinner, its thickness near Glastonbury being little over 200 feet, but still having a bed of Marlstone rock at the summit, from 1 to 2 feet thick. Round the Mendip Hills the Middle Lias becomes very attenuated, and is represented sometimes by a few feet of marly slıale, and sometimes by conglomerate resting directly on Carboniferous limestone; in other places it is overlapped by the Inferior Oolite.

Towards Bath the normal suceession is again found, but with a thickuess of only 50 or 60 feet. Northwards through Gloncestershire the beds thicken considerably, till near Stinchcombe the Marlstone is 15 feet, and the underlying sands and clays are about 150. The Marlstone here forms a conspicuous rock-bed which is often quarried. It contains Paltopl. spinatum, Belemnites paxillosus, Rhynch. tetrahedra, Pecten aquivalvis, and other fossils.

Upper Lias.-In Somerset and Dorset this stage may be described as consisting of three unequal portions (1) the Junction Bed, (2) the Upper Lias clays, (3) the Upper Lias sands. The first is a bed of pale-grey argillaceous limestone ( $1 \frac{1}{2}$ to $2 \frac{1}{2}$ feet thick), which is welded to the top of the Marlstone and contains in successive layers the characteristic species of three zones, viz.Harpoceras falciferum, Hildoceras bifrons, and Harpoceras striatulum. The clays or shales are about 70 feet thick and contain but few fossils, but species of Dumortieria have been found in them. They pass up into fine yellow sands containing large burrstones or lumps of calcareous sandstone. Of such sand there is nearly 200 feet, but inost of it yields no fossils; between 40 and 50 feet from the top a band contains Dumortieria radians and $D$. Moorei, and then come 30 feet with species of the Harpoceras aalensis type, and these are succeeded by about 5 feet of sand with opalinoid forms, so that the passage from one stage to the other here takes place very near the top of the sands. ${ }^{4}$

In Somerset, near Yeovil, there is a similar succession, but the base is formed by a band of shaly clay containing many small Brachiopoda such as Leptcena Moorei, L. Bouchardi, and Zellania liassica. This is overlain by a bed of limestone with Harp. falciferum, and reinains of fish, crustacea, and insects. Above are blue clays succeeded by sands with Ammonites of the radians type (Dumortieria), and in the higher part of these sands a 
lenticular mass of oolitic freestone is developed with a local thickness of 80 feet and containing Dum. Moorei; this is known as the Ham Hill Stone.

Northward the sands thin out entirely, so that near Bath the radians zone is represented entirely by clay, but is underlain by sands which Mr. Buckman assigns to a sub-zone intermediate between that of Lilli and that of radians, and at its base there is a condensed limestone representing lower zones.

In Gloncestershire there is another change and a different succession: (1) clays representing the falciferum and bifrons zones; (2) the Cotteswold sands, which include the zones of Harp. Lilli and 11 . variabilis; and finally a Cephalopoda Bed representing all the higher zones in successive layers of limestone. The clays vary from 50 to 130 feet, the sands are on the average 150 feet, and the limestone varies from 2 to 8 feet.

\section{The Midland Counties}

Rhætic Beds.-These form a narrow but continuous band between the Keuper marls and the dark shaly clays of the Lias, but they are rarely exposed in Worcester. In Warwickshire there are exposures of the White Lias at Knowle (near Solihull) and at Harbury, Rugby, Southam, and Eatington, and a good section has been described at Wigston, near Leicester, where the following succession was seen :-

2. Blue slales with two thin beds of limestone and sandstone $\quad 22$

1. Black shales containing Schizodus cloacinus, Protocardium rhaticum, Pteria contorka, and fish teeth . . . . . . 18

A similar succession is found in Rutland and Lincolnshire.

The Lower Lias is seldom well exposed in Oxfordshire or Warwickshire, but a boring has proved its thickness to be 450 feet, and fairly good sections are found near Harbury and Fenny Compton, where all the zones are seen except those of oxynotuni and armatum.

In the counties of Leicester, Rutland, and Lincoln the Lower Lias is both more accessible and more fully developed, and the following succession of beds has been described :-

\footnotetext{
Lower Lias, $\begin{aligned} & \text { Blue clays with septaria (Agoceras capricornus). } \\ & \text { Blue clays with thin limestones and septaria (Iihacoceras } \\ & \text { ibex and Uptonia Jamesoni). } \\ & \text { Sandy clays and sands, occasionally indurated into a stone } \\ & \text { (Deroceras armatum). } \\ & \text { Blue clays with small septaria (Oxynoticeras oxynotum). }\end{aligned}$
} 


\section{Ferruginous limestones with Amioceras semicostatum. A \\ $\{$ Dark-blue pyritous clays (Schlotheimia anyulatc). \\ Limestone and shales (Psiloceras planorbe).}

The zones of planorbe, angulata, and Bucklandi present the same features as elsewhere, and have a combined thickness of about 200 feet. They are succeeded by several beds of hard ferruginous limestone with interbedded shales (the semicostatum zone), which thicken northward till they are 27 feet thick at Scunthorpe and Frodinghan, where they are worked for ironstone.

The upper part (B) of the Lower Lias is abont 470 feet thick in the Vale of Belvoir, and a boring at Grantham showed the Lower Lias as a whole to be about 700 feet thick. The obtusum zone is thin or absent, but clays with oxynotum and raricostatum occur, and are about 90 feet thick. Northwards, however, the thickness diminishes. The lower zones (A) maintain their thickness, but the zones of oxynotum, armatum, and Jamesoni are represented by clays from 100 to 140 feet thick, surmounted by a bed of ironstone about 4 feet thick, which is known as the "Pecten Bed," from the abundance of several species of Pecten. This bed contains a mixture of Lower and Middle Lias species, and is by some regarded as the base of the Middle Lias, but its Ammonites are urmatum, Henleyi, and striatum, while the clays above it contain AEgocercus capricornus throughout and not Amaltheus margaritatus. These clays are about 70 feet thick, and consequently the total thickness of Lower Lias in this district is from 400 to 440 feet.

Middle Lias.-In the counties of Oxford and Warwick the Middle Lias is about 150 feet thick, and Mr. H. B. Woodward 5 remarks that "the Marlstone Rock-bed is perhaps nowhere better developed than in the country around Banbury. It covers an extensive area to the north-west, forning a plateau that rises gradually from about 500 feet at Banbury to the escarpnient of Edge Hill, 710 feet high, and this area is intersected by several deep valleys." The Marlstone consists of more or less ferruginous and sandy limestone, which varies from 12 to 25 feet in thickness. The outer parts are always brown from the oxidation of the iron, but the centres of large blocks are generally grey. The commonest fossils are Terebratula punctate and Rhynchonella tetrahedra, which often occur in clusters.

Upper Lias.-This division is well developed in Northamptonshire, where it has been studied and described by Mr. B. Thompson. ${ }^{6}$ He divided it into 8 zones, but the highest of these forms a passage into the overlying series, and would perhaps be better included in the latter; his 7 th zone is a nodule bed at the 
base of this, so that the restricted Upper Lias would consist of the following :-

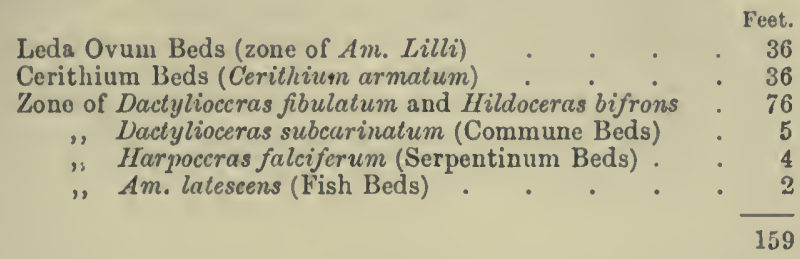

A similar set of beds is found in Rutland, but in Lincolnshire the highest beds seem to have suffered erosion before the deposition of the overlying sandstone, and the highest remaining part of the Lias belongs to the bifrons zone. On the other hand the serpentinum Beds thicken northward to about 40 feet, and the total thickness of the stage at Lincoln is about 100 feet.

\section{Yorkshire}

In the south of Yorkshire, from Brough to Kirby Underdale and Howsham, the Lias is similar in all respects to that of North Lincoln, but as soon as the valley of the Derwent is crossed a change begins to be manifest, both the Middle and Upper Lias swelling out till they again attain a development equal to that of South Lincolnshire. From Howsham the outcrop curves round by Thirsk and Northallerton to the coast between Redcar and Whitby, which exhibits an excellent section of the whole formation except the zone of Psiloceras planorbe.

The following is a résumé of the coast section :- 7

Upper, 330 feet

Middle, 140 feet

Blea Wyke sands with Harpoceras aalensis, 50 feet.

Blue shales, with Harp. striatulum and $H$. variabilis, 70 feet.

"Alum shales" with Dactylioccras commune, Hildoceras bifrons, and Leda ovum, 90 feet.

Blue shales with calcareous doggers and layers of jet in the lower part. Harpoceras serpentinum, Belemnites tubularis, Inoccramus dubius, 90 feet.

Grey shales with Dactylioceras annulatum and Belemnites cylindricus, 30 feet.

(Ironstone (Cleveland main seam) and shales below, zone of Amaltheus spinatus, $30-50$ feet.

Ironstone (lower seam) or Pecten Bed, with beds of marly sandstone below ; contains Amaltheus margaritalus and Pceten lavis, about 100 feet. 


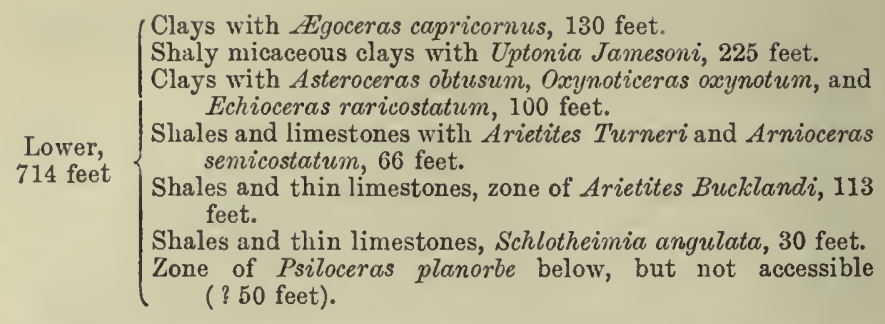

Mr. R. H. Rastall has shown ${ }^{8}$ that it is only at Blea Wyke on the coast that a complete passage from Lias to Inferior Oolite is seen. At other localities the fermginous sands which form the base of the latter (see p. 420) rest upon an eroded surface of the Lias and usually upon some part of the commune zone. In many places currents have cut channels in the Lias, and these are often filled with sand at the base of which is a layer of pebbles and phosphatic nodules.

\section{Cumberland, Ireland, and Scotland}

These areas may well be considered together, for there can be no doubt that the Liassic Series was originally continuous across the seas which now divide them.

Lower Lias.-It is interesting to find an outlier of Lias in the Carlisle basin, because it confirms the view that the northern Pennine Hills were not then in existence, but were part of the Triassic plain which became first the floor of the Keuper Lake and subsequently that of the Liassic Sea. It is believed, however, that the Rhrtic Beds are absent, and that the zone of Psil. planorbe rests unconformably on the Keuper marls. The whole country is covered with glacial drift, so that there are few exposures, but a boring near Great Orton passed through 210 feet of dark shales with bands of limestone in the lower part.

In Ireland the Lower Lias is fonnd at intervals along the coast of Antrim between the Trias and the Cretaceous rocks, but is frequently cut out by the overstep of the latter. The zone of Pteria contorta is well developed, the lower part consisting of grey shales and sandstones with fish remains, the middle of black shales with the usual fossils, and the upper of grey shales with layers of oolitic limestone, and the whole is about 80 feet thick. These beds are succeeded by Lower Lias with the same lithological facies as in England, but the series is cut off in or above the zone of Echioceras semicostatum.

The mapping of the Isle of Arran by the Geological Survey 
revealed the fact that a similar succession of beds existed there in Tertiary times, for in the conglomerate which fills a large volcanic orifice or neck (see p. 368) fragments and tabular masses of Rhretic and Liassic limestones were discovered, the fossils found in them leaving no donbt about the age of the rocks.

Farther north on the coast of Argyleshire and in the islands of Mull, Skye, and Raasay, a nearly complete succession of Liassic deposits is found, which differ in several respects from those of England. They were fully described by Professor Judd in 1878,9 from whose accomnt the following is mainly taken.

The Rhretic zone is thin and seems to be represented by about 8 feet of calcareous sandstones, limestones, and shales. The overlying beds are very hard bluish-grey limestones, alternating with calcareous grits and conglomeratic sandstones. The commonest fossil is Ostrea irregularis (a variety of 0 . liassica), but corals Thecosmilia Martini and Isastrea Murchisoni also occur, together with Cardinia concinna and spines of Acrosalenia. Ammonites are not found, but the beds may be regarded as equivalent to the planorbe and angulatum zones; their thickness is about 200 feet, and they are well seen at Applecross and on the opposite coast of Raasay (see Fig. 132).

The succeeding zone of Arietites Bucklandi is well developed, and consists of shelly limestones and shales crowded with fossils of the same species which are common in England; its thickness is 250 feet. Above are dark micaceous shales containing Arn. semicostatum, Asteroceras Brooki, and Belemnites acutus, 150 feet. The separate existence of the oxynotum zone is not determined, the fossils of this zone only occurring at Tobermory in Mull, where they are mingled with others that belong to higher horizons.

The higher part of the Lower Lias consists of sandy and micaceous shales called the Pabba shales by Professor Judd. At the base of these there are some beds in which Deroceras armatum occurs, but the greater portion of the group represents the zones Jamesoni and capricornus; these shales contain Uptonia Jamesoni, Platypleuroceras brevispina, Deroceras Davcei, Modiola scalprum, and Grypheca cymbium, and are about 250 feet thick.

In the north-east of Scotland beds of Liassic age occur in the reefs below Dunrobin Castle on the Sutherland coast. Here the basement beds consist of coarse sandstones and conglomerates, containing fragments of the cherty rock mentioned on p. 369 . These beds are succeeded by a remarkable set of estuarine deposits, consisting of sandstones and shales with thin layers of clay and coal, the whole attaining a thickness of between 400 and 500 feet; 110 fossils have been found except in the uppermost beds, 
where a few dwarfed Gryphea and Cardinia prove the occasional presence of salt water. As these beds are overlain by clays with Oxynoticeras oxynotum, they must be the estuarine equivalents of the planorbe and Bucklandi zones.

The overlying marine beds exhibit the following succession :- 10

3. Dark-blue micaceous clays with septaria, Belcmnites acutus, Platypleuroceras brevispina, Uptonia Jamesoni, Hippopodium ponderosum, and Gryphoea cymbium

2. Micaceous sandstones and clays with Gryphoea obliquata, Pecten ocquivalvis, and Belemnites acutus . . . . .

1. Blue clays and impure limestones with Oxynoticeras oxynotum, Arnioceras caprotinus, Bel. acutus, Cardinia hybrida, Lima pectinoides, and Gryphaca obliqua.

Feet.

Middle Lias.-There can be little doubt that deposits of this age succeeded the Lower Lias over the whole region of the Irish Sea and the Hebridean Sea, but the only remnants of them which have escaped destruction are in some of the Western Isles. Here they are shallow-water deposits, consisting chiefly of sandstones. They are well exposed in Scalpa and Raasay, where grey calcareous sandstones, with some beds of calcareous shale, have a thickness of 200 feet. They contain such characteristic fossils as Amaltheus margaritatus, Paltopleuroceras spinatum, Belemnites acutus, and Rhynch. tetrahedra. In Mull they are represented by soft greenish sandstones with few fossils.

In Sutherland no such beds are exposed in situ, but their former existence is proved by the occurrence of boulders of calcareous sandstone, like those of the western coast, in the boulder-clays of Moray and Elgin. These boulders enclose such fossils as Belemnites paxillosus, Modiola scalprum, Pteria incequivalvis, and Panopea elongata, and others which occur in the Scalpa sandstones of the west coast. It is quite possible indeed that such rocks (of Marlstone age) may still exist in situ beneath the vast masses of glacial clay which mantle the surface of Elginshire.

Upper Lias.-This also is only found in the Western Isles, where it presents the usual shaly facies with much pyrites and jet; the lower portion yields Harpoceras serpentinum and Dumortieria radians, and the upper beds Dactylioceras commune, with Belemnites Voltzi and Posidonomya Bronni. Sections are generally obscured by slips and grass, but the thickness averages from 75 to 80 feet.

\section{B. Continental Liassic Strata}

Jurassic rocks form a nearly complete ring round the great Cretaceous basin of the north of France, the continuity of their 
outcrop being interrupted only in the north-east where they are concealed beneath the overstepping Cretaceous deposits between the Ardenmes and the Boulonnais. It is unnecessary to burden the student with details of the local variations exhibited by the Lias in this and other parts of France, and it will suffice to give a brief account of its developnient on the eastern borders of the country in Alsace, Lorraine, and the Jura district, while the very different facies found in Provence will be referred to under the head of the Alpine region.

French geologists divide the Liassic Series into five stages, making the Rhretic one of them, but as it has really only the value of a zone it is better to include it in the overlying stage (Hettangian). If this is done we have the following stages in descending order :-

4. Toarcian. Zones of jurense, commune, and falciferum.

3. Charmouthian. Zones of spinatum, margaritatus, capricornus, and armatum.

2. Sinemurian. Zones of raricostatum, obtusum, Turneri, and Bucklandi.

1. Hettangian. Zones of angulata, planorbe, and Pteria contorta.

The French also include the zone of Lioceras opalinum in their Toarcian, but the Germans do not, and in England its equivalent is usually regarded as the base of the Inferior Oolite.

How far the Hettangian zones extend under the Paris basin is unknown, but probably all the higher stages are continuous beneath that basin and the English Channel, passing into their equivalents in the south of England. The Upper Lias has recently been reached by a deep boring at Rouen.

Hettangian.-This takes its name from Hettange in the south of Luxenburg, in which district this part of the series has an unusual thickness because it consists largely of estuarine beds, as below :-

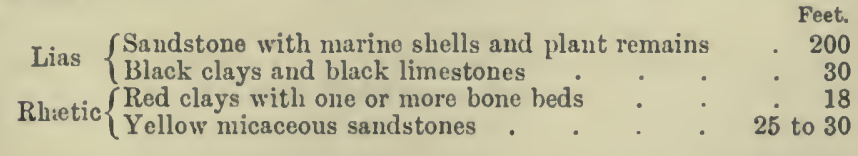

The black beds contain few fossils, but must represent the zone of Psiloceras planorbe, and the Hettange sandstone that of Schlotheimia angulata. In Alsace and Lorraine the Rhætic presents a similar facies and maintains a thickness of from 30 to 40 feet, but both the zones of Psiloceras planorbe and Schlotheimia angulata are so thin as to be scarcely recognisable.

Sinemurian.-In the north-east of France this stage consists principally of grey limestones in regular beds full of Gryphrea arcuata, 
so that they are known as the "calcaire à Gryphées," but they also contain Coroniceras Bucklandi, Arnioceras bisulcatum, and other fossils. These beds are from 100 to 130 feet thick, and are overlain by some 80 feet of unfossiliferous shales which occupy the place of the higher zones.

Charmouthian.-In Alsace and Lorraine this stage consists mainly of calcareous marls with ferruginous nodules, surmounted by hard limestones with Paltopleuroceras spinatum, the whole being about 200 feet thick. To the north-west in Luxemburg and the Ardennes the lower beds become sandy, and near Mezières the succession, according to Professor Gosselet, is as follows :-

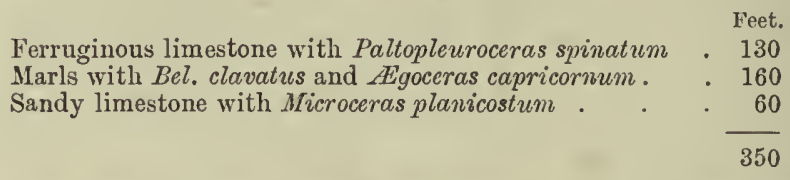

Toarcian.-In Alsace and Lorraine this group consists in the lower part of bituminous shales full of Posidonomya Bronni, but also yielding Hildoceras bifrons and Harpoceras falciferum; the higher beds are marls with Lytoceras jurense from 10 to 12 feet thick, while the shales below vary from 30 to 160 feet.

The details of the Toarcian have been more fully worked out in Normandy by Messrs. Brasil and Buckman, ${ }^{11}$ who have recognised all the Dorset sub-zones, though the whole stage is only 32 feet thick and consists entirely of shales and clays. It is directly overlain by limestone with Lioceras opalinum.

In the district of the Jura Mountains the Liassic Series is not so fully developed as the higher parts of the Jurassic System, but the whole of it is exposed in different places and has the following composition :-

Toarcian. Marls and Posidonia shales . . . . . . 150 Charmouthian. Marls with Belemnites . . . . . 100 Sinemurian. Blue clays and Gryphoea limestones . . $\quad 60$ Hettangian. Limestones . . . . . . . . . 6 Rhotic. Sandstones, marls, and limestones with a bone bed at the 50

\section{Germany}

The Lias is chiefly exposed in the south of Germany, its outcrop extending in a long strip from the foot of the Black Forest on the west through Swabia and then curving northwards by Nuremburg to Bamburg, Coburg, and Baireuth. In this area it has been 
studied by Oppel, Quenstedt (1850-88), Struckmann (1881), Waagen (1864), and Stuber (1893). Its thickness is here comparatively small, but most of the zones established in England and France have been recognised, and the general sucoession of beds is as follows:-

Upper, fGrey marls with Lytoeeras jurense.

30 feet (Bituminous shales with Posidonomya.

Middle, (Limestone with Paltopleuroceras spinatum.

100 feet Hard nuarls witl Deroceras Davei. Clays with Rhacoceras ibex and Uptonia Jamesoni.

120 to $\left\{\begin{array}{l}\text { Llays with Asteroceras obtusum and Oxynoticeras oxynotum. } \\ \text { Bituminous shales and Pcntaerinus Beds. } \\ \text { Limestones with Gryphoer and Coroniccras Bucklandi. } \\ \text { Sandstones with Schlotheimia angulata. } \\ \text { Limestones with Psiloceras planorbe. } \\ \text { Rhretic sandstones and shales (20 to } 40 \text { feet). }\end{array}\right.$

In Northern Germany there are irregular outcrops of Lias along a tract extending from the Teutoburger Wald eastward through the south to Hanover and Brunswick; the component beds being very similar to those of Swabia and Franconia. Moreover, it appears to extend northward and north-eastward below the great plains of Hanover and Prussia, for its existence has been proved by a boring at Hermsdorf near Berlin and by another at Kammin in Pomerania.

\section{Sweden}

The Lias recurs on the north side of the Baltic in Scania, where the Rhrtic position has an estuarine facies, consisting of a series of sandstones, shales, and clays with beds of lignitic coal and of clay ironstone; in fact a "carboniferous" facies, with a thickness of about 300 feet. Plant remains are very abundant, including species of Camptopteris, Lepidopteris, Thaumatopteris, Nilssonia, and Dictyophyllum with many Cycads and some coniferous trees. Overlying these deposits are shales and sandstones with marine fossils, as well as plant remains, and these appear to represent the zones of Psiloceras planorbe and Coroniceras Bucklandi. In Central Scania to the north-east the Rhretic Beds have disappeared, and the marine shales are represented by massive sandstones which lie directly on the Archran rocks and are made up of detritus derived from the latter.

\section{The Alpine Region}

In this region and in the south of Europe generally the Lias assumes a completely different facies from that which prevails in Germany and the north of France, for it passes into a series of 
massive limestones of which the thickness often amounts to several thousand feet. They indicate, in fact, a continuance of the pelagic conditions which prevailed in the same region during Triassic times.

In the Western Alps Haug has described the Lias as forming three distinct bands round the core of the Cottian Alps; the innermost consisting of crystalline limestones, often brecciated and containing large blocks of the older rocks, but frequently fossiliferous and characterised by a fauna of Corals, Lamellibranchs, and Gastropoda ; the second formed of compact limestones (never crystalline), characterised by the abundance of Ammonites; and thirdly, bedded limestones with Crinoids and many Brachiopoda. He regards these three facies as replacive, one outside the other, probably formed in zones of increasing depth of water.

The outer belt is well developed round Digne and in the Basses Alpes, where all the French divisions can be recognised, and the several thicknesses are as below given:

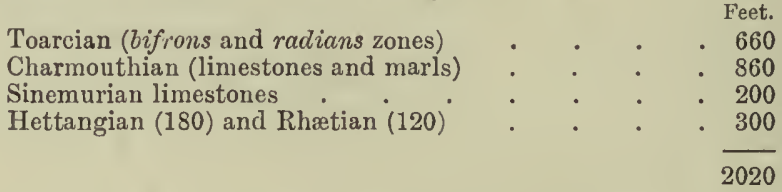

In the Tyrol and Eastern Alps the Lias is represented by red and variegated limestones and spotted marls (Fleckenmergel), all of which abound in Cephalopoda. The Rhætic zone of Pteria contorta here forms a link between the Trias and the Lias, being in some localities a part of the great Dachstein limestone, but the typical Kössen Beds are marls containing $P$. contorta and black limestones with many Brachiopoda. In the Adneth and Salzburg district the highest member of the Rhrtic is a limestone full of the coral Calamophyllia (=Lithodendron), and this is overlain by variegated limestones containing many Ammonites of the genera Arietites, Phylloceras, and Lytoceras which must represent the Hettangian and Sinemurian stages.

In the Bavarian Alps the Middle Lias is represented by variegated marls with Amaltheus margaritatus, but elsewhere it does not seem to be speciaily distinguishable in the mass of limestones and marls.

The Upper Lias (or Toarcian) is more clearly definable, its equivalent in the Bavarian Alps being red and grey limestones with Hildoceras bifrons, and in the Tatra district near Vienna by fleckenmergel with the same fossil.

Farther east the whole formation passes into a littoral facies of 
sandstones, marls, and shales, with occasional coal-seams, and this exteuds through Hungary to the Carpathian Mountains. It is evident, therefore, that the sea shallowed rapidly to the east as well as to the north.

Beyond this in Russia no representative of the Lias is known, the lowest beds of the Jurassic System in Central Russia belonging to the Cornbrash or the Callovian. Liassic deposits, however, are found again to the south-east in Servia, Croatia, and Dalmatia, and again in the Caucasus, while littoral beds with plant remains (possibly of Liassic age) have been found at Isjoun on the Donetz in South Russia.

\section{MIDDLE JURASSIC SERIES}

\section{A. Stages ANd ZoNes}

This series has always been divided into tro stages; a lower, known as the Inferior Oolite Group in England and the Bajocian in France, and an upper, best called the Bath Oolite Group and in France the Bathonian. The precise limits of these stages have, however, been matters of dispute, and are not yet settled. As stated on p. 387 , the most convenient horizon at which to draw the line between the Lower and the Middle Series seems to be at the base of the opalinum zone. This places the base of the Inferior Oolite at an horizon which can easily be followed all across England, and it is at this horizon also that the base of the series is taken on the International Geological map of Europe.

With respect to the upper limit of the Bajocian or Inferior Oolite, there is a growing prevalence of opinion that it must be placed at a lower horizon than formerly, and that the zone of Parkinsonia Parkinsoni should be included in the Bathonian; for the fauna of this zone is more closely related to that of the beds above it than to that below, and in England there is a marked stratigraphical break at its base. Again, there can be no doubt that whatever line is taken as the plane of separation between the two stages, this line should be diawn at the same horizon both in England and France, so that the stages should be completely correlative.

During the last ten years much detailed zonal work has been done both in England and France, and a large number of zones and sub-zones (or hemerre) have been proposed. For those who make a special study of this series such work is of much value, but for the general student it will suffice to indicate the broader zones which can be traced over wide areas in England, France, and Germany. These are given in the following table:- 


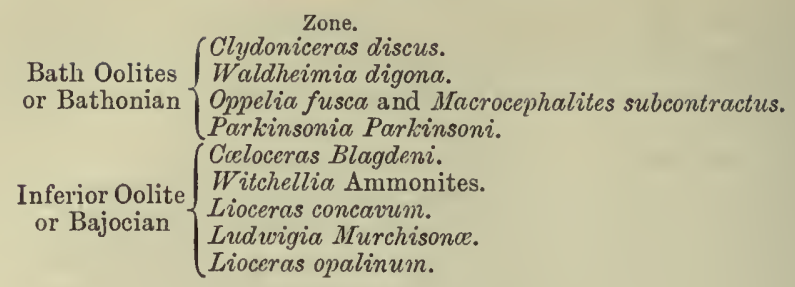

B. Life of the Period

Marine Fauna. - The fauna of the Middle Jurassic rocks is closely related generically to that of the Lias, but differs principally in the relative abundance of Corals, Echinoderms, and Gastropods. This, however, is sufficiently explained by the fact that these limestones were evidently formed in clear water, and sometimes in the neighbourhood of coral reefs. Brachiopoda, too, are individually very abundant, though the number of species is not greater than in the Lias, and the genera are the same, except that Cadomella and Spiriferina are absent. The following are the more important genera which now appear, and those to which an asterisk is prefixed did not survive the Jurassic period :-

Porifera.

Anthozoa.

Echinoderma.

Brachiopoda.

Lamellibranchia. Corbis, Corbicella, Cyprina, Isocardia, *Pachyrisma, Gastropoda.

Cephalopoda.

Pisces.

Reptilia.

Corynella, Craticularia, Holcospongia, Lymnorella, Peronidella, Verrucocælia.

Phyllocænia (=Adelastrea), *Anabacia, Cryptocœnia, Cyathophora, Stylina.

Apiocrinus, ${ }^{*}$ Clypeus, Collyrites, Nucleolites, Hemicidaris, Holectypus, *Hyboclypeus, Pedina, Pygaster, Pygurus, Stomechinus.

Terebratulina. Pteroperna, Sowerbya, Spondylus, ${ }^{*}$ Trichites.

Brachytrema, Bulla, *Cirrus, Dephinula, Fissurella, Nerinæa, Pileolus, *Purpuroidea, Rissoina.

The Ammonite genera Cosmoceras, ${ }^{*}$ Haploceras, Lioceras, Ludwigia, Macrocephalites, Oppelia, *Parkinsonia, Perisphinctes, Sonninia, and Sphæroceras.

Aspidorhynchus, Microdon, Strophodus, Ganodus, Ischyodus.

Streptospondylus, Teleosaurus.

The following are lists of the fossils which may be regarded as specially characteristic of the groups indicated :-

\section{Fossits of the Bajocian (Inferior Oolite)}

Actinozoa.

Echinoderma.
Anabacia hemispherica, Thecosmilia gregaria.

Stomechinus germinans, Pygaster semisulcatus, Hybo-

clypeus agariciformis. 
Brachiopoda. Rhynchonella (Acanthothyris) spinosa, Terebratula fimbria, T. maxillata, 'T. perovalis, T. Phillipsii, Waldheimia (Aulacothyris) carinata.

Lamellibranchia. Astarte elegans, $\Lambda$. excavata, Ceromya bajocisna, Gresslya abducta, Gryphæa sublobata, Pholadomya fidicula, Trigonia costata, T. denticulata, T. hemispherica.

Gastropoda. Cirrus nodosus, Nerinæa cingenda, Pleurotomaria ornata, Pseudomelania procera, Bourguetia striata.
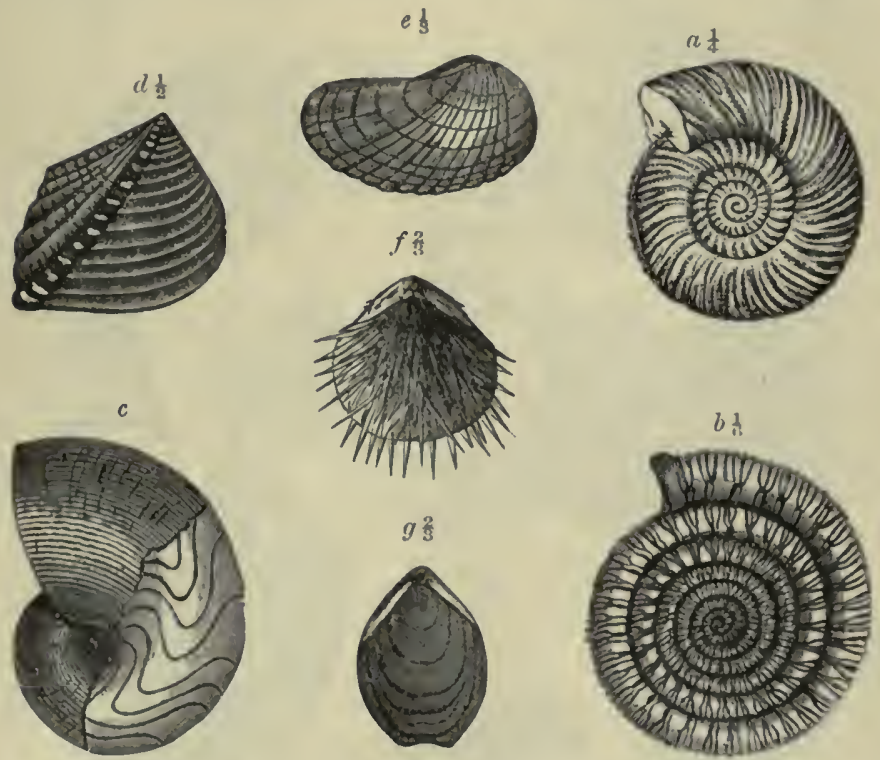

'Fig. 133.—RROUP OF INFERIOR OOLITE FOSILS.

a. Parkinsonia Parkinsoni.

b. Stepheoceras Humphriesianum.

c. Nautilus sinuatus.

g. Terebratula perovalis. d. Trigonia costata.

e. Pholadomya fidicula.

f. Rhynchoneiia spinosa.

Cephalopoda. (For Ammonites see ante, p. 410) also Steplieoceras Humphriesianum, Sonninia Sowerbyi, Nautilus truncatus, N. sinuatus.

\section{Fossils of the Great Oolite and Forest Marble}

Actinozoa.

Anabacia complanata, Isastrea explanatula, Apiocrimus Parkinsoni.

Eichinoderma. Acrosalenia hemicidaroides (ranges to Corubrash), Hemicidaris uninor, Clypeus Ploti, Collyrites ringens. 
Brachiopoda. Rhynchonella concinna, K. obsoleta, Terebratula maxillata, T. (Dictyothyris) coarctata, Waldheimia digona.

Lamellibranchia. Pteria (Oxytoma) costata, Lueina bellona, Lima cardiiformis, Grammatodon hirsonensis, Ostrea acuminata, O. Sowerbyi, Pachyrisma grande, Trigonia Goldfussi, T. Moretoni.

Gastropoda. Dicroloma (Alaria) armatum, Amberleya nodosa, Cylindrites acutus, Purpuroidea Morrisi, Nerinæa Voltzi, Patella rugosa, Nerita costulata.

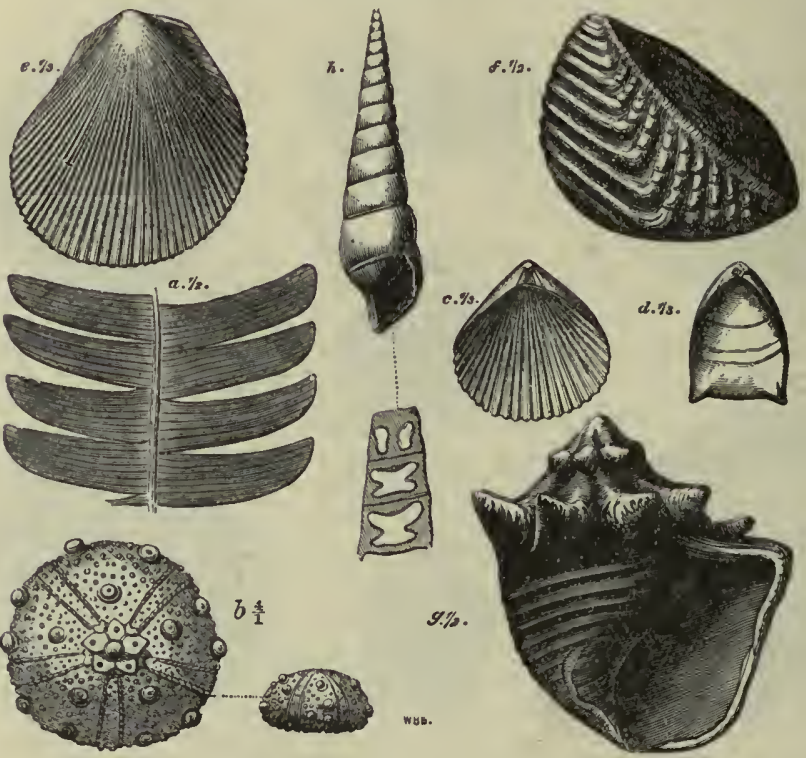

Fig. 134. GROUP OF BATHONIAN FOSSILS.

a. Pterophyllum comptum.

b. Hemicidaris minor.

c. Rhynchonella concinna.

d. Waldheimia digona. e. Lima cardiiformis.

f. Trigonia Goldfussi.

g. Purpuroidea Morrisi.

$h$. Nerinæa Voltzi.

Cephalopoda. Parkinsonia Parkinsoni, Zigzagiceras arbustigerum, Nacrocephalites subcontractum, Oppelia fusca, Nautilus Baberi.

Pisces.

Reptilia.

Strophodus magnus, Pholidophorus minor.

Steneosaurus brevidens, Cimoliosaurus erraticus.

\section{Fossils of the Cornbrash}

Actinozoa. Anabacia complanata.

Echinoderma. Holectypus depressus, Nucleolites clunicularis. 

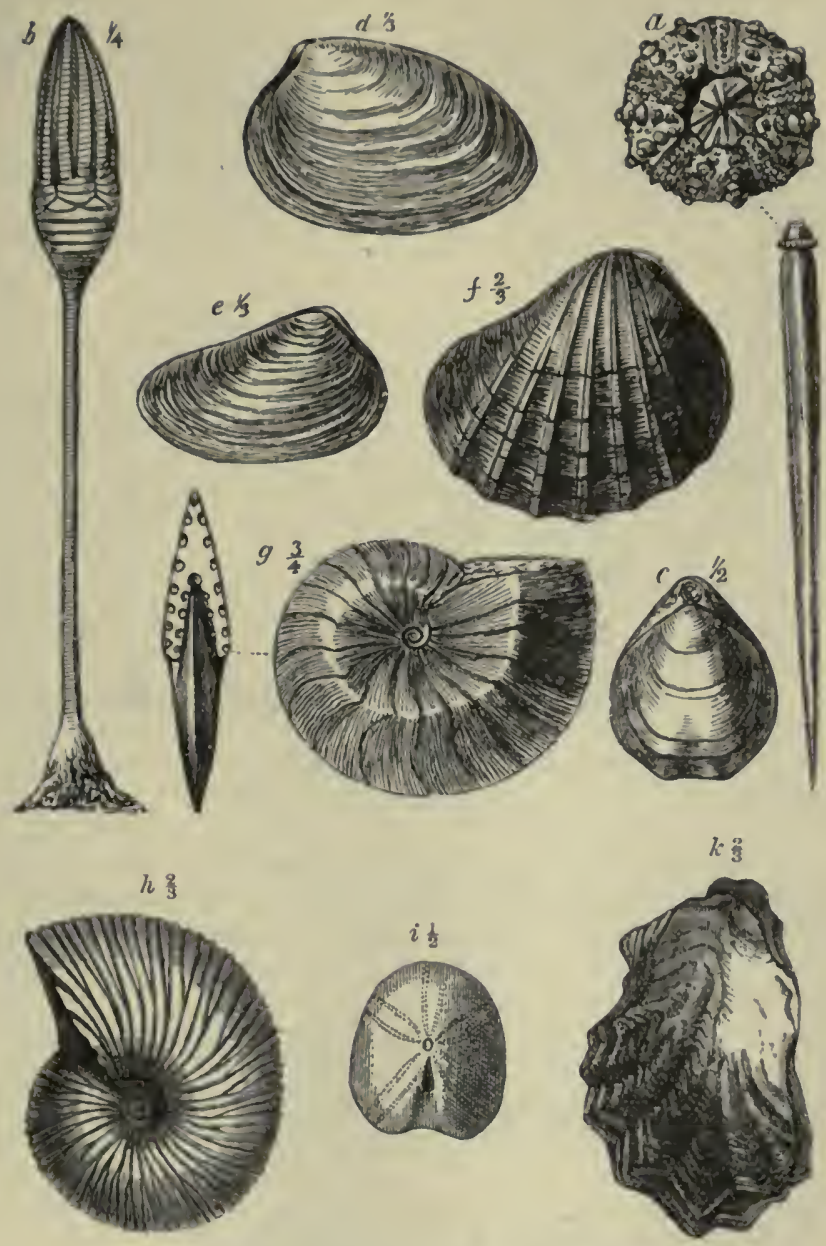

Flg. 135, GROUP OF CORNBRASH FOSSILS (WITH APIOCRINCS FROM THE BRADFORD CLAY).
$a$. Acrosalenla liemlcidaroldes.
f. Pholadomya lyrata.
b. A piocrinus Parklnsonl.
g. Clydoniceras discus.
c. Terebratula intermedia.
h. Macrocephalites macroceplalus.
d. Gresslya pereorina.
e. Pleuromya decurtata.
i. Nucleolites clunicularis.
$k$. Ostrea flabelloides. 
Brachiopoda. Terebratula intermedia, T. Bentleyi, Waldheimia obovata.

Lamellibranchia. Pseudomonotis echinata, Pecten vagans, Lima duplicata, Pleuromya decurtata, Gresslya peregrina, Pholadomya lyrata, Ostrea fiabelloides.

Gastropoda. Pseudomelania vittata.

Cephalopoda. Clydoniceras discus, Macrocephalites macrocephalus.

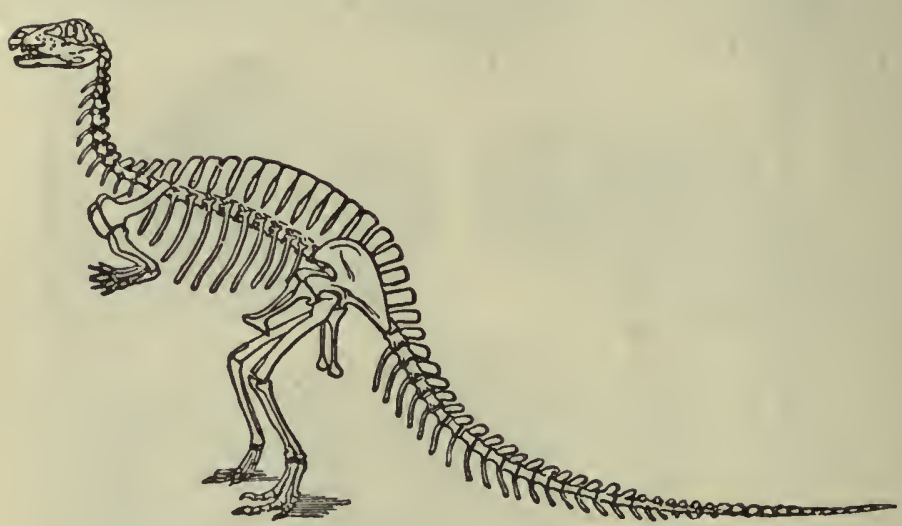

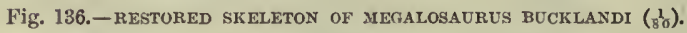
Actual length supposed to be about 30 feet.

Terrestrial and Freshwater Fauna.-The estuarine beds which occur occasionally in these rocks furnish us with some interesting remains of the plants and land animals. The borders
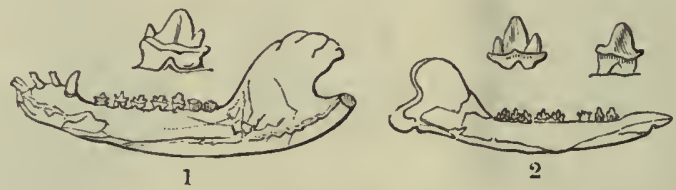

Fig. 137. -JAWS OF (1) PHASCOLOTHERIOM BUCKLANDI AND (2) AMPHITHERIUM BRODERIPI, FROM STONESFIELD.

Natural size, with enlarged views of teeth above.

of the rivers and estuaries must have been clothed with a dense vegetation, ferns of the genera Matonidium, Laccopteris, Coniopteris, Cladophlebis, Todites, Sphenopteris, Tweniopteris; cycads of many genera, Williamsonia, Ctenis, Nilssonia, Anomozamites, Otozamites, etc.; coniferous trees, such as Araucarites, Brachyphyllum, Baiera, 
and Ginkgo. Among this vegetation insects abounded, such as bettles, flies, and dragon-flies.

In the water lived molluses of the genera Cyrena, Anodonta, crocodiles of the Gavial type, and turtles (Protochelys).

On land there were small marsupials, Amphitherium, Amphityins, Amphilestes, and Phascolotherium (Fig. 137), and the Protothere Stereognathus. The liuge Dinosauria, Megalosaurus and Ceteosaurus, were also terrestrial creatures (see Fig. 136).

\section{The Middle Jurassic of Exglaxd}

Geographical Range.-Like the Lias, the Middle Jurassic Series ranges completely across England from Dorset to Yorkshire. It occupies the Dorset coast between Bridport and Weymouth, and runs inland by Yeovil, Sherborne, and Bruton to the Mendips. In Gloucestershire it gives rise to the well-known scenery of the Cotteswolds, and spreads over a considerable width of country. Thence it passes through the counties of Oxford, Nortlampton, Rutland, and Lincoln, forming the long escarpment known as the "cliff" in Lincolnshire, which runs due north from Grantham by Ancaster, Navenby, Lincoln, and Kirton to the Humber.

In Sonth Yorkshire it makes but little show, the beds being thin, but north-west of Malton they thicken, and, sweeping round to the north of Helmsley, form the high ground of the Yorkshire Wolds, which range from west to east and terminate in the cliffs between Whitby and Scarborough.

The component members of this series in England are a variable series of oolites, shelly limestones, ironstones, clays, and sands; none of the strata continuing long of the same thickness, and many of them thinning out altogether within comparatively short distances. The most persistent stratum is that which forms the summit of the series and is known as the Cornbrash. In the south of England, where the most complete succession of purely marine deposits is found, the series has been divided into the following groups and zones:-

\begin{tabular}{|c|c|c|}
\hline \multirow{2}{*}{$\begin{array}{l}\text { Bath Oolites } \\
\text { (Bathonian) }\end{array}$} & \multirow{3}{*}{$\begin{array}{l}\left\{\begin{array}{l}\text { Cornbrash } \\
\text { Forest Marble } \\
\text { Great Oolite } \\
\text { Fuller's Earth } \\
\text { Clypous and Trigonia grits }\end{array}\right. \\
\text { Terebratula Beds } \\
\text { Gryphite and Trigonia grits }\end{array}$} & hei \\
\hline & & Celoceras subcontractum. \\
\hline & & \\
\hline (Bajocian) & $\begin{array}{l}\text { Gryphite and Trigonia grits } \\
\text { Freestones and Pea-grit } \\
\text { Opalinum band }\end{array}$ & $\begin{array}{l}\text { Lioceras concavnem. } \\
\text { Ludwigic Murchisona: } \\
\text { Lioceras opalinum. }\end{array}$ \\
\hline
\end{tabular}

Zones.

Clydoniceras discus.

Celoceras subcontractum.

Parkinsonia Parkinsoni.

Lioceras concavrem.

Lioceras opalinum. 
The stratigraphical variations of this series will be best explained by taking first the Bajocian and following it across England from south to north, and then doing the same for the Bathonian. A tabular correlation will be found on p. 427 .

\section{Inferior Oolite or Bajocian}

Southern Counties.-In Dorset the limestones of this stage are thin, and the lowest zone, that of Lioceras opalinum, is represented partly by sand and sandstone, the beds being about 11 feet thick at Chideock, near Bridport, and 5 feet at Burton Bradstock (see Fig. 130). The overlying zones are brown, ironshot limestones, which at Chideock are about 8 feet thick, but at Burton they are barely 3 feet.12 Farther north, however, near Beaminster, the opalinum zone is about 16 feet and the limestones above about 5 feet, making a total of 21 feet; but the uppermost zonal horizon is not everywhere the same, and the surface of the uppermost bed, whatever it may be, is always eroded, either planed off and coated with oysters or worn into irregular hollows.

Between Yeovil and Sherborne the limestones properly belonging to the Inferior Oolite are again very thin, though well exposed in numerous quarries, and the succession given by Mr. Buckman is :-

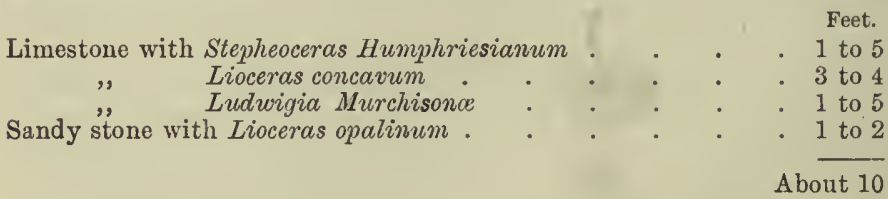

In the Mendip district by Bruton, Doulting, and Frome the Inferior Oolite is entirely absent, having apparently been raised into a broad, low anticline, the upper part of which was eroded and destroyed in the interval between the Bajocian and Bathonian epochs, so that the beds of the latter rest directly and unconformably on those of the Upper Lias or Toarcian.

North of the Mendip ridge the lower beds of the Inferior Oolite come in again with a pisolitic limestone at the base, succeeded by oolitic freestones and ragstones of much greater thickness than in Dorset or Somerset. The following is a generalised table of the succession found in the Bath and Cotteswold areas:-13 
Nimes of Beds.

Zones.

Thickners.

Terebratula Beds and Witchellia Grit

Notgrove freestone

Gryphite Grit

Lower Trigonia Grit

Freestones and Oolitic narl

Pea-grit and brown limestone

Cap of Cephaloporla Bed

Wilchellice.

36 to 55

Lioceras concavum . 20 to 35

Yudurigio Murchisonu: 40 to 160

Lioceras opalinum , 1 to 2

From 100 to 250

The Cephalopoda Bed was described on p. 399 as a condensed representative of several zones and forming a "junction bed" between the Toarcian and Bajocian of the Cotteswold district.

Above it there are generally some beds of brown ferruginous limestone, and then comes the "Pea-grit," a coarse pisolitic limestone, 4 to 20 feet thick, which extends from Dursley to Nottingham Hill near Winchcombe, a distance of about 30 miles.

The freestones are soft pale-coloured oolites in thick beds, and are locally separable into lower and upper freestones by a band of yellowish oolitic marl full of Terebratula fimbria.

The beds which form the zone of Lioceras concavum are locally called "grits," but this is a misnomer as they are really rongl shelly limestones. The Trigonia Grit is characterised by Trig. costata, T. striata, and T. sculpta, and the Gryphite Grit by Gryphoea sublobata. Other common fossils in these beds are Astarte elegans, A. excavata, Ceromya bajociana, and Pholadomya fidicula.

The Notgrove freestone occurs only in the northern part of the Cotteswold area, thickening nortluward from 4 to about 30 feet. It and the overlying beds are grouped together by Mr. Buckman, who regards them as occupying a lower lorizon than the zone of Stepheoceras Humphriesianum, which appears to be absent in the Cotteswolds.

Above the beds containing Terebratula Phillipsi there is a marked plane of erosion, the succeeding "Upper Trigonia Grit," or Parkinsoni zone, cutting across all the beds in several directions, but especially eastwards, till it lies directly on the Lias. In the northern part of the Cotteswold area, between the Vale of Winchcombe and Stow-in-the-Wold, the Inferior Oolite has been flexed into a syncline, while the Vale of Moreton to the east roincides with an anticline, the axes of these flexures running approximately north and south.

These flexures were produced and a plane of erosion cut across them before the deposition of the Bath Oolites, as shown in Fig. 141 which is modified from one drawn by Mr. Buckman.

Midland Counties. - In passing from Gloncestershire into 


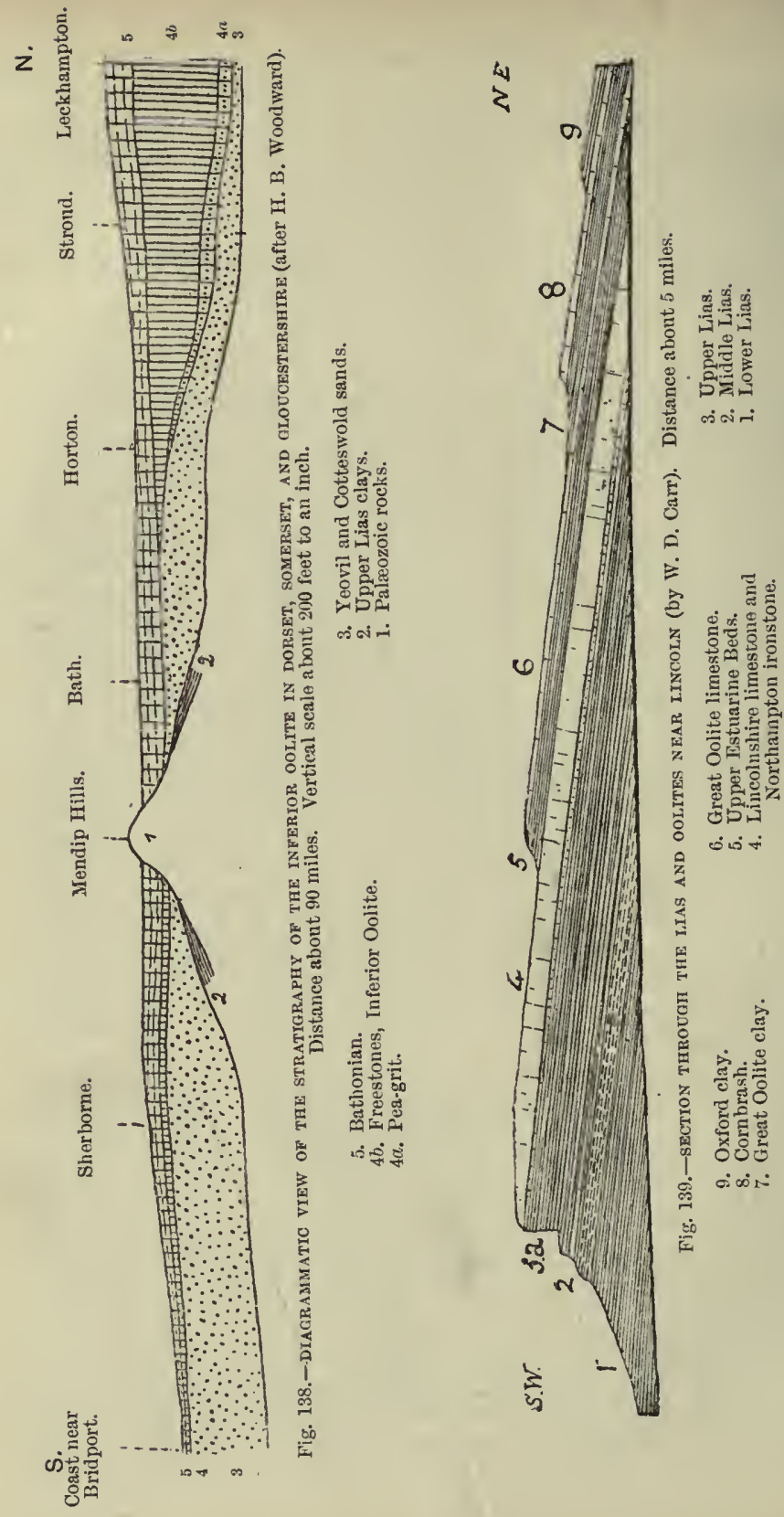


Oxfordshire the Inferior Oolite undergoes a great change. Sonth of Oxford, as above stated, there is no Inferior Oolite, its beds having been destroyed; and near Fawler the base of the Bathonian contains small blocks of the older limestones covered with Plicatula and pierced by lithodomous molluses. These conditions continue to and beyond Charlbury, but north-west of that place near Chipping Norton the Bathonian rests on a representative of the opalinum zone, consisting of a sandy limestone about 6 feet thick in which Lioceras opalinum, Rhynch. cynocephala, and other fossils occur; ınoreover this has a pebbly basement bed resting on the Upper Lias clay.

This sandy limestone may be regarded as the beginning of the Northampton sandstone, which is found again to the eastward at Steeple Ashton and Worton near Deddington, where it consists of calcareous flagstones and sands with ironstone nodules, the beds being 15 or 16 feet thick.

East of the Cherwell valley we enter Northampton; where the whole Inferior Oolite passes into an arenaceous facies with very little limestone of any kind, though with a valuable oolitic ironstone at the base. The lower beds are marine deposits and appear to represent the opalinum and Murchisonce zones, but the higher beds are of estuarine origin. Near Northampton the succession is :-

Feet.

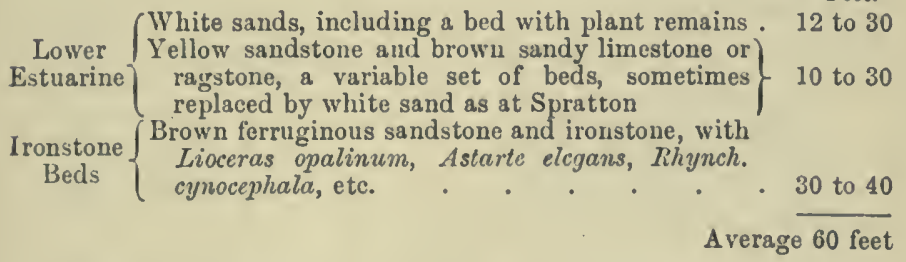

These beds continue to be the sole representatives of the Inferior Oolite till we reach the valley of the Welland, where the thin end of a lenticular mass of limestone appears above the Lower Estuarine Beds and rapidly thickens northward, becoming the important formation known as the Lincolnshire limestone, which in South lines is not less than 150 feet thick.

At its base in South Lincolnshire are some beds of fissile sandy limestone, which form a passage from the Lower Lstuarine Beds; these contain ferus (Laccopteris polypodioides), with Lucina Wrightii, Gervillia acuta, Trigonia compta, Tr. impressa, Astarte elegans, and Malaptera Bentleyi, but no Ammonites. At Collyweston (near Stamford) these beds are 12 feet thick, but they thin northward and are hardly distinguishable at Ancastel. 
The Lincolnshire limestone frequently contains beds in which corals are very abundant, and which have evidently been accllmulated in the neighbourhood of coral reefs. The upper layers, too, invariably exhibit much current bedding, indicating shallow water conditions. Ammonites are rare, but Echinodernis are not uncommon. Gastropods (Natica, Nerincea, Patella, Pleurotomaria, Trochus, Trochotoma) are common. Rhynchonellee and Lamellibranchs of many species are abundant. The fauna has eminently a shallow-water and coral-reef facies. This limestone appears to represent the higher part of the Inferior Oolite of the Cheltenham district from the Lower Trigonia Grit upward, for the Ammonites quoted from it include Coloceras Blagdeni, C. subradiatum, Stepheoceras of. Humphriesianum, and Oppelia Truelli, all characteristic of the higher zones. Mr. Hudleston also considered its Gastropod fauna to indicate the same part of the stage.

In North Lincolnshire the limestone diminishes to about 60 feet, and in South Yorkshire the lower part is represented by shaly limestones and the upper part by oolitic limestones, each set being about 30 feet thick.

Yorkshire. - When they again emerge in North Yorksliire the series has undergone much transformation, and the mass of the Inferior Oolite consists of estuarine sandstones and shales. ${ }^{14}$ Marine beds, however, occur at the top and bottom, and also as a thin zone in the midst of the Estuarine Series, the succession being as follows, and the thicknesses those in the cliff sections:-

5. Scarborough limestone

4. Middle Estuarine Beds

3. Millepore Beds (marine) .

2. Lower Estuarine Beds

1. The "Dogger" sands and sandstone

Feet.

$$
\begin{array}{lr}
. & 20 \text { to } 90 \\
. & 50 \text { to } 100 \\
\therefore \quad & 20 \text { to } 40 \\
& \quad 200 \text { to } 280 \\
\text { Average about } 400
\end{array}
$$

1. Above the Liassic shales are yellow and grey micaceous sands containing Grammoceras aalensis, Lingula Beani, Rhynchonella cynocephala. They are surmounted by a sandy oolitic ironstone, which contains many fossils-Ludwigia Murchisona, Terebratula trilineata, and Nerinoea cingenda; these sands and sandstone may be regarded as the equivalent of the Northampton sands.

2. The Lower Estuarine Series is exposed in the cliffs from Robin Hood's Bay to Huntcliff (see Fig. 140). The shales and oolitic ironstones contain plant remains in some abundance. In the midst of this series is a band of flaggy sandstone and ironstone with marine fossils known as the Eller Beck Bed. It yields Gervillia acuta, Astarte minima, Pholadomya Heraulti, and other fossils. 

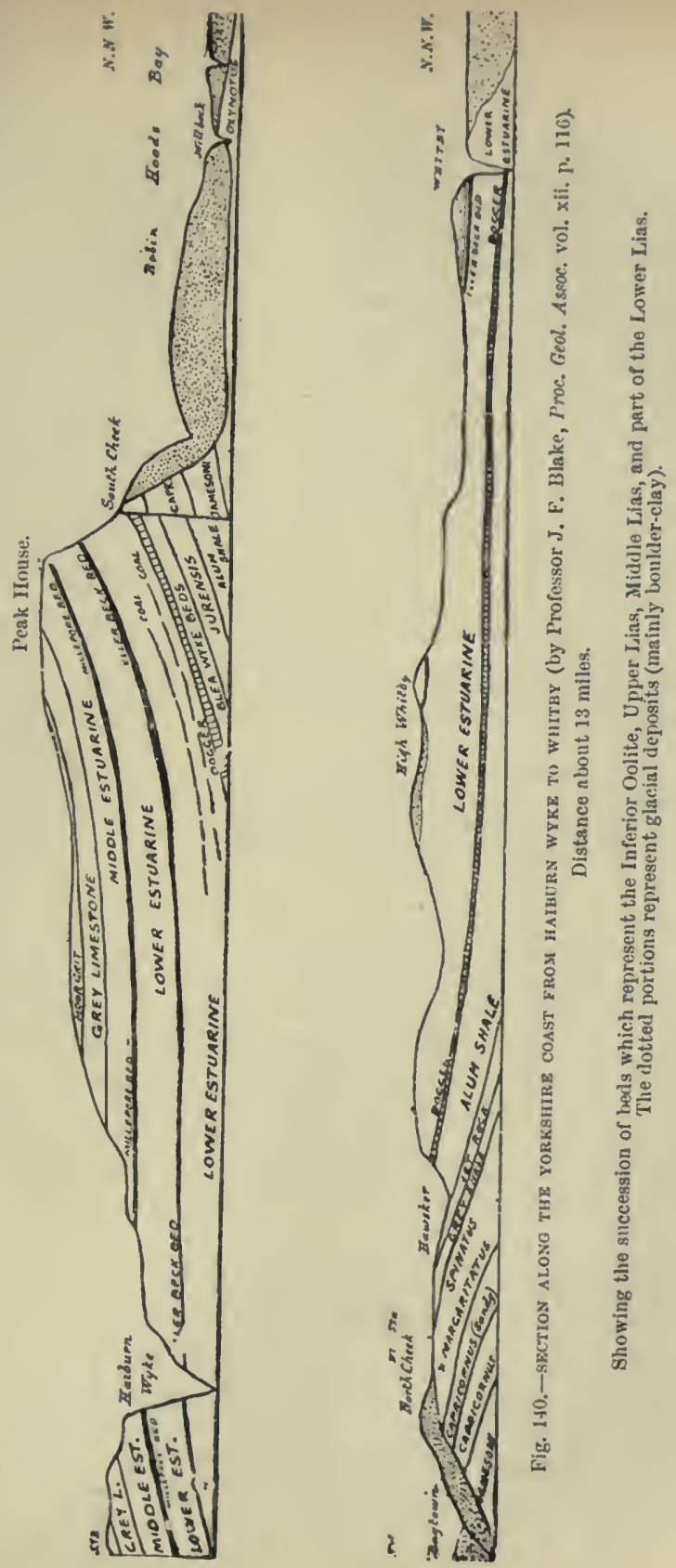
3. The Millepore Beds consist of a hard calcareous sandstone with the Bryozoan Haplocecia straminea, overlain by shales and sandstones containing Trigonia reticosta, Ceromya bajociana, Gervillia lata, Pygaster semisulcatus, and other fossils.

4. The Middle Estuarine Series consists of shales and sandstones, with thin layers of coal varying from 2 to 18 inches in thickness. The "plant bed" of Gristhorpe Bay has yielded fine specimens of ferns (Cladophlebis, Sphenopteris, Toniopteris, etc.), the cycads Nilssonia and Otozamites, and the horsetail Equisetites columnaris.

5. The beds termed the Scarborough limestone are grey, shaly limestones, often ferruginous; they contain Stepheoceras Humphriesianum, Gervillia acuta, Pseudomonotis braamburiensis, etc. They form a lenticular mass, very thin at Gristhorpe, but thickening to the north-west.

\section{The Bath Oolites or Bathonian}

Southern Counties.-In Dorset and Somerset this stage consists of four distinct members, viz. :-

4. The Cornbrash, rubbly limestones .

3. The Forest Marble, flaggy limestones

2. The Fuller's Earth, chiefly marly clays

1. Earthy, oolitic, and shelly limestones

Feet.

\begin{tabular}{rrr} 
& \multicolumn{2}{c}{ Feet. } \\
.$\quad$ & 15 to 25 \\
$\therefore \quad$ & 80 to 130 \\
& 150 to 80 \\
Average about 250
\end{tabular}

No. 1 is the zone of Park. Parkinsoni, and in South Dorset (at Chideock, Burton, Bradstock, and Beaminster) it is only 6 or 7 feet thick. Near Crewkerne, however, it has thickened to 12 or 15 feet, and near Sherborne the beds vary from 20 to 40 feet. Still farther north at Bruton and Doulting massive beds of oolitic freestone come in, thickening toward the Mendips in contrast to the thinning out of the Inferior Oolite. These beds are quarried for building stone at Doulting, where the following sequence is found below the Fuller's Earth :-

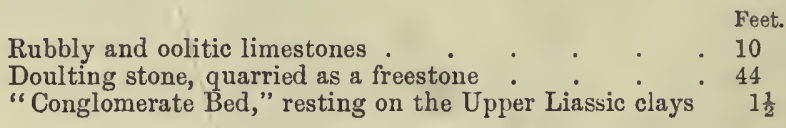

A little farther north in Vallis Vale these beds rest directly on Carboniferous limestone. The basal limestone-conglomerate is correlated by Mr. Buckman with the Upper Trigonia Grit of the Cotteswolds, and the Doulting Beds with the Clypeus Grit. Between them is a break which is filled elsewhere by the "Dundry 


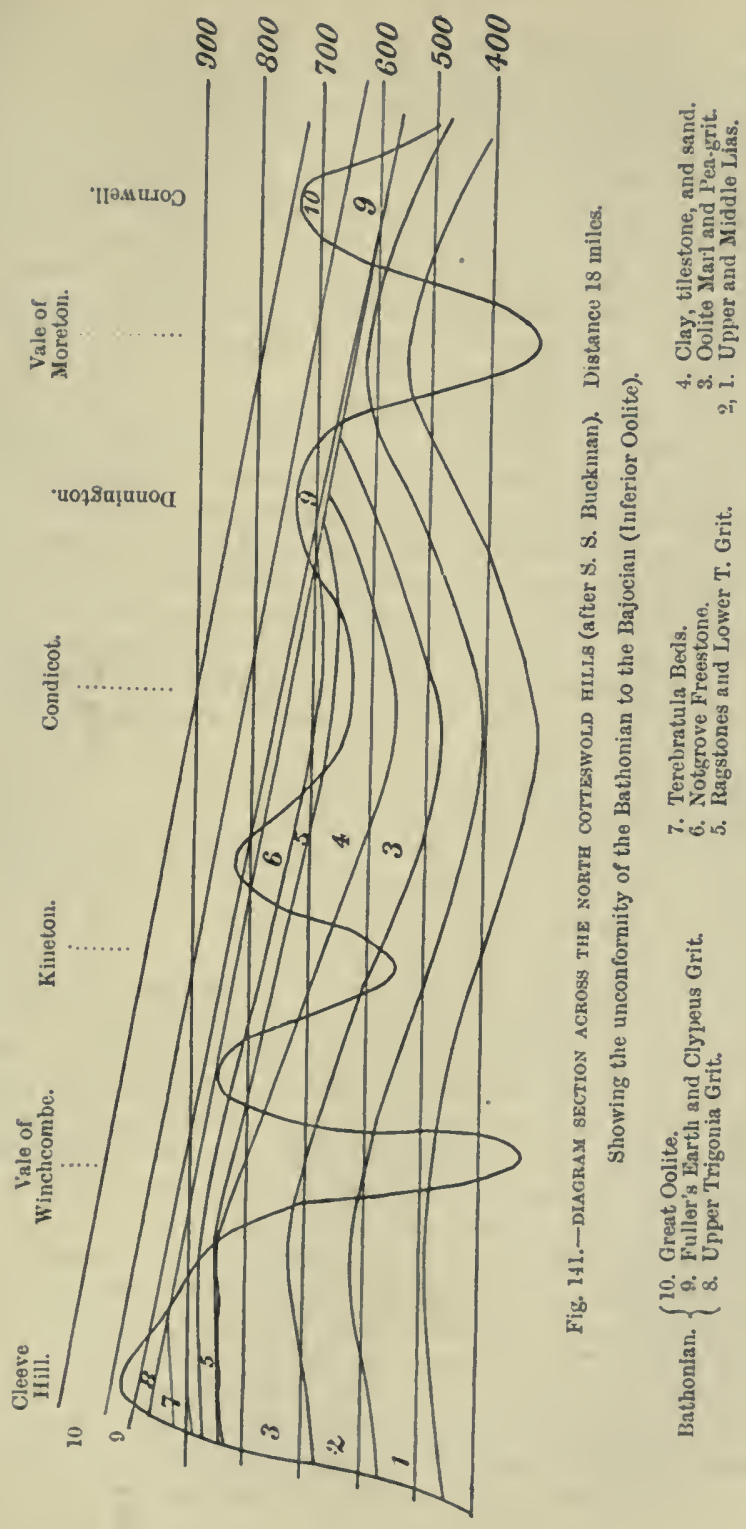


freestone" (an oolite from 4 to 27 feet thick) and a coral bed occurring at Dundry, Midford, and Stroud (6 to 8 feet).

The Fuller's Earth which succeeds the above is a marly clay, generally of a greenish or yellowish grey, but sometimes blue, and some of its beds consist of the fine soft greasy clay which is used for fulling purposes. It also includes a band of earthy limestone which is known as the Fuller's Earth Rock. This rock is thickest in Somerset, where it is often from 25 to 30 feet thick. Its characteristic Ammonite is Coeloceras subcontractum, and other commoll fossils are Ostrea acuminata, Rhynchonella varians, and Waldheimia ornithocephala.

No limestone comparable to the Great Oolite is found in Dorset or Somerset, so that it nust either be represented by the upper part of the Fuller's Earth or strong current must have prevented the accumulation of any sediment for a time.

The Forest Marble consists of shelly and flaggy limestones, which show much oblique current bedding and alternate with bands and layers of shaly clay or marl. It was formerly supposed to be over 400 feet thick, but $\mathrm{Mr}_{\mathrm{r}}$. Woodward has found this to be a mistake ; ${ }^{15}$ on the coast near Bridport it is only about 80 feet thick, and its greatest thickness is not in Dorset but in Somerset, near Sherborne, where it is about 130 feet. The limestones have been quarried at many places for building and paving stones.

The Cornbrash in Dorset and Somerset is from 15 to 25 feet thick, and consists of rubbly ferruginous limestone of a bluish-grey colour in its deeper parts, but weathering into a brown rock by oxidation of the iron, and forming a fertile soil (for fossils see p. 417 ).

In Gloucestershire the Parkinsoni zone has been divided into two sub-zones or hemeræ as Mr. Buckman calls them : (a) the Upper Trigonia Grit or garantiance hemera, consisting of hard earthy and shelly limestones with Trigonia angulata, $T$. costata, and Rhynch. spinosa; (b) the Clypeus Grit or Truellii hemera, comprising marly oolites with Clypeus Ploti, Nerincea Guisei, and Terebratula globata. The combined thickness of these beds is about 20 feet near Stroud, but 40 feet on Cleeve Cloud near Cheltenham.

The unconformity of the Upper Trigonia Grit and the manner in which its base passes across the outcrops of the underlying beds has been described on p. 421 , and illustrated by Fig. 141 .

The Fuller's Earth is traceable through the district, but thins northward. Near Stroud it is about 70 feet thick, but not more than 50 near Chedworth, where it passes up into the beds which are known as the Stonesfield slate; these are shales and laminated micaceous sandstones, which are thin in Gloucestershire but become 
of more importance in Oxfordshire. Near Bourton the beds are not more than 30 feet thick.

The Great Oolite limestone first sets in near Bradford-on-Avon, and rapidly thickens northward till, near Bath and Minchinhampton, it is from 80 to 100 feet, and includes the well-known freestone which goes by the name of "Bath Oolite" This freestone is from 10 to 30 feet thick, and occurs between two bands of shelly and oolitic limestone, each from 20 to 40 feet thick.

The Forest Marble succeeds, and near Bradford and Bath its basement bed is a band of bluish-grey clay, which is known as the Bradford clay, but is never more than 10 feet thick. It contains many fossils in a fine state of preservation, and has long been known for the abundance of Apiocrinus Parkinsoni (the pear Encrinite). It also contains Waldheimia digona, Terebratula coarctata, and other fossils which are characteristic of the overlying Forest Marble Beds. The latter are from 60 to 100 feet thick, and consist of alternating limestones and clays.

The Cornbrash forms a persistent band at the top of the series, but is never more than 15 feet thick.

Midland Counties.-In Oxfordshire the Bathonian has the following composition :-

Great Oolite limestone . . . . . 40 to 50

Stonesfield Beds and Fuller's Earth . . . . 15 to 18

Chipping Norton limestone . . . . . 12 to 15

Clypeus and Trigonia Grits . . . . . 12 to 20

The limestones of the Parkinsoni zone do not extend into Bucks, but seem to be cut by the base of the Upper Estuarine Beds, i.e. by the current action which preceded the deposition of those beds presently to be mentioned.

The Stonesfield Beds into which the Fuller's Earth seems to have passed consist of sandy clays and flaggy sandstones which have yiclded a remarkable assemblage of fossils, including the remains of five genera of small manmals - two Pterodactyles, three Crocodiles, the Dinosaur Megalosaurus, and the Turtle Protochelys, with a large number of fish and of Mollusca. Among the latter are Nerita costulata, Trigonia impressa, Gervillia acuta, Modiola imbricata, with Rhynchonella concinna. Besides these are remains of ferms, cycads, and conifers.

When traced northwards into Northampton the Stonesfield Beds pass into a set of sands and clays which are called the Upper Estuarine Series. In the absence of the Inferior Oolite limestone these beds rest on the estuarine beds of the Northampton Group, 
but the two estuarine groups are sharply divided from one another, the base of the upper group being a layer of ironstone nodules which rests on an eroded surface of the lower sands. The fossils are chiefly marine species, such as Ostrea Sowerbyi, Modiola imbricata, Perna rugosa, and Pteroperna plana, but Cyrena and plant remains sometimes occur.

The Great Oolite consists of hard limestones alternating with marly clays. These beds contain Gervillia Waltoni, Astarte angulata, Terebratula maxillata, Rhynchonella concinna, and many other fossils, and near Fairford is a white limestone which has yielded many corals, such as Isastrea explanatula, I. limitata, and Thamnastrea Lyelli.

The Forest Marble derives its name from Wychwood Forest near Burford in Oxfordshire, where it has been largely quarried. It is continued into Buckinghamshire, but near Buckingham the limestones thin out, leaving ouly the clays to represent this member of the series; these form a band which is known as the Great Oolite Clay, but it is only from 10 to 20 feet thick.

In consequence of the changes above mentioned the stage presents quite a different facies in Rutland and Lincoln, where it is less than 100 feet thick and consists of four members which are persistent through both these countries. These are:-

Feet.

4. The Cornbrash . . . . . about 15

3. The Great Oolite Clays . . . . " 20

2. The Great Oolite limestone . . . ", 20

1. The Upper Estuarine Beds . . " , 30

The Upper Estuarine Beds consist of white, blue, green, and variegated clays, with seams of lignite and occasional courses of sandy stone; the basement bed is a brown ferruginous nodular sandstone, which rests unconformably upon the Lincolnshire limestone in Rutland and Northampton, though in Lincolnshire no such evidence of erosion has been observed. The fossils are sometimes marine, sometimes estuarine forms (Cyrena, etc.).

The Great Oolite Limestone consists of soft, white, marly limestones, separated by layers of marly clay. The prevalent fossils are Ostrea Sowerbyi, O. subrugulosa, Homomya gibbosa, and Clypeus Mulleri.

The Great Oolite Clays are of many colours-blue, green, yellow, and purple; the only fossils are Placunopsis socialis and the oysters above mentioned.

The Cornbrash is as usual full of fossils; Holectypus depressus, Nucleolites clunicularis, Pseudomonotis echinata, and Macrocephalites macrocephalus are characteristic and common. 


\begin{tabular}{|c|c|c|c|c|c|c|c|c|}
\hline 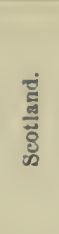 & & 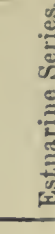 & 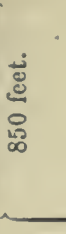 & & 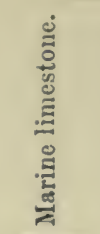 & 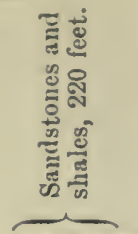 & 苟 & : \\
\hline 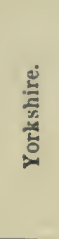 & 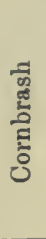 & & & 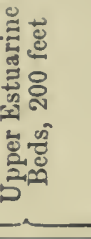 & & 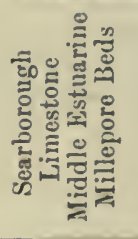 & 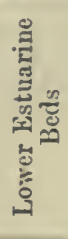 & 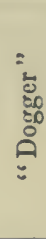 \\
\hline 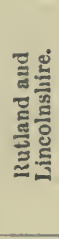 & 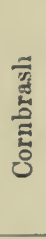 & 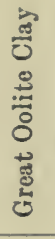 & 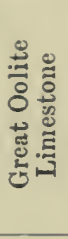 & 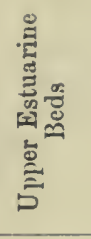 & 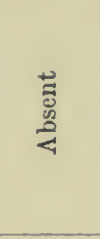 & $\underbrace{0}$ & 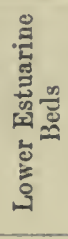 & 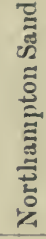 \\
\hline 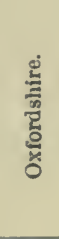 & 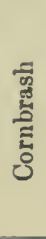 & 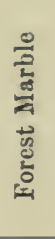 & 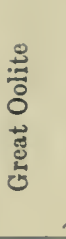 & 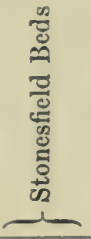 & 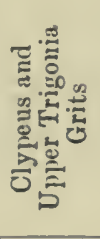 & $\begin{array}{l}\overrightarrow{3} \\
\stackrel{3}{3} \\
3\end{array}$ & 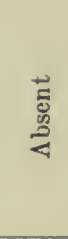 & 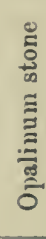 \\
\hline 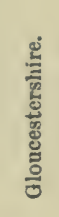 & 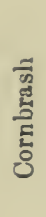 & 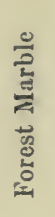 & 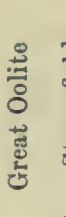 & 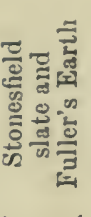 & 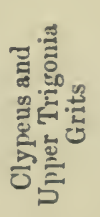 & 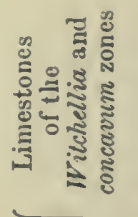 & 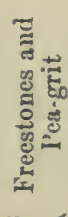 & 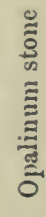 \\
\hline 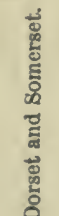 & 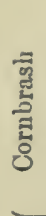 & 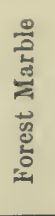 & 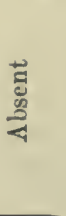 & 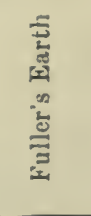 & 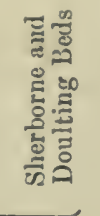 & 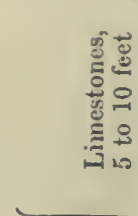 & 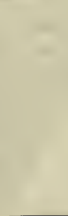 & 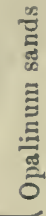 \\
\hline
\end{tabular}


On the Yorkshire coast the whole group is represented by shales and sandstones of estuarine origin, capped by a thin band of Cornbrash.

In Gristhorpe Bay this Upper Estuarine Series is 120 feet thick, consisting of marine sandstones in the lower part and shales with thin sandstones above. Farther north tliey are over 200 feet thick. A few ferns are the only fossils.

The Cornbrash is very thin, only 5 or 6 feet, but has the usual characters, being a grey rubbly ironshot limestone full of the ordinary fossils, among which are Macrocephalites Herveyi, Pseudomonotis echinata, Lima rigidula, and Waldheimia lagenalis.

\section{The Middle Jurassic in Scotland}

\section{West Coast}

"Rocks of this age," says Professor Judd,10 "must have originally had a very wide distribution, for traces of them are found at various points from the Shiant Isles in the nortl to Ardnamurchan in the south. The best exposures of their strata, however, are those which occur in the islands of Skye and Raasay" (see Fig. 132). Here the Inferior Oolite consists of the following beds :-

Beds of white sandstone with thin shaly bands containing remains of ferns and cycads

Feet.

Beds of sandstone and shale, the former passing into shelly limestones, Steph. Humphriesianum, Belemnites giganteus . . Sandy micaceous shales alternating with calciferous sandstones, Ludwigia Murchisonce, Harpoceras corrugatus, Belemnites giganteus, Lucina Wrightii, etc.

These beds are succeeded by a great thickness of strata belonging to the Bathonian Group. At the base are marine linestones almost wholly made up of comminuted shells, but containing perfect Ostrea Sowerbyi, Waldheimia lagenalis, etc. They probably represent the zone of Parkinsonia Parkinsoni and are 45 feet thick. Above them are estuarine sandstones and slales fully 500 feet thick but not well exposed.

Farther south, however, in the islands of Eigg and Muck this estuarine group is still thicker and is accessible, the following succession being seen :-

A. The lowest beds are fine conglomerates and shelly limestones full of freshwater shells, but containing also remains of Plesiosaurus, turtles, and other reptiles. Above these are black shales and limestones abounding in Cyprids, fish remains, and shells of Cyrena, 
Cyclas, and Viviparus. The thickness of the whole group is 200 feet.

B. Grey and white sandstones, sometimes passing into calcareous grits, with large concretionary siliceous masses; current-bedding and ripple-marked surfaces are frequent, but excepting plant remains fossils are rare. Thickness probably more than 500 feet.

C. The highest beds are black shales with thin bands of argillaceous limestone and bands of fibrous carbonate of lime; they are sometimes crowded with Cyrena and Cyclas, and in other places witl Viviparus, Melania, and other Gastropoda. Beds entirely composed of oysters ( $O$. hebridica) also occur, resembling those in the Purbeck Series (see postea). Thickness 150 feet.

\section{East Coast}

Beds of Middle Jurassic age occupy a small space on the coast of Sutherland south of Brora, and form two small patches at Burgh Head and Stotfield, on the coast of Elgin. They consist entirely of estuarine strata, which are lithologically comparable to those of the Great Oolite Group on the western coast. The descending succession near Brora is as follows :-

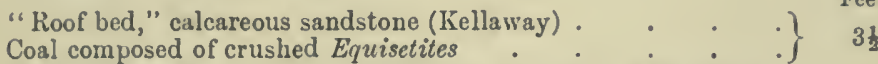

Black shales with thin coal-seams in the upper part, plants, and crushed shells of Unio, Ostrea, Cyrena, etc., abound; also teeth and scales of fish, Lepidotus, Pholidophorus, and Hybodus . . . . . . . . . .

Black, brown, and grey clays with layers of argillaceous lime. stone, Cyrena and Ostrea . . . .

White sandstones with some beds of clay; in this a few obscure mariue shells occur . . . . . . 110

The base is not seen, and whether any beds comparable to the Inferior Oolite of the west coast exist below is, therefore, unknown.

At Stotfield there are soft greenisl-white sandstones containing Ostrea Sowerbyi, Tancredia axiniformis, and Astarte hombordalisi, and are probably near the base of the Bathonian Series.

\section{E. Continental Equivalents}

\section{France}

The Middle Jurassic strata of the Parisian basin are a continuation of the British Series, and their outcrop is almost continuous round the basin, though concealed here and there beneath the transgressive Cretaceous deposits. The districts where the succession is most clearly exposed are that of Bayeux and Caen in 
Normandy, the southern border of the Ardennes, and the broad outcrop on the borders of France and Germany, extending southward to the Jura Mountains.

In Normandy the succession is as follows:-

Marly limestone and blue clay, 12 feet (=Cornbrash).

Bryozoan limestone with Waldheimia (Zeilleria) digona, Terebratula flabellum, and Eudesia cardium, 30 feet (=F. Marble).

Compact oolitic limestones with Lucina bellona, 30 to 60 feet ( $=$ Great Oolite $)$.

Caen limestone with Rhynchonella (Acanthothyris) spinosa, passing northward into Bessin limestone with Oppelia fusca, 100 feet (=Fuller's Earth).

White Oolite with Parkinsonia Parkinsoni, 60 feet.

Ferruginous Oolites with Cosmoceras subfurcatum and Strenoceras garantianum, 2 feet.

- Brown Oolite with Coeloccras Blagdeni, 1 foot.

.ี. Glauconitic limestone with Sphacroceras, 1 foot.

White limestone witl flints, Ludwigia Murchisona, and Lima heteromorpha, 9 feet.

Limestone with Lioceras opalinum and a layer of phosphatised Ammonites derived from the Toarcian at the base, 2 feet.

On the other side of France, in the French Ardennes and thence eastward into Lorraine, the series presents a different facies with a much thicker development of limestones. The succession there is :-

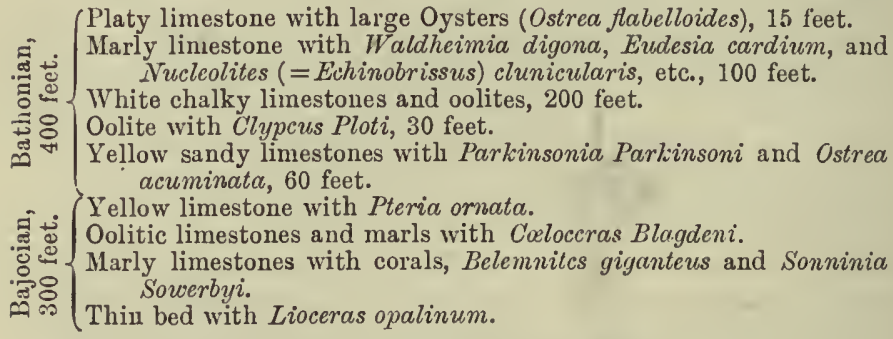

In the French Jura the succession is somewhat similar, but differs somewhat in zonal detail, being as follows :Platy limestones with large oysters, Waldheimia (Zeilleria) digona
and Nucleolites clunicularis, 26 to 120 feet.
Compact white limestones with Rhynchonella decorata, 200 feet
(= Great Oolite).

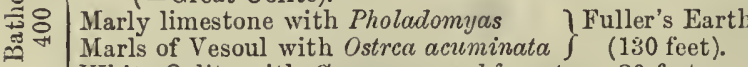

White Oolite with Cosmoceras subfurcatum, 20 feet.

(a) Crinoidal limestones with Emeleia polyschides, Witchellia, and Lioceras concavum.

Forruginous limestone with Ludwigia Murchisonce and Lioceras opalinum. 


\section{Germany}

In the south of Germany the outcrop of this series follows that of the Lias from the Black Forest through. Swabia and Franconia. In the south-west of this tract, near Tuttlingen and Nusplingen, the facies is calcareous and similar to that of the Northeril Jura, but eastward the limestones are largely replaced by clays, and the Bathonian portion becomes much thimner as if approaching a shoreline. In East Swabia the succession is as follows:-

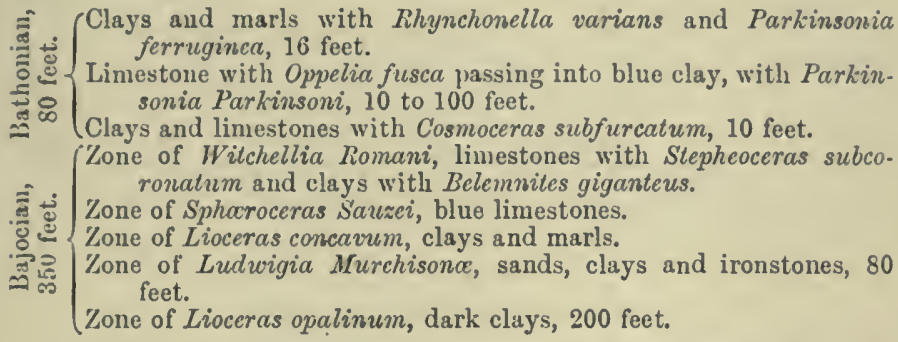

Apart from the lithological composition of the series the most noteworthy fact is the great expansion of the opalinum and Murchisonce zones, as compared with the lesser thickness of the overlying limestones. In Northern Germany there is a similar succession of shales with very little limestone, and the whole series is not more than 100 feet thick. It probably underlies the greater part of the Hanoverian and Prussian plains, and is known to occur in Pomerania; eastward in Silesia the lowest Jurassic Beds belong to the Parkinsoni zone; while in Poland near Cracow there are sands and clays of Bajocian age overlain by 100 feet of dark-grey clays with Parkinsonia wurtemburgica (Bathonian) and succeeded by a ferruginous oolite with Rhynchonella varians and Belemnites bessinus; but farther east these beds thin out, leaving the Callovian to form the base of the Jurassic System.

\section{Alpine and Mediterranean Facies}

In the western sub-Alpine region, Savoy and Lower Provence, the Middle Jurassic has a thick and special development, and is over 1000 feet thick. The Bajocian consists of regular altemating beds of marly limestone and shaly marl, characterised by the abundance of Ammonites of the genera Lytoceras and Phylloceras. The succession of zones is similar to that of the Jura and Swabia, and the same species can be taken as indices, but each zone is also characterised by one or more species of Phylloceras, and this is a 
special feature of the Mediterranean and Alpine facies. Near Digne the Bajocian is 660 feet thick. In the same region the Bathonian consists mainly of black shales which are divisible into two zones, viz. :-

2. Black marly shales with Posidonia alpina, 300 to 400 feet.

1. Black shales and marly limestone with Oppelia fusca, 170 feet.

Eastward, however, both stages pass into the condition of marly limestones, and in a more or less metamorphosed form they show themselves at intervals through the Swiss and Italian Alps, and recur in the Apennines. In the Eastern Alps (Klaus Alp) Bathonian shales with Posidonia alpina occur, and again near Vienna there is Bajocian with Phylloceras and Bathonian with Posidonia. These beds extend to the Carpathians, and occur also in Servia, where (near Milanovitz) the Bajocian is absent, and beds with Oppelia fusca and Zigzagiceras arbustigerum rest directly on crystalline schists.

\section{UPPER JURASSIC SERIES}

\section{A. Subdivision and Nomenclature}

In England, where fully developed, this series is divisible into five groups or stages-two great argillaceous formations (the Oxford and Kimeridge clays), each overlain by a group of sandstones and limestones (the Corallian and the Portland Beds); while at the summit are the Purbeck Beds, a set of estuarine and lacustrine strata which may be regarded as formed during a continuance of Portlandian conditions in the purely marine areas.

On the continent the thick clays are in many places represented by limestones and marls, so that the British names are not literally applicable; but in Germany and Northern France the general succession is similar, and many of the English names have been employed in a latinised form. In Southern France and the south of Europe generally there is a very different facies, wholly calcareous and marine with a different assemblage of fossils.

The following table shows the nomenclature used in Northern Europe, but the French stages do not exactly correspond with those of England and Germany, as will be shown in the sequel.

\section{England.}

5. Purbeck Beds

4. Portland Beds

3. Kimeridge clay

2. Corallian Beds

1. Oxford clay and Kellaways Beds
North France.

Portlandian

Kimeridgian

Corallian

(Oxfordian)

Callovian
North Germany.

Munder Mergel and Plattenkalk. Kimeridgian. Corallian.

Oxfordian. 


\section{B. Life of the Period}

The Upper Jurassic fauna is merely a continuation of that which preceded it, the genera being the same, though the species are for the most part different, only about sixty species passing from the Cornbrash into Oxford Clay.

The inost impressive feature of the later fauna is the abundance of reptilian remains. The Jurassic period has been termed the

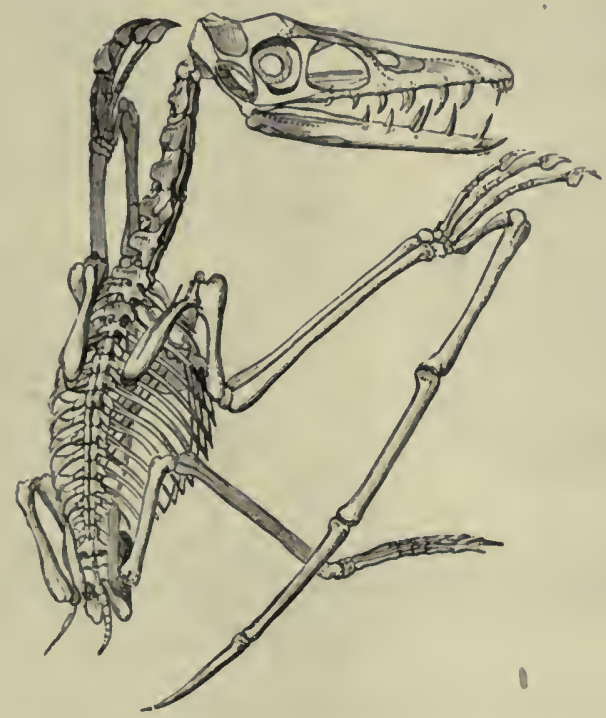

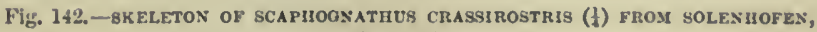
GERMANY.

"age of reptiles," and these creatures seemed to have reaclied the climax of their dominion towards the close of the period. Their numbers and the variety of their modifications are quite extraordinary. Not only did they swarm in the seas and rivers, but they peopled the land with gigantic herbivores and filled the air with winged forms. They thus adapted themselves for all kinds of food and all conditions of life with an elasticity of organisation which is truly remarkable, and to which no parallel can be found in the subsequent history of the world, unless it is among the modern Mammalia, though no nember of that class possesses powers of flight comparable to those of the Pterodactyles. 
Of Upper Jurassic reptiles, Cimoliosaurus, Peloneustes, Pliosaurus, Ichthyosaurus, with the crocodiles Teleosaurus, Steneosaurus, Daliosaurus, and Goniopholis were the chief aquatic genera. Ceteosaurus, Gigantosaurus, Iguanodon, Omosaurus, and Cryptosaurus were terrestrial Dinosaurs, and in America other remarkable genera, Brontosaurus and Atlantosaurus, both of enormous size, have been found.

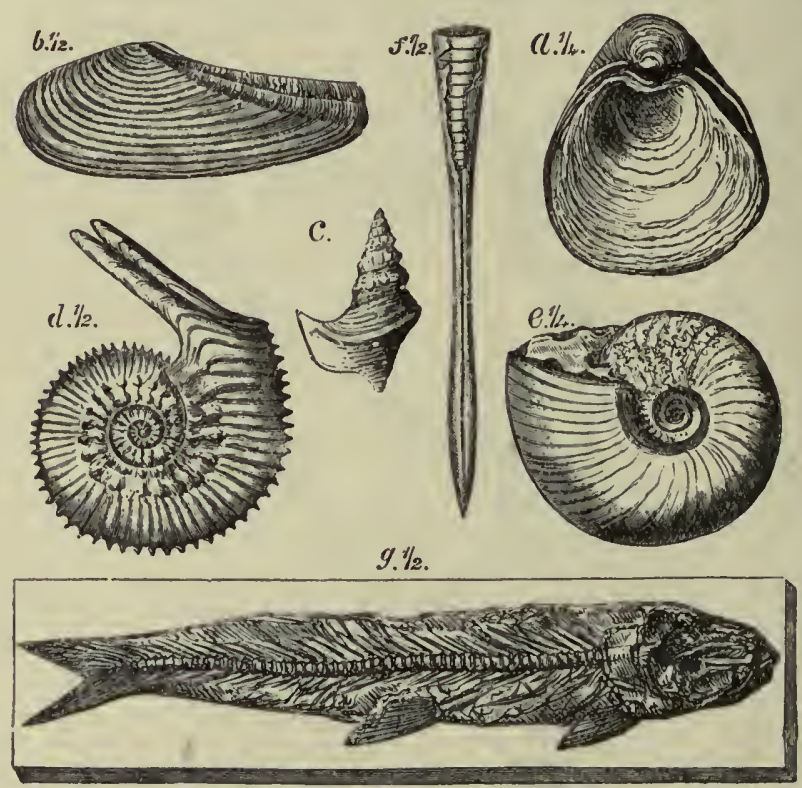

Fig. 143.-GROUP OF OXFORDIAN FOSSILS.

a. Gryphæa dilatata.

b. Anatina undulata.

c. Dicroloma compositum. d. Cosmoceras Jason.

e. Cardioceras excavatum.

$f$. Belemnites hastatus.

g. Leptolepis macrophthalmus.

Of Pterosauria species of Pterodactylus, Scaphognathus (Fig. 142), and Rhamphorhynchus were prevalent.

That small Mammalia existed throughout the Jurassic period on terrestrial surfaces there can be little doubt, but their remains are not found in purely marine deposits. The Purbeck Beds, however, have yielded no fewer than twelve genera and twenty species of marsupials, the most important genera being Plagiaulax, Belodon, Spalacotherium, Triconodon, Stylodon, and Amblotherium.

Birds also of a primitive kind had now come into existence, 
but the only known genus is Archooptcryx, whose remains occur in limestones of Portland age at Solenhofen in Bavaria. This bird had strong reptilian affinities in the structure of its liead and tail,

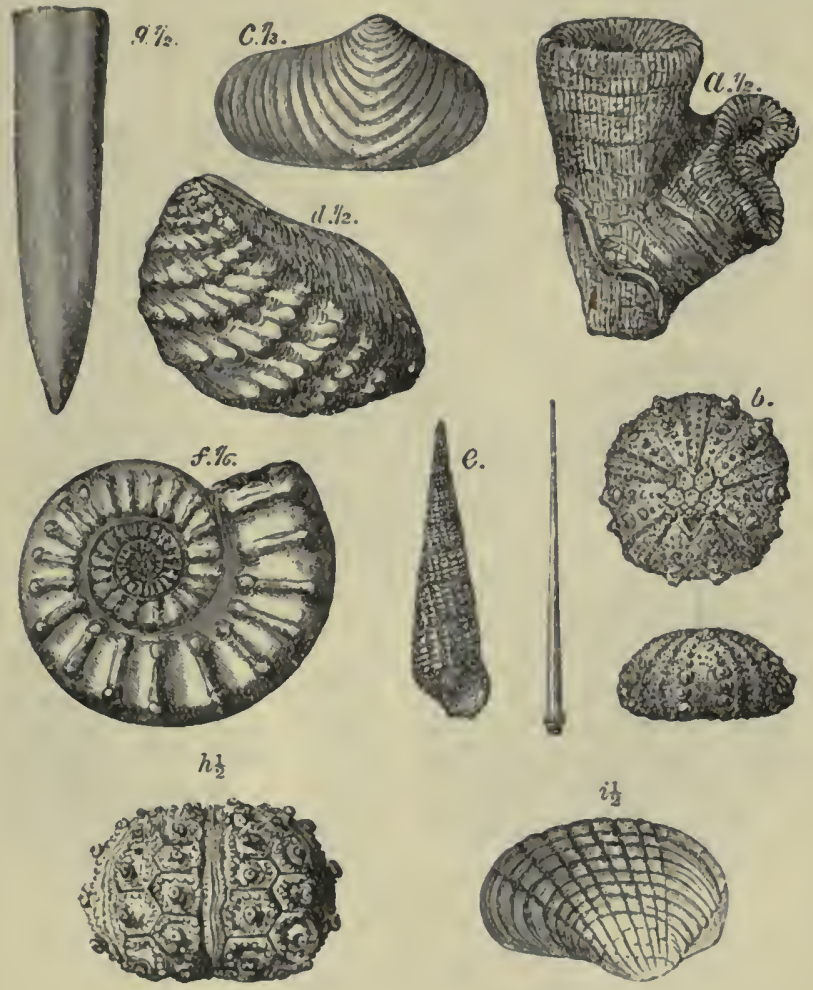

Fig. 144.-Oroup oy CORaLliad rossils.
u. Thecosmilia ammularis.
b. Acrosalenia decorata.
e. Cerithium muricatum.
c. Gonionya litterata.
d. Trigonia claveliata.,
f. Aspidoceras perarmatun.
\%. Beletnnites abbreviatus.
h. Ciclaris florigemma.
i. Pholadomya u’qualis.

and in possessing teeth, but it lad feathered wings, a feathered tail, and feet adapted for grasping boughs of trees.

Fish were evidently abundant in the seas, their teeth and scales being often found, and sometimes the entire skeleton; the chief genera are Leptolepis (Fig. 143), Aspidorhynchus (Fig. 147), Pholidophorus, Gyrodus, Lepidotus, and Hybodus. 
Of Invertebrates very few new genera make their appearance except among the Echinodermata and the Ammonoidea. The Echinoderm genera Peltastes, Acrocidaris, Glypticus, Magnosia, and Cyphosoma make their appearance. Among the Ammonoids many of Middle Jurassic forms die out, while the following appear: Aspidoceras, Cardioceras, Craspedites, Holcostephanus, Peltoceras,

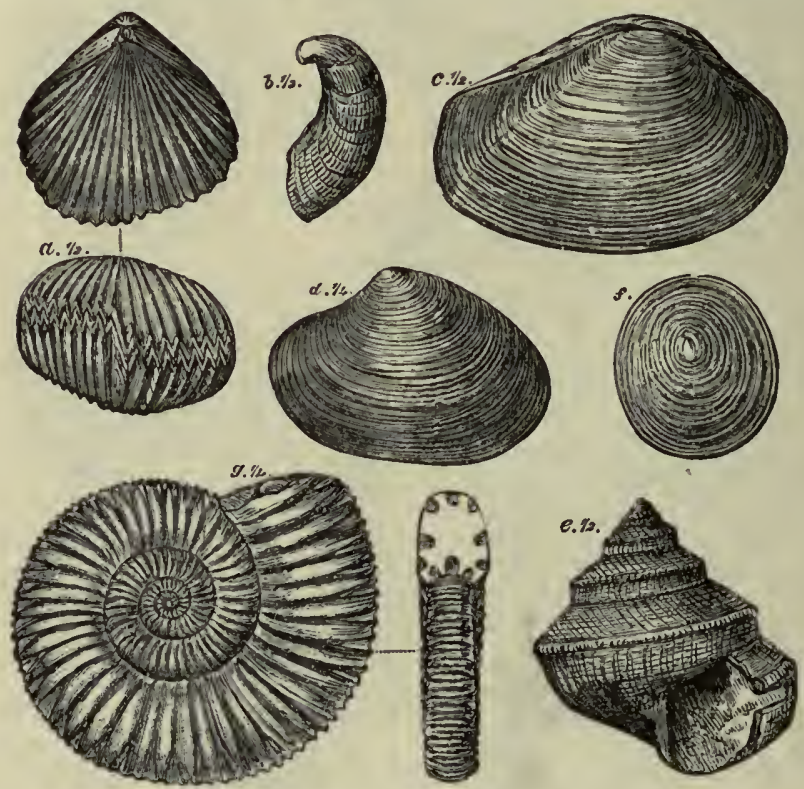

Fig. 145.-GROUP OF KIMERIDGIAN FOSSILS.

a. Rhynchonella inconstans.
b. Exogyra virgula.

c. Astarte hartivellensis. d. Thracia depressa.

e. Pleurotomaria reticulata.

f. Orbiculoidea latissima.

g. Perisphinctes biplex.

Polyptychites, and Ancyloceras. Of Dibranchiate Cephalopoda 1 Belemnoteuthis and Coccoteuthis are new.

The following are some of the characteristic species of each stage as developed in Northern Europe :-

\section{Fossils of the Oxfordian}

Brachiopoda. Rhynchonella socialis, Waldheimia impressa.

Lamellibranchia.Gryphæa dilatata, Pseudomonotis ovalis, Pecten fibrosus, Pleuromya recurva, Anatina undulata, Nucula ornata, Trigonia irregularis. 
Fastropoda. Dicroloma (Alaria) trifidnm, D. compositum, Cerithium muricatun.

Cephalopoda. Kepplerites calloviensis, Cosmoceras jason, Cosm. ornatum, Quendstedtoceras Lamberti, P'eltoceras athletum, Cardioceras cordatun, Belemnites hastatus, Bel. Oweni.

Pisces. Leptolepis macrophthalmus.

Reptilio. Cimoliosanrus plicatıs, Pliosanrus ferox.

\section{Fossils of the Corcllian Group}

Actinozor. Thecosmilia aunularis, Thamnastrea arachnoides, Th. eoncinua, Isastrea explanata.
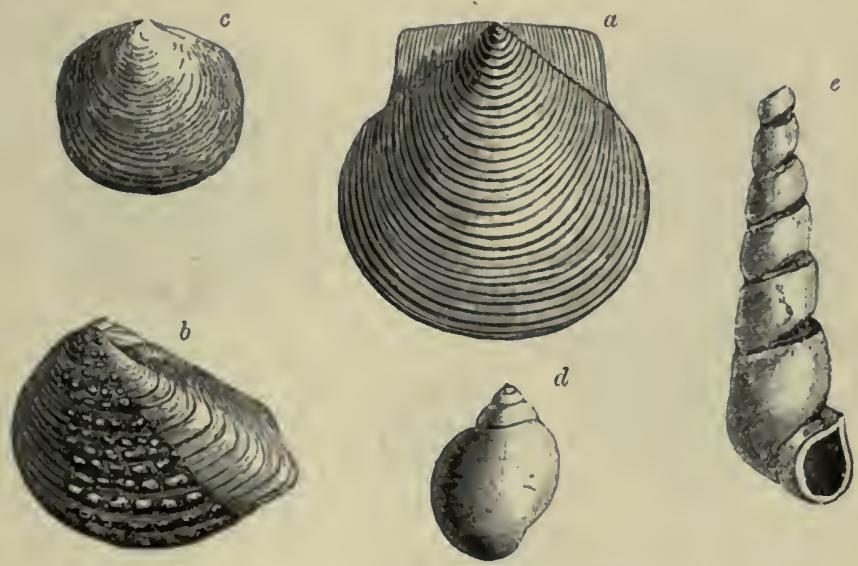

Fig. 146. - GROUP OF PORTLANDIAN FOSSIL.
a. Pecten lamellossus.
b. Trigonla gibbosa.
c. Lucina portlandica. d. Natica elegans (cast). e. Cerithium portlandicum (cast).

Echinoderma. Cidaris florigemma, Henieidaris internedia, Acrosalenia decorati, Nucleolites scutatus, Holectypus depressus.

Brachiopoda. Terebratula insignis, Waldheimia bucculenta, Rhynclionella Thurmanni.

Lamellibranchía. Gervillia avienloides, Pecten articulatus, Ostrea gregaria, Gonionya litterata, Trigonia clavellata, Tr. perlatu, Pholadoniya æqualis.

Gastropoda. Cerithium muricatun, Bourguetia striata, Pseudomelania heddingtonensis, Nerinea Goodlalli, Littorina inuricata.

Cephalopoda. Aspidoceras perarmatum, Perisplinetes plicatilis, Belenınites abbreviatus. 

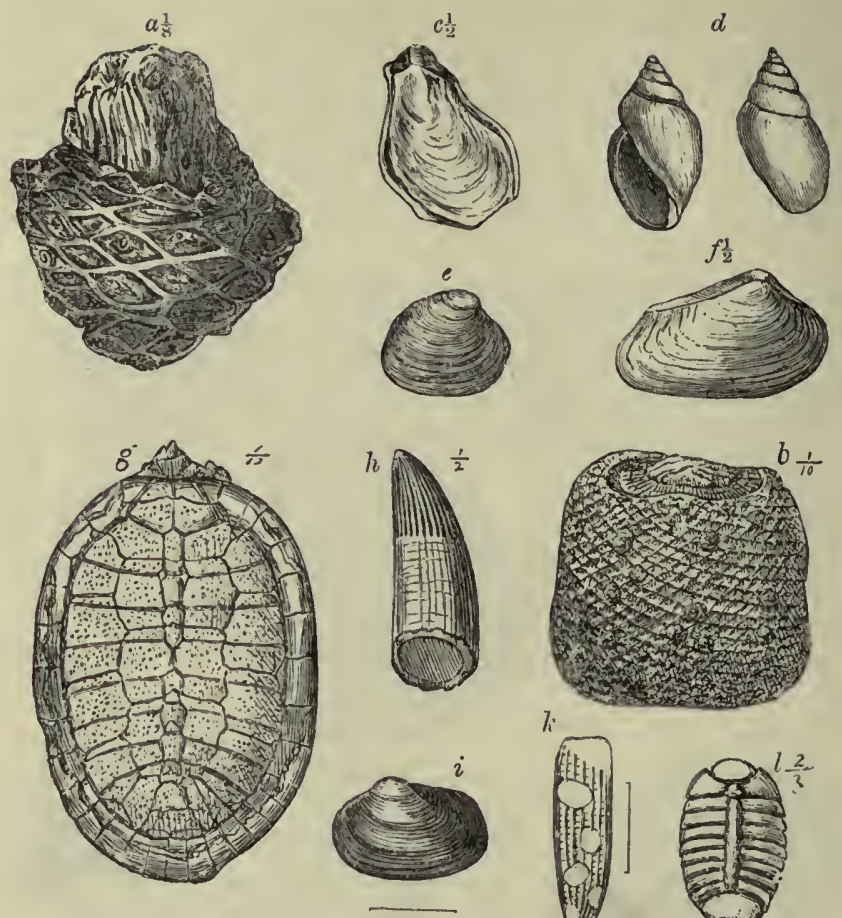

i:
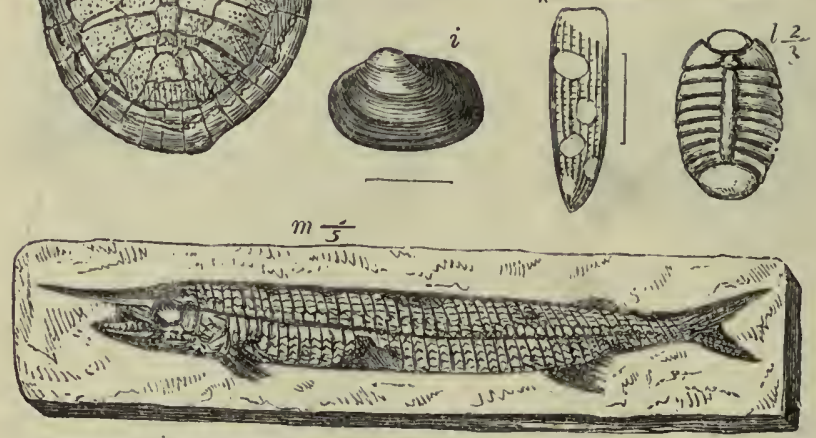

Fig. 14i.-GROUP of PURBECK FossiLs.
a. Mantellia nidifornis.
b. Mantellia inicrophylia.
c. Ostrea distorta.
e. Pliysa Bristovi.
e. Cyrena media.
f. Uuio compressus.
\%. Pleurosternon ovatum (carapace).
$h$. Goniopholis crassidens (tooth).
$i$. Cyrena elongata.
i. Bupreston stygnus (elytron).
l. Archæoniscus Edwardsi.
$m$. Aspidorhynchus Fischeri.

\section{Fossils of the Kimeridgian}

Brachiopoda. Orbiculoidea latissima, Lingula ovalis, Rhynchonella inconstans. 
Lamollibranchic. Ostreadeltoidea, Thraeia depressa, Astarte hartwellensis, A. minima, Diceras arietinum, Trigonia monilifera, Protoeardia striatula, kxogyra virgula.

Gastropodu. Pleurotomaria retieulata (also Oxfordian and Corallian), Littorina pulcherrima, Harpagodes Oeeani.

Cephalopoda. I'erisplinetes biplex, Per. nutabilis, Cardioceras alternans, Reineckia endoxus, Oppelia tenuilobata, Steneroceras ealisto, Belemnites nitidus.

licplitic. Ichthyosaurus trigonus, Ieh. entheeiodon, Plesiosaurus troelianterius, Pliosaurus macromerus, Geosaurus maximus.

\section{Fossils of the Portlandian}

Aetinozoa. Isastrea oblonga.

Brachiopode. Waldheimia boloniensis.

Lamellibrenelia. Protoeardia dissimilis, Cytherea rugosa, Perna mytiloides, Peeten lamellosus, Trigonia gibbosa, Lueina portlandica, Ostrea expansa, Aueella Pallasi.

Gastropocla. Cerithiunı portlandieum, Neritoma sinuosa, Natica elegans, Pleurotomaria rugata.

Cephalopoda. Holeostephanus giganteus, Hol. portlandieun, Perisphinetes gigas, Per. bolonicnsis.

\section{Fossils of the Purbeck Beds \\ (Estuarine, Freshwater, and Terrestrial)}

Plants. Sequoia portlandica, Cyeadeoidea nidifomis, C. mieroplyylla, Cliara Jaceardi.

Eikinalerma. Hemieidaris purbeekensis.

Crustuceu. Cypridea purbeekensis, Cy. gramulosa, Cy. punetata, Arehroniseus Edwardsi.

Lamellibranchic. Corbula alata, Cyrena media, C. elongata, Ostrea distorta, Unio valdensis.

Giestropocle.

Physa Bristovi, ' Viviparus earinifera, V. elongatus, Planorbis Fisheri, Melanopsis harpeformis.

Insecta.

Pisces.

lieptilia.

Bupreston stygnus (a beetle), and many others.

Lepidotns ninor, Hybodus striatus, Mierodon radiatus, Aspidorhynehus Fisheri.

Goniopholis, Theriosuehus, Nannosuchus (Croeodiles), Chelone and Pleurosternon (Turtles), aul Doratorhynehus (a Pterodaetyle).

Mammaliu. See ante, p. 434.

\section{The Upper Jurassic of Britain}

Geographical Range.-The clifl's of the south coast near Weymouth and Portland expose good sections of all these rocks, but the inland outcrop of the Portland and Purbeck Beds is repeatedly concealed by the overstep of the Cretaceous strata. They appear, however, for a space near Tislury in the Vale of Wardour, and again uear Devizes. From Calne and Swindon their outcrop is 
more continuous through Oxford, Berkshire, and Buckinghamshire, but the limestones die out in the last county, and only the clays remain through Bedford, Cambridge, Huntingdon, and Lincoln. In Sonth Yorkshire they are entirely concealed by the Cretaceons overstep, but in North Yorkshire there is a fine development of the Oxfordian, Corallian, and Kineridgian Groups. In Scotland the Oxford Clay exists on the west coast, and the complete series is found on the coast of Sutherland.

With regard to the eastward extension of these rocks beneath the newer systems in the south-east of England we have the testimony of four important borings. The Sub-Wealden boring near Battle traversed all the higher groups, and a large part of the Oxfordian, terminating at a depth of 1905 feet from the surface. In the Dover boring all the members of the series were found to be greatly reduced in thickness, the combined thickness of the Portlandian, Kimeridgian, Corallian, and Oxfordian being only 452 feet. A boring at Chatham proved the existence of Oxford Clay immediately below the Lower Greensand, a fact which makes it probable that there was considerable erosion of the Upper Jurassic Series before the deposition of the Lower, Cretaceous sands in that district. There is a similar gap and unconformity at Richmond, where a boring found the Lower Greensand resting directly on Great Oolite. It is probable that the Oxfordian, Corallian, and Kimeridgiau Groups originally spread over the area which underlies the Thames valley, but no traces of them have been found in any of the deep borings in Essex, Suffolk, or Norfolk, where Cretaceous rocks everywhere rest directly ou a plateau of Palæozoic rocks.

In dealing with the stratigraphy of this series, the simplest plan will be to take each stage separately, and indicate its variations from what may be regarded as its typical development in Dorset as it is followed northwards along the line of onterop.

1. The Oxford Clay (Oxfordian).-Lithologically this is divisible into two mequal parts (1) the Kellaways Beds, a set of sands and clays with beds of shelly sandstone or sandy limestone; and (2) the Oxford Clay proper, including over 400 feet of bluish clays with occasional layers of earthy limestone. Palæontologically, however, it can be divided into at least three zones, ${ }^{17}$ viz. :-

$$
\begin{gathered}
\text { Zone of Cardioceras cordatum - Blue clays with septaria. } \\
\text { ", Cosmoceras ornatum - Grey clays and shales. } \\
\text { ", Kepplerites calloviensis = Kellaways Beds. }
\end{gathered}
$$

Part of the Oxford Clay is well exposed near Weymouth, where the highest zone is about $\mathbf{2 5 0}$ feet, the central beds probably about 
200, and the Kellaways about 50 feet. These latter beds take their uame from a place called Kellaways near Chippenham in Wiltshire, where they are about 60 feet thick; in that district too the overlying beds are exposed in several places, yielding Cosm. ornatum, Cosm. Elizabethe, and Peltoceras athletum; while in the higher beds Gryphara dilatata is an abundant fossil.

In the counties of Oxford, Buckingham, Bedforl, Huntinglon, and Cambridge the thickness of the stage is about 450 feet, and the same three zones are everywhere traceable. That of Cosmoceras ornatum is well exposed in brickyards near Oxford, and that of Kepplerites calloviensis in quarries and cuttings near Bedford. Near Huntingdon and Peterborough Professor Judd recognised the following sequence:-

5. Clays with Card. cordatum and Quensted. Lamberti.

4. Clays with Cosm. ornatum and Duncani.

3. Clays with Belemnites hastatus and Bel. Orceni.

2. Shales with Nucula muda and Cosm. jason.

1. Kellaways Beds, soft sands and clays.

Near Peterborough the clays of No. 3 have yielded ten species of reptiles and five of fish. In this district also, as well as round St. Neots and St. Ives, the higher beds include bands of limestone as well as septaria, and yield the characteristic Ammonites in great abundance.

The Oxford Clay borders and underlies the western part of the Fen district, emerging on the uorth side of the river Withan near Bardney, and passing northward to the valley of the Ancholme, which drains into the Humber.

When it emerges from the Cretaceons overlap in Yorkshire the beds have a more variable composition. The liellaways zone is represented by a massive brownish calcareous sandstone, but where this first appears it is only 9 feet thick; in Gristhorpe Bay it is 24 feet, and at Scarborough, 5 miles to the north-west, there are no less than 76 feet of sandstone. It seems, however, that only the lower 62 feet of this belong properly to the Kellaways, for the highest beds contain Gryphera dilatata and Ammonites of the Ornutum Gronp, which characterise the lower pait of the Oxforl Clay elsewhere. Above this sandy zone are grey sandy sha!es 120 feet thick, containing Quenst. Lamberti, Card. cordatum, Cosm. crenatum, and other fossils. Westward both shales and sands decrease in thickness, and are only 80 feet thick" in the Howarlian Hills.

2. The Corallian Group.-This stage was termed the "Coral Rag" by William Smith in 1815, from the abundance of corals in some of its beds, and it was subsequently divided by J. l'hillips into a lower and upper "Calcareous Grit," with the "Coralline 
oolite" between them. The name "Corallian" was proposed by d'Orbigny in 1849, and is now generally adopted as more convenient for the variable group of beds which intervene between the Oxford and Kimeridge Clays. Two zones can be recognised, which can also be called the Lower and Upper Corallian, thus :-

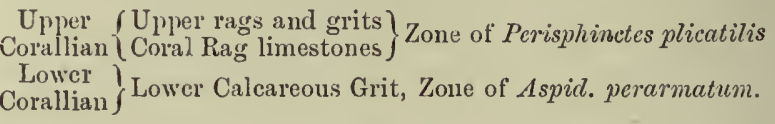

In South Dorset the Corallian has a thickuess of about 200 feet, but in North Dorset it is not more than 120, and thence northwards it varies from 80 to 100 . The component beds are well exposed in the cliffs south of Weynouth, where local names have been given to the several members of the succession by Messrs. Blake and Hudleston, ${ }^{18}$ as below :-

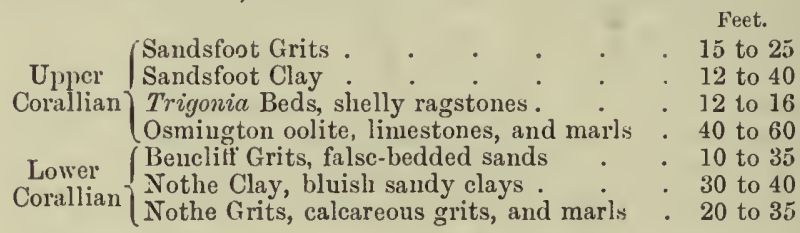

The Nothe Grits and Clays contain a mixture of Oxfordian and Corallian species-Gryphea dilatata, Cardioceras cordatum, Ostrea gregaria, and Trigonia perlata. The Osmington and Trigonia Beds represent the Coral Rag, but corals are rare; the rags contain T'rigonia clavellata, Gervillia aviculoides, Nerincea Goodhalli, Am. plicatilis, and many other fossils. The Sandsfoot Clays and Grits yield Astarte supracorallina, with Thracia depressa, Ostrea deltoidea, Rhynchonella inconstans, and Belemnites nitidus, which range into the Kimeridge Clay.

Near Abbotsbury (see Fig. 148) the Sandsfoot Grits pass into ferruginous sandstone and oolitic ironstone, the latter quarried as ore. Similar ironstone occurs at Westbury in Wiltshire, in which county the general succession is:-

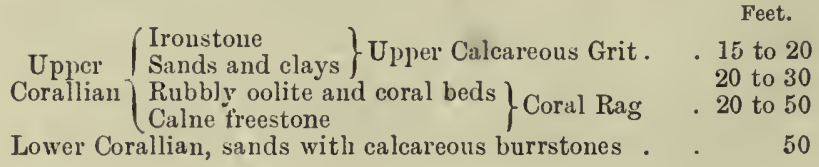

The freestone thins out rapidly north of Calne, and is not present at Faringdon, where the Upper Corallian is not more 
than 20 feet thick. In Oxfordshire this stage consists of Lower Calcareons Grit (50 to 60 feet) and Coral Rag ( 30 to 40 feet), the forner consisting of sands with calcareous burrstones, the latter of shelly and coralliferous limestone. But near Stainton St. John these beds change rapidly and appear to be replaced by clays.

In Buckingham, Bedford, and Huntington the whole of the Corallian stage is represented by the Ampthill Clay, named from the small town of Ampthill near Bedford. This clay has not yet been separated on the maps of the Geological Survey from the clays above and below, but is shown on a small map illustrating Mr. Rastall's account of Cambridge and Bedford (Geology in the Field, vol. i. p. 141), reproduced in Building of the British Isles (1911, p. 299). Its fauna includes a mixture of species belonging to the Oxford and Kimeridge Clays with a few that are more especially Corallian. The chief Ammonites are achilles, cordatum, plicatilis, and vertebrelis; with these are found Alaria bispinosa, Exogyra nana, Ostrea deltoidea, O. discoidea (allied to deltoidece but more circular), Gryphera dilatata, Cidaris florigemma, and C. Smithi. As seen near Ampthill this division consists of grey marly clay with a bed of nodular limestone $4 \frac{1}{2}$ feet thick at the base, and a band of septaria at the top.

Near Cambridge and St. Ives the Lower Calcareous Grit is represented by a bed of dark-grey ferruginous oolitic limestone, known as the Elsworth Rock, from 6 to 8 feet thick, and sometimes in two beds with clay between. This is usually overlain by clays of the Ampthill type, ${ }^{19}$ but at Upware, between Cambridge and Ely, there is an isolated mass of undoubted Coral Rag and Coralline oolite, which seems to be part of a true coral reef. One pit exposes coral limestone, with Thamnastrea arachnoides and Isastrea explanata, Cillaris florigemma, Opis, Plicatula, Lithodomus, and other inhabitants of the reef; while another pit is opened in soft yellowish oolite, withont corals, but containing Nucleolites scutatus and Holectypus depressus. This coral reef is not of large extent, for no such rock was fomd in a boring $2 \frac{1}{2}$ miles north-west of Upware.

The Ampthill Clay was recognised by Mr. Roberts in Lincolnshire. It forms a narrow band between the Oxforl and Kimeridge Clays from Bardney on the Witham to Briggs and Wrawby, and it yields the same fossils as in Bedford and Cambridge. Its thickness is not less than 20 feet, and may be more.

In Yorkshire the Corallian attains an musnal thickness and occnpies a large area of gromnd round the Vale of Pickering. It has been specially studied by Messis. Blake and Hudleston and by Mr. Fox-Strangways, from whose memoir the following tabular view of the succession near Pickering has been taken :- 


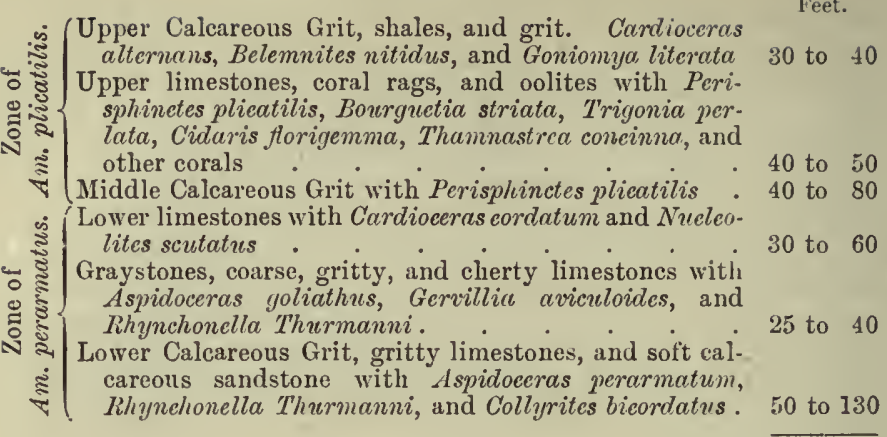

From 215 to 400

3. The Kimeridge Clay.-This formation takes its name from Kimeridge Bay near St. Alban's Head in Dorset, where it has a thickness of no less than 1000 feet and is divisible into-

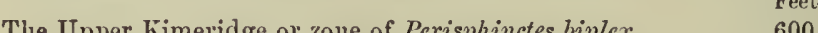

The Upper Kimeridge or zone of Perisphinetes biplex . . . 600

The Lower Kimeridge or zonc of Cardioceras alternans. . . 400

In Dorset and Wilts the lower part consists of dark clays and shales with layers of septaria and cement-stones; these beds yield Cardioceras alternans, Perisphinctes mutabilis, Ostrea deltoidea, and Rhynchonella inconstans. The upper beds are black bituminous shales and grey papery shales, often full of broken and compressed shells ; they yield Perisphinctes biplex, Protocardia striatula, Thracia depressa, Exogyra virgula, and Lucina minuscula. Reptilian bones occur throughout the Kimeridge Clay, and among them are remains of two species of Pterodactyles.

There are few good inland sections of the Kimeridge Clay, and its thickness is greatly diminished in passing through Dorset and Wiltshire, for at Swindon it is estimated to be only about 300 feet; and in Berkshire and Oxfordshire it is not much more than 100 feet, but is still divisible into the two zones.

Near Aylesbury the Kimeridge Clay is not more than 100 feet thick, and merges upward into a sandy clay containing Portlandian fossils (the Hartwell Clay). Near Leighton Buzzard, and thence through Bedfordshire, most of the Kimeridge Clay is concealed by the Cretaceous sands, and does not emerge again till we reach the neighbourhood of Papworth in Cambridgeshire, where it appears above the Ampthill Clay, and runs in a narrow belt by Knapwell, Boxworth, and Cottenham to the Fens.

Near Ely this clay has been largely dug, and both zones (upper 
and lower) have been recognised. 'The lower (from 80 to 90 feet) contains Cardioceras alternans, Astarte supracorallina, Ostrea deltoidea, etc.; the upper, of which only 16 feet is seen, contains Excogyra virgulu and Orbiculoidea latissima, but still higher beds niny be concealed beneath the Cretaceous rocks.

In Lincolnshire both lower and upper divisions are well developed, and the whole stage is probably about 600 feet thick. The lower beds are exposed near Horncastle, Wragby, Market Rasen, and Wrawhy near Caistor. At Rasen they yield many finely preserved fossils which include Cardioceras alternans, Perisphinctes mutabilis, Trigonic Juddiana, Inoceramus rasenensis, Thracia depressa, and Nucula Menkei. The upper beds are mainly shales, seen near Spilsby, Fulletby, and West Ashby, and yielding Per. oiplex, Protocardia striatula, Lucina minuscula, Lingula ovalis, and Orbiculoidea latissimu.

In Yorkshire the Kimeridge Clay is not well exposed, for though it doubtless underlies a large part of the Vale of Pickering, it is concealed by Glacial drifts, and only the highest beds are exposed on the shore at Speeton Gap. These consist of brown and black shales containing Perisphinctes biplex (?), Ostrea gibbosa, Discina latissima, and Lingula ovalis.

4. The Portland Beds or Portlandian. - Like the Kimeridge Clay, these beds are thickest in Dorset and thin nortlwards. They are well exposed between Durlstone Head and St. Alban's Head (see Fig. 149), where they are divisible as follows :-

Feet.

Upper Portlandian fFreestone Beds . . . . 40 to 50 zone of Holc. giganteus / Cherty Beds \&. . . 60 to 75

Lower Portlandian rSandy marls, sands, and ealeareous zone of Perisph. gigas i sandstolle. . . . . 130 to 160

230 to 285

'The hard sandy marls of the lower group contain Perisphinctes biplex, Exogyra bruntutana, Trigonia incurva, Tr. Pellati, and Rhynchonella portlandica. The "cherty beds" are brown earthy limestone with irregular layers and nodules of flinty chert; Pecten lamellosus and Protocardia dissimilis occur in these beds. The freestones are oolitic limestones, which are largely quarried for building stone; they contain Trigonic gibbosa, Perna mytiloides, Cerithium portlandicum, and Holcostephanus giganteus.

At Portland the snccession is similar and the total thickness about 220 feet, but at Upwey, north of Weymouth, a different facies presents itself, the whole Upper Portlandian having passed into a white clalky limestone with black and grey flints. This 


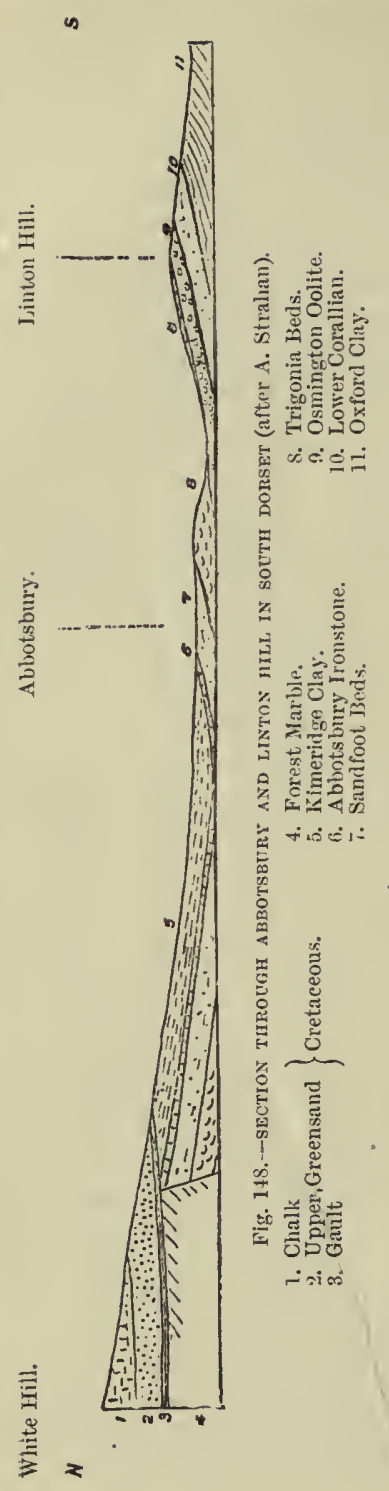

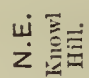

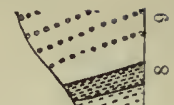

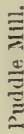

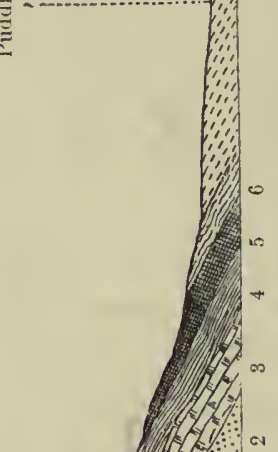

莣

$\dot{8}$

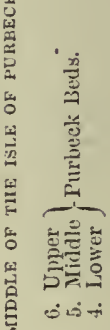

至

of

है

要

cisis: 
is not more than 30 feet thick, while the sandy beds are about 60 feet, so that the whole is less than 100 feet. In the Vale of Wardour both chalky and oolitic limestones occur, and each division of the stage is fiom 50 to 60 feet thick.

The next good exposure of the Portland Beds is at Swindon, where the limestones are partly replaced by sands. The beds are exposed in railway cuttings and quarries, and the combined succession is given by Mr. H. B. Woodward as follows :-

\begin{tabular}{|c|c|c|}
\hline & Marly and oolitic limestoncs & $\begin{array}{l}\text { Peet. } \\
6 \text { to I2 }\end{array}$ \\
\hline $\begin{array}{c}\text { Upper } \\
\text { Portlandian }\end{array}$ & $\left\{\begin{array}{l}\text { Whitish sands with lenticular layers of cal- } \\
\text { eareous sandstone . } \\
\text { Marly and oolitic limestoncs with Irigonia } \\
\text { gibbosa and Cerithium porlandicum }\end{array}\right.$ & 20 to 25 \\
\hline \multirow{3}{*}{$\begin{array}{c}\text { Lower } \\
\text { Portlandian }\end{array}$} & Blue clay weathering brown. & 14 to $20^{2}$ \\
\hline & Marly sandstone with Exogyra bruntutana. & 6 to 8 \\
\hline & Sands with dogrgers of calcureous sandstone & 30 to 40 \\
\hline
\end{tabular}

About 100

In the Midland comnties the only good exposures of the Portlandian are in Buckinghamshire near Thame, Brill, and Aylesbury, where they exhibit a special facies different from that of Dorset or Wiltshire. The succession is as follows:-

Grey marls and thin limestones, Holcostephanus

Feet. giganteus, Ostrea expanse, and Trigonic gibbosa. . . . 8 to 12

Upper

Portlund, 26 feet

Marly and shelly limestones, Trigonia gibbosa.

Greenish-yellow sand .

5 to 8

Marly and rubbly limestonc with fossils

Yellowish-green sand with a bed of small pebbles f of quartz and lydianite at the base.

5 to 6

10 to 15

8 to 10

Hartwell

Clay Pellati

20 to 30

Near 'Thame there are yellow and green sands below the pebblebed, but these thin out or pass into clay northward; the Hartwell Clay being apparently the equivalent of the Portland Sands.

The most northerly outlier of these beds is at Stewkley Warren, 4 miles west of Leighton Buzzard, where about 15 feet of them, capped by a few feet of Purbeck Beds, was at one time exposed. Beyond this they are not seen either in Bedford, Caubridge, Norfolk, or Lincoln, but derived and phosphatised Portlandian fossils are of frequent occurrence in the Lower Cretaceous sands, and consequently it is most probable that they originally extended through these counties, but were destroyed at the beginning of the Cretaceous period.

In Yorkshire, at Speeton, the Kimeridge Clay is surmounted 
by a bed of black phosphatic nodules, the "coprolite bed," and the clays above this contain Ammonites which resemble Portlandian species, so that the beds have been classed by some as Portlandian. As, however, the Ammonites are not identical with Portlandian forms, and as the Neocomian Belemnite ( $B$. lateralis) occurs throughout, with Hoplites regalis in the higher part, the beds are probably of Lower Cretaceous age (see p. 484).

5. The Purbeck Beds.-The typical Purbeck Beds are only found where the Portland Beds are completely developed. They are a variable set of beds exhibiting alternations of terrestrial, freshwater, brackish-water, and estuarine conditions, the changes from brackish to freshwater deposits being generally gradual, while the reverse changes are abrupt, indicating sudden inroads of the sea. In Durlston Bay, near Swanage, these beds are 400 feet thick, and have been divided into Lower, Middle, and Upper Groups, characterised respectively by Cypridea purbeckensis, C. granulosa, and C. punctata (see Fig. 149). The following is a summary of the cliff section:-

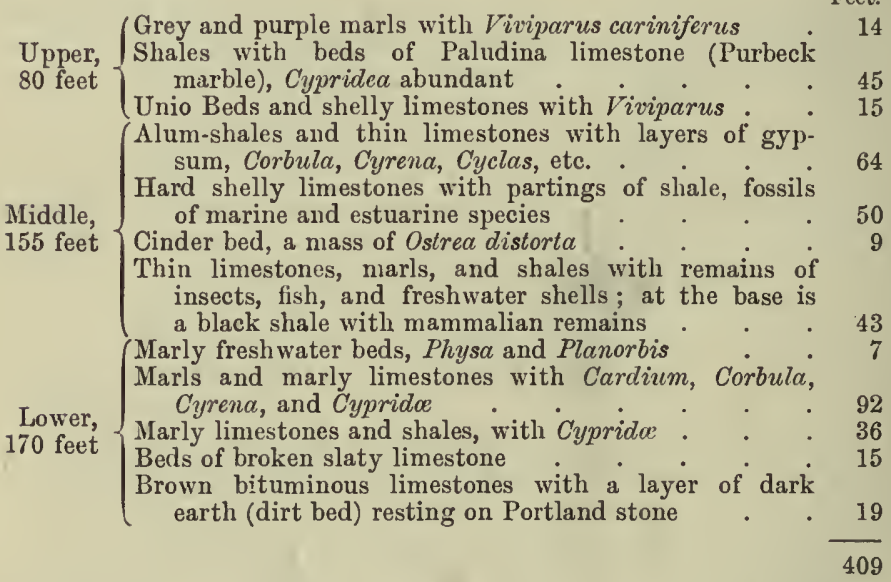

Feet.

The same series can be seen in Worbarrow Bay, Mupe Bay, and Lulworth Cove, but it becomes thinner to the westward, 250 feet at Mupe Bay, only $\$ 76$ feet at Lulworth, and at Ridgeway Hill 190 feet. $^{20}$

The lowermost beds are well exposed in the quarries at Portland, where the most remarkable stratum is the upper "dirt bed," which is a dark-brown loamy earth-an actual soil or terrestrial surface, in which cycads and coniferous trees are still rooted. 
'The Purbeck Beds are cut oft and faulted against the Chalk and (ireensand by the great Ridgeway fault, and they are not seen again till they crop ont in the Vale of Wardour (Wilts). The succession in this area, as described by Mr. W. R. Andrews and myself in 1894, ${ }^{21}$ with such subsequent corrections by Mr. H. B. Woodward ${ }^{22}$ as we accept, is as follows :-

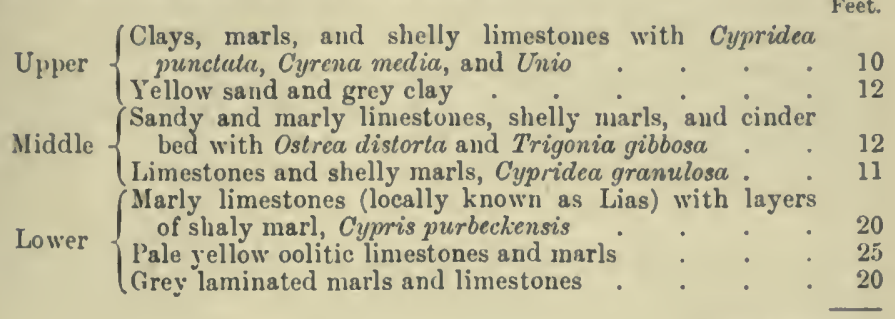

Total about 110

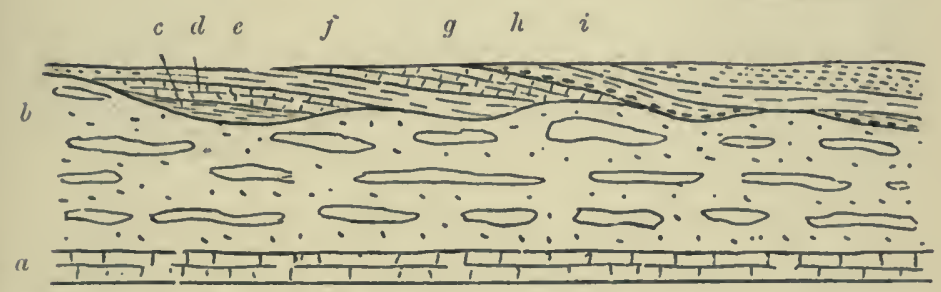

Kig. 150.-Diagramaitic view of the swindon quarrieg (after Professor J. F. Blake).

$g, h, i$. Purbeck Beds.

$c, d, c, f$. Portland limestones. b. Sand with calcareous doggers

c. Portland limestone.

The Lower Purbeck Beds are seen again at Swindon, where they rest partly on the Upper Portland and partly on the Portland sands (see Fig. 150), and their basement bed contains rolled lmmps of stone derived from the Portland Beds.

In the Midlands the Purbeck Beds only emerge from beneatl the Cretaceous strata in Oxford and Bucks. Around Thame, Aylesbury, Brill, and Whitchurch the Portland Beds are succeded by a variable group of beds with freshwater fossils, which are generally considered to be of Purbeck age. They consist of a variable series of thin<bedded limestones, marls, shales, clays, and calcareous sands, but do not exceed 30 feet in thickness, and probably represent the Lower Purbeck only, the higher beds having been removed by Cretaceons erosion. They lave yielded remains of Plants, Insects, and Cyprides, with Viviparus, Cyrena, Modiola, and the fish Lepidotus minor, Pleuropholis serrala, Aspidorhynchus, and Mesodon. 
The only other part of England where Purbeck Beds have been found is in Sussex north-west of Battle, where narrow strips of them are brought up by anticlinal flexures from below the Wealden Beds. They consist of shales with beds of limestone which were formerly quarried, and the succession proved by shafts and given by Mr. Topley ${ }^{23}$ is :-

Shales with beds of limestone and some of calcareous sandstones,

Cyp. punctata and C. granulosa . . . . 80

Black, grey, and greenish shales with ironstone nodules : . 130

Bluish-grey limestones and shales, witl Ostrea, Cardium, Cyrena,

and other fossils . . . . . . . . . . 75

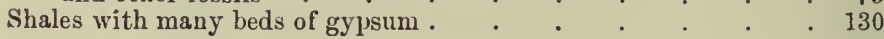

415

Purbeck Beds have also been traversed by many of the borings which have recently been made in Kent, and the records show that the group thins both to the north and east. Thus at Pluckley, about 16 miles north-east of the outcrops in Sussex, they are only 100 feet thick, and at Brabourne, about 10 miles farther east, they have diminished to about 60 feet. They were not fonnd in any of the borings to the north or east of that place, though this nay be due to the planing off of beds below the Vectian sands.

\section{The Upper Jurassic Series in Scotland}

West Coast.-The only member of the Upper Jurassic series which is found on the west coast of Scotland is the Oxford Clay. This overlies the great estuarine series in the islands of Skye and Eigg, and consists of blue clays containing Cardioceras cordatum, Card. excavatum, Quenstedticeras Lamberti, and others. Above it are Cretaceous rocks.

East Coast.-In Sutherland a much more complete series is found; the beds are seen at intervals along the coast for a distance of 16 miles, and form a narrow strip of low ground which is bounded inland by a powerful fault, and has an extreme width near Brora of about 2 miles. In this small space is found a succession of beds representing the whole of the Oxford Clay, Coral Rag, and part of the Kimeridge Clay, as below :-

Light-coloured sandstone; no fossils

Feet.

Shelly limestones, black shales, and grits with Belem-

Kimeridge $\left\{\begin{array}{r}\text { nites abbreviatus, Cardioccras alternans, Perisphinctes } \\ \text { biplex, and many others; ferns, cycads, and conifers }\end{array}\right.$ Clay

White sandstones and carbonaceous shales; estuarine beds with few fossils

Grits and sandstones; Perisphinctes biplex, Per, mutc100 


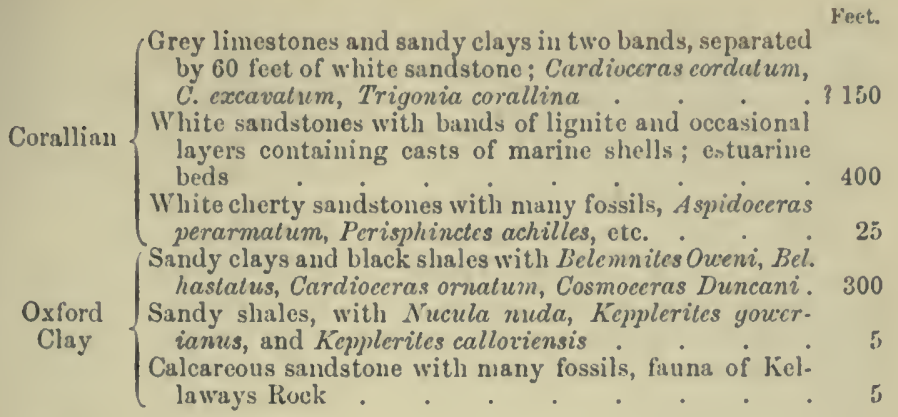

\section{E. Continentai Equivalexts}

\section{Northern and Eastern France}

In the great Parisian basin the general facies of the Upper Jurassic Series is similar to that of England, except that it is more calcareous It can be divided into a similar series of zones and sub-stages, but unfortunately the original English divisions were not founded on zones but on local lithological differences, and though the English names have been widely adopted on the Continent, they have become attached to groups of strata which do not exactly correspond with the English divisions.

Some adjustments of nomenclature will be required on both sides of the Channel in order to bring the naines of the several stages into accord. Thus French geologists lave created two stages, a Callovian and an Oxfordian, but the latter is the zone of Aspidoceras perarmatum and equivalent to the Lower Corallian of England; while the Callovian includes the ornatum clays, though these have since been separated as a sub-stage under the name of Divesian. Thus their Callovian is practically our Oxfordıan.

Again there has been much confusion about the correlation of the equivalents of the Corallian and Kimeridge Clay in France, for the beds which represent our Upper Calcareous Grit are know11 as the Astartian or Sequaniun, and have been classed in some places with the Corallian and in others with the Kimeridgian limestones. De Lapparent, following Tombeck, dropped the name Corallian altogether, and advocated an expanded Sequanian as its substitute; but Messrs. J. F. Blake and T. Roberts, who both carefully studied the Upper Jurassic Series of Eastern France and the Jura, agree in thinking that the Astartian is more closely allied to the Kimeridgian than to the Corallian."2t

On the other hand, they agree that the Euglish Kimeridge 
Clay is an exceptional argillaceous facies, and that it is represented in France and in Germany by thick masses of limestone and marl which belong to several sub-stages or zones. Even in Normandy and the Boulonnais the lighest part of our Kimeridge Clay is represented by calcareous sandstones which are faunistically linked to the Portlandian stage.

Lastly, French geologists regard the Purbeck Beds as a subordinate portion or sub-stage of an expanded Portlandian stage, and they have good reason for this because the marine equivalents of the Purbeck Group contain a fauna which is closely related to that of the Portlandian.

The student will now be able to understand the following tabular correlation of the succession found in France and in the Jura Mountains with the English subdivisions, these and the French divisions having the value of sub-stages.
England.
4. $\left\{\begin{array}{l}\text { Purbeck Beds } \\ \text { Portland Beds } \\ \text { Clays with Discina }\end{array}\right\}$
Paris Basin.
Purbeckian
Jura.
Bononian
Marls and limestones.
Clays witl Ex. virgula
3. $\left\{\begin{array}{l}\text { Clays with Ex. virgula } \\ \text { Clays with } A \text {. alternans } \\ \text { Sandsfoot Beds, etc. }\end{array}\right.$
2. $\{$ Corallian limestone
$\left\{\begin{array}{l}\text { Lower Calcareous Grit } \\ \text { Lew }\end{array}\right.$
Virguliau
Pterocerian
Astartian
Corallian
Oxfordian
1. $\left\{\begin{array}{l}\text { Oxford Clay } \\ \text { Kellaways Beds }\end{array}\right.$
Divesian
Callovian(restr.) Rough limestone.
Massive limestones.
Compact limestones.
Pale limestones.
Grey limestones and marls.
Coralliau limestones.
Oxfordian limestones.
Ironstone and clay

It will be seen that a good correlative grouping of these sub-stages into four stages would be made in accordance with the brackets, and that these stages could be called respectively (1) Oxfordian, (2) Corallian, (3) Kimeridgian, (4) Portlandian. The total thickness in the Jura is not more than 1200 feet.

The most important and interesting grouls are the Corallian, the Pterocerian, and the Purbeckian. The Corallian swells ont in Lorraine, Burgundy, and the Jura, and includes thick masses of coralliferons limestone, of ten over 300 feet thick, which the French regard as true coral-reefs; they contain Diceras arietinum, $D$. eximium, with Comoseris moandroides, and other corals.

The Pterocerian in the Ardennes, Meuse, and Aube consists of clays, marls, and limestones with Perisphinctes decipiens and Exogyravirgula, not very different from the corresponding part of our Kimeridge Clay; but southward they are replaced by massive limestones and marls containing a different set of fossils, especially Harpagodes Oceani, Natica gigas, Pholadomya Protei, and Hemicidaris Thurmanni.

The Purbeckian is divisible into two parts, the lower, about 150 
feet thick, consisting of dolonitic limestones containing Cyrena rugose, Corbula inflexu, and other marine species, the upper being a few feet of uarl witl brackish and freshwater fossils; and these beds pass up into the Valenginian, which is classed as Lower Cretaceous, but may represent the highest part of our Purbeckian as well as some of the Wealden.

\section{Germany}

The Upper Jurassic Series is well developed in Hanover, and extends westward into Westphalia beneath the Cretaceous deposits. The succession established by the labours of Seebach and Creduer has been compared with the English Series by Dr. C. Struckmann, and the following table is compiled from his unemoir, a translation of which will be found in the Geol. Mag. for 1881, p. 546 .

\begin{tabular}{|c|c|}
\hline $\begin{array}{l}\text { P'ort- } \\
\text { landian }\end{array}$ & $\begin{array}{l}\text { Serpulite linestone, } 10 \text { to } 60 \text { feet } \\
\text { IInndermergel, gypsiferous marls } \\
\text { Plattenkalk of Eimbeckhauser (platy limestones). }\end{array}$ \\
\hline $\begin{array}{l}\text { lime- } \\
\text { rillgian }\end{array}$ & $\begin{array}{l}\text { Limestones and marls with Perisphinctes gigas. } \\
\text { Virgula Beds, compact and oolitic limestones. } \\
\text { Pteroceras Beds, limestones with Harpagodes Oceani. } \\
\text { Nerince Bods (= Astartian), linrestones. }\end{array}$ \\
\hline Corallian & $\begin{array}{l}\text { Upper Cor. limestones (zone of Pecten varians). } \\
\text { Lower Cor. limestones (zone of Ostrea rastellaris). }\end{array}$ \\
\hline Oxfordian & $\begin{array}{l}\text { Hersumer Beds. Sandy beds with Aspidoceras perarma. } \\
\text { tum, Cardioceras cordatum, and Gryphaca dilatata. }\end{array}$ \\
\hline Call & Macrocephalus Beds, clays and ironstones. \\
\hline
\end{tabular}

It will be seen that the greater part of the series consists of limestones with some clays at the bottom and a remarkable development of marls near the top; these are of red and green colours and much resemble the marls of the Keuper; they are from 400 to 500 feet thick in Hanover, but thicken westward to over 1500 fiet in Westphalia, where they include limestones full of Corbula, Vivipara, and Cyclas, as well as beds of gypsum and rock-salt. The Serpulite limestone is full of small Serpula tubes, but also contains Corbula.

In the south of Germany (Swabia and Franconia) the Upper Jumssic Series is again found, but has a different palaontological facies. Its thickness is only from 800 to 1000 feet, and the succession of zones is as below:

Port. $\left\{\begin{array}{c}\text { Zone of Oppelia steraspis and Perisphinctes gigas, } \\ \text { (Plattenkalk and Solenhofen limestones) }\end{array}\right.$. Feet.

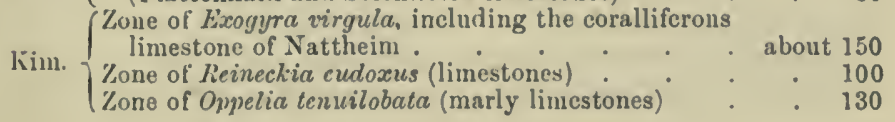


Cor. - Zowe of Peltoceras bimammatume
Oxf. $\left\{\begin{array}{c}\text { Zone of Peltoceras trasversarium and Waldheimia } \\ \text { impressa (narls, clays, and limestones) }\end{array}\right.$
Cal. $\left\{\begin{array}{c}\text { Zone of Ornatus Ammonites (clays), with Macro- } \\ \text { cephalus limestone at base. }\end{array}\right.$

The most interesting member of this series is the lithographic limestone of Solenhofen, which must have been deposited in very quiet and clear water and not far from land; for though it is of marine formation and contains several species of Ammonites and Belemnites with Crabs, Starfish, and other sea-creatures, it also encloses entire skeletons of Pterodactyles and the remains of the curious bird Archooopteryx (see p. 384), as well as the remains of dragonflies, cockroaches, wood-wasps, and ordinary flies (Musca and Empidia); all in the most beautiful state of preservation owing to the fine grain and slow deposition of the limestone.

\section{The Alpine Facies}

In the Alpine region the lower part of the "Upper Jura" has but a small developinent; the Callovian, Oxfordian, and Corallian being only represented by bands of limestone which do not always contain the characteristic species of Ammonites. The higher portion of the series, however, swells out into a massive series of limestones from 1000 to 2000 feet thick, which form a special facies of the Kimeridgian and Portlandian stages. At the base of these beds are limestones which frequently contain Oppelia tenuilobata, and consequently represent the Lower Kimeridgina (or Astartian). The middle part of the series consists of reddish

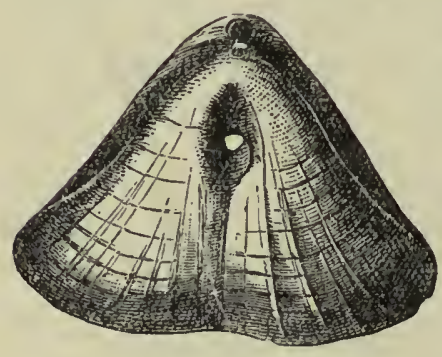

Fig. 151. - terebratula Diphya. limestones so full of Terebratula diphya (now called Pygope janitor) that they are known as the Diphya limestone. The upper beds are massive pale-coloured limestones, often called the Stramberg limestone from Stramberg in Moravia, and they also contain Pygope janitor as well as Ammonites, Diceras, Nerinæas, and Corals.

These Diphya limestones are sometimes called the Tithonian or the Tithonic facies of the Portlandian, for they contain the Portlandian Ammonoids Oppelia steraspis and Oppelia lithographica 
as well as other peculiar species, such as Phylloceras ptychoicum and Waagenia hybonota. In the Stramberg limestone Phylloceras silesiacum and Perisphinctes transitionis also occur, and this limestone may be the equivalent of our Purbeckian. This facies extends from the Ceutral Alps and the north of Italy through the Tyrol and Austria to the Carpathians and is found also in the Balkan States.

\section{The Russiun Fucies}

As already stated the oldest Jurassic deposits in Russia are of Oxfordian age, and the fauna of these and the succeeding Corallian and Kimeridgian Beds is similar to that of their equivalents in Western and Central Europe; the highest part of the series forms a special Russian or Boreal facies, differing in so many respects from the normal Portlandian that Nikitin proposed the name Volgian for this set of beds. Although the thickness of the group is very small-only a few feet of sand and shale with layers of plrosplratic nodules-several Ammonite zones have been detected in it, and it passes up into beds of Lower Cretaceous age.

The beds were evidently formed in shnllow water and under the influeuce of strong currents. The prevalent genera of Ammonites are Perisphinctes, Virgatites, Holcostephanus, and Craspedites, witl Belemnites of the absolutus type and shells of the bivalve Aucella.

The best sections are near Moscow and in the province of Simbirsk, especially between Simbirsk and Syrzan on the Volga, where, however, the beds are very thin, the succession according to Professor Pavlow being as follows in descending order :-

4. Calcareous sands with Craspcdites subditus . . . . ?6 feet

3. Glauconitic sand with Holcostephanus Bladei, Holc. triplicatus, and Pcrisphinctes of. gigas .

2. Sand with phosphate nodules and shales with Virgatites virgatus, Belemnites absolutus, etc. . . . . . 3 ,,

1. Shales with Perisphinctes Bleicheri and Aucella Pallasi " '2 ",

The subditus zone is correlated by Pavlow with the Purbeck Beds, but this is uncertain (see p. 491). It will be noticed that the underlying Portlandian is only 6 feet thick, but near Moscow the corresponding beds have a thickness of 26 feet.

\section{History of the Jurassic Period}

Liassic Time. - We have seen that it is convenient to date the beginning of this period from the subsidence whicl permitted the Sonthern Sea to make its way into the great Inland Sen which 
occupied so large a part of Northern Europe in later Triassic tiue. The level of the water in the Inland Sea seems to have been somewhat below that of the outer ocean, because the Rhrtic Beds here and there pass beyond the limits of the Keuper, but the difference of level cannot have been great, and the invasion of the area by the outer sea seems to have been accomplished quietly and with little disturbance of previously formed deposits. The sea-waters simply occupied the basins and embayments of the great lake, in which shales and limestones began to be deposited.

It is clear, however, that the mingling of sea and salt-lake waters resulted at first in the death of many of the creatures which inhabited both. The fish and marine reptiles which came in from the sea could not exist in the highly saline mixture, and their remains are found in the bone-bed which so often occurs at or near the base of the Rhætic Beds. Neither could all the Mollusca which came in with then flourish in the land-locked waters, and those that managed to exist are small in size, as if dwarfed by unfavonrable conditions.

In some localities there are several bone-beds at successive horizons, suggesting that there were several invasions of the sea over the barrier which separated the inner from the outer waters. Such irruptions may have taken place at conjunctions of high tides and southerly winds. Moreover, in Alsace and Lorraine, and again in Glamorgan, the Rhxtic sandstones and bone-beds are overlain by a band of red marls exactly like those of the Keuper, from which we may infer that communication with the outer sea was not yet permanent, and that there was a time when the area of the inland sea was again diminished by evaporation so that portions of it returned to the condition of separate salt lakes.

At length a further subsidence brought in such a body of seawater that permanent marine conditions were established, and many forms of life were able to inhabit the northern water-spaces. It was under these conditions that the shales and limestones of the Lower Lias began to be deposited.

The material of the shales was probably obtained from the erosion of Palæozoic shales, and more especially from those of the Coal-measures, large tracts of which must then have existed as part of the continental land to the west and north of the Liassic Sea. During the Permian and Triassic periods the climatic conditions had been like those of Central Asia at the present day, with a small rainfall, but in Liassic time it is evident that the climate was greatly clianged, and that much more rain fell over the whole region, so that active erosion went on, and the rivers carried much mud into the Liassic Sea. 
With respect to the limestones, it is noticeable that they are thin-bedded and compact and mostly of an earthy or argillaceous nature, so that they uust have been originally inore or less calcareous muds. Hence it is probable that the calcareous matter had a chenical or sedinentary rather than an organic origiu. Mr. H. B. Woodward thinks they may have been derived mechanically from the waste of Palwozoic limestones, ${ }^{23}$ but it is more likely that the conditions were favourable to the chemical precipitation of carbonate of lime from solution.

The geographic arrangement of land and sea in Liassic time was at first only a modification of that which prevailed in Keuper time (see Fig. 124); but the sea gradually extended itself over a larger area. There is no evidence that the Lower Lias occurs under the northern part of the Paris basin, and there is no trace of it in the Boulonnais. In Normandy it only occupied what may be called the bay of Carentan, and does not occur near Caen. The Middle Lias, however, extends much farther south, patches of it being found at intervals iu the Departments of Calvados, Orne, Sarthe, and Maine, while Upper Lias has been reached in a deep boring at Rouen. Thus it appears that by the time of the Middle Lias a channel of communication had been established between the British Sea and that which spread over the greater part of France.

There were, however, two large islands in this western part of the Liassic Sea. One of these was the central plateau of France; proof of this is found in the fact that the Charnouthian deposits, in the form of sands and conglomerates, overlap the Sinemurian at niany places round its borders, and rest directly on the Archrean rocks. Similarly in Poitou, near Thouars, the Toarcian in its turn passes beyond the Charmouthian as a consequence of continued subsidence. The other island lay farther north; it comprised a part of Eastern England and the southern part of the North Sea, with the north-east of France and the whole of Belgium.

The Liassic Sea seems to have occupied the whole of Germany and Central Europe, as well as Italy and the greater part of Spain, and it extended eastward through Hungary to the Carpathian Mountains, and through Transylvania to Kronstadt, but it does not scem to have reached so far east in Northern Europe, for no Liassic deposits have yet been found in Polaud or Western Russia.

Glevanian Time.- In the west of Europe and in those places where the succession of marine deposits is most complete, as in the south-west of England, the north of France, and the Jura Mountains, there is a more or less rapid change from Liassic Clays through sands to limestones. There is also a considerable change in the fauna, and it is evident that the sea-water became clear where it had been 
muddy, and in consequence a new fauna was able to establish itself in French and British Seas.

The cause of this change, so far as the British area is concerned, has been discussed in my Building of the British Isles, the conclusion arrived at being that there was first a slight uplift of the whole area, whereby river-erosion was checked, and that this was followed by unequal movements, some parts of the region being further raised and others depressed. These inferences appear to be applicable also to Northern France (Normandy and the Boulonnais), but not so. much to the central or southern parts of that country.

Both the Bajocian and the Bathonian are well developed round nearly the whole circumference of the Central Plateau. On the northern border they consist entirely of limestones, the Bajocian being from 150 to 250 feet thick, and the Bathonian from 300 to 400. In the Côté d'Or and along the eastern side of the Plateau the composition and thickness are similar, while on the south, in the Causses district (Tarn and Aveyron), they are represented by massive limestowes which have an aggregate thickness of 1200 feet. It is only on the south-west that the marine limestones are thin and are interstratified with estuarine deposits.

No overlap of the Lias by Bajocian or Bathonian has been recorded, so far as I can ascertain, though it must have taken place, and we may safely conclude that after some slight disturbances subsidence proceeded in this part of France, and that the central island was greatly reduced in size. The greatest subsidence was clearly over the Mediterranean and Alpine region, and a broad communication was opened up, through Provence, Dauphiny, and the Jura, between the northern seas and a warm southern sea, by means of which numerous Corals, Brachiopoda, Gastropoda, and Cephalopoda made their way into the Franco-British areas.

The Belgian island still continued to exist, though the overlap of the Bathonian in Kent and the Boulonnais shows that its area was diminished to some extent. There is evidence of another island having existed in Servia near Milanovitz, and there may also have been others within the European region.

The whole of Northerm Russia and the whole of Scandinavia. appear to have been land, into the western border of which small gulfs penetrated from the Central European Sea.

Clavinian Time.- With respect to the early part of this epoch there can be no doubt that it witnessed a still more rapid subsidence of the whole European region, a subsidence which submerged islands and carried the sea eastward across Central Russia into Asia. This change is only partially expressed in De Iapparent's maps, for though he indicates the extension of the Callovian Sea 
through Russia and northward to the Arctic Ocean, the islands in the western part of this sei are not only retained, but are suarcely diminislied in size; moreover, in his "Sketch of Oxfordian Europe" they have actually grown larger.

British geologists believe that the subsidence of the Callovian or beginning of Oxfordian time was a general one, affecting the western as much as the easteru parts of Europe. It is probable that the Upper Jurassic Clays spread over the whole platform of Palieozoic rocks which underlies the east of England, and that these clays were subsequently removed partly by subaerial erosion and partly by the planation of the area as it Eank beneath the Upper Cretaceous Sea. My view is that the whole of the AngloBelgian island was submerged beneath the seas of Oxfordian, Corallian, and Kimeridgian times, and did not reappear until the Portlandian, for the thinning of the Corallian and Kimeridge Beds in the Boulonnais is doubtless due to their subsequent planation and not to their originally thinning out against a shore-line.

Another question arises with regard to the northern extensions of the Oxfordian and Corallian Seas, for some have supposed that the comnection between Scotland and Scandinavia was severed at this time and that the Scandinavian region, together with Lapland and Finland, became a large island. There can be no doulbt that the Middle Jurassic Sea did pass round the eastern and northem sides of this land, for not only are there deposits of this age in Northern Russia in the province of Volodka, but also to the north. east of the White Sea and in the valley of the Petchora. They also occur in König Karl Land and Spitzbergen, forming a succession from Callovian to Kimeridgian, and beds of Oxfordian age have been found on the east coast of Greenland (Kuhn Island and Jaineson Land).

Hence it is quite possible that the Boreal Sea of Oxfordian time did extend southward to Scotland and thus encircled the Scandiuavian region, but it is much more probable that the counection with the Germano-British Sea was round the western side of Scotland and across the north of England than directly between Scotland and Norway. The Jurassic strata of the Western Isles were undoubtedly formed in a sea which covered the northwestern arm of the great Triassic lake, and there is no reason to suppose that Jurassic deposits were ever formed in the east of Scotland sonth of Elgin or in the south-west of Norway. The Kimeridgian Beds of Sutherland seem to have been formed in the estuary of a river which may have opened either northwards into the Boreal Sea or south-westward down tlie valley of the Great Glen. I see no reason for supposing that the Ceutral Higlulands 
of Scotland were severed from their original connection witl Norway in the Jurassic period, or that any sea flowed between the two areas until the great submergence of the Cretaceous period.

The Corallian episode probably indicates a pause in the subsidence or a diversion by some other means of the nud-bearing currents, so that for a time they did not pass over Southern or Northern England though they continued to traverse the intervening space. But matters reverted to their former condition in Kimeridgian time, and the geographical arrangement of land and sea must have continued to be practically the same.

The Portlandian deposits, however, give evidence of a great change and of a reverse movement by which the sea-floor was shallowed over the whole of Northern and Western Europe, large parts of it being once more raised into dry land. Thus a western land was formed again in the North Atlantic which included the greater parts of Britain, France, and Spain; the Anglo-Belgian island again came into existence, and was only separated from the western land by a narrow strait running through the counties of Bedford, Huntingdon, and Cambridge.

The Boreal Jurassic Sea must have retreated northward, but for a time there still remained an arm or gulf extending fron Germany across the North Sea area into Yorkshire and Lincolnshire, but the later Portland and Purbeck deposits of Hanover show that this gulf was shallow and was soon converted into a plain with lagoons and freshwater lakes.

Southern Europe was much less affected by this Portlandian and Purbeckian elevation, and marine limestones continued to be formed in a southern (Tithonian) sea which was nearly as extensive as it had been in Oxfordian and Corallian times. From this sea a gulf extended through the east of France and across the Parisian plain to terminate in the estuarine lagoons wherein the English Purbeck Beds were deposited.

The final phase of Jurassic geography was the establishment of a North Atlantic and North European continent, and the gradual transformation of the Purbeck lagoons into the Wealden lake by the continued uprise of the whole surrounding region.

In conclusion, reference should be made to Neumayr's theory that there is evidence of the existence of climatic zones in Upper Jurassic time. ${ }^{26}$ From the brief review of European deposits which has been given on pp. 451 to 455 , it will be seen that they can be grouped under three different facies: (1) a Mediterranean or Alpine; (2) a more northern facies found in Germany and Poland, in Northern France, and in England; (3) a Boreal facies occurring in the north of Russia, Spitzbergen, and Greenland. Neumayr has 
pointed ont that these three latitudinal facies are not confined to Enrope but are traceable in other parts of the world; thus the Boreal facies extends from Russia through Turkestan into Tibet, and recurs in North America; the temperate type recurs in the Caucasus and the Himalaya, and again in California; while the Mediterranean type is found in Asia Minor, Algeria, and Abyssinia, and again in Mexico.

Moreover, in the southern hemisphere the Jurassic deposits found in Sontl Africa, Argentina, New Zealand, and Australia contain a fanna which does not resenble that of the Mediterranean or Equatorial facies, but is very similar to the assemblage of genera occurring in the corresponding beds of England and Germany. The facts, therefore, so far as they are known, certainly tend to confirm Nenmayr's view.

\section{REFERENCES}

1 Jukes-Browne, Geol. Mag. 1884, p. 525.

2 H. B. Woolward, "Jurassic Rocks of Britain," vol. iii. (Lias), 1893.

${ }^{3}$ L. Richardson, Quart. Journ. Geol. Soc., vol. lxvii. p. 1.

S. s. Buckinan, Quart. Journ. Geol. Soc. vol. lxvi. p. 52 (1910).

${ }^{5}$ H. B. Woodward, Op. cit. 1. 222.

${ }^{6}$ B. Thompson, Journ. North. Nat. Hist. soc. vols, ix. xi. and xii.; see also "Articles on Northamptonshire," Geology in the Field. G. Assoc. (1910).

7 Fox-Strangways, "Jurassic Rocks of Britain," vol, i. (Yorkshire), 1892.

${ }^{8}$ R. H. Rastall, Quart. Joum. Geol. Soc. vol. lxi. p. 441 (1905).

9 J. W. Judd, Quart. Journ. Geol. Soc. vol. xxxiv, p. 660 (1878).

10 J. W. Judd, Quart. Journ. Geol. Soc. vol. xxix. p. 98 (1873).

11 S. S. Buckman, Quart. Journ. Geol. Soc, vol. lix. p. 454 (1903).

12 S. S. Buckuan, Quart. Journ. Geol. Soc, vol. lxvi. p. 52 (1910).

13 S. S. Buckman, Quart. Journ. Geol. soc, vol. li. p. 388, and vol. liii. 1. 607 .

${ }^{14}$ Fox-Strangways, Op. cit. ; and Rastall in article of "East Yorkshire" in Geology in the Field, p. 592. G. Assoc. (1910).

15 H. B. Woodward, "Jurassic Rocks of Britain," vol. iv. (Oolites), 1894.

$16 \mathrm{~J}$. W. Judd, Op. cit. (1878) p. 719.

17 H. B. Woodward, "Jurassic Rocks of Britain," vol. v. pp. 8 and 15.

13 Blake and Hudleston, Quart. Journ. Geol. Soc. vol, xxxiii. p. 260.

13 "Geology of Cambridge," Mem. Gcol. Surrey, 1880; and Jurassic Rocks of Cambridge, by 'I. Roberts. Sedgwick Prize Essay (1892).

20 See "Geology of 1sle of Purbeck," Mem. Geol. Siurvey (1898).

21 Andrews and Jukes-Browne, Quart. Journ. Geul. Suc. vol, vii. 1) 44.

2.2 H. B. Woodward, Op. cit. vol. v. p. 273.

223 W. Topley, "Geology of the Weald," Mem. Geol. Surrey, p. 30 (1S75).

2s J. H. Blake, Quart. Journ. Geol. soc. vol. xxxvii. p. 497 (1851); and T. Roberts, Quert. Journ. ('eool. Soc. vol. xliii. p. 229 (1887).

${ }_{25}$ H. B. Woodward, "Jurassic Rocks," vol. iii. p. 28.

28 Neumayr in Isenksch. Wien. Akad., vol, xlviii. p. 277 (1883), and vol. 1. p. 57 (1885). 


\section{CHAPTER XIV}

\section{THE: CRETACEOUS SYSTEM}

\section{A. Nomenclature axd Subdivisions}

THIs system takes its name from creta, the Latin word for chalk, because this well-known rock forms a conspicuous part of the system in Western Europe. Beneath the chalk, however, there is a variable series of marine sands and clays, and below these in the south of England there is a great thickness of freshwater deposits which have long been known as the Wealden, from the large area occupied by them in the Weald of Kent and Sussex. In the British area it is only in Yorkshire and Lincolnshire that marine deposits of the same age as the Wealden are found, but in other parts of Europe they attain a great thickness.

The system is divisible into two great series, a Lower and an Upper. On the European continent the whole system consists of marine deposits, and a complete sequence is also found in the north of England (Lincolnshire and Yorkshire), but in the south of England the lower part is represented by the freshwater Wealden Beds, overlain by some marine deposits which were formerly and are still often called the Lower Greensand, but for which Vectian is a much better name. ${ }^{a}$

The marine facies of the Lower Cretaceous Series is most fully developed in the south of Europe, and the nomenclature of its divisions is taken from places in the sonth of France and in Switzer-

$a$ It is high time that the vames Upper and Lower Greensand were abandoned, for they were proposed by Webster at a time (1824) when the beds between the Chalk and the Wealden were regarded as the "Greensand Formation." Thus they only perpetuate erroneous views of classification, and arc, moreover, cumbrous and misleading, for the "Lower Greensand" is more often yellow or brown than green. Hence it is desirable that the name Vectian (altered from the Vectine of Fitton) should be adonted instead of Lower Greensand, while the "Upper Greensand" falls into the group of beds for which the name Selbornian has recently been proposed. 
land. The lower portion of the series is often called the Neocomian, from Neuchatel in Switzerland, where the beds were first studied and described, but this Neocomian has since been subdivided into two parts, the Valenginian and the Hauterivian, which seem to have the value of separate stages. The Barremian takes its name from Barrême in the Basses-Alpes, and the Aptian from Apt in Vaucluse.

The Upper Series includes the Selbornian, to part of which the French Albian corresponds, and the several stages of the Chalk which have received special names on the Continent, but are in England generally known as the Lower, Middle, and Upper Chalk. The stages recognised in Western Europe are tabulated below and correlated with their British representatives.

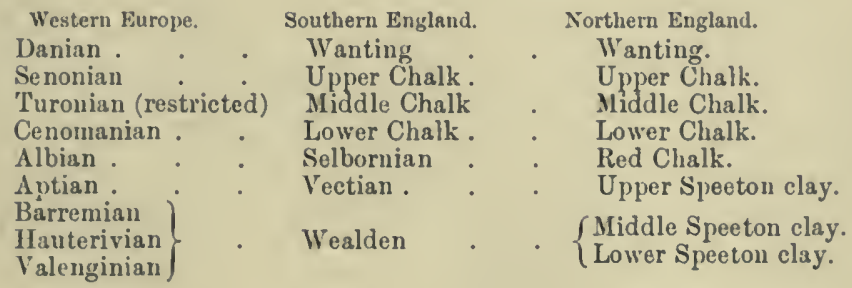

The relation of the Cretaceous strata to the underlying formations is an important matter. Throughout the greater part of Lingland there is a marked break and unconformity between the Jurassic and Cretaceous Systems, and even in Yorkshire the apparent conformity is probably deceptive, for there is nothing there which can safely be correlated with the Portlandian, and it is very doubtful whether there is any representative of the Purbeck Beds. It is only in the south of England, where the highest Jurassic Beds are fully developed, that a complete sequence of deposits is found to fill up the gap between the two systems, but these deposits are of freshwater origin and do not bridge over the gap in the marine succession.

This gap was undoubtedly caused by the elevation of the greater part of the British region into dry land, a land which extended southward into France and eastward through Belgium ; and it was only after a long period of time, marked by the formation of several thousand feet of marine deposits in the sonth of Europe, that parts of this land were again submerged and that marine deposits were laid down all across England. This change was the commencement of a great subsidence which eventually carried the Cretaceous Seas over the greater part of Europe. 


\section{B. Life of the Period}

Flora-Comparatively few traces of the vegetation of the period are found in the Cretaceous rocks of Britain except in the Wealden Beds, in which, as in the Jurassic Systenı, the predominating groups are ferns and cycads. A few conifers, horsetails (Equisetaceæ), and a Chara also occur, but Dicotyledons are unknown, although a few, the earliest of their class, have been found in the Lower Cretaceous rocks of Spain and of North America.

The flora of the Wealden presents a considerable reseniblance to that of the Jurassic strata, but as the early Cretaceous continent was only an extension of the Upper Jurassic land, such a resemblance should not cause any surprise.

In the Upper Cretaceous of the Continent Dicotyledeus form an important part of the flora, and include a number of genera which have living representatives, e.g. Acer (maple), Cinnamomum (cinnanon), Ilex (holly), Quercus (oak), Platanus (plane), Hedera (ivy), Populus (poplar), Myrica (myrtle), with Aralia, Magnolia, Eucalyptus, and the extinct genus Credneria. Cycads are less numerous than before; subsequently they became rare in Europe, and at the present day are chiefly found in the tropical and sub-tropical parts of Asia, Africa, Australia, and Mexico.

Fauna.-The general aspect of the Cretaceous fauna resembles that of the preceding Jurassic much more than that of the succeeding Eocene. Throughout the Lower Cretaceous Series many genera which were abundant in Jurassic times are still common, such as Cucullcea, Trigonia, Gervillia, Perna, Pecten, Lima, Pleuromya, and Pleurotomaria. The Ammonoid genera Holcostephanus and Perisphinctes continue to be abundant, and the Belemnitide were nearly as common, but many new genera of Cephalopoda appear, some in the lower and some in the upper division of the sistem. The Echinoid genera Holectypus, Nucleolites, and Pygurus also survive into the Lower Cretaceous, but many new genera make their appearance (see list below).

Passing to vertebrate animals, most of the Lower Cretaceous fish belong to genera which existed in Jurassic times, but Edaphodon, Lamna, and Irotosphyrona now appear, while in the Chalk many Teleostean fish resembling modern genera are found, such as Hoplopteryx, Osmeroides, Enchodus, and Portheus with the Elasmobranch Corax. Among reptiles the marine Ichthyosaurus and the Dinosaurian genera Ornithopsis and Megalosaurus survive from Jurassic time, but the Plesiosaurs are represented by Cimoliosaurus and Polyptychodon. Fresh Dinosaurs make their appearance, e.g. Iguanodon, Hypsilophodon, Hylcosaurus, Polacanthus, and Vecti- 
saurus in the Lower Cretaceous, with Acanthopholis, Anoplosaurus, and others in the Upper Cretaceous. In the sea were large lizardlike reptiles of the order Squamata (Coniosaurus, Mosasaurus, and Dolichosaurus), and in the air the Pterosauria were represented by species of Pteranodon and Ornithocheirus.

Remains of birds also occur in the Upper Cretaceous Series, but only one genus has been found in Britain, the Enaliornis of the Cambridge Greensand. In America remains are more plentiful, and three remarkable genera have been described - Hesperornis,

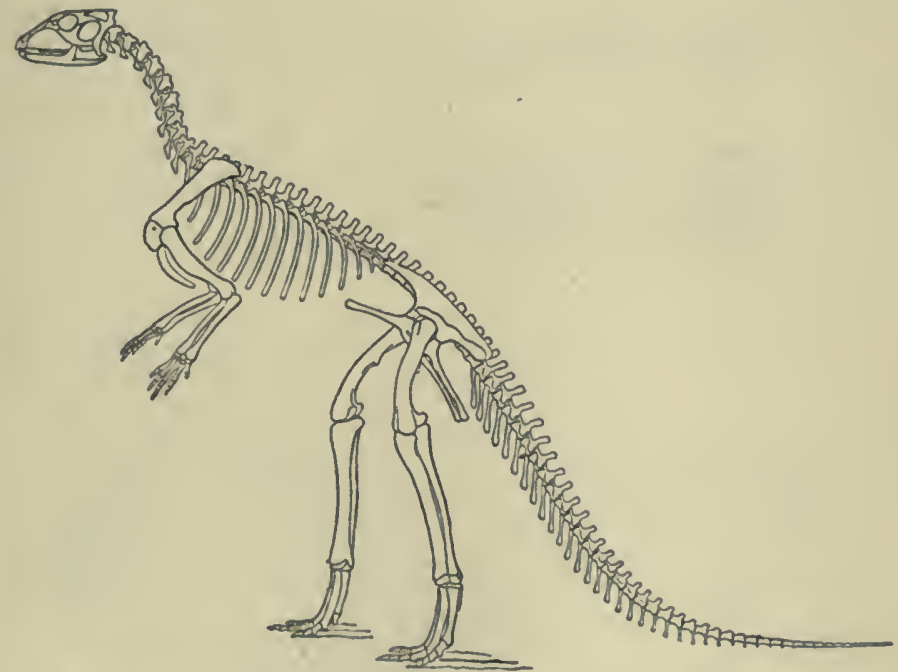

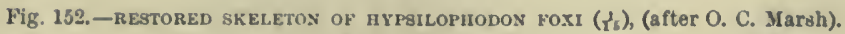
Length over 5 feet.

Ichthyornis, and Apatornis. Hesperornis was a large bird about 6 feet in length, and possessing many reptilian characters, so that it forms a link between the Jurassic Archeopteryx and more highly developed birds; its jaws were furnished with teeth planted in a long alveolar groove, its wings rudimentary, and its hind limbs strong, so that it was a wader and lived chiefly on fish. Ichthyornis and Apatornis were much smaller birds with well-developed wings, but both had reptilian skulls with teeth set in sockets, and their vertebræ were biconcave like those of Fish and Amphibians.

Mammalia also existed, though remains of them are very rare, and none have been found in England; they consist of teeth of 
small Prototheria (Cimolomys and Selenacodon) related to the Jurassic Plagiaulax, and some bones of true Marsupials referred to the genera Didelphops, Cimolestes, and Telacodon.

The following are some of the more important marine genera which first appear in the Lower Cretaceous Series :-

Porifera. Actinozoa. Barroisia, Catagma.

Echinodcrma.

Brachycyathus, Holocystis.

Crustacea.

Brachiopoda. Kingena.

Cardiaster, Catopygus, Discoidea, Toxaster (= Echinospatagus), Enallaster, Goniopjgus, Salenia.

Hoploparia, Meyeria, Mithracites.

Lamellibranchia. Crassatellites, Pectunculus, Cyprimeria, Cyclorisma, Monopleura, Requienia, Toucasia, Splærulites, Thetironia (=Thetis).

Gastropoda. Aporrhais (Ornithopus, Dimorphosoma), Avellana, Eulima.

Cephatopoda. Desmoceras, Hoplites, Schlonbachia, Crioceras, Anisoceras, Macroseaphites, Hamulina.

The following are some of the more important genera which make their appearance in Upper Cretaceous time :-

Porifera.

Camerospongia, Cephalites, Chenendopora, Coloptychium, Coscinopora, Doryderma, Guettardia, Hallirhoa, Leptophragma, Nematinion, Plinthosella, Pharetrospongia, Plocoscyphia, Siphonia, Stauronema, Ventriculites, Verruculina.

Actinozoa. Caryophyllia, Coelosmilia, Cyclocyathus, Micrabacia, Onchotrochus, Parasmilia.

Echinoderma. Caratomus, Cottaldia, Galerites (=Echinoconus), Echinocorys (=Ananchytes), Epiaster, Hemiaster, Infulaster, Micraster, Bourgueticrinus, Marsupites.

Crustacea.

Etyus, Eucorystes, Necrocarcinus, Palæocorystes, Palæga, Enoploclytia.

Brachiopoda. $\quad$ Lyra (=Terebrirostra), Trigonosemus.

Lamellibranchia. Hippurites, Radiolites.

Gastropoda. Actæonella, Cassidaria, Columbellina, Cominella, Crepidula, Fusus, Pugnellus, Volutospina.

Cephalopoda. Acanthoceras, Buchiceras, Baculites, Heteroceras, Mammites, Pachydiscus, Placenticeras, Prionocyclus, Prionotropis, Scaphites, Turrilites, Actinocamea, Belemnitella.

Pisces.

Reptilia.

Hoplopteryx, Corax, Macropoma, Osmeroides, Plethodus, Portheus, Ptychodus. Mosasaurus, Pteranodon, Ornithocheirus.

\section{LOWER CRETACEOUS SERIES}

As in the case of the Jurassic System it will simplify matters to describe the rocks and fossils of the Lower Series in England and Europe first, before dealing with those of the Upper Series. 

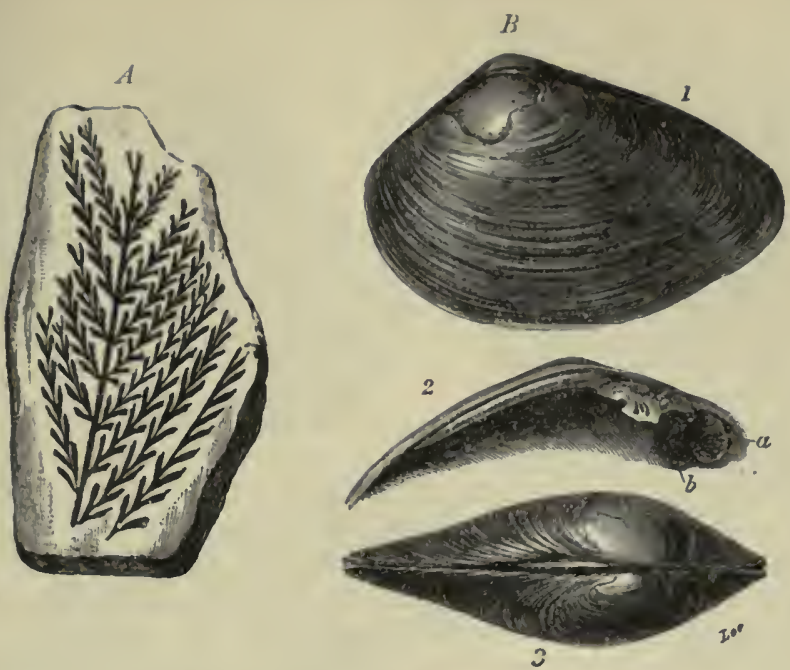

Fig. 153.-Fussils of the WeALden BEDS.

A. Onychiopsis Mantelli.
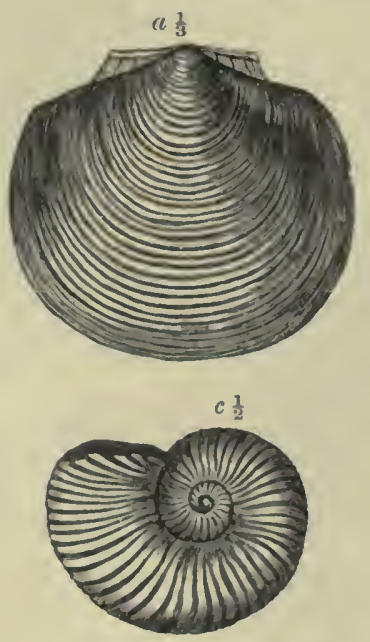

B. Unio valdensis. b
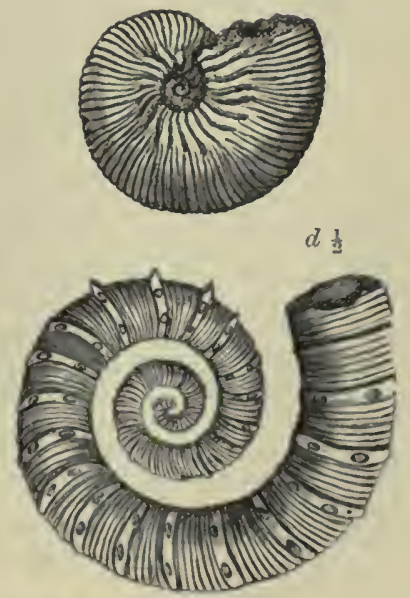

Fig. 154. - GROUP OF FOSSILS FROM THE BPEETON CLAY (Hauterivian and Barremian).

a. Pecten cinctus.

b. Hoplites speetonensis.

c. Hoplites regalis.

d. Crioceras Duvali. 
The outcrops of the Lower Series in England can be seen in any of the maps mentioned in Chapter III, p. 27, and the areas which they occupy in the western and central parts of Europe are shown on the larger geological maps of Europe. Those of the Cretaceous as a whole are indicated on the map specially prepared by Mr. Stanford for use with this volume (see p. 28).

\section{A. Lower Cretaceods Life}

The following are some of the species which characterise the several stages of this series.

Marine Fauna.-As will be seen later on, the marine facies of Northern Europe, even where it is most complete, differs greatly from that of Central and Southern Europe, and very few fossils are common to the two faunas. We shall therefore in the first place give a list of the characteristic fossils of each of the stages as developed in France and Switzerland, together with those of the English Vectian. A further list of the chief members of the northern fauna will then be given.

\section{Fossils of the Valenginian}

Echinodermata. Toxaster(Echinospatagus)Campichei, Pygurus rostratus. Lamellibranchia. Ostrea rectangularis.

Gustropoda. Nerinæa Meriani, Natica leviatlan.

Cephalopoda. Hoplites neocomiensis, Hop. regalis, Hop. occitanicus, Hop. Boissieri, Phylloceras semisulcatum, Belcmnites latus, Bel. dilatatus.

\section{Fossils of the Hauterivian}

Echinodermata. Toxaster complanatus, Holectypus macropygus.

Brachiopoda. Terebratula tamarindus, Rhynchonella lata.

Lamellibranchia. Neithea atava, Astarte numismalis, Ostrea Couloni.

Cephalopoda. Hoplites radiatus, Hop. leopoldinus, Hop. angulicostatus, Holcostephanus (Astieria) Astieri, Crioceras Duvali, Belemnites dilatatus.

\section{Fossils of the Barremian}

Echinodermata. Heteraster oblongus, Het. Couloni, Toxaster Collegnoi. Brachiopoda. Rhynchonella Moutoni.

Lamellibranchia. Requienia ammonia, Toucasia Lonsdalei.

Gastropoda. Harpagodes Pelagi.

Cephalopoda. Holcostephanus fallax, Desmoceras difficile, Crioceras Emerici, Macroscaphites Yvani.

\section{Fossils of the Aptian and Vectian}

Foraminifera. Orbitolina lenticularis.

Echinodernata. Enallaster Tittoni, Peltastes Wrighti.

Crustacea. Meyeria magna (= vectensis). 

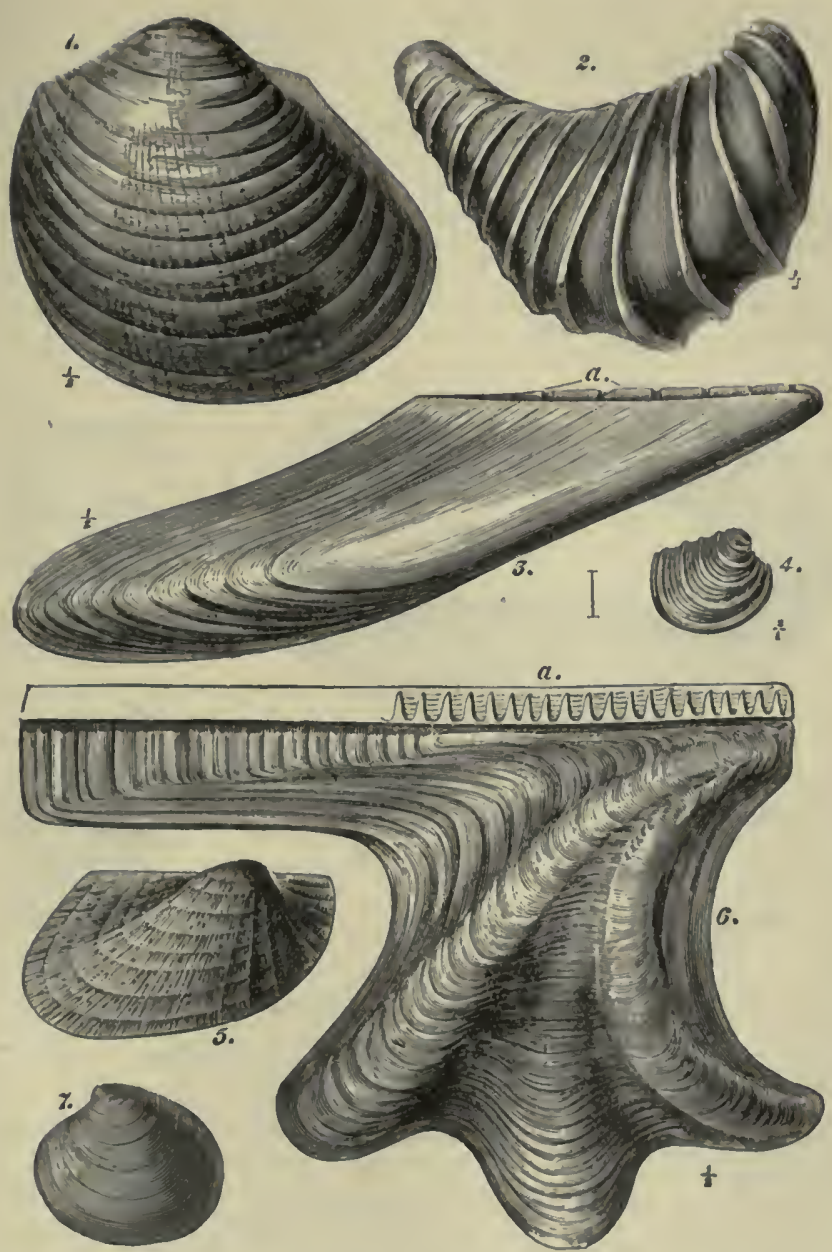

Fig. 155.-Group of VECTIAN Fossils.

1. Corbis corrugata.

2. Trigonia caudata.

3. Gervillia ancep:
4. Astarte subcostata.

i. Arca aptiensis.

6. Ierna Minllet:.

7. Cyclorisma parva. 
Brachiopoda. Terebratula sella, T. depressa, Terebratella oblonga, Terebratella Filtoni, Rhynchonella Gibbsi.

Lamellibranchio. Exogyra sinuata (=Ostrea aquila), Toucasia caudata, Trigonia caudata, Trigonia nodosa (= Trigonia rudis), Perna Mulleti, Plicatula placunea, Arca aptiensis, Astarte subcostata, Gervillia anceps, Sphaera corrugata, Cyclorisma parva.

Gasteropoda. Dicroloma robinaldina, Aporrhais Fittoni.

Cephalopoda. Hoplites furcatus, Hop. Deshayesi, Douvilleiceras Martini, Macroscaphites gigas, Nautilus pseudelegans.
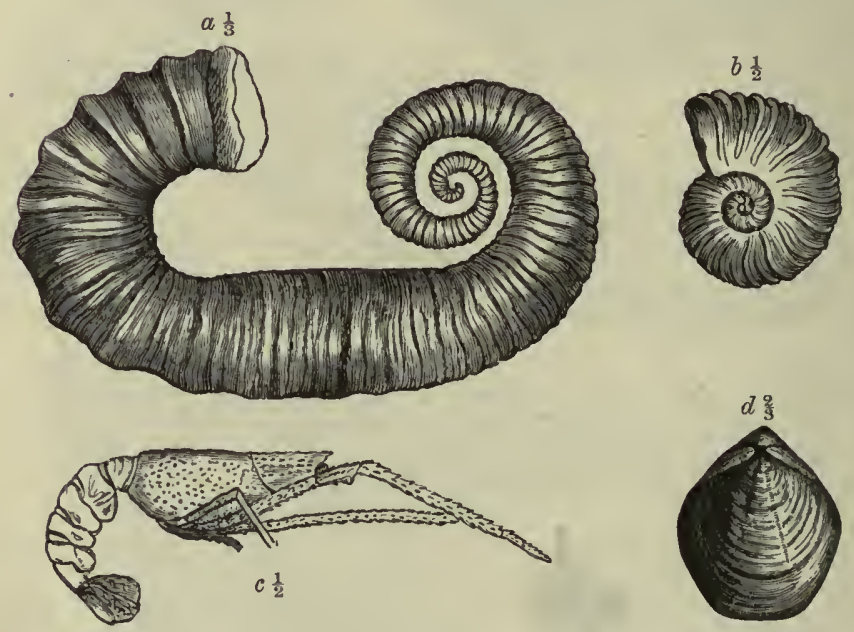

Fig. 156.-GROUP OF VECTLAN FOSSILS.

a. Macroscaphites gigas.

b. Hoplites Deshayesi. c. Meyeria magna.

d. Terebratula sella.

The northern fauna includes the following characteristic species :-

\section{Fossils of the Belemnites lateralis zone}

Lamellibranchia. Astarte senecta, Trigonia ingens, Aucella volgensis, Aucella Keyserlingi.

Cephalopoda. Holcostephanus subditus, Holc. kashpuricus, Holc. plicomphalus, Hoplites regalis ( $=\mathrm{H}$. noricus), Hoplites amblygonius, Belemnites lateralis.

Fossils of the Bel. jaculum and Holc. Decheni Zone

Crustacea. Meyeria ornata.

Lamellibranchia. Pecten cinctus, Exogyra sinuata. 


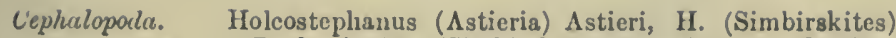
Decheni, H. (Simbirskites) versieolor, Hoplites speetonensis, Crioceras Duvali, Belemnites jaculum.

\section{Fossils of the Hoplites Deshayesi zone}

Lamellibranchia. Grammatodon securis, Corbula angulata, Nucula subangulata.

Cephalopoda. Hoplites Deshayesi, Hoplites furcatus, Ancyloceras gigas, Belemnites brunsvicensis, B. Jasekowi.

Lastly there is the freshwater facies of the English and German Wealden which represents the terrestrial and lacustrine life of the period.

\section{Fossils of the Wealden Beds}

Plantce. Chara Knowltoni, Equisetites Lyelli. Filices: Onychiopsis Mantelli, Matonidium Gopperti, Cladophlebis Albertsi, Sphenopteris Fittoni, Tenpskya Schimperi, Weichselia Mantelli. Cycadacea: Cycadites Romeri, Dionites Dunkerianus, Nilssonia Sehaumburgensis, Otozamites Klipsteini, Zamites Buchianus, Anomozamites Lyellianus. Conifera: Pinites Dunkeri, Sphenolepidium Kurrianum.

Crustacea. Cypridea valdensis, Cythere Fittoni, Estheria elliptica.

Gastropoda. Viviparus fluviorum, V. cariniferus.

Lamellibranchia. Cyrena media, C. elongata, Unio valdensis, U. compressus, U. aduncus.

Pisces. Lepidotus Fittoni, Hybodus dubius.

Rieptilia. Iguanodon Mantelli, Hypsilophodon Foxi, Ceteosaurus brevis, Hylæosaurus Oweni, Megalosaurus Bucklandi, Goniopholis crassidens, Chelone Mantelli.

\section{B. British Representatives}

In England the Lower Cretaceous rocks occupy a much smaller surface-area than those of the Upper Series, but that is largely due to their overlap by the base of the Upper Series. The subterranean extension of the Lower Series is of inportance, because the sands in its higher part are water-bearing, and borings have frequently been made in search of them. As a result of the borings already made, its subterranean extent in the east of England is now fairly well known; thus though these sands are present at Chatham they are absent at Streatham and also on the north side of the Thames beneath Middlesex, Essex, and the south of Suffolk. They were found, however, in borings near Windsor, at Hitchin, at Culford near Bury St. Edmunds, and recently at Lowestoft. Hence they probably underlie the whole of Cambridgeslire and Norfolk, and extend far under the North Sea east of Lincolnshire and Yorkshire. 


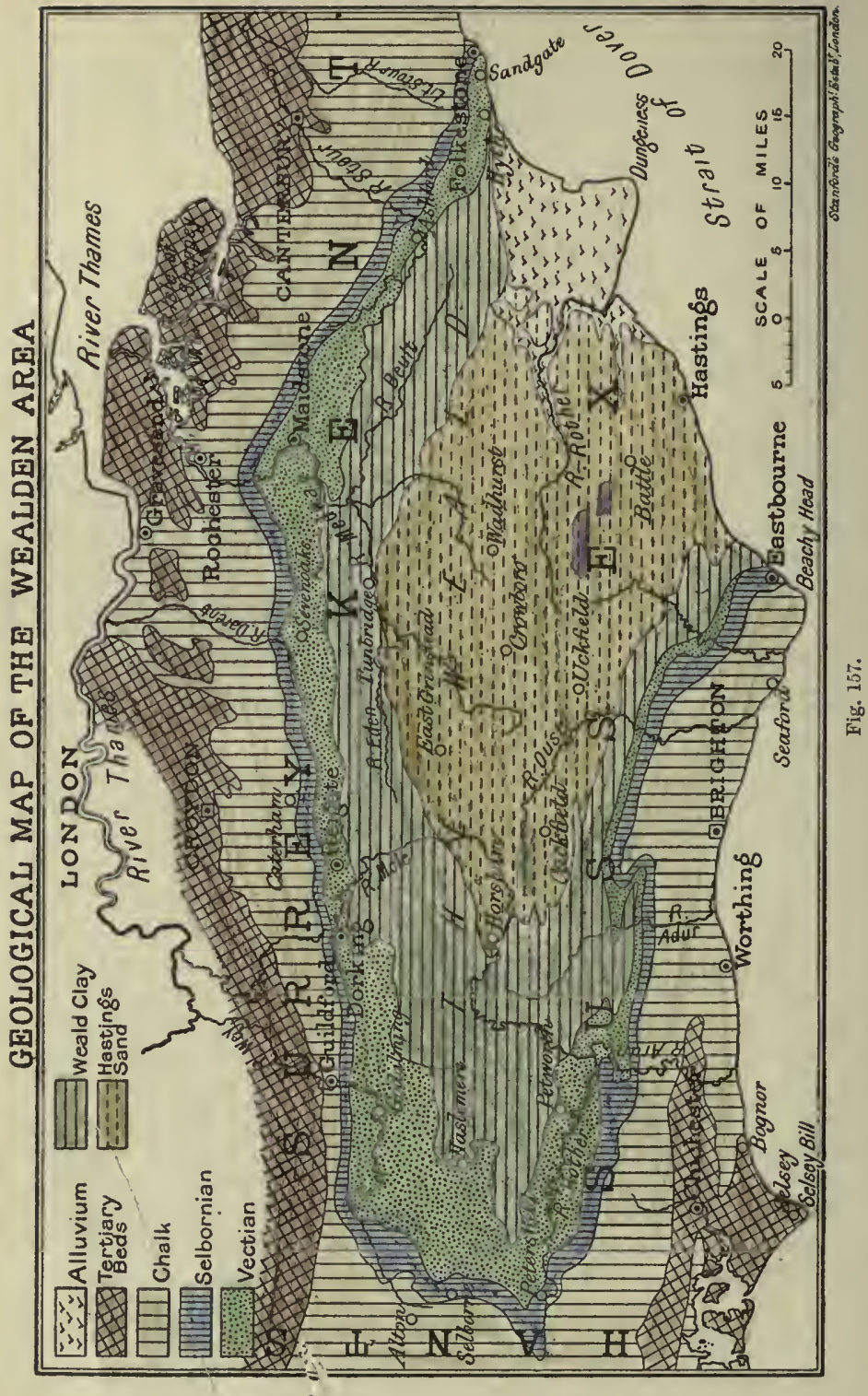


With regard to their western range, in all probability the Wealden and Vectian deposits did not extend much farther west than the most westerly portious of them now existing. In Dorset the Wealden extends to Upway near Weymouth, being there 350 feet thick, but is soon cut off by intra-Cretaceous erosion; the Vectian does not reach so far, but is cut off west of Mupe Bay; both, however, may originally have extended as far as Bridport. In the Vale of Wardour near Dinton the two are less than 100 feet thick, and cannot have reached much farther west along that line of latitude, for there the Vectian passes up into Gault.

Coming now to the surface exposures of the older Cretaceous Series, these are found in four separate districts-(1) The Wealden area, (2) The Isles of Wight and of Purbeck, (3) The Midland outcrop, a long narrow one, (4) the north-east area in Norfolk, Lincoln, and Yorkshire. The two southern areas may be described together as they exhibit a similar succession of deposits, and are undoubtedly connected beneath the Chalk of Hampshire.

\section{South of England}

The Weald is an oval-shaped area occupying portions of Kent, Surney, Hants, and Sussex (see map, Fig. 157); on the north-west and south it is bounded by the escarpment of the Chalk, but eastward it opens on to the English Channel between Eastbourne and Folkestone. The district known as the Bas Boulonnais in France is the eastern prolongation and termination of the Wealden area, and the English and French districts are undombtedly continuous beneath the English Channel. The structure of this area is generally described as that of an anticlinal ridge, but in reality it more resembles that of an oval dome or inverted boat.

Fig. 158 is a diagrammatic section across the Weald from north to south, showing its general structure and regarding only the Cretaceous rocks; Fig. 159 is a more complete and accurate section taken along a line drawn from Beachy Head to Chatham. The absence of the Lower Cretaceous below Chatham has been proved by a boring there, which entered the Oxford Clay directly below the Vectian sands, and this part of the section is reduced from that drawn by Mr. W. Whitaker. ${ }^{1}$

In the Isle of Wight, and again in Squth Dorset, from Swanage to Ridgway near Weymouth, the Lower Cretaceous Series is brought to the surface by a sharp anticlinal curvature.

The following is a tabular view of the subdivisions which have been made in the series as developed in these two districts :- 

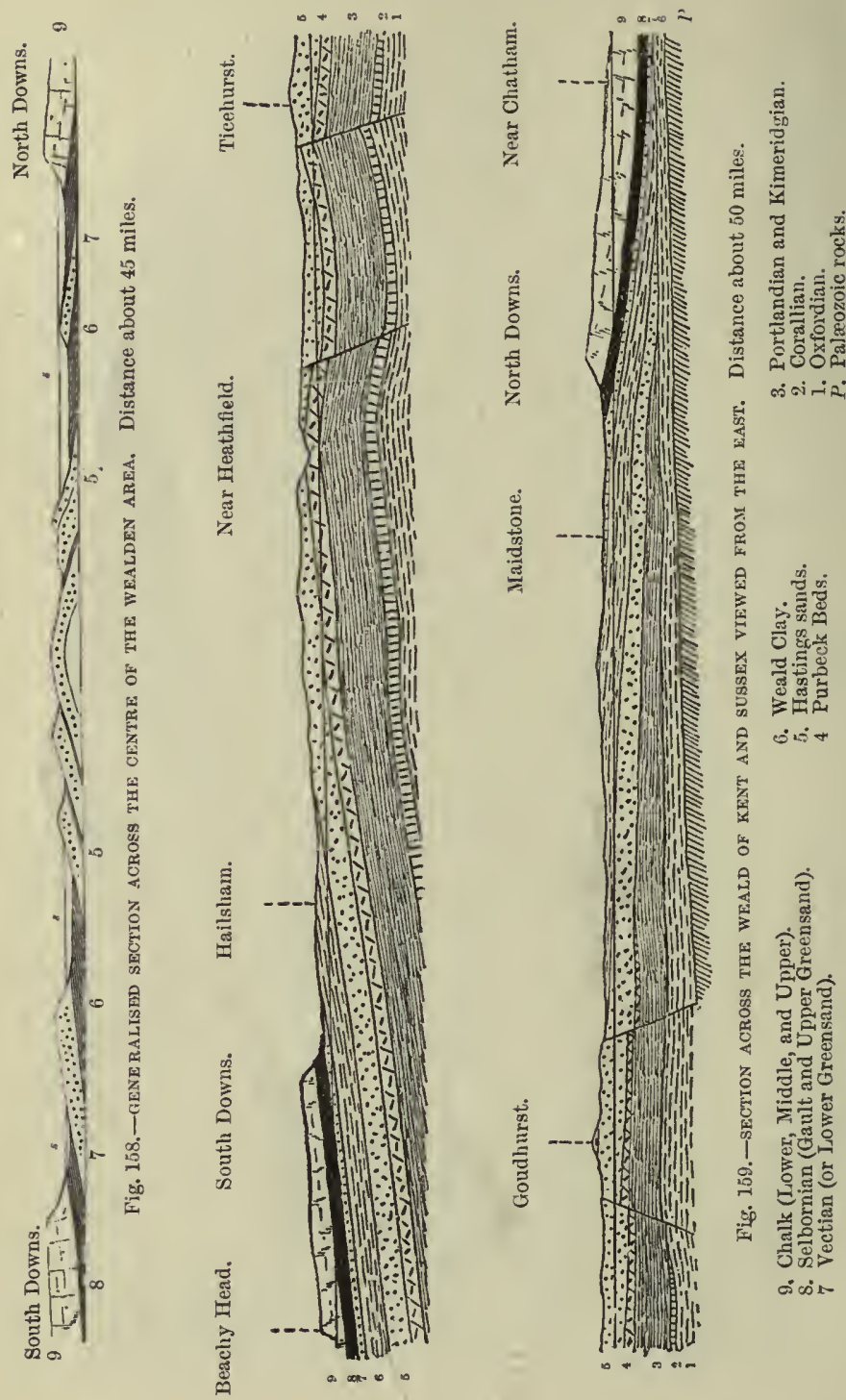
Weald.

Isle of Wight.

Thickness.

Feot.

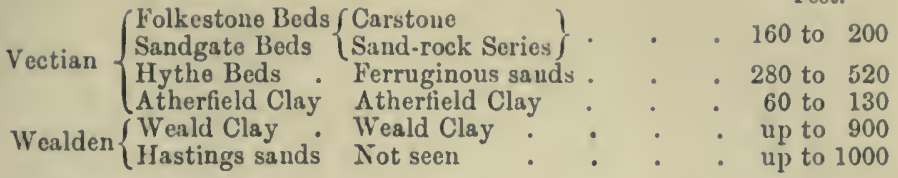

Wealden Beds.-In the Wealden area the Wealden Beds are divisible as follows, all the divisions being thickest in the western and thinnest in the eastern part of the area. ${ }^{2}$ Still farther east borings through the Chalk between Canterbury and Dover have shown that it gradually thins out; thus at Brabourne it is only about 56 feet, and in the Dover boring about 80 feet, while at Fredville it is less than 40 feet thick :-

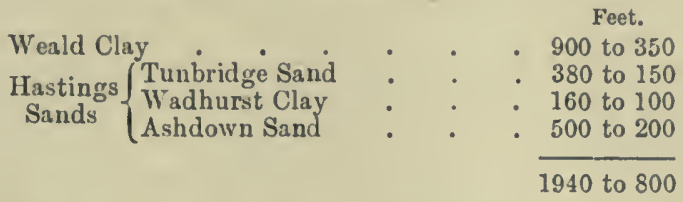

The Ashdown Sand consists of soft buff or white sand and sandstone : it is 400 feet thick in Ashdown Forest, and forms the high ground of Crowborough Beacon (800 feet high). Near Hastings and Fairlight the lower part of this sand is replaced by clays with interbedded sandstones. Plant-remains are the only fossils, and it is the Fairlight Clay which has yielded the species mentioned on p. 471; the stems of Tempskya, formerly called Endogenites erosa, being common.

The Wadhurst Clay, though never more than 160 feet thick, is palæontologically important, as it is rich in fossils, and contains a bone-bed near Battle, from which many reptilian bones and teeth have been obtained. It consists of clays and shales, with bands of irregular layers of hard calcareous sandstone (Tilgate stone). The fossils are Viviparus fluviorum, Cyrena media, teeth of Lepidotus Mantelli, Hybodus basanus, Goniopholis crassidens, with bones of Iguanodon and Megalosaurus.

The Tumbridge Sands are similar to the Ashdown Sands. Near Hastings their thickness is only 150 feet, but it increases westward, a set of mottled clays and shales appearing in the iniddle of the sands, and becoming of sufficient importance to deserve a separate name, the Grinstead Clay. In the upper sands of the Cuckfield district, which is often called the Tilgate Forest, there are large concretionary masses of calcareous grit or sandstone, such as were termed Tilgate stone by Dr. Mantell. It was in these masses 
that the remains of Iguanodon and Hylcosaurus were first discovered by Dr. Mantell, and the specimens which he figured and described are now in the South Kensington Museum.

The uppermost member of the Wealden Group consists mainly of brown and blue clays, with layers of shelly limestone and occasional beds of sand and calcareous sandstone. The limestones are known as Sussex marbles, and are composed almost entirely of Viviparus shells, those in the lower part of the clay consisting chiefly of $V$. sussexensis, while the most constant band (the Petworth and Bithersden marbles) consists of $V$. fuviorum. The minute freshwater Crustaceans (Cypridea) are also very abundant in some places, the surfaces of the more shaly beds being crowded with them. Unio and Cyrena also occur. At Haslemere the highest beds, just below the Atherfield Clay, contain Corbula and Mytilus, as well as Cyrena and Melanopsis, indicating the change from freshwater to marine conditions.

In the Isle of Wight Wealden Beds are exposed both on the eastern and western sides (see map, Fig. 172). The equivalent of the Hastings sands is not visible; the lowest beds seen are those at Brook Point in Compton Bay, and consist of a pale sandstone overlain by red and green marls in which the broken trunks of pine trees are so numerous that it would seem as if a raft of waterlogged trees had here sunk to the bottom, a frequent occurrence in the deltas of large rivers like the Mississippi ; the spot is known to local geologists as the "pine-raft." The higher beds, consisting of variegated marls or clays with thin beds of sandstone, can be seen by walking along the coast to the southward; they have yielded bones and footprints of Iguanodon, Hypsitophodon, and other reptiles, with Unio valdensis, but other fossils are rare in this lower division, which has a thickness of about 700 feet.

The higher beds are well exposed between Cowleaze Chine and Atherfield Point; they consist almost entirely of grey shales with some beds of sandstone, ironstone, and limestone. These beds are much more fossiliferous, containing species of Meta, Cypris, Cypridea, and Candona, with Cyrena, Viviparus, and Vicarya (a sub-genus of Potamides). Small oysters also occur near the top. This series of beds is about 200 feet thick, and is directly overlain by the "Perna Bed" rent ioned below.

The whol, of the Wealden comes to the surface near Swanage in Dorset, anc extends' thence along a broad valley to Worbarrow Bay on the her side of the Isle of Purbeck. At Swanage the estimated thich ness of the inmation is about 2300 feet, ${ }^{3}$ but the junction with the Purbeck is not exposed. The lower beds consist of variously colloured sands asd clays-red, yellow, grey, and 
white. The succeeding beds are red, purple, and white clays with beds of sand, and they contain layers of lignite and, in one place, the broken trumks of trees. At the top are shales (Punfield Beds) like those of the Isle of Wight, but only 34 feet thick.

The greater part of the Wealden is exposed in the cliffs of Worbarrow Bay, but here its total thickness is reduced to abont 1200 feet, and it consists entirely of alternating sands and clays with much lignite. The formation continues to diminish westward, and where last seen at Ridgway the thickness exposed is only 350 feet, but this may not be the full amount.

Wealden Clays are found over a small space in the Vale of Wardour, but are only 60 or 70 feet thick. Probably they do not extend much farther northward, but their boundary line is concealed beneath the Upper Cretaceous rocks.

Vectian.-In the Wealden district the lithological characters of the beds composing this stage are very variable, but four subdivisions are generally recognised (see p. 475 and Figs. 160, 161). Along the north side of the Weald the thickness of the Vectian varies from about 500 feet in Surrey to 240 near Sandgate, and about 130 in the boring at Dover.

The Atherfield Beds are exposed on the Kentish coast between Sandgate and Hythe, and are traceable thence all round the area occupied by the Weald Clay, except between Lewes and Eastbourne. In Surrey they are traversed by the railway cuttings at Sevenoaks and Red Hill, Panopcea plicata, Exogyra sinuata, Perna Mulleti, and Trigonia decdalea being common fossils; along this line their thickness varies from 30 to 50 feet. At Haslemere it is 60 feet, and their junction with the Wealden was observed by Mr. Salter, who says "the change from dark greyish-blue clay (Wealden) to the purely marine deposit of brown clay was marked no less by the fossils than by the change in the colour of the bed." Within a few inches of the Wealden Clay he found Pleuromya plicata abundantly embedded in the vertical position which such inolluses occupy when alive. This shows how quiet and gentle was the change from estuarine to marine conditions of deposit.

In the Isle of Wight the Atherfield Clay has at its base two beds which are together known as "Perna Bed," because Perna Mulleti is common in them and does not occur above. The lower bed consists of sandy clay with a thin basal seam of coarse grit containing rolled fragments of fossils and many broken bones and teeth of fish ; this clay is $2 \frac{1}{2}$ feet thick and is succeeded by a bed of brown calcareous sandstone also $2 \frac{1}{2}$ feet. Both layers contain many fossils. The rest of the subdivision consists of pale blue clay with many flat calcareous concretions, and the upper part is 
known as the "lobster bed," from the occurrence of Meyeria magna. Other fossils found in these beds are Hoplites furcatus, Hop. leopoldinus, Hop. Deshayesi, Corbis corrugata, Pinna robinaldina, and Enallaster Fittoni.

Hythe Beds.-In Kent, between Hythe and Sevenoaks, these beds consist of greenish-yellow sand, often niarly or argillaceous, and hard bluish-grey calcareous sandstone, the soft beds being locally known as hassock and the hard beds as rag; the latter being known as Kentish rag. The beds of rag and hassock alternate in regular layers.

From Hythe to Maidstone the thickness of these beds is only from 70 to 80 feet, but they increase rapidly westward and are 160 feet at Sevenoaks, and still thicker in Surrey. This increase of thickness is mainly due to the incoming of an upper set of sands with frequent layers of brown chert. These upper beds

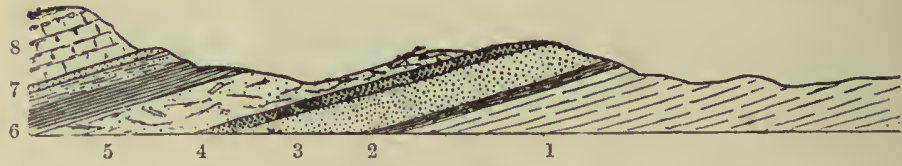

Fig. 160.-SECTION THROUGH THE LOWER CRETACEOUS SERIES NEAR DOLKING. Distance 8 miles.
8. Middle and Lower Chalk.
5. Folkestone Beds.
7. Malmstone and sand.
4. Sandgate Beds.
6. Gault marls and clays.
3. Hythe Beds.
2. Atherfield Clay.
1. Wealden Beds.

attain their maximum thickness abont Reigate, Dorking, and Leith Hill, where the lower group of soft ferruginous sand is from 100 to 130 feet, and the cherty beds are also in places over 100 feet thick. The Hythe Beds maintain this facies all round the western end of the Wealden area, but thin rapidly castward again as they are traced along the southern border, disappearing entirely near Lewes.

The chief fossils of the Hythe Beds are Terebratula sella, Exogyra sinuata, Trigonia spinosa, Tr. ornata, Actinocamax brunsvicensis, Nautilus pseudelegans, Ancyloceras Bowerbanki, Macroscaphites gigas, Hoplites Deshayesi, and Holcostephanus Hambrovi.

Sandgate Beds.-These are a variable set of beds, bnt are generally more or less argillaceous. At and near Sandgate (see Fig. 161) they consist of dark-green clayey sand full of glauconite grains and abont 70 feet thick. Fossils are not numerous, but at the base, resting on the Hythe Beds, there is frequently a layer of pebbles and phosphate nodnles, with Brachiopods and other fossils in the state of casts. 
In Surrey this division is represented by the Nutfield and Bargate Beds, which at Nutfield consist chielly of soft sandstone and Fuller's Earth (a fine silty clay). ${ }^{4}$

Between Reigate and Godalming the Bargate Beds consist of sands and hard calcareous grits (Bargate stone), with some thin layers of Finler's Earth and coarse pebbly beds at the base, con. taining phosphate nodules and many fossils; the whole thickness is about 50 feet. Avicula pectinata is a characteristic fossil of the Bargate stone; Terebratula oblonga, T. depressa, Waldheimia tamarindus, Terebratella Fittoni, T. trifida, and T. Menardi are some of the fossils occurring in the pebble beds, and with them are many fossils derived from the Oxford Clay, which must at that time have formed part of the shore-line north of Godalming.

In Hants and West Sussex the Sandgate Beds reappear in a more normal form, consisting of shaly clay at the top, with sand and sandy clay below.

In the Isle of Wight the Hythe and Sandgate Beds are represented by the Ferruginous sands, which consist of alternating beds of sand and clay, the sands of grey, green, or yellow tints and the clays brown or blue. The lowest beds are known as "the crackers," and contain Holcostephanus Hambrovii, Gervillia anceps, Trigonia caudata, Pleuromya plicata, etc. The overlying beds contain Terebratula sella in great profusion with Douvilleiceras Martini, Macroscaphites gigas, M. Hillsi, and Crioceras Bowerbanki. 'These lower beds may be called the Walpen sands, and they correspond to the Hythe Beds. Above them are the equivalents of the Sandgate Beds, comprising two beds or bands, the lower of sand with ferruginous concretions about 20 feet thick, the upper a bed of clay without fossils and 40 feet thick. The concretions yield Rhynchonella sulcata, Avicula pectinata, Thetis Sowerbyi, Cyprina angulata, and Trigonia vectiana.

Folkestone Beds.-At Folkestone these consist of light-green and grey sand with beds of hard stone, partly siliceous and partly calcareous in composition, which have been described by Dr. G. J. Hinde as veritable sponge-banks, the sponges being of the Hexactinellid order, and their fine needle-like spicules are clearly visible on weathered portions of the rock. The total thickness is about 80 feet. Fossils are not abundant in these beds, but they have yielded Avicula pectinata, Exogyra sinuata, Pecten (Neithea) atava, Neithea Morrisi, Ostrea frons, and Waldheimia pseudojurensis.

For a few miles inland the composition of the Folkestone Beds is much the same, but west of Saltwood they begin to change their character, the cherty sponge-beds disappear, and the sands are chiefly white, yellow, and brown, current-bedded, and including 

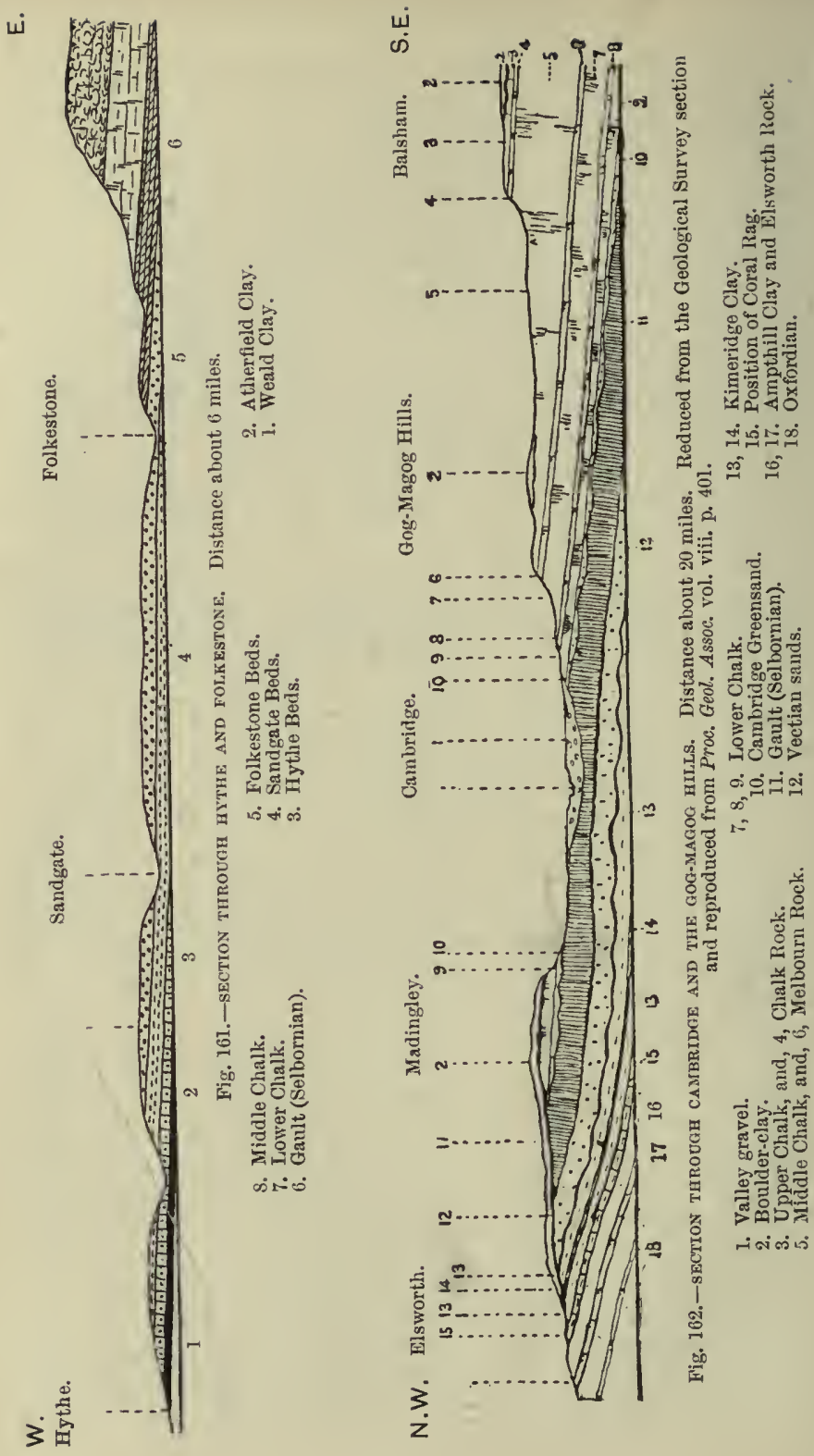
irregular layers of iroustone. This facies they preserve with little change all round the Wealden area, and consequently the name of Folkestone Beds is not a very liappy one. In Sussex they include thin bands of hard ferruginous grit, which is locally known as carstone. In Surrey and Hants they are from 130 to 160 feet thick, but like all other nembers of the Vectian, they thin eastward through Sussex, till near Eastbourne the whole stage appears to be absent, and the Gault rests directly on the Weald Clay.

The Sand-rock Group appears to be the representative of the Folkestone Beds. It consists mainly of coherent sands with bands of laminated clay, but contains no fossils. The carstone is a coarse ferruginous grit which varies greatly in thickness, being 72 feet thick at Redcliff, north of Salldown, but only from 6 to 12 feet on the western side of the island. It contains rolled pebbles and phosphatic nodules, and is considered by Mr. Strahan to be more closely connected with the Gault than with the Vectian. ${ }^{5}$ The fossils found in it comprise Desmoceras Beudanti, Plicatula carteroniana, and Lima parallela.

When followed across to Dorset the Vectian is found to be much reduced in thickness, being only 200 feet at Punfield Cove, near Swanage, 136 at Worbarrow Bay, and 66 in Mupe Bay, beyond which it is not seen. At Punfield the Atherfield Clay is 50 feet thick, and the upper part contains some remarkable fossils, especially species of Vicarya, Natica, Actcon, Cerithium, and Pleurotoma, which are common in the Rhodanian of Spain, but have not been found elsewhere in Eugland.

\section{Midland District}

The Wealden is not seen anywhere north of the Vale of Wardour, and the sands and sandstones which emerge from beneath the Gault in Berkshire, and thence at intervals northward to Cambridge and Ely, seem to beloug to the higher part of the Vectian Group, nothing comparable to the Atherfield Clay or the Hythe Beds having been observed in situ.

Near Faringdon ${ }^{6}$ (see Fig. 163) the Vectian consists for the most part of soft yellow and brown sands, with some layers of sandstoue and thin bands of ironstone, but at the base there are irregular beds of pebbly, fossiliferous gravel, compacted in places into a conglomerate. The pebbles are chiefly of quartz and porcellanous slate (lydianite). Among the fossils sponges, Brachiopods, and Echinoids are conspicuous, the following being some of these :-

Terebratula tornacensis. depressa.

Waldheimia tamarindus.
Peltastes Wrighti. Cidaris faringdonensis. Raphidonema porcatum. 


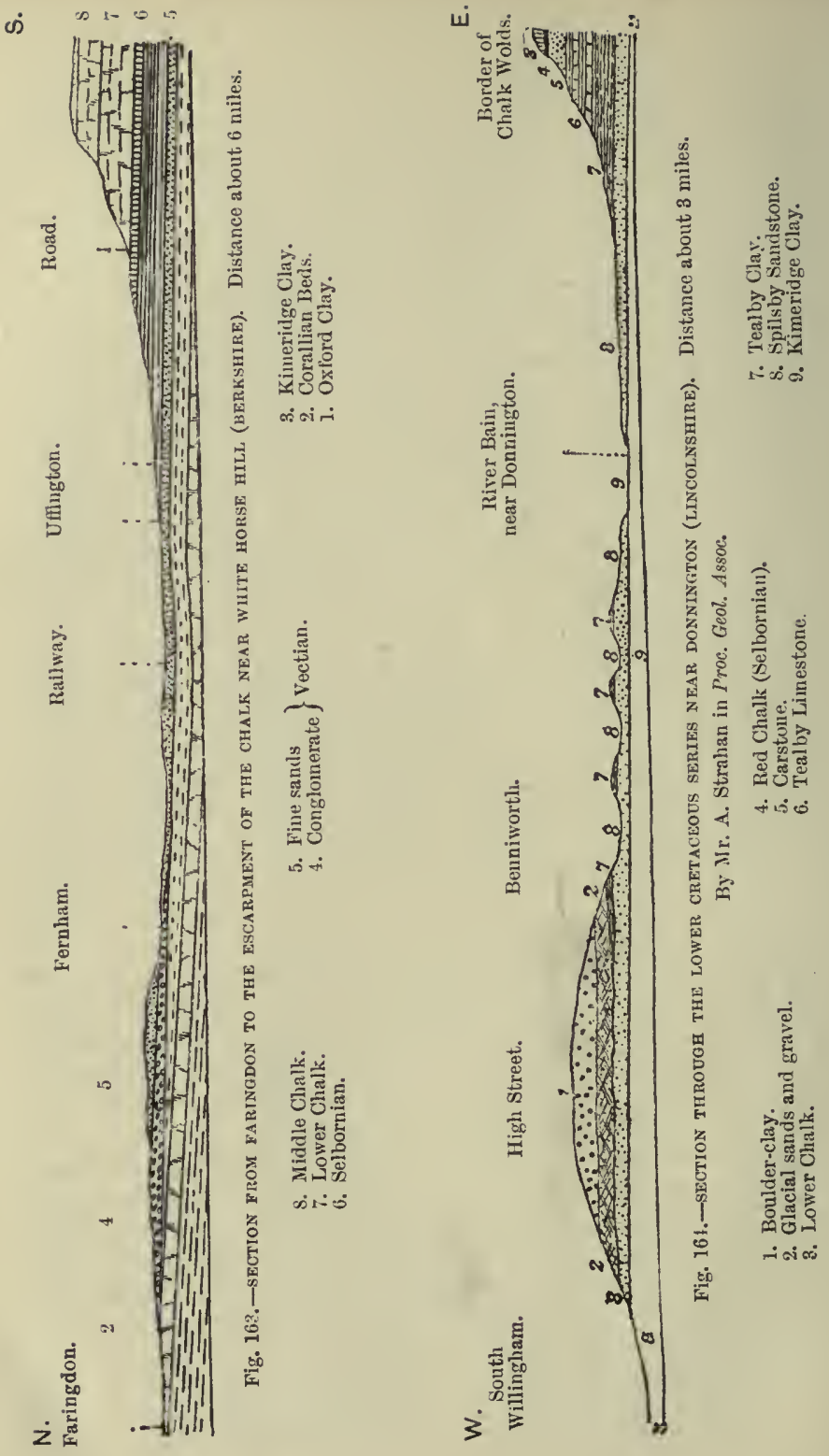


Terebratella Menarli. Fittoni.

Rhynchonella latissima.
Kaphidonema faringdonensis. Trematocystia anustomosans. Peronidella ramosa.

The summit of Shotover Hill, soutl-east of Oxford, consists of ferruginous sands with bands of ochre and cream-colonred loam, which contain remains of freshwater shells, Unio, Cyrena, and Viviparus. Similar beds occur at Wheatley, Brill, Crendon, and 'Thame, where they include beds of grey and lilac clay. At Crendon, Pecten aptiensis has been found in a layer of calcareous concretions which overlies the clays, and marine fossils have also been found at Stone near Aylesbinry. Hence there can be little doubt that the Sliotover Beds, which rest in some places on Portland, in others on the Purbeck Beds, are freshwater deposits of Aptian age. Their thickness is variable with a maximum of about 50 feet. $^{7}$

Yellow and white sands emerge from beneath the Gault near Leighton Buzzard and form a range of hills by Woburn and Ampthill as far as the neighbourhood of Shefford. Near their base are beds of phosphatic nodules, which were worked near Brickhill, and include casts of fossils derived from the underlying Jurassic Clays, together with well-preserved contemporaneous fossils. Among the latter are Terebratula sella, $T$. depressa, $T$. microtrema, T. moutoniana, and others, Terebratella Menardi, T. Fittoni, Waldheimia celtica, W. tamarindus, and others, Peltastes Wrighti, and many of the Faringdon sponges. ${ }^{8}$

The sands above are dug for glass-making purposes, and are believed to be about 200 feet thick near Woburn; they also contain a band of Fuller's Earth, which has been worked for more than a century.

These Woburn sands, passing beneath the valley of the Ivel, become conspicuous again near Sandy and Potton, with the same nodule beds near the base, in which derived reptilian bones are very abundant; thence the sands rmn through Cambridgeshire to the Fens south of Ely, near Streatham and Upware.

At Upware in the Fens of Cambridgeshire are sands and silts with two nodule beds similar to those of Brickhill and Potton, but containing a still larger number and variety of fossils. The beds are banked against the Corallian limestones, are less than 12 feet thick, and are overlain by the Gault, so that they seem on the point of thinuing out.

\section{Northern District}

This includes the Lower Cretaceons tracts in the counties of Norfolk, Lincoln, and York. Each of these exhibits a somewhat 
different facies, the deposits in Norfolk being mainly sands, while those in Yorkshire are clays and those in Lincolnshire are sands, clays, and limestones. In the two latter connties we have a more complete succession of marine deposits of Lower Cretaceous age than is found in any other part of England, and our detailed knowledge of them is mainly dne to the labours of Professor J. W. Judd and Mr. G. W. Lamplngh.? Unfortunately the Norfolk outcrop is separated from that of Lincolnshire by the breadth of the Wash, and in Yorkshire the exposed areas near Speeton are very small, their southerly continuation being concealed beneath the overlap of the Upper Cretaceous (see map, Fig. 165). Consequently correlation is rendered difficult and entirely dependent on the discovery of fossils. The probable correlation is shown in the following table:-

\begin{tabular}{|c|c|c|}
\hline Yorkshire. & \multicolumn{1}{|c|}{ Lincolnshire. } & \multicolumn{1}{c|}{ Norfolk. } \\
\hline $\begin{array}{l}\text { Clays with Belemnites } \\
\text { brunsvicensis } \\
\begin{array}{c}\text { Clays with Act. jaculum } \\
\text { Clays with Belemnites } \\
\text { lateralis }\end{array}\end{array}$ & $\begin{array}{l}\text { Carstone } \\
\text { Tealby limestone and } \\
\text { Roach ironstone } \\
\text { Tealby clay } \\
\text { Claxby ironstone } \\
\text { Spilsby sandstone }\end{array}$ & $\begin{array}{l}\text { Carstone. } \\
\text { Snettisham clay. } \\
\text { Sandringham } \\
\text { sands. } \\
\text { (Absent). }\end{array}$ \\
\hline
\end{tabular}

It will be convenient to take Yorkshire first, and in that county the only good exposure is on the coast near Speeton Gap, and lience the whole series, which has a total thickness of about 330 feet, is sometimes termed the Speeton Clay.

The base of this clay is a layer of black phosphatic nodules. embedded in stiff clay. The fossils are badly preserved, but among them Professor Pavlow identifies Belemnites absolutus with Ammonites resembling Holcostephanus Panderi and Holc. scythicus, species characteristic of beds in Russia which are regarded as Portlandian. It is a question, however, whether these fossils. are contemporaneous or derived. This bed is succeeded by clays which contain Belemnites lateralis, Holcostephanus subditus, Holc. Lamplughi, Hoplites amblygonus, with Exogyra Couloni and Astarte senecta. These clays are about 35 feet thick and were considered to be of Purbeck age by Professor Pavlow, but the continental zone of Hoplites Boissieri with which he correlated part of these beds is now regarded as the base of the Valenginian, and. the natural base of the Cretaceons System both in England and Germany is at the base of this zone of Bel. lateralis.

The overlying clays form the zone of Actinocamax jaculum and. 


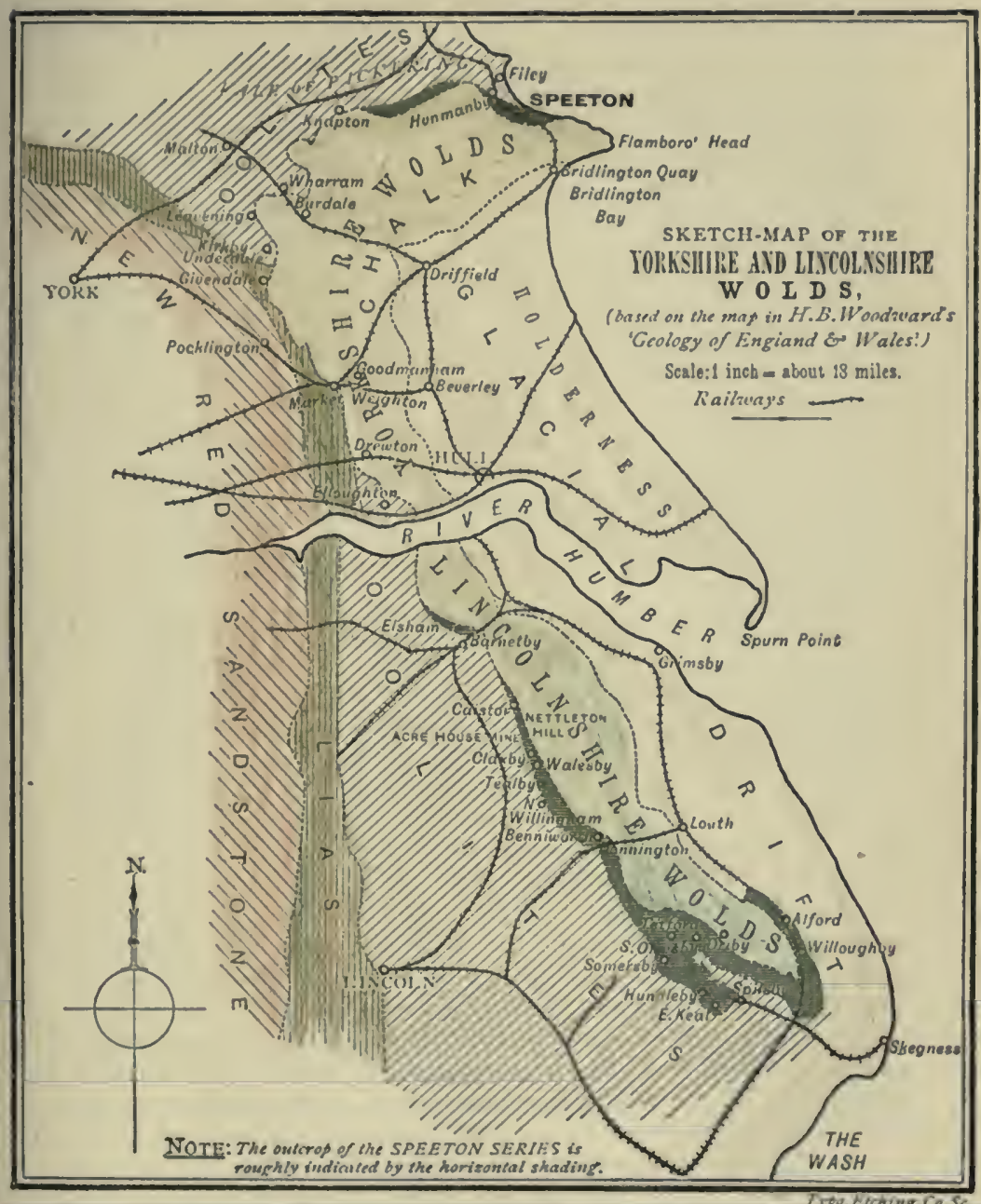

Fig. 165.-MAP OF THE CRETACEOUS AREAS IN LIXCOLNSHIRE AND YORKSUIRE.

By G. W. Lamplugh (from Quart. Journ. Geol. Soc. vol. lii. p. 1Sĩ)

The outcrops of the Lower Cretaceons Series are indicated by horizontal lines, and show up darker than the other jarts of the inap. 
are about 120 feet thick. They appear to be divisible into three sub-zones characterised by Ammonites which in succeeding order are Hoplites regalis, Holcostephanus speetonensis, and Holc. Decheni. Besides these Crioceras Duvali, Pecten cinctus, Meyeria ornata, and many other fossils occur. The whole of this zone appears to be older than the Atherfield Clay, and is therefore a marine representative of the Weald Clay.

The highest part of the Speeton Clay consists of grey and black pyritous clays containing Belemnites brunsvicensis, Hoplites Deshayesi, a large Crioceras, Arca securis, Isocardia angulata, and others. These beds are clearly equivalent to the Vectian of Southern England; their total thickness is more than 150 feet, and may be 180 , and they are succeeded by gritty clays of Gault age containing Belemnites minimus.

In Lincolnshire the Lower Cretaceous Beds emerge from beneath the Upper near Caistor, and extend thence in a gradually widening strip to the neighbourhood of Spilsby and Candlesby at the southern end of the Lincolnshire Wolds. The succession of beds found in this district is shown in Fig. 164, and the full thickness does not exceed 200 feet.

The Spilsby sandstone has a bed of derived phosphatic nodules at the base resting on the Kimeridge Clay. Above are soft yellow and grey sands, including large masses or doggers of calcareous sandstone, which are rich in fossils and yield Belemnites lateralis, Holcosteph. subditus, Holc. plicomphalus, Trigonia ingens, T. robinaldina, etc. The Claxby and Hundlesby ironstones also appear to belong to this zone, as they have yielded Bel. lateralis, Holc. Beani, Holc. Gravesiformis, Astarte senecta, Trigonia ingens, Rhynchonella multiformis, Terebratula sella.

The Tealby Clays are from 40 to 100 feet thick, and represent the zone of Bel. jaculum, yielding that fossil with Hoplites speetonensis, Crioceras Duvali, and Perna Mulleti. The Tealby limestone contains Bel. brunsvicensis, Exogyra sinuata, Pecten cinctus, and appears to pass southward into a ferruginous oolitic marl, locally called "roach." Above these calcareous beds is the carstone, which has not yet yielded any fossils except at its junction with the red chalk, where Bel. minimus and Terebratula biplicata occur.

In Norfolk the thickness of the series is rather less than in Lincolnshire. The Sandringham sands consist of light-coloured sands with some beds of brown flaggy sandstone in the upper part; they have not yielded determinable fossils, and are not like the Spilsby sands; hence it is more likely, as Mr. Lamplugh suggests, that they represent the Tealby Clay. The Snettisham Clay contains Bel. brunsvicensis, and appears to be the equivalent of the 
Tealby limestone, but it is nowhere more than 20 feet thick and thins out southward.

'The carstone of this comntry is a brown ferruginous grit, often cemented by oxide of iron into a sandstone capable of being used as a building stone. Its thickness is about $\mathbf{4 0}$ feet, and it is only at its base that fossils have been found. Some of these occur as phosphatic nodules which may or may not be derived, others occur in concretionary lumps of hard grit, and include Douvilleiceras cornuelianus, Trigonia scapha, Perna Mulleti, Isocardia angulata, and Cardium subhillanum-species which prove that this part of the carstone is of Aptian age and comparable with the Hythe Beds. Hence we may infer that the carstone of Lincolnshire is of the same age.

\section{Scotland}

Rocks of Lower Cretaceous age have been found in Caithness and Aberdeen. Those of Caithness occur at Leavad near Wick and appear to be in situ; the exposure showing 20 feet of yellow sand with doggers of hard calcareous sandstone, which have yielded species of Craspedites, Desmoceras, Crioceras, and Hamites. ${ }^{10}$ Craspedites suggests a low horizon in the series.

In Aberdeen near Cruden boulders of a glauconitic sandstone or gauze occur in boulder-clay and contain fossils which form a curious assemblage of Vectian and Selbornian species, but the presence of Holc. speetonensis, Crioceras Duvali, and Trigonia vectiana appears conclusive of their Vectian age."

\section{Coxtinental Representatives}

The Lower Cretaceous deposits of the European continent vary greatly in their lithic components, their thickness, and their fossil contents. They may be regarded as comprising three different facies of the series, (1) a southern deep-sea facies typically developed in the south-east of France (Dauphiné and Provence), (2) a central or intermediate facies found in the Jura and Switzerland, (3) a northern facies found in Germany and Russia. It will suffice to describe the typical succession in each of these regions.

\section{Provence}

The finest sections in this area are those of the Montagne de Lure and Mount Ventoux near Sisteron and Simiane. The most recent studies of the strata forming these mountains are those of MM. Kilian and Leonhardt, and I shall here follow the capable 


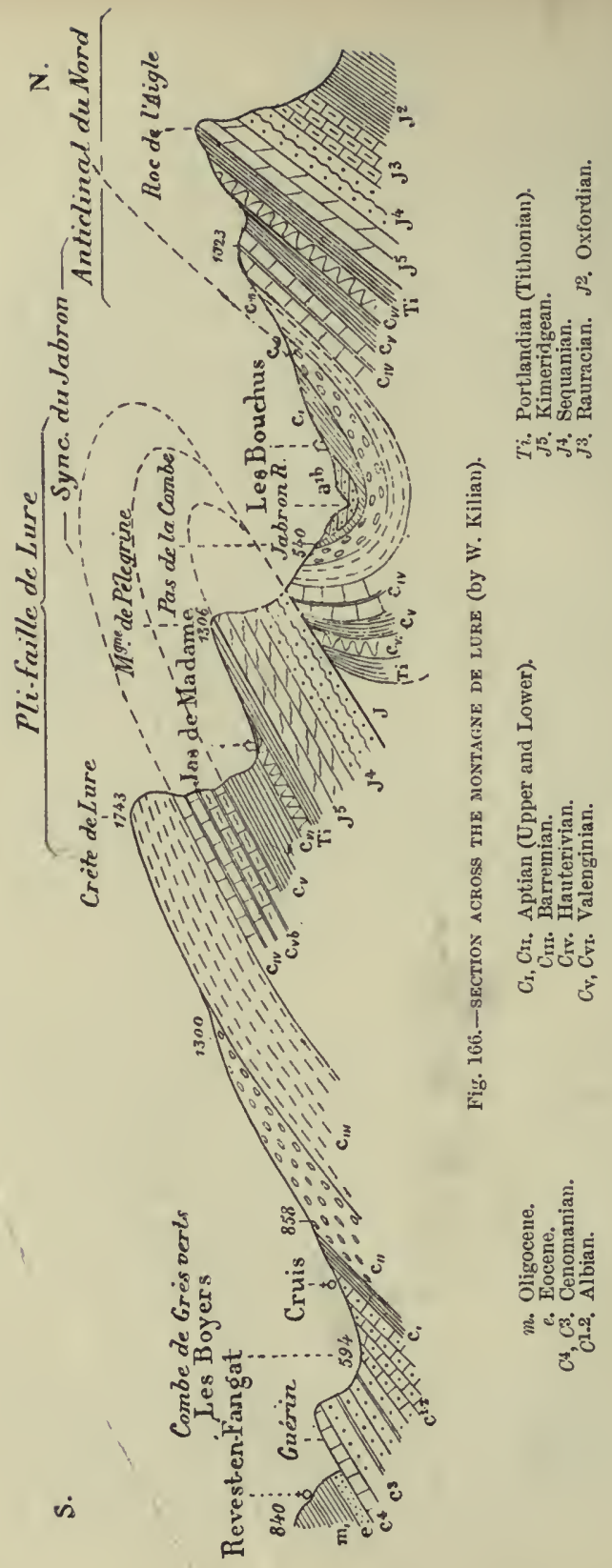


guidance of Professor Kilian with regard to the succession and the grouping of the zones. ${ }^{12}$ The illustration, Fig. 166, is reprodnced from one of his sections.

In this part of France there is a complete passage from the marine (Tithonian) facies of the Jurassic to the Lower Cretaceous, and the exact line of separation has been a matter of dispute, but Professor Kilian has made it clear that the zone of Hoplites Boissieri slionld be regarded as the fist term in the Cretaceous Series. The thickness of the several stages varies considerably in different parts of the area, but the total is about 2000 feet, and as it largely consists of limestones its formation must have occupied a long period of time.

The following is a tabular view of the succession in the M. de Inure:-

(Marls with Belemnites semicanalicutus, Oppelia nisns, Aptian, and Hoplites furcatus.

300 to 600 Limestone of Graves with Toxaster Collegnoi, etc.

Limestones with Heplites Deshayesi passing into Orbitolina limestone with liequienia ammonia.

Barremian, fLimestones with recticostalus and Macroscaphites Yvani.

200 to 400 (Limestones with Holcodiscus fallax and Crioccras Emerici.

Hauterivian, Limestones with Hoplites angulicostatus.

about 300 , Limestones with Crioceras Duvali, Hoplites radialus, and Bel. dilatatus.

Marly limestone with Hoplites neocomiensis and $H$.

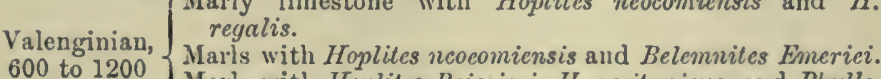
600 to $1200\left\{\begin{array}{l}\text { Marls with Hoplites ncoeomiensis and Belemnites Emeriei. } \\ \text { Marls with Hoplites Boissicri, H. occitanicus, and Phyllo- }\end{array}\right.$ ceras semisuleatum.

The limestone with Requienia ammonina, classed above as A ptian, is part of the special facies developed at Orgon in Vancluse, which was formerly regarded as the type of a stage called Urgonian by d'Orbigny but since found to pass laterally into Barremian and Lower Aptian.

\section{The Jura}

In this area the whole Lower Cretaceous Series is still purely marine, but the thickness is much less, being only from 500 to 700 feet, and Ammonoids are much less common than they are in the sonthern region, so that the same zones cannot be recognised. According to the most recent authorities the following is the general succession in the Eastern Jura and in the basin of the Rhone.

Aptian,
40 to 60
Barremian,
100 feet $\left\{\begin{array}{c}\text { Marls with Ostrea aquila and Plicatula placunea repre- } \\ \text { sented at Perte du Rhone by sandstones, underlain } \\ \text { by marls with Orbilolina lenticularis. } \\ \text { White limestone with liequicnia ammonia represented } \\ \text { at Perte du Rhone by red and grey limestones with } \\ \text { Heteraster oblongus and IIet. Conloni. }\end{array}\right.$


Hauterivian, $\left\{\begin{array}{c}\text { Yellow limestone of Neuchâtel with Toxaster complanatus, } \\ \text { Terebratula tamarindus, and Rhymchonella lata. } \\ \text { Marls of Hauterive with Hoplites radiatus, H. leopoldinus, } \\ \text { Holc. (Astieria) Astieri, and Belemnitcs dilatatus. } \\ \text { about } 300 \text { feet }\end{array}\right.$
Valenginian, with Bryozoa and Ostrea Couloni.
200 feet

\section{Germany}

The northern facies is well developed though not well exposed in Hanover. In the northern part of the province there appears to be a nearly complete marine series comparable with that of Speeton, and according to the recent observations of von Koenen the descending successiou can be made out as follows :-

Marls with Hoplites furcatus and Belemnites brunsvicensis.

4 Clay with Hoplites Deshayesi.

Clay with Ancyloceras gigas and Bclemnites Grasi.

3 Clays with several species of Crioceras and Ancylocerces with 3 Belemnites brunsvicensis.

${ }_{2}$ Clays with Crioceras Tombecki and C. capricornus.

2 (Clays with Hoplites radiatus (=noricus).

f Clays with Polyptychites tercissus and $P$. psilostomus.

1 Clays with Belemnites lateralis and Oxynoticeras Gevrili.

The figures 1 to 4 indicate a grouping which roughly corresponds with the Swiss and Jura stages, but the lowest inarine clays are not probably equivalents of the lowest Valenginian, for in Southern Hanover the marine beds are underlain by a thick estuarine and freshwater formation comparable with the English Wealden and like it consisting of sandstones in the lower part and of clays in the upper part, containing Corbula inflexa, Melania strombiformis, Cyrena, and Viviparus. In some places these clays have been observed to alternate with the lower marine clays, and the German Wealden is probably a delta formation formed by a river discharging into the Northern Sea.

\section{Russia}

The corresponding series in Russia is best exposed on the right bank of the Volga between Simbirsk and Syrzan, but its total thickness is very small, being only from 50 to 60 feet, and it must therefore be regarded as a condensed representative. The divisions recognised by Professor Pavlow and other Russian geologists are :- 
7. Shales with Hoptites Deshayesi . . . . . . 17

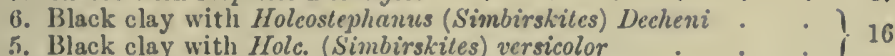

4. Sand and phosphatic nodnles, Hole. Keyserlingi . . .

3. Calcareous sandstone of Risan . . . . . 3

2. Sands and phosphate nodules with Hoplites nodiger and Hop. kashpuricus . . . . . . . . . 12

1. Sands with Craspedites subditus . . . . . . 10

The four lower zones contain Belemnites lateralis and the two upper Bel. Jasekovi, neither B. jaculum nor B. brunsvicensis occurring in Russia.

\section{UPPER CRETACEOUS SERIES}

\section{A. Stages and Zones}

As stated on $\mathrm{p} .471$, the members of this series have a far wider extension than those of the lower series; they extend southward below the English Channel into France, they pass eastward beneath the eastern counties of England, and below the floor of the North Sea into Belgium and Holland. The following is a tabular view of the stages and zones into which the English Series is divisible, with the names of the corresponding French stages:-

\begin{tabular}{|c|c|c|}
\hline Stages. & Zones. & French Divisions. \\
\hline \multirow{5}{*}{ Upper Chalk } & Ostrea lunata & \multirow{3}{*}{ Campanian. } \\
\hline & Belemnitella mucronata & \\
\hline & Actinocamax quadratus & \\
\hline & $\begin{array}{l}\text { Micraster coranguinum } \\
\text { Micraster cortestudinarium }\end{array}$ & Senonian. \\
\hline & Holaster planus & \\
\hline Middle Chalk & $\{$ Terebratulina lata & Turonian. \\
\hline Lower Chalk & Holaster subglobosus & \\
\hline & $\begin{array}{l}\text { ISchlcenbachia varians } \\
\text { Pecten asper }\end{array}$ & Cenonianian. \\
\hline Selbornian & $\begin{array}{l}\text { Schlonbachia rostrata } \\
\text { Hoplites interruptus }\end{array}$ & Albian. \\
\hline & (Douvilleiceras mammil & \\
\hline
\end{tabular}

\section{B. Characteristic Fossils}

The following are some of the species which are characteristic of each of the four stages or subdivisions of the Upper Cretaceous series :- 


\section{Fossils of the Selbornian and Albian}

Porifera.

Hydrozoa.

Chenendopora Michelini, Doryderma Benettiæ, Siphonia tulipa, Barroisia Orbignyi.

Parkeria sphærica.

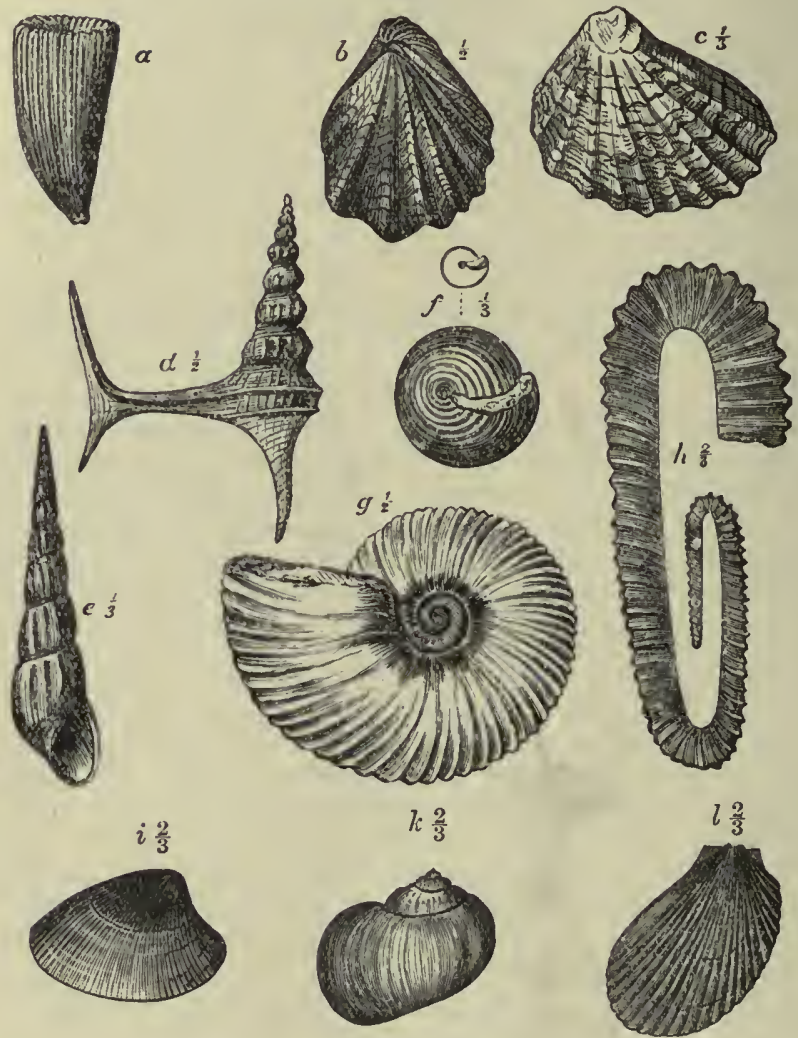

Fig. 167.-GROUP OF SELBORNIAN FOSSILS (GAULT).
a. Trochoeyathus conulus.
$b$. Inoceramus sulcatiss.
b. Inoceramus sulcaticatula gurgitis.
d. A porrhais carinata.
e. Scalaria gaultina.

f. Bellerophina minuta.

g. Hoplites splendens.

$h$. Hamites attenuatus.

i. Nucula pectinata.

$k$. Natica gaultina.

\section{l. Lima parallela.}

Actinozoa.

Cyclocyathus Fittoni, Trochocyathus conulus.

Echinoderma. Cardiaster fossarius, Cidaris gaultina, Echinospatagus murchisonianus, Cottaldia Beuettiæ, Pentacrinus Fittoni. 
Anuclide. Serpula concava, Ditrupa difformis.

Crustrceu. Etyus Martini, Necrocarcinus Beehci, l'aleocorystes Stokesi, Hoploparia longimana.

Brachiopoda. Terebratula biplicata, Terebratella jectita, Rliynchonella dimidiata, Lingula subovalis.

Lamellibranchio. Grammatodon earinatas, Cucullæa glabra, Peetunculus mmbonatus, Ostrea resiculosa, Exogyra conica, Plicatula gurgitis (= P. pectinoides), Lima gaultina,

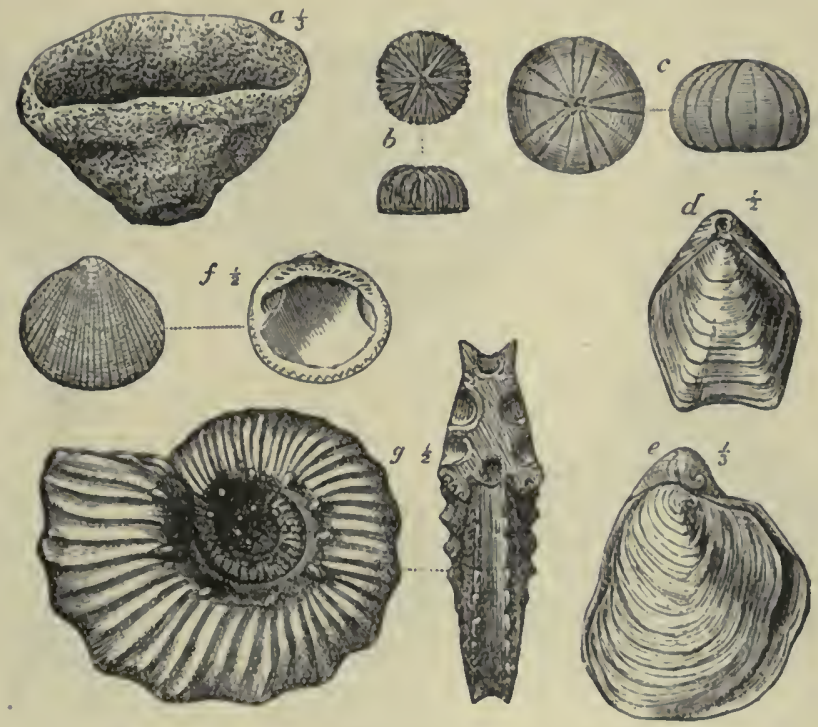

Fig. 16S.-Group OF SELBORNIAN FossIXs (GREENs.AND).
a. Chenendopora expansa.
b. Micrabacia coronula.
1. Terebratula biplicata.
c. Cottaldia Benettize.
e. Exogyra columba.
f. Pectunculus sublievis.

g. Hoplites auritus.

Inoceramus sulcatus, I. coneentricus, Nucula pectinata, Panopea mandibula, Trigonia aliformis.

Gnstropoda. Dicroloma (Anehura) carinata, D. (Perissoptera) Parkin. soni, Solarium ornatun, Bellerophina minuta, Natica gaultina, Scalaria gaultiu, Turritella grauulata.

Scaphopoda. Dentalium decussatum.

Cephalopoda. Douvilleiceras mammillatum, Desmoceras Bendanti, Hoplites interruptus, Hoplites lautus, Hoplites splendens, Hoplites auritus, Schlœubachia rostrata, Sehloenbachia varieosa, Hanites attenuatıs, Nautilus clementinus, Belemnites minimus. 
The following are common species which occur both in the Selbornian and the Lower Chalk (Cenomanian) :-

Elasmostoma consobrinum, Catopygus columbarius, Holaster lacvis, Salenia petalifera, Peltastes clathratus, Pscudodiadema variolare, $P_{s}$. ornatum, Discoidea subuculus, Kingena lima, Rhynchonella grasiana, Lima globosa, Pecten asper, P. orbicularis, P. hispidus, Ostrea vesicularis, Aucellina gryphaoides, Nautilus elegans.
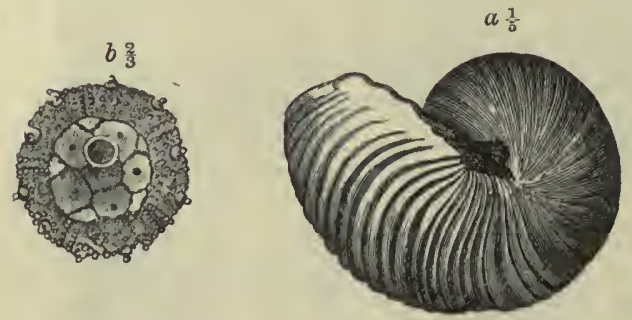

$c \frac{1}{2}$
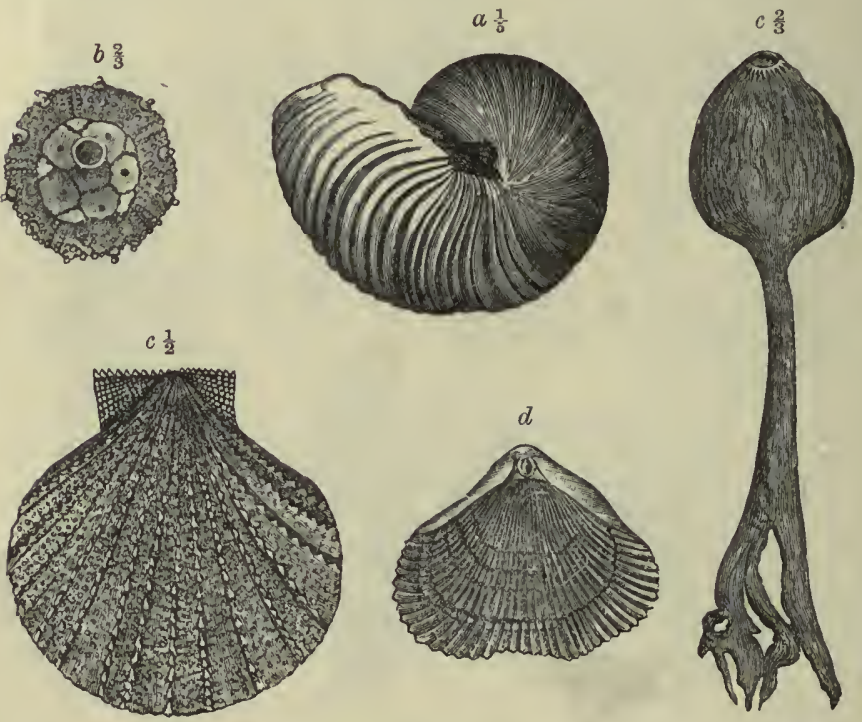

Fig. 169.-GROUP OF SELBORNLAN FOSSILS (GREENSANDS).

a. Nautilus elegans.

b. Salenia petalifera. c. Pecten asper (young).

d. Rhynchonella dimidiata.

e. Siphonia pyriformis.

\section{Fossils of the Lower Chalk and Cenomanian}

Porifcra. Stauronema Carteri, Plocoscyphia labrosa, P. fenestralis. Actinozoa.

Micrabacia coronua.

Echinoderma. Discoidea cylindrica, Holaster subglobosus, $\mathrm{H}$. trecensis, Cidaris vesiculosa.

Annelida.

Serpula umbonata, S. annulata.

Crustacea.

Brachiopoda.

Enoploclytia brevimana.

Rhynchonella Martini, R. Mantelliana, Terebratula semiglobosa, Terebratulina nodulosa.

Lamellibranchia. Cuicullæa mailleana, Inoceramus Crippsi, Lima aspera, Pecten elongatus, P. fissicosta, Plicatula inflata, Spondylus striatus, Unicardium ringmeriense. 
Siaphopoda.

Cephalopoda.
Gastropala.

Dicroloma (Perissoptera) Mantelli, Avellana cassis, Solariun bicarinatmm.

Deutalium majus.

Schlcenbachia varians, Acanthoceras rotomagensis, Acanthoceras Mantclli, Turrilites costatus, Scaphites requalis, Baculites baculoides, Actinocamax plems.

\section{Fossils of the Middle Chalk}

Echinodermata. Galerites (=Echinoconus) subrotundus, Cardiaster pygmaea, Discoidea Dixomi, Cidaris hirudo.
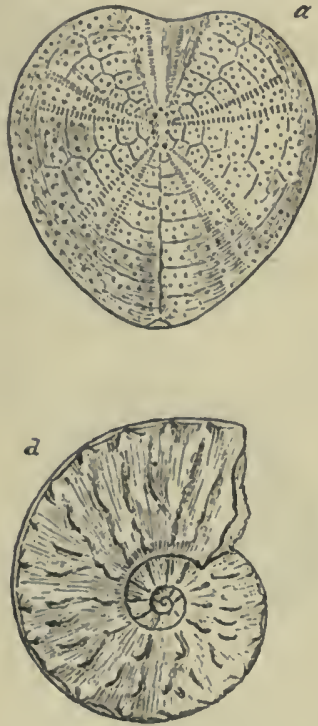
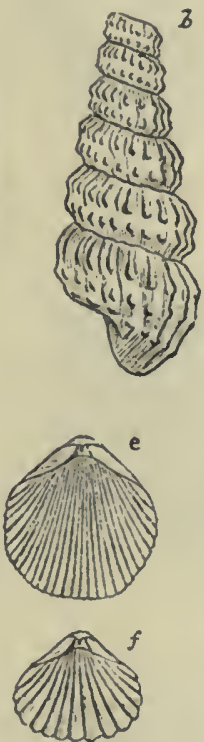

6

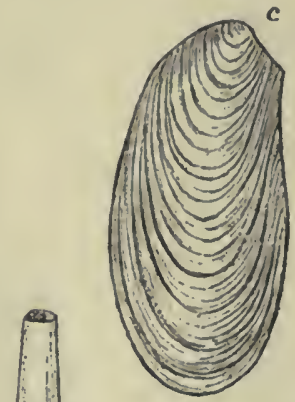

9

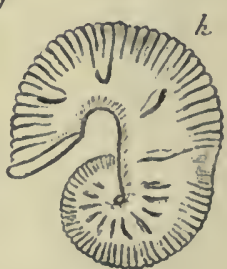

Fig. 170. - GROUP OF LOWER AND MIBDLE CHALK FOSSILS.

c. Holaster subglobosus, รै.

b. Turrilites costatus, $\frac{1}{2}$.

c. Inoceramus labiatus,

d. Schloenbachia varians, $\frac{1}{2}$. e. Rhynchonella Cuvieri, nat. size.

f. ", Mantellians, भ.

g. Actinocamax plenus,

h. Scaphites aqualis, 3 .

Brachiopola. Terebratula semiglobosa, Rhynchonclla Cuvieri, Terebratulina lata (= gracilis of most authors).

Lamellibranchia. Inoceramus labiatus (mytiloides), I. Lamarchi var. Cuvieri.

Cephalopola. Mammites nodosoides, Pachydiscus peramplus, Prionotropis Woolgari.

Fossils of the Upper Chalk (lower zones)

Porifera.

Camerospongia campanulata, Doryderma ramosum, Ventriculites impressus, V. mammillaris. 


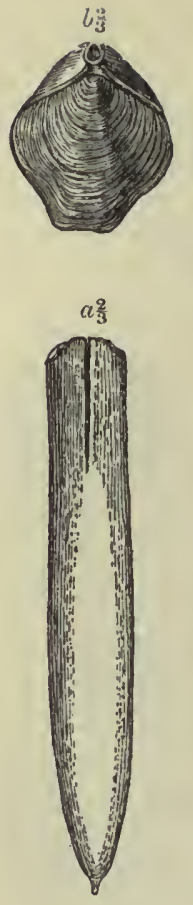

$h$

Joos000\%

$\therefore$

1 Acsogi

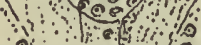

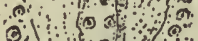
o: ov : (9) "sing
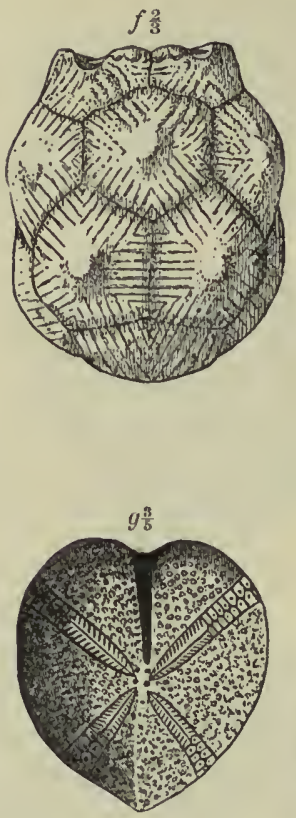

$i$

- $009060 \%$

$\because$ Hone esmo : - a doos 5. 0 of

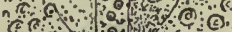
ce e s a \%
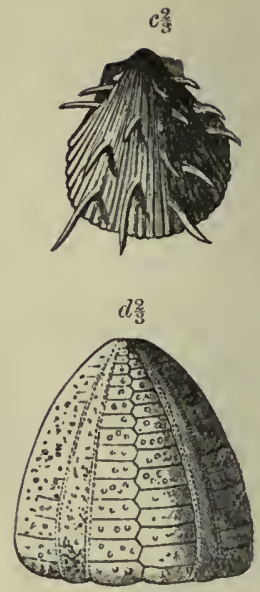

ed

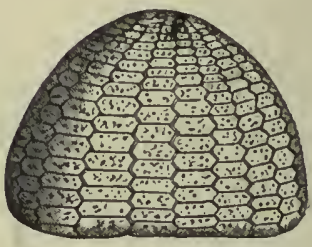

$k$

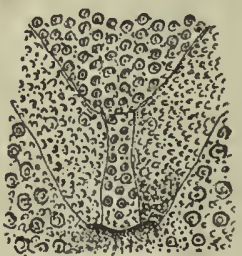

Fig. 171.-GROUP OF UPPER CHALK FOSSILS.

a. Belemnitella mucronata.

b. Terebratula carnea.

c. Spondylus spinosus.

d. Galerites conicus.

e. Echinocorys vulgaris. f. Marsupites testudinarius.

g. Mieraster coranguinum.

$h$. , Leskei (base).

i. " " prrecursor (base).

$k$. " $\quad$ coranguinum (base). 
Lichinodermu. Cidaris clavigera, C. perornata, Phymosoma (=Cyphosoma) radiatum, Holaster planus, Micraster Leskei (= breviporus), M. precursor, M. cortestudinarium, II. coranguinum, Epiaster gibbus.

Lamellibranchix. Inoceranus involutus, I. Lanarcki, and var. Brongniarti, Lima Hoperi, L. divaricata, Plicatula Barroisi.

Gastropolia. Solariella gemmata, Trochus Schliteri, Cerithium Saundersi.

Cephalopola. Hetcroceras reussianum, Scaphites Geinitzi, Baculites bohenicus.

\section{Fossils of the Upper Chalk (higher zones)}

Porifera.

Cceloptychium agaricioides, Plinthosella squammosa, Scytalia radiciformis, Siphonia Kœnigi, Stichophyma tumidum.

Anthozoa. Caryophyllia cylindracea, Coclosmilia laxa, Parasmilia Fittoni.

Echinoderma. Galerites (=Echinoconus) abbreviatus, Offaster pilula, Marsupites testudinarius, Mlicraster coranguinum, Cardiaster ananchytis.

Brachiopoda. Rhynchonella limbata, Magas pumilus, Crania costata, Terebratulina Rowei, T. gracilis.

Lamellibranchia. Ostrea acutirostris, O. curvirostris, 0 . lunata, 0. wegmaniana, Pecten Nilssoui, P. cretosus, P. Mantellianus, Spoudylus dutempleanus.

Cephalopoda. Haploceras leptophyllum, Scaphites constrictus, Bacu. lites Faujasi, Hamites cylindraceus, Actinocamax quadratus, Act. granulatus, Beleninitella mucronata, B. lanceolata.

Besides the above, the following are more or less common throughout the Upper Chalk :-

Porifera.

Anthozou. Parasmilia centralis, Axogaster cretacea.

Heterostinia obliqua, Ventriculites decurrens, V. radiatus.

Echinoderma. Echinocorys (=Ananchytes) vulgaris, Galerites (Echinoconus) conicus, Cidaris sceptrifera, Plymosoma (=Cyphosoma) Kiœnigi.

Brachiopoda. Terebratula carnea, Rhynchonella plicatilis, Rh. rcedensis.

Lamellibranchia. Ostrea semiplana, Spondylus spinosus.

\section{The Upper Cretaceous of Britain}

\section{England}

In describing the Upper Cretaceous strata it will be more convenient to take each stage separately and trace its variations across England.

Selbornian.-This stage includes the deposits which have long been known as Gault and Upper Greensand, names which date from a time when a Middle Cretaceous Series was supposed to exist, comprising the Lower Greensand, the Gault, and the Upper Green- 
sand, which were supposed to occur in regular upward succession. As the palæontology of these deposits was more carefully studied it was seen that the "Lower Greensand "was a distinct stage, but that the Upper Greensand was inseparable from the Gault, and was to a large extent merely a sandy facies of the Gault. Hence it became necessary to combine these two facies under one name as a single stage. For this the name Selbornian has been chosen from the village of Selborne in Hampshire, though the names Gault and Greeusand are convenient terms for the argillaceous and the sandy facies respectively. ${ }^{13}$ Where the stage is complete four zones can be distinguished. These are:-

\section{Zone of Pecten asper and Cardiaster fossarius. \\ 3. Zone of Schlcenbachia rostrata (=inflata). \\ 2. Zone of Hoplites lautus and $H$. interruptus. \\ 1. Zone of Douvilleiceras mammillatum.}

Of these zones the lowest is always a sand, the second is generally clay (i.e. Gault), the third may be clay or marl or malmstone or sand, the fourth is always a "greensand" or sandstone.

The typical development of the argillaceous facies is in Kent, and the beds are well exposed at Folkestone, where the "Lower Gault" consists of grey clays with several bands of phosphatic nodules and a layer of such nodules at the base embedded in darkgreen glauconitic sand. The characteristic fossils are Hoplites interruptus, H. splendens, H. lautus (upper part), Lima parallela, Pinna tetragona, Inoceramus concentricus. Below and forming the base of the stage are 5 or 6 feet of coarse green sand containing Douvilleiceras mammillatus.

The Upper Gault or zone of Sch. rostrata consists of pale-grey marly clay about 78 feet thick; this includes a bed of dark-green glauconitic sand in the upper part, and is separated from the Lower Gault by a layer of phosphatic nodules. These beds yield Schloenbachia rostrata, Sch. Goodhalli, Pecten raulinianus, Terebratula biplicata in the upper part, Schloenbachia varicosa and Inoceramus sulcatu's in the lower part.

Inland the thickness of the Gault becomes much greater and is about 200 feet near Maidstone. This increase appears to be chiefly in the Upper Gault, but it is not till we reach Westerham that the so-called "Upper Greensand" makes its appearance at the top of the Gault, and thence it thickens westward through Surrey. This deposit is known in Surrey as "firestone" and "hearthstone," and in Hampshire as "malmstone"; it is a greenish-grey siliceous stone consisting partly of fine sand and glauconite grains, partly of sponge spicules and globular colloid silica, and it passes down into sandy marls which are clearly part of the Upper Gault. 
In Hampshire, near Alton and Selborne (see map, Fig. 157), the general succession is as follows:-

5. Soft greenish sands without fossits

2 to 15

4. Malunstono with beds of calcareous stone . . 80 to 100

3. Sandy marls with Sch. rostrata and Inoc. sulcatus 30 to 50

2. Dark clays with Hoplites interruptus . . . about 100

1. Green sands with phosphatic nodules . . . 3 to 15

About 240

From the malmstone Schlonbachia rostrata, Hoplites auritus, Anisoceras armatum, Arca carinata, and Pleuromya mandibula have been obtained, and there is no doubt that it represents the greater part of the Upper Gault of Folkestone.

In Wiltshire and the Isle of Wight there is a similar succession, and the beds are well exposed in the Undercliff along the south side of the Isle of Wight, where the following are the main subdivisions :-

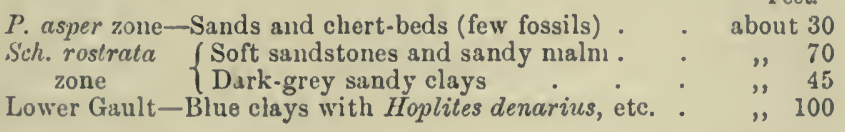

The "Gault" passes down into the "Carstone" (see p. 481), which Mr. A. Strahan is inclined to regard as representing the zone of Douv. mammillatum; but that fossil has not yet been found, and the question remains undecided.

In South Dorset the succession is similar, bnt the base of the Selbornian is sharply defined by a thin layer of quartz pebbles, while the Lower Gault becomes more and more sandy as it is traced westward. The zone of Sch. rostrata consists of green sands with beds of calcareous sandstone, and there is always a well-marked zone of Pecten asper at the top.

In Devon the beds are well exposed in the clifts between Lyme Regis and Sidmonth, the base of the Selbornian gradually passing over the Lower Lias and across the Kenper marls till it rests on the Keuper sandstones (see Fig. 131, p. 396). At the base near Lyme and Axmouth there are still some few feet of clay (Lower Gault), but westward this either thins out or passes into sand. At Beer and near Beer Head the succession is as follows:-

Zone of (Hard calcareous sandstone (few fossils) . . about 10

$P$. asper $\{$ Sandstones with chert-nodules, Exogyra digitata $\quad 60$

Zono of Soft grey sands passing down into dark-green

S. rostrata $\left\{\begin{array}{l}\text { clayey sand, Dosiniopsis caperata . . . } 90 \\ \hline\end{array}\right.$ 
In this area Pecten asper does not occur in the Selbornian, but is found in the overlying arenaceous representative of the Lower Chalk.

At Sidmouth and in the Blackdown Hills the lower sands have yielded a rich fauna, the shells being preserved in chalcedony, and the following are some of the commonest species, Sch. varicosa, Aporrhais calcarata, Turritella granulata, Protocardia hillana, Cucullcea glabra, Cytherea (Callista) plana, Dosiniopsis caperata, Lucina orbicularis, Trigonia aliformis, and Tr. scabricola.

An outlier of the Selbornian sands occurs on the Haldon Hills about 12 miles south-west of Sidmouth. Here they rest on the red Permian breccias, and are reduced to a thickness of 70 or 80 feet.

Passing now to the main outcrop of the Selbornian from Wiltshire northward, we may briefly indicate the lithological variations which it exhibits in that direction. In Berkshire and Oxfordshire the facies is similar to that of Hampshire, but the total thickness is greater, being about 300 feet. The zone of Sch. rostrata is partly represented by marls and partly by malmstones, and the bed of unfossiliferous greensand at the top is a continuous band 15 or 20 feet thick. But both the greensand and the malmstone die out in Buckinghan, leaving a purely argillaceous facies like that of Folkestone, the Lower Gault being about 150 feet thick and the Upper about 80 feet, a notable fact being tlie occurrence of a layer of phosphatic nodules at the base of the Upper Gault, embedded in glauconitic clay and lyiug on an eroded surface of the lower clays.

Traced to the north-east both subdivisions become thinner and the Upper Gault has also suffered erosion, witl the result that a layer of nodules and fossils derived from it occurs at the base of the Lower Chalk. Near Cambridge the Gault is from 140 to 120 feet thick, including a variable thickness of the rostrata zone, but at Soham, where it passes below the level of the Fenland, it is only 90 feet.

When it emerges at Stoke Ferry in Norfolk it is still 60 feet thick, but at Roydon and Grimston it is less than 20 feet and consists of red and grey marls with two beds of grey limestone. ${ }^{14}$ Farther north it passes into a red limestone, which is generally called the "Red Chalk" and is so strikingly exposed in the cliffs at Hunstanton. This red rock is only $3 \frac{1}{2}$ feet thick, and consists of three layers, each passing into the other. The lowest is sandy and of a deep brick-red colour full of Bel. minimus and Terebratula biplicata; the central part is a red nodular limestone with the same fossils and many others, including Hoplites lautus, $H$. splendens, H. tuberculatus, Inoceramus sulcatus, and Inoc. concentricus. 
The highest layer is a pale-pink limestone with few fossils. Thus the Red Chalk appears to be a condensed representative of the whole Selbor'nian stage.

It appears again near Welton and Willoughby in Lincolnshire, where it is 10 to 12 feet thick, but thins again to 4 or 5 near Caistor. In South Yorkshire the beds are about 7 feet thick, thinning to the nortl-east, till at Leavening and Wharran it is less than 2 feet, its base containing pebbles of quartz and ironstone. Eastward, however, it expands, and at Speeton it is represented by over 30 feet of material as below :-

Feet.

Smooth and firm red marl about 4

Red inarl, cuclosing lumpis of harder and nore calcareous material, with many fossils . . . . . . "16 Tough red marly chalk in irregular beds . . . . ", 10

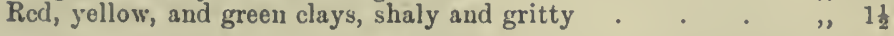

The lowest beds contain Bel. minimus and Inoceramus sulcatus, the higher hold Terebratula biplicata, T. capillata, Kingena lima, etc.

Lower Chalk-This stage as developed in the south of England is divisible into two parts or zones, the lower part forming the zone of Schlonbachia variuns, and the higher part that of Holaster subglobosus. At the base, and included in the range of Sch. varians, is the sub-zone of Stauronema Carteri, consisting of sandy glauconitic chalk which is often called the "Chloritic marl." At the top is a band of soft grey marl which is the sub-zone of Actinocamax plenus, often called Belemnite unarl from the presence of that Belemnoid.

At Folkestone the beds composing the Lower Chalk are :- ${ }^{15}$

Zonc of Hol. (7. Belemnite uarl (witl Act. plenus) subglobosus, $\{$ 6. Whitish clialk in massive beds (fow fossils). $\quad . \quad 60$

126 feet 5. Grey chalk in massive beds . . . . 60

(4. Grey marly chalk .

varians, $\left\{\begin{array}{l}\text { 3. Alternating beds of grcy marl and hard grey chalk } \\ \text { with many fossils }\end{array}\right.$

68 fect $\{$ 2. Grey clialk with reefs of sponges (Plocoscyphia) $\quad 22$

1. Soft green glauconitic chalk (Stauronema) . . 16

194

The Lower Chalk attains its greatest thickness in Wiltshire, where it is about $\mathbf{2 5 0}$ feet, the greater part belonging to the zone of Sch. varians, which includes beds of a peculiar siliceous chalk containing imperfect flints.

In the Isle of Wight the best exposure of the Lower Chalk is in the Culver Cliffs north of Sandown (see map, Fig. 172), where 


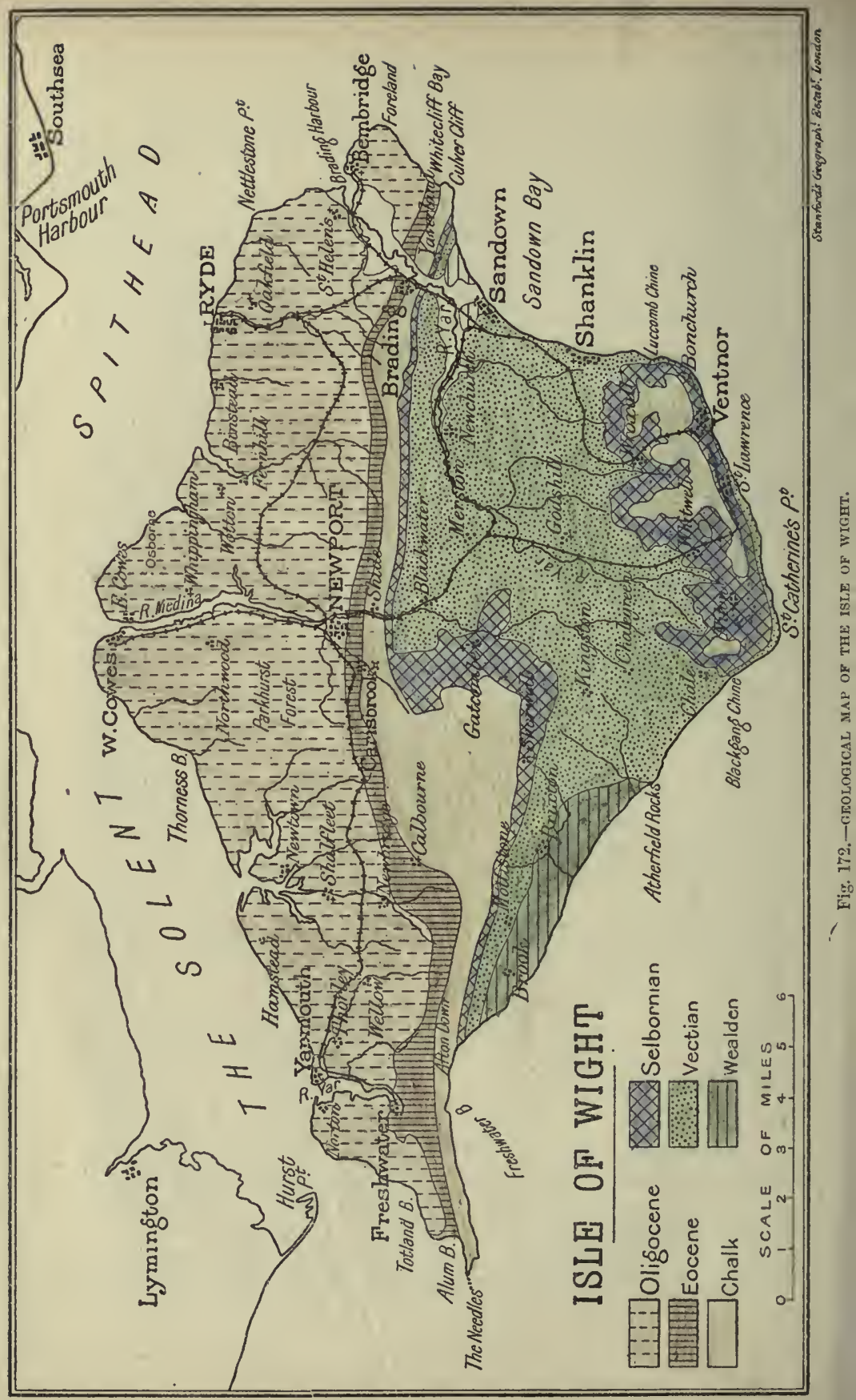


the total thickness is 212 feet, the zone of Hol. subglobosus with the Belemnite marl being 92 feet and the zone of Sch. varians about 120 feet. The basement bed or Chloritic marl is from 6 to 8 feet thick along the Undercliff (Ventnor, etc.), and abounds in phosphatised casts of Schlonbachia varians, Acanth. Mantelli, Turrilites Morrisi, and Cucullea mailleana, together with shells of Pecten asper, Rhynchonella grasiana, and Stauronema Carteri.

In Dorset there is a more decided break between the Selbornian and the Lower Chalk; the basement bed is a glauconitic chalk with phosphatic nodules and fossils, but it does not seem to be the equivalent of the Chloritic marl, for it does not contain Stauronema, while it has other fossils which in the Isle of Wight are common from 10 to 20 feet above the Chloritic marl, such as Scaphites requalis, Acanthoceras rotomagensis, Turrilites Wiesti, and Holaster subglobosus. Other common fossils are Cucullce mailleana, Unicardium ringmeriense, and Galerites castanea. The thickness of the Lower Chalk is also less (140 feet near Swanage), diminishing westward till it is only about 60 feet in West Dorset.

The Dorset facies of the Lower Chalk can be traced inland by Bridport, Beaminster, and Crewkerne to Chard in Somerset, where it is still about 60 feet thick with a highly fossiliferous bed at the base; but when it reappears on the coast near Lyme and Seaton it has undergone such a change that it ceases to be chalk, and is reduced to a thin band of calcareous sandstone enclosing large grains of quartz. Near Lyme this bed is only 3 or 4 feet thick, but at Beer Head it swells out into two beds which have a combined thickness of 18 feet and are highly fossiliferous. ${ }^{16}$

The fossils in these calcareous sandstones show that they represent the Chalk marl of more eastern counties, the commonest being Sch. varians, Acanth. Mantelli, Turr. costatus, Scaphites cequalis, Holaster subglobosus, Hol. lavis, and Galerites castanea, while species which connect them with the Cenomanian of France are Trigonia vicaryana, Pecten asper, P. puzosianus, P. subacutus, Lima tecta, Terebratula tornacensis, T. capillata, Rhynch. dimidiata, Cottaldia Benettice, and Catopygus columbarius. The sponges Elasmostoma and Trematocystia are not uncommon.

Passing to the Midland counties, we find a continuous outcrop of Lower Chalk in the lower part of the Chalk escarpment which runs from Wiltshire to Norfolk and is broken only by the valley of the Thames. North of this valley through Berks, Bucks, Bedford, Cambridge, and Suffolk the Lower Chalk has the following composition :- 
5. Soft grey shaly marl enclosing a band of hard white chalk, Actinocamax plenus . . . . . .

4. Tough blocky chalk without distinct bedding, Holaster subglobosus, Acanth. rotomagensis.

3. Totternhoe stone, hard grey sand chalk, Rhynch. Mantelliana, Lima echinata, Kingena lima, Pecten fissicosta

Feet.

3 to 5

60 to 80

2 to 20

2. Soft marls with occasional layers of hard marly rock in Oxford and Bucks, Schloenb. varians, Rhynch. Martini, Inoceramus latus.

1. Marl with green grains, passing northward into the nodule bed known as Cambridge Greensand . . . .

60 to 80

The Cambridge Greensand (see Fig. 162) commences near Barton-le-Clay (north of Luton), to which locality the nodule bed in the Gault has been traced, and there can be little doubt that all the nodules and the phosphatised fossils which occur in the Cambridge Greensand have been derived from the erosion of the Upper Gault. This derived fauna comprises some 210 species of Invertebrata, and about 80 of these have not yet been recognised elsewhere in England; out of the remaining 130 no less than 114 occur in the Gault of Folkestone, nearly all the commoner fossils occurring in the Upper Gault. ${ }^{17}$ The comnonest species are Sch. rostrata, Hoplites auritus, $H$. raulinianus, Avicula gryphooides, Terebratula biplicata, Plicatula gurgitis, and Rhynchonella sulcata, but it is noteworthy that the last is a very rare fossil in the Gault elsewhere.

The Vertebrate fauna of the Cambridge Greensand is very remarkable, the remains of many species of Ichthyosaurs, Plesiosaurs, Dinosaurs, Chelonians, and Pterodactyles having been found, together with bones belonging to a bird (Enaliornis). Most of these bones have doubtless been washed out of the Gault, but some may be Chalk Marl forms.

The indigenous fauna of the Cambridge Greensand is found in the marly matrix of the bed, and some of the species are Vermicularia umbonata, Discoidea subucula, Micrabacia coronula, Rhynchonella lineolata, Kingena lima, and Terebratulina triangularis, most of which occur also in the Chalk Marl above.

Another speciality of this district is the Totternhoe stone, so named from a place near Dunstable, where it is 20 feet thick, and is quarried for building purposes. It varies greatly, however, in thickness, and is sometimes represented by two beds of stone, with Chalk Marl between them. At its base there is usually a layer of green-coated phosphatic nodules, and small fragments of phosphate are common in the stone above.

In Norfolk the Lower Chalk becomes greatly reduced in thickness and at the same time harder and more purely calcareous, both these changes being evidently due to a diminution in the 
quantity of intermingled argillaceous matter. Thus at Heacham and Hunstanton the stage has the following composition:-18

Zone of $\int 5$. Hard whitish chalk in rather thin beds . . . 35

Offaster $\{4$. Rough dark-grey chalk with a layer of green-coated

sphcericus nodules at the base (Totternhoo stone) . .

Zone of $\int_{2}^{3}$. Hard creamy white chalk grey rough and shelly chalk with a layer

Schlan.

varians of green-coated nodules at the base . . . 4

1. Hard white nodular limestone . : : : $1 \frac{1}{2}$

The hard shelly chalk (No. 2) is often called the "Inoceramus Bed" because it is crowded with fragments of Inoceramus shells, probably of Inoc. latus. It also contains Holaster subglobosus and Acanth. rotomagensis; but the former here ranges throughout the stage, so that it is convenient to take another urchin as index for the upper zone, and for this purpose Offaster sphoricus, common in the upper beds of Lincolnshire and Yorkshire, seems best.

In Lincolnshire the only noticeable variations are (1) the red and pink coloration of two beds in the zone of Offaster sphcericus near Louth ; (2) the reappearance of the Belemnite marl, which is absent near Hunstanton, but is often 2 feet thick in Lincolnshire, and is sometimes stained dark red or purple. The Totternhoe stone is a constant bed about 2 feet thick throughout the county. ${ }^{19}$

In Yorkshire the Lower Chalk maintains the Lincolnshire facies along the greater part of the escarpment, but at Speeton it shows some changes. The zone of Sch. varians expands to 77 feet, and the lower part consists of nodular chalk in alternating pink and white bands. The zone of Offaster spharicus is 46 feet thick, and the lorrest bed is in places stained pink. At the top the Belemnite marls are well marked, enclosing a medial bed of hard smooth white chalk.

Middle Chalk. - At the base of this stage there is always a certain thickness of hard nodular chalk which forms a great contrast to the soft marl on which it rests; this rocky chalk is called the Melbourn rock from a village in Cambridgeshire.

Commencing as before in Kent, we find a good section of this stage in the cliffs near Dover, which show :-

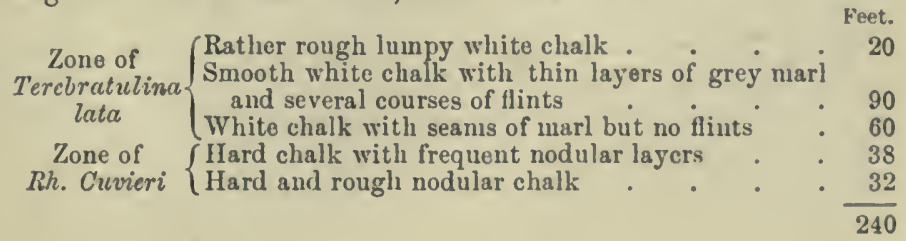


The fossils in the lower zone are Rhynchonella Cuvieri, Inoceramus mytiloides, Cardiaster pygmous, Galerites subrotundus, Discoidea Dixoni, and its variety minima. In the upper zone are Terebratulina lata, Inoceramus Cuvieri, and Micraster corbovis; here too Spondylus spinosus makes its first appearance, and Holaster planus comes in near the top.

These beds can be traced all round the Wealden area, and another fine exposure of them can be seen in the cliffs of Beachy Head, where, however, there are no flints in the zone of Ter. lata.

In the Isle of Wight, Culver Cliff and quarries near Yarbridge exhibit the following succession :-

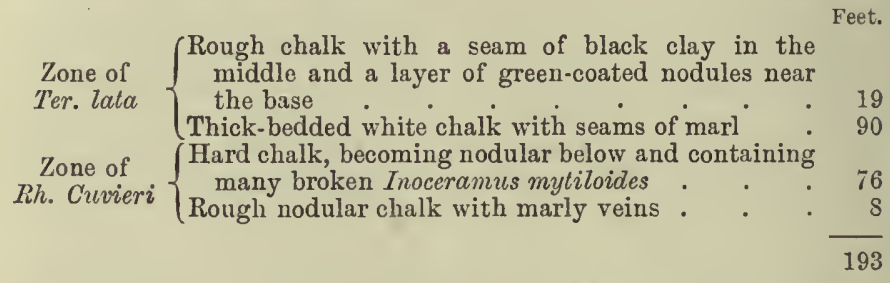

Westward in Compton Bay the thickness is reduced to 150 feet. In Dorset, at Ballard Cliff, it is only 122 feet, but the same layer of green-coated nodules occurs about 20 feet from the top and has been mistaken for Chalk rock. At White Nothe Mr. A. W. Rowe estimates its thickness at 134 feet. $^{20}$

In Devon the Middle Chalk is well exposed near Beer, and is about 100 feet thick, the zone of $R h$. Cuvieri here including some thickness of hard shelly chalk which is quarried for building purposes, and is known as Beer stone.

In the Midland counties this division exhibits the same lithological and palæontological characters as in the south of England. In Berkshire it is not more than 150 feet, but north of the Thames it rapidly thickens to about 220 feet, and maintains this thickness into Suffolk. The Melbourn rock at the base is from 8 to 10 feet thick, and consists of hard nodular chalk; it passes up into bedded chalk, in which Inoceramus mytiloides and Rhynchonella Cuvieri are generally abundant. The higher zone consists of soft white chalk with layers of grey shaly marl and occasional nodules of flint, which latter become more numerous towards the north, till in Cambridge and Suffolk flints are frequent in this zone and are often of elongate finger-like form. Fossils are seldom abundant, but Galerites subrotundus and Terebratulina lata occur, with Spondylus spinosus, Holaster planus, and Micraster corbovis in the higher part. 
In the nortli-west of Norfolk the Middle Chalk appears to be only about 100 feet thick. The Melbourn rock continues at the base of the zone of Rhynchonella Cuvieri, but the beds above are less nodular than they are farther south, and the zone of Terebratulina lata consists of hard white chalk with many layers of flints.

In Lincolnshire there is no definite Melbour'n rock, and the zone of Rhynch. Cuvieri is reduced to a thickness of 10 or 15 feet, consisting of yellowish-grey chalk full of fragments of Inoceramus shell and containing Inoc. mytiloides, Rhynch. Cuvieri, and Terebratula semiglobosa. At the top is a layer of grey shale, and the succeeding zone of Ter. lata consists of firm white chalk with frequent layers of grey flints. Inoceramus Cuvieri is the only common fossil, and the thickness of the zone may be 80 to 100 feet.

In South Yorkshire both zones are exposed in some large quarries near Hessle Station and have yielded a larger number of fossils, but little is known of the Middle Chalk in its course through Yorkshire except that the whole of it becomes very hard. Near Speeton, on the coast, the Middle Chalk is exposed in a fine range of eliffs and has been described by $\mathrm{Mr}$. A. W. Rowe. ${ }^{21}$ The zone of $R h$. Cuvieri is, as usual, in the north very thin, being less than 12 feet, but the overlying Ter. lata zone has expanded to a thickness of 210 feet, that fossil with small Rhynch. Cuvieri, Inoceramus Brongniarti, and Holaster planus being colnmon throughout the whole of it.

Upper Chalk-The chalk of this division has been divided into seven zones (see p. 491), but the higher zones are not everywhere present, having been removed from large areas in the south of England during the upheaval which preceded the formation of the Eocene deposits. These seven zones may be grouped into two sub-stages, the lower of which, including the zones of Hol. planus, Micraster cortestudinarium, and $M$. coranguinum, nay be termed the Micraster chalk, while the ligher zones may be called the Belemnite chalk until more definite names are proposed.

In Kent the Upper Chalk forms the cliffs from St. Margaret's Bay near Dover to Walmer and Deal, and again from Ramsgate round the Isle of Thanet to Margate and Reculvers, but the highest zone found in the county is that of Marsupites.

Mr. W. Hill finds a convenient base for the zone of Holaster planus in a bed which is full of scattered flints, and in which Echinocorys vulgaris makes its appearance. ${ }^{22}$ Mensured from this the thickness of the zone is about 48 feet, and it consists of a succession of bets of rough lumpy chalk, the lumps being very hard but embedded in a softer matrix, and the top is marked by a coarse hard nodular rockyichalk. In these beds Micraster Leskei, M. precursor, and Hol. planus are common. 
The complete succession of the zones exposed between Dover and Margate in descending order is as follows :-

Soft chalk in two sub-zones, the upper characterised by Marsupites and Uintacrinus, the lower by Actinocamax granulatus, and A. verus also occur.

Zone of Micr. coranguinum. Smooth chalk with many layers of black flints; Cidaris secptrifera, C. perornata, Galerites conicus, and Cyphosoma Konigi Zone of Micr. cortestudinarium. Rough nodular chalk with many flints; Mieraster precursor and Hol. placente

Feet.

Zone of Holaster planus (as above described).

On the coast of Sussex, however, higher zones come in. The Marsupite zone has been identified at Seaford Head, and above it is 170 feet of chalk containing Offaster pilula, Actinocamax granulatus, Colosmilia laxa, and other fossils of the quadratus zone. This chalk extends westward from Newhaven to Brighton, and thence to the valley of the Arun, where a succession of quarries between Houghton and Arundel shows parts of all the zones above mentioned (see Fig. 173). Still farther west chalk containing Belemnitella mucronata has been found, and this highest zone underlies the Eocene of Hampshire and is well exposed in quarries on Portsdown Hill, where an inlier of chalk is brought up within the Tertiary area by an anticlinal flexure. The total thickness of the Upper Chalk in West Sussex and Hampshire must be from 800 to 900 feet.

In the Isle of Wight the Upper Chalk forms a long and narrow outcrop across the centre of the island in consequence of the steep dip imparted to it by the flexure which carries them below the Eocene of the Hampshire basin (see Fig. 172). Its thickness is from 1200 to 1300 feet, and the thicknesses of the several zones at the western end of the outcrop, as recently determined by Mr. Rowe's measurements, are as follows :- ${ }^{23}$

Zone of Bel. mucronata. White chalk with flints, Echinocorys (pyramidal form), Cidaris serrata, Magas pumilus. . .

Zone of Act. quadratus. White chalk with some marl seams but

few fossils
Zone of Mrarsupites. Compact white chalk with fints.

Zone of Micraster coranguinum. Chalk with many layers of flint nodules and the usual fossils .

Zone of Micraster cortestudinarium. Rough nodular chalk with

Zone of Holaster planus. Hard greyish nodular chalk

Feet. 


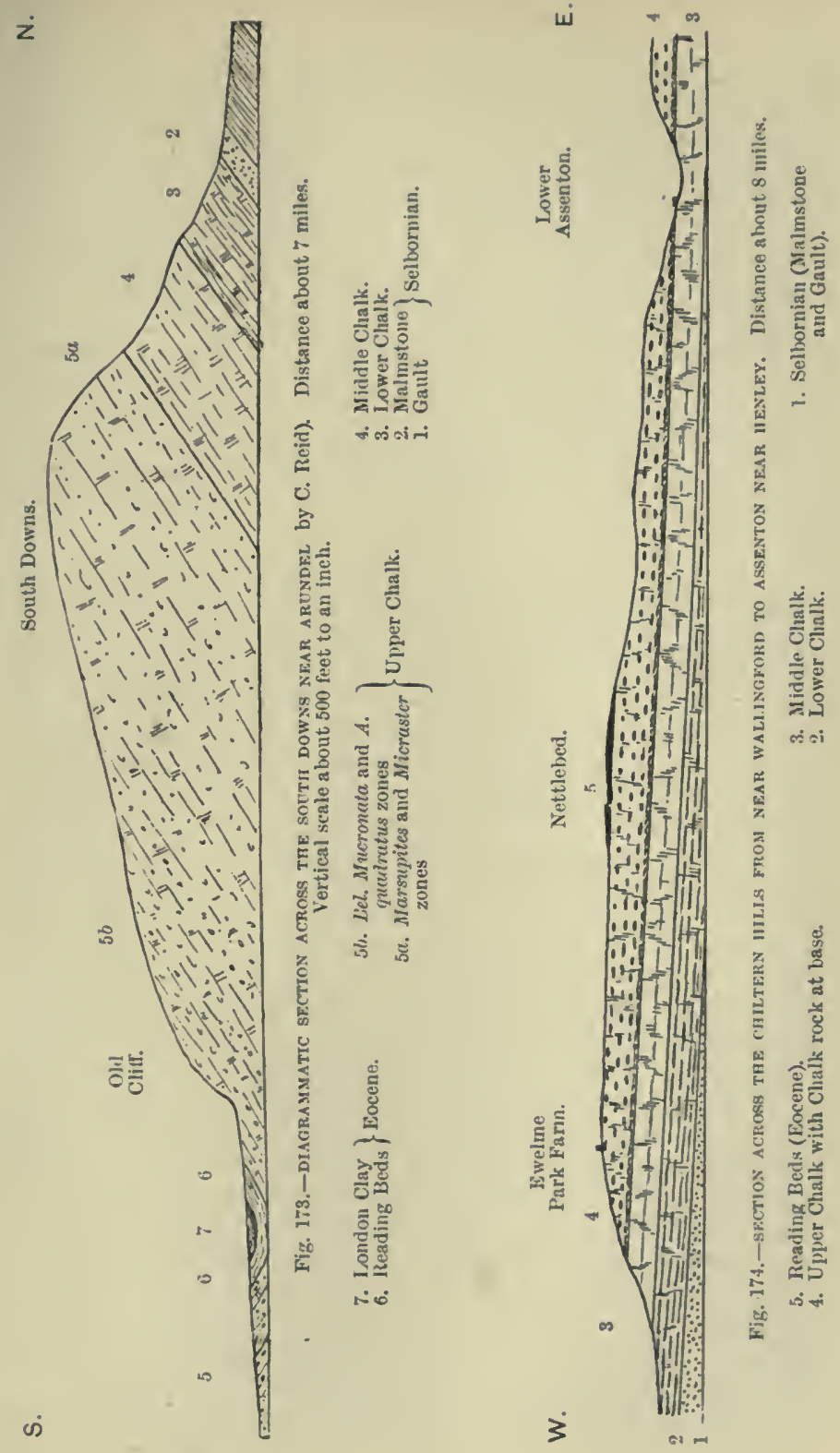


The same zones with a total thickness of about 1000 feet are found in Dorset, where Mr. Rowe has recently identified the zone of Marsupites and has been able to separate the zone of Act. quadratus from that of Bel. mucronata, assigning a thickness of 354 feet to the former and not less than 250 to the latter, ${ }^{24}$ the characteristic fossils of the one being Actinocamax granulatus, Act. quadratus, and Offaster pilula, while those of the higher zone are Belemnitella mucronata, B. lanceolata, Cardiaster ananchytis, Magas pumilus, Crania costata, and Rhynchonella limbata.

In Wiltshire and all along the inland outcrop from Salisbury Plain to Suffolk the Micraster zones are exposed in numerous chalk pits and the higher zones are all present in South Wiltshire, but north of the Vale of Pewsey the zone of Bel. mucronata does not occur, and that of Act. quadratus is gradually cut out by the preTertiary planation, till the Eocene comes to lie on the Marsupites zone.

In all these counties the lower part of the Hol. planus zone consists of several beds of very hard compact chalky limestone, generally of a creamy colour, and each bed having a layer of calcareo-phosphatic nodules at the top. This limestone is known as "The Chalk Rock"; above it there is from 15 to 20 feet of greyish nodular chalk consisting of hard lumps embedded in a soft matrix. The total thickness of the zone seldom exceeds 26 feet, so that it may be regarded as a condensed equivalent of the more expanded zone to the south.

The Chalk rock frequently contains grains of glauconite and is often full of fossils, among which Gastropods are noticeable, for these are rarely found either in Middle or Upper Chalk. The most characteristic fossils are Pachydiscus peramplus, Prionocyclus Neptuni, Scaphites Geinitzi, Heteroceras reussianum, Turbo Geinitzi, and Solariella gemmata. Holaster planus, Micraster procursor, and M. Leskei are also common.

The zones of $M$. cortestudinarium and $M$. coranguinum have the same characters and fossils as in the South Coast sections, as have also the higher zones as far as they can be traced, except in the case of the Marsupites zone which in Berkshire and the Thames Valley presents some peculiar features; for it contains two beds of brown phosphatic chalk, one at the base of the Uintacrinus band and one at the base of the upper division. These beds are well exposed in the large quarry at Taplow near Maidenhead, where the upper bed is 8 feet thick. The phosphatic matter is in the form of grains, some of which are casts of Foraminifera and others are phosphatised portions of Inoceramus shells.

In Suffolk and Norfolk the higher zones come in again from 
beneath the Eocene and include the highest zone found in England, that of Ostrea lunata. A change also takes place in the zone of Holaster planus, for in Norfolk it passes into hard white chalk with dark-grey flints, without any rocky or nodular beds.

The following is a tabular view of the Upper Chalk of Norfolk, but the thicknesses of the zones are only approximate:-

Zone of Ostrea lunata. White with beds and patches of grey chalk. Ter. gracilis, Thecidium vermiculare, Trigonosemus elegans, and many Bryozoa . . . . . . . . . Zone of Bel. mucronata. Soft white chalk with many flints, some very large and cup-shaped

Zones of Act. quadratus and Marsupites. Not yet separated from the zones above and below, Act. granulatus common. probably 400 Zones of $M$. coranguinum and $M$. cortestudinarium. Chalk with many flints, both nodules and courses . . . . . 340 Zone of Hol. planus (as above described). . . . . . . 50

The Upper Chalk of Yorkshire, as exhibited in the cliffs at and near Flamborough Head, has been the subject of special study first by Mr. Lamplugh and more recently by Mr. Rowe, ${ }^{25}$ from whose account the following résumé is taken :-

Zone of Act. quadratus. Chalk without flints, partly seen in the cliffs near Sewerby and partly inland . . . . 330 Zone of Marsupiles, in two bands, without flints . . . 208 Zone of M. corangninum, the upper part flintless, the lower with many flints and marl seams . . . . . 260 Zone of M. cortestudinarium. Hard chalk with many flints : 120 Zone of Hol. planus. Hard chalk with grey flints, both nodules and in continuous courses . . . . . . . 125

With regard to its fossils the Chalk of Yorkshire differs considerably from that of Southern and Central England. Thus, Holaster planus being just as common in the zone of Ter. lata as in its own zone, one has to rely on its association with Echinocorys vulgaris for the recognition of the latter. The zone of $\boldsymbol{M}$. cortestudinarium yields the usual assemblage, but in the overlying zone M. coranguinum is a rare fossil and its place is taken by Infulaster rostratus. Again no specimen of Actinocamax quadratus has been found in Yorkshire, and, Offaster pilula being also rare, the zone finds a local index in Inoceramus lobatus (=lingua auct., non Goldf.). It is also characterised by the abundance of fossil sponges belonging chiefly to the genera Bolospongia, Scytalia, Seliscothon, Siphonia, Heterostinia, Pachastrella, Phymatella and Verruculina, most of which do not occur in the south of England. 


\section{Ireland and Scotland}

Ireland.-Upper Cretaceous rocks appear nearly everywhere round the edge of the great basaltic plateau of Antrim, Tyrone, and Londonderry, and we may therefore safely infer that they underlie the greater portion of it. It is also clear that they once extended much farther westward than the present edge of that plateau, as is proved by a small outlier near Draperstown. They usually rest on a planed down surface of Liassic or Triassic rocks, but sometimes overstep the limits of these, as in North-east Antrim, and rest upon the Palæozoic rocks (see Fig. 186).

These Irish Cretaceous rocks were described in 1865 by Professor Tate, and an attempt to establish a zonal classification was made by Dr. W. F. Hume in 1897, as shown in the following table :- 26

Tate's Divisions.

Hume's Zones.

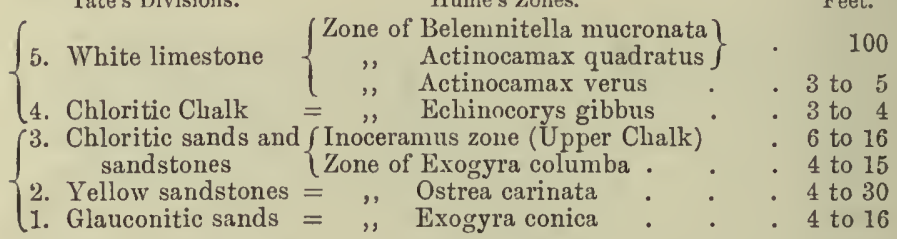

The glauconitic sands are regarded by Dr. Hume as in part equivalent to the Selbornian zone of Sch. rostratus, but the occurrence of Sch. varians, Pecten asper, and an Actinocamax like verus (probably lanceolatus, Sow.) makes it difficult to accept this view. The yellow sandstones contain layers of chert, and their fauna is a curious mixture of Selbornian and Cenomanian forms, but as the beds are shallow-water deposits it is probable that Selbornian species here survived into Cenomanian time, and the occurrence of Acanth. rotomagensis marks them as equivalents of Lower Chalk.

The so-called Chloritic sands appear to include two deposits of very different age, separated by a break and unconformity. The lowest beds are calcareous glauconitic sandstones with Exogyra columba, Pecten asper, and Trigonia crenulata, and are evidently of late Cenomanian age. The higher glauconitic sandstones, as seen north of Belfast and on the eastern coast, contain Spondylus spinosus, Galerites conicus, Rhynchonella limbata, Rh. plicatilis, and a species of Micraster with many broken Inocerami. These beds pass up into a glauconitic sandstone, often pink in colour, which yields Echinocorys vulgaris, var. gibbus, and a few other fossils.

If the fossils are correctly identified these zones of Sp. spinosus and Ech. gibbus must be regarded as a condensed representative of 
the Micraster zones of the English Chalk; the whole of the Middle Chalk and perhaps that of Hol. planus also being absent.

Above the "Chloritic chalk" is the "White Limestone," which lias a bed of nodular chalk at its base containing Act. verus and many sponges, and in the north of Antrim a similar nodular bed is succeeded by 5 feet of flintless chalk containing plates of Marsupites. Finally in conformable succession is white chalk with many flints, about 100 feet thick, having Act. quadratus near the base and Bel. mucronata in the higher part.

Scotland.-Cretaceous rocks are found again especially on the west coast of Scotland, in the island of Mull and in the district of Morvern on the adjacent mainland; as in Ireland, they belong exclusively to the upper division of the system, and though they can be correlated generally with the Irish Series, they exhibit a still more abnormal facies and a more decided approacli to littoral conditions. They are best exposed in Morvern, along the shores of Locl Aline, and beneath the singular outlying masses of Beinn-yHun and Beinn-y-Hattan. ${ }^{27}$ The general succession here is :-

4. Sandstones and white unarls with plant remains (high Cretaceous or early Eocene)

Feet.

3. White indurated chalk with bands of flints, Belemnitella macronata, and fragments of Inoceramus; some beds of glauconitic chalk at the base .

2. White sandstones without fossils, but containing a thin seam of coal. . . . . 30 to 100

1. Glauconite sands, passing sometimes into dark-green argillaceous sand, sometimes into calcareous sandstone; Pecten asper, $P$. orbicularis, Exogyra covica, but no Ammonites 20 to

On comparing these beds with those of Antrin we may safely regard No. 1 as equivalent to Nos, 1 and 2 of the Irish sequence.

The overlying white sandstones (No. 2) would appear to be homotaxial with the zone of Ostrea columba in Ireland, whatever the precise age of that may be. Above it there is a palæontological break, though apparently no uncouformity, and the liard white chalk corresponds closely to that of Ireland, except that there is no sign of the Micraster zone at its base.

\section{Continental Representatives}

\section{Northern France}

In France the Cretaceous exhibits two very different facies, that of the southern provinces being very different from that of the northern region, which is often called the Paris basin. The deposits found in the latter closely resemble those of England, and 
were evidently formed in the same sea, while those of Southem France belonged to a different marine province. Those of the Paris basin may first claim attention, and the following is a brief notice of them (see table on p. 491).

Albian.-The name of this stage is taken from the river Aube (or Alba), and in the department of that name it consists of the following members :-

Marls with Schlonbachia rostrata and Ostrea resiculose . up to 200 Clays with Hoplites splendens and H. auritus. . . : : 30 Clays with Hoplites interruptus and Douvilleiceras mammillatum ", 60 Green sands without fossils . . . . . . ", 30

Traced northward into the Departments of the Meuse and Ardenne the basal sands contain I. mammillatum, and pass into a siliceous rock (the "gaize de Draize"). The marls also pass into similar rock (the "gaize de l'Argonne"), which closely resembles our malmstone, and is undoubtedly of the same age. Still farther north, near Mons, the zone of Sch. rostrata overlaps the lower beds, and is represented by sands with layers and nodules of chert, the fauna resembling that of the Blackdown sands in Devon.

These Albian deposits pass completely under the Paris basin. They have been reached by deep borings at Paris and Dieppe. They appear again in the anticlinal uplift of the Pays de Bray, and in diminished thickness they are found in the clifts of Normandy. Near Cap la Heve the clays are about 10 feet, and the gaize with Schloenbachia rostrata is ahout 26 feet thick.

Cenomanian.-The district where this stage was first established, that of Le Mans in the Sarthe, is unfortunately one where the beds have a sandy and shallow-water facies, and are difficult to compare with the chalky facies which prevails in the eastern part of the Paris basin as it does in England. In Normandy, however, there is an intermediate type which affords valuable assistance in the correlation, and a fine section of it is visible in the cliffs near Cap la Heve:- 88

4. Greyish-white chalk with grey flints

Feet,

3. Grey chalk with cherts and phosphatic nodules . . " 10

2. Yellowish-grey silty and glauconitic chalk with many layers of grey and black cherts, and some beds of bluish marly chalk near the bottom .

1. Bluish-grey sandy glauconitic marl with black phosphatic nodules and many fossils . . . . .

The basement bed contains Stauronema Carteri and Schlonbachia varians, and is the equivalent of our Chloritic marl. The beds above contain Schloenbachia varians, Acanthoceras Mantelli, 
T'urrilites costatnes, Pecten asper, P. Galliennei, and Holaster subylobosus. Most of these also lange into No. 3, but the whitish chalk above lias few fossils.

Turonian.- The name of this stage is taken from Touraiue, where it is divisible into two sub-stages called (1) the Ligerian and (2) the Angoumian.

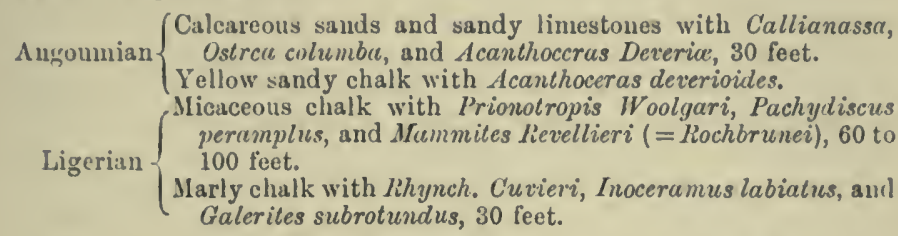

Traced northward into Normandy these beds pass into pure chalk, and near Rouen the facies is the same as in England with a thickness of about 280 feet. At the base is hard nodular chalk like our Melbourn rock, sncceeded by chalk with Mammites nodosoides, Prionotropis IVoolgari, and Galerites subrotundus, and this by soft chalk with Terebratulina lata, the higher parts of which contin Holaster planus and Micraster Leskei.

Senonian.-For this stage I retain d'Orbigny's original name instead of the awkward one of Emscherian which has beell adopted by de Lapparent or the Corbierian of de Grossouvre. The original name should not be dropped, and should be specially applied to that portion of the Chalk which is typically developed round the town of Sens and in the country of the ancient Senones. This comprises the Micraster zones, i.e. those of M. decipiens (or $M$. cortestudinarium), $M$. coranguinum, and of Marsupites (or Micraster turonensis).

In the Departments of the Yonne, Aube, and Marne, this stage consists entirely of white chalk, in which flints are often but not universally numerous, and it has a thickness of from 400 to 500 feet. Northward in the Aisue and in Picardie it passes into grey and dolomitic chalks with a less thickness, and on the western side of the Paris basin it is represented by sandy marls, hard limestones, and fine siliceous deposits ("tuffeaux"), the full thickness of which at Villedieu and Saunur is little more than 100 feet. According to M. de Grossouvre the "craie de Villedieu," coutaining Spondylus truncatus, Micraster turonensis, with species of Mortonicerns and Peroniceras, is the equivalent of the Marsupites zone.

Campanian.-This stage is typically developed in the district of Champagne, whence it takes its name, and where it has been divided into four local zones. It comprises the broider zones of Actinocamax quadratus and Belemnitella mucronata, which have a 
total thickness of about 250 feet, and its highest portion is found in the chalk of Mendon near Paris.

In the Campanian should be included a still higher zone, sometimes called Maestrichtian, which is found in Belgium near Ciply and Maestriclit and in a small isolated patch in the Cotentin (Normandy). At Ciply there is a continuous series of chalks up to the top of a phosphatic and glauconitic chalk in which the little Brachiopod Thecidea papillata is abundant. Resting unconformably on this is a conglomerate of rolled phosphate nodules and fossils which forms the base of the "Tuffeau de St. Symphorien," a soft yellowish rock composed largely of Bryozoa and containing occasional grey flints. Its fossils include Belemnitella mucronata, Baculites Faujasi, Ostrea larva (=linata), Thecidea papillatum, and Terebratula carnea. At Maestricht in Limbourg the series is carried a step higher, the tuffean with flints being overlain by another set of limestones (120 feet thick), consisting of alternating soft and hard beds. These also yield Bel. mucronata and Ostrea larva, with Hemipneustes striatoradiatus, some Gastropoda, and remains of the marine reptile Mosasaurus Camperi.

Some writers include the Maestrichtian in the Danian, but it is better to restrict the latter to deposits which are destitute of Ammonites and Belemnites. Thus restricted there is no Danian in the north of France or Belginm.

\section{Denmark and Sweden}

The Upper Cretacenus deposits of these two countries are of special interest, because they carry the series continuously up to a ligher horizon than is found in England or France, and include beds which seem to bridge the interval between Cretaceous and Eocene. Those of Scania also are transgressive and indicate the gradual northward extension of the Cretaceous Sea, which did not begin to encroach on Scandinavian land till the close of the $M$. coranguinum zone. In fact, nothing older than this zone is exposed in either country. The Danish Beds are seen at Faxe and Saltholm, where the succession is :-

5. Chalky limestone with flints, Nautilus danicus, Holaster faxensis, Ananchytes sulcatus, Terebratula carnea.

4. Limestone with Cerithium faxense and Baculites vertebralis.

3. Clay with fish remains and Ostrea lateralis.

2. White chalk with Belemnitella mucronata.

1. Chalky limestone with Actinocamax granulatus.

No. 2 is regarded as the top of the Campanian, and the higher beds as a separate stage under the name of Danian. 
In Sweden the most complete succession is found near Malıno

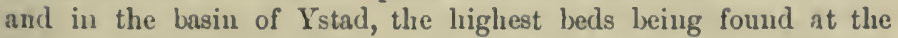
former and the lower at the latter locality. The total thickuess appears to be more than 1500 feet, and the combined succession is as follows :-

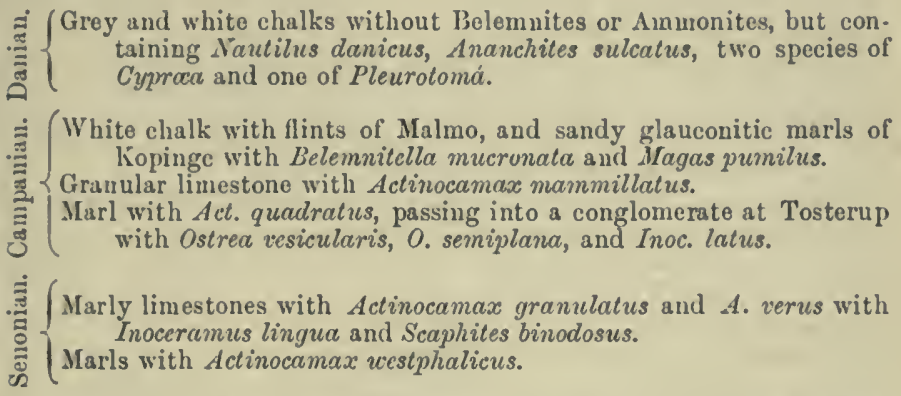

To the northward near Christianstad the Senonian is absent, and the quadratus beds rest directly on the Archiean platform with a basal conglomerate. By some authors the Danian is regarded as equivalent to the Montian of Belgium (see Chap. xv.), but its fauna is different and more closely allied to the Cretaceous.

\section{The Mediterranean Region}

A different facies is found in Southern France, Spain, and througl the whole of Southern Europe fron the Alps and Italy to the shores of the Black Sea. The Albian of this region consists mainly of sands and sandstones, the Cenomanian of sandy limestones containing Orbitolina (Patellina) concava and many species of Caprina Caprotina and Caprinula. The T'uronian and Senonian are also represented by sandstones, sandy limestones, and inarls abounding with other genera of irregular Lamellibranchs, such as Hippurites, Radiolites, and Sphcerulites, some of the beds being known as Hippurite limestones. These two divisions reach a thickness of 1500 feet in some places. The higher stages are nore local, but often comprise a great thickness of strata; thus in Provence they include some marly limestones of Campanian age, succeeded by a vast group of fresluwater deposits (the Garumnian), having a thickness of 2500 feet and yielding a large number of freshwater and terrestrial shells. In character and thickness this group is analogous to the English Wealden.

The most complete succession of marine deposits in the south of 
France is that of Aquitaine, and may be given as an illustration of the lithological development of the Mediterranean facies. According to M. Coquand and M. de Grossouvre it is as follows :- 29

ذ. Limestones of Tercis, with Micraster tercensis, in two zones, separated by Miliolina limestones and lacustrine deposits, the whole about (Eeddish-yellow limestone with Baculites anccps, Pachydiscus

Reddish-yellow limestone with Baculites anceps, Pach
colligatus, Turrilites polyplocus, and Thecidea papillata.
White limestone with Bryozoa and Belemnitella mucronata.

․․ White marly limestones with Actinocamax quadratus, Scaphitcs כु binodosus, Inoceramus latıs, and Exogyro.

Sandy limestone with Spondylus truncatus, Hippuritcs, and!Radiolites.

White and grey limestones with Mortoniceras texanum.

\section{竝}

Hard nodular limestones with Scaphites Meslei, S. Lamberti, and Micraster turonensis.

. $\begin{aligned} & \text { Soft limestones and marls with Sphoerulites. } \\ & \text { Soft beds with Radiolites, Hippurites, Sphcerulites, and Acantho- } \\ & \text { ceras Deverio. }\end{aligned}$

E्. $\left\{\begin{array}{l}\text { ceras Deverio. } \\ \text { Nodular limestone with Prionotropis Woolgari. }\end{array}\right.$

声 $\begin{gathered}\text { Sands, clays, and limestones with Ostrca, Caprina, Schloenbachia } \\ \text { varians, and Turrilites costatus. }\end{gathered}$ 竎 $\begin{gathered}\text { Only found on the Pyrenean side of the basin, where it is repre- } \\ \text { sented by black marls and limestones. }\end{gathered}$

\section{Germany, Bohemia, and Silesia}

In Westphalia and Northern Germany there is an Upper Cretaceous Series comparable to that of England and the north of France, having Gault Clays and marls at the base, succeeded by Cenomanian marls and a thick mass of chalk which includes representatives of the Turonian, Senonian, and Campanian stages.

Farther east, however, in Saxony, Bolıemia, and Silesia, a different facies is found, where terrigenous sandy inaterial prevails over that of organic origin, the clialky limestones of Western Europe being largely replaced hy sandstones which the Germans call "Quaderstein," because they are much jointed, and split into square blocks. The following is the general successiou in this area according to Schlönbach and Fritsclı :-
$\left\{\begin{array}{c}\begin{array}{c}\text { Chlomek } \\ \text { Beds }\end{array} \\ \text { Priesen } \\ \text { Beds }\end{array}\right.$
fSandstones with Placenticcras Orbignyi, Peroniceras i subtricarinatum, and $P$. vestphalicum. Clays witl ironstone nodules, Placenticeras Orbignyi and Scaphites Lamberti. Marls with Pachydiscus peramplus, Prionotropis
Neptuni, and Paculites bohemicus. 


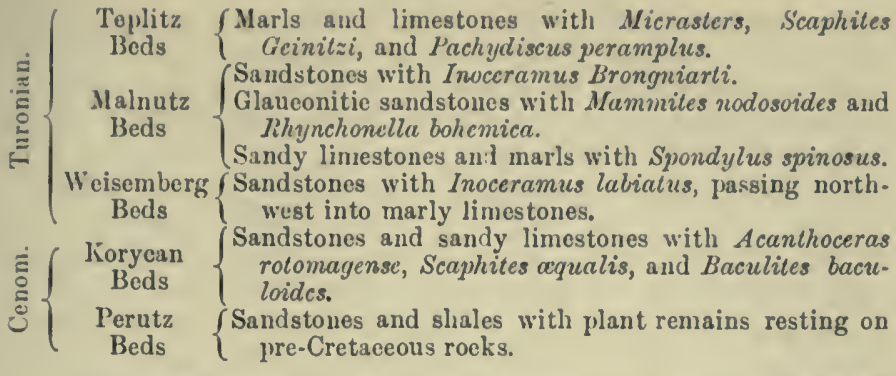

The higliest beds of this series represent the zone of Micraster coranguinum, nothing higher having been fonnd in ally part of the area.

\section{Russia}

Strata of Upper Cretaceous age occupy large areas in Southern and Central Russia, though the exposed portions are not of great extent, because so much is concealed beneath a covering of Tertiary Beds. The deposits are of great thickness, and nust include representatives of the Cenomanian, Turonian, and Senonian stages, but though Greensands with Cenomanian fossils occur at the base, fassils are scarce in the overlying chalks and marls, so that no zones have been established; moreover no definite Turonian division has been recognised, for there seems to be an intermingling of species which in Western Europe wonld be regarded as Turonian and Senonian.

Useful information concerning the Russian Chalk was collected in 1892 by Dr. W. F. Hume, ${ }^{30}$ who describes the mass of the formation as consisting of grey and white chalks with a band of marly chalk or "Chalk Marl" between them. A boring at Kharkov lias proved the great thickness of these beds, and the details given by Dr. Hume may be thus summarised :-

Feet.

Tertiary deposits . . . . . . . 133

Soft white ehalk without flints : . : $\quad .967$

Bluish and grey marly ehalk . . . . . 391

Grey chalk . • . . . . . 312

White chalk with flints . . . . 161

Grey and green sands and sandy clay . . . . $\quad 93$

2057

'The higher white chalks contain Bel. mucronata in abundance, and this species is said also to occur in the marly chalks. These deposits extend all across Southern Russia from Podolia and Volhynia on the west to Voronetz, Saratov, and Simbirsk on the 
east. From Poland and Silesia another band of chalk is believed to extend across the Moscow basin, but no deposits of Upper Cretaceous age have been found in Northern Russia, thongh it seems likely that they originally spread over those of the Lower Series.

\section{E. The History of the Period}

The history of Cretaceous time in Enrope is the history of the gradnal submergence of the large tracts of land which existed in the region at the beginning of the period. These tracts inchided (1) a large area in the north which may be called the FennoScandian region; (2) a western land inchuding the British area, the whole of Western France, and the greater part of Spain; this may be called the Atlantic region; (3) a long tract extending from the north-east of France through Central Enrope, Bohemia, and the sonthern part of Rnssia, which for want of a better name may be called the Hercynio-Sarmatian land. The Atlantic and Hercynian regions were connected by a broad isthmus across Belginm and the North Sea, and it is also possible that there was a land-connection between the Fenno-Scandian and the Sarmatian regions.

There is fairly good evidence that some of this land rose to a considerable elevation above the sea-level of early Cretaceous time, because some parts of it were never entirely submerged even after the deposition of several thousand feet of strata and the formation of chalk below water which must have been over 3000 feet deep. We know also that there were both large rivers and large lakes on this continent, and we know the actual position of two of these lakes. The one, known as the Wealden lake, occupied a large part of Southern England with the adjacent parts of what is now the English Channel. The other occupied a large area in the northwest of Germany, and appears to have heen connected with the estuary of a river which opened into a gnlf of the Northern Sea.

With regard to the Wealden lake, I think there is no donbt about its having been an enclosed inland lake with an excurrent river emerging from its sonthern side and running south-eastward through France. In spite of the views held by certain French geologists, there is no good reason for believing that the Southern Sea invaded the Pays de Bray or the Bonlonnais before Aptian time. The few species of Lamellibranchs on which they rely for the presence of the Hauterivian Sea in the Pays de Bray are all found in the Vectian of the Isle of Wight. The northern termination of this sea appears to have been in the Haute Maine, where its characteristic famna occurs in a limestone overlying a set of freshwater beds, some 60 feet thick. Such a conjunction seems 
to indicate the estuary of a river, which was probably that flowing out of the Wealden lake.

It is generally admitted that during the earlier part of this epoch, i.e. during Wealden and Neocomian times, land existed in the nortli-east of France and over Belgium and that it was connected with land over the east of England. It is my own opinion that this was a fairly broad tract of land enclosing the Wealden lake and comnecting the western land witl that of Central Europe. Further, I hold that this isthmus was never broken through till the Aptian epoch, when the Northern and Southern Seas met in a strait which passed obliquely across England from Wiltshire to Cambridge and Norfolk.

We may now turn our attention to the general position and extensions of these Southern and Northem Seas. The former appears to have covered most of Eastern France (south of the Ardennes), and to have stretched eastward through Switzerland and Italy across the soutlern part of Austria and the Damubian provinces to the Black Sea and the Crimea. The Northern Sea occupied a large part of what is now the Arctic Ocean and extended southward in two great gulfs, one on each side of the FennoScandian land.

The western gulf touched the north of Scotland (Caithness and Aberleen), and seems to have passed southward through the North Sea area into Yorkshire and Lincolnshire on the one hand and into Germany on the other. The eastern gulf occupied a large part of Northern Russia, extending southward to the Moscow basin and sonth-east to the province of Simbirsk; but near Moscow the sea was shallow, as the zone of Bel. Jasekowi is there represented by sands with plant remians but no marine fossils, so that they seem to be of brackish or freshwater origin.

The question remains whether there was any water-connection between the extremities of the eastern and western gulf, or whether Fenno-Scandia was united to the Sarmatian land. So far as the similarity of the English and Russian faunas is concerned, that both were derived from the Northern Ocean is sufficient explanation. The only evidence for the theory that the gulfs were otherwise connected is the existence of some deposits of Lower Cretaceous age at Brzezie on the borders of Posen and Poland, where fresh. water beds with Cyrena and Cypris are succeeded by sands and conglomerates which are overlain by clays with Astarte and Exogyra Couloni; but these bivalves may be of any zonal age, and only indicate the line along which the sea eventually made its way across the space between Hanover and Moscow.

Having regard to the presence of freshwater deposits of early 


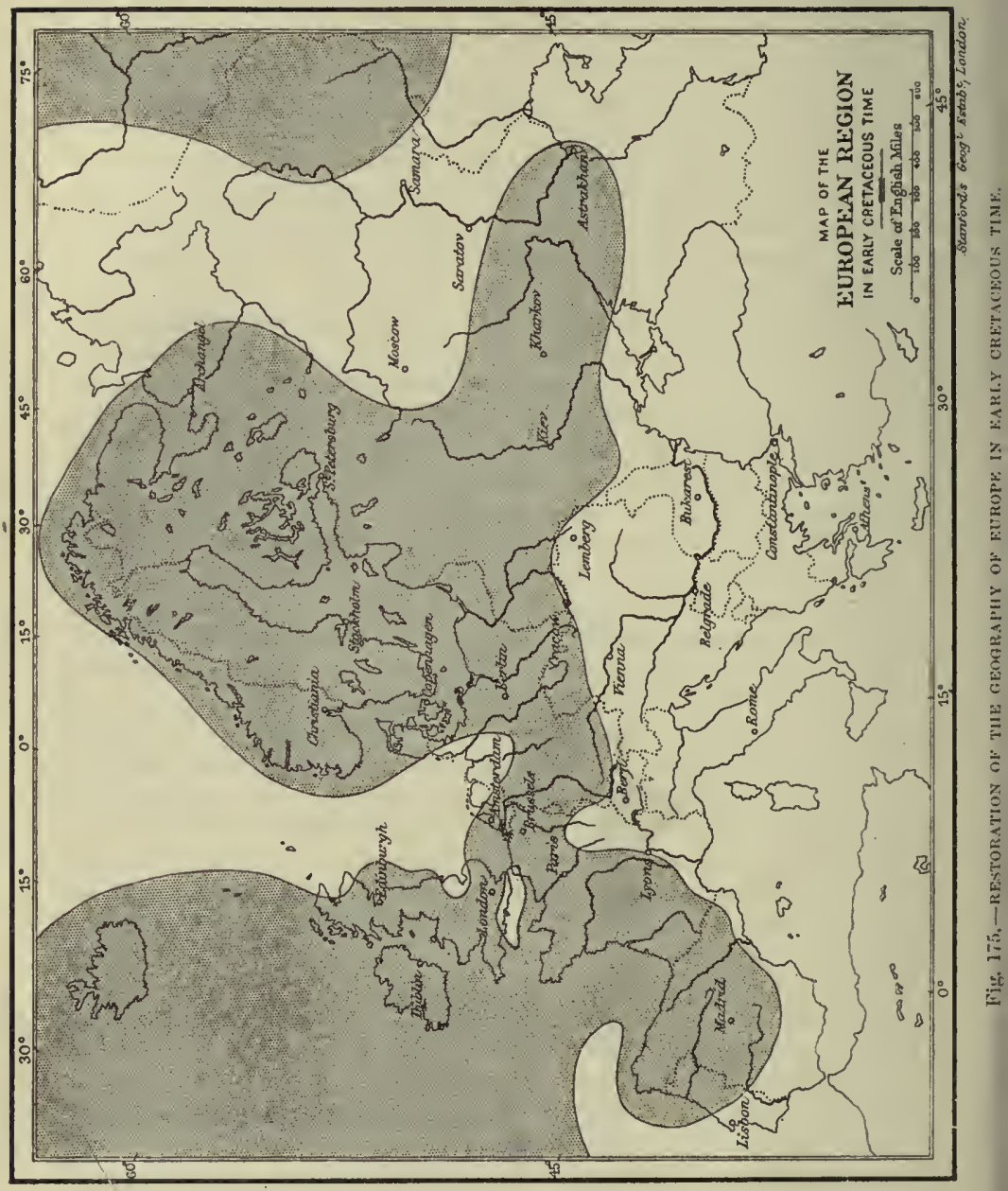


Cretaceous age in Hanover, Poser, and the Moscow area, it seems probable that Prussia and Poland were land surfaces at this time (see Fig. 175) and were not submerged till Aptian or Albian times. We know that it was in Aptian time that the subsidence carried the sea across the Finglish isthmus, and it may well have been at the same epoch that a strait was formed across Prussia and that Fenno-Scandia was reduced to the condition of a large island.

In Albian and Cenomanian times there was a more rapid subsidence, and the continental land was broken up into a number of islands. The Southern and Northern oceans were united across France and England, much of the Sarmatian land was submerged, and the central area was reduced to an island which, at any rate in Cenounanian time, extended only from the Ardemnes to Bohemia.

Minor changes subsequently took place, with a temporary elevation of the Franco-British area, during the time of the Holaster planus chalk, but the renewed subsidence of Senonian time must have still farther reduced the land-areas till the only remaining large tract of land in the European region was that of FennoScandia, for of this only a small portion was ever submerged.

This subsidence appears to have reached its maximum during the Campanialr epoch, for the zones of Actinocamax quadratus and Belemnitella mucronata seem to have had the widest extension both over Limbourg and over Scania. At this time it is probable that the British area was reduced to an archipelago of islands (see Building of the British Isles, 1911), and it is doubtful whether any part of England remained above water; even of Wales only those parts continued as islands which are now inore than 2000 feet above the sea.

French geologists seem to lave taken it for granted that Brittany and the Central Platean of France still formed islands in the Senonian and Campanian Seas; apparently because no trace of Cretaceous strata has been found upon them. But the existence of land cannot be postulated on negative evidence; the question to be considered is how far the chalk of neighbouring areas is likely to have been prolonged over them. In the case of Brittany we have every reasou to suppose that Turonian, Senonian, and higher chalks followed the Cenomanian over the Cotentin aud down the Channel area; and as no part of Brittany rises to more than 1400 feet above sea-level, while Dartmoor rises to 2000, it seems probable that if the latter was entirely submerged, the former was also.

With respect to the Central Plateau there is more to be said. Since the central and southem portions of it are over 5000 feet above existing sea-level, it might be thought that these must have remained above that of the Cretaceous Sea ; but we must remember 
that these parts were the scene of prolonged volcanic activity in Tertiary time, and that they were doubtless then raised to a higher relative level than they had previously occupied, for the northwest part of the plateau does not rise to more than 3000 feet.

The facts which liave chiefly to be considered are the characters of the Upper Cretaceous deposits which surround the Central Plateau. Those on the north and north-east sides are chalks which have the character of deep-sea deposits, being fine foraminiferal oozes in which Textularia and Globigerina are the prevalent forms. On the north-west the Senonian is largely a Bryozoan deposit formed in no great depth of water, and the Campanian is a siliceous rock analogous to "gaize," and mainly composed of sponge spicules; this may liave been accumulated in water of 200 to 300 fathoms (about 1500 feet). On the south-east side in Aquitaine we find the Senonian composed of marly limestones, which are often sandy and include banks of Hippurite and Radiolite limestone, deposits which are not of deep-water origin. The Campanian of the same area, however, consists for the most part of fine white clialky limestones in alternating solid and crumbly beds with layers of black flints. M. de Grossouvre describes this material as similar to chalk, and as "denoting a deposit formed at a much greater distance from shores, and in much deeper water than the sediments" of the Senonian. ${ }^{31}$

The successive stages of the series probably passed transgressively one beyond the other on to the flanks of the Central Plateau, and if the average depth of water under which the Campanian sediments was deposited was only 400 fathoms (i.e. 2400 feet), it is clear that large parts of the plateau must have been submerged; how much would require a special study to determine.

From the Campanian subsidence there was a gradual recovery, accompanied by a certain amount of lateral pressure which produced a warping or upward flexure of parts of the mass of deposit, so that a series of broad anticlines and synclines were formed, and the summits of the anticlines were planed off by the currents and waves of the shallowing seas. Hence, as we shall see, even the earliest Eocene deposits are more or less unconformable to the underlying Cretaceous strata.

\section{REFERENCES}

1 W. Whitaker, Quart. Journ. Geol. Soc. vol. xlii. p. 26 (1886).

2 See "Geology of the Weald," by W. Topley, Mem. Geol. Survey (1875).

3 See "Geology of the Isle of Purbeck," by A. Strahan, Mem. Geol. Survey (1898). 
+ See F. Leighton, Quert. Journ. Geol. Sac, vol. li. p. 101. (1889).

"See "Geology of the Isle of Wight," by A. Strahan, Mfem. Geol. Survey

- See Reports in Proc. Geol. Assoc. vol. xii. p. 227, and vol. xx. p. 115 (1907).

7 A. M. Davies, Proc. Geol. Assoc. vol. xvi. p. 15. 1893.

8 W. Keeping, "Fossils of Upware and Brickhill," Sedgwick Prize Fssay,

9 J. W. Judd, Quart. Journ. Geol. Soc. vol, xxiii. 1). 227, and vol. xxiv. p. 218 ; G. W. Lamplugl, Quart. Journ. Geol. Soc. vol. xlv. p. 575, and vol. lii. p. 179 ; also Mem. Geol. Survey, Explauations of Sheets 83 aud 84 (Lincoln and East Lincolnshire).

10 See Suminary Prog. Geol. Survey for 1908, p. 75, and for 1910, p. 80.

11 See Jukes-Browne and Milne in Geol. Mlag. for 1898, p. 21.

12 See Livret-guide, Congrés géol. Internat. for 1900, "Excur. Montagne de Iure."

13 See "Cretaceous Rocks of Britain," vol. i., Mem. Geol. Survey (1900).

it See Jukes-Browne and W. Hill in Quart. Journ. Geol. Soc. vol. xliii. p. 544 .

15 See W. Hill, Quart. Journ. Geol. Soc. vol. xliv. p. 320.

16 Consult "Cretaceous Rocks of Britain," vol.ii., Mem. Geol. Survey (1903).

17 Jukes-Browne, Quart. Journ. Geol. Soc. vol. xxxi. p. 256, and the "Geology of Cambridge," Mem. Geol. Survey (1881).

18 Jukes-Browne and W. Hill, op. cit. p. 561.

19 W. Hill, Quart. Journ. Geol. Soc. vol. xliv. p. 325.

20 A. W. Rowe, Proc. Geol. Assoc. vol. xvii. p. 1 (1901).

21 A. W. Rowe, Proc. Gcol. Assoc. vol. xviii. p. 193 (1904).

22 W. Hill in "Cretaceous Rocks of Britain," vol. iii., M em. Geol. Survey (1904).

23 A. W. Rowe, Proc. Geol. Assoc. vol. xx. p. 209 (1906).

24 A. W. Rowe, Proc. Geol. Assoc. vol. xvii. p. 42.

25 See G. W. Lamplugh, Proc. Yorkshire Geol. and Pol. Soc. vol. xiii. p. 65 ; and A. W. Rowe, op. cit. (1904).

28 W. F. Hume, Quart. Journ. Geol. Soc. vol. liii. p. 540 (1897).

27 J. W. Juild, Qucart. Journ. Geol. Soc. vol. xxxiv. p. 728.

28 W. Hill, Quart. Journ. Geol. Soc. vol, lii. p. 99.

29 A. de Grossouvre, "Recherches sur la Craie Supérieur," Mem. Cartc Géol. de la France, p. 351 (1901).

30 W. F. Hume, Genl. Mag. for 1892 , p. 385.

31 A. de Grossouvre, op. cit. p. 378. 


\section{CHAPTER XV}

\section{TERTIARY OR CAENOZOIC TIME}

\section{Paleogene System}

As explained on p. 11, the Tertiary deposits are ustally divided into five or six groups with a nomenclature based on the proportional number of species of Mollusca found in each group that have survived to exist at the present day. But these groups cannot be regarded as systems of the same palæontological value as those into which the Mesozoic and Palæozoic rocks have been divided. Only two such systems can be recognised in Cænozoic time, the Eocene and Oligocene divisions forming one system, the Miocene, Pliocene, and Pleistocene divisions forming a second. For these two systems the German geologist Hoernes proposed the names Palcoogene and Neogene, signifying the older and the newer kind of Tertiary life, and though not altogether satisfactory names, they have been widely adopted on the European continent.

The older Tertiaries of North-western Europe occur in several basins or broad trough-shaped areas, separated by parallel anticlines or axes of elevation. The most northern of these is known as the London basin, which, however, is only the western part of a large geo-syncline extending from Belgium across the North Sea and terminating in Wiltehire. A second but much smaller basin is known as the Hampshire basin, extending through Sussex, Hampshire, and Dorset, but bounded on the south by the sharp anticline which runs through the Isle of Wight and the Isle of Purbeck. A third is the Paris basin, occupying a broad depression in the Chalk area of Northern France. South of this, again, are the two separate basins of Aquitaine and Provence.

Some account of the Palrogene deposits in all these areas will be given in the following pages, taking first the Eocene and afterwards the Oligocene Series. 


\section{THE EOCENE SERIES}

This series has been divided into a number of stages for which diflerent names are at present used in England, France, and Belgium, as shown in the following table:-

Eingland.

Barton Beds.

Brackleshan Beds.

Bagshot Beds.

London Clay.

Woolwicls and )

Realing Beds.

Thanet-Beds.
Belgium.

Wenmelian.

Laekinian and

Brussellian Beds.

Sables de Mons.

Argile de Flandres.

Upper Lower Landenian.

Montian.
France.

Bartonian.

Lutetian.

Ypresian.

Sparnacian.

Thanetian.

Montian.

\section{A. Life of thl Period}

Eocene Life.-The difference letween the fauna of the Chalk and that of the Eocene is very great indeed, for only one species, and that is a Brachiopor (Terebratulina striata), seems to have survived the change of conditions in Britain, and not only so, but the general aspect of the Eocene fauna is quite different from that of the Cretaceous. The great reptiles of the Secondary rocks have disappeared, and with them the numerous Cephalopods which are so characteristic of the Cretaceous System-the Ammonites, Turrilites, Baculites, Scaphites, Hamites, Belemnites, and many other genera; vanished also are the Hippurites, Radiolites, and Inocerami of the Chalk, most of the Cretaceous Echinodernns, and all the deep-sea siliceous sponges (Ventriculites, Cephalites, Plocospongia, etc.).

In England the most abundant fossils are Gastropods and Lamellibranchs, many of them belonging to genera which now characterise much warmer seas than those around our islands. Brachiopods, Echinoderms, Corals, and Sponges are rare compared with their numbers in Mesozoic deposits.

The Eocene flora is marked by the abundance of Dicotyledons, especially of genera which now occur in tropical and sub-tropical regions. It should be mentioned, however, that many of the genera which now make their appearance in Britain occur in the higher Cretaceous deposits of the continent. The flora of the Woolwich and Reading Beds has a temperate aspect; it includes leaves like those of the poplar, plane, and hazel (Populus, Platanus, and Corylus). The plants of the London Clay and Bagshot sand, on the other hand, are those of a much warmer climate; they include leaves and fruits of the conifers Pinus and Sequoia, with 
the palms Nipa, Sabal, and Areca; the Dicotyledons Ficus, Aralia, Dryandra, Cassia, Eucalyptus, Magnolia, Cactus, and many kinds of Leguminose. In the Bournemouth Beds a still larger number occur, and form a different assemblage, but still one of sub-tropical aspect; this includes ferns of the genera Osmunda, Chrysodium, Pteris, and Gleichenia, the palms Sabal, Iriartea, Flabellaria, Phanicites, and a large number of Dicotyledonous leaf impressions which have not yet been properly determined.

Of invertebrate animals the following are the principal genera which now make their appearance in Britain, though some of them (particularly the Gastropods) really date from the Upper Cretaceous Beds of Europe :-

Protozoa.

Actinozoa.

Echinoderma.

Crustacea.

Lamellibranchia.

Gastropoda.

Cephalopoda.

Vertebrate animals are now abundant, the four great classes of fish, birds, reptiles, and mammals being all represented, though remains of birds are rare. The following are some of the genera found in the Eocene Series of England and France:-

Pisces.

Reptilia.

Aves.

Myliobatis, Etobatis, Pristis; Lepidosteus, Plyyllodus; Coelopoma, Goniognathus, Spliyrænodus (=Dictyodus) ; Percostoma, Sciænurus, and others.

Gavialis (a crocodile); Lacerta (a lizard); Palæophis (a sea-snake); Trionyx, Lytoloma, Argillochelys (tortoises).

Argillornis, Dasornis, Gastornis, Halcyornis, Eupterornis, Lithor'nis, Odontopteryx, all large birds. Odontopteryx had a large beak furnished witl tooth-like processes.

Mammalia.-These deserve more special description. Marsupials of the genus Didelphys were common, and with these are carnivores (Arctocyon and Palcoonictis) with strong marsupial affinities, but believed to be really placentals; a little later appear other carnivora, Pterodon, and Proviverra. The earliest known ungulate is Coryphodon, a primitive tapir from the Woolwich Beds and London Clay. Still later other genera appeared, Lophiodon, 
Pachynolophus, Paloplotherium, all related to tapirs and rhinoceroses, with Hyracotherium, which combined characters now found in the coney (IIyrax) and in the pigs. Other hog-like animals (Hyopotamus) appear in the Upper Eocene and become common in Oligocene time. There were also primitive lornless forms of deer or antelope named Dichodon and Amphitragalus. Early forms of the Proboscidea have been found in the Upper Eocene of Egypt. Sirenia are represented by Eotherium, etc. The rodents were represented by
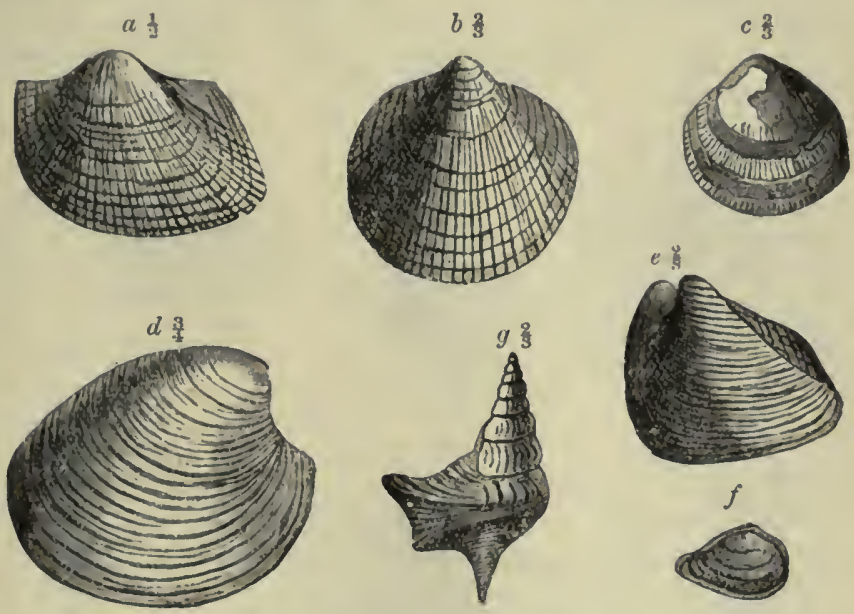

Fig. 176.-Fossils of TUE THANET BEDS.

a. Cuculliea decussata.

b. Pectunculus terebratularis.

c. Protocardium Laytoni. g. A porrhais Sowerbyi.

d. Cyprina planata.

e. Pholadomya cuneata.

f. Corbula regulbiensis.

Theridomys and Sciuroides, and the primates by the Lemuroid Microcherus.

Characteristic Fossils.-The following are some of the commoner and most characteristic species of invertebrates found in the marine and estualine deposits of the Eocene Series:-

\section{Fossils of the Thanet Beds}

Lamellibranchia. Protocardia Laytoui, Corbula regulbiensis, Cucullæa decussata (= crassatina), Pectunculus terebratularis, Cyprina scutellaria (=planata), C. Morrisi, Astarte tenera, Pholadonya cuneata.

Gastropoda.

Aporrhais Sowerbyi, Trophon subnodosum, Scala Bowerbanki. 
Fossils of the Woolwich and Reading Beds

Lamellibranchia. Corbicula cuneiformis, C. tellinella, Cyprina Morrisi, Ostrea bellovacina, O. tenera, Unio subparallela.

Gastropoda. Potamides funatus, Calyptrea aperta (=trochiformis), Melanopsis buccinoidea, Melanatria inquinata, Neritina globulus, Pitharella Rickmani.
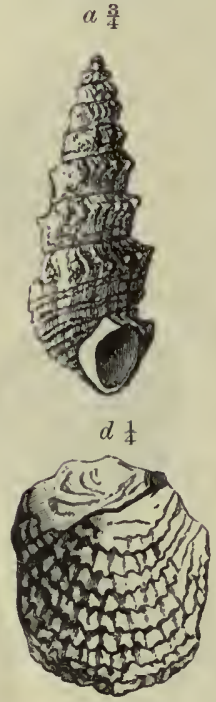

c $\frac{1}{2}$

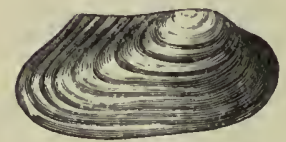

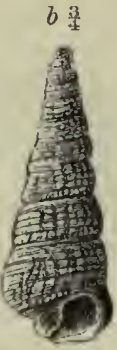

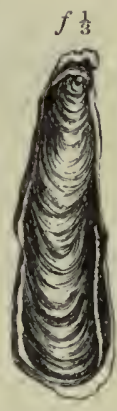

c $\frac{8}{4}$
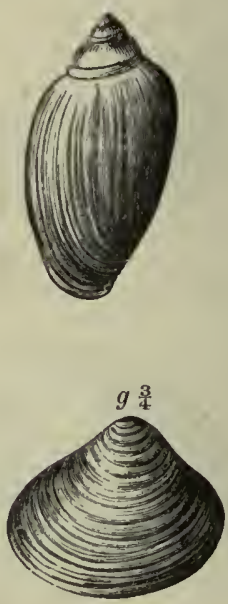

$h \frac{3}{4}$

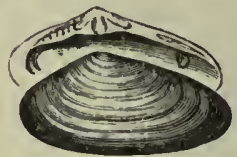

Fig. 177.-FOSSILS OF THE WOOLWICH BEDS.

a. Melania inquinata.

b. Potamiles funatus.

c. Pithareila Rickmani.

d. Ostrea bellovacina. e. Unio subparallela.

f. Ostrea tenera.

g. Corbicula cordata.

$h$. Corbicula tellinella.

\section{Fossils of the London Clay}

Annelida.

Crustacea.

Brachiopoda.
Ditrupa plana, Vermicularia bognoriensis. Hoploparia Belli, Xanthopsis Leachi. Lingula tenuis, Terebratulina striatula. 
Lamellibranchia. Cardita Brongniarti, Axinus angulatus, Dosiniopsis orbicularis, Pholadomya margaritacea, Pinua affinis, Modiola clegans, M. depressa, Panopwea intermedia, Pectunculus decussatus, 1 . brevirostris.

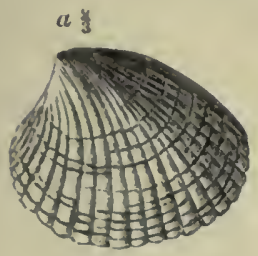

$b$ ?
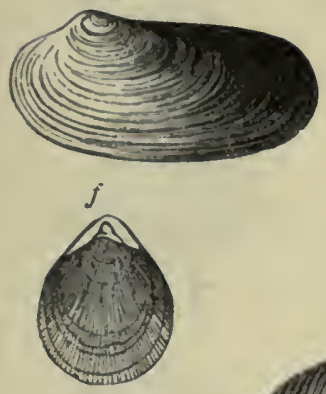

g

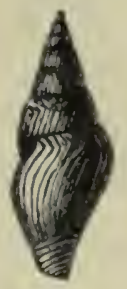

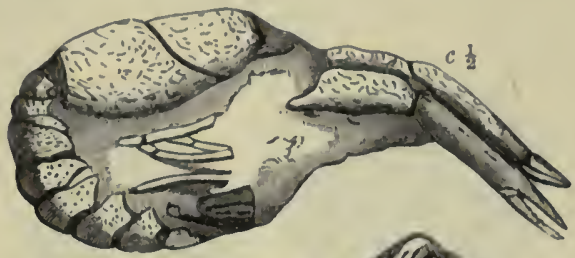

d $\frac{1}{2}$
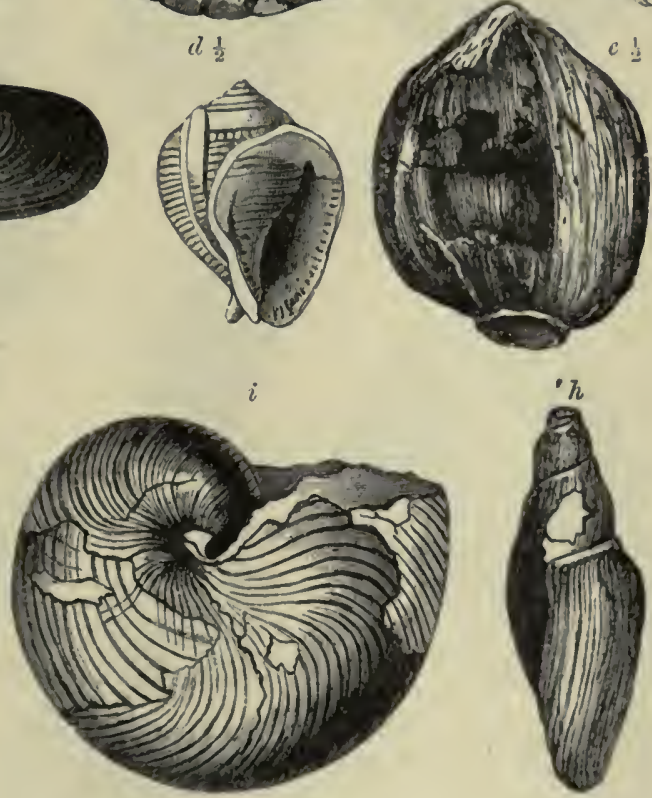

Fig. 179, - FOSSILS OF THE LONDON CLAY.
a. Cardita Bronguiarti.
b. Panoper intermedia.

d. Cassidarin ambigua

c. Nipa elliptica (fruit).

f. Terebratulina striatula.

g. Pleurotoma teretrium.

h. Voluta Wetherelli.

$i$. Nautilus imperialis.

Gastropoda.

Aporrlaais Sowerbyi, Cassidaria ambigua, Xenophora extensa, Pisania (Tritonidea) Morrisi, Natica hantoniensis, Sycum (Leiostoma) globatum, Pleurotoma (Surcula) teretrium, Pyrula Smithi, Voluta Wetherelli, Volutospina elevata.

Cephalopoda. Nautilus imperialis, N. regalis, Aturia ziczac. 


\section{Fossils of the Bracklesham Beds}

Protozoa. Actinozoa. Nummulites lævigatus, $\mathbf{N}$. variolarius.

Lamellibranchia. Arca biangula, Pecten corneus, Cardita (Venericardia), planicosta, Solen obliquus, Sanguinolaria Hollowaysi, Pectunculus pulvinatus.
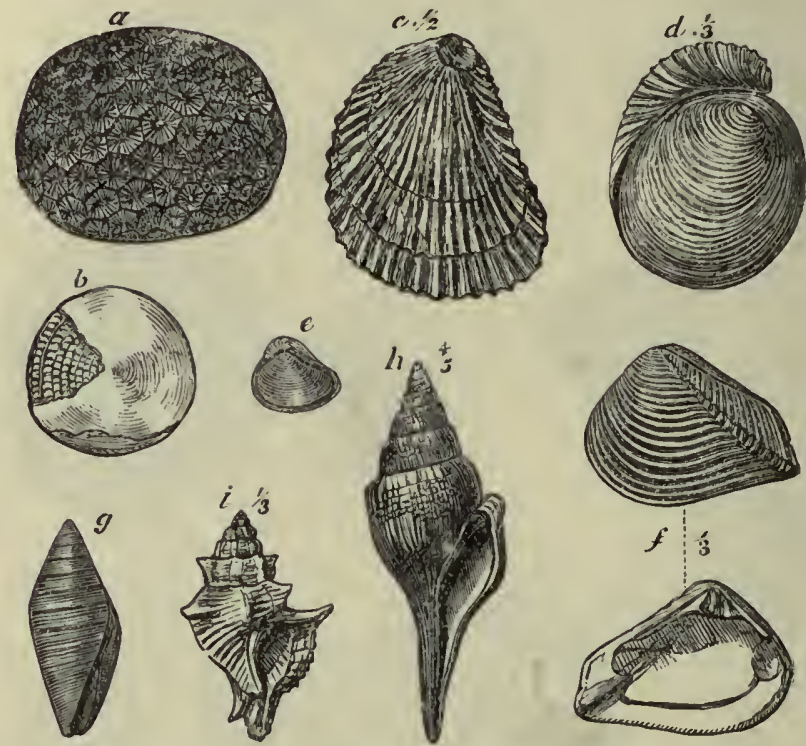

Fig. 179.-FOSSILS FROM THE BRACKLESHAM AND BARTON BEDS.

a. Litharea Websteri.

b. Nummulites levigatus.

c. Ostrea flabellula. d. Chama squamosa.

e. Corbula pisum.

$f$. Crassatellites sulcatus. g. Conorbis dormitor. $h$. Clavella longæva.

$i$. Murex asper.

Gastropoda.

Clavella longæva, Sycum (Leiostoma) pyrus (range into Barton Beds), Cassidaria coronata, Cypræa tuberculosa (var. Coombii), Cerithium (Campanile) giganteum, Turritella imbricataria, Mesalia sulcifera, Conus deperditus, Pleurotoma (Surcula) attenuata, Melongena minax, Strepsidura turgida, Voluta nodosa, V. spinosa, Ancilla buccinoides.

\section{Fossils of the Barton Beds}

Protozoa.

Echinoderma.

Nummulites elegans.

Lamellibranchs. Cardita sulcata, Crassatellites sulcatus, Cardium porulosum, Corbula pisum, C. ficus, Pecten (Chlamys) reconditus, Pectunculus deletus, Chama squamosa. 
Gastropoda. Turritella imbricataria, Rostellaria (Hippochrenes) ampla, Rimella rimosa, Conorbis dormitor, Murex asper, Typhis pungens, Fusus porrectus, Clavella longava, Buccino. fusus regularis, Pleurotoma (Surcula) rostrata, Cassidaria nodosa, Xenophora agglutinans, Olivella Branderi, Voluta athleta, V. luctatrix.

\section{B. British Eocene Deposits}

The present restricted extent of the Eocene deposits in England and their separation into two basins are due to the upheaval and
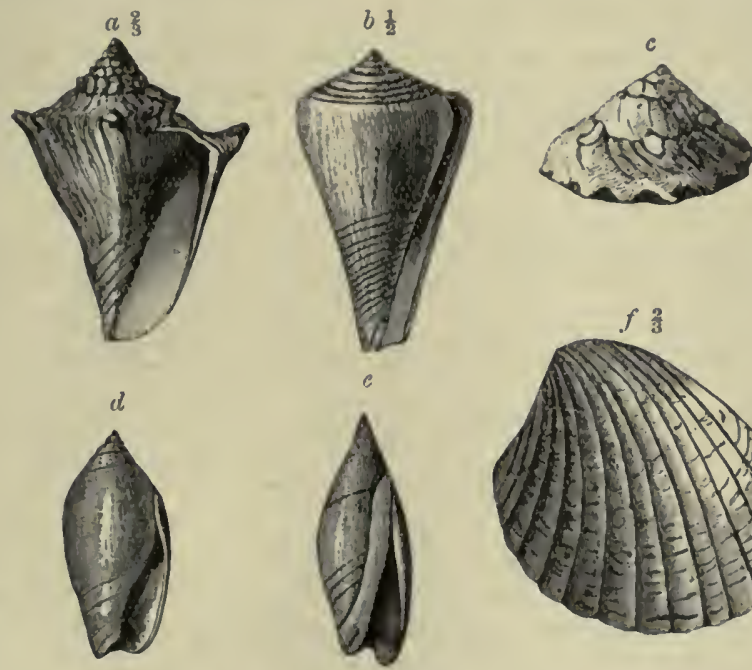

Fig. 180. - FOSSLLS OF THE BRACKLESHAM AND BARTON BEDS.

a. Voluts athleta.

b. Conus deperditus.

c. Xenophora agglutinans. d. Olivella Branderi.

e. Ancilla buccinoides.

f. Cardita planlcosta.

disturbance which took place in Miocene time, when lateral pressure from the south established a series of east and west flexures; and as the Palrogene deposits have been removed from the anticlinals, the parts which remain occupy two synclinal areas, i.e. the London and the Hampshire basins.

A glance at any geological map will show the extent of the Palaogene Beds in these two areas. The London basin extends from Hungerford in Berkshire to Reculvers in Kent, and its northern boundary passes from Reading through the counties of 
Buckingham, Hertford, and Essex to near Framlingham in Suffolk, where the influence of the syncline dies out and the boundary line then runs northward to the west of Yarmouth. Its length from Hungerford to Reculvers is about 120 miles, and its width from Sudbury to Canterbury is nearly 60 miles, but this is probably less than half its actual extent, the rest of the basin being concealed by the waters of the North Sea.

The Hampshire basin is much smaller, and lies in a trough between the anticlinal axis of Winchester on the north and the monoclinal of Prurbeck and the Isle of Wight on the south, and its extreme width is, therefore, only 25 miles, while its length from Dorchester to near Worthing in Sussex is abont 60 miles, with an outlier at Newhaven nearly 20 miles farther east. There is evidence, however, of the original extension of the Eocene through Dorset and East Devon.

In Ireland freshwater beds of Eocene age are interstratified with

Norfolk. London.

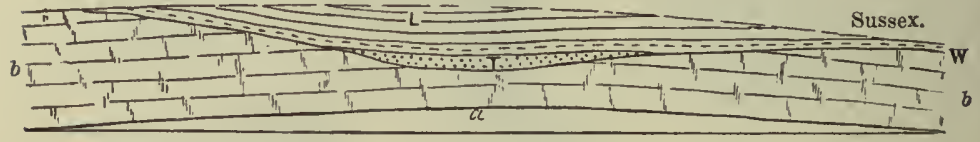

Fig. 181. Diagran to illustrate the PRE-tertiary erosion of the chalk.

b, b. Upper Chalk.

$a, a$. Base of Upper Chalk.

T. Thanet Beds,

L. London Clay.

W. Woolwich Beds.

the great sheets of basaltic lava which cover so large an area in Antrim and Derry. In Scotland a similar set of lavas, also with intercalated freshwater beds, attains a great thickness in the islands of the Inner Hebrides (Mull, Skye, etc.).

In Britain there is a decided unconformity between the Cretaceous and Palæogene Systems, a break which indicates a considerable lapse of time and a great change of physical and geographical conditions. We have seen that there are deposits in France and Belgium which partially bridge over this gap, and similar deposits may also have been formed in the British area, but if so, they were destroyed before the deposition of our lowest Eocene strata. It is now certain that large tracts of the U'per Chalk have been removed from certain areas either before or during the formation of the earlier Eocenes, for we cannot doubt that the higher parts of the Chalk were originally continuous from Hampshire to Norfolk, yet they do not now exist under the London basin, and consequently the Upper Chalk, which in Sussex 
is at least 750 feet thick, and in Norfolk is probably 1000 feet, has only a thickness of from 250 to 300 feet beneath the valley of the Thames. Moreover, where the Upper Chalk is thinnest, the London Eocenes are thickest, and there can be no doubt that these Eocenes were deposited in a broad and deep trough, which had been excavated out of the Upper Chalk. The relation of this trough to the general surface of the Chalk is indicated in the diagram, Fig. 181.

'The following are the divisions of the Eocene Series now recognised in the London and Hampshire basins. They can be grouped into Lower and Upper Eocene, but the creation of a Middle Eocene is quite unnecessary.

\begin{tabular}{|c|c|c|c|}
\hline & London 13asin. & Fe & \\
\hline Upper & Brackles- $\int$ Sands & abou & 200 \\
\hline & Clays & ", & 60 \\
\hline & Bagshot Beds. & ,. & 150 \\
\hline & London Clay & ", & 400 \\
\hline wer & Woolwich and & & \\
\hline & Reading Beds & ", & 80 \\
\hline & Thanet Bed & ", & 80 \\
\hline
\end{tabular}

About 970
Hamjushire Basin (Isle of Wight).

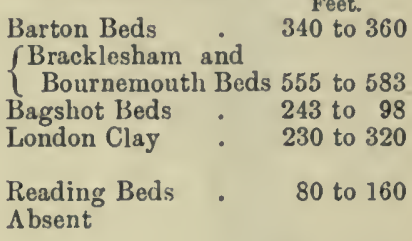

1450 to 1520

It will be seen that the Lower Eocene is more fully developed in the London basin than in Hampshire and includes the lowest division (Thanet Beds), which does not occur in Hampshire. On the other hand, the Upper Eocene is thin and incomplete near London, but is fully developed in the Hampshire basin.

The Thanet Beds, as their name implies, are well developed in the Isle of Thanet. They consist mainly of pale-coloured sands, the lowest part being always argillaceous and full of dark-green glauconitic grains, while at the base, and resting on the Chalk, there is invariably a layer of unworn green-coated flints. These flints show no signs of attrition, and are believed to have been derived directly from the underlying chalk, not by mechanical erosion, but by chemical solution; carbonated rain-water percolating tlirough the sands and dissolving the subjacent chalk, but leaving the insoluble flints behind; so that a layer of these nodules has gradually accumulated at the base of the sand, but was not there when the sands were originally deposited. This supposition is confirmed by the fact that no fossils occur in this basement-bed, whereas if the flints had ever lain ou a sea-bottom small oysters, serpulæ, etc., would certainly liave fixed themselves on to such favourable surfaces for attachment.

In East Kent the greater part of this stage consists of greenish saudy marl (50 or 60 feet), overlain by sharp greenish-grey sand 


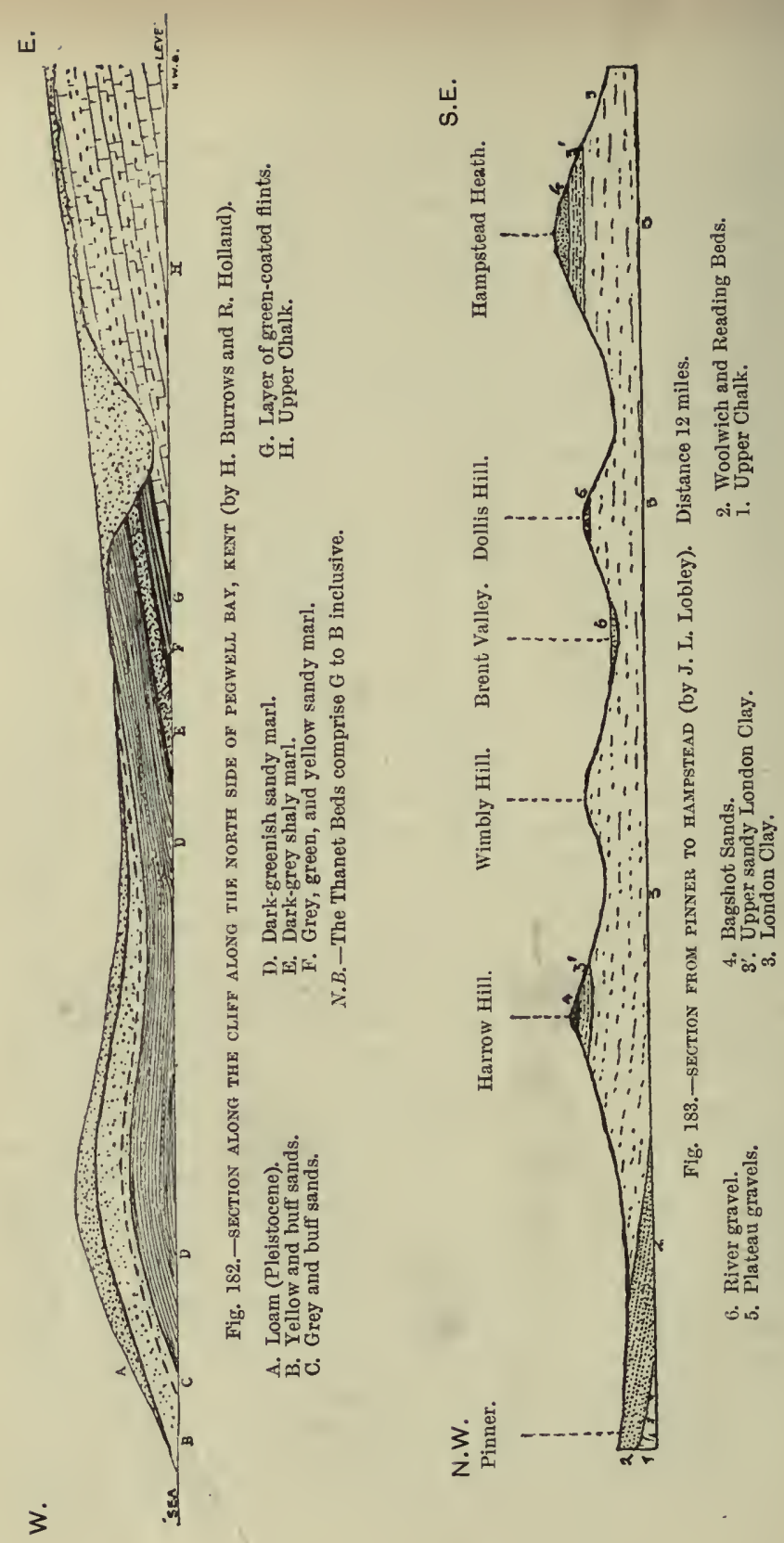


(30 to 40 feet), and both beds contain many fossils (see p. 529); the best exposme is in the cliffs of Pegwell Bay near Ramsgate, and this is illnstrated in Fig. 182. It is also seen at Reculvers on the north const of Kent. Westward the sandy marl passes into fine soft pale-green or buff sand (argillaceous at the base), while the upper sands appear to thin out, so that in the west of Kent the whole is not more than 50 feet thick; this type of the Thanet Beds is well exposed in the pits near Woolwich and Clarlton, but contains 110 fossils. Thence the outcrop rums by Crayford and Croydon to Epsom, where the sands are only 15 feet thick, thimning out entirely near Ashstead. ${ }^{1}$

The Thanet Beds thin northward as well as westward, for though well-sections at Chelmsford and Braintree show them to be about 30 feet thick, at their ontcrop near Sudbury they are only 16 feet, and they thin out to the west near Gestingthorpe.

The Woolwich, Reading, and Oldhaven Beds.-These form a much more variable group, and exhibit three different facies as they are traced from east to west:-(1) the marine type, consisting of grey sands with nuarine shells, is only found in East Kent; (2) the estuarine or Woolwich type occurs in West Kent and East Surrey, and consists of sands, clays, and pebble beds, with estutarine and freshwater shells; (3) the Reading type of the western and northern tracts consists of unfossiliferous variegated plastic clays and bright-colomred sands.

Overlying the marine and estuarine beds of the Woolwich Group in Kent and Surrey are pebbly sands and pebble beds, from 10 to 50 feet thick, which are termed the Oldhaven or Blackheath Beds by Mr. Whitaker, and are grouped by him as a third division of the Lower London Tertiaries. Their stratigraphical extent, however, is not great, and their palaontological importance is small, so that they hardly seem entitled to rank as a primary division.

The coast near Reculvers in Kent furnishes a good section of the marine type of this group, and is as follows :-

Feet.

Oldhaven Beds. - Grey and buff sands, hardened in places into a ferruginous sandstone; a layer of pebbles at base . . . Woolwich Berls. - Pale-grey sand with sharks' teeth, Corbula regulbiensis, Protocardium Laytoni, Cyprina Morrisi, etc.

Near Milton estuarine beds come in near the middle of the Woolwich Beds, and at Upuor on the Medway there are 6 feet of clay with brackish-water fossils interealated in the pale-grey sands.

At Woolwich the greater part of the beds are estuarine clays and sands, in which Melania inquinata, Potamides funatus, and Cyrena cuneiformis are common fossils Resting on an eroded 


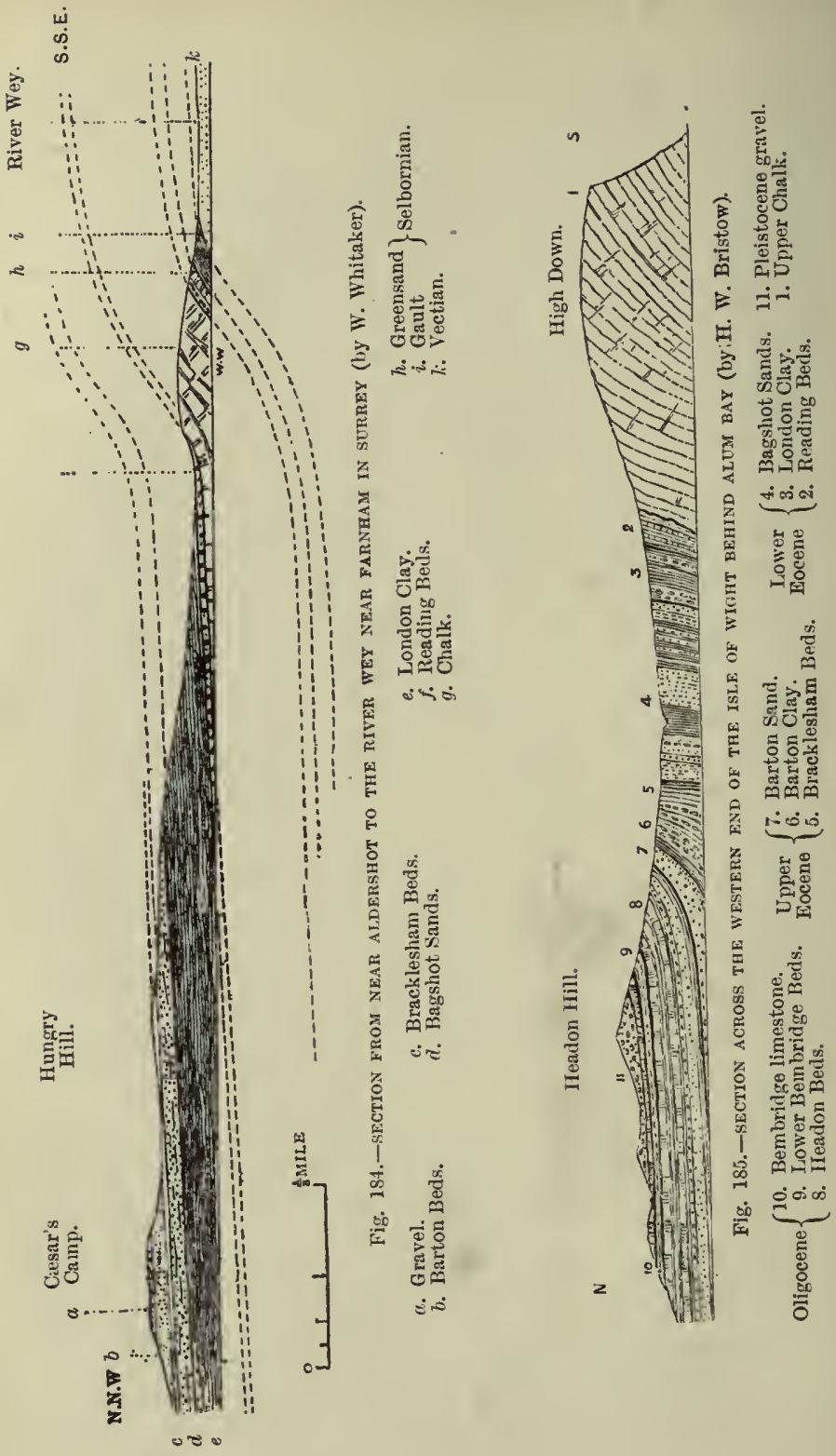


surface of the Woolwich Sands is a mass of pebbles in a sandy matrix, taking the place of the Oldhaven Beds and often called the Blacklientli Beds.

The Blackheath Beds do not extend west of Croydon, and are not found along the northern edge of the London basin. The pebbles composing them are adl well-worn and rounded flints without auy subangular pebbles such as occur on our shingle beaches; henee Mr. Whitaker concludes that they were not laid down in beaches, but were deposited by strong currents at some little distance from the shore, and his view is confirmed by the frequency of current bedding.

Beds of mottled plastic clay begin to appear in West Kent near the base, and these increase westward through Surrey, the shellbearing beds gradually dying out, till in Hampshire and Berkshire they consist entirely of mottled clays, in tints of red, yellow, grey, purple, and green, associated with beds of red, yellow, and white sand. These are known as the Reading Beds, and marine fossils only occur in the basement-bed, the ouly fossils in the clays being leaves of plants. Near Reading the groul consists of :--

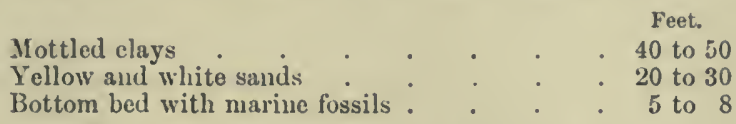

Beds of the same (Reading) type range along the northern lip of the hasin through Herts and Essex, but include some pebble beds which are occasionally concreted into the kind of conglomerate kuown as "plum-pudding stone."

They recur in the Hampshire basin, where they consist almost entirely of bright red and white mottled clays with several layers of brown sand, one of these being at the base and resting on the Chalk. No fossils except fragments of plants have yet been found in these clays, and they do not therefore seem to be of marine origin. Their thickness in Whitecliff Bay is 163 feet, at Alum Bay 84 feet, and they are still from 70 to 80 feet thick in Dorset near Bere Regis. Near Dorchester they include beds of sand and of subangular gravel consisting of Cretaceous flints and cherts.

The London Clay occupies broad areas both on the north and south side of the Thames Valley. It is of much more uniform composition than the lower group, the mass of it consisting of stifl bluish clay with lnyers of septarian nodules. The surface colour of the clay is generally brown, but this is due to the oxidation of the iron it contains by exposure to the weatler; its normal tint in deep wells and borings is a bluish-grey colour.

The basement-bed is of a different cliaracter to the rest, consisting of brown, grey, or greenish sand and sandy clay, in which 
are scattered many rolled flint pebbles; these pebbles are always black, and sometimes have the remarkable peculiarity of falling into fragments when tapped by a hammer, for though to the eye they seem compact, they are really traversed by a multitude of invisible cracks. This basement-bed is generally from 6 to 12 feet thick, and often contains fossils, of which the chief are Aporrhais Sowerbyi, Calyptrea aperta (=trochiformis), Pitaria obliqua, Panoprea intermedia, Pectunculus brevirostris, and Ditrupa plana.

The thickness of the London Clay near London is between 400 and 500 feet, but it thins gradually westward to about 270 at Wokingham, 50 near Newbury and Hungerford, and only 15 in the outlier of Great Bedwin in Wiltshire.

Fossils are not common throughout the London Clay, but sometimes occur in great profusion, especially where beds of sandy clay occur. The cliffs of the Isle of Sheppey are noted for the fossils they yield; plant remains are there especially abundant, and bones of birds, turtles, and snakes have also been found.

In the Hampshire basin, with the exception of an outlier at Newhaven, the most easterly exposure of this division in this area is at Bognor in Sussex, where beds of clay and calcareous sandstone, highly fossiliferous, are exposed on the shore, and are supposed to belong to the lower part of the London Clay.

Borings at Portsmouth Dockyard below the summit of the formation proved a thickness of 290 feet, and exposures made in extending that dockyard from 1868 to 1870 were described by Mr. Meyer, ${ }^{2}$ who found the clay divisible into three parts, each commencing with a layer of pebbles and passing upward from stiff clays into sandy clays. The lowest zone is about 100 feet thick, the middle zone has a thickness of 134 feet, and the sandy beds in the upper part of this yielded many fossils. The uppermost zone consists mainly of clays containing Cyprina planata, Pholadomya margaritacea, Rostellaria lucida, and other species.

In the Isle of Wight the London Clay is about 320 feet thick at Whitecliff Bay, but only 230 at Alum Bay. ${ }^{3}$ At neither place are many fossils to be found, but at Whitecliff the higher part contains Panopaa intermedia, Cyprina planata, Callista tenuistriata, and Pinna affinis. At 262 feet from the base there is a layer of black flint pebbles, and above this are sandy and laminated clays. In Dorset the London Clay consists chiefly of brown sandy loam with seams of sandy ironstone and a bed of flint pebbles at the base. Its thickness in the Purbeck district is from 70 to 80 feet, but it thins westward, and is finally overlapped by the Bagshot Beds near Dorchester.

Bagshot Beds.- - In the London Basin these beds occupy a 
much smaller space than the London Clay becanse they have been removed from the greater part of its surface by subsequent detrition and erosion, but there is good reason to believe that they were not only coextensive with the London Clay but sprend beyond its original borders. The chief remaining tract of Bagshot Sand is an area about 24 miles in length with a breadth of abont 10 or 12 iniles, and occupying parts of Berkshire, Hampshire, and Surrey. Aldershot, Farnborough, Bagshot, Wokingham, Ascot, and Coblıam all lie within this area. Westward there are several ontlying tracts, some large and some small; and north of the Thames in Middlesex are three small outliers capping Harrow, Hampstead, and Highgate Hills (see Fig. 183).

The extreme thickness of these sands in the Bagshot and Farnborougl country is from 130 to 150 feet. Westward at Ramsdell, in the outlier between Basingstoke and the valley of the Kennet, there is a bed of brown clay very like London Clay, and 30 feet thick, in the lower part of the Bagshot Sand.

In the Hampshire Basin the Bagshot Beds consist of bright yellow and white sands with bands of grey laminated sand and clay and (in the mpper part) layers of white pipeclay, which contain leaves and stalks of plants belonging to the genera Aralia, Cosalpinia, Comptonia, Dryandra, Ficus, Laurus, Quercus, and other Dicotyledons. Ferns are rare in the Isle of Wight, but Chrysodium lauzeanum abounds at Stndland in Dorset. This flora indicates a warmer climate than that of the Reading Beds.

There is much difference of opinion as to the thickness assignable to these beds in the Alum Bay section (Fig. 185); the Geological Sirvey classes all the sands and clays which do not yield marine fossils as Lower Bagshot, and these amount to 662 fect. Mr. J. S. Gardner, ${ }^{4}$ however, has shown that the special Bagslot flora does not occur alsove the pipeclays, and that the higher beds at Bournemonth contain a very different flora. He also thought that the lower part of these sands replaced the upper part of the London Clay, but if the latter is restricted to 233 feet, the Bagshot Sands will have a thickness of 243 feet at Alum Bay, and decrease eastward till they are only 98 feet in Whiteclift Bay.

At Studland and Corfe in Dorset the Bagshot Beds have the same facies, but westward they pass into coarse snbangular gravels, which near Dorchester overlap both London Clay and Reading Beds so as to rest directly on the Chalk. These gravels contain pebbles of Cretaceous flint and chert, Purbeck marble, with many of quartz and of Palicozoic rocks probably derived from the Permian breccias of Deronshire. Still farther west they overstep the Chalk and rest on the Selbornian Sands. 
The Bracklesham Beds.-In the London basin the lower part of this group consists of brown laminated clays, overlain by dark-green clayey sand from 12 to 20 feet thick, and succeeded by a variable set of greenish sands with bands of clay, the total thickness varying from 40 to 80 feet. These. beds have yielded a few fossils, Fusus longrevus, Turritella sulcifera, Cardita planicosta, Pecten corneus, Ostrea flabellula, Corbula striata, Nummulites lovigatus, and many fish teeth, Lamna obliqua, Carcharodon auriculatus, etc.

Above the clays is a mass of sands formerly called the Upper Bagshot Sand, but now referred to the Bracklesham Group, and possibly representing the Boscombe Sands mentioned below. At the base is a layer of small flint-pebbles, and the fine yellow and white sands which succeed are the highest Eocene Beds that oceur in the London basin. Their thickness appears to be over 200 feet, for in a boring at the Albert Asylum, Bagshot, their depth proved to be 226 feet. $^{5}$ These sands contain in the upper part blocks of white saccharoid sandstone, which, when weathered out, are known as "grey-wethers"; they are sometimes 10 to 14 feet long, and 3 or 4 deep, and they often enclose flint pebbles. Organic remains are rare, but here and there are casts of shells, and about fortyeight species were obtained by Mr. Monckton from the Tumnel Hill cutting near Pirbright on the South-Western Railway. Among these the commonest were Rimella rimosa, Natica patula, Turritella imbricaturia, Ostrea flabellula, Pecten reconditus, Cardita sulcata, Lucina mitis, Tellina scalaroides, and Corbula pisum.

These beds received their name from Bracklesham Bay in Sussex, where they contain marine shells throughout their extent along the shore, but there are no cliffs in which they can be measured.

The section in Whitecliff Bay exhibits the same marine type, and has been described in detail by the Rev. O. Fisher, ${ }^{6}$ who divided the group into four portions. Mr. H. Keeping has since been able to fix the limit between the Bracklesham and Barton Beds more exactly, and finds it to be about 70 feet lower than where Mr. Fisher placed it. Making this alteration, the thicknesses of the several parts are as follows :-

A. Green and blue clays with a bed of sand about 52 feet from the base, Nummulites variolarius, Pecten corneus, Corbula pisum, Pleurotoma plebeia, etc. . . . . . . 182

B. Yellow sands and sandy clays, Num. variolarius : . $\quad 27$

C. Sandy clays and green sands, Num. loevigatus, Sanguinolaria

Hollowaysi, Voluta spinosa, etc.
D. Laminated clays and green sands with a bed of pebbles at the base, Num. locvigatus and a few other fossils . . . 251 
It will be noticed that C and D form a zone of Nummulites levigatus, white A and B are characterised by Num. variolarius.

On reaching Almm Bay we find that the greater part of this group is represented by unfossiliferous sands and clays, probably estuarine beds, and that marine shells are only found in the uppermost 157 feet, which answer to Mr. Fisher's group A. The lower beds were formerly relegated to the Lower Bagshot, but their true position has been determined by Mr. Gardner, who has compared them bed by bed with those of the opposite cliff's of Hanpshire. 'Their thickness is 398 feet, making a total of 555 feet.

The succession of the Bournemouth and Boscombe Beds has been carefully worked ont by Mr. Gardner, who gives it as follows :-

6. Dark saudy clays with peet.

5. Hichcliff Sands, white and without fossils ${ }^{\circ} \cdot{ }^{\circ} \cdot{ }^{\circ}$

5. Hencistbury Clays, with septariat fossils contrining sliarks' teeth $\quad 31$

4. Hengistbury Clays, with septaria containing sliarks teeth $\quad 57$

2. Bournemouth marine beds, with plants and marine shells $\quad 50$

1. Bournemoutl freshwater beds, with plant renains only . ? ?400

About 590

The Freshwater Beds consist largely of sand witl occasional bands of clay in which leaves are abundant, especially those of Salix (willow), Triartea (a palm), Sequoia Coutssa, Araucaria, Eucalyptus, and the ferns Osmunda, Polypodium and Acrostichum.

The marine beds are a similar set of deposits, but among the plants are Palmacites (a cactus), Dryandra, and the fruits of the Nipa palın.

Barton Beds. - The most careful study of these beds is the memoir by Messrs. Gardner, Keeping, and Monckton, ${ }^{8}$ on which the following account is based. They divide the stage into three parts, which they call Lower, Middle, and Upper Barton, but the Geological Survey divide it into the Barton Clay and the Barton Sands, which is in some ways a more convenient division.

According to these authors the thickuesses of their divisions at the three principal sections are as follows:-

\begin{tabular}{|c|c|c|c|c|c|}
\hline & & & Barton. & Alum Bay. & Whitecliff. \\
\hline \multirow{4}{*}{$\begin{array}{l}\text { Barton Sands or Upper Barton } \\
\text { Barton Clay }\left\{\begin{array}{l}\text { Middle Barton } \\
\text { Lower Barton. }\end{array}\right.\end{array}$} & • & . & 90 & 114 & 221 feet. \\
\hline & . & . & 53 & 167 & 92 \\
\hline & . & - & 49 & 57 & 55 \\
\hline & & & 192 & 338 & 368 feet. \\
\hline
\end{tabular}

The Lower Barton has at its base a thin zone of green sandy 
clay in which Nummulites elegans (var. prestwichiana) is common, and serves to define the Barton from the underlying Bracklesham Beds. Above are grey clays and sands containing Voluta athleta, Cassis ambigua, Rimella bartonensis, and Cominella canaliculata.

The Middle Barton, or Barton Clay proper, consists mainly of grey and brown clays with bauds of septaria, and its prevalent fossils are Voluta luctatrix, $V$. ambigua, Rostellaria ampla, Murex minax, Clavella longreva, and Crassatella sulcata. At Alum Bay there is a remarkable increase in the thickuess of this group, and the upper 70 feet consist of yellowish sandy clays with many small Mollusca, no such beds being seen at Whitecliff.

The Barton Sands at Barton present the following succession :-

4. White and yellow sands with Potamides concavrs, Olivella Branderi, and Melania hordeacea . . . . . 20

3. Dark-grey sandy clay with Olivella Branderi and other shells . $\quad 26$

2. White sand without fossils . . . . . 25

1. Bluish-grey clayey sand (the Chama Bed) with Chama squammosa, Terebratula bisinuata, Terrebellum sopitum, Voluta costata, $V$. humerosa, and Conus scabriculus.

Feet.

At Alum Bay the Chama Bed is rarely exposed, and the higher beds are represented by a mass of yellow and white sand from 90 to 100 feet thick, which has been largely dug for glass-making. These sands are sometimes called the Headon Hill Sands, and at the east end of the island they thicken to 206 feet, and the Chama Bed is seen below them with a thickness of 15 feet.

\section{The Regron of Volcanic Activity}

The northern parts of the Britisl Isles were a scene of remarkable volcanic activity throughout a large portion, if not the whole of Eocene time, and evidences of this activity are found not only in the vast lava-flows above mentioned but in lava-filled fissures of great length. The region over which such phenomena have been found embraces the 11orth of England, the north of Ireland, and the whole of Southern and Western Scotland, and it must also have included the area of the adjoining seas as far south as Anglesey, as far west as St. Kilda, and as far north as the Faroe Islands - a total area of about 50,000 square miles. Its history has been written by Sir Archibald Geikie ${ }^{9}$ and Mr. A. Harker, ${ }^{10}$ and the following is an epitome of it.

This great development of volcanic action seems to liave coincided with a general elevation of the region above indicated, as if it had been pushed upward by the accumulation of a vast sea 
of liquid lava beneath it. Whether as cause or coincidence, it seems certain that great horizontal tension arose which started a series of fissures, these rumning generally from north-west to south-east, and sometimes extending for 50,60 , or even 100 miles. Into these fissures welled up the liquid rock which has consolidated into basalt, and where they reached the surface the lava welled out in vast streams like those of modern Iceland, forming the great basalt plateaux of Antrim and the west of Scotland.

This process of dyke-making and the outpouring of lava-floods was repeated again and again, till on the great plain or plateau which bordered the west of Scotland the lavas accumulated to a depth of several thousand feet. In some places 3000 feet of them still remain, and we know not how great a thickness has been removed. Here and there they filled up and obliterated river-channels like those in the island of Mull.

After the building up of these plateaus another episode took place. Large bodies of a basic magma were pushed into and through the plateau basalts and consolidated into huge domes of gabbro, troctolite, and other such coarse-grained rocks, but whether they ever extruded matter at the surface camnot be known, because the summits of the bosses are removed.

The next phase was the protrusion of material from a different ınagma, which has consolidated into acid rocks of various kinds, from glassy obsidians and rhyolites to granophyres and a rock of granitic character. These now form conical hills which resemble in some respects the trachytic hills of Auvergne.

The last phase was a second formation of fissures, producing another system of basic dykes which traverse all the previously formed rocks, cutting not only the older dykes but the great masses of gabbro and granophyre. Whether they poured lava to the surface is not known, and whether the formation was the final episode is not quite certain, for there is also a series of acid dykes whicl traverse all the older volcanics and do not appear to be cut by the later basic dykes. The age of these later basic and acid dykes is also uncertain; they may be Oligocene, or even Miocene; but whenever vulcanism did cease the whole region began to sink down again, and at the present time great parts lie below the sea.

Ireland.-The largest remaining portion of the great lava plains is the basaltic plateau of Ulster (Antrim and Derry) (see Fig. 186), which has an area of about 2000 square miles. This plateau presents steep escarpments on all sides, but the ground falls towards a central trough in which lie Lough Neagh and the valley of the river Bann. The component lavas are almost entirely basaltic, but they are divisible into a lower and upper series. The 


$$
11
$$


lower lavas rest on an irregular floor of older rock, the substratum being in most places Chalk, but between it and the lowest lavaflow there is always a bed of brown ferruginous clay full of flints. These lower lavas are mostly massive or amygdaloidal basalts, and their combined thickness is from 400 to 500 feet.

Between the two series of lavas there is a break which appears to have coincided with the plutonic phase above mentioned, when the intrusive masses of gabbro and granite were formed. In Antrim this is marked by a band of stratified beds consisting of brown and red clays with layers of lignite, beds of pisolitic iron-ore (bauxite), of volcanic sand, and conglomerates composed of pebbles of rhyolite and basalt. Over these beds are piled thick and extensive sheets of basalt and dolerite, which at Sleamish have a thickness of about 600 feet. The well-known columnar basalt at the Giant's Causeway is one of these sheets and overlies a bed of bole or laterite.

At Glenarm and at Ballypalady near Templepatrick there are thick deposits of iron-ore, the lower bed being a compact ferruginous earth known as lithomarge, which is sometimes 40 feet thick, and is overlain by pisolitic ore, and these occur some 600 feet from the base, and 400 feet from the top of the basaltic formation. At Glenarm they are associated with sandy clays and pebble beds, which enclose a seam containing well-preserved leaves and plant remains. Among these Daphnogene Kanei, Sequoia . Coutssice, Macclintockia Lyelli, and leaves of Platanus, Quercus, and Rhamnus have been identified by Baily. Mr. J. S. Gardner considers the flora to be of early Eocene age, not Miocene as previously supposed." ${ }^{11}$

Scotland.-The basaltic plateau of Ulster is only a portion of a very extensive tract of similar materials which has been largely broken $1 p$ and destroyed, but must have originally stretched northward to the west coast of Scotland, where other large remnants of it are found in the Isles of Mull, Eigg, Rum, Skye, and Raasey. In the present commection the most important Scottish locality is the promontory of Ardtun Head in the southwestern part of Mull. Here beds of gravel sand and shaly clay are intercalated between two great sheets of basalt and have yielded many plant remains. The beds were first investigated by the late Duke of Argyll, but more recently by MIr. J. S. Gardner, ${ }^{12}$ from whose account the following is taken, together with the illustrative section, Fig. 187.

The sedimentary rocks appear along the seaward face of the headland for a distance of rather more than a mile, and the succession seen in one of the quarries is as follows:- 


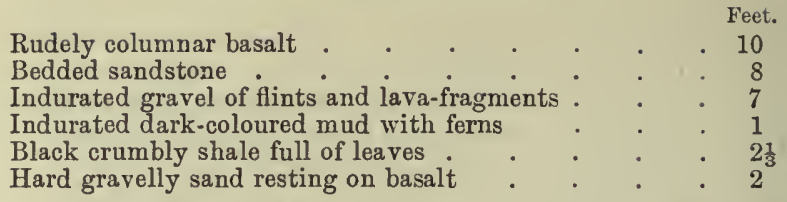

At other points there are several beds of clay or shale which contain leaves, and similar beds also occur near Carsaig. The plant remains include a fern (Onoclea hebridica) and an Equisetum, many Gymnosperms, such as Ginkgo, Podocarpus, Taxus, and Sequoia. Dicotyledons are abundant and include leaves of Platanus hebridicus, Populus arctica, Cornus hyperborea, Boehmeria antiqua, and leaves like those of Corylus, Laurus, and Rhamnus. Mr. Gardner considered the flora to be more like a late Cretaceous than a Tertiary one, but accepting its probable connection with the Antrim area, was inclined to regard it as of very early Eocene age, and not newer than the time of the Thanet Beds.

That the island of Arran was included in the area of Tertiary volcanic activity has long been suspected, but it was only in 1899 that absolute proof of the fact was obtained. ${ }^{13}$ No remnants of basaltic lava-flows remain on the island, but all the sonthern part of it is seamed with basalt dykes, and it is very probable that many of these belong to the earlier dyke-system, and that surface eruptions proceeded from them; all traces of such eruptions have, however, been destroyed.

The most remarkable feature of the island is the large volcanic vent which occupies the central district around Glen Craigagh, between Brodick and Machrie Bays. The complex of rocks by which this vent is now filled has an oval form about $3 \frac{1}{2}$ miles in length by 3 in breadth; its central portion (over 2 miles in diameter) is composed of a breccia or agglomerate, consisting largely of fragments of sedimentary rocks mixed with a smaller quantity of igneous rock-fragments. This area is surrounded by a ring of intrusive igneous rocks, which are chiefly granites, granophyres, and felspathic rocks.

Some of the rock-fragments in the central agglomerate are Old Red Sandstone, and have been blown up from below; others are large blocks of Trias, Rhætic, Lias, and Chalk, which must have fallen into the vent from above, and testify to the existence of a former covering of Jurassic and Cretaceous strata of which all other traces have been destroyed. As remarked by Sir A. Geikie in the Summary of Progress for 1900 (p. 124), "the explosion was thus certainly later than the Upper Cretaceous period and may consequently be referred to older Tertiary time. The fixing of the 
age of this vent carries with it the determination of the age of all the associated eruptive rocks. There can now be no room to doubt that the granites, quartz-porphyries, felsites, pitchstones, diorites, diabases, and basalts are all a connected series of eruptive masses, coeval with the similar assemblages in Antrin, the Inner Hebrides, and St. Kilda."

\section{Continextal Equivalexts}

The Eocene area of Belgium may be regarded as a continuation of the London basin, for the two are doubtless in actual connection heneath the North Sea. Again, the deposits of the Paris basin present such a great resemblance to those of the Hampshire basin that they can be correlated without much difficulty, and were doubtless formed within the same area of deposition. In the south of France, however, and in the south of Europe generally, the Eocene Series exhibits a very different facies, consisting largely of lard foraminiferal limestones full of Nummulites, Operculina, and Alveolina, and generally known as Nummulite limestones; with these are calcareous sandstones containing nuany large shells, reefbuilding corals, and Echinoderms of many species.

The accompanying table shows the divisions recognised in the Eocene Series of Belgium and France, and their correlation with those of England.

\begin{tabular}{|c|c|c|}
\hline England. & Belgium. & France. \\
\hline Barton Beds. & $\begin{array}{l}\text { Wemmelian, } \\
\text { sands. }\end{array}$ & $\begin{array}{l}\text { Bartonian, sands } \\
\text { and limestones. }\end{array}$ \\
\hline $\begin{array}{l}\text { Brackleshan } \\
\text { Beds. }\end{array}$ & $\begin{array}{l}\text { Bruxellian, sands } \\
\text { and sandstones. }\end{array}$ & $\begin{array}{c}\text { Lutétian } \\
\text { (Calcaire Grossier), } \\
\text { limestones. }\end{array}$ \\
\hline $\begin{array}{l}\text { Bagshot Sands, } \\
\text { London Clay. }\end{array}$ & $\begin{array}{l}\text { Sables de Mons, } \\
\text { Argile de Flandres. }\end{array}$ & $\begin{array}{l}\text { Yprésian, } \\
\text { sands only. }\end{array}$ \\
\hline $\begin{array}{l}\text { Woolwich and } \\
\text { Reading Beds. }\end{array}$ & $\begin{array}{c}\text { Landenian } \\
\text { (fresliwater beds). }\end{array}$ & $\begin{array}{c}\text { Sparnacian } \\
\text { (freshwater beds). }\end{array}$ \\
\hline Thanet Beds. & $\begin{array}{l}\text { Heersian, } \\
\text { sands and marls. }\end{array}$ & $\begin{array}{l}\text { Thanetian, } \\
\text { Marine sands. }\end{array}$ \\
\hline L & $\begin{array}{l}\text { Montian, } \\
\text { limestones. }\end{array}$ & $\begin{array}{c}\text { Montian, } \\
\text { limestone and marl. }\end{array}$ \\
\hline
\end{tabular}


The name Montian is taken from Mons in Belgium, Thanetian from our Isle of Thanet, Sparnacian from Eparnay (Sparnacum), Yprésian from Ypres in Belgium, Lutétian from Lutetia the Roman name of Paris, and Wemmelian from Wemmel in Belgium.

From the above table it will be seen that deposition began earlier both in Belgium and France than in the English area, the Montian Beds forming a kind of link between the Cretaceous and Eocene Series.

\section{Belgium}

Montian.-The beds referred to this stage have a thickness of from 200 to 300 feet, and the Geological Survey of Belgium now recognises three subdivisions which in descending order are :-

3. Freshwater beds with Physa montensis.

2. The limestone of Mons (and Upper Tuffeau of Ciply).

1. The Cerithium limestone and basal conglomerate.

The basal conglomerate lies unconformably on the higher Cretaceous strata, and the Cerithium limestone is so called from containing a large Cerithium (C. Corneti). The Mons limestone is a rough yellowish friable rock composed mainly of shell-fragments, Foraminifera, and calcareous algæ. It contains a large fauna, consisting mainly of Gastropoda, with a fair number of Lamellibranchs and a few Echinoderms; Cerithium montense, Cer. inopinatum, Turritella montensis, Mitra Dewalquei, Pseudoliva robusta, Cidaris distincta, Cassidulus elongatus, and Echinanthus Corneti are characteristic species, and there are a number of freshwater and terrestrial shells which have been washed into the deposit from neighbouring land. No Ammonites or true Belemnites occur, but the latter are represented by two species of Beloptera.

The Heersian or Lower Landenian of Mourlon consists of glauconitic sands passing laterally into soft sandstone or sandy marl. Its fauna is marine and like that of our Thanet Beds, but near Gelinden the sands include a band of white marl containing the remains of an early Eocene flora (Osmunda eocenica, Laurus Omalii, Cinnamomum Sezannense, etc.). The total thickness of the Heersian is about 60 feet.

Landenian. - This group is of freshwater origin and resembles our Woolwich Beds, consisting of sands and marls with beds of shaly lignite. The thickness is only from 30 to 50 feet.

Yprésian.-This stage falls naturally into two parts, of which the lower (Argile de Flandres) is a continuation of the London Clay. In a boring at Ostende its thickness was found to be 460 feet, but it thins eastward just as the London Clay thins westward. Fossils are scarce in this clay, but it is overlain by sands and 
sandy clays which yield Nummulites planulatus, Turritella edita, Pectunculus decussatus and other fossils, and are from 100 to 150 feet thick. Of about the same age are the sands of Mount Panisel near Mons and those of Oeltre in Flanders, which contain Pinna margaritacea, Rostellaria fissurella, Turritella edita, and Cardita planicosta.

Bruxellian, better latinised as Brussellian; this name is restricted by Belgian geologists to the lower part of a mass of sand and sandstone which corresponds to our Bracklesham Beds. Fossils are abuudant in these sands, but generally in a bad state of preservation, except sharks' teeth such as Lamna elegans, Otodus macrotus, Galocerdo minor, Enchodus Blecheri, and Myliobates toliapicus. The fruits of the Nipa palm (Nipadites Burtini) are also common. The higher sands are known as Laekinian and are characterised by $N$ ummulites Heberti, N. variolaria, and Ditrupa strangulata. The total thickness is not more than 180 feet.

The Wemmelian has a basement-bed of sandy gravel containing Nummulites variolarius, overlain by sands and a band of sandy glauconitic clay. In these beds Num. vemmelensis is a characteristic species, with Turritella sulcifera, Voluta elevata, Cardium porolosum, Tellina rostralis, and Pectunculus pulvinatus. The thickness of these beds varies from about 50 feet near Brussels to 170 at Malines, and over 200 in a boring at Anvers.

\section{The Paris Basin}

Montian.-This is not so well developed in France as it is in Belgium, because it has been deeply eroded in inany places before the deposition of the succeeding Thanet sands. It varies, consequently, in thickness from 6 feet at Meudon to 162 at Mont Aimé near Vertus. ${ }^{14}$ Typically it is a yellow granular linestone, partly oolitic and partly composed of shell debris. It is probably somewhat older than the limestone of Mons, for it contains Nautilus danicus, but with this are large Cerithia, Turritella montensis, Pseudoliva robusta, Fasciolaria prima, Lima Caroli, Corbis multilamellosa, and other Montian species. At Meudon it is succeeded by white marls which are partly of marine and partly of freshwater origin. Limestones of the same age occur in the Pays de Bray at Vigny, and at Laversine near Beauvais.

Thanetian.-Glauconitic sands which appear to be about the age of our Thanet Beds are found all along the northern and eastern borders of the Paris basin, and as a rule they rest directly on the Chalk. Such are the sands of Watten and St. Omer near Calais, which are characterised by Cyprina planata and are often indurated by a siliceous cement into a stone known as tuffeau, 
resembling gaize or malmstone and containing diatoms and sponge spicules. Farther south in the Aisne are the sands of La Fere and of Châlons-sur-Vesle, which seem to be of the same age, while westward near Beauvais are the sands of Bracheux, containing Cyprina planata, Ostrea bellovacina, Pectunculus terebratularis, etc., a fauna which is classed as Thanetian by the majority of French geologists, but as Sparnacian by Professor Prestwich. ${ }^{15}$ None of these sands extend so far as Paris.

Sparnacian. - This group corresponds very closely to our Woolwich and Reading Beds. Near Paris it consists principally of plastic clays, but at the base is a conglomerate with bones of mammals and birds, overlain by laminated clay containing Physa, Viviparus, and Unio, and near the top is a bed of sand with seams of lignite. This sand and lignite thickens eastward, while the plastic clays die out, till in the Soissonnais the group is represented by beds of lignite and black clays with associated marls and sands (30 to 50 feet). These contain Cyrena cuneiformis, Melania inquinata, and other Woolwich species. The highest beds are found at Sinceny on the Oise. They contain the same freshwater shells and consist of sands and clays with rolled flint pebbles.

Yprésian.-In France the London Clay is only found near Calais and Orchies; evidently it thinned out southward and does not appear to be represented elsewhere unless by the lower part of the sands of the Soissonnais, which are not more than 160 feet thick. These are divisible into three portions :-

Sables de Cuise with Cyrena Gravesi and freshwater shells.

Sables de Pierrefonds, Turritella edita and Nummulites planulatus.

Sables d'Aizy with Rostellaria Geoffroyi.

Lutétian.-In the Paris basin this stage consists of the beds generally known as the Calcaire Grossier. It is the most fossiliferous formation in the Paris basin, and the middle portion yields the light-yellow calcareous freestone which is the chief building stone of Paris. The group is divisible into three sub-stages as follows :-

3. Upper, thin-bedded fissile limestones with white and green marls and some beds of siliceous and dolomitic limestone, Cardium obliquum, Cerithium denticulatum, Potamides lapidum, Lucina saxorum . . . . . .

2. Soft thick-bedded limestones, some beds largely composed of Miliola and Orbitolites: Cardium granulosum, Chama calcarata, Tusus bulbiformis, Turritella imbricataria .

1. Glauconitic limestones and sands with a layer of pebbles at the base, Cerithium giganteum, Cardium porulosum, Ostrea flabellula, Nimmulites loevigatus . . . . . 25 to 70 

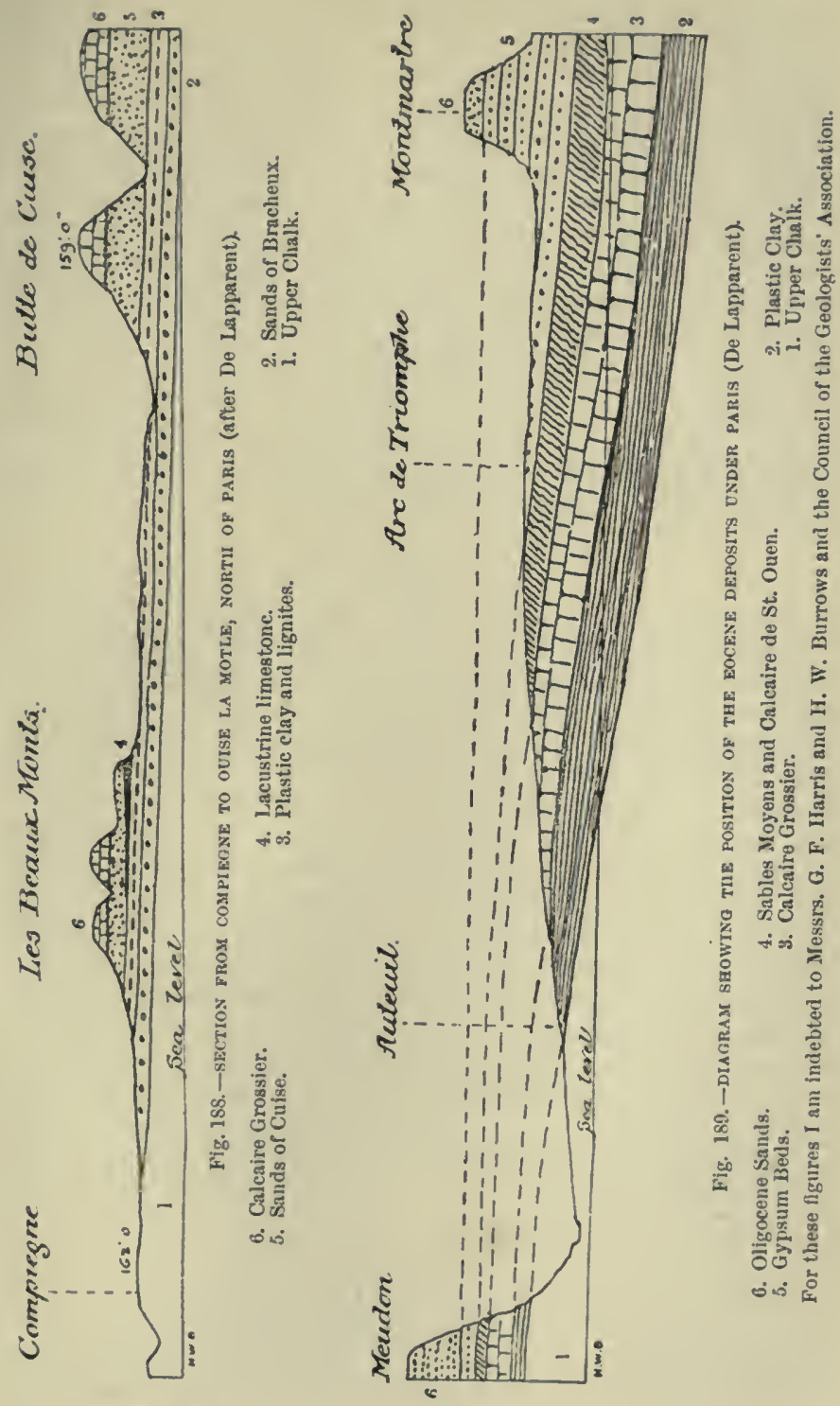
The Calcaire Grossier is succeeded by a set of sands known as the Sables Moyens or Sables de Beauchamp, which are about 30 feet thick. They form the zone of Num. variolarius and $N$. Heberti, and are also found at Anvers on the Oise, whence Mr. Dollfus has called them Anversian.16 Near Paris they are surmounted by a freshwater limestone, the Calcaire de Ducy, the fauna of which is different from that of the higher limestones.

Bartonian. - The argillaceous facies of this stage does not appear to exist in the Paris basin, where it is represented by sands alternating with freshwater limestones in the following succession, and having a total thickness of from 100 to 120 feet :-

4. Calcaire de Noisy with Limnoea longiscata.

3. Sables de Marines with Corbula pisum, Natica ambulacrum, and Voluta athleta.

2. Calcaire de St. Ouen with Limnoea longiscata.

1. Sables de Mortefontaine with Avicula, Potamides tricarinatus, and Pot. concavus (=pleurotomoides).

\section{Southern Europe}

After the general uplift which took place at the close of Cretaceous time (see p. 524) the south of Europe seems to have remained for a time above sea-level, but it gradually sank again and was covered by a sea which occupied the whole of the Mediterranean region. The mountain ranges of the Pyrenees, the Alps, and the Apenuines were not yet in existence, and the Eocene or Nummulitic Sea extended from the north of Spain and south of France through the Alpine region to Bavaria and the Carpathian Mountains, and through Italy to the Balkan States, Greece, and Asia Minor. It also occupied parts of Northern Africa.

The northern parts of this sea were shallow, and the deposits are mainly arenaceous; the central parts were deep, and the prevalent deposits are limestones crowded with species of Nummulites.

Thus in Bavaria and near Vienna the Eocene consists of-

3. The Vienna Sandstone (upper part), which in Hungary contains Num. striatus and at Häring in the Tyrol includes a thick seam of coal.

2. Vienna Sandstone (middle part) and Kressenberg Beds of Bavaria, sands and marls with a bed of limestone, Num. complanatus, and $N$. perforatus.

1. Burberg Beds; greensands with small Nummulites, Orbitoides and Opercuiina. Probably of London Clay age.

Nothing comparable with the lowest Eocene deposits of England and France has yet been found in Central Europe, large parts of which must have been land, for a special feature in the Vienna Sandstone Series is the occurrence of beds of coarse conglomerate 
and of large isolated blocks of granite and gneiss which appear to have come from Bohemia.

In Provence the Eocene is represented only by freshwater and terrestrial deposits, but sonth of it the Nummulitic Sen passed westward through the north of Spain and into Aquitaine. The Provençal deposits may be tabulated as follows, and are specially interesting from the mammalian remains which occur in them :-

Bartonian.-Freshwater clays, sands, and conglomerates.

Lutétian. - Limestones and marls with Planorbis pseudo-ammonia,

Limnaca aquensis, and Bulimus Hopei, with bones of Lophiodon

Pachynolophus, Paloplotherium, and Hyracotherium.

Yprésian. - Sands and mottled clays (freshwater).

Sparnacian.-Limestone with Physa Draparnaudi and Limncea obliqua. Thanctian.-Limestone with Physa prisca and Melania.

Montian.-Limestoncs with Physa montensis.

In the Southern Alps, Vicentin and Venetian districts, there is a more varied and complete series, and the succession according to von Hawer, but slightly modified by more recent researches, is as follows:

Ba. $\left\{\begin{array}{l}\text { Fine-grained sandstone or " macigno." } \\ \text { Limestone with Cerithium diaboli. } \\ \text { Voleanic tuffs of Ronca. }\end{array}\right.$

Limestones with Num. complanatus and $N$. perforatus.

Lu. $\{$ Limestones with Alveolina, and fish beds of Bolca.

Limestones with $\mathrm{Num}$. ataicus and Lithothannium.

Limestones with flints, Brachiopods, and Nummulites.

Li. Cosina Beds with Mclania and Chara and leaves of Dryandra and Banksia.

Miliolina limestone, with Cerithium and Anomia.

The letters to the brackets stand for Liburnian, Lutétian, and Bartonian, the Liburnian being apparently conformable to the underlying Cretaceous strata, and consequently representing nearly the whole of the Lower Eocene.

In the Northern Apennines, according to Professor Sacco, ${ }^{17}$ the Eocene Series attains a thickness of 5500 feet. At the base is a group which he classes as Suessonian (about 300 feet), succeeded by a great thickness of sandy and marly beds with marine fossils (Lutétian), surmounted by sandstones, shales, and shaly limestones with few fossils (about 5000 feet). At the top are 300 feet of grey marls with many fossils, including $N u m$. striatus and Orbitoides radians (Bartonian).

\section{THE OLIGOCENE SERIES}

\section{A. Nomexclature and Divisions}

The name Oligocene was proposed for this series by Professor Beyrich in 1854, who showed that it contained an important 
fauna, differing considerably from that of the typical Eocene strata of England, France, and Belgium, and that it attained a considerable development in Northern Germany. The older classification arranged these beds partly in the Eocene and partly in the Miocene System, but this rendered it necessary to draw a line of separation between the two so-called systems in every area of deposition, and in the midst of a perfectly continuous series. The difficulty of making this separation, and the close connection of the faunas of the groups which were formerly called "Upper Eocene" and "Lower Miocene" respectively, has induced geologists to accept Beyrich's proposal to unite these groups under the name of Oligocene.

The following table shows the divisions which have been made in the Oligocene Series of England, Belgium, and France :-

\begin{tabular}{|c|c|c|c|}
\hline England. & Belgium. & France. & Strata in Paris Basin." \\
\hline $\begin{array}{l}\text { Hamstead } \\
\text { Beds. }\end{array}$ & Rupelian. & Stampian. & $\begin{array}{l}\text { Calcaire d'Etampes. } \\
\text { Sands of Ormoy and } \\
\text { Morigny, etc. }\end{array}$ \\
\hline $\begin{array}{l}\text { Bembridge } \\
\text { Beds. }\end{array}$ & $\begin{array}{l}\text { Upper } \\
\text { Tongrian. }\end{array}$ & Sannoisian. & $\begin{array}{l}\text { Calcaire de Brie. } \\
\text { Marls and Clays. } \\
\text { Upper Gypsum. }\end{array}$ \\
\hline $\begin{array}{l}\text { Headon } \\
\text { Beds. }\end{array}$ & $\begin{array}{c}\text { Lower } \\
\text { Tongrian. }\end{array}$ & Ludian. & $\begin{array}{l}\text { Lower Gypsum Beds. } \\
\text { Iarine Marls of Ludes. }\end{array}$ \\
\hline
\end{tabular}

\section{B. LIFE OF the PerIoD}

The Oligocene flora does not differ in any great degree fron that of Upper Eocene time; species of Sequoia are still abundant; palms are common; leaves of cinnamons, laurels, figs, camphortrees, acacias, chestnuts, and other trees occur.

The invertebrate fauna is not large and is a direct development from the Eocene fauna, the genera being all survivors from the Eocene. Echinoderms were not abundant in our northern seas, but were common in the Mediterranean area, especially forms of the genera Echinolampas, Echinocyamus, and Colopleurus.

Of Vertebrates the Mammalia deserve special attention. A large number of new genera make their appearance in the gypsum beds of Paris, which correspond to our Headon Beds and form the Lower Oligocene of English and German geologists. Prominent 
aunong these are Palcotherium and Anoplotherium, the former allied both to tapirs and rhinoceroses, the latter an ungulate of comprehensive type, combining characters now found in the tapir, pig, and horse. There were several species of Anoplotherium, the largest being about the size of a donkey and having a long, thick, and strong tail which may have assisted him in swimming. Anchitherium, regarded as an ancestor of the horse, was no larger than a sheep, and had three hoofs on each foot. Hyopotamus (see p. 529) was a common hog-like animal, and Chreropotamus is supposed to have been a river log. Dichodon, Xiphodon, and Cœnotherium were horuless forms of antelopes, and Hycnodon one of the early car-

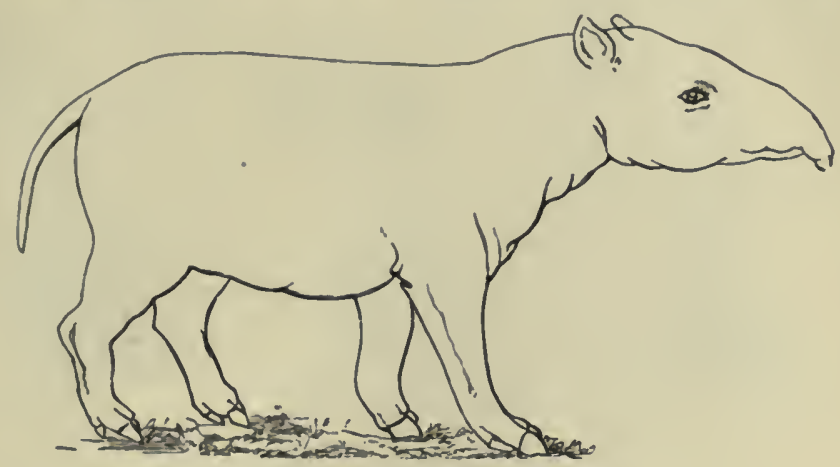

Fig. 190.-REstoration of PALAOTHERIUM Magivi.

nivores resembling the marsupial wolf of Tasmania. In Southern France the jaw of a lemur (Adapis) has been found.

In higher Oligocene deposits corresponding to our Bembridge and Hampstead Beds other genera have been discovered, such as Anthracotherium, an ungulate remarkable for its strong canine teeth, and presenting several species which vary from the size of a hog to that of a hippopotanus. This beast and species of Hyopotamus are very abundant in the higher Oligocene. Other genera now appearing are Dacrytherium, Dremotherium, Elotherium (Entelodon), all ruminants ; the small carnivore Plesictis, and toward the close of the period the genus Protapirus with Rhinoceroses. Proboscidea are represented by Palcomastodon and other genera; and the Sirenia by Halitherium.

The following are some of the fossils which are characteristic of the British Oligocene Beds, and many of them also occur in France and Belgium. Species restricted to or most abundant in one of 
the stages are given under its heading, but the following are more or less common in all three groups :-

Lamellibranchia. Corbula pisum.

Gustropoda. Potamides elegans, Tomichia Duchasteli, Bayania fasciata, Melania acuta, Melanopsis carinata, Natica labellata, Neritina concava, Viviparus lentus, V. angulosus, Planorbis obtusus, P. platystoma.

Reptilia. Trionyx incrassatus (a freshwater tortoise).

\section{Fossils of the Headon Beds and Lower Tongrians}

Actinozoa. Solenastrea cellulosa, Goniopora (=Litharea) brockenhursti, Madrepora anglica.

Lamellibranchia. In the marine beds are: Cardita deltoidea, Corbula cuspidata, Dosinia (=Cytherea) incrassata, Pecten bellicostatus, Ostrea velata, O. prora, Trinacria (=Trigonocœlia) deltoidea. In the freshwater beds are : Corbicula obovata, C. cycladiformis, Erodona (=Potamomya) plana, E. gregaria, Unio Solandri.

Gastropoda. In the marine beds are: Ancilla buccinoides, Cancellaria elongata, C. muricata, C. evulsa, Neritina aperta, N. concava, Pisania labiata, Voluta spinosa, V. geminata, V. decora. In the freshwater beds : Potamides concavus, $P$. ventricosus, $P$. vagus (=pseudocinctus), Limnæa longiscata, Melanopsis fusiformis, Stenothyra parvula, Planorbis euomphalus, P. lens, Helix occlusus.

Mammalia. Dacrytherium ovinum, Dichodon cervinns, Hyænodon minor, Palæotherium crassum.

\section{Fossils of the Osborne and Bcmbridge Beds}

Plantoe. Claara Lyelli, C. medicaginula, Flabellaria lemanonis, Cinnamomum sp.

Lamellibranchia. Corbicula semistriata, C. pulchra, C. obtusa, Ostrea vectensis, Arca Websteri.

Gastropoda. Glandina costellata, Amphidromus ellipticus, Cyclotus cinctus, Helix d'Urbani, H. pseudo-globosa, Viviparus lentus, Planorbis discus, Melania acuta, M. muricata, Potomaclis turritissima, Potamides mutabilis.

Mammalia. Anoplotherium commune, Chœropotamus gypsorum, Palæotherium magnum, P. medium, Xiphodon gracile.

\section{Fossils of the:Hamstead and Rupelian Stage}

Planta. Chara tuberculata, Andromeda reticulata, Arthrotaxis sp.

Lamellibranchia. Corbula subpisum, C. vectensis, Dosinia (Sinodia) Lyelli, Ostrea callifera, 0 . cyathula, Pectunculus obovatus, Lucina Thierense, Leda Deshayesiana.

Gastropoda. Potamides plicatus, P. elegans, Tomichia Duchasteli, Bayania fasciata, Stenothyra (=Nematura) pupa, Voluta Rathieri, Tritonium flandricum.

Mammalia. Hyopotamus bovinus, Anthracotherium minus. 

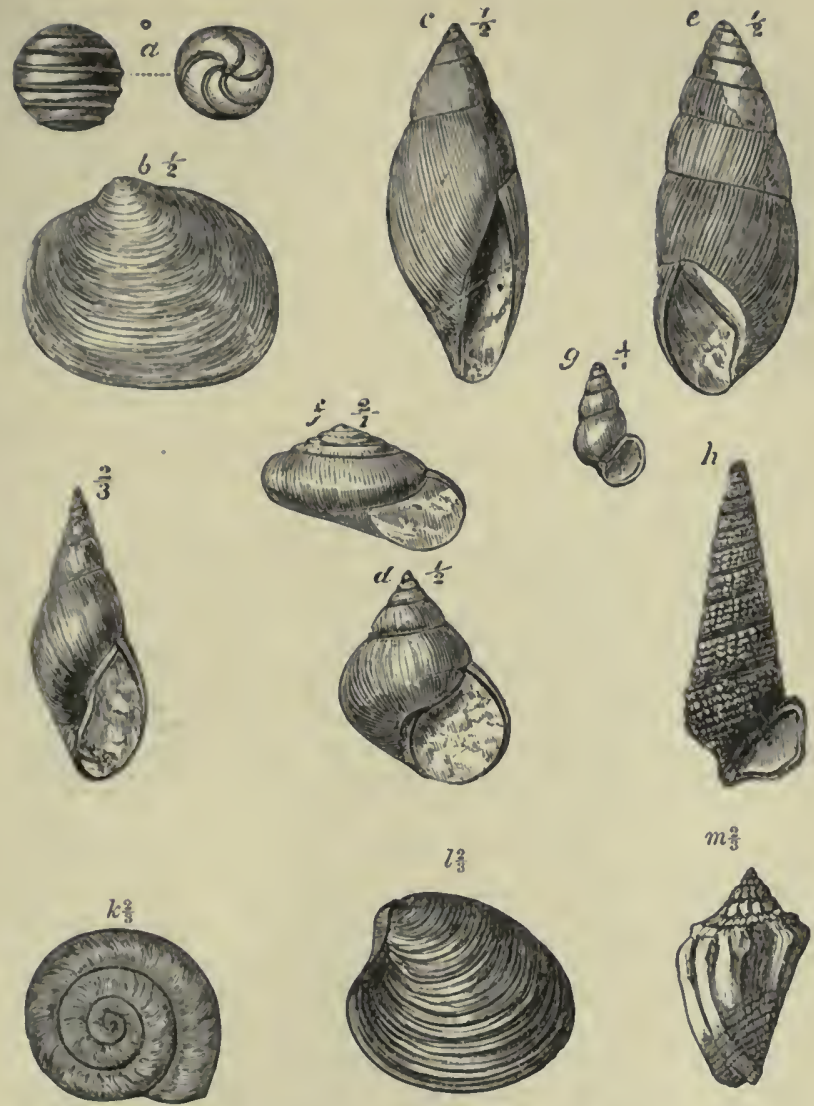

Fig. 191. - GROUP OF OLIGOCENE FOSSILS.

a. Chara medicaginula.

b. Cyrena pulchira.

c. Glandina costellata.

d. Viviparus anguiosus.

c. Amphidromus ellipticus.

f. Ilelix d'Urbani. g. Tomichia Duchastelt.

h. Potamides elegans.

i. Limnea longiscati.

$k$. Planorbis euomplialns.

l. Dosinia incrassata.

m. Voluta Rathierf.

\section{The Exalish Series}

Headon Beds.-This group is divisible into three portions, Lower, Mriddle, and Upper, the Middle portion containing marine 
and brackish-water shells, while the lower and upper are of freshwater origin. These beds underlie all the northern part of the Isle of Wight, but except at the western end their outcrop is very narrow. They are well exposed in the cliffs which extend from Headon Hill to Cliff End, and also in Whitecliff Bay at the east end of the island (see map, Fig. 172). In Hampshire they underlie a large part of the New Forest, and the Lower Headon is exposed on the coast in Hordwell Cliff. Recently they have also been found in Dorset (Isle of Purbeck). ${ }^{18}$

The section at Headon Hill may be regarded as the typical one, although the total thickness is less there than elsewhere, being only 146 feet. The succession at this place is as follows:-19

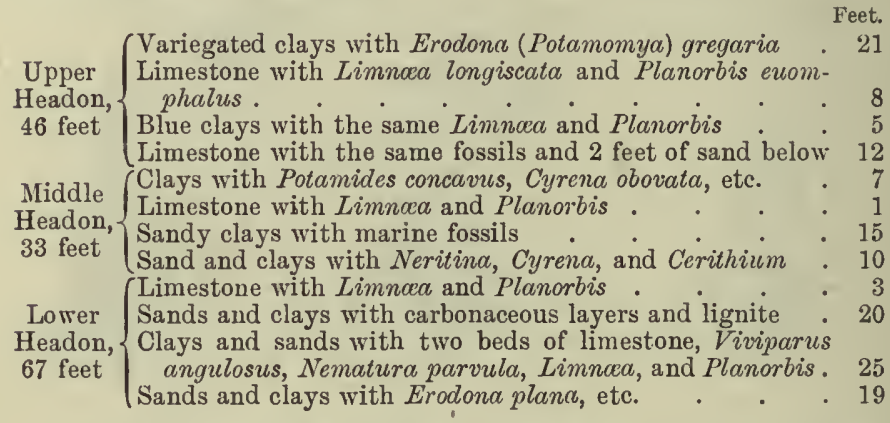

In Colwell Bay the Middle Headon contains many marine shells, such as Ostrea velata, Dosinia (Sinodia) incrassata, Corbula cuspidata, Nucula headonensis. In Whitecliff Bay the marine beds have expanded to 126 feet, and contain many of the Brocklehurst shells mentioned below, while the Lower Headon freshwater beds are reduced to 28 feet, a fact which suggests that part of these lower beds may be replaced by marine deposits.

The marine beds are found also at Brockenhurst and Lyndhurst in the New Forest, where they yield a rich fauna; 150 species of shells and corals have been found there, about half of which range up from the Barton Beds, but the fauna as a whole closely resembles that of the Tongrian in Belgium and Germany. Some of the commonest species are Rimella rimosa, Cancellaria muricata, Pisania labiata, Pleurotomaria transversaria, Voluta decora, $V$. geminata, Cardita deltoidea, Dosinia incrassata, Corbula cuspidata, with Solenastrea cellulosa and many other corals.

At Hordwell only the Lower Headon is exposed, and the beds are freshwater with a thickness of 83 feet. ${ }^{20}$ Many reptilian and mammalian remains have been found at this locality. 
Bembridge Group. - The lower beds of this group were seprated by Professor. Forlhes in 1833, under the name of the St. Helens Beds, afterwards changed to "Osborne Beds." In the Memoirs of the Geologicul Survey they are described as a separate groulp, bnt as the fossils they contain are not distinctive, and are all of freshwater species, they are certainly not entitled to rank as a stage. Professor Jndd and Mr. H. Keeping group them with the overlying Benbridge Beds under the name of Lower Bembridge marls, ${ }^{21}$ and if this is adopted the Bembridge Gromp will consist of three niembers, as below:-

Hamstead

3. Upper marls . . . . . 75

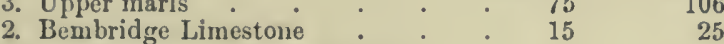

1. Lower marls or Osborne Beds . $\quad 74 \quad 80$

$164 \quad \overline{211}$

The Lower or Osborne Marls at Headon Hill and Colwell Bay consist of white, blue, and red marls with calcareous concretions which contain Limnaa longiscata, Planorbis discus, Viviparus lentus, and other freshwater shells. At Whitecliff Bay they consist of dark-green clays and sands, but are much concealed by landslips, and the best sections occur along the north-eastern coast from Osborne to Nettlestone Point; here, however, they assume a very different facies, the lower 20 feet consisting of marls, with bands of hard yellowish sandy ragstone and shell limestone full of Viviparus lentus and Melania excavata, the upper 50 feet consisting of green and yellow sands alternating with marls and clays, containing Melania excavata, Planorbis obtusus, Limncea longiscata, and Cyrence.

The Bembridge Limestone is a cream-coloured stone with interstratified marls; sometimes it is compact, sometimes quite tufaceous and concretionary; it is quarried at Headon Hill, at Sconce near Cliff End, and at Binstead near Ryde, and it is also exposed at Bembridge Point and in Whitecliff Bay. Its contents are terrestrial and freshwater, many species of Helix, Amphidromus, Achatina, Glaudina, Cyclotus, Clausilia, Limnea, Planorbis, and Viviparus occurring, with oviform bodies which are snpposed to be the eggs of the large Amphidromus; stems and seeds of Chara are common, and mammalian remains are found in the Binstead quarries.

The Upper Bembridge Marls extend from the river Yar to Bembridge and Foreland Point, and occupy some space round Osborne, Ryde, and St. Helens. At Hamstead they consist entirely of freshwater beds, chiefly blue and green clays containing Viviparus lentus, Melunia acuta, Potamaclis turritissima, Melanopsis carinata, Cyrena semistriata, and C. pulchra. 
In Whitecliff Bay there is a marine bed near the base of these marls containing Ostrea vectensis, Dosinia incrassata, Nucula similis, and Mytilus affinis. About 50 feet up is a grey sandy limestone (4 feet thick) containing Amphidromus and Glandina, and the highest beds contain Potamaclis turritissima in abundance.

The recent discovery of the Bembridge Limestone and Osborne Marls on Creechbarrow Hill in Dorset is important as showing that the Oligocene Series extended some distance westward, and that the Bembridge lake must have been a fairly large one.

The Hamstead Beds cover a large area extending from Yarmouth and Hamstead through Parkhurst Forest and across the Medina River to Brading Harbour. Throughout this tract they maintain a thickness of over 200 feet, and their base is everywhere marked by a band of carbonaceous clay. At Hamstead the succession is given by Mr. Reid as follows :-

Marine Beds with Corbula vectensis, C. pisum, Ostrea callifera,

Voluta Rathieri, Potamides plicatus, $P$. elegans . - .
Leaf and Seed Beds.-Red and green clays with carbonaceous layers

containing leaves of palms and water-lilies and seeds . 153

White Band.-Green clay with white shelly marls .

Nematura Beds. - Green and black clays with Stenothyra $(=\dot{N e m a}$ -

tura) pupa, Assiminea conica, Spharium Bristovi, Hydrobia

(Tomichia) Duchasteli

Black Band.-Black clay with Viviparus lenta and Unio

Feet.

The "white band" is only traceable as far as Parkhurst Forest, but east of the Medina it appears to be represented by a bed of fine sand which, commencing near Newport, thickens eastward till it is about 40 feet and forms a marked feature on the surface.

\section{Continental Representatives}

As in the case of the Eocene Series, the Oligocene deposits which are found in Belgium and Northern France can be correlated without much difficulty with those of our own country, but those of France include some beds which appear to be higher and newer than any which occur in England or Belgium. Again, in the central part of France there are lacustrine deposits of great thickness containing many fossils of great interest and associated with volcanic phenomena.

\section{Belgium}

The Oligocene occupies a large area in Belgium, and though the beds differ considerably in lithological character from those of the 
Hampshire basin, the general succession corresponds very closely with that of our comntry. Belgian geologists have divided them into two stages: (1) the Tongrian, from Tongres near Limbourg, and (2) the hupelian, from the river Rupel sonth of Antwerp, on which is situate the town of Boom.

Tongrian.-There is in most parts of Belgiunı a break between the Tongrian and the Eocene Series, the Oligocene having a layer of quartz-pebbles at the base which rests indifferently on various members of the lower series. ${ }^{22}$ It is divisible into two parts, a Lower and an Upper Tongrian. The Lower Tongrian is of small thickness, from 20 to 60 feet only, and consists of fine sands and sandy clays with Ostrea ventilabrum ( $=$ O. prona, Wood), Astarte Omaliusi, Cardium porolosum, Dosinia incrassata, Pecten bellicostaius, Voluta decora, Clavella longava, Cancellaria evulsa,a marine fauna which closely resembles that of Brocklehurst (Middle Headou).

The Upper Tongrian is an estuarine or fluvio-marine group, equivalent to the Bembridge Beds, and comprises three members, as below, but the total thickness is only 20 to 30 feet.

3. Sands of Vieux Joncs with Potamides plicatus and P. elegans.

2. Green clays of Hénis with Dosinia incrassata and Mfya angustata.

1. Sands of Bauterem with Cyrena semistriata, Cerithium Lamarcki, Melania muricata, Bithinia helicella, and B. plicata.

Rupelian. - This is a purely marine formation, and appears to be the equivalent of our Hamstead Beds. It conmences with the sands of Berg, characterised by the abmindance of Pectunculus obovatus, with Voluta Rathieri, Cominella Gossardi, Iritonium flandricum, and locally it includes a band of clay with Nucula compta.

The Upper Rupelian consists of a thick mass of sandy clay, the Argile de Boom, which contains many fossils, solne of the more insportant being Voluta Rathieri, Fusus elongatus, Triton flardricum, Corbula pisum, and Leda deshayesiana; it has also yielded many remains of vertebrates, including two Sirenians (Halitherium), several birds, turtles, and a number of fish, chiefly Elasinobranch (Lamna, Odontaspis, Oxyrhina, Carcharodon).

\section{Germany}

Since the name Oligocene is based upon the deposits of this age found in the north of Germany they really form the type of the series, but although they occupy a large area in that country they are to a great extent concealed beneath Miocene and newer deposits. Here and there, however, the Oligocene Beds are 
exposed at the surface, as at Latdorf near Bernberg, Egelu near Magdeburg, at Neu Brandenburg, and other places. They are the oldest Tertiary deposits in Germany, and the lowest beds are the sandy clays of Latdorf and Egeln, which contain Ostrec ventilabrum and the other fossils of the Lower Tongrian of Belgium, but the equivalents of the Upper Tongrian are not yet known at those places.

On the Prussian coast, near Königsburg, are other deposits of Tongrian age, the lowest being sands with 0 . ventilabrum and a bed containing pieces of amber, which is the resin of Pinus succinifera and other conifers. This amber encloses an immense number of insects and arachnids (about 2000 species), with leaves of Pinus, Sequoia, and other coniferi-Quercus, Acer, Castanea, Magnolia, Cinnamomum, Palms, and other trees. The overlying beds are sands with layers of lignite.

Above the Tongrian is the Septarian Clay or Rupelian, which contains the same fossils as that of Belgium, and was clearly formed in a continuation of the same sea. It reaches a thickness of nearly 500 feet, but passes eastward into the Stettin sands.

To the south-west around Mayence on the Rhine is a small basin of Oligocene deposits which must have been formed in a gulf of the Northern Sea. The lower beds are similar to those of Germany and Belgium, but the Septaria Clay passes up into marl and sand with Cyreno, semistriata and Potamides plicatus, above which are other sandy beds with P. plicatus, Mytilus Faujasi, and other brackish-water fossils, with some land-shells (Helix, etc.).

\section{Switzerland}

The northern part of Switzerland was also occupied by a sea during Oligocene time which seems to have been connected both with the Southern Sea and with the Gulf of Mayence. The area occupied by Oligocene and Miocene deposits is that of the great lakes between the Alps and the Jura, from Geneva to the Chiem See in Bavaria, a distance of 300 miles. The deposits are like those of Mayence but are much thicker, the upper or Rupelian part alone having a thickness of nearly 1000 feet and presenting the following succession:-

Freshwater beds with Helix Ramondi and Planorbis declivis $\left.\begin{array}{l}\text { Marls with Cyrena semistriata and Ostrea cyathula } \\ \text { Sandstone with Potamides plicatus and plants . . }\end{array}\right\}$ Septaria Clay (few fossils except Foraminifera) . . . . . $\quad$. 600 Sand with Ostrea longirostris, P'ectunculus obovatus, Cyrena semistriata, Potamides trochlearis, etc.

Feet. 60 300 
Sonthwarl toward the Alps these beds pass into a great inass of shales, sandstones, and conglomerates which are called Molasse by the Swiss geologists and Flysch by the Germans and Austrians. Of these sundy deposits about 5000 feet belong to the Oligocene, and the lower part of them is probably of Tongrian age, but they contaun very few fossils.

"Nothing," says Jukes, "is more calculated to strike the geological traveller on his first visit to Switzerland than the vast deposit of the 'Molasse,' occupying the central region between the Alps and the Jura. This is the country of the great lakes, extending from that of Geneva to that of Constance. The hills by which these lakes are environed have all the rugged and broken character of inountains, and rise in peaks of various altitudes up to that of 6050 feet, which is the height of Rhigi Kulu. These hills, which, if they were not overshadowed by the still loftier Alps, wonld themselves be celebrated mountains, are composed from top to botton of beds of sand and gravel, occasionally compacted into sandstones and conglomerate."

\section{The Puris Basin}

Ludian.-French geologists are not agreed as to the precise line of division between the Eocene and Oligocene Series, the fact being that there is a gradual transition from one to the other, ${ }^{23}$ but it is generally conceded that the Lower Gypsum beds of Montmartre may be correlated with the Headon Beds of Hampshire, and it is convenient to retain the name Ludian (from Ludes, near Rheims) as a designation for these beds. Near Paris they conprise three beds of gypsum, separated by beds of yellow marl which contain a few marine fossils, but in the eastern part of the basin the marls predominate and are more fossiliferous, containing Pholadomya ludensis, Curdium granulosum, Psammobia neglecta, Potamides concavus, etc. The total thickness varies from 60 to 120 feet.

Sannoisian.-This includes the highest bed of gypsum, which is 65 feet thick at Montmartre and has yielded the bones of fifty different species of mammals, inchuding Palcotherium magnum, P. medium, Anoplotherium commune, and Xiphodon gracile. This mass of gypsum may be regarded as contemporaneous with the Lower Benbridge or Osborne Beds and the Bembridge Linestone. Above are a set of marls known as the Supra-gypseous Beds; the lowest are white and blue narls with a few freshwater fossils, overlain by green marls containing Cyrena semistriata, Dosinia incrassata, Psammobia plana, Potamides plicatus, etc. Above there is another lacustrine deposit, the Calcaire de Brie, consisting 
of white marls with beds of siliceous limestone which have been used for making millstones (meulieres); total thickness about 100 feet.

Stampian.-This part of the series consists chiefly of sands which were formerly kuown as the "Sables de Fontainebleau," but being more fossiliferous near Etampes to the south of Paris are now named after that village. The lowest bed is a marl containing marine fossils, Ostrea cyathula, 0 . longirostris, and Corbula subpisum. The overlying sands of Morigny and of Ormoy yield many fossils, including Pectunculus obovatus, Lucina Thierensi, Voluta Rathieri, Tritonium flandricum, and Potamides plicatus, a fauna which correlates them with the Rupelian of Belgium. At the top is a lacustrine limestone with Helix Ramondi and Cyclostoma antiquum, formerly known as the "Calcaire de la Beauce inferieur," but now termed the Calcaire d'Etampes. The thickness of the Stampian Group near Paris is about 250 feet.

\section{Central France}

Extensive lakes were also formed in Central France during the Sannoisian epoch, and continued to exist through the Rupelian (or Stampian) and the greater part of Miocene time, leaving their records in the lacustriue deposits of the Auvergne, Cantal, and Velay. French geologists believe that there were three separate lakes, the largest and most northern occupying the valley plain of the Allier known as the Limagne d'Auvergne, the second being in Velay, and the third in the Cantal ; but the latter is now for the most part buried below the volcanic mass of that district. ${ }^{24}$

The deposits of the Limagne are the most complete and accessible; this plain has an average breadth of 20 miles, and its length from Nevers to Brionde is nearly 100 miles. It consists of nearly horizontal strata of sandstones, marls, and limestones, which often rise into low hills capped by fragments of ancient lava-streams. This tract is bounded both on the east and the west by lofty hills of granite and gneiss which rise to a height of 1600 feet above the plain and 3000 feet above the sea; and the western plateau supports a chain of extinct volcanoes from which in Miocene and Pliocene times lava-streams flowed into the valley below. The succession of the Oligocene portion of these deposits is as follows (see Fig. 194):-

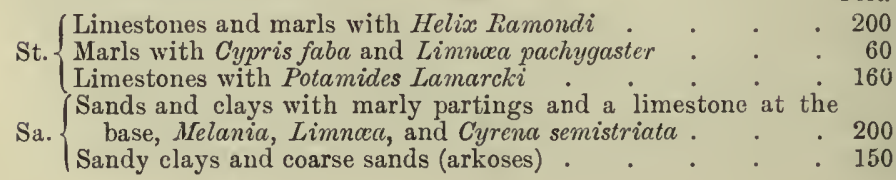


From the Sannoisian of the Velay bones of Palcotherium, Paloplotherium, and Entelodon lave been obtained.

\section{Italy and Dalmatia}

Parts of Southern Europe were covered by a more open sea than that of the northern region; it was, in fact, the Eocene Sea, shallowed and made less extensive by a slow movement of upheával. Oligocene deposits reach a great thickness in Northern Italy, being found in Liguria, around Turin, in the Vicentin, and along the range of the Apennines, and they have been classified by Professor Sacco in the following manner :- 25

Stampian. Grey sandy marls with few fossils

Feet.

Tongrian $\left\{\begin{array}{l}\text { Sandy marls and sands with beds of conglomerate, } \\ \text { Nummulice Fichteli, } N \text {. intcrmedius, Natica crassa- } \\ \text { tina, Cyrena semistriata, and bones of Anthraco- } \\ \text { therium. }\end{array}\right.$

Sestian. Sandy marls with Num. Fichteli, Num. vascus, etc. .

2000

The lowest beds are conformable to the highest of the Eocene, and the Stampian inarls are succeeded by the Miocene.

\section{GEOGRAPHY AND SEDIMENTATION}

We have seen (pp. 524 and 535) that the Cretaceous period closed with a general uplift of the whole European region, so that for a long time sedimentation was restricted to a few bays or gulfs, soine dependent on the Southern Sea, and one reaching in from the far north to Belgium and the Paris basin.

There is some reason for thinking that the Atlantic Ocean began to assume its present form in Eocene time, or at any rate that its eastern trough between Europe and the medial sub-oceanic ridge, from which the Azores rise as mountain-summits, cane into existence at this epoch; and that the depression of this trough was correlative with the nplift of the Western Franco-British region, which was acconr panied by such wonderful volcanic eruptions.

After these early changes, however, a slow subsidence ensued, and the seas gradually spread their waters over larger spaces till about the middle of the Eocene period, or in Lutétian time, these seas had acquired their greatest extension. There was still land over the greater part of France, Germany, Poland, Russia, and Scandinavia, but there was a large southern sea covering the Mediterranean area, together with the most northern parts of Africa, and stretching eastward through Asia Minor and Syria far into Asia 
The northern border of this sea passed through Switzerland, the south of Bavaria, Austria, and Southern Russia.

Westward this Nummulitic Sea passed by two channels into the western ocean, which occupied the Central Atlantic area; one of these channels lying through the south of Spain and Morocco, the other through the north of Spain, the Pyrenees, and Aquitaine, leaving Portugal and Central Spain to form a large island.

Moreover, the Atlantic Sea reached northward as far as the latitude of Cornwall, and a narrow channel of communication was established between it and the Northern Sea along the line of the English Channel. The proofs of this are found in a small outlier of Lutétian limestone lying directly on the Chalk near Orglandes in the Cotentin, in the fact of Lutétian fossils being sometimes washed up on the shore at St. Malo, and in a block of Miliolina limestone dredged up from the floor of the Channel 39 miles south of the Eddystone Rock. ${ }^{26}$

This early English Channel, however, did not remain open very long, for its closure may be inferred from the great contrast between the faunas of the Bracklesham and the Barton Beds. The Bracklesham or Lutétian fauna has a semi-tropical aspect, and a large number of species are restricted to it, while the Bartonian fauna has a greater resemblance to that of the London Clay, the southern types having become extinct.

The movement which cut off the connection between the Western and Northern Seas seems to have been an uplift of the whole western area, for the Aquitanian channel was also closed and the eastern end of the Aquitanian basin converted into an area of marshes and lagoons. Farther east, however, in the Alpine region and in Northern Italy, the sea seems to have maintained its position.

With the commencement of Oligocene time a further change took place, consisting principally in the subsidence of Germany, Poland, and Central Russia, thus opening up communication between the Anglo-Gallic Sea and the Asiatic Sea above mentioned, so that many of the same species of shells occur both in Belgium and near Simbirsk in Russia, such as Voluta suturalis, Ostrea flabella, and Astarte Bosqueti. Various minor changes also took place, the sea penetrating into the Central European land by several channels and inlets, in which a variable series of marine, brackish, and freshwater deposits were laid down, while in France some alteration of the drainage system led to the formation of several large lakes.

It seems to have been about the beginning of Oligocene time that certain important physical changes took place in the British 
region. During the Eocene perioxl all the north-western part of our region formed a tract of high platenu-land on which a remarkable series of voleanic eruptions took place, as briefly described on pp. 544 et seq. The sonthern part of this western platean is believed to have drained eastward or south-eastward across England, but after the cessation of volcanic activity crust-movements occurred, which resulted in the elevation of the Pennine range and the dome of the Lake District. Dr. Marr ${ }^{27}$ has shown that the final uplifts of both of these areas took place in Tertiary times, and I have given reasons for assigning the date to late Eocene or early Oligocene time. ${ }^{28}$

It is probable that these uplifts were correlative with the subsidences which formed the trough of the Hebridean Sea west of Scotland, and that of the Irish Channel between Ireland and Wales; these depressions then becoming broad valleys which drained southward, and thus formed new features in the geography of the British region. Moreover, the Pennine uplift was probably continued southwarl down the centre of England, forming a watershed which threw oft streains to the east and the west, and thus initiating the valleys of the Severn and the Thames.

Recurring now to the area in which the varied strecession of Eocene and Oligocene deposits took place, some remarks may be made on the source of the materials of which they consist. Of course, the sands and clays were carried down by the rivers which drained into the seas from the surrounding land, and the marine limestones are mainly of organic origin. Two kinds of sediment, however, are especially conspicuous; the one being clays of white, green, or variegated red and white tints, the other consisting of pale-coloured foraminiferal limestones.

The clays occur on many horizons, and are generally of a plastic nature; in England they are found in the Reading Beds, in the Bagshot sands, in the Bournemouth facies of the Bracklesham Beds, while in the Headon and Bembridge Beds green clays predominate, though white, red, and variegated clays are also of frequent occurrence. Similar clays occur at successive horizons in the deposits of the Paris basin.

The white clays have engaged the attention of several observers, the earliest writers attributing them to the detrition of granitic rocks and the decomposition of felspars. Mr. G. Maw, ${ }^{29}$ hovever, in 1867 dissented from this view, regarding then as more probably derived from argillaceous chalks; Dr. A. Irving ${ }^{30}$ also attributed the Bagshot pipeclays to the "decomposition of chalk and the leaching out of the iron by the action of peaty acids."

There are, however, strong objections to both these views; to 
the first because the white clays occur at a considerable distance from the nearest areas of granite. It is true that there may have been granite masses not far south of the Isle of Wight, as Mr. O. Fisher has pointed out, and there may have been others between Normandy and Devonshire; still none of them are likely to have been large enough to provide so much pure argillaceous material. Again, with respect to the Chalk, the Eocene deposits. rest nearly everywhere on Upper Chalk, which contains a very small percentage of clay. The Chalk-marl could have supplied a larger amount, but the contemporaneous outcrops must also have been some distance from the areas in which the Eocene Clays were being deposited, and a very large mass of Chalk-inarl would be required to furnish the extensive beds of white clay that seem to. have been formed. Nuch of the insoluble residue obtained from marly chalks is colloid silica, and the amount of alumina is generally small, the amount of argillaceous matter varying from 6 to 20 per cent, and much of this is glanconite, not clay.

Lastly, there seems no good reason for supposing that the white clays had a different source from the variegated clays of the Reading Beds or of the Oligocene Series. So far as is known, they only differ in colour, and this, as Dr. Irving points out, may be due entirely to the leaching action of peaty acids which would operate on clay derived from any source. He has also shown that the green colouring matter of certain Eocene sands and earths is due to decomposed vegetable nıatter, while we know that variegated white and red clays are common among lacustrine deposits of many ages all over the world.

It seems probable, therefore, that these fine Tertiary Clays are merely the fine muds brought down by rivers and streains from all parts of the country which surrounded the areas of deposition, and that their colour or want of colour is the result of the chemical actions to which they were exposed during their transportation and during the process of deposition, the red tints being due to the oxidation of iron or manganese, the green to the presence of decomposed vegetation, and the white to leaching out of all colouring matter.

With respect to the other prevalent kind of deposit mentioned on p. 569, that is more easily accounted for. The foraminiferal limestones are specially characteristic of the Mediterranean area of deposition, where they constitute masses of limestone many hundred feet in thickness. The ordinary "Nummulite limestone" has a pale buff or grey matrix, composed mainly of the debris of decayed and disintegrated Nummulites, in which are embedded more perfect tests of one or more species. The genera Nummulites, 
Orbitoides (sub-genus Orthopragmina), and Operculina are the largest and most abundant forms; next to these Alveolina is perlaps the most important as a rock-builder, and in some districts the Miliolida occur in great profusion, as in the Miliolite limestone of the Paris basin, of which rock the sub-genera Triloculina and Quinqueloculina are the clief components.

\section{REFERENCES}

1 See "Geology of the London Basin," Menn. Geol. Survey, vol. iv. (1872), and "Geology of London" (1889), both by Mr. W. Whitaker ; also the smaller Guide to the Geology of London, by the same althor (7th ed.).

2 C. J. A. Meyer in Quart. Journ. Geol. Soc. vol, xxvii. p. 74.

${ }^{3}$ See "Geology of the Isle of Wight," Mem. Geol. Survey, 2nd ed. (18S9).

4. J. Gardner in Quart. Journ. Geol. Soc. vol. xxxviii. p. 1, and P'roc. Geol. Assoc. vol vi. p. 88.

B "Bagshot Beds of the London Basin," by H. W. Monckton, Quart. Journ. Geol. Soc. vol. xxxix. p. 348 (1883).

${ }^{6}$ Rev. O. Fisher in Quart. Journ. Gieol. Soc. vol. xviii. p. 65.

7 J. S. Gardner in Quart. Journ. Gieol. Soc. vol xxxv. p. 209, and Gieol. Mag. for 1879, p. 153.

8 Gardner, Kceping, and Monckton on the Upper Eoceue Beds in Quart. Journ. Geol. Soc. vol, xliv. p. 578.

9 'The Volcanoes of Great Britain, by Sir Archibald Geikie.

10 A. Harker in Gieol. Mag. Dec. 4, vol. viii. p. 506.

11 J. S. Gardner, Quart. Journ. Geol. Soc. vol. xli. p. 84.

12 J. S. Garduer, Quart. Journ. Geul. Soc. vol, xliii. p. 270.

${ }^{13}$ Geol. Survey Summary of Progress for 1900.

14 Traité de Géologie, by A. de Lapparent, 5th ed. 1906, p. 1471.

15 Prestwich on the "Correlation of the Eocene Strata in England, Belgium, and France," Quart. Journ. Geol. Soc. vol. xliv. p. 88.

${ }_{16}$ See Harris and Burrows, "The Eocene and Oligocene Beds of the Paris Basin" (Geol. Assoc. 1891), and G. Dollfus, Proc. Geol. Assoc. vol. $x x i$. p. 101.

is Sacco in Bull. Soc. Géol. France, for 1889, p. 212, and papers in Boll. Soc. Geol. Ital. 1892, 1893, 1896.

18 W. H. Huddleston, Geol. II $a y$. for 1903, p. 197, and H. Keeping, Geol. Mag. for 1910, p. 436.

19 See "Geology" of the Isle of Wight," Mem. Geol. Survey (1889), and Keeping and Tawney in Quart. Journ. Geol. Soc. vol. xxxvii. p. 85.

${ }_{20}$ See Keeping and Tawney in Quart. Jonern. Gieol. Soc. vol, xxxix. p. 566.

21 J. W. Judd, Quart. Journ. Geol. Soc. vol. xxxvi. p. 169, and E. Keeping, Gieol. Mag. for 1887, p. 48.

22 See Van der Broeck, Ann. Soc. Geol. Belge. vol. vii. p. 208 (1893).

${ }^{23}$ Harris and Burrows (op. cit.); also G. Dollfus (op. cit.).

24 T. G. Bonney, "Volcanic Region of Auvergne," Proc. ("col. Assoc. vol. xvii. p. 191 (1901), and "Livret Guide," A uvergne Geol. Congress, Paris, 1900.

${ }_{25}$ Sacco, op. cit. supra.

26 R. H. Wortl, Journ. Marine Biol. Assoc. Plymouth, 1908, p. 118.

27 J. E. Marr, Pres. Address, Geol. Soc. (1906), p. lxxxvi.

2s Building of the British Isles, 3rd ed. p. 378 (1910).

29 G. Maw, (quart. Journ. Geol. Soc. vol. xxiii. p. 387 (1S67).

30 A. Irving, Quart. Journ. Gieol. Soc. vol. xliii. p. 378 (1887). 


\section{CHAPTER XVI}

\section{NEOGENE SYSTEM}

\section{MIOCENE AND PLIOCENE SERIES}

The Newer Tertiary strata, i.e. those which are newer than the Oligocene Series, have so much in common, both as regards their mode of occurrence and the species of fossils which they contain, that they can hardly be considered to form more than one system, and even when so grouped togetlrer it is only in the south and south-east of Europe that they constitute a series of deposits comparable in thickness and extent to those of older systems.

As explained on p. 526, the name Neogene will be adopted for this system, and it will be regarded as including the three groups or series which were termed Miocene, Pliocene, and Pleistocene by Lyell. It is true that many geologists, both in this country and on the Continent, exclude the Pleistocene from the Neagene System and place it in what they call a Quaternary or Post-Tertiary System, but the only essential difference between the Neogene and the Quaternary is that the remains of man have hitherto only been found in the latter. It would, however, be rash to say that man did not exist during the later part of Pliocene time, and thus the distinction on which a Quarternary System is based must be regarded as an assumption. No hard-and-fast line can be drawn between deposits of Pliocene and Pleistocene age, and from a purely geological point of view it is more logical and correct to say that Tertiary time merges into the Recent or Historic period than to imagine that Tertiary time ended when man first appeared.

When the Miocene, Pliocene, and Pleistocene Groups were established by Lyell the percentage of living species of Mollusca in each fauna was taken as a guide and as a criterion of age, but subsequent researehes have shown that the percentages originally adopted by Lyell cannot be sustained, and that if the principle is to be retained the proportional numbers must be altered, and further, that much latitude be allowed in certain cases. It may be considered, however, that the Miocene molluscan fauna has only from ten to forty 
living species, the Pliocene from forty to ninety, and the Pleistocene from ninety to a fauna without species that are more than locally extinct, and finally to one that does not differ from that of the surromnding comntry or neighbonring sen.

Some geologists, however, prefer to take the mammalian famnas as a guicle instead of the molluscan, and to take note of the extinction of genera rather than of the introduction of new species. Agrcement on this question has not yet been reached, and there are differences of opinion as to the respective linits of the three series.

\section{THE MIOCENE SERIES}

\section{A. Nomexclature ayd Divisions}

Although Continental geologists have differed on the question of including the stage known as Aquitanian in the Oligocene or in the Miocene, the latter view is now the prevalent opinion in France. It is adopted not only by de Lapparent in the last edition of his Traité de Géologie (1906), but its propriety has been placed almost heyond doubt by Mr. G. F. Dollfus in his recent revision of the typical Aquitanian fauna. ${ }^{1}$ His examination shows that the number of species of marine Mollusca common to the Stampian and the Aquitanian of the Bordeaux district is only thirty-four, or about 10 per cent of the total; while the number of those common to the Aquitanian and the overlying Burdigalian is 164 or 55 per cent, so that the affinity of the Aquitanian fauna with that of the Miocene is five times as great as with the Oligocene. Even when compared with the still later (Helvetian) fauna of Touraine a proportion of 38 per cent is found to be common to the two.

There is also much difference of opinion with respect to the upper limit of the series, some placing both Sarmatian and Pontian in the Miocene Series, but Fuchs and others regard the Pontian Beds, which include what is known as the Pikermi fauna, as belonging to the Pliocene. In the present state of our knowledge it seems best to draw the line of division between these two groups, and to consider the Sarmatian as the highest nember of the Miocene. Thus defined, the Miocene Series is divisible into fire stages: the Aquitanian and Burdigalian liaving their typical development in the Bordeaux district, the Helvetian in Switzerland and in Touraine, the Tortonian at Tortona in Italy, the Sarnatian in Austria and Southern Russia.

The following table shows the succession of deposits which are attributed to the Miocene in each of these districts. The only representative of the series in the British Isles are the Bovey Beds in Devonshire, which were correctly referred to the Aquitanian 
by Heer in 1867 , but were supposed to be Eocene by Starkie Gardner in 1879. ${ }^{2}$ Mr. C. Reid, ${ }^{3}$ however, has recently shown that the flora is identical with that of the lignites of Wetteran near Bonn on the Rhine.

\section{B. Life of the Period}

Flora.-The Miocene flora does not differ very greatly from that of the Oligocene period, and indicates a climate of sub-tropical warnith, but that of the highest stage furnishes evidence of a certain diminution of temperature and probably of an increase of the winter's cold. It was during this period that palms ceased to be abundant in Central Europe.

The earliest Miocene flora is that of the Aquitanian, the Bovey Beds and their equivalents in Northern Germany. This flora includes an abundance of the Conifers-Sequoia, Taxodium, and Glyptostrobus, associated with palms of the genera Phanicites, Flabellaria, and Sabal, many deciduous trees, such as Quercus, 'Laurus, Vitis, Magnolia, and Liquidambar, and several ferns, Osmunda lignitum, Lastrea styriaca, and Lygodium Gaudini. A fauna of a similar character occurs in the Swiss Burdigalian.

Another well-known flora is that of the Eninghen Beds of Switzerland, from which no fewer than 475 species of plants were obtained by Professor Heer. In this assemblage palins are rare, and the commonest trees are maples, planes, poplars, and elms, with species of Cinnamon, Camphor, Vine (Vitis teutonica), Figtree, Cypress (Taxodium) and Glyptostrobus, with a few Proteacea.

Looking to the Niocene flora as a whole, Professor Heer rentarked that "increased prominence is given to the Japanese types by the abundance of camphor-trees and Glyptostrobi; to the Atlantic element by the laurels; to the American types by the numerous evergreen-oaks, maples, poplars, planes, liquidambars, Robinia, Sequoice, Taxodia, and ternate-leaved pines; and to the types of Asia Minor by the Planerce and a species of poplar (Populus mutabilis). The greatest number and the most important of the types of the Swiss Miocene flora belong, therefore, to a belt lyiug between the isothermal lines of $59^{\circ}$ and $77^{\circ} \mathrm{Fahr}$, and in this zone America is now the region which is most correspondent to the natural character of the Swiss Miocene land."

Fauna.-Among invertebrate aninials the Echinoderms are perhaps the most noteworthy, and they are conspicuous members of the marine fauna in the French, Italian, and Austrian regions; the principal genera are Clypeaster, Echinodiscus (Amphiope), Scutella, Echinolampas, Spatangus, and Arbacia.

Nearly all the narine Mollusca belong to living genera, but form 


\begin{tabular}{|c|c|c|c|c|c|}
\hline 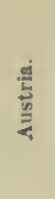 & 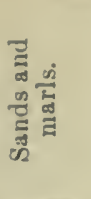 & 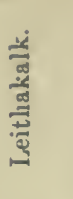 & 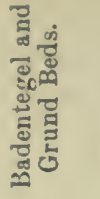 & 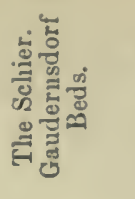 & 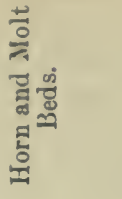 \\
\hline$\stackrel{3}{\vec{j}}$ & 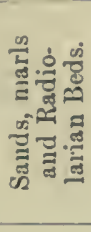 & 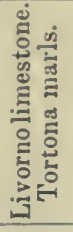 & 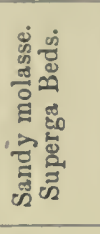 & 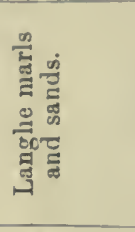 & 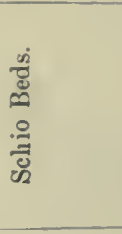 \\
\hline 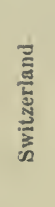 & 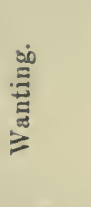 & 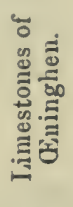 & 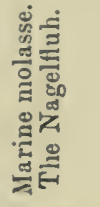 & 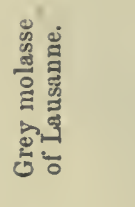 & 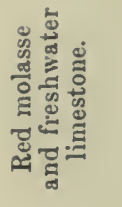 \\
\hline 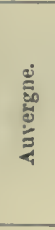 & 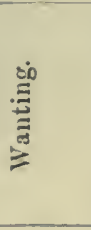 & 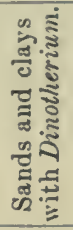 & 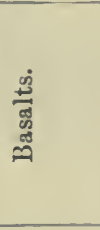 & 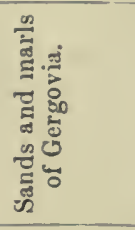 & 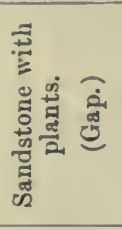 \\
\hline 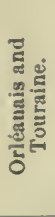 & 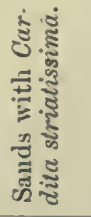 & 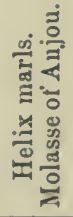 & 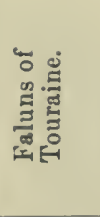 & 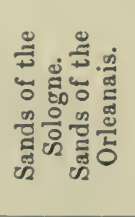 & 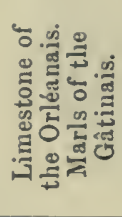 \\
\hline 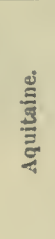 & 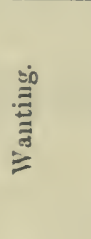 & 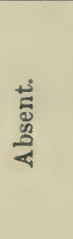 & 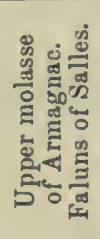 & 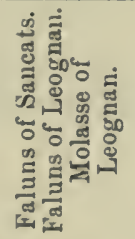 & 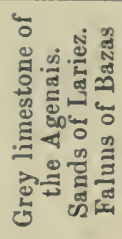 \\
\hline 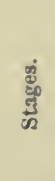 & 烝 & $\underbrace{\text { בే }}$ & $\underbrace{\text { בี }}$ & 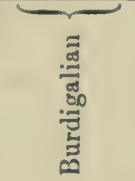 & $\underbrace{\text { క్ష }}$ \\
\hline
\end{tabular}


an assemblage wlich resembles that now found in the Carribean Sea more than that of the existing Lusitanian and Mediterranean provinces, and the same is the case with the Echinoderm fauna.

Among Lamellibranchs the prevalent genera were Arca, Lucina, Tivela (Grateloupia), Tellina, Cardita, and Ostrea. Of Gastropods

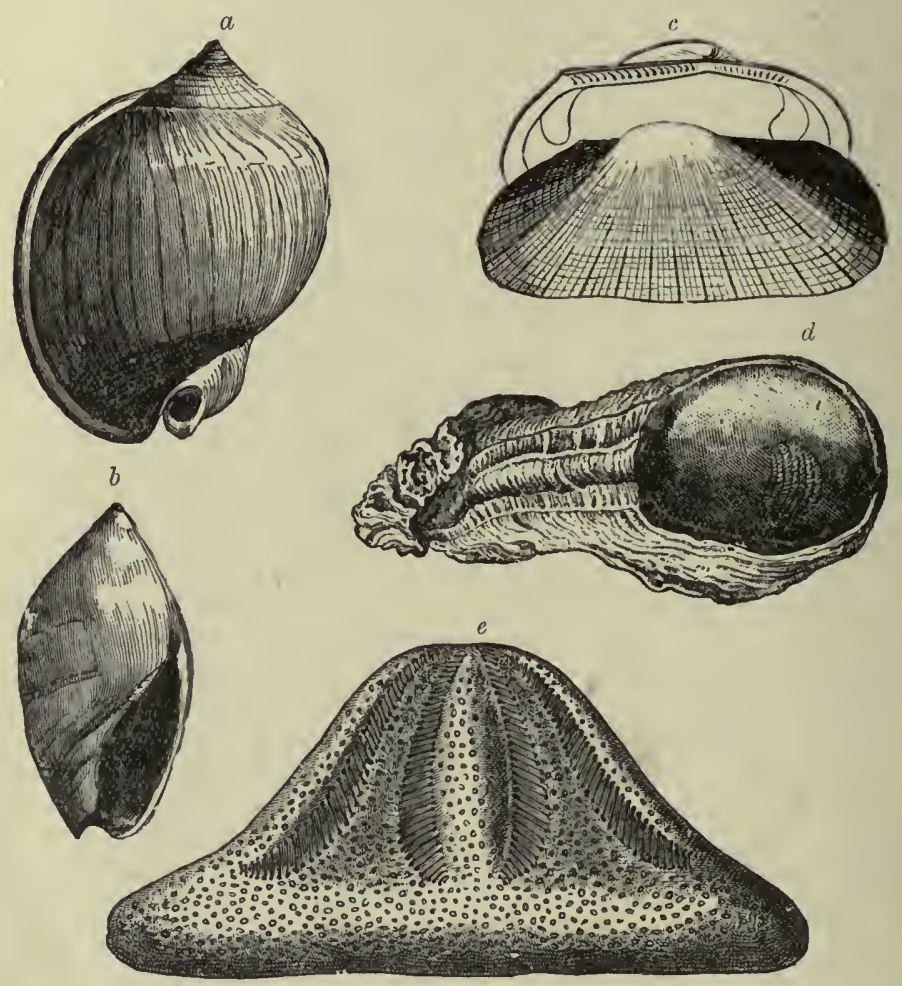

Fig. 192.-GROUP of MIOCENE Fossils (natural size).

a. Cassidea saburon.

b. Ame:la glandiformis.

mon e. Clypeaster altecostatus.

there is a most $i$ variety, the chief genera being Conus, Fusus, Melongena, fauiella, Murex, Cassidaria, Pleurotoma, Oliva, Ancilla, Turritella, Potamides, Cerithium. The only known representatives of the tetrabranchiate Cephalopoda are the generas Nautilus and Aturia; the dibranchiate order is represented by Spirulirostra. 
It is, however, the vertebrates, and especially the Mammalia, which form the most characteristic and distinctive features of the Miocene fauma. When this fauna is contrasted with that of the Oligocene the principal clianges are seen to be as follows: (1) the appearance of Proboscidea in Europe, genera Dinotherium and Mastodon; (2) the replacement of the Palaotheres and Anthracotheres by Tapirs and by true Rhinoceroses, both of the hornless (Aceratherium) and horned type (Rhinoceros); (3) the occurrence of Anchitherium, an ancestor of the horse; (4) the appearance of large cats (Mucharodus) comparable to modern panthers and tigers; (5) the appearance of monkeys and apes; (6) appearance of horned deer, Dicroceras (= Procervulus) (allied to the MIuntjac of India);

(7) the disappearance of marsupials from Europe.

The assemblage of animals was thus very different from that of Oligocene times, Aceratherium, Anthracotherium, and Amphicyon being almost the only mammals that survived from the one period to the other. The pig tribe were represented by Palcoocharus, which first appears in the highest Oligocene of the Allier, and by Hyotherium, a closely allied genus. Listriodon was another twotoed and pig-like beast. The carnivores include Machorodus (the sabre-toothed tiger), Amphicyon (a progenitor of the dogs and bears), Hycenurctos (a bear-like animal), with otters (Lutra), cats, and foxes. Beaver's made their dains across the streams; a gigantic ant-eater (Macrotherium) tore up the ant-hills with his great claws; lastly, true apes made their appearance, several forms being known (Pliopithecus, Dryopithecus), these being anthropoid apes of large size.

The Dinotherium was remarkable for laving two large tusks in the lower jaw which curve downwards and are supposed to have been used by the animal to moor himself to the banks of the lakes in which he lived while he fed upon the herbage. The Mastodon had long tusks in both jaws, and was more like an elephant in build, and probably also in habits.

\section{The MLocene in Esgl.and}

The Bovey Beds rest on Devonian and Carboniferous rocks, and occupy a basin-shaped depression between Dartmoor and the Haldon Hills, extending for about 9 miles from Pullabrook near Bovey Tracey to Kingskerswell near Newton Abbot. They consist in the lower part of thick beds of lignite and of brown clay, and in the 11 pper part of alternating beds of sand and clay, with some layers of lignite. Their total thickness has been estimated at about 600 feet, a boring at Heath field having been carried to a depth of 526 feet without reaching their base, while west of the place it is believed that higher beds come in; where the base is exposed at 
Staple Hill there is a bed of pebbles and stones overlain by some thickness of sand dipping steeply toward the east (see Fig. 193). ${ }^{4}$

The lignites are described by Pengelly and Heer as consisting mainly of Sequoia wood and the compressed fronds of Osmunda lignitum. The leaves and seeds of the following plants are also common: Nyssa, a tree now living in the southern United States; Quercus Lyelli (an evergreen oak), Cinnamomum (two species), Vitis teutonica and several other species, Palmacites (the prickly cactus), and the water plants Stratiotes Websteri and Potamogeton tenuispina.

\section{Continental Mrocene}

\section{France (Aquitaine)}

Aquitanian.-The typical Aquitanian is found in the near Bordeaux, ${ }^{5}$ and the typical marine fauna of this stage occurs in the "faluns" or calcareous shelly sands of Bazas and Lariez, some of the commoner species being Ostrea aginensis, Arca cardiiformis, Turritella Desmaresti, Protoma Basteroti, Neritina Ferussaci, Cerithium calculosum, C. fallax, Melongena Lainei, M. cornuta, Oliva clavula, and Nassa aquitanica.

These beds are overlain by a freshwater limestone containing Helix Morognesi and Planorbis Mantelli; this "calcaire gris de l'Agenais" must not be confounded with the "calcaire blane de l'Agenais," which forms the top of the Oligocene, and is characterised by Helix Ramondi and Cyclostoma antiquum (see p. 566).

Burdigalian.-The typical Burdigalian fauna is that of Leognan; some of the characteristic species are Turritella terebralis, Protoma cathedralis, Tudicla rusticula, Pecten burdigalensis, Clypeaster marginatus, and Scutella subrotunda. On the Sancats horizon Agaronia (=Oliva) Basteroti and Dorsanum baccatum are common shells.

Helvetian.-The faluns of Salles furnish another fauna in which figure Voluta (Scaphella) Lamberti, Cassidea saburon, Pecten solarium, P. scabrellus, Cardita Jouanneti, and Panopaa Menardi. Eastward these marine sands pass into a freshwater formation, the molasse of Armagnac, consisting of marls of various colours (yellow, green, and red), limestones and calcareous sandstones, the wliole said to be 1000 feet thick. The lower beds yield bones of Mastodon angustidens, Rhinoceros sansannensis, and Amphicyon major; the upper beds those of Mastodon tapiroides, Dinotherium giganteum, and Anchitherium aurelianense.

\section{Orléanais and Touraine}

Aquitanian.-The deposits of this age in the north of France are entirely of freshwater origin, and comprise the larger part of 
the formation which was formerly known as the Calcaire de la Beanee, from whieh the Calcaire d'Etampes has been separated (see p. 566). The Miocene part is now called the Calcaire de l'Orléanais, and in the Gâtina is distriet the two are divided by a band of greenish marl or elay, which is taken at the base of the Aquitanian. 'The thickness of these marls and limestones is about 100 feet, and with the Calcaire d'Etampes they overstep all the older beds both southwards and westwards so as to lie direetly on the Cretaceous and Jurassic rocks. Their eharacteristic fossils are Helix aurelianense, H. Morognesi, Limnaa pachygaster, and Planorbis solidus, with remains of Anchitherium aurelianense.

Burdigalian. - The Orléanais Limestone is overlain by an extensive deposit of granitie sands, the Sables de l'Orléanais and the Sables de la Sologne, which are divided by a band of white and green marls with Melania Escheri. The sands have been derived from the contemporaneous erosion of the Central Plateau, and outlying patehes of them extend westward to Blois and Poitiers and northward to Rouen and Havre. The thiekness of the group is about 90 feet, and the lower sands eontain remains of Mastodon angustidens and two other species, Dinotherium Cuvieri, Rhinoceros aurelianense, and Amphicyon.

Helvetian.-This does not oceur within the limits of the Paris basin, but eonsists of a number of separate traets and patehes of shelly calcareous sand around Blois, Tours, and Angers, with others to the north-west near Rennes and Dinan in Brittany. These beds' were termed Falunian by d'Orbigny from the peasant's name of falun for this kind of material, whieh resembles that known as crag in the east of England. The beds are marine, and mark an invasion of the western ocean. The most typical fauna is found near Pontlevoz and Savigné, and some of the eommoner fossils are Arca turonica, Ostrea crassissima, Pecten scabrellus, Lucina Dujardini, Trochus miocenicus, Potamides pictus, Conus (Conospira) Dujardini, and Nassa limatula.

Tortonian.-In this western area (Maine and Anjou) there is a still newer set of deposits, distinguished by the abundance of Bryozoa with fragments of Lithothamnium (a calcareous alga), many Eehinoderms of the genera Amphiope, Scutella, and Echinolampas, and the teeth of large sharks, Carcharodon and Oxyrhina.

\section{Auvergne and Velay}

Aquitanian.-Since the limestones with Helix Rumondi are now referred to the Oligocene, there is little to represent the Aquitanian in this part of France, and M. Dollfus believes that there is a gap (laeuna) or want of eontinuity in the series of laeustrine deposits. ${ }^{*}$ 

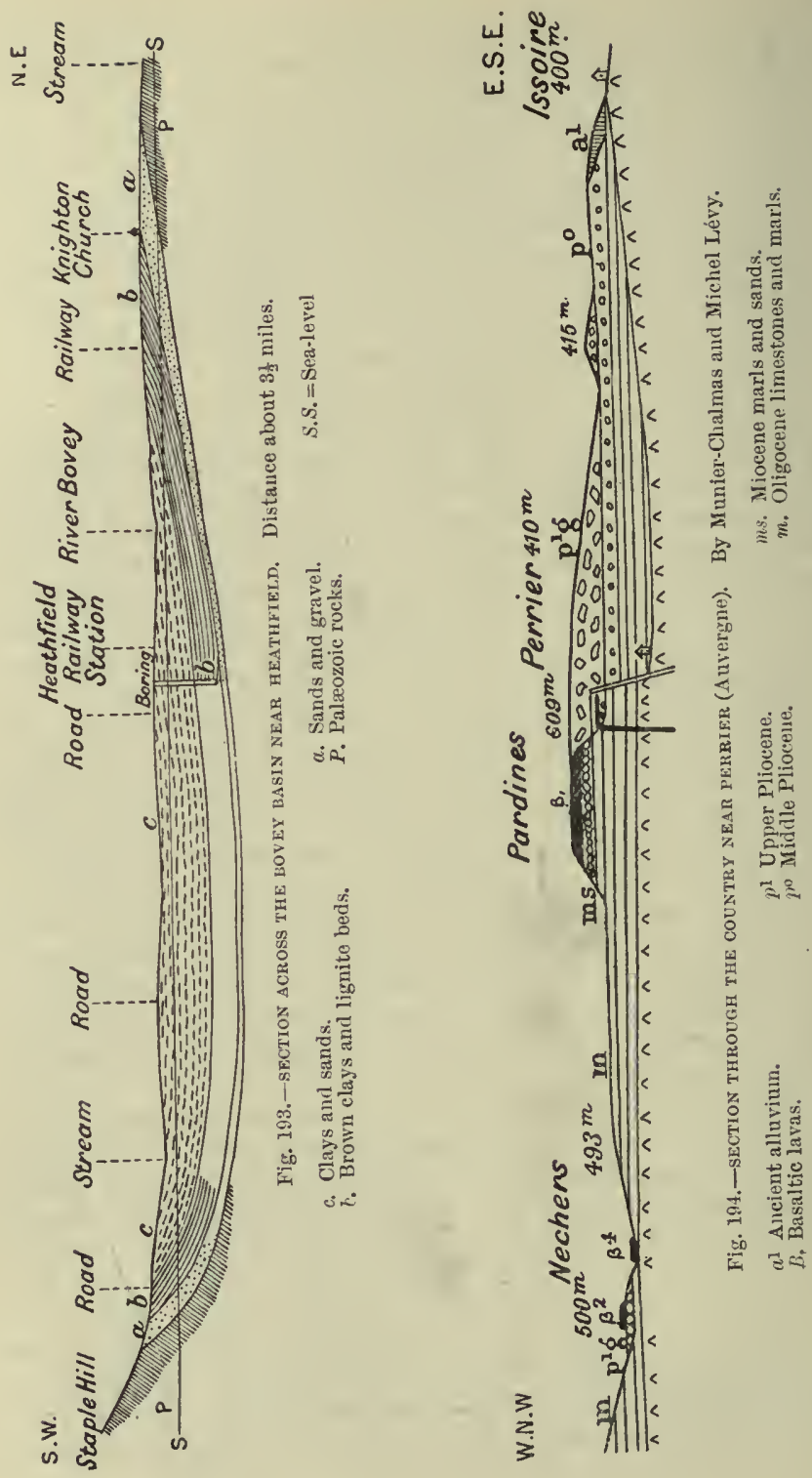
In many places the Helix limestone is directly overlain by narks with Melania Escheri, but on Gergovia hill near Mardogne there is a sundstone containing the remains of plants which seem to be an Aỵuitanian assemblage.

Burligalian. - This is represented by marls and sands containing plant remains and a few shells such as Melania Escheri, Melanopsis callosa, Cyrena and Unio. Above these beds are basaltic lava flows and thick beds of volcauic ash. ${ }^{7}$ The sands of Giveul near Moulins, which contain bones of Dinotherium, also belong to this stage.

Helvetian.-No beds of this age have yet been recognised.

Tortonian.-The deposits referable to this stage are also scanty, but beds of coarse sand and clay near Aurillac have yielded remains of Dinotherium giganteum, Hipparion gracile, and Machairodus cultridens. In the Cantal also are extensive deposits of shaly clays and lignites associated with volcanic ash and basaltic lavas which contain the same Mammalian fauna and plant-remains analogous to those of Oininghen mentioned hereafter. ${ }^{8}$

\section{Switzerland}

Aquitanian.-The only deposits in the northern plain which can be attributed to this stage (as now restricted) are the gypsiferous beds near Lausanne which overlie those containing Helix Ramondi, and in which are found other species of Helix witl Planorbis, Neritina, Potamides, and Cyrena, and bones of Anthracotherium.

- Part of the "red molasse" is probably of the same age.

Burdigalian.-Near Lausanne the above are succeeded by the "grey molasse," a set of sandstones and marls no less than 1000 feet thick, mainly of freshwater origin and containing the remains of a flora in which palms (Sabal, Phrenicites, and Flabellaria) are associated with figs, laurels, acacias, maples, cinnanon, and some Proteacere.

Helvetian.-East of Lausanne the highest fresliwater beds appear to pass into estuarine deposits with Ostrea crassissima aud Potamides lignitarum, and these are covered by the shelly marine molasse which is more fnlly developed in Freiborg and Berne. In St. Gall and Appenzell there are beds of an internediate character consisting of red marly sands witl bauds of conglomerate, the sands containing Cardita Jouanneti, Panopáa Menardi, Pectunculus pilosus, Conus ventricosus, etc. To this stage also belong a great part of the conglomerates of the Nagelfluh, which contain pebbles of varions rocks not now occurring in the Swiss Alps.

Tortonian.-The Eninghen Beds, consisting mainly of shaly linestones, occur on the northern border of the Lake of Constance, and have yielded an enormons number of plants, insects, fish, and 
reptiles. Heer described nearly 500 species of plants, and the assemblage indicates a cooler clinate than that of earlier Miocene time. It contains a mixture of generic forms which are now characteristic of widely separated countries (see ante, p. 574). Among insects wood-eating beetles are particularly abundant. With these are remains of fish and freshwater tortoises, a huge salamander (Andrias Scheuchzeri), which was taken for a human skeleton when first discovered; also bones of Dinotherium giganteum, Mastodon tapiroides, Palcomeryx eminens (a ruminant), Galecynus Eningensis (a fox having affinities with the civet cat), hares, beavers, and many small carnivores.

\section{Austria}

The Miocene has a wide exteusion in Austria, and consists there inainly of marine deposits which occupy the Vienna basin and extend thence eastward to Moravia and the Carpathian Mountains. Their thickness varies in different places, but the average may be estimated at about 1500 feet.

Aquitanian.-The lowest beds are the sands and clays of Horn and Molt containing Potamides plicatus, Pectunculus Fichteli, and Mytilus Haidingeri, which seem to represent only the higher Aquitanian.

Burdigalian.-To this stage may be referred the sands of Gaudernsdorf containing Turritella turris, T. cathedralis, and other fossils of the Léognan fauna, also the molasse of Eggensburg consisting of sand and Bryozoan limestone. Of about the same age are the gypsiferous marls known as the "Schlier" containing Pecten denudatus, Cryptodon angulatus, Solemya Doderleini, and Aturia Aturi.

Helvetian.-The Grund Beds are sandy marls which contain a fauna like that of the faumas of Touraine, and the Baden Tegel are marly clays of about the same age but containing rather a different assemblage of shells, species of Pleurotoma being more abundant, with Cardita Jouanneti, Ancilla glandiformis, Cassidea saburon, Pecten cristatus, and Corbula gibba.

Tortonian.-This seems to be represented by the Leithakalk, a limestone consisting largely of Lithothamnion and Foraminifera (Amphistegina and Triloculina), but in some beds Bryozoa are very abundant and in others Corals with many bivalve shells (Pecten latissimus, etc.), large Echinoderms (Clypeaster altecostatus, C. marginatus), and teeth of sharks (Carcharodon, etc.).

Sarmatian.-This consists mainly of sand and soft sandstone, but includes some beds of sandy limestone and marl, the whole being about 800 feet thick, but reaching 1200 feet in Galicia. 
Shells are exceedingly abuudant, but the number of species is not large, and the fama is that of an enclosed sea, with inuch cooles water than that of the older Mediterranean. The Cones, Olives, Cypreas, and Ancillas have all disappeared, and the commonest shells are species of Cerithide-Potamides pictus, Cerithium rubiginosum, Potamides disjunctus-with the bivalves Tapes gregarius, Mactra podolica, Ervilia podolica, and Cardium obsoletum The flora is similar to that of Wininghen, and the Mammalian remains include Mastodon angustidens, Anchitherium aurelianense, and Listriodon splendens.

\section{Italy}

The Miocene Series of Italy is thicker than that of Austria and unust have been found in a deeper sea, the floor of which was probably a subsiding a rea, for the beds attain a thickness of about 6500 feet.

The Aquitanian is represented by the Schio Beds of the Vicentin district, which are marls from 700 to 1000 feet thick containing the Foraminifer Lepidocyclus with Scutella subrotunda and many kinds of fish. In Liguria its equivalent probably exists in the sandy marls at the base of the so-called Laughian Group.

Burdigalian.-The typical equivalent of this is found near Langhe iu Liguria, where sandy marls with Pectens (solarium and burdigalensis) pass up into blue marls witl Aturia Aturi, Solemya

- Doderleini, and many Pteropod shells; the whole having a thickness of 2000 feet (Mayer).

Helvetian.-This stage is described as having a thickness of over 3000 feet in Liguria and as divisible into three groups, a lower consistin $\gamma$ of whitish marls full of Pteropoda (1300 feet), a middle of sandy molasse with Bryozoa and Pecten ventilabrum (650 feet), and an upper of nullipore beds with Pectens and Oysters (300 feet). The Superga Beds of Turin belong to the same stage, and contain the fauna of the Touraine falums. ${ }^{9}$

Tortonian.-Succeeding the above are abont 650 feet of blue marls with an abundant shell fauna, ricl in species of Pleurotoma and Conus with Voluta rarispina, Ancilla glandiformis, Apollon marginatus, Trochus patulus, and corals of the genera Turbinolia and Stephanophyllic. The assenblage indicates a sea that was rather warmer than the Mediterranean of the present time.

Sarmatian.-In Liguria the Tortonian is overlain by about 60 feet of marls and sands containing a limited fauna like that of the Austrian beds, Potamides pictus, Cerithium rubiginosum, Pecten cristatus, etc. In other parts of Italy, on botli sides of the Apennines, in Calabria and in Sicily, there are extensive beds of 
siliceous earths (tripoli), composed largely of Diatoms and Radiolaria, with a fauna containing some Helvetian survivals, such as Cardita Jouanneti and Pecten aduncus, nixed with the characteristic Sarmatian species of Tapes and Ervilia.

\section{Belgium and Germany}

Our survey of the European Mincene wonld not be complete without a brief notice of the Belgian and German equivalents. These are of small thickness, and comprise only two stages, the Bolderian, which probably represents the Helvetian, and the Anversian, which corresponds with the Tortonian or Sarmatian.

The Bolderian, or sands of the Bolderberg, about 30 feet thick, and contain a fairly large fauna, including Conus Dujardini, Murex Nysti, Ancilla obsoleta, Terebra Basteroti, Panopca Menardi, and Venus multilamella. They rest on the Rupelian Clay, and have at their base a pebble-bed containing blocks of septaria derived from that clay and often pierced with Pholas-borings.

The sands of Anvers (Anversian) are dark glauconitic sands about 20 feet thick, and contain layers almost entirely composed of the shells of Pectunculus pilosus; other common species are Pirula condita, Turritella subangulata, and Corbula striata.

A gulf of the Bolderian Sea seems to have extended into the north-west of Germany through Schleswig-Holstein, Mecklenburg, and Hanover, as far as the Teutoburg and Oldenburg. The deposits consist of sand at the base overlain by micaceons clay, and the commoner fossils are Terebratula grandis, Arca diluvii, Pectunculus pilosus, Isocardia cor, Pecten Janus, P. decussatus, Conus Dujardini, and C. antediluvianus.

\section{E. History of the Miocene Period}

During the course of this period a succession of uplifts and terrestrial disturbances took place by which great changes were produced in the geography of Europe. The first change, i.e. that from Oligocene to Miocene conditions, seems to have been a general uplift, causing a general retreat of the seas, both northern and southern, and raising the greater part of Northern Europe into dry land. At the same time it is clear that the elevation of this land was not great, and that its lower levels in France, Switzerland, and Germany were occupied by large lakes. The deposit formed in these lakes preserves the remains of a flora which indicates a mild semi-tropical climate, inducing a rich vegetation which supported a large nammalian famna.

These conditions seem to have continued through Burdigalian time, at any rate in Northern Europe, but in the southern region, 
and more especinlly in the south-enst, subsidence occurred which carried the sen northward through Provence into Dauphine and Savoy, through parts of Switzerland, and through Austria and Hungary to the Carpathian momtains. The history of this epoch has not yet been very clearly deciphered, and there may have been too great a desire on the part of some continental geologists to find an equivalent of each stage in every region. In other words, it is not certain whether all the stages recognised in France are represented in Switzerland and Austria ; and in some districts there are indications of a break at the base of the Helvetian stage.

Suess divided the Miocene Series of Central and Eastern Europe into two groups, which he called the first and the second "Mediterranean Stages," and he came to the conclusion that the main upheaval of the Alpine chain took place in the interval between them. Subsequent researches liave tended to confirm this view, and it is generally believed that it was at the close of the Burdigalian or the beginning of Helvetian time that the greatest orogenetic movements took place. By these movements the rocks of the Alpine ranges were bent into sharp flexures and overfolds, and whole tracts of strata were thrust northward over and along planes of dislocation. These pressures ridged up the older rocks of Switzerland and Austrin into mountains upon which rain and ruming water came into active operation, and some of the results are exhibited in the Nagelflul conglomerates of Northern Switzerland (see p. 581).

According to Suess, while the Alps were being ridged up in the manner above mentioned, "in other places, as in parts of Tuscany, Austria, Western Hungary, and Styria, great in-sinkings were formed, and in these lie leaf-bearing lignitiferous beds which are inmediately subsequent in age to the Sclilier. It is about this time that the Alpine basin of Vienna was broken in, that the Alps were separated from the Carpathians, that the eastern downbreak of the Alps with the gulf of Gratz was formed, that the way was paved for the subsequent discharge of the Danube to the east, and that the Tuscan part of the inner Apennine depression was formed or at least indicated. It is probable that most of the inner Carpathian subsidences belong to this period." It seems more likely, however, that these subsidences were of subsequent date, and led to the extension of the Helvetian Sea over these areas.

At the same time in Northern Europe the effect of these crustpressures showed itself along the old lines of Armorican and Hercynian folding, a new series of flexures was produced along these lines across the south of England and through the northeast of France, Belgium, and Germany. It was by these movements 
that the London, Hampshire, and Paris basins were formed and separated from one another, and it is specially noticeable that the sharpest flexures are along the sonthern sides of the Hampshire and London basins. The well-known monocline of the Isles of Wight and Purbeck is one of these flexures, and that of the Hog's Back ridge west of Guildford is another. The general result was to elevate the whole of Northern Europe into high ground on which no large areas of deposition seem to have existed.

After these disturbances there seems to have been a partial subsidence; the Atlantic Sea of Helvetian time invaded the west of France, and occupied not only part of the Aquitanian area but also that which is now the valley of the Loire, forming a gulf which reached as far up as Blois. The sea also passed northward by Rennes to Gahard and Dinan, so that the central aud western parts of Brittany were probably reduced to the condition of an island. The Southern Sea also spread northward through Provence and Dauphiné to the Jura, and thence round the northern side of the Alps to Austria, through parts of Bavaria to Bohemia and Poland, and eastward throngh Galicia and across the south of Russia. There must also have been some connection between the French or Swiss gulfs and the Belgian Sea, though by what route has not yet been definitely ascertained; it is certain, however, that such shells as Conus Dujardini, C. antediluvianus, and Terebra Basteroti must have come from the south.

The concluding phase of this period seems to have been produced by a general uplift of the southern region, which raised parts of the Mediterranean area into dry land and led to the formation of the shallow Sarmatian Sea, a large enclosed sea which extended from the Danubian basin through the Pontic area to the Caspian region, with a gulf that stretched southward into the Egean area. The two main basins of the Mediterranean seem also to have been occupied by shallow seas which covered parts of Italy and Sicily and reached westward to the neighbourhood of Barcelona in Spain, where sands and marls with Cerithium pictum and Mactra podolica are found, but the rest of Spain appears to have been part of the Continental area, and the westward opening of the Mediterranean into the Atlantic lay throngh Morocco.

\section{THE PLIOCENE SERIES}

\section{A. Subdivisions and Nomenclature}

In most parts of Europe the Pliocene deposits are of small thickness and of no great extent, and were mostly accumulated in 
shallow seas not far removed from the existing coist-lines of the Continent. Of such deposits gool examples exist in England and Belgium. The only areas where marine deposits of Pliocene age attain any great thickness are Holland, Italy, and the south-east of France, but there is also a large area in the south-east of Europe, where the Sarmatian Beds (see p. 573) are sueceederl by another set of deposits formed in a similar iuland sea. These Pontian Beds are only represented in Western Europe by a few isolated lacustrine and terrestrial accumulations which yield a similar mammalian fauna.

The great extent and thickuess of the Italian Series (over 2000 feet), and the abundant marine fauna which it contains at successive horizons, have caused it to be regarded as the type of the Pliocene in the south of Europe. It has been divided into three stages named after Italian localities, and those nanies have been adopted in France. In the northern region, on the other liand, names have been given to small subdivisions which have no higher stratigraphical value than zones, and are only useful in the detailed correlation of the sequence found in one area with that of another. In a former edition of this book I grouped these zones into Lower, Middle, and Upper Stages, and as these correspond very closely with the major divisions of the Mediterranean Series, the same nonenclature will be employed in the present edition.

Wiilh regard to the deposits of the eastern inland sea, there is no reason to suppose that they are older than the lowest marine Pliocene Beds of Italy, i.e. those to which the name Messinian was given by Professor Sacco; they nay therefore be included in the Lower Pliocene group or stage, and the divisions which have been made in different countries may be correlaterl as follows:-

\section{TABULAR CORRELATION OF THE PLIOCENE SERIES}

\begin{tabular}{|c|c|c|c|c|c|}
\hline Stages. & England. & $\begin{array}{l}\text { Belgium and } \\
\text { Holland. }\end{array}$ & Provence. & Italy. & $\begin{array}{l}\text { Austria and } \\
\text { Greece. }\end{array}$ \\
\hline 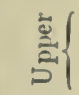 & $\begin{array}{l}\text { Cromer Beds } \\
\text { and } \\
\text { Upper Crag. }\end{array}$ & ? Absent. & $\begin{array}{c}\text { Sands } \\
\text { with Elephas } \\
\text { neridionalis }\end{array}$ & Sicilian. & Sicilian. \\
\hline$\stackrel{0}{\frac{0}{3}}\{$ & $\begin{array}{l}\text { Red Crag, } \\
\text { Walton Crag. }\end{array}$ & $\begin{array}{l}\text { Amstelian. } \\
\text { Scaldisiun. }\end{array}$ & $\begin{array}{l}\text { Sands with } \\
\text { Mastodon. }\end{array}$ & $\Lambda$ stian. & $?$ \\
\hline \{ & $\begin{array}{l}\text { Coralline Crag. } \\
\text { Lenham Beds. } \\
\text { Absent. }\end{array}$ & $\begin{array}{l}\text { Casterlian. } \\
\text { Diestian. } \\
\text { Absent. }\end{array}$ & $\begin{array}{c}\text { Congeria } \\
\text { Beds. } \\
\text { Luberon Beds. }\end{array}$ & $\begin{array}{l}\text { Plaisancian. } \\
\text { Messinian. }\end{array}$ & $\begin{array}{l}\text { Paludina } \\
\text { Beds. } \\
\text { Pontian. }\end{array}$ \\
\hline
\end{tabular}




\section{B. Life of the Period}

Plants.-The flora of the Pliocene is transitional between the luxuriant, more or less, evergreen vegetation of the Miocene period and the temperate flora of modern Europe. In Southern Europe the plant-assemblage was similar to that of Eninghen, but without palms or cactuses. Later plant-beds give evidence of a gradual refrigeration of the climate, and toward the close of the period, if we may judge from the plants of the Cromer Beds, the climate of Northern Europe cannot liave been very different from that of the present day.

Fauna.-Of the Invertebrata the majority of the species are either identical with, or merely varieties of, species now living, and the proportion of extinct species gradually diminishes from a percentage of 36 to 40 in the lowest beds to one of 10 or 11 in the highest beds. Very few of the fossils belong to extinct genera, but Congeria may be mentioned as a genus of Dreissensiidæe which is not now living.

Among the Vertebrata, however, many in the Lower Pliocene belong to extinct genera, and the majority of the species even in the higher stages are extinct. With the advent of the Pontian epoch and its southern land-connections witl Africa and Asia, a new manımalian fauna invaded the plains of Europe. This included large herds of antelopes and gazelles, varying in size and form, and for the most part allied to those of Africa. With these was an animal of intermediate form between the giraffe and antelopes (Helladotherium), allied to the short-necked giraffe or okapi recently discovered in Africa. Herds of small wild asses (Hipparion), intermediate in structure between Anchitherium and the horse, also appeared in great numbers. Numerous carnivores followed and preyed on the herbivorous animals, large cats and panthers, including Machorodus (a tiger), Hycena, Ictitherium (allied to the civet cats), Hycenictis (combining characters of cats and hyæuas), and several species of true cats (Felis). The higher Pliocene is distinguished by the appearance of elephants (Elephas), oxen (Bovid(e), true horses (Equus), bears (Ursus), and wolves (Canis lupus), and by the abundance of deer (Cervidee).

In France and Italy the Pliocene deposits are characterised by Mastodon (Tetralophodon) arvernensis, Rhinoceros (Diceros) megarhinus, R. (Colodonta) etruscus, Elephas meridionalis, Hippopotamus major, Capreolus cusanus, Elaphus perrieri, Axis pardinensis, with Machairodus cultridens, Hycena striata, bears, and wolves.

The following are some of the marine fossils which are characteristic of the several divisions of the Pliocene Series, but as the 
fuunas of the Northern and Southern Seas were somewhat different, those restricted to the southern region are indicated by an asterisk :-
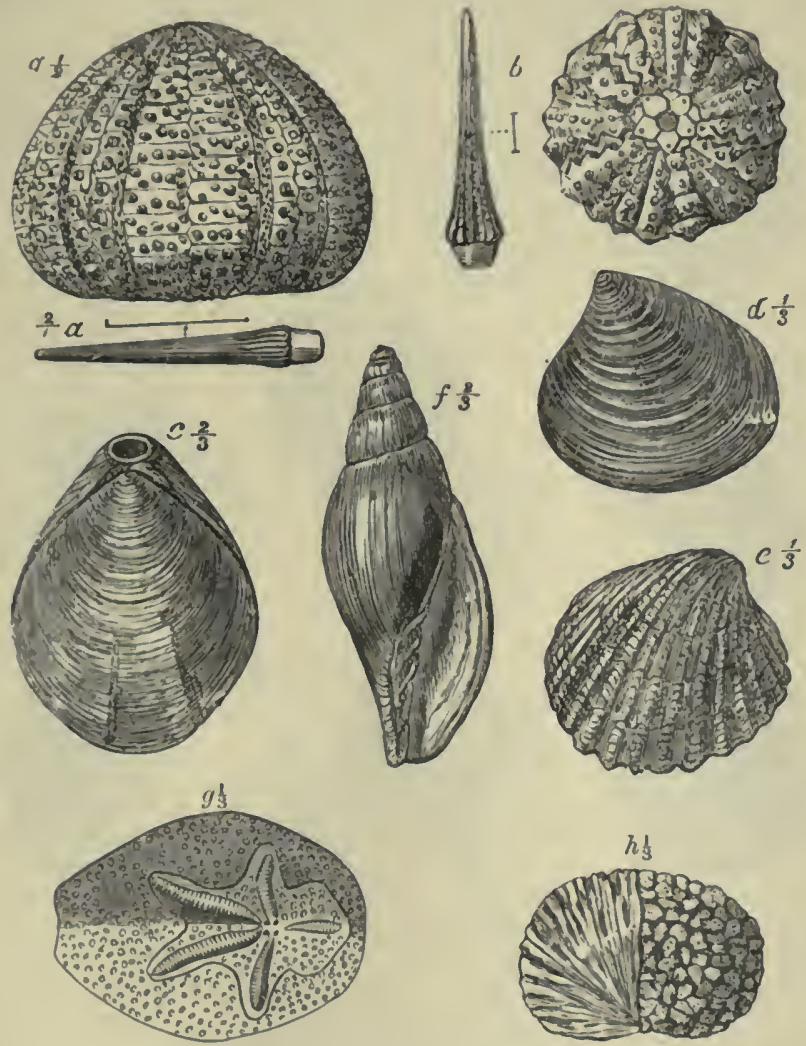

Fig. 195. GROL' OF CORALLINE URAG FOSSIL.s.

u. Echinus Woodwardi.

b. Temnechinus Woodi.

c. Cardita senilis,

f. Voluta Lamberti.

c. Terebratula grandis.

i. Astarte Omalij.

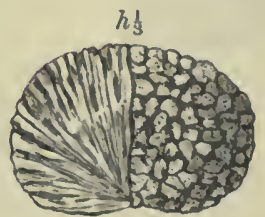

g. Brissus unicolor ( $=$ Scillip).

$h$. Fascicularia surantium.

\section{Fossils of the Lower Piiocene}

Echinodermata. Echinus Woodwardi, Tenmechinus Woodi, Brissus unicolor.

Bryozoa.

Cupularia canariensis, C. porosa, Theonoa (=Fascicularia) anrantia, Alveolaria semiovata, Salicornaria crassa. 
Brachiopoda. Terebratula spondyloides (=T. grandis).

Lamellibranchia. Arca (Anadara) diluvii, Cardium papillosum, Tellina Benedeni, Cardita senilis, Astarte mutabilis, A. Omalii, Cyprina rustica, Isocardia cor, Congeria simplex, ${ }^{*}$ C. subglobosa, ${ }^{*}$ Pecten benedictus, ${ }^{*}$ Ostrea cochlear, ${ }^{*} \mathrm{O}$. princeps.

Gastropoda. Conus (Conorbis) Dujardini, Pleurotoma (Clatliurella) consobrina, Terebra acuminata, Tritonium(Ralularia) heptagonum, Voluta (Scaphella) Lamberti, Pyrula reticulata, Fusus lamellosus, Nassa (Amyela) semistriata, ${ }^{*}$ Turritella subangulata. ${ }^{*}$
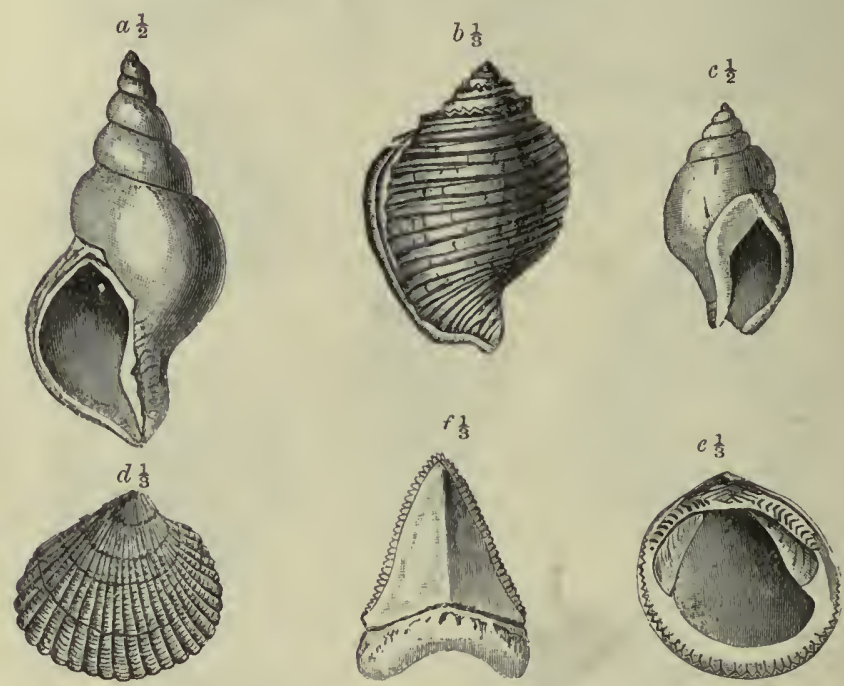

Fig. 196. - GROUP OF RED CRAG FOSSILS.

a. Neptunea contraria.

Ђ. Cassidaria bicatenata.

c. Buccinopsis Dalei. d. Cardium Parkinsoni.

e. Pectunculus glycimeris.

f. Carcharodou megalodon.

\section{Fossils of the Middle Pliocene}

Actinozoa. Balanophyllia calyculus.

Echinoderma. Echinocyamus pusillus.

Lamellibranchia. Astarte obliquata, Dosinia exoleta (lentiformis), Cardium Parkinsoni, C. angustatum, Iucina borealis, Mactra constricta, M. (Spisula) ovalis, Tellina (Macoma) obliqua, Pecten jacobæus. *

Gastropoda. Nassa (Uzita) reticosa, Neptunea contraria, N. all tiqua, N. despecta, Purpura lapillus, P. tetragona, Columbella (Anachis) sulcata, Natica hemiclausa, Scala gronlandica, Tritonofusus gracilis.

Fish teeth.

Carcharodon megalodon. 
Besides the above the following are equally common in the Coralline and Red Crags-Astarte Burtini, Mactra (Spisula) arcuata, Pecten opercularis, Pectunculus glycimeris, Venus casina, Cussidaria bicatenata, Buccinopsis Dalei, Irochus Adansoni, Turritella incrassata, Natica millepunctata, N'assa labiosa.
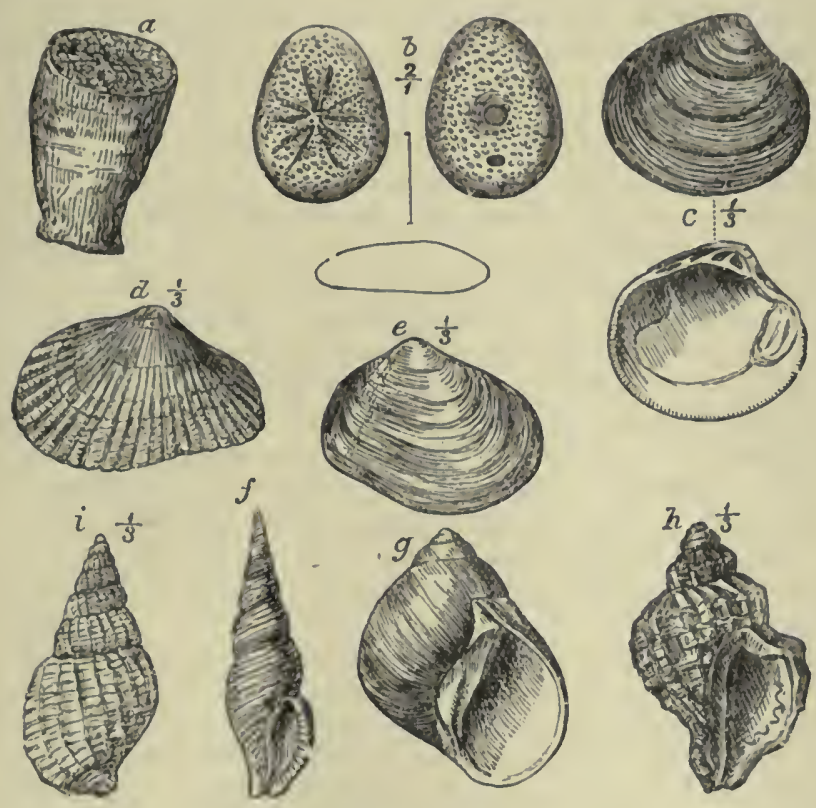

Fig. 197.-FOSSILS OF THE RED CRAO.
a. Balanophyllia calyculus.
b. Echinocyanus pusillus.
c. Astarte obliquata.
d. Cardium angustatum.

i. Nassa reticosa.

e. Mactra constricta.

f. Columbella sulcata.

g. Natica hemfclausa.

h. Purpura tetragona.

\section{Fossils of the Upper Pliocenc}

Lamellibranchia. Astarte borealis, A. compressa, Cardinm edule, Cyprina islandica, Yoldia oblongoides, Nucula Cobboldiæ, Mys truncata, Mactra (Sivisula) subtruncata, Tellina (Nacoma) calcaria, T. (Mlacoma) obliqua, T. (Macoma) pretenuis, Scrobicnlaria plana.

Gastropoda. Potamides tricintus, Buccinum gronlandicum, Melampus pyramidalis, Littorina littorea, Natica catena, Purpura lapillus, Turritella communis. 
Most of these species oceur also in the Chillesford Beds, with the addition of Cardium grcenlandicum and Yoldia lanceolata, and most of them are found in the Weybourn Crag, which latter is specially characterised by the incoming of Tellina (Macoma) balthica (=T. solidula).

The Norwich Crag has also yielded the following mammalia :Elephas antiquus, Cervus carnutorum, Equus stenonis, Trogontherium Cuvieri (an extinct beaver), Gazella anglica, Arvicola intermedius.

\section{British Pliocene Deposits}

The English Pliocene was formerly divided into two groups, a lower and an upper, it being supposed that there was a decided break between the Coralline Crag and the Red Crag, both faunally and physically; but recent researches have shown that most of the common fossils of the Coralline Crag oceur also in the more southern part of the Red Crag, while it also appears that the higher crags to the north of Aldeburgh are quite as distinct from the Red Crag as that is from the Coralline. Hence the series seems to fall naturally into three groups or stages, which may be tabulated as helow :-

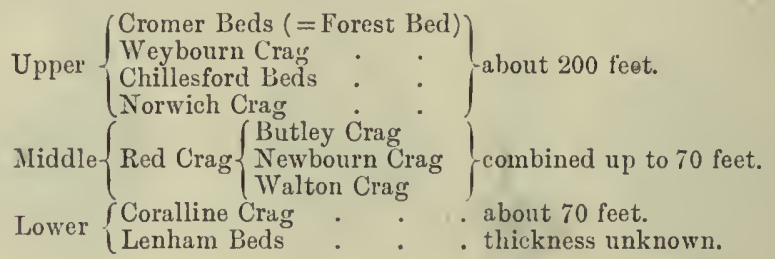

The Lenham Beds are only found in Kent, and the Coralline Crag only in Suffolk, though in Cornwall there are sands which are probably of about the same age as the latter. The newer crags occupy parts of Essex, Suffolk, and Norfolk, lying unconformably either on the London Clay or the Chalk. The only other traces of the Pliocene period in England are a deposit of sand in Dorset containing bones of Elephas meridionalis, ${ }^{10}$ and a cave in Derbyshire which has yielded bones of that and other Pliocene animals. ${ }^{11}$ In Scotland shells of Upper Pliocene species occur in the Glacial deposits of the eastern coast, and indicate a northern extension of these Crags.

Lenham Beds.-The oldest Pliocene deposits in England are certain patches of ferruginous sand which occur at intervals along the Chalk downs of Kent from the heights above Folkestone to those above Maidstone, most of them being about 600 feet above 
the sea. They were first deseribed by Professor Prestwich iu 1857, and more fully explored by Mr. C. Reid in 1886. ${ }^{13}$ The Ienhan Beds are mere remnauts of a deposit which must originally have had a wide extension, not only in Englaud but eastward through Belgium. These remunnts have been preserved becanse they have subsided into deep pipes and hollows caused by the solution of the underlying Chalk. The hollows are lined with browu clay full of unworn fliuts, and these clay walls enclose a set of sandy deposits, yellow and red sands, reddish fossiliferous sandy ironstone, and greenish aand with scattered flint pebbles.

From these beds, and chiefly from the ironstone, Mr. C. Reid obtained sixty-seven species of Molluser, and all but fifteen have been found in the Coralliue Crag, so that there cannot be unuch difference in their relative age in spite of the great difference in relative level. There are, however, some species which do not occur in the Coralline Crag, but are found in the older Pliocene or later Miocene Beds of Europe; these are Arca diluvii, Cardium papillosum, Terebra acuminata, Pleurotoma consobrina, P. Jouanneti, the first two shells being very abuudant. On the whole, therefore, the Lenham Crag is probably older than the Coralline, and Mr. F. W. Harmer thinks that it was considerably older. ${ }^{13}$

Some patches of similar and occur farther on the Surrey dowus, but no recognisable fossils have yet been found in them, and it is consequently incertain whether they are of the same age.

The nodule bed at the base of the Suffolk Crags contains many lounded lumps of tough brownish sandstone which are known as boxstones, and have evidently been derived from an older deposit. Many of these coutain fossils, and some of them are species which occur in the Coralline Crag, but two are only kuowu from the older Pliocene of the continent; these are Conus Dujardini and Volutce auris-leporis.

Coralline Crag.-This erag is only found over a small area in Suffolk between Aldelurigh and Boytou, and in three other small isolated patches at Suttou, Ramsholt, aud Tattingstone (see map, Fig. 198). It rests on an eroded surface of the London Clay, and its basement-bed (as seen at Sutton) contaius a remarkable assemblage of materials derived from older deposits, and chiefly from the London Clay; the pebbles are cliefly phosphate nodules of a dark-brown colour, but with these are fragments of septaria, a few small pebbles of quartz and fliut, aud the boxstones which have been mentioned above; there are also Crustacea and fish teetl derived from the London Clay, reptilian vertebre from the Oxford Clay, maminalian teeth of donbtfnl age, many Cetacean 


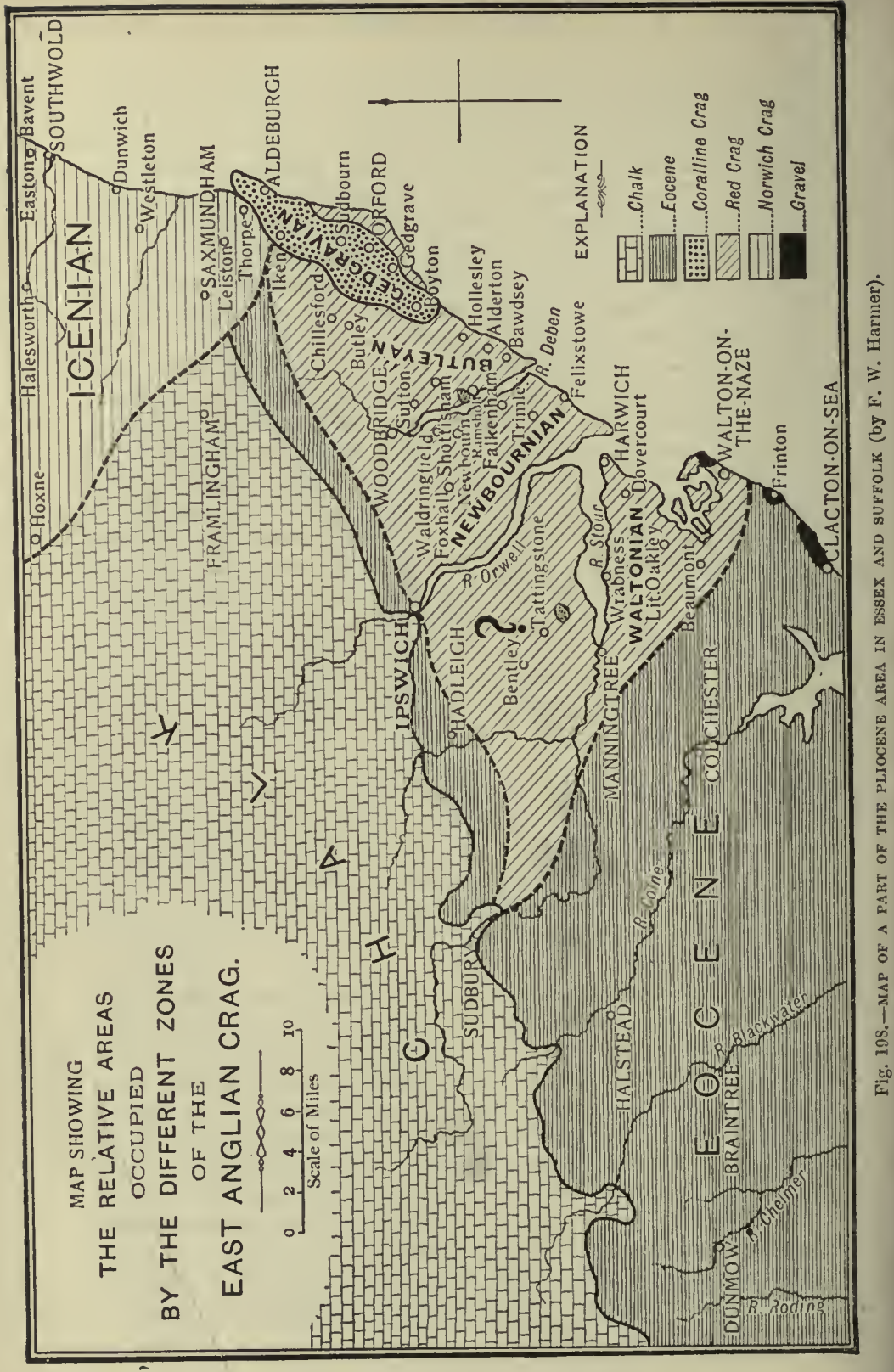


bones and teeth, and some sharks' teeth which are probably of Pliocene age, such as Odontaspis hustalis and Carcharodon Rondeleti. 1 Above the nodule bed there are yellowish marly sands and fine 4uartz sands, with layers of comminuted shells, from 30 to 40 feet thick, and these form the lower portion of the Crag; above them at Sutton, Gedgrave, and Aldeburgh come about 36 feet of a soft porous yellowish-brown calcareous rock, consisting largely of comminnted shells and fragments of Polyzoa, which are often arranged in oblique laminx, while the bedding is of that irregular kind due to the action of rapid and changeable currents. This soft limestone has probably been formed by the infiltration of carbonate of lime from the overlying Red Crag. Fossils are abundant in both portions.

The Mollusea of the Coralline Crag (if they are not drifted) indicate a sea of some depth (40-60 fathoms), with warmer water than that of the existing North Sea. According to S. V. Wood's summary in 1874 the total number of species was 391 , of which 142 were extinct, while 249 are identical with recent forms. Of these living species 205 occur in the Mediterranean, while only 1.74 occur in British seas, 50 being Mediterranean species which are not British, and 20 British species which are not Mediterranean. Wood has also pointed out " that the most abundant and therefore the most characteristic species of the Coralline Crag are southern species unknown to British seas, and that among the 154 which occur both in British and Mediterranean waters there are many which are really characteristic Mediterranean shells, and are only marked as British in consequence of some rare occurrence."

St. Erth Beds.-At St. Erth, near Hayle in Cornwall, and at an elevation of about 100 feet above the sea, there is an interesting deposit of sand and clay, the latter containing shells which prove it to be of Pliocene age. A pit near the vicarage exposed the following beds :-

Feet.

Loamy clay full of angular stones _ . . . . . . 2 to 6 Fine gravel and coarse ferruginous sand . . . 4 to 6 Clay, yellow above, blue beneath, and containing many fossils 6 Fine foundry sand, base not exposed . . . . . . ?10

The number of Mollusca which have been found in the clay is between eighty and ninety, and the grenter part of them are such as occur in the lower part of the Red Crag, but many species of a southern character are present, such as Fisus corneus, Nassa recticostata, Nassa mutabilis, Cardium papillosum, and Cardita aculeata, which do not occur in the eastern crags, while the Boreal and Arctic forms found so abundantly in the higher part of the Red Crag are absent at St. Erth. 
Mr. C. Reid has pointed out that the proportion of extinct forms, so far as the fauna has been worked out, is 41 per cent, which exactly corresponds with the proportion in the Coralline Crag; ${ }^{14}$ and in view of this and of the preponderance of southern Molluscar he concludes that the St. Erth Beds are of older Pliocene age. Mr. Robert Bell, Professor Kendall, and Mr. Harmer are, however, all opposed to this view, and consider that the St. Erth Beds correspond more nearly with the older part of the Red Crag. From the nature of the deposit, from its geographical position, and from the occurrence of beach deposits round St. Agnes Beacon up to 375 feet above the sea-level Mr. Reid infers that the fossiliferous clay was formed at a depth of 40 or 50 fathoms.

Red Crag.-Returning now to the eastern counties we cometo the deposit which is generally known as the Red Crag, this name denoting the usual reddish-brown colour of the material, which differs considerably from that of the Coralline Crag. The latter (when not decalcified) is a light-yellow ealcareous deposit consisting chiefly of organic debris with some fine sand, while the Red Crag is a ferruginous shelly sand, its unaltered portions. consisting partly of quartz-sand and partly of shells (either perfect or broken), the whole stained by a variable proportion of peroxide. of iron (from 5 to 16 per cent).

This formation covers a much larger area than the older. (Coralline) crag, and is apparently contimuous over a space of about 300 square miles in Suffolk, but is so often concealed by the sands and clays of the Glacial Series, that generally it is only on the slopes of the valleys which intersect the district that the crag actually comes to the surface. The best exposures occur in the cliff-sections of Walton-on-Naze, Felixstow, Bawdsey, and in the valleys of the rivers Orwell and Deben.

The Red Crag rests partly on the London Clay and partly on the Coralline Crag, wrapping round the isolated reefs of the latter, and filling up the hollows between them. At its base there is generally a bed of phosphatic nodules with "boxstones" and other derived pebbles, together with rolled bones and teeth of mammalia and of sharks. The manner in which the Red Crag is banked against the Coralline Crag is illustrated in the section, Fig. 199. In the pits near Sutton there is evidence of two shore-levels, an upper and a lower cliff-line. The upper cliff is about 12 feet high, the lower shore-line is about 9 feet below the upper, and these two shore-lines are traceable all ronnd the small mass of Coralline Crag which evidently formed a reef in the Red Crag Sea.

From the researches of Mr. S. V. Wood ${ }^{15}$ and MIr. F. W. Harmer ${ }^{16}$ it appears that the crag in the southern part of this area is. 
decidedly older than that in the northern part. The beds at Walton-on-Naze yield a famna that Mr. Harmer considers to be closely allied to that of the Coralline Crag, for it includes many southern species and very few of northern origin, while at Butley in the northern part of the area northern species are abundant and southem forms are comparatively rare. Thms it seems as if these Red Cragrs were deposited while the sea was gradually retreating northwarls, the slowly receding waters leaving a succession of beach and shallow-water deposits behind them. This shelly crag is seldom more than 20 feet deep at any one place, and its bedding is generally oblique, so that it may be described as consisting of a number of shelly sand-banks, eaeh composed of highly inclined laminæ, one bank often being sharply truncated by another.

Mr. Harmer lias recently divided the Red Crag into three parts on the basis of the changing proportion of northern and southern species, and these divisions may be termed the Walton Crag, the Newbourn Crag, and the Butley Crag. The relations of these crags is best expressed by the following table of percentages, in the compilation of which Mr. Harmer lias taken into account only the more abundant and characteristic species.

\begin{tabular}{|l|c|c|c|c|}
\hline & $\begin{array}{c}\text { Extinct } \\
\text { Species. }\end{array}$ & $\begin{array}{c}\text { Sonthern } \\
\text { Species. }\end{array}$ & $\begin{array}{c}\text { Northern } \\
\text { Species. }\end{array}$ & $\begin{array}{c}\text { Species of } \\
\text { Northern and } \\
\text { Southern Range. }\end{array}$ \\
\cline { 1 - 2 } Butley Crag . & 13 & 13 & 23 & 47 \\
Newbourn Crag $:$ & 32 & 16 & 11 & 36 \\
Walton Crag . & 36 & 20 & 5 & 35 \\
Coralline Crag. & 38 & 26 & 1 & 31 \\
\hline
\end{tabular}

The Walton Crag is claracterised by the abundance of Neptunea contraria, Columbella sulcata, Nassa labiosa, N. elegans, Trochus Adansoni, Buccinopsis Dalei, and Dosinia exoleta; the Newbonrn Crag by abundance of Cardium angustatum, Mactra ovalis, M. constricta, and Tellina obliqua; the Butley Crag by Neptunea antiqua, Buccinum grœnlandicum, Cardium gronlandicum, Nucula Cobboldia, Tellina obliqua, and T. prectenuis.

Norwich Crag.-This group has a more extended range than either of the older crags, since it is found more or less continuously through Eastern Snffolk from Aldeburgh to Bungay and Beceles, and thence through Norfolk to Brundall and Norwich (on the river Yare), and to Coltishall and Burgh in the Bure Valley, a distance of about 40 miles. It is well exposed at several localities in the neightourhood of Norwich, whence it takes its name; it is a variable gromp of sands, laminated clays, and pebbly gravels, 

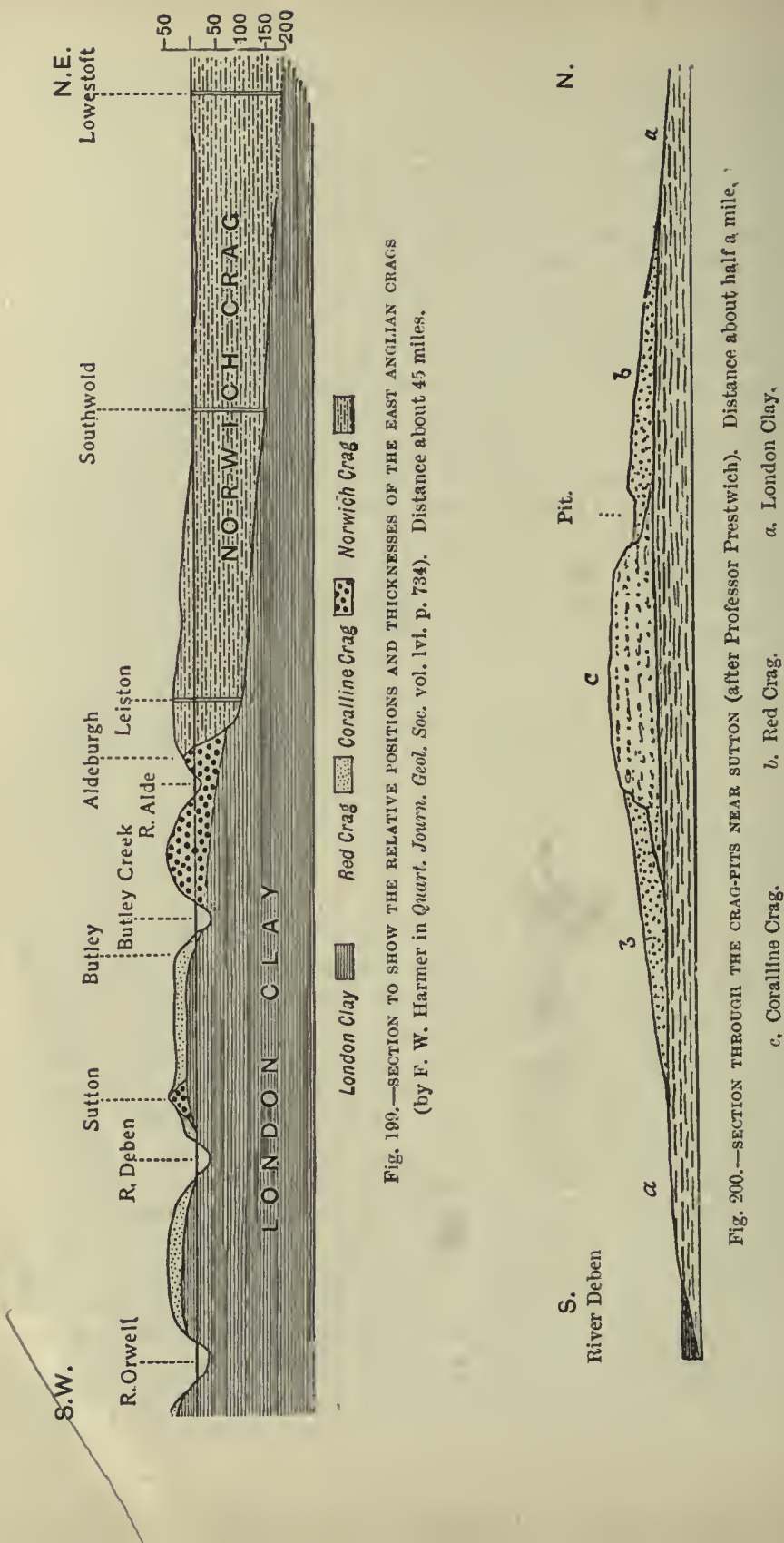

i?! II
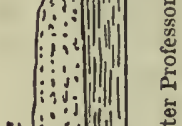

它 它

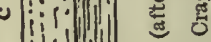

?!?

1.jin z व

(i:a)

(viv) il o 0

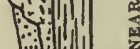

(1)

$\rightarrow 011$

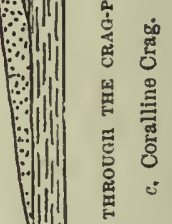

$\therefore$.

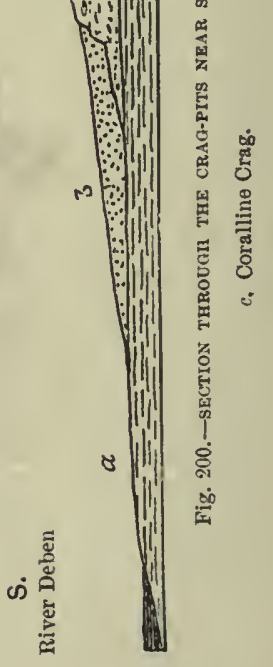


with occasional seains or patches of shells, and different local names were given to different portions of the group before it was ascertained that they all belonged to one division of the Crag.

Mr. F. W. Harmer remarks that " the Norwich Crag Beds are separated by a considerable interval [of time] from any part of the Red Crag. Their molluscan fauna has a inuch more recent character; they never exhibit the highly inclined bedding so characteristic of the Red Crag, and they attain a much greater thickness than the latter; they occupy an entirely different area, and appear to have originated under somewhat different conditions." 17

The Norwich Crag appears to cut off the Coralline Crag abruptly near Aldeburgh (see Fig. 199), and it probably also truncates the Red Crag, for the latter has never been recognised north of that place, while the newer crag thickens northward very rapidly. In a boring at Leiston, only 2 miles from the border of the Coralline Crag, it was found to be 134 feet thick, at Southwold 147 feet, and at Lowestoft 180 feet were traversed without reaching its base.

Norwich Crag is not well exposed in any cliff-section, but a few feet of it are seen at the base of the cliffs near Southwold and Easton Bavent, where the succession is as follows:-

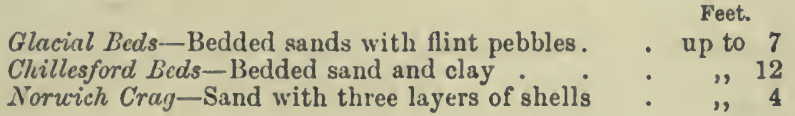

At Aldeby, on the north side of the river Waveney, a brickyard exposes a similar succession, and about sixty-six species of Mollusca have been obtained from the shelly sands. A special feature of this locality is that many of the bivalves occur with united valves in the position of life; they include Mya arenaria, M. truncata, Yoldia oblongoides, Y. lanceolata, Lucina borealis, Mactra ovalis, Scrobicularia plana, Tellina lata, and T. obliqua.

Farther west along the same valley this crag is exposed in many pits near Norwich, Bramerton, and Brundall. The beds vary from 15 to 20 feet in thickness and consist mainly of sand with occasional seams of brown clay, and have generally a bed of rolled tlints and pebbles at the base, in which mammalian bones and teeth have been found.

Chillesford Beds. - There has been much difference of opinion about these beds and their relation to the Norwich Crag. The geological surveyors (Messss. W. Whitaker and C. Reid 18) distinguish between Chillesford Crag and Chillesford Clay, regarding the former as part of the Norwich Crag and the latter as a separate and higher horizon. Mr. Harmer agrees with these 
authors that what has been called Chillesford Crag or Aldeby Beds is in most localities indistinguishable from Norwicl Crag, but he differs from them in regard to the sand below the clay at Chillesford, which he regards as belonging to the Chillesford Beds, believing it to be an exceptional bed without a parallel elsewhere.

The Chillesford Beds consist of finely laminated clay and sand, always micaceous, lying horizontally, and often in alternating layers of clay and sand. They are often from 18 to 20 feet thick; they rest indifferently on the Coralline, the Red, and the Norwich Crags, and have been traced from Walton-on-Naze to Mundesley in Norfolk, a distance of about 90 miles. Mr. Harmer has pointed out that when the exposures of these beds are plotted on a map they arrange themselves in the form of a sinuous band of gradually increasing width as it is traced northward, a form which suggests that they were formed in the estuarine portion of a large river flowing from south to north, and if this was so, the river was probably a continuation of the Rhine. ${ }^{19}$

Weybourn Crag-This is only found in the north of Norfolk, and takes its name from Weybourn on the coast near Cromer, where it consists of from 1 to 12 feet of loam and sand with a band of blue clay in the lower part and a basement bed of unworn flints resting on the Chalk. Its characteristic shell is Tellina balthica, which is very abundant and is a northern species that does not occur in the older crags. Out of fifty-three species of Mollusca only five are extinct, and all the rest are such as now live in the North Sea, nine being regarded as Arctic forms, which is a larger proportion than occur in the Norwich Crag. The fauna, therefore, seems to indicate that the Weybourn Crag is newer than the Norwich Crag, and Mr. Harmer believes it to be newer than the Chillesford Beds.

Cromer Beds. - These beds are exposed at intervals along the Norfolk coast from Happisburgh to Weybourn. They have been described by many writers, and were carefully explored for the Geological Survey by Mr. C. Reid, who found the general succession in these cliffs to be as follows :-20

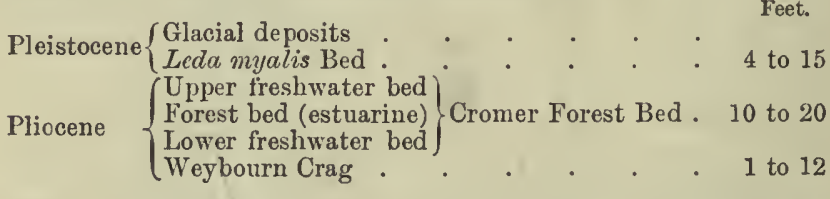

The Lower freshwater bed is a local and discontinuous deposit, its relation to the central estuarine portion resembling that of more recent "submerged forests" to the mud of modern estuaries. The 
middle division consists of clay, sand, and gravel in irregular layers, and contains a mixture of marine and freshwater shells with many mammalian bones; it received its name of "Forest Bed" from the frequent occurrence of stumps, logs, and matted roots of trees, but these are not in the position of growth, as formerly supposed; they have all been drifted, though probably not from any great distance, and Mr. Reid concludes that they grew on the side of a steep riverbank which was continually being undermined and washed away by the current, "nud settling generally in an upright position, as we should expect from the greater density of the roots and fron the weight of the adhering soil, they have formed 'snags' in the river, such as are constantly met with in streams flowing through a forestclad country."

The upper surface of this estuarine deposit is often weathered into a soil and penetrated by small roots (hence termed the Rootlet Bed), and is in some places covered by lacustrine deposits containing freshwater shells, with remains of Fish, Amphibia, and small Mammalia; this is the Upper freshwater bed.

The marine Mollusca, of which there are only nineteen species, all occur in the Weybourn Crag, and include some extinct species, as Melampus pyramidalis, Tellina obliqua, and Nucula Cobbuldice.

With respect to the land and freshwater. Mollusca these number sixty-two, of which thirty-three also occur in the Norwich, Chillesford, and Weybourn Crags. Of the others, which do not occur in older beds, some are extinct, e.g. Viviparus gibbus, Limax modioliformis, Nematura runtoniana, and Pisidium astartoides, and some no longer live in Britain, e.g. Hydrobia marginata, H. Steini, Valvata fluriatilis, and Corbicula fluminalis.

The manmalian remains are also numerous and important, and when the species are arranged in three groups, as below, it is seen that they prove the beds to have been formed just at the epoch of transition from Pliocene to Pleistocene time, a certain number being survivals from the Pliocene (either of Britain or France), and about an equal number being new-comers which range to Pleistocene or to modern times, while a few have not yet been found elsewhere.

\section{(1) Survivals jrom Pliocene, 19}

Elephas meridionalis. " antiquus.

Rhinoceros etruscus. , megarhinus.

Hippopotamus major. Equus stenonis. , caballus (horse).
Cervus poligniacus.

") Etueriarum.

". elaphus (stag).

"I verticornis (=C. belgrandi).

Machrerodus latidens.

Trogontheriuu Cuvieri.

Castor tiber (beaver). 
Ursus arvernensis. Canis lupus (wolf). Cervus Sedgwicki.
Microtus (=Arvicola) intermedius. Lutra vulgaris (otter).

(2) New-comers ranging to Newer Beds, 19

Bison bonasus (var. priscus).

Ovibos moschatus (musk ox).

Ursus spelæus (cave bear).

," ferox (grizzly bear).

Gulo luscus (glutton).

Canis vulpes (fox).

Mustela martes (marten).

Hyæna crocuta.

Sus scrofa (wild boar).

Myogale moschata (nusk shrew).
Sorex vulgaris (shrew).

,i pygmæus (pigmy slırew).

Talpa europæa (mole).

Mus sylvaticus (mouse).

Microtus arvalis (field vole). ,$\quad$ gregalis. ", amphibius (water vole).

Microtus glareolus (red vole).

Sciurus vulgaris? (squirrel).

\section{Continental Pliocene Deposits}

\section{The Pliocene in Belgium and Holland}

In these countries a succession of beds has been described which appears to correspond with the lower and middle portions of the British Series, but does not include any representative of the Norwich Crag or of the later Pliocene deposits in England. This succession, as interpreted by the researches of Messrs. Van den Broeck, Dr. Lorié, and Mr. Harmer, ${ }^{21}$ is as follows :-

4. Anstelian.

3. Scaldisian or zone of Neptunea antiqua.

2. Casterlian or zone of Isocardia cor.

1. Diestian or zone of Terebratula grandis.

The Diestian Sands occupy a position similar to that of the Lenham Beds, and are only found on the high ground along the southern side of the Belgian basin, occupying a considerable area near Louvain and Diest, but not extending far to the northward.

Near Antwerp are beds which contain a fauna similar to that of our Coralline Crag. At the base is a pebble bed covered by a blackish sand yielding sharks' teeth, Cyprina rustica, and Cardita senilis; this passes up into pale greenish-grey sand, from which above sixty species of shells have been obtained, the most abundant being Isocardia cor, Astarte Omalii, A. corbuloides, Lucina borealis, Ringicula buccinea, and Turritella incrassata, with bones of Baloena and Balcenoptera.

This zone is succeeded by the Scaldisian, which consists of red and grey sands similar to our Red Crag, and containing many of the same shells, such as Tritonofusus gracilis, Neptunea contraria, Voluta 
Lamberti, Nassa reticosa, $N$. labiosa, Purpura tetragona, Pecten maximus, and $P$. Gerardi. These beds are regarded by Mr. Harmer as the equivalents of the Walton Crag; he points out that Neptunea contraria is as abundant as in the English Beds, while no specimen of the dextral form $N$. antiqua has been found in the Scaldisian.

No newer beds are found near Antwerp, but borings in Holland, and especially at Utrecht and Amsterdam, have traversed a great thickness of Pliocene, and prove that all the zones thicken greatly toward the north. Thus the Utrecht boring was carried to a depth of 1198 feet without reaching the base of the Pliocene, and this depth is divided as follows by Mr. Harmer :-

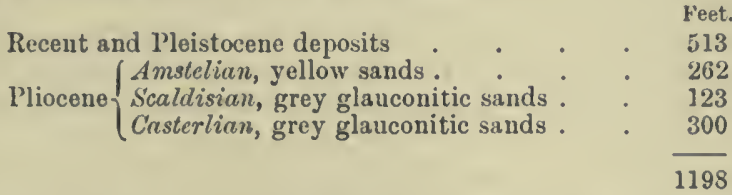

Here, therefore, the Pliocene Series is probably at least 700 feet thick. The shells obtained from the Amstelian include Nucula Cobboldice, Yoldia lanceolata, Cardium edule, Cardium gronlandicum, Tellina pretenuis, Mactra subtruncata, Mya arenaria, and Littorina littorea, an assemblage which corresponds to that of the later parts of the Red Crag.

\section{France}

In the north-west of France there are a number of small patches of reddish sand and blue clay containing a marine fauna which is clained to be Upper Miocene by Mr. Dollfus, but which has generally been regarded as Pliocene, and the latter view is supported by Mr. C. Reid. These tracts occur, some in the Cotentin, near Carenton and Valognes; some in Ile et Vilaine, near Rennes and Redon; and some still farther south, both north and south of the valley of the Loire. According to Mr. Dollfus the fauna is substantially the same at all localities. Cardita striatistrina, C. aculeata, Venus fallax, Nassa prismatica, $N$. mutabilis, and Turritella incrassata are some of the characteristic shells.

In the Cotentin the basement-bed is a layer of rolled pebbles with teeth and bones of Miocene and Eocene animals, together with shells of Terebratula grandis. This bed is overlain at Gourbesville by sands, and at St. Martin d'Aubigny by greenish clays, and the faunas of these two deposits are not quite the same. Mr. Reid states ${ }^{22}$ that of 143 species from Gourbesville 91 
occur in the Coralline Crag, and that 85 per cent of the whole are living species, which is about the same proportion as in the Red Crag. The clays of d'Aubigny, on the other hand, have only 50 per cent of living species, and contain a larger number of southern species which give them a different and older aspect; but the difference may be due to the different conditions under which the two deposits were formed rather than to difference of age.

It seems probable, therefore, that all these deposits are of about the same age as the Lenham Beds and the Diestian of Belgium, and that it was by connection between the Atlantic and the Belgian Seas across the north of France that the southern species of Mollusea made their way eastward.

In Central and Eastern France the Pliocene deposits are mainly of lacustrine and fluviatile origin, but these yield assemblages of mammalian remains by means of which they can be referred to one or other of the three stages of the series. Thus the earliest of these assemblages is that found in the ossiferous breccias of Mt. Luberon and Cucuron in Vaucluse; these beds coutain many of the same species as occur in the Pontian of Eastern Europe, especially Hipparion gracile, Rhinoceros Scheiermacheri, Palreoryx Cordieri, Helladotherium, and Dinotherium.

In the Auvergne district the general succession may be tabulated as follows:-23

Upper $\left\{\begin{array}{c}\text { Plateau basalts with tuffs and breccias containing bones of } \\ \text { Elephas meridionalis. }\end{array}\right.$ Middle $\left\{\begin{array}{l}\text { Stratified deposits of Perricr and Le Puy. } \\ \text { Upper phonolite and lianyne andesites. }\end{array}\right.$

Lower $\left\{\begin{array}{c}\text { Andesitic trachytes and porphyritic basalts with intercalated } \\ \text { breceias. }\end{array}\right.$

The stratified beds of Perrier overlie the Miocene (see Fig. 194), and have a conglomerate at the base containing bones of Mastodon arvernensis and Machorodus cultridens, succeeded by cenerites and sands, the former embedding leaves of plants which comprise maple (Acer polymorphum), beech (Fagus phocenica), and a bamboo (Bambusa lugdunensis). These beds are overlain by a breccia of trachyte fragments, among which are bones of Elephas meridionalis, Equus stenonis, and Gazella Julieni; while in Le Puy pebbly sands beneath the basalts have yielded Rhinoceros etruscus and Hippopotamus major.

Farther south we find a more complete succession of stratified deposits, without volicanic intercalations, and including a thick marine Placentian stage. These beds extend from near Lyons southward along the valley of the Rhone and spread out in Provence. The general succession is as follows:- 
Sicilian-Alluvial pebbly sands with Elcphas merielionalis.

Astian-Yellow sands with Mectodon arvemensis.

Placentian $\left\{\begin{array}{l}\text { Sands and marls with Potamides Basteroti (160 feet). } \\ \text { Marls with Nassa semistriata, Arca diluvii, ete. (500 feet). }\end{array}\right.$

Pontian $\left\{\begin{array}{c}\text { Marls of Bolléne, with Congcria simplex and Mclania } \\ \text { Matheroni, lyiug nneonformably on the Miocene (100 feet). }\end{array}\right.$

\section{Italy}

When the Pliocene is followed eastward into Liguria, the marine deposits are still thicker, presenting a series of marls and limestones over 600 feet thick, and representing the Pontian, Placentian, and Astian, and abounding in fossils. These beds are overlain by 300 feet of yellow sands with few fossils, but these also are of Astian age, and no marine deposits of Sicilian age occur in Northern Italy ; near Asti, however, and other places there are fluviatile sands and gravels containing bones of Elephas meridionalis and other Upper Pliocene species.

Pliocene deposits occupy large tracts on both sides of the Apennines and are well displayed in and near Rome. They cover alout half the island of Sicily, and are largely developed in Calalnia. In these southern areas they are over 2000 feet thick and rise to a height of 4000 feet above the sea, consisting almost entirely of marine deposits, the succession being as follows :-

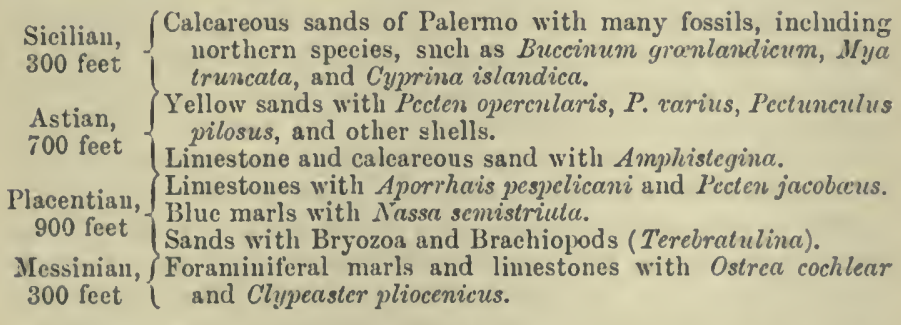

In the Val d'Arno there is an extensive lacustrine deposit over 700 feet thick, the lower part including beds of lignite with plant-remains and the bones of a tapir; the upper part yielding the bones of many mammalia of Upper Pliocene age, such as Elephas meridionalis, Rlinoceros etruscus, Eyuus stenonis, with antelopes, deer, a beal (Ursics etruscus), an ape (Macacus florentinus), and three species of Macherodus (sabre-toothed tigers). ${ }^{24}$

\section{Austria and the Balkans}

Pontian.-In Austria the Sarmatian Clays are overlain by the Congeria Beds or Pontian stage, consisting of sandy marls and 
clays which have a thickness of more than 300 feet. The prevalent shells are species of Congeria, C. conglobosa occurring in the lower part, with $C$. triangularis and $C$. rhomboidea in higher beds, with species of the peculiar Cardiidæ-Adacna and Monodacna-like those of the Caspian Sea. These Congeria Beds extend eastward through Hungary, Croatia, Roumania, and Southern Russia to the Caspian Sea and Iake Aral, which lakes, together with the Black Sea, may be regarded as remnants of the ancient and much larger Pontian Sea.

In Greece the Pikermi Beds are a lacustrine deposit of the same age; they consist chiefly of red marly clays with land and freshwater shells, varied by layers of sandy marl and lenticular beds of pebbles; in the clays are several layers of mammalian bones. ${ }^{25}$ These beds are part of a formation which has a wide extension in Attica and is regarded by Fuchs as of Pliocene (not Miocene) age, as the freshwater beds overlie deposits which contain marine shells of Pliocene species (Pecten benedictus, Ostrea undata, and O. lamellosa). The bones are mostly separate and some are broken, but many complete limbs occur with the bones in their natural position, as if they had been washed down from higher ground during heavy floods. The principal members of this fauna have been mentioned on p. 588. Similar deposits have been found in Eubœa and in the island of Samos.

Placentian.-In Austria the Pontian Clays are succeeded by some lacustrine beds with land and freshwater shells, but these are more fully developed in Croatia, Roumania, and Bulgaria, where they are known as the Paludina Beds. The lower part of these contain smooth rounded forms of Viviparus (= Paludina), but in the higher beds they are carinated. Mastodon arvernensis has been found in the lower beds. Similar beds extend through Southern Russia to the Caspian Sea and are well exposed near Odessa, where beds containing Prosodacna and Dreissensia overlie the Congeria Beds and are themselves succeeded by the "Paludina Beds."

Astian and Sicilian.-Newer Pliocene deposits, both of marine and lacustrine origin, occur at different places all over the same eastern region, and marine Pliocene Beds occur also in Cyprus and Asia Minor, but their stratigraphy has not yet been sufficiently investigated for the recognition of stages or zones.

\section{Germany}

No marine Pliocene deposits occur in Germany, but at Eppelsheim near Worms there are sands and gravels, overlying Mliocene Beds, which have yielded a Pliocene mammalian fauna 
resembling that of Pikerni, but without Helladotherium or the antelopes.

\section{E. Histony of the Pliocexe Period}

At the beginning of Pliocene time all the mountain ranges of Central and Western Europe had been formed, and the greater part of the European region was in the condition of dry land, though the coast-lines were not the same as those of the existing continent. The British area was still a compact and extensive tract of land, extending northward beyoud Ireland and Scotland, but it seems to have been separated from France and Belgium and must therefore have been a large island. We have seen that the southern aspect of the fauna of the Diestian and Coralline Crag Seas makes it almost certain that there must have been a connection with more souther'n seas, and this connection most probably lay along the line of the English Channel and through Normandy to the country between the Vilaine and the Loire, where it opened into the Atlantic. This matter is more fully discussed in my Building of the British Isles (1911).

In the south of Europe the Mediterranean Sea still existed, but probably opened southward through Egypt, for there is no evidence of any opening across Spain or by the Straits of Gibraltar until the time of the Sicilian Beds, when northern species of Mollusca first entered the Mediterranean area. This Mediterranean only covered small parts of Southern France, but seems in Placentian time to have extended up the valley of the Rhone, converting it into a sort of fiord. Thence its northern shore passed along the feet of the Maritime Alps and round the great basin of Northern Italy, the whole of that country except the ridge of the Apennines being covered by the Lower Pliocene Sea, together with nearly the whole of Sicily and parts of Northern Africa, especially in Tunis, Tripoli, and Egypt.

East of this sea, and separated from it by the ridge of the Dinaric Alps and the Highlands of Montenegro and Albania, lay the large inland sea of the Ponto-Caspian region, which extended from the Vienna basin on the west to and beyond the Sea of Aral on the east. Whether the deposits of Pontian age in Greece and the Egean area were formed in a gulf of this sea or in separate lake-basins is at present nncertain, but the probabilities are in favour of the latter view. These conditions continued to prevail in the Pontian area through Placentian time, but the waters of the great lake gradually became more and more fresh, so that the Congerias died out and their place was taken by Unio, Viviparus, and Melanopsis. 
The change from the conditions of Lower Pliocene to those of Middle Pliocene (or Astian) time seems to have been produced by a general uplift of what may be termed the central axis of Europe, in other words, across the whole of that part of Europe which lies between the parallels of $40^{\circ}$ and $51^{\circ}$; while further subsidence took place both in the southern Mediterranean and also in the northern region. Thus the Italian area continued to sink, permitting a great thickness of marine deposits to be accumulated, and the Pontian lakes continued to exist, but probably they had shrunk in size. The whole of France and the English Channel became dry land, and all direct communication between the Atlantic and the Belgian Sea was thus cut off; but farther north subsidence was taking place, forming and widening a channel between Scotland and Norway which opened into the Arctic Ocean.

The facts which relate to this gradual formation of the North Sea Basin and to the extension of the great delta of the Rhine may be mentioned more fully. Having regard to the present position of the Lenham Beds, and the progressive overlap of the newer crags toward the north, as well as the great thickness of the Pliocene deposits in Holland, we may infer that the crust movement in the Anglo-Belgian area had the effect of a tilt, which caused a subsidence on its northern side, while its southern Border was raised through at least 780 feet.

Thus all connection with more southern seas was severed. On the other liand, the subsidence to the northward allowed the sea to spread farther north than in the earlier part of the period, and before the epoch of the Newbourn and Butley Crags it would seem that part of the land which had hitherto united Scotland and Scandinavia was submerged, so that an opening was formed into the Arctic Ocean.

The Red Crag is generally regarded as a shore deposit, and by Mr. Harmer it is compared with the shelly banks and beaches which are now being formed all along the coast of Holland. These accumulations of sand and shells are attributed by Dutch geologists to the prevalence of gales from the west, and as no such shell-beds exist now on our eastern coasts this seems to explain the facts, but if such was the origin of the Red Crag we must suppose that in Pliocene time the prevalent gales were from the eastward and not from the westward, as is now the case. ${ }^{26}$

As the sea extended its area northward and the land rose on its southern border, the valley of the Rhine must have prolonged itself northward over the southeru part of the Noith Sea plain, and we have seen.(p. 600) that the Chillesford Beds may possibly 
be deposits formed in the estuary of that river. Other indications of a large river flowing from the south present thentselves in the Cromer (Forest) Beds, and Mr. C. Reid has carefully examined the stones which compose the gravelly portion of the deposit. He found the collection of pebbles to be such that if the river had flowed from the sonth, west, or north, it must have bronght a very different assemblage. "It seems, therefore, that only from the south-east and east could the stones be derived, and that the river unust have been very large is shown by the unifornity of the composition of the gravels at considerable distances apart; if this be the correct reading, the river can be no other than the Rhine, a view held by varions writers ever since the Forest Bed was first known." 27

Witl respect to the change in the clinate, the fauna of the Diestian Sand and Coralline Crag is that of a rather warm sea, and the mean annual temperature of the surrounding country must have been decidedly higher than it is now in the same latitude. The subsequent exclusion of the warm southerly current doubtless caused a general diminution of temperature, but there were other meteorologic and cosmic causes which operated in rendering the climate more and more frigid, till at length in the Weybourn Crag we find a fauna indicative of a climate somewhat colder than that which at present prevails in Norfolk. This prepares us for the great change which took place very soon after the formation of that bed.

In the Mediterranean area the closing scenes of Pliocene time were connected with the subterranean disturbances which resulted in the formation of the great voleanoes of Etna and Vesuvius and the smaller vents of the Latian Hills. The earliest volcanic eruptions appear to have been submarine, for the Astian and Sicilian deposits of Sicily, Calabria, and Rome include interstratified beds of volcanic ash and sand. It was not, however, till the close of Pliocene time that the greatest discharges began, for the building up of Etna and the elevation of the Pliocene deposits to the levels at which they are now found, i.e. more than 3000 feet above the sea, must have taken place in early Pleistocene time.

\section{REFERENCES}

1 G. F. Dollfus, "Essai sur l'étage Aquitanien," Bull. Service Carte Géol. France (1909).

2 S. Gardner, Geol. Mag. for 1879, p. 152, and Monograph. Pal. Soc. on the Eocene Flora, pp. 18, 19.

3 C. Reid, Phil. Trans. R.S. vol. 201, B. p. 161 (1910).

4 See Pengelly in Phil. Trans. vol. cliii. p. 1019 (1863), and JukesBrowue in Geol. Mag. for 1909, p. 257. 
5 See Dollfus, op. cit., and G. F. Harris, Geol. Mag. for 1890, p. 22.

6 See Dollfus, op. cit. table on p. 19.

7 See T. G. Bonney in Proc. Geol. Assoc. vol. xvii. p. 191.

8 See M. Boule, Buil. Soc. Géol. France, Ser. 3, vol. xx. p. 104.

9 See C. Mayer, Bull. Soc. Géol. Fr. Ser. 3, vol. v. p. 282, and F. Sacco, Il Bacino Terziario del Piemonte, Turin, 1889.

10 O. Fisher, Quart. Journ. Geol. Soc. vol. 1xi. p. 35.

11 W. B. Dawkins, Guart. Journ. Geol. Soc. vol. lix. p. 105.

12 C. Reid, "Pliocene Deposits of Britain," Mem. Geol. Survey (1890).

13 F. W. Harmer, Quart. Journ. Geol. Soc. vol. liv. p. 308.

14 C. Reid, Pliocene Deposits, p. 59.

15 S. V. Wood, "Monograph of the Crag Mollusca," Pal. Soc., 1872 to 1874, with Supplements in 1879 and 1884.

16 F. W. Harmer, Quart. Journ. Geol. Soc. vol. lvi. p. 705 (1900).

17 F: W. Harmer, op. cit. p. 737.

18 W. Whitaker, "Geology of Southwold," Mem. Geol. Surv. (1887), and

C. Reid, Pliocene Deposits of Britain (1890).

19 F. W. Harmer, Proc. Geol. Assoc. vol. xvii. p. 446.

20 C. Reid, op. cit. p. 146.

21 F. W. Harmer, "Pliocene Deposits of Holland," Quart. Journ. Geol. Soc. vol. lii. p. 748.

22 C. Reid, op. cit. p. 68.

23 See M. Boule in Proc. Geol. Assoc. vol. xvii. p. 204.

24 C. Reid, op. cit. p. 219.

.25 See A. S. Woodward, Geol. Mag. for 1901, p. 482.

26 F. W. Harmer, Quart. Journ. Geol. Soc. vol. lvi. p. 732.

27 C. Reid, op. cit. p. 188. 


\section{CHAPTER XVII}

\section{The Pleistocene Series}

\section{A. General Considerations}

The term Pleistocene was used by Lyell to denote the deposits which are newer than the Pliocene and yet not modern enough to be called Recent. But different writers have different ideas as to what deposits should be called Recent. It seems best to consider the Pleistocene period as including all deposits in Europe which are older than those containing metal implements of human manufacture.

Some of these deposits have obviously been formed during a time when the climate became so cold that the higher parts of the country were covered with ice and snow and the North Sea was more or less filled with ice. Such deposits are called Glacial, and the time during which they were formed is known as the Glacial period, or epoch, and sometimes as the "Great Ice Age," while all the subsequent deposits can be classed as "Post-Glacial." This, however, is not a satisfactory division of Pleistocene time, because the Glacial deposits do not extend all over Emrope, being limited to its northern parts and to a certain area round the Alps. In other parts of the region fluviatile, alluvial, and subaerial deposits were being formed, which are of a more normal character, though some of them exhibit sigus of severe climatic conditions.

The Pleistocene deposits cannot therefore be treated as one consecutive series, but unust be regarded as including two different sets of deposits, which may be called Glacial and Non-Glacial, but are only distinct from a regional point of view, some of the one set beiug contemporaneous with the other set. Again the Glacial deposits, even those of a single country like England, are not easily classified; for they vary so much in different districts and are so irregularly stratified that correlation is difficult. There is of course a general succession in time, and elaborate classifications have been formulated, but these are based upon assumptions and 
theoretical views, and must be received with great caution; for it is obvious that, owing to the special conditions under which Glacial deposits have been accumulated, ordinary stratigraplical principles cannot be applied to them.

Neither are the organic remains which occur in the Glacial deposits to be trusted as implicitly as those of other series of strata, because portions of an older deposit have sometintes been transported and mixed with newer accumulations. Bones of Manumalia are occasionally found in the Glacial Series and more frequently in Non-Glacial deposits, and they do afford a certain criterion of age, as some of them belong to extinct species and they occur in different assemblages which seem to have succeeded one another. In this way three divisions of Pleistocene time lave been distinguished, (1) a time when Elephas antiquus, Rhinoceros Mercki $(=R$. leptorhinus), and Machorodus were common animals; (2) a time when Elephas primigenius (the Manmoth), Rhinoceros tichorhinus, and Hycana speloca took their places; and (3) a period when the Reindeer (Cervus tarandus) ranged over the greater part of Europe, accompanied by many other existing species of aninals which live now within the Arctic Circle.

Lastly, it was during the Pleistocene period that man appeared in Europe, and one of the special characteristics of man is that he is a manufacturer of implements. Accordingly implenents fashioned by the hands of men are found here and there even in early Pleistocene deposits ; the older tools being always made of stone and roughly manufactured, but those of the later phases of the period showing more and more careful shaping and finishing. Stone implements thus afford another means of correlating the NonGlacial deposits of different districts and countries, but they are rarely found in or under the Glacial deposits.

The division into Glacial and Non-Glacial is therefore the only arrangement under which the Pleistocene deposits call be conveniently described, and this will be adopted in the following pages; but the reader must remember that the two sets of deposits are more or less contemporaneous.

With respect to the life of the period, it will be convenient to defer giving a list of the Pleistocene Mammalia till we deal with the Non-Glacial deposits in which they are most frequently found, but mention may be made of the ntarine shells which often occur in Glacial deposits and in beds associated with them. Those which actually occur in boulder-clays are generally broken, but those found in the interstratified sands and gravels are often perfect.

The marine mollusca of Pleistocene times all belong to living species, but those found in the Glacial deposits are such as live 
in the seas romnd the northern parts of onr islands, the species of onr sonthern consts being generally absent. The following are some of the commoner species in Glacial Beds, and some of them are shown in Fig. 201 :-

Gastropodu. Natica aflinis (clausa), N. pallida (=grcenlandica), Trophon clathratus, T. Fabricii, Buccinum undatum, B. gronlandicum, Bela turricula, Turritella communis, Scalaria grcenlandica.
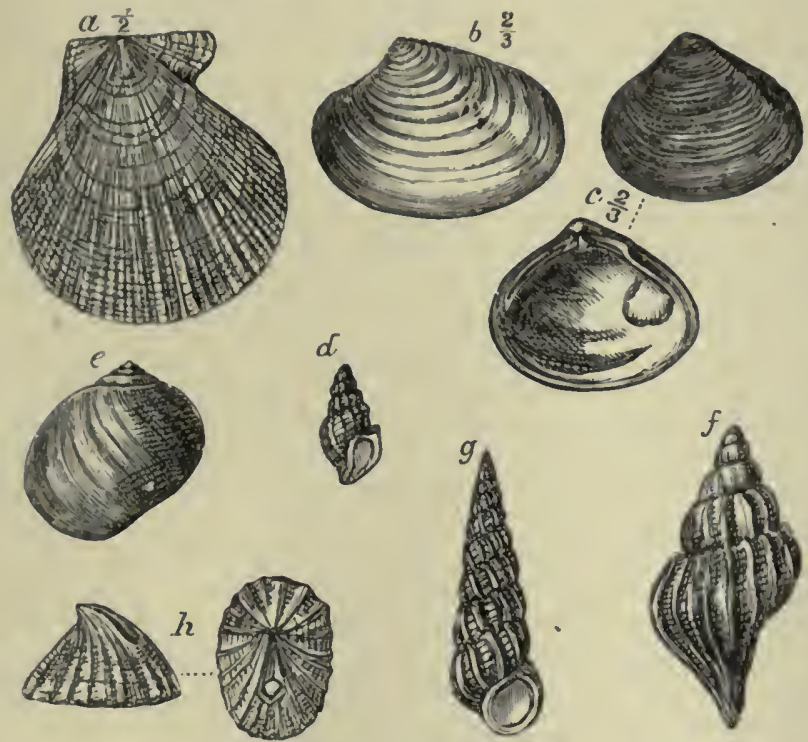

Fig. 201.-GROUP OF PLEISTOCENE MARINE SHELLS.
a. Pecten Islandicus.
b. Astarte borealis.
c. Corbicula fluminalis.
d. Trophon Fabricil.
e. Natica aflinis (=clausa).
f. Troplion clathratus.
g. Scala gronlandica
h. Puncturella noachina.

Lamellibranclia. Pecten islandicus, Leda truncata, Yoldia arctica, Y. lanceolata, Tellina lata, T. halthica, Astarte borealis, A. compressa, Panopæa norvegica, Saxicava rugosa, Cyprina islandica.

\section{B. Glaciation and Glacial Deposits}

Glacial Deposits.-These are the relics of a time when the conditions which are now confined to the Arctic and Antarctic regions prevailed over the whole of Northern Enrope. They are 
principally such as result from the action of moving masses of ice (bonlder-clays), or from the action of strong currents of water (coarse gravels), but interstratified with these there are sometimes sands, brick-earths, and laminated loams which have been deposited in quiet water and in a more gentle manner.

The chief product of the Glacial epoch is the material known as boulder-clay. There are several varieties of such clay, and it is by no means certain that they have all been formed in the same manner. Some boulder-clays are stiff compact masses of unstratified clay containing utmerous stones and boulders, and they seein to have been compacted by the passage of heavy masses of ice over them. It does not follow, however, that they were dragged along beneath the ice in the form of what has been called "groundmoraine." The prevalent view at the present day is that the materials of boulder-clay were enclosed in the moving ice, principally no doubt in the lower portion of it, but embodied in and moving with the ice. Wherever the glacier or ice-sheet melted this "englacial" material thawed out, and was dropped to form an unstratified clay full of stones and boulders. It might even accumulate by the thawing of the under surface of stationary ice during a temporary amelioration of climate, and if climate conditions again became severe a renewed movement of ice might take place in such a manner as to pass over such boulder-clays without removing them.

Other boulder-clays are of a looser texture, and are more frequently associated with sands and gravels which contain marine shells, and such clays must either have been formed where ice invaded the sea, or must be the product of an ice-sheet which had passed over a sea floor, or was moving from the sea over the retreatiug shore of a sinking land.

These shells occur at various heights above the present sea-level from 100 to over 1300 feet, and also far inland, often many miles away from the present coast-line. The question naturally arises whether they are in situ or whether they have been transported to their present positions by the agency of ice. When they were first discovered and described they were regarded as proofs of a great submergeuce, during which the British Isles sank to an extent of more than 1300 feet. Later it was perceived that this was highly improbable, because no evidence of such a subsidence exists in the south of England nor in the north of France; marine deposits in these areas being restricted to coastal belts, and not occurring at more than 130 feet above sea-level.

Latterly glacialists have tried to explain the occurrence of all marine relics at high levels on the smpposition that they were 
frozen into the base of enormons ice-sheets, which not ouly filled the basius of the North Sea and the Irish Sea, but were able to take up portions of the sea floor, and carry them up to high levels in England and Ireland. Further it has been maintained that instead of the land being lower and the seas deeper than they are now, the whole of Northern Emrope had beeu raised to a greater elevation than that at which it now stands, and that land-ice was the sole agent concerned in the transport of marine shells as well as of large stones and boulders.

These are extreme views, and the truth probably lies in a modification of them. The idea of the land being at a higher level than it is at present, either at the beginning of the Glacial Period or at the time of maximum glaciation, is a mistake. The evidence only proves that the land had previously been at a higher elevation, i.e. in Pliocene and Miocene times, and it favours the conchision that the land sank as the thickness of ice upon it increased. At the same time it must be admitted that the shells at very high levels nay not be exactly in situ, and that perfect shells have not been found in sufficient number to prove a subuergence of nore than 500 or 600 feet. Thus at Clava, near Inverness, there is a shell-bearing deposit with Arctic species at about 500 feet, and overlain by boulder-clay. A British Association Committee, appointed to investigate this and other localities, reported that the molluses at Clava had probably lived on the spot where their shells are now found.

It is probable, however, that the subsidence was greater in the north than it was farther south, and that while it may have been 600 feet in the latitude of Inverness it was not more than 130 or perhaps 160 feet in the south of England. Even such a moderate subsidence, however, would greatly facilitate the movement of icesheets over tracts which are now dry land, and would account for the transport of many rock-fragments from lower to higher levels under 500 feet. In spite of this we are still obliged to admit that there was sufficient vis a tergo to force the ice not only over the sea floors but out again and up to considerable heights on the other side. It has also been pointed out that under such conditions shearplanes may have been produced, and portions of the ice thrust forward and upward over parts in front of them. Such upward thrusts have been observed in Spitzbergen at the present day. ${ }^{1}$

Glaciation of Rock Surfaces.-In nearly all districts where boulder-clays occur the rock-surfaces which underlie the lowest clays are glaciated, that is to say they are grooved, scratched, and smoothed as they wonld be by the passage over them of heavy ice, which, when its sole is full of stones and boulders, becomes a gigantic 
rasping, graving, and moulding tool. In most cases it is found that the grooves rum parallel to the main valleys of a district, and in many cases when the directions are marked on a map it is seen that they radiate outward in all directions from some central mountain tract; but occasionally they run in one direction across some tract of country witlout any reference to its valley system,

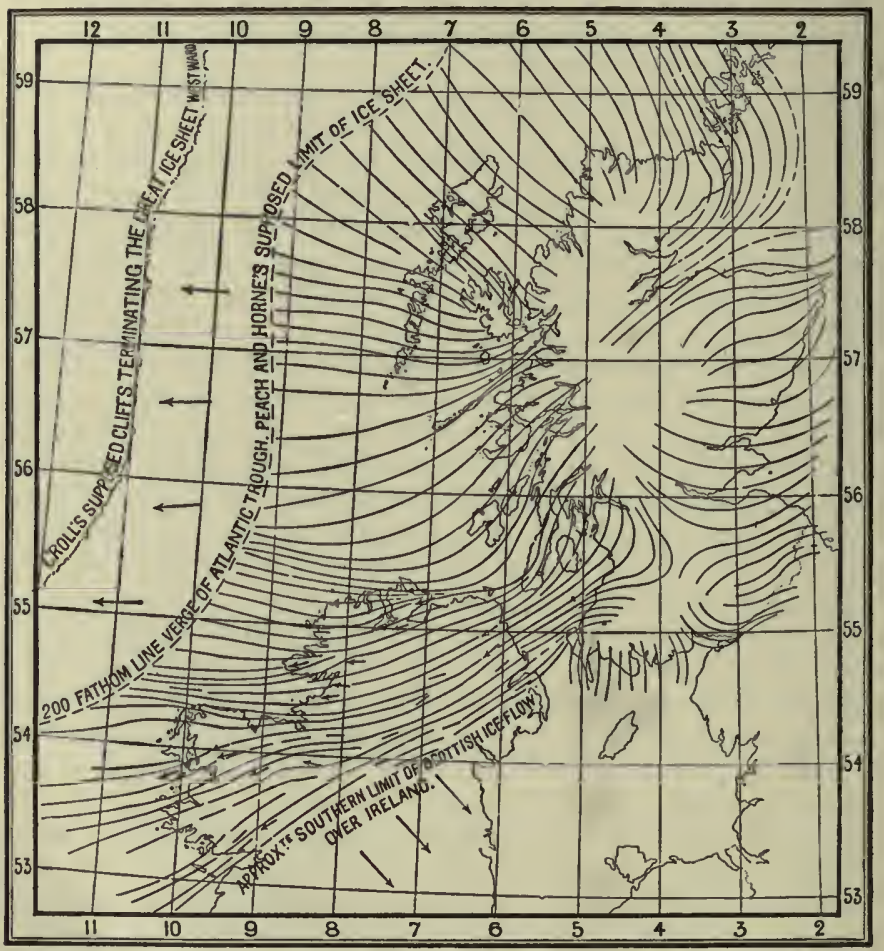

Fig. 202.-MAP SHOWING THE GLACIATION OF SCOTLAND AND THE NORTH of IRELAND (J. R. Kilroe).

(Reproduced by permission of the author and the Council of the Geological Society.)

as if the ice had been locally deflected from its natural course. This system of grooves and striations is often called the glaciation of a district or country.

Thus the plotting of the principal lines of striation in Scotland has shown that country to have been an independent centre of icedispersal, and that at the time of maximum glaciation it was wholly 
covered by snow and ice which moved ontward from the principal water-sherls; the ice-fields of the Central and Northern Highlands forming a confluent ice-sheet which spread out in all directions and descended into the neighbouring seas (see Fig. 202).

The sonth of Scotland formed another centre of dispersion, the ice flowing oft its uplands, moving chiefly in western, sonthern, and eastern directions, because free movement to the north was blocked by the more northern ice-sheet.

There are, however, exceptions to the coincidence between the direction of the strie and that of the main valleys; thus the district known as Knapdale in Argyllshire, which rises to 700 or 800 feet above the sea, is glaciated obliquely from north-east to soutlwest, as if the ice had filled up the valley of Loch Fyne, and had flowed over the ridge to the Sound of Jura. There seems also to have been a time when the ice from the Perthshire highlands went across the Ochil Hills, some of which reach a height of 2300 feet, and these are important facts to remember when the mode of glaciation is considered.

In the north of Ireland again the Giacial striation is not of a simple radiating character. According to Mr. J. R. Kilroe, the strice can be resolved into two sets, the one set having a general direction from east-north-east to west-south-west across the whole area with local variations to west and south-west in Mayo and Galway, while another set show lines of movement northward, sonthward, and south-eastward. These facts he interprets to mean that there was first a local snow-field covering all the high ground between Mayo and Autrim and shedding its ice both to the north and the south; but that at the time of maximum glaciation the Irish ice was so dominated by that flowing off the Scottish Highlands that it was forced to move westward (see Fig. 202).

The Lake district and the Welsh mountains were also independent centres, and the glaciers of the former seem to have maintained their radiating onward movement throughont the whole of the Glacial epoch, but their terminal parts were merged into the ice flowing off the south-west of Scotland. In Wales the strix also have a general radiating arrangement from two centres, the Snowdonian and Merioneth mountains forming one, the Plynlinmon Group and the highlands of Central Wales forming the other. Movement to the north and north-west was, however, blocked by the northern ice, so that Anglesey is glaciated from north-east to south-west, Denbigh, Flint, and Sonth Lancashire from north-west to south-east. Consequently the ice of North Wales moved chiefly to the east and south-east, and boulders from the Arenig mountains have been carried eastward into Shropshire and Staflordshire. 
The ice from the central ice-field of Wales was also free to flow eastward, southward, and westward, but it seems to have been partially turned aside by the mass of the Brecknock Beacons and

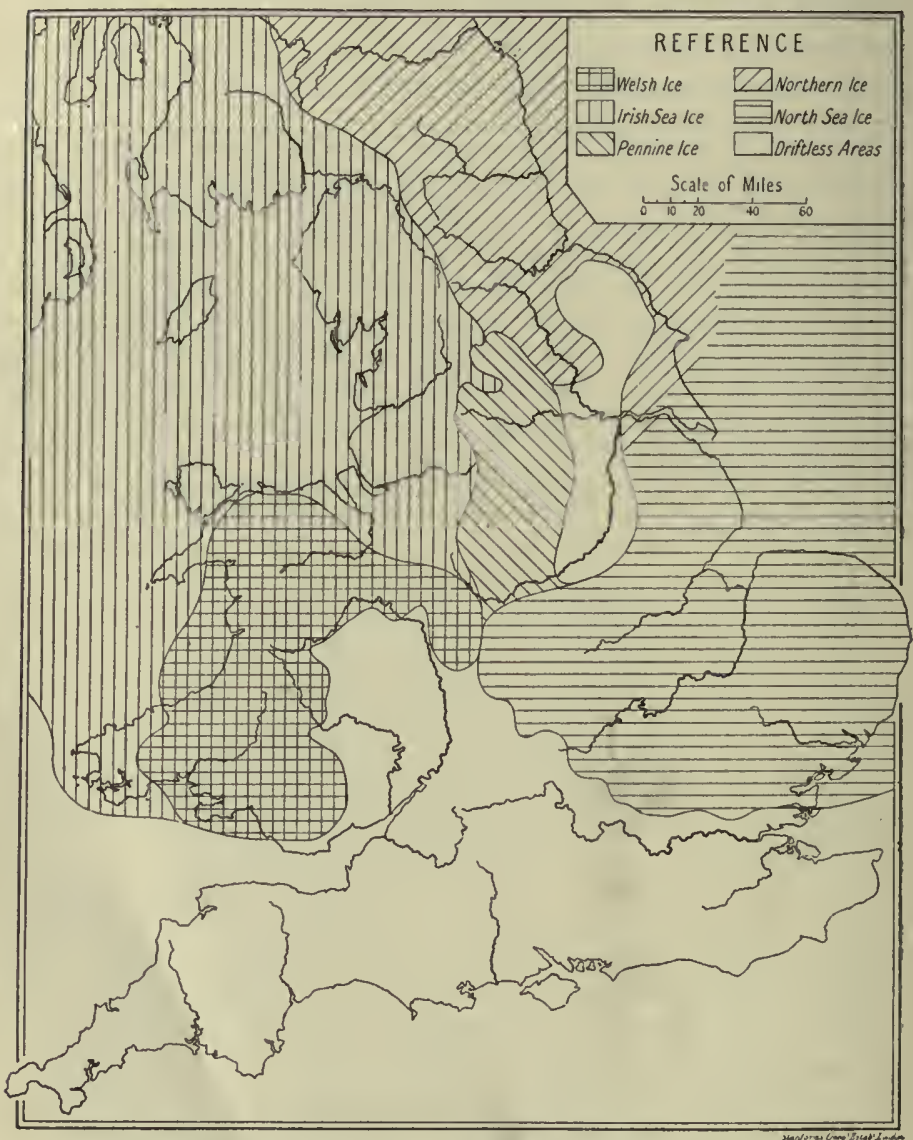

Fig. 203.-MAP SHOWING THE AREAS OCCUPIED BY THE DIFFERENT ICE-SHEETS IN ENGLAND.

to have flowed chiefly in southerly and westerly directions. Thus it overran the whole of the Sonth Wales coalfield, the strixe on the rocks of the northern borders of that area all indicating flow 
from the north. Pembrokeshire on the other hand has been glaciated by ice coming in from the Irish Channel (see map, Fig. 203).

\section{The Glacial Deposits of Britain}

No classification of the Glacial drifts has yet been proposed which is applicable to all parts of the British Isles. In some areas it is possible to establish a local succession of deposits, but all attempts to correlate those of one area with a similar series in another area have hitherto broken down.

In some districts, such as Aberdeenshire, Norfolk, North Wales, and the south-east of Ireland, there are certainly older and newer boulder-clays, differing in colour and contents, and in some places they are separated by stratified sands and gravels. We may safely infer that sucl different deposits were formed during different successive phases of the Glacial Period. In Germany the Glacial deposits appear to exhibit a greater uniformity, and it is generally held that there are two bonlder-clays, a lower and an upper, and that they indicate two epochs of advance and retreat of the northern ice.

The great variation observable in the Glacial deposits of Britain is doubtless dute to their being the product of several distinct icesheets coming from different directions. This is especially the case in England, where the influence of no fewer than five ice-sheets can be distinguished (see map, Fig. 203). At present, therefore, the British deposits can only be described in a piecemeal fashion, and brief accomts will be given of those found in the following areas :-

1. Central and Northern Scotland.

2. South Scotland and the north of England.

3. Yorkshire and Lincolnshire.

4. East Anglia.

5. The Midlands.

6. Wales and the West of England.

7. Ireland.

\section{Central and Northern Sicotland}

The Glacial deposits of Scotland may be classified as follows, but it is seldom that all the nembers are found in one locality, and it is probable that the moraines were more or less contemporaneous with the later shell-bearing clays :-

4. Moraines of local glaeiers.

3. Shell-bearing clays near the coast.

2. Upper boulder-clays with stratified sands and gravels.

1. Lower boulder-clay or till. 
The till is described as a very stiff clay full of stones and boulders, the whole being so hard and compact that it often weathers like a conglomerate. Boulder-clay of this kind occurs up to heights of 1600 feet, and is sometimes over 100 feet thick, being always thickest on the low grounds and thinning away on the highland slopes. The stones and boulders found at any given locality are principally derived from local rocks, and in the lowland clays there are not many stones which have travelled more than a few miles from their parent site; most of the fragments are smoothed and striated, and many are scratched all over, often exhibiting five or six definitely striated surfaces. The local character of the clay is also shown by its variations in colour. Hugh Miller, sen., long ago remarked that red sandstones were covered by red boulder-clay, the grey flags of Caithness by a lead-coloured clay, and the coal-measures of the Lothians by a bluish-black clay; subsequent observations have shown that the clays of these colours do not exactly coincide with the limits of the formations from which they derive their tint, but slightly overlap them in an outward direction.

'Thus, though the materials of this inland boulder-clay afford evidence of a certain antount of transport, still its local character is so strongly marked that "whatever may have been its node of production, it cannot have been carried from a distance, but must have been formed on the whole in the districts in which it is found."

In many places the hard till or boulder-clay above described is covered by deposits of a more varied character, consisting of stratified sand, gravel, and clay; such deposits occupy large areas in the central lowlands between the firths of Forth and Clyde. Associated with these beds or stranded on bare hill-sides are numerous large erraties or isolated boulders, which have usually come from points to the north or north-west of the positions they now occupy, and some have travelled distances of 50 or 60 miles ; it is to be noted that such boulders rarely occur in the boulder-clay, though they often lie on it, the travelled stones in the boulder-clay being always of small size.

Along the east coast, from Stonehaven to Peterhead, a very different kind of boulder-clay is found; this is a reddish-brown clay whieh contains broken marine shells, and often includes seams of fine sand or laminated silt; moreover, its materials appear to have been derived from the southward, from the Old Red Sandstone districts in Kincardine and Forfar, a conclusion which is confirmed by the occurrence of striæ on the rocks below, pointing from south-south-west to north-north-east. ${ }^{a}$ Near Collieston and Slains this clay rests on stratified sands and gravels which are more 
than 50 feet thick and contain numerous broken marine shells, which seem to have been derived from the destruction of Pliocene Beds, comparable to the English Crags. The red clay varies from 10 to 30 feet in thickness and reaches inland up to heights of 300 feet, while pebbly giavels with broken shells range up to 470 feet.

In the basin of the Clyde there are certain deposits which were evidently formed during the last stage of the Glacial epoch. The usual succession of these beds is as follows:-

Clyde
lieds $\left\{\begin{array}{l}\text { 3. Sandy clay or sandy gravel. } \\ \text { 2. Fine grey clay witli many perfect shells. } \\ \text { 1. Laminated reddish clay without shells. } \\ \text { Till. }\end{array}\right.$ Hard tough boulder-clay with striated stones.

There is always a layer of laminated, stoneless, and shell-less clay between the till and the shell-bearing clay (No. 2), but its thickness varies from 1 to 18 feet. The clay above is a consolidated mud through which many stones, both rounded and angular, are scattered, but its consistency is not that of boulder-clay, and the stones are not glaciated; the shells which occur in it are generally perfect, and are of northern and Arctic species. These clays fringe the Firth of Clyde from Glasgow westward, and pass up the Kyles of Bute to Loch Fyne; they are also found on the shore of Loch Lomond, but do not anywhere extend beyond 50 feet above the sea.

Inland the last phase of the Glacial epoch is marked by the occurrence of terminal moraines in many of the Highland valleys ; sometines several such moraines occur one above another, and huge blocks of rock are often perched on the top of them as well as on the neighbouring slopes, while the course of the glen above the higliest moraine is swept clear of all such detritus.

\section{Southern Scotland and North of England}

In this area there were three principal centres of dispersion, one in Galloway, whence confluent glaciers moved outwards from the central granitic hills, unother in the Lake District already mentioned (p. 617), and a third on the Hartfell, Ettrick, and Cheviot Hills, from which ice flowed chiefly eastward and southward (see Fig. 202). In each area the northward flow was short, and the main lines of transport were south and sonth-east. Thus Eskdale granite is found all over Lancashire and Cheshire, and boulders from the fells near Shap have been carried not only down the valley of the Iune, but over the Ingleborongh district into Ribblesdale, showing that at one time the ice over-rode hills up to 1500 feet above present sea-level. Another stream of boulders has passed through the Stainmoor pass and through Teesdale to the east coast of Northumberland. ${ }^{2}$ 
The whole of Southern Scotlaud and Northerri England below the level of 1600 feet is more or less covered by boulder-clay, which in many places has the same character as the Scottish till. The larger boulders embedded in this till are striated in situ in the same general direction and with the same firmness and evemness as the strix on the underlying rocks; thus the till of Northumberland may be likened to one vast irregular "striated pavement." The smaller boulders and stones frequently have their longer axes drawn into the line of glaciation, as if by a heavy dragging force noving contemporaneously with the arrangement of the material. At the surface it is often shaped into sow-backs or drumlins stretched in the same direction. All these features of the till are remarkably developed on the watershed among the Bewcastle Wastes, north of Gilsland in Cumberland. ${ }^{3}$

The composition of the till, again, shows that the outcrops of rock lying in the path of movement-all the way from the red rocks of Cumberland, for instance, to the coaly shales of Newcastle - contributed one after the other their quota of material to the mass of the clay. The texture and colour of the till thus constantly varies-it is bright Indian red on the red rocks; leaden-coloured and clayey on the carbonaceous rocks; sandy where the pale Carboniferous sandstones predominate; brown on the Cheviot porphyry; and when it rests on composite formations such as the Carboniferous limestone series, it never remains for half an acre the same. Among the slopes of the higher hills it is thin, loose, local, angular, and almost morainic-looking; in the valleys and low grounds it becomes dense and well-kneaded up, and contains a larger assortment of boulders; in the lower grounds it is often gravelly and much intercalated with seams of sand, gravel, and laminated clay; but it is the same deposit throughout.

In the south-west of Scotland, and especially in Ayrshire, broken marine shells are found in the boulder-clay up to heights of 1000 feet above the sea, and the precise manner of their conveyance against the outflow of the local ice has not yet been explained.

On the coast of Northumberland and Durham, however, there is a newer or upper boulder-clay limited to the maritime districts, and to elevations under 350 feet. It is divided from the till sometimes by stratified sand and gravel, and sometimes by an eroded junction $\backslash$ line. It seems to be the same deposit, very uniform in character, that is found along the sea-board from Aberdeenshire southward, differing from the till by its uniformly reddish colour and the fewness and smallness of its stones. 


\section{Yorkshire and Lincolnshire}

When this northern ice reached the Cleveland Hills in East Yorkshire the mass of it was diverted into the Vale of York and, reinforeed by contributions from the west, it spread out a confused mass of clays and gravels over the Triassic plain as far soutl as York and Escrick, where it has left some remarkable terminal moraines. Another lobe of this ice passed down the eastern side of the Cleveland Hills and along the coast to Flamborough Head.

Soutl of York there is a long and fairly broad area which is almost fiee of boulder-clay, a fact which is not yet fully understood, for there are boulder-clays to the west of it about Wakefield, Barnsley, and Doncaster, and one would have expected these to extend into the plains west of the river Trent.

Boulder-clays occur in East Yorkshire near the coast and over the greater part of Lincolnshire, but they are of two different types; those found on the eastern side of the Chalk Wolds being reddish and purple clays with intercalated marine deposits, while those on the western side are grey and more or less chalky clays.

The Chalky Boulder-clay covers the central parts of Lincolnshire, spreading over the Jurassic Clays east of Lincoln by Tattershall, Horncastle, Wragby, and Market Rasen; and the increase in the amount of chalky matter in the direction of the Chalk Wolds is particularly noticeable, till near these hills it becomes a stony Chalk-marl, and has been burnt for lime in some places. There is, however, very little of it on the Wolds themselves, though its occurrence at Kelstern, near Louth, proves that it originally spread over all levels below 400 feet. 4

It oceurs also in South Lincolnshire, not only on the border of the Fenland district, but on the higher ground to the west, and appears to have formed a continuous mantle which covered even the summit ridges of the Jurassic escarpment and passed southward through Rutland, Northampton, and Huntingdon. The boulderclay of the high ground between Stamford and Grantham is remarkable for containing huge masses of Lias Marlstone and Lincolnshire Limestone, which have been carried many miles from the spots whence they were quarried by the ice. These blocks appear to have come from the west and north-west. Carboniferous rocks cane from the north-west, and Chalk from the north-east, so that several ice-currents seem to have met in this area.

The boulder-clays of the eastern type occupy the area in Yorkshire known as Holderness, and underlie the whole of the eastern lowland of Lincolnshire. In both cases they and the associated sands and gravels are banked up against an ancient 

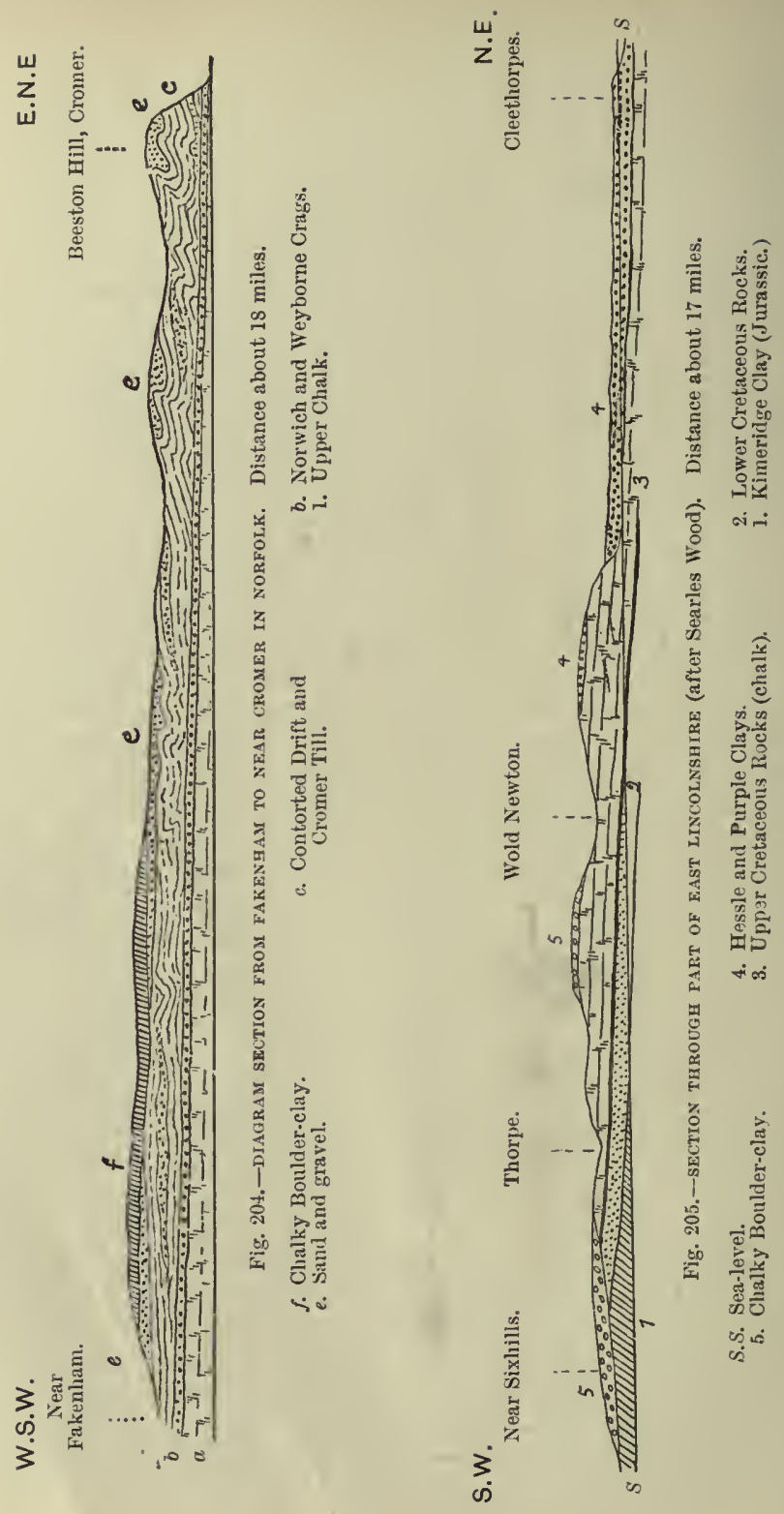
coast-line which is in many places a line of buried cliffs. Such clifl's are intersected by the present coast-line at Sewerby in Yorkshire, and though they are not seen in Lincolnshire their existence is proved by the depth of Glacial deposits found at many places on the east of the clialk-surface. These deposits also enter the valleys of the Wolds, and appear to have mantled the slopes of the hills up to a leeight of at least 380 feet.

The succession of beds seen in the cliffs near Bridlington and Sewerby is as follows, and is from 60 to 100 feet thick:- 5

5. The Sewerby gravels.

4. The Hessle Boulder-clay,

3. The Purple Boulder-clay.

2. The Basement Boulder-elay.

1. Chalky gravel and Buried-cliff Beds.

The buried-cliff leeds are only seen at Sewerby, where they are banked against the ancient coast-line above mentioned (see Fig.

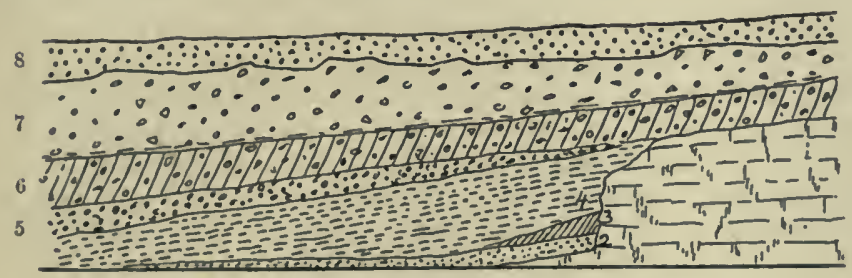

Fig. 206. -CLIFF-SECTION AT SEWERBY (after G. W. Lamplugh).

8. Sewerby gravel.

i. Purple boulder-clay.

B. Basernent boulder-clay.

3. Chalky gravel.
4. Blown sand T Buried cliff

$\left.\begin{array}{l}\text { 3. Rainwash } \\ \text { 2. Pebble beach }\end{array}\right\} \begin{aligned} & \text { Buried } \\ & \text { beds. }\end{aligned}$

i. Chalk

206). From the old beach and the overlying rainwash hones and teeth of the following Mammals were obtained: Elephas antiquus, Rhinoceros meroni, Hippopotamus amphibius and Hycrna crocuta. Elsewhere the chalky gravel appears to form a nearly continuous basal bed. The Basement Clay is of a greenish-grey colour, is sometimes 30 feet thick, and includes twisted layers or patches of sand which contain marine shells; no fewer than 110 species have been found, and among them are some which no longer live in British waters, such as Nucule Cobboldire, Tellina obliqua, Astarte borealis, Fusus spitzbergensis, and $F$. Sarsi.

The Purple and the Hessle boulder-clays have the same characters as in Lincolnshire (see below). The commonest stones in these and the lower clay have been derived from the Carboniferous rocks to the northward, but some have come from the Cheviot Hills, 
others from Teesdale and from Cumberland, while a few are identical with rocks in the south and west of Norway.

In Lincolnshire the basement-beds are nowhere visible, but borings prove that there is always a bed of chalk-rubble at the bottom, from 2 to 8 feet thick, and that this rests on a floor of Chalk which is about 80 feet below sea-level along the present coastline. The thickness of the overlying deposits is from 60 to 100 feet, and they are of two kinds, (1) a lower clay of a purplish brown colour (the "Purple Clay"), containing stones and boulders both large and sinall; (2) an upper clay (the "Hessle Clay") of dull red colour mottled with ashen grey, containing many small stones, pellets of chalk, and bits of coal, but few large boulders.

Near the border of the Wolds patches of sand and gravel are frequent, often resembling beach deposits, and containing many marine shells, some of which are perfect, but most are broken. They include Mya truncata, Corbula gibba, Mactra subtruncata, Tellina balthica, T. lata, Cardium edule, Cyprina islandica, Venus gallina, and (at Croxton) Corbicula fluminalis, which is also abundant at Kelsey in Yorkshire. At Kirmington, and about 80 feet above sealevel, an interesting deposit of laminated silk or warp occurs containing Foraminifera, Rissoa ulvoe, Scrobicularia plana, and other bivalves; it resembles the warp formed between tide marks on the present coast, and is overlain by 10 or 12 feet of beach shingle. The occurrence of such undisturbed marine silt in association with the bonlder-clays and marine gravels is of much importance. ${ }^{6}$

The correlation of the beds above described with those of more southern counties and the relation of the eastern to the western deposits are debated questions, but two opinions have been expressed, and a third view is also possible. (1) The eastern series may be newer than the western (Chalky Boulder-clay), and therefore later than any deposit in East Anglia; (2) the eastern series may be the older of the two and equivalent to the Lower Glacial of Norfolk ; (3) the eastern and western clays may be of nearly the same age but formed by different ice-streams, the one coming from the north and north-east, the other fron the north-west.

\section{East Anglia}

In the north-east of Norfolk, where the inost complete sections of the Lower Glacial Beds are found along the coast, the following succession of deposits can be recognised, but there is no place where they can all be seen in vertical succession :-

The Upper or Chalky Boulder-clay.

Lower Group $\left\{\begin{array}{l}\text { Contorted Drifts (loams and sands). } \\ \text { Brown Boulder-clay (Cromer Till). } \\ \text { Aretic plant bed and Leda myalis bed. }\end{array}\right.$ 
Above the Cromer freshwater beds and below the Glacial deposits there are two discontimnons beds which appear to be the oldest Pleistocene Beds in Norfolk.

The Leda Myalis Bed is only found between Old Hythe and Cromer, for soutl of Cromer it either thins out or is cut off by the boulder-clay. The bed consists of fine current-bedded loany sand, with thin seams of loam and gravel. The fossils are marine, and indicate a depth of 5 or 10 fathoms, as some of the bivalves occur with the valves mnited in the position of life. All the Mollusca yet found (nineteen species) belong to living species, and they include two characteristic crag shells, Neptunea antiqua and Tellina obliqua. One of the best exposures is at Runton Gap, near Cromer, where Leda myalis, Mya arenaria, and Astarle borealis may be found in position of life, and the bed is $\mathbf{1 5}$ feet thick.

The Arctic Freshwater Bed was first described in $1880^{7}$ by Mr. C. Reid, who then distinguished it from the Forest Bed, and llaced it in the Pleistocene Series, because the plants it contains indicate a great change from the climate of the earlier bed. Trees seem to have entirely disappeared, and the plants include the dwarf Aretic birch (Betula nana), the Arctic willow (Salix polaris), and mosses which now only live within the Arctic circle. It consists of a layer of clay and loam about 2 feet thick, but is not by any means continuous, liaving only at present been found at three localities on the coast, vi\%. Beeston, Mundesley, and Ostend, near Bacton. At Mundesley it lias yielded freshwater shells, elytra of beetles, and bones of Spermophilus (a squirrel-like creature).

The Cromer Till, where thickest near Happisburgh, consists of two beds of tough grey unstratified boulder-clay, with an intermediate band of finely laminated and ripple-marked clay. The boulder-clays contain fragments of marine shells, witl pebbles and boulders of many kinds of rocks, including gneiss, mica-schist, basalt, red and grey granites, "rhombynporphyr" from Norway, pieces of Carboniferous limestone, and pebbles of hard chalk which have been bored by marine annelids, and subsequently striated.

The Contorted Drift is usually a yellowish marly and sandy clay full of stones, so that it is really only a variety of boulder-clay, but it exliibits a rude kind of stratification, and includes knots, patches, and seams of sand and gravel, and the whole has a twisted, contorted, and kneaded appearance. . Another remarkable feature of the deposit is the occurrence of large tabular masses of chalk, some of which are 20 to 30 feet thick, and from 100 to 180 yards long. This drift contains boulders similar to those in the till below and many broken sliells, the latter being frequent in the 
nests and patches of sand, Tellina balthica, Cardium edule, Cyprina islandica, and Mya arenaria being the commonest species.

Near Cromer the thickness of the Contorted Drift is sometimes as much as 170 feet, and the contortions are very marked, but southward and sonth-westward the deposit passes into a set of loams, sands, and fine gravels. Moreover, the underlying Cromer Till appears to thin out, so that over large parts of Norfolk, Suffolk, and Essex the Lower Glacial Group consists only of sands and gravels, with occasional intercalations of laminated loam or brick-earth. These beds were termed "Middle Glacial" by Mr. S. V. Wood. As they are followed to the higher ground in the western parts of these counties, and to the Chalk-escarpment in Cambridgeshire, they thin out and are overlapped by the Chalky Boulder-clay, which then rests directly on the Chalk.

The Chalky Boulder-clay is an extension of that already described, and has been formed partly from the detrition of the Chalk and partly from that of the Jurassic rocks, materials from the Oxford and Kimeridge Clays being numerous, and derived fossils, such as Gryphrea arcuata, Gryphrea dilatata, Cardinice Listeri, and Belemnites abbreviatus, are not uncommon. In this respect it contrasts with the boulder-clays of the Lower Glacial Group.

This boulder-clay exhibits a fairly uniform character over Norfolk, Suffolk, Essex, Cambridge, Herts, and Middlesex, the most southerly outlier being that on Muswell Hill, north of Highgate; here the clay is of the usual pale colour, and contains occasional fragments of red chalk, which must have journeyed a distance of some 100 miles, for the nearest place whence they could have been derived is Hunstanton in Norfolk. The thickness of this great sheet of boulder-clay is very variable; sometimes only a few feet can be seen, and in other places borings have gone through 100 or 150 feet of it.

Another fact of some importance in connection with the formation of this clay is the occurrence in it of pebbles which have been carried up to a level much higher than that of their source; thus phosphatic nodules derived from the Cambridge greensand have been found at a level of 500 feet above the sea, whereas the outcrop of the parent stratum to the north and west is everywhere under 150 feet.

\section{The Midland Area}

In the counties of Derby, Stafford, Warwick, and Leicester we find the meeting ground of four different ice-lobes (see map, Fig. 203). Around Derby and Nottingham, and thence south- 
east to Leicester, there are two very different kinds of boulder. clay ; the one a reddish clay containing stones of Pennine origin, the other a chalky clay with Chalk-flints and Jurassic debris, derived from places to the north-west. This Chalky IBoulder-clay is clearly the same as that of Lincolnshire, and it is stated to overlie the Pennine Clay, but according to Mr. R. M. Deeley there is also in the Trent valley a still newer reddish clay with Pennine material, which lie calls the Newer Pennine Clay.8

There seens also to have been a dispersion of boulders in different directions from Charnwood Forest before the incidence of the ice from the north-west, for such boulders occur at places in Nottingham and Lincoln, as well as near Leicester and Coventry, that is to the north-east and east as well as the south-east and soutli-west.

In Warwickshire, from near Brounggrove to the north-east of Birmingham for a distance of some 20 miles, there is a line of boulders which have been transported from Wales, often accompanied by blocks of basalt from the Rowley Hills near Dudley. Lastly, in Stafordshire, round Wolverhampton, Canuock, and Ringeley, and even as far east as Lichfield, there are many boulders which have come from the Lake District and the south of Scotland.

\section{Wales and the West of England}

The Glacial deposits of this district are also divisible into two sets, the one set consisting of detritus which has come from the north and has been transported by ice through or over the Irish Sea, while the other set consists entirely of Welsh material and has been carried by the glaciers which issued from the Welsh mountains (see p. 617). The following account of the Glacial Drifts of Lancashire and Cheshire has been compiled mainly from the writings of Mr. Mellard Reade ${ }^{9}$ and Dr. A. Strahan. ${ }^{10}$

The whole of the lower parts of Laucashire, Westmoreland, Cheshire, and North Shropshire, from Coniston and Windermere southward and inland up to heights of 500, and in some places 600 feet above sea-level, is covered by a nearly continuous mantle of boulder-clay, which is only broken in places where Triassic or Carboniferous rise up through it. This boulder-clay, however, is not a solid mass like the till of Scotland and Northumberland, but consists of irregular masses or sheets of stony clay with local intercalations of stratified sand and gravel.

The deposits are in fact very like those of Fast Yorkshire and Lincolnshire, for the lower clays are generally purplish brown, and the upper clays resemble the Hessle Clay in being streaked 
with grey and in containing fewer stones. A good section of these drifts is exposed in the cliffs near Blackpool and is represented in Fig. 205).

Both the boulder-clays and the sands frequently contain marine shells, generally broken, but sometimes perfect, and also abundance of Foraminifera. Moreover, the Gastropod shells are seldom filled with clay or red sand, but generally with a fine white sand or silt which is full of Foraminifera, showing that they have been picked up by the ice from silty shores and sea-bottoms, and these silt-filled shells are just as common in the boulder-clay near Macclesfield, at 600 feet, as they are near the coast. Near Macclesfield, too, there are sands with the same species of shells at a height of 1200 feet above the sea.

The stones and boulders in these clays liave come principally from the Lake District and the south of Scotland. They include granite from Eskdale and gramophyr from Buttermere, other granites from Galloway, rocks from the Borlowdale Volcanic Series, Silurian Grits, and Carboniferous linestones. Mixed with these in smaller' numbers are blocks of Triassic sandstone and flints, which latter must have come from Antrim or from the west of Scotland. The finer material has, however, been largely derived from the Triassic sandstones and clays which underlie the Glacial deposits, and doubtless extend far to the west and north-west below the floor of the Irish Sea.

These deposits fill up and conceal the inequalities of a deeply sculptured pre-Glacial surface. The lakes of Coniston and Windermere are merely the upper ends of pre-Glacial valleys, the lower reaches of which are filled with Glacial drift, and where these old valleys open into Morecambe Bay the valley bottom is probably 200 or 300 feet below the present sea-level, for in Furness one such valley descends to 460 feet below sea-level and is filled with drift.

Southwards these deposits sweep over the 
Cheshire plain into Shropshire and over the lower parts of North Wales up to heights of 400 and 500 feet above the sea; while accummlations of sand and gravel with marine shells occur at still higher elevations, up to heights of more than 1200 feet on both sides of Wales. Thus, on the summit of Moel Tryfaen, a hill overlooking Caruarvon Bay, with a height of 1350 feet, there is an extensive deposit of stratified sand and gravel containing marine shells, more than sixty species having been obtained. Among the most abundant of these are Tellina balthica, Cardium edule, Astarte borealis, Cyprina islandica, and Turritella communis. It is irregularly overlain by boulder-clay, and both deposits contain erratics from Cumberland and Scotland, as well as Chalk-flints which caine probably from Ireland. These flints, as Mr. Mackintosh observes, have travelled to a higher level than their sonree, for the highest parts of the Irish chalk are between 900 and 1000 feet. ${ }^{11}$

Similar shell-bearing gravels have been found by Mr. Mackintosh at heights of 1000 to 1230 feet on the east side of the hills near Minera in Denbighshire; here also Eskdale granite, Cumberland felstones, and Chalk-flints are mixed with the debris of local rocks, and all are well rolled and rounded as if they had formed part of a sea beach. Another similar deposit of shelly sand and gravel occurs at Gloppa, near Oswestry. Within this Welsh area, however, we find tracts and patches of another kind of drift, which is clearly the product of Welsh ice, and wherever the two are in juxtaposition the local drift always lies underneath the deposits left by the northern ice. This is well shown in the cliffs of Colwyn Bay, where the following succession is visible:- ${ }^{12}$

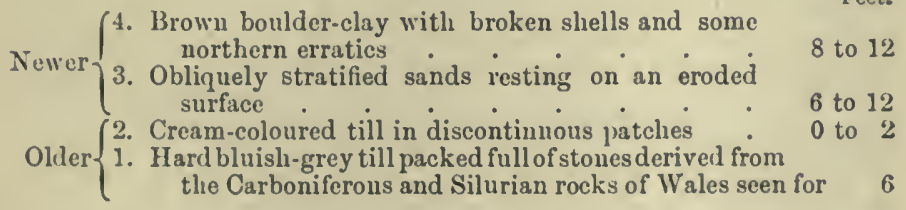

Feet.

Most of Central and Souther'u Wales was covered by another ice-field, its centre of accumulation being the high ground which extends from Plynlimmon southward and eastward through parts of Cardigan, Brecknock, and Carmarthen, and rises in many places to over 1800 feet. The thickness of the ice generated on this area was such that the ice-flow was only partially turned aside by the great mountain masses of the Brecknock Beacons and the Black Mountains, and was actually able to override the northern escarpment of the South Wales Coalfield. Proof has 
recently been found 13 that a great mass of ice passed down the valley of the Towy, but that only its lower part followed that valley westward, the upper ice-layers escaping southward over the escarpment on the sonthern side.

Much boulder - clay occurs in the track of this ice - sheet from heights of 1500 feet downward, that around Plynlimmon being described as a stiff blue clay or till crowded with rock-fragments of all sizes up to blocks of several tons weight. In South Wales much of it is coloured red by the debris of the Old Red Sandstone. In Glamorgan it passes southward into coarse angular gravel, and finally near the coast into roughly stratified gravels with rounded but striated stones. The interest of the last is increased by the fact that they overlie certain raised beaches so that the beachmaterial with its marine shells and the marine sand of the caves with the mammalian bones are thus proved to be of Glacial age. ${ }^{14}$ The shells are of recent species, but the mammals include Elephas antiquus, Rhinoceros mercki, Bison prisus, Hycena spelca, and Ursus spelceus.

In Pembrokeshire, however, there is quite a different set of Glacial deposits. Those of Northern Pembroke between Cardigan and St. Bride's Bay have been examined by Dr. T. J. Jehu, ${ }^{15}$ who found them divisible into (1) a lower boulder-clay, (2) intermediate sands and gravels, (3) an upper boulder - clay. The first is a tough bluish - grey clay containing boulders of Carboniferous Limestone, of rocks from the south-west of Scotland and many Clialkflints, together with many broken marine shells. It occurs in patches up to 600 feet above sea-level.

The sands and gravels frequently contain marine shells which are generally broken, but some are perfect. Most of the species are such as now live in the Irish Sea, but some are Arctic forms, e.g. Trophon clathratus (common), T. scalariformis, Astarte compressa, and A. arctica (=borealis); while the commonest shell is Pectunculus glycimeris. These marine sands occur up to 640 feet.

The upper clay is of a yellowish-brown colour and is best seen in the bays on the coast. The included stones are well scratched and are mostly from northern sources. It is sometimes 40 feet thick, but in places it passes into stony rubble.

In South Pembroke the deposits are similar, ${ }^{16}$ and near Nolton on St. Bride's Bay a mass of brown boulder-clay fills up a valley and forms cliffs which are 50 to 60 feet high; it includes flints and many broken marine shells. Isolated transported boulders also occur all over the country, and their disposition shows that the ice-movement was from the north-west; many come from distant sources. 


\section{Ireland}

Ireland is largely covered by Glacial deposits, alsout which nuch has been written, but no comprehensive acconnt of them lias yet been published. Enough is known, however, to make it obvious that they were accmulated under the same conditions as those of England; those of Northern and Eastern Ireland indeed greatly resemble the drifts of Western England, but those of the central and western districts constitnte rather a different type.

The central plain of Ireland " is largely covered by a widely spread mass of drift, consisting of dark sandy clay with pebbles and blocks and occasional beds of sand and gravel, which are sometimes very regularly stratified. The great majority of the pebbles are romnded fragments of Carboniferous limestone, whence the deposit usually goes by the name of the Limestone Drift. This deposit rests not only on the limestone, but sweeps up on to the flanks of all the hills which rise from the central plain. In sucl case the Limestone gravel (often) becomes largely mingled with the detritus of the rocks of which the hills are made, . . . but gravel alınost entirely composed of linestone pebbles is found up to heights of 1200 feet on the granite momtains south of Dublin. It ipreads across the lower part of this granite range, and runs down by Bray into the county Wicklow, where it is covered by beds of sand and marl that spread througl Wicklow and Wexford over all the low grounds between the mountains and the sea-coast" (Jukes).

In some cases this Limestone Drift overlies a deposit composed entirely of local rocks, as in Glenbarrow, on the northern flank of the Slieve Bloom. Here at a height of 800 feet the river-cliff, 120 feet high, exhibits the following succession :-

Coarse drift with limestone boulders . . . . . . . 50

Fine laminated sind . . 20

Rubbly sand, with angular blocks of Old Red Sandstone, the same rock lying, below

On the north-east coast there are deposits similar in all respect: to the low-level drifts of Lancaslire, consisting of red and brown boulder-clays, with frequent intercalations of sand containing marine shells. Clift-sections of such bed are freqnent aloug the coasts of Antrim and Down, and their marine origin is proved not only by the shells in the sands, but by the presence of Leda permula and Leda minuta with attached valves in bonlder-clay at Woxlburn Glen, near Belfast. ${ }^{17}$

Southwards these reddish clays appear to overlie the Limestone Drift, as seen in the cliff-sections at Killiney and Ballylirnck, sonth 
of Dublin, and they attain a great thickness near Carlow, where a colliery shaft traversed 89 feet of stiff red clay with stones of various kinds overlying 33 feet of Limestone Drift.

Drifts with marine shells occur again in Wicklow and Wexford, chiefly below 600 feet, but on Three Rock Mountain in Wexford they occur at a height of 1300 feet, and include some more southern forms, as Dosinia lincta, Venus striatula, and Venus casina.

No notice of Irish drifts would be complete without a reference to the long winding banks or ridges of gravel which are known as eskers. These ridges often rest on the surface of the other Glacial deposits, and from these the materials composing them have been chiefly derived. They often extend in sinuous lines for many miles, but are confined to the plains and low grounds, not extending above the 400 feet contour. They may therefore be regarded as among the latest of the Pleistocene deposits, but the occurrence of large boulders on these banks shows that ice was still present.

Morainic mounds occur in some of the valleys of the more inountainons regions, and testify to the existence of small valley glaciers during the last stage of the Glacial period.

\section{The Glacial Deposits of Europe}

Ice-extension.-The principal centre of ice-dispersion in Europe was the Scandinavian region. The striated rock-surfaces of Norway and. Sweden show that a great snow-field accumulated on the highlands of those countries, forming ice-sheets which radiated ontwards in all directions from the central axis of the Scandinavian chain. It has also been shown that the ice passed over mountain ridges which are 2700 feet high, so that the icesheet in such places must have been at least 3000 feet thick, and some authorities think 5000 feet a probable estimate of its maximum thickness.

To the west and north-west this ice-sheet must have advanced far into the Atlantic before terminating in ice-clift's like those of the Antarctic ice-sheet of the present day. South-westward it passed into the basin of the North Sea, and is believed to have crossed it so as to impinge upon the eastern coast of England. Southward it certainly crossed the Baltic, which is a shallow sea, and invaded the plains of Holland, Germany, and Russia. Eastward it not only crossed the Gulf of Bothnia, but passed up the Gulf of Finland and over Northern Russia to the Ural Mountains, and south-east into the very centre of the Russian plain (see Fig. 208).

In the North Sea it was met by the independent and smaller ice-sheet formed by the eastern part of the Scottish ice; and the 
sonthern linit of the conflnent and continuous ice at the time of its maximiun extension, whether floating or resting on sea-floors, is shown in Fig. 208. This southern limit passes through the Bristol Chamel and up the valley of the Severn, then across England to that of the Thames, through Belginm by Brussels and Dusseldorf to the foot of the Westplialian Hills; round the Hartz Momntains (which are glaciated to a lieight of 1470 feet) to the Eir. Mountain and the Riesen and Sudeten ranges, passing by Cracow and Vladimir into the basin of the Duieper and out again in an irregular line through Central Russia.

Glacial Deposits.-Many Swedish and German geologists have endeavoured to ednce some definite order of snccession out of the congeries of Glacial deposits which covers such a large part of their respective comntries. Mfost of the Norwegian and Swedish geologists recognise two houlder-clays, a lower bluish clay and an upper clay which is generally of a yellow colour, but in many parts of the region it seems difficult to distinguish them. In Scania, however, the distinction is more clearly marked by the frequent interposition of stratified sands and gravels, and sometimes of laminated clay containing renains of the dwarf birch and other plants. There are also loug continuous ridges of morainic material, one behind the other, which are regarded as marking successive panses in the recession of the ice-sheet.

In Germany the evidence for two distinct boulder-clays seems to be stronger, and some find reason to believe in a third. The Lower "Diluvium" is the most extensive, and is described as a bluish or brownish clay containing many boulders of Scandinavian origin, and it is the southern border of this clay which is shown on the map (Fig. 208). Alove it in many places are stratified deposits, generally sands and clays with occasionally beds of peat ; these contain plant remains and also the bones of Elephas antiquus, E. primigenius, Rhinoceros tichorhinus, Cervus megaceros, and C. elaphus. The plants in these beds are specially remarkable because they include not only pines and firs, but leaves of the aspen, poplar, onk, lormbeam, ilex, Trapa natans, and a water-lily (Cratopleura), the assemblage indicating quite a temperate climate no colder than that of Germany at the present time.

The Upper Diluvium (or boulder-clay) covers Denmark, Schleswick-Holstein, Northern Germany, and the Baltic provinces of Russia, and is associated with mounds and ridges of terminal moraines which nark the final stages in the retrent of the ieeslreet. One sucl ridge has been traced from near Nenstrelitz in Mecklenburg, sontl-eastward to Oderberg, a distance of 35 miles, and probably reaches still farther. Borings have shown that the 


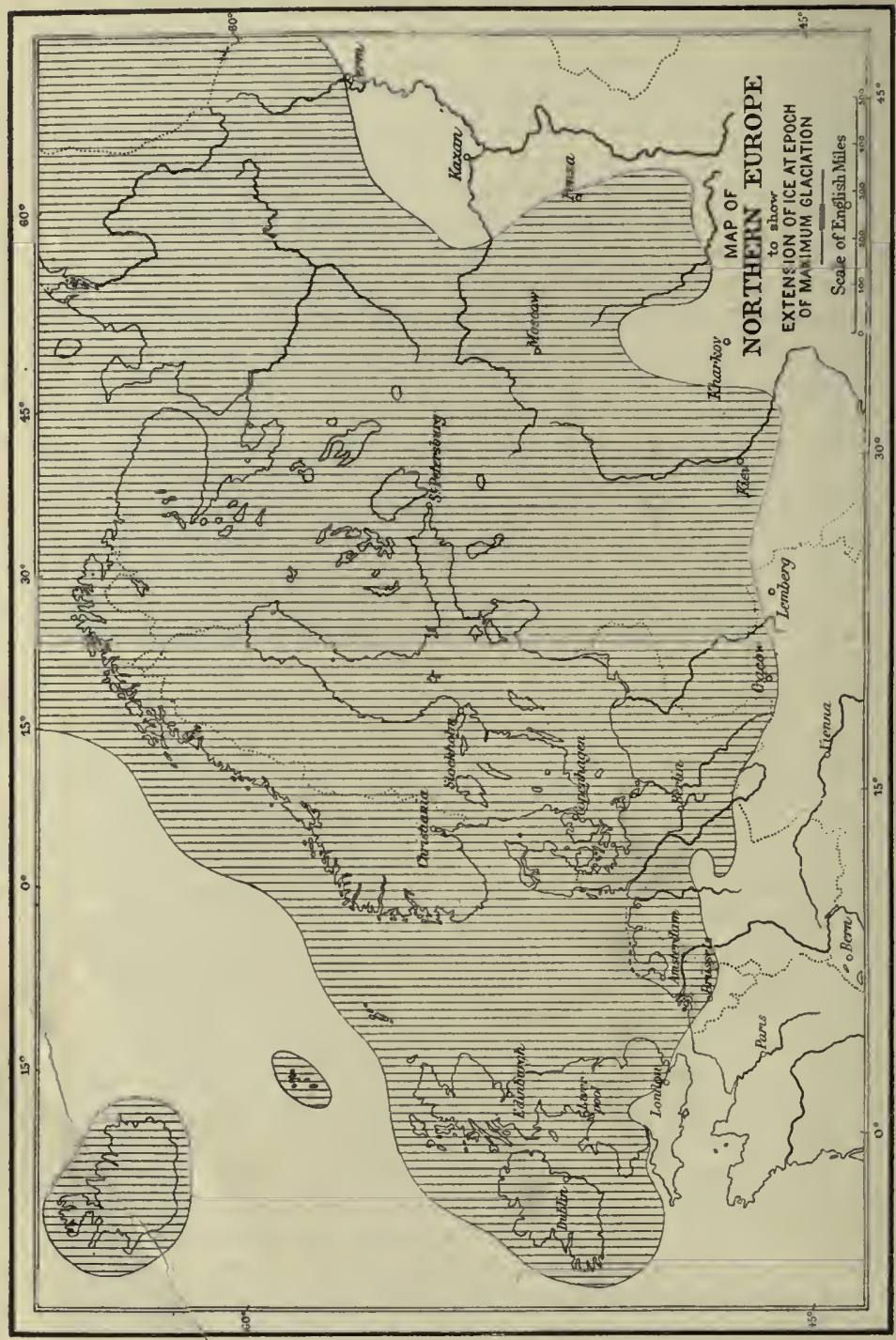

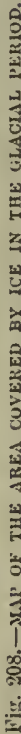


combined thickness of Glacial deposits on the German plain is variable, as might be expected, but that it is sometimes 300 feet and in a few places even more.

The Swiss Glaciers.-The refrigeration of climate which brought Aretic conditions into Northern Europe was also felt in Switzerland and caused a great extension of the Swiss glaciers, till they not only filled their valleys, but coalesced with one another, and spread out over the plains which lie both to the north and south of the Alps. Thus the glacier of the Rhone spread across the plains of Geneva and Neuchâtel onto the flanks of the Jura Mountains, where it left a long line or belt of transported boulders at an average height of 800 feet above the lakes. Similarly the glacier of the Rhine spread out far beyond the Boden See (Lake of Constance), passing northward and eastward into the drainage area of the Danube.

As in Germany so in Switzerland there is evidence of two distinct Glacial epochs or advances of the glaciers, separated by an interval of temperate climate. The older deposits are coarse gravels and a kind of boulder-clay or argillaceous moraine. The inter-glacial deposits are fluviatile gravels and sands with beds of lignite at Diirnten, Utznach, and other places, which yield leaves of plants and trees of the same species as now live at these localities, together with bones of Elephas primigenius, Rhinoceros etruscus, Ursus spelceus, and Bos primigenius. These beds rest in places on the older moraines, and are overlain by newer moraine-stuff.

Of still later date than the last advance of the glaciers are the terraces of lacustrine deposit at 150 feet above the Lake of Geneva, which prove that the lake has been lowered to that extent since the retreat of the ice during the erosion of its valley by the excurrent river (the Rhone).

\section{E. Non-Glacial Deposits}

\section{Classification and Fauna}

Relative Age.-Under this head we group those Pleistocene deposits which have not been accumulated by noving ice and are not interstratified with boulder-clays. The principal deposits of this kind may be catalogued as follows:-
1. Clay with Flints.
2. Plateall Gravels.
4. Lacustrine Deposits.
3. River Gravels.
5. Cave Deposits.
6. Raised Beaches.
7. Alluvial Levels.

These deposits are chiefly found outside the glaciated areas, 
but some of those classed as Platean gravels occur within these areas and overlie the higher boulder-clays; moreover it has been proved that some of the raised beaches and some of the Cave deposits are of Glacial age. Lastly, the assemblage of mammals found in the older river deposits is the same as that which is l'egarded as early Pleistocene (see p. 612).

Again, the older river gravels and the older cavern deposits appear to be of about the same age, and in both the stone weapons of Palæolithic man are associated with the bones of many extinct animals. In some places it seems possible to distinguish two Palæolithic horizons or ages, an older of roughly made implements associated with Elephas antiquus, and a newer of more finished weapons for which the name Mesolithic has been proposed. Some authorities recognise a third age, that in which remains of the reindeer are abundant, associated with a special type of flint implements. If the latter is in real succession and not a mere local variation the Pleistocene (non-Glacial), succession may be tabulated as follows :-

4. Neolithic, the age of domesticated animals.

3. Mesolithic $\{$ the age of the reindeer (Rangifer tarandus).

2. Mesolithic the age of Elephas primigenius and Rhinoceros tichorhinus.

1. Palæolithic, the age of Elephas antiquus.

In France another scheme of classification is employed, all the rougher implements being called Palæolithic, but classed according to type and finish in three groups, the Chelléan or Acheulian, the Moustérian, and the Magdalenian. Of these the first corresponds with the restricted Palæolithic in the above table, and the two latter with the Mesolithic.

Fauna.-The mammalian fama consists first of a number of species which are common to all or most of the phases of the period, and secondly of certain groups of species which are either restricted to one epoch or phase, or are much more abundant in the deposits of that phase. Again, many of the Pleistocene animals are survivals of the later Pliocene fauna, and of these some became extinct before Neolithic time, and some still continue to exist either in Europe or Asia.

The oldest assemblage (Palreolithic) includes Elephas antiquus, Rhinoceros mercli, Rh. leptorhinus, Hippopotamus major, Ursus speloeus, Machcerodus latidens, and Trogontherium Cuvieri.

The Mesolithic implements are associated with Elephas primigenius, Rhinoceros tichorhinus, Cervus giganteus (=megaceros), C. elaphus, Felis spelcea, Canis lagopus (Arctic fox), Equus caballus, Saiga tartarica (an antelope), Arctomys marmota (the Marmot), and species of Spermophilus. 
The Neolithic fauna is very different from the above, and includes only one extinct species (Cervus giganteus), though there are, of course, many animals which have sulsequently become extinct in Britain, such as the reindeer, brown bear, wolf, wild boar, and beaver.

Paloolithic man was a hunter only; Neolithic man was a herdsman and agriculturist, and he introduced several domesticated animals, such as the dog, sheep, goat, pig, and short-horn cow.

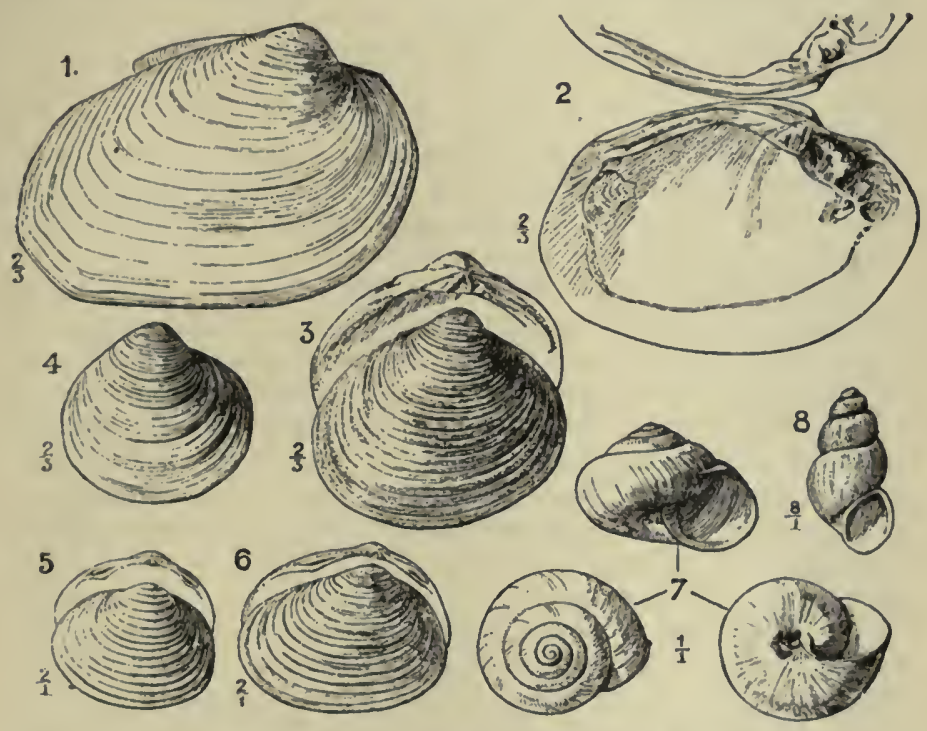

Fig. 209.-PLEISTOCENE LAND AND FRESUWATEK SHERLS WHICH AHE NOW EXTINCT IN BRITAIN.

(Reprorluced by permission of Mr. B. B. Woodward and the Council of the Geologists' Association.)
1, 2. Unio littoralis.
3, 4. Corbicula fluminalis.
5. Pisidium astartoides.
B. Pisidium amnicum.
7. Helix (Eulota) fruticum.
s. Hydrobia marginata.

The mollusean fauna of the older Pleistocene deposits, i.e. the fauna of the freshwater deposits, is also interesting, for it inclndes a few extinct species and a certain number which no longer live in Britain, though most of them still exist in Europe or Asia. Prominent among these is Corbicula fhuminalis, a species which is extinct in Europe but still lives in the rivers of North Africa; another is Vivipara diluviana, believed to be entirely extinct, as is 
also the allied species $V$. clactonensis; Neritina grateloupiana, found in the Thames valley, is also extinct though allied to the modern $N$. danubialis. A common shell in the older river gravels is Unio littoralis, which is extinct in Britain but still living in Europe. Among land shells there is Helix fruticum, now only found alive in Central Europe, and Clausilia pumila, found at Barnwell, near Cambridge, but now only living in parts of Northern Europe and in Silesia. Hydrobia marginata and Pisidium astartoides are other species found in British Pleistocene deposits but not now living in Britain. These and some of the above are shown in Fig. 209, for the use of which I am indebted to Mr. B. B. Woodward.

\section{British Deposits}

As it would be impossible within the limits of this volume to give anything like a comprehensive account of the clays, gravels, cave-earths, raised beaches, and other non-Glacial deposits in Britain, only a few examples will be described.

Clay-with-Flints.-This is a deposit or accumulation of indefinite age, occuring at high relative levels and mainly composed of materials derived from the Eocene clays and sands; hence it only occurs in the south of England and the nortli of France.

Its typical form is that of a stiff reddish-brown clay containing a large number of flints, the majority of those in the lowest layer being entire unworn Chalk-flints, while those in the higher part are angular pieces of broken flints, with some quartz pebbles and fragments of ironstone. In some districts there is also a large percentage of sand in the clay. The whole deposit lies irregularly on the Chalk, from which the unworn flints have been derived, and by the solution of which it has been let down into hollows, funnels, and pipes. This clay is often overlain by, and sometimes it seems to pass laterally into, thick deposits of loam, brick-earth, sand, and gravel, all of which may have been derived from the destruction of the Eocene Beds. ${ }^{18}$

Plateau Gravels.-This name has been given to various unstratified gravels in the southern, eastern, and midland parts of England, because they occur on the plateaus out of which the moder'n river-valleys have been excavated. In Norfolk and Suffolk they generally rest on the Chalky Boulder-clay, and consist mainly of large rolled and battered flints whence they have been called "Cannon-shot Gravels."

In the Midlands they rest on Jurassic rocks and contain a mixed collection of stones, most of which have been derived from more or less distant sources. Thus around Oxford the Plateau drift contains quartzite-pebbles from the Bunter, Carboniferous 
sandstones and cherts, Liassic stones, Red Chalk, and varions igneous rocks. The assemblage is in fact that found in the Glacial deposits to the north, and Mr. Pocock is of opinion that the gravel is of Glacial age and is in part a decalcified Glacial deposit. ${ }^{19} \mathrm{He}$ admits, however, that at lower levels, 130 to 200 feet above the rivers, it is sometimes rudely terraced as if it had been redistributed by fluviatile action.

In Berkshire and East Oxfordshire the constituents are chiefly subangular flints and materials derived from the Eocene Beds such as flint-pebbles, quartz-pebbles, sarsen-stone, and ironstone. Mr. Osborne White also regards the gravel as of Glacial age, but as belonging to more than one Glacial epoch, and he remarks that "the Plateau and Valley gravels are very often inseparable; their more level spreads appear to be but the higher and lower members of a single graduated series, the steps and lialf-landings of a ruined stair way that was never complete." 20

River Gravels.-The manner in whicl disconnected tracts and terraces of gravel, sand, and loam have been formed and left at various levels in a river-valley is explained in all text-books of Physical Geology. They represent different stages in the excavation of a valley, those at the lighest level above the existing stream being of course the oldest, and the others newer in proportion as they are nearer to the level of the modern alluvium.

The deposits in the valley of the Thames nay be taken as an example of such accumulations. In the higher parts of the valley tracts of gravel are found at various heights, now on one side of the river, now on the other; three stages or teriaces can often be distinguished, the highest being about 40 feet above the level of the river. From this highest terrace few bones have been obtained, but at the lower levels land and river shells, with remains of Elephas primigenius, Elephas antiquus, Rhinoceros tichorhinus, Bison priscus, Rangifer tarandus, Equus caballus, Canis lupus, and Ursus arctos are frequently found. Between Windsor and London the outspreads of gravel become wider and more continuous, but the surface of the older parts still rises to 30 , and even 45 feet above the river, and the shells are still of fluviatile species. Hence we may conclude that when these gravels were deposited the Thames had a much longer course than it has at present, and that this part of the valley was then far inland, otherwise the beds would be at a lower level and the shells would be estuarine.

Below London, at Ilford, Grays, Crayford, and Erith, there are a series of gravels, sands, and loams which rise to 25 or 30 feet above the river, but are nearly 60 feet above the base of the alluvium at Erith. These beds have yielded the mammalian remains 
mentioned above, and it is only at these places that Rhinoceros leptorhinus and $R$. tichorhinus have been found together. ${ }^{21}$ The presence of Rhinoceros megarhinus (a Pliocene form) and the absence of the reindeer (Rangifer tarandus) are regarded as indications of the antiquity of the deposits. Between fifty and sixty species of land and freshwater shells have been found, several of which no longer live in Britain, e.g. Cyrena (Corbicula) fluminalis, Unio littoralis, Pisidium amnicum, Hydrobia marginata, and Helix fruticum. A worked flake proving the presence of Man has also been found in the lower brick-earth. Many flint implements of Palæolithic types have also been found in high-level gravels at Acton and Stoke Newington on the north side of London.

The district now drained by the river Cam contains an interesting series of river deposits which bear testimony to the successive changes that have taken place in the drainage system of this area. ${ }^{22}$ The oldest line of gravels has no connection with the modern river-valley, but crosses it nearly at right angles near Cambridge. Patches of gravel in the hill-valleys near Balsham testify to the action of streams where none now exist, and these seem to have united to form a river which ran by Wilbraham, Quy, Cambridge, Girton, Oakington, Long Stanton, and Willingham. The deposits it has left now form long gravel-capped ridges, the base of the gravels where intersected by the Cam being about 40 , and their surface sometimes 60 feet above the modern alluvium. These fluviatile gravels appear to terminate abruptly near the fens of the Bedford Level, but were probably originally continuous with the gravels at Chatteris, Doddington, and March, which form similar ridges rising above the general level of the fens which surround them, and evidently mark the estuarine channel of a river which traversed the country when it stood at a somewhat lower level, and before the Fen-land existed. The shells found at March are chiefly marine, but include Corbicula fluminalis.

Of deposits which bear a definite relation to the modern river Cam, remains of three terraces can be recognised. The highest of them runs by Trumpington and Barnwell, about 25 feet above the alluvium, and has yielded a number of mammalian bones and teeth, with a still larger number of shells, among which Corbicula fluminalis, Unio littoralis, and Hydrobia marginata occur. These three shells do not occur in the lower terraces, which are respectively about 15 and 8 feet above the alluvium near Cambridge.

Lacustrin $\Theta$ Deposits.-Two notable instances of such deposits occur in the east of England. That of Hoxne, near Diss in Suffolk, is perhaps the best known, pits at that place exposing over 30 feet of lacustrine beds without reaching the bottom; the lower beds are 
marls containing bones of mammalia, freshwater shells, and remains of plants; these are overlain by brownish clay or brick-earth enclosing flint implements of a Palcolithic type. The plants include leaves of Salix polaris, S. myrtinites, and Betula nana (all Arctic forms), with others of more southern character, but the flora somewhat resembles that of modern Iceland. ${ }^{23}$

Similar deposits occur in a broad depression south of Hitchin in Herts, and consist of alluvial marls and silts resting on boulderclay and overlain by brick-earth with implements of Mesolithic type. ${ }^{24}$ The flora, however, does not include the Aretic species, and indicates a more temperate clinate.

Cave Deposits. - The origin of caves and the formation of the deposits found in them is explained in most books on Physical Geology. Many such caves have now been explored in England and Wales; some of them have served as dens for bears or for

W.

River Caln.

South of Trumpington.

E.

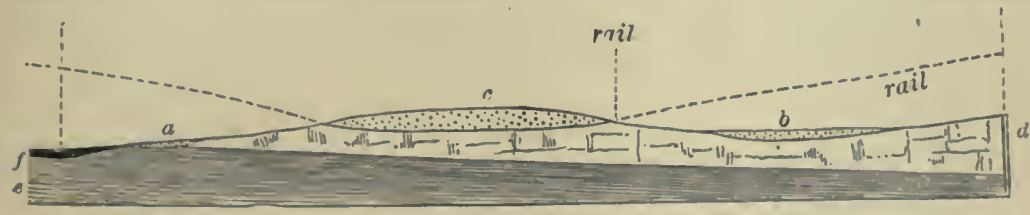

Fig. 210.-section across tue trusiplNaton Gravels. Distance 2 miles.
a. Lowest terrace.
b. Second terrace.
c. Highest terrace.
d. Chalk marl.
e. Gault.
f. Alluvium.

hyænas, and the bones of other animals belong to carcases which have been dragged in by these creatures. At other times they have served as shelter's for man, whose occupation of them is proved by the frequent occurrence of stone implements-Palæolithic in the lower beds, and sometimes Neolithic in the higher. The caves of Creswell Crags in the Magnesian limestone on the border's of Derby and Notts afford good examples of such deposits. ${ }^{25}$ In Robin Hood Cave the beds found were:-

5. Stalagmite united to the roof

Feet.

4. Breccia with bones and implements. . . . . 0 to 3

3. Cave earth with bones and implements . . . . 2 to 4

2. Red clayey sand with bones . . . . 2 to 4

1. Light-coloured sand with blocks of limestone fallen from the roof.

The lowest sand yielded no organic remains, but the red sand contained bones of many animals, all of them scored with the teeth- 
marks of the creatures which had dragged thein into the cave, and that these were hyænas is proved by the abundance of hyæna bones and teeth belonging to individuals of all ages from cubhood upwards. Flint implements are rare in the sand, but abouud in the overlying cave earth, some consisting of flint and others of quartzite, but all of Palæolithic form; bones of the same animals occur in this layer. Lastly, in the breccia above are flint and bone implements of the Neolithic type.

Some caves in the Vale of Clwyd (North Wales) have been explored by the late Dr. Hicks, and are important from their position in relation to the local Glacial deposits. ${ }^{26}$ They are known as the Ffynnon Beuno and Cae Gwyn caves, and are situate in a small valley or ravine on the east side of the Vale at a level of nearly 400 feet above the sea. The valley has apparently been filled with Glacial drift of the low-level Lancashire type (see p. 629), and one of the entrances to the Cae Gwyn cave was found to be buried beneath a bank of stratified sand, gravel, and boulder-clay, the lower layers of which entered the cave and overlay the bone-bearing cave-earth. The section at this entrance was as follows:-

Reddish boulder-clay with sandy seams

Feet. Ins.

$\begin{array}{lllllll}\text { Reddish boulder-clay with sandy seams } & \cdot & \cdot & \cdot & : & 6 & 4 \\ \text { Sand with boulders and seams of clay } & : & : & 3 & 9\end{array}$

Gravelly sand with fine laminated sand below : $\quad \begin{array}{lll}\cdot & 3 & 5\end{array}$

Red laminated clay . . . . . . . . $\quad . \quad 10$

Cave earth with bones and flint implements . . . 2 to 5

Dr. Hicks inferred that the contents of the cave were pre-Glacial, but this was not proved by the evidence, and the assemblage of mammalia is that of the later Palreolithic time, the commonest species being Rhinoceros tichorhinus, Elephas primigenius (the mammoth), and Rangifer tarandus (reindeer). They must, therefore, be regarded as inter-glacial, but anterior to the submergence which enabled the northern ice to travel so far southward.

Another important cavern is that known as Kent's Cavern, neat Torquay in Devon. This was explored by Mr. Pengelly with assistance from the British Association, and classified collections of its contents may be seen in the museums at Torquay, South Kensington, and Oxford. Where the succession was complete it read as follows :-

5. Black mould.

4. Granular stala gmite (5 $\mathrm{fe}^{-1}$ ) with some bones.

3. Cave earth with many bones and Palæolithic implements.

2. Hard crystalline stalagmite (6 to 10 feet) with bones of bears.

1. Breccia with bones of bears and rude stone implements.

The cave seems to have been first occupied by bears and 
occasionally by men of early Palreolithic race. In the cave earth (No. 3) liyana bones are the inost abundant, but remains of twentyfive other mammals were found, including Elephas primigenius, Rhinoceros tichorhinus, and Rangifer tarandus. With these were associated flint implements of two recognised Mesolithic types and a few tools made of bone. This deposit evidently represents a long period of time, and is covered by the upper stalagmite containing remains of hyæna, mammoth, fox, and horse.

Raised Beaches.-Raised beaches and sea-nargins occur along many parts of the British coast-line. The beaches consist of sand and gravel, irregularly stratified, and often containing drifted shells, sucl as may be found on modern shores. Deposits of this kind occur at Brighton and westward along the southern part of Sussex as far as Portsdown Hill, the highest level at which they are found being about 130 feet above the sea. Inland they are banked against an old line of cliffs, the position of which is shown in Fig. 173. Raised beaches exist also at Portland Bill, where the highest part of the deposit is 50 feet above sea-level, and at many places round the coasts of Devon and Cornwall.27 All these are probably contemporaneous with the raised beaches of South Wales (see p. 632), which are older than the local Glacial deposits, and in fact of meso-Glacial age.

On the Scottish coasts raised beaches and lines of cliff are found at various successive levels between 25 and 100 feet above high-water mark, four or five sometimes occurring one above another: These are of more recent age, the highest being contenporaneous with latest moraines.

Alluvial Levels.-These are marshy flats formed of the deposits left by the flood-waters of a river; they border the actual channel of the river and widen out in the lower part of its valley, till near the river's noutl they often form wide levels or narshes, which are partly of fluviatile and partly of marine origin. The depth of alluvial natter which occupies the ancient valleys of our rivers near their mouths is sometimes very great; thus at Sheerness, and also at Upchurch, near Sheppey Island, borings have proved 77 feet of such alluvium. In the Essex marshes there is sometimes 50 feet of alluvial matter. At Yarmouth there is said to be 170 feet, and in the valleys of the Yare and Wensum there appears to be sometimes 60 or 70 feet of alluvium between the present surface and the chalk which lies at the bottom of the valley.

Besides the deposits above meutioned which lie within rivervalleys, there are other tracts round our shores which have once been bays and inlets of the sea, and are now filled principally with marine silts and clays, though layers of peat with trunks of 
trees are frequently intercalated with the silts, and mark pauses in the process of silting up. Many such tracts pass beneath the present beaches, and were evidently once nuuch more extensive than they are now. Such are the marshes near Fleetwood, in Lancashire, the Bridgewater Levels in Somerset which pass beneath the Bristol Channel and must formerly have extended far down this estuary, the Pevensy Levels in Sussex, the Romney marshes in Kent, the Fens of Cambridge and Lincoln, and the marshes of the East Lincolnshire coast.

\section{Continental Deposits}

The cave earths and river deposits of France and other continental countries do not differ in any essential respect from those above described, and the French classification of them according to types of flint implements has already been mentioned (p. 638). Here, therefore, it is only necessary to describe such deposits as differ from anything existing in Britain. Of these the two chief are (1) the Loess, (2) the post-Glacial deposits of the Baltic area.

The Loess.-This deposit is found in the north-east of France, and in the valley of the Rhine as far south as Basle, over parts of Southern Germany, the lower parts of Bohemia, Moravia, Hungary, and Galicia, up into the Carpathian Mountains, and also through Poland and Silesia over the plains of Southern Russia. Though thickest in the valleys, it also extends onto the slopes of the liills and reaches up to levels of 2000 and even 3000 feet, but is there mingled with local detritus.

Loess is a fine yellowish or brownish argillaceous material, similar to some of the yellow loams which occur in fluviatile deposits, but it is unstratified and has a marked tendency to break along vertical planes and thus to form vertical walls. It is always more or less calcareous, and often contains calcareons concretions, but the upper part is generally decalcified. It appears to be a terrestrial deposit, for the fossils it contains are almost entirely land-shells and mammalian bones; freshwater shells being of rare occurrence. The commonest shells are Helix (Hygromia) hispida, Succinea oblonga, and Pupa muscorum.

Diverse views have been held with regard to the origin and the age of the loess; some have thought that it resulted from the blocking of the great rivers flowing from Central Europe, their waters being ponded back by the northern ice-sheet and large lakes thus formed. Others with more reason regard it as an æolian deposit forned during an epoch of dry cold ; that it was, in fact, an accumulation of dust carried by the wind and deposited on grassy steppes like those of Southern Siberia. This has been 
confirmed by the discovery of a steppe-fauna in the loess at Thiede in Brunswick and at Westeregeln in Prussia. This assemblage includes some northern forms, such as Elephas primigenius, Cervus tarandus, and Ovibos moschatus, associated with species that now live on the Siberian tundras such as Saiga tartarica, Myodes torquatus (a Lemming), Arctomys bobac (a Marmot), Lagomys pusillus (the tailless hare), Alactatus jaculus (a Jerboa), and several species of Spermophilus.

With regard to age it has been considered to be entirely postGlacial or late Glacial, but the evidence tends to favour the view that its formation extended over a long period of time, that its lower parts are what may be termed meso-Glacial and contain flint implements of Mesolithic types, while its higher parts are late Glacial and locally post-Glacial.

Deposits of the Baltic Region.-During the final retreat of the Scandinavian ice-sheet, the sea gradually reoccupied the trough of the Baltic, together with parts of Southern Sweden, a large part of Finland, and a small part of Russia between the Gulf of Finland and the White Sea. The Swedish geologists Munthe and de Geer assume that this was due to a concomitant subsidence, but it is quite as likely that the ice-sheet had occupied the place of the sea, which simply returned into the area as the ice retired.

The deposits of this sea are laminated clays containing Yoldia arctica, $Y$. hyperborea, Pecten islandicus, Sipho togatus, Trophon truncatus, Natica affinis, and other boreal forms which are only now found in the Arctic Ocean; hence they have been called the deposits of the Yoldia Sea. They do not occur in Germany, but are found in the south of Sweden, and thicken northwards till they attain a thickness of over 800 feet in Angermanland, so the conditions must have lasted a considerable time.

This geographical phase was brought to an end by an uplift of the region which not only raised the area north of Lake Onega, but also united Sweden to Denmark and converted the Baltic basin into an enclosed sea which quickly became a freshwater lake. This has been called the "Ancylus Lake" because Ancylus fluviatalis is a common fossil in its deposits, associated with Limnac ovata, Planorbis contortus, Bithinia tentaculata, and other freshwater shells; these deposits rest unconformably on the Yoldia Beds.

This phase was terminated by a subsidence which was greater on the western than on the eastern side, allowing the waters of the North Sea to flow freely into the Baltic area, so that the freshwater lake was quickly converted into a gulf of the sea. Moreover the opening must have been wider than it is at the 
present time, for the gulf was completely filled with salt water, and from the abundance of Littorina littorea and $L$. rudis in the grey clays left by these waters it has been called the Littorina Sea. The present conditions of brackish water with a limited and stunted fauna have been produced by a second elevation of the area.

The Ancylus Lake did not extend so far west as Christiania, where the succession of shelly clays has been described by Sars, Kjerulf, Öyen, and Brogger 28 ; the last-named recognising the following series :-

$$
\begin{gathered}
\text { Post } \\
\text { Glacial }\left\{\begin{array}{l}
\text { 6. Scrobicularia Clays with S. piperata. } \\
\text { 5. Tapes Beds with T. pullastra. } \\
\text { 4. Cardium and Ostrea Beds with C. edule. }
\end{array}\right. \\
\text { Late } \\
\text { Glacial }\left\{\begin{array}{c}
\text { 3ya Beds with Mya truncata, Mytilus edulis, Cyprina } \\
\text { islandica, Tellina baltica, etc. } \\
\text { 2. Arca Clays with Arca glacialis and Yoldia lenticula. } \\
\text { 1. Yoldia Clays with Y. arctica, Leda pernula, etc. }
\end{array}\right.
\end{gathered}
$$

Of these numbers 1 and 2 were formed during subsidence and correspond with the Yoldia Clays of Sweden. The Mya Beds were formed during the subsequent elevation and occur at a little over 200 metres above the sea (660 feet). The newer deposits range from 80 metres (260 feet) to sea-level, and the land appears to have been rising all the time.

\section{F. Some Phases of Pleistocene Geography}

The history of the Glacial epoch has yet to be written, for geologists are not yet agreed as to the interpretation of the records on which such a history must be based, or as to the causes which produced such a great change in the climate of Europe.

So far as we know there are only three sets of causes which could have wrought such a change of climate; these are (1) cosmical causes affecting the whole globe; (2) geographical changes involving the connection or disconnection of continents, and the consequent divergence or introduction of marine currents; (3) alterations in the arrangement of the areas of high and low barometric pressure, affecting the direction of prevalent winds.

The cosmical causes have been advocated by the late James Croll, who published a book on the Cause of the Ice-age in 1891, but his views have been controverted by Professor Newcombe and Mr. E. P. Culverwell. The possible geographical causes were discussed by Lyell, who argued that the elevation of land in the Arctic regions would tend to refrigerate the northern hemisphere, and that if continuous land existed between Labrador and the British Isles the climate of Northern Europe would probably become colder. Others again have suggested geographical changes 
which would alter the course of the Gulf Stream, but all these ideas are unproved hypotheses.

The alteration of meteorological conditions as a cause of climatal change has recently been discussed by Mr. F. W. Harner, ${ }^{29}$ who points out that the winds are an important factor in determining the distribution of climatal zones, and that existing deviations of the monthly or yearly isotherins from the normal are coincident generally with the direction of the prevalent winds. "The winds blow in a direction more or less parallel to the isobars; the latter group themselves ronnd centres of ligh and low pressure. ... Anomalous weather is dne to some unusnal arrangement of these areas; similarly former cases of anomalous climate can only have occurred when meteorological conditions were favonrable.

"During the Glacial period the regions covered by ice might liave been, to a greater or less extent, anticyclonic at all seasons, low-pressnre systems prevailing at the same time over the warmer regions immediately to the sonth of them and over the adjoining oceans. The relative positions of areas of high and low barometric pressure, the direction of the prevalent winds, and the consequent distribution of climatic zones would in such a case have differed from those of the present time."

The prevalence of south-westerly winds over the British area at the present time is due to the fact that the centres of cyclonic storms generally pass from the Atlantic to the north or north-west of onr islands. Under the conditions above inagined they would pass farther to the south, bringing oceanic winds over the Sahara and the Mediterranean Sea, while easterly winds wonld prevail over Britain. It lias already been mentioned that the shell-banks of the Suffolk and Norfolk Crags afford actual evidence of such easterly winds during the later part of the Pliocene period. Further, as Mr. Harmer points out, "the diversion of the prevalent winds of the northern part of the north Atlantic from a southwesterly to a south-easterly direction wonld have tended to divert the Gulf Stream, or what remained of it, towards the American coast." This abstraction of the Gulf Stream would have an enormous effect on the climate of Western Europe, equivalent, according to Dr. Croll, to a lowering of the mean annual temperature of London by $40^{\circ} \mathrm{F}$.

With regard to the actual difference in the climate of Northern Europe at the time of the greatest extension of the ice, Mr. C. Reid has estimated that the average temperature of the air along the southern margin of the ice-sheet was not higher than freezing point, and that the mean annnal isotherm of $38^{\circ} \mathrm{F}$. must then have passed throngh the soutl of England and across Central 
Europe in an oblique direction to the northern shores of the Black Sea; in other words that the mean annual temperature was $20^{\circ}$ lower than it is now along this line. ${ }^{30}$ He adds that "the Arctic plants and animals found fossil in Britain point to a similar conclusion, for the same species now flourish in a climate fully $20^{\circ}$ colder than that of the lowlands of Britain."

Of the geographical changes which took place during the Pleistocene period within the European area some have been indicated in the preceding pages, but a brief summary of the probable sequence of events may here be given, the reader being warned that I only express the views of those who seek to avoid extremes and to reconcile the different inferences which have been drawn from the facts.

At the beginning of the period, i.e. at the close of Pliocene time, the British Isles were broadly united to the continent across the English Channel and across the southern part of the North Sea to Holland and Belgium. The Rhine discharged itself into the North Sea Gulf near the coast of Norfolk, and the height of Eastern England above sea-level was about the same as at present. The western parts of the British region were, however, at a much higher level than they are now, and Ireland may have been broadly united to Scotland and England, though possibly a deep narrow estuary, receiving a river from the north, lay between Ireland and Wales.

The first formation of glaciers in Ireland, Scotland, and Wales may not have been accompanied by any terrestrial movement, and the same may have been the case in Scandinavia. But of this early glacial episode few traces remain, for nost of the glacial products of it would have been swept away by the subsequent advance of the ice.

There is good reason to believe that the great extension of the ice and the consequent formation of ice-sheets coincided with a general subsidence of Northern Europe, which enabled the ice to spread much farther south than it otherwise would have done, and to rise over the land in such a manner as to carry material from lower to higher levels. The extent of this submergence in Britain is at present uncertain, but it seems to have been greater in the north, where the ice was thickest, and less in the south where the ice-sheets terminated. TLus as stated on p. 615, Scotland seems to have been about 600 feet lower than at present, while in the south of England the difference was not more than 150 or 160 feet.

But although we may infer a subsidence of that amount in the area of the English Channel, we must not suppose that the Straits 
of Dover were formed by that subsidence. England was still united to France, but by a much narrower tract of land, possibly only by an isthuus joining the Wealden area to the Boulonnais, the invasion of the low-lying country being protected by the continuation of the South Downs across the Channel from near Beachy Head to the French coast north of the mouth of the Somme, and by the North Downs between Dover and Calais.

For an account of the subsequent elevation of the British Isles and of the final subsidence by which Ireland was separated from England and the latter from France, the reader is referred to the author's Building of the British Isles (3rd ed.). The later geographical changes in the Baltic region have already been mentioned, and the history of the Neolithic time belongs rather to the antiquary than to the geologist. For a good account of what was known up to 1880 the reader is referred to Professor B. Dawkins's book on Early Man in Britain.

\section{REFERENCES}

1 See E. J. Garwood, Quart. Journ. Geol. Soc. vol. lv. p. 681.

la See T. F. Jamieson, Quart. Journ. Geol. Soc. vol. lxii. p. 13 (1906).

${ }^{2}$ See Goodchild, "Glacial Plienomena of the Eden Valley," Quart. Journ. Geol. Soc. vol. xxxi. p. 55 (1875).

s See H. Miller on "Boulder Glaciation," Proc. Roy. Phys. Soc., Edinburgh, vol. viii. p. 156 (1884).

+ For Lincolnshire consult the Memoirs of the Geological Survey, and see Quart. Journ. Geol. Soc. vol. xli. p. 118.

5 On Holderness consult "Geology of Holderness" by C. Reid, Mem. Geol. Surrey, and G. W. Lamplugh in Quart. Journ. Geol. Soc. vol. xlvii. p. 384.

${ }^{6}$ See Rep. Brit. Assoc. for 1904, p. 272.

"See C. Reid, Geol. Mag. for 1880, p. 548, and "Geology of Cromer," Mem. Geol. Survey.

${ }^{8}$ R. M. Deeley, Quart. Journ. Geol. Soc. vol. xlii. p. 437 (1886). See also Sum. Prog. Geol. Survey for 1905.

9 M. Reade, "Drift Deposits of the north-west of England," Quart. Journ. Geol. Soc. vol. xxxix. p. 83, and "Eskdale Drift," Geol. Mag. for 1S93, p. 9.

10 A. Strahan, "Geology of the Country round Chester," $\mathbf{M} \mathrm{Km}$. Geol. Survey and Quart. Journ. Geol. Soc. vol. xlii. p. 486 (1886).

11 D. Mackintosh, Quart. Journ. Geol. Soc. vol. xxxvii. p. 366.

12 II. Reade, "Drift Deposits of Colwyn Bay," Quart. Journ. Geol. Soc. vol. xli. p. 102.

13 See "Geology of Ammanford," Mem. Geol. Survey, p. 188 (1907).

14 See "Geology of Swansea," Mem. Geol. Survey, p. 118 (1907).

15 "The Glacial Deposits of N. Pembrokeshire," T. J. Jehu, Trans. Roy. Soc. Edin. vol xli. p. 53 (1904).

16 Summary Prog. Geol. Survey for 1909, p. 25.

17 II. Reade in Proc. Liverpool Geol. Soc. for 1878.9.

18 See Jukes-Browne, Quart. Journ. Geol. Soc. vol. lxii. p. 132.

19 T. T. Pocock, "Geology of the Country around Oxford," Men. Geol. Survey, p. 96 (1908). 
20 H. J. O. White, "Geology of the Country around Hungerford," Mem. Geol. Survey, p. 85 (1907).

21 "The Geology of London," by W. Whitaker, Mem. Geol. Survey (1889).

22 "The Geology of Cambridge," MLem. Geol. Survey, p. 82 (1881).

23 C. Reid, Rep. Brit. Assoc. for 1896, p. 400.

24 C. Reid, Geol. Mag. for 1897, p. 229.

25 See J. M. Mellow, Quart. Journ. Geol. Soc. vol. xxxii. p. 240 and vol. xxxiii. p. 589.

26 H. Hicks on "Bone Caves in North Wales," Quart. Journ. Geol. Soc. vol. xlii. p. 3 and xliv. p. 561 .

27 See W. A. E. Ussher in Geol. Mag. for 1879 , p. 166, and A. R. Hunt, Trans. Dev. Assoc. vol. xx. p. 225 (1888). Also "Geology of Torquay," Mem. Geol. Survey (1903).

23 W. C. Brogger in Geol. Mag. for 1902, p. 317.

29 F. W. Harmer, Quart. Journ. Geol. Soc. vol. lvii. p. 405 (1901).

30 C. Reid, "Climate of Europe during the Glacial Period," Natural Science, vol. i. p. 427 (1892). 


\section{INDEX}

\section{Generic names are printed in Italics}

A bberley Hills, 314, 330

Abbey Hill Shales, 267

Abbotsbury, 442

Aberdarou, 119

Aberdeen, 487, 620

A berdo Limestone, 255

Acanthaspis, 238

Acanthocercis, 466

Acanthocladia, 327,343

Acanthodes, $226,31 \%, 327$

A can thopholis, 465

Acer, 464

Aceratherium, 577

Acervularia, 15t, 159, 160, 195

Achanarras, 230

Acheulian, 638

Acidaspis, 110, 113, 156, 162 , 195

Acrocidaris, 436

- Acrodus, 350, 3ะ3, 386

Acrolepis, 327

Acrosalenia, $355,413,435$

Aerothele, 93

Acrotrete, 73

Actaronella, 466

Actconina, 385

Actinocamax, 466,495

Actinoceras, 158,162

Actinocrinus, 247, 249

Actinotesma, 195

Actinodon, 327

Actinostroma, 105

Acton, 642

Ailumia, 606

Adapis, 5.57

Aclelastrea, 410

Acliantiles, 245

Eger, 385

Agoceras, 386, 388

Fillert, 99, 113

Etobutis, 525

Aetosaurus, 371

Agathiceras, 319, 344

Agenais, limestones of, 878

Agnostus, 75, 77, 114

Agoniatiles, 176

Aisne, the, 515

Alzy, Sables d', 552

Alaria, 386

Albertia, 350
Alberti, von, 348

Alblan stage, 463, 491, 514, 523

Aldborough, 593, 597, 599

Aldeby, 599

Alethopteris, 28s, 290

Allorisma, 327

Alluvial Levels, 045

Almaden, 144

Alpine Region, 62, 188, 320, $373,407,431,454,517$, $554,555,565$

Alsace, 376, 405, 406

Alston, 269

Alton, 499

Alum Bay, 540, 541, 543, 544

Alveolina, 528,570

Alveolites, 156, 195

A maltheus, 386, 389

Amberleya, 355

Amblotherium, 434

A mblypterus, 317, 327

Ambonychia, 158, 195

Amphibla, 292, 317, 340, 352

Amphicyon, 577

A mphidromus, 559

Amphilestes, 415

Amphion, 104, 110

A mphiope, 574, 579

Amphipora, 195

Amphitherium, 384, 414, 415

Amphitragalus, 529

Amphitylus, 415

Amphoracrinus, 247

A mplexus, 247

Ampthill Clay, 448

Ampyx, 110

Amstelian, 557, 603

Anabacia, 410

Ananchytes, 466

4 narcestes, 196

Anatina, 434

Ancenis, 214, 250

Anchisherium, 557

Ancilla, 528, 533, 576

Ancistroceras, 147

Ancyloceras, 436

Ancylus Lake, 647

Andalusia, 313

Andrurun Llmestone, 103
Andrews, A. R., so

Andrews, W. R., 449

Andrias, 582

Angelina, 76, 78

Angers, basin of, 214

Anglesey, rocks of, 50,122, 257

Angoumian, 515

Antisoceras, 466

Anjou, 141

Annularia, 286, 815

Anodon, 350, 415

Anomopteris, 350,370

Anomozamites, 414, 471

Anoplophora, 350, 371

Anoplosaurus, 465

Anoplotherum, 557

Anopolen us, 82

Anor Sandstone, 216

Antholites, 290

Anthracite, 321

Anthracomya, 291

Anthracosaurus, 292

Anthracusia, 291, 315, 321

Anthracotherium, 577

Antrim, 23\%, 402, 512, 545, 547,633

Antwerp, 602

Anversian, 554, 584

Apatorius, 465

A pennines, the, $432,555,55 i$, 583,605

A piacrinus, $410,413,425$

Aplln quartzite, 43

Aplin phyllites, 43

A porrhais, 466, 492, 529

A ppenzell, 580

Appleby, 236, 337

A pplecross, 45,403

A pplecross Group, 45

Applethwaite, 192

Aptian stage, 468, 457, 459

Aquitalne, 515, 524, 5 ti

Aquitanian, $573,575,578,579$, $580,582,588$

Arachnophyllum, 156, 159, 160, 105

Aralia, 464, 525

Araucaria, 385

A raucariles, 414 
Arbacia, 574

Arber, E. A. N., 301, 308, 309, $320,322,363$

Arbroath Sandstones, 232

Arca, 469, 576

Arca Clays, 648

Arcestes, 349, 351

Archreall rocks, 5, 34

Archoocalamites, 245

Archoocidaris, 247

A rchceocyathus, 72, 97

Archóconiscus, 438

Archoeopteryx, 384, 435

Archoeoscyphia, 97

Archanodon, $212,225,226,238$, 264

Archegosaurus, 327, 341

Archidesmus, 226

Archimedes, 319

Arctic Freshwater Bed, 627

Aretic Region, 238

Arctocyon, 528

Arctomys, 538

Ardara, granite of, 50

Ardennes, the, 101, 215, 430

Ardmillan Group, 135, 136

Ard namurchan, 368

Ardtun Head, 547

Are schists, 68

Arenig Mountains, 117, 118 , 123

Arenig Series, 109, 110, 116, $119,128,136$

Argile de Boom, 563

Argile de Flandres, 550

Argillornis, 528

Argyllshire, 43, 403

Arietites, 386

Arionellus, 82, 104

Arley mine coal, 297

Armagnac, 578

Armorican flexures, 314,345

Armorican Sandstone, 141

Arno, val d', 605

Arragonite shells, 19 .

Arran, Isle of, $269,359,368$, 402,548

Arthur's Seat, 267

Artinskian, 325, 343, 344

Arundel, 508, 509

Asaphellus, 76, 78

Asaphus, 110, 113

Ascoceras, 158

Ascoceras Limestone, 182

Ashburton, 207

Ashdown Sand, 475

Ashgillian, 110, 124, 132

Aspidoceras, 435, 430

Aspidorhynehus, 410, 435, 438

Astarte, 385, 436, 469, 539

Astartian, 451, 452

Asterolepis, 226

Asterophyllites, 286

Asteroplax, 238

Astian stage, 587, 605, 606

Astrocoenia, 385

Asturias, 100, 214, 281, 313

Ateleaspis, 178

Atherfield Clay, 475, 476, 477

Athyris, 214, 248
Atlantic Region, 107, 239, 283, 320,586 .

Atlantosaurus, 434

Atractites, 349

Atrypa, 110, 156, 157, 159, 160,162

Aturia, 528, 576

Aube, the, 514, 515

Auchenaspis, 158, 162

Auchmithie conglomerate, 232

Audierne, 60

Aulacoceras, 349

Aulophyllum, 247

Aulosteges, 327

Aultbea Beds, 45

Aurillac, 580

Austria, Archæan of, 62

Carboniferous of, 313

Cretaceous of, 521

Jurassic of, 455

Miocene of, 582

Pliocene of, 602

Silurian of, 188

Trias of, $373,375,379$

Autun basin, 340

Autunian, 325, 340, 345

Auvergne, 566, 579, 604

Avellana, 466

Aveyron, 340, 341

A vicula, 161, 162

Aviculopecten, 195, 246, 248

A vonian Series, 244, 262, 278

Axis, 588

Axmouth, 368, 499

Aylesbury, 444, 447, 449, 483

Aymestry Limestone, 165, 167

Ayrshire, rocks of, 134, 234, $26 \mathrm{~S}, 303,338,339,622$

Azeca, 528

Azoic era, 5

Babbacombe, 207, 333

Back well Hill, 366

Bactrites, 196

Baculites, 466

Baggy Beds, 209

Bagshot Beds, 527, 549, 551

Baiera, 325, 350, 414

Bailey, E. B., 43

Bairáia, 248, 291

Bajocian, 383, 409, 431, 45ذ

Bakevellia, 327

Bala Series, 110, 124, 128, 132,138

Bala Limestone, 125

Balachulish Limestone, 43

Balanophyllia, 528, 591

Balclatchie Beds, 136

Balkans, the, 320,605

Ballagan Beds, 267

Ballard Cliff, 506

Ballypalady, 547

Baltic Region, 103, 183, 223, 516,647

Bamboo, 604

Banbury, 400

Bangor, 53, 88

Bangor Series, 53
Bannisdale Slates, 175

Bantry Bay, 275

Baphetes, 292

Bardon Hill, 58

Bargany Beds, 177

Bargate Beds, 479

Barmouth Grits, 82

Barnstaple, 276

Barr Series, 135, 136

Barrande, Dr. J., 104, 145, 184,221

Barrandeiceras, 162

Barrémian, 463, 489

Barrois, Prof. C., 60, 100, 144, $213,214,281$

Barroisia, 466

Barrow, G., 97

Barrule Slates, 94

Barth, 94

Barton Beds, 527, 535, 543

Bartonian, 549, 554, 555

Basse Loire, 279

Basses Alpes, 408

Bath, 398, 416

Bathonian, 383, 409, 422, 428, 431,458

Battle, 440,450

Bauterem, 563

Bauxite, 547

Bavaria, 373, 375, 408, 554, 564

Bazas, 578

Beaches, raised, 645

Beaminster, 422

Bear Island, 238

Beauce, Calcaire de la, 566 , 579

Beauchamp, Sables de, 554

Bedfordshire, 443, 483, 503

Beer Head, 499, 503

Belemnite Marl, 501, 503, 505

Belemnitella, 466,496

Belemnites, 385, 390, 434, 435

Belemnoteuthis, 436

Bel fast, 359,365

Belgium, 101, 144, 186, 215, $278,310,550,562,602$

Belhaven, 267

Belinurus, 292

Bell, R., 596

Bellerophina, 492

Bellerophon, $76,78,115,158$, $162,196,249,327$

Beloceras, 196

Belodon, 352, 371, 434

Beloptera, 528

Belosepia, 528

Bembridge Beds, 556, 561

Benan conglomerate, 135

Bencliff Grits, 442

Bencraft Shales, 140

Beneckeia, 354, 371

Berg, Sables de, 563

Bergeron, J., 61, 281

Bernberg, 564

Bernician Series, 244, 263

Beroun, 104, 222

Berriedale Beds, 236

Berwickshire, 235

Berwyn Mountains, 126 
Betton Shales, 128

Beyrichia, 03, 195, 211

Bideford, 309

BInstead, 581

Birkenta, 1 is

Birkhlll Shales, 170, 178

Black Forest, the, 370,431

Black Mountsins, 228, 229, 031

Blackband Group, 297

Ilackbrook Beds, 55

13lackdown 1[11ls, 500

13lnckheatl Becls, 597, 539

Blake, J. F., 52, 57, 442, 451

Bles Wryke, 401, 402

Boghend coal, 321

Bognor, 540

Bohemia, Archrean of, 63

Caubrian of, 104

Carbuniferous of, 312

Cretaceons of, 51 s

Devonlan of, 221

Orilovician of, 145

Silurlan of, 184

Bolderian, 584

Bolospongia, 511

Bolton, H., 307

Bonney, Professor T. G., on Arcluean Rocks, 35, 53, $58,60,62$

, on Permian, 332, 345

" on Trias, 361

Bononian, 452

l3oom, Argile de, 563

Bordeaux, 578

Borkholm Bods, $14 \mathrm{~S}$

Bornich, 235, 245

13orrowdale Series, 132

Boscoinbe Sands, 542, 543

- Bothriolepis, 226

Boulder-clay, 614, 620

Boulonnais, 311

Bourboll, 340

Bourgeticrinus, 406

Bourneinouth Beds, $535^{\circ}$

Bovey Beds, 577

Bovlda, 585

Bowland Shales, 259

Bownnore Grits, 46

Boxstones, 593

Brabant, 145

Brabourne, $362,4 . j 0$

Brachycyathus, 466

Brachymetopus, 248

Brachyphyllum, 414

Brachytrema, 410

Bracklesham Beds, 527, 535, 542

Bradford Clay, 425

Branchiosaurus, 327

Brancoceras, 196, 249

Brand Beds, 58

13randenburg, 564

Branscombe, 968

Brasil, 406

Brathay Flags, 175

Bray llead Serles, 95

Brecknockshlre, 227, 631

Brecon Vans, 229, 681

Brenton IIills, 207
Brent Tor, 270

Brest, 99

Brickhlll, $4 \$ 3$

Brldgend, 397

Brldgenorth, 356

Bridilngton, 625

Brid port, 397

Brie, Calcalre de, 556, 565

Brill, 447, 449

Brioverian System, 60

Brisous, 589

Brlstol district, 232, 304, 305, 307

Brittany, Archean of, 59

Cambrian of, 99

Carboniferous of, 279

Cretaceous In, 523

Ordovician of, 141

Silurian of, 1S6, 213

Brive, 61,340

Brixlıain, 206, 346

Brocastle, 397

Brockenhurst, 560

Brockwell coal, 300

Brögger, 648

Bromsgrove, 363

Brongniart, 382

Bronteus, 195

Brontosaurus, 434

Brook Point, 476

Broquies, 340

Brora, 429, 450

Browgill Beds, 175

Brown, II. T., 332

Brownstone Series, 227, 228

Brunswick, 407

13russellian, 527, 549, 551

Brussels, 145

Bruton, 416, 422

Bryograpius, 76, 78, 94

Bryozoan reefs, 191,343

Buccinopsis, 590

Buch, von, 382

Buchensteln Beds, 373, 374

Buchiceras, 466

Buckinghamsbire, 443, 447, 500

Buckman, S. S., 387, 399, 406, 416

Budleigh Salterton, 361

Build was Beds, 165

livilth, 171

Bulla, 410

Bunter Series, $340,355,370$

Bupreston, 438

Burdlehouse Limestone, 268

Burdigalian, 573, 575, 378 , 5 r $9,580,582$

Burford, 362, 393

Burren Ijlmestones, 274

Burton Iradstock, 416,422

Busaco, 100

Butley Crag, 592

Buxiere, 340

Caban Beds, 168

Cadnant Shales, 126

Cadomilla, 355

Case Gwyn Cave, 644

Caen, 100
Caerfal Beds, 72, 79

Calrconnon Beds, 232

Calstor, 486, 501

Caithness, 230, 236, 4S7

Caithness Flags, 236

Calabrla, 605

Calsinlnker, 299

Calamites, 226, 286, 283, 325

Calamodendron, 256, 315

Calamophyllia, 350

Calamostachys, 286

Calathium, 97

Calcalre Grossler, 552

Calearoous shells, 19

Calcareous Grlt, $\mathbf{4 4 2}, \mathbf{4} 43$

Calceola, 105, 217

Shales, 217

Calerloulan area, 231, 235

Caledonlan System, 45

Callaway, Ch., 51, 57, 59, 92

Callicrinus, 156

Callipteridium, 315

Callipteris, 325

Cullonema, 196

Callovian, 432, 431, 452

Calp, the, 272

Calymene, 110, 156, 162

Cam, valley of the, 641

Camarophoria, 195, 248, 319. 327

Camarospongia, 466

Camarotarchia, 156, 162

Cambrian System, 8, 12, 70

Cambridgeshire, $443,500,500$

Cambridge Greensand, 504

Campanian, 491, 515, 516,51\%, 523,524

Campbell, 1R., 97

Camphor-tree, 574

Campil Beds, 374

Caninia, 247

Canis, 5Ss, 635

Cannel coal, 321

Cannock Chase, 356

Cannon-shot gravel, 640

Canonble area, 301

Cantal, the, 566, 5\$1

Cantrill, T. C., 11\%, 325

Cap la Hève, 514

Capreolus, 5 ss

Capulus, 249

Caradoc Hills, 89, 12S

Caradoclan, 110, 124, 129

Caratomus, 406

Curbonicola, 291

Carbonlferous System, 6, 12 , 244,285

Carboniferous Slate, 975

Carcharodon, 579, 590

Cardicuster, 460

Cardinia, 39.5

Cardiocarpus, 290

Cardioceras, 434, 438

Cardiola, 162, 195

Shales, 182

Cardiomorpha, 24!?

Cardiopteris, 345,290

Cardita, 350, 355, 531, 533 , 576,589

Cardium, 395, 590, 591 
Carinthia, 313, 373

Carinthian stage, 374,375

Carlisle, 359, 364, 365, 402

Carmarthen, 84, 117, 121, 123

Carmyllie Beds, 232

Carn Chuinnach, 42

Carnarvonshire, 52, 82, 87. 119

Carnic Alps, 320, 373

Carpathian Mountains, 432, 455,582

Carrickfergus, 365

Carstone, 481, 484, 4S7, 499

Caryocaris, 112

Caryophyllia, 466

Cassia, 528

Cassianella, 350

Cassidaria, 466, 576, 590

Cassis (=Cassidea), 528, 531

Casterlian, 587, 602, 603

Castor, 601

Catagma, 466

Catalonia, 187

Catopygus, 466

Cave deposits, 643

Cefin Slates, 82

Cement-stone Group, 267

Cenomanian, 463, 491, 514, 523

Centronella, 195

Cephalaspis, 158, 196, 224, 226

Cephalites, 466

Cephalopoda Bed, 399, 417

Cephalopteris, 238

Ceratites, $349,351,371$

Ceratodus, 351, 371, 3ss

Ceratopyge Limestone, 102

Ceritelta, 385

Cerithium, 350, 3S5, 435, 437, 576

Ceromya, 385

Cervidne, 588, 601, 638

Ceteosaurus, $384,415,434$

Chotetes, 245

Chalk, Lower, 463, 491, 501

, Middle, 463, 491, 505

"Upper, 463, 491, 507

Chalk Marl, 503, 504

"Rock, 510

Chalky Boulder-clay, 623, 628

Chama, 532

Chara, 471, 559

Chard, 503

Charmouthian, 3s3, 405, 406, 408,457

Charniouth, 394, 397

Charnwood Forest, 57, 58

Chasmops Limestone, 147

Chateaulin basin, 279

Chatelier Sandstone, 141

Chatham, 440

Cheiracanthus, 226

Cheirodus, 292

Cheirostrobus, 245

Cheirumus, 92, 156, 195

Chelidosaurus, 317

Chelléan epoch, 638

Chelone, 471

Chemnitzia, 351

Chemnitz area, 342
Chenendopora, 466, 493

Chert Beds, 51

Cherwell Valley, 419

Cheshire, 294, 355, 363

Cheviot area, 231, 235, 621

Chideock, 416

Chillesford Beds, 592, 599

Chilocyclus, 350

Chipping Norton, 419

Chiton, 156

Chloritic Chalk, 512

, Marl, 501, 503

". Sands, 512

Choropotamus, 557

Chonetes, 156, 162, 248

Chonograptus, 94

Chonophyllum, 199

Christiania, 147, 181

Chrysodomus, 525

Cliudleigh, $20 \mathrm{~s}$

Cidaris, 350, 351, 385, 435

Cimolestes, 466

Cimoliosaumus, 434

Cimolomys, 466

Cinnamon, 464, 574, 578

Ciply, 516

Cirrus, 385, 410

Cladiscites, 349

Cladophlebis, 350, 414, 471

Cladophyllia, 350

Cladyodon, 352, 363

Clare, 273

Clathrodictyon, 150

Clausthal, 221

Clava, 615

Clavella, 532

Clavinian Series, 382,458

Claxby Ironstone, 484,486

Clay-with-flints, 640

Cleidophorus, 158, 195

Cleistopora zoue, 252

Clent Hills, 330

Cleveland Ironstone, 401

Cleveland Hills, 633

Clifton, 252

Climucograptus, 110, 113

Climatius, 226

Clisiophyllum, 247

Clitheroe, 25S, 259, 336

Clogan Beds, 82

Clogher Head, 180

Clonocrinus, 156

Clough, C. T., 42, 45, 97

Clnnian, 154

Clwyd, Vale of, 644

Clyde Beds, 621

Clydoniceras, 413

Clymenia, 196

Clypeaster, 574

Clypeus, 410

Clypeus Grit, 415

Coal, formation of, 320

Coalbrookdale, 298

Coalfields, 294

Coal-Measures, 285, 294

Cobbold, G. S., 89

Coblentzian, 216, 220

Coccosteus, 196, 212, 224, 226

Coccoteuthis, 436

Codkster, 247
Coddon Hill Beds, 276

Calacanthus, 250, 292, 327

Coloceras, 386

Coclolepis, 158

Colonautilus, 249

Colopleurus, 556

Colopoma, $52 \mathrm{~S}$

Caloptychium, 466

Colosmilia, 466

Colostylina, 350

Conograptis, 110

Canotherium, 557

Coldwell Beds, 175

Cole, G. A. C., 49, 50

Coleoloides, 73

Collins, F. G., 309

Collyrites, 410

Collyweston, 419

Colwell Bays, 560

Columbella, 591

Columbellina, 466

Combemartin, 207

Cominella, 466

Comley Sandstone, 89

Commentry, 317

Compton Bay, 506

Congeria Beds, 587, 606

Congleton Edge, 258, 295

Coniferæ, 325,350 , 3S5, 574

Coniopteris, 350, 414

Coniosaumis, 465

Coniston Grits, 175

Conocordium, 158, 159, 246, 249,319

Conoceras, 112

Conocoryphe, 75,77

Conorbis, 528, 532

Contorted Drift, 627

Conularia, 76, 78

Conus, 528, 533, 576

Conwas, 126

Coomhola Beds, 211

Coral Rag, 442

Coral Reefs, 189, 190

Corallian Beds, 3S3, 432, 441, $442,443,451,452,469$

Coralline Crag, 587, 592, 593

Corax, 464

Corbicella, 410

Corbicula, 528, 639

Corbières, 281

Corbierian, 515

Corbis, $410,46 ?$

Corbula, 529, 532

Cordaites, $290,315,325$

Cordioxylon, 325

Cork, 210, 211, 274

Cornbrash, 415, 422, 424, 425, 426,428

Cornstone Series, 227

Cornwall, 144, 200, 202, 208, $275,308,334,595$

Corona Beds, 132

Coroniceras, 389

Corwen Grits, 170

Corynella, 410

Coryphodon, 528

Cosmoceras, 410,434

Cotentin, 516, 56S, 603

Cottaldia, 466, 493 . 
Cotteswold II ills, $\mathbf{4 1 5}, \mathbf{4 1 7}, \mathbf{4 2 3}$

Cotteswold Santls, $39 y$

Cottian Alps, 63, 40S

Cracoe Linestolie, 259

Cracow, 431

Crampton, 42

Craspedites, 436

C'russatellites, 466, 532

Craticularta, $\$ 10$

Craven fanlt, 258

Crediton, 333

C'redneria, 464

Creechbarrow Hill, 502

Crendon, 458

Crenipecten, 248

Crepidula, 4 tib

Creswell Crags, 643

Cretaceous System, $6,12,462$

Crinoids, growth of, 189

Crioceras, 460, 46\%

Croagmartlin Beds, 180

Crostia, 606

Croll, J., 648, 649

Croner Beds, 557, 592, 600

Croıner Till, 627

Cross Fell, 259, 261

Crossfleld, Miss, 84

Crotalocrinus, 156, 162

Croyde Bay, 209

Crurlen, 4S7

Cruziana, 75, 77

Cryptoenia, $380^{3}$

Cryptoccenia, 410

Cryptograptus, 110, 111

Cryptosaurus, 434

Ctenis, 414

Clenocrinus, 195

Ctenodonta, $76,114,158,160$, 195

- Ctenoptychius, 292

Clenopyge, 92, 93

Cucullat, 195, 195, 385, 464, 529

Cucuron, 604

Cuise, Sables de, 552

Culford, 362, 393

Cullion, 272

Culm, the, 280

Culm-measures, 308

Cultra, 327

Culver Cllffs, 501, 506

Culverwell, E. P., 648

Cumberland, $93,120,130,800$, $301,437,359,364,402$

Cuminlugstone, $\mathbf{8 3 9}$

Cupar, 236

Cupressocrinus, 195

Cupressus, 574

('urtonotus, 195, 198

Cusel Beds, 341

Cyathaxonia, 247

Cyathocrinus, 156, 195, 247

Cyathophora, 410

Cyathophyllum, 159, 160, 195, 247

Cycadiles, 471

Cycads, 325, 350, 385

Cyclocyathus, 460

Cycloiobus, 326

Cyclonema, 466,469
Cyclophyllum, 247

C'yclopterts, 226

Cyliudrites, yso

Cyphaspis, 105, 248

Cyphosomu, 430

Cyproza, $52 \mathrm{~s}$

Cypress, 374

Cypricurdiella, 249

Cypridina, 248

Cypridinelia, 248

Cyprimeria, 406

Cyprina, 410, 529

Cyrena, 415, 438, 530

Cyrtia, 156,162

Cyrtina, 156

Cyrtoceras, $76,115,157,158$, 160,249

Cyrtodonta, 195

Cyrtograptus, 155, 156, 158, 182 Cyrtotheca, 75

Cystiphyllum, 156, 195, 197

Daclistein, 373,375

Dacrytherium, 557

Dactyiliocercs, 3S6, 389, 390

Dudocrinus, 1350,351

Dadoxyion, 290

Dakosauris, 434

Dalarne, 146,148

Dalmanites, 195

Dalmatia, 373, 409, 567

Dalradian Series, 43

Dalsland, 67

Danian stage, 463,516

Daonella, 350

Dapedius, 386

Dartington, 207

Dartmouth Slates, 202

Darwin, Ch., 11, 15, 16, 20, 21

Dasornis, 528

Dasyceps, 327

Davidsonia, 195

Davies, D. O. 126

Davis, J. W., 262

Dawkins, W. B., 651

Dawllsh, 333

Dayia, 156, 161, 162

Dean, Forest of, 253, 308

Dechenella, 195

Deeley, R. M., 629

Deganwy mudstones, 129

Deiphon, 156

Delamere Forest, 357

Delepine, G., 278

Delphinula, 410

Denbighshire, 170, 174

Dendrerpeton, 292, 317

Dendrocrinus, 76

Dendrophyllia, 528

Denmark, 516

Dentalium, 871

Derbyshire, 257,359

Deroceras, 986

Derry, rocks of, 272,545

Desertmartin, 272

Destruction of deposits, 20

Devillian, 101

Devonlan System, 6, 12, 193

Devonshire, 200, 275, 308, 332 , $361,367,499,500$
Diabeg Group, 45

Dibunophyilum, 247

Diceilograptus, 110, 113

Dichodon, 529,837

Dichogriptus, 110

Dicnanugruptus, 110, 113

Dicrocercs, 577

Dicroloma, 386, 434

Dityograptus, 76

Dict yonema, 76, 77

Dictyoneura, 815

Dicynodon, 353

Dielelphys, 528

Didymograptus, 110, 111, 113

Dielasma, 195, 248, 319, 327

Diestian, 587, 602

Digne, 408, 432

Diluvium, 635

Dimeroorinus, 156

Dinetlan granite, 53

Dimodosaumus, 371

Dimorphoceras, 249

Dimorphodon, 356

Dinant, 215, 217, 241, 279

Dinantian Series, 244, 278

Dinarian stage, 374

Dingle Promontory, 178, 179 , 210

Dinotherium, 57\%

Dionites, 471

Diphya Limestone, 454

Dipiacanthus, 226

Diplodonta, 528

Diplograptus, 110, 113

Diplopora, 350,379

Diplopterus, 226

Dipleronotus, 351, 363

Dipterus, 226

Discites, 249

Discolilea, 466

Dithyracaris, 248

Divesian, 452

Dogger, tlie, 887,420

Dolgelly Beds, 86

Dolichosaurus, 465

Doliolina, 919

Dollfus, G. F. 578, 579, 603

Dolomite Mountains, 373,375

Dolomitic conglomerate, 366

Dolwen, 80

Donegal, rocks of, 49,237

Donetz basin, 281, 2s8, 409

D'Orblgny, $\mathbf{\Lambda}, 382$

Dordolot, Prof. de, 278

Dorset, Cretaceous of, $\mathbf{4 7 0}$, $481,499,509,506,510$

Eocene of, 540

Jurasslc of, $393,396,416$, $422,442,444,445$

Doryderma, 466

Dosinia, 559

Douglss, J. A., 273

Doulough Slates, 140

Doultlng, 422

Dover, 440, 475, 477, 505, 508

Downtoulan, 154, 167, 171, 175

Dremotherium, 557

Drepanaspis, 196

Dryandra, 528 
Dryopithecus, 577

Dublin, 274

Ducy, Calcaire de, 554

Dudley, 167, 299

Dufton Shales, 132

Dumfries, 338

Dunottar conglomerate, 231, 232

Dunrobin Castle, 369,403

Dunstable, 504

Dura Den, 236

Durham, 300, 334

Durlstone Head, 445, $44 \mathrm{~S}$

Durness Limestone, 96

Dusseldorf, 279

Dyas, the, 324

Dykes, Arcliæan, 38

, Eocene, 545

Earthquake fissures, 346

Easdale Slates, 43

East Anglia, 626

Echinoconus, 466, 496

Echinocorys, $46 b^{\circ}, 496$

Echinocyamus, 556, 591

Echinocystis, 156, 162

Echinodiscus, 574

Echinolampas, 556, 574, 579

Echinospatagus, 466, 496

Echinosphara, 114, 115

Echinus, 589

Edaphodon, 464

Eden, Vale of, 336, 369, 429

Edye Coal Group, 267, 269

Edinburgh, 267, 268, 302

Edmondia, 195, 249

Edzell Shales, 232

Egeln, 564

Eggensburg, 582

Eggesford Grits, 308

Eifel district, 219, 370

Eifelian stage, 217

Eigg, island of, 428,547

Eilde Flags, 42, 43

Elaphus, 588

Elbingerode, 221

Elephas, 5S8, 601, 638

Elgin, 339, 369, 429

Elginia, 327, 329

Ellergill Beds, 131

Elles, Miss O. L., 94, 119 , $126,12 \mathrm{~S}, 131,167,170$, 172,174

Ellesmere, 357

Ellipsocephalus, 104

Elotherium, 557

Elsworth Rock, 443

Ely, 444

Emscherian, 515

Enaliornis, 465

Enallaster, 466

Enchodus, 464

Encrinurus, 110, 156, 162

Encrinus, 350, 371

Endothyra, 245

Entelodon, 557

Entomis, 195, 208, 209

Enville Marls, 330, 331

Eoblattina, 315

Eocene Series, 11, 526, 527
Eotherium, 529

Eozoic, 5

Eparclizan rocks, 35

Epiaster, 466

Epidote Grits, 46

Eppelsheim, 600

Equisetites, 350, 363, 369

Equus, 601, 638

Erbray, 186, 1S7

Eretmosaurus, 386

Eriboll area, 96

Erinnys, 75, 82, 104

Erpetosuchus, 352, 369

Eryma, 355

Eryon, 385

Erzgebirge, 63, 242

Eskers, 634

Estheria, 224, 226, 315, 350, 363,371

Estuarine Beds, 419, 420, 426, 428

Etampes, Calcaire d', 556, 566,579

Etheridge, R., 206

Etua, 600

Etruria Marls, 297, 298

Etyus, 466

Eucalyptocrinus, 156

Eucalyptus, 464, 528

Euchasma, 97

Eucorystes, 466

Eugnathus, 386

Eukeraspis, 158

Eulima, 460

Euloma, 92

Eunema, 158, 162

Euomphalus, 112, 196, 246, 249,349

Eupterornis, 528

Eurynotus, 250

Eurypterus, 156, 162, 226

Exelissa, 386

Exeter, 309, 333

Exmoor, 207

Exogyra, 436, 493

Fairlight Clay, 475

Fallowfield, $336^{\circ}$

Falmouth Beds, 144

Faluns, 578, 579

Famennian stage, 219

Faou, greywacke of, 213

Farewell Rock, 305

Faringdon, 442, 481

Farrington Beds, 304, 308

Fasciculites, 589

Fasciolaria, 528

Faunas, succession of, 21

Favospongia, 162

Faxe, 516

Fearnsides, W. G., 87, 117, 118,123

Felis, 588, 638

Fell Sandstones, 264

Fenestella, 25n, 273, 327, 343

Fenno-Scandia, 65, 66

Ferriters Cove Beds, 180

Ffestiniog Beds, 86

Ffynnon-Beuno Cave, 644

Fichtelgebirge, 2so
Ficus, 528

Fifeshire, 236, 26s, 302

Finisterre, 213

Finland, 64

Firestone, 498

Fisher, O., 542, 570

Fissurella, 410

Fabellaria, 528, 574

Flagstone Group, 304

Flandres, Argile de, 550

Flett, J. S., 41

Flintshire, 257, 297

$\mathrm{r}$ lotzeere Sandstones, 310

Flysch, 565

Folkestone, 475, 498, 501

Folkestone Beds, 475, 479

Fontainebleu, Sables de, 566

Foreland Sandstones, 264

Forest of Dean, 253, 30 S

Forest Bed, 600, 601, 609

Forest Marble, 415, 422, 424, 425,426

Forfar, 231

Fossils, illustrations of, 31 preservation of, 16,17

Fox-Strangways, 443

France, Archæan of, 59

Cambrian of, 97

Carboniferous of, 278,310 , 315

Cretaceous of, 487,513

Devonian of, 212

Ordovician of, 141

Permian of, 340

Silurian of, 186

Tertiaries of, 552, 566, 603

Trias of, 376

Franconia, 407, 431, 433

Frasnian stage, 217, 219

Freestones, the, 415

Fremington Beds, 276

Fret, grey wacke of, 213

Fritsch, Dr., 317

Frodinghanı, 400

Fuller's Earth, 415, 422, 42t, 425

Fundamental Gneiss, 49

Furada Grits, 215

Fusulina, 245, 312, 319, 320, 343

Fusus, 466, 576

Gahard Sandstone, 213

Gairloch, 3S

Gaize, 514

Gala Beds, 176, 178

Galerites, 466, 496

Galloway, 521

Galway, 49, 139, 273, 274

Gamlan Shales, 82

Gampsonyx, 327, 341

Gannister Beds, 295

Ganodus, 410

Gardiner, C. T., 13S, 139, 180

Gardner, J. S., $541,543,54 T$, $54 \mathrm{~S}, 574$

Garumnian, 517

Garwood, E. T., 262, 263, 264, 345

Gastomis, $52 \mathrm{~S}$ 
Cetstrioceras, 249, 319

(iauderusclort, 5s:

(isult, 4!s

(iavialis, 528

Gedinuian stago, 216

Geilik, 32\%, 839

Geikle, sir A., on Archießn rocks, 48, 49, 51, 53, 55

on Eocene volcanoes, 548,554

" on Olu Red Sandstone, 230

" on Silurian lavas, 180

Gelinden, 550

Gembloux, 145

Geneva, lake of, 63 i

Georraplilcal restorations, 39

Geological Magazine, 30

, Record, 90

"Society, 28,30

". Survey, 30

Geologists" Associatlon, 30

Gephyroccras, 196

Germauy, Cambrian of, 104

Carboniferous of, 280,317

Cretaceous of, 490,518

Devonian of, 219

Jurassic of, $406,431,453$

Neogene of, 584, $600^{\circ}$

Palaogene of, 569

Permlan of, 341

Pleistocene of, 635

Silurian of, 185

Trias of, $369,8 \% 3$

Gervillia, 350, $371,464,469$

Giant's Causeway, 54;

Gibso11, W., 29\%, 29S

Gigantosaurus, 434

- Ginkyo, 325, 415

Glrvan district, 134, 176, 177

Glvetian stage, 217

Glacial deposits, 611, 618

Glaclatlon, 615

Glamorgan, 63:

Glandina, 559

Glasgow district, 267

Glassia, 158

Glastonbury, 398

Gleichenia, 528

Glenarm, 547

Glencoe quartzite, 43

Glengarriff $13 \approx d s, 210$

Glenkiln Shales, 135, 139

Glevanian Series, $352,45 i$

Gloppa, 631

Glossograptus, 110, 118

Glossopteris, 325

Gloucestershlre, $898,399,424$

Glyn Celriog, 1:28

Glyphora, 955

Clyphioceras, 246, 249

Glyptarca, 76

Glypticus, $480^{\circ}$

Glyptolepis, 212, 226

Glyptostrolucs, 574

Gnelssic rocks, 36,35

Gomphoceras, 158, 162, 196

Goniognathus, 5:8

Gon iom ya, 350,435
Gontopholis, 434, 185

Gonlophylluin, 150

Goniopora, 528

Goniomygus, 460

Goodchild, J. G., 285, 26\%, 337

Gordonia, 327, 339

Gossolet, J., 219, 406

Gottland, lsland of, 181

Gourbegvillo, 603

Gouriu, phyllades de, 60

Gower, $228,230,253$

Grammatodon, $3 \mathrm{S5}$

Grammoceras, $356^{\circ}$

Grammysia, 158

Grampian Serles, 48

Grampound Grits, 203

Grancluerinus, 247, 248

Grantham, 400

Granton Sandstone, 267

Grateloupia, 5\%6

Gravels of rivers, 641

Great Oolite, $415,425,426$

Greece, $600^{\circ}$

Green, J. k. N., 55, 84

Greenland, 239, 459

Greenly, E., 51

Greensand, sce Lower and Upper

Gregory, J. W., 48, 49, 63

Grès armorleain, 100, 141

", felspathique, 99, 141

"de Ilay, 142

Gresslya, 355, 413

Grittith, Sir R., 274

Griffithides, 34S

Grimston, 500

Gristhorpe Bay, 422, 428, 441

Groix, schists of, 60

Groom, T. T., 89, 92, 126

Gross Venediger Alp, 62

Grossouvre, A. de, 515, 513, 524

Ground-Moraine, 614

Grulnard Bay, 368, 369

Gryphaca, 355, 390, 434

Gryphlte Grits, 415

Guettcrita, 466

Guttenstein Limestone, 373, 374

Gwastaden Beds, 16S

Gyflin Shales, 170

Gyracanthus, 292

Gyrodus, 432

Gyrolepis, 351

Gyroporella, 370

Gyroptychius, 2:26

Hafothy Shales, 82

Hailes Sandstone, $26 \%$

Halcyornis, 52S

Haldon Hills, $329,333,500$

Halirhoa, 466

Ifulitherium, 557

Hallstadt limestone, 375

Halobia, 850,351

Halonia, 2sb

Halysites, 115, $156^{\circ}$

llam 11111 stone, 309

Hamites, 492
Hampshlre, 498, 508, 594, $539,541,560$

Ilamstead, 561, 562

Herls, 556, 562

Hamulina, 466

Hanguan Grits, 204

Hanover, 407, 431, 453, 490

II upalocrinus, 156

IIaploceres, 410

Haploctinus, 195

Hardman, E. T., 304

Harker, A., 544

Markness, Professor, 339

Harlech Beds, 79

Harmer, F. W., 593, 596, 597, $599,600,602,608,649$

Harnage Shales, 129

Harpes, 110, 156, 195, 197

Hurpucenas, $8 \$ 6,389$

Hartfell Slıales, 135, 139

Hartshlll quartzlte, 91

Hartwoll Shales, 444

Hartz MIts., 185, 220, 241, 280,342

Harwich, 102

Haslemere, 476, 475

Hastings Beds, 475

Hatherleigh, 333

Haugia, s\$6

Hauterivian, 463, 489

Haxey, borlng at, 395

Hendon Beds, 556, 560

Hearthstone, 498

Heathfield, 377, 3S1

Hebridean gneiss, $\mathbf{3 6}$

Hedera, 464

Heer, O., 574

Heersian, 549, 550

Heliolites, 156, 160, 195, 197

Heliophyllım, 195

Helix, 559

Helladotherium, 558

Helvetian stage, $573,575,578$, 579, 580, 5S2

Hemiaspis, 156, 162

Hemiaster, 466

Hemicidaris, $350,410,412$

Hemicosmites, 115

Hemipedina, 885

Iengistbury Beds, 543

Hénis, 568

Hercynlan Flexures, 314, 345

Hercynlan Land, 520

Hercynlan Series, 185, 230

Herinsdorf, 407

Herpetocrinus, 156

Hesperornis, 465

Hesse, 343

Hessle, 507

Hessle Clay, 625, 628

Heterangium, 2S5

Ileterustrea, 385

Heteroceras, 430

Heterostinia, 511

Hettanglan, 3S3, 405, 408

Hexacrinus, 195

llickling, G., 281, 338

Hicks, H., $53,78,84,100$ $117,121,172,64$

Iighcliti Sands, 543 
Highlands of Scotland, 42, 44 Hildoceras, 386

Hill, W., 507

Hilton Shales, 337

Hind, W., 255, 259, 309

Hinde, G. J., 479

Hipparion, 588

Hippopodium, 385, 390

Hippopotamus, 588, 601, 638

Hippurite Limestone, 517

Hippurites, 466

Histioderma, 95

Hitchin, 643

Hoar Edge Grits, 129

Hoernesia, 327, 350

Högbom, A. G., 68

Holaspis, 226

Holaster, 46b, 495

Holcospongia, 410

Holcostephanus, $386,436,464$

Holectypus, 410,464

Holland, 602

Hollybush Sandstone, 89

Holocystis, 466

Holopea, 97, 114, 115, 158

Holopella, 158, 160, 162

Holoptychius, 225, 226, 250

Holt, 356

Holywell Shales, 255, 257

Homalonotus, 110, 156, 161 . 162,195

Homomya, 350, 385

Homosteus, 196, 226

Homotaxis, 23

Hope Shales, 128

Hoplites, 466, 467, 470, 492 . 493

Hoploparia, 531

Hoplopteryx, 464, 466

Hordwell Beds, 560

Horiostoma, 158, 162

Horne, J., 48

Hoxne, 642

Hudleston, W. H., 420, 442 , 443

Hughes, T. M'K., 53, 81, 87 , 172

Hull, E., 211, 367

Hume, W. F., 512, 519

Hundsruch Slates, 220

$\mathrm{H}$ unstanton, 500, 505

Huntingdon, 441

Hurlet coal, 268

Huy, 145

Hyona, 588, 602

Hyonarctos, 577

Hyonietis, 588

Hyonodon, 557

Hyalonomus, 317

Hyboclypus, 410

Hybodus, 351, 386, 435

Hydrobia, 639

Hylocosaurus, 464

Hymenocaris, 75,77

Hyolithes, $73,75,76$

Hyopotamus, 528,557

Hyotherium, 577

Hyperodapedon, 353, 363, 369

Hypothyris, 248

Hypsilophodon, 464
Hyracotherium, 528

Hythe Beds, 475, 477, 478, 479

Iberg Limestone, 221

Ice, extension of, 634

Ichthyocrinus, 156, 162

Ichthyornis, 405

Ichthyosaurus, 386, 392, 434

Ictitherium, 588

Iguanodon, 434, 464

Ilfracombe Beds, 207

Illenus, 110, 114, 156, 160, 162

Imperfection of records, 16

Inferior Oolite, 383, 387, 409

Infulaster, 466

Ingleborough, 259, 260, 261

Inoceramus Bed, 505

Inoceramus, 3S5, 492, 495

Instow, 309

Inverness, rocks of, 39,41

Ireland, Archran of, 48

Cambriau of, 94

Carboniferous of, 269, 303

Cretaceous of, 512

Lias of, 402

Old Red Sandstone, 209. 237, 239

Ordovician of, 137

Pleistocene of, 617, 633

Silurian of, 178

Trias of, 365

Iriartea, 528

Irish Channel, 569

Irving, Rev. A., 367, 569, 570

Isastrea, 350, 855

Ischadites, 162

Ischyodus, 410

Islay, $39,46,47$

Isle of Man, 94, 365

Isle of Wight, $476,499,501$, $502,506,508,540$

Isocardia, 410

Isocrinus, 350, 385

Italy, Tertiary Beds of, 567, $583,605,609$

Jarrow coalfield, 304

Jasper, 51, 97

Jatulian System, 65, 67

Jehu, T. J., 632

John o' Groat's Sandstone, $236^{\circ}$

Johns, Cosmo, 260, 263

Jotnian System, 65, 67

Judd, J. W., 368, 403, 428, $441,484,561$

Jukes, J. B., 204, 210, 211, $274,275,565$

Jura Mts., 382, 405, 406, 430, 452

Juvavian, 373, 374, 375

Kalevian Systein, 65

Kammin, 407

Kampecaris, 226

Karpinsky, 344

Keele Beds, 297, 298, 328

Keeping, H., 542, 543, 561

Keisley Limestone, 132

Kellaways Beds, 432, 441
Kellerwald, 220

Kelsey, 626

Kendall, P., 596

Kendall, Professor P. F., 19

Kenmare, 211

Kent, 475, 498, 505, 507, 535

Kent's Cavern, 644

Keraderpeton, 317

Kerforne, F., 186

Kerry, 178, 210, 211

Keuper Series, 348, 362, 370

Kharkov, 519

Kidston, D., 285, 290, 296, $302,303,307$

Kilian, W., 487, 4S9

Killary Harbour, 139, 178

Kilrose, J. R., 617

Kiltorkan Beds, 211, 212

Kimberley, 335

Kimeridge Clay, 432, 444, 445

Kimeridgian, 383,459

Kinaham, G., 273

Kinderscout, 295

Kingena, 466

King, W. W., 330, 331

Kinlock Beds, 45

Kirkby Mnor Flags, 175

Kirklington Sandstone, 365

Kirmington, $626^{\circ}$

Knorria, 212, 226

Koenen, von, 490

Kohlen Keuper, 371

Königsburg, 564

Koninckinu, 350

Kossen Beds, 408

Kostromian, 325,343

Krone, 320

Kupferschiefer, 342

Kutorgina, 73, 74

Jabechia, 156

Labyrinthodon, 352

La byrinthodouts, 338

Lacerta, 520

Lacopteris, 350, 414

Lacustrine deposits, 642

Ladoga, Lake, 148

Laekinian, 527

Lagena, 245

Lagenostoma, 290

Lake District, 93, 129, 130, $569,617,622$

Lake, Ph., 172

Lamarck, 14

Lamna, 464

Lamplugh, G. W., 94, 484, 486,511

Lanark, 177, 234, 302

Lanarkia, 178

Lancashire, 258, 295, 296

Lancastrian flexures, 314

Landenian, 527, 549, 550

Langhe, 583

Languedoc, 187

Lapparent, A. de, 99, 573

Lapworth, C., 8, 71, 80, 82 $86,89,91,93,128,134$, $154,170,176,177,299$

Lapworth, H., 168

Lapworthura, 162 
J.usanius, $17 \mathrm{~s}$

Jassiogruptus, 110

Letstrea, 874

I atdorf, :564

Jatu rus, 574

Lausanne, 580

Iaval basin, 280

I a Vega Beds, 100, 101

l.enia, 815

Leavening, 501

Lebacl Beds, 341, 842

l.ebour, G. A., 268

Jeila, 990

Leda Myalis Bed, 627

Ledbury Sliales, 168

Leenane Grits, 140

Jeicester, 296, 332, 399

Leinster coalfield, 303

Leintwardine Flags, 167

LAiston, 599

l.eithakalk, 582

I.eitrim, 272

Lemhan 13eds, 587, 592

Lepulocrinus, 156, 162

Leperditia, 73, 291

J.epilodenilron, 226, 245, 2S6, 288

Jepislophloios, 245,286

Lepidusteus, 6:9

Lepilastrobus, 256

Lepirlotosaurus, 327

Lepidotus, 386, 435

Leptana, 110, 156, 159, 162

Leptirua Limestone, 147, 148

Lentite, 65

leptodomus, 195, 249

Leptogruptus, 110, 115

Ieptolepis, 3816, 434, 435

Leptophragma, 466

Leptoplestus, 93

Ieptopleuron, 953

Lesmalıagow, 234

Letterewe Limestonc, 39

Leven schists, 43

Lewisian gneiss, 86

Jeyburn, 262

Jias, the, $352,383,386$

Liburtian, 555

Lichrs, 110, 114, 115, 156, 162 , 195

Life-forms, successlon of, 21

Ligerian, 515

Liguria, 583

Lima, 350, 390, 412, 464, 492

Limagne, the, 560

Limerick, 274

Iimestone Drift, 633

Limnara, 559

Limnerpeton, 31 I

Limulus, 292

Lincolnshire Jimestonc, 419 , 420

Lincolushire, rocks of, $\$ \Omega 0$, $401,419,426,445,486$, $501,505,507,628,620$

Lincombe lill, 204

Jindstromie, 159

Lingnla, 156, 162

Lingula Flags, $72,84,85,87$, SS
L.ingulella, 73, 75, 76,77

Linnursonia, 99, 106

Linopteris, 2:0

Lioceras, 410

Liast racus, 105

Liperoceras, 380

Liquilamber, 574

listrioulon, 577

Literature of Historical Geo. logy, 26

Litharen, 528, 532

Lithomarge, 547

Lithorn is, 528

Lithastrotion, 246, 247

Lithothamnion, 579

Littorine, 380

Littry, 317, 341,37

Lituites, 110, 114

Jiver 1001,356

Iivonia, 193, 223

Lizard, the, 55,5 ?

Llanberis, 81,87

liandeinioien, $8 \mathrm{~s}$

Llandilo Beds, 109, 110, 122 , $128,131,140$

Llandovery Beds, 129, 153, $168,168,176$

Llandudno, 257

Llanfaelog, 122

Liauvirn Beds, 109, 110, 121, $128,131,140$

Lleyn promontory, 52, 119 , 126

Llyn Peris, 87

Lobites, 349

Lochinaben, 838

Loch Maree, 38, 39

Loch-na-dal Beds, 46

Lodève, 341

Loess, 646

Loganograptus, 110

Lonan Flags, 94

London Basin, 333

Loutlon Ciay, 527, 535, 589

Ioudon, gravels near, 642

longmynd, the, 55,128

Longmyndian Series, 50

Jongvilie Fiags, 129

Jonsdaleia, 247

J.ophiodon, 528

Lorne, 294

Jorraine, 404, 406, 430

Lossiemouth, 368

Lower Greemsand, 462, 498

Lowestoft, 699

Laxoneina, 196, 249, 292, 327, 949

Luarea Slates, 144

Luberon, 604

Luberon Jeds, 587

I.ucina, 350, 497, 570

Ludian, 556, 565

Ludlow 13eds, 134, 167, 17\%, 184

Iudwigia, 410

Litmulicirdium, 168

Lare, Niont de, $487,458,459$

l.utetian, $527,549,552,555$, stis

Lutra, 577, 602
Lybster Flagstones, 230

Lyckirolm limestone, 148

Lyeli, Sir C., 572,648

l.ygodium, 574

Lyme Regis, 395, 503

Lymnorella, 410

Lynton Beds, 204

Lyons, 370

Iyopora, 115

Lyra, 466

Lytoceras, 386

Lytoloma, 528

Macclesfield, 630

Macharodus, 577, 588, 601, 638

Mlacllenry, A. $49,50,139,210$

Mackintosh, D., 631

Maclurea, 97

Macroce $p$ halites, 410,413

Macrochilina, 190

Macrochilus, 249

Macroscriphites, 466,470

Macrotherium, 577

Mactra, 591

Malreporu, 528

Moneceras, 196

Maentwrog Beds, 86

Mrestricht, 516

Magdalenian age, 638

Magnesian Limestome, 334 . 335

Magnolia, 464, 528, 574

Magnosia, 436

Maiaise, C., 101, 180

Maimo, 517

Malmstone, 498

Malvern, $57,88,92,164,314$

, Shales, 92

Mammites, 466

Manchester, 336

Manstleld, 959

Mantellia, 438

Mapleweli Beds, 58

Maps (geological), 27

Marchlyn-mawr, 87

Marcou, J., 324

Margate, $50 \bar{\tau}, 508$

Marginella, 528

Marines, Sables de, 554

Mariopteris, 290

Market IRasen, 445

Marl Siate, $\mathbf{3 3 +}, \mathbf{3 9 5}$

Marlstone Rock, $397,398,400$

Mart, J. E., 94, 104, 110, 124, 174,569

Marsipiocrinus, 156, 162

Marsupites, 466,496

Marsupite zone, 507, 50 S

Mlarwood, 209

Mustorlon, 577, 588

Mustodontosaumus, 852, 363

Matagne, slates of, 219

Matiey, Cl., 51, 274

Matonidỉum, 414

Mauchline, 339

Maw, G., 569

Maw, W., 165

May Jili, 164

Mayence 564 
Mayenne, 99

Mayo, 49, 139, 178, 272

Meadfoot Beds, 202

Meadowtown Beds, 128

Mediterranean Region, 313, $517,607,609$

Medlicottia, 327,344

Meekella, 319

Megalanteris, 195

Megalichthys, 250, 292

Megalodon, 195, 350

Megalosaurus, $384,415,464$

Megaphyllites, 349

Melanatria, 530

Melania, 530

Melanopsis, 530

Melbourn Rock, 505, 507

Melocrinus, 195

Melongena, 576

Melonites, 247

Mendip Hills, 397, 416

Mendola dolomite, 374

Menevian Beds, 72, 81, 82

Merevale Shales, 93

Merioneth, 80, 82, 85, 116, 117,121

Meristella, 155, 157, 160

Meristina, 156

Mesacanthus, 226

Mesarchrean rocks, 35

Mesières, 406

Mesodiadema, 350

Mesolithic age, 638

Mesophyllum, 195

Mesozoic time, 5, 347

Messinian stage, 587, 605

Metoptoma, 249

Meudon, 551

Meyer, C. J. A., 540

Meyeria, 466, 470

Michelinia, 195, 247

Micmaccia, 91

Micrabacia, 466, 496

Micraster, 466, 496

Microcharus, 529

Microdiscus, 75

Microdon, 410

Microlestes, 384

Microtus, 602

Midlothian, 269, 302

Milanovitz, 432

Miliolina Limestone, 568, 570

Millburn Beds, 131

Millepore Beds, 420, 422

Millstone Grit, 283, 294, 295, $300,302,304,305,323$

Miocene Series, 11, 526, 575

Mithracia, 528

Mithracites, 466

Mixosaurus, 352

Modiola, 246

Modiolopsis, 114, 115, 158

Moel Ferna Beds, 172

Moel Tryfaen, 631

Moelwyn Mountains, 119

Moffat area, 136

Mohicana, 91

Moine sehists, $41,44,47$

thrust, 36,39

Molasse, 565
Monckton, H. W., 542, 543

Monobolina, 112

Monodacna, 606

Monodonta, 386

Monograptus, 155, 157

Monopleura, 466

Monotis, 350, 351

Mons, limestone of, 350

Montagne Noir, 61, 281

Montian, 527, 549, 551

Monticulipora, 115

Montigny, greywacke of, 216

Montlivaltia, 385

Montmartre, 505

Moravia, 312, 582

Moray, 339

Morecambe Bay, 630

Morigny, sands of, 566

Mortefontaine, 554

Morte Slates, 200,204

Morton, G., 255

Morvan, 376

Morvern, 368, 369, 513

Mosasaurus, 465

Moscovian Series, 245, 313

Moscow area, 281, 312, 455, 521

Mottled Sandstone, 355, 357

Mousterian, 638

Mull, Island of, $369,403,404$, 513,547

Mundesley, 627

Murchison, Sir R., 70, 109, 154,324

Murchisonia, 97, 115, 158, $162,197,249,349$

Murex, 532, 576

Muschelkalk, 348, 354, 370, 378

Mwelrea Grits, 140

Mya Beds, 648

Myalina, 195, 249

Mydrim Limestone, 124

Mylor Series, 144

Myoconcha, 385

Myophoria, 195, 350, 351, 371, 388

Myrica, 464

Mytilus, 350

Naiadites, 291

Namur, 145, 215, 217, 279

Nant-glyn Flags, 172

Narberth, 124

Nare Head, 202

Natica, 371, 385, 437, 492

Naticella, 350, 351

Naticopsis, 196, 249, 327, 349

Nautilus, $349,390,411,494$, 531

Nebulipora, 115

Necrocarcinus, 466

Nemacanthus, 388

Nemagraptus, 110

Nematinion, 466

Nematophycus, 155

Neocomian, 463

Neogene System, 12, 526, 572

Neolimulus, 156

Neolithic, 638
Neozoic era, 5,348

Neptunea, 590

Nerincea, 385, 410, 412

Nerita, 386

Neritopsis, 386

Neumayr, 460

Neuropteridium, 350

Neuropteris, 226, 287, 290

Newark, 335, 336

Newbourn Crag, 592

Newcastle Beds, 297

New Red Sandstone, 324

Newton, E. T., 364

Nicholson, H. A., 174

Nikitin, S., $343,344,455$

Nilssonia, 414

Niobe, 76,78

Nipa, 528, 531

Nithsdale, 303, 338

Noisy, Calcaire de, 554

Nomenclature of systeins, 4

Nomismoceras, 249

Norfolk, 484, 486, 500, 504, 511,597

Norian stage, 374

Normandy, Cambrian of, 100

Carboniferous of, 317

Cretaceous of, 514, 515

Devonian of, 214

Jurassic of, $406,430,457$

Ordovician of, 142

Permian of, 341

Trias of, 377

North Sea basin, 608, 634

Northampton, 362, 400, 419

Northampton Sand, 419

Northumberland, 263, 3C0, 334,622

Norway, 64, 103, 146, 238

Norwich Crag, 597

Notgrave Freestone, 417

Nothe Beds, 442

Notosaurus, 352

Nottingham, 334, 335, 359

Nucleolites, 410, 413

Nucleospira, 156

Nucula, 192

Nummulitic Sea, 568

Nuneaton, 91, 93

Nyssa, 578

Obolella, 73, 74, 75, 76

Ocbil Hills, 232

Oculina, 529

Odessa, 606

Udontopteris, $287,290,325$

Odontopteryx, 528

Eglina, 100, $11 \%$

Elhert, D. P., 99, 213

Eninghen Beds, 574, 580

Offaster, 497, 508

Ogwell, 208

Ogygia, 76, 111, 113

Oil Shale Group, 267, 268

Oland, Island of, 146, 181

Oldbury Shales, 93

Oldhaven Beds, 537

Old Red Sandstone, $6,8,193$, 223

Olenellus, 73,74 
Oleuian, 84

Ulenux, 75,77

Ollgocene sirtes, 520,355

(likiva, 328, 570

(1)ivella, 533

Olonetz, 65, tir

Umavanrus, 434

Omphalotroclus, 158,315

Un phyma, 156, 159, 160

(Inchutruchus, 460

Onclucs, $15 \mathrm{~S}$

Onychiopsis, 46\%

Opalinum zone, 409,415

Operculine, 570

ophidioceras, 158

Ophioceras, 386

Ophioderma, 8S5, 391

Ophiorlerpeton, 292, 315

Ophiolepis, 385

Opis, 3 S5

Oppelia, 410

Opponitz. Limestone, 375

Orbiculoidea, $7 \mathrm{~S}, 75,162,388$, 436

Orbitoicles, $5 \% 0$

Urbitolina, 517

Orcarlian area, 236, 242

Ordovlcian System, 8, 12. it

Organic remains, destruction of, 18

, preservation of, 16,17

Orgnn, 489

Origin of specles, 14

Orleanais, 579

Ormoy, 556, 566

Ornithochcirus, 465

Ornithopus, 466

Ornithosuchus, $\$ 52,369$

Orophocrinus, 247

Orthis, $75,76,77,78,113,114$, $115,156,157,161,162$

Orthisina, 110

Orthocerus, 76, 7S, 158, 160, $161,162,249,349$

Orthoceras Limestone, 47

Urthonota, 160

Orthotheca, 73

Osborne Beds, 561, 562

Osmeroides, 464

Osiningtoli Oolite, 442

Osmunda, 52S, $57 \mathrm{~S}$

Ostende, 550

Osteolepis, 220

Ostian Beds, 312

Ostran, $385,413,435,528,576$

Otopteris, 391

Ofnzamites, $350,385,414,491$

Ottweiler Beds, 317. 315, 341

Onen, Calcaire de St., 554

Oural Jouutains, 223

Oribos, 602

Ox Mountalns, 49

Oxforl, 400

Oxford Clay, 432, 440, 441

Oxford Limestone, 264, 265

Oxfordian stage, 3S3, 451, 432,458

Oxymoticeras, $3 \$ 6$

Pabba Shales, 403
Puchyliscus, 460

Pach ynoloplits, 529

Pechypori, 105

I'cechyrlsma, 410

I'orh ystella, 511

l'achntheou, 155

Prulstow, 208

Palararca, 76, -8, 112

I'alazaster, 102

Palaraterina, 70

Pulachinus, 156, 160, 247

Palerga, 406

Palezocarlite, 950

Palcocherus, 5 it

Pulevocoma, 162

Palcocorystes, 460

Palacocyclus, 156

Palkeouliscus, 156

I'alaogene System, 12, 526

Paluogeography", 32

Palaohatteriu, 327

Palarolithic implements, 638

Paloromustodon, 557

Palcomutela, 238

Pulcenictis, 528

Puloson iscus, 817, 327, 354, 364

Palieontographical Society, 32

Palreontology, Books on, 31

Palcophis, $52 \mathrm{~S}$

Palcophonus, 175

Pulcopteris, 212, 226

Palcosaurus, $\$ 52,366$

Pulcotherium, 557

Palreozoic era, 5

Palmacites, 578

Paloplotherium, 529

Paltopleuroceras, 356

Paludina Beds, 5S7, 606

Panopea, 531

Parabolina, 75, 75

Poracyathus, 528

Paradoxides, 75, 81

Paradoxidian Series, 81

Parallelodon, 195, 248

Parasmilia, 406

Pareiasaurus, 944

Parexus, 196, 226

1 aris basin, 352,565

Parki 226

l'urkinsonia, 410, 411

Parona, Slgnor, 69

Partuach Beds, 3\%3, 975

P'ctellit, 386

Pavlow, A., 455, 490

Pays de Bray, 520

l'ea-grit, 415

Peach and Horne, Messrs, $1 \% 6,301$

Pebble Beds, the, 356, 35?, $3 \pi 1,377$

Pebillan Series, 58

l'eckforton IIIlls, 357

Pccopteris, 290, 315, 925

l'ecten, $350,371,385,437,464$, 494

Pecten Bed, 400, 401

Jectunculus, 466, 529

Perlina, 410

l'elagosaurus, 386
Pellengare Series, 307

Jeloneustes, 434

Pelosaurus, 342

Peltastes, 43is

I'eltocerus, 438

J'elfura, 75, 70

Peinbrokeshire, 53, 79, 80, $84,109,121,228,230$, 255,632

Penorus, 385

Pondleslde Beds, 253, 25.5, 259

Pengeliy, W., 044

Penklll Berls, 17 3

Pennant Grits, 304, 807

Penuine area, 294, 314, 569, 629

Penrhyn, 81, 86, 121

Penrith Sandstone, 337, 398

Pentacrinus, 355,991

Pentactinella, 350

Pentamerus, 156, 157, 160, 161,162

Pentland Hills, 17\%, 179

Pen-y-glog Beds, 172

Percostoma, 525

Pericyclus, 2.49

Periechocrinus, 156, 162

J'erisphinctes, 430, 464

Permian System, 12, 324

Pcrna, 385, 464, 469

Perna Bed, 477

Perolinella, 410

Perrler, 580, 604

Perthshlre, 233

Peterborough, 441

Petherwin Beds, 208, 209

Placops, 110, 114, 160, 162, 195,197

Phanicites, 528, 574

Phaneropleuron, 225, 226

Pharetrospongia, 460

Phascolotherium, 384, 415

Phillipsastrea, 195, 247

Phillipsia, 246, 248

Philoxene, $196^{\circ}$

Pholadomyct, 350, 364, 385, $411,413,435,529$

Pholidophorus, 3S6, 435

Ph rugmoceras, 155, 162

Phyllocenia, 410

Phylloceras, 349,356

I'hyllodus, 328

Phyllograptus, 110, 111

Phyllopori, 115, 348

Physu, 488

lickwell Down Beds, 20 s

Pikermi Beds, 600

Pileolus, 410

Pilocerus, 90

Pilsen, 317

Pilton Beds, 209, 270

Pinacuceros, 348, 851

finacoporu, 159

Pinites, 471

Jinne, 855

Pinus, 52\%

Pirbriglit, 342

Pitharella, 830

Pitys, 245, 290

Placenticerus, 466 
Placodus, 353

Placoparia, 110, 145

Placoparia Beds, 146

Placocystis, 156, 160

Plagiaulax, 434

Plagiozamites, 315, 325

Plaisantian stage, 587, 605, $600^{\circ}$

Planera, 5\%4

Planorbis, 4 i9, 559

Plant-assemblages, 322

Plasmopora, 195

Platanus, 464, 527

Plateau gravels, 640

Plattenkalk, 432

Platyceras, 15s, 196

Platychisma, 158

Platycrinus, 247, 245

Platysomus, 250, 292

Pleistocene Series, 526, 611, 637

Plesiosaurus, 386, 392

Plethodus, 466

Pleuracanthus, 292

Pleurodictyum, 195

Pleurograptus, 111, 115

Pleuromya, 413, 464

Pleuronautilus, 293

Pleurophomus, 195, 249, 327

Pleurosternon, 438

Pleurotoma, 531, 576

Pleurotomaria, 158, 196, 249, $327,390,436,464$

Plicatula, 350, 385, 492

Plinthosella, 466

Pliocene Series, 11, 526, 586

Pliopithecus, $57 \%$

Pliosauris, 386, 434

Plocoscyphia, 466

Plougastel Grits, 213

Pluckley, 450

Plutonia, 75

Plymouth, 204, 207, 208

Plynlimmon, 632

Polacanthus, 464

Poland, 183, 222, 241, 312, 431,521

Polesworth, 332

Polyptychites, 436

Polyptychodon, 464

Pomeroy, 139, 178, 237

Pontefract, 297,335

Pontesford Hill, 56

Pontian stage, 5\$7, 605, 607

Pontypool, 307

Popcinoceras, 327, 344

Populus, 464, 527, 574

Porcellia, 196

Porlock, 367

Porsguen Slates, 213

Portheus, 464

Portlandian, 353, 432, 445, 455,460

Portland Beds, 432, 445

," Bill, 645

Pórtscatlio Beds, 144

Portsmouth, 546

Portugal, 100, 144, 187

Portunites, 528

Posidoniella, 248
Posidonomya, 246, 350

Potamides, 530, 559, 576

Potamomya, 528

Poterioceras, 196, 249

Poteriocrinus, 247

Potton, 4S3

Prague, 222

Preservation of organic remains, 16,17

Presteign, 165

Preston, 359

Prestwicl,, Sir J., 593

Prestwichia, 292

Primotilices, 289

Prionocyclus, 466

Prionotropis, 460

Pristis, 528

Probus Grits, 202

Procervulus, 577

Productus, 195, 246, 248, 327

Proptus, 110, 156, 195, $24 \mathrm{~S}$

Prolecanitcs, 196, 249

Pronorites, 249

Protapirus, 557

Protarchœan Rocks, 35

Proterosaurus, 327

Prothyris, 195

Protocarlia, 350, 385, $38 \mathrm{~s}$

Protoplasma, 315

Protosphyroena, 464

Protospondylus, 347

Protospongia, 73, 74

Provence, 431, 48 $7,489,517$, 555,600

Proviverra, 528

Przibram Shales, 64

Psammodus, 251

Psammosteus, 226

Psaronius, 289, 325

Pseudocrinus, 156

Pseudodiadema, 385

Pseudomelania, 350, 386

Pseudomonotis, 327, 351, 390

Psiloceras, 386, 389

Psilophyton, 226

Pteranodon, 465

Pteraspis, 196, 204, 226, 228

Pteria, 350, 385

Pteridosperns, 289, 325

Pterich thys, 224

Pterinoea, 158, 161, 162, 195

Pterinopecten, $24 \mathrm{~S}$

Pteris, 528

Pterocerian stage, 452

Pterodactyles, 3S4, 433, 434

Pterodon, 528

Pteroperna, 410

Ptcrophyllum, 315, 325, 350, $371,385,412$

Pterosauria, 354

Pterygotus, 156, 162, 224, 226

Ptychites, 349, 351

Ptychodus, 466

Ptychoparia, 91

Ptychopteria, 195, 195

Ptychostoma, 350

Pugnax, 248

Pugnellus, 466

Punfield Beds, 477, 4S1

Purbeck Beds, 432, 448, 449
Purbeckian, 452, 460

Purley Shales, 98

Purpura, 591

Purpurina, 386

Pygaster, 410

Pygurus, 410, 464

Pyrenees, the, 1si, 281

Pymila, 528

Quaderstein, 518

Quantock Hills, 207, 36

Queen Camel, 395

Quercus, 574, 578

Raasey, 368, 369, 403, 404, 428

Radiolarian cherts, 135,136 , $150,186,276$

Radiolites, 466

Radstock Beds, 304

Raibl Beds, 373, 375

Raised Beaches, 645

Romipora, 115

Ramsay, Sir A. C., s0, 87, 8s, 331

Ramsdell Clay, 541

Ramsey Island, 116

Rastall, R. H., 402, 443

Rastrites, $155,15 \%$

Rastrites Shales, 182

Raugraben Shales, 375

Reade, T. M., 629

Reading Beds, 527, 537, 539

Reculvers, 537

Rerl Chalk, 500

Red Crag, 5S4, 592, 596

Head Group, 232

Rẻon, 141, 142

Redonia, 112

Reed, E. Cowper, 140

Reef Limestone, 191

Reid, C., 276, 562, 503, 506, $599,600,601,603,609,649$

Reiffling Limestone, 373,374

Reigate, 478,479

Reinacl, von, 333

Relative age of strata, 2

Remopleurides, 110

Rennes, 99

Renselleria, 195

Reptilia, 384

Retzia, 162

Revinian Series, 101

Reynolds, S. H., 139, 180

Rhabdocidaris, 385

Rhacopteris, 245

Rhacophyllites, 349

Rhætic Beds, 375, 383, 395, $399,405,408,456$

Rhamphorhynchus, 434

Rhine, the, 600 , 605

Rhine valley, 219

Rhinoceros, 5ss, 601, 638

Rlinog Grits, 81

Rhipidocrinus, 195

Rhiwlas Limestone, 125

Rhizodopsis, 292

Rhizodus, 250, 292

Rhizopłyllum, 156

Rhodocrinus, 247

Rhyader Slates, 168 
Rhyuchonelli, 110, 19i, 19S, $350,350,351,411,436$, 494, 495

Rhynchuseurus, 358

Rhynchotretu, 150

Rialen Sistus, 141, 142

libbaud Serles, 195

liccarton 13eds, $1: 7$

IrIcliarison, La, 395

IRichuond, 398

kimella, 52S

Ripple-marks, 304

Rissoina, 110

River gravels, 641

Rolverts, T., 443, 451

Rubinia, 574

Rochester, boring at, 103

Rock Salt, 343, 365, 370

locroi, 101

lRogers, T., 909

Romnn Fell, 25ก, 201

Roslin Sandstone, 302

Ross, Archuean of, 36

liustellariu, 528

Rostellec Shales, 213

Rotherham, 298

Rouen, 405

Rowe, A. W., 506, 507, 50S, 510,511

Royion, 500

Rozan, limestone of, 141

lRuddy, T., 125

Rupelian, 303

Russia, Cambrian of, 104

Carboniferous of, 2S1, 312

Cretaceous of, 490,519

Devonian of, 222

Jurassic of, 409,455

Orilovleian of, 148

- Jermlan of, 324, 343 silurian of, 183

Rutland, 399

Rutotia, 199

Scebul, 528, 574

Sables Moyens, 554

Saccamminn, 245, 263

Sacco, F., 555, 567, 554

Sugenarin, 220

Saiga, 038

Sailmlior Group, 96

Salenia, 466, $4 y_{4}$

Salmian Series, 101

Salopian Series, 154, 165, 170 177

Salrock Beds, 180

Salter, J. W., 276, 477

Salterclla, 73, 91,96

Saltholm, 510

Sal zburg, 408

Samara, 343

Sancats, 578

Sand gate, 477, $47 \mathrm{~S}$

Sandgate Beds, 475, 475, 479

Sandrlngham sands, 486

Singuinouriu, 528

Stunguinolites, 249

Sannoisian, 556,565

Sao, 104
Sarnatian stage, 573, 575, 582, 583

Sarrebruck area, 311, 317, 341,370

Sarthe, the, 814

Saxonian stage, 324, 341, 342, 345

Sixxony, 325

Soulariu, 350, 386, 492

Scaldisian, 58t, 602, 603

Scalpa, $40+$

Scandinavia, $64,103,146,181$, $282,407,634,647$

Scunla, 147, 181

Scuphaspis, 15\&, 162, 226

Soupheus, 385

Scruphites, 466, 495

Scuphognathus, 433, 434

Sear Linestones, 259, 263, 265

Scarborough Limestone, 420 , 422

Scel illosaurıs, 396

Schatzlar Beds, 312

Schell wein, 320

Schizaster, 528

Schizocyst is, 156

Schizolus, 249, 319, 326, 327, $\$ 50$

Schizolepis, 350

Schizopteris, 325

Schleru Dolomite, 375

Schlier, the, 582, 585

Schlanbachia, 406,495

Schlotheimia, 356

Schmidt, 104

Scicnurus, 528

Sciuroides, 529

Scleromochlus, 369

Scaliostoma, 196

Sculithus, is

Scotland, Archatan of, 36

Cainbrian of, 96

Carboniferous of, 265, 301

Cretaceous of, 457,513

Eocene of, 547

Jurassle of, 402,450

O.R.S. of, 192

Ordovician of, 132

Pleistocene of, 617,619

Silurian of, 170

Trlas of, $30 \mathrm{~s}$

Scremerstou Beds, 264

Scuntliorpe, 400

Scutelle, 574, 579

Scytulia, 511

Seamraig IBeds, 45

Seaton, 367

Sederholnı, J. J., 65

Sedgley, 167

Sedgwick, A., 70, 72, 108, 153, 104

Seenaun, F., 222

Selborile, 499

Selbornlan, $462,403,498$

Selenucorlon, 460

Seliscothon, 511

Selous, F. C., 16

Seminula zone, 253, 259

Semitonotus, 351

Semui Beds, 22S
Senoulan, 4t33, 491, 515

Seruanian, 383, 451, 452

Sequota, 527, 574

Serpulites, 79

Serpulite Grlts, 96, 97

Servla, 409,432

Sevenoaks, 477, 478

Sewerby gravels, 625

Shells, stabllity of, 19

Shelve, 127, 128

Slieppey, Isle of, 540

Sherborn, $+16,424$

Slineton Shales, 02

Shlpman, J., 364

Sholeshook Limestone, 124

Shotover, 483

Shrewley Sandstone, 364

Sliropshire, Archaesn of, 55

Cambrian of, $\$ 9,92$

Carboniferous of, 395, 298

O.R.S. of, 227

Permian of, 328

Silurian of, 164

Trias of, 355,363

Shumurilia, 92

Sibertzew, 344

Sibly, T. F., 257

Sicllian stage, 584, 605, 606 , 609

Sidmouth, $367,499,500$

Sigillaria, 286, 2SS, 319

Silesia, 250, 312, 343, 518

Silurian System, 12, 70, 153

Simbirsk, 455,490

Sineuurian, $383,405,408$

Sion Siates, 141

Siphonia, 466, 494, 511

Siphonotreta, 110

Sisteron, 457

Skelgill Beds, 174

Skiddaw Slates, 93, 113

Skimn, 140

Skye, Island of, $45,97,368$, $309,428,547$

Slade Beds, 124

Sleddale Beds, 132

Sligo, 272

Slimonia, 156

Sinerwlck Beds, 150

Sinith, W., 3

Snettisham Clsy, 4S6

Suowilon, 123

Solssonais, 352

Solarium, 356

Sulenuslrea. 528

Solenhofen, 454

Solenopleura. 75, 97, 104

Solenopora, 203

Solenopsis, 195

Solva Beds, $72,81, \$ 2$

Somerset, Carboniferous of, 305

Jurassic of, $395,39 \%, 399$, 422,424

Permisn of, 332

Trlas of, 367

Sonninla, 110

Sorby, II. G., 19

Sorrel, Mount, 58

South Wales, see Wales 
Southwold, 599

Sowerbya, 410

Spain, 100, 144, 187, 214

Spalacotherium, 434

Sparagmite Sandstone, $6 \dot{0}$

Sparnacian stage, 527,549

Spatangus, 528, 574

Species, origin of, 14

Speeton, 505, 507

Speeton Clay, 484

Sperenberg, 343, 381

Spermophilus, 638

Spherexoch us, 110

Sphariola, 350

Sphærocodium Limestone, 182

Sphoroceras, 410

Sphcerocrinus, 195

Sphoronites, 114, 115

Sphorophthalinus, 76, 77

Sphomilites, 466

Sphenodon, 353

Sphenolepidium, 471

Sphenopteris, 226, 245, 287, 290,414

Sphenosaurus, 317

Sphyronodus, 528

Spilsby, 445, 484, 486

Spirifer, 156, 197, 248, 326, 327

Spiriferina, 248, 319, 350

Spirorbis Limestone, 297, 298, 301

Spirulirostra, 576

Spitzbergen, 459

Spondylus, 410, 496

Spongiostroma, 182, 183

St. Alban's Head, 444, 445

St. Bees, 337, 359

St. Cassian Beds, 373, 385

St. David's, 79, 116

St. Erth Beds, 595

St. Etienne, 315

St. George's Land, 282

St. Lo, schists of, 60,100

St. Ouen, Calcaire de, 554

Stachyodes, 195

Staddon Grits, 204

Staffordshire, Carboniferous of, $255,296,297,298,299$

Permian of, 328

Silurian of, 167

Trias of, 356,363

Stam pian stage, 556,566

Starfish Bed, 398

Start Point, 59

Stauria, 156

Staurocephalus, 110, 115

Stauronema, 466

Stavelot, 101

Steneosaurus, 434

Stenometopon, 369

Stenotheca, 73, 104

Stephanian Series, 245, 313, 320

Stepheoceras, 411

Stereognathus, 415

Stigmaria, 226, 288, 322

Stiper stones, 128

Stobbs, J. T., 255

Stockdale Shales, 174 "
Stomechinus, 410

Stonesfleld Beds, 425

Stonehaven, 97

Stotfield, 369, 429

Straiton Beds, 177

Stralian, A., 110, 230, 255, 481,629

Stramberg Limestone, 454

Straparollus, 196, 249

Strata, relative age of, 2, 3

Strathmore, 232

Stratigraphical Breaks, 7

Stratiotes, 578

Street, 397

Strepsodus, 292

Streptospondylus, 410

Stricklandia, 156, 157, 160

Stringocephalus, 195

Stroboccras, 249

Stromatopora, 156, 195

Stromatoporella, 195

Stromatoporoids, 181, 189, $190,207,217$

Strombodes, 160

Strophalosia, 195, 326, 327

Strophodus, 410

Strophonena, 110, 156, 159

Strophonella, 159, 162

Stur, D., 2S0, 312

Stylastrea, 385

Stylina, 410

Styliola, 208

Stylodon, 434

Subulites, 158

Succession of strata, 3

" of faunas, 21

Suessonian, 549, 555

Suess, E., 585

Suffolk, 593, 596

Sinperga Beds, 583

Surrey, 477

Sussex, 508, 540

Sutherland, $36,96,403,404$

Sutton (Glamorgau), 397

Sutton (Suffolk), 595, 596

Swabia, 407, 431, 453

Swagerina, 319

Swanage, 448, 476, 503

Swansea, 307

Sweden, 64, 65, 103, 146, 181, $407,516,647$

Swindon, 447, 449

Switzerland, rocks of, 62

, glaciers of, 637

Sycum, 528

Synchronism, 28

Synocladia, 327

Syringopora, 195, 247

Syringothyris, 246

Syringothyris zone, 253, 259

Systems, definition of, 10, 12

Taniopteris, 315, 350

Tancredia, 385

Tanne and Tannenthal, 185

Taplow, 510

Tarannon Shale, 152, 155, 162 , 168

Tate, G., 263, 512

Tatra district, 408
Taunus quartzite, 216,220

Taxocrinus, 195

Taxodium, 574

Tealby Beds, 484, 486

Teall, J. J. H., 39

Teignmouth, 333

Teilia Beds, 255

Tclacodon, $466^{\circ}$

Teleostean fislı, 347

Teleosaurus, 410, 434

Telerpeton, 353

Tellina, 576

Temnechinus, 589

Temnocheilus, 249, 327, 349, 371

Tempshya, 471, 475

Tentaculites, 115

Teratosaurus, 352

Terebratella, 385

Terebratula, 195, 350, 371, 412, 413,589

Terebratulina, 410, 451

Terebrirostra, 466

Tertiary time, 5,526

Tetractinella, 350, 351

Tetragraptus, 110, 111

," Beds, 117, 131

Teutoburger Wald, 407

'Text-books on Geology, 28

Thalassiceras, 344

Thame, 447

Thames valley, 641

Thamnastrea, 350,385

Thanet Beds, 527, 535

Thanetian stage, 527, 549, 551

Thecia, 156

Thecidium, 385, 516

Thecodontosaurus, 352, 366

Thecosmilia, $350,385,435$

Thecospira, 350

Thelodus, 158, 162

Theridomys, 529

Thetironia (=Thetis), $46 \mathrm{~b}$

Thonschiefer, 62, 64

Thornhill basin, 338

Thracia, 350, 364, 385, 436

Thurgarton, 298

Thuringia, $185,280,342,370$

Thuringian stage, 225, 334, 342

Thursius, 226

Thurso Beds, 236

Thyle valley, the, 101

Tiarechinus, 350

Tilgate Forest, 475

Till, 619,620

Tirolites, 349

Tithonian stage, 454

Toarcian stage, $383,405,406$, 408,457

Tobermory, 403

Todites, 414

Tomichia, 559

Tongrian, 556, 563

Topley, W., 450

Tornebohm, A. E., 67, 68

Tornoceras, $196^{\circ}$

Torquay, 204, 206, 207, 644

Torridonian Series, $36,38,44$ 
Tortoniau. sugc, 573, 576, 6s:2, is3

'Tortwortil, liss

Totternlioe stone, 304

Toula coui, 3:1

Touraine, 515, 575

Tournaisian stage, 251 , 278

Turuster, 466,450

Trach vice rus, 349

Trausition Beds, 255, 294, 307

Traouliors Shales, 213

Traper, 635

Trupezium, 355

Traploid breccia, 330, 331

Traquair, IR. H., 30*

Tremaloc Beds, 72, 84, 87

Trematis, 110, 115

Trematosaures, 352

Tretocenas, 158, 160

Triassic Systein, 12, 348

Trichiles, 410

Triconalon, 354, 434

Trigonia, $355,411,412,435$, $437,464,469$

Trigonia Grits, 415, 417, 423

Trigonocarpus, 290

Trigonodus, 359

Trigonasemus, 4100

Irimerocephalus, 1.05

Trinucleus, 110,115

Triplesia, 110, $150^{\circ}$

Iritonium, $3: 8$

Tritylodon, 354

Trochammina, 245

Trochocerus, $115,15 \mathrm{~S}, 162$, 196

Trochocyath us, 385,492

Trochotoma, 386

Trochus, 350

Trogontherium, 601, 68s

Trophon, 528

Tropites, 349, 351

Trumpington, 642,643

Tschernyschew, T., 319

Tuedian stage, 263, 264

Tutieau de Cipiy, 516

Tunbridge Sands, 475

Turbinolia, 5:8

Turbo, 160

Turbonitella, 249

Turin, 507

Turnford, 241

Turonian, 463, 491, 313

Turrilites, 4136,495

Turritella, 350, 350, $3 \% 0$

Twt Hiil, 33

Typhis, 52s

Tyroi, the, 3i3, 40s

Tyrone, 49, 139, 175, 237, 304

Ufa, 343

Ullmannia, 325

Ulodendron, 286

Uneites, 195

Uncouformities, ;

Underclays, 322

Unguilte Limestone, 104

Unicardium, 350 , $\$ 35$

Unio, 43S, 40\%
Upier Greensand, 4.88

Upware, 443,483

U1) way, 445

Ural Mountains, 281, 313, $313,319,343$

Uralian Series, $245,315,320$

Urgonian, 489

Uriconian rocks, 56, 5i

Uronectes, 327

U'rsus, 602

Urycordylus, 292, 317

Usher, IV. A. E., 200, 208, 908, 333

Vaienginian, $463,48 ?, 490$

Valentian Series, 154, 158, $168,176,178,184$

Valoulina, 24

Vaughan, Ir. A., 251, 252, $259,260,274,278$

Vectian, 462,463

Vectisaurus, 404

Velay, $560,567,579$

Velopecten, 350, 385

Ventonx, Mont, 4S7

Ventriculites, 466

Vermucocolia, 410

Verruculina, 466, 511

Verticordia, $52 \mathrm{~S}$

Veryan Beds, 144

Vestinautilus, 24!

Vicentin, 555, 567

Vienna, 432, 554, 582

Vienna Sandstone, 354

Vieux Jones, 563

Vigra Beds, 86

Villedien, Craie de, 515

Vireux Bcds, 216

Virgloria Limestone, 373

Virgulian, 452

Visean stage, 251, 255, 278

Viviparus, 569

Vobster Beds, 304, 307

Voicanic rock, Arcinaan, 53, $56,37,58$

"Cambrian, 10 T

"Devouian, 206, 231

", Ordovician, 116, 121, 131

"Tertiary, 544

Volgian, 455

Vologda, 344

Foltzia, 350,363

Voluta, 466, 528, 531, 539, $53 ! ?, 559$

Vosges district, 370

Walchia, $315,325,320^{\circ}$

Waldenbury lBeds, 312

Waldheimia, 391

Waies, Arciriean of, 50

Caubrian of, 78

Carbonifercus of, 253, 255

Oid IRed Sandstone, 227

PIcistocene of, $318,629,631$

Trias of, 387

Waipen sands, 479

Waiton Cras, 592, 597

Warbarrow ]3ay, 476, 477

Warberry Hill, 204, 205

Ward, Clifton, 93
Wardle Sizales, 267

Wardour, vaib of, $4+7,449$

Ware, borling at, 103

Warwicksinire, 863

Watciret, 367,395

Watcombe Clays, 393

Waterstones, 362, 363, 364

Watuey and Welch, Misses, 174

Watson, D. M. S., 899

Watts, Professor W. W., 58

Wauisortian, 279

Weaid, tise, 473

Weald Clay, 475

Weaiden Beds, 462, 463, 473

Wealden Lake, 520

Weeley, 102

Weiton, 501

Wemmelian, 527, 549, 551

Wengen Beds, 373, 37

Wenlock I Ieds, 154, 158, 165, $170,175,177,184$

Wensleydale, 260

Werfen Beds, 373, 374

Werfenian stage, 374

Westbury, 442

Westinoreiand, 93, 124, 198, $174,26 \%$

Westpilalia, 2S5, 309, 453

Westphalian Scries, 245, 285, 309

Westrngotilia, 103

Wexford, $95,197,639$

Weybourn Crag, 592, 600

Weymouth, 442

Whidborne, G. F., 207

Whitaker, W., 473, 397, 599

White Lias, 395, 399

Whitecilf Bay, $540,542,560$, 561,562

Whitelnaven, 301

Wicklow, 95, 137, 639

Wickwar, 233

Williameonia, 385, 414

Wiilougliby, 501

Wilsonfa, 156, 162

Wittslire, 442, 444, 499, 501

Woburil sands, 483

Wood, S. V., 595, 628

Wood, Jiss E. M., 170, 171, 172

Woodocrinus, 246, 277

Wood ward, H. I3., 420, 424, $447,449,457$

Woolacott, D., 334

Woolhope Shaies, 164

Limestone, 165, 103

Woolwici Beds, 52\%, 535, 587

Wrekin, The, 56

linthopsis, 528

Xenophora, 528, 539

Xiphodon, 53 i

Yarbridge, 500

leovil, 308

Yoidia Clays, 647, 648

Yoredale Beds, 23!, 260

Yorkshire, Carboniferous of, 268,295 
Yorkshire, Cretaceous of, 484 , $505,507,511$ Jurassic of, $401,420,443$, 445,447

Permian of, 335

Pleistocene of, 623
Yprésian, 549, 550, 552

Yuccites, 363

Zamites, 350, 385, 471

Zanclodon, 352, 371

Zaphrentis, 195, 247
Zaphrentis zone, 253

Zechstein, 342

Zeiller, R., 311

Zenucanthus, 317,327

Zones, 22, 158

" of fossil plants, 322

THE END

Printed by R. \& R. CLARK, LIMITED, Edinburgh 


\section{A SELECTION OF BOOKS AND MAPS ON GEOLOGICAL AND KINDRED SUBJECTS}

\section{THE BUILDING OF THE BRITISH ISLES}

BEING A HISTORY OF THE CONSTIRUCTION AND GEOGRAPHICAL EVOLUTION OF THE BRITISH REGION

BY A. J. JUKES-BROWNE, B.A., F.R.S., F.G.S.

Third Edition, licwritten and Enlarged.

488 pages, large post 8 vo, with 10 plates, 16 coloured maps, and 54 text illustrations. Cloth. Price 12s. net (12s. 4d.).

"A singularly fascinating story, told with spirit and yet with restraint by one of the great masters of British geology."-Mining Journal.

"The work is one which we consider essential to the student of the geology of the British Isles."-Science Progress.

\section{STANFORD'S GEOLOGICAL MAP OF CENTRAL EUROPE}

SHOWING ALSO THE SOUTHERN AND MIDLAND COUNTIES OF ENGLAND AND IRELAND

Reducal from the " Carte geologique internationale." One shect, 20 by 14 inches, 100 miles to an inch $(1: 6,336,000)$.

Price: Coloured sheet, 5s. (5s. 4d.).

READY IN JUNE

\section{SUB=ATLANTIC PHYSIOGRAPHY}

A new Monograph by Professor Edward Huld, LL.D., F.R.S., with one chapter by Professor J. W. Spexcer. An important work, illustrated by Eleven Charts, dealing with the form and structure of the ocean floor, with especial reference to the submarine valleys of the chief rivers entering the ocen from the land.

Folio size. I'rice, One Guinea net.

LoNnoN : EDWARD STANFORD, 12, 13, \& 14, LoNg AChe, W.C. Curlographer to IIis Majesty the King. 


\section{A SELECTION OF BOOKS AND MAPS ON GEOLOGICAL AND KINDRED SUBJECTS}

CONTRIBUTIONS TO THE PHYSICAL HISTORY OF THE BRITISH

ISLES; with a Dissertation on the Origin of Western Europe and of the Atlantic Ocean. With 27 Coloured Maps. By Edward Hull, M.A., LL.D., F.R.S., late Director of the Geolngical Survey of Ireland. Medium Sro. Cloth. 6s. net. (6s. 4d.).

"Professor Hull has rendered a signal service to students of geology by preparing and publishing a series of maps of the British Islands, in wlich he indicates, by distinctive colouring, the distribution of land and water at successive periods of geological history. No sucl series of maps, so far as we know, has ever before been published, or even attempted."-Academy.

By the SAME Author.

THE PHYSICAL GEOLOGY AND GEOGRAPHY OF IRELAND. Part I.

Geological Formation of Ireland. Part II. Physical Geography of Ireland. Part III. The Glaciation of Ireland. Second Edition, revised. With Maps and Illustrations. Post Svo. Clotll. 7s. (5s. 7d.).

PHYSICAL GEOLOGY AND GEOGRAPHY OF GREAT BRITAIN. BY Sir ANDREW C. RAMSAY, LL.D., F.R.S., etc., late Director-General of the Geological Survey. Sixth Edition. Edited by Horace B. Woodward, F.G.S., of the Geological Survey. With numerous Illustrations and a Geological Map of Great Britain, printed in Colours. Post 8vo. Cloth. 10s. 6d. (Ss. Ed.).

"No better introduction to the principles of geology could possibly be recom. niended to the English reader. It is a work of the higliest value, and one wortliy to take a foremost place among popular nianuals of science."-Nature.

GEOLOGY IN THE FIELD. The Jubilee Volume of the Geologists' Association (1858-1908). Edited by H. W. Monkton and R. Herries. A Series of Articles by competent authorities on the various districts in England and Wales visited by the Association on their excursions during the last fifty years. In Four Parts, about 900 pages, with upwards of 30 Plates and 130 Figures in the Text. Demy svo. Wrappers. Each Part, 5s. net. (5s. 3d.) Or bound in Cloth, in One volume, 23s. net (23s. 6d.); or in Two volumes, 12s. 6d. net each (12s. 11d.).

OUTLINES OF GEOLOGY : an Introduction to the Science for Junior Students and General Readers. By JAMES GE1KIE, LL.D., F.R.S. With 400 Illustrations. Fourth E'dition. Revised. Large post 8vo. Cloth. 12s. (9s. 5d.).

"The style is clear, simple, and unpretending ; the author has evidently striven to put the subject fairly before students rather than to express his own views, and las thus produced a book which cannot fail to be of great service."-Saturday Review.

PRE-HISTORIC EUROPE. A Geological Sketch. By JAMES GEIKIE, LL.D., F.R.S. With Maps and Illustrations. Medium Svo. Cloth. 25s. (19s. 3d.).

"Dr. Geikie's object in the present volume is to give an outline of what appear to have been the most considerable physical changes experienced in Europe since the beginning of the Pleistocene or Quaternary period, the period immediately preceding that which is now being wrought out, and which Dr. Geikie divides into Post-glacial and Recent. He attempts to describe, in a more systematic manner than has hitherto been attempted, that succession of changes, climatic and geographical, which, taken togetlier, corstitute the historical geology of Pleistocene, Post-glacial, and Recent times. This he does in a more thorough and complete manner than, we venture to think, has ever been done before."-Times.

LoNDON : EDWARD STANFORD, 12, 13, \& 14, LoNG ACRE, W.C. 


\section{A SELECTION OF BOOKS AND MAPS ON GEOLOGICAL AND KINDRED SUBJECTS}

SECOND EDITION-REVISED AND ENLARGEI)

Crown 8vo, cloth. Price 12s. 6d. net (12s. 10d.)

\section{STANFORD'S \\ GEOLOGICAL ATLAS}

OF

\section{GREAT BRITAIN AND IRELAND}

[Based on Reynolds's Geological Allas]

WITH PLATES OF CHARACTERISTIC FOSSILS

$$
\text { PRECEDED BY A }
$$

DESCRIPTION OF THE GEOLOGICAL STRUCTURE OF

GREAT BRITAIN AND IRELAND AND THEIR

COUNTIES; AND OF THE FEATURES

OBSERVABLE ALONG THE PRINCIPAL

LINES OF RAILWAY

BI

HORACE B. WOODWARD

$$
\text { F.R.S., F.G.S. }
$$

36 Coloured Maps and 16 double-page Plates of Fossils; with Text, 200 pages, containing 20 Sections and Vieus.

"Crammed full of information of the best quality, and written by an experienced practieal geologist who tells his readers what is to be seen of geological interest on every line of railway and in every separate comnty in the kingdom." - The Giological Magazine.

LoNDON: EDWARD STANFORD, 12, 13, \& 14, LONG ACRE, W.C. Curtographer to IIis Majesty the King. 


\section{STANFORD'S INDEXED ATLAS}

\section{or tax \\ COUNTY OF LONDON \\ WITH PARTS OF}

THE ADJACENT BOROUGHS

AND

\section{URBAN DISTRICTS}

WITH A PREFACE BY

\section{SiR LAURENCE GOMME}

Size $6 \frac{1}{4}$ by 10 inches. 166 pages of Text, and 87 Map-Sections. With an Index of upwards of 12,000 names.

SCALE OF MAPS-4 inelies to one mile.

PRICE $\{$ Strongly bound in attraetive red cloth, 7s. 6d. net (7s. 10d.)

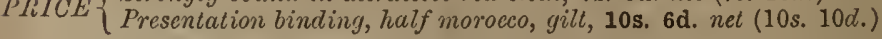

"It is admirably executed and most useful. London geography is a most complicated matter, and this should help to disentangle it."-Spectator

Detailed Prospectus, with Specimen Section, gratis.

Complete Catalogue gratis on application.

Loxdox: EDWARD STANFORD, 12, 13, \& 14, Loxg Acre, W.C. Cartographer to His Majesty the King. 


\section{2 \\ 8459}

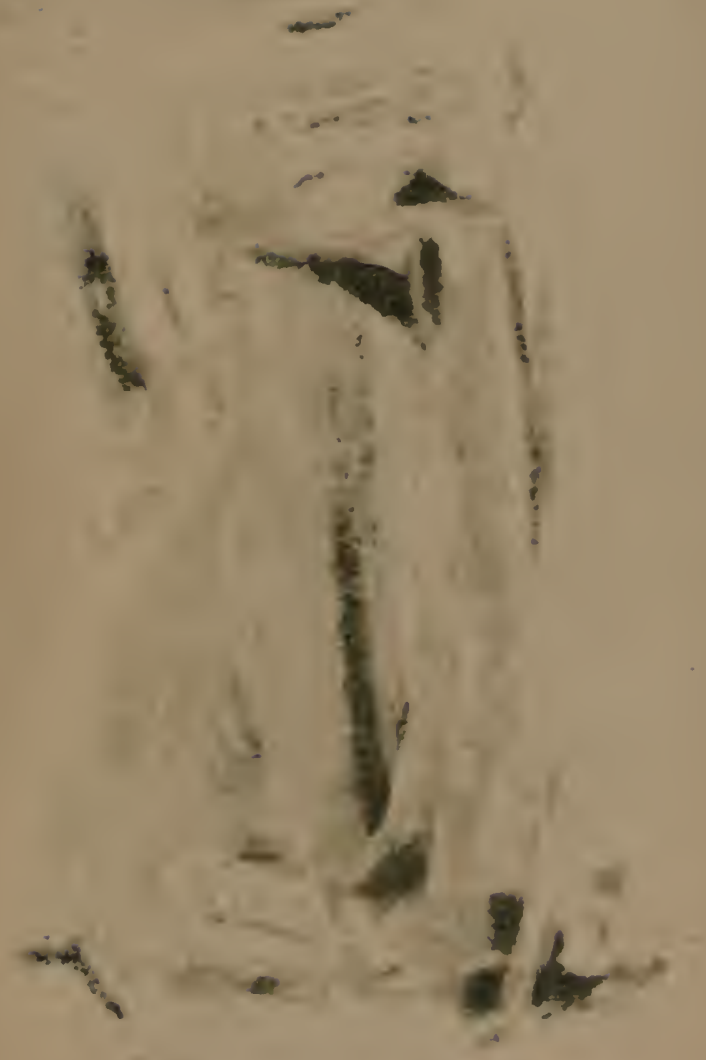



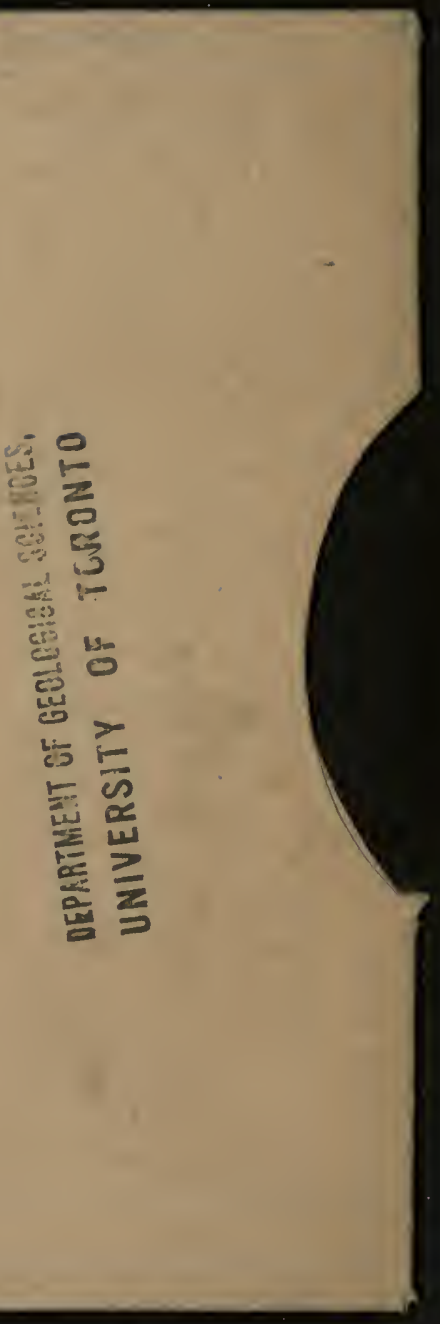
PLEASE DO NOT REMOVE CARDS OR SLIPS FROM THIS POCKET

\section{UNIVERSITY OF TORONTO LIBRARY}

$$
\begin{aligned}
& \text { S\&M } \\
& \text { A } \\
& 79
\end{aligned}
$$


